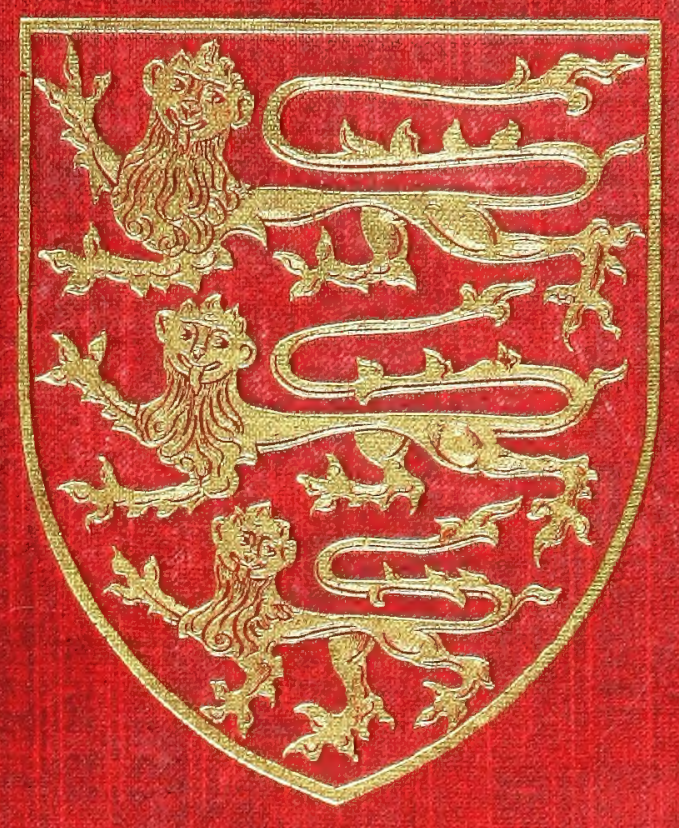



$D A$
670
V 64
B3++
V.

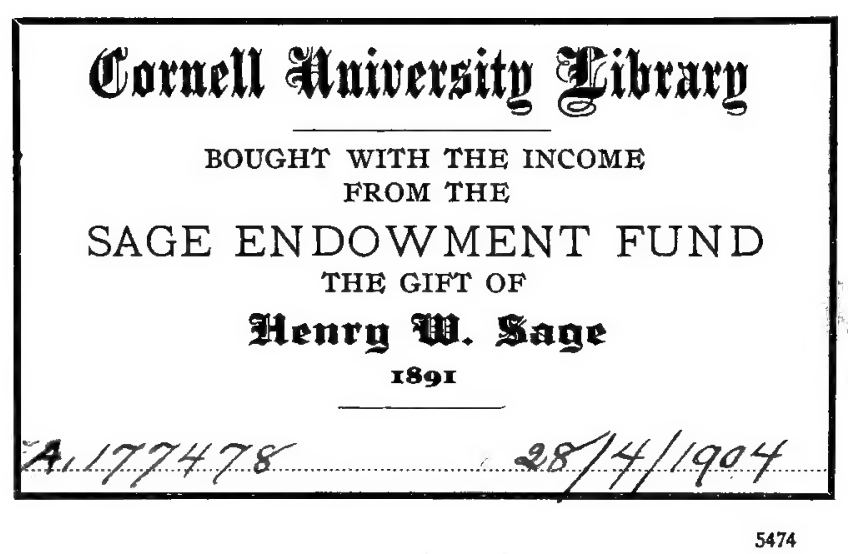




\section{Cornell University Library}

The original of this book is in the Cornell University Library.

There are no known copyright restrictions in the United States on the use of the text.

http://www.archive.org/details/cu31924088434174 


\section{The Wictoria 'ibistore of the}

Countíes of England

EDITED BY H. ARTHUR DOUBLEDAY AND WILLIAM PAGE F.S.A.

\section{A HISTORY OF BEDFORDSHIRE}

VOLUME I 
A HISTORY OF BEDFORDSHIRE IN THREE VOLUMES EDITED BY H. ARTHUR DOUBLEDAY AND WILLIAM PAGE F.S.A. 


\section{THE}

\section{VICTORIA HISTORY OF THE COUNTIES \\ O F E N L A N D \\ BEDFORDSHIRE}

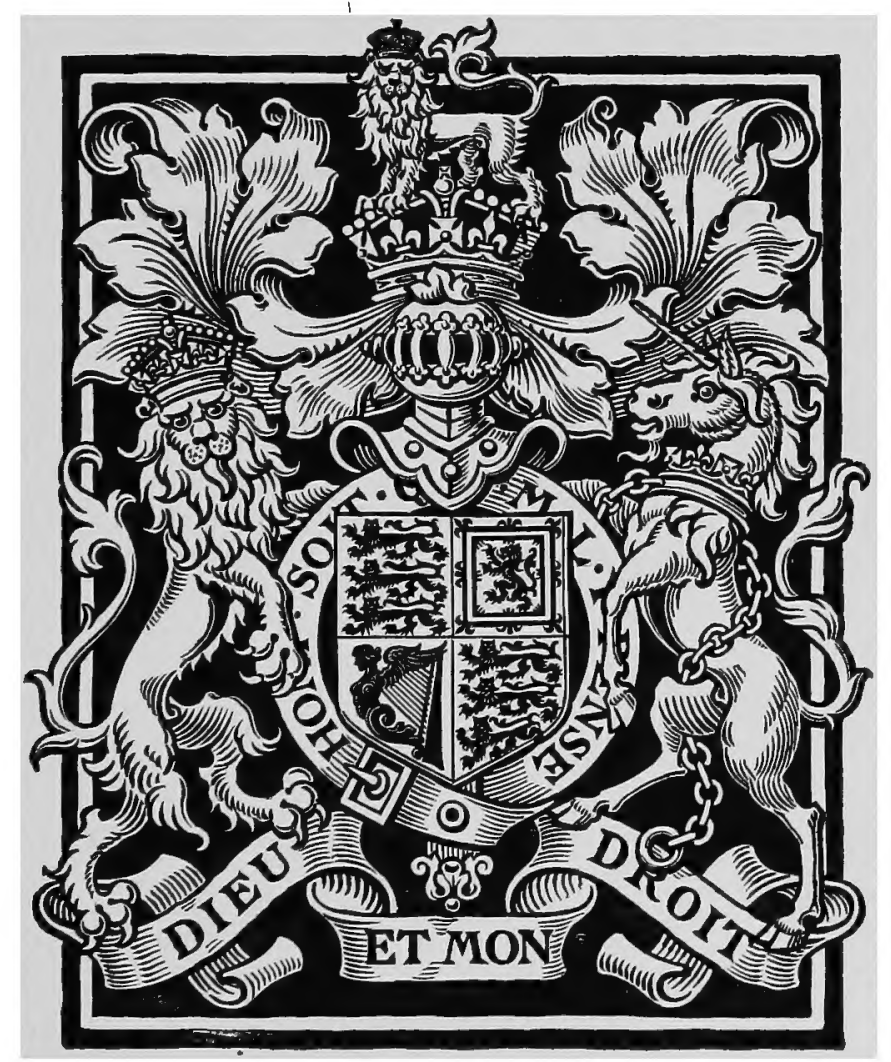

WESTMINSTER

\section{ARCHIBALD CONSTABLE}

AND COMPANY LIMITED 
This History is issued to Subscribers only By Archibald Constable Eo Company Limited and printed by Butler $E$ Tanner of Frome and London 


\author{
INSCR I B E D \\ TO THE MEMORY OF \\ HER LATE MAJESTY \\ QUEEN VICTORIA \\ WHO GRACIOUSLY GAVE \\ THE TITLE TO AND \\ A C C E P T E D T H E \\ DEDICATION OF \\ THIS HISTORY
}




\section{THE ADVISORY COUNCIL OF THE VICTORIA HISTORY}

\author{
His Grace The Duke of \\ BEDFoRd, K.G. \\ President of tbe Zoological Society \\ His Grace The Duke of Devon- \\ SHIRE, K.G. \\ Cbancellor of the University of Cam- \\ bridge \\ His Grace The Duke of \\ RutLand, K.G. \\ His Grace The Duke of \\ Portland, K.G. \\ His Grace The Dukg of \\ ARGYLL, K.T. \\ The Rt. Hon. The Earl of \\ Rosebery, K.G., K.T. \\ The Rt. Hon. The EArI of \\ Coventry \\ President of the Royal Agricultural \\ The RT. Hon. The Viscount \\ Dillon \\ President of the Society of Antiquaries \\ Thr RT. Hon. The Lord Lister \\ Late President of the Royal Society \\ The Rt. Hon. The Lord \\ Alverstone, G.C.M.G. \\ Lord Cbief $\mathcal{F u s t i c e}$
}

The Hon. Walter Rothschild, M.P.
Sir Frederick Pollock, Bart.,
LL.D., F.S.A., etc.

Sir John Evans, K.C.B., D.C.L., LL.D.

Sir Edward Maunde Thompson, K.C.B., D.C.L., LL.D., F.S.A., ETC. Director of the British Museum

Sir Clements R. Markham, K.C.B., F.R.S., F.S.A.

President of the Royal Geograpbical Society

Sir Henry C. Maxwell-Lyte, K.C.B., M.A., F.S.A., ETC.

Keeper of the Publit Records

Col. Sir J. Fareuharson, K.C.B.

Sir Jos. Hooker, G.C.S.I., M.D., D.C.L., F.R.S., ETC.

Sir Archibald Geikie, LL.D., F.R.S., ETC.

Rev. J. Charles Cox, LL.D., F.S.A., ETC.

Lionel Cust, EsQ., M.V.O.,M.A., F.S.A., ETC.

Director of the National Portrait Gallery

Albert C. L. G. Gunther, M.A., F.R.S., M.D., Pн.D.

Late President of the Linnean Society The LATE LoRd Acton and

F. Haverfield, Esq., M.A., F.S.A. The Late Sir William Flower General Editors of the Series $\left\{\begin{array}{l}\text { H. Arthur Doubleday } \\ \text { WILliam Page, F.S.A. }\end{array}\right.$
Cor. Duncan A. Johnston Director General of tbe Ordnance Survey

Prof. E. Ray Lankester, M.A.,

Director of the Natural History Museum, Soutb Kensington

Reginald L. Poole, EsQ., M.A. University Lecturer in Diplomatic, Oxford

F. York Powrll, EsQ., M.A., F.S.A., ETC.

Regius Professor of Modern History, Oxford

J. Horace Round, EsQ., M.A.

WALter Rye, EsQ.

W. H. St. John Hope, EsQ., M.A.

Assistant Secretary of the Society of Antiquaries

Among the original members of the Council were

The late Mareuess of Salisbury

The late Dr. Mandell CreighTON, Bishop of LondoN

The late Dr. Stubbs, Bishop of OXFORD F.R.S., ETC, 
In the VICTORIA History each county is not the labour of one or two men, but of several hundred, for the work is treated scientifically, and in order to embody in it all that modern scholarship can contribute, a system of co-operation between experts and local students is applied, whereby the history acquires a completeness and definite authority hitherto lacking in similar undertakings.

\section{THE SCOPE OF THE WORK}

The history of each county will be complete in itself, and its story will be told from the earliest times, commencing with the natural features and the flora and fauna. Thereafter will follow the antiquities, pre-Roman, Roman and post-Roman; a new translation and critical study of the Domesday Survey ; articles on political, ecclesiastical, social and economic history; architecture, arts, industries, biography, folk-lore and sport. The greater part of each history will be devoted to a detailed description and history of each parish, containing an account of the land and its owners from the Conquest to the present day. These manorial histories will be compiled from original documents in the national collections and from private papers. A special feature will be the wealth of illustrations afforded, for not only will all buildings of interest be pictured, but the coats of arms of past and present landowners will be given.

\section{HISTORICAL RESEARCH}

It has always been, and still is, a reproach to us that England, with a collection of public records greatly exceeding in extent and interest those of any other country in Europe, is yet far behind her neighbours in the study of the genesis and growth of her national and local institutions. Few Englishmen are probably aware that the national and local archives contain for a period of 800 years in an almost unbroken chain of evidence, 'not only the political, ecclesiastical, and constitutional history of the kingdom, but every detail of its financial and social progress and the history of the land and its successive owners from generation to generation.' The neglect of our public and local records is no doubt largely due to the fact that their interest and value is known to but a small number of people. But this again is directly attributable to the absence in this country of any endowment for historical research such as is to be found among other cultured nations. The government of this country has always left to private enterprise work which our continental neighbours entrust to a government department. It is not surprising, therefore, to find that although an immense amount of work has been done by individual effort, the entire absence of organization among the workers and the lack of intelligent direction has robbed the results of much of their value.

In the Victoria History, for the first time, a serious attempt is made to utilize our national and local muniments to the best advantage by carefully organizing and supervising the researches required. Under the direction of the Records Committee a large staff of experts is engaged at the Public Record Office in calendaring those classes of records which are most fruitful in material for local history, and by a system of interchange of communication among local editors each county gains a mass of information which otherwise would be lost.

\section{THE RECORDS COMMITTEE}

$\begin{array}{ll}\text { Sir Edward Maunde Thompson, K.C.B. } & \text { C. T. Martin, B.A., F.S.A. } \\ \text { Sir Henry Maxwell-Lyte, K.C.B. } & \text { J. Horace Round, M.A. } \\ \text { W. J. Hardy, F.S.A. } & \text { S. R. Scargill-Bird, F.S.A. } \\ \text { F. Madan, M.A. } & \text { W. H. Stenenson, M.A. } \\ \text { F. Maitland, M.A., F.S.A. } & \text { G. F. Warner, M.A., F.S.A. }\end{array}$

Many archæological, historical and other societies are assisting in the compilation of this work; and local supervision and aid are secured by the formation in each county, of a County Committee, the president of which is in nearly all cases the Lord Lieutenant.

The names of the distinguished men who have joined the Advisory Council are a guarantee that the work will represent the results of the latest discoveries in every department of research. It will be observed that among them are representatives of science; for the whole trend of modern thought, as influenced by the theory of evolution, favours the intelligent study of the past and of the social, institutional and political developments of national life. As these histories are the first in which this object has been kept in view, and modern principles applied, it is hoped that they will form a work of reference no less indispensable to the student than welcome to the man of culture. 
Family History will, both in the Histories and in the supplemental volumes of chart pedigrees, be dealt with by genealogical experts and in the modern spirit. Every effort will be made to secure accuracy of statement, and to avoid the insertion of those legendary pedigrees which have in the past brought discredit on the whole subject. It has been pointed out by the late Bishop of Oxford, a great master of historical research, that 'the expansion and extension of genealogical study is a very remarkable feature of our own times,' that 'it is an increasing pursuit both in America and England,' and that it can render the historian useful service.

Heraldry will also in this Series occupy a prominent position, and the splendours of the coat-armour borne in the Middle Ages will be illustrated in colours on a scale that has never been attempted before.

The general plan of Contents, and the names of the Sectional Editors (who will co-operate with local workers in every case) are as follows :-

Natural History.

Geology. By Clement Rzid, F.R.S., Horace B. Woodward, F.R.S., and others

Palæontology. Edited by R. LYdekrer, F.R.S., etc.

Flora (Contributions by G. A. Boulrmaer, F.R.S., F. O. Pickard-Cambridge, M.A., H. N. Dixon, F.L.S.,

G. C. Druce, M.A., F.L.S., Walter Garbtang, M.A., F.L.S., Herbert Gose, F.L.S., F.E.S.,

Fauna R. I. Pocock, Rev. T.R. R. Stebring, M.A., F.R.S., etc., B. B. Woodward, F.G.S., F.R.M.S., etc., and other Specialists

Prehistoric Remains. Edited by W. Boyd Dawxiss, D.Sc, LL.D., F.R.S., F.S.A.

Roman Remains. Edited by F. HAVERrinLd, M.A., F.S.A.

Anglo-Saxon Remains. Edited by C. Hercules Read, F.S.A., and Reginald A. Smith, B.A., F.S.A.

Ethnography. Edited by G. Laurence Gomme, F.S.A.

Dialect. Edited by Joseph Wright, M.A., Ph.D.

Place Names

Folklore

Physical Types Contributed by Various Authorities

Domesday Book and other kindred Records. Edited by J. Horace Round, M.A.

Architecture. By Various Authorities. The Sections on the Cathedrals and Monastic Remains Edited by W. H. St. John Hope, M.A.

Ecclesiastical History. Edited by R. L. Poonz, M.A.

Political History. Edited by W. H. Struenson, M.A., J. Horace Round, M.A., Pror. T. F. Tout, M.A. James Tatr, M.A., and C. H. Firth, M.A.

History of Schools. Edited by A. F. LEAch, M.A., F.S.A.

Maritime History of Coast Counties. Edited by J. K. Laughton, M.A., and M. Oprensam

Topographical Accounts of Parishes and Manors. By Various Authorities

History of the Feudal Baronage. Edited by J. Horace Round, M.A., and Oswazd Barron, F.S.A.

Family History and Heraldry. Edited by Ogwald Barron, F.S.A.

Agriculture. Edited by SIR ERNEST CLARRE, M.A., Sec. to the Royal Agricultural Society

Forestry. Edited by John Nisger, D.Orc.

Industries, Arts and Marufactures

Social and Economic History $\{$ By Various Authorities

Persons Eminent in Art, Literature, Science

Ancient and Modern Sport. Edited by the Dure of Beaurort and E. D. Cuming

Hunting

Shooting

Fishing, etc.

Cricket. Edited by Home Gornon

Football. Edited by C. W. Arcoex

Bibliographies

Indexes

Names of the Subscribers

\section{ILLUSTRATIONS}

Among the many thousands of subjects illustrated will be castles, cathedrals and churches, mansions and manor houses, moot halls and market halls, family portraits, etc. Particular attention will be given to the beautiful and quaint examples of architecture which, through decay or from other causes, are in danger of disappearing. The best examples of church brasses, coloured glass, and monumental effigies will be depicted. The Series will also contain 160 pictures in photogravure, showing the characteristic scenery of the counties.

I 


\section{CARTOGRAPHY}

Each History will contain Archæological, Domesday, and Geological maps; maps showing the Orography, and the Parliamentary and Ecclesiastical divisions; and the map done by Speed in I6ro. The Series will contain about four hundred maps in all.

\section{FAMILY HISTORY AND HERALDRY}

The Histories will contain, in the Topographical Section, manorial pedigrees, and accounts of the noble and gentle families connected with the local history; and it is proposed to trace, wherever possible, their descendants in the Colonies and the United States of America. The Editors will be glad to receive information which may be of service to them in this branch of the work. The chart family pedigrees and the arms of the families mentioned in the Heralds' Visitations will be issued in a supplemental volume for each county.

The Rolls of Arms are being completely collated for this work, and all the feudal coats will be given in colours. The arms of the local families will also be represented in connection with the Topographical Section.

In order to secure the greatest possible accuracy in the descriptions of the Architecture, ecclesiastic, military and domestic, a committee has been formed of the following students of architectural history, who will supervise this department of the work :-

\section{ARCHITECTURAL COMMITTEE}

J. BILsoN, F.S.A., F.R.I.B.A.

R. BLOMFIELD

HaROLD BRakspear, A.R.I.B.A.

Prof. Baldwin Brown, M.A.

Arthur S. Flower, F.S.A., A.R.I.B.A.

GeORGE E. Fox, M.A., F.S.A.

J. A. Gотсн, F.S.A., F.R.I.B.A.
W. H. ST. JoHn Hope, M.A.

W. H. KNOWLES, F.S.A., F.R.I.B.A.

J. T. Micklethwaite, F.S.A.

Roland Paul

J. Horace Round, M.A.

Percy G. Stone, F.S.A., F.R.I.B.A.

Thackeray TURNer

A special feature in connection with the Architecture will be a series of coloured ground plans showing the architectural history of castles, cathedrals and other monastic foundations. Plans of the most important country mansions will also be included.

The issue of this work is limited to subscribers only, whose names will be printed at the end of each History. 



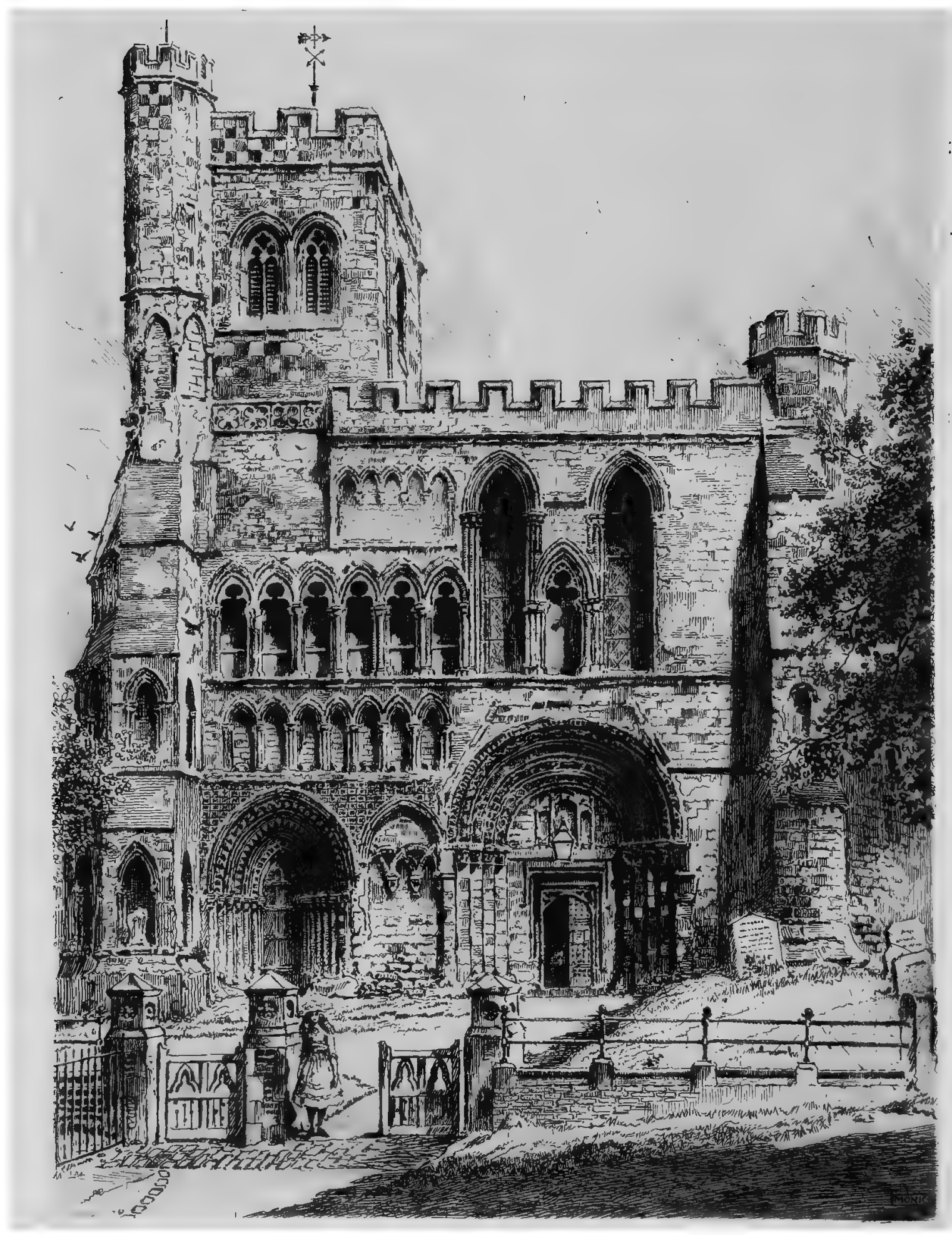




\section{THE \\ VICTORIA HISTORY \\ OF THE COUNTY OF \\ BEDFORD}

VOLUME ONE

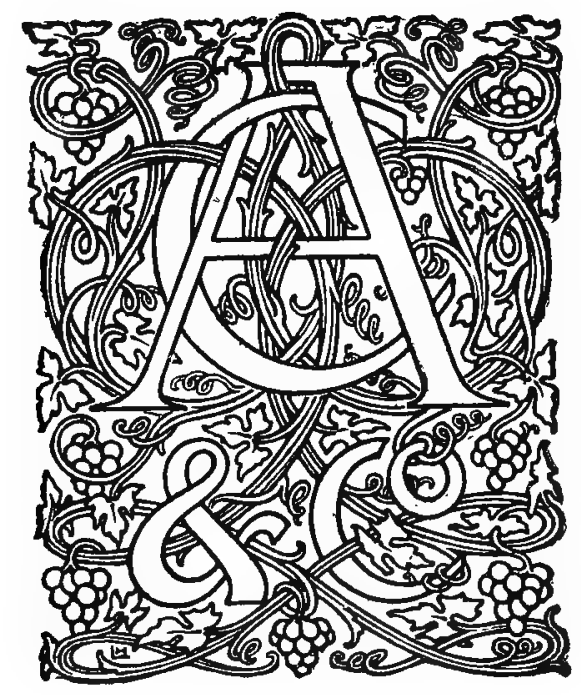

WESTMINSTER

2 WHITHALL GARDENS

I9O4 



\section{County Committee for Beofoldshite}

THE RT. HON. THE EARL COWPER, K.G., P.C.

Lord Lieutenant, Chairman

His Grace The Duke of Bedford, K.G.

The Rr. Hon. The Viscount Peel

The Rt. Hon. The Lord Alwyne Compton, M.P.

The Rt. Hon. The Lord St. John of BLETSO

Sir Robert Pearce Edgcumbe

His Honour Judge Sir Thomas W. Snagge, D.L.

The Ven. Archdeacon of Bedford

The Worshipful The Mayor of Bedford Major John H. Brooks

Francis Crawley, Esq., J.P.

Col. C. Villiers Downes, J.P.

Col. A. Fyler

C. R. WADE-Gery, Eso., J.P.

L. Stileman-Gibbard, Esq., J.P.

A. R. Goddard, Ese.
J. Hamson, EsQ.

William Marsh Harvey, EsQ.

H. Longuet Higgins, Esq.

J. E. King, EsQ., Headmaster of Bedford Grammar School.

W. W. Marks, EsQ.

J. E. Morris, EsQ.

R. R. B. Orlebar, Esq.

Guy Pym, Ese., M.P., D.L., J.P.

Arthur Ransom, Esq.

James Saunders, EsQ., A.L.S.

Col. F. Shuttleworth

Worthington G. Smith, EsQ., F.L.S., F.A.I.

Maj.-Gen. A. C. Toker, C.B.

F. A. Page-Turner, Esq., J.P.

W. Clarence Watson, Esq.

Anthony H. Wingfield, EsQ., J.P.

The ReV. V. Wyatt 



\section{CONTENTS OF VOLUME ONE}

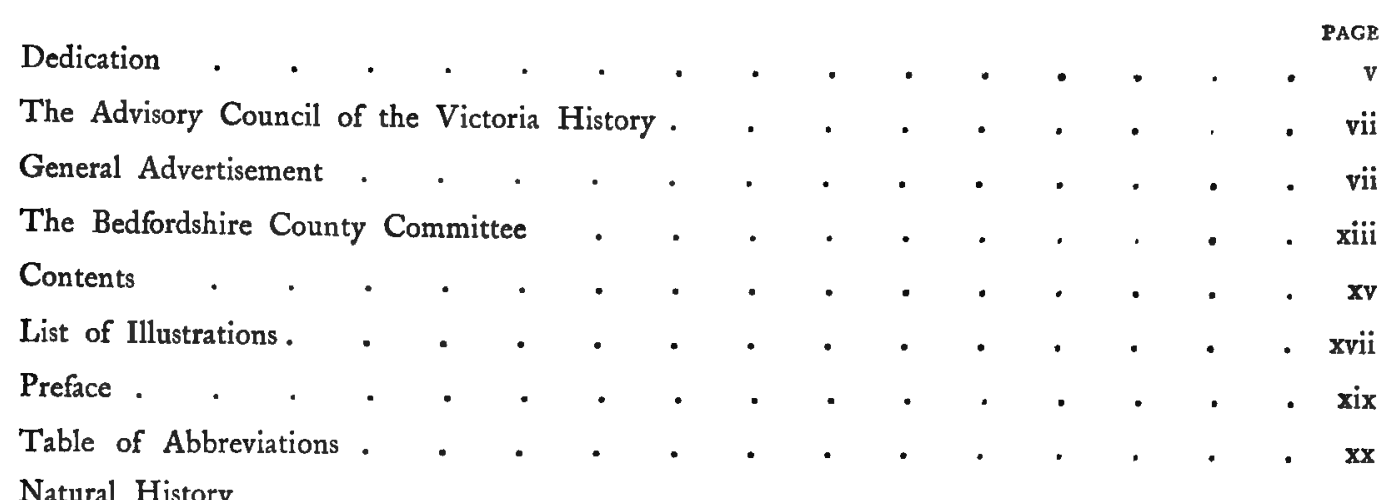

\footnotetext{
Geology • . . . . By John Hopkrnson, F.L.S., F.G.S., and JAMEs

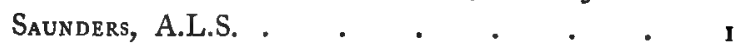

Palæontology - . . . By R. Lydekker, F.R.S., F.G.S., F.L.S. . 33

Botany . . . . . By John Hamson and G. Claridgr Druce, M.A., F.L.S. ; assisted by James SAUNDERs, A.L.S. and E. M. Holmes, F.L.S. . • • • $\quad 37$

Zoology

Mollusca (Snails, etc.) • • By B. B. Woodward, F.G.S., F.R.M.S. 69

Insecta (Insects)

Coleoptera (Beetles) . . . By the Rev. Canon Fowler, M.A., F.L.S. . . 71

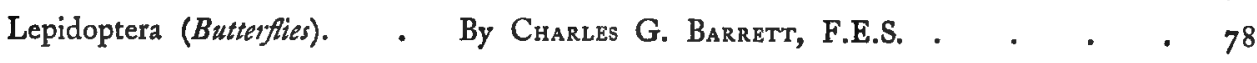

Arachnida (Spiders) • . By F. O. Pickard-Cambridge, M.A. • . $\quad 88$

Crustacea (Crabs, etc.) - . By the Rev. T. R. R. StebBing, M.A., F.R.S., F.L.S. 91

Pisces (Fisbes) . • • • By Arthur R. Thompson • • • • 98

Reptilia (Reptiles) and

Batrachia (Batracbians) . By J. LACEY Frshwick. • • . . • 102

Aves $(B i r d s)$. . . . By J. Strelle-Elliot . • • . . . 104

Mammalia (Mammals) . . " " . . . . . .

Early Man . . . • . By Worthington G. Smith, F.L.S., F.A.I. . 145

Anglo-Saxon Remains . . . By Reginald A. Smitr, B.A., F.S.A. • . 175

Introduction to the Bedfordshire

Domesday . . . . By J. Horace Round, M.A. • . . . 191

Text of the Bedfordshire Domesday. By the Rev. F. W. RAGG, M.A. . • • . 221

Ancient Earthworks. • • . By A. R. Goddard, B.A. . • • . 267

Ecclesiastical History . . . By the Sistrr Elspeth of the Community of All Saints 309 


\section{CONTENTS OF VOLUME ONE}

Religious Houses . . . By the Sister ELsPETH of the Community of All Saints

Introduction

Priory of Beaulieu

Abbey of Elstow .

Priory of Markyate

Abbey of Warden

Woburn

Priory of Dunstable

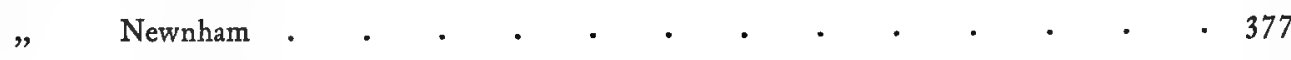

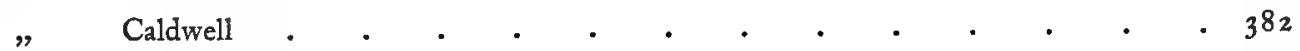

" Bushmead . . . . . . . . . . . . . . . . . $\quad$. 385

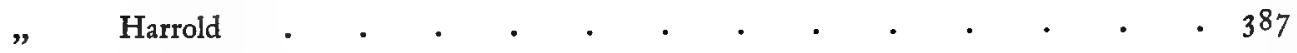

" Chicksand . . . . . . . . . . . . . . . . . . 390

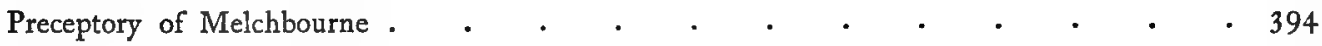

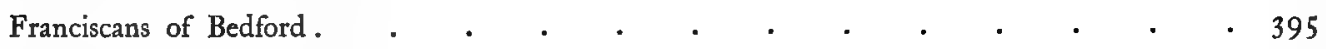

Dominicans of Dunstable . . . . . . . . . . . . . 395

Hospital of St. John, Bedford . . . . . . . . . . . . 396

" St. Leonard, Bedford . . . . . . . . . . . . . 398

" St. Mary Magdalene, Luton . . . . . . . . . . . 399

" St. John Baptist, Luton . . . . . . . . . . . . 400

" Farley near Luton . . . . . . . . . . . 400

" St. Mary Magdalene, Dunstable . . . . . . . . . . . . 400

" St. John Baptist, Hockliffe . . . . . . . . . . . 40 I

" St. John Baptist, Toddington . . . . . . . . . . . 402

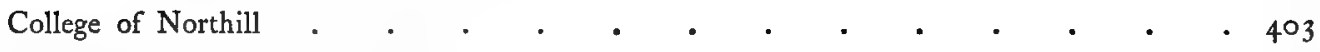

Priory of La Grave or Grovebury . . . . . . . . . 403

Index to the Bedfordshire Domesday. By the Rev. F. W. RAGG, M.A. - . . . 405 


\section{LIST OF ILLUSTRATIONS}

Dunstable Priory. Etching by W. Monk Prehistoric Remains. Figures I to 64

Pottery Vases from Graves at Kempston . Cinerary Urns from Cemetery at Kempston Bronze Brooch, Kempston Engraved Bronze Brooch, Kempston . .

Bolnhurst .

Church Panel, Shillington

Higham Gobion . . $\}$.

Etonbury .

Plan showing the course of the Ouse

Tempsford .

Willington .

Renhold

The Mount, Flitwick .

Conger Hill, Toddington

Thurleigh .

\section{Yelden}

\section{Cainhoe}

\section{Totternhoe.}

The Hills, Meppershall

Eaton Socon

John of Gaunt's Hill, Sutton Park Bletsoe Castle 


\section{LIST OF ILLUSTRATIONS}

Ancient Earthworks (continued) -

The Creakers

Newnham Priory

Keysoe Park

Mossbury or Mowsbury

The Camps, Bushmead

John Bunyan .

Seals of Religious Houses

\section{LIST OF MAPS}

\begin{tabular}{|c|c|c|c|c|c|c|c|c|c|c|c|c|c|}
\hline Geological Map & - & $\cdot$ & • & . & - & $\cdot$ & . & ${ }^{\circ}$ & $\cdot$ & - & - & between & xxii, I \\
\hline Orographical Map & . & • & $\cdot$ & - & • & . & $\cdot$ & . & . & & . & $"$ & 24,25 \\
\hline Botanical Map & . & $\cdot$ & . & - & $\bullet$ & . & $\cdot$ & . & . & $\cdot$ & $\cdot$ & $"$ & 36,37 \\
\hline Pre-Historical Map & . & - & . & . & - & - & $\cdot$ & . & - & - & - & $"$ & I $44, I 45$ \\
\hline Anglo-Saxon Map & - & - & - & . & - & . & - & $\cdot$ & $\cdot$ & $\cdot$ & - & $"$ & 174,175 \\
\hline Domesday Map & . & - & $\cdot$ & $\cdot$ & $\cdot$ & $\cdot$ & $\cdot$ & . & . & - & - & $"$ & 190,191 \\
\hline Earthworks Map & . & - & - & ${ }^{\circ}$ & - & . & - & . & . & $\cdot$ & - & ", & 266,267 \\
\hline Ecclesiastical Map & - & . & - & - & - & . & . & . & - & . & - & facing & $34^{6}$ \\
\hline
\end{tabular}

\section{CORRIGENDA}

Page 209, line I8, for 'Wellow' read 'Willey.'

Page 235, last line but one, for 'Beauchamp barony of Bedford" read 'Beauchamp barony of Eaton.' 


\section{PREFACE}

7 HE present work is the first attempt to compile a history of the county of Bedford from original sources. Although Bedfordshire,

1 like most English counties, possesses a wealth of materials for local history, no systematic collection and arrangement of these materials has been undertaken hitherto. The work of some of the contributors has consequently been done under great difficulties.

The editors regret that it has been impossible to follow a strict chronological sequence in the present volume. The chapter on the Romano-British period will appear in a later volume.

It may be desirable to point out that in the chapter on the religious houses, descriptions and illustrations of the buildings have been purposely omitted. They more properly belong to the parish in which the houses were situate and will be dealt with there under the section on Topography.

For the use of some of the illustrations in this volume the editors have to thank Mr. Worthington G. Smith and the Council of the Society of Antiquaries. 


\section{TABLE OF ABBREVIATIONS}

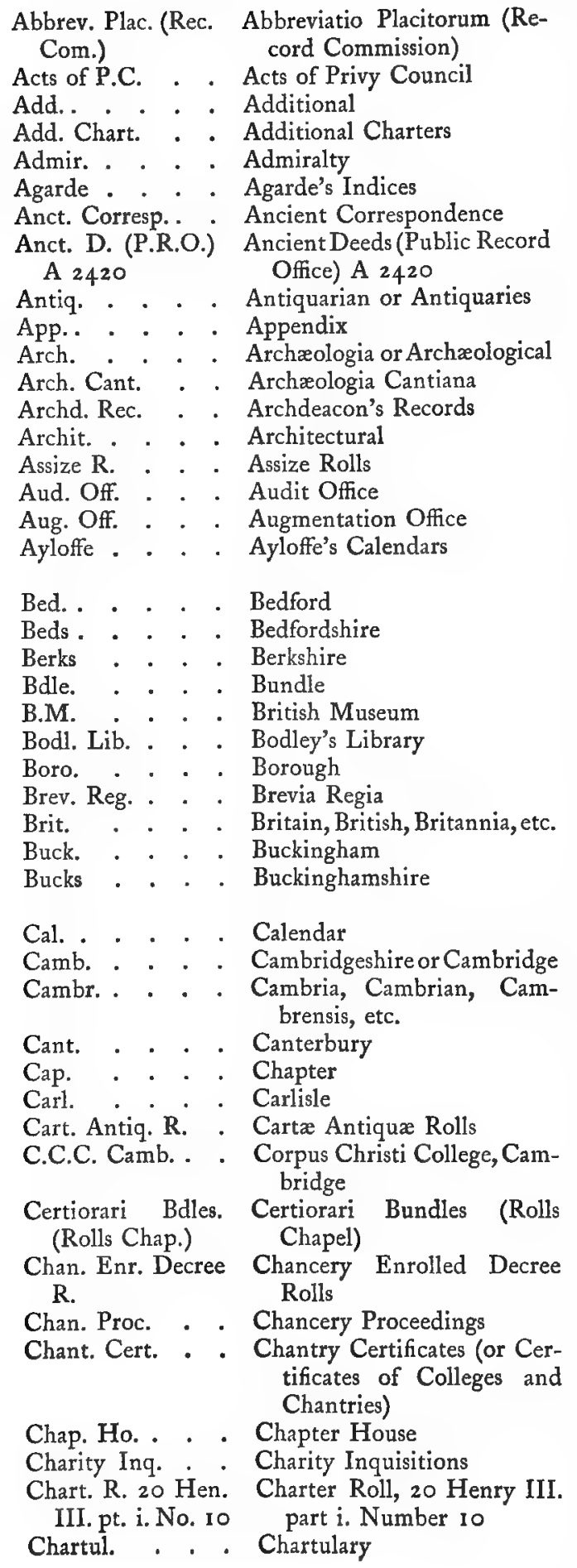

Chas. . . . Charles

Ches. . . . Cheshire

Chest. . . . Chester

Ch. Gds. (Exch. Church Goods (Exchequer

K.R.) King's Remembrancer)

Chich. . . . Chichester

Chron. Chronicle, Chronica, etc.

Close. . . . Close Roll

Co. . . . . County

Colch. . . . Colchester

Coll. . . Collections

Com. . . . Commission

Com. Pleas. Common Pleas

Conf. R. . . . Confirmation Rolls

Co. Plac. . . . County Placita

Cornw. . . . Cornwall

Corp. . . Corporation

Cott. Cotton or Cottonian

Ct. R. . . . Court Rolls

Ct. of Wards . . Court of Wards

Cumb. . . . Cumberland

Cur. Reg. . . . Curia Regis

D. and C. . . . Dean and Chapter

De Banc. R. . . De Banco Rolls

Dec, and Ord. Decrees and Orders

Dep. Keeper's Rep. Deputy Keeper's Reports

Derb. . Derbyshire or Derby

Devon . . . Devonshire

Doc. . . . Documents

Dods. MSS. . . Dodsworth MSS.

Dom. Bk. . . . Domesday Book

Dors. . . . . Dorsetshire

Duchy of Lanc. : Duchy of Lancaster

Dur. . . . Durham

East. . . . Easter Term

Eccl. . . . . Ecclesiastical

Eccl. Com. . Ecclesiastical Commission

Edw. . . . Edward

Eliz. . . . Elizabeth

Engl. . . . England or English

Engl. Hist. Rev. - English Historical Review

Epis. Reg. . . . Episcopal Registers

Esch. Enr. Accts. . Escheators Enrolled Accounts

Excerpta e Rot. Fin. Excerpta e Rotulis Finium

(Rec. Com.) (Record Commission)

Exch. Dep. . . Exchequer Depositions

Exch. K.B. - . Exchequer King's Bench

Exch. K.R. - . Exchequer King's Remembrancer

Exch. L.T.R. . . Exchequer Lord Treasurer's Remembrancer

Exch. of Pleas, Plea Exchequer of Pleas, Plea Roll R.

Exch. of Receipt . Exchequer of Receipt 


\section{TABLE OF ABBREVIATIONS}

Exch. Spec. Com. Exchequer Special Commis- Misc. Bks. (Exch. Miscellaneous Book (Ex-
sions

Feet of F. . . . Feet of Fines

Feod. Accts. (Ct. Feodaries Accounts (Court of of Wards) Wards)

Feod. Surv. (Ct. of Feodaries Surveys (Court of Wards) Wards)

Feud. Aids . . . Feudal Aids

fol. . . . Folio

Foreign R. . . Foreign Rolls

Forest Proc. - . Forest Proceedings

Gen.

Genealogical, Genealogica,

Geo. . . . George

Glouc. · · . Gloucestershire or Gloucester

Guild Certif. Guild Certificates (Chancery) (Chan.) Ric. II. Richard II.

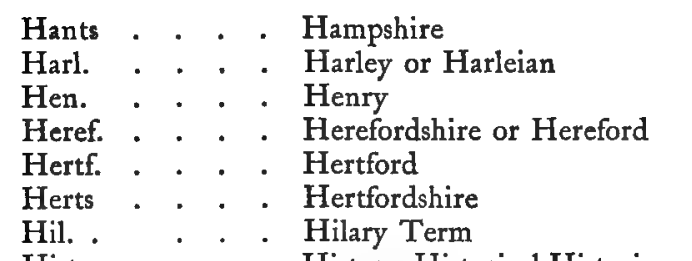

Hist. . . . History, Historical,Historian, Historia, etc.

Hist. MSS. Com. Historical MSS. Commission

Hosp. . . . . Hospital

Hund. R. . . . Hundred Rolls

Hunt. . . . Huntingdon

Hunts . . . Huntingdonshire

Inq. a.q.d. . . Inquisitions ad quod damnum

Inq. p.m. . . Inquisitions post mortem

Inst. . . . . . Institute or Institution

Invent. . . . . Inventory or Inventories

Ips. . . . . Ipswich

Itin. . . . . . Itinerary

Jas. . . . . James

Journ. . . . Journal

Lamb. Lib. . . Lambeth Library

Lanc. . . . . Lancashire or Lancaster

L. and P. Hen. Letters and Papers, Hen. YIII. VIII.

Lansd. . . . Lansdowne

Ld. Rev. Rec. . . Land Revenue Records

Leic. . . . Leicestershire or Leicester

Le Neve's Ind. - Le Neve's Indices

Lib. . . . . Library

Lich. . . . Lichfield

Linc. . . . Lincolnshire or Lincoln

Lond. . . . London

m. . . . Membrane

Mem. . . . Memorials

Memo. R. . . Memoranda Rolls

Mich. . . . Michaelmas Term

Midd. . . . . Middlesex

Mins, Accts, - . Ministers' Accounts
T.R. or Aug.

Off.) brancer, Exchequer Treasury of Receipt or Augmentation Office)

Mon. . . . Monastery, Monasticon

Monm. . . . Monmouth

Mun. . . . . Muniments or Munimenta

Mus. . . . . Museum

N. and Q. . . Notes and Queries

Norf. . . . Norfolk

Northampt. . . Northampton

Northants . . Northamptonshire

Northumb. . . Northumberland

Norw. . . . Norwich

Nott. . . . Nottinghamshire or Nottingham

N.S. . . . . New Style

Off. . . . . . Office

Orig. R. . . . Originalia Rolls

Oxf. . . . Oxfordshire or Oxford

p. . . . . . Page

Palmer's Ind. . . Palmer's Indices

Pal. of Chest. . . Palatinate of Chester

Pal. of Dur. . . Palatinate of Durham

Pal. of Lanc. - Palatinate of Lancaster

Par. . . . . Parish, Parochial, etc.

Parl. . . . . Parliament or Parliamentary

Parl. R. . . . . Parliament Rolls

Parl. Surv. . . . Parliamentary Surveys

Partic. for Gts. . Particulars for Grants

Pat. . . . . Patent Roll or Letters Patent

P.C.C. . . . Prerogative Court of Canterbury

Peterb. . . . Peterborough

Phil. . . . Philip

Pipe R. . . . . Pipe Roll

Plea R. . . . . Plea Rolls

Pope Nich. 'Tax. Pope Nicholas' Taxation (Re(Rec. Com.) cord Commission)

P.R.O. . . . Public Record Office

Proc. . . . Proceedings

Proc. Soc. Antiq. . Proceedings of the Society of

pt. . . . . Part Antiquaries

Pub. . . . Publications

R. . . . . Roll

Rec. Records

Recov. R. . . . Recovery Rolls

Rentals and Surv. . Rentals and Surveys

Rep. . . . . . Report

Rev. . . . . Review

Ric. . . . . Richard

Roff. . . . Rochester diocese

Rot. Cur. Reg. . Rotuli Curiæ Regis

Rut. . . . . Rutland

Sarum . . Salisbury diocese

Ser. . . . . Series

Sess. R. . . Sessions Rolls

Shrews. . . . Shrewsbury 


\section{TABLE OF ABBREVIATIONS}

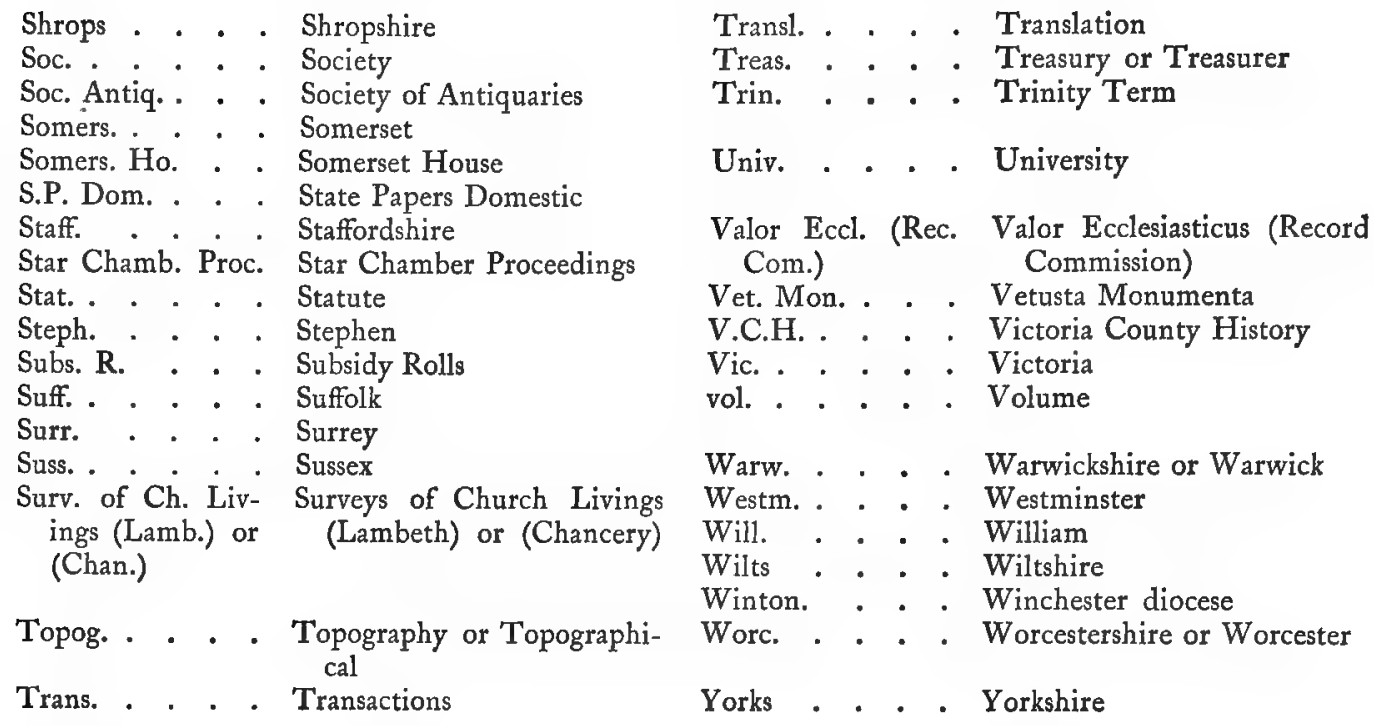




\section{A HISTORY OF BEDFORDSHIRE}






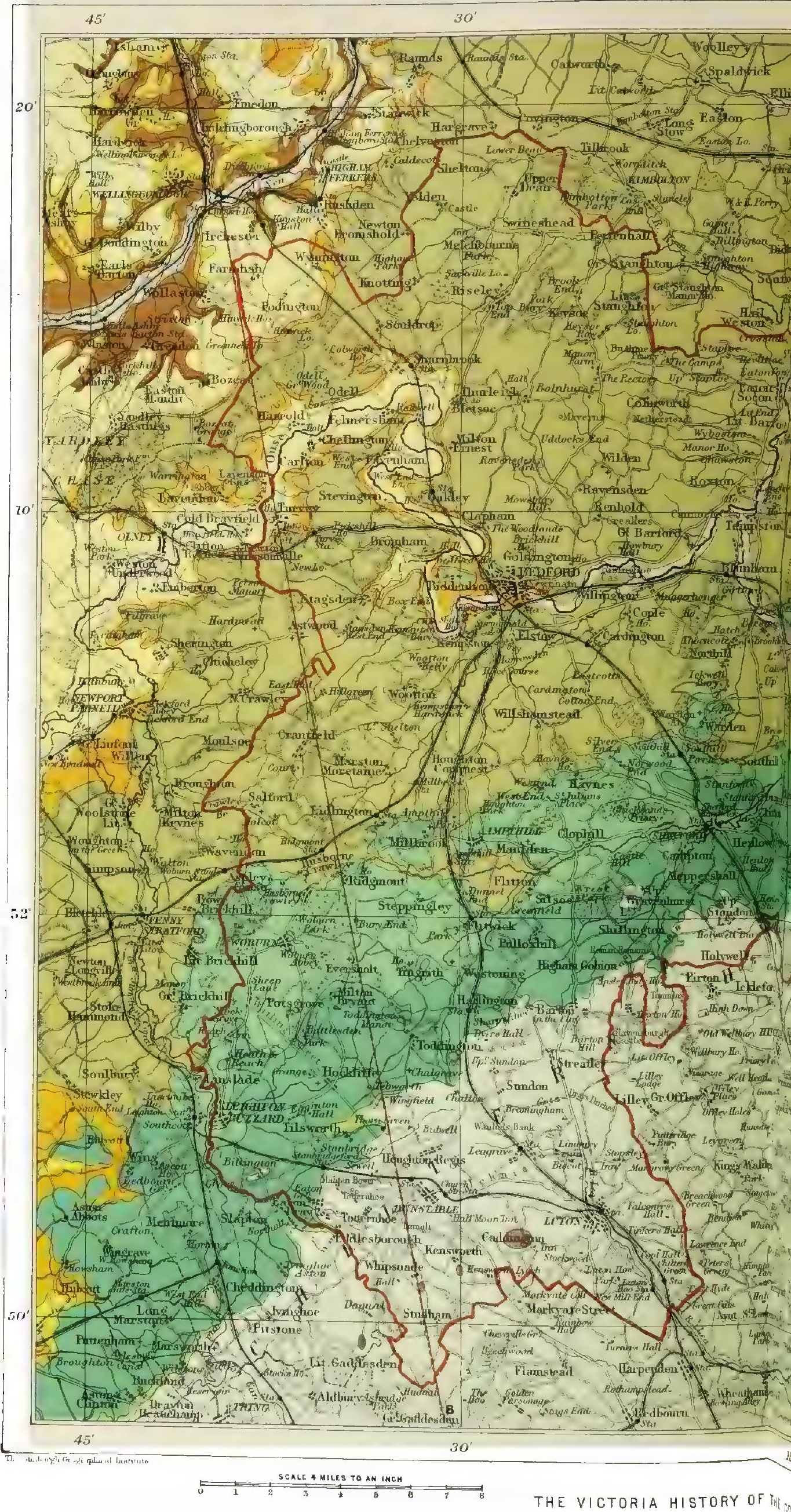


. 


\section{GEOLOGY}

$7 \mathrm{HE}$ strata which form the groundwork of Bedfordshire, underlying the surface-soil and other superficial accumulations, consist of rocks of Jurassic and Cretaceous age. With the exception of the oldest bed that comes to the surface in the county, which is an estuarine deposit, they are entirely of marine origin. The freshwater or lacustrine beds which were deposited in the south of England at the commencement of the Cretaceous period are absent, and so also are the estuarine which were laid down in that area before the close of the Jurassic period. With this break in the succession of the strata there appears to be a slight unconformability, the Cretaceous rocks not lying quite evenly upon the Jurassic. A few small outliers of beds of Eocene age rest upon the Cretaceous rocks, indicating the former extension of the Eocenes of the London Basin far to the north of the main mass. The strata dip more or less towards the south-east, so that, proceeding in a north-westerly direction, they are seen to crop out successively in descending order.

Bedfordshire is almost entirely within the catchment-basin of the Great Ouse. Its surface slopes on the whole from south-west to northeast, towards the great marshy tract of the Bedford Level through which the Ouse flows on its way to its embouchure in the Wash. It presents a series of shallow valleys and gently rising hills which follow in the main the same direction as the general inclination of the surface and coincide with the strike or trend of the strata. A rather prominent and very picturesque ridge crosses the county from Leighton Buzzard to Sandy, defining the limits of the Jurassic and Cretaceous rocks and forming the water-parting between the valley of the Ouse and that of its tributary the Ivel. Each of these valleys, when viewed from the hills on its southern margin, owing to its shallowness presents the appearance of a plain, that on the north consisting of Jurassic rocks with hills of but slight elevation, and that on the south of Cretaceous rocks rising along its south-eastern margin into hills which attain a considerable altitude. The most prominent of these are known as the Barton Hills and the Dunstable Downs. They form the north-eastern termination of the Chilterns, a range of hills situated entirely on the Chalk and gradually approaching its escarpment in its passage through Oxfordshire, Buckinghamshire, and the west and north-west of Hertfordshire. In crossing the south-east of Bedfordshire this range forms the waterparting between the catchment-basin of the Ouse and that of the 


\section{A HISTORY OF BEDFORDSHIRE}

Thames, and attains an elevation of about 800 feet at the highest part of the Dunstable Downs between Kensworth and the Five Knolls. Although the most striking feature of the county, these hills do not present abrupt or rugged outlines, their contour being rounded and gently undulating, the result of very gradual and long-continued sub-aerial denudation.

\section{THE CONCEALED PALÆOZOIC LAND-SURFACE}

Owing to the absence of deep borings in Bedfordshire we are without any actual knowledge of the disposition of the Palæozoic rocks which underlie the Mesozoic strata, but we may form some idea of it from the facts which borings made beyond the limits of the county have revealed. A few miles to the south-east a ridge of Silurian rocks underlies Hertfordshire at a depth of about 800 feet, the strata dipping to the south at a high angle, and upon the southern flanks of this old ridge repose Devonian rocks dipping a little west of south at a much less inclination. A few miles to the west or north-west, in Northamptonshire, the Carboniferous Limestone has been met with at a depth of 980 feet. The Coal Measures occur at a great depth in Oxfordshire and come to the surface in Warwickshire.

From this evidence, and that afforded by other borings at a greater distance, we may infer that the old Silurian ridge of Hertfordshire is the southern fold of an anticline which probably passes under Luton and is flanked on its northern fold by Devonian rocks which extend at least so far to the north as Bedford. This ancient land-surface sinks as it trends from east to west, in which direction the Devonian rocks are succeeded or overlaid by Carboniferous, but it is scarcely likely that any more recent division of that series than the Carboniferous Limestone comes on within the county. There may however be, in the north, a syncline or the southern margin of one in which the Millstone Grit may lie, possibly succeeded by the Coal Measures.

During Permian and Triassic times this area, with the whole of the south-east of England from Norfolk to Kent and Sussex, was probably a land-surface over which rivers flowed; in the earlier period towards the north, depositing their sediment in the lakes or inland seas which existed just before the close of the Palæozoic epoch; and in the later period, after a further upheaval of the land, in a westerly direction towards the more extensive sea which, at the commencement of the Mesozoic or Secondary epoch, divided the east of England from Wales and western Devon. The shore-line of this Triassic sea, which we know from its deposit of rock-salt to have been land-locked, was some distance to the north of Bedfordshire but not far from its western border. In the succeeding Liassic period, with which Jurassic times commenced, owing to the gradual sinking of the land, the sea became oceanic, encroaching upon the area which now comprises the county and laying down sediment within it. It is at this point therefore that our certain knowledge of the geology of this district commences. 


\section{GEOLOGY}

\begin{tabular}{|c|c|c|c|}
\hline Period & Formation & Character of Strata & $\begin{array}{c}\text { Approximate } \\
\text { thickness in feet }\end{array}$ \\
\hline Recent & $\begin{array}{llll}\text { Alluvium } & \cdot \\
\text { Valley Gravels . } & \cdot & \cdot & \cdot \\
\end{array}$ & $\begin{array}{l}\text { River-mud, etc. } \\
\text { Gravels of existing rivers }:\end{array}$ & $\begin{array}{l}1-10 \\
5-20\end{array}$ \\
\hline Pleistocene & 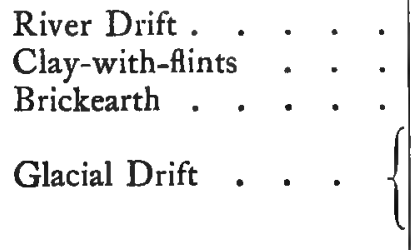 & $\begin{array}{l}\text { Older river-gravel and sand } \\
\text { Reddish clay (on Chalk only). } \\
\text { Loam and sandy clay } \cdot \cdot \cdot \\
\text { Gravel and sand } . \\
\text { Boulder-clay with chalk and } \\
\text { erratics. . . . . . }\end{array}$ & $\begin{array}{r}5-10 \\
1-20 \\
5-30 \\
10-20 \\
3-100\end{array}$ \\
\hline Eocene & Reading Beds . . . . & Plastic clay, loam, and sand . & ? ro shown \\
\hline $\begin{array}{c}\text { Upper } \\
\text { Cretaceous }\end{array}$ & 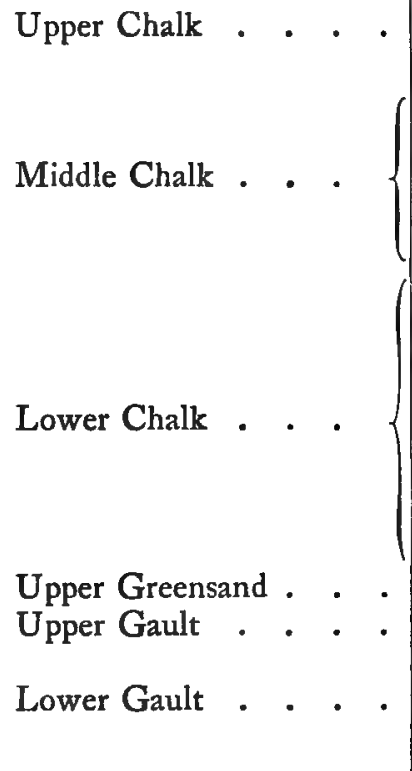 & 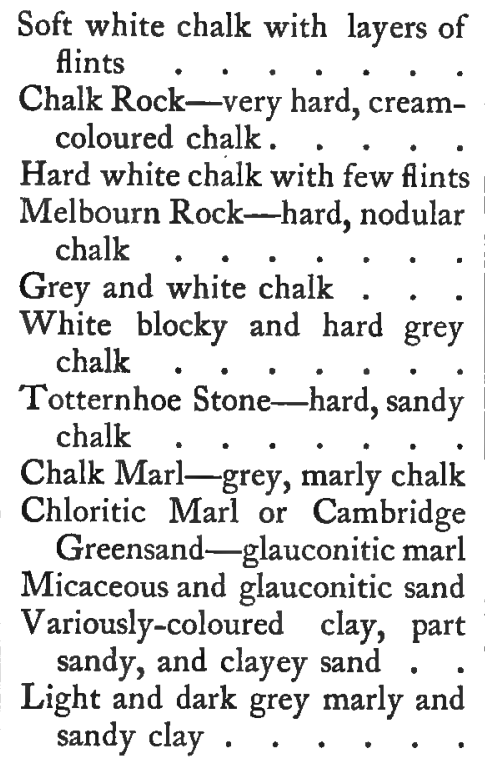 & $\begin{array}{c}100 \text { shown } \\
2-15 \\
200-210 \\
8-10 \\
2-6 \\
60-80 \\
20 \\
70-80 \\
? 10 \\
0-20 \\
25-30 \\
150-280\end{array}$ \\
\hline $\begin{array}{c}\text { Lower } \\
\text { Cretaceous }\end{array}$ & Lower Greensand . . & $\begin{array}{l}\text { Woburn Sands and Potton Beds } \\
\text {-brown ferruginous sand- } \\
\text { stone, dark clay, and light- } \\
\text { coloured sands, rarely green. }\end{array}$ & $230-280$ \\
\hline Upper Jurassıc & $\begin{array}{llll}\text { Kimeridge Clay } & \cdot & \cdot & \cdot \\
\text { Ampthill Clay } & \cdot & \cdot & \cdot \\
\text { Oxford Clay } & & & \\
\text { Kellaways Rock } & \cdot & \cdot & \cdot\end{array}$ & $\begin{array}{l}\text { Dark-coloured clay and shale. } \\
\text { Black clay with bands of lime- } \\
\text { stone . . } \\
\text { Greenish grey and brown clay } \\
\text { Calcareous grit, shale, and sand- } \\
\text { stone . . . . . . }\end{array}$ & $\begin{array}{c}10 \\
40-60 \\
300-400 \\
10-50\end{array}$ \\
\hline Middle Jurassic & $\begin{array}{l}\text { Cornbrash . . . . . } \\
\text { Great Oolite Clay. . . } \\
\text { Great Oolite Limestone . } \\
\text { Upper Estuarine Series . } \\
\text { Inferior Oolite. . . . }\end{array}$ & $\begin{array}{l}\text { Tough grey limestone and clay } \\
\text { Variegated clays, partly calca- } \\
\text { reous . } \\
\text { Limestone, marl, and clay } \\
\text { Variegated sandy clays and lime- } \\
\text { stones . } \\
\text { Northampton Sands - brown } \\
\text { sandstone and ironstone }\end{array}$ & $\begin{array}{r}2-15 \\
5-10 \\
25-30 \\
15-30 \\
? 12\end{array}$ \\
\hline Lower Jurassic & Upper Lias . . . . . & Blue clay and shale . . & 66 seen \\
\hline
\end{tabular}




\section{A HISTORY OF BEDFORDSHIRE}

The geological formations represented in Bedfordshire, with their chief lithological characters and approximate thickness, are given in the table on the preceding page, in descending order, the names of the formations which do not come to the surface in the county being printed in italics.

In the following account of the Jurassic and Cretaceous rocks, at the head of each division are given the geographical names adopted for the formations or their subdivisions by continental and by some English geologists, the lithological names in general use in this country, and the life-zones represented in the county.

\section{LOWER JURASSIC}

\section{Toarcian . . Upper Lias . . Zone of Ammonites communis}

The oldest formation of the occurrence of which within the county we have actual evidence is the highest division of the Lower Jurassic series, the UPPER LIAs, and that does not come to the surface, having only been met with in well-borings at Sharnbrook and Felmersham, where it appears as a blue clay. The greatest thickness passed into being 66 feet, it is not likely that the lower zone of the Upper Lias, that of Ammonites serpentinus, has been reached. The strata rise towards the north-west, and both zones crop out in Northamptonshire. The mud of which the Liassic clays are composed was probably derived from the erosion of Carboniferous shales, the sediment having been deposited in the sea whilst its bed was sinking, a process which had been going on throughout Permian and Triassic times.

\section{MIDDLE JURASSIC}

Bathonian $\left\{\begin{array}{l}\text { Cornbrash . . . . Zone of Ammonites discus } \\ \text { Great Oolite . . . } \\ \text { Upper Estuarine Series } \\ \text { Inferior Oolite. . . }\end{array}\right.$

The Inferior Oolite is represented only by the Northampton Sand, a passage-bed between the Lias and the Oolites, and by some geologists considered to belong to the older formation. It has been sunk into at Wymington, yielding a supply of water. It comes to the surface in the adjoining county of Northampton, where it consists of sandy ironstones with a thin bed of coarse oolitic limestone on the top. It represents the Midford Sand of Dorset and Somerset and the lower part of the Inferior Oolite of Cheltenham, and indicates a change of conditions to a more shallow sea than that of the Liassic period.

The UpPer Estuarine Series is the oldest formation which comes to the surface in the county. At Bedford it is 70 feet beneath the surface, and its outcrop, which is not a continuous one, is some miles to the north-west. It consists of sand and sandy clay of various colours, with irregular layers of limestone here and there, and is of fluvio-marine origin, showing alternations of marine and freshwater conditions, and 


\section{GEOLOGY}

yielding, besides aquatic forms of life, remains of land plants and animals. It varies much in thickness within short distances, and in fact is not a persistent bed, sometimes occurring only in 'pockets' or 'pipes' let down into the underlying strata. The Series is a richly fossiliferous one in some places, but not here, and it represents in time the Stonesfield Slate of the south of England, from which have been obtained many fine fossils that adorn the walls of our museums.

While estuarine and freshwater conditions continued in the north, marine conditions set in from Lincolnshire southwards, commencing with the deposition of oolitic limestone. This does not indicate a deep sea, for the limestone was in all probability the detritus of coral reefs, which are built up in shallow water on a slowly-sinking sea-bed. The influx of the sea must have been from the south, and the warm currents thus brought in would be favourable to the growth of corals. The Great Oolite here consists of two divisions which are not very distinct from each other-the Great Oolite Limestone and the Great Oolite Clay. The former is by far the most persistent, extending through the midland and southern counties, while the latter is represented in the south of England by the Forest Marble, a shallow-water and perhaps partly estuarine deposit which gradually takes its place.

The Great Oolite Limestone is quarried for lime-burning and for use as a building-stone at several places near Bedford, where its thickness varies from 25 to 32 feet. It extends from Kempston south of Bedford westwards to Cold Brayfield, Carlton, and Harrold, and northwards to Puddington and Farndish. It usually consists of pale grey, dark blue, and bluish-grey limestone, either earthy, oolitic, or flaggy, in beds of varying thickness (from I foot to 10 feet) separated by thinner beds of pale grey, dark blue, or mottled clay or clayey marl, both limestone and clay frequently being crowded with specimens of Ostrea sowerbyi. The limestone is occasionally false-bedded or current-bedded, which indicates shallow-water deposition, this inference being confirmed by the great variations in the thickness and character of the beds which take place within short distances. After $O$. sowerbyi the next most frequent fossil is $O$. subrugulosa. Myadæ are abundant, and remains of saurians and fishes also frequently occur.

The water-supply of Bedford is derived from this formation. The water has been analysed, with that from the River Ouse adjacent to the pumping-station, by Professor. Attfield, F.R.S. ${ }^{1}$ Both waters are hard, but the well-water is about twice as hard as the river-water.

The Great Oolite Clay is very variable in colour, calcareous in places, contains selenite, and has at or near its base a nodular ironstone band about which the clay is sometimes dark and carbonaceous. It occurs near Bedford but is not persistent; the Cornbrash, at West End, Stevington, resting directly on bluish oolitic limestone. It is only a few feet in thickness.

1 See Trans. Herts Nat. Hist. Soc, iv, xxviii.-xxix (1 888). 


\section{A HISTORY OF BEDFORDSHIRE}

The CoRnBrash consists of tough pale-grey rubbly limestone, usually shelly and sometimes sandy, and occurring in irregular layers parted by bands of softer limestone and occasional seams of marly and sandy clay. In most of its exposures it is seen to be crowded with fossils, chiefly Lamellibranchiata, the prevailing genera being Avicula, Ostrea, Pecten, and Lima. It is by some geologists considered to be distinct from the Great Oolite, and by others to be a member of it, being everywhere its highest subdivision. It appears to have been laid down at a considerable distance from land in a rather shallow sea varying in depth from time to time. Rarely exceeding Io feet in thickness, and being a persistent and well-marked formation, it is of value in the determination of the general dip of the strata. The river Ouse, in its devious windings through Bucks and Beds, has cut through it into the Great Oolite Limestone, the inclination of the river-bed being a little less than the dip of the Cornbrash. Thus at Bradwell near Stony Stratford the river-bed is 200 feet above mean sea-level, and the Cornbrash just comes up to the 300 feet contour-line; at Harrold the height of the river is I 30 feet, and that of the Cornbrash 210; and at Bedford the river is 80 and the Cornbrash I 20 feet above sea-level. There appears to be a local upheaval at Bradwell in Bucks, but in its range through Beds the dip of the Cornbrash seems to be very slight and fairly uniform, its direction being considerably to the east of south-east. It follows that this is the direction of the dip of the Jurassic strata above and below which are conformable with it, while the Cretaceous rocks dip in a more southerly direction.

The Cornbrash is quarried for building, road-making, and limeburning. Its presence near Bedford was known in the early days of geology (so far back as 18 I 8 ), when it was called the 'Bedford Limestone.' To the rubble on its surface the name 'Cornbrash soil' was given, this being an old agricultural term for certain stony or brashy soils which are well suited to the growth of corn. ${ }^{1}$ The average width of its exposure in the county is about a quarter of a mile and does not vary greatly.

\section{UPPER JURASSIC}

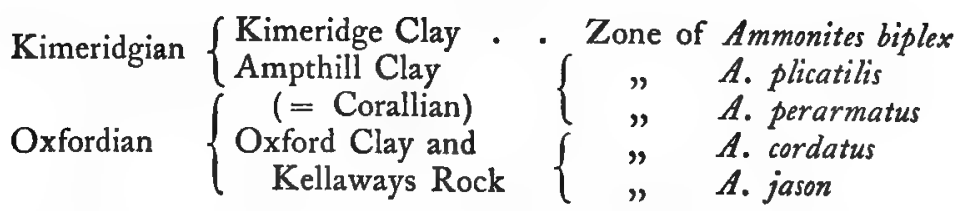

The Kellaways Rock is usually considered to be a subordinate division of the Oxford Clay, coming in above the lower portion of the clay, the great mass of which is always above it. Although it is so mapped by the Geological Survey, it would perhaps be better either to call the lower bed of clay the Kellaways Clay, as suggested by $\mathrm{Mr} . \mathrm{H}$. B. Woodward, or to group the clay and 'rock' together under the name of Kellaways Beds. While the clay indicates a rather deep sea, the rock

1 H. B. Woodward, Jurassic Rocks of Britain, iv. $380,451$. 


\section{GEOLOGY}

gives indications of shallow-water conditions, for its sandy nature and the presence in it of lignite, as at Oakley north of Bedford, point to the proximity of land, while its ammonites indicate that a fairly deep sea was not far distant. The best sections are to be seen in the vicinity of Bedford, where it generally occurs as a calcareous sandstone with a thick bed of sand at its base and a thin layer of shelly limestone at its summit, from 7 to 10 feet of clay separating it from the underlying Cornbrash. The sandstone often takes the form of irregular concretions or ' doggers' of varying size up to ro feet in diameter imbedded in sand and sometimes united in pairs like the figure 8. Many of these nodular concretions may be seen projecting from the sides of the cutting on the Midland Railway at Oakley. The clay contains selenite and ' race'; the sand is destitute of fossils ; but the sandstone is very fossiliferous, having numerous Mollusca, including Myacites recurvus in abundance, and species of Ammonites, Ancyloceras, Pleuromya, etc. Gryphea bilobata and Belemnites oweni occur in shelly layers.

Although the OXFORD CLAY is usually a greenish-grey and brown clay, it is by no means entirely clay. The following strata were pierced in a boring at Northill, three miles north-west of Biggleswade :-

Boulder Clay, 104 feet.

Oxford Clay : green clay, $12 \mathrm{ft}$; ; blue clay, $10 \mathrm{ft}$; ; blue clay and shells, $9 \mathrm{ft}$; ; dark green clay, $13 \mathrm{ft} .6$ in. ; black stone, 4 ft. 6 in. ; greenish clay and shells, $20 \mathrm{ft}$. ; live sand, $9 \mathrm{ft}$; sandy blue clay, $9 \mathrm{ft}$; 位d-rock, $7 \mathrm{ft} .4 \mathrm{in}$.; blue clay and shells, 2 ft. 6 in.; rock and blue clay, 1 ft. 9 in. ; limestone, 2 ft. 8 in. ; sandy blue clay, $3 \mathrm{ft}$; ; blue stone, $3 \mathrm{ft}$. 6 in.; sandy clay, $4 \mathrm{ft}$. ro in.; limestone, $4 \mathrm{ft}$. ; sandy clay and stone, $3 \mathrm{ft}$. Total depth, $223 \mathrm{ft} .7 \mathrm{in}$.

This section is of interest not only for the great variation which it shows in the strata which here constitute the higher portion of the Oxford Clay, but also in bringing to light such an enormous thickness of boulder clay. In giving it $\mathrm{Mr}$. H. B. Woodward 's says that " portions of the upper beds grouped with the Oxford Clay may represent the Ampthill Clay.' Elsewhere there are bands of limestone near the top of the Oxford Clay, as at Sandy, 2 miles north-east of Northill, where there is stiff grey clay with ferruginous concretions, selenite, and a band of earthy limestone from 6 to 8 inches thick; at Ampthill Park where the railway-cutting exposes dark blue clay with symmetrical crystals of selenite and seams of hard grey limestone varying from a foot to I 8 inches in thickness; and at Ridgmont and Aspley Guise near Woburn. The great mass of the formation, which attains a thickness of nearly 400 feet, is more homogeneous in character, indicating a prolonged period of deep-sea conditions over an extensive area, although near its base lignite and saurian bones have been found. It would appear that the sea-bed was sinking during its formation more rapidly than the sediment accumulated, and yet very slowly if the vast period of time which this accumulation must have occupied be considered. Its fossils are mostly pelagic forms, ammonites preponderating and Ammonites cordatus being 


\section{A HISTORY OF BEDFORDSHIRE}

abundant. Right across Bedfordshire, from Leighton to Potton, the Lower Greensand covers much of the upper portion of the Oxford Clay as well as the succeeding Ampthill and Kimeridge Clays, overlapping these formations, and more to the north the lower portion is overlaid by boulder clay. This makes its precise limits difficult to ascertain in some districts, but it is known to extend over the greater part of North Beds. There are many brickfields in it, and where boulder clay overlies it an admixture of the two clays is found to be advantageous in brick-making. Boulder clay over Oxford Clay makes a very tenacious soil, retentive of moisture and well suited to the growth of corn.

The Ampthill Clay was formed under much the same conditions as the Oxford Clay below it, and the Kimeridge Clay above, and constitutes a passage-bed between them, having an admixture of their fossils. Being a comparatively deep-sea representative of the Corallian beds, which owe their origin to the destructive action of the sea on coral-reefs, it is frequently called Corallian, but the term is scarcely applicable. The two life-zones of the Corallian stone-beds are very distinct, but although both are probably present in the Ampthill Clay, they cannot be distinguished in either Beds or Cambs owing to the Oxfordian and Kimerigian fossils being mixed. The Ampthill resembles the Oxford Clay in not being a bed of clay only. In the cutting north of Ampthill railway station it consists of a thin septarian band with Ostrea discoidea in and beneath it ; 50 feet of marly shale and stiff clay, with selenite, a layer of calcareous nodules with Iscbyodus, and a rusty band with Ammonites cordatus and other fossils; a thin band of pale earthy limestone ; 6 feet of grey and yellow marly shale; and a rubbly rock-bed at the base, $4 \mathrm{ft}$. 6 in. thick, and containing numerous fossils; the whole (given in descending order) resting upon Oxford Clay and being surmounted by Kimeridge Clay. 'The outcrop of the Ampthill Clay is concealed for the most part by the overlapping of the Lower Greensand.

In this section at Ampthill there appears above the Ampthill Clay a bed of clay and dark-blue shale, 10 feet thick, with Ammonites biplex, Ostrea deltoidea, and other fossils, which is of KIMERIDGE CLAY age, and has boulder clay resting unconformably upon it. The Kimeridge Clay must here have suffered very considerable denudation. Elsewhere it usually varies from 400 to 1,000 feet in thickness, but near Aylesbury it is not more than 100 feet thick. Here only its base is seen, the higher beds having been washed away, together probably with the succeeding Portland Beds, of which the only trace in the county consists of fossils in the Lower Greensand which have been derived from Portlandian strata. It was probably the presence of these fossils which led Professor A. C. Ramsay to say that outliers of the Portland Stone occur in Bedfordshire, rightly adding that 'the whole has evidently been exposed to denudation before the deposition of the Cretaceous rocks.'

1 Furassic Rocks of Britain, v. 135.

${ }^{2}$ Pbysical Geology and Geograpby of Great Britain, ed. 5, p. 191. 


\section{GEOLOGY}

THE BREAK IN THE SEQUENCE OF THE JURASSIC AND CRETACEOUS STRATA

It will be seen from the foregoing that although the Kimeridge Clay in this district is in immediate contact with the Lower Greensand, the two formations are in point of time widely separated; but the slight unconformability between them gives very little indication of the great changes which occurred in the distribution of land and sea, and of the vast amount of sediment which was elsewhere deposited between the close of the Jurassic period in this district and the commencement of the Cretaceous.

With the increasing depth of the Jurassic sea, the western margin of the land of the south-east of England was gradually encroached upon; but it was not until Cretaceous times that the whole of this area was completely submerged, and it is doubtful how far until then the sea covered that portion of it which is now known as Bedfordshire. Towards the close of the Jurassic period the sea became shallower; but the Portland Beds, consisting mainly of sands and limestone, appear to have been laid down on the whole in clear water at some distance from the estuaries of rivers. The Portland sea probably extended over part of the county, and on the upheaval of the sea-bed its sediment would form the surface of the land, constituting a plain flanking the Palæozoic hills of Middlesex, Hertfordshire, and South Bedfordshire. That this plain was subjected to denudation we know, for not only have the Portland Beds been washed away on the north of these hills, leaving a few of their fossils as witnesses of their former presence, but a great part of the underlying Kimeridge Clay has also been removed.

About this period considerable earth-movements took place here and elsewhere, the result in Bedfordshire being an elevation of the strata towards the west or a depression towards the east, and in Hertfordshire a depression by which the Palæozoic range of hills was ultimately submerged some $\mathrm{I}, 000$ or 2,000 feet. This was probably between the close of the Portland and the commencement of the Purbeck period, or mainly in this interval, for not a single species is known to pass from the one formation to the other, which indicates a great lapse of time. It is true that some forms, such as Ammonites and Belemnites amongst the Mollusca, and Icbtbyosaurus and Plesiosaurus amongst the Vertebrata, maintained their existence as genera and are well represented in the local strata of both the Jurassic and the Cretaceous period, but no species appears to have survived the changes which took place between the deposition of the Kimeridge Clay and that of the Lower Greensand.

The Portland Beds are marine; the Purbecks are partly marine and partly freshwater, and they seem to have been deposited chiefly in an extensive lagoon on the eroded surface of the Portlands. In the south of England they are succeeded by the freshwater Wealden strata, 2,000 feet in thickness, of which no trace is known to exist beyond the Vale of Wardour ; unless the silicified wood found at Brickhill near Woburn, 


\section{A HISTORY OF BEDFORDSHIRE}

and the plant, Endogenites erosa, and remains of Iguanodon from Potton, have been derived from the Wealden as suggested by Mr. Walter Keeping. ${ }^{1}$ In all probability however the deposition of the Wealden strata over the south-east of England, which must have occupied a great length of time, took place whilst the whole of Bedfordshire was above sea-level, and therefore whilst the Kimeridge Clay was subjected to sub-aerial denudation, by which its higher beds, with the overlying Portlandian, were removed.

During the long period occupied in the accumulation of the Cretaceous strata there was a nearly continuous and usually gradual change from comparatively shallow seas to those which were much deeper if not truly oceanic, occasionally interrupted by temporary elevations of the sea-bed. These alterations in the depths of the marine areas were accompanied by important changes in the character of the fauna. Many of the earlier Cretaceous forms became extinct and were superseded by others of newer types, noteworthy amongst which are the echinoderms Holaster, Galerites, and Micraster; the lamellibranch Hippurites; the cephalopods Hamites and Scaphites; the fishes Lamna, Otodus, and Ptycbodus; and the reptile Polyptycbodon; species of all of these genera having been recorded for the county.

\section{LOWER CRETACEOUS}

Vectian or Aptian. Lower Greensand. Zone of Terebratula sella

Owing to the absence of beds of Wealden age the Lower Cretaceous rocks are in this district represented only by the Lower GREENSAND, which is the equivalent of the higher division of the Vectian of the south of England and the Aptian of western Europe; the lower division consisting in the Wealden area and the Isle of Wight of the Atherfield Clay, a very fossiliferous marine deposit having no representative in Bedfordshire.

The Lower Greensand extends across the county from Leighton Buzzard to Potton, forming a very picturesque range of hills running generally from south-west to north-east. For some portion of its extent it is concealed by the boulder clay and alluvium of the valley of the Ivel, and on reappearing it attains a considerable elevation in the vicinity of Sandy, having there a rather steep and very prominent escarpment. Its maximum thickness is about 220 feet and its exposure is several miles in width, the area it covers being more extensive than in any other of the midland counties. In passing under the newer strata in a south-easterly direction it thins out rapidly, terminating in the adjoining county of Hettford somewhere between Hitchin and Ware. It was the absence of the knowledge of this fact which led the late Sir Joseph Prestwich to believe that it might form a valuable water-bearing stratum for the supply of London; but although he was mistaken on this point, owing to no boring having at that time $(185 \mathrm{I}$ ) been carried to a

1 In Geol. Mag. dec. 2, vol. ii. p. 375. 


\section{GEOLOGY}

sufficient depth to prove that it thus thinned out, his ' Geological Inquiry respecting the Water-bearing Strata or the Country around London' is a classic of geological literature replete with valuable information.

Near Leighton the Lower Greensand consists for the most part of white and light-coloured sand known as 'silver sand,' which has an industrial value. ${ }^{1}$ It is now chiefly obtained for filter-beds, but it is in places so free from iron and other colouring matter that it has been used for glass-making. The larger quartz grains show signs of attrition, being rounded and polished, like the sands of the sea-shore.

At Leighton and near Silsoe a bed of dark-brown ferruginous sandstone is exposed which is sufficiently indurated to be of service for building purposes, several churches in this part of the county being built of it, but it weathers rather rapidly and very unevenly. This ' carstone,' as it has been called, is a local feature which has been stated to be dependent on the presence beneath the sand of beds of clay which have arrested the percolation of ferruginous water. ${ }^{2}$ Opposite the Castle Hill near Clophill there is a very instructive section showing 10 feet of dark-coloured clay, called by the workmen 'black clay' to distinguish it from the 'blue clay' of the Gault, occurring in three distinct beds of about equal thickness with thin layers of sand between them, dark-red carstone being above the clay and light-coloured sand beneath it; but elsewhere the carstone is frequently seen resting on light-coloured sand with no trace of clay. The sand is, wherever exposed, seen to be partially or wholly false-bedded, showing that it was deposited in a shallow sea with shifting currents. The false-bedding is also evident in the carstone whether it occurs in a continuous layer or in isolated masses which are called 'doggers.' Concretions of brown iron-oxide are of frequent occurrence.

At the base of the series near Woburn, and at a rather higher horizon near Potton, there is a peculiar bed of variable thickness ( 6 inches to 2 feet) consisting for the most part of pebbles with water-worn fossils derived from a distant source, and containing also numerous (so-called) ' coprolites.' The pebbles are of quartz, quartzite, limestone, ironstone, slate, etc., and they are sometimes cemented into a hard rock by carbonate of lime. Sub-angular fragments of rock also occur. Most of the fossils are derived from older beds, the majority of Upper Jurassic and some of Lower Cretaceous age. With these may sometimes be found fossils proper to the formation, that is which lived in Vectian times. The indigenous fossils are chiefly brachiopods and lamellibranchs; the derived fossils, teeth and bones of saurians and fishes. At Millbrook have been found remains of the saurians Icbtbyosaurus, Plesiosaurus, and Dakosaurus, and of the fishes Spharodus, Pycnodus, and Acrodus. Most of these also occur in the neighbourhood of Potton; and in addition a previously undescribed brachiopod, Terebratula dallasii, and

1 Analyses of this sand from Heath near Leighton are given in E. W. Lewis's Lectures on the Geology of Leigbton Buzzard, p. 61 (1872).

2 H. B. Woodward, Geology of England and Wales, ed. 2, p. 379 (1887). 


\section{A HISTORY OF BEDFORDSHIRE}

a cycadian stem, Cycadoidea yatesii, ${ }^{1}$ amongst other forms, have been found there. One of the most abundant of the derived fossils is Ammonites biplex. The bed has long been worked for the phosphate of lime which its coprolitic nodules contain, but all the workings in the county are now closed.

At a higher horizon are beds of fullers' earth which have formed an item of local commerce for the last two centuries. This earth occurs in 'tabular lenticular masses,' " the areas and thicknesses of which vary considerably. It is an ' earthy hydrated silicate of alumina' possessing saponaceous and detergent qualities which render it of use in certain industrial operations. Its colour varies in the different seams, its hues being sometimes sharply defined and at other times graduated; the variations in shade are not accompanied by important alterations in chemical composition. A peculiarity of this mineral is that although it has an argillaceous base it has no coherent properties, being quite unsuited for the manufacture of pottery. For a long period it was obtained by sinking ' earth-wells,' usually unprotected by masonry or brickwork. This method was superseded about the year 1890 , when two companies were formed for working the bed. The most modern machinery was employed and extensive mining operations were carried on for some time, but the concerns did not prove a financial success and the works were closed in 1901 .

Quite recently ${ }^{3}$ a fossiliferous band of much interest has been discovered at the summit of the series in pits which have been opened on Shenley Hill near Leighton in order to obtain the silver sand before mentioned. The fossils occur in blocks of "hard, horny-looking, gritty limestone' between two undulating floors of iron-grit at the junction of the Lower Greensand with the Gault. These blocks, as well as the irongrit bands, afford evidence of having been ' uncovered on the sea-floor,' where they have been eroded by current-action, but " the shells embedded in the limestone, although fragile, are in splendid preservation, and rarely show even the slightest traces of abrasion.' Brachiopods are by far the most numerous; next come the pectens; spines of echinoderms are rather plentiful ; and amongst other fossils are joints of a crinoid, carapaces of a crustacean, and polyzoa with which many fossils are encrusted. The chief interest in this discovery lies in the fact that the fauna has a decidedly Upper Greensand facies ; so much so that were not the stratigraphical position of the bed so clearly defined it might have been concluded to be of Upper Greensand age. Similar forms of life doubtless appear under similar conditions, but the connection is here so close that it leads to the inference that the Lower and Upper Greensand must somewhere be continuous, the fauna of the Lower Greensand migrating under

1 Carruthers, Geol. Mag. iv. 199, pl. ix. (1867).

2 A. C. G. Cameron, The Geology of the Fuller's Earth (1893). Mr. Cameron has added greatly to our knowledge of the geology of Bedfordshire, and this is the best account we possess of fullers' earth as it occurs in the county.

${ }^{3}$ G. W. Lamplugh and J. F. Walker, 'On a Fossiliferous Band at the Top of the Lower Greensand near Leighton Buzzard,' Quart. Fourn. Geol. Soc. lix. 234-65 (1903). 


\section{GEOLOGY}

the altered conditions of the Gault period and coming back with no further change than would occur in its natural process of development and modification elsewhere during the deposition of the Gault.

The town of Leighton Buzzard derives its water-supply from the Lower Greensand, but the formation is not here a very satisfactory waterbearing one. The yield is sufficiently copious, but the presence of iron in a form exceedingly difficult to get rid of is a great drawback. The water is rather hard, but is much softened by ebullition. ${ }^{1}$

A well for the supply of Biggleswade has recently ( 1903 ) been sunk into the same formation, the Greensand having been reached at a depth of $\mathrm{I}$ I 0 feet. At $\mathrm{I} 70$ feet it was found to contain a seam of rock, which, with the sand immediately overlying it, is coloured green through the presence of grains of glauconite.

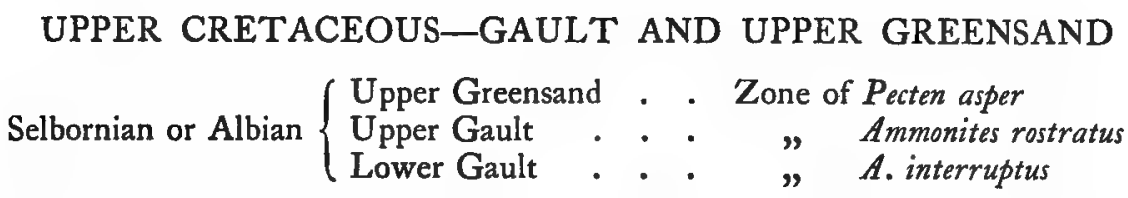

While in the Vectian epoch only a small portion of England was submerged, all in its eastern division; in the Selbornian the sea extended so far to the west as Devonshire, and probably covered the whole of the Midland as well as the Eastern Counties. The sea-bed sank as it gradually extended, and may have reached a depth of several hundred fathoms before the close of the period. The composition and fossil contents of the LOWER GAULT however indicate a comparatively shallow sea, not so deep as 100 fathoms and probably not averaging more than half that depth. The passage from the Lower Greensand to the Lower Gault is in some places continuous and in others shows a decided break, apparently owing to the former not having been entirely submerged when the deposition of the latter commenced. Thus in a brickfield south of Leighton no distinct line of demarcation can be seen, the Gault clay gradually becoming more sandy downwards until it passes into a clayey sand with small pebbles, and that into a coarse yellow sand, obliquely bedded, the pebbly bed marking the base of the Gault and indicating current-erosion. In a sand-pit north of Leighton, on the other hand, a well-marked plane of division may be seen, "I 4 feet of dark-grey clay with small patches of bright-red clay at the base resting directly on yellow sand."

The Lower Gault stretches right across Bedfordshire, from south of Leighton to west of Potton, but in a portion of its course eastwards from Heath and Reach it is covered by drift deposits; it is again exposed to the south of Flitton, Silsoe, and Shefford. On the slopes of the Lower Greensand hills to the north of the Ivel valley there are several small outliers of it, and there is a large one north of Shefford. It is the

1 Analyses by Professor Attfield have been published in Trans. Brit. Assoc. of Waterworks Engineers, iii. 199, 224, 225 (1 899).

Jukes-Browne, Cretaceous Rocks of Britain, i. 284-5. 


\section{A HISTORY OF BEDFORDSHIRE}

erosive action of a tributary of the little river Ivel (the Flit) which has cut them off from the main mass; they form however but a slight indication of the former extent of the Gault to the north and west.

The Lower Gault is usually a light or dark grey marly clay. Where it is worked for brickmaking near Silsoe it is called 'blue clay,' and it is used mixed with the 'black clay' of the Lower Greensand before mentioned. At Arlesey its higher part is extensively worked, a section about 50 feet in depth showing a transition from dark clay at the base to that of a much lighter colour at the top. It there contains from 26 to 3 I per cent of carbonate of lime. ${ }^{1}$

Near the base of the clay there is usually a bed of phosphatic nodules which has been worked at various places for making into artificial manure. Many fossils have been found in and with these nodules, species or Ammonites and Belemnites prevailing, and by far the most abundant species being Belemnites minimus. In a brickyard at Heath near Leighton the nodule-bed contains an admixture of Lower and Upper Gault fossils; while at Campton near Shefford, apparently about the same horizon, 20 to 25 feet from the base of the Gault, there is a nodule-bed with fossils, all of which, with the exception of Terebratula biplicata, are of Lower Gault age. ${ }^{2}$

An interesting relic in proof of the existence of the Gault beneath the south of the county is furnished by a brick which is built into the wall of the market room of the Cock Inn, Luton, bearing the legend 'F. Burr, 465 feet, Jan. I 828.' This brick was made from material brought up from the bottom of a boring for an artesian well at the Old Brewery adjoining. From the estimated thickness of the beds from the Middle Chalk to the Upper Gault inclusive, it is safe to assume that the stratum in which the boring terminated was Lower Gault.

Another bed of phosphatic nodules marks the base of the UPPER GAULT, which in this district is a much more calcareous formation than the Lower Gault, containing about 50 per cent of carbonate of lime. The sequence of formation was continuous, but the alteration in the mineral composition of the Upper Gault indicates that it was here deposited at a much greater distance trom the shore of the Cretaceous sea than was the Lower Gault. In fact it was laid down in a sinking sea with a receding shore-line. It is a marly clay much resembling the Chalk Marl in appearance and composition, Mr. William Hill having found it by microscopical examination ' to consist of calcareous matter in a fine state of division enclosing many small particles which are probably shell-fragments and some tests of Foraminifera." ${ }^{3}$ It is not of the same composition throughout, for this light-grey marl passes up into a darker grey sandy and micaceous marl."

When traced across the county in an easterly direction it is seen to diminish in thickness, its basal nodule-bed being brought nearer and nearer to the overlying Chalk, until, between Barton and Shillington, it

\footnotetext{
${ }^{2}$ Jukes-Browne, Cretaceous Rocks of Britain, i. 319.
${ }_{4}^{3}$ Loc. cit.
} 


\section{GEOLOGY}

disappears altogether, the Chalk Marl resting directly upon the Lower Gault. This thinning-out is most probably due to erosion, for the nodulebed which forms the base of the Chalk Marl contains phosphatic fossils derived from the zone of Ammonites rostratus, that is to say of Upper Gault age.

From recent borings the Gault appears to be much thicker in the south of the county than has hitherto been supposed.

The UPPER GREENSAND is not a continuous bed; after running through the greater part of Buckinghamshire it dies out before it reaches Bedfordshire, re-appearing again near the boundary of the two counties. It can be traced, but not very clearly, in the parishes of Eddlesborough, Eaton Bray, and Tilsworth ; its maximum thickness in the county being 20 feet. 'It consists of fine yellowish-grey micaceous sand passing up into dark-green glauconitic sand, which in turn passes up into the glauconitic sand that forms the base of the Chalk Marl.'1 Only one fossil, Aucellina (Avicula) gryphacoides, has been recorded from it in the county and that with some doubt, its horizon being uncertain.

In the opinion of Mr. Jukes-Browne the restricted area of the Upper Greensand in this district is not due to the erosion of a much larger deposit, but to the present outcrop marking the easterly extension of the original shore-line. $\mathrm{He}$ also thinks that beyond its eastern limit near Kateshill there was a land-surface which was unaffected either by erosion or deposition until the period of the Chalk Marl, when the area was submerged beneath the Cretaceous sea. The absence of the Chloritic Marl in this locality tends to confirm this view.

UPPER CRETACEOUS-THE CHALK

\begin{tabular}{|c|c|c|c|c|}
\hline Senonian & Upper Chalk & $\begin{array}{l}\text { Chalk-with-flints. } \\
\text { Chalk Rock . }\end{array}$ & Zone of & $\begin{array}{l}\text { Micraster cor-bovis } \\
\text { Heteroceras reussianum }\end{array}$ \\
\hline Turonian & Middle Chalk & $\begin{array}{l}\text { Soft white Chalk } \\
\text { Melbourn Rock } \\
\text { Soft grey Chalk } \\
\text { Tough blocky Chalk. }\end{array}$ & $\begin{array}{l}" \\
" \\
"\end{array}$ & $\begin{array}{l}\text { Terebratulina lata } \\
\text { Rbyncbonella cuvieri } \\
\text { Actinocamax plenus } \\
\text { Holaster subglobosus }\end{array}$ \\
\hline Cenomanian & Lower Chalk & $\begin{array}{l}\text { Totternhoe Stone } \\
\text { Chalk Marl } \\
\text { Chloritic Marl }\end{array}$ & $"$ & $\begin{array}{l}\text { Pecten fissicosta } \\
\text { Ammonites varians } \\
\text { Scaphites aqualis }\end{array}$ \\
\hline
\end{tabular}

The Chalk is essentially a pelagic formation, and during its deposition the whole of England, with the exception of the mountainous districts of Cumberland and Westmorland, North and South Wales, and Devonshire, was submerged. The depth of the sea gradually increased on the whole, but varied greatly from time to time, and at one period especially, when the Chalk Rock was being tormed, it must have been comparatively shallow; but there is no indication of the proximity of a shore-line in our area during the deposition of the Chalk.

The lowest bed of the Chalk is very different from the white limestone which gives the name to the formation; the ChLORITIC MARL, which immediately succeeds the Upper Gault, being usually a grey or bluish

\footnotetext{
1 Jukes-Browne, Cretaceous Rocks of Britain, i. 287.
} 


\section{A HISTORY OF BEDFORDSHIRE}

sandy clay containing phosphatic nodules and numerous organic remains. It is regarded as the westerly extension of the Cambridge Greensand, the fossils which it yields being identical with those found in this bed in Cambridgeshire. The phosphatic nodules, with their associated fossils, have in all probability been derived from the denudation of the Upper Gault, which appears to have extended before this period considerably to the west of its present limit. The Chloritic Marl extends from Arlesey in the extreme east of the county, westerly by Shillington, Barton, and Sharpenhoe, and probably so far as Harlington, towards which place it is concealed by newer beds.

During the period in which the coprolite-pits were being worked, numerous fossils were brought to light, especially in the neighbourhood of Barton and Sharpenhoe. That the assemblage of organisms was very remarkable may be seen from its inclusion of the reptilian genera $I c b-$ thyosaurus, Plesiosaurus, and Pterodactylus, and the cephalopods Ammonites auritus, $A$. studeri, $A$. mantelli, and Belemnites minimus. Some of these were derived from the Gault during the extensive denudation to which it was subjected, and others are of the age of the bed in which they occur; but when the attempt is made to distinguish between the two series, the difficulties which present themselves are well nigh insuperable. An attempt to do so has however been made by Mr. A. J. Jukes-Browne in a paper ' On the Relations of the Cambridge Gault and Greensand.'

The Chalk Marl is an impure limestone, dark in hue and somewhat plastic in texture, which features are due to a small admixture of silt. Its mineral composition indicates that it was deposited in much deeper water than the Gault. It attains its maximum development over an area which extends due east from Berks through the counties of Herts and Beds, north and south of which it rapidly diminishes in thickness. This change is accompanied by differences in its mineral constituents, that to the north indicating an increase in the depth of the sea in which it was laid down, and that to the south-west a decrease in the depth.

During the progress of the works connected with the extension of the Midland Railway, numerous fossils were found in this stratum, some of which are worthy of mention. Two specimens of a previously undescribed crustacean were obtained (one from the dark grey portion of the bed and the other from the higher and lighter-coloured part of it) which were figured and described, with specimens from elsewhere, by Dr. Henry Woodward under the name of Palaga carteri. ${ }^{2}$ The cephalopods include Ammonites varians in abundance, Actinocamax (Belemnites) lanceolatus, a rare species, and Turrilites mantelli, previously recorded only from the south of England. Of reptilian remains a portion of a jaw of Icbtbyosaurus campylodon with teeth in situ is the most noteworthy.

The Chalk Marl, as well as some other divisions of the Chalk, contains numerous nodules of iron-pyrites, a mineral which is locally

\footnotetext{
1 Quart. Fourm. Geol. Soc, xxxi. 256-3 16.

2 Geol. Mag. vii. 496, pl. xxii (1870).
} 


\section{GEOLOGY}

known as 'crowgold,' but is nowhere present in the county in sufficient quantity to be of commercial value. The stratum plays an important part in connection with the water-supply of the district. The argillaceous character of the middle portion renders it partially impervious to water, so that at its junction with the overlying porous portion numerous springs arise, which however are now fewer in number and smaller in volume than they were some twenty years ago. This feature was strikingly exemplified during the excavation of the extensive cutting at Chalton, the flow of water in the Chalk Marl being so copious that in driving a heading into the escarpment the workmen had to wear miners' costume, as their clothing was in a state of constant saturation. The Chalton cutting is the only exposure of the bed of any importance in the county. A sandy layer near its base is not exposed here.

The Totternhoe Stone takes its name from the village of Totternhoe about three miles west of Dunstable, where it attains its maximum development which does not exceed 22 feet. Away from this locality it rapidly diminishes in thickness. It is a dark grey, slightly arenaceous, compact limestone, with a peculiar grain to which the term 'curly' is applied by the quarrymen. The comparative coarseness of the materials of which it is composed, and the presence of siliceous particles, indicate that there was a temporary increase in the force of the currents which effected its deposition, over those which prevailed during the era of the Chalk Marl. Scattered irregularly through it are numerous dark brown amorphous masses, and at its base there is usually a layer of green-coated phosphatic nodules; a further indication of current-action. Many springs arise from it at the foot of the Dunstable Downs and elsewhere.

Totternhoe Stone was formerly extensively employed in local architecture, numerous churches in the south of the county affording examples of its use, but it is not sufficiently indurated to withstand for any great length of time the climatic changes to which it is subjected when used for exterior decoration. It weathers badly, as may be seen from the present condition of the west front of Dunstable Priory Church. ${ }^{1} \quad$ It is much more suitable for interior work; but even for this it has long been superseded by more durable materials brought from a distance. The numerous and extensive relics of excavations on Totternhoe Hill show that this stone has been quarried for a very long period. Until about the middle of the nineteenth century it was customary to construct tunnels which commenced at the outcrop of the stone and were carried a considerable distance into the hillside. In later times tramways were used to bring the material to the surface, the incline, corresponding with the dip of the bed, being only slight. This system was then superseded by open quarrying, the whole of the overlying bed of Lower Chalk being removed and used for making lime. This method of working terminated during the last decade of the nineteenth century, consequent upon the cessation of the demand for the material.

This is now undergoing restoration, the material employed being a Bath stone. 


\section{A HISTORY OF BEDFORDSHIRE}

The Totternhoe Stone has yielded at its headquarters numerous organic remains. Of these it may suffice to mention the crushing teeth of the fishes Ptychodus polygyrus, $P$. latissimus, $P$. decurrens, and $P$. mammilaris, the cephalopod Nautilus atlas, and the lamellibranch Pecten orbicularis, specimens of all of which are in the museums of Luton and St. Albans. Another exposure occurs in the Midland Railway cutting at Chalton, where it is visible on the face or the excavation when viewed from the bridge which carries the road to Sundon. This section has furnished Pecten fissicosta, $P$. orbicularis, Ammonites varians, and several fine examples of Nautilus elegans, the largest of which, about 8 inches in diameter, is now in the Woodwardian Museum, Cambridge.

Overlying the Totternhoe Stone is a tough grey blocky limestone, the zone of Holaster subglobosus, which in some of its exposures has a yellowish tinge at the base, doubtless due to the presence of iron oxide. In its passage upwards it becomes light grey or white. The lines of deposition are indistinct, and it was evidently laid down under tranquil conditions. Its mineral composition and fossil contents indicate that there was a gradual increase in the depth of the sea during its deposition; one result of which was that many of the genera of Mollusca which previously existed died out or migrated to other districts and were succeeded by others which were adapted to the altered conditions. The stratum contains a high percentage of lime, this material averaging at least three-fourths of its bulk. There is also present a small amount of silica, both organic and inorganic, the former consisting of spongespicules and the latter of siliceous granules. Oxide of manganese is often present in the form of a fine black deposit on the surface of the blocks into which it separates during weathering, as well as distributed unequally through the mass.

The fossils of this division of the Lower Chalk are both numerous and interesting. Conspicuous amongst them are the palatal teeth of several species of Ptychodus, and the pointed teeth of Lamna, Corax, and Notidanus, the latter occurring only rarely. The lamellibranchs are represented by species of Inoceramus, Plicatula, and Spondylus, and the brachiopods by Rbyncbonella cuvieri, Terebratula semiglobosa, and Terebratulina striata. Gastropods are of rare occurrence. Echinoderms are represented by the characteristic Holaster subglobosus, and crustaceans by Enoploclytia. Examples of these fossils are to be seen in the Luton and St. Albans museums. Exposures of the bed are not unfrequent along the line of the Chalk escarpment at Totternhoe, Sewell, Puddle Hill Sundon, Sharpenhoe, and Barton.

Overlying the zone of Holaster subglobosus is a soft grey chalk or shaly marl known as the zone of Belemnitella plena, or to use the most modern terminology, Actinocamax plenus. This is remarkably persistent across England from the south-west to the north-east coasts. The presence of a seam of impure limestone at this horizon indicates a marked change in the conditions under which it was deposited, and in explanation of its formation the theory has been advanced that a sub- 


\section{GEOLOGY}

arctic current set in from a northerly direction, from its coldness traversing the lower part of the sea and effecting the extinction, at least locally, of many of the Mollusca, as only a few species survived the interval which elapsed between the deposition of the Lower and Middle Chalk. Mr. Jukes-Browne has identified the following fossils found in this bed between Luton and Leagrave: Rbyncbonella cuvieri, $R$. plicatilis, Ostrea vesicularis var. baylei, Ptychodus decurrens, Lamna gracilis, and a crustacean of the genus Lepas.

The escarpment of the Lower Chalk forms the most striking physical feature of South Beds as well as of the adjoining counties through which it passes. In most of its course it rises abruptly from the plain lying at its base, often to a height of 200 feet above it, clothed only with closely-cropped herbage. Occasionally the monotonous though not unpleasing rounded contour of the hills is relieved by groves of trees, mostly beech, the best illustrations of which are in the parishes of Sundon and Streatley. In several places the escarpment is intersected by the remarkable 'coombes' which are a striking feature of this range of hills. These have been formed mainly by the erosive action of springs which in former times were much more copious than they are now, and also issued at higher levels. This process of erosion still continues, but on a greatly reduced scale, the Barton and Streatley valleys furnishing examples. On the eastern side of Barton there originates a narrow precipitous valley which describes a semicircle in the heart of the hills. It starts from the base of the north-west angle of Ravensbury Castle (a Roman camp), takes a southerly curve, then turns south-easterly, and finally debouches in a north-easterly direction in the parish of Hexton, Herts. The spring which has been the prime factor in the formation of the coombe is known as 'Burwell,' and now originates at the angle at which the valley is deflected from an easterly to a north-easterly course. At Pegsdon, on the eastern confines of the county, there is a peculiar coombe designated 'Pegsdon Barns,' the sides of which are as smooth and sharply defined as though they had been cut by human agency. When this valley is approached from the northern end of Lilley $\mathrm{Hoo}$ it opens out to the observer with startling suddenness.

Many springs formerly existed at the junction of the Lower with the Middle Chalk at Houghton Regis, Leagrave, Limbury, and Biscot, but they are now greatly reduced in number and volume.

The MeLbourn Rock, which forms the base of the Middle Chalk, has been traced in the neighbourhood of Dunstable, Houghton Regis, Sundon, and Barton. There are outliers of it on Totternhoe Knoll. Sections are exposed in chalk-pits about a mile south-east of Leagrave, and between that village and Sundon. Its thickness in the county is about $\mathrm{ro}$ feet. It is an impure limestone having in its lower part many well-defined nodules which are often greenish-grey in colour, especially after weathering. Some of these nodules have on their surface shells of immature Ostrea, which suggests that they were exposed on the soft ooze of the sea-bed for a considerable period before they were covered 


\section{A HISTORY OF BEDFORDSHIRE}

with silt. The upper portion has a yellowish tinge, it is less fossiliferous than the lower, and its nodules are not so easily distinguished from the surrounding matrix.

The coarse gritty texture of the Melbourn Rock, to which the term 'rag' is applied by the workmen, is mainly due to the presence of the remains of Globigerina and other Foraminifera, and of the triturated tests of marine Mollusca. The most abundant fossil in this district is Ostrea vesicularis var. baylei; other less common forms are Rbyncbonella cuvieri, Plicatula inflata, and Actinocamax plenus (Belemnitella plena).

The central division of the Middle Chalk, comprising the zones of Terebratulina gracilis (or lata, as it is now called) and Holaster planus, consists of a soft white limestone about 200 feet in thickness, which is much more homogeneous in texture than the Melbourn Rock. The lines of deposition are occasionally indicated by thin seams of grey marl which persist over a considerable area. When exposed on the face of a section these seams are seen to be broken at intervals by slight faults varying from a few inches to 2 or 3 feet in depth. Examples are present in the cuttings for the Midland Railway south-east of Luton. In the cutting at the twenty-ninth mile from London there are at least half a dozen faults in 200 yards, appearing like a series of steps, and there are others which are obscured by vegetation. In the next cutting southeastwardly there is a conspicuous fault about 10 yards in length and with a downthrow of 2 or 3 feet. These faults appear to have been produced by the upheaval of the Chalk and its shrinkage from desiccation.

The sea in which this portion of the Chalk series was formed seems to have been deeper than that in which the Lower Chalk was laid down, though not so profound as the ocean in which the Globigerina-ooze of the present day is being deposited.

The fossils in this division are both numerous and interesting, including the typical species Terebratulina lata and Holaster planus, wellpreserved examples of Terebratula semiglobosa, Spondylus spinosus, and Galerites albo-galerus, and occasionally the teeth of Lamna, Corax, and Ptychodus. Broken fragments of Inocerami are abundant. Other less common forms are the curious Hippurites mortoni, and aptychi, the mandibles of belemnites, three specimens of which have been found in the neighbourhood of Luton and are now in the Blackmore Museum, Salisbury.

This portion of the Middle Chalk occupies a considerable surface over the south of the county, and is largely devoted to arable agriculture. The hard seams of chalk above and below it (the Chalk Rock and Melbourn Rock) have been important factors in the production of the existing outlines of the Chalk escarpment, and by their resistance to erosion they have greatly assisted in the formation of the 'lynchets' which are not uncommon over this area.

The uniformity in texture of the great mass of the Middle Chalk, and the slight changes in the general features of its fauna, suggest that subsidence and deposition nearly balanced each other, so that an almost 


\section{GEOLOGY}

uniform depth of water was maintained during its formation. Flint nodules become numerous in its higher part, indicating an increase in the number of silex-secreting organisms living in the seas of the period.

The CHALK Rock consists in this district of two bands of indurated limestone, each about 2 feet thick, separated by about 10 feet of soft white chalk known as the Micraster-bed. The 'rock' itself, so termed from its hardness, is cream-coloured, sometimes with a greenish tinge owing to the many glauconitic grains which it contains. It is often sub-crystalline, sometimes shows a conchoidal fracture, and in places is so hard that when struck with a hammer it has a metallic ring. The hardest seams are nodular, the nodules being slightly phosphatic, very irregular in shape, and cream-coloured with a green coating.

The fossils of the Chalk Rock are numerous and varied, consisting chiefly of Foraminifera, sponges, echinoderms, and Mollusca. The delicate microscopic tests of the Foraminifera are often in fragments, and the former existence of branched sponges is sometimes indicated by tubular cavities occasionally containing a powdery substance in which sponge-spicules are present. The state of preservation of the remains of the Mollusca varies considerably. As a rule the shells of the gastropods and cephalopods have perished, casts of both the interior and exterior being present, the latter exhibiting the ornamentation, which can be reproduced by means of a wax impression. The lamellibranchs usually have their shells well preserved, as is also the case with the tests of the echinoderms and brachiopods, but they are difficult to extract owing to the hardness of the matrix.

The general features of the organic remains indicate a marked difference in the conditions under which they lived from those which existed when the softer beds of the Middle Chalk were deposited. The prevailing species, especially of the gastropods, prove that at this period the sea-floor was not deeper than from 150 to 200 fathoms, this being the extreme depth at which their modern representatives are found. Taking all the observed facts into consideration, it is probable that the Chalk Marl and Chalk Rock, which are separated by 400 feet of Cretaceous beds, were deposited in seas the depths of which were very similar. A few species are common to both horizons, ${ }^{1}$ indicating that, although absent from this area, they maintained their existence during the interval in some other locality.

The Chalk Rock appears to form the summit of the escarpment of the Chalk along the Dunstable Downs as seen from the plain below, but the higher ground behind is on the Upper Chalk. It may be traced westwards along the ridge from the Five Knolls, and sections of it are exposed in a pit near the top of the downs. Sections may also be seen on both sides of the Luton valley near the 500-feet contour line. Owing to its extreme hardness it is affected much more slowly by denudation than the associated softer beds, so that its presence has largely determined

1 See H. Woods, 2uart. Fourn. Geol. Soc. liii. 396. 


\section{A HISTORY OF BEDFORDSHIRE}

the existing outlines of the hills overlooking the valley of the Lea in South Bedfordshire. The most instructive exposure is that on the Midland Railway between the $28 \frac{\mathrm{I}}{4}$ and $28 \frac{\mathrm{I}}{2}$ mile marks. At the deepest part of the cutting the following beds are seen in descending order :The base of the Upper Chalk with numerous flints, about 20 feet; upper seam of Chalk Rock, 2 feet; white chalk with few flints (the Micraster-bed), Io feet; lower seam of Chalk Rock, 2 feet; Middle Chalk with few flints, 30 feet. The beds are approximately parallel and are interrupted with occasional faults, the dislocations being very apparent in the seams of Chalk Rock.

The series of beds thus shown indicates several variations in the depth of the sea which were accompanied by changes in the fauna. That for the Middle Chalk below the Chalk Rock suggests a deep sea of I,000 fathoms or more; that for the lower bed of Chalk Rock much shallower water; again a deepening for the Micraster-bed, followed by another period of shallower water during the formation of the upper bed of Chalk Rock; and then a great depression of the sea-floor during the deposition of the Upper Chalk.

Much original work on the palæontology of the Chalk Rock has been accomplished in recent years, especially by Dr. Morison ${ }^{1}$ and $\mathrm{Mr}$. Henry Woods, ${ }^{2}$ the latter of whom has figured and described several species found near Luton. The most prevalent forms which occur in this district are the sponges $V$ entriculites, Cepbalites, and Plocoscypbia; the echinoderms Micraster, Holaster, and Echinocorys; the gastropods Trocbus, Turbo, Avellana, Aporrbais, and Pleurotomaria; and the cephalopods Nautilus, Ammonites, Scapbites, Turrilites, Baculites, Ptycboceras, and Heteroceras. Taken in the aggregate these genera present a group which is incomparable with any other in the Chalk series.

The absence of flints in the Chalk Rock, and the finding of a pebble of quartzite in it near Luton, are noteworthy.

The deepening of the sea at the commencement of the Senonian or Upper Chalk period was accompanied in this area by a great palæontological break which indicates a cessation of deposition of strata for a prolonged interval after the formation of the Chalk Rock. The presence of dislocations in the lines of bedding in the Middle Chalk and their absence in the Upper Chalk are confirmatory of the assumption that there were great oscillations in the level of the sea-floor at the close of the Middle Chalk period. The surface of the Chalk Rock also sometimes appears to show indications of erosion.

The UPPER Chalk, of which only the lower portion is present in Bedfordshire, covers the summits of the hills in the south of the county, and is often concealed by accumulations of gravel, loam, and clay. That it has been subjected to an enormous amount of denudation is attested by the numerous flints which are present in the superficial deposits of the district. Those in the drift gravels are usually much

1 'Notes on the Chalk Rock,' Trans. Herts Nat. Hist. Soc. v. 199-202 (1889).

2 'The Mollusca of the Chalk Rock,' Quart. Foum. Geol. Soc. lii. 69-98, liii. 377-404 (1896-7). 


\section{GEOLOGY}

waterworn, while those in the clays, having been subjected to less attrition, retain their angular form. Each separate flint is an index of a much larger amount of chalk which has been removed; and so numerous are the flints over this area that it is a popular belief that 'stones grow,' the supposition being that the supply is maintained by their production within the soil by some occult influence. This is more particularly the case in the soil covering the superficial stratum known as clay-with-flints.

Considered lithologically the Upper Chalk is a soft, white, almost pure limestone which in weathering separates into thin flakes. It contains flint both in the nodular and tabular forms. Its exposures in this district are neither numerous nor extensive; they lie chiefly between Luton and the extreme south of the county. A chalk-pit at East Hyde exposes about 20 feet of this stratum. Near the top of the section is a thin layer of marly chalk similar to those which occur in the Middle Chalk but remarkably even. About 3 feet below this, and parallel with the lines of deposition, is a thin seam of flint which breaks into small fragments under weathering. There are also present numerous flint nodules, most of which are disposed in layers, a few being distributed unequally through the mass of chalk.

The most typical fossils which have been recorded from this stratum in Bedfordshire are Ecbinocorys vulgaris, Ostrea normanniana, Pecten quinquecostatus, and Belemnitella quadrata.

Between the period of the Upper Chalk, which closes the Mesozoic epoch in western Europe, and the commencement of the Cainozoic epoch, important changes were effected in the life-history of this part of the globe, whole genera of organisms becoming extinct. As examples represented in the Mesozoic strata of the county may be named the marine reptiles Icbtbyosaurus, Plesiosaurus, and the winged Pterodactylus, and also the cephalopods Ammonites, Scapbites, and Belemnites. The allied genus Nautilus, which occurs in several of the local beds, still survives, being now found in tropical seas.

The Chalk once extended very much farther to the north-west than it now does. Proofs of such former extension of one formation over another are furnished by outliers, which are detached portions of the main mass. Instances of such outliers of the Chalk Marl on the Gault occur at Billington Hill near Leighton, and between Upper and Lower Gravenhurst. These however only give a slight idea of the former extent of the great Chalk formation. The Chalk of the southmidland and eastern counties was once continuous with that of Lincolnshire and Yorkshire, having since been cut through by the rivers which flow into the Wash.

\section{EOCENE-READING BEDS}

A long interval must have elapsed between the close of the Mesozoic era in western Europe and the commencement of the Cainozoic, and this was more prolonged in Bedfordshire than in the south of 


\section{A HISTORY OF BEDFORDSHIRE}

\section{England owing to the absence of the latest Cretaceous and earliest}

Eocene strata.

There are great contrasts between the Upper Chalk and the Reading Beds, which, when present in this area, lie in contact with it. Palæontologically the contrast is between the fauna of a deep sea and that of an estuary; stratigraphically between a nearly pure limestone of organic origin slowly and evenly deposited, and bright-coloured clays, sands, and pebbles accumulated rapidly and distributed irregularly. The arm of the sea in which these beds were deposited extended from the district which is now the south midlands, to Hampshire or beyond, including the areas known as the London and Hampshire Tertiary Basins. The northern margin of the London Basin runs through the south or Hertfordshire, and beyond and not far from it there is a series of Eocene outliers of considerable extent followed by another of much smaller ones; and far away to the north, in South Beds, a few very small ones have escaped the complete denudation which has removed the intervening mass, testifying to its former extension. These are in the parishes of Caddington, Kensworth, and Studham, the largest being near Ringsall.

In the superficial deposits of the valley of the Lea, within our county, there are frequently found large masses of conglomerate or 'pudding stone,' which are probably of the same origin as the Hertfordshire conglomerate. As they are but slightly waterworn they may have been dropped into their present position owing to the dissolution of the softer strata of the Reading Beds of which they formed a part. One that was met with in a shallow excavation just south of Luton measured 6 feet long, 3 feet wide, and 2 feet thick. The pebbles of the Reading Beds, which are thus locally consolidated into a conglomerate with a siliceous matrix, are almost invariably chalk-flints, indicating that the higher Cretaceous strata were subjected to an enormous amount of erosion at the beginning of the Eocene epoch.

\section{PLEISTOCENE}

The greatest change of climate which is definitely known to have taken place in this area and western Europe generally, occurred between the Eocene and Pleistocene epochs, tropical conditions giving place to arctic. The tropical fauna and flora of the London Clay became subtropical in later Eocene times, and continued so during the Oligocene and Miocene periods. Early in the Pliocene period temperate conditions set in, and before its close the climate had become boreal or arctic. This change or climate was accompanied by considerable alterations in the distribution of land and sea, the whole of south-eastern England from the Severn to the Humber being at first submerged, then rising so far above the waters that Britain became joined to the continent, neither German Ocean nor English Channel existing, and finally again becoming submerged. It was probably about this time, that is towards the close of the Pliocene period and before the last great submergence, that our 



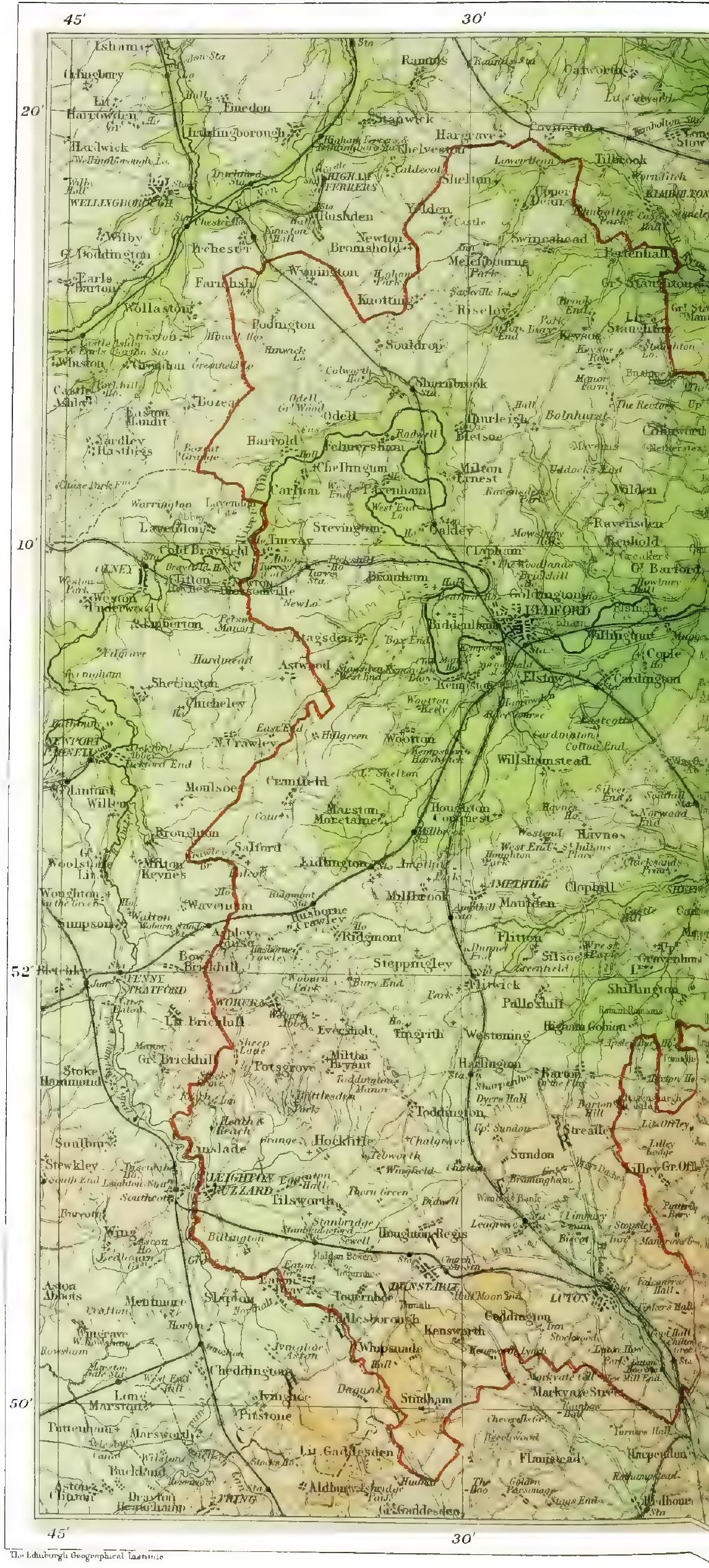


PHICAL MAP.

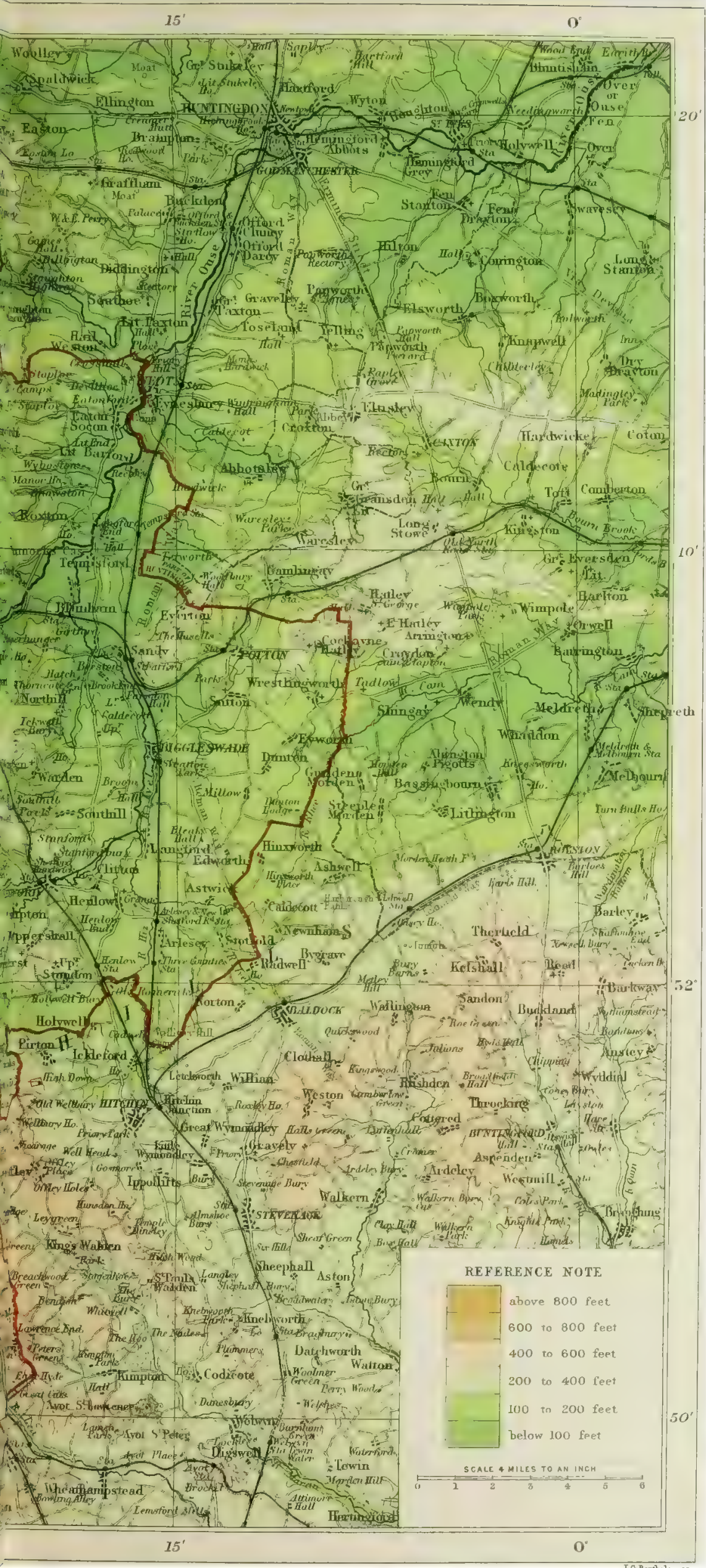

THE COUNTIES OF ENGLAND

County Boundary shown thus 



\section{GEOLOGY}

existing south-eastern river-system originated, and that the northern escarpment of the Chalk commenced to be formed by the erosion of a river with its tributaries flowing towards the north. There is no reason to suppose that any great physiographic alteration has taken place since that time in the lower valley of the Thames, besides its deepening and its widening on the north where it has encroached upon the catchmentbasin of the northerly-flowing river; but many changes must have taken place in the course of the latter river during the long period in which it has been developing into the present sinuous Ouse.

But the features then impressed upon this district were afterwards obliterated by the great ice-sheet which advanced from the north and ploughed up the surface, leaving its record in the chalky boulder clay which covers the greater part of Bedfordshire. This is not nearly the earliest of the Pleistocene deposits, earlier beds of a very varied nature, showing great changes to have taken place both in climate and in the distribution of land and water, having been deposited elsewhere. It is thus seen that a very long period elapsed of which there is no record in the county, even in Pleistocene times, and to this must be added the whole of the interval since almost the commencement of the Eocene period. It would be useless to give a sketch of the geological history of Britain during all this time, for how Bedfordshire fared would have to be left to the imagination. ${ }^{1}$ What was the condition of the district when the chalky boulder clay was deposited, whether the land was submerged or not, is a disputed point ; but from the presence here and there of marine shells in beds of gravel and sand intercalated with the boulder clay, it seems most probable that in the southern portion of its course the ice-sheet travelled over submerged land, abrading the submarine hills and filling up the submarine valleys by material dropped into the sea from icebergs or from the under-surface of the ice to which it was frozen and from which it would become detached on the partial thawing of the ice as warmer latitudes were reached. The northern land from which this ice-sheet came, whether Scandinavia or Scotland or no farther than Shap Fell, was no doubt much above the level of the sea, the submerged area probably extending over the whole of the midland and eastern counties, including Bedfordshire.

The 'great chalky boulder clay,' as it has been called, covers an area in these counties of nearly 5,000 square miles, including nearly the whole of Bedfordshire except the valley of the Ouse, which has been cut through it, and part of the county south of Bedford where it occurs in patches. Portions of the hills of the Lower Greensand and of the Chalk are free from it, and in some places it is difficult to say whether it is present or not, for over the Oxford Clay and the Gault there has been such a mixture of the older and newer clays that the presence of the boulder clay can only be inferred by the drifted rocks and fossils which occur in it and work up to the surface of the land. This admix-

1 Part of this period is treated of in the V.C.H. Hertford, in the account of the Westleton Shingle and Middle Glacial sands and gravel, on Pp. 18-23. 


\section{A HISTORY OF BEDFORDSHIRE}

ture of the clays is of great benefit to agriculture owing to the amount of chalk which the boulder clay contains.

While this clay occurs in such cases only as a thin sheet, sometimes it attains a great thickness. Over a considerable area it is from 30 to 50 feet thick; in the valley of the Ivel near Sandy, as already stated, it is known to attain a thickness of $\mathrm{IO}_{4}$ feet, and in the same valley near Biggleswade it has recently been ascertained to be 90 feet in depth. In each of these localities it has been cut through in wellsinking, and in the latter a transported mass of Ampthill Clay, 67 feet in thickness, was found in its midst. ${ }^{1}$ At the well at Northill near Sandy, which is west of the Ivel, the surface-level is about I ${ }_{5}$ feet above ordnance datum, and the base of the boulder clay which rests on Oxford Clay is therefore nearly at mean sea-level, while at the well near Biggleswade the surface-level is 160 feet above ordnance datum, and the base of the boulder clay which rests on disturbed and denuded Gault is 55 feet above mean sea-level. There is evidently a Glacial or pre-Glacial valley here which has been filled up by boulder clay, and it would be of great interest if its further extension could be traced. Biggleswade is on its eastern flank; Northill may or may not be in its centre, but cannot be far off it; and the evidence points to the conclusion that the Ivel flows through a valley of earlier formation than that of the Ouse above the junction of the two rivers; but whether this valley, now nearly filled up by boulder clay, was the deep channel of a glacier or that of a powerful river which flowed in Pliocene times, if so probably during the period of greatest elevation of the land, cannot be determined without much further knowledge of the contour of the old land-surface beneath the boulder clay than we now possess.

The boulder clay is a tenacious brownish or bluish clay containing numerous subangular fragments of rocks of various kinds, and sometimes large boulders, transported from a distance, with lumps of hard chalk and Liassic and Oolitic fossils, usually water-worn. Its boulders are ice-scratched, and glacial strix may even be seen on its chalk pebbles. These are usually of hard chalk, red as well as white, very similar to that of the Yorkshire Wolds. The harder rock-fragments are of granite, syenite, quartzite, limestone, etc., from a distant source, and flints from the Chalk ; and the 'boulders,' as shown above, sometimes take the form of huge masses of adjacent strata of a soft nature. Chalk in the boulder clay has even been quarried.

At Toddington, a village situated nearly at the top of a hill which rises to a little over 500 feet above sea-level, there is a bed of gravel the precise geological age of which is uncertain. It has been described by Mr. Worthington Smith ${ }^{2}$ from information given to him by the late Major W. C. Cooper of Toddington Manor. It is a flint-gravel with many

1 An account of this discovery was given by Mr. Henry Home in a paper read before the Geological Society on 24 June 1903 , and published since this was in type (Quart. Fourn. Geol. Soc. lix. 375-81).

2 In Man, the Primeval Savage, p. 69. 


\section{GEOLOGY}

rocks and fossils drifted from a distance, including basalt, porphyry, granite, slate, encrinital limestone, red sandstone, rocks and fossils from the Coal Measures, Lias, and Oolites, and ironstone from the Lower Greensand, etc. Major Cooper has also found in it 'a good red-tinted example of Pectunculus glycimeris . . a apparently from the Crag,' and 'a patella from one of the hind legs of Cervus elapbus.'

This gravel appears from its constituents to be of glacial origin, but differs somewhat from the Middle Glacial sands and gravels below or intercalated with the boulder clay in Hertfordshire and elsewhere. It may possibly represent the plateau or 'cannon-shot' gravel which overlies the chalky boulder clay in many places in the eastern counties, and which ' may perhaps have resulted in part from the melting away of the ice-sheet that formed the clay.' ${ }^{1}$ It is difficult to account for the presence in it of a bone of the red deer, but that may have been derived from beds of later Pliocene age, and it does not necessarily indicate a non-marine origin for the gravel. ${ }^{2}$

Bedfordshire was certainly beneath the sea at the close of the Glacial epoch, if not during the deposition of the boulder clay, and before the land again rose milder conditions had set in. There are evidences of successive stages of elevation before the present level was attained and the British Islands were finally cut off from the continent of Europe. It was during this period that much the greater part of our present fauna and flora was introduced from the continent, and that early man reached Britain, for his advent must have preceded the formation of the Straits of Dover by which England was finally severed from France. It was also during this period of elevation that the present river-system of Bedfordshire originated, except in the case of those streams which took the course of existent or pre-Glacial valleys not entirely filled up by boulder clay. Snow-fields had not altogether disappeared from Britain, for as our present mountainous districts rose higher and higher after their submergence to a depth of at least 2,000 feet, they were again covered by ice and snow, the glaciers from which have left icegrooved rock-surfaces and moraines as evidence of their passage down the valleys. In the lowlands the rainfall was probably copious, and as the rivers in the midland and eastern counties flowed over boulder clay, percolation would be small and most of the rain which fell would flow off the surface and make the rivers large and swift and the rate of denudation much greater than it is now. This is the period of the formation of the older river-gravels, much of the material of which was derived from the erosion of the boulder clay, the clay being carried down the swift-flowing streams in suspension, leaving sheets of gravel, and being deposited as alluvium when the current became less swift.

The river Ouse in its passage across the county flows in a valley

1 H. B. Woodward, Geology of England and Wales, ed. 2, p. 510.

2 Since the above was in type we have seen, near the summit of the hill west of Toddington, exposures of this bed of gravel and sand which we consider to be a local development of the boulder clay (the higher part here) into which the bed merges. 


\section{A HISTORY OF BEDFORDSHIRE}

of Recent alluvium usually flanked on either side by Pleistocene gravel forming a bed from 10 to 20 feet thick resting on Oolitic strata at a considerably higher level than the present surface of the river. Between Felmersham and Bedford the river is very sinuous, below Oakley the gravel exceeds a mile in width, and below Bedford its width exceeds 2 miles, in places extending to 4 miles. At Tempsford, where the Ivel joins the Ouse, the bed of gravel narrows to about a mile in width. The Ivel and the Hiz have formed similar but less extensive beds of gravel along their courses, and so has the Lea, the town of Luton being situated on such a bed about half a mile in width, which extends, though narrower for the most part, to above Leagrave Marsh for some distance beyond the present source of this river.

The old river-gravels of the Ouse near Bedford have been described by Sir Charles Lyell in his Geological Evidences of the Antiquity of Man. ${ }^{1}$ It was at Biddenham, about 2 miles west of Bedford, that in I $861 \mathrm{Mr}$. James Wyatt first found the earliest traces of man in these gravels which here form the capping of a low hill nearly encircled by one of the windings of the river. Sir Joseph Prestwich had ascertained that the valley was bounded on both sides by Oolitic strata capped by boulder clay through which it had cut its way, and also that the gravel 'contained bones of the elephant, rhinoceros, hippopotamus, bos, equus, and cervus, which animals he therefore inferred must have been posterior in date to the boulder clay.' In the same gravel many land and freshwater shells had been found by Sir John Evans. These discoveries induced $\mathrm{Mr}$. Wyatt to very carefully watch the excavation of the gravel from day to day for some months, and at last he saw two well-formed implements thrown out by the workmen 'from the lowest bed of stratified gravel and sand, i 3 feet thick, containing bones of the elephant, deer, and ox, and many freshwater shells.' The implements occurred at the base of the gravel and rested immediately on Oolitic limestone at a height of 40 feet above the present level of the river. Since then Mr. Wyatt found several other flint tools in this gravel, and also a freshwater mollusc, Hydrobia marginata, which occurs in the south of France but no longer inhabits the British Isles. Remains of Elephas antiquus have been discovered in the same gravel at Biddenham and elsewhere, and 'at Summerhouse Hill, which lies east of Bedford, lower down the valley of the Ouse, and four miles from Biddenham,' Mr. Wyatt obtained 'a flint implement associated with bones and teeth of hippopotamus.' Sir Charles Lyell concluded that the Bedford sections 'teach us that the fabricators of the antique tools and the extinct Mammalia coeval with them, were post-glacial, or, in other words, posterior to the grand submergence of central England beneath the waters of the glacial sea.'

The most important discovery of flint implements in the county is that of Mr. Worthington G. Smith at Caddington, an account of which

1 First edition (1863), pp. $163-6$; $4^{\text {th }}$ ed. $(1873)$, pp. $214-7$. The quotations here given are from this, the last, edition. 


\section{GEOLOGY}

is given in his work, Man, the Primeval Savage (1894). Caddington lies nearly at the head of a dry valley which must have been excavated by a stream at one time flowing past Kinsbourne Green, Harpenden, and Sandridge, between the valleys of the Ver and Lea, and joining the Colne near Wilkins Green about midway between St. Albans and Hatfield, a distance, measured along the windings of the present valley, of I 4 miles. This valley commenced in a swamp, outlying portions of which may have drained into the Lea on the east and the Ver on the west. Boulder clay then covered the hills; only one patch of it has been left in position within a mile of Caddington, but its former presence elsewhere in this district is proved by the occurrence of a claystained Grypbaa and ice-scratched flints which must have been washed out of it, and by seams of the boulder clay itself which have been carried down to the horizon of the swamp. Close to the village 'an ancient chalk valley, filled in with water-laid brick-earth ... serpentine on plan, as if made by a brook, has been followed in its curved course, and dug out by the brickmakers for the clay.' This appears to have led into the present dry valley of Ailey Green which joins the valley of the Ver at Friars Wash.

The brickfields at Caddington are in loam or brick-earth overlying the Chalk, and it is in these that Mr. Worthington Smith has discovered a Palæolithic floor or old land-surface on which primeval man lived near a shallow lake or swamp on the margin of which he established a manufactory of tools and weapons of flint. The heaps of flints have been found which were gathered together for the purpose, the finished and unfinished implements, and the flakes which have been struck off them, and Mr. Smith has pieced together the implements and flakes and built up the original flint. Many of these are described and illustrated in his work, in which he says that his Caddington reattachments then numbered over five hundred.

The Palæolithic workshops at Caddington are some feet beneath the present surface of the ground. The brick-earth in which they lie is mixed in places with Reading and other Tertiary clays and pebbles which have been washed into it from an old land-surface, and it frequently shows evidence of strong current-action, while around are patches of re-deposited chalk-with-flints and long stretches of red clay-with-flints, chiefly on the higher ground. In one section one workshop was seen a few feet above another, the older one having been covered up by an accumulation of brick-earth, on the surface of which the industry was again carried on. ' The descent of the red-brown stony clay,' Mr. Smith says, 'finally drove the Palæolithic people away from the position.' And from the way in which the implements were left, finished and unfinished, and the presence of heaps of unworked flints, he is of opinion that the workmen were driven away in a hurry.

The implements found in and about these Palæolithic workshops, which are of lustrous flint, are not the oldest known to occur in this neighbourhood; for others, ochreous in colour and more primitive in 


\section{A HISTORY OF BEDFORDSHIRE}

type, are found here and there in the brick-earth, having been washed down from the higher land with the material by which the Palæolithic floor was covered up. But little of this higher land now exists, Caddington, the site of which then was near the bottom of the valley, being now nearly at the top of the hill. A flint from this brown drift has been found with apparent ice-scratchings, one of which stops suddenly at an artificially-flaked surface, showing that the scratches were made before the flint was chipped; and neither here nor elsewhere has a glacial scratch or groove been seen on an artificially-worked surface. Nowhere can evidence be found of a pre-Glacial flint-chipping animal; but man may have existed for ages before he acquired the art of chipping flints to a fine edge and so first left evidence of his presence.

The ochreous implements found in the brick-earth of the Caddington hillside are probably of the same geological age as the older implements of the valley-gravels. Both date back to an earlier period than that of the deposition of the beds in which they occur, having been washed into these beds from a pre-existing land surface; but the lustrous implements were fashioned during intervals of non-deposition of the brick-earth, the men who made them being contemporary with that formation.

While the brick-earth is mostly if not altogether water-laid, the clay-with-flints which caps the hills of Upper Chalk has a very different origin. It is the residue of the Chalk left after its dissolution by water holding carbonic acid in solution, and also of Tertiary and more recent clays which formerly covered the Chalk. Its formation has doubtless been going on during the whole of the time that the Chalk has been above the level of the sea, and it is still proceeding, but it may generally be considered as of (post-Glacial) Pleistocene and Recent age. It is a stiff brown and red clay containing unworn flints, which are often much broken up by frost and by the plough, and its presence may be recognized in ploughed fields by the soil appearing to consist of little else than broken flints. The surface of the Chalk, except when covered by an impervious stratum, is exceedingly uneven, owing to its unequal dissolution, and the clay-with-flints upon it may be of any thickness, from less than a foot when its surface is fairly even, to many feet when a 'pipe' is formed which the clay-with-flints fills up. A layer of flints in the Chalk may sometimes be seen extending across a pipe, let down a little where embedded in the clay. In an old chalk-pit on Farley Hill, now closed, a line of Chalk Rock nodules occupied a similar position in a broad but shallow pipe of brown clay.

\section{RECENT}

The Recent accumulations of Bedfordshire are unimportant, except in connection with the Neolithic flint implements which they contain. They consist almost entirely of the alluvium of existing rivers, which is nowhere of great extent. There are far wider stretches of alluvium in the valley of the Colne than there are in Bedfordshire in that of the 


\section{GEOLOGY}

Ouse, and it is not until after the Lea leaves the county that there is any considerable sheet of alluvium in its valley. Alluvium is a silty deposit of sandy clay or peaty mud, in which there may be seams of gravel. It contains recent land and freshwater shells, sometimes bones of existing animals, and occasionally Neolithic flint implements. These are fairly common on both sides of the Lea from its source at Leagrave to its outflow in the Thames. Many such implements have been found in the county, but as they do not occur in regularly-stratified deposits, usually being found on the surface of the ground or just under the surface-soil, and occasionally in alluvium, their consideration rightly belongs to the domain of Pre-historic Archæology.

\section{EARLY NOTICES OF BEDFORDSHIRE GEOLOGY}

The earliest notices of the geology of Bedfordshire relate to strata of economic importance, to petrifying earth, and to mineral springs. The soil of the county was mentioned so early as I 6 i $5 ;^{1}$ petrifying earth at 'Aspley-Gowiz' (Guise) near Woburn claimed much attention from the year $1660{ }^{2}$ and the fullers' earth of Woburn from the year $1662 .^{3}$ In I 680" it was stated that a gold mine had been discovered at "Pollux Hill' near Silsoe, and the statement was repeatedly copied, even being mentioned as a fact in Calvert's Gold Rocks of Great Britain and Ireland (1853). Although the Society of Mines Royal seized the mine and granted a lease of it, the 'gold' was merely flakes of mica in drifted stones occurring in a bed of gravel. On the Ordnance Map (old series) 'Gold Mine' marks the position north-east of Pollox Hill in a field which is still called Gold Close.

A petrifying spring at Barton was first mentioned in $173^{8} ;^{\circ}$ mineral springs generally were frequently alluded to from the year $1808,{ }^{6}$ some dozen localities for them being mentioned in various works; and ferruginous water at Priestley Bog near Woburn was analyzed by Sir Humphrey Davy in $1813 .^{7}$ It is probably of the same origin as the mineral water of Flitwick Moor and somewhat similar in composition. The Totternhoe Stone seems to have been first described in $1820 ;{ }^{8}$ and although Professor Henslow called attention to the value of phosphatic nodules for manure in I 845 , the 'coprolites' of Bedfordshire do not appear to have been noticed until $1866^{\circ}$

1 John Speed's [Description of England and Wales]: 'Bedfordshire.' (Without title-page or pagination.)

2 Childrey's Britannia Baconica, p. 86.

3 Fuller's History of the Worthies of England, P. I 14.

4 Abbot's Essay on Metallic Works, p. 203. (Not seen ; referred to in Calvert's Gold Rocks, p. Ior, under the above date. See also p. I09, in which he gives a list of unauthenticated gold localities.)

5 Atlas Geographicus, i. 150 .

- Batchelor's Agriculture of the County of Bedford, p. I 5 .

7 Elements of Agricultural Chemistry, p. 291.

- E. Hanmer, 'Letter describing the Totternhoe Stone,' Ann. Pbilos. xvi. 59. (It was in this year that William Smith published his Geological Map of Bedfordsbire, the earliest geological map of the county.)

- Rev. P. B. Brodie, 'On a Deposit of Phosphatic Nodules at Sandy in Bedfordshire'; Geol. Mag. iii. 153-5. (With analysis by Dr. Voelcker.) 


\section{A HISTORY OF BEDFORDSHIRE}

The first mention of Bedfordshire fossils seems to have been in the year $1728,{ }^{1}$ and since then much work has been done on the palæontology of the county, the results having been given in numerous papers.

The chief interest in the geology of Bedfordshire has continued to lie in the economic products and the fossils of its strata, but it was thought advisable to devote the most attention in the preceding pages to the geological bistory of the county, and especially to the physical changes which it appears to have undergone.

1 Dr. John Woodward, An Attempt towards a Natural History of the Fossils of England, ii. 93, I04. See also vol. i. (1729), pt. I, pp. 60,62 ; pt. 2 , pp. 67,72 . 


\section{PALÆONTOLOGY}

$\mathrm{B}$

EDFORD is a county of comparatively little interest to the vertebrate palæontologist, although it is probable that if the remains of reptiles from the Oxford Clay were collected as carefully as they have been in the neighbouring county of Huntingdon, the number of species from that formation might be very largely increased. Apparently only two species of fossil vertebrates-one a plesiosaur and the other a reptile of unknown affinity-have been named on the evidence of Bedfordshire specimens. The four horizons from which vertebrate fossils have been obtained in the county are the Pleistocene gravels of the valley of the Ouse near Bedford, the Cambridge Greensand, the Lower Greensand beds of Potton and the Oxford Clay. Most, if not all, of the vertebrate fossils in the Potton Sands are derived from older formations, chiefly the Kimeridge Clay, and they are therefore of much less interest than would be the case were they native to the deposit in which they occur.

The occurrence of mammalian remains in the gravels of the Ouse valley was first recorded by the late $\mathrm{Mr}$. James Wyatt, ${ }^{1}$ whose collection now belongs to the corporation of Bedford. The most important pits whence the remains were obtained are those of Cardington, Harrowden, Biddenham and Kempston. The species recorded by Mr. Wyatt (many of whose specimens were submitted to Sir R. Owen) are as follows :-

The wild ox or aurochs (Bos taurus primigenius), the red deer (Cervus elaphus), the reindeer (Rangifer tarandus), the Pleistocene hippopotamus (Hippopotamus ampbibius major), the woolly rhinoceros (Rbinoceros antiquitatis), the straight-tusked elephant (Elephas antiquus) and an undetermined species of bear. Specimens in the Wyatt collection are referred to the mammoth (Elepbas primigenius), Pleistocene bison (Bos priscus), and cave-bear (Ursus spelaus).

As I learn from private information, the Chalk-notably its middle and lower divisions-has yielded remains of fishes. Among these, the ridged and pustulated quadrangular crushing teeth of the ray-like Ptychodus are by no means uncommon, as are the pointed teeth of sharks of the genus Lamna, while those of another type of shark, Corax, are more rarely met with. Other remains of fishes have been referred to the genera Cimolicbthys and Enchodus.

1 See Quart. Fourm. Geol. Soc. xvii. 366 (1861), xviii. 113 (1862), xx. 183 (1 864). 


\section{A HISTORY OF BEDFORDSHIRE}

Two reptiles have also been identified from the Chalk of the county, namely the common Cretaceous fish-lizard Icbtbyosaurus campylodon, of which an imperfect jaw is known from the Totternhoe Stone at Chalton; and the large short-necked pliosaurian Polyptychodon interruptus, of which the large fluted conical teeth occur in the Chalk-marl.

I am informed that Mr. W. Ransom of Hitchin has in his collection remains of the cave-lion (Felis leo speleaa) and wild horse (Equus caballus fossilis) from Langford.

Mr. J. S. Elliott has shown me a tooth of the above-mentioned saurian Icbtbyosaurus campylodon and another of a shark from the Cambridge Greensand of Henlow ; and the coprolite-pits in that formation have doubtless yielded many other vertebrate remains similar to those from Cambridgeshire.

Among the reptilian remains from the Potton Sands is included the base of a dinosaurian skull, described by Professor H. G. Seeley ${ }^{1}$ as Craterosaurus pottonensis; it is too imperfect to afford decisive evidence as to the affinity of the animal to which it belonged. Bones and teeth of the great three-toed bipedal reptile of the Wealden, the Iguanodon, occur not uncommonly in these deposits; as well as those of its carnivorous cousin Megalosaurus. Crocodiles are represented by the huge Dacosaurus (or Geosaurus) maximus, of which the conical and carinated teeth have been washed out of the Kimeridge Clay and reburied in these deposits.

Remains belonging to both groups of the great marine saurians characteristic of the Secondary period are also common in the Potton Sands. Of the ichthyosaurs, or group in which the head is large, the neck short, the eyes furnished with a ring of bones, and the bones of the paddles articulated together in a pavement-like manner, the Cambridge Museum possesses a fine series of remains from these deposits. Of the second group, or plesiosaurs, in which the neck is often long and the bones of the paddles are of more normal type, several forms are known. Among the long-necked and small-headed types are Colymbosaurus trocbanterius, C. brachistospondylus and Murcenosaurus truncatus, all of which occur typically in the Kimeridge Clay. From the same formation are derived the large triangular teeth of Pliosaurus-a short-necked and large-headed member of the group-which are of such common occurrence in the Potton beds.

Scales, spines, palates and teeth of several kinds of Jurassic fishes are likewise met with in the Potton beds. Among these it will suffice to mention the large button-like teeth and polished rhomboidal scales of the Kimeridgian ganoid Lepidotus maximus, the palates of the pycnodont ganoid Gyrodus cuvieri, the elongated crushing teeth of the shark Hybodus obtusus, derived from the Kimeridge or Oxford Clay, and the dental plates of Iscbyodus torwnsendi, a species belonging to the same group as the modern chimæra, whose remains occur typically in the Portland Limestone of Wiltshire and Dorsetshire.

\footnotetext{
1 Quart. Fourn. Geol. Soc. xxx. 183 (1874).
} 


\section{PALÆONTOLOGY}

From the Oxford Clay of Bedford the late Professor J. Phillips described the fore-limb of a long-necked plesiosaurian under the name of Plesiosaurus eurymerus. The species, of which nearly perfect skeletons have subsequently been obtained from the same formation in Huntingdonshire, is characterized by the great width and shortness of the upper bone (humerus) of this limb, and is now known as Cryptoclidus eurymerus. Another plesiosaurian, Peloneustes pbilarcbus, which is nearly related to Pliosaurus, is represented in the Oxford Clay of the county by an imperfect skeleton (now in the British Museum) from Kempston. Finally, an imperfect dermal spine in the same collection from the Oxford Clay of Bedford indicates the occurrence of an armoured dinosaur probably belonging to the genus commonly known as Omosaurus. 




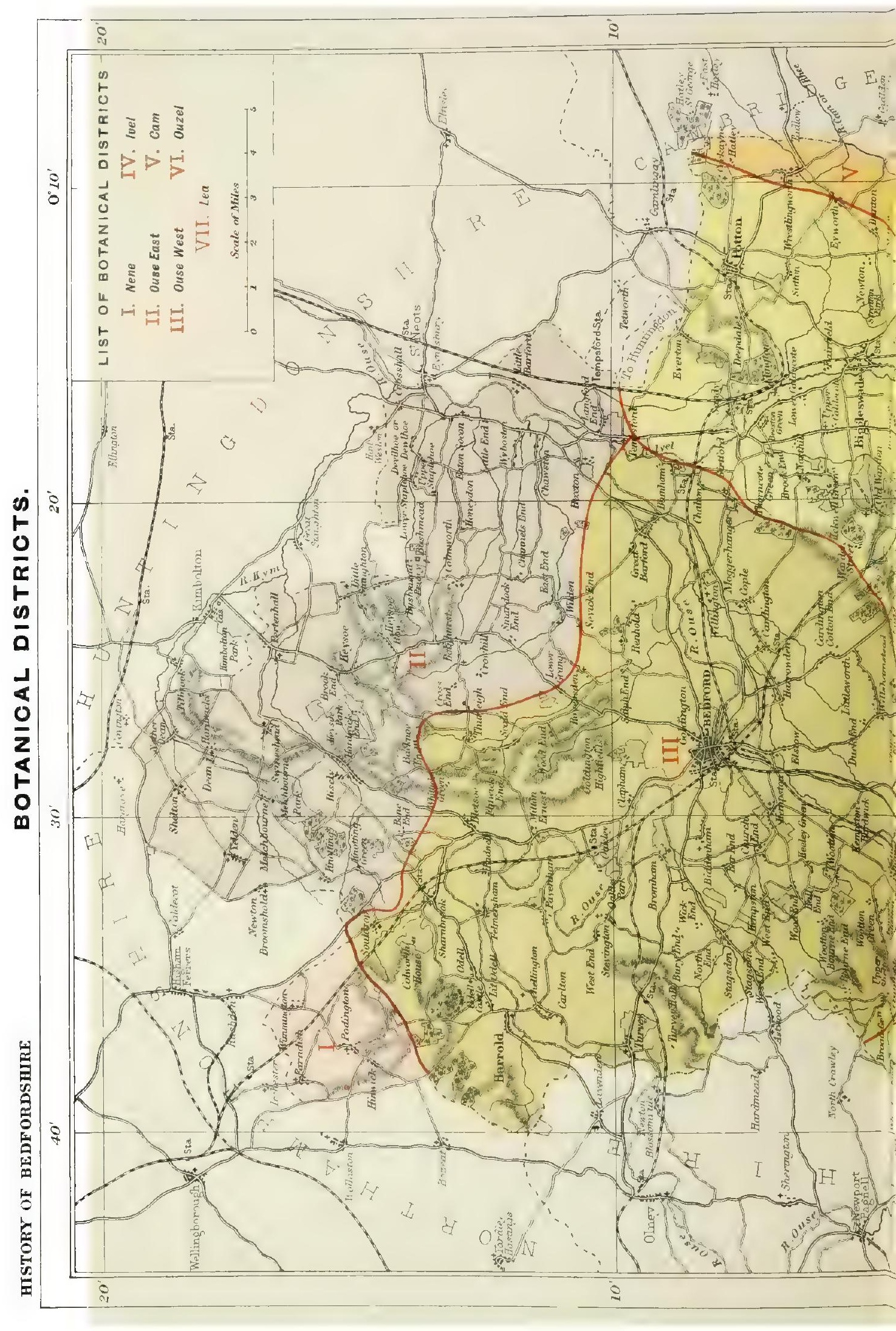




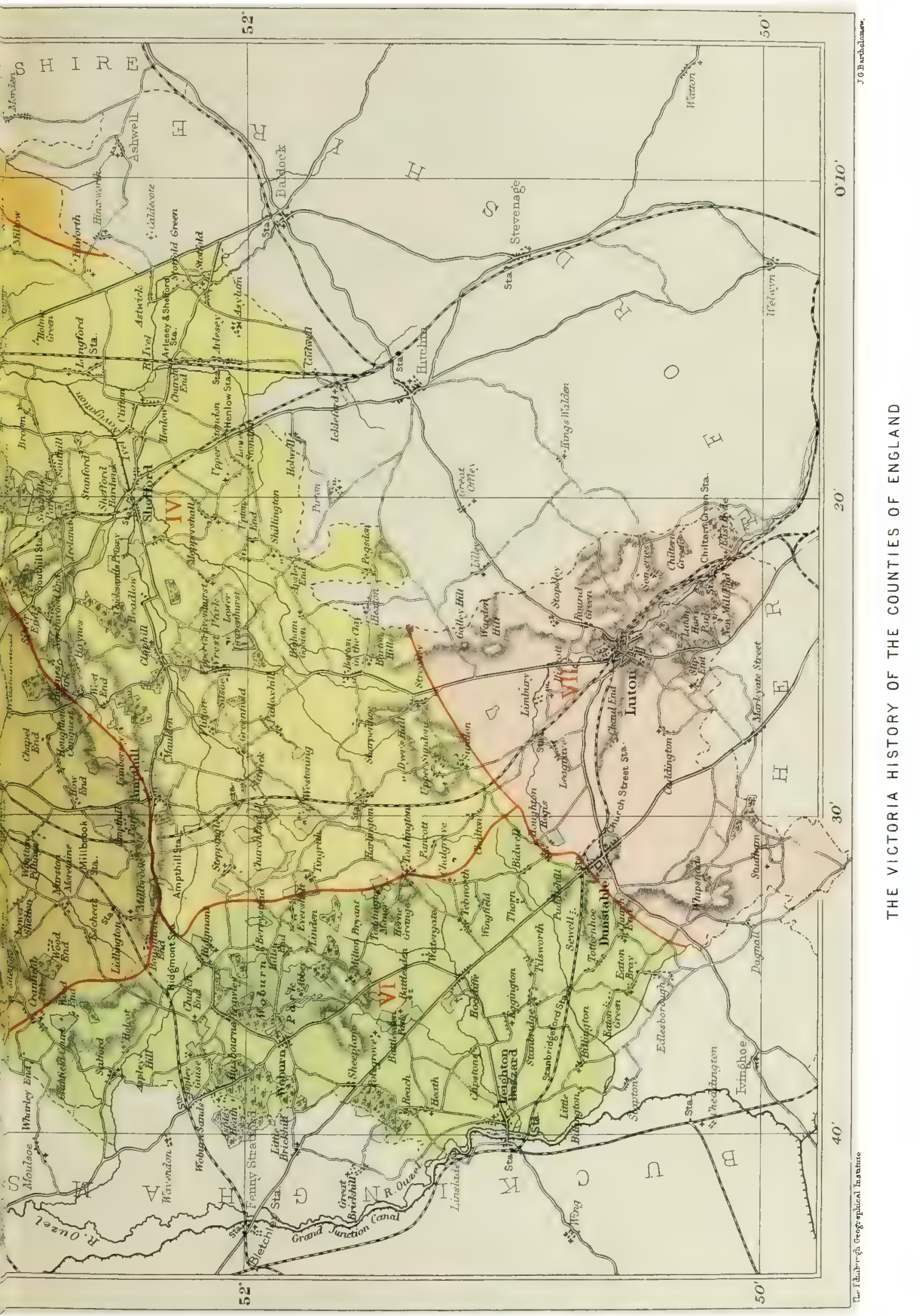





\section{BOTANY}

$\mathrm{I}$

T must be confessed that although a considerable proportion of the species of plants which actually occur have been put on record, yet their distribution through the various parishes of the county is at present inadequately known, and the knowledge of such critical genera as the brambles, roses and eyebrights, the segregation of which has during the last years of the nineteenth century been made the object of special study, is most imperfect. The publication of this sketch of the flora of the county, incomplete as it avowedly is, will, it is to be trusted, stimulate local workers to fill up the lacunæ, and to prepare a complete flora such as exists for so many other counties.

It is true a very excellent work on the subject, the Flora Bedfordiensis by the Rev. Charles Abbot, D.D., of Oakley Raynes, was published in I 798, but necessarily a work issued at that date is insufficient in detail, and has an archaic nomenclature. Moreover shortly after its publication the Enclosure Act led to a considerable change in the vegetation of the county from the introduction of hedges as separating boundaries to the fields, and from the enclosure of commons, some of which had at one time a heathy growth, but which soon under the influence of cultivation lost much of their original flora, and either as pasture or arable land became like their neighbours in possessing few plants of interest; indeed so rare has the true heath (Erica cinerea) become that it now exists, it is said, in only one locality in the county. The higher cultivation of arable land and the more complete system of drainage have likewise been factors in gradually eliminating some of the original species from their homes and replacing them by less interesting and more widely distributed plants. Nor is the process arrested; each decade threatens some local species, and witnesses the encroachment of common plants. Need we wonder then that several plants mentioned by Abbot have either become extinct, or are now so scarce as to have evaded the observation of recent botanists.

The area of the county is small, indeed only Hunts, Middlesex and Rutland are smaller in England. Compared with other counties its flora is small also; there are several reasons, apart from the mere extent of surface, why this should be so, the chief of these perhaps being the excellent condition of tillage and cultivation of the surface soil, which necessarily means that the aboriginal features of the flora have long ago disappeared; while, although so much of the surface is below two hundred feet in altitude, yet the drainage is so complete that few marshes, 


\section{A HISTORY OF BEDFORDSHIRE}

and still fewer bogs, remain. Bedfordshire has neither any large expanses. of water such as the East Anglian broads, with their interesting aquatic vegetation, nor any rocky escarpment on which a rupestral flora could grow, as in the Derbyshire dales; indeed the limestone of the Great Oolite only comes to the surface in small and widely separated patches, and were it not for the long line of the Chalk escarpment, and the elevations of the Greensand at Woburn and Sandy, the flora would possess but few species of an attractive character. In the few pages allotted to this subject it is desired to give the salient features of the county botany and to show how they compare with those of some of the bordering counties.

In its general character Bedfordshire has much in common with the botany of Buckinghamshire and Hertfordshire, since the dominating feature in each is the long range of the Chalk hills, and the picturesque escarpment of the Lower Greensand about Woburn also extends into Buckinghamshire.

As there is no sea coast, there is, with the exception of a few casuals, no maritime flora. The physical character of the county is very varied for so small an area, but for botanical purposes the geological formations offer naturally two main divisions which are not disproportionate in size. Putting it briefly, the northern division is clay, with a river valley of alluvium, gravel and limestone; the southern division has a lighter soil, which in turn falls into two divisions, Greensand and Chalk, with a slice of Gault sandwiched between them. In the following observations the terms northern and southern divisions will denote these geological characteristics.

In the north most of the hills are capped with Boulder Clay, which also forms a broad patch between the windings of the Ouse. The Oxford Clay comes to the surface south of the county town as far as Lidlington, where it is succeeded by the Lower Greensand. Following the course of the Ouse, besides the gravels and alluvium there are exposures in bands of Oolitic limestone and Oxford Clay and Cornbrash-the latter forming a persistent bed of slight thickness and about a quarter of a mile wide. The Lower Greensand enters the county at Leighton Buzzard and crosses it about mid-way. Aspley Guise, Lidlington, Millbrook, Haynes, Southill, Sandy and Everton are on its northern edge. At Leighton, Heath, Tingrith, Pulloxhill, Silsoe, Campton, Shefford, Eyworth and Potton, the Greensand is contiguous with the Gault, which extends in a narrow band from Eaton Bray on the south-west to Arlesey on the east. Along the line of contact the surface soil is often of a mixed character, chiefly owing to farming operations. The Lower Chalk succeeds the Gault at Dunstable, Eggington, Chalgrave, Toddington, Harlington, Hexton, Stondon, Arlesey and Stotfold. The Chalk without flints is well developed in the south of the county. A flora typical of the Chalk is found on the downs of Luton and Dunstable, and the characteristic orchids are plentiful in those localities but are not confined to them. The bee (Opbrys apifera), the fragrant (Habenaria conopsea), 


\section{BOTANY}

butterfly ( $H$. cbloroleuca), and the helleborines Epipactis latifolia and $E$. violacea are not infrequent in the northern division, owing apparently to the calcareous nature of the subsoil in many parts. Among plants which seem to occur only on the Chalk are the pasque flower (Anemone Pulsatilla), which flourishes on the slopes of the chalk combes near Barton, the blue milk vetch (Astragalus danicus), the horse-shoe vetch (Hippocrepis comosa), the squinancy wort (Asperula cynancbica), the field ragwort (Senecio campestris), the mountain cat's-foot (Antennaria dioica), the Canterbury bell (Campanula glomerata), the felwort (Gentiana Amarella), and the ground pine (Ajuga Chamapitys). In the list of chalk-favouring plants there are possibly others that are practically limited to the Chalk.

The Lower Greensand is responsible for several plants which in its absence would be rare or non-existent in the county. It is a warm and greedy soil, which in parts will grow little more than pines and larches, but where it is mixed with clay a very productive loam is formed, well adapted for market-gardening, as at Biggleswade, Sandy and Potton. The phosphatic nodules known as coprolites are found at the base of the Greensand at Sandy, Shillington, Sutton, Potton and Ampthill. Two other seams of coprolites occur in the Gault near Barton, but as they are usually found at some depth it would be difficult to say how far the coprolites affect the character of the flora. Among the plants which have been found only on the Greensand are the silver cinquefoil (Potentilla argentea), the saw-wort (Serratula tinctoria), the sheep's scabious (Fasione montana), the bilberry (Vaccinium Myrtillus), and the lily of the valley (Convallaria majalis). In the list there are several others that prefer the Greensand, and possibly some of them are limited to it. The grasses Aira pracox and $A$. caryophyllea occur not only on the Greensand, but also on a patch of Tertiary sand in the south of the county.

The river Ouse at Bedford is about 90 feet above sea-level. Luton rises from $35^{\circ}$ to $45^{\circ}$ feet, Dunstable to 483 feet, and Dunstable downs to 799 feet. The northern part of the county is hilly, though the heights rarely exceed 300 feet. In the centre and on the eastern side the county is flat right away into Cambridgeshire, but it can hardly be described as fen country.

For the last hundred years, especially, the county has been under very high cultivation, particularly in the market-gardening districts. The most interesting piece of marshland is undoubtedly Flitwick Moor, which is a peat bog on Greensand, associated with the river Flitt, and containing a chalybeate water derived from the ferruginous subsoil in contact with vegetable acids. At Gravenhurst there was formerly an interesting moor where such plants as the marsh arrow-grass (Triglocbin palustre) and the marsh helleborine (Epipactis palustris) grew. Mr. C. Crouch reports that the former is still found on what survives of the moor, though the orchid is apparently extinct in the county; and in referring to such plants as the flea sedge (Carex pulicaris), the butterwort (Pinguicula vulgaris), and the grass of Parnassus (Parnassia palustris), which he found on the dry chalk of the Markham Hills, he 


\section{A HISTORY OF BEDFORDSHIRE}

speaks of them as seedling survivals of an ancient bog which filled the present valley. In August, I90 I, Mr. Saunders, after many years' search, at last found Erica cinerea in a green lane near Pepperstock. There was only a small patch, and it was evidently a relic of the flora of a large common that formerly existed. At Stevington, Ampthill, Potton and elsewhere there are remains of ancient marshland, which would probably repay more careful examination than they have received. Some of the older woods contain interesting native plants, such as the wild licorice (Astragalus glycyphyllos), the crested cow wheat (Melampyrum cristatum), the nettle leaved bell flower (Campanula Trachelium), and the birds'-nest orchid (Neottia Nidus-avis).

The following table corrected to the present date shows the number of species which are reported on good authority to have been seen growing in a wild state in the various counties, the standard adopted being practically that of the last edition of the London Catalogue, which has already been followed in the accounts of the botany of the counties of Northampton, Buckingham, Berks, etc.

\begin{tabular}{|c|c|c|c|c|c|}
\hline $\begin{array}{l}\text { Native plants } \\
\text { Denizens and colonists }\end{array}$ & $:$ & $\begin{array}{l}\text { Beds } \\
762 \\
85\end{array}$ & $\begin{array}{c}\text { Bucks } \\
845 \\
97\end{array}$ & $\begin{array}{c}\text { Herts } \\
795 \\
95\end{array}$ & $\begin{array}{c}\text { Northants } \\
765 \\
85\end{array}$ \\
\hline & & 847 & 942 & 890 & 850 \\
\hline
\end{tabular}

In addition many named varieties, several hybrids, and many species of casual occurrence, or undoubtedly alien, have been recorded.

Taking the London Catalogue as a standard of specific limitation, the total number of British species is about 2,000, but of these 250 are not native, I 44 are confined to the coast, while at least 200 are found only in northern latitudes, or only extend to the same latitude as Bedfordshire in mountainous situations in the west of England and Wales, 17 are exclusively Irish, and about 20 belong to the Channel Isles, and are not real constituents of the British flora. It will therefore be seen that about $\mathrm{I}, 35^{\circ}$ species remain which might be found in the county ; but such is not the case, and some of the influencing reasons have already been given, while others, such as soils and altitudes, need not now be referred to.

Bedfordshire, although it has no species peculiar to itself, however possesses some plants of considerable interest, among which may be mentioned the great pig-nut (Carum Bulbocastanum), which is limited to Bucks, Herts and Cambridgeshire, and is found locally in some plenty in arable fields on the Dunstable downs; the crested cow-wheat (Melampyrum cristatum), which apparently has its western limit in the county (unless indeed it really occurs in Bucks and Hants, whence it has been reported, but on somewhat uncertain evidence), occurs in some of the woodlands. Another eastern species, the sulphur clover (Trifolium ocbroleucon, Huds.), which occurs sparingly, also has its western range in this county and Surrey. Another very local species is the box (Buxus sempervirens), which by some authorities is considered to be native on the Dunstable downs, and in a few other localities such as Box Hill in 


\section{BOTANY}

Surrey, at Edlesborough and Ellesborough in Bucks, etc., but which in most of its habitats in Britain is certainly an introduced shrub. A specially interesting species is the grass $P$ bleum pbalaroides, which at one time was wrongly called $P$. Boebmeri, and has a peculiarly restricted area in Britain in the counties of Beds, Herts, Essex, Cambridge and Suffolk. The beautiful pasque flower (Anemone Pulsatilla) still occurs in the locality given by Abbot, on Barton Hills, with the mountain cat's-foot (Antennaria dioica), a very rare species in the southern midlands, although known in Northants, Oxfordshire, etc. A rare species of charad, Nitella mucronata, was found by Mr. C. Davis in 1882 in the Ouse.

\section{BOTANOLOGIA}

As will be gathered from the foregoing notes the foundation of Bedfordshire botany was laid by the Rev. Charles Abbot, D.D., who was born probably at Winchester about I76I, and was vicar of Oakley Raynes and Goldington, Beds. He was elected a fellow of the Linnæan Society in 1793 and in 1798 published the Flora of Bedfordiensis. He became D.D. Oxon in 1802 . His herbarium is still preserved at Turvey Abbey, and has been critically examined by Mr. R. A. Pryor, B.A., F.L.S. (the author of the Flora of Herts), who published some interesting details respecting it in the Fournal of Botany, x. (I88 I) 40 et seq. ; and Mr. E. M. Holmes, F.L.S., has also reported on the lichens and algæ. Dr. Abbot was a frequent correspondent of Sir James E. Smith, to whom he sent many specimens, several of which are figured and described in Englisb Botany. He also noticed Asarum europaum in the Thames valley.

The Flora Bedfordiensis included not only the flowering plants and the higher cryptogams, but also the mosses, liverworts, lichens, algæ and fungi ; though, owing to changes already alluded to, many species are no longer to be found in the stations mentioned by Abbot, and some are, it is to be feared, no longer existing in the county.

These missing species include the fen orchis (Malaxis paludosa), a tiny plant which once grew on the sphagnum bogs at Potton, the cranberry (Vaccinium Oxycoccos or Oxycoccos quadripetala), the petty whin (Genista anglica), the Lancashire asphodel (Nartbecium ossifragum), which grows at Brickhill just outside our area, the black bog rush (Scbonus nigricans), the white beaked bog rush (Rynchospora alba), the deer's clubrush (Scirpus caspitosus), the marsh St. John's wort (Hypericum elodes), the marsh fern (Lastrea or Dryopteris Thelypteris), the horse-tail (Equisetum byemale) and the flea bane (Pulicaria vulgaris); and the extinction or diminution of these may all be attributed to drainage or cultivation.

Among others which cultivation has either extirpated or rendered much more rare, are the maiden pink (Diantbus deltoides), the cress (Draba muralis), the star thistle (Centaurea Calcitrapa) and the grass Glyceria distans; the latter Abbot called Poa retroflexa. The misnomers in Abbot's Flora ${ }^{1}$ include Spergula pentandra, by which probably a form

1 See papers in Fournal of Botany (1881), pp. 40-6, 66-73. 


\section{A HISTORY OF BEDFORDSHIRE}

of the corn spurrey ( $S$. sativa) was meant; Carex montana, for which Abbot cites Leers, but Leers' $C$. montana is really $C$. ericetorum. The specimen in his herbarium is immature, but is probably C. pilulifera, and Abbot may well have been led astray by Linnæus, since the $C$. montana of Linnæus' Flora Suecica is correctly named, though the $C$. montana of the Species Plantarum is really C. pilulifera. Galium pusillum, by which early British botanists meant the plant now identified with $G$. sylvestre of Pollich, is not that species but only a form of $G$. Mollugo. His G. erectum is also a form of G. Mollugo, L. Abbot's Cerastium pumilum is not the plant of Curtis but probably a form of $C$. semidecandrum, which is still plentiful in the localities he gives, and as we gather from his herbarium where $C$. semidecandrum is represented by another species. The Polypodium cristatum from Potton Marshes and Aspley Wood is not Lastrea cristata, but $L$. spinulosa, the Callitriche autumnalis is $C$. bamulata; the former plant is absent from the midlands, and his $C$. verna is probably $C$. obtusangula. The wild everlasting pea (Latbyrus latifolius), which he records from Haynes and Bromham, is, as his herbarium shows, only $L$. sylvestris, which still occurs in the county, and sometimes with broader leaflets than those of the southern plant. His Galium spurium is really $G$. tricorne. His Veronica agrestis is $V$. polita, the grass Festuia fuitans is Glyceria pedicellata, Towns. Funcus sylvaticus is represented by Luzula vernalis, DC. ; his Vicia latbyroides is really $V$. angustifolia, and Ervum tetraspermum is Vicia birsuta, Gray; his Hieracium murorum is probably $H$. sciapbilum; his Viola canina is $V$. Riviniana; his Orcbis latifolia is O. incarnata; his Carex distans is $C$. binervis; his $C$. panicea is represented by a specimen of $C$. remota; and C. caspitosa is $C$. Goodenowii.

Mr. J. McLaren, formerly gardener to Mr. Whitbread at Southill Park, where his herbarium is preserved, was a careful investigator.

The Rev. W. Crouch, sometime curate of Lidlington, seems to have made an extensive collection of plants between the years I 84 I and I 846 . His herbarium is in the possession of Mr. Charles Crouch of Ridgmont, himself for many years an industrious observer and recorder.

The Rev. W. W. Newbould, M.A., F.L.S., the well known botanist, occasionally visited the county, and has left some records which are quoted as the Newbould MS. He supplied a considerable number of records of Bedfordshire plants to Topograpbical Botany.

Mr. W. Hillhouse, Professor of Botany at Mason College, Birmingham, was formerly at the Bedford Modern School, and when there compiled a list of the county plants in which several appeared for the first time as Bedfordshire species.

Mr. James Saunders, A.L.S., of Luton, has been one of the most assiduous workers in recent times at the flowering plants of Bedfordshire, of which he published a very complete list of species found in the south of the county in the Fournal of Botany for 1883 . He has also worked at the Characeæ, of which he discovered the rare Tolypella 


\section{BOTANY}

intricatd for the first time as a Bedfordshire plant, as well as several commoner forms. He has turned his attention also to the mosses, and more recently to the Mycetozoa.

Mr. T. B. Blow of Welwyn, Herts, made some additions to the county flora which were published in the Report of the Botanical Record Club. He also found Phalaris phalaroides in the county.

Mr. R. A. Pryor, F.L.S., the author of the Flora of Herts, added several plants to the county list including Vicia gracilis and Potamogeton pralongus. He also made a critical examination of Abbot's herbarium and published accounts of it in the Fournal of Botany, in which also appeared a valuable paper in 1875 on the plants of the county.

The following are the principal sources from which the information given in the following pages has been in the main collated :-

Flora Bedfordiensis, by Charles Abbot, M.A., F.L.S. (1798), abbreviated (Abbot); Plant Records of J. McLaren of Cardington; Plant Records of William Hillhouse, F.L.S., 1875 and 1876 ; List of the Wild Flowers of South Bedfordshire; also a List of Plants observed in North Beds, but at that time unknown in South Beds, by James Saunders, I881, abbreviated (J.S.) ; Bedfordshire Plant List, by J. Saunders and A. Ransom (I 882); 'The Wild Flowers of Bedfordshire' (List published in the Luton Advertiser), by James Saunders (1900); Plant Records by Charles Crouch, up to 190I ; Plant Lists collated, with additions by local observers, and noted by the botanical secretaries to the Beds Natural History Society, by J. Hamson, I 886 to I90I ; various Herbaria referred to in the lists ; Records of Musci, Characex, Hepaticæ and Mycetozoa, by James Saunders ; Hymenomycetes and other fungi, by J. Hamson, I 885 to I $90 \mathrm{I}$, who has also made a collection of Mosses which, with the records by Dr. S. Hoppus Adams, mostly refer to the northern division; Records of Flowering Plants noticed by G. Claridge Druce, abbreviated (Druce).

\section{THE RIVER DRAINAGE AS A BASIS FOR THE DIVISION OF THE COUNTY INTO BOTANICAL DISTRICTS}

In the lists of the Flora of the various British counties which have been published during the latter part of the nineteenth century, it has been the almost universal custom to select the river drainage of each county as a means of subdividing it into districts, thereby showing the plant distribution in a more scientific manner, and enabling the student of phyto-geography to more easily compile a flora of a river basin which might be contained in several counties. There is no doubt such a plan possesses considerable advantages, but it also presents difficulties, and these are especially felt when the water partings are obscure, but they are not greater or indeed so formidable as those which are met with if the boundaries were made conterminous with a geological stratum or a surface soil. Therefore in order to bring the county into line with those of its neighbours which have a published flora, a plan is here suggested for dividing Bedfordshire into districts based upon its drainage, which shall as far as possible be uniform with those adopted for the counties of Herts, Buckingham, and Northants. Bedfordshire is contained in the two great basins of the Ouse and Thames, but by far the larger portion belongs to the former river, which has a most erratic course through the county and forms its western border for about three miles; it has a tributary in the south-west in the Ouzel, and a considerable feeder in the Ivel with its tributaries the Hiz and Flitt. In the north- 


\section{A HISTORY OF BEDFORDSHIRE}

east of the county a small portion about Podington and Wymington is drained by a brook, which belongs to the Nene drainage, and corresponds with the Nene B district of Druce's Flora of Northamptonsbire; a narrow strip on the eastern side containing the parishes of Cockayne, Hatley, Wrestlingworth, and a portion of Edworth belongs to the Cam drainage, itself, like the Nene, a tributary of the main Ouse. We may therefore subdivide the county into seven botanical districts, namely :-

$$
\text { Ouse. }\left\{\begin{array}{c}
\text { I. THE NENE, which has its counterpart in the Harper's Brook or Nene B district } \\
\text { of Druce's Flora of Northamptonshire. } \\
\text { 2. THE EAST OusE. } \\
\text { 3. THE WEST OusE, which has its counterpart in the Ouse district of Druce's } \\
\text { 4. THE IvEL, which corresponds with the Ivel district, No. 2, of Pryor's Flora of } \\
\text { Hertfordshire. } \\
\text { 5. THE CAM, corresponding to district I, the Cam, of Pryor's Flora of Hertfordshire. } \\
\text { 6. THE OuzE, which corresponds with the same district in the Flora of Bucking- } \\
\text { bamsbire. }
\end{array}\right.
$$

Thames. 7. THE LEA, which has its counterpart in district No. 6 of Pryor's Flora of Hertfordshire.

\section{The boundaries of the above districts are briefly as follows :-}

\section{The Nene District}

is a small portion in the north of the county containing the parishes of Podington, Wymington and Farndish, having its southern limitation in the Forty-foot Lane, which is practically the water-parting of the Nene and the Ouse drainage. Lotus tenuis is the only plant recorded for this area from near Podington.

\section{The East Ouse District}

is bounded on the north by Northants, and on the east by Hunts as far as to Cold Arbour, which is about two miles east of Roxton. From Roxton to the Forty-foot Lane near Wymington Wold in the north, the separating line from the West Ouse district is traced by Florns Wood, between Wilden and Ravensden to Tilwick farm. Then by Cross-end farm and Bletsoe Park, Harner Wood, and Souldrop village to the Nene boundary.

The botany of this district is much less known than that of the other portions of the county. Keysoe Park and Melchbourne Woods should repay systematic search, and the river flora itself is sure to yield additional species to those recorded. The gravelly soils should also prove remunerative.

Among the interesting species recorded for the district are :-

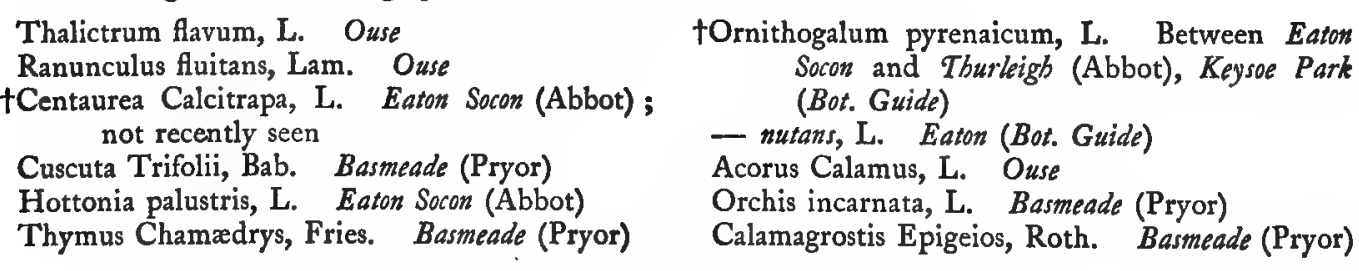

\section{The West Ouse District}

is bounded on the north and east by the district of the East Ouse which has been described. It is separated from the Nene district by the Forty-foot Lane to Dungey Corner, from which place to Nun Wood it is limited by the county of Northampton. At the latter place the county boundary of Bucks is followed by Harrold Lodge to the river Ouse, which then becomes the county boundary as far as to the vicinity of Newton Blossomville. Thence the Bucks boundary limits the West Ouse district until the road from Broad Green to North Crawley is

$t$ before a plant name means that the plant is recorded for one district only.

* means probably extinct.

A plant name in italics signifies that it is not native in the district. 


\section{BOTANY}

met with. From this point where the Ouzel district is reached the water-parting of the two districts is traced by Cranfield to Boughton End; the Ouzel district is then replaced by the Ivel district, and the separating line is drawn along the Ampthill road to Malden, and thence by West End to Wilshamstead, Moggerhanger and Herring's Green to Blunham Station, where it meets the East Ouse district near Roxton.

The West Ouse district, although it includes the northern escarpment of the Lower Greensand hills, is on the whole a very flat and low-lying area, chiefly on clay soils, or consisting of extensive alluvial deposits, and in many instances the strata are obscured by drift deposits, and for some distance the glacial clay obscures the porous bed-rock of the Lower Greensand, so that the flora of this area differs essentially from that of the Ivel and Ouzel districts, in which not only plants characteristic of arenaceous soils are well represented, but also those peculiar to or fond of cretaceous ground. Hence in this area Pelophilous or clay-loving plants naturally predominate.

This district was however the one in which Dr. Abbot lived and in which the greater part of his research was made, so that many local plants are recorded for it.

Among the species recorded for the district are :-

Clematis Vitalba, L.

Thalictrum flavum, L. Common by the Ouse

Ranunculus fluitans, Lam. Ouse

- Lingua, L. Goldington, Oakley (Abbot)

Myosurus minimus, L. Biddenbam, Fenlake (Abbot)

Helleborus fæidus, L. Stagsden, Brombam, Steventon (Abbot)

- viridis, L. Goldington (Abbot)

Delphinium Consolida, L. Near Bedford (Abbot)

Berberis vulgaris, L. Clapbam, Milton Ermest, Honey Hills (Abbot)

Nymphæa alba, L. Ouse; as well as a small pinkflowered form

Papaver somniferum, L. By the railway, Turvey

- Lecoqii, Lam.

Cheiranthus Cheiri, L. Wall of Bedford Castle (Abbot)

Alyssum calycinum, Jacq. Biddenham

Sisymbrium Sophia, L. Common (Abbot); sporadic

Diplotaxis muralis, DC. Railway

Erysimum cheiranthoides, L. Near Bedford, etc.

†Lepidium latifolium, L. Kempston; alien or incorrectly named

Stellaria palustris, Retz. Ford End (Abbot)

Saponaria officinalis, L. Brombam

Silene noctiflora, L. Oakley (Abbot)

Sagina apetala, Ard.

- nodosa, Fenzl. Steventon (Abbot)

Cerastium arvense, L. Ford End (Abbot)

Geranium columbinum, L. Biddenbam (Ábbot), etc.

- lucidum, L. Elsiow, Caldwell (Abbot)

- pyrenaicum, Burm. Ford End (Abbot)

Genista tinctoria, L. Clapham, Steventon (Abbot)

Cytisus scoparius, Link. Amptbill

Ononis spinosa, L. Too abundant in stiff soils

Anthyllis Vulneraria, L. Oakley (Abbot)

Trifolium medium, L. Brombam and Milton (Abbot)

- striatum, L. Biddenbam (Abbot)

- ochroleucon, Huds. Clapham (Abbot)

Astragalus glycyphyllus, L. Brombam, Oakley (Abbot); Turvey (Miss Higgins)

Lotus tenuis, Waldst. and Kit. Near Bedford
†Vicia gracilis, Lois. Clapham (R. Pryor)

Lathyrus Nissolia, L. Putnoe, Brombam (Abbot)

- sylvestris, L. Brombam (Abbot); under the name $L$. latifolius

†Geum rivale, L. Putnoe Wood (Abbot)

Cratægus oxyacanthoides, Thuill. Near Bedford

Sanguisorba officinalis, L. Fenlake (Abbot)

Pyrus communis, L. Thurleigb (Abbot)

- Aria, Ehrh. Near Fenlake (Abbot); probably planted here

†Chrysosplenium alternifolium, L. Lidlington (W. Crouch)

Parnassia palustris. Steventon, Turvey (Abbot)

Sedum dasypbyllum, L. Ford End (McLaren)

S. album, L. Steventon (Abbot)

Drosera rotundifolia, L. Cleat Hill, Ravensden

Hippuris vulgaris, L. Ouse

Lythrum Hyssopifolia, L. Goldington Green, Oakley, Westfeld (Abbot)

Epilobium obscurum, Schreb. Elstow (Newbould)

- tetragonum, L. Elstow (Pryor), Bedford

* Cicuta virosa, L. Oakley Springs (Abbot)

Smyrnium Olusatrum, L. Ravensden, Oakley (Abbot) ; Elstow

Apium graveolens, L. Wilshamstead, Goldington (Abbot) ; Elstow

- repens, Reichb. f. Steventon, Goldington Green (Abbot)

Enanthe fistulosa, L. Ouse

- silaifolia, Bieb. Fenlake (Abbot); the true plant

- fluviatilis, Colem. Ouse

Carum segetum, Benth. and Hook. Goldington, Clapham (Abbot)

- Carui, L. Thurleigh (Abbot)

Sium latifolium, L. Ouse

$\uparrow$ Antbriscus Cerefolium, Hoffm. Goldington (Abbot)

tCaucalis daucoides, L. Oakley, Westfield (Abbot)

- latifolia, L. Oakley, Thurleigh (Abbot)

Pimpinella major, Huds. Common (Abbot) var. dissecta, Druce. Trwin Woods

Adoxa Moschatellina, L. Cleat Hill, Ravensden, Lidlington

Sambucus Ebulus, L. Between Brombam and Stagsden 


\section{A HISTORY OF BEDFORDSHIRE}

Dipsacus pilosus, L. Goldington, Kempston (Abbot)

Bidens cernua, L., var. minima. Kempston Pits (Abbot)

Erigeron acre, L. Thurleigh, Biddenbam (Abbot)

Inula Helenium, L. Ravensden, Steventon (Abbot); Thurleigb Lane (Ransom), Cox's Pits near Bedford (McLaren)

Tanacetum vulgare, L. Brombam (Abbot)

Pulicaria vulgaris, Gartn. Goldington, Ravensden (Abbot)

Carduus tenuiflorus, Curt. Near Bedford (Abbot)

*Centaurea Calcitrapa, L. Biddenbam (Abbot)

Lactuca virosa, L. Near Bedford (Pryor), Houghton Conquest (C. Crouch)

†Mariana lactea, Hill (Silybum). Woods, Amptbill Park (J.S.)

Crepis taraxacifolia, Thuill. Lidlington (Druce)

Campanula Trachelium, L.

- Rapunculoides, L. Common near Bedford (J.H.)

Anagallis corulea, Schreb. Oakley, Westfield (Abbot)

Samolus Valerandi, L. Ouse

Lysimachia vulgaris, L. "

Vinca major, L. Ravensden, Glapham (Abbot)

Menyanthes trifoliata, L. Kempston (Abbot)

Blackstonia perfoliata, Huds. Brombam (Abbot)

Pulmonaria officinalis, L. Between Thurleigh and Milton Ernest (Abbot)

Cynoglossum officinale, L. Elstow, Cleat Hill

Symphytum officinale, L., var. patens (Sibth). Ouse (Abbot)

Cuscuta europæa, L. Common (Abbot)

Solanum nigrum, L. Garden ground

Atropa Belladonna, L. Brombam (McLaren); doubtfully native

Linaria Elatine, Mill. Brombam, Clapham (Abbot)

- spuria, Mill. Clapham, Brombam, Steventon (Abbot)

- viscida, Mönch. Oakley (Abbot)

Limosella aquatica, L. Goldington Green (Abbot), Fenlake (McLaren)

Antirrbinium majus, L. Bedford, Elstow (Abbot)

Melampyrum cristatum, L. Common (Abbot), as in Troin Woods near Clapbam

Lathræa Squamaria, L. Oakley Hill

Orobanche major, L. Oakley (Abbot)

Utricularia vulgaris, L. Brombam

Verbena officinalis, L. Goldington, Wilden (J.H.)

† Mentha citrata, Ehrh. Wild in a ditch near Bedford (Abbot)

Leonurus Cardiaca, L. Ford End (Abbot)

Salvia pratensis, L. Near Ford End Farm (Abbot)

†Stachys germanica, L. On a hill two miles from Bedford (Bot. Guide) ; i if native

Marrubium vulgare, L. Elstow (Abbot)

Plantago arenaria, W. \& K. Cardington

Chenopodium urbicum, L. Near Bedford (Abbot)

var. intermedium

- hybridum, L. Mill Lane, Bedjord (Abbot)
Chenopodium murale, L. Common (Abbot); not so now

Atriplex deltoidea, Bab. Ouse side

Polygonum Bistorta, L. Thurleigh (Abbot)

- minus, Huds. Goldington, Elstow (Abbot)

Rumex maritimus, L. Goldington Green (Abbot)

- acutus, L. Bedford (Pryor)

Daphne Laureola, L. Near Lidlington (Druce)

Euphorbia platyphyllos, L. Near Bedford (Abbot)

Mercurialis annua, L. Ford End (McLaren)

Salix triandra, L. Thurleigh, Fenlake (Abbot); Bedford

- purpurea, L. Thurleigh (Abbot)

- rubra, Huds. Bedford (Bot. Guide)

Hydrocharis Morsus-ranæ, L. Fenlake (Abbot), Goldington (J.S.) ; Ouse

Spiranthes autumnalis, Rich. Thurleigh (Abbot)

Ophrys apifera, Huds.

Habenaria conopsea, Benth. Clapbam (Abbot)

- viridis, Br. Steventon, Thurleigh (Abbot)

Neottia Nidus-avis, Rich. Clapbam (Abbot), etc.

Epipactis palustris, Crantz. Steventon (Abbot)

Iris foetidissima, L. Brombam, Steventon (Abbot)

Narcissus Pseudo-narcissus, L. Glapham (Abbot), Ravensden, Cranfield

Polygonatum multiflorum, All. Thurleigh (Abbot)

Fritillaria Meleagris, L. Brombam (Abbot)

Paris quadrifolia, L. Renhold, Clapham, Thurleigh (Abbot)

Colchicum autumnale, L. Amptbill Park

Ruscus aculeatus, L. Oakley (Abbot)

Typha angustifolia, L. Knotting Green (Abbot), Lidlington (C. Crouch)

Acorus Calamus, L. Ouse

Alisma ranunculoides, L. Marston (Miss Stevenson)

†Potamogeton prælongus, Wulf. Ouse (Pryor)

- lucens, L., var. acuminatus. Ouse (J.S.)

- compressum, L. Fenlake (Abbot)

Carex axillaris, Good. Fenlake (McLaren)

- acuta, L. Fenlake (J.S.)

†- strigosa, Huds. Putnoe, Renbold (Abbot)

Calamagrostis Epigeios, Roth. Cardington, Hougbton Conquest

- lanceolata, Roth. Sheer Hatcb Wood (Abbot)

Apera Spica-venti, Beauv. Ford End (Abbot)

Bromus secalinus, L. Buryfeld, Bedford (Abbot)

- commutatus, Schrad. Brombam (Abbot)

†Brachypodium pinnatum, Beauv. Clapbam (Abbot), Houghton Conquest Park (Bot. Guide)

tGlyceria distans, Wahl. Clapham Lane (Abbot)

Hordeum sylvaticum, Huds. Thurleigh, Putnoe (Abbot)

Lolium temulentum, L. Fenlake (Abbot)

Asplenium Trichomanes, L. Cardington

Scolopendrium vulgare, Symons. Elstow, Lidlington

†Botrychium Lunaria, Sw. Oakley, Westfield (Abbot)

†Nitella mucronata, Kütz. River Ouse near Bedford (C. H. Davies)

Tolypella glomerata, Leonh. Near Bedford (J.S.) 


\section{BOTANY}

\section{The Ivel District}

has for its boundaries those of the West Ouse district already described from near Roxton to Boughton End. At this place it touches the Ouzel district, from which it is separated by a line drawn across the county from Boughton End to Eversholt, Toddington, Chalgrave, and Chalton Cross; it then borders the Lea district along the Icknield Way until the Herts county boundary is reached, and this limits it as far as to Edworth. Here the Cam district comes in, and the water parting is traced by Dunton, and west of Eyworth, to Tadlow, where the Cambridge county border then limits it on the north as far as to Cold Arbour, at which point an arbitrary line is drawn across county to about a mile west of Tempsford, and thence southwards to Blunham station. The district is also watered by the Flitt and Hiz streams. The greatest elevation is about 530 feet near Streatley, but a large extent of the area is below 200 feet.

The Ivel district is perhaps the most interesting portion of the county from a botanist's point of view, since it comprises a great variety of soils, including the bare chalk of the downs, the flat valley of the Flitt with its extensive deposits of peat and a rich uliginal fora, and the southern slopes of the Lower Greensand ridge, which affords a warm porous soil with a varied selection of characteristic plants. The country too is very charming from a scenic point of view, and there are still spots untouched by cultivation, where the lover of nature may revel, and where the student may yet make additions to the county fora.

The meadows by the Flitt from Flitwick to Flitton are particularly rich in bog species, notwithstanding some attempts at drainage having been made, and there are detached portions of bog-land which occur as far as to Shefford.

Here occur the sundew (Drosera rotundifolia), the marsh violet (Viola palustris), the small valerian (Valeriana dioica), the bog bean (Menyanthes trifoliata), the marsh bedstraw (Galium palustre) and its variety elongatum, the marsh and the heath louseworts (Pedicularis palustris, $P$. sylvatica), the bog stitchwort (Stellaria uliginosa), the ivy-leaved crowfoot (Ranunculus hederaceus), a large form of the common spearwort (R. Flammula), the scorpion grass (Myosotis cespitosa), the starworts Callitriche hamulata and C.platycarpa. The cotton grass (Eriophorum angustifolium) is peculiarly plentiful, and the sedge vegetation includes the very local Carex canescens, besides $C$. pulicaris, C. rostrata, C. disticha, C. leporina, C. flava, C. echinata, C. acutiformis, C. Goodenowii, and great tussocks of $C$. paniculata. Scirpus setaceus is local, and Lotus uliginosus and the marsh willow-herb (Epilobium palustre) also are found.

On the soil reclaimed from the bog there is a considerable growth of the rare hemp nettle (Galeopsis speciosa), discovered here by Mr. Saunders in I883; the borage (Borago officinalis) as well as a form of the prickly comfrey (Symphytum asperrimum) also occur, and the North American snowberry (Symphoricarpus racemosus) is semi-naturalized.

There are remains of alder coppices, showing that at one time the vegetation must have been in great part woodland, and here and there a bush of the grey willow (Salix cinerea) and much more rarely $S$. aurita occur. The rushes include $\mathcal{F}$ uncus supinus, $\mathcal{F}$. acutiforus, $\mathcal{F}$. lamprocarpus, $\mathcal{F}$. conglomeratus and $\mathcal{F}$. effusus. Luzula or Funcoides multiflora and its variety erecta are frequent; here and there are patches of ling (Calluna Erica), and on the drier parts may be occasionally seen Poa pratensis as the var. subcoerulea as well as Festuca ovina and its variety paludosa. Molinia varia, Phragmites communis, Glyceria fluitans, Agrostis vulgaris, Sieglingia decumbens, the pond-weed Potamogeton polygonifolius, Pour., and the form ericetorum, have been observed.

The Lower Greensand about Ampthill affords abundance of the cress Teesdalia nudicaulis, of the scorpion grasses Myosotis collina and $M$. versicolor, of the chickweed Cerastium semidecandrum, which Abbot mistook for C. pumilum, the buck's-horn (Plantago Coronopus), the hair grass (Aira precox), the foxglove (Digitalis purpurea), the hawkweed Hieracium boreale, the vetch Vicia angustifolia and its variety Bobartii, the sheep's scabious (Fasione montana), the holly (Ilex Aquifolium), the heath hair grass (Deschampsia flexuosa), the meadow saxifrage (Saxifraga granulata), the thale cress (Sisymbrium thalianum), the broom Cytisus scoparius, the clovers Trifolium arvense, T. filiforme and T. striatum, the bird's-foot Ornitbopus perpusillus, the sandwort Buda rubra, etc.

The chalk downs afford a characteristic flora, and some very local species are found on the Barton Hills. Among these rarities are the pasque flower (Anemone Pulsatilla), the mountain cat's-foot (Antennaria dioica), and the blue milk vetch (Astragalus danicus). Abbot found a cress (Draba muralis), which was figured in English Botany from a Bedford specimen, but the plant appears to be extinct, and it was probably introduced and not indige- 


\section{A HISTORY OF BEDFORDSHIRE}

nous; Wilbury Hill is one of the few British localities for the grass Pbleum phalaroides, Wibel, at one time known as $P$. Beebmeri.

The cultivated fields also have three choice species, namely the ground pine (Ajuga Chamepitys), the great earth nut (Carum Bulbocastanum), and the great corn rattle (Rbinantbus major). Besides these the arable ground affords the fumitories Fumaria densifora, F. Vaillantii and $F$. parviflora, the candytuft (Iberis amara), the crimson poppy (Papaver hybridum), the toadflaxes Linaria spuria, L. elatine, and L. viscida, the Venus' looking-glass (Specularia bybrida), the grass Bromus secalinus, the hone-wort Carum segetum, and the bur parsley Caucalis nodosa.

The grassy downs are resplendent with the rock-rose (Helianthemum Chamacistus), the lady's-fingers (Antbyllis Vulneraria), the horse-shoe vetch (Hippocrepis comosa), the small scabious (Scabiosa Columbaria), the squinancy wort (Asperula cynancbica), the field ragwort (Senecio campestris), the Carline thistle (Carlina vulgaris), the musk thistle (Carduus nutans), the marjoram (Origanum vulgare), the milkwort (Polygala vulgaris), the orchids Orchis pyramidalis, Habenaria conopsea; the perfoliate yellow-wort (Blackstonia perfoliata), the felwort (Gentiana Amarella), the Canterbury bell (Campanula glomerata), and the mullein (Verbascum Thapsus), etc. The grasses consist of Koeleria cristata and its var. gracilis, Festuca ovina, F. rigida, F. rubra, Bromus erectus, Avena pubescens, $A$. pratensis, Briza media, etc.

The yew (Taxus baccata) is almost certainly native in the district, but the scarcity of the juniper (funiperus communis) is remarkable, since it is so frequent on the chalk escarpment of Buckinghamshire.

The rarer plants of the Ivel district include :-

Clematus Vitalba, L.

†Thalictrum calcareum, Jord. Flitwick (R. H. Webb, )

Ranunculus Lingua, L. Reed Pond, Sundon (J.S.)

†- Baudotii, Godr.

- fluitans, Lam. Ivel

- parviflorus, L. Tingrith (W. Couch)

- acris, L., var. Steveni (Andrz.) Flitwick (Druce)

Aquilegia vulgaris, L. Barton Leete (Abbot)

Berberis vulgaris, L. Steppingley

Papaver dubium, L., var. Lamottei (Lam.) Flittwick (Druce)

var. Lecoqii (Lam.) Clopbill

Capnoides claviculata, Druce (Corydalis). Clopbill, Kings Wood

†Draba muralis, L. E. B. Plate (Abbot); drawn from a Bedford specimen

Erophila stenophylla, Jord. Amptbill (Druce)

Erysimum cheiranthoides, L. Flitwick (J.S.)

Diplotaxis muralis, DC. Railway

Viola palustris, L. Ampthill (J. H.), Wessoning (C. Crouch)

- hirta, L., var. calcarea, Bab. Barton (J.S.)

"Dianthus deltoides, L. Everton, Potton (Abbot)

Cerastium quaternellum, Fenzl. Amptbill Warren, Clopbill (Abbot) ; Flitroick (McLaren)

- viscosum, L., var. apetalu m (Dum.) Amptbill (Druce)

[- pumilum, Curtis. Amptbill (Abbot) ; error, it should be C. semidecandrum]

Stellaria media, Cyr., var. Boræana (Jord.) Ampthill, Flitroick (Druce)

Silene noctiflora, L. Barton Hills (J.S.)

- anglica, L. Barton (Abbot)

- Cucubalus, Wibel, var. puberula (Jord.) Barton (Druce)

Sagina ciliata, Fries. Amptbill (Druce)

- nodosa, Fenzl. Ampthill (Abbot), Flitwick (Druce)

Arenaria leptoclados, Guss. Flitwick (Druce)
Saponaria officinalis, L. Harlington (J.S.)

Claytonia perfoliata, Donn. Amptbill on the Maulden road

Montia fontana, L., var. minor (All.) Flifwick (Druce)

"Hypericum elodes, L. Potton (Abbot)

- calycinum, L. Haynes

Geranium sanguineum, L. Potton, an escape (Abbot)

- pusillum, L. Amptbill (Druce)

- columbinum, L. Pegsdon

Erodium cicutarium, L'Hérit. Ampthill, etc.

- moschatum, L'Hérit. Abbot (1801), Eversbolt (McLaren), Amptbill Warren

Genista anglica, L. Amptbill (Abbot)

Medicago Falcata, L. Flitrvick

+ - lappacea, Desv. Near Caddington (Pryor)

Trifolium scabrum, L. Flitwick (McLaren), Potton, Amptbill (Abbot)

- ochroleucon, Huds. Potton, Everton (Abbot)

- subterraneum, L. Amptbill, Clopbill (Abbot)

Lotus uliginosus, Schk. Flitwick

- tenuis, W. \& K. Haynes

Vicia angustifolia, L., var. Bobartii, Koch. Amptbill (Druce)

[- lathyroides, L. Amptbill, Maulden, Clophill (Abbot), but his specimens are $V$. angustifolia]

Lathyrus sylvestris, L. Haynes (Abbot)

- Nissolia, L. Wilbury

Potentilla argentea, L. Amptbill, frequent

†- palustris, Scop. Flitwick Marsh (J.S.)

Alchemilla vulgaris, L. Sundon Poterium polygamum, W. \& K. Railway banks,
etc.

Cratægus oxyacanthoides, Thuill. Pulloxbill, etc. (C. Crouch)

Pyrus Aria, Ehrh. Warden

* Parnassia palustris, L. Amptbill (Abbot) tSedum album, L., var. teretifolium (Haw.)
Barton (J.S.) 


\section{BOTANY}

"Drosera longifolia, L. Potton (Abbot)

- anglica, Huds.

Callitriche obtusangula, Le Gall. River Flitt (Druce)

Peplis Portula, L. Ampthill (Abbot)

Hydrocotyle vulgaris, L. Flitwick, etc.

Smyinium Olusatrum, L. Between Silsoe and Barton (C. Crouch); Gravenburst (W. Crouch)

Apium graveolens, L. Barton (C. Crouch)

- inundatum, Reichb. Amptbill (Abbot)

Bupleurum rotundifolium, L. Barton Hills (Abbot)

Carum segetum, B. \& H. Barton Hills, Wilbury

- Petroselinum, B. \& H. Flitwick railway

- Carvi, L. Gravenburst

Pimpinella major, Huds., and var. dissecta, Druce. Flitwick

Anthriscus vulgaris, Bernh. Common about Ampthill

Enanthe silaifolia, Bieb. Potton (Abbot) ; possibly this was $E$. Lacbenalii

- fistulosa, L. Flitruick

Adoxa Moschatellina, L. Sundon, Streatley, etc.

Galium Mollugo, L., var. elatum (Thuill.) This is Abbot's G. pusillum from Shefford; therefore G. sylvestre Poll., with which it has been wrongly identified, is still a desideratum to the Beds flora.

- erectum, Huds. Flitwick ; Abbot's G. erectum is G. Mollugo var. elatum

Valeriana officinalis, L Barton (Druce)

- sambucifolia, Mik. Flitwick

Dipsacus pilosus, L. Near Ampthill, Glopbill, $W$ arden, etc.

Solidago Virgaurea, L. Clopbill Woods (J.S.)

Erigeron acre, L. Barton, etc.

Filago minima, L. Flitroick, etc.

- apiculata. Flitwick (J.S.)

Inula Helenium, L. Pulloxbill, Higbam Gobion (C. Crouch)

Taraxacum erythrospermum, Andrz. Amptbill (Druce)

Tanacetum vulgare, L. Maulden (J.S.)

Anthemis arvensis, L. Flitwick (J.S.)

Cnicus eriophorus, Roth. Sundon (J.S.)

Onopordon Acanthium, L.

Serratula tinctoria, L. Aspley

Arnoseris pusilla, Gærtn. Amptbill, Maulden (Abbot) ; Potton, Clophill, etc.

Crepis taraxacifolia, Thuill. Near Ampthill (Druce)

Hieracium boreale, Fries. Clopbill (J.S.)

- tridentatum, Fr. Shefford (R. A. Pryor)

Hypochœris glabra, L. Amptbill, Sandy, Potton (Abbot)

Jasione montana, L. Amptbill

Campanula Trachelium, L. Streatley, Barton (J.S.)

- latıfolia, L. Barton Leete (J.S.)

- rapunculoides, L. Between Barton and Hexton (Messrs. Carruthers)

"Oxycoccus quadripetala, Gilib. The Cranberry, Potton (Abbot)

Erica Tetralix, L. Ampthill, Potton (Abbot); Maulden (W. Crouch)

- cinerea, L. Potton (McLaren)

I
Hypopitys Monotropa, Crantz.

†Centunculus minimus, L. Ampethill Moor (Abbot)

Cuscuta europæa, L. Fliswick, 1841 (Rev. R. H. Webb)

- Epithymum, Murr. Barton Hill, Amptbill Warren (Abbot)

Atropa Belladonna, L.

Antirrbinum majus, L. Midland railway, Harlington (J.S.)

Linaria repens, Mill. Dunstable Dowuns

tRhinanthus major, Ehrh. Chalky fields on Barton Hills (J.S.)

Verbena officinalis, L.

Mentha longifolia, Huds. West Flitrvick (J.S.)

Marrubium vulgare, L. Sundon

Salvia Verbenaca, L.

- verticillata, L. Flitwick (C. Crouch)

Lamium hybridum, With. Maulden (Miss Berrill)

Teucrium Chamedrys, L. Warden (Abbot)

"Utricularia minor, L. Amptbill, Potton (Ábbot)

Pinguicula vulgaris, L. Barton (C. Crouch)

Lathræa Squamaria, L. Sundon (J.S.)

Orobanche major, L. (O. Rapum-genista, Thuill.) Ampthill (Abbot)

Polygonum minus, Huds. Flitwick Marsh (J.S.)

Eupborbia Cyparissias, L. Barton Leat Wood (Eng. Fl.)

Viscum album, L. Barton, etc.

tUrtica pilulifera, L. Shefford

Salix aurita, L. Flitwick (Druce), Warden (Abbot)

Castanea sativa, Mill. Silsoe

Populus tremula, L. King's Wood, Flitwick (J.S.)

Quercus sessilifiora, Salisb. Amptbill

Ceratophyllum demersum, L. Pulloxhill (J.S.)

Juniperus communis, L. Barton (Abbot)

Salix repens, L. Flitwick, Ampthill

Alisma Plantago, L., var. lanceolatum (Afz.) Flitwick Marsh (J.S.)

- ranunculoides, L. Amptbill (Abbot)

*Epipactis palustris, Crantz. Gravenhurst, 1842 (C. Crouch)

Cephalanthera pallens, Rich. Streatley, etc.

* Malaxis paludosa, Sw. Potton Marshes (Abbot)

Neottia Nidus-avis, Rich. Sundon, etc.

Orchis ustulata, L. Barton Downs

Habenaria conopsea, Benth. Barton

- viridis, Br. Sundon (J.S.)

Ophrys apifera, Huds. Barton, Streatley, etc. (J.S.)

- muscifera, Huds. Streatley, Sundon (J.S.)

- aranifera, Huds. Soutbill (Abbot)

Spiranthes autumnalis, Rich. Pegsdon and Barton Hills (J.S.), Haynes

Iris fotidissima, L. Flitwick West (J.S.), Haynes, etc.

Narcissus Pseudo-narcissus, L. Maulden, Warden, etc.

Galanthus nivalis, L. Sandy (Abbot)

Ornitbogalum nutans, L. Potton (Mr. Bond Smith)

- umbellatum, L. Everton Heath (Abbot)

Triglochin palustre, L. Gravenburst Moor, Westoning (C. Crouch), Amptbill Bogs (Abbot) 


\section{A HISTORY OF BEDFORDSHIRE}

\author{
*Potamogeton alpinus, Balb. Clopbill (W. \\ Crouch) \\ - pusillum, L., var. tenuissimus, Ivel (J.S.) \\ Paris quadrifolia, L. In chalk and clay, not \\ arenaceous soils \\ Ruscus aculeatus, $\mathrm{L}$. \\ Colchicum autumnale, L. Barton (Abbot) \\ Allium ursinum, L. Cbalton (J.S.) \\ *Narthecium ossifragum, Huds. Amptbill Bogs \\ (Abbot) \\ Typha angustifolia, L. Clopbill (C. Crouch) \\ Juncus obtusiflorus, Ehrh. Harlington Brickyards \\ (J.S.) \\ *Schœnus nigricans, L. Amptbill, Potton (Abbot) \\ Scirpus sylvaticus, L. Flitwick Marsh (J.H.), \\ Westoning \\ *- cæspitosus, L. Amptbill, Flitton Moors \\ (Abbot) \\ *Rynchospora alba, Vahl. Ampthill Moor and \\ Potton (Abbot) \\ †*Carex dioica, L. Ampthill (Abbot) \\ - flava, L., var. minor, Towns. Soutbill \\ (J.S.) \\ Acorus Calamus, L. Tingrith Park; planted \\ (J.S.) \\ Apera Spica-venti, Beauv. Streatley (J.S.)
}

Calamagrostis Epigeios, Roth. Maulden (C. Crouch)

†- lanceolata, Roth. Cbicksands (C. Crouch)

Catabrosa aquatica, Beauv.

†Phleum phalaroides, Wibel. Wilbury Hill (T. B. Blow)

Poa compressa, L. Streatley (J.S.)

Festuca sciuroides, Roth. Amptbill (Druce)

Bromus commutatus, Schrad. Barton (J.S.)

Nardus stricta, L. Flitwick (McLaren)

Lomaria Spicant, Desv. Flitwick (J.S.)

Asplenium Adiantum-nigrum, L.

†Lastrea uliginosa, Newm. Flitruick (McLaren), I 885

1 - cristata, Presl. Potton (Abbot), probably L. spinulosa was meant

* - Thelypteris, Presl. Potton (Abbot)

Aspidium aculeatum, Sw. Flitruick (J.S.), Potton, Gbicksands

Scolopendrium vulgare, Symons. Toddington

Ophioglossum vulgatum, L. Sundon (J.S.)

Equisetum maximum, Lam. Barton (J.S.)

? *Lycopodium clavatum, L. Potton Heath (Ábbot)

? * - inundatum, L. Amptbill (Abbot)

Nitella mucronata, Kuetz. Sandy (J.S.)

†Tolypella intricata, Leonh. Near Sundon (J.S.)

\section{The Cam District}

is very small and narrow and is bounded on the west by the Ivel district as already described, and on the east by Hertfordshire. As the water-partings are obscure, no part of the district being above 200 feet in altitude, it may be well to merge it in the Ivel district which it so closely resembles.

\section{The Ouzel District}

is in the south-west of the county and has for its eastern boundary the districts of the West Ouse and the Ivel district already described, but in the south it is separated from the Lea district by the Icknield Way from Chalton Cross by Houghton Regis to the Bucks boundary, which it touches above Edlesborough, and this county bounds it on the western side to Wharley End.

This district is very varied in scenery as well as in its geological character. The streams which feed the Ouzel rise from the juncture of the Chalk with the impervious soil at its base, and cutting through the Upper Greensand and crossing the Gault also drain the picturesque country about Heath and Reach and Woburn Woods, which are on the Lower Greensand; they finally pass through the country situated on the Oxford Clay, and that covered by the Ouse gravels. The latitude near Birdshill is 550 feet, at Toddington 485 feet, at Heath and Reach 460 feet, while no part appears to be below 200 feet.

There are some boggy portions still left undrained near Aspley, also some interesting meadows with peat near Totternhoe, and the warm dry soil about Heath and Reach and Woburn affords a large number of ericetal species; then the Chalk escarpment has its typical cretaceous vegetation, and its grassy slopes afford abundance of the rock-rose (Helianthemum Chamoecistus), the lady's-fingers (Anthyllis Vulneraria), the horse-shoe vetch (Hippocrepis comosa), the milkwort (Polygala vulgaris), the carline thistle (Carlina vulgaris), the stemless and muskthistles (Cnicus acaulis and C. nutans), the field ragwort (Senecio campestris), the yellow-wort (Blackstonia perfoliata), the marjoram (Origanum vulgare), the thyme (Thymus Chamedrys), the orchids Orchis pyramidalis, O. ustulata, Habenaria conopsea, etc., the bee orchis (Ophrys apifera), the grasses Bromus erectus, Avena pratensis, A. pubescens, Festuca ovina, F. rigida, F. rubra, Kaeleria cristata), the squinancy wort (Asperula cynancbica), the Canterbury bell (Campanula glomerata) and the scabious (Scabiosa Columbaria).

The arable fields on the Chalk have the candytuft (Iberis amara), the great earth-nut (Carum Bulbocastanum), the crimson poppy (Papaver bybridum), the rattle Rbinaritbus major, if indeed this be correctly named, the bur parsley (Caucalis nodosa), the Venus looking-glass 


\section{BOTANY}

(Specularia bybrida), the toadfaxes Linaria Elatine, L. spuria, L. viscida, and the calamint (Calamintha arvensis).

The heathy district near Leighton Buzzard, Woburn and Aspley affords a completely different flora from the Chalk.

Here occur in open places the cress Teesdalia nudicaulis, the pearl-wort (Sagina ciliata), the sand-wort (Buda or Arenaria rubra), the St. John worts (Hypericum bumifusum and $H$. pulchrum), the scorpion grass (Myosotis collina and $M$. versicolor), the wood pea (Lathyrus montanus), the buck's horn (Plantago Coronopus), the clovers Trifolium arvense and T. striatum, the sheep's scabious (Fasione montana), the climbing fumitory (Capnoides claviculata), the cudweeds Gnaphalium sylvaticum and Filago minima, the chickweed (Cerastium semidecandrum), the hemlockleaved stork's-bill (Erodium cicutarium), the silvery cinquefoil (Potentilla argentea), the crane'sbill (Geranium pusillum), the hawkweeds Hieracium umbellatum and $H$. boreale, the golden rod (Solidago Virgaurea), the dog violet (Viola canina), the grasses Molinia varia, Agrostis canina, Deschampsia fexuosa, Aira caryopbyllea, A. pracox, Festuca ovina and var. paludosa, F. sciuroides, the foxglove (Digitalis purpurea), the grass Poa pratensis var. subcoerulea, the sedge Carex pilulifera, and the musk mallow (Malva moscbata var. beteropbylla). The cultivated ground on this light soil yields the small succory (Arnoseris minima), the corn camomile (Chrysanthemum segetum), the spurrey (Spergula sativa), the grass Bromus secalinus, the bird's-foot (Ornithopus perpusillus), the saw-wort (Serratula tinctoria), etc.

The woods and bushy portion have, in addition to the planted pines and larch, a native growth of huckleberry (Vaccinium Myrtillus), heather (Calluna Erica), the lily of the valley (Convallaria majalis), the aspen (Populus tremula), the grasses Molinia varia and Poa nemoralis, the wood rush (Luzula maxima or Funcoides sylvaticum), the foxglove (Digitalis purpurea), and the fern Lomaria Spicant.

The boggy parts yield the local sedge, Carex canescens, the bog pimpernel (Anagallis tenella), the marsh bedstraw (Galium uliginosum), the sedges Carex ecbinata, C. fava var. minor, the biting persicaria (Polygonum Hydropiper), the blinks (Montia fontana as the var. minor), the grass Sieglingia decumbens, the marsh violet (Viola palustris), the rushes Funcus supinus, Funcoides multifforum and var. erectum, and the grass Molinia varia.

On clay soils, as about Cranfield, Salford, etc., we have the graceful sedge Carex pendula, not only by hedges but in the woodlands, where also occur the spurge laurel (Daphne Laureola), the small burdock (Arctium minus), the water elder (Viburnum Opulus), the grass Calamagrostis Epigeios, the violet Viola Reichenbachiana, the grass Milium effusum, the cow wheat (Melampyrum pratense), the gromwell (Lithospermum officinale), etc.

The riverside vegetation includes Epilobium roseum, E. obscurum and a hybrid of the two, the winter cress (Barbarea vulgaris var. divaricata), the sedge Carex paludosa (which is probably Abbot's C. acuta), C. riparia, etc.; the willows Salix triandra, S. Smithiana, S. cinerea, S. caprea, S. purpurea, S. viminalis; the orach (Atriplex deltoidea), the water chickweed (Stellaria aquatica); the black poplar (Populus nigra) is not uncommon, and $P$.canescens and $P$. alba occur, but all as planted trees.

The maple (Acer campestre) is very frequent and is often a good sized tree, and is found with glabrous var. leiocarpa, as well as hairy fruit coverings (var. bebecarpa). The wych elm (Ulmus campestris) is not uncommon, but like the common elm (U. sativa) may be a planted tree.

The streams have Potamogeton densus and $P$. crispum, and Zannichellia palustris.

The ponds have Ranunculus beteropbyllus, $R$. peltatus, $R$. Drouetii and Ceratophyllum.

In the pastures the rest harrow (Ononis spinosa) is frequent; the eyebright (Euphrasia) is almost universally $E$. nemorosa, and the rattle is Rbinantbus minor.

Other plants of the Ouzel district :-

Clematis Vitalba, L.

Thalictrum flavum, $L$.

Ranunculus heterophyllus, Web. Woburn Sands, etc. (Druce)

- pseudo-fluitans, forma. Ouzel (J.S.)

- divaricatus, Schrank. Aspley (J.S.)

Myosurus minimis, L. Salford (Druce)

Berberis vulgaris, L. Woburn

Papaver Lecoqii, Lam. Near Eaton Bray (Druce)

Bunias Erucago. Leighton Mill (Druce)
Erophila stenophylla, Jord. Wobum (Druce)

Comelina sativa, Crantz. Clover fields near Woburn Sands (Druce)

Erysimum cheiranthoides, L. Woburn

Diplotaxis muralis, DC., var. Babingtonii. Railway near Woburn Sands (Druce)

Hesperis matronalis, L. Woburn Sands

Brassica elongata, Ehrh. Casual at Leigbion Mill (Druce)

Viola tricolor, L., var. agrestis (Jord.) Woburn (Druce) 


\section{A HISTORY OF BEDFORDSHIRE}

Viola tricolor, $\mathrm{L}$.

var. subtilis (Jord.) Woburn (Druce)

var. Deseglisei (Jord.)

- canina, L. Heath and Reach" (J.S.)

Polygala serpyllacea, Wahl. Heatb and Reach, Woburn (Druce)

Silene anglica, L. Woburn

Lychnis alba $\times$ dioica. Wobum (Druce)

Cerastium semidecandrum, L. Aspley (this is Abbot's C. pumilum); Heath and Reach (Druce)

- viscosum, L., var. apetalum, Dum. Woburm (Druce)

Arenaria leptoclados, Gun. Common about Leigbton and Woburn (Druce)

Claytonia perfoliata, Donn. Leighton Buzzard

tGeranium pheoum, L. Eversbolt (Abbot)

Erodium moschatum, L'Hérit. Eversholt (Mc Laren); the plate in $E . B$. was drawn from a Bedfordshire specimen sent by Dr. Abbot

- cicutarium, L'Hérit., var. pimpinellæfolium (Sibth.) Aspley (Abbot)

Rhamnus Frangula, L. Aspley, Eversholt (Abbot)

Hypericum calycinum, L. Wobum

- quadrangulum, L. Aspley

Malva moschata, L., var. heterophylla, Lej. Woburn (Druce)

Tilia parvifolia, Ehrh. Aspley, planted (Druce)

Medicago denticulata, Willd. Leighton

Melilotus alba, Desv. Leighton (Druce)

Trifolium filiforme, L. Leighton, Aspley ; common on the Greensand

Vicia Lathyroides, L. Near Leighton (Druce)

- sylvatica, L. Eversholt

- angustifolia, L., var. Bobartii. Leighton (Druce)

Potentilla argentea, L. Common on the Greensand

Alchemilla vulgaris, L. Eversbolt (Abbot); Totternboe (J.S.)

var. filicaulis (Buser) Near Woburn (Druce)

Cratægus oxyacanthoides, Thuill. Salford (Druce)

Pyrus communis, L. Eversbolt

Sedum Telephium, L., var. Fabaria (L.) Aspley Wood (Abbot)

Chrysosplenium oppositifolium, L. Toddington (J.S.)

Callitriche obtusangula, Le-Gall. Near Salford (Druce)

Epilobium roseum, Schreb. Near Salford (Druce)

- roseum $\times$ obscurum.

- obscurum, Schreb.

- angustifolium, L.

- tetragonum, L. Salford

Pimpinella major, Huds. Totternboe

Caucalis nodosa, Scop. Eaton Bray, etc.

Anthriscus vulgaris, Bernh. Heath and Reach (J.S.)

Carum Carvi, L. Tottermboe, apparently native (J.S.)

Bupleurum rotundifolium, L. Wobum

Galium uliginosum, L. Heath and Reach (J.S.)

Valeriana officinalis, L. Eaton Bray (Druce)
Valeriana sambucifolia, Mik. Woburn (Druce)

Valerianella dentata, Poll. Eaton Bray (Druce)

Filago spathulata, Presl. Birchmore near Woburn

- apiculata. G. Sm. Heath and Reach, etc. (Druce)

Gnaphalium sylvaticum, L. Aspley (Abbot), Leighton (J.S.)

†Centaurea Solstitialis, L. Totternboe Knolls (J.S.)

Tanacetum vulgare, L. Ridgmount

Serratula tinctoria, L. Aspley, Salford Wood (Druce)

Senecio sylvaticus, L. Aspley

Hieracium sciaphilum, Uecht. Aspley (J.S.)

- boreale, Fries. Abundant about Aspley (Druce)

Arnoseris pusilla, Gærtn. Leighton Buxzard (Druce)

Taraxacum erythrospermum (Andr.) Heatb and Reach (Druce)

Crepis taraxacifolia, Thuill. Aspley (Druce)

Campanula latifolia, L.

Pyrola minor, L. Aspley

Cuscuta europæa, L. Tottermboe (J.S.)

- Epithymum, Murr. Leighton (Druce)

- Trifolii, Bab. Salford (Druce)

Veronica montana, L. Eversholt (Abbot only)

Pedicularis palustris, L. Totternboe, Heath and Reach (J.S.)

- sylvatica, L. Heath and Reach, etc.

Orobanche major, L. Aspley

Anagallis tenella, L. Tottermboe, Heath and Reach (J.S.)

Lysimachia nemorum, L. Aspley (J.S.)

Lemnanthemum peltatum, Gmel. Stanbridge Ford (J.S.) ; perhaps planted

Menyanthes trifoliata, L. Ridgmont

Myosotis cespitosa, Schult. Heath and Reach (Druce)

Verbena officinalis, L. Totternboe (J.S.)

Pinguicula vulgaris, L. Totternboe Mead (Worthington Smith)

Salvia Verbenaca, L. Toddington (J.S.)

Rumex Hydrolapathum, Huds. By the Ouzel; this is the $R$. aquaticus of Mr. Saunders' list

Populus tremula, L., var. villosa, Lang. Rather common in Salford Wood (Druce)

Quercus sessiliflora, Salisb. Near Heath and Reach, Salford, etc. (Druce)

Ophrys muscifera, Huds.

Orchis latifolia, L. Totternboe (Worthington Smith)

Neottia Nidus-avis, L. Salford Wood (Druce)

Epipactis violacea, Bor. Woburm (Abbot in Eng. Bot. Supp.)

Polygonatum multiflorum, All. Aspley (W. Crouch)

Maianthemum Convallaria, Weber. Aspley; but requires confirmation

Fritillaria Meleagris, L. Eaton Bray (H. C. Chambers)

Juncus squarrosus, L. Aspley (J.S.)

Sparganium neglectum, Beeby. Near Salford (Druce)

Potamogeton pusillus, L. Near Salford (Druce)

Scirpus setaceus, L. Tottermboe (J.S.) 


\section{BOTANY}

+Carex elata, All. (=C. stricta, Good.) Markham Hills (J.S.)

- pulicaris, L. Eversholt (McLaren)

- binervis, Sm. Totternhoe (J.S.)

- echinata, Murr. Aspley, Woburm, Heath and Reacb

- flava, L. Totternboe (J.S.), near Eaton Bray (Druce) var. minor, Towns. Woburn (Druce)

- acuta, L. Totternhoe (C. Crouch)

- pilulifera, L. Woburn, etc. (Druce)

- disticha, Huds. Salford

Phleum pratense, L., var. nodosum (L.). Eaton Bray (Druce)

Anthoxanthum Puelii, Lec, and Lam. Heath and Reach

Calamagrostis epigeios, Roth. Near Leighton (J.S.), Cranfield (Druce)

Setaria viridis, Beauv. Leigbton Buzzard

Melica uniflora, Retz. Woods and hedges
Festuca Myurus, L. Aspley, Heath and Reacb (J.S.)

Poa nemoralis, L. Rather common

- compressa, L. Leighton

Bromus commutatus, Schrad. Totternboe (J.S.)

†Alopecurus fulvus, Sm. Near Heath and Reach (Druce)

Phalaris canariensis, L. Woburn Sands, etc.

Lolium italicum, Braun.

Lastrea spinulosa, Desv. Aspley (J.S.) "

- dilatata, Presl. Woburn (Druce)

Scolopendrium vulgare, Symons. Toddington (J.S.)

*Osmunda regalis, L. Aspley (Abbot)

Polystichum aculeatum, Presl. Eversholt

Equisetum maximum, Lam. Wobum (Druce)

Chara hispida, L. Totternhoe (J.S.)

- fragilis, Desv.

- contraria, Kutz. " " "

Tolypella glomerata, Leonh. "Near Woburn (Druce)

\section{The Lea District}

is a small irregularly shaped portion of the county which lies to the south of the Icknield Way, and has for its southern boundary the county of Herts, from which it is only artificially divided.

The river itself rises from springs near Houghton Regis and from others in Leagrave Marsh three miles above Luton, and cuts through the chalk escarpment before entering Hertfordshire. The greatest altitude of the district is about 630 feet. A small portion may belong to the drainage of the Colne, itself a Thames tributary.

It has an expanse of grassy chalk downs, bare chalky arable fields, and woodlands where brick-earth gives the subsoil, and marshy ground about Limbury, and it includes also the rich park of Luton Hoo and its ornamental waters.

Although the area is small it has had the advantage of being well explored by Mr. J. Saunders of Luton, so that the list of interesting species recorded for it is quite out of proportion to the area it includes.

It will not be necessary to repeat the names of the plants common to the chalk downs, as they are already given for the Ivel and Ouzel districts; the other interesting species found in this district include :-

Ranunculus Drouetii, Sch. Limbury with the variety Godronii, Gren. (J.S.)

Anemone apennina, L. Luton Hoo (Abbot)

Helleborus viridis, L., var. occidentalis, Druce. Limbury (J.S.), Wbipsnade (Worthington Smith)

- faetidus. Lynchetts near Luton (J.S.)

Papaver Lecoqii, Lam. Luton (R. Pryor)

Erysimum cheiranthoides, L. Luton (J.S.)

Hesperis matronalis, L. Luton Hoo (J.S.)

Camelina sativa, Crantz. Luton deodorizing works (J.S.)

Neslia paniculata, Desv. Casual, Luton (Pryor)

+Viola permixta, Jord. New Mill End (J.S.)

- canina, L. Cbiltern Green Common (J.S.)

Stellaria aquatica, Scop. New Mill End (J.S.)

- palustris, Retz. Luton Hoo Park (Mr. J. Ekins)

Sagina nodosa, Fenzl. Leagrave (J.S.)

Geranium lucidum, L. Marslets near Luton (J.S.)

- pyrenaicum, Burm. Luton Hoo (Abbot)

Hypericum calycinum, L. Luton Hoo

- quadrangulum, L. Luton (Bot. Guide)
Onobrychis viciæformis, Scop. Apparently indigenous on the ancient greensward of the Chilterns (J.S.)

Melilotus arvensis, Desv. Luton (R. Pryor)

Prunus Padus, L. Luton Hoo Park, probably planted (J.S.)

Alchemilla vulgaris, L. Luton Hoo (U.S.)

Epilobium angustifolium, L. Whipsnade (J.S.)

- obsurum, Schreb. Limbury, Luton Hoo (J.S.)

Saxifraga granulata, L. Limbury (J.S.)

Carum Bulbocastanum, Koch. Limbury (J.S.)

Adoxa Moschatellina, L.

Hippuris vulgaris, L. Luton Hoo Lake (J.S.)

†Myriophyllum alterniflorum, DC. Pepperstsck (J.S.)

Peplis Portula, L. Studham (J.S.), Luton Hoo (J. Catt)

Sambucus Ebulus, L. Limbury (J.S.)

Arctium majus, Sckhuhr.

Erigeron acre, L. Leagrave (J.S.)"

Picris hieracioides, L. Pepperstock (J.S.)

Lactuca muralis, Fres. Luton Hoo (J.S.), near Dunstable (Pryor)

Hieracium umbellatum, L. Cbiltern Green (J.S.) 


\section{A HISTORY OF BEDFORDSHIRE}

†Campanula patula, L. Luton Hoo (J. Edge)

- latifolia, L. Whipsnade, Studham Common (J.S.)

Cuscuta Trifolii, Bab. See paper by Mr. Carruthers on the devastation of Swedish turnips at Dunstable (Foum. Royal Agric. Soc. vol. ix. pt. i.), where it is stated that the plant not only fed on the foliage but actually on the turnips themselves.

Erica cinerea, L. Pepperstock (J.S.)

Pyrola minor, L. Woods near Luton (Abbot), (? if in Beds)

Hypopitys Monotropa, Crantz. New Mill End (J.S.)

Vinca minor, L. Limbuty, New Mill End (J.S.)

Menyanthes trifoliata. Limbury, Leagrave Marsb (J.S.)

Atropa Belladonna, L. Whipsnade (Abbot)

Hyoscyamus niger, L. Limbuty (J.S.)

Digitalis purpurea, L. Luton Hoo (J.S.)

Linaria repens, Mill. Luton with the hybrid L. vulgari-repens (R. Pryor)

Mimulus Langsdorffi, Donn. Luton Hoo (J.S.)

Lysimachia nemorum, L. Chiltern Green (J.S.)

Ajuga Chamæpitys, Schreb. Luton Downs (Abbot)

Rumex maritimus, L. Nerv Mill End (J.S.)

Polygonum Bistorta, L. South of Luton (J.S.)

- maculatum, Trim. and Dyer. Lea Side (J.S.)

$\dagger$ Aristolochia Clematitis, L. Thoroughly naturalized in a wood at Luton Hoo (J.S.)

Daphne Laureola, L. Lengrave, New Mill End (J.S.)

Ceratophyllum demersum, L. Luton Hoo Lake in fruit, 1882 (J.S.)
Carpinus Betulus, L. Fine trees near Luton and at New Mill End (J.S.)

Populus canescens, Sm. Caddington (J.S.)

Salix purpurea, L. Limbury (J.S.)

Triglochlin palustre, L. Luton

Zannichellia palustris, L., bracbystemon, Gay. Luton Hoo, sources of the Lea (J.S.)

Potamogeton perfoliatum, L. Limbury Pond (J.S.)

- pusillum, L. New Mill End (J.S.)

- pectinatum, L. Luton Hoo Lake (J.S.)

Butomus umbellatus, L. River Lea (J.S.)

Habenaria viridis, R. Br. Pepperstock (J.S.)

Cephalanthera pallens, Rich. New Mill End (J.S.)

Tulipa sylvestris, L. Whipsnade (Abbot)

Polygonatum multiforum, All. Luton Hoo (J.S.)

Ornithogalum umbellatum, L. Limbury (J.S.)

Alluin ursinum, L. East Hyde (J.S.)

Orchis ustulata, L. Dunstable Downs

Iris foetidissima, L. Luton Hoo

Scirpus multicaulis, Sm. Woodside, Pepperstock (J.S.)

Carex disticha, Huds. Luton Hoo (J.S.)

- leporina, L. Pepperstock (J.S.)

- Goodenowii, Gay. Biscot (J.S.)

Sieglingia decumbens, Beauv. Pepperstock (J.S.)

+Bromus arvensis, L. Not uncommon near Luton (J.S.)

Lomaria Spicant, Desv. Luton Hoo (J.S.)

Asplenium Trichomanes, L. Luton Hoo

Scolopendrium vulgare, Symons. ",

Chara fragilis, Desv. Limbury (J.S.), with var. Hedwigii

Nitella opaca, Ag. Sources of the Lea at Biscot (J.S.)

\section{THE BRAMBLES (Rubi) ${ }^{1}$}

The brambles of Bedfordshire are only imperfectly known, but the extensive area of the Lower Greensand is especially prolific in species, and systematic search would probably reveal a large number. The areas of the Chalk and Clays are poor and afford little beyond Rubus ulmifolius, $R$. corylifolius with its varieties cyclopbyllus and sublustris, and the dewberry ( $R$. casius), the latter being especially frequent in damp woods and by the sides of wet ditches. The woodlands on the Clay also have $R$. leucostacbys, and occasionally $R$. radula and $R$. ecbinatus. The Chalk, where it comes to the surface, is also singularly poor, but where, as at Chiltern Common, it has a covering of brick earth or tertiaries a much more varied selection of brambles is to be met with. The richest districts are Woburn, Heath and Reach, the neighbourhood of Leighton Buzzard and Ampthill.

At Woburn, in both Bucks and Beds, is a variety of $R$. birtus, namely flaccidifolius (P. J. Müller), which is unknown elsewhere in Britain ; and in this neighbourhood the writer has met with $R$. pyramidalis, $R$. fissus, $R$. plicatus, $R$. Lindleianus, $R$. rbamnifolius, $R$. pulcberrimus, $R$. macropbyllus, $R$. rudis, $R$. dasypbyllus, $R$. dumetorum, $R$. corylifolius and 


\section{BOTANY}

var. sublustris. The raspberry $R$. idceus is local, but is found in all the larger districts and is common locally.

Several other species are recorded in various works, but the specific limitations are now so different from what they were when the records were made that it is impossible, with accuracy, to determine what species (as we now understand them) they are identical with, and it is safer to ignore them, a course which has been followed in the Handbook of the British Rubi, by the Rev. W. Moyle Rogers.

\section{THE ROSES (Ros $x)$}

The roses, like the brambles, have been much neglected so far as critical study goes, and such records as have been made are in many cases unsatisfactory.

The dog rose (Rosa canina) is widely distributed and shows more variation on clay soils. Among the modifications of it that the writer has met with are $R$. lutetiana, Leman, which is the commonest form, and is generally distributed, although less abundant, on the Greensand; $R$. dumalis, Bechst., under which is placed the biserrata of English writers, is also very common. $R$. dumetorum, Thuill., with which is grouped $R$. urbica, Leman, is widely distributed and occurs about Salford (Ouzel) in many situations. $R$. verticillata, Mérat, is local ; it occurs near Eaton Bray (Ouzel). The field-rose $(R$. arvensis, L.) is abundant in the woods and hedges on clay soils. The peduncles vary much as regards their armature of bristles; an extreme form is var. gallicoides, Baker. $R$. micrantba, Sm., is local, but is rather more frequent on the Chalk. The sweet brier (R. Eglanteria, L. $=R$. rubiginosa, L.) is rare and only scattered through the district, and is often only an escape from cultivation. The downy rose ( $R$. mollissima, Willd., $R$. tomentosa, Sm.) is rather rare; it occurs in a few localities, chiefly on hilly ground, as near Aspley (Ouzel), and usually as the var. subglobosa (Sm.)

\section{CR YPTOGAMS \\ THE CLUBMOSSES (Lycopodiacea)}

This order is probably extinct in Bedfordshire. According to Abbot, Lycopodium clavatum grew on Potton Heath, and L. inundatum at Ampthill, at the end of the eighteenth century, but there is no modern record of either.

\section{THE FERNS (Filices)}

Although there are old-established woods in Bedfordshire, the ferns are not numerous. The hard fern (Lomaria Spicant) is frequent on sides of ditches at Aspley and Flitwick. The black maiden hair (Asplenium Adiantum-nigrum) was found on Stafford Bridge by Abbot, and is mentioned as not uncommon in the South Beds list, I88I. Wall-rue ( $A$. Ruta-muraria) has been frequent on walls in the north since Abbot's

1 By J. Hamson, Bedford. 


\section{A HISTORY OF BEDFORDSHIRE}

time. A. Tricbomanes has been found at Stafford Bridge, Luton Hoo and Cardington. Aspidium aculeatum is native but very local ; Eversholt, Flitwick, Potton and Chicksands have been returned as stations. The hart's-tongue (Scolopendrium) is not common ; for many years it has grown in a well at Elstow, and it has been found on Newnham walls, at Lidlington, Luton Hoo and Toddington. Polypodium cristatum was noted by Abbot at Potton and Aspley, but Lastrea spinulosa was probably meant, and it has several modern stations. L. uliginosa was certified as correct by Dr. F. A. Lees, being found by McLaren at Flitwick in 1885 . L. Thelypteris grew on Potton Marsh in Abbot's time, and the name occurs in Hillhouse's list, I876, which also includes $L$. dilatata without station. The adder's tongue (Opbioglossum) is widely distributed, but the moonwort (Botrycbium), which Abbot found in Oakley West Field, is apparently extinct, as is also the royal fern (Osmunda), which formerly grew in Aspley Wood, and of late years has been found at Little Brickhill just outside the county boundary.

\section{THE HORSETAILS (Equisetacea)}

The great horsetail (E. maximum) is generally found on marshes, especially in the north, but is rarer in the south. The mud-horsetail (E. limosum) is frequent on bogs, and Mr. Saunders gives the Ivel near Sandy as a station for the var. fuviatile, which $\mathrm{Mr}$. Hillhouse also met with. Abbot recorded E. byemale at Potton and Ampthill, and $E$. sylvaticum at Haynes Wood, but there has been no recent confirmation of either.

\section{MARSILIACEÆ}

None have been found in the county.

\section{THE MOSSES (Musci) ${ }^{2}$}

As Bedfordshire is an inland county and possesses no mountains the following moss list of some 160 species and varieties is not so extensive and varied as it might be with different physical features. The sphagnums or bog mosses are found only on the Lower Greensand formation, which stretches across the middle of the county. The most noteworthy species in the list are Dicranum montanum and Hypnum Sendtneri, the latter of which it is feared has recently been exterminated through the ploughing up of its only known station.

The nomenclature and arrangement is that of the London Catalogue, ed. 2 (see, South Bedfordshire Mosses,' J. Saunders, Fourn. Botany, xxii. 47).

SPHAGNACEX

Sphagnum acutifolium, Ehrh. var. tenue " rubellum

- fimbriatum, Wils.

- squarrosum, Lind. var. laxum

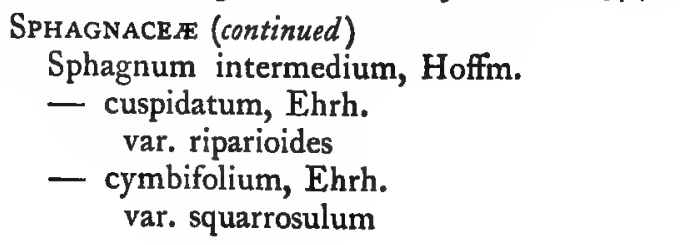

1 By J. Hamson, Bedford.

2 By James Saunders, Luton.

56 


\section{BOTANY}

WEISSIACE FE

Weissia viridula, Brid.

- cirrhata, Hedw.

Dicranella varia, Hedw.

- heteromalla, Hedw.

- Schreberi, Hedw.

- cerviculata, Hedw.

Dicranum montanum, Hedw. Aspley, very rare

- scoparium, L.

- majus, Thurn.

- palustre, Schimper.

Campylopus flexuosus, Brid.

Leucobryum glaucum, L.

BRUCHIACE IE

Pleuridium nitidum, Brid.

- subulatum, $L$.

Seligeria calcarea, Dicks. (Bryum calcareum Pottiace e of Abbot) East Hyde, I 903 (J.S.)

Phascum cuspidatum, Schreb.

- rectum, Sm.

Pottia cavifolia, Ehrh.

- minutula, Schweg.

- truncata, L.

- intermedia, Turn.

- lanceolata, Dicks.

Didymodon rubellus, B. \& S.

Ditrichum flexicaule, Schweg.

Trichostomum tophaceum, Brid.

Barbula muralis, $L$.

- ambigua, B. \& S.

- unguiculata, Dill.

- fallax, Hedw. var. brevifolia

- convoluta, Hedw.

- tortuosa, L.

- subulata, L.

- lævipila, Brid.

- ruralis, $\mathbf{L}$.

- intermedia, Brid.

Ceratodon purpureus, L.

Calymperace.

Encalypta vulgaris, Hedw.

GrIMMIACE E

Grimmia apocarpa, L.

- pulvinata, Dill.

Zygodon viridissimus, Dicks.

Orthotrichum saxatile, Brid.

- affine, Schrad.

- diaphanum, Schrad.

- Lyellii, H. \& T.

Funariacese

Physcomitrella patens, Hedw.

Physcomitrium pyriforme, $L$.

Funaria fascicularis, Dicks.

- hygrometrica, $\mathrm{L}$.

BARTRAMIACE

Bartramia pomiformis, $L$.

Philonotis fontana, $\mathrm{L}$.
BRYACE E

Leptobryum pyriforme, L.

Webera nutans, Schreb.

- cruda, Schreb.

- carnea, L.

Bryum pendulum, Hornsch.

- inclinatum, Swartz.

- bimum, Schreb. Flitwick

- murale, Wils. Luton Hoo

- atropurpureum, W. \& M.

- cæspiticium, L.

- argenteum, L.

- capillare, L.

- pseudo-triquetrum, Hedw.

- roseum, Schreb.

MNIACEA

Mnium affine, Bland.

- undulatum, Hedw.

- rostratum, Schrad.

- hornum, L.

- punctatum, Hedw.

Aulacomnium androgynum, I.

- palustre, $\mathbf{L}$.

Tetraphidacere

Tetraphis pellucida, L. Aspley

Polytrichiace

Atrichum undulatum, L.

Pogonatum nanum, Neck.

- aloides, Hedw.

- urnigerum, L.

Polytrichum formosum, Hedw.

- piliferum, Schreb.

- juniperinum, Willd.

- commune, $\mathbf{L}$.

Fissidentace e

Fissidens bryoides, Hedw.

- incurvus, W. \& M.

- viridulus, Wils.

- crassipes, Wils. Brombam

- adiantoides, Hedw.

- taxifolius, L.

RIPARIACE $x$

Cinclidotus fontinaloides, $\mathrm{Hedw}$.

Fontinalis antipyretica, $\mathrm{L}$.

- dolosa, Cardot. Limbury

Cryphæa heteromalla, Hedw.

LEUCODONTACE $F$

Leucodon sciuroides, $L$.

Neckeracex

Neckera crispa, L. On the chalk hills

- complanata, L.

Homalia trichomanoides, Schreb.

LESKEACE

Leskea polycarpa, Ehrh.

Anomodon viticulosus, L.

Thuidium tamariscinum, Hedw.

HYPNACE E

Thamnium alopecurum, L.

Climacium dendroides, $\mathrm{L}$.

Isothecium myurum, Poll. 


\section{A HISTORY OF BEDFORDSHIRE}

HYPNACEFE (continued)

Homalothecium sericeum, L.

Camptothecium lutescens, Huds.

Brachythecium glareosum, B. \& S.

- albicans, Neck.

- velutinum, L.

- rutabulum, L. var. longisetum, Bry. Eur.

Eurhynchium myosuroides, L.

- striatum, Schreb.

- crassinervium, Tayl.

- piliferum, Schreb.

- Swartzii, Turn.

- prælongum, Dill.

Rhynchostegium tenellum, Dicks.

- confertum, Dicks.

- murale, Hedw.

- ruscifolium, Neck.

Plagiothecium denticulatum, I. var. aptychus, Spruce

- undulatum, L.

Amblystegium serpens, $L$.

- riparium, L.

Hypnum aduncum, Hedw. var. Kneiffii, Bry. Eur.
HYPNACEE (continued)

Hypnum exannulatum, Gümb.

- Sendtneri, Schpr. Totternhoe; probably exterminated about $189^{\circ}$

- fluitans, L.

- filicinum, $L$.

- commutatum, Hedw.

- cupressiforme, L. var. tectorum, Schpr. On thatch var. filiforme, Bry. Eur. On trees var. ericetorum, Bry. Eur. On heaths

- resupinatum, Wils.

- patientiæ, Lindb.

- molluscum, Hedw.

- palustre, L.

- chrysophyllum, Brid.

- stellatum, Schreb.

- cordifolium, Hedw.

- cuspidatum, L.

- Schreberi, Ehrh.

- purum, L.

- stramineum, Dicks. Flitwick

Hylocomium splendens, Dill.

- squarrosum, $\mathrm{L}$.

- triquetrum, $\mathbf{L}$.

\section{THE SCALE-MOSSES AND LIVERWORTS (Hepatica) ${ }^{\mathbf{1}}$}

There are about two hundred species of Hepaticæ catalogued for the British Isles and of these only about twenty appear in the appended list. It is evident therefore that there is room for original investigation of the local forms of these plants.

It is desirable that modern records should be obtained for Abbot's Fungermannia viticulosa, $\mathcal{F}$. tamariscifolia and $\mathcal{F}$. fissa.

\section{Marchantiace E}

Marchantia polymorpha, L. Damp places, marshes and in greenhouses; frequent

Concephalus conicus, L. Banks of rivulets, etc. ; very local (Sewell)

Ricciella fluitans, L. In still waters; very local; Luton Hoo, near the Lower Island

\section{JUNGER MANNIACE $E$}

Frullania dilatata, L. On trees; frequent

Radula complanata, $\mathrm{L}$

Porella platyphylla, L. O' tree "roots, in shady places; not uncommon; Chaul End, Caddington, Luton Hoo

Lepidozia reptans, L. Shady banks ; local ; Aspley Woods, Heatb and Reach

Cephalozia divaricata, Sm., E. B. Shady banks, marshes, etc. ; local ; Flitwick, Barton, Heath and Reach

Lophocolea bidentata, L. Damp woods; frequent
JUNGERMANNIACEA (continued)

Lophocolea heterophylla, Schrad. Damp woods; frequent

Diplophyllum albicans, L. Moist woods ; rare; Heath and Reach

Plagiochila asplenoides, L. Damp woods and shady banks ; local; Streatley, Flitwick

Jungermannia bicrenata, Lindenb. On old tree roots on shady banks; rare; woodside by the path to Caddington

Blasia pusilla, L. Banks of rivulets ; rare ; Hazelwood Lane, Abbot

Pellia epiphylla, L. Ditch banks, etc.; local ; Amptbill, Flitwick

- calycina, Tayl. Banks of rivulets ; local; at the foot of Markham Hills

Aneura pinguis, L. Banks of rivulets; local; Barton Springs

- multifida, Gray. Woods; common; Abbot

Metzgeria furcata, L. Shady banks; local; Limbury, Harlington, Amptbill

1 By James Saunders, Luton. 


\section{BOTANY}

\section{THE STONEWORTS (Characea) ${ }^{1}$}

The Charas or stoneworts constitute a well-defined group of aquatic plants, the English appellation being given to them on account of the quantity of lime that is secreted by some of the species. They are always submerged, and are to be found in ponds, pools, lakes and streams, affecting chiefly quiet waters, although sometimes occurring in rapidly running brooks. They are often the first kind of vegetation to occupy pools that have been newly formed, such as water holes in clay pits and reservoirs that are uncovered. In such situations they may sometimes be observed to have filled nearly the whole of the available space, to the temporary exclusion of other vegetation. It is also noteworthy that they occasionally die away rapidly from an apparently congenial habitat, and although they may have fruited abundantly, and the mud below contains multitudes of their fruits, they do not reappear for several years. Apparently they have exhausted the constituents in the water that are necessary to their existence, and do not start a fresh growth until the conditions are again favourable for that purpose. It may happen that, in the meantime, other aquatic plants, such as water-buttercups and pondweeds, have occupied the site, and the Characex can only find a precarious existence, or fail to reappear for an indefinite period. In the waterways of the Fen districts they often occur in enormous quantities, and as their tissues contain a large proportion of mineral matter, they add annually in their decay an appreciable amount of soil. Their presence may often be detected by the fotid odour they exhale when left uncovered by receding waters.

The only two forms mentioned by Abbot (1798) are Chara vulgaris and $C$. tomentosa, the latter probably that now known as C. bispida. The most noteworthy record given below is that of Nitella mucronata, found in 1882 by C. H. Davis, after having been unrecorded in Great Britain for fifty years.

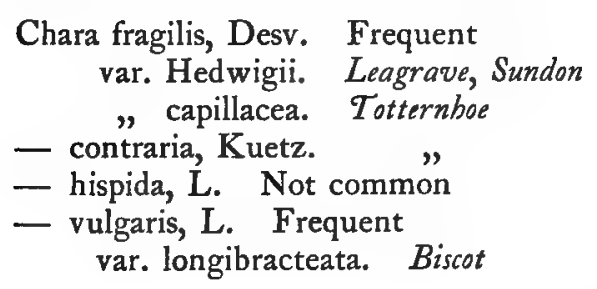

Tolypella glomerata, Leonh. Rare; Leagrave, near Bedford

- intricata, A. Br. Rare; Brammingham, Sundon

Nitella mucronata, Kuetz. Rare; River Ouse, Bedford, River Ivel, Sandy

- opaca, Ag. Frequent

\section{$\mathrm{ALG} \circledast^{2}$}

Practically the only available information concerning the freshwater algæ is in Abbot's records. A few microscopists have examined specimens from time to time but have kept no records, and apparently have had no means of determining species. Mr. E. M. Holmes, curator of the Museums of the Pharmaceutical Society of Great Britain, has been Britain.

1 By James Saunders, Luton.

2 Revised by E. M. Holmes, curator of the Museums of the Pharmaceutical Society of Great 


\section{A HISTORY OF BEDFORDSHIRE}

good enough to revise Abbot's list. In modern nomenclature it appears therefore that the following species were noted by that investigator.

\section{CYANOPHYCE压}

Nostoc commune, Vauch. Common

- pruniforme, C. Ag. On the heath in Wrest Park

Aphanizomenon Flos-aquæ, Ralfs. Common

\section{CHLOROPHYCE $\&$}

Spirogyra porticalis, Vauch. Common Hydrodictyon reticulatum, Lagerh. Woburn, Aspley
Enteromorpha intestinalis, Link. Common Trentepohlia aurea, C. Ag. Barton Hill Cladophora canalicularis, Kutz. Millponds, :common

- fracta, Kütz. Common

- glomerata, Kütz.

Vaucheria sessilis, D., var. cæspitosa, Cooke. Rare; Luton Hoo

\section{RHODOPHYCE E}

Batrachospermum moniliforme, Roth.

With regard to Conferva bullosa, Vaucberia sessilis (Conferva ampbibia), and Spirogyra porticalis (Conferva rivularis), Mr. Holmes remarks that he does not positively identify the species, but has compared the references with the illustrations given by Dillenius (as quoted in Abbot's work) but the illustrations do not show any structural details. As regards Conferva bullosa, concerning which Abbot says, 'threads matted, enclosing bubbles of air,' Mr. Holmes remarks, 'I have seen Cladopbora fracta lifted to the top of the marsh ditches by gas given off by the weed in sunshine, and there could be no other alga of a bright green colour growing in the situations described and in matted tufts that does the same.' The Vaucheria is stated by Abbot to grow on damp walls, but $\mathrm{Mr}$. Holmes says it is found in spring time in runnels of water at the foot of damp walls by farmhouses, etc. Abbot's description of the branches uniting into points when dry exactly applies to it. The Spirogyra named is most likely the one intended, but the structure is not given by Dillenius.

\section{THE LICHENS (Lichenes)}

In this section we have also to rely upon the observations of Abbot and the revision by Mr. E. M. Holmes. In the following list the numbers refer to the records in the Flora Bedfordiensis.
879 Collema
896 Collema nigrescens, Ach.
85 I Calicium hyperellum, Ach. (?)

The Lichen flavus of old authors apparently included the sterile thalli of several lichens. C. byperellum, common on old oaks, is probably the species intended by Abbot, as he mentions that Lichen flavus grows ' on oak barks.'

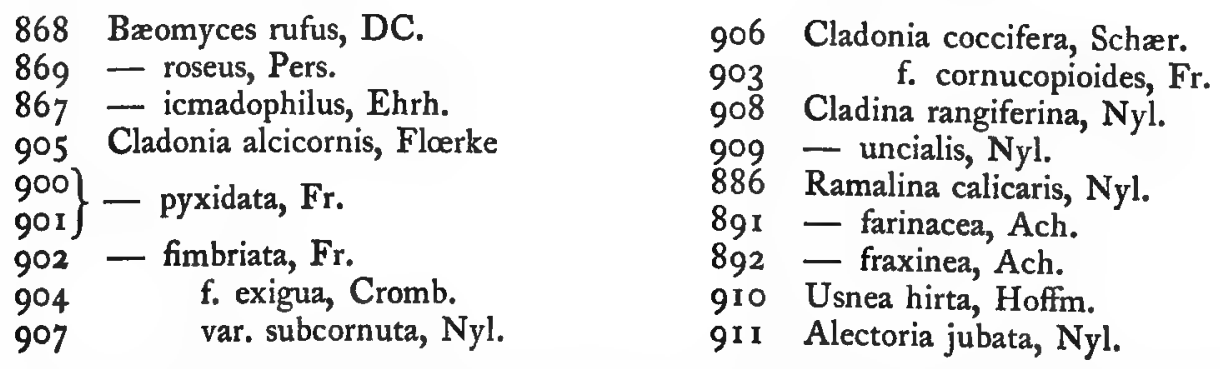
Britain.

1 Revised by E. M. Holmes, Curator of the Museums of the Pharmaceutical Society of Great 


\section{BOTANY}

895 Evernia prunastri, Ach.

890 var. stictocera, Hook.

883 Parmelia saxatilis, Ach.

888 - caperata, Ach.

880 - subaurifera, Nyl.

882 - physodes, Ach.

896 Lobaria pulmonaria, Hoffm.

897 Peltidea aphthosa, Ach.

898 Peltigera canina, Hoffm.

899 - horizontalis, Hoffm.

881 Physcia parietina, De Not.

888 - lychnea, Nyl.

889 - ciliaris, DC.

885 - aipolia, Nyl.

849 Leproloma lanuginosum, Nyl. (?)

886 Lecanora saxicola, Ach.

888 - laciniosa, Nyl.

876 - citrina, Ach.
87 I Lecanora aurantiaca, Nyl.

875 - galactina, Ach.

878 - subfusca, Nyl.

865 - sulphurea, Hoffm.

873 - atra, Ach.

876 - parella, Ach.

857 - calcarea, Somm.

863 - fuscata, Schrad.

$865\}$ Pertusaria amara, Nyl.

870 - communis, DC.

877 Urceolaria scruposa, Ach.

864 Lecidea quernea, Ach.

869 - sanguinaria, Ach.

858 - calcivora, Ehrh.

86 I - canescens, Dicks.

862 - cæruleo-nigricans, Lightf.

850 - canescens, Ach.

Although Lichen incanus is referred by subsequent writers to Lecidea pacbycarpa, Duf., that is a comparatively rare species, whilst Abbot's L. incanus is stated to be common on the bark of trees; he probably refers to the undeveloped growth of $L$. canescens in a sorediate condition.

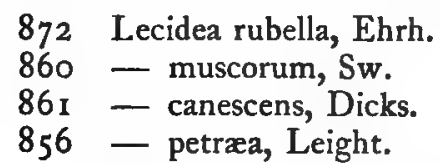

854 Opegrapha varia, Pers., f. pulicaris, Leight.

853 Graphis scripta, Linn.

863 Verrucaria nigrescens, Pers.

The rarer species in this list are Bcomyces icmadopbilus, Alectoria jubata, Peltidea apbthosa, Lecidea sanguinaria and Peltigera borizontalis, which are usually found in upland or subalpine districts; Peltidea apbtbosa generally occurs in limestone woods, as in Derbyshire, where it is frequent. Of the commoner lichens, which are almost certain to occur in districts where other species equally common are found, there is no doubt that many would be detected in the county by careful search and that this list might be largely increased.

The first three lichens in Abbot's list, Nos. 849, 850 and $85 \mathrm{I}$, used to be placed in the genus Lepraria, but all three, as well as the rest of this spurious genus, consist of undeveloped sorediate thalli, and probably each included several species. Licben incanus was probably $L$. canescens, but might be an undeveloped Pertusaria or Lecanora bamatomma or even $L$. rubra, all of which have whitish powdery thalli. Similarly Lichen albus may have been Leproloma lanuginosum or several others, and $L$. flavus is likewise doubtful. These therefore cannot be regarded as positive records. Mr. Holmes has followed Crombie's British Lichens as far as Urceolaria scruposa and for the remainder Leighton's Lichen Flora of Great Britain.

\section{FUNGI $^{2}$}

Abbot gave considerable attention to the larger forms of fungi, and also includes in his list some of the smaller ones. About a hundred 


\section{A HISTORY OF BEDFORDSHIRE}

years after his time Mr. J. Hamson took up the subject. His records were confirmed in the first instance by Mr. Worthington G. Smith and afterwards for several seasons by Mr. W. B. Grove of Birmingham, who also revised Abbot's list of fungi in terms of modern nomenclature. At that time the modern list was of almost equal length with that of Abbot's, allowance being made for microscopic forms which Mr. Hamson did not collect. Mr. E. M. Langley of Bedford has also been a collector of fungi for several years; the initials ' E.M.L.' indicate that the specimens were found by Mr. Langley and examined by Mr. Hamson. The initials 'W.B.G.' and 'W.G.S.' signify that the specimens were seen and named by $\mathrm{Mr}$. Grove and Mr. Worthington Smith respectively. Those to which no initials are attached or are followed by such remarks as 'common' are on the authority of Mr. Hamson alone. A list of the recent finds was revised by Mr. W. B. Grove, read by him before the Birmingham Natural History and Philosophical Society, Io April 1894, and published in the Fournal of that society, vol. i. No. I 3. The fairly well established records number about 266 so far, but many others have been found though doubtfully recorded, and some which have the reputation of growing in the county have not been seen by the author.

Mr. Grove's notes on Abbot's Fungus Flora are set out at length in the Midland Naturalist, xvi. (1893), 212, 235. It will be sufficient to state here that according to the identifications, which Mr. Grove has very carefully traced, thirty-eight species of Agaricus found by Abbot have been rediscovered, together with seventy-eight fresh records; but sixteen of Abbot's species have not been since met with or only doubtfully. Abbot gives five Coprini, and they have all been found again. $\mathrm{He}$ gives Bolbitius titubans, but the modern record is B. bydropbilus. Of his four species of Cortinarius only one, binnuleus, is in the modern record. Gomphidius viscidus survives from Abbot's time, as does Paxillus involutus; but, singular to say, $P$. atrotomentosus, so common in recent years, is not in his list. Of Hygrophorus he gives five species, all rediscovered with seven additions. He records Lactarius torminosus and piperatus. The latter is not in the modern list, which contains eleven in all. He records only Russula nigricans of that genus; Cantharellus cibarius and $C$. retirugus, but not aurantiacus, which is very common; and seven species of Marasmius, of which the first five constitute the modern records, but $M$. Hudsoni and M. epipbyllus have not been confirmed. Lentinus tigrinus and lepideus are now frequent, but Abbot found only L. cocbleatus. His two species of Panus have not since been noticed, but Lenzites flaccida is known at Ampthill together with $L$. betulina. Abbot gives only four Boleti, of which piperatus is not in the modern list. Out of eleven Polypori three, viz. varius, lucidus and intybaceus have not been since met with. He gives a much longer list of the Pezize than that below. The comparison might be pursued further with regard to many of the other families and genera; but most of the common forms mentioned by Abbot have been rediscovered. A considerable number of his records can however be only doubtfully recognized. It is interesting to note 


\section{BOTANY}

that Cyanopballus caninus, which has been found by Mr. Saunders in Luton Hoo Park, was recorded by Abbot at Silsoe.

In the fir woods on the Greensand the fungi grow in great profusion. Paxillus atrotomentosus, which Stevenson notes as rare, is really the prevailing form on fir stumps in these woods. It has come up regularly and in great quantity every season since 1885 . Species of Boletus, notably elegans, and also of Russula are common in these woods. Agaricus rubescens is very frequent, but $A$. muscarius is only occasionally found. The dangerous form, $A$. phalloides, is frequent in the Southill woods and probably elsewhere. $A$. procerus and $A$. rbacodes are both favourite esculents with the Bedford fungophagi; but though numerous other kinds have been eaten by local specialists and their friends, the only kind that has any popular vogue outside the mushrooms is $A$. personatus, locally known as the blue-leg. This is extensively used for making ketchup. The shaggy top (Coprinus comatus) comes next in popularity, mainly because it is easily identified ; but the people will not look at such superior sorts as the champillon, the morell, and the chanterelle, of which the first is abundant, the second frequent, and the third locally plentiful at Woburn.

In the following list the names of the Hymenomycetes are those of Stevenson's British Fungi:-

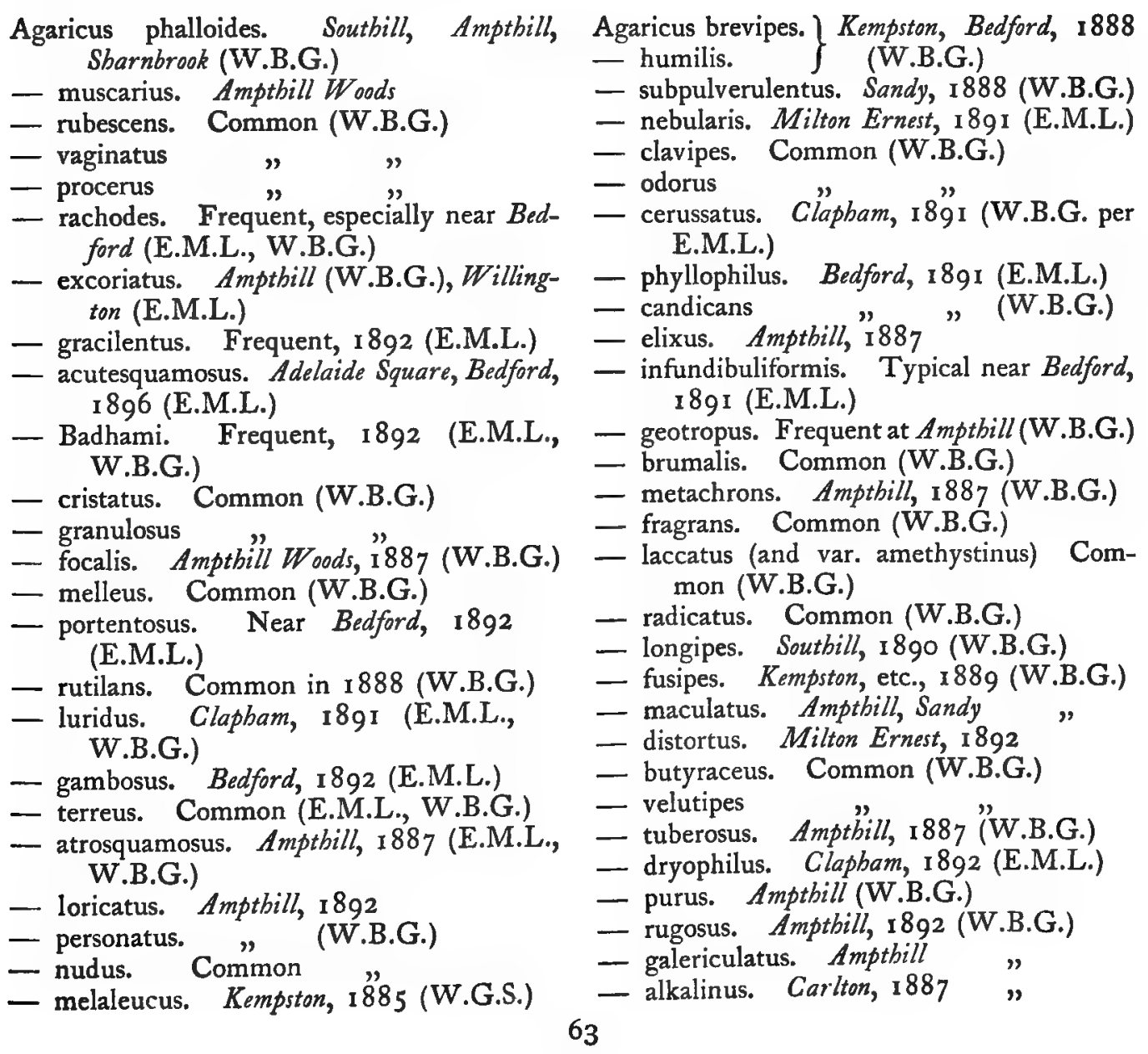




\section{A HISTORY OF BEDFORDSHIRE}

Agaricus ammoniacus. Sandy, 1887 (W.B.G.)

- tenuis. Sandy, Amptbill

- epipterygius. Amptbill, I887

- fibula. Sandy, 1887 and since (W.B.G.)

- "Swartzii. Amptbill, I 887 (W.B.G.)

- corticatus. 1892 (E.M.L.)

-- ulmarius. Common (W.B.G.)

-- lignatilis. Amptbill, etc., frequent

- circinatus. I 892 (E.M.L.)

- ostreatus. Common (W.B.G.)

- euosmus. Bedford, 1889 and since (W.G.S.)

- septicus. Amptbill, 1887 (W.B.G.)

- speciosus. Amptbill, abundant, 1892 (W.B.G.); the thin grey variety, Bedford, 1898

- parvulus. Biddenbam, 1887 (W.B.G.)

- cervinus. Pavenbam, I887

- chrysophæus. Kempston, 1887 ",

- sericeus. Ampthill, etc., I 887

- prunulus. Frequent (W.G.S., W.B.G.)

- " orcella. Soutbill (W.B.G.)

- cretatus. Common (W.B.G.)

- pascuus "

— durus. Common at Bedford (W.B.G.)

- pudicus. Bedford on elder, 1887

- comosus. Ampthill, I892 (W.B.G.)

- squarrosus. Common (W.B.G.)

- aurivellus. Great Barford, 1896

- Bongardii. Soutbill Park, I 887 (W.B.G.)

- rimosus. Common (W.B.G.)

— asterosporus. Bedford, 1887 (W.B.G.)

- geophyllus. Ampthill, I887

- fastibilis. Kempston and near "Bedford (W.G.S., J.H., E.M.L.)

- glutinosus. Near Bedford, I892 (E.M.L.)

- crustuliniformis. Ampthill, 1892

- nudipes. Near Bedford, I 892 (E.M.L.)

- lentus. Bedford, I 887 (W.B.G.)

- flavidus. Amptbill, Bedford (W.B.G.)

- melinoides. Bedford, I887 ",

- striapes. Kempston, very rare "

- pediades. Pavenham, I887

- tener. Common (W.B.G.)

- furfuraceus. Common (W.B.G.)

- inquilinus. Bedford, I 887 ,

- mollis. Bedford, Kempston "

- Elvensis. Near Bedford" (E.M.L., W.B.G.)

- arvensis. Common (W.B.G.)

- campestris var. praticola. Common var. rufescens. I901 (E.M.L.)

- sylvaticus. Near Bedford,! 89 I (E.M.L.)

- zruginosus. Common (W.B.G.)

- coronillus. Kempston, 1887 "

- semiglobatus. Common "

- sublateritius. Frequent"

- fascicularis. Common "

- lachrymabundus. Kempston, "I885 (W.G.S.)
Agaricus velutinus. Common (W.B.G.)

- Candolleanus. Kempston (W.G.S., W.B.G.)

- appendiculatus. Common (W.B.G.)

- areolatus. Kempston (W.G.S.)

- fonisecii. Frequent (W.B.G.)

— corrugis " separatus. Common in 1890

- fimiputris. Common

- campanulatus "

- papilionaceus

— gracilis. Bedford (W.B.G.)

- atomatus. Brombam

- disseminatus. Common

Coprinus comatus. Common (W.B.G.)

- atramentarius " "

- niveus. Common

- micaceus " (W.B.G.)

- domesticus. Amptbill, I887

- plicatilis. Common (W.B.G.)

Bolbitius hydrophilus. Amptbill, $\mathbf{1 8 8 7}$ (W.B.G.)

Cortinarius callisteus. Great Warden, 1892

- tabularis. Amptbill, 1887 (W.B.G.)

- hinnuleus. Bedford, I887

Gomphidius viscidus. Frequent (W.B.G.)

Paxillus giganteus. Common in 1892 (W.B.G.)

- involutus. Common (W.B.G.)

- atrotomentosus. Ampthill, Sandy (W.B.G.)

- lepista. rgor (E.M.L.)

Hygrophorus hypothejus. Amptbill, common (W.B.G.)

- pratensis. Common (W.B.G.)

- virgineus " "

- ovinus. Carlton, 1891

- ceraceus. Ampthill (W.B.G.)

- coccineus. Frequent ",

- puniceus " "

- conicus. Common "

- calyptraformis. Carlton, I 887 (W.B.G.)

- chlorophanus. Amptbill, I886

- psittacinus. Common (W.B.G.)

- nitratus. Brombam, I887

Lactarius torminosus. Frequent (W.G.S., W.B.G.)

- insulsus. Frequent (W.B.G.)

- trivialis. Frequent in 1892

- pyrogalus. Sandy, 1887; Great Warden, I 892 (W.B.G.)

- vellereus. Oakley, 1892 (E.M.L., W.B.G.)

- deliciosus. Sandy, 1887; Amptbill, Soutbill, etc. (W.B.G.)

- quietus. Common (W.B.G.)

- rufus

- volemus. Clapham, I 886

- mitissimus. 1892 (E.M.L.)

- subdulcis. Frequent (W.B.G.) 


\section{BOTANY}

Russula nigricans. Ampthill, Soutbill

$$
\text { (E.M.L., W.B.G.) }
$$

- adusta. Soutbill, I 887 (W.B.G.)

- delica. Frequent, I892 (E.M.L.)

- cyanoxantha. The commonest species (W.B.G.)

- heterophylla. Southill, I89o (W.B.G.)

- foetens. Frequent (W.B.G.)

- Queletii. Ampthill

- ochroleuca " I 886 "(W.B.G.)

- integra. Oakley, I891 (E.M.L.)

Cantharellus aurantiacus. Common, assuming various forms (W.B.G.)

- cibarius. Woburn, plentiful, 1896

Marasmius peronatus. Common (W.B.G.)

- oreades. Common; rare in 1887 (W.B.G.)

- ramealis. Frequent (W.B.G.)

- rotula. Kempston, I887 (W.B.G.)

- androsaceus. Sandy ,

Lentinus tigrinus. Banks of Ouse (W.B.G.)

- lepideus. On railway bridges, etc. ; common (W.B.G.)

Lenzites betulina. Ampthill (W.B.G.)

- Haccida. Amptbill, 1889

Boletus luteus. Common at Ampthill

- elegans. Sandy, I888; Amptbill, 1891

- Havus. Amptbill (W.B.G.)

- granulatus. Ampthill and Sandy (W.B.G.)

- bovinus. Amptbill, 1889

-- badius. Frequent (W.B.G.)

- chrysenteron. Nortbill, Amptbill (W.B.G.)

- subtomentosus. Soutbill, I 888 (W.B.G.)

- edulis. Not common (W.B.G.)

- fragrans. Near Bedford, I 893 (E.M.L.)

- impolitus. Ampthill, frequent

- Satanas. Oakley, I 892 (E.M.L.); $W_{0-}$ burn, 1897 (J.H.)

- purpureus. Ampthill, 1889, per Mr. Ferraby

- laricinus. Ampthill, I 888

Fistulina hepatica. Amptbill Park, etc., frequent (W.B.G.)

Polyporus rufescens. Pavenham, 1889 (W.B.G.)

- perennis. Ampthill (W.B.G.)

- squamosus. Common ",

- lucidus. Ampthill, 1887"

- frondosus. 1892 (E.M.L.)

-- sulphureus. Common in 1892 (W.B.G.)

- chioneus. Frequent (W.B.G.)

- fumosus. Frequent in 1887

- adustus. Kempston, 1887 (W.B.G.)

- hispidus. Frequent in 1887

- dryadeus. Carlton, 1887 (W.B.G.)

- applanatus. Bedford, 1888

- fomentarius. (W.B.G.)

- igniarius. Oakley (E.M.L.)

- fulvus. Brombam
Polyporus ulmarius. Common (W.B.G.)

- fraxineus. Lidlington

- annosus. Common (W.B.G.)

- versicolor

- abietinus. Amptbill, I 88 "

Trametes gibbosa " " per Mr. Ferraby (W.B.G.)

- suaveolens. Bedford, I 887 (W.B.G.)

Dxdalea unicolor. Ampthill, Kempston (W.B.G.)

- quercina. Amptbill, 1892 (E.M.L.)

Hydnum auriscalpium. Amptbill, 1885 (W.G.S.)

Thelephora laciniata. Common (W.B.G.)

- molissima. Amptbill, I 885 (W.G.S.)

Stereum purpureum. Bedford, Ampthill; frequent

- hirsutum. Nortbill, 1886 (W.G.S.)

- spadiceum. Amptbill

Auricularia mesenterica. Common (W.B.G.)

Corticium corrugatum. Sharnbrook, 1885 (W.G.S.)

- aridum. Ampthill, 1885 (W.G.S.)

Clavaria muscoides. Amptbill, 1887 (W.B.G.)

- coralloides. Amptbill, I 886 and since

- cinerea " 1887

- rugosa $"$ frequent (W.B.G.)

— fusiformis. Amptbill, 1887 and since" "

- argillacea. Amptbill, 1887

Calocera viscosa. Common (W.B.G.)

Tremella mesenterica. Amptbill, 1889, per Mr. Ferraby (W.B.G.)

Dacryomyces stillatus. Bedford (W.B.G.)

Phallus impudicus, L. Common at Ampthill

Mutinus (Cyanophallus) caninus, Fr. Luton Hoo Park (J. Saunders, W.G.S.)

Bovista plumbea, P. Common (W.B.G.)

Lycoperdon giganteum, Batsch. Common (W.B.G.)

- cælatum, Fr. Amptbill, 1887

- gemmatum, Fr. Common (W.B.G.)

- pyriforme, Schœff. Kempston, etc., I887 (W.B.G.)

Scleroderma vulgare, Fr. Bedford, etc., I 887 (W.B.G.)

- verrucosum, P. Southill, etc., 1887 (W.B.G.)

Cyathus striatus, Hoffm. Amptbill, 1887 (W.B.G.)

- vernicosus, DC. Bedford, I 887 (W.B.G.)

Tubercularia vulgaris, Tode. Common on currant twigs (W.B.G.)

Verticillium agaricinum, $\mathrm{Ca}$. On Agaricus ostreatus, Ampthill, I887, per Mr. Ferraby (W.B.G.)

Melasmia acerina, Lev. Amptbill, common on sycamore leaves (W.B.G.)

Ptychogaster albus, Ca. Common in pine woods (W.B.G.) 


\section{A HISTORY OF BEDFORDSHIRE}

Morchella esculenta, L. Ampthill and Sandy

- crassipes, P. Amptbill, 1877 and since; frequent (W.B.G.)

Peziza badia, P. Pavenham (W.G.S.)

- vesiculosa, Bull. Kempston, etc. (W.G.S.)

- calycina, Schum. On larch twigs (W.B.G.)

Tuber xstivum, Vitt. Amptbill, Flitwick; common, per Mr. Ferraby

Xylaria polymorpha, Grev. Ampthill, 1887 (W.B.G.)

- Hypoxylon, Grev. Common (W.B.G.)
Mucor fusiger, Lk. On Agaricus fusipes W.B.G.)

Sporodinia grandis, Lk. ) Growing on LacSyzygites megalocarpus,
Ehr.

Reticularia umbrina, Fr. Amptbill, I 888 (W.B.G.)

Didymium squamulosum, A. et $\mathrm{S}$. On Pol. fumosus, Amptbill, 1887 (W.B.G.)

Tubulina cylindrica, Bull. Sandy, 1887 (W.B.G.)

Trichia varia, P., var. genuina. Amptbill, I 887 (W.B.G.)

Mr. Grove adds : As bearing on the subject of the Bedford Fungus Flora, it may be mentioned that, in the later volumes of the English Fungi, Sowerby figures two other Bedford species which he received from Abbot :

t. 242. Ag. tremulus, Schœeff. $\quad$ t. 437. Xylaria pendunculata, Fr.

as well as (t. 362) Ag. planus, which is probably a form of $A g$. crustuliniformis, and (t. $3^{69}$, f. 8) Peziza nigra and (t. $3^{89}$, f. 8) Peziza Abbotiana, which are, perhaps, both unrecognizable.

In Cooke's Handbook there are two records of Bedfordshire Fungi :

p. 253. Boletus rubinus, Sm. Near Dunstable p. 748. Genea hispidula, B. Bedfordsbire

And in his Illustrations two more are figured:

t. 876. Paxillus atrotomentosus, Fr. Woburn t. 922. Hygrophorus puniceus, Fr. Bedfordshire (W.B.G.)

\section{MYCETOZOA OR MYXOMYCETES ${ }^{1}$}

The curious group of organisms usually known as the Mycetozoa forms one of the numerous links that connect the animal and the vegetable kingdoms. They frequently occur as denizens of damp woods, where they creep about on rotten tree roots or fallen branches, during one stage of their existence. They are also to be found on decaying heaps of leaves or straw, especially if such accumulations have been undisturbed for several months. In these situations they are occasionally to be met with in immense quantities, so much so that portions of the heap appear as though covered with hoar frost from the numerous calcareous sporangia that have been formed on them.

In the following list of the species that have been recorded for Bedfordshire, the most noteworthy are Badbamia ovispora, Fuligo ellipsospora, Diachea subsessilis, Chondrioderma testaceum, and Lycogala flavofuscum.

It is also worthy of remark that out of the two hundred species that are catalogued for the whole world in Mr. A. Lister's Monograph which was issued by the British Museum authorities, upwards of ninety have been found within ten miles of Luton. The most prolific district 


\section{BOTANY}

in Bedfordshire for these organisms is the parish of Flitwick, for which at least sixty species have been recorded (see 'Mycetozoa of the South Midlands,' J. Saunders, Fourn. Bot. xxxviii. 83 ). ${ }^{1}$

Ceratiomyxa mucida, Schroed.

Badhamia hyalina, Berk. var. papaveracea

- utricularis, Berk.

- nitens, Berk.

- macrocarpa, Rost.

- panicea, Rost.

- lilacina, Rost.

- rubiginosa, Rost.

- ovispora, Racib. First British record

- foliicola, Lister

Physarum leucopus, Link

- citrinum, Schum.

— viride, Pers.

- nutans, Pers. var. violascens var. leucophæum

- calidris, Lister

- compressum, Alb. and Schw.

- straminipes, Lister. Sp. nov.

- didermoides, Rost. var. lividum

- cinereum, Pers.

- vernum, Somm. (E. Saunders)

- bivalve, Pers.

- diderma, Rost.

- contextum, Pers.

- conglomeratum, Rost.

Fuligo septica, Gmel.

- ellipsospora, Lister. First European record

Craterium pedunculatum, Trent.

- leucocephalum, Ditm.

- mutabile, Fries

Leocarpus vernicosus, Link

Chondrioderma spumaroides, Rost.

- testaceum, Rost.

- Michelii, Rost.

- reticulatum, Rost.

- niveum, Rost.

- radiatum, Rost.

Diachæa elegans, Fries

- subsessilis, Peck. First European record

Didymium difforme, Duby

- serpula, Fries

- clavus, Rost.

- farinaceum, Schrad.

- nigripes, Fries

- effusum, Link

- Trochus, Lister. Sp. nov.

Spumaria alba, DC.

Lepidoderma tigrinum, Rost. (Miss G. Lister)
Stemonitis fusca, Roth. var. confluens

- splendens, Rost.

- ferruginea, Ehrenb.

- Smithii, Macbride

Comatricha obtusata, Preuss.

- typhoides, Rost.

- Persoonii, Rost.

- rubens, Lister

Enerthenema elegans, Bowen

Lamproderma physaroides, Rost.

- irideum, Massee

- violaceum, Rost.

Brefeldia maxima, Rost.

Lindbladia tubulina, Fries

Cribraria argillacea, Pers.

- aurantiaca, Schrad.

Dictydium umbilicatum, Schrad.

Licea flexuosa, Pers.

Tubulina fragiformis, Pers.

Dictydizthalium plumbeum, Rost.

Enteridium olivaceum, Ehrenb.

Reticularia Lycoperdon, Bull

- lobata, Lister

Trichia affinis, de Bary

- persimilis, Karst.

- scabra, Rost.

- varia, Pers.

- contorta, Rost. var. inconspicua

- fallax, Pers.

- Botrytis, Pers. var. munda, Lister

Hemitrichia rubiformis, Lister var. Neesiana

— intorta, Lister

- clavata, Rost.

Arcyria ferruginea, Sauter

- albida, Pers. var. pomiformis

- punicea, Pers.

- incarnata, Pers.

- Alava, Pers.

Perichæna depressa, Libert.

- populina, Fries

- variabilis, Rost.

Margarita metallica, Lister (Miss Crouch)

Prototrichia flagellifera, Rost.

Lycogala flavo-fuscum, Rost. First British record (C. Crouch)

- miniatum, Pers.

1 All records have been verified by A. Lister, whose assistance is gratefully acknowledged. 



\section{ZOOLOGY}

MOLLUSCS

Although the physical features of Bedfordshire are such as to favour molluscan life, students of the mollusca are conspicuous by their absence, and only one paper, that by Mr. J. Saunders, Midland Naturalist (1888), xi. I 52, has been published on the conchology of the area. From this and the Records of the Conchological Society, supplemented from the observations of Mr. Cox and the Rev. C. McN. Rushforth the following list has been compiled.

Only 74 species out of the 139 known to exist in the British Islands have thus been actually found; but the names of fourteen others preceded by an asterisk [*] have been included in the list, because judging from the records of neighbouring counties they must certainly exist in the area. So far as our opinion can be formed from such scanty material this molluscan fauna is of the average British type.

A notable inhabitant is the Roman snail (Helix pomatia), which however was living in England before the advent of the Romans. It is a very local species, and in this county is found near Luton.

\section{A. GASTROPODA}

\section{PULMONATA \\ a. STYLOMMATOPHORA}

Limax maximus, Linn.

- favus, Linn.

Agriolimax agrestis (Linn.)

* - lavis (Müll.).

* Amalia sowerbii (Fer.)

* - gagates (Drap.)

Vitrina pellucida (Mull.)

Vitrea crystallina (Mull.)

- alliaria (Miller). Woburn Sands; Ampthill

- glabra (Brit. Auct.) Woburn Sands;

Luton; Sharnbrook

- cellaria (Mull.)

- nitidula (Drap.)

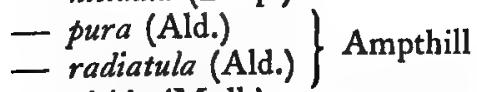

- radidata (Mull.)

- fulva (Mall.)
Arion ater (Linn.)

- bortensis, Fér.

- circumscriptus, John.

* - subfuscus (Drap.)

Punctum pygmaum (Drap.) Bromham ; Woburn

Pyramidula rotundata (Müll.)

Helicella virgata $(\mathrm{Da} \mathrm{C}$.)

- itala (Linn.)

- caperata (Mont.)

- cantiana (Mont.)

* Hygromia fusca (Mont.)

- granulata (Ald.)

- bispida (Linn.)

- rufescens (Penn.)

Acantbinula aculeata (Mull.)

Vallonia pulcbella (Mull.)

Helicigona lapicida (Linn.)

- arbustorum (Linn.)

Helix aspersa, Mull. 


\section{A HISTORY OF BEDFORDSHIRE}

Helix nemoralis, Linn.

- bortensis, Mull.

Buliminus obscurus (Mull.)

Cocblicopa lubrica (Mall.)

Azeca tridens (Pult.) Near Luton; near Bedford; Barton-le-Clay; Ampthill

Calianella acicula (Mull.)

Pupa cylindracea (Da C.)

- muscorum (Linn.)

Spbyradium edentulum (Drap.) Local and rare

Vertigo antivertigo(Drap.) Near Ampthill; Tottenhoe

- substriata (Jeff.) Near Ampthill

- pygmea (Drap.)

* Balea perversa (Linn.)

Clausilia laminata (Mont.)

- bidentata (Ström.)

Succinea putris (Linn.)

- elegans, Risso

\section{b. Basommatophora}

Carychium minimum, Mull. $\left.\begin{array}{l}\text { Ancylus fuviatilis, Mull. } \\ \text { Velletia lacustris (Linn.) }\end{array}\right\}$ Limbury
Limnea auricularia (Linn.)

- pereger (Müll.)

- palustris (Mull.)

- truncatula (Mull.)

- stagnalis (Linn.)

Planorbis corneus (Linn.)

- albus, Mül.

- nautileus (Linn.)

- carinatus, Mull. R. Ivel

- marginatus, Drap.

- vortex (Linn.) Limbury

* - spirorbis, Mull.

- contortus (Linn.)

- fontanus (Lightf.) Limbury

Physa fontinalis (Linn.)

* - bypnorum (Linn.)

\section{PROSOBRANCHIATA}

Bitbynia tentaculata (Linn.)

* - leacbii (Shepp.)

* Vivipara contecta (Millett)

*Valvata piscinalis (Mull.)

* - cristata, Mull.

Pomatias elegans (Mull.)

Neritina fluviatilis (Linn.) Great Barford

\section{B. PELECYPODA}

* Dreissensia polymorpha (Pall.)

Unio pictorum (Linn.)

- tumidus, Retz.

Anodonta cygnea (Linn.)

Spberium corneum (Linn.)

* Pisidium amnicum (Mull.)
Pisidium pusillum (Gmel.)

- nitidium, Jenyns. Limbury

- fontinale (Drap.) and the variety $P$. benslowianum

- milium (Held.) Biscot 


\section{INSECTS}

The county of Bedford cannot be said to rank high in regard to the number of its species of insects in various groups. The paucity of its insect fauna may in great part be attributed to high farming, as well as to the nature of its soil. Yet the admixture of its clay with the great oolite and the more sandy formation towards Woburn furnishes a variation of soil which is favourable to insect life, and it is very possible that further investigation-especially by a larger number of workers-may add considerably to the list of species found in the county up to the present time. The only orders which appear to have been studied in the county are the Coleoptera (beetles) and the Lepidoptera (butterflies and moths) : of the former order from seven to eight hundred species have been recorded; of the latter over six hundred.

\section{COLEOPTERA}

The records of Coleoptera from Bedfordshire have hitherto been very few and far between, and the county has evidently never been worked by any of the older collectors, except perhaps for an odd day or two. Hydroporus marginatus, indeed, was first taken in Britain near Woburn by the Rev. Hamlet Clark, and Harpalus discoideus used to be regarded as a great prize when it was found near Sandy more than half a century ago, but these instances are quite exceptional, and at first it appeared hopeless to attempt to draw up any list at all. Mr. H. Willoughby Ellis of Knowle near Birmingham, however, has been kindly collecting during the past summer with a view to this list, and I am much indebted to him for the large number of species which he has recorded, and for all the trouble he has taken in the matter. I must also express my thanks to Mr. Herbert Studman of the School House, Woburn, for a few interesting records.

It will probably be found in time that Bedfordshire contains a large number of good species. The banks of the Ouse will certainly furnish many, and there are woods and parks which cannot but contain a fair proportion of the rarer species which occur in the adjacent counties.

Most of the species mentioned below are common, but there are a few very interesting insects among them. Among these may be mentioned : Homausa acuminata, Ischnoglossa corticina, several good species of Homalota, Megacronus inclinans, Asemum striatum, Euplectus piceus, and last but not least Bagous cylindrus, which was found by Mr. Ellis in numbers a short time ago.

Most of the insects mentioned in the list have been taken by 


\section{A HISTORY OF BEDFORDSHIRE}

Mr. Ellis within about ten miles of Leighton Buzzard. Dr. Power lived in Bedford during the last years of his life ; if he had been younger and able to collect, even for a few weeks, our knowledge of the beetles of the county would be very much enlarged, for he always seemed to know intuitively where to find the scarcest species.

\section{Cicindelide}

Cicindela campestris, $L$.

\section{Carabider}

Cychrus rostratus, $\mathrm{L}$.

Carabus catenulatus, Scop.

- nemoralis, Müll.

- violaceus, $\mathbf{L}$.

- granulatus, L.

Notiophilus biguttatus, $F$.

- aquaticus, $\mathbf{L}$.

Leistus spinibarbis, $\mathbf{F}$.

- fulvibarbis, Dej.

- ferrugineus, $L$.

Nebria brevicollis, $F$.

Elaphrus riparius, $\mathbf{L}$.

- cupreus, Duft.

Loricera pilicornis, $\mathbf{F}$.

Clivina fossor, $\mathrm{L}$.

Dyschirius globosus, Herbst

Broscus cephalotes, L. Dawson (Geod. Brit. p. II4) has the following note on this species: 'It is not, as has been commonly supposed, exclusively a coast species, for it has been taken by T. V. Wollaston, Esq., on a sandy common near $\mathcal{T}$ wigmoor in the north of Lincolnshire, forty miles from the sea; and I myself have captured specimens near Woburn in Bedfordshire, more than double that distance from the coast'

Badister bipustulatus, $\mathbf{F}$.

Acupalpus meridianus, $L$.

Bradycellus distinctus, Dej.

- verbasci, Duft.

- harpalinus, Dej.

Harpalus rufibarbis, $F$.

- ruficornis, $\mathbf{F}$.

- æneus, F.

- rubripes, Duft.

- discoideus, F. Woburn; also recorded by Dawson from Sandy

- latus, L.

- tardus, Panz.

Stomis pumicatus, Panz.

Platyderus ruficollis, Marsh.

Pterostichus cupreus, L.

- versicolor, Sturm

- madidus, $F$.

- niger, Schall.

- vulgaris, $L$.

- nigrita, $F$.

- minor, Gyll.
Carabide (continued)

Pterostichus strenuus, Panz.

- diligens, Sturm

- picimanus, Duft. Woburn

- vernalis, Gyll.

- striola, F.

Amara fulva, Dej.

- apricaria, Sturm

- ovata, $\mathrm{F}$.

- similata, Gyll.

- lunicollis, Schiödte

- familiaris, Duft.

- trivialis, Gyll.

- communis, Panz.

- plebeia, Gyll.

Calathus cisteloides, Panz.

- flavipes, Fourc.

- mollis, Marsh.

- melanocephalus, $\mathrm{L}$. var, nubigena, $\mathrm{Hal}$.

- piceus, Marsh.

Pristonychus terricola, Herbst Anchomenus angusticollis, $\mathrm{F}$.

- dorsalis, Mull.

- albipes, F.

- oblongus, Sturm

- marginatus, $L$.

- parumpunctatus, $F$.

- viduus, Panz. var. moestus, Duft.

- micans, Nic.

- fuliginosus, Panz.

- gracilis, Gyll.

- piceus, L.

- thoreyi, Dej.

Olisthopus rotundatus, Payk.

Bembidium rufescens, Guér.

- obtusum, Sturm

- guttula, F.

- mannerheimi, Sahlb.

- biguttatum, F.

- riparium, Ol.

- æneum, Germ.

- articulatum, Panz.

- lampros, Herbst var. velox, Er.

- decorum, Panz.

- nitidulum, Marsh.

- quadriguttatum, $\mathrm{F}$.

- quadrimaculatum, Gyll.

- femoratum, Sturm

- littorale, Ol.

- Alammulatum, Clairv. 


\section{INSECTS}

\section{Carabide (continued)}

Tachypus flavipes, L.

Trechus discus, F. Islands of the Ouse, Dawson

- micros, Herbst

- minutus, $\mathrm{F}$.

- secalis, Payk.

Patrobus excavatus, Payk.

Demetrias atricapillus, $L$.

Dromius linearis, $\mathrm{Ol}$.

- agilis, F.

- meridionalis, Dej.

- quadrimaculatus, $\mathbf{L}$.

- quadrinotatus, Panz.

- melanocephalus, Dej.

Blechrus maurus, Sturm

Metabletus foveola, Gyll.

- truncatellus, $\mathrm{L}$.

\section{HALIPLID $A$}

Brychius elevatus, Panz.

Haliplus flavicollis, Sturm

- ruficollis, De G.

- lineatocollis, Marsh.

DyrTsCIDF

Noterus sparsus, Marsh.

Laccophilus interruptus, Panz.

- obscurus, Panz.

Coelambus versicolor, Schall.

- inæqualis, $F$.

Deronectes assimilis, Payk.

- depressus, $\mathrm{F}$.

Hydroporus pictus, $\mathbf{F}$.

- rivalis, Gyll.

- lineatus, F.

- angustatus, Sturm

- gyllenhali, Schiödte

- palustris, L.

- erythrocephalus, $L$.

- nigrita, $\mathbf{F}$.

- pubescens, Gyll.

- planus, $F$.

- marginatus, Duft. First taken in Britain at $W$ oburn by the Rev. Hamlet Clark

Agabus guttatus, Payk.

- nebulosus, Forst

- chalconotus, Panz.

- bipustulatus, L.

Platambus maculatus, $L$.

Ilybius fuliginosus, $\mathbf{F}$.

- ater, De G.

Colymbetes fuscus, $\mathrm{L}$.

Dytiscus marginalis, L.

Acilius sulcatus, L.

Gyrinus natator, Scop.

- marinus, Gyll. var. opacus, Sahl.

Orectochilus villosus, Mull.

\section{HYDROPHILIDE}

Hydrobius fuscipes, $L$.

Anacœena globulus, Payk.

- limbata, F.
HYDROPHILIDE (continued)

Laccobius sinuatus, Mots.

Limnebius truncatellus, Thoms.

Chætarthria seminulum, Herbst

Helophorus nubilus, $F$.

- aquaticus, $L$. var. æqualis, Thoms.

- æneipennis, Thoms.

- brevipalpis, Bedel

Hydrochus elongatus, Schall.

Octhebius pygmæus, $\mathbf{F}$.

Hydræna nigrita, Germ.

Sphæridium scarabæoides, F.

- bipustulatum, F. var. marginatum, $\mathbf{F}$.

Cercyon hæmorrhous, Gyll.

- hæmorrhoidalis, Herbst

- obsoletus, Gyll.

- flavipes, F.

- lateralis, Marsh.

- melanocephalus, $L$.

- unipunctatus, L.

- nigriceps, Marsh.

- analis, Payk.

- granarius, Thoms.

- minutus, Muls.

Megasternum boletophagum, Marsh.

Cryptopleurum atomarium, Muls.

\section{StAPHYLINIDEE}

Homøusa acuminata, Maerk. Woburn

Aleochara fuscipes, $\mathrm{F}$.

- bipunctata, OI.

- lanuginosa, Grav.

- moesta, Grav.

- nitida, Grav.

- morion, Grav.

Microglossa suturalis, Mann.

- nidicola, Fairm.

Oxypoda opaca, Grav.

- alternans, Grav.

- longiuscula, Er.

Ischnoglossa prolixa, Grav.

- corticina, Er. Woburn Park

Ocyusa incrassata, Kr. Woburn; Leighton Buzzard

Phloeopora reptans, Grav.

Ocalea castanea, Er.

- badia, Er.

Chilopora longitarsis, Er.

Myrmedonia humeralis, Grav.

Astilbus canaliculatus, F.

Thamiaræa cinnamomea, Grav.

Alianta incana, Er.

Homalota gregaria, Er.

- eximia, Sharp ${ }^{1}$

- fragilis, $\mathrm{Kr}^{1}{ }^{1}$

- longula, Heer ${ }^{1}$

1 These three species were taken by Mr. Ellis amongst sand and shingle on the margin of a brook near Leighton Buzzard. 


\section{A HISTORY OF BEDFORDSHIRE}

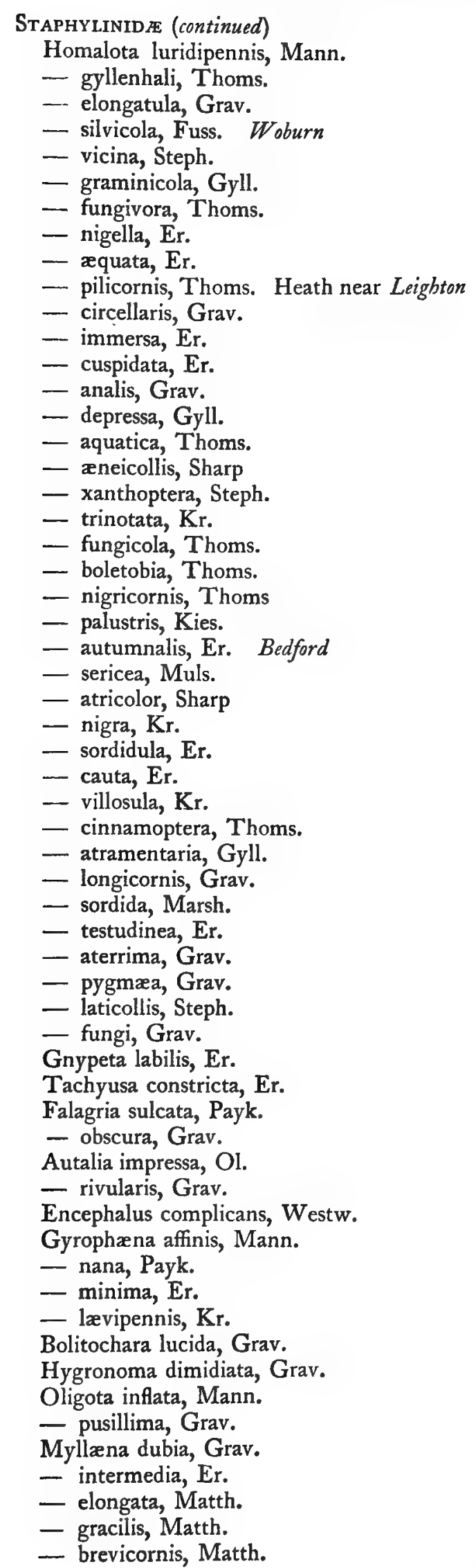

\author{
Staphyinidere (continued) \\ Hypocyptus longicornis, Payk. \\ Conosoma littoreum, L. \\ - pubescens, Grav. \\ - lividum, Er. \\ Tachyporus obtusus, $\mathrm{L}$. \\ - chrysomelinus, L. \\ - humerosus, Er. \\ - hypnorum, F. \\ - pusillus, Grav. \\ - brunneus, $\mathrm{F}$. \\ Cilea silphoides, $\mathrm{L}$. \\ Tachinus humeralis, Grav. \\ - rufipes, $L$. \\ - subterraneus, $\mathrm{L}$. \\ - marginellus, $\mathrm{F}$. \\ - laticollis, Grav. \\ Megacronus cingulatus, Mann. \\ - analis, $F$.
}

- inclinans, Grav. Heath near Leighton

Bolitobius lunulatus, L.

- trinotatus, Er.

- exoletus, Er.

- pygmæus, $\mathrm{F}$.

Mycetoporus splendens, Marsh.

- lepidus, Grav.

Heterothops prævia, Er.

Quedius mesomelinus, Marsh.

- fulgidus, $\mathrm{F}$.

- cruentus, Ol.

- cinctus, Payk. (impressus, Panz.)

- fuliginosus, Grav.

- molochinus, Grav.

- picipes, Mann.

- maurorufus, Grav.

- rufipes, Grav.

- boops, Grav.

Creophilus maxillosus, $\mathrm{L}$.

Leistotrophus nebulosus, $\mathbf{F}$.

Ocypus olens, Müll.

- brunnipes, F.

- morio, Grav.

Philonthus splendens, F.

- laminatus, Creutz.

- æneus, Rossi

- proximus, $\mathrm{Kr}$.

- addendus, Sharp. In moss, Leighton Buzzard

- politus, F.

- varius, Gyll.

- marginatus, $\mathbf{F}$.

- albipes, Grav.

- cephalotes, Grav.

- sanguinolentus, Grav.

- varians, Payk.

- micans, Grav.

- trossulus, Nord.

Xantholinus glabratus, Grav.

- punctulatus, Payk.

- linearis, $\mathrm{Ol}$. 


\section{INSECTS}

STAPHyLINIDa (continued)

Xantholinus longiventris, Heer

Baptolinus alternans, Grav.

Othius fulvipennis, $\mathrm{F}$.

- melanocephalus, Grav.

Lathrobium elongatum, L.

- boreale, Hoch.

- fulvipenne, Grav.

- brunnipes, F.

- terminatum, Grav. var. immaculatum, Fowler

- multipunctum, Grav.

Stilicus rufipes, Germ.

- orbiculatus, Er.

- similis, Er. Heath near Leighton

- affinis, Er.

Medon melanocephalus, F.

Sunius angustatus, Payk.

Pæderus littoralis, Grav.

Dianous coerulescens, Gyll.

Stenus guttula, Mull.

- bimaculatus, Gyll.

- Juno, F.

- speculator, Er.

- providus, var. Rogeri, $\mathrm{Kr}_{\text {. }}$

- buphthalmus, Grav.

- atratulus, Er.

- exiguus, Er.

- brunnipes, Steph.

- impressus, Germ.

- pallipes, Grav.

- flavipes, Steph.

- pubescens, Steph.

- binotatus, Ljungh.

- bifoveolatus, Gyll.

- cicindeloides, Grav.

- similis, Herbst.

- tarsalis, Ljungh.

- paganus, Er.

- latifrons, Er.

Oxyporus rufus, $\mathrm{L}$.

Bledius fracticornis, Payk.

Platystethus arenarius, Fourc.

Oxytelus rugosus, Grav.

- insecatus, Grav.

- sculptus, Grav.

- sculpturatus, Grav.

- tetracarinatus, Block

Haploderus coelatus, Grav.

Trogophloeus bilineatus, Steph.

- elongatulus, Er.

Syntomium æneum, Mall.

Lesteva longelytrata, Goeze

- pubescens, Mann.

Olophrum piceum, Gyll.

Lathrimæum atrocephalum, Gyll.

- unicolor, Steph.

Homalium rivulare, Payk.

- excavatum, Steph.

-- cæsum, Grav.
STAPHYLINIDFe (continued)

Homalium pusillum, Grav.

- punctipenne, Thoms.

- rufipes, Fourc.

- planum, Payk.

- concinnum, Marsh.

- deplanatum, Gyll.

Anthobium torquatum, Marsh.

Proteinus ovalis, Steph.

- brachypterus, $\mathbf{F}$.

Megarthrus denticollis, Beck.

Phloeobium clypeatum, Mull.

\section{SilPHIDF}

Clambus pubescens, Redt.

- minutus, Sturm

Agathidium seminulum, L.

- Levigatum, Er.

Amphicyllis globus, F. Woburn

Liodes humeralis, Kug.

Necrophorus humator, Goeze

- mortuorum, F.

- vestigator, Hersch.

- vespillo, L.

Silpha thoracica, $\mathbf{L}$.

- rugosa, $L$.

- sinuata, $\mathrm{F}$.

- atrata, L. var. brunnea, Herbst

Choleva angustata, F.

- cisteloides, Fröhl.

- spadicea, Sturm. Billington

- velox, Spence

- nigricans, Spence

- grandicollis, Er.

- nigrita, Er.

- tristis, Panz.

- chrysomeloides, Panz.

- fumata, Spence

Catops sericeus, F.

Colon brunneum, Latr. Brickbill

SCYDMANIDEE

Scydmænus collaris, Mull.

Eumicrus tarsatus, Mall.

Pselaphide

Pselaphus Heisei, Herbst

Bythinus validus, Aubé

Bryaxis fossulata, Reich.

- juncorum, Leach

Euplectus signatus, Reich.

- piceus, Mots.

Phalacride

Stilbus testaceus, Panz.

\section{CocCINELLID}

Anisosticta 1 9-punctata, L.

Adalia bipunctata, L.

Mysia oblongoguttata, L.

Coccinella ro-punctata, L.

- hieroglyphica, L.

- I I-punctata, L.

- 7-punctata, $\mathrm{L}$. 


\section{A HISTORY OF BEDFORDSHIRE}

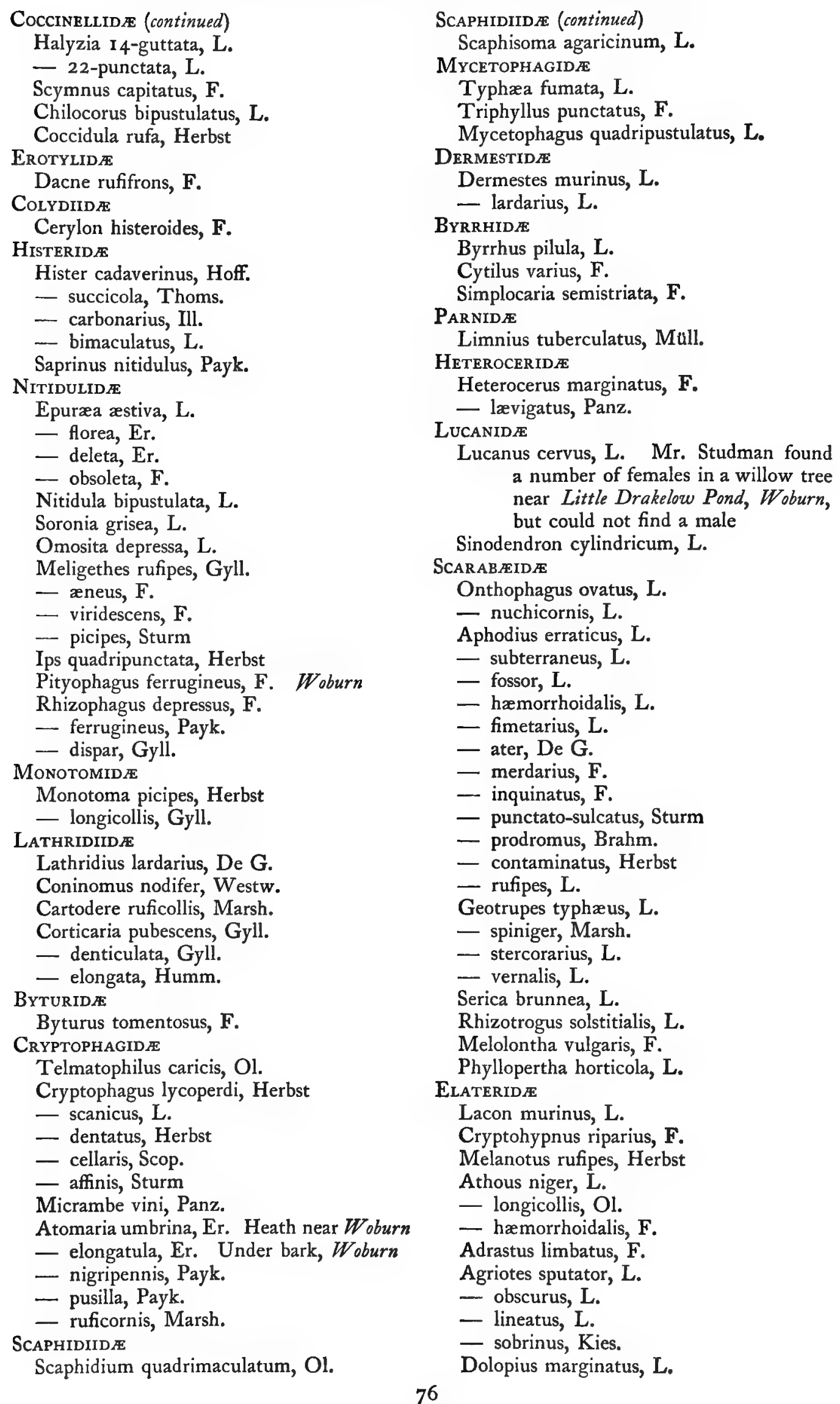




\section{INSECTS}

Elateride (continued)

Corymbites tessellatus, $\mathbf{F}$.

- quercus, Gyll.

Campylus linearis, $\mathrm{L}$.

DASCIILIDAE

Helodes minuta, L.

Microcara livida, $\mathbf{F}$.

Cyphon coarctatus, Payk.

- variabilis, Thunb.

Scirtes hemisphæricus, $L$.

LAMPYRIDE

Lampyris noctiluca, L. Very plentiful near Little Brickbill, and probably general

TELEPHORIDA

Telephorus rusticus, Fall.

- lividus, L.

- nigricans, Mull.

- lituratus, Fall.

- figuratus, Mann.

Rhagonycha fuscicornis, Ol.

- fulva, Scop.

- testacea, L.

- limbata, Thoms.

Malthinus punctatus, Fourc.

Malthodes marginatus, Latr.

- pellucidus, Kies.

MeLYRIDe

Malachius bipustulatus, $L$.

Dasytes ærosus, Kies.

Cleride

Necrobia ruficollis, $\mathbf{F}$.

- violacea, L.

PTINIDF

Ptinus fur, $\mathbf{L}$.

Niptus hololeucus, Fald.

ANOBIIDFE

Anobium domesticum, Fourc.

Ptilinus pectinicornis, $\mathrm{L}$.

Cisside

Cis boleti, Scop.

- bidentatus, Ol.

- fuscatus, Mell.

Octotemnus glabriculus, Gyll.

\section{Cerambycides}

Aromia moschata, $\mathrm{L}$.

Asemum striatum, L. In stumps of Scotch fir, Woburn

Callidium violaceum, $\mathrm{L}$.

Clytus arietis, $\mathrm{L}$.

Rhagium inquisitor, $\mathrm{F}$.

- bifasciatum, $\mathbf{F}$.

Toxotus meridianus, Panz.

Strangalia armata, Herbst

Grammoptera ruficornis, $F$.

BrUCHIDE

Bruchus pectinicornis, L. In granary, Leighton

- rufimanus, Boh.
Eupoda

Donacia limbata, Panz. (lemnæ, F.)

- simplex, F.

- semicuprea, Panz.

- sericea, $L$.

Lema lichenis, Vœt.

Crioceris asparagi, $\mathrm{L}$.

Camptosomata

Cryptocephalus aureolus, Suffr.

- labiatus, $L$.

Crclica

Timarcha violacea-nigra, De G.

Chrysomela staphylea, $\mathrm{L}$.

- polita, $L$.

Phytodecta olivacea, Forst.

Gastroidea polygoni, L.

Phædon tumidulus, Germ.

- armoraciæ, L.

- cochlearix, $\mathrm{F}$.

Phyllodecta vitellinæ, L.

Hydrothassa marginella, L.

Prasocuris phellandrii, $L$.

Luperus rufipes, Scop.

Lochmæa capreæ, L.

- suturalis, Thoms.

Galerucella tenella, L.

Longitarsus melanocephalus, All.

Haltica oleracea, L.

Phyllotreta undulata, Kuts.

- nemorum, $L$.

- exclamationis, Thunb.

Sphæroderma testaceum, F.

Crepidodera transversa, Marsh.

- ferruginea, Scop.

- aurata, Marsh.

Plectroscelis concinna, Marsh.

Psylliodes chrysocephala, L.

Cryptosomata

Cassida flaveola, Thunb. (obsoleta, Ill.)

- viridis, $\mathrm{F}$.

TEnebrionid

Tenebrio molitor, $\mathbf{L}$.

- obscurus, F.

Tribolium ferrugineum, $\mathbf{F}$.

Helops striatus, Fourc.

LAGRIIDI

Lagria hirta, L.

Crstelide

Cistela marina, $\mathbf{L}$.

Pythidere

Rhinosimus planirostris, F.

EDemerid $\pi$

Edemera lurida, Marsh.

Pyrochroider

Pyrochroa serraticornis, Scop.

MORDELlid $\pi$

Anaspis frontalis, $\mathrm{L}$.

- ruficollis, $\mathrm{F}$.

Anthicide

Notoxus monoceros, $\mathrm{L}$. 


\section{A HISTORY OF BEDFORDSHIRE}

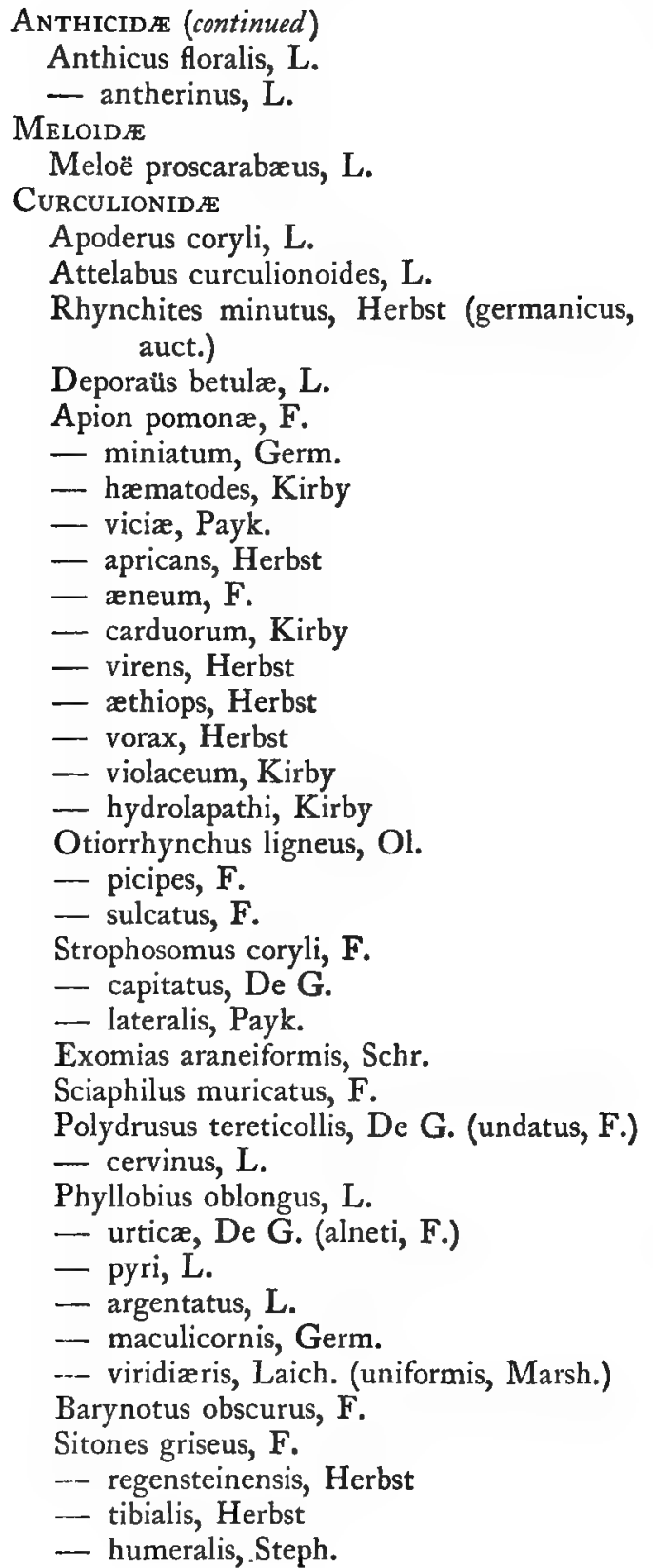

Curculionide (continued)

Sitones lineatus, L.

- sulcifrons, Thunb.

Hypera rumicis, $L$.

- nigrirostris, $\mathbf{F}$.

Liosoma ovatulum, Clairv.

Orchestes quercus, L.

- alni, L.

- rusci, Herbst

- salicis, L.

Grypidius equiseti, F.

Erirrhinus acridulus, $L$.

Dorytomus vorax, $\mathbf{F}$.

- maculatus, Marsh.

Bagous cylindrus, Payk. ${ }^{1}$

Anoplus plantaris, Naez.

Miccotrogus picirostris, $\mathrm{F}$.

Gymnetron pascuorum, Gyll.

Anthonomus ulmi, De G.

- pomorum, L.

Cionus blattariæ, F.

Cœliodes rubicundus, Herbst

- quadrimaculatus, $L$.

Poophagus sisymbrii, F.

Ceuthorrhynchus assimilis, Payk.

- contractus, Marsh.

- quadridens, Panz.

- pollinarius, Forst.

- litura, $\mathbf{F}$.

Ceuthorrhynchidius floralis, Payk.

- melanarius, Steph.

- troglodytes, F.

Rhinoncus pericarpius, L.

Calandra granaria, $L$.

Magdalis pruni, $\mathrm{L}$.

SCOLYTIDAE

Scolytus destructor, $\mathrm{Ol}$.

- multistriatus, Marsh.

Hylastes ater, Payk.

Myelophilus piniperda, L. Recorded by Mr. Studman as doing serious damage to pine woods near Woburn

Dryocæetes villosus, $\mathbf{F}$.

\section{LEPIDOPTERA}

For the means of furnishing any really passable catalogue of the Lepidoptera of the county of Bedford I am indebted in a very great degree to the kindness of Mr. A. E. Gibbs of St. Albans, whose large acquaintance with this county has been of the greatest assistance in drawing together the available information. Mainly through his help, valuable lists have been received of the larger Lepidoptera for Bedford

$1 \mathrm{Mr}$. Ellis tells me that this very interesting species occurs in a small boggy place near Leighton, and that he has taken it in hundreds. The bog often dries up in summer, and the insects congregate under the matted grass in one spot about ten yards square; although the bog covers some acres he has never found a specimen outside this small area. 


\section{INSECTS}

and the adjoining district from the Rev. O. W. Harries and Dr. W. G. Nash, and of these and also the smaller groups from Mr. J. Sharpin. Mr. W. Bond-Smith has furnished a useful list of the larger species found at Potton, and Mr. Herbert Studman a list of a few species at Woburn. At Luton excellent work was done by Mr. J. A. Saunders, now unhappily deceased, and to documents left by him, and obligingly lent by his father Mr. Jas. Saunders, A.S.S., to Mr. A. E. Gibbs, I am indebted for the extensive list of species both of Macro- and MicroLepidoptera supplied for that district.

\section{RHOPALOCERA}

Aporia cratægi, Linn.(Black-veined White Butterfly) Reported by Mr. H. Studman to have formerly occurred near Woburn

Pieris brassicæ, Linn., rapæ, Linn., napi, Linn. (White Butterflies) Abundant everywhere

Anthocharis cardamines, Linn. (Orange-tip) Generally distributed

Colias hyale, Linn. (Pale Clouded Yellow) Bedford, Woburn; plentiful in 1900 and 1901

- edusa, Linn. (Clouded Yellow) Bedford, Potton; abundant in the year 1900

Gonepteryx rhamni, Linn. (Brimstone Butterfly) Bedford, Luton, Potton; frequent in clover fields

Chrysophanus phlzeas, Linn. (Small Copper) Generally distributed

Polyommatus arion, Linn. (Large Blue) Haworth in 1803 says: "Taken in Bedfordsbire and sent to me by my friend Dr. Abbot'; Professor Westwood (1849) adds that it was taken in the 'Mouse's pasture' near Bedford, and that Mr. J. C. Dale took it there again in 1819; further that it was taken on commons near Brombam

- agestis, Hb., medon, Esp. (Brown Argus) Bedford, on hillsides

- alexis, Hb., icarus, Rott. (Common Blue) Generally common

- adonis, $\mathrm{Hb}$., bellargus, Rott. (Clifden Blue) On chalk hillsides near Bedford

-- corydon, Scop. (Chalk-hill Blue) On chalk hillsides near Bedford

- alsus, Schiff. (Bedford Blue) Hills and railway banks around Bedford and Luton

- argiolus, Linn. (Holly Blue) Bedford

Thecla quercts, Linn. (Purple Hairstreak) Generally about oaks in woods

- betulæ, Linn. (Brown Hairstreak) Reported near Woburn by Mr. H. Studman

- pruni, Haw. (Black Hairstreak) Found near Bedford by Dr. Nash
Thecla w-album, Knoch. (White Letter Hairstreak) Bedford and Woburn about wych elm

Apatura iris, Linn. Recorded at Clapham Park Woods by Professor Westwood ( 1849 ) on the authority of the Rev. W. T. Bree

Vanessa polychloros, Linn. (Large Tortoiseshell) This fine butterfly seems to be well distributed over the county

- urticæ, Linn. (Small Tortoiseshell) Abundant everywhere

- io, Linn. (Peacock Butterfly) ) All

- atalanta, Linn. (Red Admiral) generally

- cardui, Linn. (Painted Lady) distributed

Argynnis paphia, Linn. (Silver-washed Fritillary) Generally distributed in woods

- adippe, Linn. (High Brown Fritillary) Recorded near Bedford by Dr. Nash, and near Woburn by Mr. McKay

- euphrosyne, Linn. (Large Pearl-border) Bedford district, in woods

- selene, Schiff. (Small Pearl-border) Common in woods about $W_{\text {oburn }}$

Melitæa athalia, Esp. (Heath Fritillary) Recorded in Aspley $W_{\text {oods, fifty years ago, }}$ by Westwood

- artemis, Hb. (Greasy Fritillary) Clapham Park Woods ; Prof. Westwood

Melanargia galathea, Linn. (Marbled White) On chalk hills near Bedford

Pararge ageria, Linn. (Speckled Wood Butterfly) Bedford, in lanes and wood borders

- megæra, Linn. Generally distributed

Epinephile janira, Linn. (Meadow Brown) Generally common

- tithonus, Linn. (Gatekeeper) Generally common

- hyperanthus, Linn. (Ringlet) Plentiful in woods

Cononympha pamphilus, Linn. Common in every grass field

Syrichthus malva, Linn., alveolus, $H b$. Bedford, Luton, Potton 


\section{A HISTORY OF BEDFORDSHIRE}

Hesperia linea, Fab., thaumas, St. C. Bedford, Luton; in marshy places

- lineola, Ochs. This species, of recent discovery as British, has been found by Dr. Nash and Rev. O. W. Harries in woods and lanes near Bedford

- sylvanus, Esp. Generally common
Cyclopides paniscus, Fab., palæmon, St. C. Recorded by the late Professor Westwood at Clapham Park Woods and near Luton

Nisoniades tages, Linn. Bedford, Luton; on hillsides and railway banks

\section{HETEROCERA}

Smerinthus ocellatus, Linn. (Eyed Hawk Moth) Bedford, Potton, common at Woburn

- populi, Linn. (Poplar Hawk) Generally distributed, on poplars

- tiliæ, Linn. (Lime Hawk) Widely distributed, about limes and elms

Acherontia atropos, Linn. (Death's Head) Occasionally found; larva in potato fields

Sphinx convolvuli, Linn. Bedford, Potton; an occasional visitor

- ligustri, Linn. (Privet Hawk) Generally distributed ; larva on privet hedges

Chærocampa celerio, Linn. Dr. Nash reports: 'A specimen is said to have been taken in Bedford twenty years ago'

- elpenor, Linn. (Elephant Hawk) Bedford, Woburn

- porcellus, Linn. (Small Elephant) Bedford, Potton; among ladies' bedstraw

Macroglossa stellatarum, Linn. (Hummingbird Hawk) Generally distributed; to be seen occasionally in gardens, hovering at tubular flowers

- fuciformis, Linn. (Broad-bordered Bee Hawk) Dr. Nash records this species in woods near Bedford

- bombyliformis, Esp. (Narrow-bordered Bee Hawk) Dr. Nash also records this species in woods near Bedford

Sesia tipuliformis, Linn. Generally common about currant bushes

-- myopæformis, Bkh. Taken by Mr. W. Bond-Smith at Potton

- cynipiformis, Esp. Recorded by Westwood in Clapham Park Woods

Sphæcia bembeciformis, Hb. Bedford

- apiformis, Linn. (Hornet Clearwing) Bedford, Woburn; on poplars

Procris statices, Linn. Luton

Zygæna trifolii, Esp. (Five-spot Burnet) Found by Mr. H. Studman near Woburn

- filipendulæ, Linn. (Six-spot Burnet) Bedford, Luton, Potton; common

Zeuzera æsculi, Linn., pyrina, St. C. (Wood Leopard) Bedford, Woburn, Potton; not plentiful

Cossus ligniperda, Fab. (Goat Moth) Generally distributed
Hepialus hectus, Ochs. Bedford, Luton; in woods

- Iupulinus, Linn. Generally abundant in meadows

- sylvinus, Linn. Bedford, Luton

_ velled

- humuli, Linn. (Ghost) Generally common

Halias prasinana, Linn.)

- quercana, Schiff.

Earias chlorana, $\mathrm{Hb}$.

Taken in woods around Bedford

Sarrothripa revayana, W. V. Found by Mr. J. Sharpin near Bedford

Nola cucullatella, Linn. Bedford, Luton; among fruit trees

Calligenia miniata, Forst. Bedford, Luton

Lithosia complana, Linn. Taken near Potton by $\mathrm{Mr}$. W. Bond-Smith

- complanula, Bdv., lurideola, St. C. Taken at lamps near Bedford and Luton

- griseola, Hb. Bedford

Euchelia jacobææ, Linn. (Cinnabar) Generally common among ragwort and groundsel

Deiopeia pulchella, Linn. One specimen taken near County School by Dr. Nash, July 1894

Arctia caia, Linn. (Common Tiger) Everywhere common

- villica, Linn. (Cream-Spot Tiger) Reported by Mr. W. Bond-Smith at Potton

Phragmatobia fuliginosa, Linn. Bedford, Potton Spilosoma mendica, Linn. (Muslin) Bedford, Potton

- lubricepeda, Linn. Common everywhere

- menthastri, Schiff.

Porthesia chrysorrhæa, Linn." Reported at Bedford by the Rev. W. O. Harries, and at Woburn by Mr. H. Studman

- auriflua, Fab., similis, St. C. Generally common on hawthorn hedges

Liparis salicis, Linn.. Bedford, Potton; about willow or poplar

Dasychira pudibunda, Linn. Bedford, Potton - fascelina, Linn. Taken near Bedford by Dr. W. G. Nash

Orgyia antiqua, Linn. (Vapourer) Common everywhere, and conspicuous in the autumn by its lively dancing flight, about roads and shrubberies, in the sunshine 


\section{INSECTS}

Demas coryli, Linn. Bedford, also taken at Luton at 'light'

Pocilocampa populi, Linn. Bedford, Luton, Potton; sometimes to be seen flying around gas-lamps in December

Trichiura cratægi, Linn. Bedford, Luton, Potton; but scarce

. The large silken habiEriogaster lanestris, tations of the larvæ of Linn. these two species are not

Clisiocampa neustria, uncommon on hawLinn. thorn hedges and fruit

Lasiocampa trifolii, Esp. Dr. W. G. Nash reports that he has reared this species at Bedford

- quercus, Linn. Generally distributed

Odonestis potatoria, Linn.

Gastropacha quercifolia, Linn. Bedford, Woburn, Potton

Saturnia carpini, Schiff., pavonia, St. C. Bedford, Woburn, Potton

Cilix spinula, Schiff., glaucata, St. C. Generally distributed about hawthorn

Cerura furcula, Linn. (Kitten) Bedford, Luton; about sallow

- bifida, Hb. Recorded at Bedford by Dr. W. G. Nash

- vinula, Linn. (Puss Moth) Generally distributed among willow

Notodonta dictæa, Linn., tremula, St. C. Bedford, Luton; among poplar

- ziczac, Linn. Bedford

- dromedarius, Linn. Luton

Lophopteryx camelina, Linn. Bedford, Luton

Pterostoma palpina, Linn. Bedford, Potton; among poplar

Petasia cassinea, Schiff. Bedford

Pygæra bucephala, Linn. Generally common

Diloba cæruleocephala, Linn. " "

Gonophora derasa, Linn. Bedford, in woods

Cymatophora duplaris, Linn.

- ocularis, Linn. Bedford, taken at 'sugar,' and the pupa dug up from roots of poplar

Asphalia diluta, Schiff. Luton

Acronycta aceris, Linn. Bedford, Potton; about sycamore

- megacephala, Schiff. Bedford, Luton; on poplars

- tridens, Schiff. Larvæ taken at Potton

- psi, Linn. Generally common

- rumicis, Linn. Bedford

- ligustri, Schiff. Potton

Agrotis suffusa, $\mathrm{Hb}$. Bedford, Luton

- saucia, $\mathrm{Hb}$. "

- segetum, Schiff. Everywhere abundant ; very injurious in turnip fields

- puta, $\mathrm{Hb}$. Bedford; not very common
Agrotis exclamationis, Linn. Most abundant, and mischievous to growing turnips

- nigricans, Linn. Luton

- porphyrea, $\mathrm{Hb}$

- ravida, Hb. Bedford, very local

Axylia putris, Linn. Generally distributed

Triphæna fimbria, Linn. Bedford, in woods

- janthina, Esp. Bedford, Potton; in gardens and woods

- interjecta, Hb. Bedford, Luton; in woods and hedges

- orbona, Fab. Everywhere abundant

- pronuba, Linn. " "

Noctua augur, Fab. Bedford, Luton"

- plecta, Linn.

- c-nigrum, Linn. Bedford, Luton, Potton

- triangulum, Tr. Bedford, Luton; in woods

- festiva, $\mathrm{Hb}$.

- rubi, Viewig. " "

- xanthographa, Fab." Everywhere abundant

Eurois adusta, Esp. Luton, in woods

Charæas graminis, Linn. Bedford

Heliophobus popularis, Fab. Luton, Bedford, Potton

- cespitis, Fab. Potton

Aplecta advena, Fab. Bedford

- nebulosa, Hufn.

Hadena thalassina, Rott. "'

- pisi, Linn. Bedford, Potton

- oleracea, Linn. Common in gardens everywhere

- dentina, Esp. Bedford

- chenopodii, Fab., trifolii, St. C. Generally distributed

Mamestra brassicæ, Linn. Universally abundant, and mischievous in gardens

- persicariæ, Linn. Bedford, Luton, Potton

Hecatera serena, Fab. Bedford, Luton; a very pretty object on a tree trunk

Dianthecia carpophaga, Bkh. Luton

- cucubali, Fuessl. Luton

- capsincola, $\mathrm{Hb}$. Potton

-- conspersa, Esp. Luton

Polia Alavicincta, Fab. Bedford, Luton, Potton

- chi, Linn. Bedford; usually a northern species

Dryobota protea, Bkh. Bedford

Chariptera aprilina, Linn. Bedford, Luton, Potton; about oaks

Miselia oxyacanthæ, Linn. Bedford, Potton; its dark variety, capucina, occasionally

Luperina testacea, $\mathrm{Hb}$. Generally abundant

Cerigo cytherea, Fab., matura, St. C. Bedford

Hama anceps, Hb., sordida, St. C. Luton

Xylophasia lithoxylea, Fab. Generally common

- sublustris, Esp. Bedford, very local

- polyodon, Linn., monoglypha, St. C. Universally abundant 


\section{A HISTORY OF BEDFORDSHIRE}

Xylophasia hepatica, $\mathrm{Hb}$. Luton

- rurea, Fab.

Apamea basilinea, Fab. Luton, Bedford

- gemina, $\mathrm{Hb}$. Bedford

- oculea, Gn., didyma, St. C. Abundant everywhere

Miana strigilis, Clerck. Generally common

- fasciuncula, Haw. Bedford

- furuncula, Tr., bicoloria, St. C. Bedford, Luton

Eremobia ochroleuca, Esp. Recorded in Bedfordshire, Westwood and Humphrey, ii. 228

Dipterygia pinastri, Linn., scabriuscula, St. C. Bedford

Euplexia lucipara, Linn. Generally common

Phlogophora meticulosa, Linn. Common everywhere

Hydræcia nictitans, Bkh. Bedford

- micacea, Esp. Bedford, Luton

Gortyna Alavago, Esp., ochracea, St. C. Bedford, Luton

Tapinostola fulva, $\mathrm{Hb}$. Luton

Leucania conigera, Fab. Bedford, Luton

- lithargyria, Esp. Bedford; probably everywhere

- impura, Hb. Everywhere abundant

- pallens, Linn. " "

- straminea, Tr. Reported at Bedford by Mr. A. Sharpin

- comma, Linn. Bedford

Tæniocampa gothica, Linn. Generally common at sallow bloom

- cruda, Tr., pulverulenta, St. C. Abundant about sallows

- stabilis, View. Abundant about sallows

- instabilis, Esp., incerta, St. C. Common about sallows

- gracilis, Fab. Bedford, Luton

Pachnobia rubricosa, Fab. Bedford

Rusina tenebrosa, Hb. Bedford, Luton

Mania maura, Linn. Generally distributed

Nænia typica, Linn. Common everywhere

Amphipyra pyramidea, Linn. Bedford, in woods

- tragopogonis, Linn. Generally common, often coming into houses

Hydrilla arcuosa, Haw. Luton, in fields

Stilbia anomala, Haw. Bedford

Caradrina morpheus, Tr. Generally common in gardens

- alsines, Bkh. Bedford, Luton

- blanda, Tr., taraxaci, St. C. Generally distributed

- cubicularis, Bkh., quadripunctata, St. C. Abundant everywhere

Grammesia trilinea, Bkh., trigrammica, St. C. In all woods

Calymnia trapezina, Linn. Common in woods
Calymnia diffinis, Linn. Bedford, among elm - affinis, Linn.

Orthosia ferruginea, Schiff., "circellaris, "St. C. Generally common

- pistacina, Schiff. Generally common

- litura, Linn. Bedford, Potton

- lunosa, Haw. Bedford

- lota, Linn.

- macilenta, Hb. ",

Xanthia citrago, Linn. Bedford, among lime

- cerago, Schiff., fulvago, St. C. Bedford, Luton

- silago, Hb., flavago, St. C. Bedford, Luton

- aurago, Schiff. Taken at Potton by Mr. W. Bond-Smith

- gilvago, Esp. Bedford, not rare

Cerastis vaccinii, L. Generally common

- ligula, Esp., spadicea, Stn. Bedford, Luton, Potton

Scopelosoma satellitia, Linn. Bedford, Luton

Xylina semibrunnea, Haw. Bedford, Potton, at ivy bloom

Xylocampa lithoriza, Bkh., areola, St. C. Bedford

Calocampa exoleta, Linn. Bedford

- vetusta, $\mathrm{Hb}$.

Cucullia verbasci, Linn. Bedford, Potton; larvæ on Verbascum and Scrophularia

- umbratica, Linn. Bedford, Luton; at flowers in gardens in the evening

Plusia chrysitis, Linn. Generally distributed

- pulchrina, Haw. Luton

- iota, Linn. Luton, Bedford, Potton

- gamma, Linn. Everywhere abundant, buzzing about flowers

Habrostola urticæ, Hb., tripartita, St. C. Potton, Luton, Bedford

- triplasia, Linn. Bedford, Potton

Heliothis marginata, Fab., umbra, St. C. Taken near Bedford by Rev. O. W. Harries

Heliodes arbuti, Fab., tenebrata, St. C. Bedford, in meadows

Acontia luctuosa, Esp. Bedford, a very local species

Bryophila perla, Fab. Generally common on walls

Gonoptera libatrix, Linn. Generally distributed. Fond of hiding in cellars during the winter

Catocala nupta, Linn. Generally distributed, sitting on trunks of willows

Euclidia mi, Clerck. Bedford, Luton, Woburn

- glyphica, Linn. Bedford

Herminia barbalis, Linn. Luton, among sallow

- tarsipennalis, Tr. Luton

- grisealis, Hb. Bedford

Hypena rostralis, Linn. ",

- proboscidalis, Linn. Everywhere among nettles 


\section{INSECTS}

Rivula sericealis, Scop. Luton

Brephos parthenias, Linn. Bedford

Ourapteryx sambucata, Linn. Generally

Rumia cratagata, Linn. $\}$ common

Angerona prunaria, Linn. Woods near Bedford

Venilia maculata, Linn. Woods near $L u-$ ton

Cabera pusaria, Linn. Generally common in woods; the var. rotundaria has been found near Bedford by Mr. J. Sharpin

- exanthemaria, Scop. Generally distributed

Bapta temerata, Schiff. Bedford, at the margins of woods

- taminata, Schiff. Potton, Bedford; at the edges of woods

Macaria liturata, Linn. Luton, Bedford; among Scotch fir

Halia wavaria, Linn. Everywhere in gardens among currant bushes

Panagra petraria, Hb. Near Bedford, among brake-fern

Strenia clathrata, Linn. Bedford, Potton, Luton; common among clover

Fidonia atomaria, Linn. Luton, common on heaths

- piniaria, Linn. Plentiful in all fir woods

Odontoptera bidentata, Linn. Generally distributed

Ennomos alniaria, Linn., tiliaria, Stn. Bedford, Luton; among alder

- fuscantaria, Haw. Potton, among ash

- angularia, Schiff., quercinaria, St. C. Bedford

Crocallis elinguaria, Linn. Generally distributed, on hedge banks

Himera pennaria, Linn. Bedford, Luton; common in woods

Selenia illunaria, Hb., bilunaria, St. C Generally common in lanes

- illustraria, Hb., tetralunaria, St. C. Recorded at Bedford by the Rev. O. W. Harries

Pericallia syringaria, Linn. Bedford

Epione apiciaria, Schiff. Bedford, Luton; in lanes among sallow

Metrocampa margaritata, Linn. Generally common in woods

Ellopia fasciaria, Linn., prosapiaria, St. C. Luton, among Scotch fir

Biston hirtarius, Linn. Bedford, Luton

- prodromarius, Schiff.

- betularius, Linn. Generally distributed

Phigalia pilosaria, Schiff., pedaria, St. C. $L u-$ ton, Potton

Cleora lichenaria, Schiff. Luton

Tephrosia biundularia, Esp., crepuscularia, Schiff. Bedford, on tree trunks

- punctularia, Schiff. Luton
Boarmia repandaria, Linn. Bedford, Luton; probably everywhere

- rhomboidaria, Schiff., gemmaria, St. C. Generally distributed

Hemerophila abruptaria, Thunb. Bedford, Luton

Hibernia rupicapraria, Schiff.

- leucophæaria, Schiff. Luton

- progemmaria, Hb., marginaria, St. C. Everywhere abundant

- defoliaria, Linn. Generally distributed in woods

Anisopteryx æscularia, Schiff. Bedford, Luton

Abraxas grossulariata, Linn. Abundant in gardens everywhere

- ulmata, Fab., sylvata, St. C. Bedford district, in woods

Ligdia adustata, Schiff. Bedford, Luton; among spindle

Lomaspilis marginata, Linn. Bedford, Luton ; among sallow

Pseudoterpna cytisaria, Schiff., pruinata, St. C. Generally distributed

Geometra papilionaria, Linn. Bedford district

Iodis vernaria, Linn.

- lactearia, Linn.

Nemoria viridata, Linn. Recorded at Bedford by Mr. J. Sharpin

Phorodesma bajularia, Schiff., pustulata, St. C. Recorded at Potton by Mr. W. BondSmith

Hemithea thymiaria, Linn., strigata, St. C. Bedford, Luton

Ephyra porata, Linn. Bedford, among oak

- punctaria, Linn.

- trilinearia, Bkh., linearia, St. C. "Bedford district, among beech

- omicronaria, Schiff., annulata, St. C. Bedford district, among maple

- pendularia, Linn. Bedford, among birch

Acidalia scutulata, Schiff., dimidiata, St. C. Generally common

- bisetata, Bkh. Common in woods

- dilutaria, Hb., osseata, St. Man. Bedford

- incanaria, Hb., virgularia, St. C. Generally common in gardens

- immutata, Linn. Luton

- promutata, Gn., marginepunctata, St. C.

- remutata, Hb. Bedford, Potton; probably in all woods

- aversata, Linn. Generally distributed

Timandra imitaria, $\mathrm{Hb}$. Bedford, Luton

Bradyepetes amataria, Linn. " ,

Ania emarginata, Linn. " "

Melanippe subtristata, Haw., sociata, St. C. Common everywhere

Melanthia rubiginata, Schiff., bicolorata, St. C. Luton

- ocellata, Linn. Generally distributed

- albicillata, Linn. Bedford, Woburn

- unangulata, Haw. Luton 


\section{A HISTORY OF BEDFORDSHIRE}

Anticlea badiata, Schiff. Bedford, Potton

- derivata, Schiff., nigrofasciaria, St. C. Bedford, Potton, Luton

Coremia montanata, Schiff. Abundant in all woods

- fluctuata, Linn. Abundant in all gardens

- ferrugata, Linn. Everywhere common

- unidentaria, Haw. Generally distributed

- quadrifasciaria, Linn. Bedford, Luton

- pectinitaria, Fuessl., viridaria, St. C. Luton

- didymata, Linn. Bedford, Luton; probably everywhere

Asthena luteata, Schiff. Bedford, Potton, Luton

- candidata, Schiff. Bedford, Luton

Emmelesia affinitata, Steph. Luton, among Lychnis

- alchemillata, Linn. Luton, among Galeopsis

- albulata, Schiff. Luton, in meadows among yellow-rattle

- decolorata, Hb. Bedford, among Lychnis

Cidaria miata, Linn. Bedford, Potton, Luton

- corylata, Thunb. Luton, in woods

- russata, Schiff., truncata, St. C. Generally abundant

- suffumata, Schiff. Luton

- prunata, Linn. Luton, in gardens

- dotata, Linn, associata, St. C. Bedford, Potton, Luton; in gardens

- fulvata, Forst. Bedford, Luton

- pyraliata, Bkh., dotata, St. C. Luton

- testata, Linn.

Scotosia vetulata, Schiff. Bedford, "among Clematis vitalba

- rhamnata, Schiff. Bedford, Luton; among Clematis vitalba

- dubitata, Linn. Bedford, Luton, Potton; comes to 'light'

- certata, Hb. Luton, Potton ; among Berberis and Mahonia

Camptogramma bilineata, Linn. Abundant in every hedge

Phibalapteryx lignata, Hb., vittata, St. C. Luton, in damp meadows

- vitalbata, Schiff. Bedford, Potton, Luton; among Clematis vitalba

- tersata, Schiff. Luton, among Clematis vitalba

Thera variata, Schiff. Bedford, Luton; among fir

Hypsipetes impluviata, Schiff., trifasciata, St. C. Bedford, among alder

- elutata, Schiff., sordidata, St. C. Generally abundant

Oporabia dilutata, Schiff. Generally distributed

Cheimatobia brumata, Linn. Everywhere abundant

Chesias spartiata, Schiff. Potton, among broom
Chesias obliquaria, Schiff,, rufata, St. C. Potton, among broom

Anaitis plagiata, Linn. Generally distributed

Eubolia palumbaria, Schiff., plumbaria, St. C. Bedford, Luton

- bipunctaria, Schift. Luton, on chalk hills

- cervinata, Schiff. Luton, Potton; among mallow

- mensuraria, Schiff., limitata, St. C. Generally common

Eupithecia venosata, Fab. Bedford, Potton; among Silene inflata

- centaureata, Schiff,, oblongata, St. C. Common in gardens

- succenturiata, Linn. Potton

- subfulvata, Haw. Bedford, Luton

- satyrata, Hb. Bedford

- castigata, Haw. Generally common

- nanata, $\mathrm{Hb}$. Luton

- subnotata, Hb. Bedford

- vulgata, Haw. Common everywhere

- tenuiata, Hb. Bedford, among sallow

- sobrinata, $\mathrm{Hb}$. Luton, among juniper

- coronata, Hb. Bedford, Luton

- rectangulata, Linn. Generally common in orchards

Herbula cespitalis, Schiff. Bedford, Luton

Botys urticalis, Linn. Everywhere among nettles

- forficalis, Linn. Frequent everywhere in gardens

- verticalis, Schiff., ruralis, Scop. Generally distributed among nettles

Scopula olivalis, Schiff. Generally common

- prunalis, Schiff. $\}$ in hedges

- lutealis, Haw. Luton, among thistles

- ferrugalis, $\mathrm{Hb}$. Luton, in hedges

Ebulea crocealis, $T r$. Bedford, among fleabane

- sambucalis, Schiff. Bedford, Luton; probably everywhere

Cataclysta lemnalis, Linn. Bedford, about

Paraponyx stratiotalis, Linn. $\}$ water-plants

Hydrocampa nymphæalis,
Linn.

- stagnalis, Don. about water

Aglossa pinguinalis, Linn. Generally common about stables

Pyralis costalis, Fab., fimbrialis, Schiff. Bedford

- farinalis, Linn. Generally common in houses and corn stores

- glaucinalis, Linn. Luton

Nomophila hybridalis, Hb. Generally common

Scoparia cembra, Haw. Luton

- ambigualis, Tr. Generally common on tree trunks

- dubitalis, Curt. Bedford, Luton

- mercuralis, Linn. Bedford 


\section{INSECTS}

Platyptilus gonodactylus, Schiff. Bedford, Argyrotoza conwayana, Fab. Bedford, Luton, among coltsfoot

Mimæsioptilus pterodactylus, Linn., fuscus, Retz. Bedford, Luton among ash

Edematophorus lithodactylus, Tr. Bedford, among fleabane

Pterophorus monodactylus, Linn. Luton, - pruniana, Hb. Generally abundant among probably everywhere

Aciptilia pentadactyla, Linn. Bedford, Luton, Woburn

Orneodes polydactyla, $\mathrm{Hb}$. Bedford, Luton

Crambus pratellus, Linn. Everywhere abundant among grass

- pinetellus, Linn. Bedford, Luton

- perlellus, Scop. Bedford

- tristellus, Schiff. Common everywhere among grass

- geniculeus, Haw. Luton

- culmellus, Linn. Everywhere abundant among grass

- hortuellus, $\mathrm{Hb}$. Everywhere among grass

Ephestia elutella, $\mathrm{Hb}$. Bedford

Nephopteryx spissicella, Fab. "”

Rhodophæa consociella, $\mathrm{Hb}$. ",

- tumidella, $\mathbf{Z k}$.

Hypochalcia ahenella, Schiff. "Taken at 'light' at Luton

Aphomia sociella, Linn. Bedford, Luton

Tortrix podana, Scop. Generally distributed

- xylosteana, Linn.

- sorbiana, Hb. Bedford,

》)

- rosana, Linn. Abundant everywhere

- diversana, Tr. Recorded at Luton by the late Mr. J. A. Saunders

- heparana, Schiff. Generally distributed

- ribeana, $\mathrm{Hb}$. Generally common

- corylana, Hb. Bedford, Luton

- unifasciana, Dup. Generally common

- ministrana, Linn. Luton

- costana, Schiff. "

- forsterana, Fab. Generally distributed

- viridana, Linn. Abundant among oaks

Sideria achatana, Schiff. Bedford, among hawthorn

Dichelia grotiana, Fab. Bedford

Leptogramma literana, Linn. ",

Peronea sponsana, Fab. Luton, among beech

- cristana, Schiff. Bedford

- variegana, Schiff. Generally common

- ferrugana, Tr. Bedford, in woods

- comparana, Hb. Luton

Teras contaminana, $\mathrm{Hb}$. Common in every hawthorn hedge

- caudana, Fab. Luton

Dictyopteryx loeflingiana, Linn. Luton, about oaks

- holmiana, Linn. Luton, Bedford

- bergmanniana, Linn. Abundant everywhere among rose

- forskaliana, Linn, Luton, among maple

Ptycholoma lecheana, Linn. Generally distributed

Penthina capreana, Hb. Luton, among sallow sloe

- variegana, $\mathrm{Hb}$., cynosbatella, Linn. Everywhere common

- gentianana, Hb. Bedford, Luton; reared from heads of teazle

Hedya ocellana, Schiff. Bedford

- dealbana, Frol. Bedford, Luton

- aceriana, Mann. Luton, on poplars

Spilonota suffusana, Koll. Bedford, Luton, about hawthorn

- rosæcolana, Dbld. Bedford, among roses in gardens

- roborana, Schiff. Generally common among wild rose

Pardia tripunctana, Schiff. Generally common among wild rose

Aspis udmanniana, Linn. Bedford, Luton; among bramble

Sericoris bifasciana, Haw. Bedford

- lacunana, Schiff. Everywhere common

Roxana arcuana, Linn. Woods near Bedford

Orthotænia striana, Schiff. Bedford, Luton

Cnephasia musculana, Hb. Generally distributed

Sciaphila nubilana, Hb. Bedford, among hawthorn

- subjectana, Gn. Abundant everywhere

- virgaureana, Tr. " "

- pascuana, Hb. Bedford

- chrysantheana, Dup. "

- communana, H.S. "

- hybridana, Hb. " Luton

Bactra lanceolana, Hub. Everywhere among rushes

Phoxopteryx unguicella, Linn. Bedford, on heaths

- biarcuana, Steph. Recorded at Bedford by Mr. Sharpin

- lundana, Fab. Among clover everywhere

- mitterbacheriana, Schiff. Bedford, among oaks

Grapholitha ramella, Linn. Bedford

- nisella, Linn. Bedford, Luton

- nigromaculana, Haw.

- trimaculana, Don. Generally common among elm

- penkleriana, Schiff. Generally common among alder

- nævana, Hb. Generally common among holly and fruit trees

Hypermecia cruciana, Linn. Generally common among sallow 


\section{A HISTORY OF BEDFORDSHIRE}

Batodes angustiorana, Haw. Generally common among privet and fruit trees

Podisca corticana, Schiff. Generally common among oak

- solandriana, Linn. Luton, in hedges

Semasia janthinana, Dup. Bedford, about hawthorn

Halonota cirsiana, Zell. Luton

- brunnichiana, Schiff. Luton, among colt'sfoot

Coccyx strobilella, Linn. Bedford, among spruce fir

- pygmæana, $\mathrm{Hb}$. Bedford district, among fir

- tædella, Linn. Bedford district, among spruce fir

- splendidulana, Gn. Luton, among oak

- argyrana, $\mathrm{Hb}$. " on oak trunks

Hemimene fimbriana, Steph. Bedford, among oak

Retinia buoliana, Schiff. Bedford, among fir

- pinivorana, Zell.

Carpocapsa splendana, Hb. Bedford, among oak

- pomonana, Linn. Everywhere among apple trees

Stigmonota compositella, Linn. Bedford, Luton; among clover

- regiana, Zell. Bedford, Luton; on sycamore trunks

Dicrorampha politana, Schiff. Bedford, among yarrow

- petiverella, Linn. Generally common

Catoptria ulicetana, Haw. Everywhere abundant among furze

- hypericana, Hb. Luton, among St. John's wort

- fulvana, Steph. Bedford, Luton; among knapweed

- scopoliana, Haw. Luton, among black knapweed

Phtheocroa rugosana, $\mathrm{Hb}$. Luton, among Bryonia dioica

Aphelia pratana, Hb., osseana, St. C. Bedford, Luton

Tortricodes hyemana, Hb. Bedford, Luton; among oak

Lobesia permixtana, $\mathrm{Hb}$, reliquana, Stn. $\mathrm{M}$. Bedford

Eucelis aurana, Fab., mediana, Schiff. Luton

Hemerosia rhediella, Linn. Luton, among hawthorn

Eupcecilia nana, Haw. Luton, among birch

- angustana, $\mathrm{Hb}$. »

- ciliella, Hb. Luton, among Primula

Conchylis francillana, Fab. Bedford, among wild carrot

Argyrolepia sub-baumanniana, Dbld. Luton, among Scabiosa columbaria

- zephyrana, $\operatorname{Tr}$. On railway banks near Luton
Argyrolepia cnicana, Dbld. Luton, among marsh thistles

Xanthosetia hamana, Linn. Bedford, Luton; among knapweed

- zogana, Linn. Bedford, Luton; among knapweed

Simaethis fabriciana, Linn. Over nettles everywhere

Dasystoma salicella, $\mathrm{Hb}$. Bedford

Diurnea fagella, Schiff. On tree trunks generally

Epigraphia steinkellneriana, Schiff. Bedford, Luton

Taleporia pseudo-bombycella, Ochs. Bedford

Scardia cloacella, Haw. Bedford, Luton

- arcella, Fab. Luton

Tinea imella, Hb. Recorded at Bedford by Mr. Sharpin

- ferruginella, Hb. Bedford

- rusticella, Hb. ",

- tapetzella, Linn. Everywhere in harness rooms and houses

- pellionella, Linn. (The common clothesmoth.) In houses everywhere

- fuscipunctella, Haw. Bedford, Luton

- pallescentella, Stt.

- lapella, Stt. Bedford, Luton

Tineola biselliella, Hemm. Bedford, in houses

Lampronia quadripunctella, Fab. Luton

- luzella, Hb. Bedford

Incurvaria masculella, Schiff. Generally common

Nemophora swammerdammella, Linn. Bedford, in woods

- schwarziella, Zell. Bedford, Luton

- metaxella, Hb. Bedford, in marshy places

Adela degeerella, Linn. Bedford, in woods

- viridella, Jinn. Generally common in woods

Swammerdamia apicella, Don. Luton, about blackthorn

- spiniella, Zell. Luton, Bedford ; about blackthorn

- oxyacanthella, Zell. Bedford, about hawthorn

- pyrella, Vill. Luton, Bedford; about fruit trees

Scythropia cratagella, Linn. Bedford

Hyponomeuta pedella, Linn. Common everywhere in hawthorn hedges

Prays curtisella, Don. Bedford, among ash

Plutella cruciferarum, Zell. Abundant everywhere

- porrectella, Linn. Bedford, among Hesperis matronalis

Cerostoma radiatella, Don. Common in all woods

- costella, Fab. Woods near Bedford

Ypsolopha alpella, Schiff. Bedford

Harpipteryx scabrella, Linn. " 


\section{INSECTS}

Harpipteryx xylostella, Schiff. Common Glyphipteryx fuscoviridella, Haw. Bedford about honeysuckle - thrasonella, Scop. Bedford, doubtless

Phibalocera quercana, Fab. Bedford, Luton; in oak woods

Depressaria costosa, Haw. Generally common among furze

- liturella, Schiff. Bedford, Luton; among Centaurea

- umbellana, Steph. Bedford, Luton; among furze

- scopariella, Zell. Luton

- arenella, Schiff. Generally common

- propinquella, Tr. Bedford

- subpropinquella, Stn. Bedford, Luton

- alstromeriana, Linn. " "

- purpurea, Haw. "

- conterminella, Zell. Bedford

- yeatiana, Fab.

- applana, Fab. Abundant everywhere

- weirella, Stn. Bedford

- chærophylli, Dbld. Luton

- nervosa, Haw. Bedford

- badiella, Hub. Bedford, Luton

- heracliana, De Geer. ,

Gelechia peliella, Zett. "Bedford, taken by Mr. Sharpin

- diffinis, Haw. Bedford

Ceratophora rufescens, Haw. Luton

Brachmia mouffetella, Schiff. Bedford

Bryotropha terrella, Schiff. Abundant everywhere

- domestica, Haw. Luton

Lita maculea, Haw. Bedford, Luton

- tricolorella, Haw. Bedford

- hubneri, Haw. Recorded at Bedford by Mr. Sharpin

Teleia notatella, Hub. Bedford

- vulgella, Hub. Bedford, Luton

- dodecella, Linn. Bedford

- triparella, Zell. "

Pocilia gemmella, Linn. ",

- albiceps, Zell.

"

Nannodia hermannella, Fab. Bedford

Tachyptilia populella, Linn. Luton

Brachycrassata cinerella, Linn. Bedford

Parasia lappella, Linn. Bedford

Chelaria hubnerella, Don. Luton

Harpella geoffrella, Linn. Bedford

Dasycera sulphurella, Fab. Common everywhere among decayed wood

Ecophora minutella, Linn. Luton

- lunaris, Haw. Bedford

- unitella, Stt.

- flavifrontella, Hub." Luton

- fuscescens, Haw. Bedford

- pseudospretella, Stt. Generally too common

Endrosis fenestrella, Scop. Generally too common in houses among rushes everywhere

- equitella, Scop. Luton, in gardens about stonecrop

- fischerella, Zell. Luton, probably everywhere

Heliozela sericeella, Haw. Bedford

Argyresthia ephippella, Fab. Bedford, about cherry trees

- nitidella, Fab. Common in hedges everywhere

- conjugella, Zell. Luton, among mountain ash

- semifusca, Haw. Bedford

- andereggiella, Fisch. Reported at Bedford by Mr. Sharpin

- curvella, Linn. Bedford, in orchards

- albistria, Haw. Luton, in hedges

- godartella, Linn. Bedford, among alders

- brockeella, $\mathrm{Hb}$.

- pygmæella, Hb. Bedford, among "allow

Cedestis farinatella, Zell. Bedford, Luton; among fir

Gracilaria swederella, Thunb. Bedford, among oak

- syringella, Fab. Bedford, Luton; in gardens

- tringipennella, Zell. Luton, among ribwort plantain

Coriscium brongniardellum, Fab. Bedford, among oak

Ornix avellanella, Stt. Luton, Bedford; among hazel

- anglicella, Stt. Luton, Bedford; among hawthorn

- betulæ, Stt. Bedford, among birch

- torquillella, Stt. Bedford, among blackthorn

- guttea, Haw. Bedford, among apple

Coleophora albitarsella, Zell. Luton, among ground ivy

- laricella, Hub. Bedford, upon larch

- murinipennella, Fisch. Bedford

- nigricella, Steph. Bedford, probably everywhere

- siccifolia, Stt. Bedford, Luton

- viminetella, Zell.

- Iutipennella, Zell.

Chauliodus chærophyllellus. Bedford, among Umbelliferæ

Laverna fulvescens, Haw. Bedford, among Epilobium

- ochraceella, Curt. Luton, among Epilobium

- hellerella, Dup. Bedford, Luton

Asychna modestella, Dup. Luton

Chrysocorys festaliella, Hb. Luton, among bramble 


\title{
A HISTORY OF BEDFORDSHIRE
}

Chrysoclista flavicaput, Haw. Luton, in hedges

Elachista albifrontella, $\mathrm{Hb}$. Bedford, Luton

- luticomella, Zell. Luton

- nigrella, Hb. Luton, probably everywhere

- megerlella, Zell. Bedford

- triatomea, Haw. ",

- rufocinerea, Haw. Common everywhere

- cygnipennella, $\mathrm{Hb}$. Bedford, Luton

Tischeria complanella, Hb. Bedford

- marginea, Haw.

Lithocolletis hortella, Fab.

- sorbi, Frey.

- quercifoliella, Fisch. Everywhere abundant among oak

- cramerella, Fab. Everywhere common among oak
Lithocolletis coryli, Nicelli. Luton, among hazel

- emberizxpennella, Bouch. Luton, among honeysuckle

Lyonetia clerckella, Linn. Bedford

Cemiostoma laburnella, Heyd. Luton

Bucculatrix cratægi, Zell. Luton, about hawthorn

- aurimaculella, Stt. Luton, among ox-eye daisy

Nepticula floslactella, Haw. Luton

- aurella, Fab. Luton, among bramble

Eriocrania calthella, Linn. Bedford, Luton; among Caltha

- seppella, Fab. Bedford, Luton; on Veronica chamædrys

Micropteryx subpurpurella, Haw. Bedford, Luton; among oak

\section{ARACHNIDA}

\author{
Spiders, etc.
}

Scarcely any collections of the members of this order have been made in the county of Bedford, though there is no reason to suppose that it should prove less prolific in species than other neighbouring counties. Several species however have been observed in the neighbourhood of Woburn Abbey by Lord Tavistock, and others have been taken by Mr. F. P. Smith-thirty-five species only, all told.

\section{ARANEE \\ ARACHNOMORPHA \\ DYSDERIDE}

Spiders with six eyes and two pairs ot stigmatic openings, situated close together on the genital rima; the anterior pair communicating with lung books, the posterior with tracheal tubes. Tarsal claws, two in Dysdera, three in Harpactes and Segestria.

I. Segestria senoculata (Linnæus).

Woburn Abbey (Lord Tavistock) ; Luton (F.P.S.)

\section{DRASSID压}

Spiders with eight eyes, situated in two transverse rows. The tracheal openings lie immediately in front of the spinners. The tarsal claws are two in number, but the anterior pair of spinners are set wide apart at their base, and the maxillæ are more or less impressed across the middle.

\section{Drassodes lapidosus (Walckenaer) \\ Luton (F.P.S.)}

\section{CLUBIONIDE}

Spiders with eight eyes, situated in two transverse rows. The tracheal openings lie immediately in front of the spinners. The tarsal claws are two in number, but the anterior pair of spinners are set close together at their base, and the maxillæ are convex and not impressed across the middle.

3. Clubiona pallidula (Clerck)

Luton (F.P.S.) 


\section{SPIDERS}

\section{THOMISID曆}

Spiders with eight eyes, situated in two transverse rows, two tarsal claws and anterior spinners close together at their base. Maxillæ not impressed. The crab-like shape and sidelong movements of these spiders are their chief characteristics, enabling them to be easily distinguished from the more elongate Drassidee and Clubionidae.
4. Xysticus cristatus (Clerck)
Luton (F.P.S.).
6. Tibellus oblongus (Walckenaer)
Luton (F.P.S.)

\section{Philodromus aureolus (Clerck) \\ Luton (F.P.S.)}

\section{ATTID㢃}

The spiders of this family may be recognized in a general way by their mode of progression, consisting of a series of leaps. More particularly they may be known by the square shape of the cephalic region and the fact that the eyes are arranged in three rows of $4,2,2$, the centrals of the anterior row being much the largest. Otherwise the spiders are simply specialized Clubionids with two tarsal claws and other minor characters possessed in common with other members of this family.

7. Salticus scenicus (Clerck)

Woburn Abbey (Lord Tavistock); Luton (F.P.S.)

\section{PISAURID压}

Spiders with eight eyes in three rows of $4,2,2$; the small anterior eyes being sometimes in a straight line, sometimes recurved and sometimes procurved. Those of the other two rows are situated in the form of a rectangle of various proportions and are much larger than the eyes of the anterior row. The tarsal claws are three in number. Pisaura runs freely over the herbage, carrying its egg-sac beneath the sternum; while Dolomedes is a dweller in marshes and swamps.

8. Pisaura mirabilis (Clerck)

Woburn Abbey (Lord Tavistock) ; Luton (F.P.S.)

Known also as Dolomedes, or Ocyale, mirabilis.

\section{LYCOSID}

The members of this family are to be found running freely over the ground, and carrying the egg-sac attached to the spinners. Many of the larger species make a short burrow in the soil and there keep guard over the egg-sac. Eyes and tarsal claws as in the Pisauridae, with slight differences.

$$
\begin{aligned}
& \text { 9. Lycosa ruricola (De Geer) } \\
& \text { Luton (F.P.S.) } \\
& \text { I0. Pardosa amentata (Clerck) } \\
& \text { Luton (F.P.S.) }
\end{aligned}
$$

\author{
I I. Pardosa lugubris (Walckenaer) \\ Woburn Abbey (Lord Tavistock); Luton \\ (F.P.S.) \\ 12. Pardosa annulata (Thorell)
}

Luton (F.P.S.)

\section{AGELENID尼}

Spiders with eight eyes, situated in two straight or more or less curved transverse rows. Tarsal claws, three. The species of this family spin a large sheet-like web, and construct a tubular retreat at the back of it, which leads to some crevice amongst the rocks or in the herbage, or in the chinks in the walls of outhouses and barns, wherever the various species may happen to be found. The habits of Argyroneta, the water spider, are however quite different. The posterior pair of spinners is much longer than the others in the more typical genera of this family.

\section{Tegenaria parietina (Fourcroy)}

Woburn Abbey (Lord Tavistock)

Abundant in the London district. Known also as $\mathcal{T}$. guyonii and $\mathcal{T}$. domestica.
14. Tegenaria derbami (Scopoli) Luton (F.P.S.)

A very common species everywhere. 


\section{A HISTORY OF BEDFORDSHIRE}

15. Agelena labyrintbica (Clerck)

Woburn Abbey (Lord Tavistock); Luton (F.P.S.)
Abundant, forming large sheet-like webs on the herbage, with a funnel-shaped tubular retreat.

\section{ARGIOPID $F$}

The spiders included in this family have eight eyes, situated in two rows, the lateral eyes of both rows being usually adjacent, if not in actual contact, while the central eyes form a quadrangle. The tarsal claws are three, often with other supernumerary claws. The web is either an orbicular snare, as in the case of the 'common garden spider,' or consists of a sheet of webbing, beneath which the spider hangs and captures its prey as it falls upon the sheet. This immense family includes those usually separated under the names Epeiride and Linyphiide.

16. Meta segmentata (Clerck)

Woburn Abbey (Lord Tavistock); Luton (F.P.S.)

17. Meta meriane (Scopoli)

Woburn Abbey (Lord Tavistock)

18. Tetragnatha extensa (Linnæus)

Woburn Abbey (Lord Tavistock)

19. Pacbygnatha clerckii, Sundevall Luton (F.P.S.)

20. Cyclosa conica (Pallas) Woburn Abbey (Lord Tavistock)

2 I. Zilla $x$ - notata (Clerck) Woburn Abbey (Lord Tavistock)

22. Araneus cucurbitinus, Clerck Woburn Abbey (Lord Tavistock); Luton (F.P.S.)
23. Araneus diadematus, Clerck

Woburn Abbey (Lord Tavistock); Luton (F.P.S.) and Leighton Buzzard.

24. Araneus umbraticus, Clerck

Woburn Abbey (Lord Tavistock)

25. Linyphia triangularis (Clerck)

Luton (F.P.S.)

26. Stemonyphantes lineatus (Linnæus)

Luton (F.P.S.)

27. Leptbyphantes minutus (Blackwall)

Luton (F.P.S.)

28. Centromesus sylvaticus (Blackwall)

Luton (F.P.S.)

29. Kulczynskiellum fuscum (Blackwall)

Luton (F.P.S.)

\section{THERIDIID $\approx$}

The members of this family have eight eyes, situated very much like those of the Argiopide; but the mandibles are usually weak, the maxillæ are inclined over the labium, and the posterior legs have a comb of stiff curved spines beneath the tarsi. The web consists of a tangle of crossing lines, and the spider often constructs a tent-like retreat wherein the egg-sac is hung up. The tarsal claws are three in number.
30. Theridion tepidariorum, C. L. Koch
Woburn Abbey (Lord Tavistock)
32. Theridion lineatum (Clerck) Luton (F.P.S.)
31. Theridion denticulatum (Walckenaer) Luton (F.P.S.)
33. Steatoda bipunctata (Linnæus) Woburn Abbey (Lord Tavistock)

\section{DICTYNID压}

The spiders belonging to this family possess three tarsal claws, and the eyes, eight in number, situated in two transverse rows, the laterals being in contact. The cribellum (or extra pair of spinning organs) and the calamistrum (a row of curving bristles on the protarsi of the fourth pair of legs) are present in all members of the family. They construct a tubular retreat with an outer sheet of webbing, which is covered with a flocculent silk made with the calamistrum from threads furnished by the cribellum.
34. Amaurobius similis (Blackwall)
Luton (F.P.S.)
Common. Known also under the name Ciniflo.
35. Amaurobius ferox (Walckenaer) Woburn Abbey (Lord Tavistock)
Common. Known also under the name




\section{CRUSTACEANS}

The latter half of the nineteenth century was a period the most stirring and the most fruitful for natural history that the world has ever known. To promote the study of it clubs, societies, associations either sprang up afresh or were quickened into renewed and more vigorous activity over a wide area. A persistent and varied industry was thus excited, the results of which, after being orally explained and discussed within a small circle, were afterwards in many cases with more or less completeness printed and published. Though no doubt this was often done only to gratify an author or a little coterie of friends, the unintended consequences were not unimportant. The collected reports were frequently to a high degree miscellaneous. There was little editorial sifting of wheat from chaff. The circulation was usually very limited. Hence it has come to pass that on science is laid a twofold burden; first the task of searching for publications often far from easy to meet with, and then the task of discovering whether there are any useful facts or opinions to be gleaned from them on any particular theme out of the wilderness of all possible themes which they are capable of embracing. The Abstract of Proceedings and Transactions of the Bedfordsbire Natural History Society and Field Club, beginning with the year 1876 , is very much a case in point. A perusal of these records at the library of the National Museum in Cromwell Road is a pleasant enough study in itself, but in regard to the crustaceans of the county the information to be derived from it is scanty in the extreme. In a way the carcinologist is debarred from complaining, seeing that a far more popular subject is exposed to equal neglect. For Mr. W. B. Graham exclaims in this very abstract : 'Multitudinous, however, as the insect fauna of Bedfordshire unquestionably is, yet in the entomological world the county is almost wholly ignored.' ${ }^{1}$ In words to precisely the same effect it may be declared that, multitudinous as the crustacean fauna of Bedfordshire unquestionably is, yet in the carcinological world the county is almost wholly ignored.

Of the higher Malacostraca only one species is here to be expected, and that by good hap satisfies expectation, since Mr. James Saunders, A.L.S., writing from Luton, January 19, I 902, kindly informs me that 'crayfish are abundant in the river Lea south of Luton Hoo.' ${ }^{2}$ This lobster-like macruran, Potamobius pallipes (Lereboullet), the river crayfish, should certainly not be neglected. Professor Huxley, taking its

1 Abs. Proc. Trans. Beds Nat. Hist. Soc. and Field Club for the year 1876-7 (Jan. 1, 1878), p. 127.

2 Lysons, Magna Britannia (1806), i. 21 , mentions it 'among the fish of the Ouse.' 


\section{A HISTORY OF BEDFORDSHIRE}

vernacular name as the title of a book at once wonderfully learned and lucid, has shown how this common, clean and hardy species can be made as it were a compendium of all zoology; how the consideration of its structure and vital powers, its birth and breeding, its distribution and alliances will lead the inquiring disciple onward step by step through all the philosophy of life. For those who are content to learn from it the general plan which with endless modifications runs through crabs, lobsters, shrimps, woodlice and all the other Malacostraca, there is scarcely a species more convenient than the crayfish. Its stalked eyes, its two pairs of antennæ, its lips, stomach and intestine, its carapace, the six pairs of jaws, its five pairs of trunk-legs, its jointed pleon and the pleopods, its tail-fan, and within the body the liver-like gland, the heart, the brain and ventral nerve-chain, and all the arrangement of the muscles are easy for the most part to distinguish in specimens prepared for the table or otherwise preserved. Its behaviour alive in the aquarium is not without interest. The shedding of the skin, known as ecdysis or exuviation, is worth observing by those who can secure the chance. Those who can study the creature in its native haunts have ever the opportunity not only of amusing themselves, but of instructing others. For of any complex living organism all the efforts of all the zoologists can seldom or never so exhaust the interest that true lovers of nature need despair of discovering some new charm or wonder in the creature or its ways.

The sessile-eyed Malacostraca are constructed on the same general plan as the stalk-eyed Decapoda or ten-footed crustaceans, to the macruran or long-tailed division of which the crayfishes belong. In some fullgrown crabs and in some larval forms of lobster-like and shrimp-like species the stalked eyes attain a quite exorbitant length. With respect to the crabs, it is true, the epithet may not quite literally apply, because the orbits are usually as long as the eyes; but when these stilted organs are raised out of their sockets they present a remarkable appearance. In the crayfish however, as in the common crab, there is no great length of stalk to attract attention, and therefore little regard is in general paid to the substantial difference in ophthalmic structure which separates such forms from the Isopoda and Amphipoda. These latter groups have the eyes seated in the head, without stalks either long or short. They are not ten-footed, but fourteen-footed. Their branchial or respiratory apparatus is not, as in crabs and shrimps, concealed by the carapace. Their size in all the British land and freshwater species is limited to a low standard. In their general appearance the fondest admirer would scarcely claim any high degree of dignity and grace. They are not by any means warmly esteemed, except by those who have learned to appreciate modest merit and neglected virtue. Man the omnivorous does not even pay them the compliment of eating them, though there is little doubt that they all have a good shrimp-like flavour. But in spite of all prejudices on our part and dissimilarities on theirs, and in the teeth of such contemptuous designations as woodlice, slaters and pill-bugs, the terrestrial Isopoda are as truly malacostracan crustacea as the lobster and 


\section{CRUSTACEANS}

the crayfish. The species of woodlice in England amount to more than a score. Many of them are so generally distributed that it will be no exaggerated estimate to credit Bedfordshire with half a score of them. Mr. James Saunders assures me that he often meets with them when he is hunting for mycetozoa, and certainly in that or any similar research Pbiloscia muscorum (Scopoli) could not well fail to be met with. Oniscus asellus, Linn., Porcellio scaber, Latreille, and Armadillidium vulgare (Latreille) make themselves familiar everywhere. But none, even of these the commonest of the common, appear to have been specially recorded for this county.

The two sessile-eyed groups agree in the character of the eyes. They agree in having seven segments of the middle body freely movable, and not as in the Decapoda covered by the carapace. They agree also to a great extent in the distribution of their appendages, for they follow up the two pairs of antennæ, not by six pairs of jaws and five pairs of trunk-legs, but by four pairs of jaws and seven pairs of trunk-legs. But these features of agreement do not exclude strongly-marked differences. The Isopoda, whether terrestrial or aquatic, being usually flattened from above downward, are fitted for walking; whereas the Amphipoda, being as a rule laterally compressed, in clumsy attempts at an upright gait commonly fall over on one side and have to slidder. A more important distinction depends on the position of the breathing organs. These in the Amphipoda are sacs or vesicles, simple or pleated or twisted, attached to some or all of the trunk-legs except the first pair. In the Isopoda they are not in the trunk or middle body at all, but in the tail part, otherwise known as abdomen or pleon. Some of the appendages of this pleon, the thin-skinned flattened pleopods, are respiratory. The equivalent appendages in the pleon of the Amphipoda have no such function, although they may be considered in some measure auxiliaries to it. That the Amphipoda are represented in Bedfordshire does not rest upon conjecture, for early in February, I 902, Mr. James Saunders very obligingly collected from the river Lea near Luton some specimens which he packed in damp moss and dispatched by post. They reached me the following day, languid but still alive, and proved to be, as Mr. Saunders supposed, the wide-ranging Gammarus pulex (Linn.). This may be taken as a typical representative of the Amphipoda at large, but especially of the Gammaridea, the most extensive of the three sections into which the whole group has been divided. Just as nature has been at the pains to distribute Asellus aquaticus (Linn.) over all parts of England as if with intent to provide a type of water-breathing isopods, so has Gammarus pulex in the companion group been made everywhere available. At all events no English naturalist can excuse an utter ignorance of sessile-eyed crustacea on plea or pretence that specimens are not procurable for investigation. The beginner will soon find his wits well exercised if he attempts to compare the common freshwater gammarus with two other species that are common on the seashore, namely G. locusta and G. marinus. He might at first impatiently refuse to believe that the three species 


\section{A HISTORY OF BEDFORDSHIRE}

were distinct one from another, but he would not easily persuade the latter two to live in fresh water, in which the first finds itself happy and at home. Without going into every detail, it may be pointed out that the sides of the head project angularly in G. locusta, but are rotund in G. pulex, and that the accessory branch of the upper antennæe is more numerously jointed and longer in the former than in the latter. At the other extremity of the organism the last appendages, known as the third uropods, pretty well agree in these two species by having two elongate branches; but in G. marinus the inner branch, instead of being only a little shorter than the outer, is scarcely a third of its length. In the Isopoda the appendages of the pleon form five pairs of pleopods (swimming feet) and one pair of uropods (tail feet). In the gammaridean Amphipoda there are three pairs of pleopods and three of uropods. In these pleopods each appendage consists of a stem with two many-jointed flexible setose branches, and this description, though admitting of some exceptions, applies with extraordinary uniformity throughout the group. When the animal is alive in its own element its natatory limbs are in tolerably constant motion, and that even when the body is stationary. The purpose of this is to keep a current of water continually bathing the branchial sacs, and when there are eggs in the mother's pouch to give them also the benefit of the invigorating stream. The maternal marsupium is formed by membranaceous laminæ which, like the respiratory vesicles, are attached to several of the trunk-legs at the upper part. In contrast to the pleopods the uropods have branches which are not flexible. They seem to be purely locomotive, enabling the animal to make leaps or to jerk itself along, or in tube-building species to execute manœuvres which may best be described as turning head over heels.

In almost every marine province the Malacostraca form a demonstrative portion of the fauna. It is only in specially favoured regions that they are conspicuous as occupants of fresh water. The other half of the crustacean class, upon which O. F. Müller, towards the close of the eighteenth century, bestowed the designation Entomostraca, is rather differently situated. For, though these so-called ' insects covered by a shell' are extremely abundant in the sea, they also inhabit inland waters, not only with surprising diversity of form and ubiquity of range, but with no sort of regard for Malthusian prudence in their rate of proliferation. In regard to this division of the subject there is fortunately something to be gleaned from existing records. One quotation indeed might have been earlier given as applying not to a part of the class, but to the whole. The statement is of a character rather elementary, yet with certain reserves useful to be borne in mind. In a paper on 'Antennæ,' Mr. H. J. Sheppard begins by saying: 'Antennæ are horn-like members placed on the head, peculiar to insects and crustaceans; the former generally have two, the latter more than two." ${ }^{1}$ To this it might be objected that horns are usually stiff and antennæ usually flexible; and

1 Abs. Proc. Trans. Beds Nat. Hist. Soc. and Field Club for the years 1877-81 (Oct. I, I 882), p. 20 . 


\section{CRUSTACEANS}

again that myriapods, without being either insects or crustaceans, are possessed of antennæ. But the point that chiefly concerns our present subject is the fact that crustaceans are distinguished alike from myriapods and insects by having the pairs of antennæ twofold. It cannot be said however that they always make quite as much of this distinction as they might. In the woodlice the first pair of antennæ are exceedingly small and often hidden away as if these isopods were ashamed of them. Also in Talitrus, the sandhopper, a genus of semi-terrestrial amphipods, a similar diminution occurs. In many of the Entomostraca likewise the first antennæ are small and inconspicuous, and that is the case with more than one of the species presently to be mentioned.

The Entomostraca are at present divided into three principal sections-Branchiopoda (branchial-footed), Ostracoda (shelly), Copepoda (oar-footed). Not much of the nature in each case can be explained by the mere meaning of the name. The Ostracoda are called shelly because, like some mollusca or shellfish, they have the body capable of a complete enclosure between two valves. But some of the Branchiopoda have a similar bivalvular security, entitling them to boast equally with the Ostracoda that the carapace is their castle. The Copepoda use their feet for locomotion in the water, but so far as that is concerned there are some of the stately phyllopods to which the name of oar-footed would as well or even better apply.

The Branchiopoda are divided into Phyllopoda (the leaf-footed), Cladocera (the antlered), Branchiura (the branchial-tailed). The last is by far the smallest of the three divisions, and has in England only a solitary representative, Argulus foliaceus (Linn.). It so happens however that this is among the very few recorded crustaceans of Bedfordshire, yet it comes into the list by what sportsmen would probably call a fluke, for the mention of it is not in any discussion of its own class, but only as incidental to ichthyology. In a paper on 'The Fish of the River Ouse,' Mr. A. R. Thompson observes that 'the Argulus foliace (or roach louse) is also found upon roach and other coarse fish : it is a small crustacean of a disc-shape and attaches itself by means of two suckers on the underside.' It is a vicious little parasite, varying in length when adult from an eighth to nearly a third of an inch. Fishes that would seek revenge by swallowing their foe are soon glad to give it up again. Scientifically it is interesting as belonging to a very small yet distinct and widely-dispersed group. It was at one time placed not in the Branchiopoda but among the parasitic Copepoda. Its mouth organs are considerably modified from any normal standard, the first pair of maxilla being evanescent or lost, while the second pair are metamorphosed into suckers. These, as above mentioned, are the organs of adhesion. For sucking the juices of its victim its uses, not the suckers, but its mouth, an efficient apparatus being formed by the sharp glandular organ called the stimulus, and by a combination of the lips and mandibles.

1 Abs. Proc. Trans. Beds Nat. Hist. Soc. and Field Club for the years 1882-3, 1883-4 (May, 1885), p. 93 . 


\section{A HISTORY OF BEDFORDSHIRE}

To Mr. James Saunders I am again indebted for a reference to the circumstance that at a microscopical meeting of the Bedfordshire Natural History Society on January 20,1880 , among other objects of pond life 'Dapbne vetula' was exhibited. The use of this name carries the mind back to 1776 , when the species intended was actually so called by O. F. Müller. The conspicuously-branched second antennæ, to which the name Cladocera is due, and which all the Cladocera possess except the females of a single genus, are also responsible for the name Daphne. Müller avowedly chose it in allusion to the shrubby antennæ, but afterwards exchanged it for Daphnia, in order that his shrubby genus in zoology might not be confounded with the botanical shrub. At the same time he changed the specific name from vetula, 'a little old woman,' to sima, 'snub-nosed.' Eventually his genus Dapbnia was found to be too comprehensive, and this particular species was assigned to a new genus, Simocephalus, by Schoedler, who restored the original specific name, so that the Cladocera of Bedfordshire are now represented by Simocepbalus vetulus (Müller). In Dapbnia the head is carinate above; in Simocephalus the head is convex and blunt. This genus is also devoid of the sharp angle or the more or less prolonged spine into which the species of Dapbnia almost always have the valves produced behind. Like the rest of the Daphniidæ, Simocephalus has one branch three-jointed and the other four-jointed in the large second antennæ, which are its swimming organs.

For definitely assigning Ostracoda to the county I can rely on the sure authority of Mr. D. J. Scourfield. In I 896 the presence of Candona pubescens (Koch) 'at Pavenham, Bedfordshire,' was noted by Brady and Norman in an appendix to their "Monograph of the Marine and Freshwater Ostracoda of the North Atlantic and of North-Western Europe." But whereas they expressly attribute this record to Mr. Scourfield, he himself in 1898 states that the only known British locality for the species in question is Wanstead Park in Essex, 'as the reference to Pavenham in Brady and Norman's "Monograph" . . . was made under a misunderstanding. ${ }^{2}$ To compensate for this disappointment he has lately informed me by letter that he has received from his cousin two other nearly related species, Candona candida (O. F. Müller) and Erpetocypris strigata (O. F. Müller), the locality for both of them being Pavenham. Both belong to the family Cypridæe in the section Podocopa. The generic name Erpetocypris means the creeping Cypris, and in the definition Brady and Norman say that 'the power of swimming is lost, and the habits of the animals, which creep along the bottom, are thus

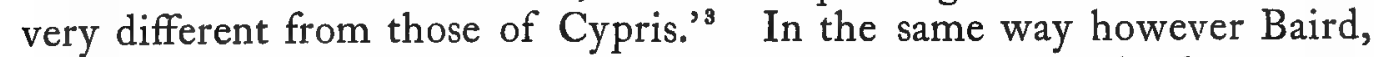
in defining Candona, remarks that 'the animal creeps at the bottom or upon aquatic plants, instead of swimming freely through the water.' But Candona, though similar in habit to Erpetocypris, is distinguished from it, as also from Cypris, by having no branchial plate on the second maxillæ. Erpetocypris strigata has the lower margin of the shell nearly

1 Trans. R. Dublin Soc. (1896), ser. 2, v. 729.

3 Trans. R. Dublin Soc. (1 889 ), ser. 2, iv. 84 .

2 The Essex Naturalist (1 898), x. 322. 96

British Entomostraca, Ray Society (1850), P. I 59. 


\section{GRUSTACEANS}

straight, the surface smooth, variously banded with pale yellow and green.' In Candona candida the lower margin is sinuated, especially in old examples and adult males, and the surface of the shell is smooth, pearly or yellowish white, with darker yellow cloudings towards the dorsal margin."

Of the Copepoda, Dr. Brady in his Revision of the British Species of Freshwater Cyclopidae and Calanida attributes to Bedfordshire two species, both from Pavenham and both on Mr. Scourfield's authority. They are both extensively distributed species, Cyclops bicuspidatus, Claus., and Diaptomus castor (Jurine), the former assigned by Brady to the family Cyclopidæ, the latter to the Calanidæ. ${ }^{3}$ The genus Diaptomus, Westwood, should rather be included in a family Diaptomidæ, of which it is the earliest and apparently the most extensive genus, comprising three or four scores of species. The range of $D$. castor is stated to be the whole of Europe, its occurrence in North America also having been reported, but not thoroughly ascertained. The length of a specimen varies from a twelfth of an inch to an eighth or even a seventh. Cyclops bicuspidatus is smaller still, as it reaches its upper limit in a twelfth of an inch, while starting from a nineteenth. In Diaptomus the first antennæ are twenty-five jointed ; in Cyclops the number of joints in these appendages varies from six to eighteen, reaching seventeen in C. bicuspidatus.

According to Mr. A. R. Thompson's paper above quoted many species of fish frequent the waters of the river Ouse. The supposition therefore is well warranted that in the same waters parasitic Copepoda frequent those fishes. It is indeed quite certain that the hitherto unrecorded crustaceans of Bedfordshire would fill a far longer catalogue than can be composed of those which have as yet been publicly noticed.

1 Trans. R. Dublin Soc. ser. 2, iv. 85.

2 Brady, Trans. Linn. Soc. (London, 1870 ), xxvi. 383. 79,94 .

3 Nat. Hist. Trans. Northumberland, Durbam and Newcastle-upon-Tyne (1891), vol. xi. pt. I, pp. 


\section{F ISHES}

The river Ouse, which runs through this county, and the Ivel, which joins it at Tempsford, together with the Lea, which rises in Bedfordshire, are tenanted by many species of freshwater fish which may be considered indigenous; other species have been introduced, some of which have multiplied to a certain extent, but have not yet become common.

It is probable that salmon in very early times were found in the Ouse, although the rivers of England west of a dividing line running from Portland to the Humber may be considered as salmon rivers rather than those east of that line. The alteration of the course of the Ouse in the fen districts by the cutting of the 'Hundred Foot' and the erection of the tidal Denver Sluice, together with the obstruction of the numerous water-mills and weirs, have probably tended to prevent the free passage of salmon up the river from its mouth at King's Lynn in Norfolk.

The Ouse from Bedford to its mouth is roughly a hundred miles long, and the water at Bedford Bridge is nearly 100 feet higher than at Lynn; the fall therefore being about I foot per mile makes the river better adapted for coarse fish than for the Salmonida.

There are however three authentic records of salmon having been captured in this county within the past sixty years. One was taken in the eel trap at Cardington Mill about the year 1840 or I84I, weighing about $6 \mathrm{lb}$., and was exhibited by a fishmonger at Bedford. Mr. George Street of Maulden, who rented Cardington Mill from 1852 to I 862 , informs me that a salmon, weighing about Io $\mathrm{lb}$., in fine condition, was taken in his eel trap at the time of a very high flood in July (probably 1853), and was sent by him to a fishmonger at Bedford for inspection, and afterwards presented to the late Mr. S. C. Whitbread, the lord of the manor. Owing to the excessive rainfall in $1852-3$ the river Ouse was more or less in flood throughout the winter and spring, which would therefore facilitate the passage of salmon in spite of the obstructions of the sluices and weirs previously referred to. A male salmon weighing $9 \frac{\mathrm{I}}{2} \mathrm{lb}$. was caught in the eel trap at Kempston Mill, December 22, I 880 .

The introduction of trout into the Ivel took place several years ago, with the result that many good specimens have been taken and are still found in that river, which appears to be well adapted to their growth and development. A cast of one (Salmo fario) taken by the late Frank Buckland, weighing upwards of $9 \mathrm{lb}$., was in the possession of $\mathrm{Mr}$. 


\section{FISHES}

Beaumont of Astwick; and the stock has been frequently replenished by fry artificially hatched. Mr. Pope of Biggleswade formed an association for stocking the Ivel with trout about twenty years or more ago, which hatched out several thousands of fry annually. It was found that the fish thrived well and grew to a good size-he himself took one spinning of $8 \frac{3}{4} \mathrm{lb}$.- but owing to the fact that they would not rise to the fly, having so much other natural food, the enterprise was abandoned about fourteen years ago. A trout was taken at Stopford Mill, weighing exactly $8 \mathrm{lb}$., in 1899 . Preserved by J. H. Wright of Clifton.

22 April, 1899. A man caught a trout in my meadows this day just 2 feet long; he had taken two previously, one $2 \mathrm{lb}$., the other $3 \frac{1}{2} \mathrm{lb}$. The former we guessed at $5 \mathrm{lb}$.

Josiah King of Langford.

A trout of $3 \frac{1}{2} \mathrm{lb}$. was taken in the eel trap at Cardington Mill, February I 8 , I 880 .

The Bedford Angling Club also attempted the introduction of trout into the Ouse in the year I 875 , when 3,000 young fry were placed in the river at Biddenham, and again in $188 \mathrm{I}-2$, when 600 yearling trout (Salmo fario), varying from 4 to 7 inches in length, were turned in at Kempston and Renhold; but, probably owing to the abundance of pike, the attempt was not attended with much success.

Two trout were taken in the eel trap at Milton Mill in April, I 896, weighing between 2 and $3 \mathrm{lb}$. each. One of $5 \mathrm{lb}$., length $22 \frac{1}{2}$ inches, is in the possession of Mr. George of Tempsford, taken August 22, 1892, below Roxton Sluice. Trout were common in the stream flowing from Luton Hoo, where they were strictly preserved, as well as in the river Lea more or less generally.

Barbel have also been introduced into the Ouse by the Bedford Angling Club. In the year 1876 thirty-one fish, weighing from I $\mathrm{lb}$. to $5 \mathrm{lb}$. each, from the Thames, presented by the Maidenhead Association, were put in at Kempston; and again in 1888 thirty-eight barbel from the Trent, varying in weight from $3 \mathrm{lb}$. to $10 \mathrm{lb}$., were put in at Clapham and Renhold. These fish appear to have bred and distributed themselves both above and below Bedford. One was taken at Sharnbrook in 1898 weighing $\mathrm{I} 2 \mathrm{lb}$. Others have been taken as far below Bedford as St. Neots; and on October 4, I90I, a barbel of $6 \frac{1}{2} \mathrm{lb}$., captured by an otter, was found on the bank of the Ouse at St. Neots. A barbel weighing $6 \mathrm{lb}$. was taken at Sharnbrook, May, I $88 \mathrm{I}$.

A few tench of the golden variety were presented to the Bedford Angling Club by the Duke of Bedford in 1874 , and were placed in a pond at Clapham Park by permission of the late James Howard, Esq., M.P., in the hope that they would breed; in 1876 they were found in their original number and put into the Ouse, but there was no appearance of any young fry.

Carp from ponds in the county have also been put into the Ouse, 


\section{A HISTORY OF BEDFORDSHIRE}

but have not since been met with. A crucian carp was taken some years ago by Mr. F. Newbery in the eel trap at Milton Mill.

From the following list it will be seen that there are only eighteen different forms of freshwater fishes which may be considered indigenous to the county.

\section{TELEOSTEANS}

\section{ACANTHOPTERYGII}

1. Perch. Perca fuviatilis, Linn.

Plentiful in the Ouse in all parts, especially near the places where the water lily abounds. It attains a weight of $4 \mathrm{lb}$. and upwards. One was taken at Willington in 1900 weighing $2 \mathrm{lb}$. Io oz. ; one at Clapham in the same year of $3 \frac{1}{4} \mathrm{lb}$. ; one taken by $\mathrm{Mr}$. P. Addington with an artificial minnow from under Tempsford Bridge weighing $4 \frac{1}{4} \mathrm{lb}$; and one was caught in Southill Lake a few years ago by my son weighing $4 \frac{1}{2} \mathrm{lb}$. Three were taken by $\mathrm{Mr}$. George at Tempsford about 1882 in the course of an hour, weighing $2 \mathrm{lb}, 2,2 \frac{1}{4} \mathrm{lb}$. and $2 \frac{1}{2} \mathrm{lb}$.; and I took three at Clapham in 1899 in less than half an hour in one spot, each weighing close upon $2 \mathrm{lb}$.

2. Ruff (commonly Pope). Acerina cernua, Linn.

Locally, Joey Ruff.

Usually found at the bottom of the river up to about 5 inches in length.

3. Miller's Thumb or Bullhead. Cottus gobio, Linn.

Found under stones in the gravelly parts of the river and in small streams that are not sluggish.

\section{HEMIBRANCHII}

4. Three-spined Stickleback. Gastrosteus aculeatus, Linn.

Davis's History of Luton.

5. Ten-spined Stickleback. Gastrosteus pungitius, Linn.

These are more frequently found in the various brooks and ponds rather than in the rivers.

\section{HAPLOMI}

6. Pike (commonly Jack). Esox lucius, Linn.

This fish is abundant in all parts of the Ouse and in various lakes in the county, and grows to a large size. The largest I have seen taken from the Ouse weighed $28 \frac{1}{4} \mathrm{lb}$., and was caught at Kempston many years ago by the late Mr. W. Bailey, surgeon, of Bedford. The head of a pike of $3^{6} \mathrm{lb}$. was in the possession of the late Mr. C. Palgrave of Bedford, and the fish was said to have been left on the meadows near Bedford after a heavy flood and there captured. One of $2 \mathrm{r} \frac{1}{4} \mathrm{lb}$. was taken at Clapham in the Ouse in 1893 , and I took one in the Ouse at Oakley in February, 1878 , a female fish measuring 40 inches in length and weighing $20 \mathrm{Ib}$. A pike of 30 lb., taken at Luton Hoo by H.R.H. the then Princess of Wales, now Queen Alexandra, is preserved in the "fish house' there; also one taken by Mr. Forbes in 1875 , length $47 \frac{1}{2}$ inches, weight $36 \mathrm{lb}$. In August, I 894, there was an accidental influx of sewage from the sewage farm at Luton into the lake, which killed a great number of pike. There is a photograph showing about sixty pike killed at the time, all very large fish. About 500 in all were destroyed.

At Southill Lake in June, 1897 , when the lake was accidentally run off, a female pike $46 \frac{1}{2}$ inches long, and weighing $32 \frac{1}{2} \mathrm{lb}$, and a male 45 inches long weighing $26 \mathrm{lb}$., were taken and presented to Mr. J. Steele-Elliott, who has them preserved.

\section{OSTARIOPHYSI}

\section{Gudgeon. Gobio fluviatilis, Flem.}

Found in all parts of the shallow gravelly bed of the river up to about 5 inches in length.

8. Chub. Leuciscus cepbalus, Linn.

Found commonly in the deep pools in the Ouse near the rapid parts of the stream, and weighing up to nearly $6 \mathrm{lb}$. One was taken by myself a few years ago at Milton Mill of $5 \frac{1}{2} \mathrm{lb}$, and one of $5 \frac{1}{4} \mathrm{lb}$. taken at Blunham about 1882 is in the possession of Mr. George of Tempsford. They are frequently taken with the fly or minnow up to 3 and $4 \mathrm{lb}$. The chub appears to preserve its 'habitat' to a great extent, and keeps constantly to its selected parts of the river.

\section{Roach. Leuciscus rutilus, Linn.}

A very common and gregarious fish in all parts of the river. One $3 \mathrm{lb} .6 \mathrm{oz}$, taken at Luton Hoo about $189 \mathrm{I}$, and another $2 \mathrm{lb}$. ro oz., caught about the same time, are pre- 


\section{FISHES}

served in the 'fish house' there. I took one in the Ouse at Clapham in July, I900, weighing over $2 \mathrm{lb}$. One of $2 \mathrm{lb} .2 \mathrm{oz}$. and one of $I \frac{3}{4} \mathrm{lb}$. were taken by Mr. A. R. Lindley at Great Barford, June 23, I 898. A roach weighing $3 \frac{1}{2} \mathrm{lb}$. was caught in the Ouse at Bedford, September 2, 1872, by Mr. J. Savage.

IO. Rudd. Leuciscus erythrophthalmus, Linn.

This fish is not nearly so common as the roach. It is occasionally met with up to I $\frac{1}{2}$ lb. I took one of that weight a few years ago at Clapham. One $2 \mathrm{lb}$. weight was caught, March, I90I, near Sandy, by Mr. A. Rylett (Field, March 16, I901). A rudd weighing $2 \mathrm{lb} .6 \mathrm{oz}$. was taken in the Ouse by Mr. H. Thody, September, 1875 : length $15 \frac{1}{2}$ inches, girth 12 inches.

\section{I1. Dace. Leuciscus dobula, Linn.}

It frequents the clear and rapid waters of the river and swiftly running brooks, and is a gregarious fish, varying in weight to about $\frac{3}{4} \mathrm{lb}$.

12. Bleak. Leuciscus alburnus, Linn.

Found in all parts of the river in large numbers near the surface.

\section{Minnow. Leuciscus phoxinus, Linn.}

Found in shoals in most of the shallow gravelly parts of the river and in the various brooks. It appears to be plentiful at times in certain parts of the river, and then to change its locality, appearing again in other parts where it was formerly comparatively scarce. This is probably caused by the frequent changes in the scour of the sandy beds of the stream produced by heavy floods. A minnow 4 inches in length, girth $2 \frac{1}{2}$ inches, was caught at Clapham Ford, May 3, I 88I.

14. Tench. Tinca vulgaris, Cuv.

Although more frequently found in lakes and ponds, it is present in the Ouse in the deep parts of the river. It attains a weight of $4 \frac{1}{2} \mathrm{lb}$. to $5 \mathrm{lb}$. One was taken by myself of $4 \frac{1}{2} \mathrm{lb}$. at Blunham Mill in the Ivel in June, I 897 , and two were taken in Southill lake in June, r897, weighing $5 \mathrm{lb}$, and $4 \frac{8}{4} \mathrm{lb}$,, and are in the possession of Mr. J. SteeleElliott.

I 5. Bream. Abramis brama, Linn.

The Ouse is considered one of the best bream rivers in England, and Bedfordshire is always held particularly famous for this fish. It is found in large numbers in all deep parts of the river, and attains a large size. One of $9 \mathrm{lb}$. was taken at Bromham in 1898 , and many are taken every season of from 4 to $5 \mathrm{lb}$. Whilst proving the right of the lord of the manor a brace were netted from the Ivel at Blunham Mill pit, July 16, I882. One weighed $1 \circ \frac{1}{4} \mathrm{lb}$, and passed into the possession of Mr. P. Addington, and the other, weighing $9 \frac{3}{4} \mathrm{lb}$., is now in the possession of Mr. George at Tempsford. The largest recorded is one of $12 \frac{1}{4} \mathrm{lb}$. taken at Southill in June, 1897, when the lake was accidentally drawn off, and is remarkable as being the only one found in the lake. It was presented to Mr. J. Steele-Elliott, who has it preserved.

16. Loach. Cobitis barbatulus, Linn.

Found more in brooks than in the river itself, secreting itself under stones. It used to be common in a brook, now partially filled up, near the Midland Station, Bedford.

\section{APODES}

17. Eel. Anguilla vulgaris, Turt.

Found in large numbers in all parts of the rivers, especially in the Ouse, where it has been a source of profit from a very early date. The eel grows to a great weight; the heaviest appear to come from the upper parts of the Ouse near Olney, and Lavendon in Bucks. One of $9 \mathrm{lb}$. was taken at Roxton Sluice about 1880. It has long been a matter of doubt where they breed; but they are now known to go down to the sea to spawn in deep water. I have noticed them in the latter part of the summer at the side of the Ouse near Bromham as small threadlike specimens of about an inch or more in length. Countless numbers of 'elvers,' which are very small, ascend some rivers as the Thames, Exe and Severn, where their annual migration in the spring is termed the 'eel-fare' or 'travel.'

\section{CYCLOSTOMES}

18. Lampern. Petromyzon fluviatilis, Linn.

This is mentioned in Davis's History of Luton, and I am informed by Mr. F. New-

bery that he has taken it at Milton Mill on the Ouse.

Nore.-I am indebted to Mr. J. Steele-Elliott of Clent, Worcestershire, for many interesting notes and other information contained in the above paper. 


\section{REPTILES \\ AND BATRACHIANS}

The physical features of a country determine to a great extent the distribution of its fauna, and the county of Bedford may roughly be divided into two zones so far as the reptiles and batrachians are concerned.

There is first the low land, frequently flooded, lying around the river Ouse which affords food and shelter to the moisture loving reptiles and batrachians; secondly, the belt of warm greensand which, entering the county at Leighton Buzzard, passes by Woburn, Ampthill and Sandy, and out of the county beyond Potton. This stretch of country, undulating in many places and covered with woods and bracken, forms a secure retreat for those reptiles which love warmth, and it is in these two belts of land that most of the reptiles and batrachians of the county are found. The northern portion of Bedfordshire with its cold clay soil, and the southern portion with its chalk downs, are not favourable to reptilian and batrachian life.

Although the orders Lacertilia and Ophidia, and the class Batrachia, are represented, the county cannot be considered rich in species. I have not been able to find the smallest of our newts, known as the palmated newt (Molge palmata), although I have sought for it far and wide, and Mr. Steele-Elliott agrees with me in thinking that it cannot be reckoned among our local fauna. He informs me that he has searched every likely looking clay pit, well, village pond, and other such waters without finding a trace of it. The edible, or green frog as it is sometimes called (Rana esculenta), is not met with outside the Woburn Park estate. Some years ago a number of these batrachians were imported from the continent by the Duke of Bedford and let loose in the gardens at Woburn Abbey, and the colony still continues to exist.

The natterjack toad (Bufo calamita) is also absent. This is rather curious because it exists on the borders of the counties of Cambridge and Hertford.

There is no record of the smooth snake (Coronella lavis) ever having been seen, and I think that it may be safely asserted that it does not exist in the county. Probably the same assertion may be made of the sand lizard (Lacerta agilis). It has been sought for diligently in the localities that would be likely to harbour it, and without success, but I have captured it at Perry in Huntingdonshire, only a mile or two over the border. Owing to the high state of cultivation the number of individuals of existing species of reptiles is not great, and the number is each year getting less, the lizards and snakes being killed whenever they are met with. It is earnestly to be hoped that the spread of education will do something towards removing that foolish prejudice against creeping things which so 


\section{REPTILES AND BATRACHIANS}

widely exists in the rural districts, and that the day is not far distant when the ruthless destroyers of our harmless little reptiles will realize that these animals should be protected, as they play an important part in maintaining what is known as the balance in the economy of Nature.

\section{REPTILES}

\section{LACERTILIA}

I. Common Lizard. Lacerta vivipara, Jacq. This lizard is plentiful on the greensand, particularly at Shefford Warren.

2. Slow-worm or Blind-worm. Anguis fragilis, Linn.

This harmless limbless lizard suffers from its general resemblance to the snake, from which it may be distinguished by the absence of broad ventral scutx, the scales being alike all round the body. In length it probably does not average more than 12 or 14 inches. It is fairly common in the same locality as the viper.

\section{OPHIDIA}

3. Common or Ring-snake. Tropidonotus natrix, Linn.

This, the largest of our English reptiles, known locally as the grass snake and the water snake, is occasionally met with in the meadows adjoining the river Ouse. The average length of a full grown ring-snake is about a yard. Two years ago I had a very fine specimen brought to me which was very nearly 4 feet in length. These snakes are perfectly harmless; they feed chiefly on frogs which abound in the meadows adjoining the river. They do not confine themselves to this diet, but occasionally make a meal of the fish from the river. One of the specimens in my collection came to an untimely end by an attempt to vary his diet in this way. He seized a roach in the river, brought it on the bank and was choked in endeavouring to swallow it. Every year these snakes are decreasing in numbers and now they are very rarely seen, the country people consider them to be poisonous and kill them whenever they have the opportunity. 4. Viper or Adder. Vipera berus, Linn.

It inhabits the woods and bracken which clothe the greensand district. Specimens have been taken in the neighbourhood of Potton, Westoning, Shefford and Woburn. Although the viper can hardly be said to be common it is certainly more often met with than the ring-snake. Unlike the latter, as a rule, it frequents dry, warm situations and is found in the woods and bracken which stretch across the county from Leighton Buzzard to Potton. One was run over a short time ago by a cart between Woburn and Aspley Guise, and three years ago a man was bitten by a viper in the neighbourhood of Westoning. The locality where this accident took place is of a swampy nature. I have found vipers in Holme $\mathrm{Fen}$ in Huntingdonshire, but the swampy moorland in the neighbourhood of Westoning is the only locality of this nature in Bedfordshire in which I have known vipers to occur. The gamekeeper informs me that he has killed several near Westoning. He says they are fairly common about that village.

Formerly this snake was more abundant: the earliest reference I can find to the viper in our county is a mention of it by John Bunyan, ${ }^{1}$ to which my attention has been drawn by Mr. Steele-Elliott. As Bunyan was born in 1628 , and the incident he mentions took place in his boyhood, it would seem that 250 years ago the viper was found near Elstow.

\section{BATRACHIANS}

\section{ECAUDATA}

5. Common Frog. Rana temporaria, Linn. Abundant everywhere.

[Edible Frog. Rana esculenta, Linn.

Found only on the Woburn Park estate, and imported from the continent by His Grace the Duke of Bedford.]

6. Common Toad, Bufo vulgaris, Laur. Common everywhere.

\section{CAUDATA}

7. Great Water Newt. Molge cristata, Laur.

This is also known as the common wartynewt. It is found in ponds all over the county.

8. Common Smooth Newt. Molge vulgaris, Linn.

Known also as the small newt, eft, or evet ; is abundant everywhere.

1 Grace Abounding. 


\section{B I R D S}

Bedfordshire at the hands of the zoologist has received less attention than almost any other English county. Only one work, and that touching but briefly upon its vertebrata, has been published. In the History of Luton and its Hamlets ( 1855 , and a second edition in 1874 ), a list of species is given with a few particulars, but unfortunately several of the records are untrustworthy. In addition to this work, the scattered notes in the Zoologist and Field and local newspapers form almost the only printed records from which information has been gleaned.

With the exception of the chalk-hill range running through the south of the county (where, until about twenty years ago, the stone curlew still continued to nest and dotterel whilst on migration were annually known to tarry awhile) there is but little attraction for any rarer breeding species, other than that which a highly cultivated county with a considerable number of smaller woodlands more or less generally dispersed would offer.

Early in the past century when our woods were more extensive the common buzzard and kite still nested, and possibly the honey buzzard, and the hen harrier also still frequented the more open areas; but of our hawks the sparrow hawk and kestrel alone remain, the hobby not having been known to nest since 1892 . Several pairs of ravens continued nesting until the middle of the century, the last pair being exterminated from Woburn about $\mathrm{I} 87 \mathrm{I}$; the carrion crow, though considerably reduced in numbers, still remains with us. On several estates where there is a considerable amount of fir plantation the nightjar is still evident, but in lesser numbers than formerly, and the long-eared owl is fairly abundant. The existence of several small 'heronries' is within the memory of some of our older inhabitants, but the nests of one or two pairs only are to be found now, and these are not in the localities that were formerly chosen. The preserved waters in the parks at Southill, Woburn and Battlesden are the favourite resorts of the great crested grebe (and until quite recently the little grebe), as well as Luton Hoo. Pochard ducks have nested in considerable numbers around the latter pools; teals in many instances, particularly at Southill, and shovel ducks have bred in the county on several occasions.

With the exception of the now much restricted Flitwick Marshon which until the year I 90 I at least one pair of snipe nested-little undrained land remains. The meadow-pipit is another bird awaiting extermination as a breeding species ; one pair only could be found nesting at Flitwick during the spring of 1902, and the only other haunts of 


\section{BIRDS}

the present day seem to be on Dunstable Downs where a few pairs can also be found. Although redshanks probably bred on our low-lying meadow lands years ago no certain evidence can be obtained; but they appeared at Newnham in 1896 and several pairs continued nesting until I 899. It is possible that the black tern may once have nested also in the county. To what extent such a small area as the sewage farm at Newnham can, under varying conditions, influence the appearance of rarer migrants and nesting species will be shown in the accompanying notes. The Ouse is the highway which brings so many of the rarer waterfowl, and along the Ouse valley a regular stream of migratory waders, geese, ducks, gulls, terns, etc., journey every spring and autumn on their way from coast to coast. The large flocks of lapwings and golden plovers, and the numbers of hooded crows and various other species that winter with us are evidently migrants that have come from our eastern coasts and followed the course of the Ouse.

In cases where the record of a bird's occurrence is open to doubt or its appearance is due to artificial introduction the entry in the following list is placed within square brackets.

Brackets placed round the name of the original describer of a species indicate that he did not employ the generic name which is now adopted.

I. Missel-Thrush. Turdus viscivorus, Linn.

Locally, Screaming-Thrush.

A common bird throughout the county. It is one of our earliest breeding species, frequently nesting towards the end of March, and at times even earlier. A fawn-coloured variety in the possession of Mr. Cane is said to have been taken locally.

\section{Song Thrush. Turdus musicus, Linn.}

Nests abundantly everywhere. Many thrushes forsake their haunts as the winter approaches, and remain absent during any lengthy spell of severe weather. An instance of a nest of a thrush having been found near Luton in the side of a round wheat-stack is recorded by Morris in his British Birds. Several pied varieties of this thrush have been obtained.

\section{Redwing. Turdus iliacus, Linn.}

An abundant winter visitant. As is the case with the fieldfare, prolonged severe weather tends very much to reduce their numbers. Redwings generally arrive with us earlier than the fieldfare. Often the first intimation of their presence is the note of a migrant passing overhead during the night. About the middle of October seems to be the usual date of their arrival, and they depart again at the end of March or early in April.

4. Fieldfare, Turdus pilaris, Linn.

Locally, Felt, Felfer.

Generally towards the latter end of October or in early November small flocks of fieldfares arrive, their number being considerably added to as the winter advances. During the more open period, when insect food is obtainable, they frequent, in company with redwings, the grass lands, where, in such districts as the meadows of Goldington and Cardington, they may be seen together in thousands. At the first fall of snow, or as soon as the ground has become frozen, they are driven to seek a living among the bushes and hedgerows, feeding upon the berries in company with redwings, blackbirds, thrushes, etc. Should unusually severe weather prevail for a long time, many starve, and others, half starved, are compelled to migrate elsewhere. Under such conditions it takes several years to recoup their numbers. The fieldfare is the last of our winter visitants to return to its breeding haunts, staying with us until late in April and frequently till May. A pied fieldfare was killed at Bolnhurst about 1863 .

\section{Blackbird. Turdus merula, Linn.}

Our blackbirds undoubtedly vary in numbers owing to migration, but many are also resident with us, except perhaps during prolonged severe weather; yet even then, so long as a small supply of food is obtainable, some prefer not to forsake their summer haunts. Although a general favourite, this bird becomes troublesome in the fruit season. Albinos, pied, yellow and other varieties are frequently obtained.
I 


\section{A HISTORY OF}

6. Ring Ousel. Turdus torquatus, Linn.

From the frequency with which this bird is obtained, notwithstanding that it is rather shy in its habits on migration, it must pass through the county in the spring and autumn in fair numbers. Mr. A. F. Crossman reports one seen by himself as late as in 8 January 189I. A male was picked up in May I 896 which had killed itself against the telegraph wires. Mr. J. King, writing to me in reference to this bird around Langford, states that it is generally seen in October, rarely in the spring; that in the autumn it feeds upon hips and haws and in the spring upon the ivy berries growing over some old hawthorns alongside the river. He reports one shot 27 October 1861; another 3 October 1869; a female on 13 October of the same year; a male I4 April 1870, which had been about the meadows some days, and which he had frequently heard singing; others in 1875 and 1886 , and 27 September 1889 ; one shot 3 May 1892 ; another seen by him 29 April 1895 feeding also upon the ivy berries; and one shot 19 October 1898 , having been in that locality in company with redwings, blackbirds, and thrushes about the hedgerows several days. One was killed at Clifton 6 April I 893, and two at Chawston in the autumn of 1892 . Professor Newton has seen this bird at Everton, and other records include one shot at Tingrith in 1897 .

7. Wheatear. Saxicola cenanthe (Linn.)

At the present day by no means a common nesting species. Of late years the wheatear seems to have restricted its breeding range to the southern portions of the county where it breeds in very limited numbers. It is now known only as a common spring and autumn migrant in other parts of Bedfordshire, whereas at one time it seems to have bred regularly in limited numbers in various other localities. The wheatear used to breed in the Newnham ruins, at Cox's Pits and in the old stone walls of the gardens at Stevington and Sharnbrook; in 1892 two pairs frequented the brickyard along the Clapham road, when they stayed some considerable time, but it is uncertain whether they attempted to nest. Mr. J. King saw a nest containing young in a rabbit hole near Hexton about thirty years ago, and informs me of a pair that remained in a field near Clifton all the summer ; although his brother searched well he failed to find their nest. Mr. C. F. Woods says the wheatear bred regularly on Crawley Heath during his residence at Woburn 1858 68. On the downs below Whipsnade on the borders of the county they continue nest-

\section{BEDFORDSHIRE}

ing, four of their nests being found in May, 1898 , and I have personally observed this bird during the nesting time in other localities around that neighbourhood.

\section{Whinchat. Pratincola rubetra (Linn.)}

A fairly common summer migrant. It can be found frequenting meadows and rough grassy lands, but by far the most favourite haunts of this bird are the railroads, where the embankments and cuttings form rough grassy slopes which suit its requirements admirably.

\section{Stonechat. Pratincola rubicola (Linn.)}

Formerly known to nest in several localities. Those seen nowadays are usually on migration or are wintering with us. At Henlow they nested until about 1870 , and also on Rowney Warren. Along the Clapham road and in the ballast hole along the Ampthill road they bred until about 1890 . The only nesting place I know now is between Southill and Shefford.

\section{I0. Redstart. Ruticilla phoenicurus (Linn.)}

One of our handsomest summer migrants, but by no means so commonly distributed here as in many other counties, and its numbers have probably decreased of late years. It is however fairly abundant, and may be found nesting throughout the county. Even in the town of Bedford several pairs nest regularly in the old pollard willows along the embankment and elsewhere. An interesting instance of the nesting of the redstart came under my notice while rambling with $\mathrm{Mr}$. King over the Southill estate on 18 May 1894 . He was telling me that many years ago a pair of these birds had nested, season after season, on a ledge under the porch of one of the cottages in the park. On passing by we called upon the old tenant, and to our surprise we found a nest on the same site containing young. By the side of it, separated only by an upright, was another nest containing one egg, which the tenant informed us had been forsaken by the old birds, and the second nest had been built beside it. Upon Mr. King referring to his notes he found, strange to say, that exactly twenty years ago on that day the female had been caught on her nest by a lad, under the same porch. At that time the eggs were frequently robbed, and the pair once tried nesting at the end of the house, at another time in an outhouse at the bottom of the garden, and again in the hole of a tree not far away, but came back again to the porch, where we were informed redstarts have nested regularly ever since. 


\section{BIRDS}

I I. Black Redstart. Ruticilla titys (Scopoli)

This somewhat rare winter migrant to the British Islands has been recorded for the county several times. Four occurrences came under the personal observation of $\mathrm{Mr}$. A. Covington, the particulars of which are as follows : In November 1860 one was searching for food among the crevices of the stonework of the old hostelry in the Old George yard at Bedford; another was observed on Sunday, 29 December 1872 , on the carving of the south porch of St. Paul's Church ; it seemed rather shy, but he was able to watch it for several minutes; it eventually flew up to one of the pinnacles. One shot in the town was taken to him on the following day, and was probably the same bird. The third was observed 17 February 1899 near Clapham Park. Two others also passed through his hands, shot at Barford and Clapham, both whilst perched on hurdles forming sheep pens. Mr. Cane killed one of this species near Luton about I865, and saw another at a later date, which however was not obtained. He heard also of a third being seen in that locality.

12. Redbreast. Erithacus rubecula (Linn.)

The robin is far too numerous and familar to need any reference to its distribution, except that its numbers with us are considerably added to by immigrants at certain periods of the year. Instances of odd situations chosen for nesting accommodation by the robin are numerous.

\section{Nightingale. Daulias luscinia (Linn.)}

From its abundance the greater part of the county must be well suited to its habits; any small spinney with a fair amount of undergrowth will be made the nesting haunt of at least a pair of these birds; in larger plantations and woods many pairs can be found, and frequently a thick hedgerow or a garden shrubbery will tempt a pair to nest regularly. It seems more numerous in some years than in others.

I 4. Whitethroat. Sylvia cinerea (Bechstein)

Locally, Haybird, Nettle-Creeper, Cut-Throat.

The commonest warbler amongst our summer migrants. Its fragile nest can generally be found about the hedgerows or among the undergrowth of small spinneys.

15. Lesser Whitethroat. Sylvia curruca (Linn.)

Compared in numbers with the previous species this bird is far less common, but yet it may be termed fairly abundant, and I think, from my own observations and those of others, will be found equally distributed over the county. Mr. A. Covington once had a lesser whitethroat pass through his hands which had the whole of the under part suffused with pale salmon colour.

16. Blackcap. Sylvia atricapilla (Linn.)

In my wanderings over the county I have always found the blackcap a fairly common summer migrant, which experience is shared by various friends and correspondents. It is generally distributed, frequenting the numerous small plantations and woodlands where suitable undergrowth can be found for its nesting requirements.

17. Garden-Warbler. Sylvia bortensis (Bechstein)

Another summer migrant visiting us in numbers about equal to those of the blackcap, frequenting similar situations, and whose habits are almost identical. To the best of my knowledge it would be described as common in any part of the county.

18. Goldcrest. Regulus cristatus, Koch.

In such localities as Ampthill, Woburn, Aspley, Rowney, Southill, and Warden, or probably where fir plantations are abundant, we find the goldcrest fairly common during the breeding season, and I have found it frequently nesting in many other districts where isolated or small groups of suitable trees meet its requirements.

19. Firecrest. Regulus ignicapillus (Brehm) A very uncommon winter visitor. Mr. A. Covington mentions two specimens of the firecrest as having passed through his hands; a male which was killed in the firwoods at Ampthill about 1873 , and a female which was killed with a stone by a lad in one of the hedgerows there.

20. Chiffchaff. Pbylloscopus rufus (Bechstein)

A common summer migrant arriving in our county towards the end of March and staying with us until late in September.

21. Willow-Warbler. Pbylloscopus trochilus (Linn.)

Locally, Oven-Bird, Banking-Bottle, WillowWren.

From the domed construction of the nest the willow-warbler has received its local names. A willow-warbler was shot near the old bridge at Newnham as late as 27 December in 1878 .

22. Wood Warbler. Pbylloscopus sibilatrix (Bechstein)

Although I can name many localities where 


\section{A HISTORY OF BEDFORDSHIRE}

several pairs of the wood-warbler breed, such as around Woburn, Southill, Luton Hoo, the woods adjoining Ampthill Park and the plantations near Clophill, also in the Aspley Woods, Everton, and at Bromham, yet we must consider this bird as a rather uncommon summer migrant and very local in its distribution. With us it seemingly prefers the fir plantations with their sparse undergrowth to the oak or other mixed woodlands where the under-cover is more dense.

\section{Reed-Warbler. Acrocephalus streperus (Vieillot) \\ Locally, Reed-Bird, Reed-Wren.}

Wherever reed beds abound there also shall we find this summer migrant plentiful. There are many of its haunts in close proximity to the town of Bedford, and throughout the whole course of the Ouse it occurs very commonly. On the Ivel at Blunham, Clifton, Langford, and other places I have found it abundant, and it is no doubt frequent all along this waterway. At Southill Lake it nests freely, and the lake at Luton $\mathrm{Hoo}$ is a favourite haunt also. The majority of these nests are built, as is usual, suspended between the reeds, but not a few are found in osier beds built similarly upon the osiers and often at a considerable distance from the ground.

\section{Sedge-Warbler. Acrocephalus phragmitis} (Bechstein)

A summer migrant, and common everywhere ; along the banks of our rivers throughout their course, and about every stream, pool, pond, ditch or wherever moist herbage grows, and even some distance away from any such situation we find its nest. It is generally placed in low bushes, on the stumps of osiers or amongst the rank herbage, seldom more than 2 or 3 feet from the ground, but sometimes higher; one nest that came under my notice at Tempsford situated in the top of one of the numerous tall hedgerows found around that neighbourhood was fully 8 feet above the ground. Mr. J. King kindly gave me a nest with the eggs of this bird taken at Langford 28 May 1897 which were pure white, without any markings upon them whatever. He once shot a sedge-warbler as late as December, having seen it several times previously along the river.

25. Grasshopper-Warbler. Locustella navia (Boddaert)

A very scarce summer migrant. According to Mr. J. King, Sherhatch Wood near Cople seems to have been a veritable stronghold for this bird in our county. In I $89 \mathrm{I}$ he found a nest containing young in his osier bed close to his house at Langford. It has also been heard in the woods at Stagsden and Bromham, also at Harlington, Thurleigh, Oakley and Pegsdon. Its nest is also said to have been found at Clapham, Thurleigh, Kempston and near Woburn. During the year Ig0I I found two pairs nesting on Flitwick Marsh, and its song was heard at Clapham Park and in one of the osier-bed islands in the river at Cox's Pits.

26. Hedge-Sparrow. Accentor modularis (Linn.)

A resident throughout the year, and very common, evidently preferring, like the robin and sparrow, the close vicinity of the haunts of man. White, buff and pied varieties of this bird have been met with.

\section{Dipper. Cinclus aquaticus, Bechstein}

The slow-flowing Ouse and our sluggish brooks offer the dipper but little attraction. The only authorities for including it in our fauna are Mr. Cane, who states that about thirty years ago one was obtained in Luton Hoo Park, and Mr. W. J. Chalk who saw one on the Ivel in March 1900.

\section{Bearded Reedling. Panurus biarmicus (Linn.)}

The only information that I have relating to the occurrence of this bird in the county was given to me by $\mathrm{Mr}$. A. Covington, who was told by an old sportsman and ornithologist that he had killed two or three specimens of this bird when shooting down the river fifty to sixty years ago. In Mr. Covington's possession is an old male given to him in the flesh which was said to have been shot along the river below Great Barford in the winter of 1867 . It is unfortunate that Mr. H. Thompson, as the authority on the list of birds given in $T$ be History of Luton, I 855 , only briefly refers to this bird as rare, without verifying its actual occurrence.

\section{Long-Tailed Tit. Acredula caudata (Linn.) \\ Locally, Long-Tom, Pudding-Bag.}

Resident and generally common. Its wonderfully constructed nest will be known to most of us, and the family parties of this interesting little bird, which roam about the country, implicitly following their leaders, are a common enough sight. Mr. A. Covington once dissected one of their nests, which contained no less than 2,050 feathers besides wool and other materials used in the construction of the lining. 


\section{BIRDS}

30. Great Tit. Parus major, Linn.

Locally, Large Tom-Tit.

The great tit is common generally, nesting as a rule in holes of trees, but occasionally selecting some very odd sites in which to build. During the winter months the pairs still seem to prefer their own company, but occasionally when a good supply of food offers more than usual attraction, several may be seen together, or at other times may be observed accompanying the other species of tits, goldcrests, etc., about the woods, though generally preferring the company of the blue tits to that of the others; often these two species hold themselves somewhat aloof from the rest. A buff variety shot at Broom was in the possession of Mr. J. King.

3r. Coal-Tit. Parus ater, Linn.

Although fairly common, the coal-tit is by no means as plentiful as the blue and great tits as a breeding species, but when the migratory flocks arrive to winter with us its numbers are increased considerably.

\section{Marsh-Tit. Parus palustris, Linn.}

Resident and somewhat commoner as a breeding species than the last named, and distributed, I think, generally over the county. It is the most unsociable of all the tits, for except when accompanied by their young seldom more than a pair are ever seen together.

33. Blue Tit. Parus caruleus, Linn. Locally, Tom-Tit, Little Tom-Tit.

A very common resident ; and its handsome plumage, its vivacious movements and its partiality for the haunts of man make it a great favourite. Mr. A. Covington states that he has had several pied varieties of this tit pass through his hands.

34. Nuthatch. Sitta casia, Wolf.

A resident wherever old timber abounds; hence the neighbourhood of our numerous old parks offers the nuthatch irresistible attraction. In such localities as Ampthill, Woburn, Luton Hoo, Silsoe, Southill, Warden, Blunham, Tempsford, Turvey, Bromham and in many another district, it can be very often observed, and its note will be constantly heard to verify its presence. In such localities it nests plentifully, often utilizing the same site year by year.

35. Wren. Troglodytes parvulus, Koch. Locally, Jenny Wren.

A numerous resident and universal favourite. Mr. J. King has found in the winter time as many as six or eight wrens roosting together in one hole, and thinks possibly they may have been one family party. At Woburn, Mr. C. F. Woods was examining one evening in the winter time some martins' nests situated under his stable eaves, when he found as many as five wrens sleeping together in one of the nests.

36. Tree-Creeper. Certbia familiaris, Linn.

A common resident. In winter it appears to be more numerous than in summer, but this may be due to the fact that the leafless trees give us better opportunities for observation. The old timbered parklands during the nesting period seem to offer the treecreeper special attractions, and nowhere is it more common than at Ampthill, Woburn, Turvey, Southill, and Bromham Parks; in the latter I have always found it particularly abundant.

37. Pied Wagtail. Motacilla lugubris, Temminck.

Locally, Water-Wagtail, Dishwasher.

As the winter approaches, this wagtail forsakes the majority of its summer haunts and will be but rarely seen. Along our waterways a few remain the winter through, or until severe weather forces them to migrate. They may be often observed roosting together in considerable numbers in the willows and reed beds by the water.

38. Grey Wagtail. Motacilla melanope, Pallas.

Except during the nesting period, the grey wagtail can be found generally distributed and fairly abundant throughout the county, haunting the smallest streams and ponds as well as our larger waterways, and is not infrequently noticed far removed from any water. The sewage farm at Newnham seems to offer special attraction for these birds during their winter sojourn; a few at least will invariably be found there.

\section{Yellow Wagtail. Motacilla raii (Bona- parte) \\ Locally, Yellow Dishwasher.}

A fairly abundant summer migrant to some parts of Bedfordshire. Nesting generally in growing crops, its eggs are seldom obtained. I have seen numbers of these birds roosting on the bed of rushes at the junction of the New Cut and the Ouse at Cardington; in my diary on 9 August 1892 I noted a company of about 200 yellow wagtails flushed from this locality.

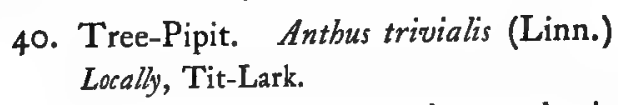

An abundant summer migrant, having a 


\section{A HISTORY OF}

preference for certain localities; it will be found nesting in woodlands with thin undergrowth, and uncultivated districts generally.

41. Meadow-Pipit. Antbus pratensis (Linn.)

Better known within the county as a winter migrant than as a resident. Numbers appear during the autumn and distribute themselves generally where suitable food can be found. Towards the latter end of September and onwards one or more pairs, and frequently small parties, can often be flushed from among the turnip crops; our meadow lands, especially during floods, have also great attractions for it, and on the sewage farm at Newnham throughout the winter it is a very common bird indeed. As a nesting species within Bedfordshire it must now be considered very local. It formerly had several nesting haunts close to Bedford, as for instance the Longholm meadows, but it has ceased to breed here and elsewhere for several years past. A few pairs still nest on the Dunstable downs, and during the year 1902 I found a nest with young on Flitwick Marsh.

\section{Great Grey Shrike. Lanius excubitor,} Linn.

This bird formerly seems to have occurred most winters, a year seldom passing without one or more being received at the local taxidermist's, or reported as having been seen within the county; but now several years may pass without one being recorded. Four have come under the personal notice of $\mathrm{Mr}$. J. King, two of which were shot by himself, one 12 December I 866, and the other 9 November I 867. His son shot a third on 6 January r873. He failed to get within shot of the fourth bird. He tells me that all these birds frequented the same dead ash tree in his meadows at Langford, perching always on the topmost branches. During the past thirty years about a dozen county specimens have passed through the hands of $\mathrm{Mr}$. A. Covington. Four or five have been sent to Mr. Cane, one killed at Dunstable, another, about three years ago, at Sutton. Three have been received by Mr. J. S. Wright, one of which was caught in a ground clap-net. John Cole shot another I 7 October 1880 at Haynes. Dr. Sprigge told me of one that was killed previous to I 894 on the Wilden road near Great Barford. Another, in my own possession, was taken near Clophill about the year I 848 ; Mr. P. Addington saw a grey shrike near Wyboston about I 873 ; Dr. Edward Hamilton shot a male near Dunstable 25 November 1848 , that had alighted on the top of a decayed ash

\section{BEDFORDSHIRE}

tree (evidently a favourite site), and Mr. C. F. Woods sends me the record of a male killed at Hockliffe in 1861. The most recent records of this species are one killed at Fenlake in November 1898 , and another shot near Luton in the winter I900-1.

\section{Lesser Grey Shrike. Lanius minor,} J. F. Gmelin.

The addition of this rare visitor to our county list is made on information kindly sent to me by the late Lord Lilford. The Duchess of Bedford informed him that she and a gentleman staying at Woburn saw there in the first week of September 1894 a bird that they have little hesitation in considering as of this species. The only other British species for which it could possibly be mistaken is Lanius excubitor, and the date of its occurrence at Woburn puts this supposition almost out of the question.

\section{Red-backed Shrike. Lanius collurio, Linn. Locally, Butcher-bird.}

A regular summer migrant, but, taking the county generally, less numerous perhaps than in some other counties. Probably commoner now with us than in former years.

\section{Waxwing. Ampelis garrulus, Linn.}

Many instances have come to my knowledge of this irregular winter visitor being recorded in our county, and no doubt there are many others that could be added to the present list. One, an adult male, is recorded in the Zoologist, 1847 , as shot 23 January at Luton. One was picked up at Houghton Conquest in the winter $1872-3$, and another was killed at Aspley Guise about 1879. In the winter $1882-3$ waxwings were reported commonly about the county, and one was shot at Fairfield, Biggleswade, on 15 January. Two were given to me by Mr. J. King, one of which was shot in Southill Park, and the other in Henlow Park the same winter, about 1856. Another, which was alone, was shot by his son in the meadows at Langford 20 January 1885 . During the same winter one was picked up dead at Ampthill. A male was shot at Odell Rectory 19 January 1890 , one near Bedford the same year, and another at Odell in January 1893. A specimen in the writer's possession was caught in a field at Girtford 31 January 1895, and another was shot at Upper End farm, Shillington, on the same date. Mr. A. Covington writing on this bird states that he has had specimens pass through his hands from many localities, the last one being from Wilden in January 


\section{BIRDS}

1895. He once had a fine old male, shot in a yew tree in the Grove, Bedford.

\section{Pied Flycatcher. Muscicapa atricapilla, Linn.}

This bird probably passes through the county annually but in very limited numbers on its spring and autumn migration. On 13 May I 87 I Mr. J. King shot a female in his garden at Langford. Mr. W. R. Butterfield of St. Leonards-on-Sea gives me particulars of a specimen of this bird in his collection, an adult male, which was killed near the river Ouse in the vicinity of Bedford, September 1895. Mr. A. Covington says he has never had a local specimen through his hands, but has a note of one shot at Wilshamstead in the autumn of 1870 . Mr. Cane informed me that a male was shot at Pepperstock from a pair that were said to have a nest in the hole of an apple tree. Colonel Barclay mentions that he observed the pied flycatcher during 1898 at Tingrith.

\section{Spotted Flycatcher. Muscicapa grisola, Linn. \\ Locally, Wall-bird.}

A common summer migrant equally distributed throughout the county. Frequently nests in private gardens and the public walks and grounds of towns; in Bedford it nests regularly. Mr. A. Covington told me of a pair that built near his house in Lurke Street, Bedford, in the fork of a grape vine trained to the wall, for nineteen years in succession, and were still doing so when he left that neighbourhood. Mr. C. F. Woods mentions a pair that built their nest for four consecutive years on the hinge of a pair of very heavy doors at Woburn.

\section{Swallow. Hirundo rustica, Linn.}

Generally arrives about the middle of April, but in some years it may be a few days later. Its departure takes place usually at the end of September or early in October, though many may have left us before these dates. The swallow has been observed with us as late as November. There are many osier and reed beds locally where swallows and martins congregate to sleep in enormous numbers. Several white varieties or albinos have been recorded.

49. House-Martin. Chelidon urbica (Linn.)

Although the house-martin arrives at about the same time as the swallow, and one of its first thoughts seems to be to visit its old nesting haunts, as a rule it is somewhat later than the latter bird in starting incubation, it being seldom before the second week in June that its full complement of eggs is found. It evidently rears at least a second brood, as young birds may be observed in the nest very late in the year. Mr. A. Need sent particulars to the Field, 1898, of two pairs still with young in nests on his house at Leighton Buzzard during the first week of October. Departure takes place generally about the end of September and early October, but they are frequently observed in some numbers up to the middle of the latter month. Mr. J. King mentions seeing one on 4 November 1898 at Langford. In the Field some fifteen or twenty are mentioned as staying within the county as late as 17 November in 1875 . A perfectly white house-martin is reported as having been seen about the neighbourhood of Bedford (Field, I I August I 877).

\section{Sand-Martin. Cotile riparia (Linn.)}

The sand-martin is generally the first of the swallow family to arrive. Mr. J. King has observed it at Langford as early as 26 March 1897, and on 3 April 1899 ten or more came under my observation flying around Southill Pool. Departure takes place towards the end of September, although many may leave at a much earlier date. By far the largest breeding station within the county is the colony at Sandy, where they nest in the sandy cutting close to the railway station in numbers roughly estimated at a thousand pairs, and perhaps this is considerably below the correct figure. Two white sand-martins were killed by $\mathrm{Mr}$. J. Cole at Haynes many years ago ; one is in Mr. T. Cane's possession, and the other retained by Mr. Cole himself.

\section{Greenfinch. Ligurinus chloris (Linn.) Locally, Green Linnet.}

A resident species which, with the exception of the common sparrow, considerably outnumbers any of our other species of finches. During the autumn and winter they flock together in considerable numbers in company with many other species, but particularly with the common sparrow, and remain gregarious, often as late as April, some time after other species have left them. For sleeping accommodation the flights of greenfinches resort to certain of the numerous tall hedgerows so common in some of our districts, where they congregate in hundreds towards the evening. This they continue to do so long as the leaves remain to afford them sufficient shelter; when these fail they resort to evergreens.

52. Hawfinch. Coccothraustes vulgaris, Pallas.

This bird has probably increased in num- 


\section{A HISTORY OF}

bers of late years. Nowadays in any locality in our county, whenever carefully sought for, it will undoubtedly be found. At Southill I cannot call to mind ever visiting the park without observing this bird more or less freely, and in at least five instances have found its nest also. Mr. A. Covington also informs me that in 1893 he had three nests, each containing six eggs, brought to his notice, all taken from an orchard in the vicinity of that park. Mr. J. King speaks of them as fairly plentiful at Southill previous to 1844 . In Bromham Park four nests were found, one of which, on 2 I May I 893, contained six young. At Flitwick, Ampthill, Luton Hoo, Silsoe, Great Barford, Chicksands Priory, Woburn and Turvey it breeds also, and I have observed it in numerous other localities.

\section{Goldfinch. Carduelis elegans, Stephens.}

Before the passing of the Wild Birds Protection Acts of 1880 and I $88 \mathrm{I}$ the goldfinch, owing to the constant persecution of birdcatchers, was fast verging on extinction. Now its numbers seem again rapidly on the increase. In the cottage gardens and orchards, particularly around the neighbourhood of Bromham and also at Colmworth I have found it of late years quite commonly. But at present in many other districts where it was once common it does not seem as yet to have re-established itself.

\section{Siskin. Carduelis spinus (Linn.)}

An irregular winter migrant. Its numbers vary considerably and its occurrence is not frequent. Their favourite haunts with us are larch and alder trees, where they are likely to be found in numbers. ${ }^{1}$ A flock of 70 or 80 siskins was feeding on the larches in Rowney Warren on I April 1902.

55. House-Sparrow. Passer domesticus (Linn.)

When corn was considerably more valuable than in present years, 'sparrow clubs' existed to keep this bird as much as possible in check. In certain parts of our county many of the country people used to term this bird the ' theck sparrow,' or, to be more literal, ' thatch sparrow,' deriving the prefix from the serious damage done to thatched buildings, in which they so freely made holes for nesting purposes. Now that corn is of less consideration, thatched dwellings far less numerous, and sparrow clubs few and far between, sparrows

1 The reported nesting of the siskin 'in Bedfordshire' (Zoologist, I 880) is an error. It should have been reported as ' in Buckinghamshire.'

\section{BEDFORDSHIRE}

have undoubtedly increased, and are more often than not left to their depredations.

\section{Tree-Sparrow. Passer montanus (Linn.)}

An abundant resident, gregarious, but with a decided preference for its own species. Probably its unobtrusive habits and its similarity in plumage to the house-sparrow cause it to be oyerlooked by the casual observer. For nesting, usually holes in trees, in the vicinity of water, are chosen, more particularly in the pollard willows, which are so common along all our streams. I have found a nest in the thatch of outbuildings; in another instance two nests were placed in some drain pipes built into a wall alongside Cople Brook, and, again, a nest containing the very unusual number of seven eggs I took out of one of the wooden bridges spanning the New Cut at Newnham. Occasionally it has been found building inside old magpies' nests.

\section{Chaffinch. Fringilla caelebs, Linn.}

A very familiar species and generally distributed; gregarious with numerous other birds throughout the greater part of the year. When flights of the brambling are observed it will be noticed that the company of the chaffinch seems almost indispensable to them. Pied, buff coloured and albino specimens have occasionally been obtained.

58. Brambling. Fringilla montifringilla, Linn.

One of our migratory finches, occurring only during the winter months. Its numbers greatly vary according to the severity of the weather. In some winters great numbers are seen in Woburn Park, which they frequent to feed upon the beech mast there. Mr. J. King has observed them in flocks feeding under the beech trees in Southill Park. My father has also seen this bird in great numbers at Muggerhanger, and I have met with them very commonly at Chicksands Park. In favourable seasons, from November to the end of February or early March, the brambling is taken very freely, occasionally in hundreds, by the bird-catchers in the southern portion of the county, mixed with the flights of chaffinches, linnets, greenfinches, and other birds. Mr. A. Covington has informed me that he once had over forty of these birds sent to him, which had been killed at one shot when about to roost in some evergreens.

59. Linnet. Linota cannabina (Linn.) Locally, Brown Linnet, Red Linnet.

A widely distributed resident. From information obtained from bird-catchers I learn that they must at certain times become very 


\section{BIRDS}

numerous during their migratory movements. As many as twenty dozen have been taken by one pair of nets in a morning on the Dunstable downs. The greatest number of birds is taken during sleety weather. They tell me that when one man works the nets and another drives the flocks of birds in the required direction as many as fifty dozen birds of various kinds have been taken by two men working two pairs of nets. For the linnet decoy or call-bird a mule goldfinch-canary trained with the linnet's note is preferred. White, buff and pied varieties have often been taken.

\section{Mealy Redpoll. Linota linaria (Linn.)}

There is little reason to doubt the occurrence of this arctic form of our commoner species within the county during some winters. At present the only information I have been able to gather was given to me by a birdcatcher living at Clifton, who, to my knowledge, is a very trustworthy man. He said the common redpoll was particularly common in 1894 , frequenting the numerous alder trees that grow along the sides of the Ivel, between Chicksands and Stanford, where during the autumn of that year he secured within a few hours one morning no less than fifty-four of the commoner species. It was during the same winter when redpolls were exceptionally numerous that he caught two mealy redpolls along with others from the same locality. Four or five altogether have been taken by him from the same district.

61. Lesser Redpoll. Linota rufescens (Vieillot)

The lesser redpoll is a well known winter migrant, occurring generally in small fights of a dozen or more. As a nesting species I am inclined to think that it is becoming more common, for previous to the year I 894 I have only been able to obtain information respecting one instance of its nesting. This was a nest found by Mr. King at Clifton about 1870, which contained young. During 1894 Mr. King kindly forwarded me two nests with eggs, both of which he had found in the neighbourhood between Langford and Biggleswade. Since then to my personal knowledge one pair at least has continued to nest in the same locality. Mr. Crossman also sent me word that he had found a nest containing six eggs of this species on 10 June 1899 in the old ballast hole along the railway between Bedford and Cardington; on the same day another nest with five eggs was found by a lad. Both of these nests were built in willow trees. In July I 898, I saw a pair of old birds with young between Shefford and Clifton, and

I in 1903 two pairs nesting near Southill Lake. A white variety of this species was taken near Luton in 1894 .

\section{Twite. Linota flavirostris (Linn.)}

A winter migrant, occurring more particularly during the autumn. Throughout the county generally a few whilst accompanying the flights of linnets seem to be taken by the bird-catchers every year, and in the neighbourhood of the chalk hills in the south of the county it is I believe a fairly common bird.

63. Bullfinch. Pyrrbula europaca, Vieillot.

Fairly common; in the winter migratory arrivals seem to add to the numbers of our resident birds, and it is then this bird becomes more conspicuous, as it can be seen haunting the wayside hedgerows, feeding upon the dock and various other seeds and hedge fruit, with a particular weakness for the berries of the privet. Unlike any of the other finches, seldom more than a pair, or at the most a small party of four or five, will be found together.

64. Crossbill. Loxia curvirostra, Linn.

Flights of the common crossbill varying in numbers may I think be considered now of regular winter occurrence, but owing to their quiet and inconspicuous habits numbers of the birds might frequent a locality for perhaps many years without coming under observation. And I do not think their numbers vary at all with the severity of the weather, for in several of the past mild winters they have been as numerous as in any other years. In their regular haunts, as for instance the fir plantations of Ampthill, Woburn, Southill, Rowney Warren and Sandy, records of their occurrence are far too numerous for me to give in detail; sometimes they have been noticed in small parties, and at other times in much larger numbers. A flight observed at Woburn 23 October 1897 contained upwards of fifty birds, and in the winter $1898-9$ at Rowney Warren I understand they were very numerous. ${ }^{1}$

\section{Two-barred Crossbill. Loxia bifasciata (Brehm)}

A flock of about twenty of these birds was found haunting one of the fir plantations at Ampthill on 3 January 1890 , from which five were secured with the aid of catapults;

1 The nesting of this species in our county as recorded in Science Gossip, 1868 , is incorrect; both nest and eggs have since come into my possession and are certainly proved not to be of this species. 


\section{A HISTORY OF BEDFORDSHIRE}

one of them however afterwards escaped. During the same winter this bird had been notified from several other counties, indicating that a considerable number must have arrived as early as the previous autumn.

66. Corn-Bunting. Emberiza miliaria, Linn. Locally, Bunting Lark.

Resident and a partial migrant. In the enclosed and wooded districts this bird is seldom observed. The more open lands of the eastern portion of the county offer it far greater attractions, particularly the neighbourhood of Wilden, the Eastcotts, and the cultivated lands generally bordering the Ouse and Ivel. Still more frequently will its monotonous song be heard in the vicinity of the chalk hill range in the south of the county, where around Totternhoe in particular I have found it remarkably abundant. In proportion to its numbers I do not think any bird is more subject to pied variation.

67. Yellow Hammer. Emberiza citrinella, Linn.

A very common resident and generally distributed.

\section{Cirl Bunting. Emberiza cirlus, Linn.}

The distribution of the cirl bunting in Bedfordshire has yet to be more fully investigated. In December I 869 Mr. A. L. Jessopp found this bird in some numbers at Clapham Park, and he secured altogether ten males and one female. The males numbered about thirty, and were associated with some reedbuntings; the female birds, which kept in a separate flock, were only about six in all, and were very difficult to get near. 'I think there is little doubt,' adds Mr. Jessopp, ' that from what $I$ was able to learn at the time that the cirl bunting nested in that locality the previous year.' Mr. A. Covington adds that a few of these birds seem to visit us occasionally in the winter. In addition to those above mentioned, all of which passed through his hands, another, a male, was brought to him which had been killed at Oakley in January 1870 , and in the winter following he had two more from Bromham. Another was obtained at Wilden (Zoologist, 1871). Mr. A. F. Crossman observed one in 1889 between Clapham and Oakley. There is another specimen I am told in the headkeeper's possession at Woburn which was killed from a small party in the park. Mr. Cane of Luton tells me that in his forty years' experience as a taxidermist only three have passed through his hands. G. Smith has in twenty years' experience of bird- catching only taken two specimens, both of which were in the neighbourhood of Limbury about 1887 . The only instance I can as yet obtain of this bird having been found nesting is from information kindly sent to me by $\mathrm{Mr}$. W. Ruskin Butterfield. 'On the morning of 25 May I 896,' he writes, 'whilst in the company of my friend Mr. A. Page Page, we observed in the parish of Cardington a male cirl bunting, and with the aid of a pair of field-glasses we watched it some considerable time. Later in the day we returned to the same place, and I had the satisfaction of flushing the female from off her nest and four eggs; we watched her and saw her joined by the male.'

69.' Reed-Bunting. Emberiza schoeniclus, Linn.

Locally, Reed-Sparrow, Black-headed Bunting.

Fairly common. Throughout the whole course of the Ouse, Ivel and other smaller streams, pools, disused ballast holes and marshy patches of ground, particularly Flitwick Moor, this bird will generally be found, nesting always in the vicinity. In the winter time it is frequently forced to seek sustenance further afield, and can then be met with on stubble fields and even busy amongst the hedges along the roadside, sometimes in small parties. Several buff-coloured specimens have been obtained.

70. Snow-Bunting. Plectrophenax nivalis (Linn.)

An irregular winter visitant, always restricted in its migratory movements to the southern portion of the county, where, in the neighbourhood of the chalk hills, such as around Barton, Luton and Dunstable, numbers are said to be taken. G. Smith, who has had considerable experience as a birdcatcher in these localities, speaks of this bird as generally appearing in December, when, during a continued spell of exceptionally severe weather, droves of a hundred or more have been known to occur. Writing to me in the winters of $1893-4$ and $1894-5$ he stated that this bird had occurred commonly, some very good specimens being caught. In other parts of the county it appears as a very scarce straggler. Of the few that have been brought under my notice one was taken at Clapham Park, and another at Willington, about 1870 ; both are now in my brother's possession; a third at Clapham in

1 The record of the Lapland bunting (Calcarius lapponicus) having occurred in Bedfordshire, in the Field, 3 I January 1874 , was an error in identification of the species. 


\section{BIRDS}

January I 894 ; a fourth, shot I believe at Biddenham, was set up for the late Mr. C. Howard. Mr. A. Covington says that one or more of these buntings used to be brought in every winter. He saw three together in company with two stonechats near Cardington Cross in March 1897, and again, two at Putnoe in February 1899. On 7 November 1900 a male was obtained at Keysoe and another at Ampthill in November 1903.

\section{Starling. Sturnus vulgaris, Linn.}

An exceedingly numerous resident though a partial migrant, and it is probable that large numbers are autumn immigrants and winter with us.

72. Rose-coloured Pastor. Pastor roseus (Linn.)

The only instance of this rare migratory straggler to our islands occurring in Bedfordshire was brought to my notice by the late Mr. Cane, taxidermist of Luton, who stated that a young bird of the year was killed at Barton-in-the-Clay in August $1855^{1}$

\section{Jay. Garrulus glandarius (Linn.) Locally, Jay-pie.}

In all the larger woodlands this bird becomes very common if game preserving is not carried out too strictly, but even then it seems capable of withstanding all the devices used for its total extermination.

\section{Magpie. Pica rustica (Scopoli)}

In years past, before game preserving became so extensive as at present, the magpie was common generally, but nowadays it has become far more local. In the poorer agricultural districts, where no quantity of game can be supported, we now find this bird most abundant; in such districts as around Stagsden and Turvey and even more so in the neighbourhood of Bolnhurst and Thurleigh it is very common. Throughout the whole of the northern portion of the county it occurs more or less plentifully, whereas in the southern half it is rarely met with, and in many parishes is unknown. A variety, with the usual black portion of the plumage considerably pied with white, was killed many years ago at Sherhatch Wood.

\section{Jackdaw. Corvus monedula, Linn.}

Although a fairly common resident, it is by no means so abundant a bird with us as in other parts of the midlands. In many of the parks, where the holes in old timber offer suitable accommodation, such as at Woburn, Ampthill, Silsoe, Turvey and Bromham, it

\section{See also the Naturalist, I 856.}

nests very freely. Formerly it nested in many of the church towers in the county, but at the present day I am only aware of one at Marston Morteyne church.

\section{Raven. Corvus corax, Linn.}

Until the middle of the nineteenth century the raven must have been fairly well known as a resident bird within the county, in all probability continuing to nest regularly whereever it had done so from time immemorial. As Davis, on the authority of Mr. H. Thompson in his History of Luton and Neigbbourbood, published in 1855 , refers to the raven as common, we can at least infer that one or more pairs had nested regularly up to that date in that particular district. At Haynes Park in 1849 a pair still had their home. A former keeper there, named Franklin, told me these birds each year occupied a group of tall elms, which were known as the 'Raven tree clump.' As soon as the young were strong upon the wing the whole family departed from that immediate locality, and were not seen again till the old pair returned the following spring. Occasionally one of the pair would be shot, but the remaining bird, after a lapse of a few days' absence, always returned with a fresh mate, whence no one knew. Although his father, who was at that time head-keeper, frequently gave orders for the destruction of these birds, on account of the damage caused by them amongst the young poultry and game, no one cared to carry out his orders ; as for himself, he added, he would sooner have lost his situation than have killed one. They continued breeding there up to the time he left that neighbourhood. "In Silsoe Park, a pair built every year in the large elm trees that stood on Cain Hill ; the young ones were frequently robbed and taken up to London by some of the servants and sold. This pair still continued nesting there in the year in which the present house was being rebuilt' (J. S. Wright). 'At Southhill Park, some fifty years ago, when I was working on that estate, every year a pair nested in one of the large oaks, standing between the house and the lake. They still continued nesting there when I left that village in 1844 ' (J. King). The last nesting haunt of the raven in the county, as far as I am able to ascertain, was in Woburn Park. 'To my knowledge a pair nested in Woburn Park from 1848 to 1871 , in which year I left there. For twenty years they built in what was known as " the big beech," a tree unique for its perfectly smooth bole, measuring in height some 54 feet to where the branches all grew out together in a 


\section{A HISTORY OF}

crown; it was within the huge cup thus formed that the nest was placed. On 23 March 1852 I was drawn up to the nest by means of a rope, and it contained three young, which were secured. The old ones came very close but did not attack me in any way. The young were taken home, which would be about a mile away, the parents, nevertheless, paying them frequent visits. The youngsters were allowed a fair amount of freedom, after their wings had been clipped, and on more than one occasion the old ones came circling down upon them from a great height and attacked them fiercely, and when we went to the rescue seemed loath to retreat. One year the hen bird was shot whilst nesting, but the male by the following day had brought another mate home, whence I know not, as I never knew of another pair in the county, although I understood a pair nested in Beechwood Park, near Hemel Hempsted. The same year (that would be in 1856 ) they built in another beech tree hard by, which was much higher and placed in a very conspicuous position. I managed to climb up to it and took the eggs. They added to the nest and occupied it a second year, and again the nest was robbed, when they went back to the old nest. How many times they were successful in bringing forth their brood I cannot say, but $I$ am inclined to think it was not many, and considering how often the nest was harried and the old ones shot at (not always with the intention of killing them) it is wonderful how they stuck to the place. The ravens did no particular damage that $I$ am aware of' (C. F. Woods). 'An uncle of mine, long since deceased, often took the eggs and young of ravens at Bolnhurst and Keysoe Wood; he sometimes saw several in company together feeding on the carcase of a sheep or lamb; frequently a crow or two would be in their company, but had to remain at a respectful distance until their superiors had gorged sufficiently. And from information I have been able to gather, the raven probably bred at Thurleigh also, in fact there is little doubt that sixty or seventy years ago it was a very well known bird with us' (A. Covington). 'Used to breed in the fir trees at Allington Hill, near Little Barford, for twenty years or more, previous to 1865 , or thereabouts' (P. Addington).

\section{Carrion-Crow. Corvus corone, Linn.}

This species is fast disappearing. Fifty years ago it must have been a common bird with us, distributed generally throughout the county. During 1899, in which I gave the distribution of this bird special attention, a

\section{BEDFORDSHIRE}

very liberal census would not exceed more than twenty pairs nesting within the county. But a few years since it bred regularly in the plantations around Clapham, Ravensden and 'Thurleigh ; at Bromham in Salem's Thrift; at Stagsden, in Hanger's Wood ; in Odell and Carlton Woods, and at Elstow and Harrowden; also on the island in the Biddenham backwaters, as well as the plantation known as Doctor's Corner or Devil's Spinney near the Clapham Viaduct; but such localities know this bird no more. Its only remaining haunts of which $I \mathrm{am}$ aware are in the neighbourhoods of 'Turvey, Stagsden, Stevington, Bromham, Rowney Warren, Clophill, Wootton, Milton Bryant, Podington, Colmworth, Pavenham and Leighton Buzzard.

\section{Hooded Crow. Corvus cornix, Linn. Locally, Royston Crow.}

Although a fairly common bird throughout our county, it confines itself more particularly to the river valleys, especially where the country is low-lying and open. One seldom fails to notice this bird along the river below Bedford during the winter in such localities as Fenlake and Goldington, and a very favourite haunt is the sewage farm at Newnham, where I have observed at times several feeding together. On the Ivel too it is of regular occurrence, as many as four or five having come under my notice in a walk from Shefford to Langford. It is usually alone, but, in many instances, its mate will be noticed not very far away. This bird reaches us generally in October and departs again in March. The specimens I have been able to examine in the flesh vary considerably in size.

\section{Rook. Corvus frugilegus, Linn.}

The rook, so frequently mis-named the crow, is common in all parts of the county. Rookeries are generally observed in the vicinity of houses, and the birds show a distinct preference for the mansion to the humble cottage. There are however a few instances where they seem to be more independent, discarding the habitation of man altogether, and locating their nests in the trees upon some of the quiet lying islands in the upper reaches of the river. On the other hand, one may count a dozen or more sites that are occupied for nesting purposes within the town of Bedford itself. Pied variations are not infrequent; cream-coloured and several albinos have also been obtained.

\section{8o. Sky-Lark. Alauda arvensis, Linn.}

This bird is probably nowhere better known 


\section{BIRDS}

or more numerous than in Bedfordshire. The Dunstable downs have long been noted for the number of sky-larks caught there. It often passes over our county in considerable flights on migration. Buff, pied, white and other varieties have been frequently met with.

\section{Wood-Lark. Alauda arborea, Linn.}

The only specimen recorded was shot at Oakley in 1867 , and passed through the hands of Mr. A. Covington.

\section{Swift. Cypselus apus (Linn.) Locally, Devilin.}

A common summer migrant. It nests in the town of Bedford, but to a very great extent is restricted to the vicinity of the older portion in the neighbourhood of St. Mary's and St. John's. It arrives during the first few days of May and departs at the end of August.

\section{Nightjar. Caprimulgus europaus, Linn.}

Locally, Goatsucker, Night Hawk, Fern Owl.

A summer migrant decreasing numerically in most of its present haunts. It is known to nest at Turvey, and has been observed from time to time in Odell and Clapham Woods. In many of the fir woods around Leighton Buzzard it is still fairly common, and at Aspley Woods several pairs have come under my notice ; around Ampthill, Maulden and Clophill several pairs may still be found, but at Flitwick, Major Brooks says it is now rare. At Warden, Southill and Rowney Warrens it is far less plentiful than formerly; on the latter in recent years I have never found more than two pairs of birds in any one day; whereas as recently as ten years ago $\mathrm{Mr}$. J. King has found as many as five or six nests there in a day's ramble. The fir plantations at Sandy, especially Sandy Warren, are the favourite haunts of this bird, where owing to the careful protection given to wild life generally by Viscount Peel they are likely long to remain. When upon the southward migration it may occasionally be flushed from varied localities and situations.

\section{Wryneck. Iÿnx torquilla, Linn. Locally, Cuckoo's Mate.}

Although the wryneck may still be heard more or less frequently about the county, it is unfortunately nowadays decreasing in numbers. It is one of our earliest summer migrants, not arriving as is generally supposed with the cuckoo-whence its local namebut often fully a fortnight earlier.
85. Green Woodpecker. Gecinus viridis (Linn.)

Locally, Whetile, Laughing Lady.

A far commoner bird with us than either of the other two species of woodpeckers, and generally distributed throughout the county, particularly in the vicinity of old timber. In such localities as Bromham, Stagsden, Turvey, Odell, Colworth, Ampthill, Flitwick, Woburn, Southill, Warden, Renhold, Muggerhanger, Tempsford, Roxton and Bushmead, I have notes of it nesting rather commonly. Mr. A. Covington remarks that this species is far commoner now than in former years.

86. Great Spotted Woodpecker. Dendrocopus major (Linn.)

At Rowney Warren, Sandy, Clophill and in Ampthill and Turvey Parks, I have found this species nesting, in the latter locality the excavation used being certainly of several years' standing. Mr. J. King used to find its eggs rather frequently at Southill and Warden, and the bird is still plentiful there. It nests also at Woburn Park and probably does so at Bromham and Bushmead Parks; at Henlow Park it is also said to be a resident species. Professor Alfred Newton occasionally saw this woodpecker around Everton when he resided there, $1847-8$. Davis mentioned it as a common species around Luton. It is more numerous during the winter months, and judging from the numbers received by the local taxidermist, our resident birds must, especially in some years, be considerably added to by migratory sojourners. A variety considerably pied with grey has been obtained.

\section{Lesser Spotted Woodpecker. Dendrocopus minor (Linn.)}

This species is about as numerous as the last named, but being a much smaller bird is more likely to escape general observation, though probably it does not roam the country as freely as the former species during the winter. At least one pair nest regularly in Turvey and Bromham Parks. I have also found it during the nesting season at Roxton Spinneys and at Kempston; I believe this bird is a resident also at Henlow Grange and Woburn. Mr. J. King adds Warden and Southhill, where in the latter park years ago he found two nests, both of which contained young.

\section{Kingfisher. Alcedo ispida, Linn.}

Notwithstanding its too numerous persecutors this bird is still fairly common except perhaps in a few localities. The kingfisher is early in its nesting, generally being found 


\section{A HISTORY OF BEDFORDSHIRE}

with eggs early in April. My friend, Mr. W. Knight, informed me of a pair having a nest containing six eggs as early as $28 \mathrm{March}$, and $I$ have known them with young still in the nest as late as 6 August.

\section{Hoopoe. Upupa epops, Linn.}

One was shot at Thurleigh by a Mr. King many years ago (A. Covington), another at Woburn Park about 1868, and one in the writer's possession was obtained by $\mathrm{Mr}$. J. Cole at Haynes in the autumn of 1876 . A fourth was shot 5 October 1890 by a keeper to one of the shooting tenants of Lord St. John at Melchbourne, and is now in his lordship's possession (see also the Field, I 890). Another was killed between Luton and Dunstable about I 885, and passed through $\mathrm{Mr}$. T. Cane's hands.

\section{Cuckoo. Cuculus canorus, Linn.}

A common summer migrant, arriving generally about the middle of April, and leaving Juring the first week in July ; immature birds remain with us until September. I have notes of a cuckoo's egg being found at Langford as early as 8 May, and of a young one, several days old, as early as 18 May. In addition to the usual foster parents there are records of the nests of the greenfinch, chaffinch, yellow hammer, willow warbler, chiffchaff and whinchat being chosen.

\section{White or Barn Owl. Strix fammea, Linn.}

Still fairly abundant in old timbered parks, such as Ampthill, Woburn and Bromham, where several pairs may be found nesting. In former years when farming was a profitable industry, and barns in which to store grain were more needed than at present, an 'owl hole' would frequently be left in the barn at the top corner of the gable end to allow this bird an entrance, so that the rats and mice might be kept in check. A pied variety with the tail and the whole of the wing feathers pure white was shot at Harrold in January I 894 .

\section{Long-eared Owl. Asio otus (Linn.)}

This species still nests frequently in the fir woods and spruce plantations between Sandy and Potton; during 1900 at least three pairs nested at Rowney Warren and two pairs in the small plantations at Sharpenhoe; a pair nest regularly in one of the fir plantations at Maulden. It formerly bred in Southill Warren and may still do so, as also in Warden Warren and the fir woods around Ampt- hill and Woburn. Judging from the thousands of pellets of this species that I have been able to examine from those localities, there is little doubt that this owl is comparatively harmless to game preserving and well deserving of protection, as in no single instance have I ever detected any remains of the young of game; mice, voles and various species of finches comprising nearly their entire prey.

93. Short-eared Owl. Asio accipitrinus (Pallas)

A regular winter visitor, but as a rule in very limited numbers, and solitary birds are usually found. Mr. C. T. Lindsell whilst partridge-driving at Cople in November I 894 observed nine or ten together ; five were seen some years ago at Biddenham sitting in some sedgey-grass ; four were killed in one day at Woburn, and I understand that it occurs frequently on Flitwick Moor. Mr. J. King refers to its having been killed around Biggleswade. The earliest migrant noted was one killed 17 October 1878 , and the latest, one shot 3 April 1895 , as it rose out of the flags alongside the river.

\section{Tawny Owl. Syrnium aluco (Linn.)}

By no means a common species with us and rarer than formerly. I have known of several nests at Bromham and Southill, and in recent years have found its eggs also at Wilden. At Turvey it nests regularly, and it may still continue to do so at Woburn, Ampthill, Haynes, Odell, Tempsford and Warden ; in the last-named locality Mr. J. King once found a nest containing the unusual number of six eggs.

\section{Little Owl. Atbene noctua (Scopoli)}

For many years the late Lord Lilford endeavoured to establish this species at Oundle Park in Northamptonshire and eventually succeeded in so doing, a nest and eggs being found there in 1889 . No doubt the numbers of this species that have been shot in recent years have originated from this locality. Mr. J. Wilkerson mentioned this bird nesting regularly of late years in the neighbourhood of Wyboston, and during 1900 a nest containing four or five eggs from which the young were reared was found at Great Barford. A female killed near Southill on 22 May contained eggs, so was also probably nesting at the time. A nest from which two young were taken was found at Harlington in 1902 and a pair were nesting near Ampthill in 1903 (Field). In 1862 one was caught at Woburn and was kept alive by $\mathrm{Mr}$. C. F. Woods for three months, but it eventually escaped. 


\section{BIRDS}

96. Marsh-Harrier. Circus aruginosus (Linn.)

The late Mr. T. Cane informed me that he had observed this species about 1865 over "The Bogs" close to Luton, which was then a marshy swamp extending about a mile. One in his collection was killed there about 1870. Mr. A. Covington has also heard of this harrier being shot along the Ouse years ago, but has never seen a local specimen.

\section{Hen-Harrier. Circus cyaneus (Linn.)}

Early in the last century this species evidently still nested in Bedfordshire. Mr. J. King can call to mind information given to him some fifty years ago by an old man, who remembered both the hen-harrier and the kite in this county. Mr. A. Covington's uncle, who lived at Keysoe, knew this bird well ; but it was not so common in that particular neighbourhood. Again an old farmer who lived at Colmworth used to speak of it as common in that parish in his boyhood days; he had found its eggs on two or three occasions, and described their colour and the position of its nest. More recent records of its wanderings into the county are as follows : a female shot at Sutton Park in November 1865; another in the possession of Dr. Sprigge, which was shot between Roxton and Tempsford; one in similar plumage in the possession of $\mathrm{J}$. Clark, head keeper at Woburn, which I have examined, trapped at Potsgrove about August I892; and another shot at Ickwell about 1880 .

\section{Buzzard. Buteo vulgaris, Leach.}

The early history of this bird in the county is generally associated with that of the kite, and where particulars are obtained of the one formerly nesting so probably will records also be found of the other. The most recent nesting of this species mentioned by Mr. A. Covington was at Putnoe Wood, where a hen bird was shot upon the nest by his informant; in another instance, where a nest was situated in a clump of trees near Knight's Lane, Oakley, the hen bird was shot whilst leaving the nest and her three eggs. Occurrences of this bird with us in later years are by no means rare, as it is still common in many localities of Wales and Scotland, whence it may occasionally wander to the midland counties.

\section{Rough-legged Buzzard. Buteo lagopus (J. F. Gmelin)}

The inclusion of this species rests upon three occurrences only. One was shot at Luton in 1839 (Beds Mercury), another which I have recently examined was shot by Mr. P.
Addington near Colmworth Wood in November 1892 , and the third, a male, was trapped by $\mathrm{Mr}$. H. Gates at Sundon early in December 1894. It had been seen about for some two months previously and was caught while feeding on a rabbit.

\section{[Golden Eagle. Aquila chrysaittus (Linn.)}

The Rev. F. O. Morris states (Brit. Birds, vol. i. pt. i. ed. 4) that two of this species were seen in the neighbourhood of the park of Woburn Abbey, Beds, in the winter of I 820, and one of them was shot by Thomas Judge, the Duke of Bedford's gamekeeper; another occurred in the same neighbourhood late in the autumn of 1844 . I have failed to trace any particulars respecting either of these records, as no such specimens are preserved at the abbey at the present day, nor is anything known of them.]

\section{White-tailed Eagle. Haliaëtus albicilla (Linn.)}

The following particulars of the occurrence of this eagle in the county are taken from the Field: 'On 15 March 1863 one was observed in the parish of Cardington. It was shot at, and its wing broken; it was found to be blind in one eye, the cornea of the left eye being quite opaque. It was kept alive for a few days, eating portions of a lamb which were put into its mouth. When it was first taken the plumage appeared perfect, except the tail feathers, the ends of which were rather worn. The tail feathers were greyish in colour. It was added to the collection of Mr. Barlow of Cambridge' (Wm. Thurnall, Bedford). What eventually became of the specimen I am unable to add, as the collection was dispersed by auction some twenty-five years ago.

\section{I. Sparrow-Hawk. Accipiter nisus (Linn.)}

Fairly abundant, but undoubtedly a gradually decreasing species. It is very conservative in its nesting haunts, returning year after year to the same wood or spinney regardless of the constant persecution it may receive. When one of a pair is killed the other soon finds another mate, and they will take up the same quarters as before; if both are killed, the locality will be selected the following year by another pair. The more wooded parts of the county are naturally their favourite breeding haunts, and in such localities as Stagsden, Turvey, Bromham, Bolnhurst, Thurleigh, and the range of woods from Southill to Clophill, it has been known to nest regularly for many years. 


\section{A HISTORY OF BEDFORDSHIRE}

102. Kite. Milvus ictinus, Savigny.

Evidently by no means a rare nesting species in the county during the early years of the past century, but it must have been exterminated soon afterwards, for no recent record can be traced of this bird even as a visitant with us. The only two instances that can be given are one shot at Bromham Park some time in the 'thirties,' and another some few years afterwards in Cleat Lane near Clapham Wood. An old gamekeeper named Goodliff assured me that in his early days (about 1813 ) both the kite and buzzard built fairly commonly in the woods at Keysoe and Bushmead, and he had often taken the eggs of both species. Another keeper said it formerly nested in the woods around Haynes. Mr. J. King from another old informant learned that it once nested in a row of elm trees between Langford and Holme, and he says his father could remember this bird occasionally being seen at Southill. Mr. A. Covington reports it as formerly nesting around Bolnhurst and Keysoe, where his uncle knew it well and had taken its eggs, and also reared young birds from the nest. A pair built a nest in Silsoe Woods, but both were destroyed.

103. Honey-Buzzard. Pernis apivorus (Linn.)

A rare summer visitant; it probably nested in limited numbers in former years. About I852 a honey-buzzard was caught in a vermin trap in the woods at Haynes Park, and is now stuffed and in possession of the owner of the property (Naturalist, B. R. Morris, 1855). In June $187 \mathrm{I}$ a female was taken at Silsoe, and eggs as large as sloes were found in the ovaries. Its crop contained grasshoppers and other insects (Zoologist). A very dark female in the writer's possession was shot at Warden Warren 27 May i874. On 2 October 1883 one was shot at Harrold and passed through the hands of Mr. A. Covington. A female that I recently examined was obtained at Potton Wood 8 June rgor.

104. Peregrine Falcon. Falco peregrinus, Tunstall.

This bird is a regular winter visitor to our county, occurring most frequently from November till February, and in single instances only as early as August and as late as April. Seldom a year passes without reports of one or more being seen or killed. Most examples are in immature plumage.

105. Hobby. Falco subbuteo, Linn.

This bird formerly nested in Keysoe Wood; the last pair that frequented Bromham Park were shot from the nest by the keeper in
June I 865 . About 1880 a nest of young was taken at Colmworth, and passed into the hands of Mr. Bryant, poulterer, Bedford. According to Mr. P. Addington it used to nest regularly in Colmworth Wood, utilizing the crows' old nests. A former keeper at Odell Wood shot three young hobbies just after leaving their nest, one of which I have seen; and I was told by Gell, the present gamekeeper, that about I 883 , when first he came to Odell Woods, he set traps in the various crows' nests, and once caught a hobby in a small wood by the road; during the afternoon of the same day he shot another close by. He also informed me that his father had two specimens set up in a case, which were shot near Knotting Wood. The most recent records of the hobby nesting in Bedfordshire occurred in the woods adjacent to Turvey Park on the Stagsden side. In I 890 Cowley, a working man with a good knowledge of local birds, took four eggs from a wood close to Turvey Park; in I 891 Mr. D. Campbell took three, and on 31 May 1892 he and Mr. A. F. Crossman took four more from a plantation in the same locality; in each case the nest of the carrion crow had been adopted. The female of a pair in the woods at Turvey was killed in I 897 . Mr. J. King mentions that the last instance of the hobby near Langford was in 1894 , and gives the following records in that neighbourhood: one shot on 16 September 1853 , another a week later; one on 18 May 1854, and one on 22 September 1891 . In 1901 one was trapped in a wood near Podington.

106. Merlin. Falco asalon, Tunstall.

A scarce winter visitant, and of far more frequent occurrence years ago, when several might have been observed at the local taxidermist's shop. Now a year or so may pass without even one being recorded. Immature birds are far commoner than adults, and occur throughout the winter months. The parish of Elstow seems always to have been the principal locality in which this bird has been obtained. Mr. A. Covington states that about twenty-five years ago he received as many as three in one week from that place. The following are some of the most recent occurrences: At Elstow in 1889 , on 30 January 1897 , and in September 1898 , also in November I9OI and January 1902; at Renhold close to the river about 1888 ; at Harrowden in April 1890 and on Io November 1891; at Felmersham on 24 February 1894 ; at Newnham on the sewage farm in October I 894 ; at Cardington on 29 October 1897 and at Tingrith about 1898 . 


\section{BIRDS}

107. Kestrel. Falco tinnunculus, Linn.

Common, nesting plentifully, though somewhat locally, even in unpreserved districts. During the winter months it is a partial migrant, as at that time several may be seen together about the meadow lands and especially in the neighbourhood of Goldington and Cardington, whereas in the summer it will rarely be observed. The nests of the magpie, both old and new (if the latter have already been robbed of the rightful owner's eggs), are usually adopted, and also crows' nests, holes in trees being next in favour. Occasionally the nest of the sparrow-hawk is selected, and in one instance I have found their eggs in the fork of an ivy-covered oaktree.

\section{Osprey. Pandion baliaètus (Linn.)}

An occasional spring and autumn migrant. The earliest recora is one shot at Luton in 1839 (Beds Mercury). One formerly in the possession of Mr. W. King was shot by him in 1852 at the moats in Biggin Spinney, Roxton; another was shot on the Ivel at Blunham by Mr. Triplow in 1877 , both of which have come under my observation. One shot at Turvey in July 1863 is preserved at the Abbey, and another frequented the river between Stevington and Oakley about 1867 for over a fortnight. Davis (History of Luton, ed. 2) refers to one killed in Luton Park about 1844 , and Dr. C. Sprigge saw one near Roxton Bridge about 1894. According to $\mathrm{Mr}$. J. Wilkerson the osprey has occurred twice near Chawston, the last instance being in 1889 . On 18 May 1894 Mr. King and I saw an osprey at the pool in Southill Park. The most recent occurrence is a male shot at Southill 31 August 1900.

109. Cormorant. Pbalacrocorax carbo (Linn.)

A rare straggler inland. Three have come within the knowledge of Mr. A. Covington, but only one, which was shot at Sutton in 1 863 , was received by him in the flesh; one of the others was killed previous to that year on the brick-kiln in one of the brickyards along the road to Clapham. Mr. T. Cane received one to set up which had been shot about 1865 as it sat on the roof of Toddington church. Mr. J. King mentions having seen one about 1875 at Southill Lake, and on 3 May rgor another came under my observation there-it was sitting on the brickwork surrounding the pool island.

I Io. Shag or Green Cormorant. Phalacrocorax graculus (Linn.)

Another rare straggler inland. Mr. J. King mentions an immature bird which was caught in a potato field at Biggleswade on 29 August 1877 , and the following instances are given by Mr. A. Covington: One killed at Biddenham Backwater about 1859; an immature bird received by him about 1868 that had been killed on the river at Kempston; another taken to him alive on 28 August 1 887 -it had been caught by a man at Renhold, who had seen two birds alight on a pond during a very high wind, and by running up was able to catch one, which was apparently exhausted.

\section{I I. Gannet or Solan Goose. Sula bassana} (Linn.)

Very rarely observed. Mr. A. Covington remembers one being caught alive locally many years ago, but he cannot call to mind the name of the place. In February 1895 Mr. J. King saw two gannets at Langford flying over during the first week of that month. They were passing at a good height from south-west to north-east.

\section{Common Heron. Ardea cinerea, Linn.} Locally, Heronshaw, Mollhern.

A common winter visitant, and at times I have seen them in flights of as many as ten together, but no heronry now exists in the county. Until about 1869 they bred in Luton Hoo Park, when by an accident in a high wind some trees were blown down on what is known as 'The Island' and destroyed their nests (Davis, Hist. of Luton, ed. 2, I874). Isolated nests have occasionally occurred. Two were built in the Cowhill rookery at Woburn about 1855 , but being within a stone's throw of the London road they were harried, and the birds did not attempt nesting there again (C. F. Woods). Dr. Sprigge records that a pair nested on a fir tree in the six-acre plantation at Tempsford about 1890. In the Twin Woods at Clapham at least a few pairs nested regularly until about 1850 , or possibly a few years later. A pair attempted nesting about 1880 in the tall poplar trees close to the island in the river between Cardington and Castle Mills, and previous to 1895 another pair nested on the small island in the lake at Southill Park. When I visited this island in May 1899 a nest which the birds had placed there in that year was on the horizontal branch of a tree overhanging the water, but only partly constructed. Either the owners had forsaken it, or they had no intention at the time of completing it. I was assured that they were in no way molested. The only locality in the county where at least two pairs nest regularly, and have done so 


\section{A HISTORY OF BEDFORDSHIRE}

for certainly the last thirteen years, is on Sandy Warren, which is accounted for without doubt by the great interest taken in these birds by Viscount Peel.

I 3. Night-Heron. Nycticorax griseus (Linn.)

In Montague's Ornithological Dictionary, edited by Edward Newman, the following is recorded: "We are informed by Lord Upper Ossary that this species was shot on the borders of the river Ouse in the year 1791, a few miles from Ampthill, and that it is now in his lordship's museum. It is remarkable, too, that the bird was killed in the summer.' There is however no such specimen now in existence at Ampthill House, neither can I gain any additional information relating to the above occurrence. Mr. J. King once saw a bird alight in his meadows at Langford which seemed to him most probably of this species. He got within less than a hundred yards, and distinctly recognized its dark back as it rose.

I 1 . Little Bittern. Ardetta minuta (Linn.)

A female or immature specimen, which was obtained in September 1894 by some youths whilst boating down the river, was shown to me by Mr. G. Pestell ; it had been shot as it sat upon the head of a pollard willow near Castle Mills. Upwards of thirty years ago a case containing two of these birds was sent to Mr. A. Covington for repairs. The owner informed him the birds had been killed in the county many years previously. These were evidently the specimens in the late Mr. T. Cane's possession, of which similar particulars to the above were given.

\section{I . Bittern. Botaurus stellaris (Linn.)}

A visitant in most severe winters. The earliest record I can trace was one shot at Blunham about 1850 , and in January I 856 one is mentioned in the Zoologist as obtained at Lawrence End near Luton. Mr. C. F. Woods mentions one killed at Tingrith Manor 1 858-9, which he saw in the flesh. Since then there have been numerous records of this bird. The spell of sharp weather that was experienced in the winter 1899-1900 brought a remarkable number of bitterns into the British Islands, in several counties numerous records being given, and in Bedfordshire such a 'bittern year' is hardly likely to occur again.

\section{16. American Bittern. Botaurus lentiginosus} (Montagu)

An example of this rare straggler was shot by $\mathrm{Mr}$. Cocking from the brook by the old racecourse at Elstow I 3 November I 886, and is still in his possession. Mr. Covington, in whose hands I saw the bird whilst being set up, informs me that it was a female, and in very good condition; the stomach contained at the time the remains of three small dace and a water shrew.

I 7 . Grey Lag-Goose. Anser cinereus, Meyer.

Probably a regular passing migrant in the spring and autumn, but very seldom alighting ; it may be occasionally observed in winter. From 'The Bogs' near Luton, which are now drained and under cultivation, Mr. T. Cane once saw three grey lag-geese that had been killed at one shot. The first and last of this species that ever came under Mr. Covington's observation as having occurred locally were two that were brought into his shop about 1868 , by a farmer who had killed them from a small flock at Ravensden. During the same winter another goose, evidently of the same species from the description given him at the time, was shot from a small 'gaggle' (probably the same birds) at Biddenham.

\section{8. White-Fronted Goose. Anser albifrons} (Scopoli)

Probably this species need not be considered as rare with us, for although only two instances of its occurrence in the county can be given, the quantities of geese observed during any severe winter might frequently include this particular bird. Mr. A. Covington mentions that a male was killed out of a flock of fourteen at Cople about I 863, and passed through his hands. Another, in the writer's possession was shot from a party of four on the Cardington meadows on 19 December I 90 I.

I 9. Bean-Goose. Anser segetum (J. F. Gmelin)

There seems little doubt that the somewhat frequent information received of 'grey' geese haunting the neighbourhood of our waterways during the more severe winters would generally refer to this particular species, which usually occurs in small ' gaggles' of five or six up to fifteen or twenty in number; at times far larger flocks appear. Mr. P. Addington shot two bean-geese from a flight of seven along the Ouse at Wyboston Corner in January about 1870 , one of which I have examined; one in the possession of $\mathrm{Mr}$. J. King was killed from a small flight at Southill on 10 December $187 \mathrm{I}$, and two were shot from a flock of seven that were on the Biddenham and Kempston meadows 28 December I 883 . 


\section{BIRDS}

120. Bernacle-Goose. Bernicla leucopsis(Bechstein)

A very unfamiliar species with us. An adult male purchased by Mr. Covington about I 885 had been shot near Renhold; it was alone when killed and was in extremely poor condition. Mr. A. F. Crossman records that on 24 December 1890 a flight of eight flew over the river quite close to him near the Britannia Iron Works in Bedford.

\section{21. Brent Goose. Bernicla brenta (Pallas)}

Evidently occurs far more commonly in Bedfordshire than the previous species. On I I February I87 I four were killed at Great Barford by Dr. C. Sprigge from a flight of thirteen. An adult male was obtained by Mr. J. Bennett close to the town of Bedford on 3 December 1877 , and others had been seen the day before at Cardington (see also Zoologist, I 878). Mr. A. Covington mentions two locally obtained specimens and also a flight of forty-seven which he saw near Clapham Wood on 4 October I88I; they were going very slowly at the time and he obtained a good view. A few days later he heard of a black-headed goose being shot in the neighbourhood of Pavenham. Mr. A. F. Crossman observed a solitary brent goose passing over the Clapham road, near the Bedford waterworks, on 10 March 1892 , and several were said to have been seen on the sewage farm 5 November of the following winter. Mr. W. J. Chalk once saw a flock passing over a hedge at the back of the rectory at Wilden, so low as to come within ten yards of him; and Mr. C. F. Woods records occasional winter visitants to Woburn.

122. Whooper Swan. Cygnus musicus, Bechstein.

An occasional visitant, more particularly during severe winters, and nearly always observed passing onwards without alighting. I have seen one in the possession of Mr. J. Cole, which was killed with one or more mute swans at Newmill End near Luton in the winter 1 890-I. Mr. A. Covington is aware of only one instance of its being obtained locally, when one was killed at Milton many years previous to its first coming under his observation in 1865 . Mr. C. F. Woods mentions that in the long frost which set in on Christmas Eve, either in $1862-3$ or $1863-4$, a party of seven, two adults and five birds of the year, came to the Basin and Large Drakelow Pools at Woburn, and remained several weeks, most of them being killed.
123. Bewick's Swan. Cygnus bewicki, Yarrell

A rare winter visitor. Three were procured within a mile of Woburn in the latter end of January 1864 (C. Hervey Smith, Zoologist, I 864). Mr. A. F. Crossman says that two wild swans came under his observation on 29 November I 890 near Cardington Locks, which he considered were of this species. Their note was tong, tong, and as he was able to get within one hundred yards of them, he particularly noticed their small size.

124. Common Sheld-Duck. Tadorna cornuta (S. G. Gmelin)

Occurs with us at rare intervals. In the severe and continued winter, I 894-5, Mr. J. Wilkerson mentions that about twenty were observed along the Ouse in the neighbourhood of Wyboston Corner. One, an odd bird, was killed about February and passed into the possession of Mr. J. Addington, who has also seen this duck in that district, the last time being in February 1900, when two came comparatively near to him while duck-shooting upon the floods. Two together were also seen by Dr. C. Sprigge at Great Barford about I 887 . Mr. A. Covington has preserved two that were killed locally, both adult males, one being obtained at Cardington in 1864 , and the other from Great Barford several years later. $\mathrm{He}$ purchased a case containing two immature sheld-ducks many years ago ; they were simply labelled 'Goldington.'

125. Mallard or Wild Duck. Anas boscas, Linn.

In the winter our home-bred birds are frequently added to considerably by numbers of immigrants, probably continental birds, and when the weather is in any way severe, especially after a north-east wind, duck-shooting along the waterways and at our various lakes may be carried on for a time with fair success. When the Ouse and other streams are in flood, large flights may frequently be observed. In very mild winters even small flights are rarely seen along our rivers. Pied, creamcoloured and white variations have been met with.

126. Gadwall. Anas strepera, Linn.

A rare visitant. Mr. J. King shot an immature male on 5 April 186I on the Ivel at Langford; in this specimen the crescentic margins on the feathers of the breast were as yet visible in one of the feathers only. Mr. A. Covington mentions a female killed at Blunham during the winter $1889-90$ in company with mallards. 


\section{A HISTORY OF BEDFORDSHIRE}

127. Shoveler. Spatula clypeata (Linn.)

A visitant in small numbers probably during most winters, and is one of the four species of duck that have been known to nest with us. At Luton Hoo a pair were said to have nested in the park in 1893. I have visited these pools almost every year since, but have never been able to find this species there again. At the sewage farm at Newnham, one if not two pairs of shovelers nested in 1898 . The first nest found was on 5 May, and contained four eggs, which were taken ; the nest was in the middle of a large tuft of rushes growing out in the water of the 'sewage-lake' that existed at that time. On 21 May a nest containing six eggs, which were also taken, was found among the thick grass in a small osier bed within the same field, and in addition to these, I understand, two other eggs were also eventually procured. During the previous year, shovelers were said to have frequented the same locality during the nesting season, and it seems probable that they may also have nested, especially as small eggs of a duck were said to have been found. They have not infrequently been killed on the river in the vicinity of Wyboston; several instances of the 'spoonbill' duck being shot in past years have been brought under my notice. One was obtained in 1889 from the moat around Chawston Manor; Dr. C. Sprigge shot this species at Great Barford about I890, when a pair together were observed by him upon the floods. In November I 889 a female was shot from the Ouse at Goldington. Two adult males were also killed 3 January 1891 at Kempston, and a pair had been killed from the same water many years previously. Another, also a male, was shot in the same parish shortly after the two drakes were obtained. A solitary female was killed by myself on the Ouse at Goldington 7 January 1892 , and on 27 July of the same year one was seen down the river below Bedford. A female was shot 25 September 1897 on the Newnham farm, and another by Colonel $\mathbf{H}$. Barclay at the pools in Tingrith Park in 1899.

\section{Pintail. Dafila acuta (Linn.)}

A winter visitor, resorting to our rivers and pools most years, but in very limited numbers; formerly more numerous. Females and immature males are far more plentiful than adult males. At the lake in Southill Park one was killed about I 860 , and came under the observation of Mr. J. King. Dr. C. Sprigge once saw three or four together on the flooded meadows at Great Barford. One was shot near
Castle Mills in the winter I889-90, another, a fine male bird, killed near Harrold Hall II January 1892 , and an adult female shot at the Newnham farm 18 September 1894. In the winter I 899-1 900 several were secured : a female at Roxton, two females at Renhold, and a beautiful adult drake shot from the Ouse at Goldington.

\section{Teal. Nettion crecca (Linn.)}

A winter visitor, and is frequently met with on all our larger waterways and pools. It seems evident that in former years and in certain favoured localities it once bred regularly. Mr. J. King can recall at least three nests with eggs being found in the vicinity of the lake at Southill, several eggs from which he has kindly presented to me. In one instance, whilst the keepers and others were gathering pheasants' eggs in the park, those of the teal were also picked up, and remained unrecognized until hatched in an incubator. In more recent years I have never met with it on the lake later in the spring than 9 April, but the head keeper assures me that a nest and eggs were again found in 1893 . At Luton $\mathrm{Hoo}$ a pair were seen by the water keeper nesting as recently as 1895 ; they bred in the vicinity of several water-holes in one of the woods of the park some distance away from the larger pools.

\section{Garganey. 2uerquedula circia (Linn.)}

One of the rarer of the numerous species of ducks that visit us; formerly more frequent. A fine old male, which is now in the possession of Mr. J. Smith, was killed at Fenlake about 1872 ; another, also a male, was shot at Ravensden in November I 890 , and a female was obtained near the ford at Clapham in the spring of $189 \mathrm{I}$. The most recent occurrence was one killed at Milton about 1892 . One was observed on the pool at Luton Hoo by Mr. W. C. Thompson, and several local specimens have been reported to me, but without any additional particulars.

\section{Wigeon. Mareca penelope (Linn.)}

Throughout the winter, and more particularly during the early months of the year, the wigeon is frequently met with in numerous localities along the Ouse, and on many of our larger sheets of water. It occurs generally in small parties, but occasionally in flights from fifteen to twenty and upwards; adult males are few in number compared with females or birds of the year.

\section{Pochard. Fuligula ferina (Linn.)}

Still fairly abundant as a winter and spring 


\section{BIRDS}

visitor, occurring more particularly in small parties from November till the following March. It is not so numerous as in former years, and in localities where it was once of annual occurrence it is now seldom observed. The inequality in the numbers of the two sexes is remarkable, males almost invariably outnumbering the females. On 16 April 1896 I counted about thirty upon the two pools in Luton Hoo Park, and learnt from the water keeper that considerable numbers had been breeding there for many years past; on a second visit on 26 May of the same year upwards of forty of this species were counted, most of the females being then with young. One nest I examined was situated among the rushes close to the margin of the pool ; this, I was informed, was almost invariably the situation chosen there, the majority of nests being unapproachable from the banks. Visiting the park in $1899 \mathrm{I}$ found the number of pochards considerably decreased, and again, on 7 May I90I, only three in all could be noted. On 15 May following a pair were noticed on the smaller pool in Battlesden Park, where previously they had not been identified at all during the breeding season. Davis, in his History of Luton and Neigbbourhood (both in the 1855 and second edition of 1874 ), refers to this species as a winter visitor, so that it has evidently only bred there in later years.

\section{Ferruginous Duck. Fuligula nyroca (Guildenstädt)}

A rare visitor. One that is now in my collection was bought by $\mathrm{Mr}$. J. Cole, taxidermist, when in the flesh, during the winter of 1890-I, having been shot on the river Lea, at Newmill End, close to Luton Hoo Park.

\section{Tufted Duck. Fuligula cristata (Leach)}

Although not so frequent as several others of the duck family, it is constantly met with, either singly, in pairs or small parties, from October onwards throughout the winter; it is found along the Ouse, Ivel and other streams. Mr. W. C. Thompson assured me that this species bred at Luton Hoo Park in 1894, but the water keeper there could not confirm this beyond that they remained there till late in the spring. When I visited the pools on 16 April 1895 there were six or eight together, several beautiful males being among the party. Upon visiting the park again in May 1896, and in following years during the same month, I have failed to find this species.

135. Scaup-Duck. Fuligula marila (Linn.)

The occurrence of this duck in any winter is now the exception rather than the rule as in former years. It has been met with almost as frequently along the Ouse as either the pochard, tufted duck, or goldeneye, and on the Ivel and in the neighbourhood of Langford Mr. Josiah King used to consider it even commoner than those species, being only outnumbered by the mallard and teal. It is some years since I heard of its being obtained. Very few adult males have been obtained locally; not more than a dozen have passed through the hands of Mr. A. Covington during over thirty years' experience as a local taxidermist, and Mr. J. King could never obtain one.

\section{Goldeneye. Clangula glaucion (Linn.)}

Immature specimens of the goldeneye seem to occur somewhat frequently upon our rivers, and at times it is as numerous as the pochard or tufted duck, but adult males of this species are far rarer than either of the latter. Usually a pair or an odd bird only will be met with, or small parties rarely numbering more than four or five.

\section{Long-tailed Duck. Harelda glacialis (Linn.)}

So far as it has been possible to ascertain only two records of this rare arctic species have been locally obtained. A female was shot along the New Cut at Goldington during a heavy snow in the winter of $1870-1$, and eventually passed into the possession of $\mathrm{Mr}$. A. L. Jessopp (see also Zoologist). Another, an immature bird, is in the small but interesting collection belonging to Mr. G. Pestell. It was picked up dead some few years ago, also out of the New Cut.

\section{Common Scoter. Edemia nigra (Linn.)}

Although this bird cannot be considered as a common inland visitor with us it has been obtained too frequently in our county to be classed as rare. It has, I believe, generally been observed singly, and apparently always during the autumn movements. Mr. J. King shot a male on the Ivel near his house at Langford on 2r October, 1858. Mr. A. Covington records the following instances: In November 1865 a boy from Ravensden brought in a fine old male in beautiful plumage; another was reported some few years afterwards during October at Harrold, and on 4 November 1883 another male was brought in from Great Barford. In addition a female was shot at Fenlake in I 886 . On I I July 1870 a flight of ten of these ducks was observed by Mr. P. Addington when shooting along the 


\section{A HISTORY OF BEDFORDSHIRE}

Ouse at Tempsford, and seven males and two females, all adults, were actually obtained by him. A male was killed on 19 August 1879 by Mr. G. Hare at Campton, and Mr. W. Mills informs me he has one in his possession, which was killed on 14 October I 890 on the Ouse at Cardington.

\section{Velvet-Scoter. Edemia fusca (Linn.)}

An adult male is in the possession of $\mathrm{Mr}$. J. Cole, taxidermist, of Leagrave ; it is cased in company with a common scoter, the two having been killed together close to Luton Hoo Park in the winter of $1890-1$.

The common scoter is not mentioned by Davis, but strange to say Anas fusca is included as a winter visitor occasionally.

140. Goosander. Mergus merganser, Linn.

Of occasional occurrence. Some thirty or more years ago $\mathrm{Mr}$. A. Covington saw an adult male that was shot at Cox's Pits; he also mentions a female killed near Turvey in I 862, and has in his possession another obtained in the winter of 1870 and the head of one killed on 20 January 1891 at Sharnbrook. Mr. J. S. Wright informs me that a female was shot at Campton Mills by Mr. G. Hare on 2 December 1879, and he has set up several other local specimens. On 24 October 188x one was shot at Langford. "There is a beautiful adult male among the valuable group of locally-killed ducks in Mr. P. Addington's possession, which was killed by him, he believes, in February, about 1870 , from Friars Pits, Tempsford; it was accompanied by a female at the time. On another occasion he saw three others together at Great Barford. A female, which I have seen in the possession of Mr. C. L. Hall, and which he obtained at Newnham 28 November 1874 , was recorded by him at the time in the Field.

\section{I4I. Red-breasted Merganser. Mergus ser-} rator, Linn.

Very occasionally met with and far less often recorded than the previous species. Only about six have passed through the hands of $\mathrm{Mr}$. A. Covington, all being either in the immature plumage or adult females. There is one in the possession of $\mathrm{Mr}$. P. Addington which he killed when in company with eight others during a hard winter, about 1875, at Wyboston Corner. A flight of eight ducks, which Mr. A. F. Crossman believed were mergansers, was observed by him at Southill Lake on 23 April 1894.

142. Smew. Mergus albellus, Linn.

Only at rare intervals has this bird wandered so far inland as to reach our waters. Mr. A. Covington informs me that three adult males were shot at Pavenham about I870; a year or so after he received an adult male from Milton and a female a few days later from Goldington. In the winter of $1874-5$ a female was killed at Clapham, the head of which came into his possession, and he has heard of one or more other instances, but not personally verified the species. In every instance he adds that, as in the case of the goosander and the merganser, they have invariably been killed during hard weather. Two, evidently immature females, that I have seen in the possession of $\mathrm{Mr}$. P. Addington were shot about 1870 , though not during the same winter; one he obtained near Tempsford Bridge and the other between Great Barford and Tempsford; in both instances they were unaccompanied. Dr. C. Sprigge also sends me word of two killed by him at Great Barford about 1895.

143. Ring-Dove or Wood-Pigeon. Columba palumbus, Linn.

Locally, Wood-Pigeon.

Not only is this bird a common resident but its numbers are considerably increased by immigration during the winter months, and the damage caused to the grain and pea crops in the summer is added to by the destruction among the root crops in the winter. Mr. J. King gives the following account of an amazing flight of ring-doves he observed in the winter of 1895 . "It was from the 5 th to the 8 th of December, that, not thousands, but hundreds of thousands, were passing over, going from north-east to south-west. They were, as a rule, in rather scattered flocks, but occasionally followed rather quickly; then perhaps ten minutes or so would elapse before another flight came into view. They were passing each morning from daylight until ten or eleven o'clock. Some flocks must have contained many hundreds, sometimes small parties of not more than ten to twenty. The flight line seemed to be over Biggleswade, then passing immediately above Holme Mills-few flew as wide as Langford-generally well beyond the range of a gun. About a week after the above dates they came over for one day only, in almost as large numbers. These vast flights puzzle me considerably as the winter has been such a mild one.'

144. Stock-Dove. Columba aenas, Linn.

Locally, Little Pigeon.

An abundant resident at Woburn, Ampthill, Luton $\mathrm{Hoo}$ and Bromham Parks, whilst in other parts of the county it is found nesting 


\section{BIRDS}

very commonly. It continues nesting over a very considerable portion of the year, in fact exceeding that of any other of our breeding species. I have particulars of a nest with eggs taken at Bedford Ford End as early as 8 March I 893, and another elsewhere also with eggs on 12 March 1899; then we have the record of $\mathrm{Mr}$. C. M. Prior (Zoologist) of finding fresh eggs as late as 2 October in I 875. I have occasionally found these birds utilizing old nests of the magpie.

I45. Turtle-Dove. Turtur communis, Selby.

A summer visitor, becoming more numerous every year. Twenty years ago we looked upon the finding of the nest of this bird as of some rarity, but nowadays it is by no means an uncommon incident in any neighbourhood; and in its more favoured haunts, particularly the small plantations between Wootton and Marston, or again in Muggerhanger Grove, it nests very commonly. Its arrival generally takes place during the last week in April or early in May and its departure about the middle of September.

I 46. Pallas's Sand-Grouse. Syrrhaptes paradoxus (Pallas)

During the immigration of sand-grouse that reached the British Islands in considerable numbers in 1863 and several years following, no record of its occurrence is found any nearer than in the adjoining county of Northampton. In 1888 , when that wonderful irruption of some thousands reached our shores, many favoured us with their presence, but received I am afraid little better reception than that meted out to them only too generally. Mr. J. H. Barnard records that a flock of about fourteen visited the neighbourhood of Cople in May of that year and stayed for upwards of three weeks; and $\mathrm{Mr}$. A. Covington informs me that sand-grouse were also reported from Cranfield and Kempston ; in the latter locality one was taken alive on $3 \mathrm{July}$, and after being kept some few days again set at liberty. There is a specimen in the Modern School Museum which was picked up dead under telegraph wires at Thurleigh on II June, and another was obtained there shortly afterwards, but unfortunately not preserved. Another was killed at Caddington during the same year.

147. Pheasant. Phasianus colcbicus and $P$. torquatus, Linn.

Both the black-necked pheasant $(P$. colchicus) and the ring-necked pheasant ( $P$. torquatus) are common with us, as well as the intermediate forms produced by the inter-breeding of these two species. At Woburn several other species of pheasant have been turned out on the estate.

\section{Partridge. Perdix cinerea, Latham.}

Very abundant. All the occurrences of albinism and white variations, which seem to have been unusually plentiful with us, have occurred in one particular district, namely between Pertenhall and Bolnhurst, some four miles distant from each other. All may have arisen from one common stock, but it more probably bears out the statement that partridges reared on heavy clay lands are often poor in colour; nevertheless it seems strange that with so much similar land in the county the records should be confined to this one locality.

\section{Red-legged Partridge. Caccabis rufa} (Linn.)

An introduced species now abundant throughout the county, though not in any way as numerous as our indigenous bird. Mr. J. Allen mentions that it was first killed in the neighbourhood of Ampthill at Brickhill Pastures in $\mathrm{r} 860$, and $\mathrm{Mr} . \mathrm{W}$. J. Chalk that one was shot by his grandfather at Wilden in 1845. According to Davis it was common in the neighbourhood of Luton in 1855 .

I 50. Quail. Coturnix communis, Bonnaterre.

A summer migrant, but it is very doubtful if it occurs every year with us ; it was formerly far more plentiful. There is little doubt that this bird is far oftener met with in the vicinity of the chalk hills in the south than in any other part of the county. The land between the Embankment and Goldington Road (particularly about that part where Howbury Street now stands) used to be almost invariably frequented by quails and most years a few were killed. Mr. J. King shot one on 22 June I 854 near Stanford Mill and another at Langford on 3 July following, but not recently, and Major Brooks also mentions that the quail has been absent for years from Flitwick where formerly he often shot it. Numerous records have been supplied by $\mathrm{Mr}$. A. Covington, Mr. J. Cole, Mr. A. F. Crossman and others.

\section{I. Corn-Crake or Land-Rail. Crex pra-} tensis, Bechstein.

A fairly abundant but decreasing summer migrant. It arrives generally at the latter end of April or early in May, and leaves again usually in September, but often later, October birds being commonly met with. One was taken on 3 January a few years ago in the Grammar School grounds, Bedford, and another on 7 December 1899 at Henlow. 


\section{A HISTORY OF}

152. Spotted Crake. Porzana maruetta

Occurs with us regularly, though in small numbers, whilst on migration in the spring and autumn, but is far more commonly obtained during the latter movements. Mr. A. Covington has received altogether about two dozen specimens, the minority of which have been shot, and the remainder picked up along the railway, having killed themselves against the overhead wires. He mentions that most occur on the low meadows at Clapham and Oakley, and at Goldington and Fenlake, being generally obtained during April and August, though a few have occurred in September and one as late as 7 November 1894 . Mr. J. King has occasionally shot this species at Langford, and killed one at Clifton on II November 1867. Mr. H. Pestell has one which was found dead on II June 1892 under the telegraph wires at Elstow, and according to Mr. J. Cole several have been obtained at Leagrave Marsh, the most recent being one that killed itself against the railway wires on 7 September 1897 . The last local occurrences of this bird were two in 1898 , one shot at Cox's Pits and another at Goldington, and on 3 November I 900 an unusually large adult bird was shot from the New Cut, the gizzard of which was full of seeds.

153. Little Crake. Porzana parva (Scopoli)

A very rare visitor. The only instance which has come under my notice was one caught by a dog at Longholm, close to the town of Bedford, on 2 May 1901.

154. Water-Rail. Rallus aquaticus, Linn.

A regular winter resident, varying considerably in numbers, but not very abundant. It is likely to be found in most localities where there are sufficient water and unlimited skulking accommodation for its requirements. During a continued frost its numbers increase for a time, but if such weather is prolonged a re-migration further south takes place, and the birds return when the weather becomes open again. In the severe weather of December 1 899 , fifteen were taken to one of the local taxidermists within a fortnight.

155. Moor-Hen. Gallinula chloropus (Linn.)

It is extremely common along the Ouse, Ivel and our larger streams and pools; in some favourite localities regular colonies appear, and almost in every waterway and pond, no matter how isolated, where there is the least bit of cover, either under or above the water, and some sort of accommodation for a nest, the moor-hen will be found. This bird re-

\section{BEDFORDSHIRE}

mains about its nesting haunts throughout the year, unless frost compels it to seek sustenance elsewhere. A pied variety, having the upper breast of ash-grey and under plumage white, was shot at Felmersham in January 1895 ; one with the head, neck and lower breast of a light buff colour was killed in October 1900.

156. Coot. Fulica atra, Linn.

Unlike the moor-hen, this bird is restricted in its nesting haunts almost entirely to the few pools that occur on several of the larger estates within our county, such as at Woburn, Luton Hoo, Southill and Battlesden, where they are in each instance exceedingly plentiful for the area of the waters. Although one would expect to find at least a few pairs nesting alongside our sluggish Ouse, especially in the private reaches of the river, such is very rarely the case. The majority remain at their breeding haunts the year through, provided the weather remains open, but after a few days' continued frost they are frequently found along our principal waterways, though seldom more than a solitary bird or at most two in company, the greater number evidently departing direct to the coast.

\section{Great Bustard. Otis tarda, Linn.}

One said to have been killed on Mr. P. Addington's farm at Wyboston about I 840 by Mr. Martin George, at whose sale it was purchased for $£ 2$, passed into the possession of $\mathrm{Dr}$. Rix of St. Neots. At his death it was again sold. Unfortunately I am unable to trace its present whereabouts.

\section{Stone-Curlew. Edicnemus scolopax (S. G. Gmelin)}

Until the middle of the nineteenth century this species was a familiar summer migrant to the neighbourhood of the chalk hills running through the south of Bedfordshire and occurred in other parts of the county, probably more or less frequently during its spring or autumn movements. Davis wrote of it as common around the neighbourhood of Luton in 1855 ; and $\mathrm{Mr}$. T. Cane, whose local knowledge of that district carries him back also into as early years, mentions it as frequenting the Dunstable downs, but commonest around Streatley. Mr. J. King informs me that about Hexton and Pegsdon Hills he has flushed two or three pairs during the day, and has seen them at Langford on two or three occasions. Mr. C. F. Wood mentions that between $1860-70$ a pair or two nested between Toddington and Houghton Regis where he once put up five. One was obtained at Wilden in September 1864 , another came 


\section{BIRDS}

under the writer's observation which was shot by a schoolfellow at Milton, in September 1884 , and one was shot at Offley in 1886. According to $\mathrm{Mr}$. J. Cole they used to be more common on the Dunstable downs than elsewhere, and he has received one to be stuffed which was killed in that locality so recently as I 894 ; a year or two previously he had two immature birds that had been shot between Luton and Dunstable, a quantity of the down being still upon them.

159. Dotterel. Eudromias morinellus (Linn.)

Formerly common along the chalk-hill range running through the south of the county, but occurring far more freely in spring than during their autumn movements. Mr. $\mathrm{J}$. Cole shot three near Luton in $189 \mathrm{I}$, and Mr. J. C. Wright mentions that two were killed about 1875 on the high land known as Bandy-Knowles, between Clifton and Shefford. Mr. A. Covington has one in his possession killed at Oakley previous to 1840 , and has seen another, a very fine plumaged bird that was shot many years ago at Milton; the most recent occurrence he mentions was one shot at Bolnhurst about 1892 .

\section{I6o. Ringed Plover. Egialitis biaticula} (Linn.)

Although far more frequently observed during the spring and autumn, I do not think there is a month when this bird does not occur; with the exception of the dunlin it is probably the commonest seafaring wader that visits us, frequently staying for several days together. The sewage farm at Newnham seems to offer it far greater attraction than any other locality, and it is here that most specimens are obtained. In other parts of the county it is of somewhat unusual occurrence, evidently preferring any open shallow waters to the attractions of our waterways.

161. Golden Plover. Charadrius pluvialis, Linn.

A common winter visitant, and may be observed more or less frequently in all parts of the county, although it is as a rule very conservative in its sleeping and feeding haunts. It occurs in the fields bordering the Ouse and Ivel with great regularity, and in the district between Newnham, Goldington and Willington it may, in company with the lapwing, frequently be observed in thousands together. It is seen on the lands between Clifton and Langford, especially in the neighbourhood of Langford Common, also at Stondon and in the fields along the roadside between Bedford and Bromham and in many other localities.

I
162. Lapwing. Vanellus vulgaris, Bechstein. Locally, Peewit.

Fairly abundant, but somewhat local as a resident. In the autumn its numbers are swelled considerably by continental arrivals, which in some years are very numerous.

163. Oyster-Catcher. Hamatopus ostralegus, Linn.

Of occasional occurrence. Mr. A. Covington mentions one shot near Longholm, close to the town of Bedford, during a heavy snowstorm either in 1866 or the following year, and according to Dr. Sprigge three oyster-catchers appeared at Great Barford about July 1880 .

164. Black-winged Stilt. Himantopus candidus, Bonnaterre.

One instance of this rare straggler's occurrence within the county can be recorded. It was shot about 1855 from Pinfold Hole, a disused sandpit situated by the roadside between Chicksands and Shefford. Through the kindness of Mr. C. Tanqueray I was enabled to examine this particular specimen.

165. Grey Phalarope. Phalaropus fulicarius (Linn.)

Occurs at rare intervals whilst on migration, especially during its autumnal movements. On 22 September 1866 one that is in the possession of $\mathrm{Mr}$. A. Covington was killed from the Elstow Brook, and a second specimen was received by him from Beeston, which had been shot whilst swimming about on a farm pond 2 October 1879. Both were remarkably tame, and the plumage in both instanoes intermediate between the summer and winter dress. Dr. Sprigge has one in his possession which was killed about 1875 by a keeper at Tempsford. Two have passed through the hands of Mr. T. Cane of Luton, and would probably be the same birds as recorded by Davis, one of which was killed from some water alongside the high road. Mr. J. S. Wright has also had a locally obtained specimen to set up. Another example was observed about I 885 by Mr. J. King whilst it was swimming about on his flooded meadows.

166. Red-necked Phalarope. Phalaropushyperboreus (Linn.)

A very rare visitant on migration. The Rev. E. W. Boling has a specimen, evidently a female, which was shot on the glebe pond at Houghton Conquest on I June about I 890 . 


\section{A HISTORY OF BEDFORDSHIRE}

167. Woodcock. Scolopax rusticula, Linn.

Thinly distributed in many of our more suitable woods and plantations from October onwards, but there is little doubt that it is gradually decreasing in number. Several instances of its remaining to nest within our county have been recorded. A nest with four eggs in it was found at Chicksands Priory Woods on I5 April I 828. ${ }^{1}$ In the Field, I 868, a young bird is mentioned as having been caught on 17 April in one of our woods (the particular locality not being mentioned) by a labourer, who, whilst sitting on the ride eating his dinner caught sight of old and young together, and secured one of the young as a witness of the fact. Another contributor to the same newspaper, also writing under a nom-de-plume, sends particulars of one caught from a brood of young by one of the keepers in Charle Wood, Woburn, about the same date, so possibly it may be the same bird as above quoted. About 1863 two young woodcocks scarcely able to fly were taken to Mr. A. Covington. In 1899 a nest containing four eggs was found in Maulden Wood, where also it has been reported as nesting in previous years.

168. Great Snipe. Gallinago major (J. F. Gmelin)

Of occasional occurrence as a winter visitant. The first within Mr. Covington's knowledge was shot previous to 1860 at Willington, and another was killed about the same year on the Renhold side of the river. In September 1866 one came into his hands which was shot at Biddenham. About 1878 two were shot at the Newnham farm in the one season, and on 3 October 1885 an old male was shot in the same locality. An immature bird in $\mathrm{Mr}$. Covington's possession was brought to him in September 1887 ; it had killed itself against the telegraph wires by the New Cut. Mr. P. Addington, referring to the hundreds of snipe he obtained at Wyboston, mentions having only shot one, and that in November about 1860 .

169. Common Snipe. Gallinago coelestis (Frenzel)

Locally, Full Snipe.

Except in continued severe weather, when a re-migration takes place, the common snipe may be found fairly plentiful along our waterways, ditches, and in other suitable localities from the autumn to the following spring; at

1 White's Natural History of Selbourme (1853). Edited by Capt. Thomas Browne. times erratic arrivals in considerable numbers take place, and a 'wisp' may sometimes be flushed together. There is ample evidence that it was once far more numerous than nowadays, in many districts cultivation and drainage having greatly restricted, if not completely changed, its former haunts, as for instance Crawley Moor and a large portion of Flitwick Moor. Throughout the summer of I 897 two pairs were frequently observed and heard drumming over the Newnham farm, but whether they bred or not I cannot say. There is little doubt that it nested formerly in the vicinity of our lowlying meadow lands, as also at Staughton and on Flitwick Moor, where a nest and eggs were seen in I 875 by the late Mr. T. W. Overman. During the summer of 1901 I frequently flushed this bird off that moor, and on several occasions at least three snipe were seen there. On 27 May I flushed one of the birds over and over again from the same spot, to which it would almost immediately return, but failed to find the young which were undoubtedly close at hand. A cream-coloured variety was seen by Mr. T. Taylor at Tempsford.

170. Jack Snipe. Gallinago gallinula (Linn.)

A regular winter resident, but varying in numbers. It arrives usually in October and occasionaliy in September (as early as 3 Septeñoer 1893), remaining with us until the following March and not infrequently well into April.

\section{Dunlin. Tringa alpina, Linn.}

In the autumnal and spring migrations, as also in its winter movements, this bird utilizes the valley of the Ouse with great regularity, and the enormous number of birds that occasionally pass over the town of Bedford probably contain large flights of this little wader. It frequents any expanse of water with a stretch of mud in the vicinity, and at such an attractive site as the Newnham farm it is particularly noticeable throughout the greater part of the year. It is commonest in August and March, but almost a regular visitant in greater or lesser numbers from the end of July till the following May, and not uncommonly a straggler has been seen even in June. I have seen them as late as 2I May I 899, several being in their full summer plumage, and again as early as 3 July 1900 , when five were in company with other waders in the above locality. Mr. A. Covington records that on 28 July 1886 nine adult males in perfect plumage were picked up under the telegraph wires near the New Cut and 


\section{BIRDS}

brought to him; several others considerably mutilated were also found. During his experience of nearly thirty-six years, among the hundreds of locally killed dunlins that he has handled, there have been seven or eight of the much larger type of bird, with the bill more curved, and extremely white on breast and belly; these have generally been obtained alone, or at most two or three together. The last he received were two out of three killed at Fenlake in the winter of 1896 .

172. Little Stint. Tringa minuta, Leisler.

Five instances at least can be given of this rare passing migrant being obtained. A specimen formerly in the possession of $\mathrm{Mr}$. J. King, which his son killed at Langford on 29 September 1860 ; another which I have seen, in the possession of Mr. A. Covington, killed 2 November I 889, in the New Cut; an immature bird shot on 21 October I 898 on the irrigation farm at Newnham by $\mathrm{Mr}$. $T$. Harding, and two others obtained from the same locality on 22 September 1902.

\section{Curlew-Sandpiper. Tringa subarquata (Güldenstädt)}

Another rare migratory visitant. The only records at present are an immature bird shot on 12 October 1872 by one of the old walls at Newnham, and six others obtained from that locality on II and I 8 September I 902.

1 74. Knot. Tringa canutus, Linn.

A very uncommon straggler inland. One was killed from a brook at Ravensden, and two others were obtained at Elstow on 2 and 3 October 1884 which had been picked up, one dead and the other with a broken wing.

\section{I75. Sanderling. Calidris arenaria (Linn.)}

A rare visitor. Mr. A. Covington informs me that in January 1868 a large flock appeared in the neighbourhood of Fenlake and remained in that locality for two or three weeks; several were brought to him at the time, and one or two others were obtained much later. $\mathrm{He}$ has also received several odd birds from different localities bordering the Ouse. The last specimen which he remembers was killed in January 1880 during a deep snow from a ditch along the Kimbolton road near to Cleat Hill.

176. Ruff ( ㅇ Reeve). Machetes pugnax (Linn.)

Although this bird was probably a common visitor to Bedfordshire formerly, it is now but a rare straggler in autumn. A reeve was brought to Mr. Covington in September 1877 , which had been shot at Cardington, and $\mathrm{Mr}$.
J. King's brother shot one about 1870 near Shefford Mill. An immature bird was killed about 1880 at Newnham. In the autumn of I 894 six or seven ruffs remained at Newnham for about a week in association with other waders; one, a reeve, which was killed on I 3 September, was kindly shown to me by Mr. Harrison, another an immature bird was obtained on 23 August 1897, and in its stomach were the remains of several small beetles.

\section{Common Sandpiper. Totanus bypoleucus} (Linn.)

A most regular and plentiful passing migrant ; in the spring it may be found with us from the third week in April onwards to the second week in May, reappearing at the latter end of July and throughout August, evidently in many instances remaining with us a week or more at a time. At these periods of the year one seldom fails to find at least a few solitary birds at several of its more favoured haunts ; as at Newnham farm, or about the gravelly shallow stretches of our waterways, such as at Castle Mill, Old Mill near Great Barford, Wyboston Corner, and many other places along the Ouse and Ivel. In the spring movements they are most frequently seen in pairs, but in the autumn small parties may be sometimes observed. Mr. A. Covington has known an odd bird occasionally to stay the summer through at Goldington, and in the neighbourhood of the Biddenham Rapids a pair once remained throughout their nesting period.

I 78. Wood-Sandpiper. Totanus glareola (J.F. Gmelin)

A single instance of this far more uncommon but similar species occurring locally is given by $\mathrm{Mr}$. A. Covington, to whom a male was brought in May, about I875, that had been shot from a pond at Thurleigh. Davis adds this bird to his list as of occasional occurrence, but it is doubtful whether the species had been correctly verified by him, especially as it is omitted altogether in his second edition.

\section{Green Sandpiper. Totanus ochropus (Linn.)}

A migrant in the spring and autumn, and appears most regularly in its latter movements. It frequently occurs in some numbers together, and in many instances remains upwards of a week or more at a time. Solitary birds are not infrequently met with throughout the winter months, but I cannot venture to say whether these are the 


\section{A HISTORY OF BEDFORDSHIRE}

same birds or not that arrived the autumn previously. It has occurred here probably during every month of the year, including even June, although, curiously, it is a species which has never yet been known to nest within the British Islands. Whenever I have been at Newnham during the first week in August I have invariably met with this species.

180. Redshank. Totanus calidris (Linn.)

This bird passes over the county somewhat regularly, though probably in small numbers, whilst upon its migratory flights. An occasional bird or a pair sometimes break their journey and remain a day or so with us during the spring or autumn, and a few have occurred in the winter. Not infrequently they are flushed from ditches and brooks remote from the river. In all probability it was formerly known as a nesting species in Bedfordshire, for Mr. A. Covington remarks that sportsmen that have known the county from the early part of the past century have spoken of the redshank as at one time nesting regularly in various of our marshy meadows. At Newnham farm in 1896 , if not a year or so previously, a small colony of redshanks, some two or three pairs in all, located themselves, and one nest at least was robbed of the eggs ; but young were evidently reared during that year. In I $897 \mathrm{Mr}$. Covington sent me particulars of a clutch of four eggs which he had seen, which had been taken on 2 I April. On the day following he observed five redshanks together at Longholm; four additional clutches of eggs were also found during that season. In the same year, besides the pairs nesting on the Newnham farm, one or possibly two pairs probably nested on a field known as part of Fenlake Marsh, where they were frequently flushed, and on 20 August I 897 three were seen together at Newnham. In 1898 two or three pairs continued nesting at Newnham, and a young one in the down was found and liberated again by Mr. A. F. Crossman. On I I May I 899 when I visited the farm there appeared to be two pairs there, and the same day I was fortunate enough to flush a redshank off Fenlake Marsh and find her nest, which contained four eggs. On 2 I May I again visited Newnham and saw four birds. Since I 900 , when the site of this lake of sewage had again passed under cultivation, I have been unable to hear of any redshanks even visiting their former haunts.

\section{Spotted Redshank. Totanus fuscus (Linn.)}

A rare visitor. Mr. J. King kindly pre- sented a specimen to me which was obtained by him at Langford 17 September 1856. $\mathrm{Mr}$. T. Cane once had a dusky redshank brought to him about 1870 from 'The Bogs,' which are now drained.

\section{Greenshank. Totanus canescens (J. F. Gmelin)}

So long as there are sufficiently attractive feeding haunts, the greenshank may be regarded as a regular visitor to us during its migratory movements, particularly in the autumn. At the Newnham farm in recent years, when the large extent of sewage water was left exposed upon the land, this bird occurred annually. In other parts of the county it is occasionally reported from time to time, being usually flushed from ponds and ditches and other isolated waters. In the Zoologist one is mentioned by Mr. C. M. Prior, shot in September 1878 as it rose from a ditch at Goldington. One in the writer's possession was killed at Stanford about I 880 . Two, presumably of this species, were seen at Newnham by Mr. A. F. Crossman in September I 893, and in August I 894 I heard from Mr. E. F. Harrison of several being there in the company of dunlins and some ruffs. 'Two'specimens were shown to me by $\mathrm{Mr}$. $\mathrm{H}$. Nicolls killed at Newnham in I 895. On 23 May 1897 I saw at some distance what was evidently a greenshank, and on 2 I May I $898 \mathrm{Mr}$. Crossman observed a single bird also in the same locality. Mr. A. Covington says that upwards of a dozen local birds have passed through his hands, which were in every instance killed in the month of August. The first he can call to mind was one killed from a pair that rose from a pond at Putnoe in August $\mathbf{1} 868$, and the most recent, one of two seen, that was killed at Turvey in August 1896.

\section{I83. Bar-tailed Godwit. Limosa lapponica (Linn.)}

An uncommon visitor. Two were shot at Goldington on separate occasions during the winter I 866-7, and purchased by Mr. A. Covington, who also had another specimen from Ampthill in the beautiful red plumage pass through his hands in May 1887 . In the Field, 1870 , one is recorded killed on 21 May of that year near Ampthill. One in full breeding plumage, in my possession, was obtained near Stanford about 1877 ; another I have seen in the collection of Mr. G. Pestell, which I understand was killed at Newnham, and $\mathrm{Mr}$. W. Addington has one which was shot at Wyboston in 1870. 


\section{BIRDS}

184. Black-tailed Godwit. Limosa belgica (J. F. Gmelin)

Occurs very occasionally during migration. Morris ${ }^{1}$ mentions it as having been obtained at Cardington, but without any additional remark. One which I have seen in the possession of Mr. H. Manning was shot by him near the park at Luton about I885; the third instance is an immature male shot by Mr. G. Pestell by the osier bed at Goldington during the first week of September-1897; another was in company with it at the time, but though wounded was not secured.

\section{Common Curlew. Numenius arquata (Linn.)}

Of irregular though by no means uncommon occurrence with us; but being wary in its habits it is seldom obtained. Mr. A. Covington mentions one shot at Longholm about 1860 , two brought to him from Riseley in the month of July, and one shot at Little Staughton in September 1896 . A variety with neck partly pied with white was killed at Willington about I 890 . During the long severe winter I $894-5$ one was picked up dead on Mr. H. Dillamore's farm at Sandy, and a few curlews frequented the sewage farm at Newnham in 1894. Mr. H. Pestell has observed a solitary curlew occasionally at Elstow, the last was seen in December I 897, flying over the old racecourse. On 4 January 190 I one was shot at Roxton, another was picked up dead at Kempston on the following day, and on 8 January three were seen together at Langford, two of which were eventually killed. On 15 and 24 July of that year curlews were reported to me passing on migration during the night over the town of Bedford and at Langford.

\section{I86. Whimbrel. Numenius phacopus (Linn.)}

Evidently a regular passing migrant, occurring in small flights during the spring and autumn. Like the curlew this bird is more frequently seen than obtained, and as it usually flies high overhead is often unrecognized. Not more than six locally obtained birds have been received by Mr. A. Covington, shot either in May or September. Harrold, Kempston, Turvey and Cardington are localities in which four of them were obtained. The last he saw was one which had killed itself against the telegraph wires in 1896 . In 1894 one was killed at Streatley by $\mathrm{Mr}$. Osborn, and one in Colonel H. Barclay's possession was killed at Tingrith in 1868 .

$$
1 \text { British Birds, by F. O. Morris (1860). }
$$

Mr. J. King mentions a flight of about a dozen, which flew quite low over Langford on 5 May 1895 . One was killed Io May 1896 at Brickhill Pasture by Mr. J. Crisp.

\section{Black Tern. Hydrocbelidon nigra (Linn.)}

Although for about the last fifty years it has not been known to nest in the British Islands, this bird is nevertheless fairly common as a passing migrant with us. In the early part of the last century it must have occurred here in considerable numbers whilst journeying to and fro from its nesting haunts in the Fenlands; the nearest point-Whittlesea Mere-at which it was known to nest until about I 843 not being more than twenty miles distant from our county. Mr. A. Covington informs me that until about 1870 it appeared regularly in small companies along our river every May, and in one instance he heard of seven being killed from a flock of about thirty. Year by year since its numbers have decreased on the spring migration, and adult birds are now seldom obtained. During one morning in August 1896 he counted thirty-two, all immature birds, on the Newnham farm. On I5 May I 90 I the writer observed nine together in Woburn Park over the Basin Pool, where they remained at least all the morning, flying backwards and forwards over the water.

\section{Common Tern. Sterna fluviatilis, Naumann.}

A common passing migrant with us. The buoyant flight of this or the following species may often be recognized over many of our larger pools, as well as along the Ouse and Ivel. Generally single birds will be observed, but not infrequently small parties of some six or eight together.

189. Arctic Tern. Sterna macrura, Naumann.

Evidently not so numerous as the last species. Owing to the difficulty of distinguishing these two terns upon the wingeven at close quarters-records based on observation alone are unsatisfactory. Five which were brought to Mr. A. Covington during one week, were shot near the Common Bridge over the river just above Bedford about August I 866. The last he set up was one from Bletsoe I 9 September I 894. An adult was shot near Sharnbrook, Bedfordshire, in August I 885 (Lilford, Birds of Northamptonshire and Neigbbourbood). The water keeper at Luton Hoo has one which was killed at the lake there in May 1899. 


\section{A HISTORY OF BEDFORDSHIRE}

190. Little Tern. Sterna minuta, Linn.

By far the least plentiful of the four terns that visit us. In thirty-seven years of taxidermy Mr. A. Covington can remember receiving but five local specimens; they came from Fenlake, Willington and Harrold, and in every instance appeared during their spring migration northwards. In addition he mentions a male and female that were shot near Willington church in the month of June about 1865. Mr. R. J. Cawse has one, he says, in his possession which he shot on the Ivel at Biggleswade in 1883 . I saw a single bird on II May I 899 at Newnham, which was resting upon a small patch of ground in one of the flooded parts of the farm.

191. Black-headed Gull. Larus ridibundus, Linn.

Perhaps the commonest of the sea-gulls that one may so frequently observe as far inland as Bedfordshire. It evidently seems to be a regular migrant, journeying to and from its nesting colonies during the spring and autumn, but more particularly, I think, during the latter period. Often driven inland after heavy gales.

192. Common Gull. Larus canus, Linn.

This is one of the least common of the gulls which occur with us. Apparently it does not appear in the county with any regularity in the spring or autumn like several others of the gull family, but this may be more easily accounted for by the total absence of breeding stations in England; their visits seem therefore more particularly in the nature of winter records, and at this season evidently under conditions of stormy weather only. Adult plumaged birds are nearly always obtained. One I have seen was shot at Blunham in 1836 ; another was killed near Bedford on 7 September 1892 and one at the Newnham farm on 3I December of the same year. On 2I January 1893 one was picked up dead at Ravensden, and in February 1900 one was obtained at Keysoe. During the winter I 900-I one was killed at Barton and set up by Mr. J. Cole, who remarks that it is the only one of this species he has ever had that had been obtained locally.

\section{Herring-Gull. Larus argentatus, J. F.} Gmelin.

Evidently utilizes the valley of the Ouse very regularly during its migratory periods of the year, and often at no inconsiderable height, but in these overland movements it seldom alights again before reaching the coast. During April and early May we may frequently see this bird either singly or in small parties; greater numbers are seen throughout August and September, the majority being immature birds. Throughout the winter months solitary birds not infrequently appear.

\section{Lesser Black-backed Gull. Larus fuscus,} Linn.

Like the last species it is more frequent with us during its local migrations in the autumn, but it is frequently met with all through the winter, and whilst on its return journeys overland in spring. Immature birds comprise by far the greater proportion of those obtained.

\section{Great Black-backed Gull. Larus mar- inus, Linn.}

Very rare. Mr. G. B. Clarke records an adult shot in the spring of 1849 at Hockliffe (Naturalist, 1851). Three have been received by Mr. A. Covington, the last of which was shot from near the New Cut at Goldington in the winter $1892-3$.

\section{Kittiwake. Rissa tridactyla (Linn.)}

Almost as plentiful a species locally as the black-headed gull, but, unlike that bird, not particularly noticeable during any migratory season of the year, though appearing freely from November until the following February. It generally occurs inland in the wake of every storm that beats upon our coasts, very frequently reaching us in an exhausted condition, as numbers of them are picked up dead, and often in localities far removed from any water. The birds seen are usually solitary, but occasionally two or three may be observed together.

\section{Pomatorhine Skua. Stercorarius pomato- rbinus (Temminck)}

On 18 October 1879 a male bird of this species, which has since passed into my possession, was taken by a countryman to Mr. A. Covington. It had been shot by the man from a ploughed field at Ravensden. When skinned it was found in very poor condition and the stomach quite empty (see also Zoologist).

\section{Razorbill. Alca torda, Linn.}

The only local record that can at present be given is that of an old stuffed specimen mounted in company with a green woodpecker, which $\mathrm{Mr}$. A. Covington purchased at a local sale. The label on back of case stated, 'Razorbill from Fenlake.'

\section{Guillemot. Uria troile (Linn.)}

A very rare species, and probably never 


\section{BIRDS}

found in this county except when driven under the stress of severe weather, for when procured they are generally picked up dead, or in a very exhausted condition and unable to fly. An old specimen came into the hands of Mr. A. Covington some years ago that had been shot close to Milton Mill. One was picked up at Renhold 26 November 1893 ; others have been obtained at Sharnbrook, Goldington, and two in addition at Milton, one in November 1893, and an adult specimen in 1894 .

\section{Little Auk. Mergulus alle (Linn.)}

There are many instances of this little arctic visitor being storm driven into our county. The earliest noted is one that was picked up near Bedford in the winter $1861-2$, which, although not actually seen by $\mathrm{Mr}$. A. Covington, was sufficiently described to him to leave little doubt as to its being correctly named. Davis (History of Luton, I 874 , ed. 2) refers to four having been taken near Luton in the last thirty years ; particulars of only two are given, one of which was obtained in Hertfordshire and the other found at Barton in January 1870 . The late Mr. T. Cane also mentioned to me one having been received by him from Caddington in the last week of January 1895, and he had a second during that winter. In the Field one is recorded by Mr. Allen as having been picked up dead after severe gales on 8 December I878, upon the allotment gardens at Husborne Crawley. Again in the same journal Mr. W. F. Higgins sends particulars of one killed at Turvey on 22 November 1882 . One in the possession of Mr. J. Day of Roxton was picked up dead on 2 I November I 894 near Colmworth Woods. In the exceptionally severe weather at the end of January I 895 two came into the hands of $\mathrm{Mr}$. J. S. Wright, one found on 20 January at Hinxworth in Hertfordshire, and another, which is now in my possession, was picked up on 2 February, almost dead, in Haynes Park. The most recent was one, a male, picked up near Hanger's Wood, Stagsden, on 19 February I90I; when found it was still alive, but in a very exhausted condition.

\section{Puffin. Fratercula arctica (Linn.)}

The very few obtained are probably stormdriven birds, occurring more particularly with us during their spring and autumnal movements. Several have been received by $\mathrm{Mr}$. A. Covington, but have generally been found dead or nearly so. One he mentions was picked up in the middle of Clapham Wood, and he has received others from near Castle
Mills, Willington, Turvey and Harrold, the most recent from Kempston at the latter end of March I 90 I after a westerly gale. A uniform cream-coloured specimen was sent to him in the autumn of 1880 which had been picked up at Girtford. On 5 January I 895 a female was caught at Marston, and a male in the same parish two or three days later. Colonel H. Barclay has one in his possession which was picked up dead in Tingrith Park in November I 893, driven in by the great storm at that time.

202. Great Northern Diver. Colymbus glacialis, Linn.

A very rare winter visitor. Morris ${ }^{1}$ refers to one being met with in Bedfordshire on the river Ouse 4 February 1830 , which is evidently the same bird now in the possession of Mr. J. F. Day of Kettering, who kindly informs me that one was shot by Mr. William Francis, his grandfather, during that year and month. It was shot on the ice on the Ouse near Cardington Mill. Another which was purchased by Mr. A. Covington in the flesh in December 1876 had been shot on the river at Cox's Pits, Biddenham, after being hunted and fired at several times before being secured.

\section{Red-throated Diver. Colymbus septen-} trionalis, Linn.

The local specimens handled in the flesh by Mr. A. Covington have not shown any trace of the red neck of its summer plumage, and all have been extremely fat. One was killed at Kempston about I 890 near the Hill Grounds, another at Pavenham in January 1898 , and the last received by him was killed near Felmersham in January I 897 ; in its gullet there were nine roach, each from 3 to 4 inches long. Another, a male, was also shot at Felmersham in January I886 by Mr. A. W. Saunders, who informed me when I examined the specimen in his possession that when killed it was absurdly tame and never attempted to escape by either diving any distance or attempting to get upon the wing. One was shot by Major Duberly on the Ouse by his house at Fenlake on 18 November 1891, and another was obtained by Mr. Hassall close to the railway bridge over the river at Cardington on 17 November 1893.

204. Great Crested Grebe. Podicipes cristatus (Linn.)

Until a few years ago known only as a winter visitant, occurring not uncommonly

1 British Birds, by F. O. Morris (1860). 


\section{A HISTORY OF BEDFORDSHIRE}

upon the Ouse and Ivel from September onwards until the following February. Mr. J. King, who was formerly resident at Southill for many years, has no knowledge of their having attempted to breed there until I 894 , when in company together we found them so doing. But it is evident from conversations I had with the keepers that the birds had first frequented the lake one or two years previously, and as they remained throughout the greater part of the year probably nested. On I 8 May of that year we found a pair had a nest and eggs and the old bird was evidently sitting; a previous laying of three eggs had been destroyed on 23 April, close to where the present nest was situated. When visiting the pool again in August of that year, I found that the second laying had been fully successful, the old birds being then accompanied about the pool by their young. On 17 April I 895 two pairs were upon this sheet of water; but, not visiting Southill again in that year, I am unable to say with what results. Subsequently on 3 April I 899 one pair were present, and on 12 May following three grebe were observed. On 3 May 1901 three pairs and one odd one were upon the pool, of which two pairs at least remained and nested there. Her Grace the Duchess of Bedford has been kind enough to favour me with particulars of this species on the pools at Woburn. It was first observed there in I 894, when a pair nested and reared three young. Four of the five left in the autumn, one staying until the hard frost set in during that winter, and one returned immediately when the weather opened. When visiting the various pools within Woburn Park on 15 May Igor seven of these grebe were upon the pools, one pair of which were accompanied by their three young, and another had a nest containing two recently laid eggs, to which a third was eventually added. The numbers observed on these pools on this occasion may be possibly accounted for by Battlesden Lake having been drained and left dry. I visited Battlesden Pool on I6 May I899 and five adult birds were then present; two pairs were evidently nesting, one nest of which could be inspected from the side, and contained a single egg. In Mr. C. F. Wood's experience of Woburn and Battlesden from $1849-72$ he never knew or heard of this grebe in either locality. At the larger pool in Tingrith Park, Colonel H. Barclay says that to his knowledge they nested only in I 899 , the eggs being successfully hatched and the young reared; but the year following only a single bird returned to the pool, remaining some little time before departing again; since then they have not reappeared in that particular locality.

\section{Red-necked Grebe. Podicipes griseigena (Boddaert)}

A rare winter visitant. In February I 863 one was shot by a farmer on a pond at Renhold; the bird was skinned and eaten, but Mr. A. Covington was, fortunately enough, enabled to obtain the mutilated remains and identify the species. Another, a female, is in the possession of the writer; it was picked up alive on I I February I 870, during hard weather, in the farmyard of the Hill farm at Wilden (see also Zoologist). A third which I have also examined is in the possession of Mr. J. Lund of Bedford, and was killed on the small reservoir above the Clapham road on 8 November I885. A rednecked grebe recorded in the Field, I880, proves upon examination to be but a specimen of the great crested grebe.

206. Slavonian Grebe. Podicipes auritus (Linn.)

Another winter visitant, but seems to occur far oftener than the previous species. About a dozen have been received by $\mathrm{Mr}$. A. Covington in the flesh, nearly always in February or March during their return movements north, and invariably in the winter plumage. Blunham, Willington, Pavenham, Milton, Harrold, Odell, and by the ash-plantation along the river at Clapham are localities where they have been obtained. The most recent was one found at the edge of a pond along the Kimbolton road about I 890 , apparently exhausted and frozen to death. Several have been received by $\mathrm{Mr}$. J. S. Wright at various times. One which I have seen in the possession of Mr. J. Cole of Leagrave was shot at Luton $\mathrm{Hoo}$, and others have also been received by him from around that neighbourhood. One in the possession of $\mathrm{Mr}$. J. King was shot on 27 March 1865 at Southill Lake. That recorded by Mr. C. M. Prior in the Zoologist, shot near Bedford during the last week in February 1879 , is very probably the specimen now in my possession, which was shot by $\mathrm{Mr}$. J. Bennett on the overflows at Fenlake about that year. Another in my collection was obtained near the bridge at Felmersham on 2. February I 895 .

207. Little Grebe. Podicipes fluviatilis ('Tunstall)

Locally, Dabchick, Didchick, Diadobber.

Still plentiful as a winter visitor on all our larger streams, and with the exception of within a few miles from Bedford-where its 


\section{BIRDS}

numbers are less frequent owing to its being too freely harassed-it occurs commonly throughout the whole course of the Ouse and Ivel, particularly on the former river between Willington and St. Neots. During continued frosts they suffer considerably, often allowing themselves to be caught with the hand, and being occasionally even picked up in the streets of Bedford. Until about I 885 they nested regularly on several ballast-holes close to the town of Bedford, one locality in particular being the ballast-hole along the Hitchen line at Elstow, close to the London and NorthWestern Railway station, and once at least, some years previously, in the lime-pit holes at Cox's Pits. At that time Mr. A. Covington frequently received specimens during the spring in the full summer dress, most of them having been killed against the telegraph wires. At another ballast-hole close to Biggleswade station several pairs used to nest, as witnessed by $\mathrm{Mr}$. J. King, but we failed to find them continuing to do so in 1895 or since. Again several nests have been found by him alongside the Ivel at Langford; and at Southill, on the small Basin Pool, one or more pairs nested regularly formerly, but had ceased to do so about 1890. They have nested also at Woburn, Ravensden, Tingrith and Luton Hoo.

208. Storm-Petrel. Procellaria pelagica, Linn.

Occasionally found, and generally during the autumn. The following have been recorded: One picked up near the Ashburnham Road, Bedford, on 30 October 1879; one shot by Mr. G. Steadman at Ridgmount on 13 October 1880 , as reported at the time in the Field; another during the same month of that year, caught in the old tanyard at Shefford; one found in the Midland Road, Bedford, on 7 October 1889 ; one caught whilst fluttering against the windows of the old Borough Police Station in Silver Street,
Bedford, on 20 October 1890; and one caught by Mr. J. Bennett in his garden in Peel Street, Bedford, on 5 December I 893. Major Brooks sent me word in 1894 that one had been taken at Toddington a few years previously. Another was picked up dead near Colmworth Wood in 1894 , and one in November, 1878 , at Staplow, both of which were seen by Dr. Sprigge.

\section{Leach's Fork-tailed Petrel. Oceano- droma leucorrboa (Vieillot)}

Mr. F. J. Thynne informs me that one was picked up in Wilstead Park on 16 November, 1877 , and is still in his possession at Haynes; and during the last week of December 1878 a male was picked up alive under one of the street lamp-posts near the Grove, in the town of Bedford (see also the Zoologist). On 2 November I 880 a flock of seven of these birds was said to have been observed along the river at Goldington, and $\mathrm{Mr}$. Covington, from the description given at the time, thinks they were undoubtedly of this species ; two days afterwards one was sent him from Fenlake, the adjoining parish.

\section{Manx Shearwater. Puffinus anglorum (Temminck)}

Occasionally driven inland by storm. One in the collection of Mr. T. Cane of Luton was taken at Stopsley, some two miles north of that town, and another in my collection was picked up alive at Cotton End near Haynes in the autumn of 1885 .

\section{1. Fulmar. Fulmarus glacialis (Linn.)}

The only occurrence on record is an adult bird picked up at Goldington on I October I 888 , which was placed upon a pond where it survived a few days. It was eventually taken to $\mathrm{Mr}$. A. Covington, and when skinned was found to be extremely emaciated.

\section{ADDENDA}

White Wagtail. Motacilla alba, Linn.

One picked up under telegraph wires at Turvey in the spring of 1902, and an adult male obtained at Newnham in September of that year, were verified by Mr. A. S. Covington (see also Beds Times).

Great Skua. Megalestris catarrbactes (Linn.)

One that is in the writer's possession was caught alive by Mr. J. Cole on I I May I 902 on Bankey Park pond near Leagrave. It had a large sea fishing-hook it its throat, to which cord and two pieces of wood with lettering thereon were attached.

Black-throated Diver. Colymbus arcticus, Linn.

On 20 February 1897 one was reported by $\mathrm{Mr}$. Tomalin as having been seen on a fishmonger's stall at Northampton said to have been shot at Wootton, Beds (Fourn. Nortbants Nat. Hist. Soc, and Field Club). 


\section{MAMMALS}

In compiling the record of mammals the same difficulty has been experienced as in the case of the vertebrata generally. With the exception of a local list given by Davis in his History of Luton (I855), there is no trace of any other work upon the subject. A work of a century ago would now be invaluable for reference to many species already exterminated, whose local history has all but passed away. Unfortunately there seems to be no one resident in the county who has specially studied the local mammalia, and this accounts for the omission of many little known mammals from this list. During the past century the marten and the black rat have disappeared, and the polecat may now also be considered extinct in the county. Amongst those species as yet unrecorded within Bedfordshire, and which would in all probability on careful investigation be found, are the lesser shrew (Sorex minutus) and several of the Cheiroptera.

\section{CHEIROPTERA}

I. Long-eared Bat. Plecotus auritus, Linn. Abundant.

2. Barbastelle. Barbastella barbastellus, Schreber.

Bell-Barbastellus daubentonii.

Evidently uncommon, and personally I have never seen a local specimen. One was taken in 1868 in the bedroom of a house in the Clapham road, another a few years after was knocked down by a boy with his cap near Brickhill farm, and a third found dead in Fosterhill Road in Bedford about the same year. The most recent was one picked up alive also in that road by $\mathrm{Mr}$. A. Covington in August Ig0I, which he retained for a time before liberating.

3. Great or White's Bat (Noctule). Pipistrellus noctula, Schreber.

Bell-Scotophilus noctula.

White-Vespertilio altivolans.

Common, haunting more particularly the neighbourhood of our rivers and larger pools, where not infrequently they may be observed in company with swifts (Cypselus apus), with which they seem equally adept when upon the wing at taking the Mayflies and other aquatic insects. At times I have observed this bat capture the larger beetles also. They sleep in the holes of trees, frequently in colonies. On 3 August 1897 I took exactly fifty from an old beech tree at Warden Warren, and $I$ have heard of about as many being taken in other localities. A matutinal flight seems often to be taken by this as well as some of the other species.

4. Pipistrelle. Pipistrellus pipistrellus, Schreber.

Bell-Scotopbilus pipistrellus.

Very common. They sleep in buildings, especially in churches.

5. Daubenton's Bat. Myotis daubentoni, Leisler.

Bell-Vespertilio daubentonii.

The first occurrence of this species recorded in the county is given in the Zoologist 1893 , when two were obtained on 9 August from several flying by the river close to Cardington Mill. I have since observed this species in many other sheltered haunts along the Ouse and over the lake at Southill.

6. Natterer's Bat. Myotis nattereri, Leisler.

Probably not very uncommon within the county, although seemingly local. It is first recorded in the Zoologist 1903 , when several were observed during August in that year at Turvey and one obtained. 


\section{MAMMALS}

\section{INSECTIVORA}

7. Hedgehog. Erinaceus europeus, Linn.

Fairly abundant generally, particularly in the northern half of the county. An albino female was taken in a trap at Wrest Park, Silsoe, in December 1878 (Field, also Zoologist).

\section{Mole. Talpa europoea, Linn.}

Very common. Varieties are occasionally obtained. One, orange-coloured, with a reddish stripe down the belly and a few black stripes across the back, was taken I 7 February I 877 (Zoologist). Mr. A. Covington has also received three others of a pale fawn colour, one of which was trapped at Bromham; and one of a uniform bright salmon colour which showed a delicate pink next the skin when the fur was blown aside. Pale silvery grey specimens have been received by him in some ten or more instances; one at Goldington about 1895 , and two dingy white varieties from Stevington, as well as occasional pied variations, but in the latter the spots and blotches were always restricted to the under parts.

In addition to the mole being rather a favourite prey of the weasel $I$ have not infre- quently found their remains either in the nest or among the pellets of the tawny owl.

\section{Common Shrew. Sorex araneus, Linn. Locally, Hog Mouse.}

Very common generally. In many small spinneys during the spring months I have at times noticed considerable numbers together running about the undergrowth.

\section{Water Shrew. Neomys fodiens, Pallas. Bell-Grossopus fodiens.}

Not very abundant and somewhat locally distributed. A favourite haunt is the stream flowing through the 'Green' at Goldington ; it also occurs more or less commonly at Ravensden, Stagsden, Harrowden and Renhold. I once procured it at Biddenham near Kempston Mill. Mr. A. Covington refers to its being formerly abundant in the ditch along the Kimbolton road near Gipsy Lane, but having now entirely disappeared from that locality. One in his possession was taken by him in 1861 when a schoolboy in the old spring at Clapham.

\section{CARNIVORA}

\section{I. Fox. Vulpes vulpes, Linn. Bell-Vulpes vulgaris.}

Fairly abundant throughout the county, but its numbers naturally depend upon the protection afforded. The head keeper at Southill informed me that once during a very heavy thunderstorm, when the young pheasants were knocked off their roosting perches by the gale, he found as many as seventy-six that had been killed by foxes during the night. Mr. P. Addington assures me that in one instance he found a litter of no less than ten cubs.

\section{Pine Marten. Mustela martes, Linn. Bell-Martes abietum. \\ Locally, Marten Cat.}

During the early years of the last century the pine marten was still in evidence in our county, but was more particularly confined to the larger woodlands. A rapid extermination must have however followed soon afterwards, as records of a more recent date seem entirely absent, and at the present time I do not suppose there is any one living who has any local knowledge of the marten except from hearsay. Davis, in his History of Luton ( 1855 ), refers to it as 'rare,' and in his second edition
(1 874), 'almost extinct,' whereas there seems little doubt that it had been exterminated even long before his first edition. Mr. A. Covington remarks that he has heard his uncle speak of having occasionally obtained it around his home at Bolnhurst, and his mother when a girl had a cape made of marten cat skins and a muff of polecat skins. The animals had been caught by her father and brother in the locality. The last two that he ever heard of were one trapped in a fir tree at Sandy, and of more recent date one seen by a $\mathrm{Mr}$. Ruff. It had been trapped at Keysoe Wood (then of far greater acreage than now) and suspended to a hazel in one of the ridings. He also adds that keepers generally used to sell the skins of both these and polecats to the furriers. In a conversation I had some years ago with an old keeper, named Franklin, he assured me his father once killed a marten cat at Haynes about I 840 , and he had heard of it being obtained at Wootton. In the Field (1859) is to be found an interesting account of the capture in Odell Wood of a pine marten and four kittens by an old gamekeeper in about the year 1819 . The old cat brought up the kittens successfully in confinement, and although the mother was never 


\section{A HISTORY OF}

tamed the young became as docile as domestic cats.

\section{Polecat. Putorius putorius, Linn. Bell-Mustelo putorius.}

Until about the middle of last century the polecat was still fairly common, more particularly in the well wooded districts. Many of the old inhabitants, especially gamekeepers and woodmen, have told me they were familiar with this species in their early days, but nowadays almost the only evidence that remains are the few stuffed specimens that one may occasionally come across. At Renhold Wood four or five were killed by Goodliff, who was keeper there many years ago. They were not uncommon in the woods around Bolnhurst, and in Clapham Woods as many as six or seven are stated to have been taken in one week; at Stanford and Newnham they have occurred, and in more recent years were comparatively well known around Wootton, Maulden and Melchbourne. Major Brooks remarks on its occurrence formerly at Flitwick and $\mathrm{Mr}$. Rouse Orlebar around Hinwick. About 1850 one was seen by Mr. J. King at Southill Fields and another in Southill Park about I870; one obtained at Sherhatch Wood about 1842 , and another, a very beautiful old male, trapped in February about I 876 by the keeper at Wilshamstead Wood, are both now in the writer's possession. One was found at Little Staughton in 1867 , and a male, which had got its head through some palings and had been unable to extricate itself at Warden in March 1873. Another male was trapped near Turvey Mill in April I 880, and about I 882 another, a large specimen, was trapped under an old archway at Sharnbrook; all four were mounted by Mr. A. Covington. During the winter I878-9 a polecat was said to have been seen several times at Putnoe. One was killed at Chicksands Priory 28 March 1879 (Zoologist), a male trapped I I March I 883 at Henlow Grange (Field) and another trapped at Ickwell Bury 8 December 1883 (Field). One which I have seen in the head-keeper's possession at Woburn was killed in the park about I 886, and a fine old male, which I have also been able to examine, was trapped at Elstow Gorse 26 October 1898 and measured 22 inches when in the flesh.

14. Stoat (Ermine). Putorius ermineus, Linn. Bell-Mustela erminea.

Fairly common wherever its numbers are not rigidly kept down by game-preserving. Specimens that have more or less assumed the

\section{BEDFORDSHIRE}

arctic winter dress are not at all uncommon, and many individuals that have undergone almost the complete change of dress have been obtained; upwards of a dozen of these have passed through the hands of Mr. A. Covington, and in every instance he adds they were large old males. A correspondent writing to the Field I 879 , respecting a stoat's nest and larder found by him on 26 May at Stratton Park, Biggleswade, mentioned that it contained four field mice, twenty-seven partridges' eggs (not one of which was injured) and parts of several rabbits. The female and eleven young were killed from the nest, a number considerably in excess of the usual litter of about six.

\section{Weasel. Putorius nivalis, Linn.}

$$
\text { Bell-Mustela vulgaris. }
$$

Common generally, in spite of gamekeepers' efforts to reduce its numbers. Several albinos have been obtained, one at Blunham and another at Great Barford, as I am informed by Dr. Sprigge. In the winter $1896-7$ another was taken in a stable at Luton, and still more recently one is recorded in the Field shot 25 October I 898 by Mr. Rouse Orlebar on his lawn at Hinwick. Two albinos at least have been received by $\mathrm{Mr}$. A. Covington, one from near Ravensden church in I 89 I and another near the pond in Goldington village in 1889 ; in addition he mentions having had several varieties with the white chest and belly spotted with brown.

\section{I6. Badger. Meles meles, Linn. Bell-Meles taxus.}

Now rare, a few remaining in certain favoured haunts, whence those that are occasionally killed may have wandered. Until about the middle of last century it was fairly well known throughout the county, and badger-baiting at the local fairs was one of the attractions. Along the chalk-hill range, particularly in the neighbourhood between Sharpenhoe and Hexton, many have been killed in recent years, and in the former locality the remains of one were found by $\mathrm{Mr}$. A. F. Crossman in June 1893 ; several badger-earths have come under my personal observation there, and from this locality they seem frequently to wander into the adjoining parishes. At Silsoe it has several times occurred. Davis (History of Luton, 1874) refers to one being caught at Barton some two or three years previously. A stuffed badger that I have seen in the boat-house at Luton $\mathrm{Hoo}$ was taken at Stockings Wood about 1887 and weighed $28 \mathrm{lb}$; others I learnt have since been taken on that estate. Colonel Hanbury Barclay 


\section{MAMMALS}

states that in March r gor badgers had an earth at $\mathrm{T}$ ingrith, his keeper having seen a badger in the woods a week previously. In the spring of 1891 a mother with young was dug out of an earth at Harrold; the female was preserved and is in the possession of Mr. A. Covington, who had received one a few years previously from Carlton. A young one about six weeks old was sent to him from Harrold in 1890 , and two others some three months old and another young one from the same neighbourhood in I 899 . In I 895 a female that had been obtained at Ampthill was also preserved by Covington, and he mentions that in the 'sixties' two live cubs were brought to his shop that had been taken in the south of the county. A male weighing I $8 \mathrm{lb}$. was trapped 26 October I 899 on Rowney Warren, and a female weighing $19 \mathrm{lb}$. on 19 April I 900 at Sutton Park.

\section{Otter. Lutra lutra, Linn. Bell-Lutra vulgaris.}

The otter is by no means as rare in this county as is generally supposed, and probably more plentiful than formerly. It occurs throughout the whole course of the Ouse and the Ivel, and though the animal itself is not often seen its tracks are to be found on the land adjoining these streams. In one of $\mathrm{Mr}$. J. King's meadows at Langford there is a track which has been constantly used for years. This track cuts off a bend of the river and possesses a curious feature in that the banks at either end have never shown any trace of scoring. Mr. King assures me that he has seen otters leap upon the bank from the impetus gained in swimming. This may account for the difficulty experienced in trapping this animal. Mr. A. Covington states that he has mounted upwards of twenty otters that have been obtained locally, and $\mathrm{Mr}$. J. S. Wright more than a dozen. A former water keeper at Biggleswade informed me that he had trapped and shot seven in that neighbourhood. The following records form but a small proportion of the full list which might be given if dates and other particulars had in all cases been preserved: A male otter weighing $26 \mathrm{lb}$. was shot at Milton Mill 17 April 1837 (Beacon and Beds Mercury). A young dog otter killed at its holt near Stevington church, and afterwards a female by Mr. Reeve's hounds I 8 May 1837 (Beds
Mercury). On 28 December 1878 three young, apparenly less than a fortnight old, found in a nest of sedge and rushes in the reed beds near Castle Mill (Zoologist). A female, weight $16 \mathrm{lb}$, trapped in the Ivel at Sandy 23 October 1879 (Field). An adult killed, weighing 2 I lb., at Biggleswade 29 July 1883 (Field). One about a third grown, killed at Langford I 7 December I883, and an old male in the same locality I April I 885 . At Beeston one of $24 \mathrm{lb}$. weight was shot 25 December 1885 (Field). A male was shot at Langford I 9 January I 886, another 26 September I 887 , and others 18 December I 893 and 28 May 1895 . An old one and a young killed at Bromham Hall on the same day in 1890 . In January 1886 one of three young, about four weeks old, was killed at Odell; and at the same place in February I 895 three young were found together on an old wooden bridge, evidently having been dislodged by the floods. A male weighing 30 lb. obtained at Shefford 1894. Two young ones, taken below Bromham Bridge 1894 , were reared by hand. An adult shot Io February 1895 on the island adjoining Bedford old baths, and two days later two young ones, about three weeks old, were taken from under the boards at the back of the bathing sheds. A female shot, and two of three young taken from a bed of rushes on the canalized barge-way near Cardington 30 October I 898 . Three half grown otters were seen by the writer 24 December 1900 on the islands near Roxton Bridge, and on 26 December one of about the same size was flushed on the Ouse at Blunham. During January 1902 one was frequently seen disporting itself in the evening in the river close to Bedford Bridge. On 24 January a male was caught and released again at Biddenham. In the same and following year during the months of June several were seen by the writer between Little Barford and Great Barford. In the latter locality I found a much used holt, a large hole in the brickwork of the sluice at Old Mills some I 8 inches above the usual water level. It contained a quantity of dry rushes, and the edges of brickwork were considerably polished by the pads of the animals. Dr. Sprigge mentions that some young found at Great Barford were suckled by a cat. The writer has come across specimens with yellowish buff spots and blotches on the under parts.

\section{RODENTIA}

18. Squirrel. Sciurus leucourus, Kerr. Bell-Sciurus vulgaris.

More or less abundant in the woodlands possession obtained in November I894 at and well-timbered parks, and very common in the larger fir plantations. A variety in $\mathrm{my}$ 


\section{A HISTORY OF BEDFORDSHIRE}

Rowney Warren has the white of the under parts considerably extended, white feet, and a white line along the upper part of the back. Dr. Sprigge mentions seeing one in the woods at Clophill in I898, which appeared to him to be quite black, and $\mathrm{Mr}$. A. Covington once had one sent him which had the tail pied black and white.

19. Dormouse. Muscardinus avellanarius, Linn.

Bell-Myoxus avellanarius.

In an article upon the range of dormice in England and Wales (Zoologist, I885), Mr. J. F. Woods, who formerly lived at Woburn, states that in 1856 he found several in that parish, also at Great and Bow Brickhill and on the Chiltern Hills in Buckinghamshire. Writing to me in reference to these particulars, he adds that the dormice were taken in Lowe's Wood, Charle Wood, about half a mile from the shire oak, the county border, and that since then he had also heard of their being in Milton Wood at Milton Bryant.

20. Harvest Mouse. Mus minutus, Pallas.

I have not yet met with this species in the county; neither have I ever been able to trace any of its remains amongst the thousands of owls' pellets that I have examined from various localities. My father nevertheless mentions that it was not uncommon around his home at Blunham about 1830 , and that he has found its nests there. Mr. J. King also assures me that when a resident at Southill about 1870 he found it tolerably common around there, but he never met with it elsewhere.

\section{Wood Mouse or Long-tailed Field Mouse.} Mus sylvaticus, Linn.

Abundant everywhere, and at times a very destructive little animal, especially in the market gardening lands, where it feeds on cucumber and marrow seeds. During last year I was assured by one man that he had trapped over seventy of this species in a few days on a piece of land about an acre in extent, the traps being baited with the marrow seeds only.

\section{House Mouse. Mus musculus, Linn.}

Very abundant generally. Pied varieties have been occasionally met with.

23. Brown Rat. Mus decumanus, Pallas.

Far too common. Two albinos in my possession were caught at Cockayne Hatley in May 1895, and two of the melanistic form were killed at Stotfold in December
I 896. Others which I have also been enabled to examine were killed-one in the neighbourhood of Luton about 1885 , and another near Harlington in 1901. A male and female were killed at Astwick Mills 8 December I 896 . One was obtained during the summer of the same year at Kempston, and several specimens have been received by Mr. A. Covington from other localities.

24. Black Rat. Mus rattus, Linn.

Probably at one time common enough; the only information we have of its more recent existence is that Davis (History of Luton, I 855 ) records it then as rare in that neighbourhood; it is not improbable that he may have mistaken the black form of the brown rat (Mus decumanus) for this species.

\section{Field Vole. Microtus agrestis, Linn. Bell-Arvicola agrestis. \\ Common generally.}

26. Bank Vole. Evotomys glareolus, Schreber. Bell-Arvicola glareolus.

Fairly abundant. Since this species was first recorded in Bedfordshire (Zoologist, 1 895) I have occasionally found it even exceeding the field vole in number. In some owls' pellets recently examined from Sandy, Bromham, Clophill, Sharpenhoe and Rowney Warren, the remains of 155 mice (chiefly $M$ us sylvaticus), 2 rats, 9 field voles and ro red bank voles were found, besides $3^{8}$ finches and 8 insectivorous birds.

\section{Water Vole. Microtus ampbibius, Linn.} Bell-Arvicola ampbibius.

Common in the immediate vicinity of all our waterways, streams and larger pools. I have sometimes noticed considerable damage to osier beds caused by this vole gnawing and felling the osiers in a similar way to the beaver felling trees, but for what purpose I fail to understand; no portion of the felled osiers had apparently been used as food. An albino of a dingy-cream colour with pink eyes was shot at Henlow Park 23 March 1899. Several of the melanistic forms have been taken; one from a pond at Clapham Park in 1867 ; also two from near the river ford of that village, and two or more from Biddenham many years previously.

28. Common Hare. Lepus europaus, Pallas. Bell-Lepus timidus.

Not so generally numerous as formerly, depending for its existence on the amount of protection afforded it. A jack hare shot at 


\section{MAMMALS}

Ickwell Bury on 28 October I 886 had the fore part of the body pure white, as far as the top of the shoulder (Field). Mr. T. Cane has given me particulars of another that was shot at Dunstable ; it also had the fore parts white, including the shoulders and fore legs, one eye being normal in colour, the other white with a black pupil. One of a uniform pale grey colour was sent in to $\mathrm{Mr}$. A. Covington from Sharnbrook about 1868 ; also another, very similar but patched with white, from Wilshamstead shortly afterwards.

29. Rabbit. Lepus cuniculus, Linn.

Common, but varying considerably in numbers in various localities, and on the whole by no means so abundant as in many other counties. On 4 May Igor I saw two entirely white young ones in company with others on the Sharpenhoe downs. 




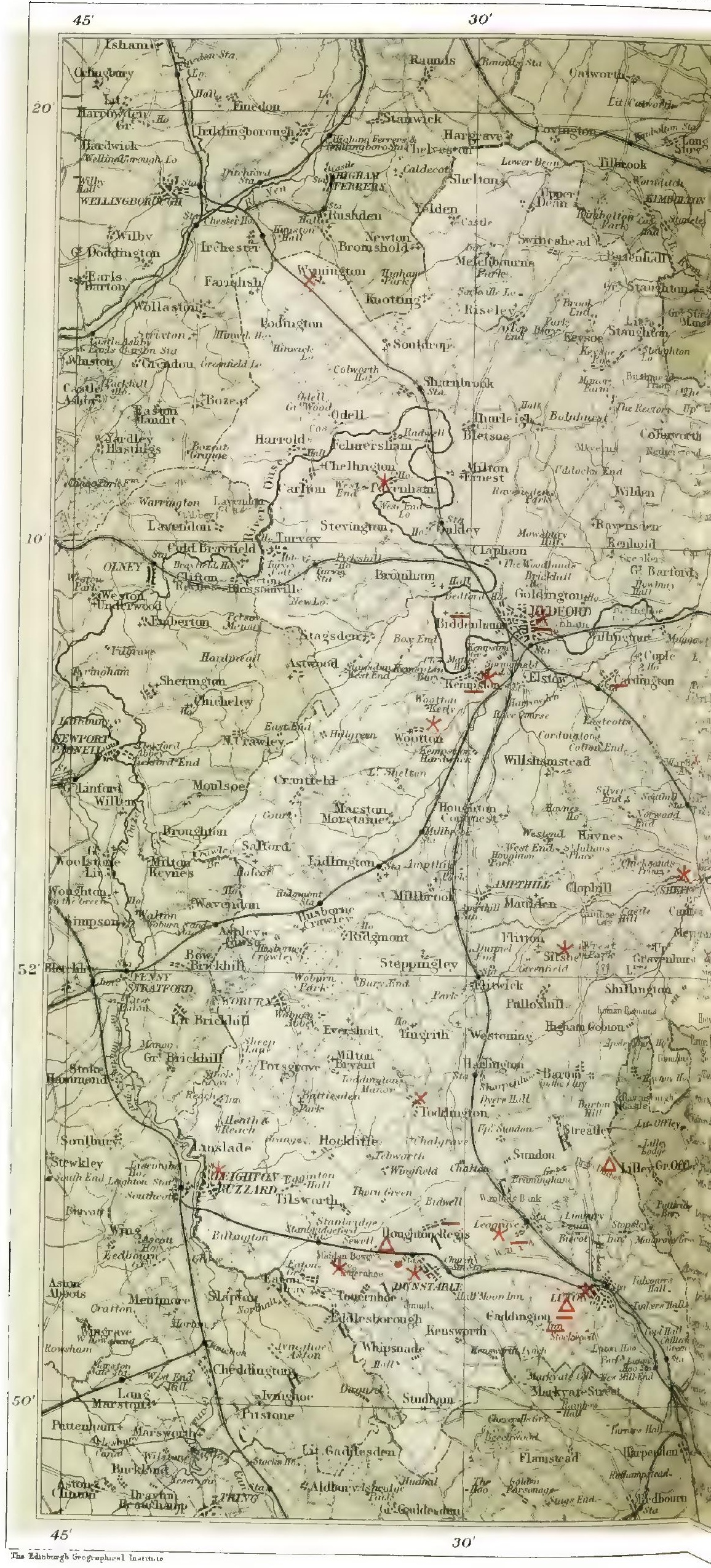


OHC REMAINS.

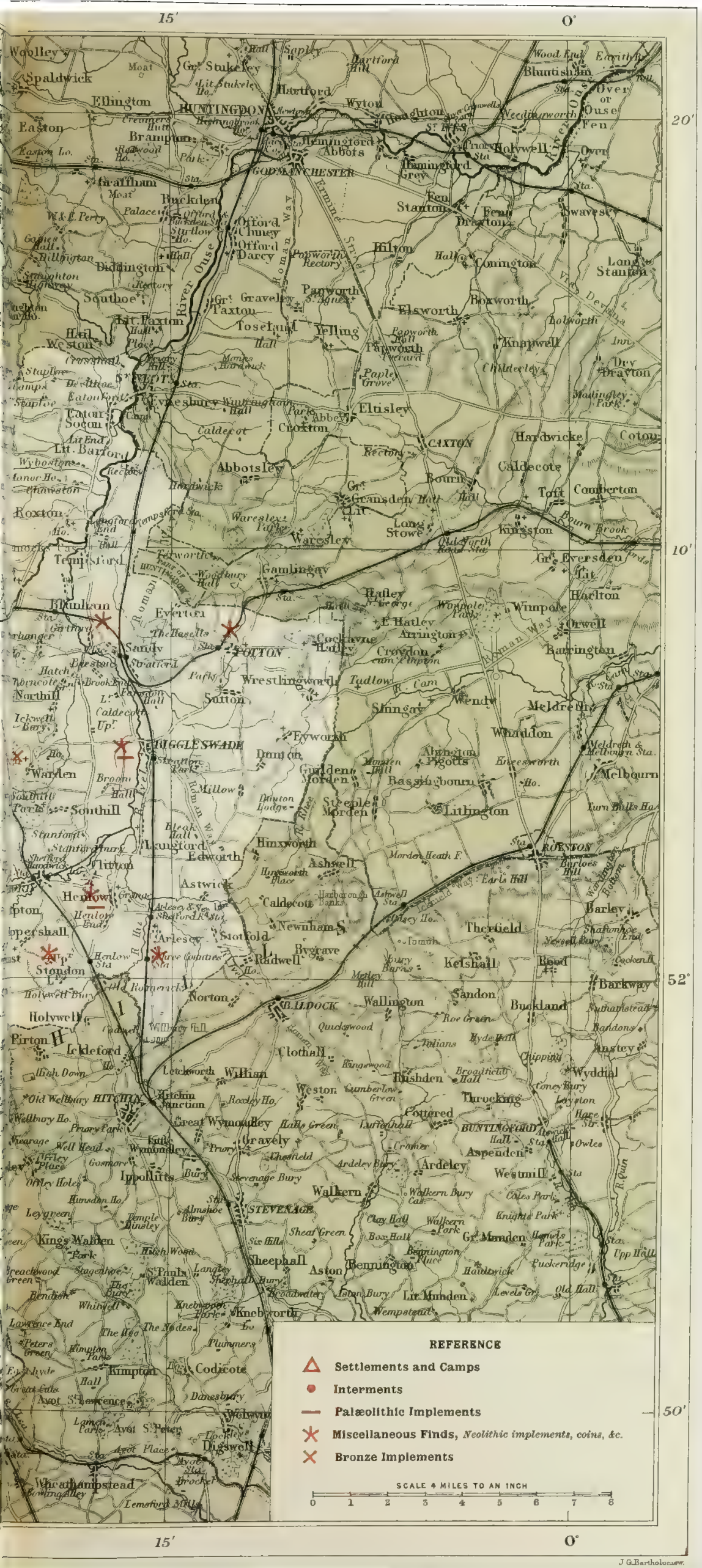





\section{EARLY MAN}

HE prehistoric remains found in Bedfordshire are numerous and of considerable importance, and it is interesting to note that through the action of Mr. (now Sir) John Evans some of the earliest English discoveries of palæolithic implements were made in this county. Mr. Evans visited a gravel pit at Biddenham near Bedford in the expectation of finding palæolithic implements, and although he did not at the time succeed in finding any, the search was vigorously and successfully taken up by the late Mr. Wyatt of Bedford, who as long ago as the early part of I 86I discovered an important series, the chief specimens of which are now in the British Museum. In I 830 a palæolithic implement (fig. I) was picked up at Dallow farm near Luton by a farmer, who, although ignorant of its real nature, was struck by its odd shape and preserved it among some other curious stones. It came at length into the possession of the writer. It may be added that a large number of palæolithic implements has been found in situ at Caddington in the same neighbourhood.

As far as Bedfordshire is concerned there is reason to believe that man's first appearance was made in the early part of the quaternary period, or the pleistocene age, as it is termed by geologists. This was after the deposit of the boulder clays and gravels belonging to the glacial period or periods, and before the deposition of the contorted drift.

Palæolithic stone tools have been found near Bedford at Biddenham, at Kempston, Harrowden, Fenlake and Cardington; at all these places the writer has discovered examples, especially at Kempston, in large numbers. The valley of the Ouzel at Bossington near Leighton Buzzard has also yielded specimens.

Eight miles to the east of Bedford, at Tempsford, the Great Ouse is joined by the Ivel; at this place, and at eight miles to the south at Langford and Henlow, implements have been discovered. Palæolithic flakes and remains of the mammoth have been procured at Eaton Socon, three and a half miles to the north of Tempsford, and palæolithic flakes at Flitwick two miles to the south of Ampthill. Near Henlow the Ivel is joined by the Hiz, and at Ickleford, four miles south of Henlow on the border of Hertfordshire, similar discoveries have been made. 


\section{A HISTORY OF BEDFORDSHIRE}

Palæolithic flakes and mammalian remains have also been discovered at Round Green and Ramridge End one mile north-east of Luton. Other localities are Houghton Regis one mile north of Dunstable, Stanbridge Ford two miles west of Dunstable, near Sewell and near the source of the Ver at Markyate Street at the extreme south of the county.

The more remarkable discoveries are those made by the writer in the brick-earth and contorted drift on the hilltops south of the county, chiefly at and near Caddington, between Dunstable and Luton.

The gravel pits at Bedford, in which palæolithic implements and the bones of Pleistocene mammalia occur, rest on Oxford Clay and the Cornbrash, the upper portion of the Lower Oolite. Resting on the Oxford Clay and capping the adjoining hills is the Upper Chalky Boulder Clay. The valley has been excavated through the Boulder Clay and Oxford Clay, and the implement-bearing gravel contains materials derived from these deposits. No palæolithic implements occur in the two clays, and it is obvious that the deposits in the valley are later in age than the deposits on the hills which have been cut through and exposed in section on the hillsides.

The valley gravel near Bedford is about i 3 feet thick. It consists of subangular flints, yellow, ochreous and brown in colour; oolitic debris; pebbles of quartz and sandstone; new red sandstone conglomerates, and other old rocks derived from the Boulder Clay or other glacial deposits. Its fluviatile character is shown by the numerous shells of land and freshwater mollusca.

Two implements from the Bedford gravels are illustrated in figs. 2

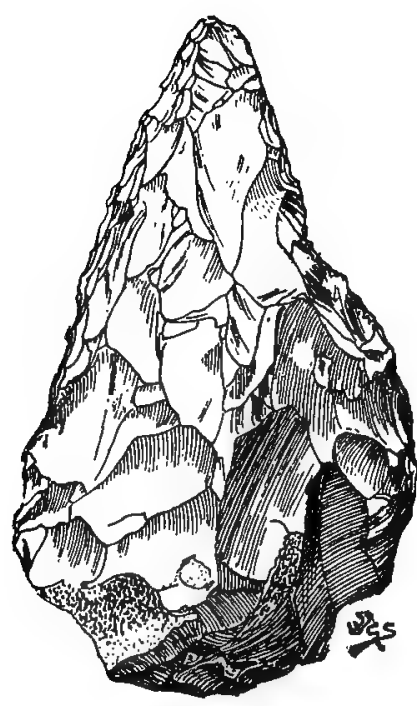

Fig. 2.

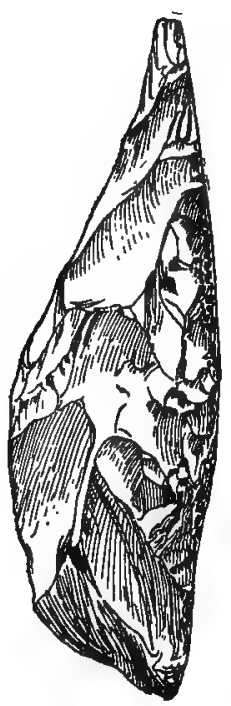

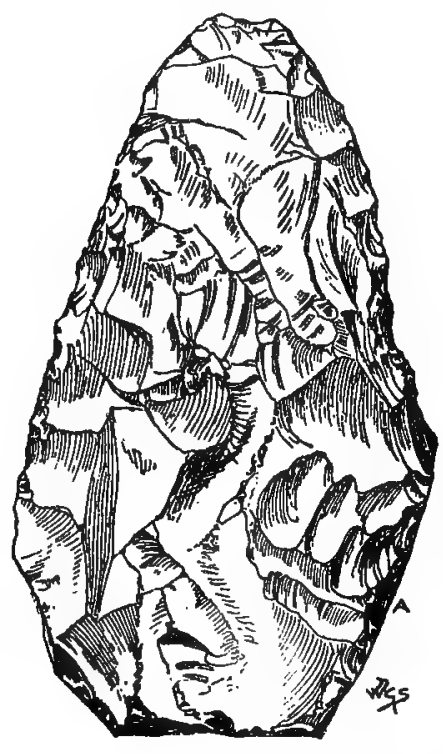

FIG. 3 .

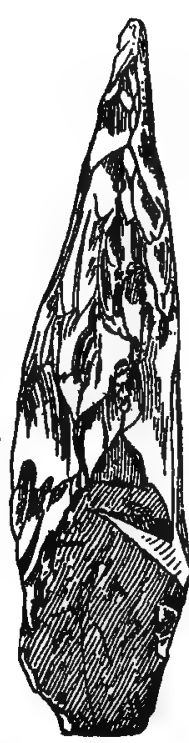

and 3. A third, made from a large natural flake of flint, is shown in
fig 4. One side of this implement, shown on the right, is plain, and, fig 4. One side of this implement, shown on the right, is plain, and, with the exception of one or two human touches, it is natural and covered with glacial striæ. No striæ occur on the portions worked by human 


\section{EARLY MAN}

hands; therefore the implement is of post-glacial age, otherwise the human and non-human work would be equally striated. Excellent
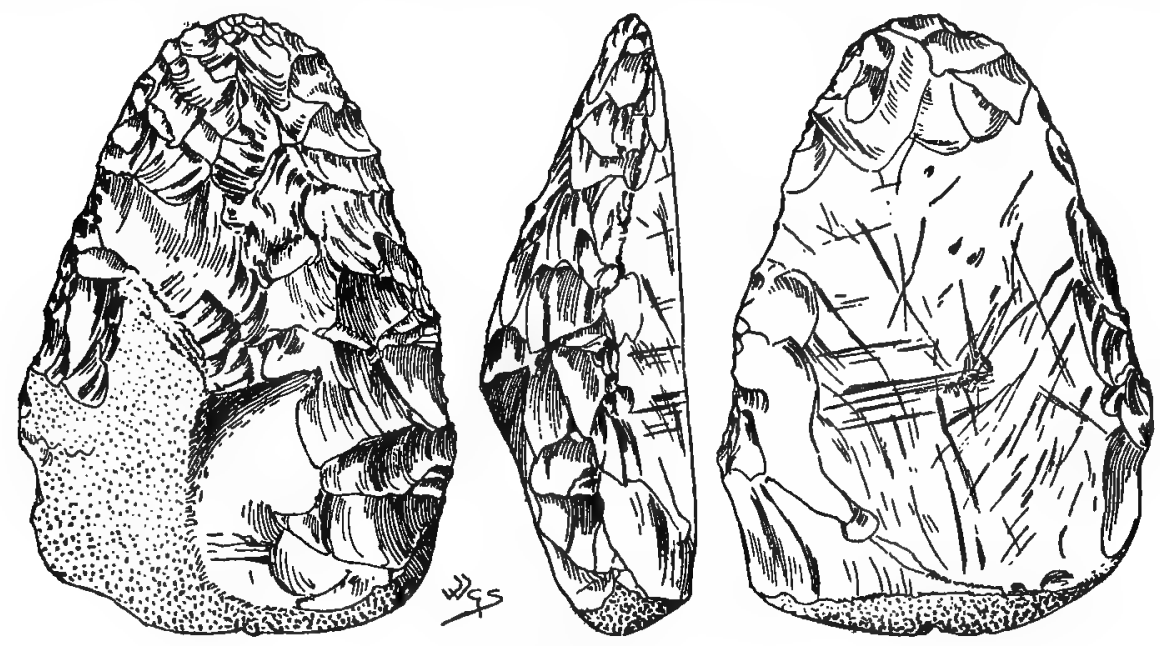

Fic. 4 .

examples of Bedford implements with the original crust striated and the worked parts not striated may be seen in the British Museum.

Implements of the largest size and greatest beauty have been found in the Bedford gravels. They vary greatly in age; some of the newer are sharp and lustrous, and white or yellow in colour ; others and older, abraded, dull and brown. Some again are highly finished, others are very rude. It is remarkable that ovate or roundish implements are rare at Bedford, the prevailing type being pointed. In the south of the county, however, pointed implements are rare and ovate common.

Bedford implements are commonly full of natural fractures made by the pressure of other stones in the gravel bed, so that they are frequently cracked through whilst still in situ, and drop in pieces as soon as disturbed. Absolutely perfect examples are therefore not very common, whilst pieces such as butts, points or fragments from the bodies or sides of implements
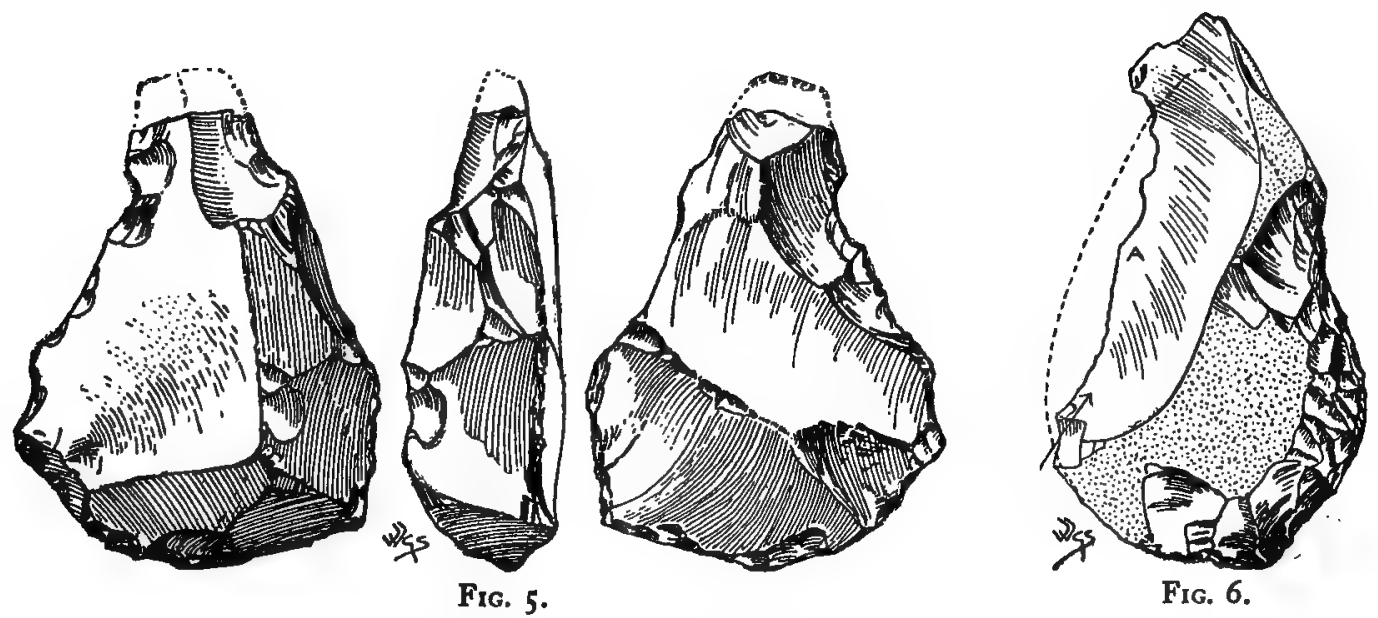

Fig. 6.

are quite common in the excavated heaps of gravel in the pits or by the roadsides. 


\section{A HISTORY OF BEDFORDSHIRE}

The accompanying illustrations are taken from characteristic implements from the Bedford gravels :-

Fig. 5 shows an implement in an initial state, roughed out but never finished; the point has been accidentally broken off.

Fig. 6 shows an implement spoilt in manufacture and discarded. The blow, indicated by the arrow, has ruined the implement, and a large flake, in place of a small one as shown by the surface at $\mathrm{A}$, has been dislodged. The dotted line indicates the form of implement the maker probably had in view.

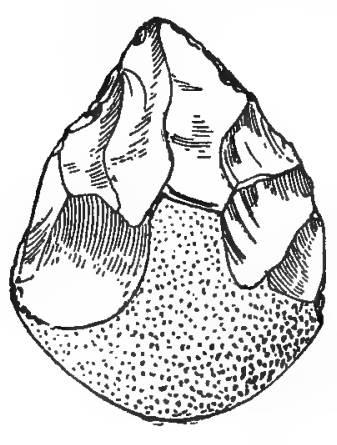

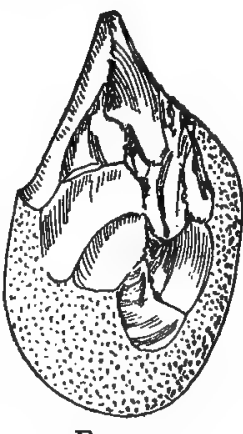

FIG. 7 .
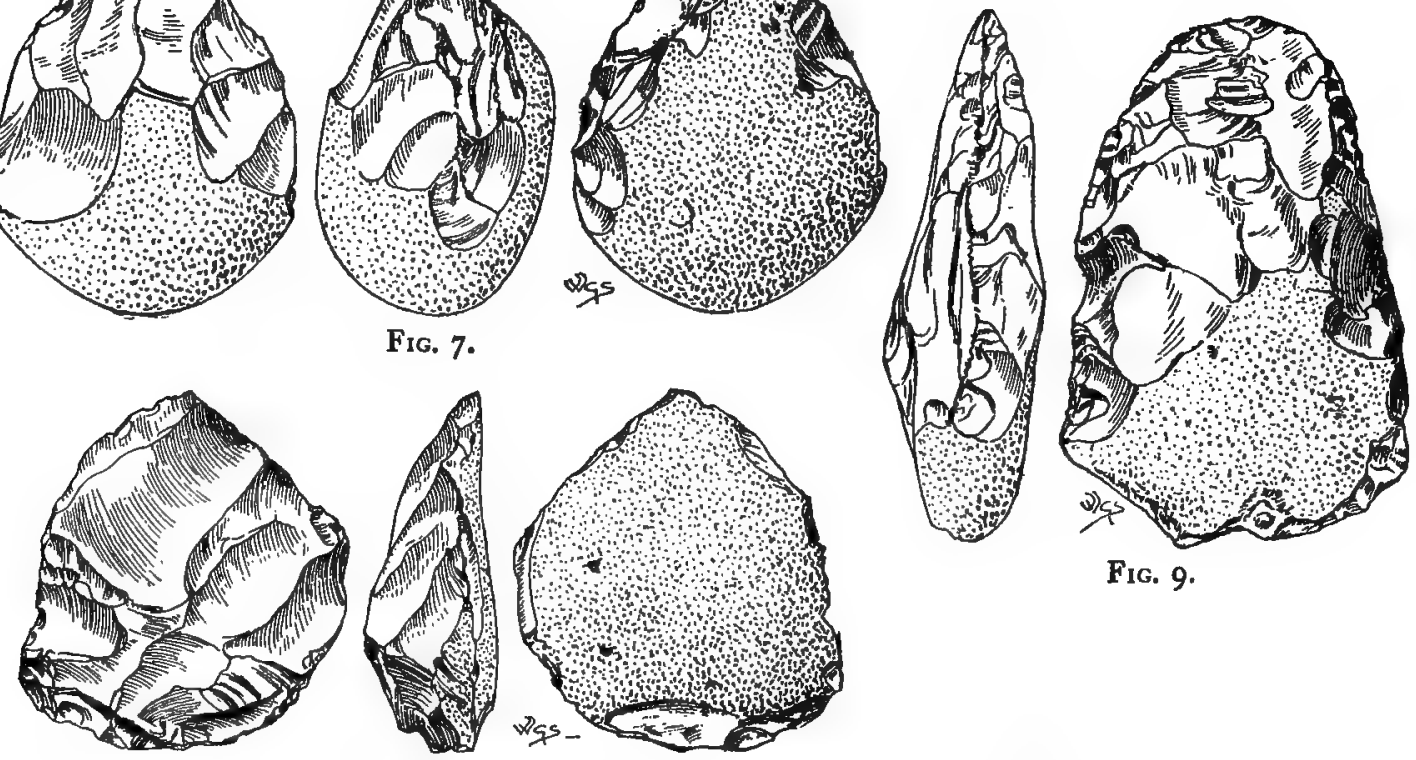

FIG. 9 .

FIG. 8.

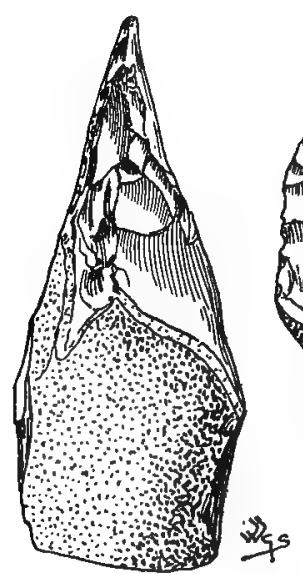

FIG. 9A.
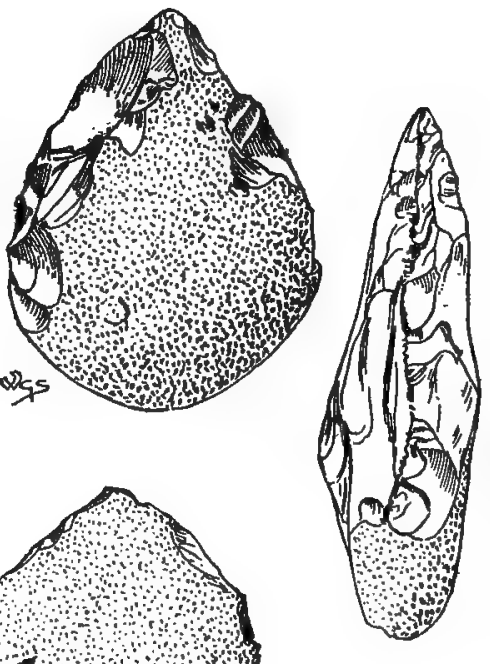

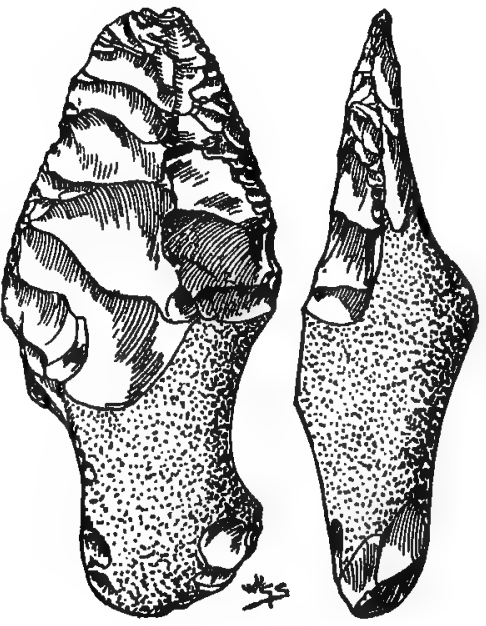

Frg. Io.

Fig. 7 shows a rude implement, made by flaking an ovoid nodule of flint to a point. It is a tool probably made in haste for some temporary purpose.

In fig. 8 is shown an implement made from an outside piece of flint. It is only flaked on one side, the crust side being left almost unworked, 


\section{EARLY MAN}

Fig. 9 shows a typical Bedford implement, of ovate form, worked on both sides.

Fig. 9A shows a chisel or wedge-shaped implement of a somewhat uncommon form.

Fig. Io shows an implement resembling in shape a hafted dagger The stone from which it was made was obviously selected for its convenient natural handle. It was probably used for piercing and cutting.

Fig. I I shows an implement naturally perforated with a round hole at the base. The stone from which it was made was probably selected for this peculiarity.

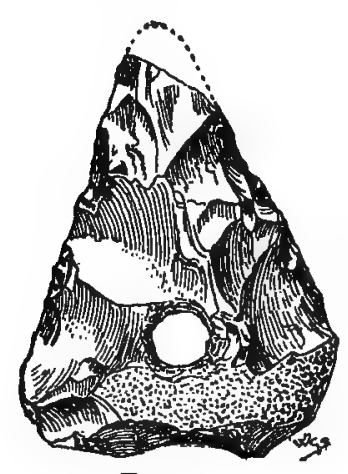

FIG. II.

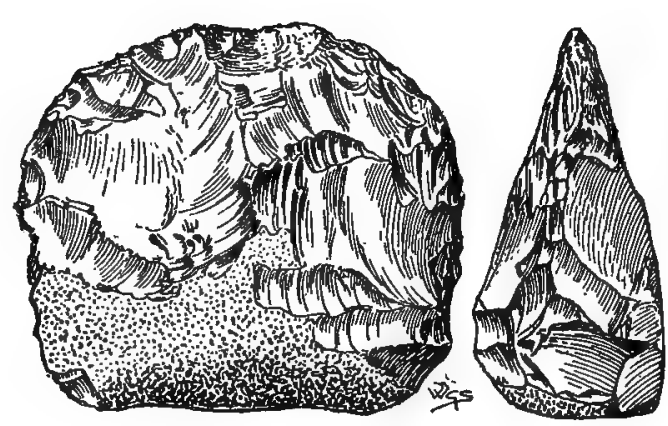

FIg. 12.

In fig. I 2 is shown a chopper-like implement, the natural crust of the flint being left at the base for convenience of handling.

Fig. I 3 shows an ovate, much abraded, dull, opaque brown implement, probably of the greatest palæolithic antiquity as regards Britain, but as no glacial stria are found on implements of this class in
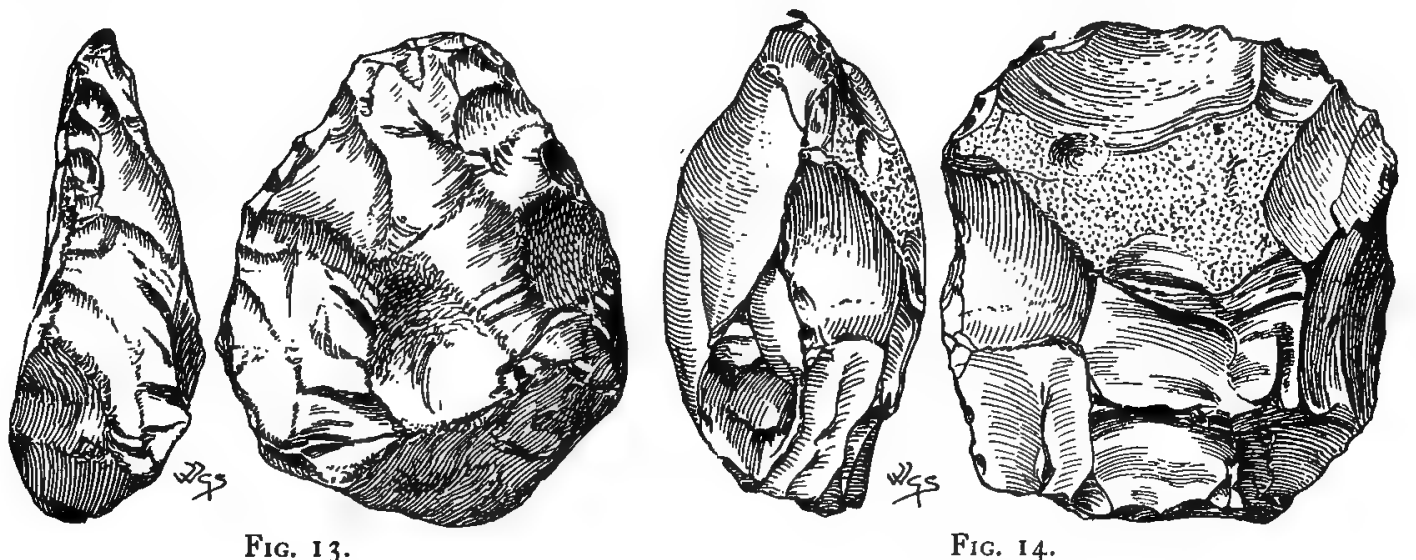

Bedfordshire they are probably post-glacial. Pointed forms also occur. Implements and flakes of this age were sometimes reflaked or repointed by later races of palæolithic men.

Fig. I 4 shows an implement apparently suitable for hammering or smashing bones.

In fig. 5 are given views of two scrapers, made as usual from flakes. The scraping edges are indicated at AA. The bulb of percussion is on 


\section{A HISTORY OF BEDFORDSHIRE}

the plain side, not illustrated, but seen on the edge views at вв. These were probably used for scraping flesh from bones, chiefly perhaps by the older folk who had no teeth equal to the task.

Fig. I6 shows a peg-like tool made from a flake, the bulb of percussion being on the plain side at A. Many examples of tools of this nature, some more highly finished, have been found. They somewhat resemble the neolithic fabricator or strike-light.
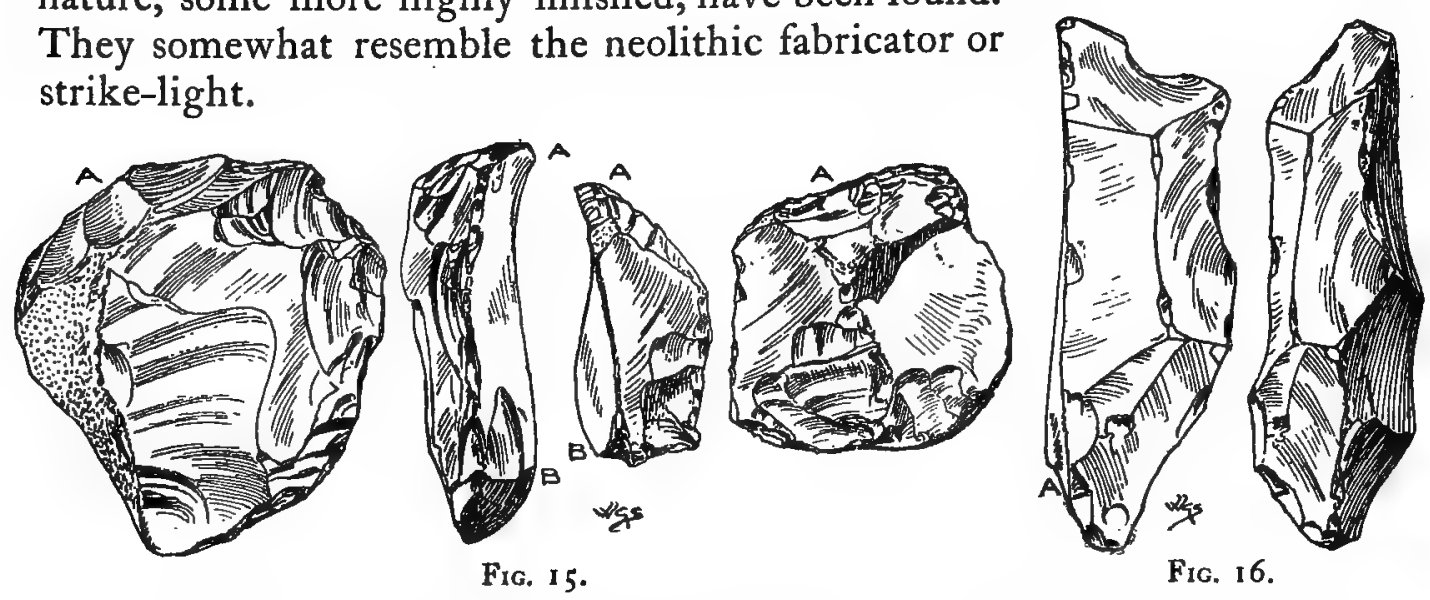

A fossil from the chalk named Coscinopora globularis is common in the Bedford gravels. These curious fossils are each about the size of a cherry, white in colour and furnished with a natural perforation. Collections of them have several times been found in company with implements and flakes, and it is possible that palæolithic people used them for personal decoration as beads. Many have been found with the natural orifice enlarged as if for more convenient insertion of a ligament. Examples from Bedford are in the British Museum.

Until quite recent times it was customary to speak of palæolithic tools as river-drift implements because they were almost invariably found associated with beds of gravel, sand and clay, which had previously been laid down by our present rivers. The implements nearest a river and on the lower terraces were considered to be the newer, and those on the higher terraces the older. From the first however certain implements found on certain high positions and more or less removed from the present rivers were suspected to be of a still greater age, and to belong to the river drift of streams which, owing to the then different configuration of the country and a subsequent change in the valleys, did not run in the present river valleys. In some instances ancient affluents of present rivers, as shown by the contours on maps, must have been dry long prior to neolithic times, because neolithic implements and flakes are now spread generally all over the dry surfaces. There is a former affluent of the Lea of this class at No-man's-land Common near Wheathampstead, Herts, and when the dry banks of this earlier rivulet are excavated palæolithic implements are found.

A good palæolithic flake was found by the writer at Dunstable in 1884 . This, with one or two minor finds of the same class, and the finding of implements at Dunstable later on, led him to search the hills, 


\section{EARLY MAN}

and in 1889 he found at Caddington the first ochreous abraded implement in situ. The height was 595 feet above the ordnance datum, and I 6 feet above the chalk valley. No river is in the neighbourhood, the nearest water, one and a half miles to the south, being a tiny brook, which becomes further southwards the river Ver, and still further south the Colne.

There seems reason to believe that the living places of palæolithic men were not confined to river banks, but that they often extended their place of habitation to inland lakes, ponds and swamps, whether on hills or in valleys. It is however certain that when they lived on what are now the Caddington Hills in south Bedfordshire the present valleys had not been excavated. What are now hilltops were valleys in palæolithic times, surrounded by higher ground with upper chalk and red clay-withflints.

All the implements on the hills, new and old alike, are without exception newer than the Tertiary deposit. The newer men and the older lived on the same swampy ground surrounded by higher lands. The old watercourses no longer exist as such, but they are represented by shallow dry valleys which in their lowest parts still sometimes give rise to temporary drains or brooks.

The first implements found by the writer at Caddington belonged to the older, ochreous and slightly abraded type, but it was subsequently found that under the layer of abraded implements was a series of strata of brick-earth, and upon each stratum were palæolithic implements and flakes. These implements were neither abraded nor ochreous. The lowest stratum was in some cases 40 feet below the present surface, as at Folly Pit near Caddington church, where, at this depth, implements rest direct on the chalk and are covered with brick-earth. The sharp-edged implements are the newer, and they are not confined to Caddington but occur in situ in brick-earth in different directions for several miles. In late palæolithic times the neighbourhood of Caddington was extensively peopled. That the people actually lived and made their tools there is proved by the fact that nearly 600 flakes have been replaced on implements or on other flakes. Examples of these restorations are in the British Museum, University Museum, Oxford, and elsewhere.

The men who lived on the palæolithic floors, chiefly of brick-earth, at Caddington, represented the latest of the palæolithic races. They were in the same stage of savagery or barbarism as the palæolithic men who lived in caves and under rock shelters. As the Caddington men had no homes of this kind they probably made rude shelters or huts of trees and branches. The tools they used were as a rule beautifully made and regular in shape. The ovate implement with a slightly thickened base prevailed as a type ; pointed tools were rare; and the scraper was well known. The flint for tool making and the pebbles of quartzite for the necessary hammers were close at hand in the Tertiary deposit, in the chalk-with-flints and the red claywith-flints. A typical ovate example is shown in fig. 17 and a smaller specimen in fig. 18. The latter is now in the collection of Sir John Evans. 


\section{A HISTORY OF BEDFORDSHIRE}

A chisel-ended example is illustrated in fig. 19 , and four views of another beautiful example of the same class in fig. 20 . In fig. $2 \mathrm{I}$ is represented a well-made acutely pointed implement, a rare form in south Bedfordshire, and in fig. 22 is a sketch of a very rough specimen from the same deposits

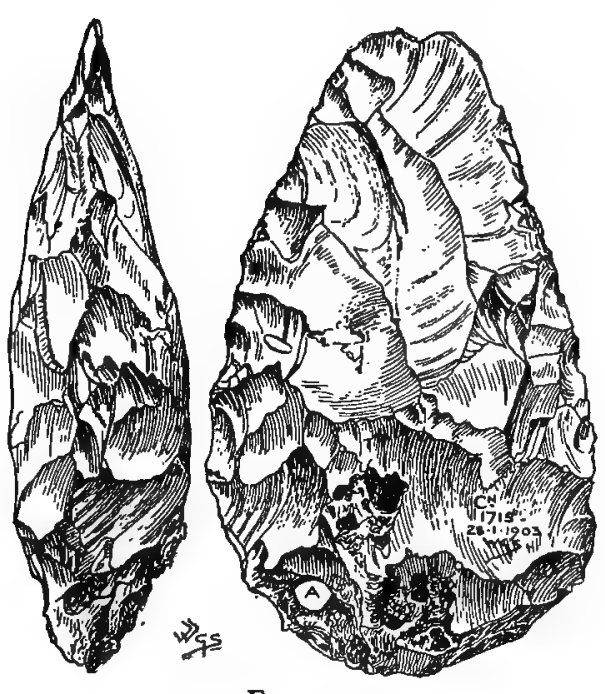

FIG. 17.

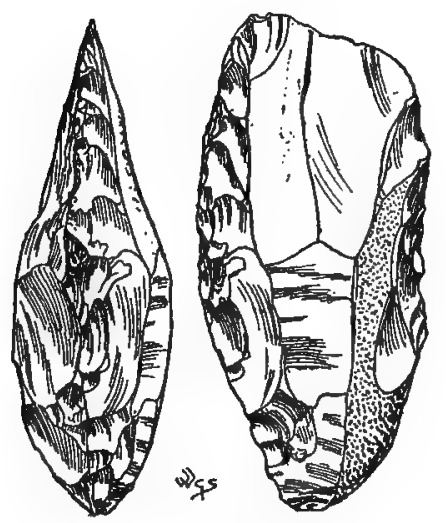

Fic. 19 .

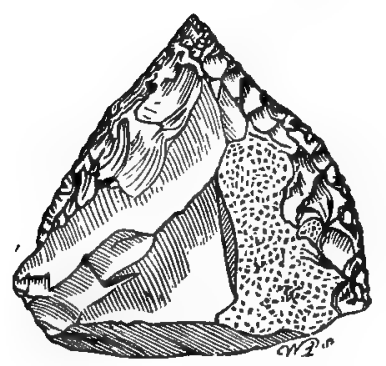

FIC. 21 .

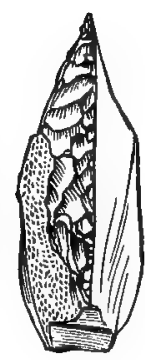

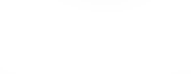
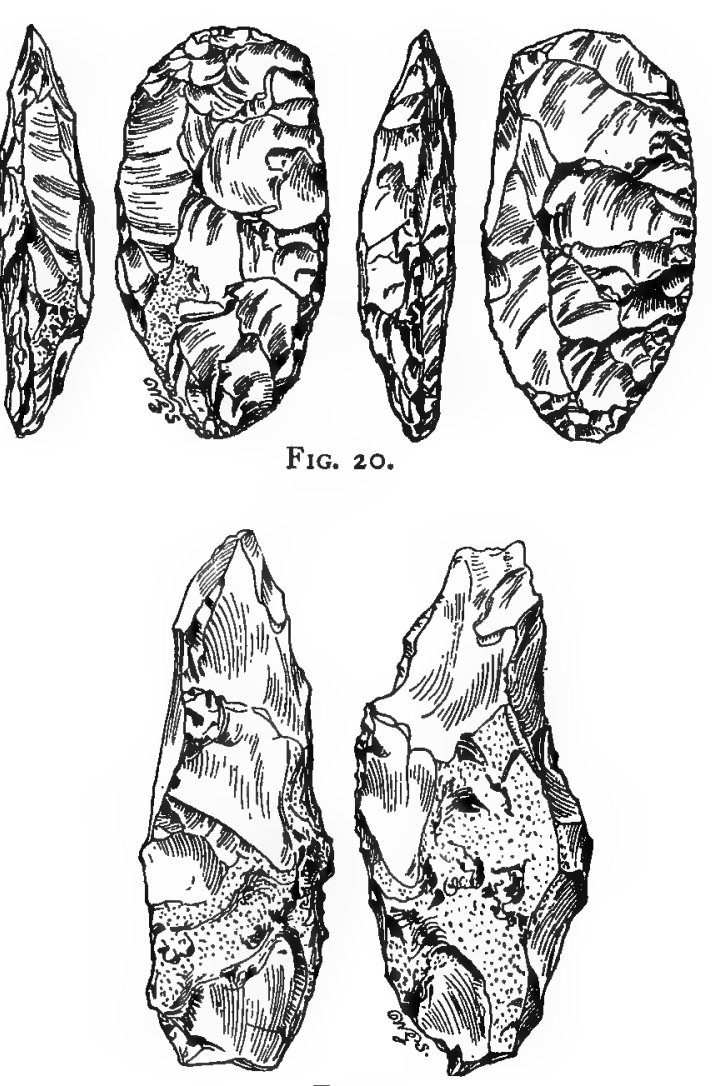

FIG. 22.

with the highly finished examples, showing that rudeness alone is no criterion of age. This specimen was probably made by a beginner, or in some sudden emergency. Tools of this class do not indicate stages of evolution from lower to higher forms; they are simply failures, make-shifts, attempts on intractable flints, or accidental abortions, made by the men 


\section{EARLY MAN}

who were capable of making and did make the finest and most regularlyshaped tools.

In the brick-earth deposits scrapers are fairly common. A fine, elaborately worked example is shown in fig. 23 ; one with less work is illustrated in fig. 24. A few finely-worked, small implements and lance-like
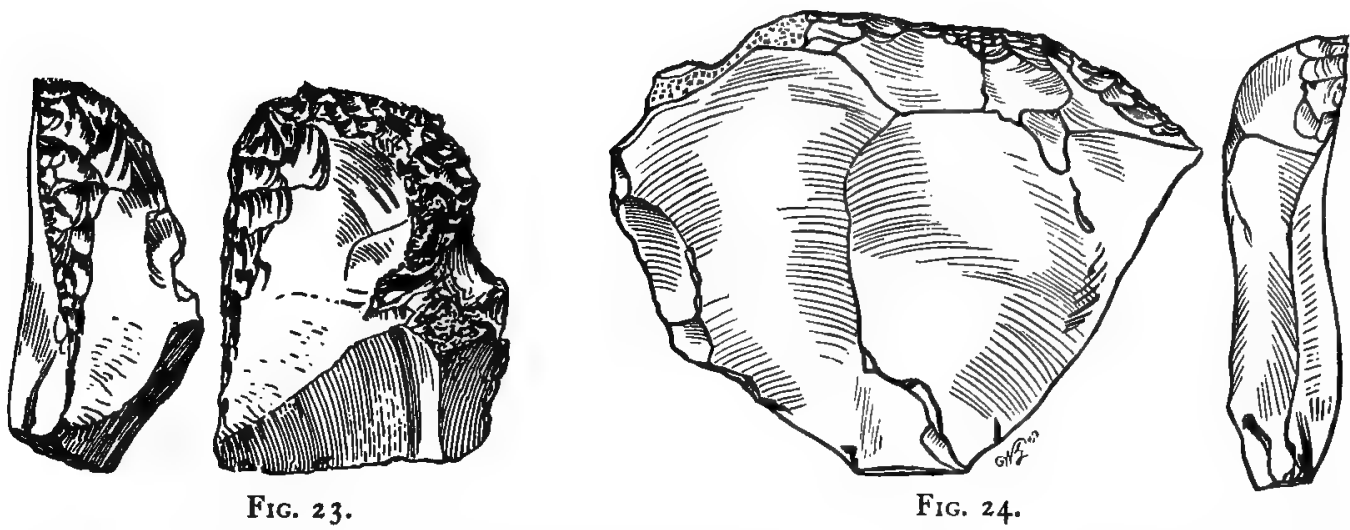

forms, some only 2 inches in length, have been found. Various forms of implements of erratic shape and some of uncertain use occur. One of these is illustrated in fig. 25. Flints of this class were possibly throw-stones or

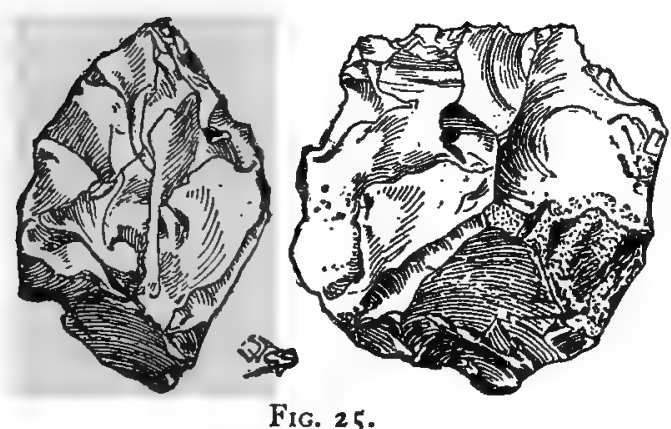

Fig. 25 .

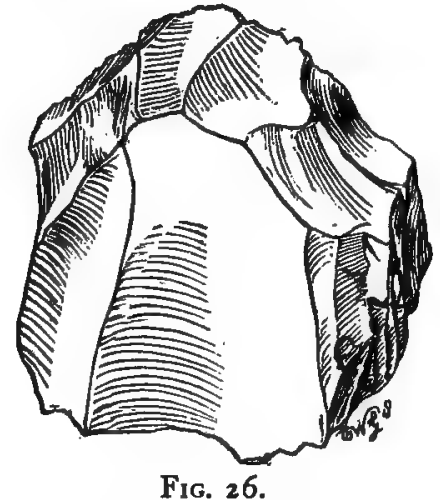

Fig. 26.

missiles; the one illustrated weighs $6 \frac{\mathrm{I}}{2} \mathrm{oz}$. Several other specimens and some more symmetrical have been found. A core from Caddington is shown in fig. 26 for comparison.

At Caddington the surfaces upon which the palæolithic folk lived are at times clearly visible on the sides of excavations, sometimes merely as a line of somewhat different colour from the mass of brick-earth. On a line of this sort have been found several implements without flakes or any other stones. At other times there have been many flakes, with implements finished and unfinished, broken examples, failures, cores, flakes and blocks of selected flints approximating in shape, and suitable for implements, all in the position in which they were left by the implement makers. It was possible to see, by careful observation of the surrounding litter of flakes, the places which the tool makers actually occupied while manufacturing implements. Certain of the flakes had been trodden upon and broken, but 


\section{A HISTORY OF BEDFORDSHIRE}

the broken pieces remained in juxtaposition. Before these positions could be seen it was necessary to remove from Io feet to 40 feet of brick-earth.

In fig. 27 is represented one edge and face of a large implement found at Caddington. In fig. 28 the back of this implement is shown, and on the
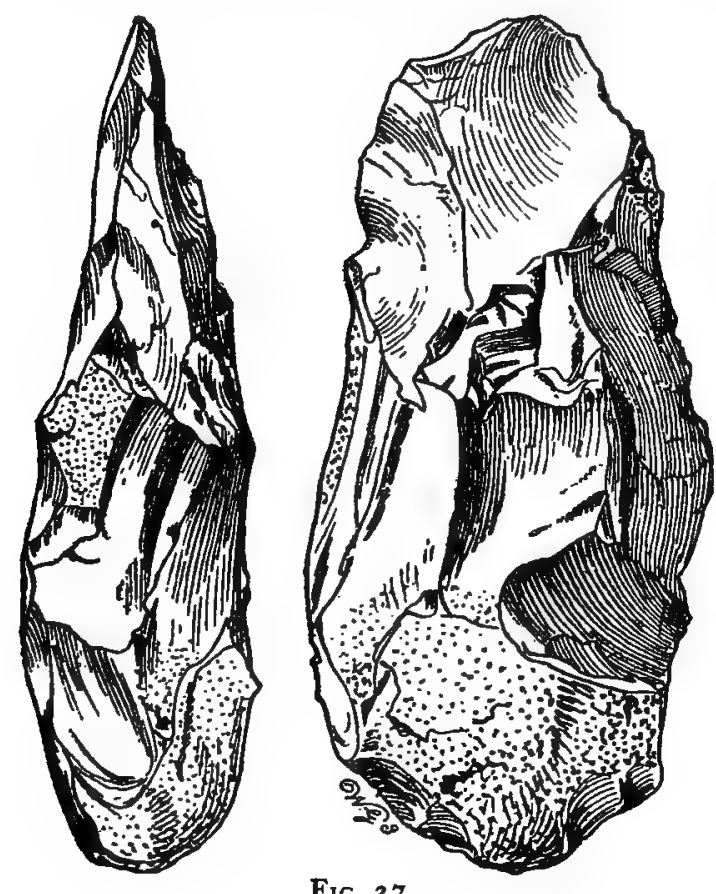

right three conjoined flakes, which were found four years before the implement, in April and August 1890. These three flakes fit on to the back of the implement. Fig. 29 shows, on the left, the appearance of the left edge with flakes conjoined to the back and one flake to the front at $A$. On the right is shown the front of the implement with one flake reattached at $\mathrm{A}$, and conjoined flakes behind. Fig. 30 is a representation of the back of the implement, as covered with re-united flakes, part of the tool itself being seen at $A$ and $B$, and on the right, the right edge of the implement with

Fig. 27.
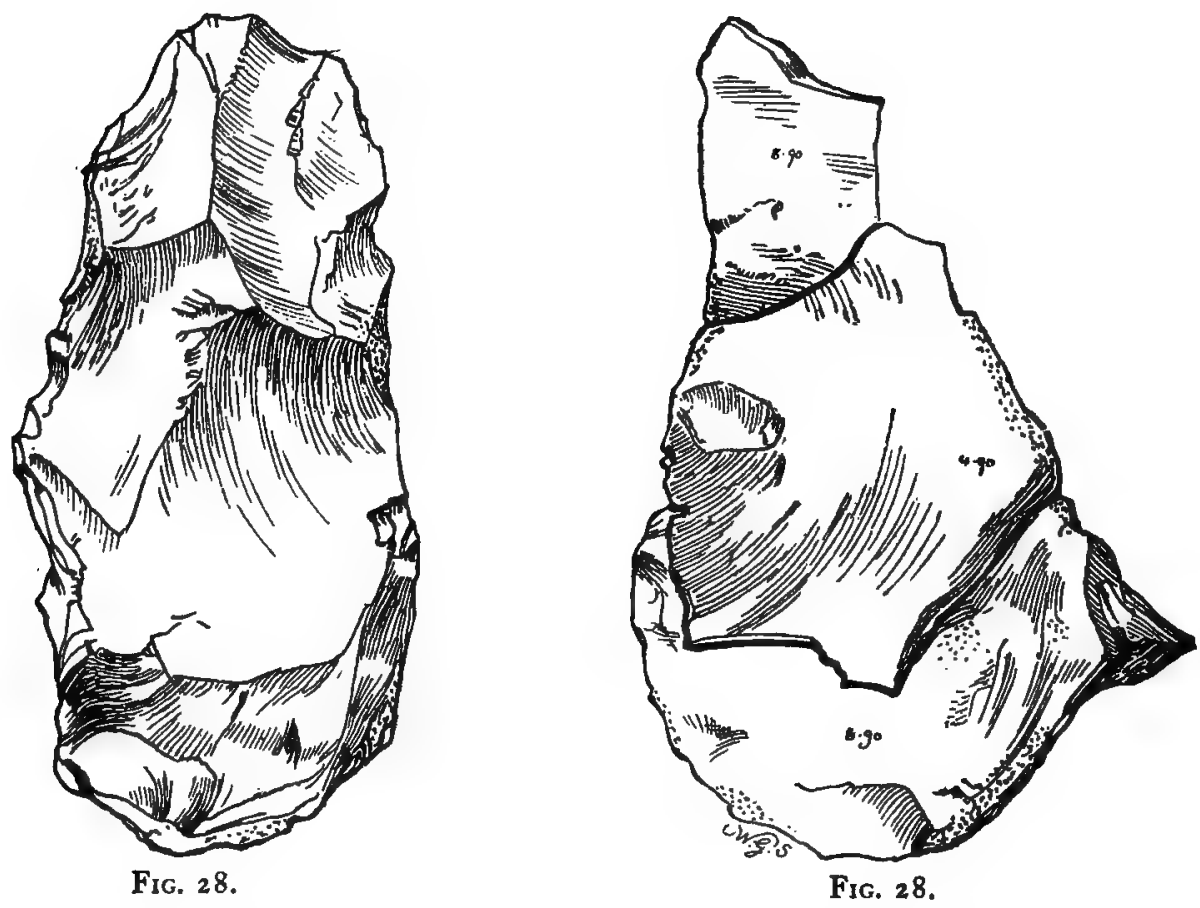

flakes conjoined. With the flakes re-attached the implement weighed 2 lb. $9 \frac{\mathrm{I}}{4} \mathrm{oz}$.

Palæolithic implements of apparently the greatest age occur in the I54 

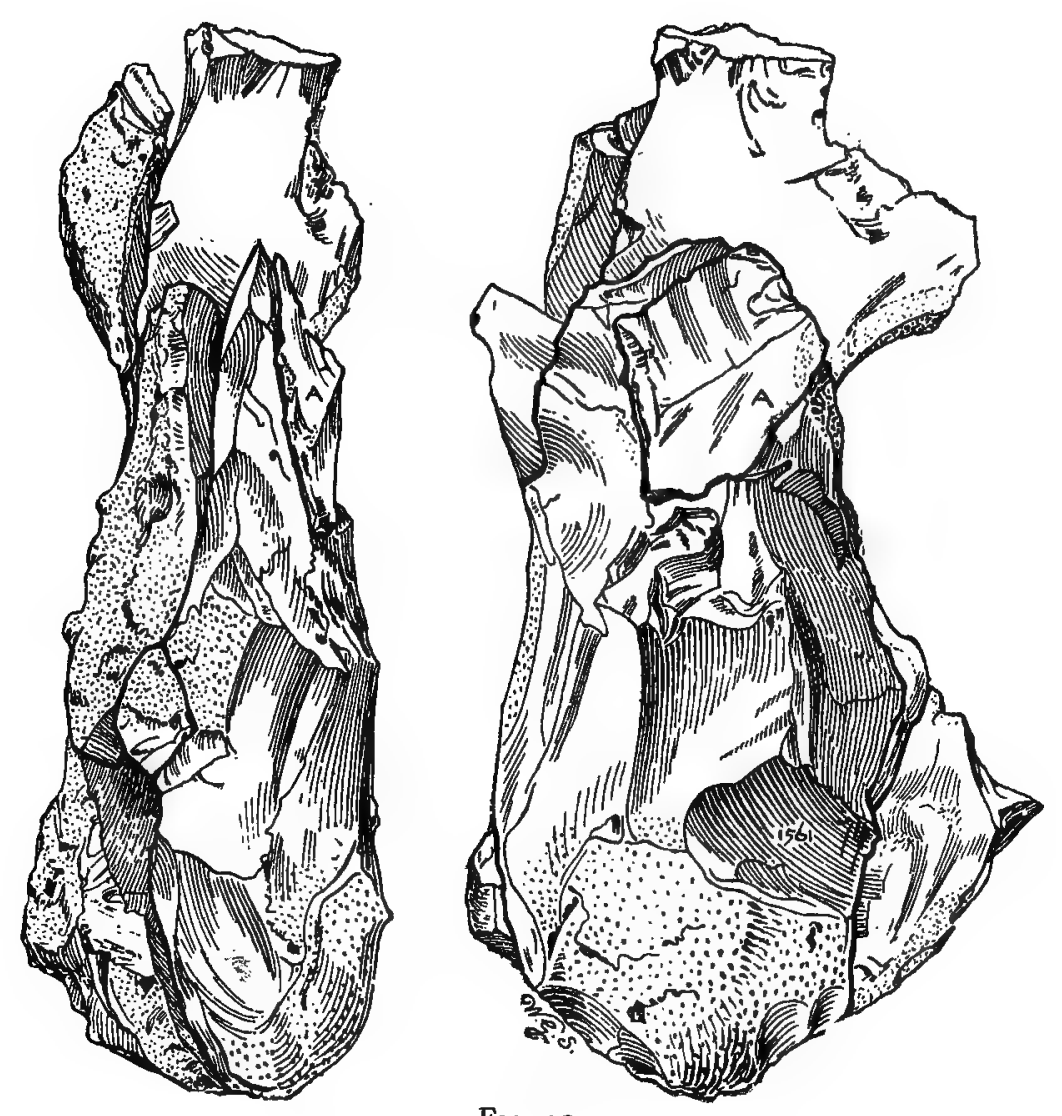

FIG. 29.
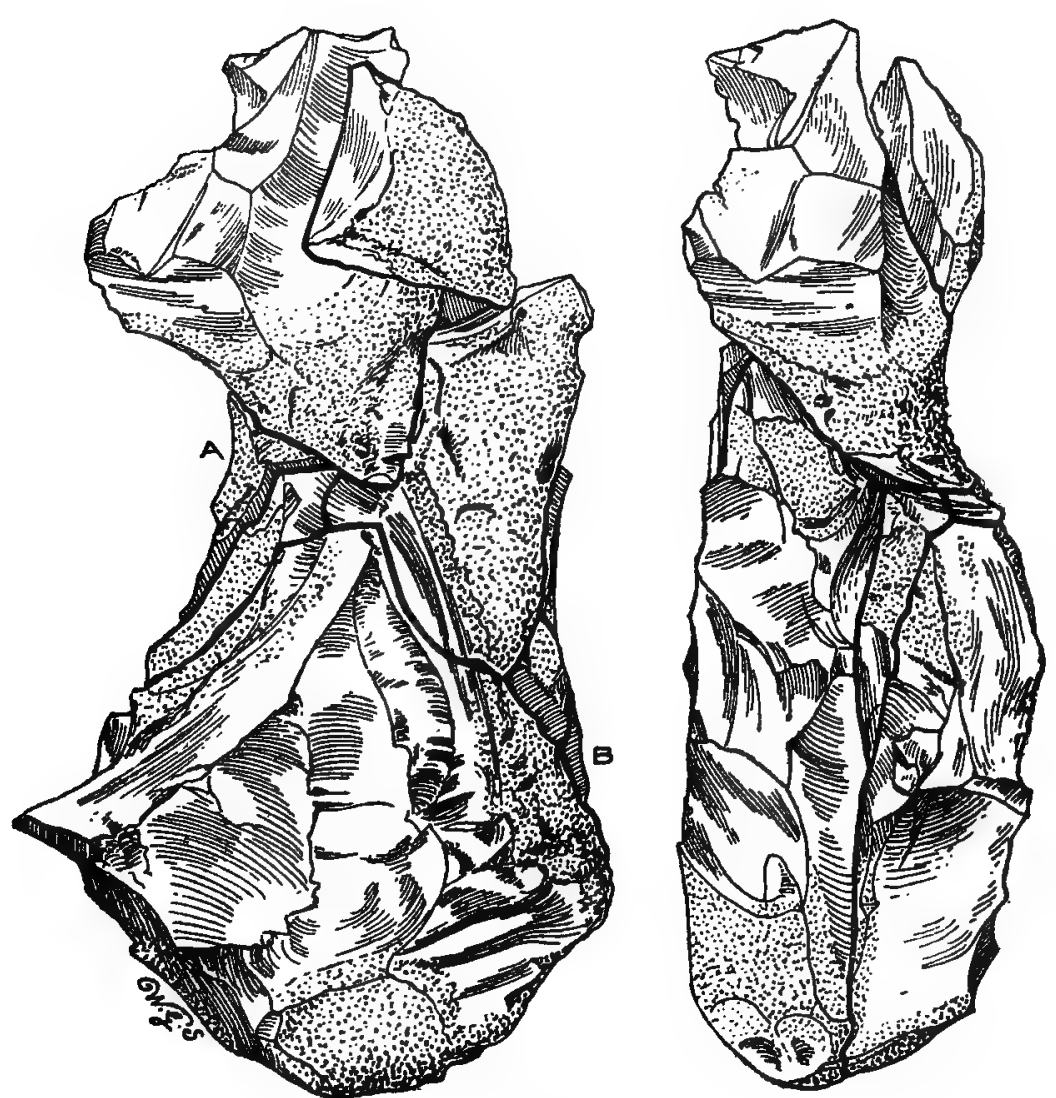

Fig. 30.

I 55 


\section{A HISTORY OF BEDFORDSHIRE}

surface deposit named contorted drift. They almost invariably lie too deep to be turned up by the plough, so are rarely found on the surface. This fact is of great importance, for there must needs be some doubt as to the age and origin of implements found on the surface. The contorted drift at Caddington has usually the deep red colour and tenacity belonging to red clay-with-flints. Red clay-with-flints occurs in situ in the neighbourhood close by, and it must have been extensively present, together with chalk-with-flints before the contorted drift was deposited. In a disturbed or relaid state both red clay-with-flints and chalk-withflints are apparently extensively but irregularly deposited over the hills of south Bedfordshire. The contorted drift in its passage over the old land surface of chalk, Tertiary deposit, chalk-with-flints and red clay-with-flints, brick-earth, and ancient gravels, necessarily incorporated the materials of these deposits into its own substance, and as palæolithic implements, both older and newer, were resting on these deposits it follows that palæolithic implements of all ages are found in it. Such is the case, for a few implements with edges as sharp as knives have been found, together with others, which, from their general rudeness, peculiar colour and mineral condition are obviously very much older.

The older palæolithic implements range in style from very rude tools to occasional implements of the highest finish and regularity of form. There is no abrupt line of demarcation between rude and finished forms. The ruder predominate, but every intermediate form occurs. They vary in colour, according to the tint of the contorted drift in which they are found, from dark brown and liver colour to dark and pale red, and yellow. The progress is continuous throughout in workmanship, colour, mineral condition and abrasion. Notwithstanding these facts it is obvious that some of the older tools are very much older than others, but as no tools are glacially striated and no implements occur in the local and sometimes adjoining glacial deposits it seems desirable, with our present knowledge, to consider the oldest of the old tools as post-glacial in age. Every known form of palæolithic implement occurs amongst these older tools; pointed, ovate, chisel-edged, fabricator-like tools, missile-like nodules, scrapers, cores, flakes and all the erratic forms common to implement-bearing gravels. The majority of the older tools are a little abraded, in a few the abrasion is considerable.

Amongst these remains are numerous pieces of tabular flint with edges sometimes artificially but more often naturally chipped or bruised. The chipped edges of these flints vary in colour in exactly the same manner as the chippings upon the finished implements. The chipping therefore may be classed as older or newer, whether artificial or natural, and it is evident that it belongs to the latest palæolithic period.

In naturally broken flints it commonly happens that one part has a weak and thin edge. This thin edge is especially liable to become broken in a way that suggests a hollow scraper, but such natural stones must not be confounded with true hollow scrapers, which are amongst the latest, highly specialized stone tools. 


\section{EARLY MAN}

A skilfully made ochreous ovate and slightly abraded implement is illustrated in fig. 3I. It is now in the collection of Sir John Evans. A more finished ochreous example, now in the British Museum, is shown in fig. 32. Specimens still ruder are frequent in the contorted drift. The same deposit at Caddington produced the original of fig. 33 , an instrument of the highest possible finish. It is nearly perfect in shape, and its cutting edges are designedly incurved. Some of the flakes that were detached in its manufacture were minute and as thin as writing

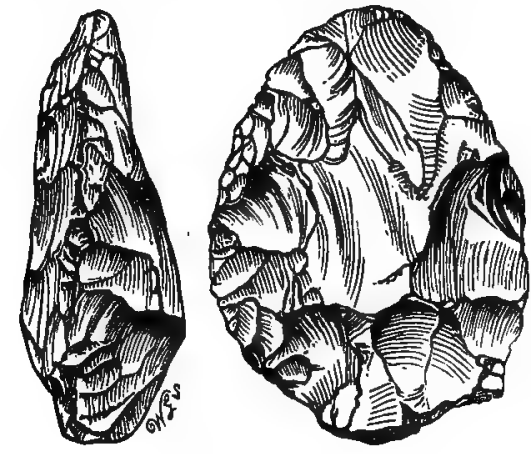

Fig. 3I.

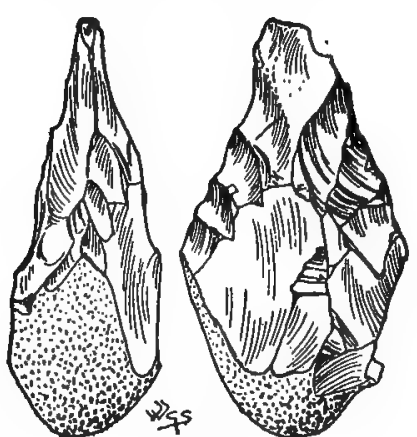

Fig. 34.

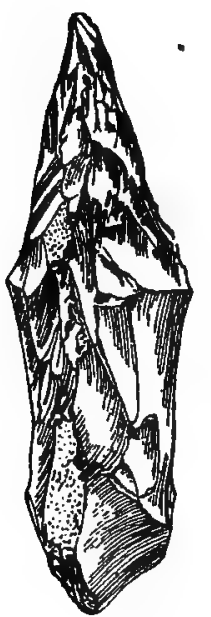

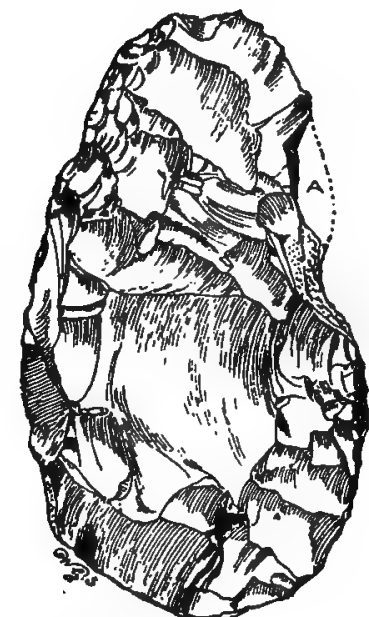

FIG. 32.

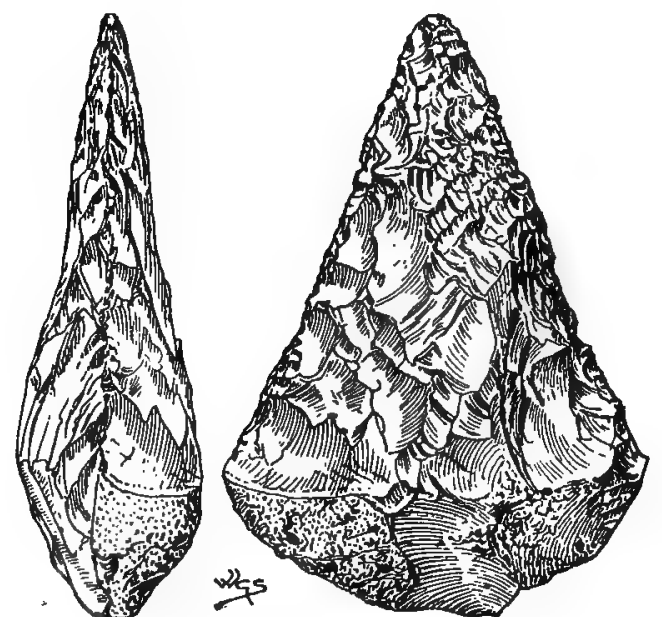

FIG. 33 .

paper. It is slightly abraded and chocolate-brown in colour. From the same deposit and close by in the same pit at Caddington an implement of the rudest class has been found, in precisely the same mineral condition, of precisely the same colour and abraded to precisely the same extent. The original of fig. 34 , a pointed implement probably made in haste, by a few well directed blows, was also found in the same deposit as the last, and at the same place.

The elaborate inplement was not, during the stay of primeval man in what is now Bedfordshire, evolved from the rude forms. Both were made at the same time, by men of the same race, and many examples by the same man. The original of fig. 33 seems to have been made with more care than was actually necessary for any work that a savage might have ever wished to execute. The rude tools had as much work ex- 


\section{A HISTORY OF BEDFORDSHIRE}

pended upon them as was necessary. The man who made the original of fig. 34 could have made the original of fig. 33 had he felt so disposed. The rude specimen doubtlessly possesses primitive characters, but the man who made it was not more primitive than the man who made the elaborately worked implement.

An example of a scraper is illustrated in fig. 35 ; and a smaller, finer,

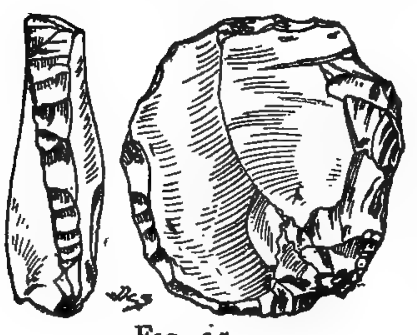

FiG. 35 .

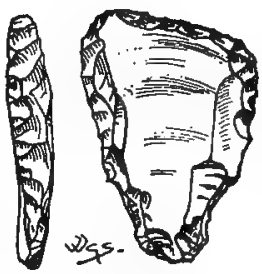

Fig. 36 . and more elaborate specimen in fig. 36. Both these have a well marked bulb of percussion on the plain side.

A rude and remarkable palæolithic implement, roughly hewn from a massive bulbed flake of Hertfordshire conglomerate, is illustrated in fig. 37 . It is faintly ochreous and lustrous, and very different in appearance as regards colour from newly broken conglomerate. It was found in an excavation of contorted drift on Caddington Common. It appears to be an attempt at an implement of the well known hump-backed form, rather

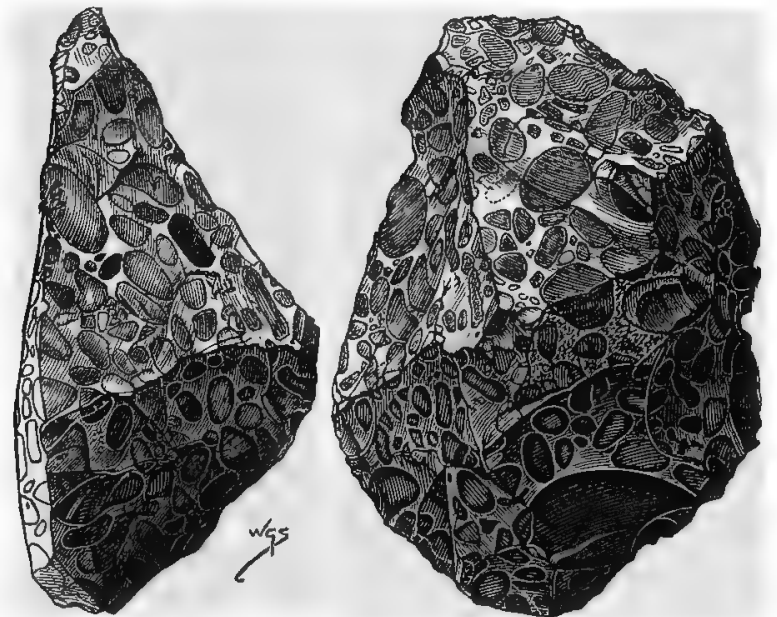

Fig. 37 .

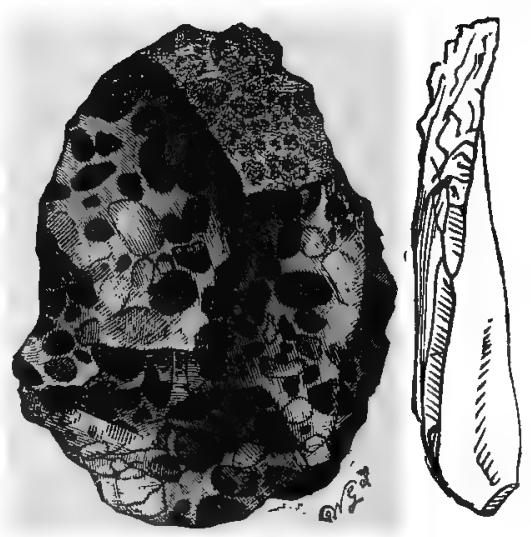

Fig. 38 .

than a finished tool, and perhaps owing to the highly intractable nature of the stone it was left in a roughly hewn state. A flake of Hertfordshire conglomerate, found in a field near by, is illustrated in fig. $3^{8}$, and two other palæolithic flakes of the same material have been procured from Caddington. ${ }^{1}$

\section{THE NEOLITHIC AGE}

There appears to have been a gap of unknown centuries between the departure of palæolithic man from Britain and the arrival of his Iberian, non-Aryan, neolithic successor. The lapse of time was sufficiently long to allow of the covering up of such of man's implements

1 All the examples of palæolithic implements illustrated in this article, with the exception of one or two given to Sir John Evans, have been presented to the British Museum. 


\section{EARLY MAN}

as were left in limestone caves, by thick coatings of stalagmite, and for a considerable encroachment of the sea owing to the gradual depression of the land between Britain, France, Germany, Denmark and Scandinavia.

The palæolithic and neolithic ages were probably continuous in southern Europe, northern Africa and in Asia; the local break in Britain being caused by the depression of the land and its isolation from the continent of Europe. The general contour of the country and its river drainage was much the same in neolithic times as now.

Neolithic man probably arrived in Britain across the Straits of Dover by means of rude canoes formed of tree trunks hollowed out by fire, or on rafts, but the actual date of his arrival is unknown. He came long before the introduction of bronze. Sir John Evans states that cutting tools of stone began to be superseded in this country 500 or 600 years B.c. ${ }^{1}$ He probably migrated to this country from the east or south-east, from lands that were the native homes of some of the quadrupeds he brought with him, viz. from the central plateau of Asia. In this position domestic animals had been for long ages under the dominion of man. This conclusion as to the place from which neolithic man started is confirmed by the seeds he brought with him and planted, such as wheat, barley, culinary peas, etc.

The land at the beginning of the neolithic period consisted of thick virgin forest, bush and bog; there were probably few men and consequently no roads or trackways. The climate was wet, more hot in summer and more cold in winter than now. The exposed heights, such as the chalk hills of Bedfordshire, were probably covered with bush. The lowlands were forest and swamp. The neolithic folk in course of time occupied all parts of Great Britain. They were Iberians, a long-headed race which dominated northern and western Spain and gave the ancient name of Iberia to what is now Spain and Portugal. They were the Silures of Tacitus, the men who erected cromlechs, made avenues or alignments of unhewn stones, threw up long tumuli or barrows, and in places where large stones occurred constructed chambered tumuli and erected circles of large stones.

There is what appears to be a remarkable long barrow on Dunstable Downs near Pascombe Pit, but its age must remain uncertain till it has been opened and the contents examined. On the northern base of Dunstable Downs and on the northern side of the Icknield Way a considerable number of interments are reported to have been disturbed in 1784 . These, at the time, were considered to be comparatively modern, and to represent the people of Dunstable who had died of the plague in I 603 and 1625 . The remains of a long barrow standing east and west still exist in a mutilated state in Union Street, Dunstable. Fifty years ago this barrow was very distinct and was called Mill-bank, from its former use as a foundation for a windmill. Two hundred yards to the east was

1 Sir John Evans, Ancient Stone Implements, ed. 2, p. 147. 


\section{A HISTORY OF BEDFORDSHIRE}

a large round barrow, and an ancient trackway could be traced from between these barrows to the chief entrance of the British camp named Maiden Bower. Flint flakes are abundant round the sites of both barrows.

The people of the later stone and bronze ages lived chiefly in places where water was conveniently at hand, in camps protected by ramparts, ditches and palisades. They had look-out huts on all the high positions and in places bordering their trackways. Their houses were huts or wigwams of sticks and skins.

The chief neolithic weapons and tools were the axe and adze, often partly or wholly ground, the pick, lance, dagger, arrow, sling-stone, knife and scraper. There were also many minor tools, some of unknown use. These relics are generally distributed over Bedfordshire, being more commonly found in valleys, on plains, and near rivers and watercourses than on the hills.

The newer stone implements are often called 'surface implements,' because they are commonly found on the surface of the ground. They are best seen in harrowed fields after showers of rain. They are constantly turned up by the plough, and are not uncommon on heaps of flints in fields, by the roadside and in cart ruts. They are often found in and near ancient camps, by water-courses, in sheltered places at hill bottoms, and in tumuli.

It will be convenient to illustrate the neolithic and later surface weapons and tools of Bedfordshire at this place. Some examples are many years older than others, but none are so old as the palæolithic age. These implements are spread irregularly all over Bedfordshire. Strange as it may appear, centuries of field cultivation have made but little difference in the nature of their positions. The interior of the camp called Maiden Bower near Dunstable contains, or has contained, many stone implements and flint flakes. For a certain number of yards outside the camp the same abundance prevails, but beyond a given circuit both implements and flakes are rare. The camp and the adjoining fields have been under cultivation for centuries, yet the old average of worked and unworked stones still holds good. Under the turf on the top of the earthen bank which surrounds this camp, a group of several stone mullers was found, and at another time a collection of sling or throwstones on the very spot where they were made and laid down for use. Luton.

The same is true of the camp called Waulud's Bank near Leagrave,

A little more than a mile south of Dunstable there is a place named on the ordnance maps Mount Pleasant, a large, high, wind-swept, almost treeless hill. Immediately to the south of this place surface implements and flakes have been found in abundance, but always within a given circuit; outside this region even flakes are rare. Mount Pleasant in ancient British times must have been a living place and a place of manufacture of stone tools. A similar prolific place occurs at half a mile southwest of Dunstable, just east of the place named 'California' on the 


\section{EARLY MAN}

ordnance maps. Other places of the same sort occur between the base of Dunstable Downs and the Icknield Way.

The celt, so named from its chisel-like cutting edge, is one of the best known of neolithic implements. It occurs in an unground, partly ground, or wholly ground state, and was used mounted in a handle or unmounted. One out of several known methods of mounting a celt is

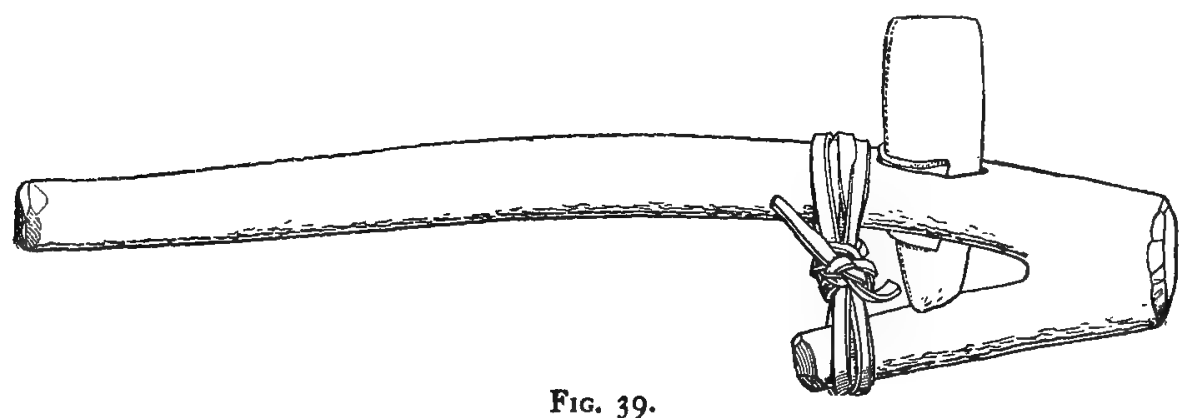

illustrated in fig. 39, where a wholly polished specimen is shown mounted as an axe. When the cutting edge is mounted in a horizontal position, the stone forms an adze.

A common, wholly chipped form of celt from Mount Pleasant near Dunstable is illustrated in fig. 40.

An unfinished specimen from Dunstable Downs is illustrated in fig.

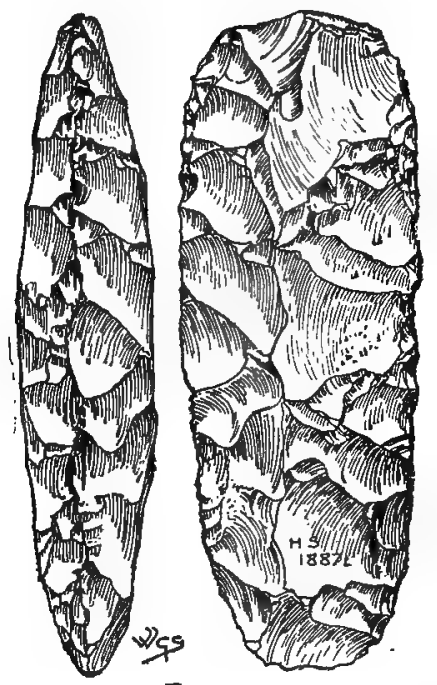

Fig. 4 O.
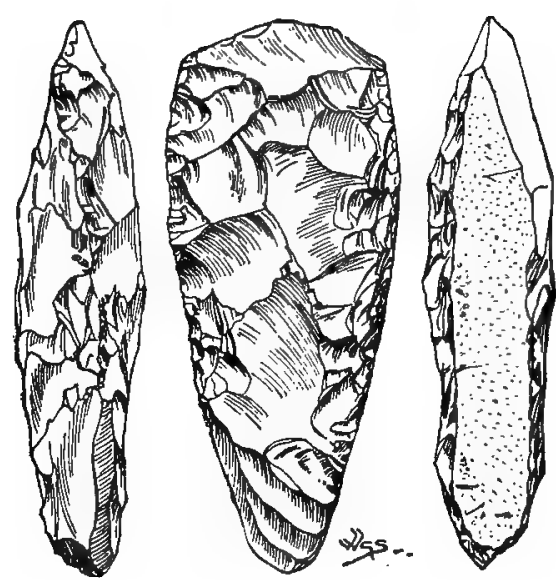

Fig. 4I.

4I, where the left edge is finished and the right remains in a perfectly untouched state.

An almost wholly polished specimen from Dunstable is shown in fig. 42 .

A wholly polished example, found on a heap of stones in a field at Bedford, is illustrated in fig. 43. This specimen both from its peculiar form and material is evidently of Irish origin. It is made of dolerite and is now in the collection of Sir John Evans.

A fine example of a partially ground celt, 8 inches long, has been 


\section{A HISTORY OF BEDFORDSHIRE}

found not far from Billington near Leighton Buzzard; another example, shorter, thicker and heavier, was found at Soulbury near the same place.

Small celt-like implements, especially when one side is left flat, are commonly termed chisels or gouges. A specimen from Waulud's Bank, Luton, is illustrated in fig. 44. Large attenuated examples have been described as picks.

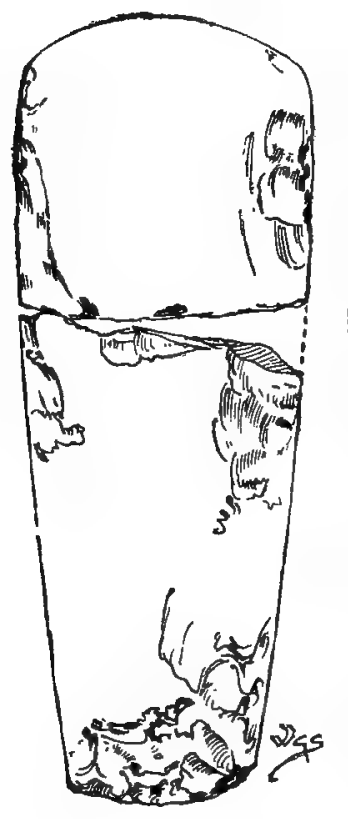

FIG. 42 .

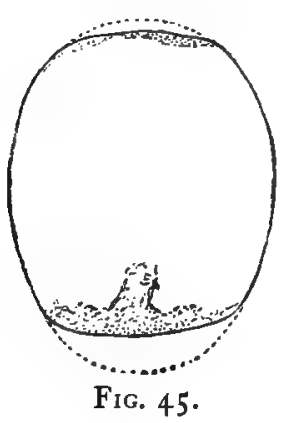

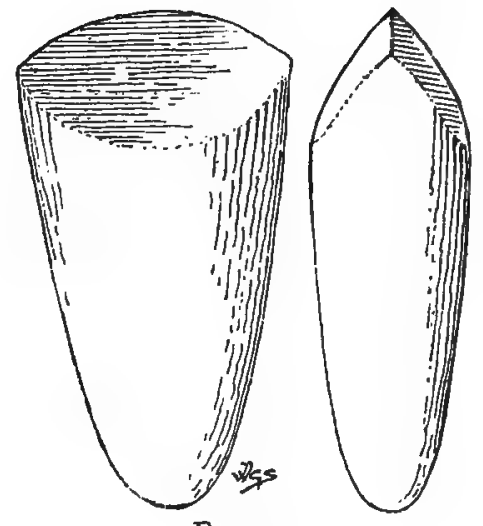

FIG. 43 .
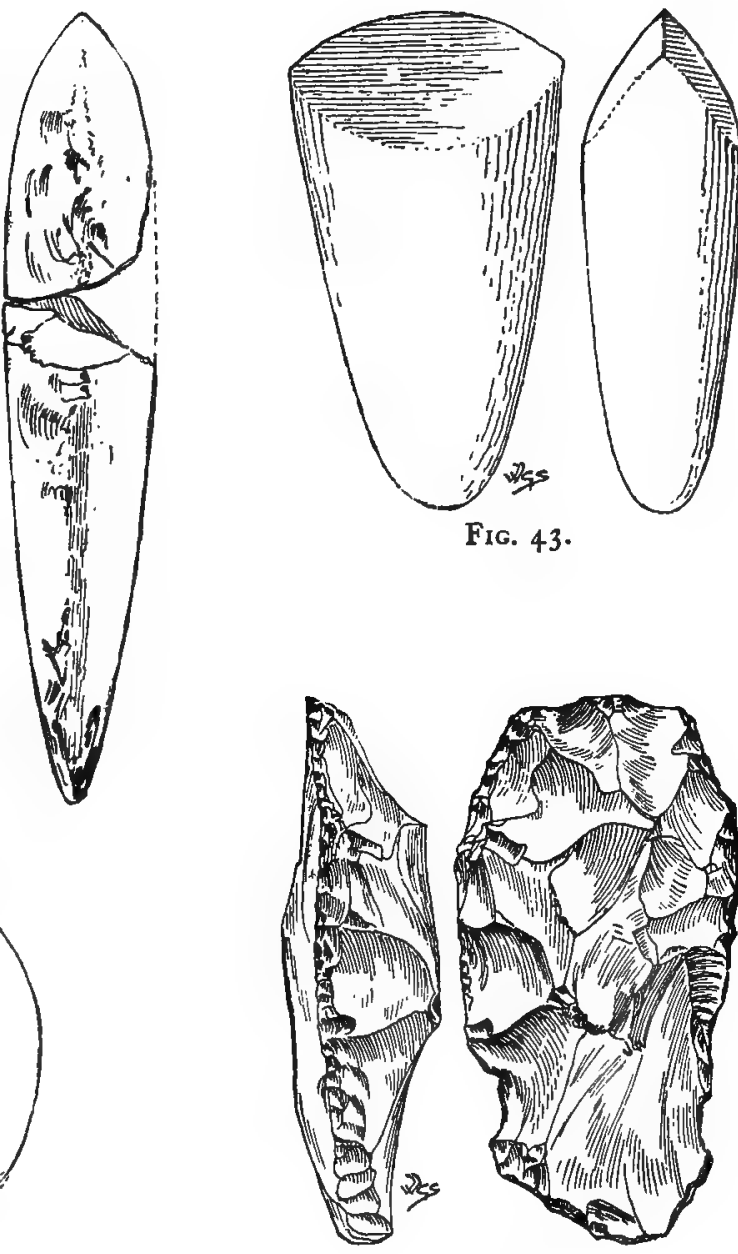

Fig. 44.

Celts from Dunstable and Waulud's Bank, Luton, Kempston and Pavenham are illustrated and described by Sir John Evans.

Of perforated hammers but few Bedfordshire examples are recorded. A hammer made from a perforated quartzite pebble was found at Bartonin-the-Clay in $190_{3}$, and near by was found a small drilled bead-like pebble of translucent quartz.

Hammer-stones unperforated tor handles, and sometimes in the form of pebbles, occasionally occur, but it is not easy to detect the marks of wear in every case. An example of a quartzite hammer-stone with both ends worn off by hammering, from Waulud's Bank, Luton, is illustrated in fig. 45 . 


\section{EARLY MAN}

Examples of an elongate form of hammer-stone made of flint are much more easily found, and these are of fairly frequent occurrence. A specimen from Caddington, abraded at both ends, is shown in fig. 46.

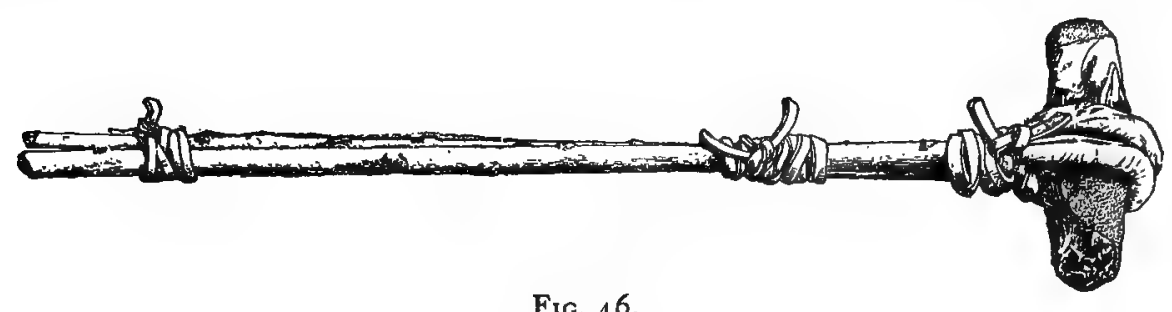

This is illustrated in a mounted state fixed in a stem of bent sallow and tied with leather thongs. Such an instrument could be used not only as a hammer but also as a weapon.

Spherical hammer-stones, mullers, or pounders are frequent. These are usually abraded all over. They were probably used for bruising corn, breaking bones, and pounding pieces of tlint into small fragments for use in clay for pottery. The example illustrated in fig. 47 is from the foot

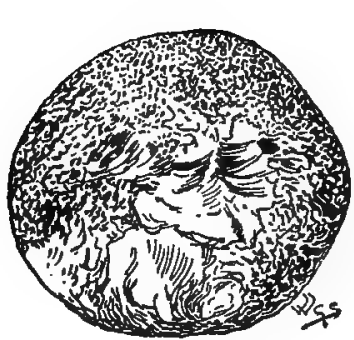

Fig. 47.

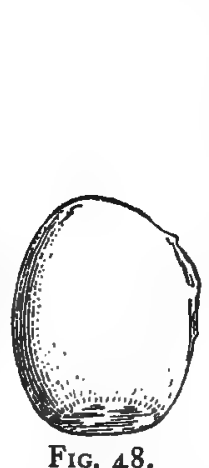

Fig. 48.

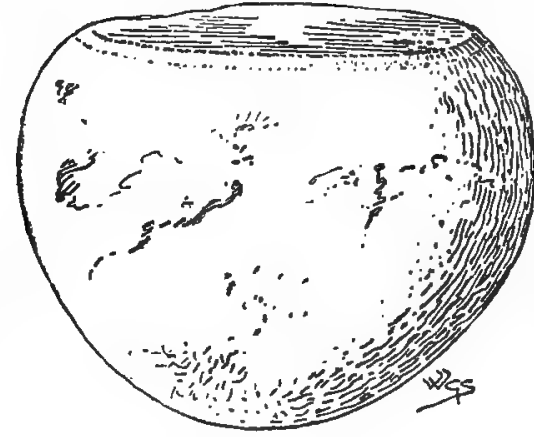

FiG. 49.

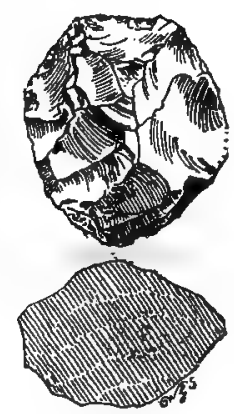

FIG. 50 .

of Dunstable Downs. Such implements are common in camps in company with flakes. They have been found close to Maiden Bower. One specimen in the writer's collection was found close to the right hand of a contracted skeleton in a ruined tumulus on Dunstable Downs (see fig. 59).

A class of tool most difficult to find is the polishing stone. These are pebbles of flint or quartzite, with one end rubbed flat by the final polishing of flint celts. A beautiful example from Maiden Bower, Dunstable, is illustrated in fig. 48. It came from a hole into which broken pots, broken bones and flint flakes had been thrown in prehistoric times; the upper abraded part is black, lustrous and finely striated. Another of somewhat larger size was also found at Maiden Bower. A larger example of quartzite from Waulud's Bank, Luton, is illustrated in fig. 49 .

Sling-stones or throw-stones are frequent in Bedfordshire, especially in or near camps. They are remarkably uniform in size and make. They are about the size of a large walnut and usually chipped all over to a circular or ovoid form. They were probably used with a wooden or leathern sling, and perhaps often thrown with the hand. An example, 


\section{A HISTORY OF BEDFORDSHIRE}

somewhat larger in size than usual, from Waulud's Bank, Luton, is illustrated in fig. 50. One is often asked why stones of this class were made when pebbles and broken flints are so common in the fields, but the fact is there are very few pebbles or broken flints of suitable shapes and sizes for slinging or throwing. The natural stones are too large or too small, too flat, too angular or too long; one has only to look over a stony field for suitable natural sling-stones to find that none are to be found. The evidence at Maiden Bower shows that these stones were kept in heaps on the rampart, ready for use. Slingers when on a slinging expedition probably carried a collection in a bag suspended at the waist.

Simple flint flakes and the cores from which they have been struck are common in Bedfordshire. Many of the small implements now to be mentioned are made from flakes slightly trimmed. Sometimes long flakes occur with one or both edges artificially serrated; these are considered to be saws.

Scrapers are amongst the commonest tools met with in neolithic positions; they are generally horseshoe-shaped, plain on one side and worked on the other. They are usually a little larger than a penny and about $\frac{3}{8}$ inch in thickness; the upper edge was the part used
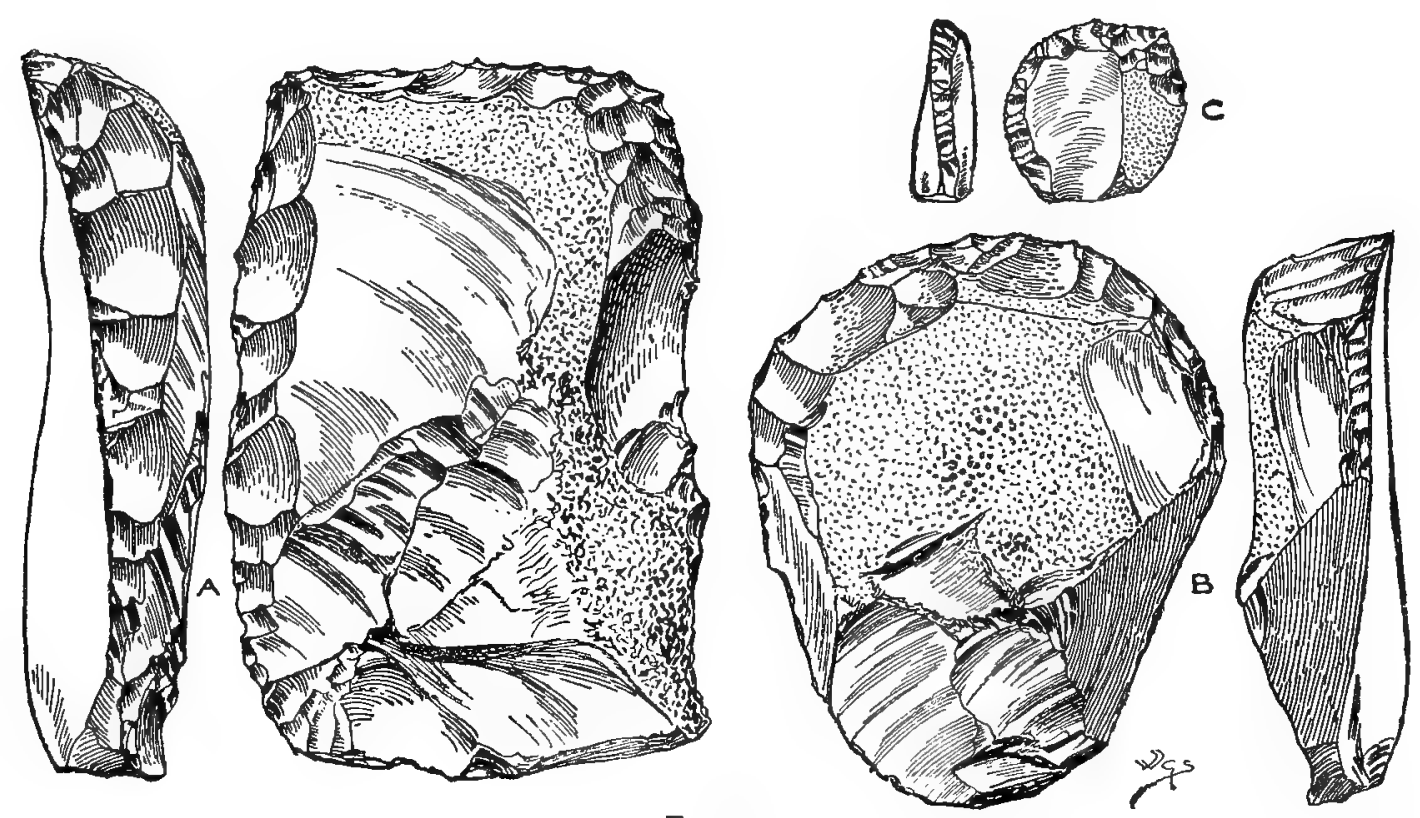

FIG. 5 I.

for scraping. In the accompanying illustration, fig. $5^{\mathrm{I}}$, the two lower scrapers are from Dunstable Downs; the oblong example $A$ is larger and more angular than usual; the specimen $\mathbf{B}$ is typical; the smaller example $\mathrm{c}$ is under the average size.

Flakes are sometimes neatly chipped into the form of borers, awls or drills, as illustrated in the three examples from Leagrave near Luton, fig. 52. These finely pointed little tools were probably used for boring holes in skins, bone needles, etc.

Common in neolithic positions are little tools called knives or I 64 


\section{EARLY MAN}

trimmed flakes. They vary greatly in shape, but are always made from thin flakes, with the edges trimmed to a somewhat even cutting

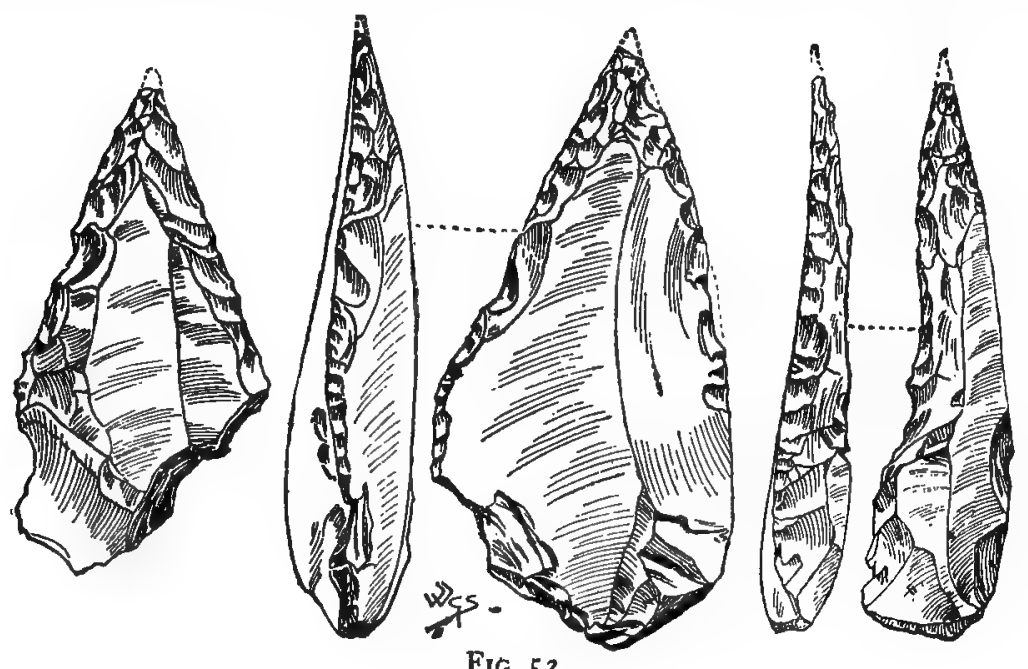

edge. They are often oval, sometimes resembling lanceheads, but sometimes they are circular. Two common forms are illustrated in

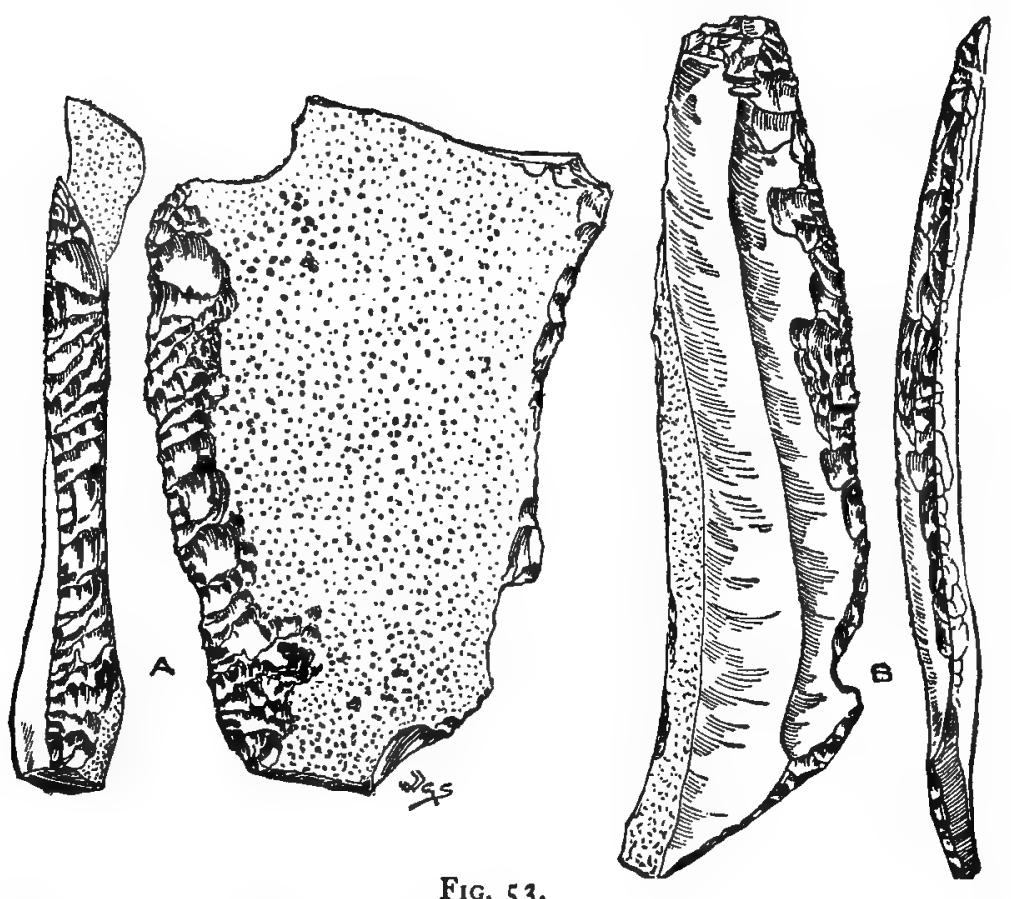

fig. 53. The one marked $\mathrm{A}$ is from Dunstable, and в is from Kempston, Bedford.

Amongst the smaller antiquities in stone none are more beautiful than the spear-, lance-, javelin- and arrow-heads. As a rule these are all made from very thin flakes. As the finer articles are extremely delicate, and as Bedfordshire is a thoroughly agricultural county, it follows that many of the thinner and more highly finished examples are found in a broken state. Many javelin- and arrow-heads must have been lost by the 


\section{A HISTORY OF BEDFORDSHIRE}

makers, owing to their being thrown and shot about in all directions. They are often found as isolated examples long distances from camps.

The larger examples are termed spear-, lance- or javelin-heads; three
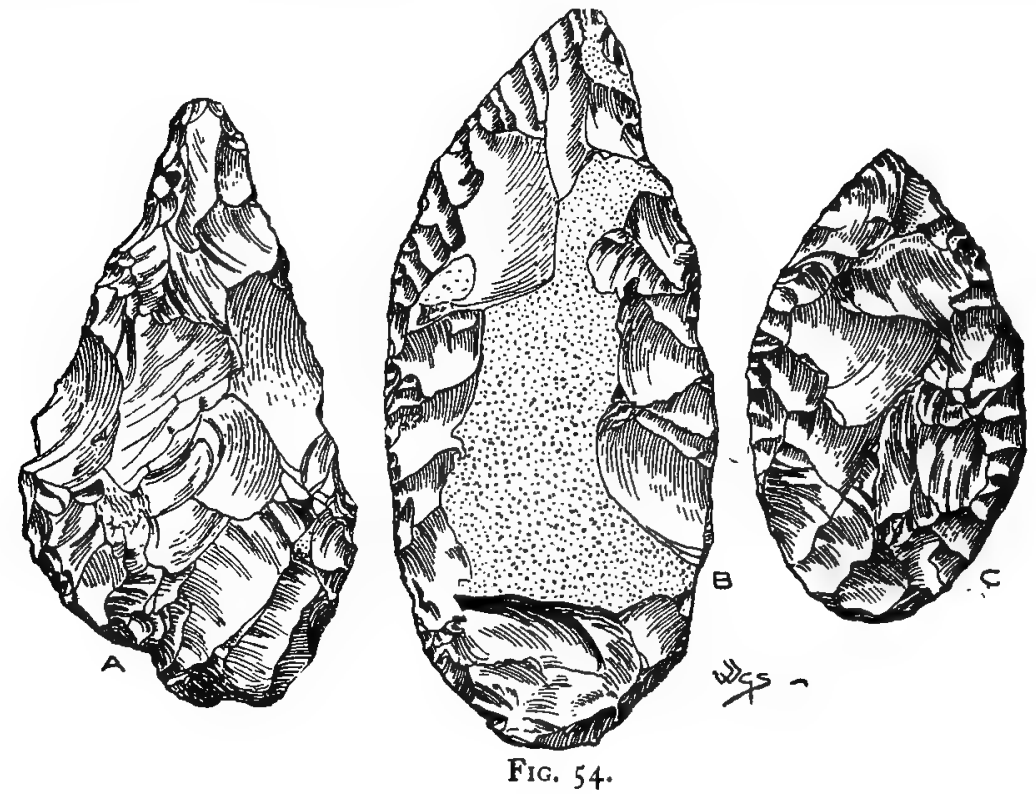

are illustrated in fig. 54 ; those marked $A$ and $B$ are from Maiden Bower, Dunstable ; c is from Waulud's Bank, Luton.

It is probable that all the recognized forms of arrow-head occur in Bedfordshire. In fig. 55 four tanged examples are illustrated from Leagrave and Dunstable Downs.

Two sub-triangular specimens are shown in fig. 56 ; $\mathrm{A}$ is from Caddington, B from Leagrave, Luton.

Three examples of the leaf-shaped class are illustrated in fig. 57, all from Maiden Bower, Dunstable.

A bracer or wrist-guard of stone, made for the protection of the arm of the bowman against the blow of the string in shooting, has been found at Sandy, and is now in the collection of Sir John Evans.

Fabricators and flaking tools are the last to be mentioned. They may have been used as punches, flakers or rubbers, and in some instances perhaps as strike-lights. Whatever these tools may have been designed for they are common in Bedfordshire, especially in camps. Sometimes they are very long, at other times shorter; sometimes the ends are comparatively sharp, at other times they are very blunt and abraded.

Three examples are illustrated in fig. 58 ; the first is from Maiden Bower, Dunstable, with ends very much abraded as if from constant striking on a pebble or block of iron pyrites for the production of fire; the next is from Dunstable Downs, and is comparatively sharp although attenuated. Other much more elongated examples occur. The third is from Mount Pleasant, Kensworth, and is unusually stumpy in form, but undoubtedly of the flaking or fabricating class. 

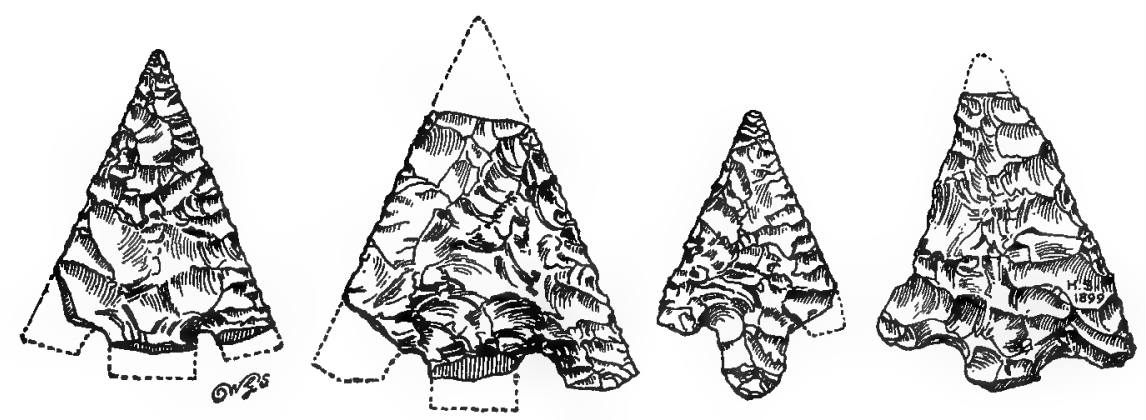

Fig. 55.
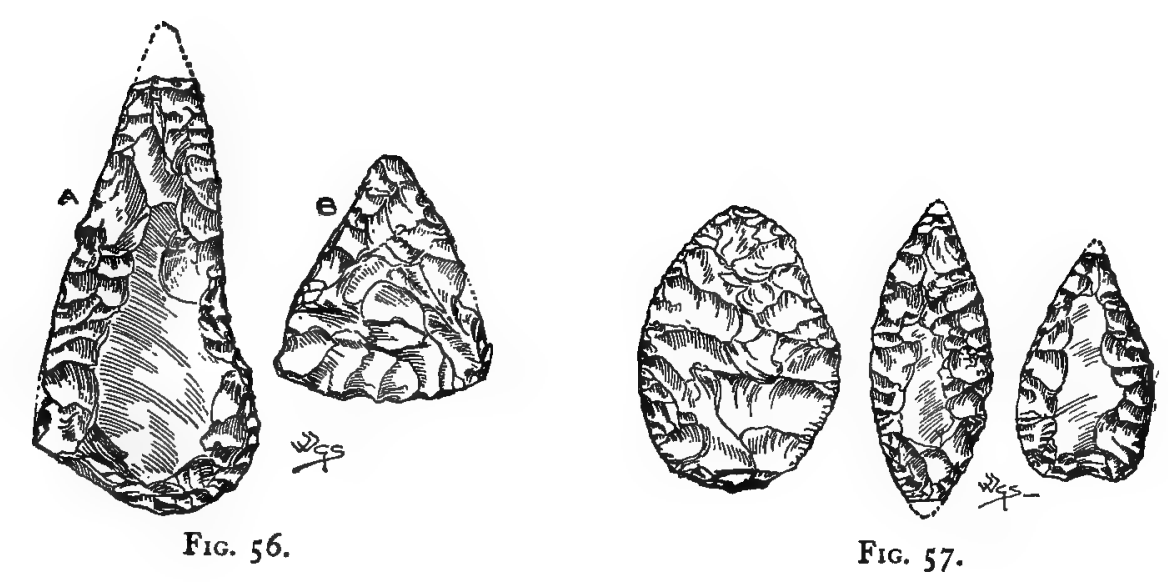

FIG. 57.

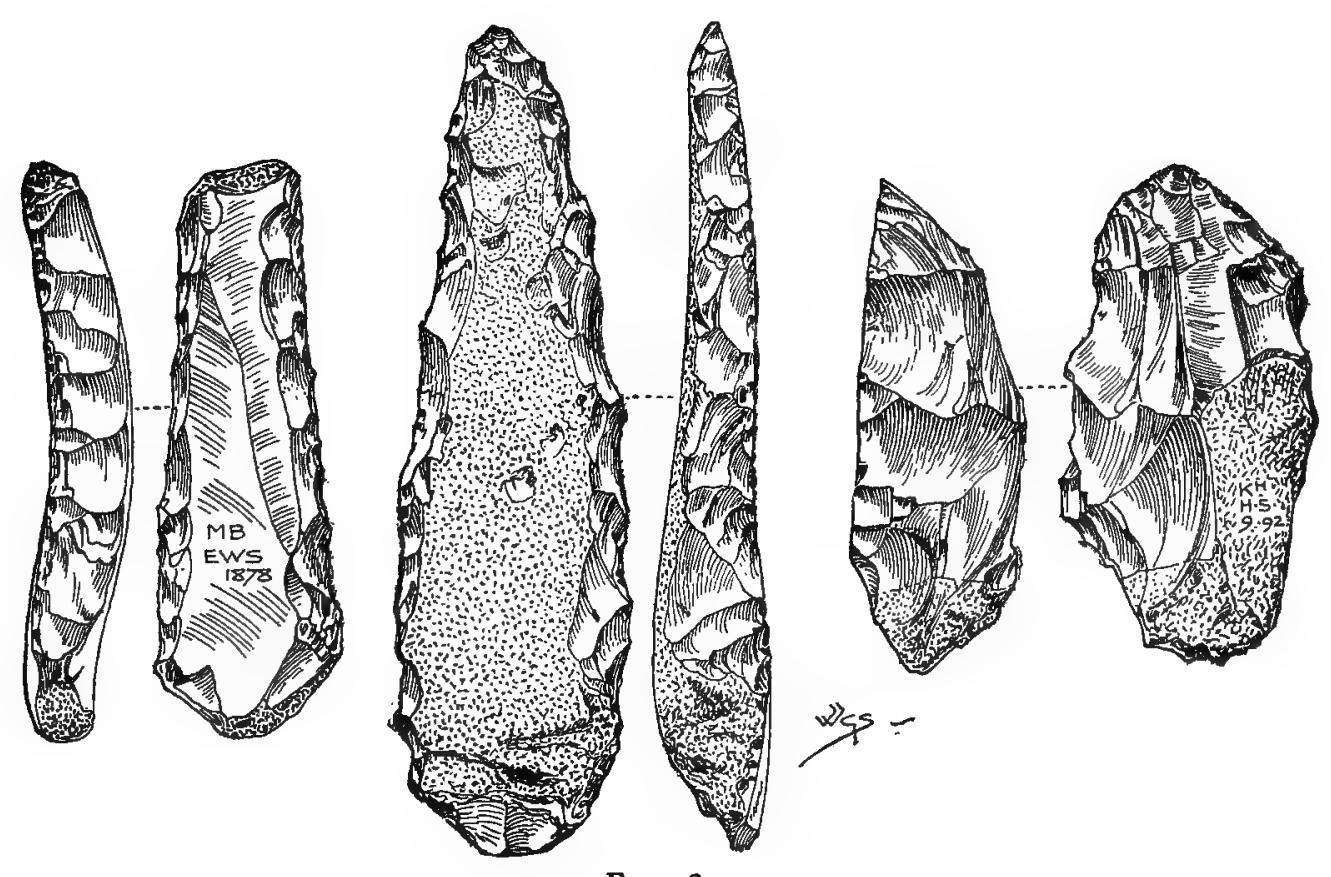

FIG. 58. 


\section{A HISTORY OF BEDFORDSHIRE}

\section{THE BRONZE AGE}

The later Celtic Aryans or Celtæ were a tall race, the males averaging in height $5 \mathrm{ft} .8 \frac{\mathrm{I}}{2} \mathrm{in}$., and the women were also tall. The skulls of the Celtæ were broad or round, as seen from above, with strongly developed brow ridges and powerful jaws.

Their houses were bee-hive huts, of stone where procurable; elsewhere, as in Bedfordshire, the houses were of hewn planks and clay, roofed with straw or fern. Pottery was made, but the potter's wheel was unknown. Dyers used dyes of various colours. The trades of the bronzesmith and bronze-founder were introduced. The husbandmen used sickles of bronze. A vast number of bronze articles were imported, and others

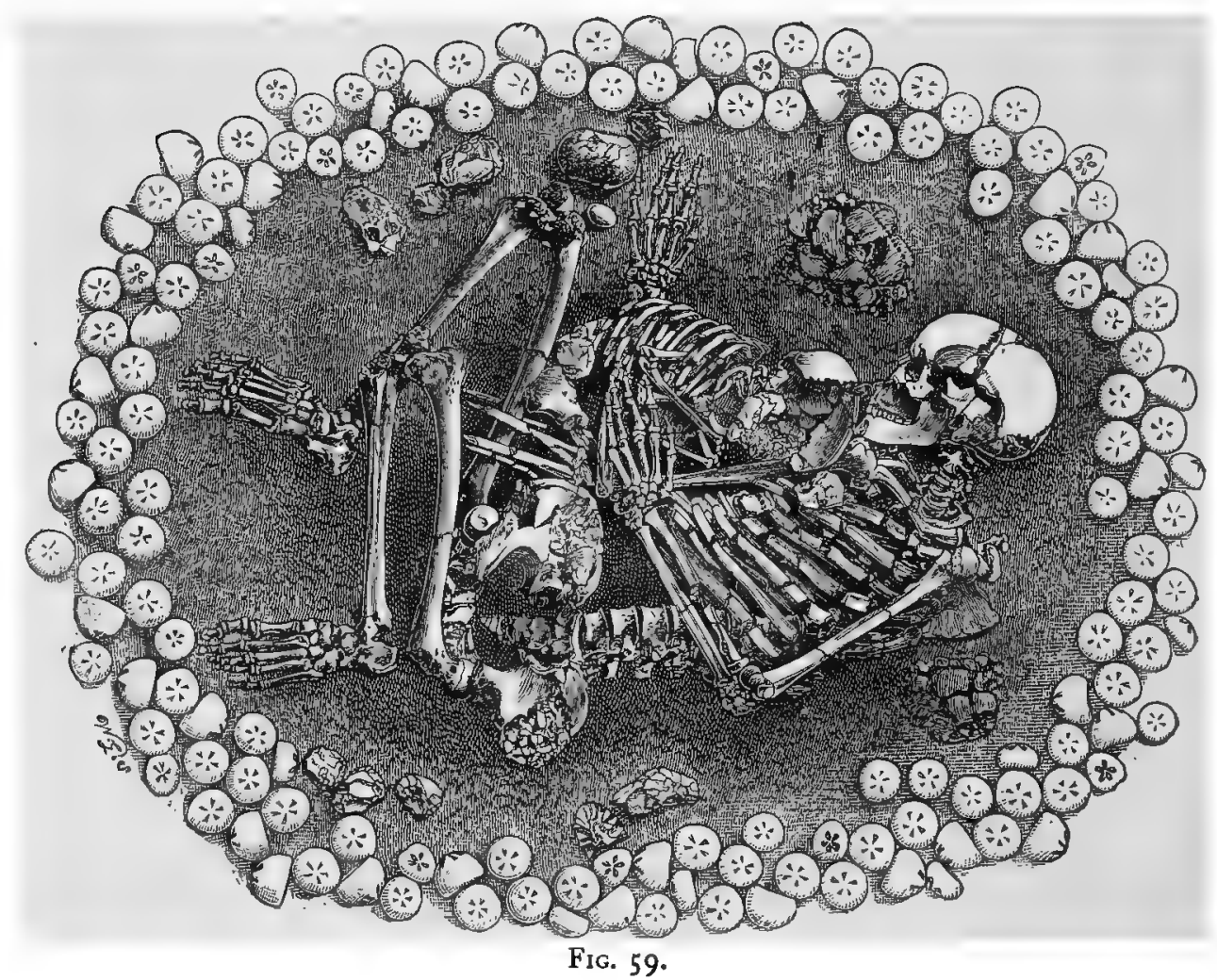

were made in southern Britain where civilization was higher than in the north and the midlands.

The people of the bronze age usually disposed of their dead by burning, but as bronze age customs progressed very slowly it is not uncommon to find evidences of cremation and inhumation in one and the same round tumulus. Sometimes a central and older interment of a tumulus may represent inhumation, and subsequent interments round the circumference represent cremation, or cremations and inhumations may occur side by side round the circumference. In a cremation burial the small pieces of burnt bone were carefully collected and placed in a cinerary urn, which was then buried in the tumulus. In several instances on Dunstable Downs mere holes have been dug in the chalk near the circumference of the I68 


\section{EARLY MAN}

tumuli, and into them the pieces of burnt bone have been placed without urns and then covered with earth.

The accompanying illustration, fig. 59, represents a contracted interment in the circumference of a large round tumulus examined by the writer, which once existed on Dunstable Downs. The tumulus has now been levelled for agricultural purposes. Its position was one third of a mile south-east of the 'Five Knolls' on Dunstable Downs, in the field on the east side of the road. The chief skeleton represents a woman, one of the bronze age dolichocephali, $4 \mathrm{ft}$. I I $\frac{\mathrm{I}}{2} \mathrm{in}$. in height and from eighteen to twenty-five years of age; the child clasped by the mother was about five years of age. Near the head of the woman were two broken pots, near the right hand a stone muller and a white pebble; elsewhere in the grave were two other mullers, two scrapers and two very rudely chipped celts. About 200 fossil Echini were found surrounding the skeleton as illustrated. The owner of the land, Mr. F. T. Fossey, found an arrow-head in the excavated material but lost it again. Near by, in the same tumulus, the remains of a cremation were found buried in a small hole excavated in the chalk. Another tumulus, a little to the south of this, contained in its circumference the skeleton of a crouching boy about fourteen years of age; between the hands was a nodule of iron pyrites.

Very few finds of bronze implements have been recorded from Bedfordshire, and the county is unrepresented in the bronze age collection of the British Museum. This is not because bronze antiquities have not been found in the county, but because they have not been preserved, and when found by field workmen have been lost again, or sold for old metal. The late Mr. Joseph Cooke, the former owner of Maiden Bower, the camp near Dunstable, once told the writer that when he was a boy his father had a quantity of bronze weapons in one of his barns at Sewell, but none are there now, and Mr. Cooke did not know what had become of them. There can be no doubt that the people of the bronze age were spread over the whole county, and further investigations may bring many remains of this age to light. Sir John Evans ${ }^{1}$ records the finding of two bronze spear-heads, $7 \frac{3}{4}$ inches and 6 inches, near Toddington, and about sixty socketed celts at Wymington. ${ }^{2}$ A socketed celt has been found at Toddington. ${ }^{3}$

In fig. 60 is shown a piece of antler, from which a number of long narrow pieces have been sawn or cut out, as if for the manufacture of rude pins. In fig. 61 a bone is shown with the surface cut and end pointed with a knife to form a long bone peg. In fig. 62 two views of a bone are given, showing numerous axe marks

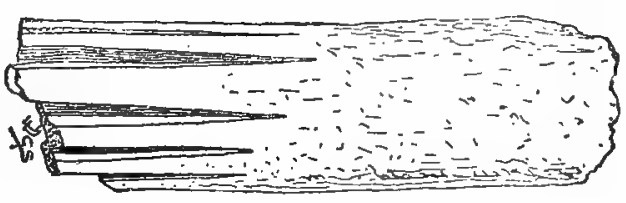

FIG. 60. which have been delivered by a polished stone or bronze celt. These

1 Ancient Bronze Implements, p. $321.2 \quad 2$ Op. cit. p. I13.

${ }^{3}$ Man, the Primeval Savage, p. 316 , fig. 230. 


\section{A HISTORY OF BEDFORDSHIRE}

objects are from Maiden Bower, including the one illustrated at $\mathrm{A}$ in fig. 63, part of the humerus of Bos primigenius broken for the extraction of the marrow for food. This is one of the rarest of bronze age animals ; part of a similar bone of the Celtic ox, $B$. longifrons, is shown at $\mathrm{B}$ to illustrate the difference in size of the two animals. These bones were found with many hundreds of others in a bronze age excavation in the chalk on the west side of Maiden Bower. Amongst the bones were two human teeth, a lower human jaw with teeth much worn, four pieces of a human skull, and a small piece of one of the long bones of a human leg.

\section{THE LATE CELTIC OR IRON AGE}

There is no definite separating line between the ages of the later stone, bronze and iron implements. Stone implements continued to be extensively made and used during the whole of the bronze age and during the age in which iron was known, and its use was continued during the Roman and part of the post-Roman times. In the form of 'flint and steel' for tinder boxes and in gun flints the last feeble remnants of the stone age in Britain have lasted till modern times.

Sir John Evans states that the bronze age practically ceased for cutting instruments in the third or fourth century B.c. and that in the southern parts of Britain iron was known in the fourth or fifth century B.c. Prehistoric iron weapons and tools are rarely found in Britain, owing to the rapid destruction of the metal in the soil, and the writer has no record of the finding of any in Bedfordshire. In the iron age between 200 B.c. and I 00 B.c. the first British coins appeared, many of which have been found in Bedfordshire.

Two of the most important late Celtic antiquities found in this county are in the form of vases fashioned on the lathe in Kimmeridge shale. They were discovered in a sepulchral deposit at Warden, ${ }^{1}$ or Old Warden, and are now preserved in the Archæological Museum at Cambridge. As will be seen from the accompanying illustration of one of the pair (fig. 64), they are of elongated and remarkably elegant form, each being made in two separate pieces and about I 4 inches high. No less than ten cordons are turned round the body of the vases. The bases are deeply moulded, and the necks are short but highly finished. The resemblance of these vases, in form although not in material, to some of the late Celtic pottery found at Aylesford, Kent, is remarkable, and has been pointed out by Dr. A. J. Evans, V.P.S.A.

The traces of pre-historic huts are common in south Bedfordshire; there is a large group on Blows Downs near Messrs. Forders' lime works, Dunstable, with isolated examples distant from the group; there are several isolated huts on Dunstable Downs, an extensive group on Totternhoe Hill, and many on the downs, on the east side of Valence-end farm, two and a half miles south-west of Dunstable; others are on the Warden 


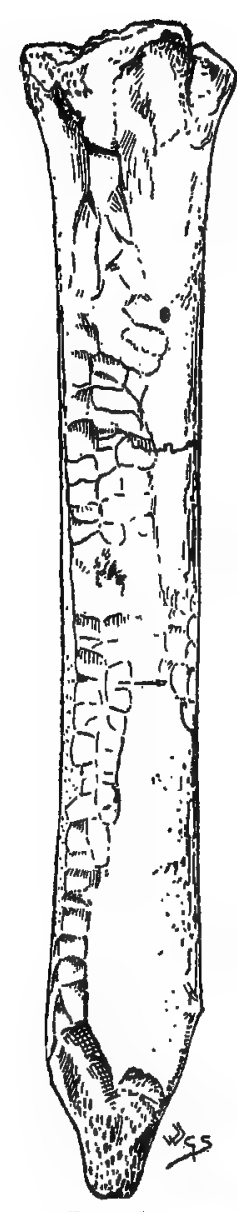

FIG. 6I.

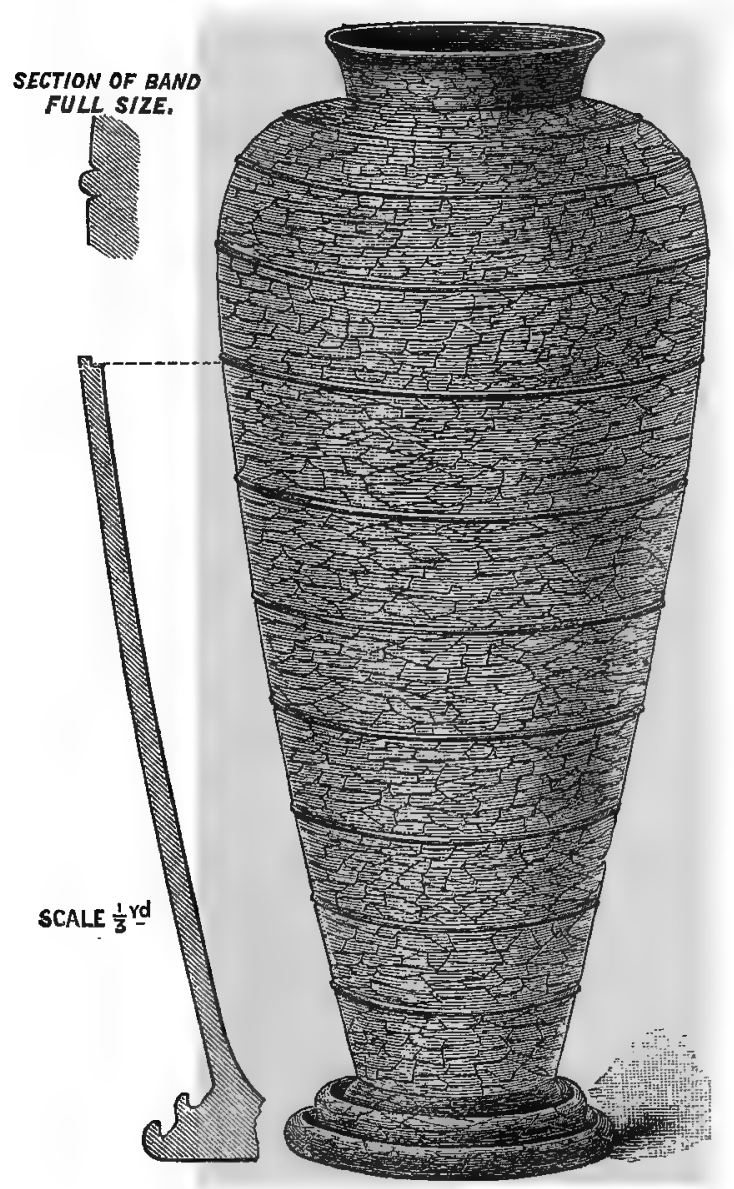

F1G. 64 .

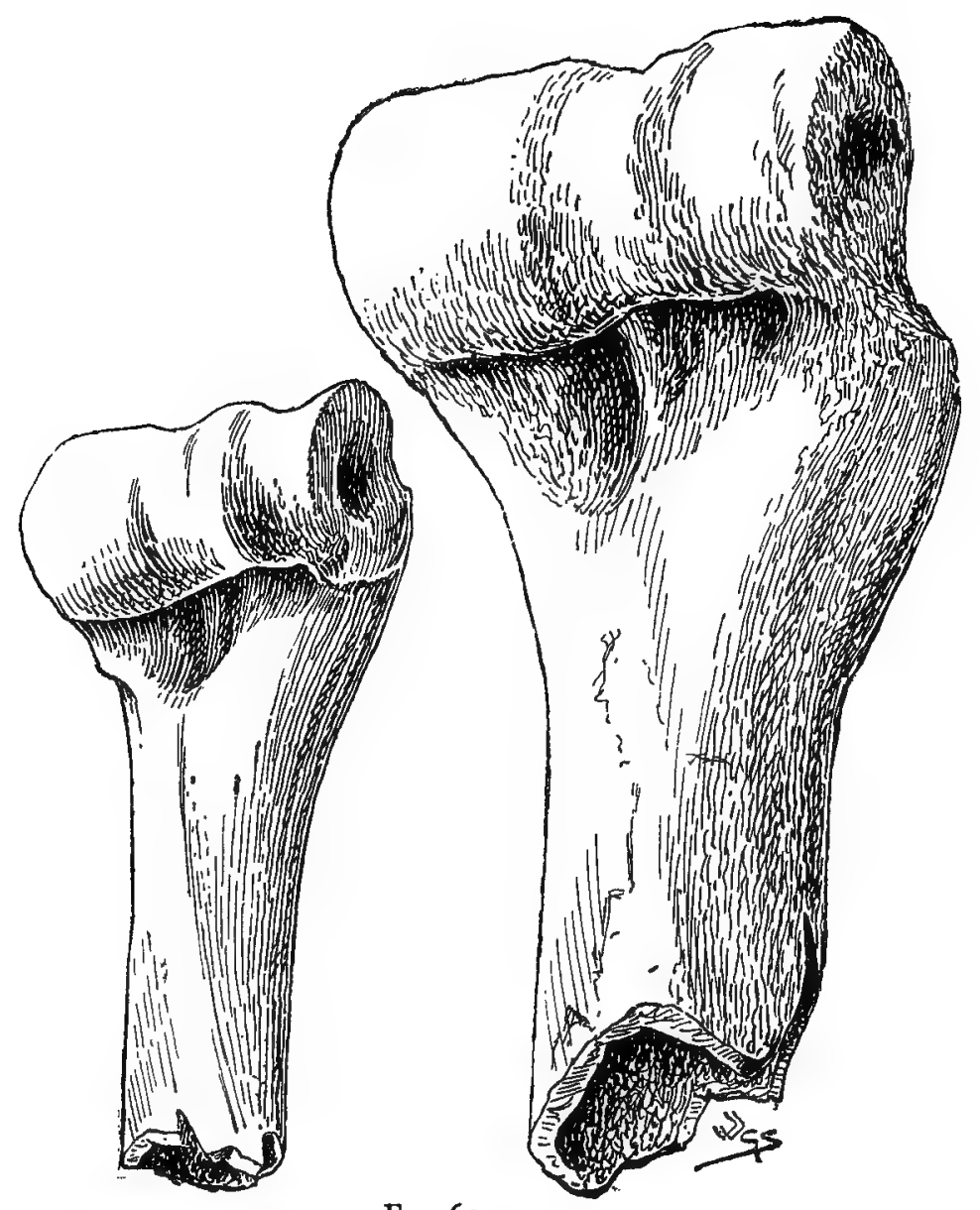

FIG. 63.

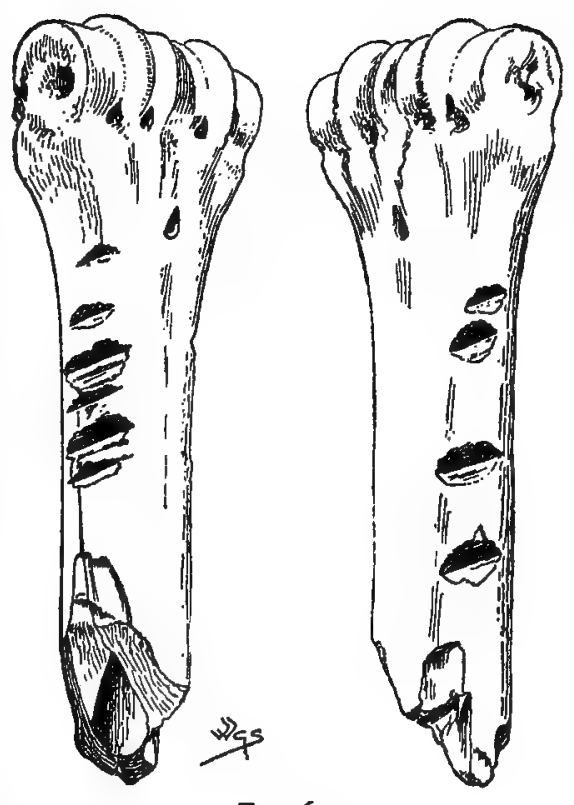

Fig. 62. 


\section{A HISTORY OF BEDFORDSHIRE}

Hills and on Gully Hill, Luton. Some occur in old pastures in the valleys, where the surface has never possibly been disturbed since Roman times. One such pasture with huts occurs in the second field on the west of Totternhoe church. The hut remains are often most difficult to see, and when they occur in flat pastures no eyes but those which are highly trained and experienced can detect the sites. Even on grassy hillsides these sites are very easily overlooked; they are best seen in sunshine either early in the morning or late in the evening. Even the pathways used by the prehistoric inhabitants can under these conditions sometimes be made out.

It is impossible to tell the age of a prehistoric hut without exploration. Externally it is a slight depression in the soil, about 12 feet in diameter. When on a hillside a slight drain-like depression in the direction of the bottom of the hill may sometimes be seen. This cutting was made by the hut dwellers for carrying away water in times of sudden flooding of the floor during heavy rain-storms, although provision was also often made against too much wet by a circular cutting round the hut.

Several prehistoric huts in south Bedfordshire have been excavated. They were all of Celtic, iron age or Romano-British period. The original excavation of each was about 4 feet. When the floor was reached sometimes nothing was found. On one hut floor, near Messrs. Forders' works on Blows Downs, there was a flint scraper, a fragment of a British pot, a metatarsal bone of a horse and a number of flint flakes. On the floor of an adjoining hut an extended human skeleton was found. The original owner of the bones was a little over $5 \mathrm{ft}$. Io in. high. The skull and chief part of the bones were unfortunately put into the lime kilns with chalk for lime. On this hut floor were seven flint flakes, part of a British pot and a block of iron pyrites.

A hut, in the pasture already mentioned, on the west side of Totternhoe church, was uncovered by the late vicar, the Rev. S. A. Woolward, and a friend in 1899 . On the floor of this hut were parts of two Roman mill-stones or querns, seven flint flakes, two spindle-whorls, two sharpening stones or hones, pieces of stag's antler, three pieces of Roman pots and a piece of a thick Roman tile with the impression of the foot of a large dog. Outside the hut was a collection of thousands of shells of the common garden snail, Helix aspersa. These were used for pounding up and mixing with clay for Romano-British pots, as was shown by the pottery found close by.

Sometimes there is no indication whatever above ground that a hut floor exists beneath. Such a floor was accidentally found at Buncer's farm, Caddington, in 1895 . A small shallow hole had been dug in this field on its southern boundary. On looking into this hole a thin horizontal line of flint flakes was seen a foot below the surface. Altogether I, I 42 flint flakes were exposed on a restricted level floor of earth, which was perhaps one half of the original number, as many flints had been lost in the digging of the test hole, some slipped into an adjoining pool of water, and others were taken to fill in the ruts of a road. In addition to the flakes there were two celts, four scrapers, one arrow-head, several 


\section{EARLY MAN}

hammer-stones and waste pieces, several bones, a horse's tooth, several pieces of Roman pottery and two corroded Roman coins. Many of the flakes were ultimately replaced on each other or on to the blocks from which they were originally struck. The position was the flint-working place of a Romano-Briton.

\section{ANCIENT BRITISH COINS}

Many ancient British coins in gold, silver, copper, brass and tin have been found in Bedfordshire, ${ }^{1}$ though it is difficult to say how many, if any, were struck within the county boundaries. Some of the inscriptions show that the coins were produced at Verulam. Only the uninscribed coins can be included as possibly of prehistoric date. It was after the invasion of Julius Cæsar that British coins bore inscriptions, so that inscribed British coins really overlap Roman history.

Leagrave near Luton is a famous position for both uninscribed and inscribed British coins, but the chief place, though invariably given as Leagrave, is really Limbury, one and a half miles north-east of Leagrave. The coins are found on the east side of the Icknield Way south-east of the Bramingham road, half a mile north of Limbury on the top of a hilly field called ' Gooseberry-bush Hill' or 'Muswell Hill,' just north of a footpath and within the very small 400-feet contour marked on the 6-inch ordnance map, Bedfordshire, sheet xxx. N.E.

\section{UNINSCRIBED}

Leagrave, gold ; Shefford, gold ; Sandy, gold ; Leighton Buzzard, gold ; Girtford, gold, tin ; Stondon, copper ; Dunstable, copper, brass.

\section{INSCRIBED}

$G O L D$

TASCIO RICON $=$ Tascovian, Tasciovanus, whose capital was Verulam, father of Cunobelinus B.C. 30-A.D. 5. Leagrave, Dunstable, Biggleswade.

ADDEDOMAROS = perhaps to a prince of the Eceni. Leagrave.

CVN = Cunobelinus, died a little before A.D. 43. Potton.

CAMV obv. - CVN rev.=Camulodunum (Colchester)-Cunobelinus. Potton, Stondon, Shefford.

\section{SILVER}

TASC $=$ Tasciovanus. Biggleswade

\section{COPPER AND BRASS}

VERLAMIO $=$ Verulam. Sandy.

VER " Sandy, Arlesey.

VIR " " Upper Stondon, Arlesey.

VIIR " Langford.

TASC. Biggleswade.

CVNOBELINVS REX obv.-TASCIOVANVS rev. Arlesey, Sandy, Langford.

CVNO obv.-TASCIO rev. Biggleswade.

CVNOBELINI obv.-TASCIO rev. Biggleswade.

CVNOB obv.-TASCIOVANTIS rev. Clifton, Sandy.

RVFI (?) = Rufinus, a possible son of Tasciovanus. Biggleswade.

1 Sir John Evans, Coins of the Ancient Britons, and supplement to that work, E. Latchmore (Cambridge Antiq. Soc. May 1890). 


\section{A HISTORY OF BEDFORDSHIRE}

\section{Topographical List of Prehistoric Antiquities in Bedfordshire ${ }^{1}$}

Arlesey.-British coins [Evans $C ., 546,547]$.

BARTON-IN-THE-CLAY.-Neolithic quartzite hammer and drilled pebble.

BedFord.-Palæolithic implements [Evans S., 530, 645]. Neolithic hammer-stone [Evans S., 245]. British coin [Evans $C ., 315]$.

Biddenham.-Palæolithic implements [Evans S., 531-3, 680; Arch. xxxix. 69].

Biggreswade.-Palæolithic implements [Evans S., 538]. British coins [Evans C., 79, I 18, I I 9, 21 8, 237, 255, 258, 263, 27 I, 299, 326, 328, 329, 332, 333, 352,537, 569].

Caddington.-British hut floors found at Buncer's farm. Numerous palæolithic implements [W.G.S. ; Evans S., 598-600].

Cardington.-Palæolithic implements [Evans S., 531].

Dunstable.- Numerous neolithic implements and prehistoric camp at Maiden Bowet [Evans S., 69, 281, 301, 310, 334, 374, 376, 379, 415]. Numerous British hutcircles in the Dunstable districts [W.G.S. $323-5$ ].

Dunstable Downs.-Neolithic implements and interments [Evans $\left.S_{.,} 72\right]$. British coins [Evans C., 54I].

Flitton, Silsoe.-Coin of Cunobelinus [Evans $C ., 560$ ].

Henlow.-Palæolithic implements [Evans $S ., 536]$. British coins [Evans $C ., 569]$.

Houghton Regis. - Part of palæolithic implement [Evans S., 578 ; W.G.S., 91].

KEMPSTON.-Neolithic and palæolithic implements [Evans $S_{\text {., }}$ 105, 125, 340, 353, 531, 535 ; W.G.S., I I 7, 243]. British coins [Evans C., 558].

Leighton Buzzard.-Long neolithic celt [Evans $C ., 9 \mathrm{I}$ ]. British coins [Evans $C ., 50]$.

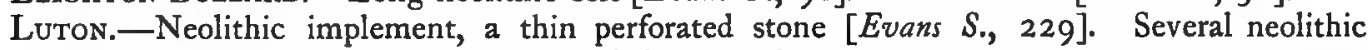
hut-floors in the Luton district [W.G.S., 323-5].

Dallow Farm.-Palæolithic implement, found in I 830 [Evans S., 598].

Lilly Hoo.-British coins [Evans $C$., 123 ].

Leagrave.-Palæolithic implement [Evans S., 598 ; W.G.S., 90]. British coins [Evans $C_{.}$, $435,539,577]$.

WAULUD's BANK, - Neolithic camp and implements [Evans $S ., 68]$.

Pavenham.-Ground neolithic celt, found in Miller's Bog [Evans S., IOI].

PotTon.-British coins [Evans C., 300, 435, 559].

SANDY.-Stone wrist guard, or bracer (neolithic ?) [Evans $S_{., 427]}$. British coins [Evans $C$., $229,309,329,435,439,449,475,485,568,57$ I]

ShrFford.-British coins [Evans C., 447, 568].

Silsoz.-See FlitTon.

STONDON, UPPER.-British coin [Evans C., 26I].

Toddington.- Two leaf-shaped bronze spear-heads, with rivet-holes through the sockets [Evans B., 320 ; W.G.S., 316].

TOTTERNHOz.-Neolithic bone [W.G.S.]

Warden (or Old W ARden). - Vases of Kimmeridge shale of late Celtic period [Arch. lii. 352].

Wootton.-British coins [Evans C., 63].

WYMINGTON.-Hoard of about sixty bronze celts; specimens are in the cabinet of Sir John Evans, K.C.B. [Evans B., I I 3, 466].

1 The following abbreviations have been adopted :-

Evans $B .=T$ he Ancient Bronze Implements, Weapons and Ornaments of Great Britain, by John Evans, F.S.A. (1881)

Evans C. $=$ The Coins of the Ancient Britons (1 864) and Supplement (1890) by John Evans, F.S.A.

Evans $S_{.}=$The Ancient Stone Implements, Weapons and Ornaments of Great Britain, ed. 2, by Sir John Evans (1897).

W.G.S. = Man, the Primeval Savage, by W. G. Smith (1894). 



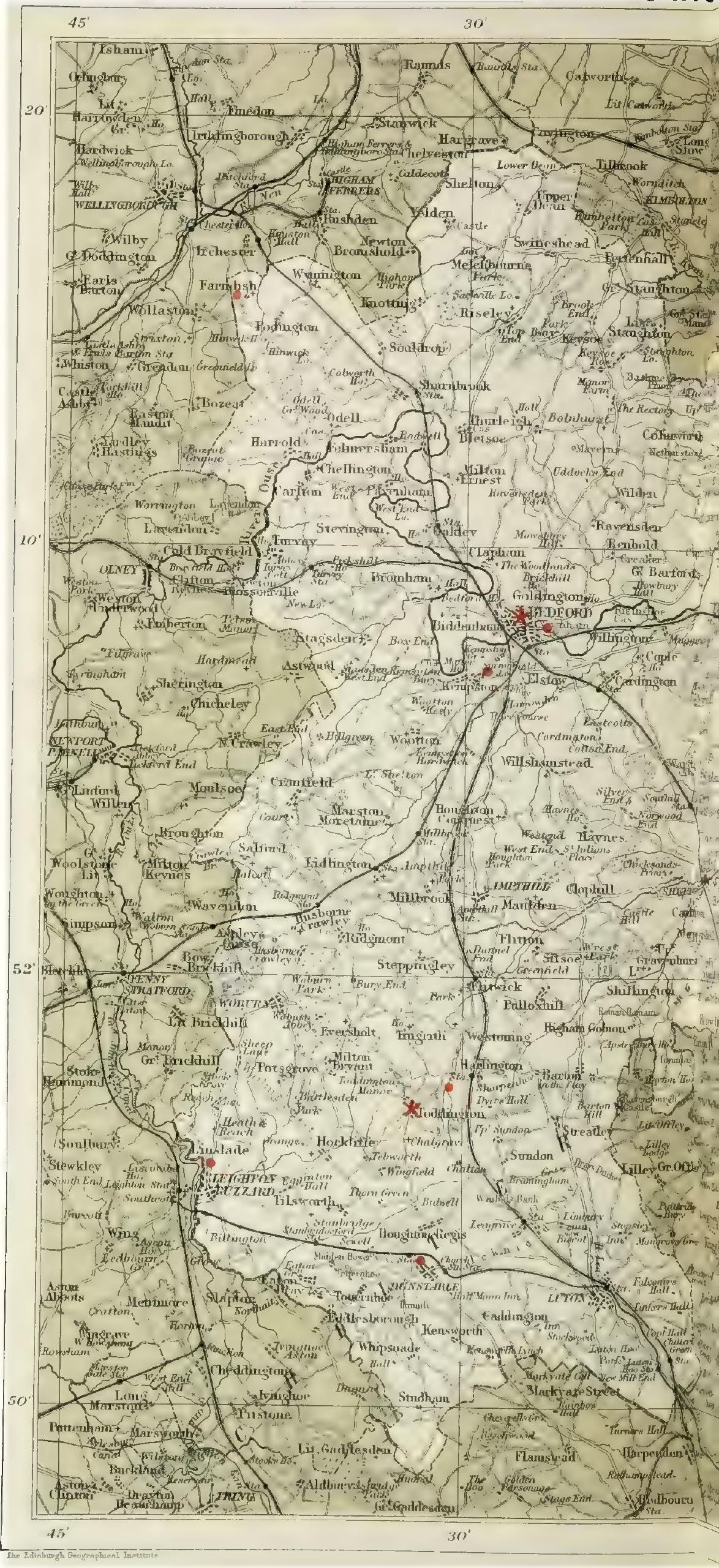

THE VICTORIA HISTORY OF TH 


\section{SAXON REMAINS.}

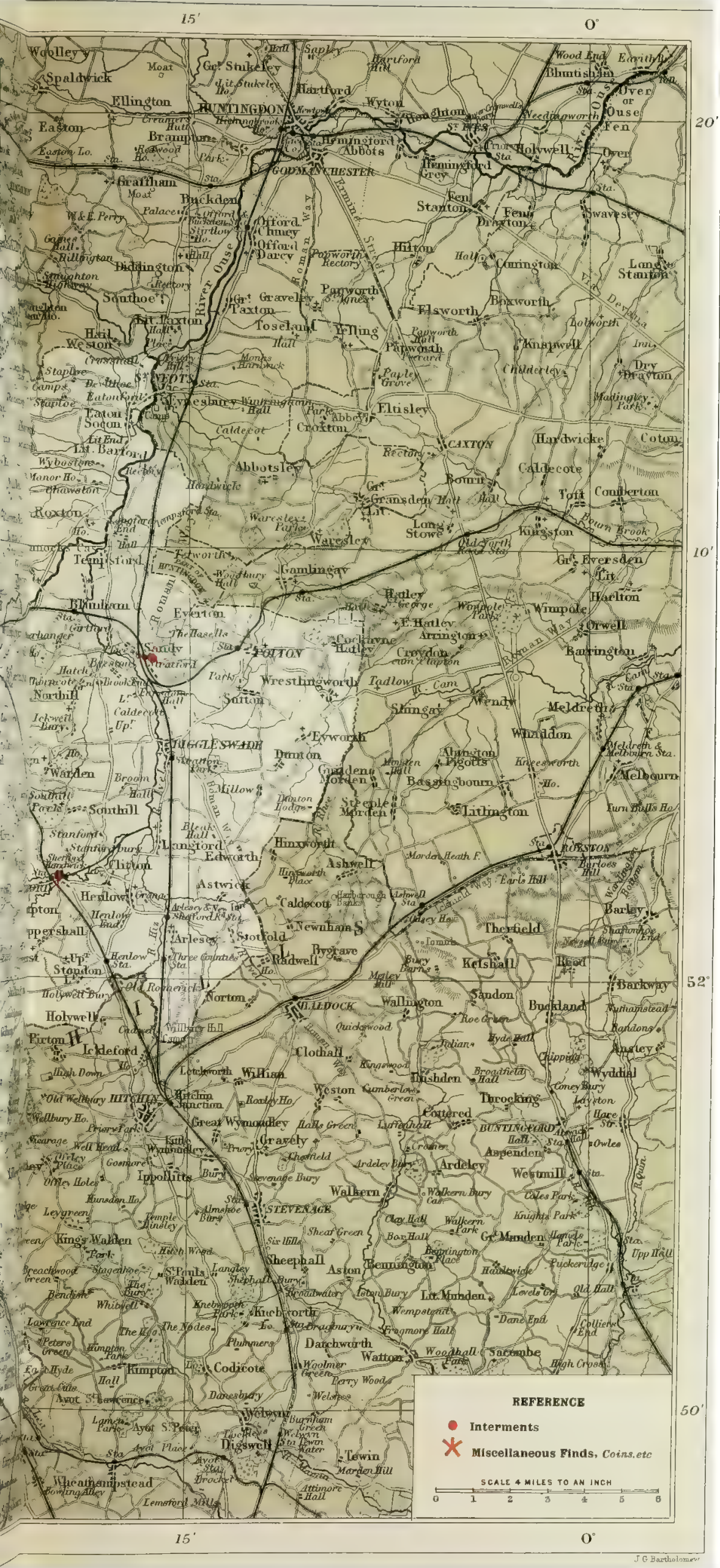





\section{ANGLO-SAXON REMAINS}

$\mathrm{O}$ F the centuries immediately succeeding the Roman withdrawal from Britain there is little to be learnt from history, and so far archæology has afforded no clear knowledge of the period, though such excavations as those conducted by the late General Pitt-Rivers in Wiltshire and Dorset have done something to lift the veil. On the chalk range of the Chilterns, which form the southern boundary of Bedfordshire, only a few faint traces of early Anglo-Saxon settlements have as yet been noticed. Some years ago a considerable number of human skeletons were found in extended positions on the Limbury side of Waulud's Bank, an earthwork near Dunstable. A quantity of broken pottery that may have been Anglo-Saxon was found at the same time, but it is impossible now to decide on the date of the interments or the nationality of the interred. In this part of the country the newcomers seem to have preferred the plains and river-valleys. Groups of interments and sometimes large cemeteries mark the sites chosen by the Teutonic tribes when they first came to settle in this island, and it was not till the wide acceptance of Christianity, perhaps in the first half of the eighth century, that consecrated ground in the neighbourhood of churches was set apart for burials, and the haphazard selection of sites for this purpose in the open country prohibited by the Church. As a rule therefore interments, that from their contents or surroundings may be assigned to a pagan population, date from the obscure period between the Roman withdrawal and the establishment of Christianity in the various petty kingdoms in Britain; and it is to the early practice of burying with the dead their weapons, ornaments and utensils that is due our knowledge, scanty as it is, of the rise and growth of the various settlements.

In Bedfordshire the alluvial soil in the valleys of the Ouse and its tributaries, the Ivel and the Ousel, certainly attracted many of the early comers; and, apart from considerations of water supply, facilities for agriculture no doubt constituted the main inducement. As will presently be seen, discoveries of this kind in the county are few and scattered, so that it is impossible to distinguish with any degree of certainty any local groups; but it should be noticed that while to the north of the countytown only one interment is recorded, south of the Ouse a link between most of the sites as yet determined may perhaps be found in the road- 


\section{A HISTORY OF BEDFORDSHIRE}

system already existing at that date. Thus Leighton Buzzard and Toddington lie six miles apart on either side of the great Roman highway to Chester; and Dunstable is at the point of junction between that and the still earlier Icknield Way, which probably led the advance bands of immigrants into what is to-day the shire of Bedford. Fifty miles divide Dunstable and Newmarket; and the British road which runs betweer them, sometimes flanked by the parallel Ashwell Street, seems to explain discoveries of characteristic West Saxon remains in its vicinity. Whether the defensive earthworks across Newmarket Heath were erected to stop such an advance may be doubted, but that and other parallel embankments are evidently directed against an enemy on the west, and no Saxon (as distinguished from Anglian) remains have been as yet discovered to the east of those lines.

A summary description of the few and mostly unimportant discoveries in the county is necessary before any closer connection between them can be established; and to convey some idea of the remains that probably await discovery within the county it will be advisable to start with a remarkable cemetery from which an extensive series of relics is exhibited in the British Museum.

On the western boundary of the town of Bedford is the straggling village of Kempston; and the road to Marston and Woburn, which branches off about two miles west of St. Mary's church, skirts a field that has long been dug for gravel. During the year I $86_{3}$ the excavations in this field laid bare a certain number of human remains, and further exploration revealed a cemetery of Anglo-Saxon date. A detailed description ${ }^{1}$ of the graves was submitted to the Bedfordshire Architectural and Archæological Society in the following year by Rev. S. Edward Fitch, M.D., who had watched the excavations and illustrated about forty of the antiquities discovered in five coloured plates. ${ }^{2}$ His comments on the cemetery were summarized by Mr. Roach Smith, who also published the notes of Mr. James Wyatt, a geologist whose attention was drawn to the burials while engaged on a geological examination of the gravel.

The road formed approximately the northern limit of the cemetery, though a few interments were found beyond it; and the large number of burials it contained were found to vary in size, depth and position, some being not more than 18 inches below the surface, others at a depth of nearly 5 feet. There was no attempt at a universal orientation, as skeletons were discovered lying at all angles with one another, and directed to almost every point of the compass. The fact that many skeletons of men, women and children were found entirely undisturbed shows that this was a common burial ground, and not the site of a battle where the fallen had been hastily interred. Various modes of burials were noticed; some of the graves contained skeletons laid at full

1 Rep. Assoc. Arcbit. Soc. 1864, p. 269.

2 These and the journal of discoveries are reproduced in Roach Smith's Coll. Antig. vi. 201 (see also p. I 66). 


\section{ANGLO-SAXON REMAINS}

length face upwards, while many cinerary urns of pottery containing the ashes of the dead were also recovered whole, all lying near the surface and sometimes arranged in straight lines. Fragments of other urns could not be pieced together, and Mr. Fitch concluded that many cremated burials had been disturbed by Saxons or others who opened the ground to deposit, whether in an urn or the bare earth, the dead of a later generation. He was of opinion that urn-burial was the more ancient rite practised in this cemetery, but that at a later date the burial of the unburnt body was contemporary with the deposit of human remains in urns. Observations on other sites confirm the priority of urn-burial, and there was no doubt a transition period during which cremation fell into disuse, but it would be difficult to prove that it persisted in this case till the cemetery was closed. According to all accounts there is here no question of Christian interments in coffins, neither the contents nor direction of the graves suggesting that any are later than the conversion of the English during the seventh century. Accepting therefore the chronology of the Anglo-Saxon Cbronicle for the Saxon conquest of the district, the cemetery may be approximately dated between the years $55^{\circ}$ and $65^{\circ}$, but there are some objects from the graves that were manufactured, if not interred with their owners, about the middle of the fifth century, and it is quite possible that the cemetery was in use for two hundred years, or longer if Dr. Arthur Evans is right in referring them to the third century.

Forty years ago there were few to study Anglo-Saxon remains and fewer still to report at length on the exploration of a cemetery; but, for the time, the find at Kempston is recorded with remarkable fidelity and detail. Still many particulars, not at that time regarded as essential, are omitted from the account, and the value of the important series of relics now in the national collection is thereby somewhat impaired. Of certain broad features there can be no doubt; the burials were not arranged according to any definite plan, and cinerary urns were discovered among unburnt interments in all parts of the cemetery. But besides these were a few that call for special remark. On I 6 November I 863 a pit was discovered in the cemetery, over 7 feet in length, from 3 to 4 feet wide and the same in depth, where a body stretched at full length had been consumed by fire. About 2 feet from the surface was a large quantity of ashes, and among them were found portions of a human skull, vertebræ and other bones, all charred, but the leg bones showing less traces of fire than the rest of the skeleton. In the ashes and on the left side of the body was a long iron spearhead with a portion of the wooden shaft left in the socket, and also an iron knife; while surrounding these remains lay numerous pieces of charred wood, and ends of branches not quite burnt through. It seemed as if the pit had been partially filled with live embers, on which the deceased was laid, and then large branches heaped above it. Bones of some small animal, perhaps a rat, were also found, and had no doubt been burnt on the same occasion; while an urn 9 inches high, half filled with the burnt 


\section{A HISTORY OF BEDFORDSHIRE}

remains of some small animals, was found at the feet of a skeleton in another part of the cemetery. Three skeletons seem to have been discovered in a bent or sitting attitude, and one at least of these was that of a warrior who had been buried with his spearhead, knife and an urn. It is clear from this and other cases that urns of a considerable size were sometimes placed in the grave with an unburnt body, though in other cemeteries urns above 6 inches in height may generally be considered as proof of cremation. Another peculiarity of certain graves at Kempston was the presence of rough slabs of stone placed irregularly over the unburnt body. Though there is here no mention of similar stones along the sides of the grave, it may be of interest to compare the more complete tombs built in this fashion at Long Wittenham and Frilford, Berks, as well as at places in Northumberland, Westmorland, Leicestershire and Gloucestershire.

In the original account urns are frequently mentioned as being found with skeletons, generally lying near the head and filled with

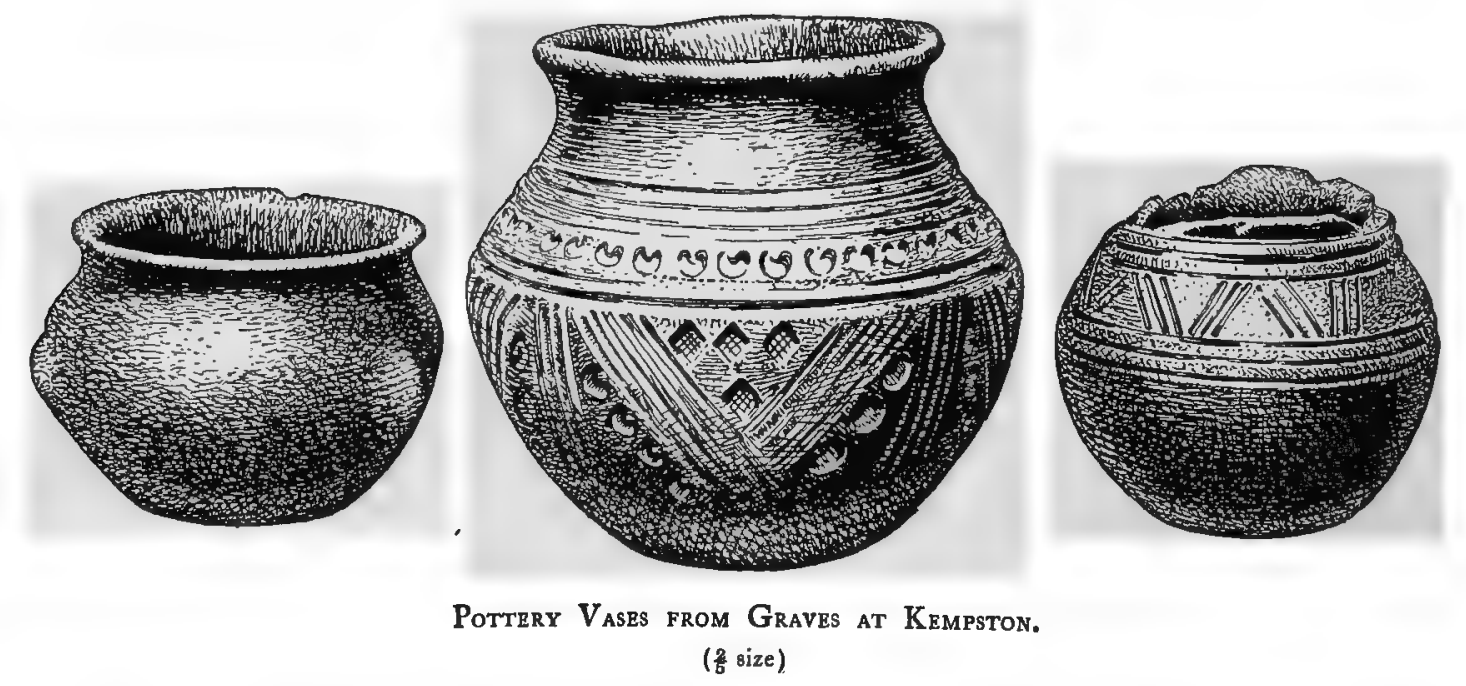

earth. A few are expressly stated to have contained human bones, but in one instance it was doubtful whether these had been cremated. The smaller vases (see fig.), of which there are six from Kempston in the national collection, including one of Roman manufacture, are generally supposed to have contained liquid or food for ceremonial purposes, and the custom seems to have survived till the middle ages, when vessels of holy water were frequently placed in the tomb; but there are nine urns (see fig.) plain or ornamented with impressed patterns from this site in the British Museum that were doubtless used to contain the burnt remains of the dead, and some had intentionally been buried in a line. Bone combs are frequently found in these cinerary vessels, and at Kempston a fragment with four teeth was found that had been placed in the urn after the act of cremation and so had itself escaped the fire. Other cinerary urns contained a piece of fused bronze, a drop of molten glass that may have been a bead, and an earthenware spindle-whorl. 


\section{ANGLO-SAXON REMAINS}

From the unburnt burials the brooches are the most interesting and instructive relics. They appear to have been found even in the graves of men at Kempston, ${ }^{1}$ and were generally worn in pairs by the other sex. First must be mentioned two brooches which are undoubtedly
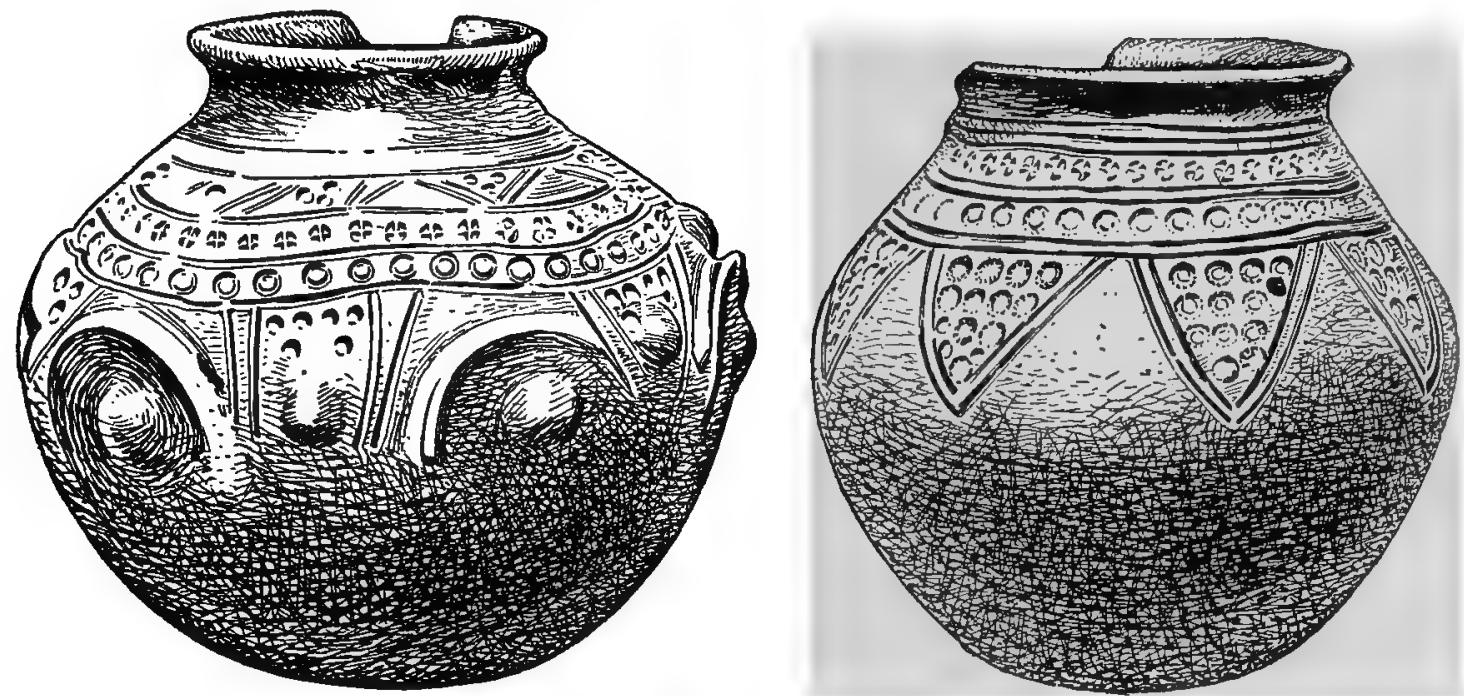

Cinerary Uris from Cemetery, Kempston.

$$
\text { (1 } \frac{1}{8} \text { size) }
$$

earlier than the bulk of the collection, and have been referred by Dr. Bernhard Salin to the first half of the fifth century. ${ }^{2}$ The claws at the head of one of these (see fig.) are survivals of the fastenings by which the long spiral spring of the pin was secured, and the facetting of the lower part is evidently derived from brooches and other ornaments of the

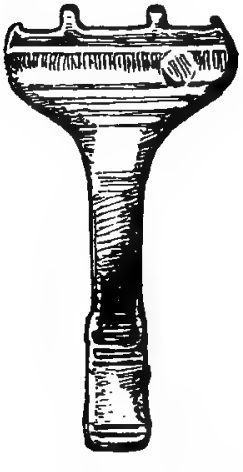

Bronze Brooch, Kempston.

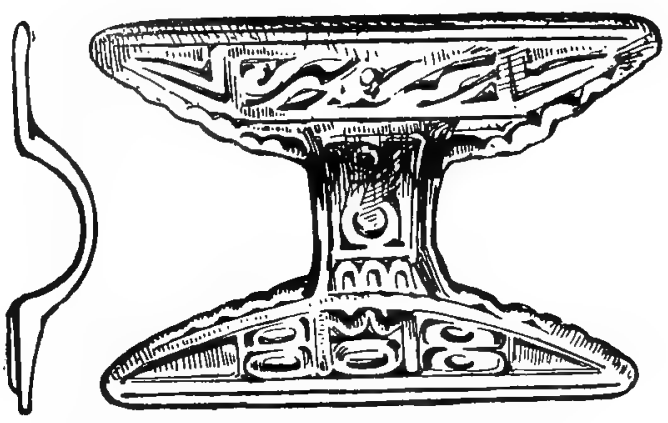

Engraved Bronze Brooch, Kempston.

late Roman period, that is prior to the fall of the western empire in the middle of the fifth century. The second brooch (see fig.) is of a peculiar form hardly represented in this country, only two other specimens being published, both from Cambridgeshire. Behind the broad

1 Roach Smith, Coll. Antig. vi. 169, 17 I.

2 Kongl. Vitterbets Historie och Antiquitets Akademiens Manadsblad (1 894), pp. 23, 29.

3 Op. cit. fig. 9, from Haslingfield ; and Hon. R. C. Neville, Saxon Obsequies, pl. 2, from grave 35 at Little Wilbraham. 


\section{A HISTORY OF BEDFORDSHIRE}

head, which is similar in size and decoration to the lower end, are traces of two perforated projections to hold the wire on which was threaded the spiral spring of the pin; and the length of the spring associates this and the other two examples rather with the brooches of the Danish moss-finds than with the specimens commonly found in England, which have no spiral but a simple hinge. The ornament too on the Kempston brooch, though not so well preserved or executed as that on the Haslingfield example, is directly descended from a Roman original and consists of floral scrolls. Four other types have been recovered from this site, and three are illustrated on the plate. Perhaps the most characteristic are of circular form (figs. I I, I 3), with a thin embossed gilt plate attached by cement to a bronze plate, which constitutes the base of the brooch and holds the pin and catch. Round the edge is a vertical band of bronze which serves to retain the cement and the ornamented face in position, though it is often itself found detached. A specimen of unusual size, $2 \frac{3}{4}$ inches in diameter, was exhibited to the Society of Antiquaries $^{2}$ in 1865 , but the average diameter for brooches of this 'applied' type is $2 \frac{1}{2}$ to 3 inches. As regards its origin, it should be observed that practically all the Saxon and Anglian brooches of the pagan period, as opposed to the jewelled specimens from Kent, are made all in one piece, while the type in question is formed of three metal parts in addition to the hinge-pin at the back.

The embossed design on the Kempston specimens is generally in the form of a cross or star with human faces rudely delineated at the end of or between the arms (figs. I I, I 3). It is unlikely that such a complicated pattern was a Teutonic invention of that time, and it may be possible to trace its beginnings to the late Roman period when models must have existed for such examples as those published from Gloucestershire and Neufchâtel, Seine-Inférieure. ${ }^{3}$

The second type, hardly less common at Kempston, is one that seems closely connected with the early occupants of the upper Thames valley, and there is sufficient historical evidence that this was one of the principal seats of the West Saxons. The 'saucer' brooch (figs. 6, 7) is generally smaller than the 'applied' variety just described, and has an average diameter of $I \frac{I}{2}$ to 2 inches. It is made all in one piece, and consists of a concave disc of fairly stout bronze, with the face gilt and incised with simple geometrical designs such as stars and scrolls, or with rude representations of the human features (fig. 6). Diminutive specimens, sometimes known as 'button' brooches and almost invariably engraved with the human face, are found in the Jutish districts of Kent and the Isle of Wight, also occasionally in Wiltshire and Berkshire, and a pair occurred in the Kempston cemetery, but must be regarded as exceptional, though their design seems to have been copied on somewhat larger examples here.

A comparatively large number of a type with a small bow and

\footnotetext{
1 Proc. Soc. Antig. ser. 2, ii. 42 I. 2 Ibid. iii. 97.

3 Figured in Proc. Soc. Antiq. iv. 38 and 237 respectively.
} 




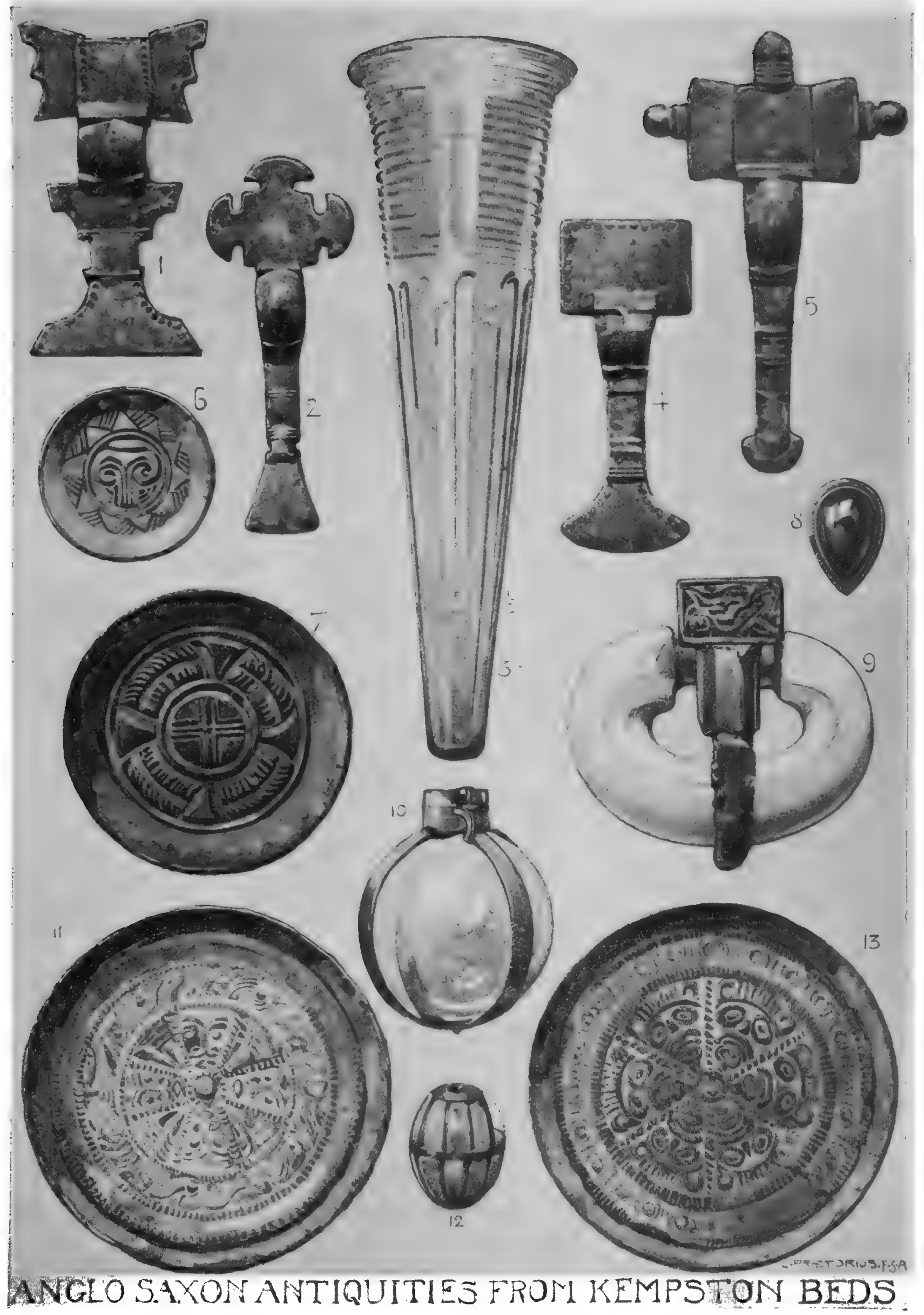





\section{ANGLO-SAXON REMAINS}

square head (figs. I, 2, 4), averaging 3 inches in length, were found at Kempston and at Toddington and Leighton Buzzard, as well as in various parts of the country. They seem to have been derived from a Scandinavian type of which only one or two examples have been found at Kempston (fig. 5), but do not seem connected with any particular tribe in England. The middle portion of a fine large square-headed variety of Anglian origin was recovered at Kempston, possibly from a cinerary urn ; but this was obviously exceptional, and the whole collection from Kempston has a decidedly Saxon appearance.

By far the richest grave in the cemetery was that of a woman, with whom had been buried no less than 120 beads of glass, crystal and amber, some of which were found near the left wrist. A ring of toilet articles and a carbuncle pendant set in gold (fig. 8) were also found, as well as a remarkably well preserved glass cup (fig. 3 ), $1 \circ \frac{I}{2}$ inches in height, with fine threads of glass applied to the surface. It is of conical form and pale green in colour, showing not the slightest trace of decay. The tapering end of a very similar cup from Longbridge, near Warwick, and a more complete specimen from East Shefford, Berks, are in the British Museum, but the form is a rare one and in this country is scarcely met with outside Kent. ${ }^{1}$

Several other objects of special interest were found in female graves, chief among them being three small cylindrical bronze boxes that had evidently been attached by a chain to the girdle and served as workboxes (see fig.) ${ }^{2}$ One that had been highly gilt lay by the right arm of a skeleton, and contained some spun thread and wool of two twisted strands, probably intended for embroidery. The lid had been kept on by the insertion of a small piece of coarse linen, but both parts were attached by separate chains to the longer girdle chain. In an adjoining grave another of these boxes lay on the right leg. This specimen also had been gilt and had the lid attached by an ingenious arrangement; while within was a fragment of worsted fabric, and some linen textile

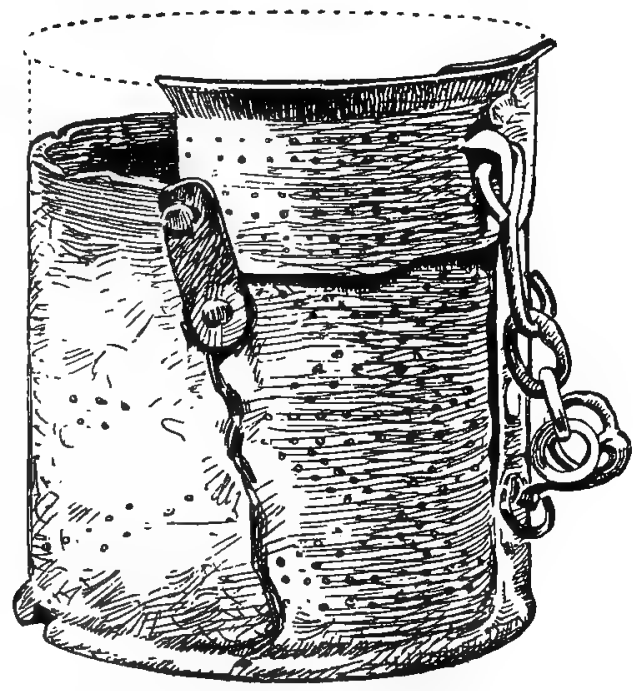

Bronze Workbox, Kempston. of three distinct qualities. Traces of what may have been leather indicated that the box had been carried in a pouch of that material. Leather seems also to have been used for bracelets, though the clasps are

1 One from Ozingell is figured in Coll. Antig. iii. pl. 3, fig. 8 ; two others from High Down, Sussex, in Arch. liv. 377, 378, pl. xxvii. fig. 1 .

2 This is shown by specimens found in the East Riding, Yorks, and at Hurdlow, Derbyshire, containing needles and thread (Catalogue of Mortimer Museum, Driffield, p. 2 I). Two others from East Riding, Yorks, are in the British Museum, and one was found at Cransley, Northants. 


\section{A HISTORY OF BEDFORDSHIRE}

generally all that remain; these are constantly found near the wrist, and a pair at Sleaford, Lincolnshire, ${ }^{1}$ were still attached to the original material when found.

In three or four of the graves shell fragments of combs and possibly of an armlet were found but they are in the last stages of decay; unlike a fine buckle (fig. 9) of the same material, which both for size and decoration may be compared with specimens of crystal found in Frankish graves on the continent. ${ }^{2}$ Bracelets and perhaps armlets of beads had also been worn; and large numbers of beads, probably in the form of necklaces or festoons, had been deposited in many of the graves of women. With the exception of a remarkable barrel-shaped specimen (fig. I 2), the bronze partitions of which are filled with some kind of shell, they are of the usual kind, the majority being of variegated glass and many of roughly-shaped amber, while the central bead of a necklace was often a large crystal. A sphere of this material (fig. Io) was recovered in its double loop of silver, but the loop was more probably for attaching this amulet to the girdle than to the necklace. These mysterious crystals again are mostly found in Kent, but examples are by no means uncommon in the Frankish graves of Normandy and the Rhine. As long ago as 1793 Rev. James Douglas, the author of Nenia Britannica, considered that they were used for purposes of divination or crystal-gazing; and against the view that they were merely ornaments attached to the girdle is the fact that more than once they have been found lying in metal spoons with perforated bowls. ${ }^{3}$

A list of known specimens has been prepared in recent years in connection with Scottish charms and amulets. ${ }^{4}$ The assistant keeper of the museum at Edinburgh states that balls of rock crystal have been found in various parts of Europe, and especially in England, mostly in connection with interments of the (Scandinavian) Iron age, that is, from about the fifth century of our era. 'Many of these balls when found were enclosed within narrow bands of metal, chiefly of silver, but sometimes of gold or bronze. Formerly these balls were considered by archæologists to have been used for magical purposes, but the general opinion now is that they were worn on the person as ornaments. At a much later period however the use of crystal balls for magical purposes appears to have been common in England.' 'The Clach Dearg, or stone of Ardvoirlich, much resembles the Anglo-Saxon specimens, and is figured along with the Clach-na-Bratach, or stone of the Standard, and another in a mount of the seventeenth century, in the papers referred to.

The graves of warriors are marked by the spearhead and remains of the shield, such as the iron boss and handle; while to one shield had been affixed by rivets a tin-plate device in the form of a fish (see fig.),

1 Arch. 1. 387 ; other examples have been found at Warren Hill, Suffolk, and at Marston Northants.

${ }^{2}$ Lindenschmit, Altertbimer unserer beidnischen Vorzeit, iii. pt. x. pl. 6.

3 V.C.H. Hants, i. 388 , figs. $18,22$.

4 Mr. G. F. Black, in Proc. Soc. Antiq. Scot. $1892-3$, p. 522 ; cf. $1894-5$, p. 439. 


\section{ANGLO-SAXON REMAINS}

very similar to an example found in an Anglian grave at Kenninghall, Norfolk. ${ }^{1} \quad$ Four swords of the usual two-edged type were found in the cemetery, one near the surface and the others in separate graves. They were originally about 3 feet in length, and one lay on the left side of

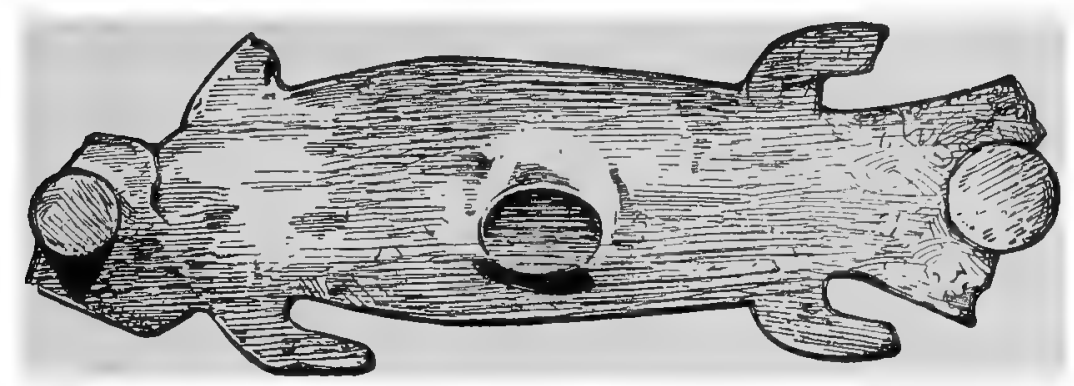

Tin-plate Badge, a Fish, Kempston.

the skeleton between the arm and the body, reaching 2 or 3 inches below the knee ; in the same grave, 5 feet deep, was also a small bucket with bronze hoops and iron handle. Though now in poor preservation, this clearly belongs to the same class as others in the British Museum from Hampshire, Berkshire, Lincolnshire, Cambridgeshire and Northamptonshire, and perhaps served the same purpose as the small vases placed in the graves.

The iron spearheads seem to have been at the right or left of the skull indifferently, and one at least had the blades alternately depressed in a manner common at that period. ${ }^{2}$ In two graves of men were found what appeared to be girdle-knives but without a cutting edge. These were perhaps made specially for funeral purposes, and may be compared with one from Lewes, and another found in a cinerary urn at Long Wittenham, Berks. ${ }^{3}$

In 1856 , some years before the exploration of the cemetery described above, a relic of remarkable rarity was found at Kempston, and described by Mr. James Wyatt. ${ }^{4}$ In digging for gravel, perhaps in the same field, the labourers came upon remains of several human skeletons, and among them an iron spearhead, shield-boss and an earthenware urn (see fig.) of a peculiar character. Its shape is distinctive, the body being deeply fluted at intervals and the shoulder ornamented with groups

1 The fish occurs as a decorative motive on a jewel from Hardingstone (V.C.H. Northants, i. 233 , fig. I on plate), and on a buckle from Crundale, Kent, in the British Museum.

2 Several of this kind have been published, and four were recently found in a cemetery at Droxford, Hants.

3 Arch. xxxviii. 333, 342. 4 Coll. Antiq. iv. 1 59. It is now preserved in the Library at Bedford. 


\section{A HISTORY OF BEDFORDSHIRE}

of dots enclosed in triangles. It is of dark ware, about $3^{\frac{1}{2}}$ inches high, and in a hole made through the bottom a piece of greenish glass, about the size of a shilling, was inserted before the vessel was fired. Mr. J. M. Kemble drew attention to a similar vessel found on the Elbe near Bardewick, Lüneburg, which had had two pieces of green glass, probably of Roman manufacture, let into the bottom and side; but the nearest parallel in this country is a vase found at Richborough, though in this case the pieces of glass were fixed on, and not in, the body of the vessel. Another skeleton found shortly afterwards in the same field at Kempston had several thin discs of metal about the neck; but as Roman remains have also been found there, this burial may have belonged to the earlier period.

An urn that resembles that just described in having groups of dots enclosed in triangles or chevrons is preserved in the library of Clare Hall, Cambridge. ${ }^{1}$ It is said to have been found at Dunstable, and probably contained cremated human remains. Another cinerary

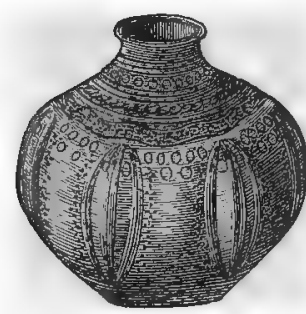

Cinerary $U_{\text {Rn, }}$ Sandy. ( $\left(\frac{1}{8}\right.$ size) urn of remarkable size (see fig.), ${ }^{2}$ the ornament on the body of which is not by any means unusual, was found in I $85^{\circ}$ near Cæsar's Camp, Sandy, not on the Roman site at the foot of the hill, but to one side of it, near the railway bridge. This urn and another ${ }^{3}$ were 9 inches high and 3 feet in circumference, and in the same place were found wooden coffins and a skeleton, on the chest of which had been placed a shallow vessel of lead, perhaps a chalice. Two such vessels of lead or pewter have in fact been found in what were no doubt the graves of Christian priests near Canterbury and at Reading."

From Sandy comes also a well made bronze bowl in the British Museum, but no particulars of its discovery are available. It seems to belong to the earliest Anglo-Saxon period, if not to the close of the Roman occupation, and may be the work of a British craftsman, though a larger specimen was found in the Anglian cemetery at Sleaford, Lincolnshire. ${ }^{5}$ It is 9.3 inches in diameter and quite plain, with the edge turned inwards at an angle and slightly thickened, evidently belonging to the same class as several found at Irchester, ${ }^{6}$ in the adjoining county of Northampton, and not far from the Bedfordshire border; also at Sturmere in the north-west corner of Essex. ${ }^{7} \quad$ It has been suggested that they were used for libations or other ceremonial purposes, and their discovery in sets with strainers lends support to the view. It is clear they were never intended for cooking, and examples of this type retain

1 Coll. Antiq. ii. 233, pl. liv. fig. 2.

2 Figured in Proc. Soc. Antiq. ii. Iog; for the site see Rep. Assoc. Arbit. Soc. Beds, 1853, p. 427, and Coll. Antiq. ii. 234.

3 Probably that in the Library at Bedford. A smaller cinerary urn is in the British Museum.

"V.C.H. Berksbire, i. 'Anglo-Saxon Remains.'

5 Arcb. 1. 395.

6 Assoc. Archit. Soc. Northants, 1875 , p. 90 ; V.C.H. Nortbants, i. 239.

7 Arch. xvi. 364 , pl. Ixix. 


\section{ANGLO-SAXON REMAINS}

no handles or any traces of them, unlike another well known class chiefly found in Kent with a pair of drop handles, or a third kind, found in various parts of the country, that had three hooks for suspension attached by means of enamelled discs to the side just below the moulded rim.

Discoveries of Anglo-Saxon burials have been made in Toddington parish on several occasions, but all on Sheepwalk Hill. In i86 I a skeleton was found close to a gravel pit there, but the only object associated with it was a bronze spiral finger-ring which was presented to the Society of Antiquaries by Major Cooper Cooper, from whose reports to the society ${ }^{1}$ the following account is compiled. At the close of $\mathrm{I}_{88}$ the ground was opened about 100 yards distant, almost in a direct line between Toddington and Harlington churches, one mile from the former, half a mile from the latter, and one mile north of Foxborough Hill, the site of a Romano-British cemetery.

On a spot where a skeleton had been found seven years before, another was discovered lying on a bed of concrete 4-6 inches thick, and not less than 9 feet square. It was nearly perfect and lay face downwards, the accompanying spearhead and knife of iron determining the sex. Close by was a third skeleton lying at right angles to the last and with the head to the south-east. On the shoulder were two bronze brooches ${ }^{2}$ of the small square-headed variety, similar to many found at Kempston (as fig. 4). They are of very frequent occurrence, and do not seem to have been confined to any particular locality. A year later bones that had been previously disturbed were found 5 yards off, and on a lower level, 3 feet from the surface, the skeleton of a woman with the head to the north-west. Below the waist lay an iron knife, and an iron object which seems to have been a 'girdle-hanger,' or châtelaine, with holes for attaching a bag of some kind by means of thread. At the head was a small urn (see fig.) rightly described as of Merovingian type, with a white incrustation on the inside. Six other skeletons were

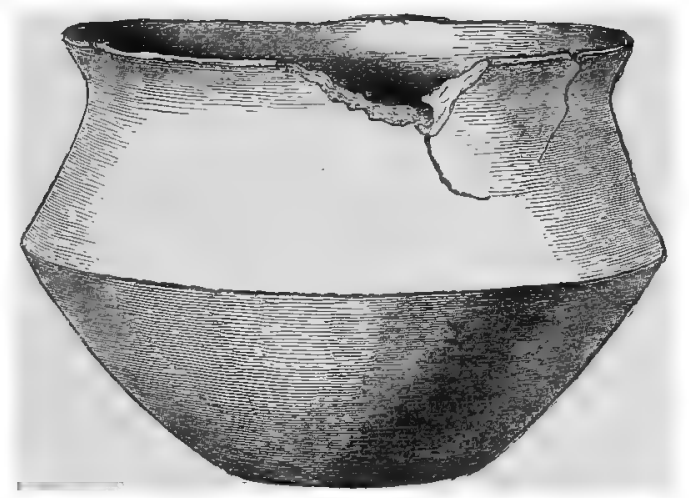

Merovingian Urn, Toddington.

(1 $\frac{1}{2}$ size) found here without any article of note, but in a woman's grave about 3 feet from the surface, with the head to the south, was a circular brooch $I \frac{I}{2}$ inches in diameter (apparently of the 'applied' variety) laid upon the chest, with beads of jet and glass, a bronze pin and two fingerrings.

Early records of discoveries at Bedford are imperfect and unpro-

1 Proc. Soc. Antiq. ser. 2, i. 399 ; x. $36,173$.

2 They are compared with fig. 45 I (from Peterborough) of Ll. Jewitt's Grave-mounds and their contents. 


\section{A HISTORY OF BEDFORDSHIRE}

vided with illustrations, so that there is now little opportunity of testing their accuracy or identifying relics said to be of Anglo-Saxon date. There is little internal evidence of such origin in several sharply pointed tines of deer-horn found at Bedford Castle about 1854 , with a number of arrowheads, beads of vitrified paste and of agate or carnelian. ${ }^{1}$ The tines measured about $3 \frac{\mathrm{I}}{2}$ inches in length and were thought to have served as the heads of missile weapons; but though the beads may well have been of the glass and amber usually found in Anglo-Saxon graves, such primitive lance heads as those described suggest a much earlier period. In I $88 \mathrm{I}$ a number of Roman and Saxon remains including pottery of both periods are said to have been discovered in Castle Lane, on what was thought to be the site of a Roman villa, ${ }^{2}$ but nothing that can be held to confirm the testimony of the Anglo-Saxon Chronicle with regard to Bedford is recorded till $\mathrm{i} 896$, when workmen employed in making a road through a field (now Russell Park), presented to the town by the Duke of Bedford, found three skeletons placed in a line east and west, the feet being towards the east. Close to two of the skulls lay spearheads of a common type, and a few yards south of the bodies was found an iron sword ${ }^{3}$; this was of the ordinary two-edged kind just a yard in length including the tang, with a uniform breadth of 2 inches. The
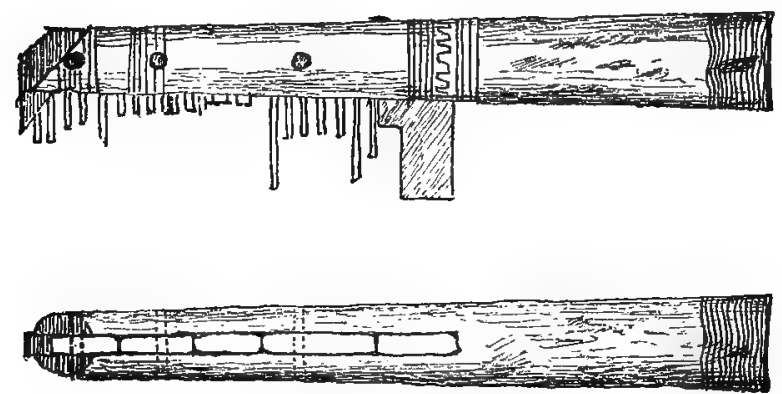

Bone Comb, Bedford. (1) size)

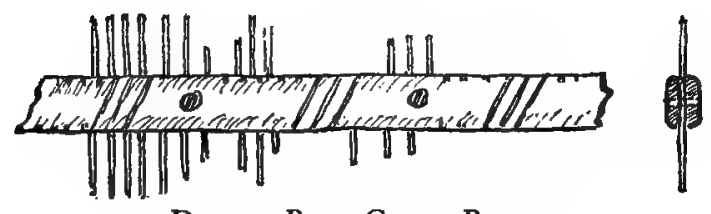

Double Bone Comb, Bedford. ( $\frac{1}{2}$ size) site is near Newnham, three quarters of a mile east of the county town on the north bank of the Ouse, and $5^{\circ}$ yards from the river. The skeletons were $3 \frac{\mathrm{I}}{2}$ feet below the surface in a bed of river alluvium, but though the surrounding soil was carefully sifted, no further relics of the period were discovered. ${ }^{4}$ This would not be surprising if, as is alleged, it was on this site that the Danes were repulsed from Bedford in the days of Edward the Elder, and these were the remains of burghers slain in action. The burial of weapons and ornaments with the dead would by that time be unusual, as the Church discouraged the practice.

At the end of 1887 excavations for a malting in Horne Lane disclosed two bone combs, one of which at least belongs to a Danish type, perhaps three or four centuries later than the battle of $57 \mathrm{I}$. They were

1 Fourm. of Arch. Inst. xi. 295.

2 Building News, 7 October, 1881.

3 These are now in the Council Chamber at the old Harpur Schools, Bedford.

- Report of Mr. J. Gwyn Elger, local secretary, in Proc. Soc. Antig. xvi. I I4. 


\section{ANGLO-SAXON REMAINS}

found 10 feet from the surface in a thick deposit of black mud overlying a bed of peat, and representing, as Speed's map shows, a wide ditch or creek which joined the Ouse a few yards south of the spot. ${ }^{1}$ The more perfect specimen (see fig.) resembles several from sites accessible to the Danish freebooters of the ninth and tenth centuries, such as York, the lower Thames and the Witham. It is 6 inches long, and the teeth, in five sections of ten or twelve each, are inserted in a tapering stem of circular section, the thickest end of which forms the handle. Iron rivets are used to keep the teeth in place, but the only ornament consists of wavy lines engraved round the butt and a rude design on one side. The second (see fig.) is a double comb, the teeth in sections as before and fastened with rivets, while the decoration takes the form of slanting lines engraved along the middle.

At Shefford, the name recalling an important West Saxon site in the Lambourn Valley, Berks, two saucer brooches characteristic of that people have been found in an ancient cemetery. ${ }^{2}$ The numerous vases and other remains from this site show however that the graves are of Romano-British origin; and the saucer brooches, which were a pair with gilt faces and iron pins, are perhaps the only traces of early Saxon occupation. That these came from a grave is practically certain, as it is unlikely that two brooches of exactly the same pattern would have been accidently lost on the same spot and have remained together on or near the surface for thirteen centuries.

A few relics from Leighton Buzzard ${ }^{3}$ were presented to the British Museum by Dr. Edward Lawford, F.S.A. Leighton Heath was brought under cultivation about fifty years ago, and on it at that time, about a mile north of the town, were two conspicuous grave mounds (tumuli), both circular and surrounded with a trench. About a quarter of a mile distant, at a place called Dead-man's Slode (Slade), there appears to have been an AngloSaxon cemetery where cremation was exclusively practised. Several burial urns of dark clay, hand-made and imperfectly fired, had been previously discovered, with the usual decoration consisting of rows of bosses, and zig-zags interspersed with dots and rings, impressed in the soft clay; and in 1880 sand was being dug in an adjoining pit when three ornaments were noticed which had no doubt once been interred with their owner. A gilt bronze saucer brooch, just over $\mathrm{I} \frac{\mathrm{I}}{2}$ inches in diameter, with a central

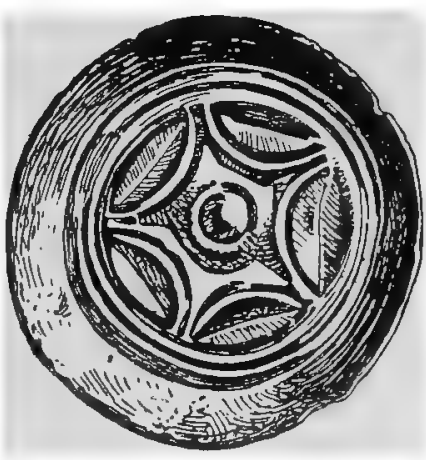

BroNZR-GILT Brooch, Leighton Buzzand. boss and design consisting of a five-pointed star (see fig.), points to intercourse with the West Saxons; though the probability that the burial was by way of cremation leaves the nationality of the original owner an

1 Proc. Soc. Antiq. xii. I I 5.

2 Fourn. of Arch. Inst. vii. 7 I (fig. p. 79); see also a paper on Shefford by Sir Henry Dryden in Pub. of Camb. Antiq. Soc. 4to, vol. i. (1845-6).

Compare one from Fairford, Gloucs, in Akerman's Pagan Saxondom, pl xix. fig. 


\section{A HISTORY OF BEDFORDSHIRE}

open question, towards the solution of which the common bronze brooch and small crystal bead, found at the same time, contribute little.

It will thus be seen that, apart from the discoveries at Kempston, there is as yet little material for a history of the district now known as Bedfordshire before the Chronicles become explicit and trustworthy. It is the province of archæology to supply the links that are missing in the written records, and at the same time to test the remainder; and enough has perhaps been recovered from its soil to show that before the county was constituted there were Anglo-Saxon settlers of at least two branches of the race, who may have approached their future homes from opposite directions. It may be safely laid down as a general rule that in this country cremation was an essentially Anglian rite, as it is almost confined to the districts known to have been occupied by the people to whom we owe the name of England. Not that unburnt burials are by any means unknown in those districts; they are in fact very plentiful, and in some parts of Northamptonshire, Cambridgeshire and East Anglia both rites were practised almost to the same extent. But in the centre and south of England cremation is certainly the exception, and is very rarely met with south of the Thames. The presumption is therefore that the Saxons of Essex, Sussex and Wessex, as well as the Jutes of Kent and south Hampshire, preferred to bury their dead in the extended position generally noticed in their districts. Where both methods of interment were adopted in the same cemetery, as at Kempston, the question arises whether the two classes of burials were contemporary, and if contemporary whether they indicate difference of blood among the inhabitants at that time.

Brief and spasmodic as are the early entries in the Chronicle, they do at any rate give some clue to the solution of the question. Authentic English history may be said to begin with the supremacy of Kent under Ethelbert in the closing years of the sixth century. Wessex was meanwhile extending her borders, and as the power of the Æiscings declined, Northumbria came to the front and was the leading kingdom among the Anglo-Saxons, till the Anglians of Mercia, under the redoubtable Penda, threatened the northern frontier of the West Saxons in the second quarter of the seventh century. In spite of sundry reverses Mercia maintained her rôle as the great midland power through this and the following century, but it was not apparently till the year 779 that Wessex ceased to hold territory north of the Thames, and it has yet to be determined how far her dominion extended along the Chilterns and the Cotswolds before expansion was checked by the advance of the Mercian southward from the Trent.

It is possible that cinerary urns, which occur in some numbers even at Long Wittenham and Frilford in Berkshire, mark in Bedfordshire an Anglian element in the population, before the general acceptance of Christianity rendered uniform the burial customs throughout English territory. If on the other hand cremation had here been the universal heathen rite, it is to be expected that the reformed burials would all be 


\section{ANGLO-SAXON REMAINS}

orientated in the Christian manner, with the head laid at the west end with the idea of facing the eastern sky at the resurrection. It has been already observed that no such uniformity exists in the Kempston cemetery, and graves are found in various directions elsewhere in the county. Hence the conclusion seems inevitable that we have to do with a mixed population which used the same burial ground but buried their dead each according to his ancestral traditions. Brooches of West Saxon type found at Kempston, Shefford and Leighton Buzzard are evidence either of settlements from Wessex on those sites or of ready intercourse with the occupants of the upper Thames valley. Buckinghamshire has yielded similar specimens from several localities, and the conquest of Bedford rests on the same authority as the capture and occupation of the four towns in $57 \mathrm{I}$. Discoveries in the soil to this extent confirm the record of the Chronicle; but if a West Saxon advance was possible under the escarpment of the Chilterns, it was also possible for immigrants from the eastern coast to gain a footing in the district. In addition to the fifth century brooches already described from Kempston, there may also be mentioned as indicating an early settlement in this part of Britain the peculiar jug-shaped cinerary urn discovered in the neighbouring county of Northampton at Great Addington.'

The late Mr. Grant Allen in a posthumous work ${ }^{2}$ expressed his opinion that, though the West Saxons held what is now Oxfordshire and Buckinghamshire for a considerable time after their victory at Bedcanford, they do not appear to have made any permanent settlement in Bedfordshire itself. 'This flat and fenny district was first really occupied by the Middle English, a tribe of Teutonic colonists who effected their entry into Britain by the Wash, and advanced towards the interior by the marshy basins of the Nene and Ouse.'

Where all is so problematical, it is idle to gainsay such a deduction from the county's natural features; but the unmistakable West Saxon stamp of brooches found at Shefford, Kempston and Leighton Buzzard might serve as a still stronger argument in favour of its partial occupation by that tribe before the spread of Christianity among them, and archæology suggests that they entered the district from the west and south-west. As already mentioned the urn-burials at Sandy, Kempston, Dunstable and Leighton Buzzard point to an Anglian connection, either with the Mercians of the midlands or with the inhabitants of East Anglia ; and another link in the chain that binds Bedfordshire to the Fen district has been discovered at Farndish in the extreme north-west corner of the county, near Irchester, Northamptonshire. In the British Museum are a number of amber beads from this site found about 1828 with a skeleton in a bank which here forms the county boundary, and with them was a small bronze brooch of a peculiar type (see fig.) almost identical with specimens from Soham, Cambs, and Kenninghall, Norfolk, ${ }^{3}$ in the same collection. Though no further details of the Farn-

1 V.C.H. Northants, i. 242.

2 County and Town in England, p. 87.

3 Another coincidence in this cemetery has been already noticed on p. 7 . 


\section{A HISTORY OF BEDFORDSHIRE}

dish find are preserved, it is allowable to argue from such a coincidence,

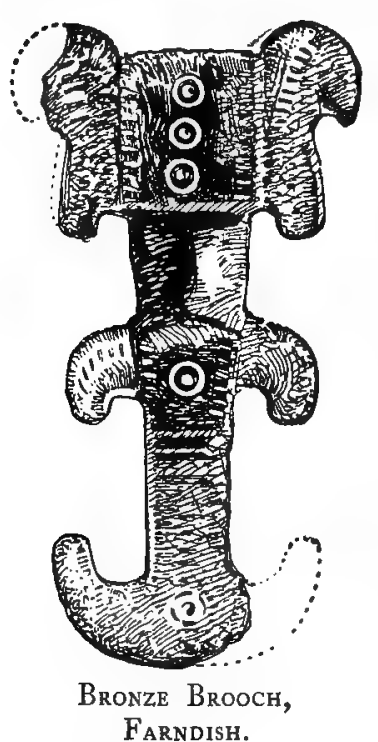
and to conclude that these horned brooches were made and worn by fellow-tribesmen in the two localities, who interred their dead without cremation. It is to this district that the South Gyrwa are assigned, and it is tempting to identify them with this folk, who lived in Anglian surroundings and yet had different burial rites; but it has been suggested ${ }^{\mathbf{1}}$ that the Gyrwa were Britons who had retained their territory and independence, and the question must remain an open one.

Two silver pennies of the Anglo-Saxon period may be mentioned as having been found in the county and published on account of certain special features. The earlier of the two, from the Canterbury mint, was discovered at Bedford and can be dated within three years. On the obverse is the name of Archbishop Ethelhard as 'pontifex,' and on the reverse that of Offa, King of Mercia (757-96). The coin was described by Sir John Evans, ${ }^{2}$ who assigned it to the years $790-3$, the former being the date of Ethelhard's nomination to the see of Canterbury, and the latter that of his full recognition as archbishop on receiving his pall from Rome. The other piece is from Toddington, and was struck for King Ceolwulf of Mercia (822-3 or 4 ) by a moneyer whose name appears as Elhun, but who is supposed to be same as Almund. ${ }^{3}$

An interesting relic of the late Anglo-Saxon period from the county may be mentioned in conclusion. Reference has already been made to some east-and-west burials in Russell Park that may conceivably be later than the seventh century, and contemporary with another sword preserved at Bedford, ${ }^{4}$ of the date and origin of which there is still some uncertainty. The place of its discovery is indefinite but not far from the county town, and this serviceable weapon may have been wielded by one of the Danes who made an unsuccessful attack on Bedford in $92 \mathrm{r}$. It is $35 \frac{1}{4}$ inches long, and complete except for the bone or wooden portion of the handle. The blade slightly tapers, and is double-edged with a shallow groove running down either face, as on most swords of the Viking period. The handle however is not quite so heavy as usual, the pommel being diminutive, and the straight guard of 3.3 inches somewhat short in proportion, in this respect resembling the early Anglo-Saxon type. On one face of the blade near the hilt is perhaps a trace of a damascened circular mark, ${ }^{5}$ a not uncommon feature on swords of this class, that are supposed to have been exported from Normandy and the mouths of the Rhine, and often bear the name of a maker VLFBERHT.

1 Rev. Edw. Conybeare, Popular History of Cambridgesbire, p. 42.

2 Numismatic Chronicle, new ser. (1865), v. 352 , pl. xiv. No. 2.

3 Op. cit. p. 168 ; cf. Catalogue of Anglo-Saxon Coins (British Museum), i. 40.

4 Recently restored at the instance of the Bedford Arts Club.

- Cf. A. L. Lorange, Den yngre jermalders Svard, pl. iii. fig. 5. 


\section{NOTES TO DOMESDAY MAP}

Compiled by F. W. RAGG, M.A.

With Notes by J. HORACE ROUND, M.A

IN this map those manors in which the King had an interest have a scarlet line under them; a blue line (broken) is under those in which the principal ecclesiastical tenant, Ramsey Abbey, held land; a green line denotes those of which part or all was held by Hugh de Beauchamp, the greatest lay tenant in the county. The name of a manor or of a Hundred is often given in more than one form by Domesday, but only one of these forms can be shown on the map. It has been found impracticable to give the boundaries of the Domesday Hundreds, but their names will be found on the map together with index letters showing to which Hundred each manor appertained (as shewn below). The modern river names have been added for the convenience of the reader.

The map illustrates the influence of the rivers, which were probably larger then than now, on the grouping of the manors, and the text illustrates their course and extent by its entries of meadows and watermills, both of them then valuable possessions.

\section{LIST OF THE HUNDREDS.}

A Stodene, Stodden.

B Wilga, Wilge.

C (Half) Buchelai, Bochelai, Bocheleia.

D Bereforde.

E (Half) Weneslai.

F Bicheleswade, Bichelesworde.

G Wichestanestou, Wichenestanestou.

H Radeburnesoca, Radborgestoche, Radbernestoch, Radborgestou, Ratborgestoc, Ratborgestou.

I Manesheve.

K Flictham.

L Clistone, Cliftone.

M (Half) Stanburge, Stamburge.

N Odecroft (pre-Domesday). Bedford itself is a Half Hundred.

When, through the omission of the heading, a vill seems to be placed in the wrong Hundred, the letter denoting that Hundred is added in parentheses.

\section{REFERENCE TO OOLOURING}

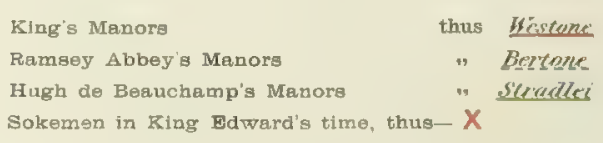

Scele of Inglish Miles

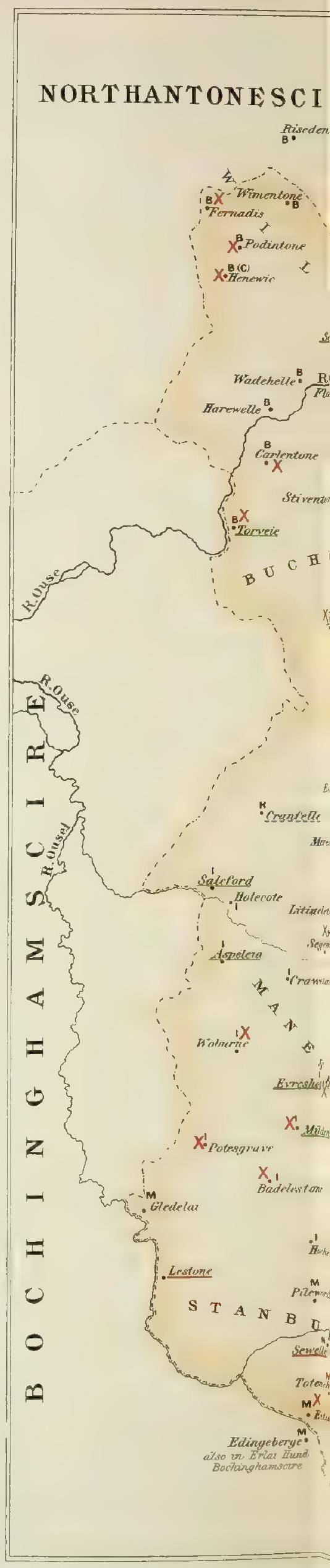




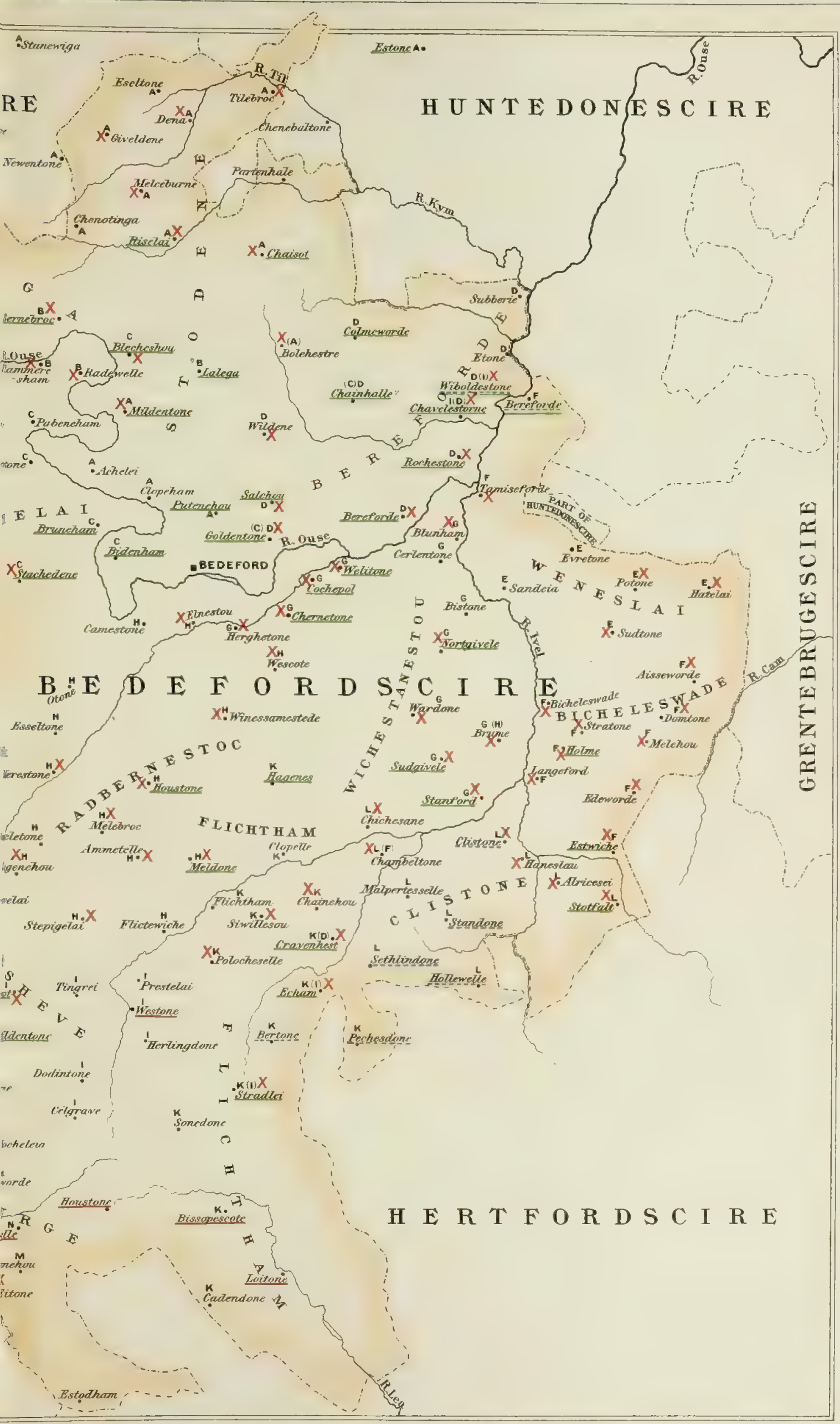





\section{DOMESDAY SURVEY}

Assessment of the county, pp. 191-193-The royal demesne, p. 194.-Bedford, p. 195The tenants-in-chief, spiritual and lay, pp. 1 95-204-Fate of English holders, pp. 205-207 - Problems of tenure, p. 207-Legal antiquities, pp. 208-212-Sources of wealth, p. 21 2-Identification of manors, pp. 213-216-The Bedfordshire Hundreds, p. 217.

I F the Domesday student were asked to name the feature of most interest to himself in the survey of Bedfordshire, he would probably name its 'hidage.' For it ranks next to its neighbour Cambridgeshire as a county illustrating the system of hidation, that is assessment, which was based on a unit of 'five hides.' This, which is the true key to Domesday, is a discovery of our own time. It was formerly supposed that the Domesday hide was either an actual measure of area or at least the representative of some definite value. But it is now known that manors (or more correctly vills) were assessed to the 'geld,' that is the land tax, in purely arbitrary multiples of the 'five-hide unit.' A small matter, it may seem, and of no general interest. We have, however, to remember what Domesday really was, and why the survey was made. 'One great purpose,' Professor Maitland says of Domesday, ' seems to mould both its form and its substance ; it is a geld-book.' ${ }^{2}$ And because it was the chief purpose of the survey to record assessment, we will deal with the assessment of the county first of all.

The large number of assessments recorded as exactly ten or five hides can hardly fail to strike the intelligent observer; but these are usually those of a vill (roughly speaking, a parish) in the hands of a single holder. When a vill was divided between two or more distinct tenants-in-chief, the assessment of each portion is recorded separately, and the total therefore is not obvious. Where, as at Husborne Crawley, a vill was divided into moieties, the assessment of each, it is true, is entered as five hides; but in several cases the portions were unequal and the assessment consequently fractional. To ascertain the amount at which the whole vill was assessed we have to reconstitute the total by adding up the fractions, a task often of difficulty and sometimes open to doubt. In Feudal England (pp. 55-7) I adduced illustrations from Mr. Airy's 'digest' of the Bedfordshire survey, ${ }^{3}$ and these I may here repeat :-

it is only Mr. Airy's work that enables us to reconstruct the townships, and to show how fractions-apparently meaningless-fit in, exactly as in Cambridgeshire, with one

1 See Feudal England, pp. 44-69, and Maitiand's Domesday Book and Beyond, pp. I 56-64, 450.

2 Domesday Book and Beyond, p. 3.

3 Digest of the Domesday of Bedfordshire (Bedford), 1881 . 


\section{A HISTORY OF BEDFORDSHIRE}

another. His work is all the more valuable from the fact that he had no theory to prove, and did not even add together the factors he had ascertained. His figures therefore are absolutely free from the suspicion that always attaches to those adduced to prove a case.

\begin{tabular}{|c|c|c|c|c|}
\hline Risely & Tempsford & Wymington & Cople & Eversholt \\
\hline ห. จ. 1 & ค. V. & n. V. & H. $\quad \mathrm{V}$. & H. $\quad$. \\
\hline 70 & I I I $\frac{3}{4}$ & 03 & 40 & 20 \\
\hline I 0 & I I & 30 & 5 & $7 \frac{1}{2} \circ$ \\
\hline$\frac{1}{2} 0$ & $4 \quad I$ & 40 & 0 & $\frac{1}{2} 0$ \\
\hline$\frac{1}{2} 0$ & $\begin{array}{ll}T & \\
2 & 0\end{array}$ & $\frac{1}{2} 0$ & & \\
\hline 10 & I & 03 & & \\
\hline & & 10 & & \\
\hline 100 & 100 & 100 & 100 & 10 \\
\hline Clophill & Northill & Potsgrove & Eyeworth & Holwell \\
\hline H. V. & H. v. & H. v. & H. v. & H. v. \\
\hline 0 & $1 \frac{1}{2} \circ$ & I 0 & 90 & $3 \frac{1}{2} 0$ \\
\hline 4 & $1 \frac{1}{2} 0$ & $7 \frac{1}{2} 0$ & 0 & $6 \frac{1}{2} 0$ \\
\hline 0 & $\frac{1}{2} 0$ & 10 & & \\
\hline & $6 \frac{1}{2} \circ$ & $\frac{1}{2} 0$ & & \\
\hline 100 & 100 & 100 & 10 & 100 \\
\hline & & Houghton & & \\
\hline Odell & Pavenham & Conquest & Dean & \\
\hline m. v. & n. v. & H. v. & n. v. & \\
\hline $4 \frac{1}{2} \quad \frac{1}{3}$ & $2 \frac{1}{2} 0$ & 50 & 40 & \\
\hline $5 \quad \mathrm{I} \frac{2}{3}$ & 50 & $\frac{1}{2} 0$ & $\frac{1}{2}$ & \\
\hline & $2 \frac{1}{2} 0$ & $4 \frac{1}{2} 0$ & $\begin{array}{ll}2 & 7 \frac{1}{4} \\
0 & 1\end{array}$ & \\
\hline$\longrightarrow$ & - & $\longrightarrow$ & & \\
\hline 0 & 100 & 100 & $10 \quad 0 \frac{1}{4}$ & \\
\hline
\end{tabular}

Of these fourteen ten-hide townships the last is selected as an instance of those slight discrepancies which creep in so easily, and which account for so many apparent exceptions to the rule. Passing to other multiples of the five-hide unit we have :-

\begin{tabular}{|c|c|c|c|c|c|}
\hline Oakley & Thurleigh & Blunham & Marston & Roxton & Dunton \\
\hline r. v. & H. V. & н. V. & M. v. & & H. $\quad$ v. \\
\hline 40 & $0 \quad 1$ & $4 \quad I$ & ( 2 (less $\frac{1}{2}$ virg.) & I I & 8 I) \\
\hline 10 & $\frac{1}{2} \circ$ & $0 \quad 1$ & $10\left\{8\right.$ (plus $\frac{1}{2}$ virg.) & $\circ 4$ & $\left.\begin{array}{ll}1 & 3\end{array}\right\}$ \\
\hline & $\frac{1}{2} 0$ & $\frac{1}{2} 0$ & I & $1 \mathrm{I}$ & $50)$ \\
\hline & $0 \quad 1$ & 100 & $5 \frac{1}{2}$ & $7 \frac{1}{2} \quad \mathbf{I}$ & $\left.4 \frac{1}{2} \circ\right\}$ \\
\hline & $\begin{array}{ll}3 & 0 \\
\frac{1}{2} & 0\end{array}$ & & $\left\{\left\{\begin{array}{l}3 \\
\frac{1}{2}\end{array}\right.\right.$ & 83 & $\frac{1}{2} \quad 0$ \\
\hline 50 & o & 150 & 150 & 200 & 200 \\
\hline
\end{tabular}

I now give three illustrations of slight discrepancies :-

\begin{tabular}{|c|c|c|c|c|c|c|}
\hline Streat & & Sut & & & Eaton & Socon \\
\hline & v. & H. & v. & & н. & v. \\
\hline I & 0 & 0 & $3)$ & & 20 & 0 \\
\hline & $I$ & & 0 & & 6 & 3 \\
\hline $4 \frac{1}{3}$ & 0 & I $\frac{1}{2}$ & 0 & & 0 & $1 \frac{1}{2}$ \\
\hline 0 & $\frac{2}{3}$ & $\frac{1}{2}$ & 0 & 5 & 0 & $\frac{1}{2}$ \\
\hline & $\frac{2}{8}$ & $0^{-}$ & $3 \frac{1}{2}$ & & 9 & I \\
\hline & & 0 & ( $\left.\frac{1}{2}\right)$ & & 0 & $5 \frac{1}{2}$ \\
\hline & & 2 & 0 & & 2 & $\frac{1}{2}$ \\
\hline & & $0_{1}$ & 3 & & 0 & 1 \\
\hline & & $\frac{1}{2}$ & 0 & & & \\
\hline & & 0 & I $\frac{1}{2}$ & & & \\
\hline & & 1 & 0 & & & \\
\hline 9 & $3 \frac{2}{3}$ & 9 & $\circ \frac{1}{2}$ & & $4^{\circ}$ & I \\
\hline
\end{tabular}

1 These letters stand for 'hides' and 'virgates' ; the 'virgate' was the quarter of the 'hide' and was divided into thirty 'acres,' which it must be remembered were not measures of area. 


\section{THE DOMESDAY SURVEY}

In the first case there is a deficiency of $\frac{1}{120}$, and in the second of $\frac{7}{80}$, while in the third we find an excess of $\frac{1}{160}$. No one can doubt that these were really ten-hide, ten-hide, and forty-hide townships. We have to allow, in the first place, for trivial slips, and in the second for possible errors in the baffling work of identification in the present day.

The essential point to be borne in mind is that the principle of assessment in units of 'five hides' has to be tested by examining the survey of the county as a wbole. When this is done the evidence in its favour is, in Bedfordshire, overwhelming. That it is not so absolutely perfect as in Cambridgeshire is largely due to the fact that we have for the latter county transcripts of the jurors' actual returns, hundred by hundred and vill by vill. These returns were broken up for the compilation of Domesday Book by re-arranging the contents under 'fiefs,' and thus the unity of the vill's assessment became obscured in what, as the above tables show, was often a multitude of fractions. Mr. Ragg, who has made an independent analysis for the purpose of the present work, has attempted the reconstruction of the vills hundred by hundred, and from his results we glean further cases in point :-

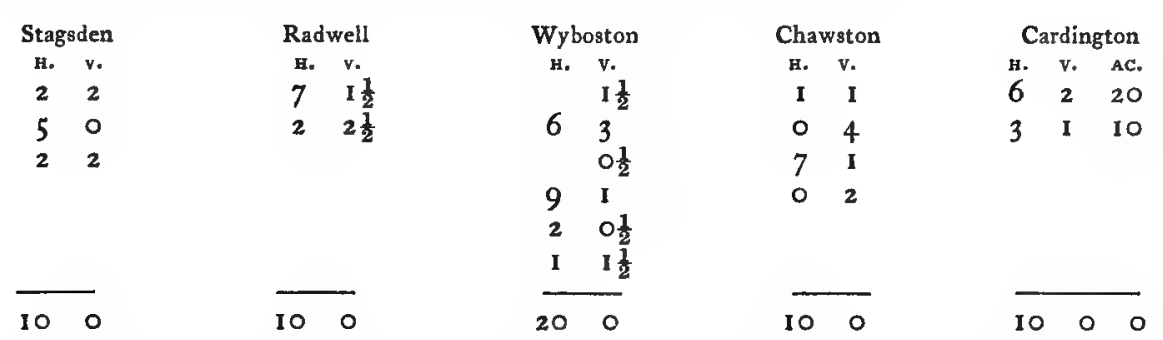

The last two instances are peculiarly striking, and we may observe that even the fractions adapt themselves to the payment of the 'geld,' for when this tax was at two shillings on the 'hide,' five 'acres' would pay a penny and two and a half a halfpenny.

Apart from assessment, the Bedfordshire Domesday is of interest for its surveys of the royal manors, for the light it throws on the difficult question of tenures on the eve of the Conquest, for disputed titles to estates, for allusion to exchanges of lands, and for the frequent mention of Ralf Tallebosc, who, although dead at the time of the survey, had left his mark on several places, and whose widow and daughter were holding lands which were often the subject of rival claims.

King William's share in the spoils of the Conquest was represented in this county, at first sight, by those lands only which came to him as Crown demesne ; for, strange as it seems, Harold is not mentioned in its survey as having held any manor within its borders. ${ }^{1}$ And this Crown demesne was of a very peculiar character. Instead of being scattered about the county as was usually the case, it lay in a belt along its southern border through the manors of Leighton Buzzard,

\footnotetext{
1 He had, however, annexed Weston(ing) to his manor of Hitchin (Herts); and it thus came to King William.
} 


\section{A HISTORY OF BEDFORDSHIRE}

Houghton Regis and Luton. ${ }^{1}$ The first and last of these were assessed at 30 hides apiece, the other at 10 hides. In the form of the revenue derived from these three manors we detect at once a note distinctive of Crown demesne in the half day's ferm (dimidiam diem ad firmam regis) that was due from each of them. The constituents of this antique render are specified as wheat, honey, and the other things recognized as part of it, the honey being probably required for mead. But in addition to this traditional due there was also a money payment, amounting to $\oint_{0} 22$ from Leighton, $£_{3} 0$ from Luton, and $\oint_{0} \mathrm{I}$ o from Houghton, payable in each case in weighed money. This is an unusual feature, but there is nothing in the text to show that it is a Norman addition. Of the antiquity of the miscellaneous dues there can be no question, for they are found occurring similarly in other counties; for the queen's use Leighton and Houghton contributed each 2 ounces and Luton 4 ounces of gold; for a sumpter-horse and for the king's hounds various amounts were paid, the payment for the former being here grouped with others. The payment, however, for a sumpter-horse alone is found in Domesday as twenty shillings. In addition to all these payments Ivo (not Ralf). Tallebosc had enacted, it would seem, an additional payment (misit de cremento) of $£_{0} 7$ apiece in the case of Leighton and Luton and of $£_{0} 4$ in that of Houghton, partly in weighed and partly in assayed silver, with an ounce of gold further from each of them to the sheriff himself.

The closest parallel to the dues from these royal manors is found in the adjoining county of Cambridgeshire, where several royal manors, in the days of Edward the Confessor, paid their rent to the Crown partly in 'three days' ferm' (frmam trium dierum) and partly in money. Wheat and honey are specified, in their case also, as comprised in the 'ferm,' but malt (brasium) is mentioned in addition. In Cambridge this payment in kind had been commuted for money; in Bedfordshire, apparently, it had not. The additional payments for special purposes due from the Bedfordshire manors are not mentioned in Cambridgeshire, and only occur, it would seem, elsewhere in Domesday among the payments due from counties as a whole.

The churches of the three royal manors were, as was usually the case, important and richly endowed; but they must be reserved for treatment in another section below. The point which remains to be considered here is the arbitrary action of Ralf (not Ivo) Tallebosc in annexing manors and altering hundreds when in charge of the Crown demesne. In the manor of Leighton Buzzard he had, we read, incorporated two considerable estates which had formerly belonged to private owners; in that of Houghton Regis he had similarly incorporated Sewell; and in that of Luton, Biscot. In these last two cases the added estates were actually taken out of their Hundreds by Ralf, though he seems to have compensated the Hundred of Flitt by robbing another Hundred for its benefit.

1 Dunstable is not mentioned, because it was subsequently created, on the royal demesne, by Henry I., the bulk of it being taken from Houghton Regis. 


\section{THE DOMESDAY SURVEY}

For a parallel to such action we must turn to Hitchin, not far away, in Hertfordshire. As held by King William in 1086 it had been swollen by the action of Norman sheriffs of that county; but of one at least of its additions we read that it was Earl Harold who had annexed it to Hitchin, ' 'by violence and wrongfully as the shire testifies.' The importance of such evidence lies in its suggestion that there may have been similar changes effected in the days before the Conquest in places where Domesday does not make any mention of the fact.

Of Bedford itself the account in the Survey is singularly short and unsatisfying. As the county town it is entered apart from the rest of the shire, and is not even treated as included in the royal demesne ${ }^{2}$; but it differs from the chief towns of the shires surrounding in the singular brevity of its description. Cambridge, for instance, fills a whole column of Domesday, and the account of Northampton is nearly as long; to Huntingdon is assigned a column and a half, and to Buckingham and Hertford respectively the greater part of a column. Why the entry on Bedford should be restricted to seven lines it seems impossible to explain. Even of this terse entry more than half is occupied with an act of agression on the part of the Bishop of Lincoln. We are left in ignorance of so important a matter as the annual value of Bedford to the Crown, and the only fact, indeed, on which we obtain information is the assessment of the town (villa); for it is not styled a borough (burgus), although we read, towards the end of the Survey, of its ' burgesses.' This assessment is akin to that of Cambridge and of Huntingdon; for while Cambridge is assessed at a whole Hundred, and Huntingdon at 50 hides, Bedford is assessed at half a Hundred, that is, presumably, at 50 hides. So too Shrewsbury was assessed at 100 hides and Chester at $50{ }^{3}$ But the peculiarity in the case of Bedford is that its assessment was only for land and sea service, and implied probably a contribution of ten men to either. ${ }^{4}$ It would seem from this that the town was not assessed to the 'geld,' and that such is the meaning of Domesday when it says that it was never apportioned into 'hides' (bidata) with the exception of one 'hide' with which St. Paul's was endowed.

In its regular and stately course the great Survey proceeds from the lands of the king himself to those of the spiritual lords. At the head of these are those alien magnates, the Bishops of Coutances and Bayeux, who held their great fiefs, extending over many counties, in a personal, not an official capacity. The former was a trusted friend of the Conqueror; the latter was William's half-brother. In Bedfordshire as in Northamptonshire Geoffrey, Bishop of Coutances, held the bulk of his estates as successor to an English landowner, Borgeret, Borgret, Borred, Borret, Burgret, Burred or Burret, 'thegn of King Edward.' These estates lay largely along the Northamptonshire border, namely at Knot-

\footnotetext{
1 'Apposuit Heraldus comes in Hiz' (fo. 133 ).

${ }^{2}$ For the importance and the implication of this separate treatment see Maitland's Domesday Book and Beyond, pp. $176-80,212$.

a Compare Feudal England, p. 156 ; and my paper in Domesday Studies, pp. I I 7-2 I.

4 Ibid.
} 


\section{A HISTORY OF BEDFORDSHIRE}

ting, Newton Bromshold, Rushden, Melchbourne, Yelden, Shelton, Dean and Riseley. From the Northampton Survey we learn that the bishop claimed as Burred's successor the 'homage' of William Peverel's sokemen, at Rushden, Irchester and Raunds (fo. $225 \mathrm{~b}$ ), together with some land at Podington (in Bedfordshire) which had been held by 'two "men" of Burred" (fo. 229). The account of these lands illustrates alike the position of a great English landowner, with thegns and sokemen under him, on the eve of the Norman Conquest, and the system by which a Norman magnate was placed in the shoes of his English predecessor, all whose rights he thereby acquired.

Two of his Bedfordshire estates, however, had come to the bishop in another way. They are alleged to have been held by him 'pro Excambio de Bledone,' a phrase which there is nothing to explain, but which recurs in Buckinghamshire, where two estates are similarly alleged to be held 'de Excambio pro Bledone' (fo. 145b). It is clear that the place spoken of must be Bleadon, Somerset, although in the survey of that county there is nothing to connect it with the bishop. He must, however, have disgorged it in exchange for these lands in Beds and Bucks, such incidental mention of changes being found elsewhere in Domesday. ${ }^{1}$ It can hardly be said that the bishop left any mark on the county, save through his tenant Geoffrey de 'Traillgi'-who doubtless derived his name from Trelly, a few miles to the south of Coutances-with whom originated the Bedfordshire family and 'barony' of Trailly.

The fief of the Bishop of Bayeux was soon forfeited to the Crown, and is only remarkable in this county for two cases of subinfeudation, that is, of an under-tenant enfeoffing a man under him. Ansgot of Rochester and Herbert son of Ivo, who held here of the bishop, were considerable tenants of his in Kent, the sphere of his power. The Bishop of Lincoln, in whose diocese the county then lay, had only succeeded to a small estate in his official capacity, the others in his possession having previously been held by English owners, now forfeited.

Of the English religious houses some had lost by the Conquest, Harold's foundation at Waltham in honour of the Holy Cross being despoiled, here as in Essex, in favour of a Norman prelate, the Bishop of Durham. Ramsey Abbey complained bitterly that the valuable manor of Clapham belonged to the endowment of its monks, a claim which its neighbours endorsed, though Miles Crispin had possession at the time of the Survey. Probably, as happened in other cases, Miles had obtained it as successor to the Englishman, Brihtric by name, who had held it, not in his own right, but as a tenant of the abbey.

At Bedford itself St. Paul's, a house of secular canons, had lost more than it gained. The Bishop of Lincoln had robbed it of its local en-

2 In this county we shall see below Ralf Tallebosc had received lands in exchange for Ware in Hertfordshire, and William Spech held two manors in exchange for 'Totingedone.' 


\section{THE DOMESDAY SURVEY}

dowment, entered as worth no less than $f_{0} 5$ a year; and it was poor compensation for this that 'Leuiet,' an English priest, had bequeathed to it since William's accession one virgate at Biddenham, to which Ralf Tallebosc had added three more, for the whole of this was only worth I 3 s. It held indeed of Countess Judith, seemingly as a fresh endowment, 3 hides at Harrowden, but even this was only worth 30 s. If, as I have assumed above, 'the church of Bedford with its possessions,' which was held by Bishop Remi, was identical with the endowment (of the same value) of St. Paul's, which he had annexed, the alternative description is worth noting. $\quad$ The well-endowed church of Leighton (Buzzard), worth $f_{4}$ a year, was also held by Remi, as it had been by his predecessor Bishop Wulfwi. Of the two royal manors, Luton and Houghton (Regis), the churches, with their appendant estates, were held by 'William the Chamberlain.'

In his erudite history of Luton church, ${ }^{2} \mathrm{Mr}$. Cobbe has discussed the exact position of this 'William the Chamberlain,' contending that he was probably ' an ordained clergyman,' but there is nothing to show that this was so beyond his holding the churches of Luton and Houghton; and it is proved, as Mr. Cobbe observed, by the Gesta Abbatum of St. Alban's, that a younger 'William the Chamberlain' actually claimed to hold the church and its appendant estate of the Earl of Gloucester. The whole story is very curious, and illustrates the temptation presented by church endowments, ${ }^{3}$ when they were so valuable as at Luton, where the six ploughlands of glebe were assessed at 5 hides. Mr. Cobbe arrived at the conclusion that this estate is now represented by Dallow manor in Luton. There can be no reasonable doubt that William the Chamberlain, who also held lands in capite at Battlesden, Potsgrove, and Totternhoe, was identical with the man of that name who held land, also in capite, at Hartwell, Bucks, and at Wincot, Gloucestershire, who was joint-fermor of a Crown manor in Cambridgeshire, and who held of the Bishop of London at Stepney and of the abbot of Westminster in Essex.

Mr. Cobbe, it would seem, was not acquainted with the cartulary of Ramsey Abbey, which contains charters of considerable importance in connection with William the Chamberlain." These show us a man of that name, probably the Domesday tenant's son, residing at Luton under Henry I. and restoring to Ramsey Abbey its estate at Pegsdon (in Shillington) in this county, of which the abbey was in full possession at the time of Domesday. They further establish his identity as William the Chamberlain ' of London,' which accounts for the appearance of a tenant so styled on the Earl of Gloucester's fief, Luton having been bestowed on Robert, the first earl, by his father, Henry I.

1 The similarly double entry of his tenure of the church of Leighton makes the identity certain.

2 Luton Church, by Rev. Henry Cobbe (1899).

3 A good instance in point is found at Colchester, where the church of St. Peter's, which 'two priests' had held before the Conquest, was endowed with a good estate. A quarter of this endowment, at the time of the Survey, was in the hands of 'Eudo Dapifer,' and the rest was claimed by Robert son of Ralf de Hastings.

Ed. Rolls Series, i. 142-4. 


\section{A HISTORY OF BEDFORDSHIRE}

Of other than local religious houses, St. Neots (Hunts) had lost to Richard de Clare some of its lands in Eaton Socon across the Bedfordshire border, while it still held, as tenant to his wife, some land on the Huntingdonshire side of the river. The evidence of Domesday here affords an interesting confirmation of the statement in the Liber Eliensis that Richard (who is there erroneously styled Gilbert) de Clare took advantage of the Ely revolt to despoil the lands of Einulfsbury-as St. Neots was then termed-and to expel the Ely monks by whom it was then held. These, it alleges, he replaced by foreign monks from Bec.'

St. Alban's again appears to have lost a hide at Stotfold to Hugh de Beauchamp. From other sources we learn that it lost more than this. Oswulf the son of Frane, a wealthy thegn, had given to Abbot Leofstan under the Confessor land at Studham, ${ }^{2}$ which is found, however, at the time of the Survey, with the rest of Oswulf's estates, in the hands of the Norman lord of Belvoir. The gift had been witnessed by a neighbouring lord, Leofwine 'Cilt' of Caddington, who himself held his lands at Caddington and Streatley for life only with reversion to St. Alban's under the gift of his father Eadwine. ${ }^{3}$ Domesday ignores the gift under both these places, and shows us his Streatley land in the hands of Nigel 'de Albini.'

The cathedral church of London had acquired his estate at Caddington; and the great abbey of St. Edmund at Bury, which flourished under the Conqueror's rule, had received from Earl Waltheof and his wife a substantial addition to its endowment. Foreign monks had obtained as yet strangely little in the county, Nigel of Albini alone bestowing on those of St. Nicholas of Angers a small portion of the manor that he held at Henlow. The nunnery of Elstow, however, was an addition to the local houses, being founded since the Conquest by Countess Judith.

As to the laymen holding lands, at the time of the survey, in the county, we must not expect to find their names or even their descendants in the male line among the local landowners of modern times. Even of the list of local gentry in the reign of Henry VI., Fuller, its editor, wrote in the seventeenth century :-

Hungry Time hath made a [Gluttons Meal] on this [Catalogue of Gentry] and hath left but a very little [morsell for manners] remaining; so few of these are found extant in this [Shire], and fewer continuing in a [Gentile Equipage].

The name of one, the Mordaunts of Turvey, is still found in the Baronetage (creation of I6II), and, although no longer connected with the county, invites mention here on account of the assertion still found

1 Liber' Eliensis (Ed. Anglia Christiana Society), pp. 239-40: 'Quam violenter locus de Enulfosbury abstractus sit Elyensi ecclesia.' The Sudbury land in Eaton Socon, which belonged to St. Neots, had been wholly annexed by Richard; while at Wyboston, which the house had formerly held ' in almoin,' it now held only as Richard's tenant.

Kemble, Cod. Dipl. iv. 280-1 (No. 945).

3 Ibid. iv. 259 (No. 920). 


\section{THE DOMESDAY SURVEY}

in Burke's Peerage and similar works that its founder, 'Osbert le Mordaunt,' obtained a manor at Radwell by the gift of his brother, Eustace de St. Gilles, who had received it from King William in return for his services in the Conquest. To this tale the Domesday Survey affords no support, and I have elsewhere denounced as a mere concoction the charter on which it rests. ${ }^{2}$ It was printed in that curious work, Succinct genealogies of the noble and ancient bouses of . . Mordaunt of Turvey ( 1685 ), for which the eccentric Earl of Peterborough, then head of the Mordaunts, and a rector of Turvey appear to have been jointly responsible. The family, however, was already seated at least as early as the thirteenth century at Turvey.

The three great local barons whose fiefs had their 'heads' in the county were Hugh de Beauchamp, Walter the Fleming, and Nigel 'de Albini '-whose name, in French, would be represented by Néel d'Aubigny. All three were succeeded in their lands by lines of heirs longer than was usual in the case of Domesday barons. The last of the Beauchamps ' of Bedford' fell at the battle of Evesham (1 265), his sisters succeeding him in his lands; and the lands of Albini 'of Cainhoe' similarly passed, a generation earlier, to the sisters of the last of the male line; but the heirs male of Walter the Fleming continued to hold his barony of 'Wahull' (now Odell) down to the days of Henry VIII., and the Domesday fief remained afterwards in the hands of the heirgeneral." Cainhoe and 'Wahull' were from the first part of their respective baronies ; ${ }^{3}$ but the Domesday account of the town of Bedford is too meagre for us to discover what, if any, connection Hugh de Beauchamp had with it in 1086. As the Bishop of Coutances had, we have seen, brought with him a tenant from the region of his cathedral city, so had Nigel 'de Albini' brought with him a namesake from what was probably the same district, the Côtentin. This was Nigel 'de Wast,' who derived, I think, his name from Le Vast, east of Cherbourg, as would his lord from (St. Martin d')Aubigny, north-east of Coutances. Under his lord he held five estates in Beds and one in Bucks, but these probably escheated afterwards, for his adjoining manors of Ampthill and Milbrook are subsequently found in the hands of the lords of the fief. A noteworthy entry in its Domesday description tells us that Nigel ' de Albini ' was holding 25 acres in Maulden," which John de Roches had annexed to the wrong of the men of that vill (super bomines qui villam tenent). Under the holdings of Ramsey Abbey we read that at Barton-in-the-Clay the abbot had been wrongfully disseised, he claimed, by John de Roches of 12 acres of meadow, which were held at the time of the survey by Nigel 'de Albini' and Walter the Fleming. Thus we have, in two places, incidental mention of John de Roches as a predecessor of Nigel, together with a hint

1 See 'The Companions of the Conqueror' in Monthly Reviev, iii. 107.

2 Domesday Book, with its entry of this fief, was actually produced in the House of Lords, some years ago, in the 'Wahull' peerage case.

3 For the moated mounds at each, on which stood the barons' castles, see the section on 'Ancient Earthworks,' below.

4 Maulden lay between his manors of Ampthill and Clophill. 


\section{A HISTORY OF BEDFORDSHIRE}

that Walter the Fleming was also a successor of John. In Nigel's case, at any rate, we can connect this aggression with his tenure of land at Streatley adjoining Barton.

Unlike Nigel 'de Albini,' whose lands had been held before the Con- quest by many and chiefly by small owners, Walter the Fleming held his fief mainly in Bedfordshire and wholly in Northamptonshire as successor to Leofnoth, a great thegn, whose 'men,' Ordric and Lant, are mentioned in the former county. But another thegn, Leofwine, had preceded him in some of his Bedfordshire estates.

More than five columns of the survey are devoted to the fief of Hugh de Beauchamp, which is chiefly remarkable for its previous history. As I have shown in my introduction to the 'Domesday Survey of Hertfordshire,' a great estate in Bedfordshire as well as in that county had belonged to an English thegn Anschil (or Aschil) ' of Ware,' ${ }^{2}$ who must have been so named from having there his chief seat. This estate had passed to Ralf Tallebosc, who exchanged Ware itself (which is found at the time of the survey in the hands of Hugh de Grentmesnil) for certain lands in Bedfordshire. The six entries of lands held 'pro excambio de Warres' (or 'Wares') relate to this exchange. As is usually the case in Domesday, we only learn the history of the fief by incidental allusions. For instance, we read of Hugh's valuable manor of Stotfold, which had belonged to 'Aschil,' that it was rented at $f_{0} 3^{\circ}$ a year at the time of Ralf Tallebosc's death. For further allusions we have to turn to the entries of other fiefs. Thus under that of the Bishop of Lincoln we find William de Caron complaining that his father had been disseised by Ralf Tallebosc of land which Hugh de Beauchamp was holding at the time of the survey; under that of William de Warenne we find Hugh de Beauchamp claiming land at Tillbrook on the ground that his predecessor (antecessor) Ralf Tallebosc had been duly seised of it ; and a few lines lower down we find 'Aschil' spoken of as Hugh's predecessor with no mention of Ralf's intermediate tenure. On the opposite page of Domesday Eudo dapifer complains that Ralf 'when he was sheriff' disseised him of some woodland at Sandy, which Hugh now holds. So also the wife of Hugh de Grentmesnil complains that Hugh de Beauchamp is holding land which Ralf had wrongfully annexed 'when he was sheriff.'

There is thus abundant evidence to show that Hugh was the recognized successor of Ralf. But Ralf had left a widow, Azelina, who held some of his lands in dower. Of these some lay at Henlow, a 'berewick'

1 V.C.H. Herts, i. 284.

2 I have there established the identity of 'Anschil' and 'Aschil,' but the Bedfordshire survey enables us to go further still. In it we read of Hugh's manor of Colmworth that his predecessor there was 'Achi a thegn of King Edward.' As his predecessor is regularly styled 'Aschil' in the survey of this county, 'Achi' would be taken for a different man. Yet on the previous page (213) we read of Hugh's estate at 'Estone' that its soke always belonged to 'Culmeworde,' a manor of 'Aschil'; and of William de Warenne's estate there we similarly read that 'Aschil' retained its soke in his manor of 'Colmeborde.' And both these estates had been held by 'men' of 'Aschil.' We may therefore claim 'Achi' as here yet another variant of Anschil or Aschil, and may therefore do so in the case of Hugh's manor of Haynes as in that of Colmworth. 


\section{THE DOMESDAY SURVEY}

of the manor of Stotfold (in which Ralf had succeeded Anschil), and Hugh claimed these as not being part of her dower. Ralf had left a daughter as well as a widow, and in the adjoining county of Herts we find her entered as a tenant-in-chief of 4 hides at Hunsdon ('Hodesdone'), though these are described as 'of the fee of Hugh de Beauchamp' (fo. I 42b). As restless there as in this county Ralf had transferred one of these hides from Stanstead Abbots to Hunsdon.

But the matter is further complicated by the devolution of the estates of a great Bedfordshire thegn, Wulfmar of Eaton Socon, the 'Etone' of Domesday. ${ }^{1}$ His estates ran south through Wyboston, Chawston, Tempsford, Barford, Blunham and Sandy, to Sutton and Hatley Cockayne, extending over the Cambridgeshire border into Gamlingay and Hatley. With the exception of his land at Barford, the whole of his estates appear to have passed either to Eudo 'Dapifer' or to Ralf Tallebosc's widow, who seems to have held her share, the smaller one, as part of her marriage portion. As with the three local baronies of which I have spoken above, that of which Eaton Socon was the head deserves special notice, because it has a part as the barony of 'Etone' in the feudal history of the county. Escheating to the Crown in I I 20 on the death of Eudo 'dapifer,' it was granted to one of the house of Beauchamp, but it must be carefully distinguished from the barony of 'Beauchamp of Bedford."

There would seem to be no actual proof of a connection between these two lines of the name of Beauchamp, however probable it may seem; nor is it known whether either line was connected with the Worcestershire house. As bearing, however, on the origin of the Beauchamps ' of Bedford,' it is interesting to note the unusual circumstance that three, if not four, of their under-tenants derived their names from places within what is now a single canton, that of Tilly-sur-Seulles in the

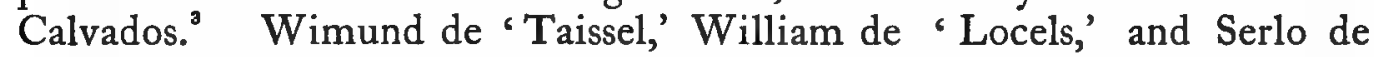
'Ros' were clearly named from Tessel (-Bretteville), Loucelles and Rots within this canton. Osbert de 'Broilg,' therefore, may possibly be named from Brouay, which was also within it, for the list of the knights of the barony, in 1166, is headed by Robert de 'Broi' (or 'Bray')."

We have now dealt with the Domesday fiefs which became local baronies, all of them appearing as such in the returns of 1166 except that of Eaton (Socon), which was not included in those returns. ${ }^{5}$

Of the other Bedfordshire tenants-in-chief the first in order is the Count of Boulogne, whose lands, in which he had succeeded Alwold, ' a

1 See the section on 'Earthworks' for its noteworthy early castle.

2 There is confusion between them in Dugdale's Baronage (i. 224). See Geofrey de Matrdeville, p. I71.

3 Beauchamp itself occurs as a place-name in Moyaux and in Vouilly, both of them in the Calvados.

4 Red Book of the Exchequer, p. 319. The Domesday name, however, is more suggestive of Breuil, a name borne by several places in the Calvados.

${ }^{6}$ See ibid. p. 318 for a later entry of it. 


\section{A HISTORY OF BEDFORDSHIRE}

thegn of King Edward,' lay in the north-west of the county. They are chiefly remarkable as being held of him, with the exception of two hides at Sharnbrook by Ernulf of Ardres ('Arde'), from whom they descended to the Counts of Guînes." Stevington was the chief manor." Walter Giffard belongs to the adjoining county of Buckingham, as does his great tenant Hugh de Bolbec, though he held of him Woburn and two other manors in Bedfordshire. William de Warenne held in Bedfordshire only dependencies of his lordship of Kimbolton across the Huntingdonshire border." In this county as in others William de Eu (' $\mathrm{Ow}$ ') held his lands as successor to a great Wiltshire thegn, 'Alestan' of Boscombe, whose estates were scattered about the country.

Short as is the entry of the lands held by Miles Crispin it raises some points of interest. I have already spoken of the complaint by the monks of Ramsey Abbey that his rich manor of Clapham had been held of them for life only by his English predecessor, ${ }^{4}$ but the men of the Hundred also asserted that two sokemen with small holdings in Milton (Ernest) had been wrongfully added to Clapham by Robert de 'Olgi.' Now this statement distinctly implies that Robert had preceded Miles in his tenure of Clapham, a fact of much interest in view of the traditional belief that Miles married Robert's daughter. That Robert and Miles were in some way connected is proved not only by their both succeeding to lands of Wigod of Wallingford-a fact which attracted Mr. Freeman's notice and led him to suggest that they both married daughters of Wigod-but also by their both succeeding to lands of a certain Brihtric, a fact, it would seem, unnoticed. In Bedfordshire 'Brixtric, thegn of King Edward,' was the only English predecessor of Miles, and in Buckinghamshire Miles had similarly succeeded, in fourteen cases, to the lands of a 'Brictric' variously described as 'a thegn of King Edward' and 'a man of Queen Edith.' In Buckinghamshire also Robert d'Ouilly was holding two valuable manors of which one had been held by Brihtric, 'thegn of King Edward,' and the other by Brihtric of Queen Edith, while some land held by men of Brihtric at Wigginton across the Hertfordshire border had also passed to him. We can thus identify the Bedfordshire 'Brictric' as a wealthy thegn who had 'men' of his own and lands in more than one county.

1 See Feudal England, pp. 462-4, where Mr. Freeman's errors on the point are corrected.

2 It should be observed that 'Alwold (sic), a thegn of King Edward,' was the count's predecessor in all his Bedfordshire lands except at Stevington itself, which is entered as having been held by "Adelold a thegn of King Edward.' 'The two names would certainly be deemed distinct, and yet the entry, on the fief of the Bishop of Bayeux, of land at Turvey which had been held by 'a man of Alwold of Stevington' ('homo Alwoldi de Stivetone'), proves that the names were identical and incidentally that Stevington was Alwold's seat. I have elsewhere (p. 200) shown that Anschil of Ware is indifferently styled 'Aschil' and 'Achi' in the survey of this county. These instances are important as evidence of the almost incredible variations in the forms of Englishmen's names given by the Domesday scribes.

${ }^{3}$ See Testa de Nevill, p. 249 ; "Honor de Kenebauton verumptamen est in comitatu Huntedon, sed villate pertinentes sunt in comitatu Bed[ford].' (Compare p. i i 4 below.)

4 The complaint was clearly ineffectual, for Clapham continued to form part of t the Honour of Wallingford' (as Miles' fief was termed).

${ }^{5} \mathrm{He}$ is also found in Worcestershire as 'a thegn of Queen Edith,' and possibly in Gloucestershire as 'a thegn of King Edward.' 


\section{THE DOMESDAY SURVEY}

William Spech who appears as the holder of considerable estates in the county must have been a predecessor of Walter Espec, the famous leader at the Battle of the Standard (I I 38 ), for one of the three Cistercian abbeys founded by the latter was at Warden in this county, a manor which was held by William Spech at the time of the Survey. Two of Walter's sisters and co-heirs married Trailly and Ros, names which appear in the Bedfordshire Domesday as those of under-tenants, and the house of Ros became his heirs in the north.

Robert de Toeni (of Belvoir) obtained, here as elsewhere, the lands of Osulf, son of Frane, a wealthy thegn, while the single manor held by Robert Fafiton illustrates the opposite system of devolution; for the lands of his English predecessor Alwin 'Horim' (or 'Horne') had been given in the adjoining county of Hertfordshire to Derman, and Robert's lands, which were in four counties, were derived from different owners.

Flemings were well represented in this part of England, and the entry of Walter the Fleming's lands is followed by those of estates held by 'Walter brother of Seier,' who may possibly have been his father's brother, for a Seiher-the name is distinctively Flemish-is incidentally alluded to, under Southill, as having been Walter the Fleming's predecessor in the course of William's reign. Moreover, both these barons had the same English predecessor, the thegn Leofnoth; and, lastly, Segenhoe was afterwards held as part of the 'Wahull' barony, which is very strong evidence.

Fellow-countrymen of theirs soon follow in Hugh the Fleming and in Sigar and Gunfrey de Chocques ('Cioches') from what we call French Flanders, of whom the two latter were Northamptonshire barons. Gilbert of Ghent also held land in the county.

It is strange to find Osbern Fitz Richard, the lord of Richard's Castle, Herefordshire, holding estates so far east as this, but he seems to have had a special grant of the lands of Stori, a Bedfordshire 'man' of Earl Tostig. There is nothing to show how Archbishop Stigand had come to hold a considerable estate in Biggleswade (with Stratton and Holme) and Dunton, with some outlying appendages, or why it was divided between Richard Pungiant and Ralf 'de Insula,' neither of whom appears elsewhere as succeeding him. Albert of Lorraine, as I have elsewhere shown, ${ }^{1}$ was a 'clerk' or 'chaplain' (although there is nothing to show it in the entry of his Bedfordshire estates), who enjoyed the favour alike of Edward the Confessor and of William, and received from them lands and houses. Of Chalgrave, in the south of this county, we read that he had held it in Edward's days.

The three columns devoted to the lands of Judith, widow of Earl Waltheof, are of interest for the light they throw on the 'comital' history of the county. Mr. Freeman, in his special study on 'The great earldoms under Eadward,' arrived at the conclusion that the shires of Huntingdon and Northampton, which were appurtenant to the earldom

' See The Commune of London and other Studies, Pp. 36-7. 


\section{A HISTORY OF BEDFORDSHIRE}

of Northumberland, passed to Earl Waltheof on the fall of Harold's brother Tostig in 1065 . In Huntingdonshire, he wrote, Domesday ' implies the succession of Siward, Tostig, and Waltheof by speaking of "men" and of rights which belonged first to Tostig and afterwards to Waltheof.' But, he added, "of Bedfordshire I cannot speak with any certainty.' 2 So far as actual possessions go, there is little to choose in Bedfordshire between Harold's brothers, Earl Gyrth and Earl Tostig ; as for Harold himself he had but one 'man' in the county. Gyrth had held Kempston in its western, Tostig Potton in its eastern half, both of them important manors with satellites, which were held alike by Countess Judith in $1086 .^{3}$ In the case of Potton, however, there is a peculiarity ; we read not only of Potton itself, but also its 'berewick' Charlton : ' Hoc M[anerium] tenuit rex Edwardus et fuit comitis Tosti.' This is an ambiguous phrase which I interpret as meaning that King Edward had held the manor after Tostig's forfeiture, but it might conceivably mean that the king had given it to Tostig. A further complication is introduced by the fact that lands at Cardington and Harrowden which had been held by a 'man' of Tostig could not be sold without the leave of the lord of Kempston.

The 'sphere of influence,' as shown by their 'men,' of the two earls was but small in the county. Of Tostig's man 'Stori,' I have already spoken. Four other 'men' of his are mentioned, and one of Gyrth's, but no succession of earls is indicated, nor are we shown how Countess Judith came by so much land in the county. Her husband, Waltheof, had but few 'men' within its borders, while in Cambridgeshire he had a good number.

From the lands of Countess Judith, the Conqueror's relative, to those of Bedford burgesses is a sharp change. Four of these burgesses who had been holding land in Biddenham before the Conquest continued to do so at the time of the survey, and their manors are followed by those of five other 'survivals,' who, in spite of the heading, had nothing, I take it, to do with the burgesses. Edward had been allowed by the king's writ to hold ' in almoin' half a hide which had belonged to his father, and Almar similarly half a virgate. Godmund retained three virgates and Alric one virgate, which they had held respectively before the Conquest. The arrangement of Domesday here is bad; on the next page (2I $8 \mathrm{~b}$ ) we find, after the king's reeves, the names of more Englishmen who had been allowed to retain small holdings of land. These vary from three or four virgates to a quarter of a virgate. Holders of this class were usually grouped together, at the end of the survey of a county, as 'king's thegns,' and this was actually done with Alwin and his holding at Keysoe, under Huntingdonshire (fo. 207b) ; but Domes-

1 Norman Conquest (1870), ii. 559 .

2 Ibid p. 567 . In the section dealing with 'Religious Houses' there will be found a curious claim, in 1327 , by the abbess of Elstow to the (earl's) 'third penny' of Bedford under a charter of Malcolm IV. (Earl of Huntingdon under Henry II.). Although unsuccessful, the claim connects Bedford with the earldom of Huntingdon and Northampton.

${ }^{3}$ Compare pp. 257,258 below. 


\section{THE DOMESDAY SURVEY}

day seems by its arrangement to have deemed them an anomalous class.

The small English holder, when he retained his land, was usually doomed to pass sooner or later beneath the domination of a foreign lord. Even Norman, who held at Beeston no less than seven hides under William as under Edward, held them only, at the time of the survey, as a tenant of Eudo dapifer. Smaller men were fortunate indeed if they could retain their own land as tenants of a Norman lord. At Astwick, 'Ledmar,' a man of Earl Tostig, had ' himself' held the half-hide which he only held at the time of the survey under Hugh de Beauchamp; at Thurleigh, Leofric, who held a virgate under Miles Crispin, had held it ' himself' in King Edward's time as a 'man' of Miles' predecessor Brihtric, but he and 'Ledmar' had power, we read, at that time to sell or assign their land. The change in their status is instructive.

Of two Englishmen, each of whom held of Countess Judith, at the time of the survey, half a hide in Sutton, we read that they had been ' the king's men and had power to sell.' Here we seem to detect the same alteration of status. At Dean there is a change of tenure of an unusual character : 'the very same' eleven sokemen who had held an estate in King Edward's time with power to assign their land held it, in I 086, as 'sokemen of King William'; but Ralf Tallebosc had assigned the land ' in ministerio regis'-whatever that may mean. We must not think of these sokemen as holding the estate jointly, for the Domesday hundred rolls of Cambridgeshire show us that in such cases each of the sokemen had his own separate holding. There is, however, one entry unique for this county, if not for the whole country, in which tenure in common is actually asserted; at Goldington we read of a hide which 'the men of the vill held in common and could sell."'

As contrasting with the instances given above of a change of status in those who had become under-tenants at the time of the survey, we may take the exceptional case of Leofwine, who continued to hold at Clifton, after as before the Conquest, a small estate ('one hide') under the abbot of Ramsey. For Leofwine ' could not alienate this land from the abbey'; he had not the power to sell.

The last section of the county survey is of value for the light it throws on the doings of the king's reeves. Entry after entry shows us the restless $\mathrm{R}$ alf Tallebosc assigning, as sheriff, to the king's service (in ministerio regis) lands which had not belonged to it in King Edward's time. Ten small estates head the list, and others follow lower down at Beeston and Dean. It is exceedingly difficult to discover the precise effect of Ralfs action in connection with these estates. Sewell and Biscot he seems to have annexed, with King William's consent, to the royal manor of Houghton (fo. $20 \mathrm{gb}$ ), and seventeen hides to that of Leighton (Buzzard) ; but these estates (fo. 209) are found in the hands of royal bailiffs (prefecti or prepositi) — ' reeves,' the English would have called

\footnotetext{
1 See for this 'notable case' Domesday Book and Beyond, pp. 142-3.
} 


\section{A HISTORY OF BEDFORDSHIRE}

them, who claimed that they had the king's consent for holding them. These lands had belonged to thegns or sokemen who had power to dispose of them, but the Domesday commissioners hardly seem to be concerned with the wrongs of the previous holders; they are rather examining the titles of those who were then in possession, and who 'said' they held by the king's grant. How closely the evidence of title was examined is seen in the entry that, of $3 \frac{1}{2}$ virgates held by Chetelbert at Carlton, he had taken possession (occupavit) of $2 \frac{1}{2}$ for which he could neither prove livery of seisin nor vouch any man to warranty. Still more remarkable is the case, on an earlier page, of Ernwi the priest (fo. 2 I I), who held a hide at Harrowden, which his father had held before him in King Edward's time. He could neither prove livery of seisin nor produce the king's writ to account for his possession of his father's land, which ' the Hundred ' consequently charges him with taking possession of to the king's injury (super regem). Two burgesses of Bedford had similarly got into trouble by buying land since the Conquest without the transfer being ratified by the king. This was at Biddenham, where it was found, on scrutinizing the holdings of Godwine and Ordwi, that the former had 'done service' to no one for that portion of his land which he had bought and could not prove livery of seisin (nec de ea liberatorem babuit), while Ordwi had similarly 'done service' to no one for the land he had bought there.

Of others, on the contrary, it is recorded that they were able to produce the king's writ and seal. At Henwick Edward duly produced both the writ and the witness of 'the Hundred' that the king had granted him his small paternal estate 'in alms'; and so did 'Almar' at Sharnbrook. Even the Church was not exempt from having to produce its title in the case of newly acquired land, and the canons of St. Paul's of London proved their right to Caddington by showing the king's writ. ${ }^{1}$ The larger portion of Caddington, which lay in Hertfordshire and is surveyed under that county, had been held by the same thegn before the Conquest and had been similarly acquired by the canons. It is worth noting that Domesday is silent as to their producing, for that portion, any evidence that the king had sanctioned its acquisition. For what was done in the one case must have been done in the other, and I conclude, therefore, that in this, as in so many matters, the silence of Domesday is not evidence, and that in all such cases proof was called for and produced. It must always be remembered in reading the survey that its chief object was the ascertainment of the king's rights and dues, and that it was this that the Commissioners would specially keep in view.

Whether William actually promulgated any universal rule as to Englishmen and their lands, and, if so, what that rule was, can only be matters of inference. So far as we can judge, all but a few specially favoured individuals were deprived of the lands they had held, or at most were allowed to retain a fragment or were placed in subjection to a Pauli.’

1 'Canonici habent brevem regis in quo continetur quod ipse hoc manerium dedit æcclesiæ sancti 


\section{THE DOMESDAY SURVEY}

Norman lord. And even the exceptions, there is reason to believe, were further reduced after Domesday. ${ }^{1}$ But it is probable that, with his usual policy, William did not, all at once, go so far as this. Bedfordshire supplies us with one of Domesday's hints to that effect in the case of Radwell, where the Norman lord alleged, of some land, that his predecessor who had held it in King Edward's time, had lost it under King William through non-payment of a due. Ralf Tallebosc is alleged to have obtained it by paying the due in his place. ${ }^{2}$ This predecessor would seem to have been Tofig the huscarl of King Edward, who held land at Sharnbrook and Radwell, in which case his tenure after the Conquest is remarkable enough.

The problems raised by the tenure of land in England on the eve of the Conquest are among the most difficult of those with which the Domesday student has to deal. And this difficulty is greatly increased by the singular laxity of the scribes in their use of formulas. As I have observed in Feudal England (pp. 24-6) :-

Dare, vendere, and recedere are all interchangeably used, and even any two of them (whether they have the conjunctive 'et' or the disjunctive 'vel' between them) are identical with any one. It would be possible to collect almost any number of instances in point. Further, the insertion or omission of the phrase 'sine' (or 'absque') 'ejus licentia' is immaterial, it being understood where not expressed. So too with the words 'cui voluit.' In short, like the translators to whom we owe the Authorized Version, the Domesday scribes appear to have revelled in the use of synonym and paraphrase.

My illustrations were drawn from Cambridgeshire, but Bedfordshire is rich in examples. We read of the former English holders that they had power 'dare et vendere ' or 'dare vel vendere,' with the addition, at times, of ' cui vellet ' or ' quo voluit,' or ' ubi voluit,' or in other cases of 'sine' (or 'absque ') 'licentia.' Or again we have such a vague formula as 'quod voluit de terra sua' (or 'de ea') 'facere potuit.' It is no matter, therefore, for surprise that even the genius of Professor Maitland has not enabled him to solve the difficulties presented by the complication of tenures, jurisdiction and personal relations which the Normans found in existence.

We may select, however, from the county survey a few instances which appear to bear specially on questions of tenure. A fourhide estate at Dean had been held by six sokemen, who were the 'men' of Borred, but were (as I read it) of the king's soke. They had power to sell $3 \frac{I}{2}$ hides of this land and to ' withdraw' themselves to another lord without Borred's permission; but half a hide they could neither give nor sell without his leave. Of a two-hide estate at the same place we read that it had been held by the same three sokemen

1 The most striking instance of this, perhaps, is the fief of Turchil of Warwick, which passed from his heirs before long into the hands of the Earls of Warwick.

2 'postquam rex W. in Angliam venit ille gablum de hac terra dare noluit, et Radulfus Taillgebosc gablum dedit, et pro forisfacto ipsam terram sumpsit.' This appears to bear on the curious statement in Heming's Cartulary (i. 278) that, under Cnut, an order was made that any one four days in arrear with his payment of taxes forfeited ipso facto his land, which then passed to the first person who came forward and paid the tax. 


\section{A HISTORY OF BEDFORDSHIRE}

who were holding it of William de Warenne in 1086. One of them could not 'give or sell' his land without his lord's permission; 'but the other two could do so' (fo. 2I I b). In Tillbrook, the next parish, the sokemen who had held it 'were so (ita) of the king's soke that they could give and sell their land to whom they would and withdraw themselves to another lord without the leave of him under whom they were' (fo. $2 \mathrm{I} \mathrm{Ib}$ ). At Tempsford again three sokemen, men of Wulfmar of Eaton (Socon) had held $4 \frac{\mathrm{I}}{2}$ hides; ' one of them could not assign his land without his lord's permission; the other two could do as they would' (fo. 21 2). There are other entries resembling these. Of a holding at Warden we read that he who had held it 'could neither sell or assign it without the permission of him who held Biggleswade' (fo. 217). Lastly we have the singular entry that Cainhoe had been held by Ælfric, 'a thegn of King Edward,' who had power 'to assign and sell' (the land) 'without his leave' (fo. 2 I 4). Here the king appears in the position of a private lord.

There is one entry indeed which seems to give us light; at Stanford, we read, I $\frac{I}{8}$ hides had been held by 'four sokemen,' of whom three were free, but the fourth . . . could neither assign nor sell (his land). ${ }^{1}$ The antithesis here seems to be clear, and yet Domesday elsewhere speaks of men who, although free, 'could not sell' their land.'

At Easton (now in Hunts) three entries afford us instances of a man having power to sell his land, but not the profits of jurisdiction over it, which 'remained' the property of his lord. 'Two 'men' of Anschil of Ware held there half a hide apiece, and in each case the profits of jurisdiction would remain annexed to Anschil's manor of Colmworth. ${ }^{8}$ Elfwine, a man of the Bishop of Lincoln, could do what he would with his land, ' but the soke remained the bishop's.'

Kempston, similarly, had over lands at Elstow, and at Willshamstead near it, inalienable rights of jurisdiction." The Elstow case helps to illustrate the complication of the problem, for the sokemen there were 'men' of King Edward, and yet their 'soke' belonged to Kempston, which was a manor of Earl Gyrth. A tenant might have the power to 'withdraw' himself (recedere) and become, by the act of 'commendation,' the 'man' of another lord without thereby conferring on that lord the right of jurisdiction over his land.

On the practice of 'commendation,' which seems to have played a considerable part in the eleventh century, the practice which placed the weak beneath the strong for safety, we may learn something from

1 'tenuerunt 4 sochemanni, quorum 3 liberi fuerunt, quartus vero unam hidam habuit, sed nec dare nec vendere potuit' (2 I $2 \mathrm{~b}$ ).

${ }^{2}$ Feudal England, p. 34.

3 'potuit vendere cui voluit, sed socam ipse Anschil retinuit in Colmeborde, manerio suo' (2 I I b); ' dare et vendere potuit, sed soca semper jacuit in Culmeworde manerio Aschil' (2 I 3); 'quod roluit de ea facere potuit; soca tamen semper episcopi fuit' (210). The loose variation of formula should be noted.

4 'Hoc manerium tenuerunt iiii sochemanni ; homines regis Edwardi fuerunt ; terram suam dare et vendere potuerunt, sed in Camestone jacuit semper soca eorum.' 'Hoc manerium tenuerunt viii sochemanni et dare et vendere potuerunt . . . sed soca jacuit semper in Camestone’ (2 17 ). 


\section{THE DOMESDAY SURVEY}

Bedfordshire. Of the valuable manor of Aspley Guise we read that Leofgifu, who had held it, was 'commended' to Earl Waltheof, but could betake herself with her land to whatever lord she would. ${ }^{\text {. It is }}$ possible that these words were added to explain why the manor had not passed to the earl's widow and successor. That the act of homage involved in 'commendation' gave the lord certain rights is shown by an interesting dispute between Hugh de Beauchamp and William de Warenne. 'Avigi,' a 'man' of Anschil of Ware, Hugh's English predecessor, had held a virgate at Easton, which is found, in 1086 , in William's hands, but is claimed against him by Hugh, presumably on the ground of the homage done to Anschil. 'Avigi' had also held there T.R.E. five virgates, which King William allowed him to retain' granted ' them to him, Domesday puts it-' commending' him to Ralf Tallebosc's care for his life. But Avigi, on his death bed, had alleged himself to be the 'man' of William de Warenne and consequently William was found seised of it in 1086." Another case of the king's 'commending' an Englishman with his land to one of his officers is found in Wellow Hundred, where a sokeman was so 'commended' to 'Osiet the king's bailiff' (of the Hundred), who was to provide him with food and clothing for life. As Osiet is found in possession at the time of the survey, it looks as if he had obtained the land on condition of paying to its former holder a kind of life annuity, the well known ' corrody ' system employed by religious houses.

More distinctly entitled to rank as legal antiquities are the Domesday manor, the cases of 'disseisin,' the mortgage, the marriage-portion, and the reversion after death.

On that most perplexing question the meaning of 'manor' (manerium) in Domesday the evidence of the Bedfordshire survey is of very great importance. For after recapitulating the theory at which he has arrived on the subject, Professor Maitland proceeds to make this admission :-

In later days we may well find a manor holden of another manor, so that a plot of land may be within two manors. If this usage of the term can be traced back to Domesday Book as a common phenomenon, then our doctrine is in great jeopardy. But we have noticed no passage which clearly and unambiguously states that a tract of land was at one and the same time ${ }^{3}$ both a manerium and also a part of another manerium.

Now Wootton was a 'ten-hide vill,' the whole of which was held, as a single manor, by Albert of Lorraine. Domesday says of it : 'Hoc $M$ [anerium] tenuit Almar homo Tosti comitis,' and then immediately proceeds to state of Albert's three hides at Shelton (in Marston Morteyne adjoining): 'Hoc $M[$ anerium] fuit et est membrum de Otone [Wootton]; Almar tenuit homo Tosti comitis' (fo. 216b). On the

1 ' commendata Wallef comitis et quo voluit cum terra sua recedere potuit.'

2 ' Hic, die mortuus est, dixit se esse hominem W. de War' et ideo Willelmus saisitus est de hac terra.'

3 The italics are the professor's own.

- Domesday Book and Beyond, p. 128. 


\section{A HISTORY OF BEDFORDSHIRE}

opposite side of the county we read of Countess Judith's manors of Everton and Hatley (Cockayne), both near Potton, as follows:

$\mathrm{M}[$ anerium $]$. . . Euretone . . . Hoc $M[$ anerium $]$ comes Tosti tenuit et jacuit in Potone M[anerio] proprio comitissæ M[anerium] ... In Hatelai ... Hoc $M$ [anerium] Tosti comes tenuit et jacet in Potone manerio proprio comitissæ (fo. 2I $7 \mathrm{~b})$.

Nothing could well be clearer or less ambiguous than this; in the above cases we have 'a tract of land' entered as 'at one and the same time both a manerium and also a part of another manerium.'

Again a Charlton entry is of value in this connection. Bedfordshire, Professor Maitland observed, is one of those counties in which ' the symbol $M$., which represents a manor,' is found in the margin of the text. From this and from the occurrence of the phrase 'tenuit pro uno manerio' he concludes that manerium was 'an accurate term charged with legal meaning,' that ' manerium has some exact meaning,' and ' that this term has a technical meaning . . . we cannot doubt.' ${ }^{1}$ This conclusion I have elsewhere traversed, arguing that the phrase 'pro uno manerio' is, on the contrary, mere surplusage, and that Domesday uses indifferently the terms manerium and terra." Now we read of Charlton, a manor assessed of ten hides, to which the symbol M. is prefixed :-

Hoc manerium (sic) tenuit rex Edwardus et fuit Tosti comitis. Hec terra fuit Berew[ita] de Potone T.R.E. ${ }^{3}$ ita quod nullus inde separare potuit $(2 \mathrm{I} 7 \mathrm{~b})$.

The point of the second clause is that Charlton, though formerly an appurtenance of Potton, was now held by a different person ; but I cite it as showing the alternative use of the terms manerium and terra. A precisely similar entry is found on fo. 2 I $3 b:-$

terram etc.

In Cochepol tenet Robertus de Hugone iiii hidas pro uno manerio . . Hanc

So also on the fief of the Bishop of Coutances we read of a four-hide estate held of him by Geoffrey de 'Tralgi,' to which the symbol M. is prefixed :(210).

Hoc Manerium tenuerunt iii $\operatorname{soch}[\mathrm{emann}] \mathrm{i}$... Hanc terram tenet episcopus

The entry which follows it and relates to Turvey contains precisely the same formula. Lastly we read of Count Eustace's estate at Odell, to which the symbol M. is not prefixed :-

In Wadelle tenet Ernulfus de Arde . . . pro uno Manerio de comite Eustachio

... Hanc terram tenuit Alwoldus (2 I I).

The danger of crediting the Domesday scribes with a technical and exact use of terms is here further illustrated.

Allegations of 'disseisin' are not unfrequent in the survey. Ralf Tallebosc is charged with having 'disseised' William de Caron's father

1 Domesday Book and Beyond, pp. 107-8, I $20,128$.

2 'The Domesday Manor' in English Historical Revierv, xv. 293-5.

a The words 'Manerium Juditæ comitissæ' are here interlined. 


\section{THE DOMESDAY SURVEY}

at Easton (210), Eudo 'dapifer' (apparently) at Sandy (212), and Nigel 'de Albini' at Clophill (2 I 4). In this last case it is expressly recorded that Nigel was ' seised' of the land after he had possession of the 'honour.' Hugh de Beauchamp claims seven acres at Chawston of which his predecessor was 'seised,' though he himself is 'disseised' (215). We advance a step further when, besides alleging the fact, the claimant further alleges that he has been wrongfully (injuste) disseised; Rannulf brother of Ilger alleges that he has been 'wrongfully disseised' of land at Pavenham (2I 5). Alfred of Lincoln claims that Walter the Fleming has 'wrongfully disseised him of land at Wymington, which his predecessor had been seised of in King Edward's time, and he himself subsequently. And the men of the Hundred support this claim and further testify that the Bishop of Coutances has 'wrongfully disseised' Alfred of woodland which his predecessor had in King Edward's time (215b). The abbot of Ramsey claims that John de Roches had 'wrongfully disseised' him of land at Barton; and here again 'the Hundred' testifies that this is so (2 rob). At times, with its usual love for variety, Domesday substitutes 'occupavit' for 'desaisivit' ; at Maulden, for instance, ' the men of the Hundred' allege that this John de Roches has 'wrongfully taken possession (occupavit)' of land, to the injury of those who hold the vill (2I4). In another place Ralf Tallebosc is charged with having 'wrongfully taken possession of land when he was sheriff' (2i 7 b). At Totternhoe violence (vis) occurs as accompanying the spoliation. ${ }^{2}$ The interest of all these phrases lies in their anticipation of that disseisin ' injuste et sine judicio' which formed the subject in the next century of the famous 'assize of novel disseisin.'

Mortgage-the gage of land to give it its exact description ceives illustration at Biddenham, where Ordwi, a burgess of Bedford, held a virgate 'in vadimonio' (2 I 8 ). But its most interesting occurrence is in the case of a virgate of land at Southill which Leofwine, a wealthy thegn, had held as mortgagee in King Edward's day. The mortgagee, as we should now say, had been paid off since the Conquest, but Walter the Fleming kept hold of this with the rest of Leofwine's land. Oddly enough it is the king who is looked on as the injured party $(235 \mathrm{~b})$. $^{\mathrm{B}}$

The marriage portion (maritagium) as distinguished from dower meets us chiefly on the fief of Ralf Tallebosc's widow, where it proves that she must have been the daughter of some considerable holder of land. It occurs, however, also, on the fief of Nigel 'de Albini,' one of whose tenants, Pirot, held 3 hides of his land at Streatley 'de maritagio

1 The use of the term 'honour' in Domesday is always worth noting.

2 'reclamat W. camerarius ii hidas quas ejus antecessor tenuit T.R.E. sicut Hundret testatur, sed episcopus baiocensis per vim ei abstulit' (2 I6).

${ }^{3}$ See History of English Law (1 895), ii. 44-52, and especially p. 44 : 'The necessity of keeping the peace is often insisted on by those who are describing the great possessory action, the assize of novel disseisin. Every disseisin is a breach of the peace; a disseisin perpetrated with violence is a serious breach.'

1 Ibid. ii. II7-23.

6 'postquam rex W. venit in Angliam ille ipse qui invadiavit hanc terram redemit, et Seiherus eam occupavit super regem.' Walter had succeeded Seiher. 


\section{A HISTORY OF BEDFORDSHIRE}

suæ feminæ' (2 I 4 b). A good instance of the gift of land in reversion to a religious house is found at Goldington, where Ælfric 'Wintremelc' so granted his half-hide to the canons of St. Paul's. ${ }^{1}$

For agriculture the Bedfordshire survey is of no appreciable interest. But in those counties where Ramsey Abbey happened to hold land we can always, at least, compare the jejune figures of Domesday with the abbey's own survey of its lands in the reign of Henry I. The great manorial plough drawn by eight oxen, on which Domesday bases all its calculations, was the rule on the Ramsey Abbey manors, and two such teams are found at Barton and three at Shillington in the days of Henry $\mathrm{I}^{3} \quad$ In Domesday the importance of the plough dwarfs all other sources of agricultural wealth; but the right of multure, by which the peasants were compelled to bring their grain to be ground at the lord's mill, formed in certain cases an appreciable item in his revenue. Of the watermills on the Ouse one may select for mention as being of considerable value those at Harrold and Odell, each of which was returned as worth $\oint_{\mathrm{I}} \mathrm{I} 6 \mathrm{~s} .8 \mathrm{~d}$. and 200 eels a year, while that at Tempsford returned $£ 2$ and I 20 eels, and the two at Eaton Socon $\oint_{\mathrm{I}} \mathrm{I} 6 \mathrm{~s}$. $6 d$. and 100 eels. The eels so often found in Domesday as forming a portion of the mill's render came, of course, from the mill-pool. The two mills at Sandy on the Ivel were worth no less than $f_{2} 2$ Ios., and two at Biggleswade above it $\oint_{0} 27$.

Woodland, though of service for many purposes, was valued in Domesday according to the ' mast' it afforded as food for swine. Down by the streams the water-meadows provided hay for the plough-oxen; and even pasture for the farm stock is entered at times in the survey. The rents paid in money or in kind for the use of some of these rights are of considerable interest to the student. At Meppershall, for instance, the woodland yielded ' de consuetudine silvæ' ten shillings in addition to providing feed for 200 swine, and at Westoning three shillings in addition to feeding 400 ; at Cranfield it yielded the 'iron for the ploughs' in addition to feeding a thousand; and at Westcote it similarly provided the ironwork in addition to supplying feed. At Segenhoe there were yearly received ten rams 'de consuetudine silvæ,' and at Harlington one ram and a load of beans in addition, in each case, to the feed. In the Ivel valley the Biggleswade meadows, besides providing hay for the ten plough-teams of the manor, produced from the surplus hay five shillings a year; while at Langford, higher up the stream, they produced two shillings in addition to supplying hay for sixteen teams. The most notable entry of 'pasture' is that at Langford, where we read that it produced six shillings besides providing feed for 300 sheep. At Henlow the 'pasture' produced tenpence. One may also, perhaps, mention here a

1 "Quam postea canonicis S. Pauli sub W. rege dedit ut post mortem suam haberent omnino concessit' (2 1 8b). It was of great importance to the canons to have their reversionary right thus recorded in Domesday. A contemporary of Flfric, named Edward, had similarly granted to St. Paul's his land in reversion, but Otto, the Domesday tenant, who married his widow, refused to let St. Paul's inherit it, as it was entitled to do, on her death (Domesday Studies, p. 556).

2 Cartularium monasterii de Ramesia (Rolls Series), iii. $274,307$. 


\section{THE DOMESDAY SURVEY}

point relating to the woodland, namely that at Southill there are two entries of 'half a hide' of woodland, and at Sandy one of three acres. The reckoning of woodland on this system is rare in Domesday, and at present obscure.

Among miscellaneous rural features we may note Eudo Dapifer's two acres of vineyard-probably newly planted-at Eaton Socon, Hugh de Beauchamp's 'park' for beasts of the chase at Stagsden, and the fishstew (vivarium piscium) of 'Osbern the fisher' at Sharnbrook.

Of urban or commercial life Domesday tells us little; and in Bedfordshire this is peculiarly the case. We read of burgesses of Bedford, of market dues at Luton and Leighton (Buzzard), and that is about all. But in this connection one may note a point bearing on money, namely that two 'ores' are entered as the value of some land on fo. 2I $8 \mathrm{~b}$. It is proved by Cambridgeshire evidence that this 'ore' was sixteen pence.

No general statement can be made as to the effect of the Conquest on the wealth and prosperity of the county. Mr. Pearson's tables show a decrease of about twenty-five per cent in values, for the whole county, when those of 1086 are compared with those on the eve of the Conquest; and this decrease is most marked on the lands of the lay barons. But when we come to examine for ourselves the values, manor by manor, we find the variations between them at these two periods, and at that intervening date when the land was received by the grantee, varying in too erratic a fashion for any conclusions to be drawn from them. All that can be said is that the value was, as might be expected, usually lowest at the time of the grant.

The last subject that we have to consider is that of identification. When dealing with the work of our predecessors in this branch of inquiry, we have to remember that they are sometimes found to have been misled by a fancied resemblance, and that they may even have fallen a prey to the pranks of perverse etymologists. Weston and Easton, for instance, are names not uncommon, the origin of which, one would have thought, must be obvious to all. Yet of Westoning-originally Weston-omitted in the Bedfordshire survey, we find Mr. Airy writing thus :-

Westoning is not mentioned in the Record, nor is there any vacancy in or on the borders of the Hundred of Manshead for which it appears eligible. Early mention of it occurs by the name of Weston Tregos, and it became Weston-Ing after its purchase by Sir William Inge, Chief Justice of the King's Bench in I 317 , so that the original name of the place is merely Weston. Now, Mr. Monkhouse in his Bedfordshire etymologies tells us that Weston in Anglo-Saxon means a wilderness; and that all the 'Westons' and 'West Ends' were tracts of waste and barren land. If such were the case with the present Westoning, its absence from the Record as a distinct manor or property is quite intelligible; and looking at its position on the map I am inclined to think that it formed the 'westen' or waste of Priestley (now a hamlet of Flitwick), and that whatever there was of taxable value about it is included in the return of that manor (p. 44).

So too he endeavoured to identify the mysterious 'Estone' by means of this etymology, arguing that 'the high clay table of Little Staughton ... was one of a series of westens,' and that- 


\section{A HISTORY OF BEDFORDSHIRE}

there is no difficulty with regard to the omission of the W from Estone, as that letter was assumed or dropped according to the taste of the speaker. . . . Besides, in many parishes of the county the 'westen' has actually dropped the ' $\mathrm{W}$ ' at the present time, and appears as 'East End' instead of 'West End,' in each case being the old westen or waste, and having no reference whatever to the points of the compass.

Lastly he wrote of the puzzling 'Segresdone' :-

I take it for granted that Segresdone is only another form of 'sacristan' or 'sexton,' and that the land which bore the name had some connection with an ecclesiastical establishment.

The absence of any history of the county and the paucity of printed records relating to its feudal tenures have greatly increased the difficulty of identifying Domesday manors; for the surest identification is that which is proved by feudal descent. Some progress, however, has, it is hoped, been made. It has hitherto been insufficiently realized that in studying Domesday for a county, the surveys of adjoining counties have to be kept in view. Thus, in Bedfordshire, we find, along the Northamptonshire border, portions of Podington ( $\frac{1}{2}$ hide) and Farndish ( $\frac{3}{4}$ hide) surveyed under that county, while portions of Newton Bromshold and of Rushden are surveyed under Bedfordshire. Stanwick, although it all belonged to Peterborough Abbey, is surveyed partly under one and partly under the other. On the Buckinghamshire border, a third of Edlesborough, which is now wholly in that county, is placed by Domesday under Bedfordshire, while Meppershall was assessed partly under Bedfordshire and partly under Hertfordshire at the time of the Great Survey. ${ }^{2}$ Caddington was then as now divided between the two counties. So also, on the Huntingdonshire border, Everton, which is now wholly in Bedfordshire, was then surveyed as divided by the border, Rannulf brother of Ilger holding the Huntingdonshire portion ( 7 hides) in capite, and the Bedfordshire portion ( 5 hides) under the Countess Judith.

These cases may serve to introduce the singular tangle of Beds and Hunts in the extreme north of the former county. Swineshead is still an island in Bedfordshire, Tillbrook bushes cutting it off from Huntingdonshire, to which it belongs. In Domesday it appears as a manor assessed at five hides, and all in the hands of Eustace the sheriff (of Hunts), who held there half a hide in chief, and the rest under William of Warenne, of whose lordship of Kimbolton it was part. This lordship, in which William had succeeded Harold himself, had clearly a disturbing effect on several estates in its neighbourhood, William, for instance, stretching out his hands over Tillbrook and part of Dean. Of the still mysterious ' Hanefeld' we are told that it had always belonged to Kimbolton, but was assessed rightly in Bedfordshire. ${ }^{3}$ Again, in Keysoe, adjoining Swineshead, 3 virgates are surveyed in Huntingdonshire as a part of the lordship of Kimbolton, and I virgate as lying in Beds, though

1 I have appended at the end of the Domesday text extracts from the surveys of other counties which relate to lands now in Bedfordshire.

2 'Pro iiii hidis se defendit in Bedefordescire. In Herefortscire ipsa villa se defendit pro iii hidis et una virgata' (see p. 255 below, and compare the Victoria History of Herts, vol. i.)

3 'Warram dedit semper juste in Bedefordscira' (see p. 232 below). 


\section{THE DOMESDAY SURVEY}

assessed in Hunts, ${ }^{1}$ and as held, after as before the Conquest, by Alwin. I have no doubt that this was the Alwin surnamed 'Deule' who had held Pertenhall (now in Bedfordshire), between Keysoe and Kimbolton, under the Bishop of Lincoln, ${ }^{2}$ and who had also preceded his Norman tenants on some other manors in Bedfordshire. ${ }^{3}$ Of this Pertenhall (a place supposed to be unmentioned in Domesday ${ }^{4}$ ) we read that it lies in Bedfordshire, but renders (its) geld and service in Huntingdonshire. ${ }^{5}$

From this tangle-which is continued along the border of Northamptonshire and Huntingdonshire-we may now pass to the great 'crux' of the Domesday Survey of Bedfordshire, the mysterious manor of 'Estone,' which is the subject of ten separate entries under seven different fiefs. Mr. Airy guessed, we have seen, that it was that of Little Staughton, but its name disappears from view, in Bedfordshire, after the date of Domesday. ${ }^{6}$ The clue, which is faint but, I think, sufficient, is found among the 'claims' (clamores) at the end of the Huntingdonshire survey. We there read of an 'Estone,' which (it is incidentally observed) is assessed in Bedfordshire, that it belongs to the abbot of Ely's manor of Spaldwick, but that Eustace (the sheriff of the county), a noted despoiler of the church, had seized a sixth of a hide there. ${ }^{7}$ Of the identity of this 'Estone' there is no doubt whatever ; it is Easton some three or four miles north-east of Kimbolton, and a little more than a mile south-east of Spaldwick. The latter manor had dependencies in Easton, Long Stow, and Little Catworth lying round it. ${ }^{8}$ Assuming that this Huntingdonshire Easton was the 'Estone' of the Bedfordshire survey, we now see why William de Warenne is shown therein to have made himself master of certain lands there, as at Tillbrook and Dean; Kimbolton was the centre of them all. That Easton was associated, as a fact, with Kimbolton as with Spaldwick, is shown by the Hundred Rolls, where we read of one hide there that it is of the Honour of Kimbolton, ${ }^{9}$ though the bulk of it appears to have been then dependent on Spaldwick. ${ }^{10}$

There is nothing stranger prima facie in this Huntingdonshire Easton being then a detached portion of the nearest Bedfordshire Hundred than is the converse phenomenon in the case of Swineshead; but it is right to add that the identification rests wholly on the statement that the holding of Eustace there, and therefore presumably all Easton, was for purposes of assessment in Bedfordshire." ${ }^{11}$ Nor, so far as our limited knowledge of Huntingdonshire history extends, does Easton appear subsequently as part of Bedfordshire. That Domesday should enter it under

1 ' Jacet in Bedefordscira sed geldum dat in Hunted'scire.'

2 See p. 266 below.

3 See p. 227 below. It is singular that this Alwin Deule (who had also preceded Eustace, the sheriff, at Perry near Kimbolton) seems to be wholly omitted from Ellis' Domesday Index.

- Airy. ${ }^{5}$ See p. 266 below.

- I have sought in vain for a manor of the name in Bedfordshire, and Mr. Ragg could only suggest that it was 'probably near Thurleigh.'

7 'Qua jacet in Estone et geldat in Bedefordscire' (fo. 208).

8 See the Inquisitio Eliensis and the Inquisitio Comitatus Cantabrigiensis (ed. Hamilton, p. 166).

9 Vol. ii. p. 632. hides,

11 The $\frac{1}{6}$ hide held by Eustace is virtually just what is wanted to raise the total assessment to Io 


\section{A HISTORY OF BEDFORDSHIRE}

that county with no hint of its peculiar position further illustrates the character of the survey as essentially a record of assessment for geld.

Westoning, supposed by Mr. Airy to be unmentioned in Domesday, is surveyed under Hertfordshire as 'Westone,' the survey expressly recording that its assessment belonged to Bedfordshire." Wrestlingworth, he asserted, was surveyed under Cambridgeshire ; but 'Warateworde,' to which he referred, proves to be Wratsworth in Orwell. As Wrestlingworth was held of the Honour of Huntingdon, it must be sought for among the manors of the Countess Judith in Domesday. As illustrating the great uncertainty surrounding the identity even of important manors in the Bedfordshire survey one may instance the 'Lalega' of Domesday, which lay in the Hundred of Willey and was divided between four of the local tenants-in-chief. This was certainly the manor of 'La Leye,' as it is styled in the Hundred Rolls, the 'Lega' or 'La Leye' of the feudal aids; but where was it? The Public Record Office identifies it as Lee (now a farm) in Puddington. ${ }^{2}$ The British Museum, however, no less confidently identifies the 'La Leigh' of I 357 as Thurleigh. ${ }^{3}$ The question is virtually decided in favour of the latter by the 'Nomina villarum' of I316, where 'Lega' appears as a vill of the Hundred of Willey and Thurleigh does not ${ }^{4}$; but in any case the feudal descent establishes that identity.

Of the places remaining unidentified 'Hanefelde' (I hide) and 'Segresdone' ( 1 virgate) were in Stodden Hundred, and 'Chenemondewiche,' a considerable estate of $3 \frac{3}{4}$ hides, in that of Biggleswade. Mr. Airy traced this last down to 'Kimwick' in the cartulary of St. Neot's, and I have found it as 'Kym'yke' in the Valor Ecclesiasticus (temp. Hen. VIII.) ; but its present identity is unknown. I suspect, however, that it lay in the neighbourhood of Blunham or Sandy. It is found in the Testa (p. 243), as 'Kenemu' de' wyk,' held with Blunham (which precedes it in Domesday) by Henry de Hastings as seneschal of St. Edmund's Abbey. 'Elvendone,' in Stodden Hundred, was not, I think, Yelden, of which the undoubted form was 'Giveldene,' and which is complete as a ten-hide manor without it. The credit of identifying 'Subberie' as a manor in Eaton Socon belongs to Mr. Airy. ${ }^{B}$ I do not accept his conclusion that 'Cudessane' was merely a scribal error for 'Chichesane,' because the former is found in two distinct entries; but, as 'Cudessane' and 'Chichesane' (Chicksand) between them amount to Io hides, they may well have been adjacent holdings with a common termination.

1 'Sed Wara hujus manerii jacuit in Bedefordscire T.R.E. in hundreto de Maneheve, et ibi est Manerium et fuit semper' (see the Victoric History of Herts, vol. i.) This use of 'Wara' must be carefully distinguished from that (also in the Bedfordshire survey) which is found in the phrase, "dare warras,' though both relate to the payment of geld. 'Wares' or 'Warres,' which occurs repeatedly on the fief of Hugh de Beauchamp, is, of course, quite distinct from either and denotes Ware, Herts.

2 Feudal Aids (1899), i. 614. This identification was probably suggested by the fact that half a knight's fee ' in Lega et Podyngtone " was held of the great fee of Wahull. But this combination does not involve the proximity of the two places.

3 Index to the Cbarters and Rolls (1900), p. 742.

1 Feudal Aids, i. I7. See the evidence printed in the Wahull peerage case.

- It occurs four times in Feudal Aids, vol. i., but is not there identified, the name having vanished from the map. 


\section{THE DOMESDAY SURVEY}

It may be expected that the exploration now being made among all our records for this history of the county will further diminish the number of the names still awaiting identification.

\section{THE BEDFORDSHIRE HUNDREDS}

The importance of the Hundreds in the Great Survey is far greater than any one could gather from the pages of Domesday Book. For the fortunate preservation of a transcript of the actual returns of the Inquest, in the case of the county of Cambridge, shows us that each Hundred was surveyed separately in turn, and that the return for each Hundred was made by its own sworn jurors. The contents of these returns were subsequently cut down and re-arranged under the fiefs of the several tenants-in-chief.

But although the surveys of the Hundreds, and even of the vills within them, were broken up for the purpose of this re-arrangement, traces of the system on which the survey was actually made are still to be found in the order in which the Hundreds recur. This is a point of considerable importance, to which, till quite lately, little attention has been given. In Bedfordshire the order in which the returns from the Hundreds were arranged appears to have been as follows: (I) Manshead ; (2) 'Stanburge' ;' (3) Redbornstoke ; (4) Stodden ; (5) 'Buchelai' ; (6) Flitt ; (7) Willey ; (8) Barford ; (9) Biggleswade ; (1 o) 'Weneslai'; (I I) Wixamtree ; (I 2) Clifton." Three of these, which were 'half' Hundreds, have subsequently disappeared, 'Stanburge' becoming absorbed in Manshead, 'Buchelai' in Willey and 'Weneslai' in Biggleswade. $^{3}$

In addition to the Hundreds enumerated above there was the town of Bedford, which stood apart, and the royal demesne, which is not assigned to any Hundred by name. This belt of demesne, in the extreme south of the county, is now divided between the Hundreds of Manshead and of Flitt. As is sometimes the case in Domesday, there is incidental mention of yet another Hundred, the identity of which is obscure. We read of Sewell (under Houghton Regis), that it was formerly in 'Odecroft' Hundred, but that Ralf Tallebosc took it thence and placed it in Houghton Regis, even as he took Biscot out of Flitt Hundred and placed it in Luton. This has yet to be explained.

To the order in which the Hundredal headings occur in the text of the survey there is, as Mr. Ragg and I have observed, one conspicuous exception. The fief of Hugh de Beauchamp is entered in two portions ;

\footnotetext{
1 Standbridge, from which it derived its name, is a place between Leighton Buzzard and Houghton Regis.

Mr. Ragg, who has independently investigated this subject, is in entire agreement with this order. Only the relative position of 'Manshead' and 'Stanburge' on his list as on mine seems doubtful. 3 'Weneslai' had dropped out before Kirby's Quest ( $1284-6$ ), in the returns to which, as in those of 1316, the 'half Hundreds' of 'Stanbrigge' (or 'Stanbrugge') and of 'Boclowe' (or 'Buckelowe') are surveyed with Manshead and Willey respectively. After the returns of 1316, these half Hundreds also drop out of the list (see Feudal Aids, i. I-2 I). 


\section{A HISTORY OF BEDFORDSHIRE}

the second portion, which begins with Aspley (Guise) in Manshead Hundred, is devoted to those manors which were held of him by undertenants, and in it the Hundreds recur in their regular order ; but in the first part, which deals with the manors he held in demesne, this order is not observed. In that part we begin with Stodden, 'Buchelai,' Wixamtree and Clifton, but then proceed with Redbornstoke, Flitt and Barford. On comparing this arrangement with the regular sequence of the Hundreds, it will be seen that the fief is entered, as I said, in two portions, and, moreover, that the first portion can itself be divided into two halves. ${ }^{1}$

Mr. Ragg has suggested, as the result of his careful analysis of the survey, that if we assumed the royal demesne to have formed a Hundred of its own, and reckoned Bedford as a half Hundred, Bedfordshire would have had at the time of the survey ten whole and four half Hundreds, representing, in all, the equivalent of twelve. Professor Maitland also reckons the Domesday Hundreds as twelve, ${ }^{2}$ but he derived the figure from Dr. Stubbs, who must have obtained it differently, namely from the headings in the text. In any case it is noteworthy that the 'county hidage' assigns $\mathrm{I}, 200$ hides to Bedfordshire, ${ }^{3}$ which is not far from the Domesday total. But we must not be tempted by these figures to hazard conjectures here as to an earlier state of things on which, in the present state of our knowledge, it is premature to speak.

1 Mr. Ragg has observed that the lands of St. Albans, in the adjoining county of Herts, present a similar exceptional grouping in two halves, of which the first deals with the manors in hand.

2 Domesday Book and Beyond, p. 459.

3 Ibid. p. 456. 


\section{TRANSLATION OF THE DOMESDAY TEXT}




\section{NOTE}

The date of the Domesday Survey is 1086, and the two previous periods referred to are King Edward's time (T.R.E.), which is usually the time of his death, and the time at which the manor was acquired by the Norman holder. The letter ' $M$, prefixed to an entry, stands for $\mathrm{M}$ [anor]. The 'hide' is the unit of assessment to the 'geld,' and the 'virgate' its quarter ; thirty (geld) acres went to a virgate. The caruca was a plough drawn by eight oxen, and the arable land was reckoned by the number of ploughs required to till it ; 'land for half a plough' (or 'for four oxen') merely means half a plough land. The term 'demesne' is used both of those manors which a lord kept in his own hands (instead of enfeoffing a tenant therein), and of that portion of a manor which was kept in hand (as a kind of home farm), the peasantry holding the rest of it under the lord. The 'bordars' were a class of peasants intermediate between the villeins and the serfs.

It should always be remembered that when Domesday enters a man as holding a certain place, it does not necessarily mean that he held the whole of it, for there may be similar entries relating to other portions of it. 
fo. 209

\section{BEDEFORDSCIRE}

BEDEFORD [Bedford] was assessed as (defendebat se pro) a half hundred T.R.E., and it is so (facit) now for the host and for ship service (in navibus). The land of this vill was never divided into hides, nor is it now except one hide which belonged to (jacuit in) the church of St. Paul in almoin T.R.E., and now belongs (thereto) of right. But Bishop Remigius put it out of almoin (and tenure) of the church of St. Paul, unjustly as the men say, and now holds it and all that belongs to it. It is worth 100 shillings.

\section{$\left[\begin{array}{c}\text { NAMES OF } \\ \text { HOLDERS OF LANDS }\end{array}\right]$}

I KING WILLIAM
II The Bishop of Bayeux
III The Bishop of Coutances
III The Bishop of Lincoln
v The Bishop of Durham
vI The abbot of St. Edmund
vII The abbot of Peterborough
viII The abbot of Ramsey
Ix The abbot of Westminster
x The abbot of Thorney
xI The abbess of Barking
xII The canons of London
xIII The canons of Bedford
xIII Ernuin the priest
xv Count Eustace
xvi Walter Gifard
xviI William de Warenne
xvIII William de Ow
xIx Milo Crispin
xx Ernulf de Hesding
xxI Eudo 'Dapifer'
xxII William Pevrel
xxIII Hugh de Beauchamp
xxIII Nigel de Albingi
xxv William Spech

xxxil Walter the Fleming

xxxin Walter brother of Seiher

xxxiII Hugh the Fleming

xxxv Hugh the Butler (pincerna)

xxxvi Sigar de Cioches

xxxviI Gunfrid de Cioches

xxxviII Richard son of Earl Gilbert

xxxIx Richard Pungiant

$\mathrm{xL}$ William the Chamberlain

xII William Lovet

XLII William

xLIII Henry son of Azor

xLIIII Osbern son of Richard

XLv Osbern son of Walter

XLvi Osbern the Fisherman

xLVII Turstin the Chamberlain

xLvin Gilbert son of Salom(on)

xLIX Albert of Lorraine

L David de Argentan

LI Ralf 'de Insula'

LII Gozelin the Breton

LIII Countess Judith

LIII Adeliza wife of $\mathrm{H}$ (ugh) de Grent(maisnil) 


\section{A HISTORY OF BEDFORDSHIRE}

\author{
xxvi Robert de Todeni \\ xxvIr Gilbert de Gand \\ xxvirI Robert de Olgi \\ xxIx Ranulf brother of Ilger \\ xxx Robert Fafiton \\ xxxI Alvred of Lincoln
}

\section{THE KING'S LAND}

M. Lestone [Leighton Buzzard] a demesne manor of the king is now assessed (se defendit pro) at 47 hides. T.R.E. there were but 30 hides (there). ${ }^{1}$ Of these 47 hides 43 are in the king's hands. There is land for 52 ploughs. On the demesne are 6 , and the villeins have 46 . There are 4 score and 2 villeins and 30 bordars and 2 serfs and 2 mills worth (de) 30 shillings, meadow (sufficient) for 40 plough teams and woodland (to feed) 100 swine. The toll from the market yields 7 pounds. In all it pays yearly 22 pounds of weighed money (ad pensum) and half a day's (provision for the) king's ' ferm' in grain and honey and other things pertaining to the ' ferm.' For the queen's use it pays 2 ounces of gold ; and for I packhorse and for customary payment for the dogs 70 shillings; and 100 shillings weighed money (ad pensum) and 40 shillings of blanch (albo) silver which (boc) Ivo Talliebosc imposed in addition (misit de cremento); and $\mathrm{I}$ ounce of gold for the use of the sheriff yearly.

Of the land of this manor Wenesi ${ }^{2}$ the chamberlain held ro hides of King Edward which Ralf Talliebosc added to (apposuit in) Lestone [Leighton], whereto they did not belong T.R.E., and again the same Ralf added (apposuit) to this manor other 7 hides which were not in it T.R.E. These 7 hides Starcher, a thegn of King Edward, held.

The church of this manor Bishop Remigius holds, with 4 hides which belong to it. These 4 hides are reckoned in the 47 hides of the manor. There is land for 3 ploughs (in them). On the demesne is $\mathrm{I}$, and the villeins have $\mathrm{I}$, and there could be another. There are 6 villeins and 6 bordars and meadow (sufficient) for 3 plough teams. This land, with the church, is and was worth 4 pounds. ${ }^{3}$ Bishop Wlwi held it T.R.E.

\section{Loitone [Luton], a demesne manor of}

1 Because 7 hides had been added, as explained lower down in the entry.

${ }^{2} \mathrm{He}$ had also held the manor of Turweston, Bucks (J.H.R.)

${ }^{3}$ Compare the entry on p. 227 below.

\author{
LV Azelina wife of $\mathrm{R}$ (alf) \\ Talgeb(osc) \\ LVI Burgesses of Bedford \\ 'Lvi The king's bailiffs (prefecti) \\ and bedells and almsmen
}

the king, is assessed at (se defendit pro) 30 hides. There is land for 4 score and 2 ploughs. On the demesne are 4 ploughs. The villeins have 4 score all but 2 . There are 4 score villeins and 47 bordars, and 6 mills yielding roo shillings, meadow (sufficient) for 4 plough teams, woodland (to feed) 2,000 swine, and from dues (come) ro shillings and 8 pence. From the toll and the market (come) 100 shillings. In all it yields yearly 30 pounds of weighed money (ad pensum) and half a day's (provision for the king's 'ferm ') in grain and honey and other customary dues pertaining to the king's 'ferm' : to the queen 4 ounces of gold, and for (de) a packhorse and other small dues 70 shillings, and for customary payments for the dogs 6 pounds and 10 shillings; for the additional payment which Ivo Tallebosc imposed (misit) 7 pounds weighed money (ad pensum) and 40 shillings of blanch (albi) silver, and I ounce of gold for the sheriff.

The church of this manor is held by William the king's chamberlain with 5 hides of land which belong to it. ${ }^{5}$ These 5 hides are part of $(d e)$ the 30 hides of the manor. There is land (in them) for 6 ploughs. On the demesne is $I$, and the villeins have 5. There are 1 I villeins and 4 bordars and 3 serfs, and I mill worth Io shillings. The church yields 20 shillings yearly. There is woodland (to feed) 50 swine. In all it is and was worth 60 shillings. This church with its land Morcar the priest held T.R.E. ${ }^{\circ}$

fo. 2ogb

M. Houstone [Houghton (Regis)] a demesne manor of the king is assessed at $\mathrm{I} 0$ hides. There is land for 24 ploughs. On the demesne are 2 ploughs and the villeins have 22 . There are 38 villeins and 12 bordars, meadow (sufficient) for 12 plough teams and woodland (to feed) Ioo swine. In all it yields yearly Io pounds, weighed money (ad pensum), and supply of half a day's (provision of) grain and honey and other things pertaining to the king's

4 So the MS.

5 See Introduction.

${ }^{6}$ His lands at Potsgrove and Battlesden (see p. 252) had similarly passed to William the chamberlain (J.H.R.) 


\section{THE HOLDERS OF LANDS}

'ferm.' For (de) small dues and a packhorse, 65 shillings; and for customary payments for the dogs 65 shillings; and for the queen 2 ounces of gold ; and for the additional payment (de incremento) which Ivo Tallebosc imposed (misit), 3 pounds, weighed money, and 20 shillings of blanch (albo) silver; and I ounce of gold for the sheriff.

The church of this manor is held by William the chamberlain with half a hide which belongs to it; this is part of the 10 hides of the manor. There is land (in it) for a half plough, which is there. It is worth 12 shillings yearly.

Sewelle [Sewell ${ }^{1}$ ] was assessed at 3 hides T.R.E. There is land for 2 ploughs. A plough and a half plough are there and there could be another half plough. Meadow is there (sufficient) for 4 oxen. There are I villein and 4 bordars. This land is and was worth 20 shillings. Walrave, a man of Queen Eddid, held it and could assign it (dare) to whom he wished. It belonged to Odecroft hundred ${ }^{2}$ (T.R.E.) ; but Ralf Taillebosc added it to (apposuit eam in) the manor of Houstone [Houghton] with King William's consent, for the sake of the additional payment (per crementum) which it gave to him. ${ }^{3}$ So state the men of the same Ralf according to what they heard him say.

\section{Flictham [Flitt ] Hundret}

Bissopescotr [Biscot ${ }^{4}$ ] was assessed at 5 hides T.R.E. There is land for 5 ploughs. There are 2 ploughs on the demesne, and 10 villeins have 3 ploughs. There are 3 serfs and meadow (sufficient) for 4 plough teams. In all (totis valentiis) it is worth 40 shillings; when Ralf Taillebosc held it (was worth) the same amount; T.R.E. 6o shillings. This manor Edwin, a man of Asgar, the staller, held and could do with it what he wished. Ralf Talliebosc added it to Loitone [Luton], the king's manor, for the sake of the additional payment (per crementum) which it gave him; and separated it (foras misit) from the hundred in which it was assessed T.R.E. On the other hand he took other 5 hides from another hundred and placed them in Flictham Hundred.

1 In Houghton Regis near Totternhoe.

2 It would seem that this Hundred is not elsewhere mentioned (J.H.R.)

${ }^{3}$ But this might be read as implying that the king gave his consent in consideration of the increased rent (J.H.R.)

4 In Luton near Leagrave and Limbury.

\section{THE LAND OF THE BISHOP OF BAYEUX}

\section{IN the Half Hundret of Stanburge} [STANBRIDGE $]^{5}$

M. The Bishop of Bayeux holds EItone [Eaton (Bray)]. ${ }^{8}$ It is assessed at 12 hides and I virgate. There is land for 20 ploughs. In the demesne are 2 hides and on it are 4 ploughs and there could be 2 more. The villeins have 8 ploughs and there could be 6 more. There are 20 villeins and 13 bordars and 2 serfs, meadow (sufficient) for 6 plough teams, woodland (to feed) 300 swine, and from it (come) I2 pence (besides). In all (totis valentiis) it is worth 16 pounds. When received (it was worth) 20 pounds; T.R.E. the same sum. This manor Alsi, a man of Queen Eddid, held and could assign and sell.

\section{In the Hundret of Manesheve [MANSHEAD]}

Ansgot of Rovecestre [Rochester] holds I hide in EvREshot [Eversholt] of the Bishop of Bayeux's fee $(f e d o)$. There is land for 2 ploughs. One is there and there could be another. There are 4 villeins and I bordar, meadow (sufficient) for I plough team, and woodland (to feed) 50 swine. In all it is worth 20 shillings ; when received 20 shillings; T.R.E. 40 shillings. This land T.R.E. 4 thegns held and could assign and sell.

The same Ansgot holds of the same bishop in Mildentone [Milton (Bryant)] 4 hides. There is land for 4 ploughs. On the demesne is I plough and there could be another. The villeins have 2 ploughs. There are 4 villeins and 3 bordars and 8 serfs, meadow (sufficient) for 4 plough teams, and woodland (to feed) 30 swine. In all it is worth, and was worth when received, 4 pounds; T.R.E. 40 shillings. This land 7 sokemen held and could assign and sell T.R.E.

\section{In The Hundret of Stodene [Stodden]}

Tovi the priest holds half a hide of the bishop in Bolehestre [Bolnhurst]. There is land for $I$ plough and it is there and I villein and I bordar, meadow (sufficient) for a half plough team and woodland (to feed) 30 swine. In all it is worth 10 shillings and (was worth) as much when received, T.R.E. 12 shillings. This land Azor a man of Bored held and could sell to whom he wished.

In the same (vill) 2 sokemen hold of the

5 Now part of Manshead Hundred.

- See note under 'Etone' on p. 234 below. 


\section{A HISTORY OF BEDFORDSHIRE}

bishop half a hide. There is land for I plough and it is there with 2 bordars. There is woodland (to feed) 4 swine. In all it is worth Io shillings and (was worth) the same when received; T.R.E. I 2 shillings. The same men hold it now who held it T.R.E. They could assign or sell it.

\section{In the Half Hundret of Bochelai ${ }^{1}$}

Herbert son of Ivo holds of the bishop 3 hides and 3 virgates in Stachedene [Stagsden]. There is land for 4 ploughs. There are now $3 \frac{1}{2}$ ploughs and there could be a halt plough more. There are 12 villeins and 7 bordars, meadow (sufficient) for I plough team and woodland (to feed) 40 swine. In all it is worth 7 pounds, (was worth) when received 9 pounds, T.R.E. 12 pounds. This land 12 sokemen held. They were King Edward's men and could sell it.

\section{IN THE HundReT OF Wilga [Willey]}

Two sokemen hold in Carlentone [Carlton] I hide and I virgate of Herbert son of Ivo and he of the bishop. ${ }^{2}$ There is land for I $\frac{1}{2}$ ploughs and these are there, and meadow (sufficient) for I plough team. In all it is worth 26 shillings and 8 pence; when received and T.R.E. (was worth) 30 shillings. This land the same men held who now hold it and they could assign and sell it.

In Torvere [Turvey] Wimund holds of Herbert and he of the bishop I hide. ${ }^{2}$ There is land for I plough and it is there, and meadow (sufficient) for a half plough team. In all it is worth 20 shillings; when received, and T.R.E. (was worth) 40 shillings. This land a man of Alwold of Stivetone [Steventon] ${ }^{3}$ held and could sell.

\section{IN THE Hundret OF Bereforde [BARFORD]}

M. Herbert holds of the bishop, and his nephew Hugh holds of him, ${ }^{2} 5$ hides in WILDENE [Wilden]. There is land for 16 ploughs. On the demesne there are now none; there could be 3 . The villeins have ro ploughs and there could be 3 more. There are 20

1 Now part of Willey Hundred.

2 These exceptional cases of an under-tenant having under-tenants himself should be noted (J.H.R.)

3 The previous holder of Steventon is recorded below as 'Adeloldus teignus R.E.,' but this Turvey entry suggests that he may have been the 'Alwoldus' who was the tenant of the other manors which had passed, with Steventon, to Count Eustace (J.H.R.) sokemen and I 2 bordars and I serf; meadow (sufficient) for 6 plough teams, woodland (to feed) 6 swine. In all it is worth 9 pounds; when received 12 pounds; T.R.E. 20 pounds. This manor 24 sokemen held and could assign and sell their lands to whom they wished.

\section{THE LAND OF THE BISHOP OF COUTANCES}

\section{IN STODEN [StodDen] HundRet}

M. The Bishop of Coutances holds ChrnoTINGA [Knotting]. It is assessed at 5 hides. There is land for 5 ploughs. In the demesne are 3 hides, and on it are 2 ploughs. The villeins have 3 ploughs. There are 8 villeins and 5 bordars and 4 serfs, meadow (sufficient) for 2 plough teams and woodland (to feed) 400 swine. It is worth 4 pounds; when received, (was worth) 3 pounds; and as much T.R.E. This manor Burret held T.R.E.

M. The bishop himself holds Melceburne [Melchbourne]. It is assessed at ro hides. There is land for Io ploughs. In the demesne are 3 hides, and on it are 3 ploughs. The villeins have 7 ploughs. There are 13 villeins and 15 bordars and 3 serfs, meadow (sufficient) for [ ] plough teams, and woodland (to feed) Ioo swine. It is worth 8 pounds, when received (was worth) 100 shillings, T.R.E. 6 pounds. This manor Burret held and there were 6 sokemen there. They could assign and sell their land without (his) leave.

M. The bishop himself holds in Dena [Dean] 4 hides. There is land for [ ] and they are there. There are 6 sokemen and 6 bordars and 2 serfs. It is worth 60 shillings; when received (it was worth) the same sum; T.R.E. 40 shillings. This manor 6 fo. 210

sokemen held. They were men of Borret. Three hides and a half which were of the king's soke they could assign and sell and put with themselves under another lord (ad alterum dominum recedere) without leave of Borred. $\mathrm{Half}$ a hide however they could not assign nor sell without his leave.

M. Geoffrey de Traillgi ${ }^{4}$ holds of the Bishop of Coutances Giveldene [Yelden]. It is assessed at 10 hides. There is land for I 5 ploughs. On the demesne are 4 ploughs and the villeins have $1 \mathrm{I}$. There are 17 villeins and I knight (miles) and 12 bordars and I serf, meadow (sufficient) for 4 plough teams and woodland (to feed) 20 swine. In all (totis

- See Introduction. 


\section{THE HOLDERS OF LANDS}

valentiis) it is worth 9 pounds; when received (was worth) 100 shillings ; T.R.E. 8 pounds. This manor Borred held and in it were 5 sokemen who held 5 hides of this land and could assign or sell (them) to whom they wished.

M. Of the bishop himself William his steward (dapifer) holds Eseltone [Shelton]. It is assessed at 5 hides. There is land for 6 ploughs. On the demesne are 2 ploughs and the villeins have 4 . There are 14 (villeins?') and 5 bordars and 3 serfs, and I mill (worth) 3 shillings, meadow (sufficient) for I plough team, and woodland (to feed) 4 swine. It is worth 100 shillings; when received, (was worth) 60 shillings; T.R.E. 4 pounds. This manor Ulveva held under Borret. She could not assign nor sell (it) without his leave.

In Estone [Easton ${ }^{1}$ ] 4 sokemen hold of the Bishop of Coutances 3 virgates of land. There is land for I plough and it is there. This land is and was worth 10 shillings; T.R.E. 5 shillings. The same men who hold it held it (T.R.E.). They were men of Burred and could assign (it) to whom they wished. In these 3 virgates the bishop claims against Sigard de Cioches 20 acres of woodland which belonged to them (ibi jacuerunt) T.R.E. and this the men of the hundred (court) attest.

M. In Rrselai [Riseley] 2 Frenchmen and 6 Englishmen hold of the bishop 6 hides. There is land for 7 ploughs and they are there. There are 6 villeins and 7 bordars and I serf, meadow sufficient for 3 plough teams, and woodland to feed 200 swine. It is worth 72 shillings; when received, (was worth) the same; T.R.E. 100 shillings. Of this land Burred held 2 hides in demesne, and 6 sokemen, his men, held 4 hides, which they could assign and sell just as they wished ( $u b i$ voluerunt).

In BULEHESTRE [Bolnhurst] the same bishop holds 3 virgates of land in exchange for (pro excambio de) Bledone [Bleadon]. ${ }^{2}$ There is land for $I \frac{I}{2}$ ploughs, and these are there. One villein is there and 4 bordars, and meadow (sufficient) for I plough team and woodland (to feed) 20 swine. It is worth I 5 shillings; when received (was worth) the

1 Co. Hunts (see Introduction).

2 A Buckinghamshire estate of the bishop (fo. $145 \mathrm{~b}$ ) is described with more exactness as 'de excambio pro Bledone.' Each of these estates was alleged to form part of lands given to the bishop in exchange for Bleadon, Somerset (J.H.R.) same ; T.R.E. 20 shillings. This land Gudmunt, a man of King Edward, held and could sell to whom he wished.

In Newentone [Newton Broomshold] the bishop's steward (dapifer) William holds of him I virgate. ${ }^{3}$ It is and was worth 12 pence; T.R.E. 16 pence. This land Alwin, a man of Borred, held; he could not assign or sell it without his leave.

\section{In the Hundret of Wilga [Willey]}

Geoffrey de Tralgi holds of the bishop 4 hides." There is land for 5 ploughs. On the demesne are 2 and the villeins have 3 . There are 14 villeins and 5 bordars and 4 serfs, and meadow (sufficient) for 4 plough teams. It is and was worth 100 shillings. This manor Turbert, a man of King Edward, held and could sell. This land the bishop holds in exchange for (pro excambio de) Bledone [Bleadon ${ }^{5}$ ]. So his men say.

M. In TornaI ${ }^{6}$ [Turvey] the same bishop holds 4 hides. There is land for 6 ploughs. In the demesne are 2 hides, on it 3 ploughs. There 3 villeins have 3 ploughs and (there are) 8 bordars and I serf and $I$ mill (worth) 20 shillings, meadow (sufficient) for 2 plough teams and woodland (to feed) 40 swine. It is worth 6 pounds; when received was worth 40 shillings, T.R.E. 6 pounds. This manor 3 sokemen, men of King Edward, held and could assign and sell. This land the bishop has in exchange for (pro excambio de) Bledone [Bleadon ${ }^{5}$, as his men say.

In HENEWIC [Hinwick ${ }^{7}$ ] Turstan holds of the bishop $I_{\frac{1}{2}}$ hides. There is land for 2 ploughs. On the demesne is I, and 3 villeins have I plough and (? there is) I bordar. It is worth 20 shillings.

\section{In SERnEBRoc [Sharnbrook] a certain}

3 The rest of Newton Broomshold ( 2 hides less half a virgate) is surveyed under Northants, and was held of the Bishop of Coutances by 'William' (J.H.R.)

4 In the later Hundred of Willey, Biddenham, Chellington, and Hinwick are all associated with Trailli (Testa de Nevill, p. 248 ; Feudal Aids, i. 12). But as Biddenham was in 'Buchelai' Half Hundred at the time of Domesday, these 4 hides were probably in Chellington, which is not mentioned by name in the Survey. Mr. Airy, however, I find considered them to represent Souldrop, but he was not guided by feudal evidence (J.H.R.)

- See note 2 above.

6 i.e. Toruai.

7 In Puddington alias Podington. 


\section{A HISTORY OF BEDFORDSHIRE}

Englishman, Turgis, holds of the bishop half a hide. There is land for I plough and it is there and I villein, and meadow (sufficient) for I plough team. It is worth 6 shillings; when received (was worth) 3 shillings; T.R.E. I 5 shillings. This land Alwin, a man of Borret, held and could assign to whom he wished.

In the same vill 7 sokemen hold of the bishop 3 hides. There is land for 3 ploughs and they are there and woodland (to feed) 24 swine. It is worth 24 shillings; when received (was worth) the same; T.R.E. 60 shillings. The same men held it T.R.E. They were men of Borred and could assign or sell it without his leave.

In the same (vill) Humphrey holds of the bishop half a hide. There is land for I plough and it is there, and 2 bordars, and woodland (to feed) 30 swine. It is worth 6 shillings; (was worth) when received ro shillings; T.R.E. 20 shillings. This land Alvric, a man of Borred, held and could sell to whom he wished.

In the same (vill) the bishop holds half a hide. There is land for 6 oxen. ${ }^{1}$ There are 4 bordars. It is worth 3 shillings; was worth as much when received; T.R.E. 5 shillings. This land Borred, a thegn of King Edward, held and could do (with it) what he wished.

In Risedene [Rushden ${ }^{2}$ ] Alwold holds of the bishop half a hide. There is land for 6 oxen. There is a half plough, and there is meadow (sufficient) for 6 oxen. It is worth 5 shillings; was worth as much when received; T.R.E. Io shillings. This land Alvric held; he was a man of Borred, and could sell to whom he wished.

\section{IIII. THE LAND OF THE BISHOP OF LINCOLN}

\section{In Stodene [Stodden] Hundret}

Bishop Remigius holds in Dene [Dean] 2 hides and half a virgate, and Godfrey holds it of him. There is land for $3 \frac{1}{2}$ ploughs. On the demesne are 2 ploughs and the villeins have $1 \frac{1}{2}$. There are 8 bordars and 2 serfs

1 i.e. three-quarters of a plough-team.

2 Partly in Northamptonshire. The bishop was claiming 6 hides of Rushden ('Risdene') in Northants against William Peverel on the ground that they had been held by sokemen of (his predecessor) Borred. See the Victoria History of Northants, vol. i. (J.H.R.) and meadow (sufficient for) I plough team. It is worth 40 shillings; when received (was worth) 30 shillings; and as much T.R.E. This land Godric, a thegn of King Edward, held, and he could do what he wished with his land.

In Estone [Easton ${ }^{3}$ ] William de Caron holds I hide and half a virgate of the bishop. There is land for I plough and it is there, and I bordar and 3 serfs, and meadow (sufficient) for I plough team, and woodland (to feed) 100 swine. It is worth 15 shillings; when received (was worth) ro shillings; and as much T.R.E. This land Alwin Deule, ${ }^{4}$ a man of the Bishop of Lincoln, held and could do with it what he wished. The soke however was always the bishop's. In this land belonging to the bishop's fee (episcopatus) William de Caron lays claim to 60 acres, field and woodland (inter planum et silvam) against Hugh de Beauchamp, ${ }^{5}$ of which Ralf Taillebosc disseised the father of the same William who held this same land T.R.E., as the men of the hundred (court) say.

In Riselai [Riseley] Godfrey holds I hide of the bishop. There is land for I plough, and it is there. One villein is there and $\mathrm{I}$ bordar, meadow (sufficient) for a half plough team and woodland (to feed) 20 swine. It is and was worth ro shillings; T.R.E. 20 shillings. This land.Godric, a thegn of King Edward, held and could do (with it) what he wished.

\section{IN The HalF Hundret of Buchelai ${ }^{6}$}

Ernuin the priest holds of Bishop Remigius I hide and I virgate in BIDEHAM [Biddenham]. There is land for I plough, and it is there. One villein is there, and I mill yielding 2.5 shillings yearly, and meadow (sufficient) for I plough team. It is and was worth 40 shillings. This land Levric, a man of the Bishop of Lincoln, held, but he could not assign or sell (it) without his leave.

\section{IN the Hundret of Bereforde [Barford]}

Ivo Tallebosc holds of the bishop half a hide in Goldentone [Goldington]. There is land for a half plough, and it is there with 2 villeins. There is meadow (sufficient) for

3 Co. Hunts (see Introduction).

4 Interlined. See page 227, note 2, below.

5 As successor to Ralf Tallebosc (J.H.R.)

${ }^{6}$ Now part of Willey Hundred. 


\section{THE HOLDERS OF LANDS}

a half plough team. It is and was worth 6 shillings. Alwin Sac, ${ }^{1}$ a man of the Bishop of Lincoln, held it and could do with it what he wished.

\section{IN THE Hundret of Bichelesworde} [BIGGLESWADE]

William de Caron holds of Bishop $R$. in Tamiseforde [Tempsford] I hide and I virgate and 3 quarters (partes) of 1 virgate. There is land for 2 ploughs and there is I villein. Meadow is there (sufficient) for I plough team, and 2 mills worth (de) 40 shillings, and 120 eels. It is worth 60 shillings; when received (was worth) 40 shillings; T.R.E. roo shillings. Alwin Deule ${ }^{2}$ held it. He was the king's man and could do with it what he wished.

u. $2 \mathrm{IOb}$

In the Hundret of Cliftone ${ }^{3}$ [Chifton]

William de Caron holds of Bishop R. 3 hides and half a virgate in CLIFTONE [Clifton]. There is land for 2 ploughs. One is there, and there could be another. There are 3 villeins and 2 serfs and meadow (sufficient) for 2 plough teams. It is worth 20 shillings, and (was worth) as much when received; T.R.E. 4 pounds. This land Alwin Deule, a man of King Edward, held and could assign to whom he would (quo voluit).

In Chichesane [Chicksand] the same William holds of the same bishop half a hide. There is land for a half plough. It is and was worth 12 pence; T.R.E. 2 shillings. Alwin Deule ${ }^{1}$ held it and could assign it to whom he would.

The church of BEDEFord [Bedford] with its endowments (adjacentibus) is worth 100 shillings.

The church of LEstone [Leighton] is worth 4 pounds. ${ }^{4}$ These Bishop Remigius holds.

\section{THE LAND OF THE BISHOP OF DURHAM}

\section{Bicheleswade [Biggleswade] Hundret}

The Bishop of Durham holds of the king in Melehou [Millow] $4 \frac{1}{2}$ hides. There is land for 4 ploughs. In the demesne are $3 \frac{1}{2}$ hides, and on it is I plough and there could

1 Interlined.

2 He had held also at two places in Huntingdonshire (J.H.R.)

${ }^{3}$ MS. has Clistone.

4 See details of its endowment on p. 222 above. be another. The villeins have 2. There are 4 villeins and I serf. It is worth 40 shillings; was worth as much when received; T.R.E. 60 shillings. This land King Edw(ard) gave to the church of the Holy Cross of Waltham ${ }^{5}$ - so the men of the hundred (court) attest.

\section{In the Hundret of Cliftone [Clifton]}

The same bishop holds 8 hides in AlriceseI [Arlesey] and 2 thirds (partes) of I virgate. There is land for 8 ploughs. On the demesne are 3 ploughs, and 8 villeins have 4 , and there could be a 5 th. There are 5 bordars and 2 serfs, and 2 mills worth 26 shillings and 8 pence, and meadow (sufficient) for 3 plough teams. It is and was worth 7 pounds; T.R.E. 8 pounds. This manor the canons of the Holy Cross of Waltham ${ }^{5}$ held in almoin T.R.E.

\section{THE LAND OF ST. EDMUND}

\section{In the Half Hundret of Bocheleia ${ }^{3}$}

Abbot Balduin of St. Edmunds has in Bidenham [Biddenham] half a hide, and Ordui of Bedeford [Bedford] ${ }^{7}$ holds under him. There is land for a half plough and it is there, and there are 2 serfs and meadow (sufficient) for a half plough team. It is and was worth 6 shillings. This land Ulmar, a priest of King Edward, ${ }^{8}$ held. He could assign it to whom he wished, but Ordui when he was reeve (prepositus) of the borough took it from him as forfeiture for something (pro quadam forisfactura), and now he says he holds (it) of the abbot of St. Edmund, but the men of the hundred (court) say that this was unjustly taking possession (quia injuste eam occupavit).

\section{IN THE Hundret OF Bicheleswade [BIGGLESWADE]}

The same abbot of St. Edmund holds Chenemondewiche [ $].^{9}$ It is assessed at 3 hides and 3 virgates. There is land for 4 ploughs. In the demesne are I hide and 3 virgates, and on it are 2 ploughs, and 6 villeins have 2 ploughs and I mill worth I 3 shillings and 4 pence. There is meadow

5 Waltham Abbey, Essex (see Introduction).

- Now part of Willey Hundred.

$7 \mathrm{He}$ appears among the burgesses of Bedford at the close of the county survey (p. 264) as holding other land here of the king (J.H.R.)

${ }^{8}$ This was probably the same "Ulmar' the priest who had a small estate at Streatley (J.H.R.)

9 ? Kendals in Wrestlingworth (F.W.R.) But see Introduction for this difficult locality (J.H.R.) 


\section{A HISTORY OF BEDFORDSHIRE}

(sufficient) for $\mathbf{I}$ plough team. It is worth 60 shillings; (was worth) when received 30 shillings; T.R.E. 4 pounds. This land 2 sokemen held and could assign to whom they wished. This land Earl Wallef ${ }^{1}$ and his wife gave to St. Edmund in almoin T.R.W.

\section{IN THE HUNDRET OF Wichestanestou [WIYAMTREE]}

The same abbot holds 4 hides and I virgate in Blunham [Blunham] of the king. There is land for 4 ploughs. In the demesne are 2 hides and 3 virgates and on it are 2 ploughs. There 8 villeins have 2 ploughs, and there are 5 bordars and I serf and I mill worth 20 shillings, and meadow (sufficient) for 4 plough teams. It is worth 4 pounds; when received (was worth) 70 shillings; T.R.E. 6 pounds. This land 4 sokemen held and could assign or sell to whom they wished.

\section{THE LAND OF ST. PETER OF BURG ${ }^{2}$ [PETERBOROUGH]}

\section{In Stodene [STODden] Hundret}

The abbot of Burg [Peterborough] holds Stanewica [Stanwick ${ }^{3}$ ]. It is assessed at $2 \frac{1}{2}$ hides. There is land for $2 \frac{1}{2}$ ploughs. One plough is there; another and a half plough could be added. There are 2 villeins and 2 bordars, and meadow (sufficient) for 2 plough teams. It is worth 30 shillings ; (was worth) when received 50 shillings; T.R.E. 40 shillings. This manor St. Peter of Burg held T.R.E.

\section{THE LAND OF ST. BENEDICT OF RAMESY [RAMSEY]}

\section{IN RADEBURNESOCA [REDBORNESTOKE] HUNDRET}

M. The abbot of St. Benedict of Ramesy [Ramsey] holds Cranfelle [Cranfield]. It is assessed at ro hides. There is land for 12 ploughs. In the demesne are 2 hides, and on it are 2 ploughs. There I 8 villeins have 10 ploughs. There are 2 bordars and 5 serfs, and meadow (sufficient) for 2 plough teams, and woodland (to feed) I,000 swine and (rendering) iron for (the) ploughs. ${ }^{4}$ In all

1 Waltheof.

2 This heading, having been omitted, has been inserted in the margin (J.H.R.)

3 Now all in Northamptonshire. The rest of Stanwick (I hide and I virgate) is surveyed under that county, and was similarly held by the abbot of Peterborough (J.H.R.)

- This phrase is explained by a Buckingham- it is worth 9 pounds; when received (was worth) a like amount; T.R.E. I 2 pounds. This manor belonged and belongs to (jacuit et jacet in) the church of St. Benedict.

\section{In Furctham [Flitt] Hundret}

M. The same abbot holds Bertone [Barton in the Clay]. It is assessed at I I hides. There is land for I 2 ploughs. In the demesne are 3 hides, and on it are 2 ploughs and there could be a third, and 20 villeins have 9 ploughs. There are 7 bordars and 6 serfs and I mill (worth) 2 shillings, meadow (sufficient) for 6 plough teams, and woodland (to feed) 200 swine. In all it is worth 10 pounds; (was worth) as much when received; T.R.E. 12 pounds. This manor has, T.R.E. and since, belonged to (jacuit semper in) the church of St. Benedict.

With this manor the abbot claims against (reclamat super) Nigel de Albini ${ }^{5}$ and Walter the Fleming (Flamens') I 2 acres of meadow which belonged to it (ibi jacuerunt) T.R.E. but John de Roches dispossessed him of it unjustly. The hundred (court) attests this.

M. The abbot himself holds Pechesdone [Pegsdon]. ${ }^{6}$ It is assessed at 10 hides. There is land for 14 ploughs. In the demesne are 2 hides, and on it are 2 ploughs and there could be a third. And 37 villeins have II ploughs. There are 7 bordars and 5 serfs, and 2 mills worth (de) 27 shillings and 8 pence, meadow (sufficient) for 3 plough teams and woodland (to feed) 60 swine. It is worth Io pounds; (was worth) as much when received; T.R.E. I 2 pounds. This manor belonged and belongs to (jacuit et jacet in) the demesne of the church of St. Benedict.

\section{In Bereford [Barford] Hundret}

In Wiboldestone [Wyboston] ${ }^{7}$ Eudo Dapi$\mathrm{fer}^{8}$ holds I $\frac{1}{2}$ virgates under the abbot of Ramesy. It is waste, but yet worth 16 pence. This land belonged to (fuit in) the church of St. Benedict T.R.E.

shire entry (fo. 146), which runs: "Silva mille porcis et de redditu silvæ ferra car' sufficienter.' In addition to providing feed for pigs the woodland in such cases appears to have paid a rent in ploughshares or other iron for the 'ploughs.' There are some other instances in Bucks and another instance in Beds itself (J.H.R.)

${ }^{5} \mathrm{He}$ held land in the adjoining parish of Streatley (J.H.R.)

- In Shillington.

7 In Eaton Socon.

$8 \mathrm{He}$ held Eaton Socon and part of Wyboston 


\section{THE HOLDERS OF LANDS}

In Bicheleswade [Biggleswade] Hundret

M. In Bereforde [(Little) Barford] Eudo Dapifer holds 5 hides of the abbot's fee, and Osbern holds of him. There is land for 5 ploughs. On the demesne is 1 plough and 9 villeins have 4 . There are 4 bordars and 3 serfs, and I mill (worth) I 2 shillings and I 25 eels, and meadow (sufficient) for 2 plough teams. It is worth 4 pounds; when received (was worth) 3 pounds; T.R.E. 4 pounds. This manor the abbot of St. Benedict holds and it belonged to St. Benedict (fuit ibi) in almoin T.R.E.

\section{In Clistone [Clifton] Hundret}

In Chistone [Clifton] Lewin holds I hide under the abbot. There is land for a half plough and it is there and meadow (sufficient) for a half plough team. It is and was worth 10 shillings; T.R.E. 20 shillings. The same man held it then, but could not alienate it from the church (abecclesia separare non potuit).

M. The abbot himself holds SEThLindone [Shillington]. It is assessed at 10 hides. There is land for I 4 ploughs. In the demesne are 2 hides, and on it are 2 ploughs, and 27 villeins have 12 ploughs. There are 5 bordars and 4 serfs, and a broken (down) mill which yields nothing, meadow (sufficient) for 6 plough teams, and woodland (to feed) 100 swine. It is worth 12 pounds, and was worth as much T.R.E. and after (semper). This manor belonged to (jacuit in) the church of St. Benedict T.R.E.

M. The abbot himself holds Holewelle [Holwell] for $3 \frac{1}{2}$ hides. There is land for 4 ploughs. In the demesne is I hide, and on it is I plough, and 8 villeins have 3 ploughs, and (there are) 1 bordar and 2 serfs and meadow (sufficient) for I plough team. It is worth 4 pounds and was worth as much T.R.E. and after (semper). This manor belonged and belongs to (jacuit et jacet in) the demesne of the church of St. Benedict.

In Standone [Stondon] the same abbot holds half a hide. There is land for a half plough and it is there. This land belongs and belonged to (jacuit et jacet in) the demesne of the church of St. Benedict. It is worth I 5 shillings.

fo. $21 x$.

\section{THE LAND OF ST. PETER OF WESTMINSTER}

In Clistone [Clifton] Hundret

M. The abbot of Westmonasterium [West- minster] holds $6 \frac{1}{2}$ hides in Holewella [Holwell]. There is land for 6 ploughs. In the demesne are 3 hides and half a virgate and on it are 2 ploughs, and I I villeins have 4 ploughs. There are 4 bordars and 3 serfs, and 2 mills (worth) 20 shillings, and meadow (sufficient) for I plough team. It is and was worth 100 shillings. This manor belonged and belongs to (jacuit et jacet in) the demesne of the church of S. Peter.

\section{THE LAND OF ST. MARY OF TORNYG [THORNEY]}

M. The abbot of Torny [Thorney] holds 2 hides and I virgate of land in BolemEsTre [Bolnhurst]. ${ }^{1}$ There is land for 5 ploughs. In the demesne is $I$ carucate of land besides (extra) ${ }^{2}$ the 2 hides and (I) virgate, and on it is 1 plough, and 9 villeins have 5 ploughs. There are 5 bordars, meadow (sufficient) for I plough team, and woodland (to feed) 106 swine. It is worth 60 shillings; when received 40 shillings; T.R.E. 6 pounds. This manor \#lfleda held of King Edward. She could assign (it) to whom she wished. It belonged to (jacuit in) the church (monasterio) of Torni [Thorney] on the day on which King Edward was living and died. This the men of the hundred (court) attest.

\section{THE LAND OF THE CHURCH OF BERCHINGES [BARKING]}

\section{IN RADBERNESTOCH' [RADBORNESTOKE]} HUNDRET

The abbess of Berchinges [Barking] holds Litincletone [Lidlington]. It is assessed at Io hides. There is land for I I ploughs. In the demesne are 2 hides, and on it are 2 ploughs; there could be a third; and 23 villeins have 8 ploughs. There are 16 bordars and 7 serfs, meadow (sufficient) for 8 plough teams, and woodland (to feed) 400 swine. It is worth 8 pounds; (was worth) as much when received, and T.R.E. I 2 pounds. This manor belonged and belongs to (jacuit et jacet in) the demesne of the church of St. Mary of Berchinges.

\section{THE LAND OF ST. PAUL OF LONDON}

\section{In Fictham [Flitt] Hundret}

M. The canons of St. Paul of London

1 In Stodden Hundred.

2 This is the 'inland,' or land not assessed for geld, found as demesne in some counties (J.H.R.) 


\section{A HISTORY OF}

hold Cadendone [Caddington]. ${ }^{1}$ It is assessed at 5 hides. There is land for 6 ploughs. In the demesne are 2 hides, and on it are 2 ploughs and there could be 4 more. There are I villein and 4 bordars and 2 serfs and woodland (to feed) 200 swine. It is worth 40 shillings; (was worth) when received to shillings; T.R.E. I oo shillings. This manor Lewin Cilt ${ }^{2}$ held T.R.E. The canons have the king's writ in which is contained (babetur) that he gave this manor to the church of St. Paul.

\section{XIII. (THE LAND) OF ST. PAUL OF BEDEFORD [BEDFORD] ${ }^{3}$}

\section{In the Half Hundret of Buchelai ${ }^{4}$}

Osmund, canon of St. Paul of Bedeford [Bedford], holds in BIDEHAM [Biddenham] of the king 3 virgates. There is land for I plough, and it is there, and I villein and I bordar, and meadow (sufficient) for I plough team. It is and was worth Io shillings. This land Leviet the priest held in almoin of King Edward and afterwards of King William, which priest at death gave to the church of St. Paul I virgate of this land. Ralf Tallgebosc added (the) two other virgates to the same church in almoin.

In the same (vill) Ansfrid the canon holds I virgate. There is land for 2 oxen ${ }^{5}$ (to plough) and they are there, and meadow (sufficient) for 2 oxen. It is and was worth 3 shillings. This land Marwen held (and) could sell to whom she ${ }^{6}$ wished. This land Ralf Tallebosc assigned (apposuit) in almoin to the church of St. Paul.

\section{[XIV.] THE LAND OF ERNUI THE PRIEST}

\section{In Wichestanestou [Wixamtree]} HUNDRET

Ernuin the priest holds I hide in HerGHETONE [Harrowden ${ }^{7}$ ]. There is land for $\mathbf{I}$ plough and there is a half plough there, meadow (sufficient) for a half plough team,

1 Another portion (Io hides) of Caddington lay in Hertfordshire and had similarly belonged to Lewin (Cilt) before the Conquest and become the property of St. Paul's before 1086 (J.H.R.)

2 Interlined.

3 Compare the Bedford entry at the opening of the survey (J.H.R.)

${ }^{4}$ Now part of Willey Hundred.

5 i.e. a quarter of a plough-team.

- Marwen is probably a female name (J.H.R.)

7 In Eastcotts.

\section{BEDFORDSHIRE}

and woodland (to feed) 4 swine. It is worth Io shillings; (was worth) when received 5 shillings; T.R.E. Io shillings. This land the father of the aforesaid man held. $\mathrm{He}$ was a man of King Edward. Ernuin (iste) cannot prove livery or show writ (non babet liberatorem nec breve), but he took possession of this land to the king's hurt (super regem), as the hundred (court) attests.

\section{THE LAND OF COUNT EUSTACE}

\section{IN THE Half Hundret of BochelaI ${ }^{8}$}

Count Eustace holds in Bruneham [Bromham] I $\frac{1}{2}$ hides. Ernulf de Arde ${ }^{9}$ holds of him. There is land for $I \frac{1}{2}$ ploughs. $A$ half plough is there and there could be a plough (besides). There is meadow (sufficient) for I $\frac{1}{2}$ plough teams. It is worth Io shillings, (was worth) when received 20 shillings, and as much T.R.E. This land Alwold and Levric men of King Edward held and could assign and sell to whom they wished.

M. In Struentone [Stevington] the same Ernulf holds of the same count 3 hides. There is land for 24 ploughs. On the demesne is I plough and there could be 3 (more). And Io villeins have 5 ploughs and there could be I 5 more. There are I I bordars and 2 serfs, meadow (sufficient) for 4 plough teams and woodland (to feed) 20 swine. In all (totis valentiis) it is worth 14 pounds, (was worth) when received 20 pounds; T.R.E. 30 pounds. This manor Adelold, ${ }^{10}$ a thegn of King Edward, held and could sell to whom he wished.

In Stachedene [Stagsden] an Englishman, Godwi, holds I virgate of Count Eustace. There is land for a half plough, and I ox ploughs there. ${ }^{11}$ This land is worth 2 shillings; when received (was worth) 5 shillings ; T.R.E. Io shillings.

M. In Pabeneham [Pavenham] Ernulf de Arde ${ }^{9}$ holds $2 \frac{1}{2}$ hides. There is land for 3 ploughs, but they are not there. There is I mill (worth) 20 shillings. There are 2 bordars and meadow (sufficient) for 3 plough teams. It is worth 25 shillings; when received (was worth) 40 shillings; T.R.E. 4 pounds. This manor Alwold, a thegn of King Edward, held.

\footnotetext{
${ }^{8}$ Now part of Willey Hundred.

${ }^{8}$ See Introduction, p. 202.

10 See p. 224 , note 3 .

11 i.e. there was land for 4 oxen to plough, but only I ox was there (J.H.R.)
} 


\section{THE HOLDERS OF LANDS}

\section{IN Wirge [WirLEY] HuNDReT}

Ernulf de Arde holds in Torveie [Turvey] of Count Eustace I hide. There is land for 2 ploughs. On the demesne is $I$ and there could be another. There are $\mathrm{I}$ villein and I bordar and meadow (sufficient) for I plough team. It is worth Io shillings, (was worth) when received 20 shillings, and as much T.R.E., This land Alwold, a thegn of King Edward, held and could assign to whom he wished.

In W ADELLE [Odell] Ernulf de Arde holds $4 \frac{1}{2}$ hides and the third part of 1 virgate as 1 manor of Count Eustace. There is I plough on the demesne and there could be another and 3 villeins have 2 ploughs and there could be a third. There are 7 bordars and 2 serfs, meadow (sufficient) for 3 plough teams and woodland (to feed) 50 swine. It is worth 60 shillings; when received (was worth) I 00 shillings; T.R.E. 8 pounds. This land Alwold, a thegn of King Edward, held and could sell to whom he wished.

In SERnEBURg [Sharnbrook] Robert son of Rozelin holds of Count Eustace 2 hides. There is land for 4 ploughs. On the demesne are 2 ploughs; and 4 villeins have 2 . There are 3 bordars and 4 serfs, meadow (sufficient) for 2 plough teams and woodland (to feed) 60 swine. It is worth 40 shillings, (was worth) as much when received; T.R.E. 4 pounds. This land Alwold, a man of King Edward, held and could sell.

\section{THE LAND OF WALTER GIFARD}

\section{In Manesheve [Manshead] Hundret}

M. Walter Gifard holds Woburne [Woburn]. It is assessed at 10 hides. There is land for 24 ploughs. Hugh de Bolebec ${ }^{1}$ holds of him. On the demesne are 2 ploughs and there could be other two. There 8 villeins have 6 ploughs and there could be 14 more. There are 7 bordars and 4 serfs, meadow (sufficient) for 6 plough teams, and woodland (to feed) 100 swine. It is worth 100 shillings; (was worth) when received $\mathrm{I} 2$ pounds ; T.R.E. I 5 pounds. This manor Alric, a thegn of King Edward, held, and in this manor were 6 sokemen; they held 2 hides of this land and could do what they wished (therewith).

M. In Badeiesdone [Battlesden] Richard

1 See Introduction.
Talebot holds 9 hides of Walter Gifard. ${ }^{2}$ There is land for 8 ploughs. On the demesne are 2 ploughs and there could be a third. fo. 2 2xrb

There 7 villeins have 5 ploughs. There are Io bordars and meadow (sufficient) for 8 plough teams. It is worth I oO shillings; (was worth) as much when received; T.R.E. 8 pounds. This manor 7 sokemen held T.R.E. and could do what they wished with $(d e)$ their land.

\section{IN RADBORGESTOC [REDBORNESTOKE] HUNDRET}

In Merestone [Marston (Morteyne)] Hugh de Bolebec ${ }^{1}$ holds of Walter Gifard 2 hides all but half a virgate. There is land for 3 ploughs. On the demesne is 1 plough and 6 villeins have 2 ploughs. There are 5 bordars, and meadow (sufficient) for 3 plough teams, and woodland (to feed) 300 swine. It is worth 50 shillings; (was worth) when received 20 shillings; T.R.E. 4 pounds. This land 2 thegns held T.R.E. and could assign to whom they wished. In regard to this land Erfast a man of Nigel de Albingi ${ }^{3}$ claims a half of an enclosure (dimidiam sepem) which belonged to the manor of Erfast's predecessor, as the men of the hundret (court) attest.

M. In MeLdone [Maulden] Hugh Bolebec ${ }^{4}$ holds of the same Walter 3 hides. There is land for 4 ploughs. On the demesne are 2 ploughs and 5 villeins have 2. Meadow is there (sufficient) for 4 plough teams, woodland (to feed) 50 swine. It is worth 50 shillings; (was worth) as much when received; T.R.E. 4 pounds. This manor Alwin brother of Bishop Wlui held and could assign to whom he wished.

\section{In Bicheleswade [Biggleswade] Hundret}

In DomTone ${ }^{5}$ [Dunton] Ralf de Langetot ${ }^{\circ}$ holds of Walter Gifard I hide and 3 virgates. There is land for 2 ploughs and they are there and 4 villeins and 2 bordars. It is worth 33 shillings and 4 pence and was worth as much T.R.E. and after (semper). This land 4 soke-

2 A Richard Talbot is returned as holding two knights' fees on the Giffard fief in 1 I 66 (J.H.R.)

${ }^{3} \mathrm{He}$ held of Nigel the rest of Marston, viz. 8 hides and half a virgate (J.H.R.)

4 'Bolebec' is interlined.

5 Probably a scribal error for 'Donitone' (J.H.R.)

${ }^{6} \mathrm{He}$ also held under Walter Giffard in Suffolk (J.H.R.) 


\section{A HISTORY OF}

men held and could sell their land. They were Archbishop Stigand's men.

M. In Melehou [Millow] the same (ipse) Ralf holds of the same Walter 5 hides. There is land for 5 ploughs and they are there, and 8 villeins and 4 bordars. It is and was worth 100 shillings T.R.E. and after (semper). This manor Io sokemen held and could assign or sell their land to whom they wished.

In Stratone [Stratton ${ }^{1}$ ] Fulcher of Paris $\left(\right.$ Parisiacus $\left.^{2}\right)$ holds of Walter Gifard I hide and I $\frac{1}{2}$ virgates. There is land for 2 ploughs. On the demesne is I plough and I villein is there and 5 bordars with I plough, and meadow (sufficient) for 2 plough teams. It is worth 28 shillings ; (was worth) as much when received; T.R.E. 30 shillings. This land 3 sokemen held and could assign or sell to whom they wished.

M. In Cudessane ${ }^{3}$ [Chicksand $\left.{ }^{4}\right]$ Germund holds of Ralf Langetot ${ }^{5} 3 \frac{1}{2}$ hides as I manor. There is land for 3 ploughs. On the demesne is $\mathrm{I}$; and $\mathrm{I}$ villein and 3 bordars (are there) with 2 ploughs and (there is) I serf. Meadow is there (sufficient) for 3 plough teams and woodland (to feed) 40 swine. It is worth 40 shillings; (was worth) when received 20 shillings; T.R.E. 60 shillings. There could be I mill there. This manor 4 sokemen held and could assign and sell.

M. In Chambeltone ${ }^{3}$ [Campton] Ralf de Langetot ${ }^{5}$ holds of Walter Gifard $4 \frac{1}{2}$ hides and the fourth part of I virgate. There is land for 4 ploughs. There is I plough on the demesne; and 4 villeins have 3 ploughs and a mill is there worth $3^{6}$ shillings and 3 pence ; meadow (sufficient) for 4 plough teams, and woodland (to feed) 40 swine. It is worth 60 shillings; when received (was worth) 20 shillings; T.R.E. 70 shillings. This land 6 sokemen held and could assign to whom they wished.

1 In Biggleswade.

${ }^{2} \mathrm{He}$ also held here under Countess Judith, and he held under her and under Nigel de Albini at Holme adjoining (J.H.R.)

3 These two manors were in Clifton Hundred, but the hundredal heading has been omitted (J.H.R.)

4 See Introduction.

5 Compare p. 231 , note 6 , above. The instance of holding under an under-tenant should be noted (J.H.R.)

${ }_{6}$ ? corrected to 2 .

\section{BEDFORDSHIRE}

\section{THE LAND OF WILLIAM DE WARENE}

In Stodene [STodden] Hundret

William de Warenna holds in Dene [Dean] 2 hides, and 3 sokemen hold of him. There is land for 3 ploughs and they are there. There are 5 bordars and $I$ serf. It is and was worth 30 shillings T.R.E. and after (semper). This land the same sokemen held who hold it now. One of these could not assign or sell his land without his lord's leave. The other two could do this. Of half a hide and half a virgate of this land William Spec was put in possession (saisitus) by the king and given livery (per ejus liberatorem), but William de Warenna, without writ from the king, disseised him and took away 2 horses from his men and has not yet restored (them). This the men of the hundred (court) attest.

M. William de Warenne himself holds Tilebroc [Tillbrook]. It is assessed at 5 hides. There is land for 6 ploughs, and they are there and 20 sokemen and 4 bordars, and meadow (sufficient) for 5 plough teams. It is worth roo shillings; (was worth) as much when received; T.R.E. 4 pounds. This manor the same sokemen held who hold it now, and they belonged in such way to the king's soke and sake (ita de soca et saca regis fuerunt) that they could assign and sell their land to whom they wished and put themselves under another lord (recedere ad alium dominum) without the leave of him under whom they were. This land of Tilebroc [Tillbrook] Hugh Beauchamp claims against William, and the men of the hundred (court) bear testimony in regard to it that Ralf Tallebosc, his predecessor, was seised of it by the king and held it.

\section{In Hanefelde [}

] William de Warenna holds 3 virgates of land. There is land for I plough and it is there. It is and was worth 10 shillings T.R.E. and after (semper). This land always belonged to (jacuit in) Chenebaltone [Kimbolton], but gave its 'wer' (warram) always of right (juste) in Bedefordshire.?

In Estone [Easton ${ }^{8}$ ] William de Warenne holds 1 virgate. There is land for 2

7 That is to say, it belonged to William de Warrenne's manor of Kimbolton just across the Huntingdonshire border, but was assessed in Bedfordshire, in which it was locally situate (J.H.R.)

8 Co. Hunts (see Introduction.) 


\section{THE HOLDERS OF LANDS}

ploughs, and they are there, and 1 villein and 2 bordars, and meadow (sufficient) for I plough team and woodland (to feed) 100 swine. It is worth 20 shillings; when received was worth 40 shillings; T.R.E. 20 shillings. This land was held by Avigi a man of Aschil, predecessor of Hugh Beauchamp. ${ }^{1}$ He could sell to whom he wished, but the soke Aschil himself retained in his manor of COLMEBorde [Colmworth]. This land Hugh Beauchamp claims against William de Warenne. And all the sworn men of the sheriffdom (vicecomitatu) bear testimony that this land does not belong to William.

In the same vill William de Warenne holds I hide and I virgate. There is land for I plough, and it is there, and 2 bordars, and meadow (sufficient) for I plough team. It is worth ro shillings; (was worth) as much when received; T.R.E. I5 shillings. This land Avigi held and could assign to whom he wished T.R.E. This King William afterwards granted to him and by his writ commended (him) to Ralf Tallebosc that he might protect (servaret) him for his life. ${ }^{2}$ On the day on which he died he stated that he was William de Warenne's man and accordingly William is in possession of this land.

In the same (vill) the same William holds I virgate of land. There is land for 2 oxen $^{3}$ (to plough) and there are there 4 oxen. It is and was worth 2 shillings, T.R.E. 3 shillings. This land Blach, a man of Augi, ${ }^{4}$ held and could assign to whom he wished.

In the same (vill) Tedric holds of William I virgate and the fourth part of I virgate. There is land for I plough, and it is there, and meadow (sufficient) for I plough team and woodland (to feed) 24 swine. It is and was worth ro shillings; T.R.E. 6 shillings. Godric, a man of the sheriff, held it and could assign to whom he wished.

\section{THE LAND OF WILLIAM DE OW}

\section{In Fitctham [Flitt] Hundret}

M. William de Ow holds Sonedone [Sundon]. It is assessed at Io hides. There is land for 16 ploughs. In the demesne are 4 hides, and on it are 4 ploughs. There 20 vil-

1 "Belcamp" interlined.

2 On this interesting case of commendation see the Introduction (J.H.R.)

3 i.e. a quarter of a plough-team.

- This name is clearly the same as the 'Auigi' above, and the fact that a 'man' of Aschil had himself a 'man' under him should be observed (J.H.R.) leins have I 2 ploughs. There are I I bordars and $\mathrm{r} 2$ serfs, meadow (sufficient) for 4 plough teams and woodland (to feed) I00 swine. In all (totis valentiis) it is worth Io pounds ; (was worth) when received 8 pounds, T.R.E. 20 pounds. This manor Alestan of Boscumbe, ${ }^{5}$ a thegn of King Edward, held. In this same vill I knight (miles) has I plough.

\section{fo. 212}

In Stradier [Streatley] Walter holds of William de Ow I hide. There is land for 2 ploughs. On the demesne is I plough, and 2 villeins have 1 plough. (There are) 3 bordars and 3 serfs, meadow (sufficient) for I plough team and woodland (to feed) 20 swine. It is worth 30 shillings; (was worth) when received 20 shillings; T.R.E. 40 shillings. This land Goduin, a man of Alestan, thegn of King Edward, held and could sell to whom he wished.

\section{In Bicheleswade [Biggleswade] Hundret}

In Melehou [Millow] William de Ow holds half a hide. There is land for a half plough, and it is there with I bordar. It is and was worth Io shillings. This land Godmar, a man of Alestan, held and could sell to whom he wished.

M. In EDEWORDE [Edworth] 2 knights (milites) hold of William de Ow 7 hides and $3 \frac{1}{2}$ virgates. There is land for 8 ploughs. On the demesne are 3 ploughs, and 8 villeins have 5 ploughs. There are 2 bordars and 5 serfs and meadow (sufficient) for 2 plough teams. It is worth 8 pounds; when received (was worth) Io pounds; and as much T.R.E. This manor Alestan of Boscum(b)e held, and 2 sokemen, his men, were there and had $1 \frac{1}{2}$ hides and could sell to whom they wished.

In Holme [Holme ${ }^{6}$ ] Ulvric holds of William de $\mathrm{Ow} 3$ virgates of land. There is land for I plough and it is there. It is worth 16 shillings; (was worth) when received 12 shillings; T.R.E. 20 shillings. This land Elveva, a 'man' (bomo) of Aschil, held and could assign to whom she ${ }^{7}$ wished.

\section{In Chistone [Clifton] Hundret}

In Alriceseie [Arlesey] Burnard holds ${ }^{8} 5 \frac{1}{2}$ hides and two-thirds (partes) of 1 hide. There is

5 See Introduction, p. 202.

- In Biggleswade.

7 'Elveva' (Elfgifu) is a female name.

8 i.e. of William de Ow. Burnard was probably the Bernard who held of him in Hants and Wilts (J.H.R.) 


\section{A HISTORY OF BEDFORDSHIRE}

land for 6 ploughs. On the demesne is I plough and 13 villeins have 5. And (there are) Io bordars, and I mill (worth) ro shillings, and meadow (sufficient) for 6 plough teams. There is a market worth $(d e)$ Io shillings. It is and was worth T.R.E. and after (semper) 7 pounds. This manor Alestan of Boscum(b)e held, and there was I sokeman, his man, there who had two-thirds (partes) of I hide and could assign to whom he wished.

In Chambeltone [Campton] Fulbert holds half a hide of William de Ow. There is land for a half plough, and it is there with I villein. This land is and was worth 5 shillings T.R.E. and after (semper). This land Alwin, a man of Alestan, held and could assign to whom he wished.

\section{THE LAND OF MILO CRISPIN}

In STOden [Stodden] Hundret

M. Milo Crispin holds Clopeham [Clapham]. It is assessed at 5 hides. There is land for 30 ploughs. Besides these 5 hides there are 10 carucates of land in the demesne $\xi^{1}$ on it are 8 ploughs and there could be 2 more. There 18 villeins have 20 ploughs, and (there are) I 5 bordars and 4 serfs, and meadow sufficient for 6 plough teams, and 1 mill (worth) 40 shillings, and woodland (to feed) 200 swine and (worth) 6 pence (besides). In all (totis valentiis) it is worth 24 pounds; (was worth) as much when received; and T.R.E. 12 pounds. This manor Bricxtric, a thegn of King Edward, held of the abbot of Ramesy. The abbot and monks claim (reclamant) this manor since it is and was, T.R.E., for their support (de victu eorum), and the whole hundred (court) bears witness to the fact (de boc).

In Middeltone [Milton (Ernest)] 2 sokemen had 16 acres of land and gave their 'wer' (warram) in the same Middeltone, but could sell or assign their land to whom they wished. These sokemen Robert de $\mathrm{Olgi}^{2}$ attached to (apposuit in) Clopeham [Clapham], unjustly, as the men of the hundred (court) say, because they never belonged thereto T.R.E. (nunquam ibi jacuerunt).

\section{In Wilga [Willey] HundRet}

In LALEGa [Thurleigh] Levric holds of Milo I virgate of land. There is land for I plough, and it is there. It is and was worth Io shillings T.R.E. and after (semper). The same man held it T.R.E. He was a man of Brixtric and could assign or sell it.

1 See p. 229 , note 2.

2 See Introduction, p. 202.

\section{THE LAND OF ERNULF DE HESDING}

In Manesheve [Manshead] Hundret

Ernulf de Hesding holds Dodintone [Toddington] of the king. It is assessed at $15 \frac{1}{2}$ hides. There is land for 30 ploughs. There are 10 carucates of land in the demesne, and on it are 7 ploughs, and there could be 3 more : (this is) besides the $15 \frac{1}{2}$ hides. $^{3}$ There 42 villeins have 20 ploughs. There are 19 bordars and 19 serfs, meadow (sufficient) for 30 plough teams, and woodland (to feed) 300 swine. In all (totis valentiis) it is worth 25 pounds; (was worth) as much when received; T.R.E. 30 pounds. This manor Wlward Levet held T.R.E.

In Cergrave [Chalgrave] Ernulf holds the third part of I virgate of land. It is and was worth 2 shillings T.R.E. and after (semper). This land Edward Wit ${ }^{4}$ held T.R.E.

\section{THE LAND OF EUDO SON OF HUBERT}

M. Eudo 'Dapifer' holds Etone [Eaton Socon ${ }^{5}$. It is assessed at 20 hides. There is land for 16 ploughs. In the demesne are $7 \frac{1}{2}$ hides and on it are 4 ploughs. There $3^{8}$ villeins have 12 ploughs. There are 7 bordars and 8 serfs, and 2 sokemen who could not assign or sell their land. There are 2 mills worth $(d e) 36$ shillings and 6 pence, and 100 eels, meadow (sufficient) for 12 plough teams, and woodland (to feed) 400 swine, and 2 acres of vineyard. In all it is worth 15 pounds, (was worth) when received 8 pounds, T.R.E. ro pounds. This manor Ulmar of Etone [Eaton Socon], a thegn of King Edward, held. In this manor were 2 sokemen who could assign and sell their land. Of this land Tedbald a man of Countess Judith claims I hide, of which Eudo disseised him after he came to this manor.

3 See p. 229 , note 2.

- 'Wit' is interlined.

5 Eaton Bray and Eaton Socon, which lie at opposite extremities of the county, are at first sight difficult to distinguish in Domesday, because the Hundredal heading is here omitted, and because both manors escheated from their Domesday holders to the Crown. But as "Etone" is here followed by $W y$ boston and Chawston, immediately south of Eaton Socon, we are clearly dealing with Barford Hundred, in which are situated all three. Moreover, it is noteworthy that Eaton Bray and Eaton Socon appear persistently as 'Eytone' and 'Etone' respectively (Feudal Aids, vol. i.), just as they appear in Domesday as 'Eitone' and 'Etone' respectively. Eaton Socon is further discussed in the Introduction (J.H.R.) 


\section{THE HOLDERS OF LANDS}

In Wiboldestone [W yboston $^{1}$ ] Eudo holds 6 hides and 3 virgates. There is land for 5 ploughs. In the demesne are $4 \frac{1}{2}$ hides, and on it are 2 ploughs, and 8 villeins have 4 ploughs. There are 8 bordars and 3 serfs, and meadow (sufficient) for 2 plough teams. In all it is worth 3 pounds; (was worth) when received 20 shillings; and T.R.E. Io pounds. This land 4 thegns of King Edward held and could sell to whom they wished.

In Chavelestrorne [Chawston ${ }^{2}$ ] Eudo holds I hide and I virgate. There is land for I plough, and it is there. There are 4 villeins, and meadow sufficient for I plough team. It is and was worth Io shillings; T.R.E. 20 shillings. This land 2 men of King Edward held and they could assign and sell it.

In Bicheleswada [Biggleswade] Hundret

In Tamiseforde [Tempsford] Eudo holds I hide and I virgate of land. There is land for 2 ploughs. In the demesne is $\mathrm{I}$ hide, and on it is I plough, and there is I villein with I plough and there are 2 bordars and I serf, and I mill (worth) Io shillings, and meadow (sufficient) for 2 plough teams. It is and was worth 40 shillings; T.R.E. 45 shillings. This land 2 sokemen held and could assign to whom they wished.

In the same vill William de Carun ${ }^{3}$ holds 4 hides and I virgate of Eudo Dapifer. There is land for 4 ploughs. On the demesne are 2 ploughs, and 8 villeins have 2 ploughs and there are 6 serfs, and I mill (worth) I 2 shillings, and meadow (sufficient) for 4 plough teams. It is worth 60 shillings; (was worth) when received 40 shillings, and T.R.E. 60 shillings. This land 3 sokemen, men of Ulmar of Etone [Eaton Socon], held ; one of these could not assign his land without his lord's leave; the other two could do what they wished (with their land).

\section{In the Half Hundret of Weneslai}

M. Sandeia [Sandy] Eudo 'Dapifer' holds. It is assessed at 16 hides and $I$ virgate. There is land for 16 ploughs. In the demesne are 8 hides and I virgate, and on it are 3 ploughs, and 24 villeins have 8 ploughs and there could be 5 more. There are 6 bordars and 2 serfs, and 2 mills worth (de) 50 shillings, meadow sufficient for 16 plough teams, and pasture for the live stock of the vill. In all it is worth

1 In Eaton Socon.

2 In Roxton.

3 Robert de Carun was holding here in I 284-6, under the Beauchamp barony of Bedford (J.H.R.)

4 Now part of Biggleswade Hundred.
12 pounds; when received 8 pounds; T.R.E. 10 pounds. This manor Ulmar of Etone [Eaton Socon], a thegn of King Edward, held. Eudo claims here 3 acres of woodland against Hugh Beauchamp which Ulmar held; but $R$ (alf) when he was sheriff disseised him, and accordingly Eudo has refused to give the 'wer' (warras) of this woodland. ${ }^{5}$ This (boc $i d e m$ ) the men of the hundred (court) attest.

In Sutrone [Sutton] Alwin holds of Eudo 3 virgates of land. There is land for 6 oxen $^{6}$ (to plough), and they are there and I villein. There is meadow (sufficient) for the oxen. It is worth 6 shillings, (was worth) when received 3 shillings, and T.R.E. 1o shillings. This land 2 sokemen held and could sell to whom they wished.

In Wichestavestou [WiXamtree] Hundret

In Sudgivele [Southill] William de Caron holds half a virgate of land of Eudo. There is land for 2 oxen $^{7}$ (to plough), and they are there, and meadow (sufficient) for 2 oxen. It is worth 3 shillings, T.R.E. 4 shillings. This land Alric held and could assign to whom he wished.

fo. 212b

In Stanford [Stanford ${ }^{8}$ ] William de Caron holds of Eudo 4 hides. There is land for 4 ploughs. On the demesne are 2, and 3 villeins have 2 ploughs, and (there are) 2 serfs, and 2 mills worth (de) 29 shillings and 50 eels ; meadow (sufficient) for 4 plough teams, and woodland (to feed) 60 swine and (worth) 2 shillings (besides). In all it is worth 4 pounds; (was worth) when received 40 shillings ; T.R.(E.) 4 pounds. This land Ulmar of Etone [Eaton Socon], a thegn of King Edward, held. In this land was I sokeman, man of this Ulmar; he had half a hide and could sell.

In the same (vill) are 7 sokemen holding 7 acres of land; they were men of UImar and could assign their land. Hugh de Beauchamp (Belcamp) holds it now.

In Bluneham [Blunham] Domnic' holds of Eudo I virgate of land. There is land for $2 \operatorname{oxen}^{7}$ (to plough), and they are there, and meadow (sufficient) for 2 oxen. It is worth 2 shillings; (was worth) when received 3 shillings, and T.R.E. 5 shillings. This land 4 sokemen held and could assign and sell.

5 i.e. to pay what was assessed on it.

- i.e. three-quarters of a plough-team.

7 i.e. a quarter of a plough-team.

8 In Southill. 


\section{A HISTORY OF BEDFORDSHIRE}

In Bistone [Beeston ${ }^{1}$ ] Rolland holds of Eudo 3 hides. There is land for 3 ploughs, and they are there. On the demesne are 2 ploughs; and 4 villeins have I plough. There are 2 bordars and $\mathrm{I}$ serf, and meadow (sufficient) for 3 plough teams. It is worth 30 shillings; (was worth) when received 20 shillings, and T.R.E. 40 shillings.

In the same (vill) Norman holds of Eudo 4 hides. There is land for 4 ploughs. On the demesne is I plough; and 4 villeins have 3 ploughs. There are 2 serfs, and I mill (worth) 30 shillings, and meadow (sufficient) for 4 plough teams. It is worth 40 shillings ; (was worth) as much when received, and T.R.E. 50 shillings. These 4 hides and the 3 above, this Norman held T.R.E. and T.R.W. Now Eudo holds it of the king, as his men say, but it is not part of the fee (of) Lisois. ${ }^{2}$

In the same (vill) Pirot ${ }^{3}$ holds of Eudo I hide. There is land for I plough and it is there with I bordar. There is meadow (sufficient) for I plough team. It is worth Io shillings; (was worth) when received 5 shillings, and T.R.E. 20 shillings. This land Ravan, a man of Ulmar of Etone [Eaton Socon], held and could assign to whom he wished.

In Nortaive [Northill] Pirot ${ }^{3}$ holds of Eudo $1 \frac{1}{2}$ hides. There is land for $I \frac{1}{2}$ ploughs. One plough is there and there could be a half plough (more) and there are 3 villeins and I bordar, meadow (sufficient) for $I \frac{7}{2}$ plough teams and I mill (worth) 14 shillings. It is worth 20 shillings, when received (was worth) Io shillings and T.R.E. 25 shillings. This land Ravan, a man of Ulmar of Etone [Eaton Socon], held and could sell.

In the same (vill) Ralf holds $I \frac{1}{2}$ hides of Eudo. There is land for 2 ploughs and they are there and 5 bordars and 3 serfs and meadow (sufficient) for 2 plough teams and woodland (to feed) I00 swine. It is worth 3 pounds, was worth when received 40 shillings, T.R.E. 60 shillings. This land 2 sokemen held and could assign and sell.

\section{In Chiston [Clifton] Hundret}

M. In Chistone [Clifton] William de

1 In Sandy.

2 Fee of Lisois de Moustiers, Eudo's predecessor (J.H.R.)

${ }^{3} \mathrm{He}$ also held under Eudo in Cambridgeshire, Essex and Suffolk, and must have been ancestor of Ralf Pirot who held 4 fees in II 66 on the fief which had been Eudo's. See also p. 244, note 4 below (J.H.R.)

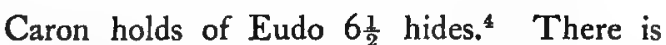
land for $4 \frac{1}{2}$ ploughs. On the demesne are 2 ploughs, and 9 villeins have $2 \frac{1}{2}$ ploughs. There are 1 bordar and 3 serfs, and 2 mills worth (de) 40 shillings and 150 eels, and meadow sufficient for $4 \frac{1}{2}$ plough teams. In all it is worth roo shillings; (was worth) when received 4 pounds ; T.R.E. 6 pounds. This manor Ulmar of Etone [Eaton Socon] held, and there were 3 sokemen there. They had I hide and half a virgate which they could sell to whom they wished.

\section{THE LAND OF WILLIAM PEVREL}

\section{In Stanburge [Stanridge] Hundret ${ }^{5}$}

M. William Pevrel holds of the king Pileworde ${ }^{6}$ [Tilsworth] and Ambrose ${ }^{7}$ holds of him. It is assessed at $\mathrm{I} 0$ hides. There is land for 8 ploughs. On the demesne is I plough and there could be another, and 10 villeins have 6 ploughs. There are 6 bordars and 3 serfs, meadow (sufficient) for 6 plough teams, and woodland (to feed) Ioo swine. This woodland Oswi took away and the hundred (court) says that it belonged to (jacuit in) this manor T.R.E. In all it is worth 6 pounds; when received (was worth) 4 pounds, and T.R.E. Io pounds. This manor Levric son of Osmund, and thegn of King Edward, held.

\section{IN WIIGA [W ILlEey] HundReT}

In Risedene [Rushden ${ }^{8}$ ] Malet holds of William Pevrel I virgate of land. There is land for $2 \operatorname{oxen}^{9}$ (to plough), and they are there. It is and was worth 16 pence; T.R.E. 2 shillings. This land Samar the priest, a man of Countess Goda, held and could assign to whom he wished.

\section{THE LAND OF HUGH DE BEAUCHAMP (BELCAMP)}

\section{In Stodene [Stodden] Hundret}

M. Hugh de Beauchamp holds CHaIsor

4 Robert de Caron gave a mill here to St. John's Abbey, Eudo's foundation at Colchester (J.H.R.)

${ }^{5}$ (Half Hundred.) Now part of Manshead Hundred.

6 This name was probably written in the return made from the Hundred, with the Anglo-Saxon $p$ (thorn); and this mistaken by the Domesday clerks for P (F.W.R.)

${ }^{7} \mathrm{He}$ also held of William Peverel in Notts, Northants and Bucks (J.H.R.)

8 Partly in Northamptonshire, where William

Peverel held in the portion lying there.

${ }^{\theta}$ i.e. a quarter of a plough-team. 


\section{THE HOLDERS OF LANDS}

[Keysoe]. It is assessed at 5 hides less I virgate. ${ }^{1}$ There is land for 5 ploughs, and they are there, and 9 villeins and 6 bordars and I serf, and I mill (worth) 2 shillings, and meadow (sufficient) for 4 plough teams, and woodland (to feed) 200 swine. In all (totis valentiis) it is worth 100 shillings; when received 4 pounds, and T.R.E. 100 shillings. This land Aschil, a thegn of King Edward, held, and there were 12 sokemen there who had $3 \frac{1}{2}$ hides which they could assign and sell to whom they wished.

In RiselaI [Riseley] Hugh holds I hide and it is an outlying part (berewich) of Caisot. There is land for 2 ploughs and they are there. This land Aschil his predecessor held.

\section{In Buchrlai Half Hundret ${ }^{2}$}

M. Hugh himself holds Putenehou [Putnoe $\left.{ }^{3}\right]$. It is assessed at 4 hides. There is land for 5 ploughs. In the demesne are 2 hides, and on it are 2 ploughs; and 6 villeins have 3 ploughs. There are 4 bordars and 2 serfs, and I mill (worth) 30 shillings and 100 eels, and woodland (to feed) 100 swine. It is worth 4 pounds; when received (was worth) 40 shillings, and as much T.R.E. This manor Aschil, a thegn of King Edward, held.

M. Hugh himself holds Stachedene [Stagsden ${ }^{4}$ ] It is assessed at 5 hides. There is land for 5 ploughs. In the demesne are 2 hides and on it are 2 ploughs; and I 2 villeins have 3 ploughs. There are 8 bordars and 2 serfs, meadow (sufficient) for I plough team and woodland (to feed) 100 swine. 'There is a park for beasts of the chase (parcbus ferarum silvaticarum). In all (totis valentiis) it is worth 100 shillings; when received (was worth) 40 shillings, and T.R.E. I 00 shillings.' ${ }^{\prime}$ This manor 2 men of King Edward and I man of Earl Harold held, and each could assign his land to whom he wished.

\section{Hugh himself holds Chainhalle}

1 This virgate is entered under Huntingdonshire. See Introduction (J.H.R.)

2 Now part of Willey Hundred.

${ }^{3}$ Now in Goldington, which is in Barford Hundred.

4 Now in Willey Hundred.

5 The words within quotation marks are added at the foot of the folio, having been omitted in the text.
[? Channells End $\left.{ }^{8}\right]{ }^{7}$ It is assessed at 5 hides. There is land for 5 ploughs. In the demesne are 2 hides, and on it are 2 ploughs, and I 2 villeins have 3 ploughs. There are 9 bordars and 5 serfs, meadow (sufficient) for 3 plough teams, and I mill (worth) 40 shillings and r 00 eels, and woodland (to feed) roo swine. In all (totis valentiis) it is worth 8 pounds; (was worth) when received Ioo shillings, and T.R.E. 7 pounds. This manor Aschil, a thegn of King Edward, held.

In the same (vill) Hugh holds half a hide which belongs to (jacet in) Putenemou [Putnoe $\left.{ }^{8}\right]$. There is land for I plough and 4 oxen are there and 2 bordars. It is and was worth 2 shillings. This land Anschil, a thegn of King Edward, held.

In Gondentone [Goldington] Hugh holds 3 hides and I virgate which belongs to (jacet in) Putenehou [Putnoe]. There is land for 3 ploughs, and they are there, and 7 villeins and I bordar, and meadow (sufficient) for I plough team, and I mill (worth) 30 shillings and I00 eels. In all it is worth 60 shillings; (was worth) as much when received, and T.R.E. 4 pounds. Of this land Ralf Tallgebosc had 2 hides and 3 virgates in exchange for (pro excambio de) Warres [Ware]. ${ }^{9}$ This land 9 sokemen held and could assign or sell to whom they wished.

\section{In Wichestanestou [Wixamtree] HUNDRET}

In Sudgible [Southill] Hugh holds 2 hides and I virgate. There is land for 3 ploughs and they are there, and meadow (sufficient) for 3 plough teams, and woodland (to feed) I 00 swine. It is and was worth 40 shillings; T.R.E. 50 shillings. This land 8 sokemen held and could do what they wished with it.

In Stanford [Stanford ${ }^{10}$ ] Hugh holds I hide and half a virgate of land. There is land for $I \frac{1}{2}$ ploughs, and they are there, and 4 villeins and I bordar, and meadow (sufficient) for $I \frac{1}{2}$ plough teams. It is and was worth 20 shillings T.R.E. and after (semper). This land 4 sokemen held, of whom 3 were free; the fourth had I hide but could neither assign nor sell.

M. In Chernetone [Cardington] Hugh holds $6 \frac{1}{2}$ hides, and 2 thirds of 1 virgate. There is land for 8 ploughs. In the demesne

\footnotetext{
${ }^{6}$ In Colmworth.

7 In Barford Hundred. $\quad{ }^{8}$ In Goldington

${ }^{\circ}$ See Introduction. 10 In Southill.
} 


\section{A HISTORY OF BEDFORDSHIRE}

are $2 \frac{1}{2}$ hides, and I plough is on it; and $I 2$ villeins have 7 ploughs. There are 6 bordars, meadow (sufficient) for 3 plough teams, and woodland (to feed) I20 swine, and I mill fo. $2 \times 3$

(worth) 40 shillings and I 00 eels. In all it is worth 6 pounds; (was worth) when received I oo shillings; T.R.E. 6 pounds. This manor 13 sokemen held and could go to what lord (quo) they wished with their land.

M. Hugh himself holds Welitone [Willington]. It is assessed at Io hides. There is land for 9 ploughs. In the demesne are 5 hides, and on it are 3 ploughs, and there could be a fourth; and 13 villeins have 5 ploughs. There are 8 serfs, and I mill (worth) 12 shillings and 100 eels; meadow (sufficient) for 5 plough teams and woodland (to feed) 40 swine. In all (totis valentiis) it is worth 7 pounds, (was worth) when received 40 shillings and T.R.E. 6 pounds. This manor Aschil, a thegn of King Edward, held, and there were 8 sokemen there who could go (recedere) with their land to what lord $(q u 0)$ they wished. Of this land they had 7 hides.

\section{In Clifton [Clifton] Hundret}

M. Hugh himself holds Stotfalt [Stotfold]. It is assessed at 15 hides. There is land for I 5 ploughs. In the demesne are 5 hides, and on it are 3 ploughs; and $2 \mathrm{I}$ villeins have 12 ploughs. There are 14 bordars and 6 serfs, and 4 mills worth (de) 4 pounds and 400 eels, and meadow (sufficient) for 7 plough teams. In all (totis valentiis) it is worth 25 pounds; when received (was worth) 12 pounds, and T.R.E. 20 pounds. On the day on which Ralf Tallebosc died it was farmed at (ad frmam pro) 30 pounds. This manor Aschil, a thegn of King Edward, held. He himself had $9 \frac{1}{2}$ hides, and 7 sokemen held the remainder of the land and could sell (it) to whom they wished. One hide of this land belongs to the church of St. Alban, and the men of the hundred (court) say it belonged to it (ibi jacuit) T.R.E.

\section{IN Ratborgestou [REDBORnESTOKE] HUNDRET}

In MeLdone [Maulden] Hugh holds half a hide and half a virgate. There is land for I plough, and it is there, and I villein and I bordar; meadow (sufficient) for I plough team and woodland (to feed) 20 swine. It is worth 10 shillings; when received (was worth) 5 shillings, and T.R.E. I 2 shillings. This land Goduin, a man of Aschil, held and could assign and sell.
M. In Houstone [Houghton (Conquest)] Hugh holds 5 hides. There is land for 6 ploughs, and they are there, and 8 villeins and 6 bordars and 2 serfs, meadow (sufficient) for 6 plough teams, and woodland (to feed) 200 swine. It is and was worth 100 shillings; T.R.E. 7 pounds. This manor 7 sokemen held and could assign to whom they wished.

\section{In Flictham [Flitt] Hundret}

M. Hugh himself holds HaGenes [Hawnes (or Haynes)]. It is assessed at 5 hides. There is land for 8 ploughs. In the demesne are $2 \frac{1}{2}$ hides, and on it are 3 ploughs; and I 4 villeins have 5 ploughs. There are 9 bordars and I serf, meadow (sufficient) for I plough team, and woodland (to feed) 500 swine. In all (totis valentiis) it is worth Io pounds; when received (was worth) 7 pounds, and as much T.R.E. This manor Achi, a thegn of King Edward, held

\section{In Bereforde [Barford] Hundret}

M. Hugh himself holds Salchou [Salpho ${ }^{1}$. It is assessed at 5 hides. There is land for 8 ploughs and they are there. This land I I sokemen hold and the same men held it T.R.E. and could assign and sell to whom they wished. There is meadow (sufficient) for 2 plough teams, woodland (to feed) 50 swine. In all it is worth I 00 shillings, was worth as much when received, and T.R.E. 8 pounds. This land Ralf Tallgebosc had in exchange for (pro excambio de) Wares [Ware], as his men say; and when received, it was worth 8 pounds.

\section{In Manesheve [Manshead] Hundret}

M. Aspereia [Aspley (Guise)] is assessed at Io hides. Acard' de Ivri holds it of Hugh. There is land for 12 ploughs. On the demesne are 2 ploughs, and there could be a third; and 16 villeins have 8 ploughs and there could be a ninth. There are 4 bordars and 5 serfs, and I mill (worth) Io shillings; meadow (sufficient) for to plough teams and woodland (to feed) 50 swine. In all (totis valentiis) it is worth 8 pounds; when received I 00 shillings; T.R.E. Io pounds. This manor was held by Leveva, (who was) commended to Earl Waltheof (commendata Wallef comitis) and could go to what lord (quo) she wished with her land.

M. SAlEFord [Salford] is assessed at 5 hides. There is land for 5 ploughs. On

1 In Renhold. Now corruptly 'Salph end' (J.H.R.) 


\section{THE HOLDERS OF LANDS}

the demesne is I plough, and I 2 villeins have 4 ploughs. There are I bordar and 4 serfs. A mill is there (worth) 9 shillings and 4 pence, meadow (sufficient) for 5 plough teams, and woodland (to feed) 150 swine and through (de) other due(s) worth Io shillings (besides). In all (totis valentiis) it is worth 4 pounds; (was worth) when received 60 shillings ; T.R.E. 100 shillings. This manor Turchil, a thegn of King Edward, held and could assign to whom he wished.

M. In Eureshot [Eversholt] Ralf holds $7 \frac{1}{2}$ hides of Hugh as I manor. There is land for 8 ploughs. On the demesne are 2 ploughs, and I5 villeins have 6 ploughs. There are 4 serfs, meadow (sufficient) for 8 plough teams, and woodland (to feed) 100 swine. It is worth roo shillings; (was worth) when received 3 pounds, and as much T.R.E. This manor Turgis, a thegn of King Edward, held and could sell.

M. In Middeltone [Milton (Bryant)] William Froissart holds of Hugh 6 hides as I manor. There is land for 6 ploughs. On the demesne are 3 ploughs, and 6 villeins have 3 ploughs. There are 3 bordars and 4 serfs, meadow (sufficient) for 6 plough teams; woodland (to feed) 40 swine. It is worth 6 pounds, (was worth) when received 4 pounds, and T.R.E. 8 pounds. This manor Auti a housecarl of Earl Algar held and could do with it what he wished.

M. The same William holds of Hugh Cravenhest [Gravenhurst]. It is assessed at $3 \frac{1}{2}$ hides. There is land for 4 ploughs. On the demesne are 2 ploughs, and 4 villeins have I ; there could be another. There are 3 bordars and 4 serfs, meadow (sufficient) for 4 plough teams, and woodland (to feed) I00 swine. It is worth 60 shillings; was worth as much when received, and T.R.E. Ioo shillings. This manor 5 sokemen held and could assign and sell their land to whom they wished.

M. In Straillei [Streatley] ${ }^{2}$ William de Locels holds 4 hides and I virgate of Hugh as I manor. There is land for 6 ploughs. On the demesne is I plough and there could be another, and 7 villeins have 4 ploughs. There are 5 bordars and I serf, and woodland (to feed) I6 swine. It is worth 4 pounds;

1 This and the two manors which follow belong to the Hundred of Flitt. The hundredal heading has been omitted.

2 See note I above. (was worth) when received 40 shillings; T.R.E. 100 shillings. This manor Aschil, a thegn of King Edward, held, and there was I sokeman there, his man, having I hide, which he could assign to whom he wished.

M. The same William holds of Hugh, Echam [Higham (Gobion) ${ }^{3}$ ]. It is assessed at 8 hides. There is land for I I ploughs. On the demesne are 4 ploughs, and I 4 villeins have 7. There are 2 bordars and 5 serfs, meadow (sufficient) for 6 plough teams, and woodland (to feed) roo swine. It is worth 8 pounds; (was worth) as much when received; and T.R.E. 12 pounds. This manor 5 sokemen held and could assign their land to whom they wished.

\section{In Stodden [Stodden] Hundret}

In Estone [Easton ${ }^{4}$ ] Wimund ${ }^{5}$ holds of Hugh half a hide. There is land for 3 ploughs, and they are there. There are 2 villeins and 6 bordars, and woodland to feed 40 swine. It is worth 30 shillings; when received and T.R.E. (was worth) 20 shillings. This land Oviet, a man of Aschil, held and could assign and sell; but the soke always belonged to (jacuit in) Culmeworde (Colmworth), Aschil's manor.

In RiseLaI [Riseley] Alvric the priest holds of Hugh half a hide. There is land for a half plough, and it is there and 4 bordars. It is worth 5 shillings, when received (was worth) a like sum, and T.R.E. 8 shillings. This land Uvenot a man of Godric the sheriff held and could assign to whom he wished.

In Middeltone [Milton (Ernest)] William Basset holds of Hugh 2 hides less half a virgate. There is land for 3 ploughs. On the demesne are 2 ploughs and I villein has I plough. There are 4 bordars and 2 serfs, meadow (sufficient) for 2 plough teams, and woodiand (to feed) 6 swine. It is worth 30 shillings; (was worth) as much when received, and T.R.E. 40 shillings.

\section{IN THE Half Hundret of Bochrlai ${ }^{\circ}$}

M. In Blecheshou [Bletsoe] Osbert de Broilg ${ }^{7}$ holds of Hugh $2 \frac{1}{2}$ hides. There is land for 4 ploughs. On the demesne is I

3 See note I above.

- Co. Hunts (see Introduction)

5 This must be Wimund de Taissel, who also held of Hugh at Barford and Colmworth (J.H.R.)

- Now part of Willey Hundred.

7 See p. 240 , note 4, below. 


\section{A HISTORY OF BEDFORDSHIRE}

plough and 7 villeins have 3 ploughs. There are 2 bordars and 2 serfs and a moiety of a mill (worth) Io shillings, meadow (sufficient) for I plough team, woodland (to feed) I oo swine. It is and was worth 60 shillings T.R.E. and after (semper). This manor Aschil held, and 3 sokemen had there 3 virfo. $2 \times 3 \mathrm{~b}$

gates and could sell (them) to whom they wished.

In Bideham [Biddenham] Serlo de Ros ${ }^{1}$ holds I hide of Hugh. There is land for I plough, and it is there; and I bordar and I serf, and meadow (sufficient) for I plough team. It is and was worth ro shillings T.R.E. and after (semper). This land was held by Alsi of Bruneham [Bromham ${ }^{2}$, a man of Queen Eddid, and he could assign (it) to whom he wished.

M. In Bruneham [Bromham] Serlo de Ros $^{3}$ holds 6 hides of Hugh. There is land for 6 ploughs. On the demesne are 2 ploughs, and 16 villeins have 4 ploughs. There are 5 bordars and 6 serfs, and 1 mill worth 20 shillings and 125 eels, meadow (sufficient) for 6 plough teams, and woodland (to feed) 40 swine. In all it is worth 7 pounds; was worth when received 100 shillings; T.R.E. 4 pounds. This land Alsi, a man of Queen Eddid, held and could sell.

\section{IN Wilga [Willey] HundRet}

In ToRvei [Turvey] Warner holds I hide of Hugh. There is land for 2 ploughs. On the demesne is I plough and I villein (has) I plough. There are 4 bordars. It is worth Io shillings; (was worth) as much when received, and T.R.E. 20 shillings. This land 2 sokemen held and could assign to whom they wished.

In Sernebroc [Sharnbrook] Osbern de Broilg ${ }^{4}$ holds $\mathrm{I} \frac{1}{2}$ virgates of Hugh. There is land for 3 oxen $^{5}$ (to plough). It is and was worth 2 shillings T.R.E. and after (semper). This land 3 sokemen held and could assign and sell.

$1 \mathrm{He}$ also held at Biddenham under William Spech. See p. 246 below (J.H.R.)

2 See the next entry.

3 See note $I$ above.

4 This is the same as the Osbert (sic) de Broilg who held at Bletsoe, 'Osbern' and 'Osbert' being used indifferently (J.H.R.)

5 i.e. three-eighths of a plough-team, just as I $\frac{1}{2}$ virgates was three-eighths of a hide.
In LALEGA [Thurleigh ${ }^{6}$ ] Leviet holds half a hide. There is land for 2 ploughs and they are there. There are 4 bordars and $\mathrm{I}$ serf, and woodland (to feed) 30 swine. It is worth 30 shillings; when received was worth I5 shillings; T.R.E. 30 shillings. This land Moding, a man of Queen Eddid, held and could sell.

\section{In Bereford [Barford] Hundret}

In Wiboldestone [Wyboston 7] Wimund holds half a virgate of $\mathrm{Hugh}$ and it is and was worth 2 shillings T.R.E. and after (semper). This land Aschil, a thegn of King Edward, held.

In Calnestorne ${ }^{8}$ [Chawston ${ }^{9}$ ] Riwalo ${ }^{10}$ holds of Hugh 4 virgates. There is land for 2 oxen (to plough). There are 2 bordars, and meadow (sufficient) for 2 oxen, and woodland (to feed) 60 swine. It is worth ro shillings; (was worth) when received, I 5 shillings; T.R.E. 20 shillings. This land 2 sokemen held and could assign to whom they wished.

In Rochestone [Roxton] Rualon holds of Hugh I hide and I virgate. There is land for I plough; meadow (sufficient) for I plough team; woodland (to feed) 4 swine. There are 2 bordars and I serf. It is worth Io shillings; when received and T.R.E. (was worth) 20 shillings. This land 4 sokemen held, men of King Edward, and could sell.

In Bereforde [(Great) Barford] Rualon holds of Hugh 3 hides. ${ }^{11}$ There is land for 4 ploughs. On the demesne are 3 ploughs, and 3 villeins have I plough. There are 5 bordars and 3 serfs, and I mill (worth) 22 shillings and 4 score eels, and meadow (sufficient) for 2 plough teams. It is worth 3 pounds; (was worth) when received 30 shillings, T.R.E. 3 pounds. This land 3 sokemen, men of King Edward, held and could sell.

In the same (vill) Wimund de Taissel holds of Hugh 5 hides and 2 thirds (partes) of I hide. There is land for I I ploughs. On the demesne are 5 ploughs and 16 villeins have 6 . There are 6 bordars and 1 serf;

${ }^{6}$ Land in 'Lega' was subsequently held of the (Beauchamp) 'barony of Bedford' (J.H.R.)

7 In Eaton Socon.

8 i for Caluestorne.

$\theta$ In Roxton.

10 This name is identical with the Rualon of the next two entries and is Breton (J.H.R.)

11 MS. has car' corrected, by underlining, to bid. 


\section{THE HOLDERS OF LANDS}

meadow (sufficient) for I plough team. It is worth Io pounds; was worth when received 20 shillings; T.R.E. 60 shillings. This manor 3 sokemen held and could assign and sell.

M. The same (ipse) Wimund holds of Hugh Colmeworde [Colmworth]. It is assessed at 5 hides. There is land for 10 ploughs. On the demesne are 2 , and 12 villeins have 8 ploughs. There are 13 bordars and I serf, and woodland (to feed) 200 swine. It is and was worth 100 shillings, T.R.E. 4 pounds. This manor Achi, a thegn of King Edward, held; and 8 sokemen were there, who could assign and sell their land to whom they wished.

In Bereforde [(Great) Barford] Anschetil the priest holds of Hugh $\mathrm{I} \frac{1}{2}$ hides. There is land for 2 ploughs. On the demesne is I plough, and I villein (has) I plough. There are 6 bordars and 3 serfs, and 1 mill (worth) 7 shillings, and meadow sufficient for I plough team. It is and was worth 40 shillings, T.R.E. and after (semper). This land 2 sokemen held and could sell.

In the same (vill) Tetbaud holds of Hugh 1 hide and 3 virgates and the third part of $I$ virgate. There is land for 3 ploughs. On the demesne are 2, and I villein has I plough. There are 8 bordars and I serf, and meadow (sufficient) for I plough team. It is worth 40 shillings; (was worth) when received 20 shillings, and T.R.E. 60 shillings. This manor 3 sokemen held and could assign and sell.

In Goldentone [Goldington] Roger son of Teodric holds of Hugh 2 hides. There is land for 3 ploughs. On the demesne are 2 ploughs, and 3 villeins have I plough. There are 2 bordars, and meadow (sufficient) for I plough team. It is worth 30 shillings; when received (was worth) 20 shillings; T.R.E. 40 shillings. These 2 hides Ralf Tall[ge]b[osc] held in exchange for (pro excambio de) Wares [Ware]. This land 3 sokemen held who could assign their land to whom they wished.

In the same (vill) Richard holds of Hugh 3 hides as 1 manor. There is land for 3 ploughs. On the demesne are 2 ploughs, and 5 villeins have I plough. One serf is there, and meadow (sufficient) for 2 plough teams. It is worth 40 shillings; (was worth) when received to shillings, and T.R.E. 6o shillings. These 3 hides Ralf Tall[ge]b[osc] held in exchange for (pro excambio de) Wares [Ware]. This manor was held by Almær, a man of Aschil, and he could sell it.
In the same (vill) Walter holds or Hugh I hide. There is land for 1 plough, and it is there; and meadow (sufficient) for a half plough team, and there are 2 serfs. It is worth 15 shillings; (was worth) when received ro shillings, and T.R.E. 15 shillings. This land is (held) in exchange for (est escambium de) Wares [Ware]. This land the men of the vill held in common and they could sell it.

\section{In Bicheleswade [Biggleswade] Hundret}

In Holma [Holme ${ }^{1}$ ] Mortuing holds of Hugh I virgate. There is land for 3 oxen (to plough), and they are there. It is worth 3 shillings; (was worth) T.R.E. 5 shillings. This land I sokeman held under Aschil and could sell and assign it.

In Estwiche [Astwick] Bernard holds of Hugh I hide and I virgate. There is land for $2 \frac{1}{2}$ ploughs. On the demesne is 1 plough, and 2 villeins have $2 \frac{1}{2}$ ploughs. There are 3 bordars and meadow sufficient for 4 oxen. It is worth 20 shillings; when received and T.R.E. (was worth) ro shillings. This manor 6 sokemen held and could sell.

In the same (vill) Wenelinc holds of Hugh half a hide. There is land for I plough, and it is there. There are 3 bordars. It is worth Io shillings; (was worth) when received 5 shillings; and T.R.E. 20 shillings-and they ${ }^{2}$ could sell it.

In the same (vill) Ledmar holds halt a hide. There is land for a half plough and it is there. There are 3 bordars, and I mill worth $(d e) 9$ shillings and 4 pence. It is and was worth 20 shillings T.R.E. and after (semper). The same man who holds it held it T.R.E. He was a man of Earl Tosti, and he could sell (it) to whom he wished.

\section{In Wichestanestou [Wixamtree] HUNDRET}

In Stanforde [Stanford ${ }^{3}$ ] Roger holds of Hugh I hide. There is land for $1 \frac{1}{2}$ ploughs, and they are there, and 4 villeins and I bordar, meadow (sufficient) for $I \frac{1}{2}$ plough teams, and woodland (to feed) 16 swine, and a moiety of a mill worth $(d e) 5$ shillings. In all it is worth 15 shillings; (was worth) when received 5 shillings; T.R.E. Io shillings. This land Æilmar of Ow $(\mathrm{Ouu})$ held and could sell to whom he wished.

In Cochepol [Cople] Robert holds of Hugh 4 hides as $I$ manor. There is land for

\footnotetext{
1 In Biggleswade.

2 So MS.

3 In Southill.
} 


\section{A HISTORY OF BEDFORDSHIRE}

4 ploughs. On the demesne are 2 ploughs, and 6 villeins have 2 ploughs. There are I bordar and I serf, and meadow (sufficient) for I plough team. There is woodland all over (super totam) Chochepol [Cople] (enough to feed) roo swine. It is worth 60 shillings; when received (was worth) 20 shillings, and T.R.E. 6o shillings. This land 3 sokemen held and could sell.

In the same (vill) Raynald holds of Hugh I hide and I virgate. There is land for I plough, and it is there, and 2 bordars, and meadow (sufficient) for 4 oxen. It is worth Io shillings; (was worth) when received 5 shillings; T.R.E. ro shillings. This land 2 sokemen held and could sell to whom they wished.

In the same (vill) Gunfrey (Gonfrid') holds of Hugh I hide and half a virgate. There is land for I plough, and it is there. There are I villein and I serf, and meadow sufficient for 4 oxen. It is worth Io shillings; (was worth) when received 5 shillings, and T.R.E. Io shillings. This land 2 sokemen held. They were the king's men and could sell.

In the same (vill) Norman holds of Hugh I hide. There is land for I plough, and 2 oxen are there and meadow (sufficient) for 4 oxen. It is worth 6 shillings; when received (was worth) a like sum, and T.R.E. 8 shillings. Of this land Aschil held 3 virgates fo. 214

which belonged to (jacuit in) Weltone [Willington], his manor, and Alestan held I virgate which he could sell to whom he wished.

In the same (vill) Branting held I hide of Hugh. There is land for I plough, and it is there, and meadow (sufficient) for 4 oxen. It is and was worth ro shillings T.R.E. and after (semper). This land 3 sokemen held and could sell to whom they wished.

In the same (vill) Robert holds of Hugh 3 virgates. There is land for I plough and it is there, and meadow (sufficient) for 4 oxen. It is and was worth $7 \frac{1}{2}$ shillings T.R.E. and after (semper). This land 2 sokemen held and could sell.

In the same (vill) Roger the priest and Liboret hold half a hide and half a virgate. There is land for 6 oxen $^{1}$ (to plough) and they are there, and meadow (sufficient) for 4 oxen. It is and was worth 5 shillings T.R.E. and after (semper). This land 3 sokemen held and could sell to whom they wished. Nine hides of this manor of Chochepol [Cople] Ralf Tallgebosc had in, exchange for (pro excambio de) Wares [Ware], his men say, and when he received them they were worth 4 pounds.

In Nortgible [Northill] Walter holds of Hugh half a hide. There is land for a half plough, and it is there, and meadow (sufficient) for a half plough team. It is worth 5 shillings; when received (was worth) a like sum, and T.R.E. Io shillings. This land Osiet, a man of King Edward, held and could sell to whom he wished.

\section{In Clistone ${ }^{2}$ [Clifton] Hundret}

In Cudrssane [? Chicksand $\left.{ }^{3}\right] 3$ sokemen hold of Hugh 2 hides. There is land for $I \frac{1}{2}$ ploughs, and they are there, and I bordar, and meadow (sufficient) for I plough teams, and woodland (to feed) 4 swine. It is worth 20 shillings, (was worth) as much when received, and T.R.E. 30 shillings. This land 4 sokemen held and could sell to whom they wished.

\section{THE LAND OF NIGEL DE ALBINGI}

\section{In Manesheve [Manshead] Hundret}

M. In Crawelai [(Husborne) Crawley] Turgis holds of Nigel de Albini (Albiniensi) 5 hides as I manor. There is land for 5 ploughs. On the demesne are 2 ploughs; and there could be 3 belonging to the villeins (villanorum). There are I villein and 7 bordars and $I$ serf, and meadow (sufficient) for 5 plough teams. In all it is worth 30 shillings; when received (was worth) 40 shillings, and T.R.E. I00 shillings. This manor 9 thegns held and could sell their land to whom they wished.

IN The same HundReT Turgis holds of Nigel I hide. There is land for I plough, and the plough is there, and 2 serfs and woodland (to feed) ro swine. This land is worth I 5 shillings; (was worth) when received 10 shillings; T.R.E. 20 shillings. This land was held by Suglo, a man of Alric son of Goding, and he could sell it to whom he wished.

M. Trngrer ['Tingrith] Turgis holds of Nigel for 2 hides and I virgate. There is land for 3 ploughs. On the demesne is I plough and 4 villeins have 2 ploughs. There are 2 bordars, meadow (sufficient) for 3 plough teams, and woodland (to feed) I 50 swine. It is worth 40 shillings; was worth when received 30 shillings; T.R.E. roo shillings.

\footnotetext{
${ }^{2}$ For Cliftone. $\quad{ }^{3}$ See Introduction.
} 


\section{THE HOLDERS OF LANDS}

This manor 2 thegns held and could sell to whom they wished.

In Prestelai [Priestley ${ }^{1}$ ] Turgis holds of Nigel $1 \frac{1}{2}$ hides. There is land for 2 ploughs and they are there; meadow (sufficient) for 2 plough teams; woodland (to feed) 40 swine. There are I villein and 4 bordars. It is worth 20 shillings; (was worth) as much when received, and T.R.E. 60 shillings. This land 5 thegns held and could assign and sell.

M. Nigel holds Herlingdone [Harlington]. It is assessed at 5 hides. There is land for 10 ploughs. On the demesne are $3 \frac{1}{2}$ ploughs and there could be 2 more. There 12 villeins have 5 ploughs. There are 6 bordars and Io serfs, meadow (sufficient) for 4 plough teams, woodland (to feed) 400 swine, and I ram and I load of oats (are proceeds) from the woodland. It is worth 6 pounds; when received (was worth) 4 pounds ; T.R.E. 9 pounds. This manor 4 thegns held and could sell to whom they wished.

\section{IN RATBORGESTOCHE [REDBORNESTOKE] HUNDRET}

In Esseltone [Shelton ${ }^{2}$ ] Erfast holds of Nigel I hide. There is land for I plough, and the plough is there; meadow (sufficient) for a half plough team; woodland (to feed) 40 swine. There are $I$ villein and 2 bordars and $I$ serf. It is worth 20 shillings, (was worth) when received 15 shillings, and T.R.E. 20 shillings. This land was held by Alward a man of Alric son of Goding and he could assign it to whom he wished.

In the same (vill) Stephen holds of Nigel half a hide. There is land for a half plough and it is there with 2 bordars; meadow is there (sufficient) for 2 oxen; woodland (to feed) I 2 swine. It is worth 6 shillings; when received (was worth) 3 shillings, and T.R.E. Io shillings. This land Fuglo, a man of Alric son of Goding, held and could sell to whom he wished.

M. In Merstone [Marston (Morteyne)] Erfast holds of Nigel 8 hides and half a virgate. There is land for 10 ploughs. On the demesne are 3 ploughs, and I 4 villeins (are there) with 8 ploughs. There are 2 bordars and 4 serfs, meadow (sufficient) for 8 plough teams, woodland (to feed) 300 swine. It is worth 7 pounds; when received 100 shillings; T.R.E. 12 pounds. This manor 2 I sokemen held

1 In Flitwick.

2 In Marston Morteyne (J.H.R.) who could sell or assign their lands to whom they wished.

M. Nigel de Wast ${ }^{3}$ holds of Nigel de Albini (Albiniensi) MELebroc [Millbrook]. It is assessed at 5 hides. There is land for 6 ploughs. On the demesne are 2 ploughs and 4 villeins (are there) with 4 ploughs. There are 2 bordars, and 2 mills worth ( $d e) 6$ shillings, meadow (sufficient) for 2 plough teams, woodland (to feed) 100 swine. It is worth 3 pounds; (was worth) when received 30 shillings, and T.R.E. IoO shillings. This manor Goduin son of Lewin held ${ }^{4}$ who could all sell or assign their land to whom they wished.

M. The same (ipse) Nigel de Wast holds of Nigel de Albini Ammetelle [Ampthill]. It is assessed at 5 hides. There is land for 8 ploughs. On the demesne are 2 ploughs and 6 villeins have 4 ploughs and there could be 2 more. There are 2 bordars and I serf, meadow (sufficient) for 6 plough teams, woodland (to feed) 300 swine. It is worth 4 pounds; when received (was worth) 40 shillings; T.R.E. 4 pounds. This manor 7 sokemen held and could sell and assign their land to whom they wished.

The same Nigel holds of Nigel Brume [Broom ${ }^{6}$ ]. It is assessed at 5 hides. There is land for 5 ploughs; and so many are there with 9 villeins and 5 bordars. There is woodland (to feed) 30 swine. It is worth 40 shillings. Seven sokemen held it and could assign and sell it.

In MrLdone [Maulden] John de Roches ${ }^{\theta}$ took unjust possession of 25 acres to the hurt of (super) the men who hold that vill; so the men of the hundred (court) attest; and now Nigel de Albini has them.

M. Nigel de Albini (Albiniensis) holds WEs-

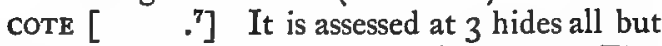
I virgate. There is land for 6 ploughs. Five are there and there could be a sixth. There

${ }^{3}$ See Introduction, p. I 99.

4 MS. is probably defective.

5 In Southill and near Biggleswade, in Wixamtree Hundred. This is probably the identification. The entry is inserted in the margin, having been omitted, and is placed next to the other holding of Nigel de Wast, without note of what Hundred it was in. I think it was in Wixamtree (F.W.R.)

- See Introduction.

7 Formerly Westcote, a hamlet in Willshamstead, which was in Redbornestoke Hundred (J.H.R.) 


\section{A HISTORY OF BEDFORDSHIRE}

are 5 villeins and II bordars, meadow (sufficient) for 2 plough teams, woodland to feed Ioo swine and yielding iron (ferrum) for the ploughs. ${ }^{1} \quad$ It is worth 60 shillings ; (was worth) when received 40 shillings, and T.R.(E.) 6 pounds. This manor 7 sokemen held and could assign and sell their land to whom they wished.

\section{In Flictham [Flitt ] Hundret}

M. Nigel himself holds Clopelle [Clophill]. It is assessed at 5 hides. There is land for 8 ploughs. In the demesne are 3 hides, and on it are 2 ploughs; and 5 villeins have 6 ploughs. There are 5 bordars and 1 serf meadow (sufficient) for 4 plough teams; woodland (to feed) 200 swine and (worth) 12 pence (besides). It is worth 6o shillings, (was worth) when received 30 shillings, and T.R.E. 8 pounds. This manor 2 thegns held, men of Earl Tosti. Of these 5 hides Nigel himself claims I virgate which his predecessor held T.R.E. Nigel himself was seised of it after he came into (possession of) the honour (ad bonorem venit). But Ralf Tallgebosc disseised him.

M. Nigel himself holds Chainehou [Cainhoe]. ${ }^{2} \quad$ It is assessed at 4 hides. There is land for 6 ploughs. There are 2 hides and 3 virgates in the demesne; 2 ploughs are on it, and there could be 2 others. There 3 villeins have 2 ploughs, and (there is) I mill worth (de) 6 shillings, and meadow (sufficient) for 8 plough teams. There is woodland (to feed) 100 swine and (worth) 2 shillings besides. There are 3 bordars and 5 serfs. It is worth 60 shillings; when received (was worth) 30 shillings, and T.R.E. 100 shillings. This manor Alvric, a thegn of King Edward, held and could assign and sell without his leave.

M. In Siwilessou [Silsoe] a certain concubine of Nigel's holds 2 hides. There is land for 4 ploughs. On the demesne is I plough, and 2 villeins have 2 ploughs and there could be a third. There are 3 bordars and 1 serf ; meadow (sufficient) for 3 plough teams; woodland (to feed) 50 swine. It is worth 30 shillings; was worth as much when received and T.R.E. This land was held by Alvric the little (parvus), a thegn of King Edward.

M. Roger and Ruallon hold of Nigel de

1 See Introduction, p. 212.

2 This became the head of the barony (J.H.R.)
Albini ${ }^{3}$ Polochessele [Pulloxhill]. It is assessed at Io hides. There is land for I 3 ploughs. On the demesne are 2 ploughs and there could be 2 others, and I I villeins have 9 ploughs. There are I 3 bordars and 2 serfs; meadow (sufficient) for 6 plough teams; woodland (to feed) roo swine. It is worth Io pounds; when received (was worth) 8 fo. $214 \mathrm{~b}$ pounds, and T.R.E. 13 pounds. This manor 8 sokemen held and could assign and sell their land to whom they would.

M. In Stradir [Streatley] Pirot ${ }^{4}$ holds of Nigel (de) Alb(ini) 4 hides and the third part of I hide as I manor. There is land for 6 ploughs. On the demesne are 2 ploughs and 4 villeins have I plough and there could be 3 more. There are 4 bordars and I serf; meadow (sufficient) for 3 plough teams; woodland (to feed) 20 swine. There a certain ${ }^{5}$ has I plough. It is worth 4 pounds ; when received (was worth) 40 shillings; T.R.E. 6 pounds. This manor Lewin Cilt held, and 3 other thegns of King Edward and they could sell their land to whom they wished. Three hides of this land Pirot holds by marriage as his wife's (de maritagio suce femine ), and I hide and a third part of I hide he holds in fee of Nigel de Albini.

In Mildenrone [Milton (Ernest) ${ }^{6}$ ] Turgis holds of Nigel 3 hides all but I virgate. There is land for 4 ploughs. On the demesne is I plough and 4 villeins have $2 \frac{1}{2}$ ploughs and a half plough ${ }^{7}$ villeins and 3 bordars. There is meadow (sufficient) for 3 plough teams. It is worth 30 shillings; (was worth) as much when received, and T.R.E. 40 shillings. This land 6 sokemen held and could assign or sell their land to whom they wished.

\section{In Wilge [Willey] Hundret}

In Carlentone [Carlton] Chetel holds of Nigel 1 hide and the third part of I hide. There is land for $1 \frac{1}{2}$ ploughs, and they are

3 'ten' Nigell' de albin',

4 See p. 236 , note 3 . Ralf Pirot held 5 fees and John Pirot I fee of Robert de Albini on this fief in 1166 (J.H.R.)

5 Word probably omitted in MS.

${ }^{8}$ Milton Ernest was in Stodden Hundred, but the hundredal heading is omitted. The $2 \frac{3}{4}$ hides here entered is exactly the amount required, with the other Milton Ernest entries, to complete the 10 hide unit (J.H.R.)

7 So MS., apparently defective. Probably the text should read: "And there could be half a plough more' (J.H.R.) 


\section{THE HOLDERS OF LANDS}

there, and 3 villeins and 2 bordars, and meadow (sufficient) for $\mathrm{I} \frac{1}{2}$ plough teams. It is worth 20 shillings; (was worth) when received ro shillings, and T.R.E. I 5 shillings. This land Golderon a man of Levenot held and could assign to whom he wished.

In the same (vill) Bernard holds of Nigel I hide and half a virgate. There is land for $I_{2} \frac{1}{2}$ ploughs, and they are there, and 5 bordars; meadow (sufficient) for I plough team, and I mill (worth) 13 shillings and 4 pence. It is worth 40 shillings; (was worth) when received 20 shillings, and T.R.E. 30 shillings. This land 3 sokemen held and could assign to whom they wished.

In Radewelle [Radwell ${ }^{1}$ ] Nigel Wast holds of Nigel de Albingi 7 hides and $\mathrm{I} \frac{1}{2}$ virgates. There is land for 5 ploughs. On the demesne is $\mathrm{I}$, and 6 villeins have 4 ploughs. There are 6 bordars and 3 serfs, and 1 mill worth (de) Io shillings, and meadow (sufficient) for 5 plough teams. It is worth 4 pounds ; (was worth, as much when received, and T.R.E. 8 pounds. This manor 10 sokemen held and could assign their land to whom they wished.

In Tornera ${ }^{2}$ [Turvey] Nigel de Wast holds of Nigel de Albingi I hide and half a virgate. There is land for $1 \frac{1}{2}$ ploughs and they are there and 5 bordars; meadow (suffcient) for I plough team, woodland (to feed) 20 swine. It is worth 13 shillings; (was worth) as much when received; T.R.E. 30 shillings. This land Alward a man of Bishop Wlwi held and could assign to whom he wished.

\section{In Bereforde [Barford] Hundret}

In W IBoldestune [W yboston ${ }^{3}$ ] Pirot ${ }^{4}$ holds of the king 9 hides and I virgate of Nigel's fee. There is land for 9 ploughs. On the demesne are 4 ploughs and 12 villeins have 5 ploughs. There are 6 bordars and meadow (sufficient) for 2 plough teams. It is worth 6 pounds; (was worth) when received 4 pounds; T.R.E. Io pounds. This manor 12 sokemen held and could sell to whom they wished.

\section{In Bicheleswade [Biggleswade] Hundret}

Fulcher of Paris ${ }^{5}$ (parisiacensis) holds half a hide of Nigel. There is land for I plough, and it is there, and meadow (sufficient) for I plough team, and I serf. It is worth 52 shillings;

1 In Felmersham.

2 For Torueia.

3 In Eaton Socon.

4 See p. 244, note 4, above.

6 See p. 232 , note 2, above. when received (was worth) 10 shillings; T.R.E. 30 shillings. This land Samar, a man of Lewin held and could sell.

In Holme [Holme ${ }^{\theta}$ ] the same (ipse) Fulcher holds of Nigel $\mathrm{I}$ hide and half a virgate. There is land for 2 ploughs, and they are there, and 3 villeins, and meadow (sufficient) for I plough team. It is worth 20 shillings, was worth when received 10 shillings, and T.R.E. 30 shillings. This land 7 sokemen held and could assign and sell.

\section{In Wichestanestou [WIXAMTREe] HundRET}

In Herghetone [Harrowden ${ }^{7}$ ] Nigel holds 6 hides. There is land for 8 ploughs. In the demesne are $I \frac{1}{2}$ hides and half a virgate, and on it is 1 plough; and 14 villeins have 7 ploughs. There are 10 bordars and 2 serfs, meadow (sufficient) for 2 plough teams, and woodland (to feed) 50 swine. In all it is worth Ioo shillings; (was worth) when received 4 pounds, and T.R.E. 100 shillings. This manor I4 sokemen held and could assign and sell their land to whom they wished.

\section{In Cuistone ${ }^{8}$ [Cuifton] Hundret}

In Chistone [Clifton] William de Caron holds 2 hides of Nigel. There is land for $\mathrm{I}_{2} \frac{1}{2}$ ploughs. One plough is there, and there could be a half plough (more). Meadow is there (sufficient) for I plough team. It is worth 15 shillings, when received (was worth) ro shillings, and T.R.E. 20 shillings. This land 4 sokemen held and could assign and sell.

In HanksLau [Henlow] Erfast holds of Nigel $5 \frac{1}{2}$ hides. There is land for $5 \frac{1}{2}$ ploughs. On the demesne are 2 ploughs, and Io villeins have $3 \frac{1}{2}$ ploughs. There are 3 serfs and I mill worth $(d e) 5$ shillings, and meadow sufficient for 5 plough teams. From pasture (come) ro pence. In all (totis valentiis) it is worth I Io shillings, (was worth) when received 4 pounds, and T.R.E. 7 pounds. This land 9 sokemen held and could assign and sell to whom they wished.

Of these $5 \frac{1}{2}$ hides the monks of St. Nicholas of Angers now hold of Nigel 3 virgates in almoin.

In Alricrseia [Arlesey] Erfast holds of Nigel 3 virgates and the third part of 1 virgate. There is land for I plough, and it is there and meadow (sufficient) for I plough

\footnotetext{
- In Biggleswade.

7 In Eastcotts.

8 For Cliftone.
} 


\section{A HISTORY OF}

team. It is worth 17 shillings, (was worth) as much when received, and T.R.E. 20 shillings. This land 2 sokemen held and could sell to whom they wished.

\section{THE LAND OF WILLIAM SPECH}

\section{In Manesheve [Manshead] Hundret}

M. William Spech holds in Holecote [Holcutt] 4 hides as I manor, and Ralf Passaq(uam) holds of him. There is land for 3 ploughs. On the demesne is I plough, and 5 villeins have 2 ploughs. There are 8 bordars and I serf, and I mill (worth) 5 shillings and 4 pence, and woodland (to feed) 50 swine. In all it is worth 60 shillings; when received 20 shillings; T.R.E. 40 shillings. This manor Alward Belrap, a man of Alric, held and could sell to whom he wished. This land is (held by William) in exchange for (est de excambio de) Totingedone [Toddington $\left.^{1}\right]$, which he exchanged for it.

\section{IN RATBERNESTOCHE [REDBORNESTOKE] HUNDRET}

William son of Rainald holds of William Spech StePIGELaI [Steppingley]. It is assessed at 5 hides. There is land for 7 ploughs. On the demesne are $\mathrm{I} \frac{1}{2}$ ploughs, and $\mathrm{I} 4$ villeins have $5 \frac{1}{2}$ ploughs, and (there are) 2 serfs, meadow (sufficient) for 7 plough teams, and woodland (to feed) 100 swine. In all it is worth 4 pounds, (was worth) when received 40 shillings; T.R.E. 8 pounds. This manor was held by Almar, a man of Alvric of Flictewite [Flitwick ${ }^{2}$ ], and there were 2 sokemen, his men, there, who could sell their land to whom they wished.

\section{In Flictham [Flitt] Hundret}

In STRAdlei [Streatley] Hugh holds of William two-thirds (partes) of 1 virgate. There is land for 2 oxen $^{3}$ (to plough). It is and was worth 2 shillings T.R.E. and after (semper). This land Alvric, a man of Alvric the little, held and could sell to whom he wished.

M. In Bideham [Biddenham] Ralf and Serlo de Ros hold of William 4 hides less $1 \frac{1}{2}$ virgates. There is land for 4 ploughs. On the demesne are 2 ploughs, and 6 villeins have 2 ploughs. There are 2 bordars and 2 serfs, and 1 mill (worth) Io shillings, and

1 Toddington ('Dodintone') appears above as held by Ernulf de Hesdin in 1086 (J.H.R.)

2 The name of the holder of Flitwick is given below as Alwin.

3 i.e. a quarter of a plough-team.

\section{BEDFORDSHIRE}

meadow (sufficient) for 4 plough teams. It is worth 40 shillings; (was worth) when received 20 shillings, and T.R.E. 40 shillings. This manor I I sokemen held and could assign and sell their land to whom they wished. This land William states that he has in exchange for (pro excambio de) Totingedone [Toddington ${ }^{4}$ ].

\section{In Wilge [Willey] Hundret}

In Henewic [Hinwick] Walter holds of William I hide. There is land for 2 ploughs. A half plough is there, and there could be another and a half. It is worth Io shillings ; (was worth) as much when received, and T.R.E. 20 shillings. This land was held by Ulnod, a man of Ulsi son of Borgret, and he could assign to whom he wished.

In Wimentone [Wymington] Walter holds of William 3 virgates. There is land fo. 215

for a half plough. It is worth 2 shillings; (was worth) when received 10 shillings, and T.R.E. Io shillings. This land Levric, a man of Borgred, held and could assign to whom he wished.

\section{IN Bereforde [Barford] Hundret}

In Chavelestorne [Chawston '] William son of Raineward holds of William 7 hides and I virgate. There is land for 7 ploughs. On the demesne is I plough, and 16 villeins have 6 ploughs. There are 2 bordars and I serf, and I mill worth (de) I 3 shillings and 4 pence, meadow (sufficient) for 7 plough teams, woodland (to feed) ro swine. In all it is worth 6 pounds, (was worth) when received 4 pounds, and T.R.E. 9 pounds. This land 12 sokemen held and could sell to whom they wished.

Of these 7 hides and 1 virgate the men of William Spech claim $\mathbf{I} \frac{1}{2}$ acres of meadow against (super) the men of Eudo Dapifer ; and the hundred (court) attests that his predecessor had it T.R.E. ; and the same William claims against (super) a certain man of Hugh de Beauchamp other 7 acres of land of which he was disseised, but of which his predecessor was seised. Of the aforesaid land Eudo Dapifer claims I acre against (super) Ruallon a man of Hugh de Beauchamp. ${ }^{6}$

In the same (vill) William Gros holds half a hide of William Spec. There is land for a half plough and it is there, and meadow (sufficient) for a half plough team. There

\footnotetext{
4 See note I.

5 In Roxton.

${ }^{6}$ He held of him at Chawston,
} 


\section{THE HOLDERS OF LANDS}

are 2 villeins. It is worth 5 shillings, (was worth) when received 5 shillings, and T.R.E. ro shillings. This land 2 men of King Edward held and could sell to whom they wished.

M. In Rochrsdone [Roxton] William Spec holds 8 hides and 3 virgates. There is land for 8 ploughs. In the demesne are 4 hides and 3 virgates, and on it are 2 ploughs, and 12 villeins have 6 ploughs. There are I bordar and I serf, and I mill worth (de) 33 shillings and 260 eels, meadow sufficient for 3 plough teams, woodland (to feed) 20 swine. It is worth 7 pounds, (was worth) when received 50 shillings, and T.R.E. 10 pounds. This manor 12 sokemen held and could sell their land to whom they wished.

In Bicheleswade [Biggleswade] Hundret

M. In Aisseworde [Eyworth] William Spec holds 9 hides as one manor. There is

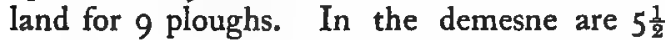
hides, and on it are 3 ploughs, and I 3 villeins have 6 ploughs. There are 2 bordars and 6 serfs, and I mill worth (de) 8 shillings, and meadow (sufficient) for 9 plough teams. It is worth 7 pounds, when received (was worth) the same, and T.R.E. 8 pounds. This manor 20 sokemen held and could assign or sell their land to whom they wished without leave of their lords.

\section{In Wichenestanestou [WiXamtRee] HUNDRET}

M. In Sudgivele [Southill] 2 Frenchmen hold of William Spech 5 hides and half a virgate. There is land for 7 ploughs. On the demesne are 4 ploughs, and 8 villeins have 3 ploughs. There are 8 bordars and 6 serfs, meadow (sufficient) for 7 plough teams and woodland (to feed) 200 swine. It is worth 4 pounds and Io shillings; (was worth) when received 4 pounds; T.R.E. 3 pounds. This manor 16 sokemen held and could assign and sell their land to whom they would.

In Stanford [Stanford ${ }^{1}$ ] Hugh holds of William Spech I hide. There is land for I plough and it is there, and the moiety of a mill (worth) 5 shillings. There are 2 serfs, meadow sufficient for I plough team, woodland to feed 20 swine. It is worth I 5 shillings, when received (was worth) 20 shillings, and as much T.R.E. This land Lemar, a thegn of King Edward, held.

M. In Wardone [Warden] William Spec 1 In Southill. holds 9 hides of the king as one manor. There is land for 9 ploughs. In the demesne are $3 \frac{1}{2}$ hides, and on it is I plough and there could be another. There 18 villeins have 7 ploughs. There are 4 bordars and 4 serfs, and I mill (worth) I 2 shillings, and meadow sufficient for 6 plough teams. It is worth 6 pounds, (was worth) as much when received, and T.R.E. 8 pounds. This manor 8 sokemen held and could assign their land to whom they would.

In Bistone [Beeston ${ }^{2}$ ] William Spech holds $3 \frac{1}{2}$ virgates. There is land for I plough. A half plough is there and there could be (another) half plough. There is meadow (sufficient) for a half plough team. It is worth Io shillings, (was worth) as much when received, and T.R.E. 20 shillings. This land Lewin Cilt, a king's thegn, held.

In Nortarvele [Northill] Walter Spec holds $6 \frac{1}{2}$ hides as one manor. There is land for 7 ploughs. In the demesne are 4 hides and on it are 3 ploughs, and Io villeins have 4 ploughs. There are 4 serfs and a moiety of a mill worth (de) I 3 shillings, meadow sufficient for 7 plough teams and woodland to feed 200 swine. In all it is worth 6 pounds, (was worth) as much when received, and T.R.E. 8 pounds. This manor 6 sokemen held. They could assign and sell to whom they wished T.R.E.

\section{THE LAND OF ROBERT DE TODENI}

\section{In Stanburge [Stanbridge] Hundret ${ }^{3}$}

M. Rotbert de Todeni holds of the king Estodham [Studham], and Baldric holds of Robert. It is assessed at 6 hides. There is land for 6 ploughs. On the demesne are 2 ploughs and to villeins have 4 ploughs. There are I bordar and 4 serfs, and woodland to feed 100 swine. It is worth 4 pounds, (was worth) when received 40 shillings, and T.R.E. 8 pounds. This manor was held by Osulf son of Frane, a thegn of King Edward."

$$
\text { [ } \left.{ }^{5}\right]
$$

In AcheleI [Oakley] 2 knights (milites) hold of Robert 4 hides. There is land for 8 ploughs. On the demesne are 3 ploughs and

\footnotetext{
2 In Sandy.

${ }^{3}$ Half Hundred. Now part of Manshead Hundred.

4 See Introduction.

5 The name of the Hundred is apparently omitted. It should be 'Stodene.'
} 


\section{HISTORY OF BEDFORDSHIRE}

there could be a fourth. There 7 villeins have 4 ploughs, and (there are) 3 bordars and 5 serfs, and I mill (worth) 26 shillings and 200 eels, and meadow (sufficient) for 4 plough teams. It is worth 4 pounds, (was worth) when received a like sum, and T.R.E. 4 pounds and Io shillings. This land Osulf, a thegn of King Edward, held.

\section{IN Wilge [Willey] Hundret}

In Torvei [Turvey] 2 knights (milites) hold of Robert 2 hides and I virgate. There is land for $4 \frac{1}{2}$ ploughs. On the demesne are 2 ploughs, and 3 villeins have 2 ploughs and there could be a half plough (more). There are 6 bordars and 2 serfs, meadow (sufficient for) I plough team, and woodland (to feed) Io swine. It is worth 40 shillings, (was worth) when received 60 shillings; T.R.E. 70 shillings. This land the aforesaid Osulf held.

\section{THE LAND OF GILBERT DE GAND}

\section{In the Half Hundred of Stanburge ${ }^{1}$}

Gilbert de Gand holds Edingeberge [Edlesborough $\left.{ }^{2}\right]$. It is assessed at 10 hides. There is land for 7 ploughs. In the demesne are 5 hides and on it are 4 ploughs, and 10 villeins have 4 ploughs. In all (totis valentiis) it is worth I 10 shillings, when received (was worth) a like sum, and T.R.E. 10 pounds. This manor Ulf, a thegn of King Edward, held and could do with it what he wished.

\section{THE LAND OF ROBERT DE OILGI}

\section{IN Wilge [WILley] HundRET}

Rotbert de Olgi holds in LALEga [Thurleigh], and Richard Basset holds of him, half a hide. There is land for 2 ploughs. One is now there and there could be another. There are 1 villein and 3 bordars and 2 serfs, and woodland (to feed) 30 swine. It is and was worth 40 shillings T.R.E. and since (semper). This land Oviet, a thegn of King Edward, ${ }^{3}$ held and could sell to whom he wished. The men of Eudo claim this land through the

1 Now part of Manshead Hundred.

2 Now wholly in Bucks. Gilbert de Gand is entered under Bucks as holding 20 hides at ' $\mathrm{Ed}$ dinberge,' so that one-third of it was reckoned as in Beds at the time of the Survey (J.H.R.)

'This was probably the 'Oviet,' a man of King Edward, who had been succeeded by Countess Judith at Sharnbrook close by (J.H.R.) predecessor of their lord, all whose lands $\mathrm{King}$ William gave to him (sibi).

In the same (vill) Salomon the priest holds I virgate of Robert de Olgi. There is land for I plough and it is there with I bordar. It is and was worth Io shillings T.R.E. and after (semper). This land Alwin, a man of Bishop Wlwi held, and could sell.

\section{THE LAND OF RANNULF BROTHER OF ILGER}

\section{In The Half HundRet of Bochelai ${ }^{5}$}

Rannulf, Ilger's brother, holds 5 hides in Pabeneham [Pavenham] and Robert son of Nigel of him. There is land for 6 ploughs. On the demesne is I plough, and there could be another; and 9 villeins have 2 ploughs and there could be other 2 . There are 2 bordars and 3 serfs, and meadow sufficient for 6 plough teams. It is worth 3 pounds, (was worth) when received 4 pounds, and T.R.E. 6 pounds. This manor Goduin, a thegn of King Edward, held. Of this land Rannulf, Ilger's brother, claims 12 acres of arable against Gilbert son of Salomon, ${ }^{6}$ and 4 acres of meadow against Hugh de Grentmaisnil, ${ }^{7}$ of which Rannulf has been unjustly dispossessed. And the men of the half hundred (court) state that this land which Hugh and Gilbert are now holding belonged T.R.E. to (jacuit ad) the land which Rannulf, Ilger's brother, holds.

\section{THE LAND OF ROBERT FAFITON ${ }^{8}$}

\section{In Fictham [FittT] Hundret}

Rotbert Fafiton holds Fictha [Flitton] of the king. It is assessed at 5 hides. There fo. $2 \times 5 \mathrm{~b}$

is land for 6 ploughs. In the demesne are 2 hides, and on it are 2 ploughs. There 3 villeins have 2 ploughs and there could be 2 others. There are 3 bordars and 4 serfs, and meadow (sufficient) for 6 plough teams, and woodland (to feed) 50 swine. In all it is worth 60 shillings, (was worth) as much when received, and T.R.E. Ioo shillings. This manor Alwin Horim, a thegn of King Edward, held.

4 The predecessor in question was probably Lisois de Moustiers (see p. 236 , note 2, above).

6 Now part of Willey Hundred.

${ }^{6}$ He held at Felmersham, the next parish to Pavenham (J.H.R.)

7 Hugh's wife appears below as holding land in Milton (Ernest) facing Pavenham across the Ouse, on the banks of which this meadow must have been (J.H.R.)

8 See Introduction. 


\section{THE HOLDERS OF LANDS}

\section{THE LAND OF ALVRED OF LINCOLN}

In Wilge [WiLley] HundRet

M. Alvered of Lincoln holds in WIMENTONe [Wymington] 3 hides, and Gleu holds of him. ${ }^{1}$ There is land for 4 ploughs. On the demesne is 1 plough and there could be another. There are $I$ villein and 6 bordars and 3 serfs with 2 ploughs, and meadow sufficient for 2 plough teams. It is worth 40 shillings; (was worth) when received 50 shillings; T.R.E. 60 shillings. This manor Goduin Franpold held and could sell. With these 3 hides Alvered claims against Walter the Fleming half a hide of which he dispossessed him unjustly, as the men of the hundred (court) bear testimony, since his predecessor was seised of it T.R.E., and the same Alvered was afterwards possessed of it. ${ }^{2}$ With this land, besides, the same Alvered claims against the Bishop of Coutances ${ }^{3}$ woodland (to feed) Ioo swine, which land his predecessor had T.R.E., but the bishop dispossessed him of it unjustly, as the men of the hundred (court) attest.

\section{THE LAND OF WALTER THE FLEMING}

\section{In the Half Hundret of Stanburge}

M. Walter the Fleming holds Totenehou [Totternhoe] and Osbert holds of him. It was assessed at 15 hides T.R.E. But after that King William came to England it was assessed $^{5}$ only at (non se defendit nisi pro) ro hides, and the men who held and still hold (the) 5 hides kept back all the king's dues and 'gafol' (gablum) and still keep them back. There is land for ro ploughs. On the demesne are 2 ploughs, and 22 villeins have 4 ploughs and there could be 4 others. There are 2 bordars and 4 serfs. There are 3 mills worth (de) Io shillings and 8 pence, meadow (sufficient) for 4 plough teams, and woodland

$1 \mathrm{He}$ also held of Alvred in Lincolnshire at Cuxwold, Rothwell, and two other places (J.H.R.)

${ }^{2}$ Opposite this entry in the MS., in the next column, stands the entry of this contested halfhide on the fief of Walter the Fleming (J.H.R.)

${ }^{3}$ This may refer to the Bishop's holding at Rushden adjoining, entered at the end of his fief on p. 226 (J.H.R.)

4 Now part of Manshead Hundred.

5 It is scarcely possible to give in English the exact force of the Domesday formula 'se defendit.' But, in this instance, the reduction must not be taken as an act of the authorities. It seems rather to represent an unauthorized pretension of the holders (J.H.R.)

I (to feed) 150 swine. In all it is worth 8 pounds; (was worth) when received 10 pounds; T.R.E. 16 pounds. This manor Levenot a thegn of King Edward held and could sell to whom he wished.

\section{In Stoden [Stodden] Hundret}

In Mrldentone [Milton (Ernest)] Rainald holds of Walter 2 hides. There is land for 3 ploughs. On the demesne is I plough, and 2 villeins have I plough, and there could be another. There is I bordar; meadow is there (sufficient) for 2 plough teams. It is worth 20 shillings, (was worth) as much when received, and T.R.E. 25 shillings. This land 2 sokemen, men of Brictric, held and could assign to whom they wished.

\section{IN Wilge [Willey] Hundret}

In TorneI" [Turvey] Hugh holds of Walter I hide. There is land for 2 ploughs. On the demesne is $I$, and 8 bordars and $I$ serf are there with I plough. Meadow is there (sufficient) for I plough team, woodland (to feed) 40 swine. It is worth 30 shillings, (was worth) when received 10 shillings, and T.R.E. 40 shillings. This land Levenot, a thegn of King Edward, held and could sell to whom he wished.

M. In Wadehelle [Odell "] Walter the Fleming holds of the king 5 hides and I virgate and two-thirds (partes) of I virgate. There is land for 5 ploughs. In the demesne are 2 hides and on it are 2 ploughs, and there are 13 villeins with 3 ploughs. There are 5 bordars and 5 serfs, and I mill worth $(d e) 36$ shillings and 8 pence and 200 eels, meadow (sufficient) for 5 plough teams and woodland (to feed) 60 swine. It is worth 100 shillings, (was worth) when received 8 pounds, and T.R.E. Io pounds. This manor Levenot a thegn of King Edward held, and there I sokeman had a half hide which he could assign to whom he wished.

M. In Podintone [Puddington (or Podington)] Hugh holds of Walter $I$ hide and 3 virgates. There is land for $5 \frac{1}{2}$ ploughs. On the demesne are 2 ploughs, and 4 villeins have $3 \frac{1}{2}$ ploughs. There are 9 bordars and 2 serfs, meadow (sufficient) for I plough team, woodland (to feed) 20 swine. It is worth 4 pounds and ro shillings; (was worth) when

- For Toruei.

7 This was the head of the barony (see Introduction, p. 199). 249 


\section{A HISTORY OF}

recerved 50 shillings, and as much T.R.E. This manor Levenot, a thegn of King Edward, held.

M. In Wimentone [Wymington] Osbert holds of Walter 4 hides as I manor. There is land for 5 ploughs. On the demesne are 3 ploughs, and there are $\mathrm{I}$ villein and 8 bordars and 4 serfs with $\mathrm{I}$ plough. Meadow is there (sufficient) for 2 plough teams. It is worth 3 pounds, (was worth) as much when received, and T.R.E. 4 pounds. Lant, a man of Levenot, thegn of the king, held this manor, and there I sokeman had I hide and could assign it to whom he wished.

In the same vill the same Osbert holds of Walter half a hide. There is land for a half plough, but it is not there. It is worth 2 shillings; (was worth) when received 4 shillings; and T.R.E. Io shillings. This land Goduin Franpalt held and could assign to whom he wished. This same land Alvred of Lincoln claims against Walter the Fleming. ${ }^{1}$

In LAI.EGA [Thurleigh ${ }^{2}$ ] Hugh holds of Walter 3 hides as I manor. There is land for 7 ploughs. On the demesne are 2 ploughs and 8 villeins have 5 ploughs. There are 12 bordars and 3 serfs and woodland (to feed) I 50 swine. It is worth 100 shillings; (was worth) when received 60 shillings; T.R.E. 4 pounds. This manor Levenot, a thegn of King Edward, held.

In the same (vill) Raynald holds of Walter half a hide. There is land for 2 ploughs. On the demesne is I plough, and 4 bordars (are there) with I plough. It is worth 20 shillings, (was worth) when received Io shillings, and T.R.E. 5 shillings. This land Ordric, a man of Levenot, held and could sell.

\section{In Bicheleswade [Biggleswade] Hundret}

In Stratone [Stratton ${ }^{3}$ ] [ ${ }^{4}$ ] holds I hide and I virgate. There is land for $I \frac{1}{2}$ ploughs, and a plough and a half plough could be there. ${ }^{5}$ There are 3 bordars, and meadow (sufficient) for I plough team. It is and was worth Io shillings T.R.E. and after (semper). This land Lewin a thegn ${ }^{6}$ of King Edward held and could assign and sell. This belongs

1 See p. 249, note 2, above.

2 A third of a knight's fee in Thurleigh (Lega), is found held of the barony of "Wahull' (J.H.R.)

3 In Biggleswade.

4 Name omitted in MS.

- Probably error for 'I plough is there, and there could be a half plough (more).'

' MS. 'Steign.'

\section{BEDFORDSHIRE}

and belonged to (jacet et jacuit in) Langeford [Langford], the manor of the same Walter.

In Holme [Holme ${ }^{8}$ ] Walter holds I hide. There is land for $I_{\frac{1}{2}}$ ploughs. One plough is there, and there could be a half plough (more). There are 3 bordars; meadow (sufficient) for $I \frac{1}{2}$ plough teams. It is worth 20 shillings, (was worth) when received 16 shillings; T.R.E. 20 shillings. This land 2 sokemen held and could assign to whom they wished.

In Estwiche [Astwick] Hugh holds I virgate of Walter. There is land for 2 oxen ${ }^{9}$ (to plough), and they are there. There are I bordar and I mill worth $(d e)$ I 3 shillings. It is and was worth I6 shillings T.R.E. and after (semper). This land Lewin, a thegn of King Edward, held.

M. Walter himself holds LANGEFORD [Langford]. It is assessed at ro hides. There is land for 16 ploughs. In the demesne are 4 hides and I virgate, and on it are 4 ploughs, and there could be a fifth. There are 12 villeins 7 bordars and 5 serfs with 9 ploughs, and there could be 2 ploughs more. There are 2 mills worth (de) 26 shillings and 8 pence, meadow (sufficient) for I6 plough teams, and worth 2 shillings besides (de superplus). From pasture (come) 6 shillings, and there is pasture besides for 300 sheep. There is woodland (to feed) 16 swine. In all it is worth I 5 pounds and Io shillings, (was worth) when received 10 pounds, and T.R.E. I 5 pounds. This manor Lewin, a thegn of King Edward, held, and there I sokeman had I hide and could assign it to whom he wished.

\section{In Wichestanestou [WiXamtree] HUNDRET}

In Sudgivele [Southill] Walter holds half a hide of woodland which his predecessor held T.R.E.

In the same vill Alric holds of Walter I virgate. There is land for 4 oxen (to plough), and they are there, and meadow (sufficient) for 4 oxen. It is worth 5 shillings, (was worth) when received 3 shillings; T.R.E. Io shillings. This land Lewin, a thegn of the king, held in mortgage (vadimonio) T.R.E. But after King William came to England he

7 The Langford entry comes three places lower down.

\footnotetext{
8 In Biggleswade.

i.e. a quarter of a plough-team.
} 


\section{THE HOLDERS OF LANDS}

who had mortgaged this land redeemed it, and Seiher took possession of it to the king's hurt (super regem), as the men of the hundred (court) testify.

\section{In Cliston ${ }^{1}$ [Clifton] Hundret}

In Hanslaue [Henlow] Hugh holds of Walter $3 \frac{1}{2}$ hides. There is land for $3 \frac{1}{2}$ ploughs. On the demesne is I plough and there could be another. There are 4 villeins with 2 ploughs, and (there are) 4 bordars and 2 serfs, meadow (sufficient) for $3 \frac{1}{2}$ plough teams, and I mill worth (de) 34 shillings. In all it is worth 60 shillings, (was worth) when received 40 shillings; T.R.E. 70 shillings. This land 6 sokemen held and could assign their land to whom they wished.

fo. 216

XXXIII. THE LAND OF WALTER BROTHER OF SEIER

\section{In RAtBORGESTOC [REDBORNESTOKE] HundReT}

M. Walter, Seiher's brother, holds SEgeneHou [Segenhoe ${ }^{2}$ ]. It is assessed at 10 hides. There is land for Io ploughs. In the demesne are 4 hides, and on it is I plough and there could be 2 ploughs (more). There 24 villeins have 7 ploughs. There are 4 bordars and 3 serfs, meadow (sufficient) for 8 plough teams, woodland (to feed) 300 swine, and from dues of the woodland come Io rams yearly. In all it is worth 6 pounds, when received (was worth) Io pounds, T.R.E. I 6 pounds. This manor Levenot a thegn of King Edward held, and there I sokeman had half a hide and could sell it to whom he wished.

\section{In Flictham [Fitite] Hundret}

M. In Sewilessou [Silsoe] Hugh holds of Walter 4 hides as I manor. There is land for ro ploughs. On the demesne are 2 ploughs; and 6 villeins and 8 bordars and 4 serfs are there with 7 ploughs, and there could be an eighth. There is I mill worth (de) 26 pence. Meadow is there (sufficient) for 6 plough teams, woodland (to feed) 100 swine and (worth) 2 shillings (besides). In all it is worth 8 pounds, (was worth) when received 100 shillings; T.R.E. I I pounds. This manor Levenot, a thegn of King Edward, held, and there 3 sokemen held half a hide and could assign and sell it to whom they wished. This half hide Hugh holds of the king, as his men say.

\section{For Clifton.}

2 In Ridgmont. The Ordnance Survey's spelling Legenhoe appears to be a mistake.

\section{XXXIV, THE LAND OF HUGH THE FLEMING}

In Wilga [Willeex] Hundret

Hugh the Fleming holds of the king in Podintone [Podington] 2 hides and 1 virgate. There is land for $2 \frac{1}{2}$ ploughs. In the demesne is half a hide, and on it is I plough, and 3 villeins have $1 \frac{1}{2}$ ploughs. There are 6 bordars and I serf. It is worth 30 shillings, (was worth) as much when received, and T.R.E. 40 shillings. This land 4 sokemen held and could sell to whom they wished.

Hugh himself holds in HaNewich [Hinwick $^{3}$ ] $\mathrm{r} \frac{1}{2}$ hides of the king. There is land for 3 ploughs. On the demesne are 2 ploughs, and I villein and 4 bordars and 3 serfs (are there) with I plough. It is worth 30 shillings, (was worth) when received 20 shillings, and T.R.E. 40 shillings. This land Alwold a man of Bishop Wlwi held and could sell.

In SeRnebroc [Sharnbrook] Robert holds of Hugh half a hide and one fourth part of I virgate. There is land for I plough and it is there, and I bordar and I serf, and meadow sufficient for I plough team. It is worth Io shillings, (was worth) when received 5 shillings; T.R.E. 20 shillings. This land Levric a man of the abbot of Ramesy held and could assign to whom he wished.

\section{THE LAND OF HUGH THE BUTLER}

\section{In STOden [Stodden] Hundret}

Hugh the butler holds of the king in Estone [Easton ${ }^{4}$ ] 2 hides and 3 virgates. There is land for 4 ploughs. In the demesne is I hide and on it are 2 ploughs. There are 4 villeins and I bordar and I serf with 2 ploughs, and meadow (sufficient) for I plough team, and woodland (to feed) 200 swine. It is worth 40 shillings, (was worth) when received 70 shillings, and T.R.E. 40 shillings. This manor Wig a thegn of King Edward held, and there I sokeman had half a hide and could assign it to whom he wished.

\section{In Segresdone [} 5] Hugh holds I virgate, and it is worth 12 pence; (was worth) T.R.E. 2 shillings. This land Alwin a man of Earl Harold held and could assign to whom he wished.

\footnotetext{
3 In Puddington or Podington.

4 Co. Hunts (see Introduction).

5 See Introduction.
} 


\section{A HISTORY OF BEDFORDSHIRE}

\section{THE LAND OF SIGAR DE CIOCHES}

In Stoden [STodden] Hundret

Sygar de Cioches holds in Estone [Easton ${ }^{1}$ ] 2 hides of the king. There is land for 5 ploughs. In the demesne are 2 carucates of land besides the 2 hides, $^{2}$ and on it are 2 ploughs, and 6 villeins have 3 ploughs. There are 12 bordars and 2 serfs, meadow (sufficient) for I plough team, woodland (to feed) 60 swine. It is worth 4 pounds; when received (was worth) 3 pounds; T.R.E. 4 pounds. This land Wig, a thegn of King Edward, held and could assign and sell to whom he wished.

\section{THE LAND OF GUNFREI DE CIOCHES}

\section{IN Wilga [Willey] Hundret}

Gunfrey (Gunfridus) de Cioches holds in HANEWIC $^{3}$ [Hinwick] I hide and 3 virgates. Tetbald holds of him. There is land for 3 ploughs. On the demesne is I plough and there could be 2 (more). There are 3 villeins. It is worth 20 shillings ; (was worth) when received 10 shillings; T.R.E. 40 shillings. This land 2 sokemen held and could assign and sell to whom they wished.

\section{THE LAND OF RICHARD SON OF COUNT GILBERT ${ }^{4}$}

\section{IN Bereford [Barford] Hundret}

Richard son of Count Gilbert holds in SubBerIe [Sudbury ${ }^{5}$ ] $\mathbf{r}$ virgate of land which belongs to (jacet in) the church of St. Neot, and belonged thereto (jacuit in) T.R.E.

In WiboldesTone [W yboston ${ }^{8}$ ] the monks of St. Neot hold of the aforesaid Richard 2 hides and half a virgate. There is land for a half plough, but it is not there. Woodland (is there to feed) Ioo swine. It is worth II shillings, (was worth) when received a like sum; T.R.E. 2I shillings. This land belonged to (jacuit in) the church of St. Neot, T.R.E., in almoin.

1 Co. Hunts (see Introduction).

2 See p. 229 , note 2.

3 In Puddington or Podington.

- Alias Richard 'de Clare' or 'de Tunbridge,' ancestor of the house of Clare and founder of St. Neot's priory (J.H.R.)

5 In Eaton Socon. Mr. Airy described it as 'situated by the river at the northern extremity of the parish towards Little Paxton' (J.H.R.)

- In Eaton Socon.

\section{THE LAND OF RICHARD PUNGIANT $^{7}$}

In Bicheleswade [Biggleswade] Hundret

M. Richard Puniant holds of the king in Daintone [Dunton] 8 hides and [ ${ }^{8}{ }^{8}$ virgate as one manor. There is land for 8 ploughs. In the demesne are 4 hides and I virgate, and on it are 3 ploughs. There 12 villeins have 5 ploughs, and (there are) 2 bordars and 3 serfs, and woodland (to feed) 60 swine. In all it is worth 8 pounds, (was worth) when received 6 pounds, and as much T.R.E. This manor Archbishop Stigand held.

In Tamiserorde [Tempsford] Robert holds of Richard P[un]g[iant] 2 hides of the king's fee. There is land for 2 ploughs. On the demesne is I plough, and (there are) 4 villeins with I plough, and meadow (sufficient) for I plough team. It is worth 30 shillings, (was worth) when received 20 shillings and T.R.E. 20 shillings. This land 3 sokemen held and could assign to whom they wished.

\section{In Wichestanstou [Wixamtree] Hundret}

In Sudgivele [Southill] Richard Pungiant holds half a hide of woodland which Archbishop Stigand held T.R.E.

\section{THE LAND OF WILLIAM THE CHAMBERLAIN ${ }^{9}$}

\section{In Manesheve [Manshead] Hundret}

William the chamberlain holds in PotesGRave [Potsgrove] I hide of the king. There is land for I plough and it is there, and meadow (sufficient) for I plough team. It is worth I 5 shillings, (was worth) when received a like sum and T.R.E. 40 shillings. This land Morcar the priest of Lintone ${ }^{10}$ [Luton] held and could sell.

In Badelestone (Battlesden) Robert holds of William the chamberlain half a hide. There is land for a half plough. It is worth 5 shillings; (was worth) when received a like sum; T.R.E. 7 pounds. ${ }^{11}$ This land Morcar the priest held and could sell.

$7 \mathrm{He}$ held land in six counties, but his whole fief was not large (J.H.R.)

8 This figure must be right, for the addition of the I hide and 3 virgates in 'Domtone' (p. 23I, above) completes the ro hide unit (J.H.R.)

9 See Introduction.

10 For Liutone (see p. 222).

11 So MS. ; probably error for shillings. 


\section{THE HOLDERS OF LANDS}

\section{In the Half Hundret of Stanburge ${ }^{1}$}

M. William himself holds TOTENEHOU [Totternhoe] of the king. It is assessed at 7 hides less $\mathrm{I}$ virgate. There is land for 6 ploughs. In the demesne are 3 hides and 3 virgates, and on it is I plough. There 4 villeins have 3 ploughs. There are 4 bordars and 4 serfs and 1 mill (worth) 3 shillings, meadow sufficient for 3 plough teams, and woodland to feed 20 swine. It is worth 50 shillings, was worth when received a like sum ; T.R.E. 8 pounds. This manor Lewine a man of Earl Waltheof (Wallef) held. With this manor William the chamberlain claims 2 hides which his predecessor held T.R.E., as the hundred (court) testifies. But the Bishop of Bayeux ${ }^{2}$ took them from him by force and gave them to Adelulf his chamberlain.

\section{THE LAND OF WILLIAM LOVET}

\section{In Manesheve [Manshead] Hundret}

M. William Lovet holds in Craurlai [(Husborne) Crawley] of the king 5 hides as one manor. There is land for 5 ploughs. In the demesne are 2 hides and 2 ploughs are on it; and 5 villeins have 2 ploughs and there could be a third. There are 3 bordars and 2 serfs, and 2 mills (worth) 10 shillings, and meadow sufficient for 5 plough teams. It is worth 40 shillings; (was worth) when received 30 shillings; T.R.E. 100 shillings. This manor Grimbald a man of King Edward held and could assign to whom he wished.

\section{IN RADBORgESTOU [REDBORNESTOKE] HunDRET}

M. William himself holds FLICTEWiche [Flitwick] of the king. It is assessed at 5 hides. There is land for 7 ploughs. In the demesne are 2 hides and on it are 2 ploughs. There 3 villeins have 3 ploughs and there could be 2 more. There are 7 bordars, and I mill (worth) 4 shillings, meadow (sufficient) for 5 plough teams and woodland (to feed) 100 swine. It is worth 50 shillings, (was worth) when received 60 shillings, T.R.E. 8 pounds. This manor Alwin, a thegn of King Edward, held.

1 Now part of Manshead Hundred.

2 The bishop held the adjoining manor of Eaton Bray. Adelulf or Adelold, the bishop's chamberlain (compare Calendar of Documents in France, pp. 530-1) held under him in Kent and also had a grant from him at Southwark (J.H.R.)

\section{THE LAND OF WILLIAM}

IN WIIGe [Willey] Hundret

William holds of the king in FERNADIs [Farndish ${ }^{3}$ ] 2 hides. There is land for $2 \frac{1}{2}$ ploughs. On the demesne are 2 ploughs and 3 villeins have a half-plough. There are 2 bordars and I serf and meadow (sufficient) for I plough team. It is worth 40 shillings, (was worth) when received 20 shillings, T.R.E. 40 shillings. This land 3 sokemen held and could assign and sell to whom they wished.

fo. $216 \mathrm{~b}$

\section{THE LAND OF HENRY SON OF AZOR}

IN Wilga [W ILLEY] HundRet

Henry son of Azor holds in FrRnadis [Farndish ${ }^{3}$ ] of the king I hide. There is land for I plough, and it is there, and there are 2 villeins and meadow (sufficient) for a half plough team. It is and was worth 10 shillings; T.R.E. 20 shillings. This land 2 sokemen held and could assign to whom they wished.

\section{XLIIII. THE LAND OF OSBERN SON OF RICHARD ${ }^{4}$}

\section{IN Stodene [Stodden] Hundret}

Osbern son of Richard holds in Estone [Easton ${ }^{5}$ ] half a hide and half a virgate and Hugh Hubald ${ }^{6}$ holds of him. There is land for I plough, and it is there with I serf. There is meadow (sufficient) for I plough team; woodland (to feed) 20 swine. It is worth 10 shillings, when received (was worth) a like sum, and T.R.E. I 2 shillings. This land Stori, a man of Earl Tosti, held, and there a certain sokeman had half a virgate which he could assign and sell.

In RiselaI [Riseley] Hugh Hubald ${ }^{7}$ holds of Osbert ${ }^{8}$ son of Richard half a hide. There is land for a half plough and it is there with I bordar. There is meadow (sufficient) for a half plough team. It is and was worth 5 shillings; T.R.E. 8 shillings. This land Alwin a man of Stori ${ }^{9}$ held and could assign to whom he wished.

\footnotetext{
3 Now in Podington.

1 Lord of Richard's Castle, Herefordshire (J.H.R.)

5 In Hunts (see Introduction).

- A Henry 'Hubold' is recorded to have held half a fee (but in Shropshire) on the Richard's Castle fief in 1212 (J.H.R.)

7 See note $6 . \quad 8$ So MS.

9 See p. 254 , note 3 .
} 


\section{A HISTORY OF BEDFORDSHIRE}

In Carssot [Keysoe] Hugh Hubald ${ }^{1}$ holds of Osbert I virgate. There is land for 2 oxen (to plough). It is and was worth 2 shillings; T.R.E. 4 shillings.

M. The same (ipse) Hugh holds of Osbern Elvendone ${ }^{2}$ [ ]. It is assessed at $I$ hide and I virgate. There is land for $I \frac{1}{2}$ ploughs and they are there, and meadow sufficient for I plough team; woodland to feed 34 swine. It is and was worth 10 shillings; T.R.E. I 5 shillings. This manor Alwin a man of $\mathrm{Stori}^{3}$ held and could assign to whom he wished.

\section{THE LAND OF OSBERN SON OF WALTER}

\section{In Bicheleswade [Biggleswade]} HUNDRET

M. Osbern son of Walter holds of the king in Bereforde [(Little) Barford] 3 hides as one manor. There is land for 3 ploughs. On the demesne are 2 ploughs and 4 villeins have I plough. There are 2 bordars and 5 serfs and meadow (sufficient) for I plough team. It is worth 60 shillings; (was worth) when received 40 shillings; T.R.E. 60 shillings. This manor Ulmar of Etone [Eaton Socon] a thegn of King Edward held.

\section{THE LAND OF OSBERN THE FISHERMAN}

\section{In Wilge [Willey] Hundret}

Osbern the fisherman holds in SERNEBROC [Sharnbrook] of the king half a hide. There is land for I plough and it is there. A mill is there (worth) I 6 pence; meadow (sufficient) for a half plough team, woodland (to feed) Io swine, and a fish-stew (vivarium piscium). There are I villein and 2 bordars. It is worth 26 shillings; (was worth) when received ro shillings, and T.R.E. 40 shillings. This land Tovi housecarl of King Edward held ${ }^{4}$ and could sell. With this land the same Osbern claims I virgate and the fourth part of I virgate which his predecessor held T.R.E. But after King William came into England he refused the 'gafol' (gablum) due from this land and Ralf Taillgebosc gave the 'gafol' and took

1 See p. 253 , note 6 .

$2 \hat{l}=$ Giveldone, = Yeldon. But see Introduction.

${ }^{3}$ 'This was evidently the 'Stori' of the first entry, so that we have here a 'man' of Earl 'Tosti(g) who has himself a 'man' of his own as a his tenant (J.H.R.)

4 He had also held at Radwell, just to the south of Sharnbrook (J.H.R.) possession of the land itself as forfeit and handed it over to a certain knight (militi) of his.

In Carlentone [Carlton] the same Osbern holds of the king $\mathrm{I}$ hide and $\mathrm{I}_{2} \frac{1}{2}$ virgates. There is land for 2 ploughs. On the demesne is I plough, and 2 villeins have I plough. There are 4 bordars, and meadow (sufficient) for 2 plough teams. It is and was worth 20 shillings (T.R.E. ${ }^{5}$ ); T.R.E. 40 shillings. This land Goduin Frambolt, ${ }^{8}$ a thegn of King Edward, held and could sell.

\section{THE LAND OF TURSTIN THE CHAMBERLAIN ${ }^{7}$}

\section{IN BuchelaI Hundret ${ }^{\circ}$}

Turstin the chamberlain holds of the king in Pabeneham [Pavenham] $2 \frac{1}{2}$ hides as one manor. There is land for 3 ploughs. In the demesne is I hide and I plough. There are 6 villeins with 2 ploughs and $I$ bordar, and meadow (sufficient) for 3 plough teams. It is worth 40 shillings, (was worth) when received a like sum, and T.R.E. 45 shillings. This land Alsi, a man of Alli his brother, held and could [sell ?]

In Henewic [Hinwick ${ }^{9}$ ] Turstin holds of the king I hide and 3 virgates. There is land for 2 ploughs. In the demesne is I hide and $I$ plough and (there are) 2 villeins with I plough and I bordar, and meadow sufficient for I plough team. It is worth 30 shillings, when received (was worth) Io shillings; T.R.E. 30 shillings. This land Goduin Frambolt, a thegn of King Edward, held.

\section{In Wichestanestou [WiXamtren]} HUNDRET

In Bistone [Beeston ${ }^{10}$ ] the aforesaid Turstin holds half a hide of the king. There is land for a half plough, but it is not there; meadow is (sufficient) for I plough team. This land has been laid waste (devastata est), but when Turstin received it, it was worth Io shillings; T.R.E. 20 shillings. This land Goduin a man of Earl Tosti held and could assign.

5 MS. inserted by error.

- He had also held at Wymington in this Hundred (see p. 250), and, as the next fief shows, at Hinwick near Wymington (J.H.R.)

$7 \mathrm{He}$ also held in Hampshire and Wiltshire.

${ }^{8}$ Half Hundred. Now part of Willey Hundred.

9 In Puddington or Podington.

10 In Sandy. 


\section{THE HOLDERS OF LANDS}

\section{In Clistone ${ }^{1}$ [Clifton] Hundret}

In Chambeltone [Campton] Turstin holds of the king 2 hides (and) ${ }^{2}$ all but the fourth part of I virgate. There is land for $I \frac{1}{2}$ ploughs. In the demesne are $I$ hide and I virgate and three-quarters (partes) of I virgate, and on it is I plough. There 2 villeins and $I$ bordar have a half plough. Meadow is there (sufficient) for I $\frac{1}{2}$ plough teams; woodland (to feed) 20 swine. It is worth 30 shillings, and was worth T.R.E. 40 shillings. $^{3}$ This land 3 sokemen held and could assign and sell to whom they wished.

\section{THE LAND OF GILBERT SON OF SALOMON}

\section{In Clistone * [Clifton] Hundret}

M. Gilbert son of Salomon holds MALPERTESSELLE [Meppershall] of the king. It is assessed at 4 hides in Bedefordescire ${ }^{5}$; there is land for 4 ploughs. In Herefortscire ${ }^{5}$ (Herts) the same (ipsa) vill is assessed at 3 hides and I virgate; there is land for 3 ploughs. In all there are 7 ploughs. In the demesne are 5 hides and on it 3 ploughs and there could be 2 more. There 5 villeins have 2 ploughs and (there are) 4 bordars and 2 serfs; meadow (sufficient) for 7 plough teams, woodland (to feed) 200 swine, and from dues of woodland (come) Io shillings. It is and was worth 6 pounds; T.R.E. Io pounds. This manor Lewin Cilt, a thegn of King Edward, held, ${ }^{6}$ and in this manor were 4 sokemen. They held 2 hides and could sell them to whom they wished.

\section{IN Wilge [W ILley] HundRet}

M. In Flammeresham [Felmersham] Gilbert holds $7 \frac{1}{2}$ hides. There is land for 8 ploughs. In the demesne are 4 hides, and on it are 3 ploughs, and 4 villeins have 4 ploughs. There are 6 bordars and meadow (sufficient) for 4 plough teams. It is worth 100 shillings, (was worth) when received 12 pounds and as much T.R.E. This manor 6 sokemen held and could sell.

1 For Cliftone.

2 Erroneously inserted in MS.

3 But possibly the scribe has omitted something between 'valuit' and 'T.R.E.'

4 For Cliftone.

5 i.e. 4 hides of it are assessed in Bedfordshire ; 3 hides and 1 virgate in Hertfordshire (see the Victoria History of Herts, vol. i.)

${ }^{6}$ See pp. 198, 230.

\section{THE LAND OF ALBERT OF LORRAINE (LOTHARIENSIS) ${ }^{7}$}

\section{In Manesheve [Manshead] Hundret}

M. Albert of Lorraine holds of the king Celgrave [Chalgrave]. It is assessed at 8 hides and two-thirds (partes) of I virgate. There is land for 10 ploughs. In the demesne are 3 carucates of land, and on it are 2 ploughs. There 13 villeins have 8 ploughs. There are 4 bordars and 6 serfs, meadow (sufficient) for 8 plough teams, woodland (to feed) 50 swine. It is worth 7 pounds; when received (was worth) 6 pounds, and as much T.R.E. This manor the same Albert held T.R.E. and could assign to whom he wished.

\section{IN RADBERNESTOC [REDBORNESTOKB] HUNDRET}

M. Albert himself holds OTONe [Wootton]. It is assessed at Io hides. There is land for II ploughs. In the demesne are 2 hides and on it are 3 ploughs. There 20 villeins have 7 ploughs, and there could be an eighth. There are 6 serfs, meadow (suffcient) for 5 plough teams, woodland to feed 400 swine. It is worth Io pounds, when received (was worth) 8 pounds; T.R.E. Io pounds and 15 shillings. This manor Almar a man of Earl Tosti held and could sell.

In EsseLtone [Shelton ${ }^{8}$ ] Albert holds 3 hides. There is land for 5 ploughs. In the demesne is $I$ hide, and on it are 2 ploughs. There are 7 villeins with 3 ploughs and there are 4 serfs, meadow (sufficient) for 3 plough teams, and woodland (to feed) 100 swine. It is worth 40 shillings; (was worth) when received 20 shillings; T.R.E. 45 shillings. This manor was and is a member of Otone (Wootton). Almar a man of Earl Tosti held it.

\section{In Wilga [Willey] Hundret}

In SERNEBRoc [Sharnbrook] Albert holds 2 hides and the fourth part of $\mathbf{I}$ virgate. There is land for 3 ploughs. In the demesne is I hide, and on it are 2 ploughs, and there are 4 villeins with I plough. There are 4 bordars and 4 serfs, and I mill (worth) 16 shillings, meadow (sufficient for 2 plough teams, woodland (to feed the swine. It is worth 50 shillings; when reccived (was worth) 30 shillings; T.R.E. 60 shillings. This land Algar a man of Queen Edid held and could assign to whom he wished.

\footnotetext{
7 See Introduction, p. 203.

8 In Marston (Morteyne).
} 


\section{A HISTORY OF BEDFORDSHIRE}

\section{THE LAND OF DAVID DE ARGENTAN (ARGENTOMO)}

\section{In Stodene [Stodden] Hundret}

David de Argentan holds in RiselaI [Riseley] I hide of the king. There is land for I plough, but it is not there. There are I villein and 3 bordars. It is worth Io shillings, (was worth) when received 20 shillings and T.R.E. a like sum. This land Homdai a man of Earl Harold held and could sell to whom he wished.

fo. 217

\section{THE LAND OF RALF DE INSULA ${ }^{1}$}

\section{In Bicheleswade [Biggleswade] HUNDRET}

M. Ralf de Insula ${ }^{1}$ holds of the king in Stratone [Stratton ${ }^{2}$ ] 4 hides as one manor. There is land for 8 ploughs. There are 7 and there could be an eighth. There are ro villeins and 2 bordars, and meadow (sufficient) for 4 plough teams. In all it is worth 12 pounds, (was worth) when received 3 pounds; T.R.E. 100 shillings. This manor Stigand the archbishop held.

M. Ralf himself holds Picheleswade [Biggleswade]. It is assessed at 10 hides. There is land for 10 ploughs. In the demesne are $5 \frac{1}{2}$ hides and on it are 3 ploughs. There are 7 villeins with 7 ploughs and 10 bordars and 3 serfs, and 2 mills worth (de) 47 shillings, meadow (sufficient) for 10 plough teams and (producing) 5 shillings from the hay. It is worth I 7 pounds, (was worth) when received 15 pounds ; T.R.E. 10 pounds. This manor Stigand the archbishop held, and there 2 sokemen had half a hide which they could sell and assign.

M. In Holme [Holme ${ }^{2}$ ] the same Ralf holds 2 hides. There is land for 5 ploughs and they are there. There are 6 villeins and meadow (sufficient) for I plough team. It is worth 40 shillings, (was worth) when received 30 shillings, and T.R.E. 40 shillings. This manor Archbishop Stigand held and there 3 sokemen had 2 virgates of land and could sell.

IN Wichestanestou [WiXamtREE] HUNDRET

In WARDONE [Warden] the same Ralf holds of the king $1 \frac{1}{2}$ virgates. This land

1 It is not certain how this name should be Englished (J.H.R.)

2 In Biggleswade. belongs to (jacet in) Bicheleswade [Biggleswade] and it is valued (est appreciata) there ${ }^{3}$; and he who held it T.R.E. could not assign or sell it without the leave of him who held Bicheleswade [Biggleswade].

\section{THE LAND OF GOZELIN THE BRETON}

\section{In Manesheve [Manshead] Hundret}

M. Gozelin the Breton holds of the king in Poresgrave [Potsgrove] $7 \frac{1}{2}$ hides as one manor. There is land for $7 \frac{1}{2}$ ploughs. In the demesne are 3 hides, and on it are 3 ploughs. There 3 villeins have 2 ploughs, and there could be 2 others and a half plough. There are 6 bordars and 3 serfs and meadow (suffcient) for 5 plough teams. It is worth 50 shillings, (was worth) when received 100 shillings ; T.R.E. Io pounds. This manor 4 thegns held and could assign and sell their land to whom they wished.

\section{IN the Half Hundret of Stanburge [STANBRIDGE]}

Gozelin himself holds GiederaI [Gladley (farm) ${ }^{5}$ ] for $2 \frac{1}{2}$ hides. There is land for $I$ plough, and there are there 4 oxen, ${ }^{8}$ and $\mathbf{I}$ mill (worth) I6 shillings, meadow (sufficient) for I plough team, woodland (to feed) I00 swine. It is and was worth 20 shillings; T.R.E. 40 shillings. This land Wigot, a huntsman of King Edward, held and could sell to whom he wished.

\section{THE LAND OF COUNTESS JUDITH}

\section{IN RADBORgESTOC [REDBORNESTOKE] HUNDRET}

M. Countess Judith holds in MrLdone [Maulden] 5 hides and $\mathrm{I} \frac{1}{2}$ virgates and the nuns of Elnestou [Elstow] hold of her in almoin. There is land for 5 ploughs. On the demesne are 2 ploughs, and 7 villeins have 3 ploughs. There are 2 serfs and $\mathbf{I}$ mill (worth) 3 shillings, meadow (sufficient) for 5 plough teams, and woodland (to feed) I00 swine. It is worth 60 shillings, (was

3 The reason for its being separately entered is evidently that it was assessed for 'geld' in Wixamtree Hundred as lying in Warden (J.H.R.)

* Now part of Manshead Hundred.

5 Formerly in Leighton Buzzard; now in Heath and Reach. It was a separate manor (J.H.R.)

$B$ i.e. half a plough-team. 


\section{THE HOLDERS OF LANDS}

worth) when received 4 pounds; T.R.E. 7 pounds. This manor Alwold, a thegn of King Edward, held, and there I sokeman had half a virgate and could assign to whom he wished.

In Houstone [Houghton (Conquest)] Hugh holds of Countess Judith half a hide. There is land for 1 plough, and it is there; and 2 bordars, and woodland (to feed) 25 swine. It is and was worth 10 shillings; T.R.E. I 2 shillings. This land Lepsi a man of Earl Tosti held, and could assign and sell to whom he wished.

M. The countess herself holds WINEsSAMESTEDE [Willshamstead] and nuns hold it of her. It is assessed at 3 hides. There is land for 6 ploughs: On the demesne are 2 ploughs. There I I villeins have 4 ploughs, and (there are) II bordars and I serf, and meadow (sufficient) for a half plough team. It is worth 7 pounds and 6 shillings; when received (was worth) 45 shillings ; T.R.E. Io pounds and ro shillings. This manor 8 sokemen held and could assign and sell. Countess Judith gave it to St. Mary of Elnestou [Elstow] in almoin, but the soke has always belonged to (jacuit in) Camestone [Kempston].

M. Elnestou [Elstow] is assessed at $3 \frac{1}{2}$ hides. The nuns of St. Mary hold it of Countess Judith. There is land for 7 ploughs. On the demesne are 2 ploughs, and 14 villeins have 5 ploughs. There are I I bordars and 4 serfs, and I mill worth (de) 24 shillings, meadow (sufficient) for 4 plough teams, and woodland (to feed) 60 swine. It is worth 100 shillings, (was worth) when received 40 shillings; T.R.E. Io pounds. This manor 4 sokemen held. They were men of King Edward and could assign and sell their land, but their soke always belonged to (jacuit in) Camestone [Kempston].

M. Camestone [Kempston] is assessed at Io hides. There is land for 20 ploughs. The countess holds it. In the demesne are 2 hides and on it are 4 ploughs, and 18 villeins have 12 ploughs and there could be 4 more. There are 12 bordars and 8 serfs, and I mill worth (de) 5 shillings, meadow sufficient for 20 plough teams, woodland (to feed) 200 swine, and from pasture come 2 shillings. In all it is worth I 8 pounds, when received 22 pounds; T.R.E. 30 pounds. This manor Earl Guert held, and there 2 thegns had $2 \frac{1}{2}$ hides and $1 \frac{1}{2}$ virgates and could assign and sell to whom they wished.

257

\section{IN Stoden [STodden] Hundret}

In Bolehestre [Bolnhurst] Hugh holds half a hide of the countess. There is land for I plough, and it is there with 2 bordars. There is meadow sufficient for 4 oxen, ${ }^{1}$ woodland to feed 20 swine. It is worth 1o shillings; (was worth) when received 5 shillings; T.R.E. I 2 shillings. This land Almar, a thegn of King Edward, held and could assign and sell.

In Acheleia [Oakley] Milo Crispin holds of the countess I hide. There is land for $I \frac{1}{2}$ ploughs. One plough is there and there could be a half plough (more). There are 3 bordars and meadow sufficient for I plough team. It is and was worth 10 shillings; T.R.E. 20 shillings. This land Goduin, a man of Earl Harold, held and could sell.

\section{In the Half Hundret of Buchelai ${ }^{2}$}

In BLAcheshou [Bletsoe] Osbern holds of the countess $2 \frac{1}{2}$ hides. There is land for 4 ploughs. On the demesne is 1 plough and 6 villeins have 3 ploughs. There are 3 bordars and 3 serfs, and a moiety of a mill (dim' molin.) worth (de) ro shillings, meadow (sufficient) for I plough team, woodland (to feed) I 00 swine. It is and was worth 60 shillings T.R.E. and after (semper). This manor Leveva, ${ }^{3}$ a ' $m a n$ ' (bomo) of King Edward, held and could sell and assign to whom she wished.

In BRUNEHAM [Bromham] Hugh holds of the countess 2 hides. There is land for 2 ploughs, and they are there, and 5 villeins and 2 bordars, and 1 mill worth 40 shillings and 100 eels." It belongs indeed to the fee of the countess, but does not 'lie' (jacet) in this land. There is meadow (sufficient) for 2 plough teams. It is worth 20 shillings; when received and T.R.E. was worth 10 shillings. This land Goduin a man of Earl Harold held and could sell.

In Stachedene [Stagsden] Hugh holds of the countess I hide. There is land for I plough, and it is there, and 2 villeins and 2 bordars, and woodland (to feed) 40 swine. It is and was worth 10 shillings; T.R.E. 20 shillings. This land 2 sokemen, men of King Edward, held and could sell to whom they wished.

1 i.e. half a plough-team.

2 Now part of Willey Hundred.

3 This is a female name, 'Leofgifu' (J.H.R.)

4 MS. anguillus. 


\section{A HISTORY OF BEDFORDSHIRE}

\section{In Wilga [Willex] Hundret}

In FaLmeresham [Felmersham] Gilbert holds of the countess $3 \frac{1}{2}$ hides. There is land for 3 ploughs. On the demesne is I plough, and there are 2 villeins with 1 plough and there could be another plough. There are 4 bordars, and I mill worth $(d e)$ ro shillings, and meadow (sufficient) for I plough team. It is worth 3 pounds, when received (was worth) I00 shillings and as much T.R.E. This land Alli, a thegn of King Edward, held.

In RADEwelle [Radwell'1 ] Hugh holds 2 hides and $2 \frac{1}{2}$ virgates of the fee of the countess. There is land for $I \frac{1}{2}$ ploughs and they are there. There are I villein and I bordar and I serf, and meadow (sufficient) for I plough team. It is worth 20 shillings, (was worth) when received Io shillings; T.R.E. 40 shillings. This land Tovi a housecarl of King Edward held.

Gilbert de Blossevile holds of the countess Harewelle [Harrold]. ${ }^{2}$ It is assessed at io hides. There is land for 16 ploughs. On the demesne there could be 3 ploughs; one is there; and (there are) 10 villeins with 7 ploughs, and there could be 6 more; meadow is there (sufficient) for 6 plough teams, woodland (to feed) 200 swine, and I mill worth (de) 36 shillings and 8 pence and 200 eels. In all it is worth 6 pounds; when received was worth 16 pounds; T.R.E. 20 pounds. This manor 3 thegns of King Edward held and could sell to whom they wished.

In SERNEBRoc [Sharnbrook] Hugh holds of the countess 3 virgates of land. There is land for I plough and it is there. There are $I$ villein and $I$ bordar and meadow (sufficient) for I plough team. It is worth IO shillings; was worth when received 5 shillings; T.R.E. 20 shillings. This land Oviet a man of King Edward held and could assign to whom he wished.

fo. $2 I 7 b$

IN the Hundret of Bereforde [Barford]

Osbern holds 2 hides and 3 virgates. ${ }^{3}$ There

1 In Felmersham.

2 He held of the Countess also at Lavendon, Bucks, close to Harrold (J.H.R.)

a The only place in this Hundred with which the heirs of the Countess seem to have been associated was Sudbury in Eaton Socon, where balf a fee was held of the Honour of Huntingdon is land for 3 ploughs. On the demesne are 2 ploughs, and there are 3 villeins with $\mathbf{I}$ plough. There are 2 bordars and I serf, meadow (sufficient) for I plough team, woodland (to feed) 200 swine. It is worth 40 shillings; (was worth) when received io shillings; T.R.E. 50 shillings. This land Ulfech a steersman of King Edward held and could sell.

In Potone [Potton ${ }^{4}$ ] Hugh holds of the countess half a virgate of land. There is land for I plough, and it is there with I bordar. It is and was worth 5 shillings; T.R.E. 2 shillings. This land Earl Tosti held in his manor of Potone [Potton]. ${ }^{5}$

\section{In Bicheleswade [Biggleswade] Hundret}

In Stratone [Stratton ${ }^{6}$ ] Fulcher of Paris (de parisio) holds $3 \frac{1}{2}$ virgates of the countess. There is land for 2 ploughs. On the demesne is I plough. There are I villein and 5 bordars; meadow (sufficient) for I plough team. It is and was worth 8 shillings; T.R.E. 20 shillings. This land Alwin, a man of King Edward, held and could sell.

In Holme [Holme ${ }^{6}$ ] Fulcher holds of the countess half a hide. There is land for a half plough, and a half plough is there ; meadow is there sufficient for a half plough team. There is $\mathbf{I}$ villein. It is and was worth 7 shillings; T.R.E. Io shillings. This land Alwin a man of King Edward held and could assign and sell.

In the same (vill) 2 men hold of the countess I virgate. There is land for 2 oxen ${ }^{7}$ (to plough) and they are there. It is and was worth 5 shillings T.R.E. and after (semper). This land Goduin, a man of King Edward, held and could sell.

\section{In the Half Hundret of Weneslai ${ }^{8}$}

M. Countess Judith herself holds Potone [Potton]. It is assessed at 10 hides. There is land for I 2 ploughs. In the demesne are $3 \frac{1}{2}$ hides and on it are 3 ploughs. There are I 8 villeins and 2 sokemen with 8 ploughs, and there could be a ninth plough. There are 13 bordars and 3 serfs and I mill worth 5 shillings ( $v$ solidorum), meadow (sufficient) for

in the fourteenth century (Feudal Aids, i. 15, 33) (J.H.R.)

\footnotetext{
4 Now in Biggleswade Hundred (J.H.R.)

5 See the Potton entry below.

6 In Biggleswade.

7 i.e. a quarter of a plough-team.

8 Now part of Biggleswade Hundred.
} 


\section{THE HOLDERS OF LANDS}

I 2 plough teams, pasture for the live stock of the vill. In all it is worth 12 pounds; when received (was worth) Ioo shillings; T.R.E. I 3 pounds. This manor King Edward held, and it was (before that) (fuit) Earl Tosti's. There were 4 sokemen there who had I hide and I virgate and could assign to whom they wished.

In Sudtone [Sutton] Torchil holds ${ }^{1}$ I $\frac{1}{2}$ hides. There is land for $\mathrm{I} \frac{1}{2}$ ploughs. One plough is there and there could be a half plough more. There are 4 bordars, meadow (sufficient) for $I \frac{1}{2}$ plough teams and (worth) I 6 pence besides. It is worth Io shillings, (was worth) when received 8 shillings; T.R.E. 20 shillings. This land 3 sokemen held and could sell.

In Sudtone [Sutton] Alwin holds of Countess Judith I hide. There is land for I plough. There are 3 bordars and meadow (sufficient) for 2 plough teams. It is worth 8 shillings. Six sokemen held it and could assign and sell (it). ${ }^{2}$

In the same (vill) Levegar holds half a hide. There is land for a half plough, and it is there, and meadow (sufficient) for a half plough team and (worth) 12 pence (besides). It is worth 5 shillings; (was worth) when received and T.R.E. Io shillings. The same man who holds it now held it (T.R.E.). He was a king's man and could sell (it).

In the same (vill) Robert holds $3 \frac{1}{2}$ virgates. There is land for I plough, but there are only 2 oxen $^{3}$ there. Meadow is (sufficient) for $I$ plough team. There are 3 bordars. ${ }^{4}$ It is and was worth 8 shillings; T.R.E. Io shillings. This land 2 sokemen held and could sell.

In the same (vill) Sueting and Robert hold I $\frac{1}{2}$ virgates of land. There is land for 4 oxen ${ }^{5}$ and they are there; meadow (sufficient) for I plough team; and I bordar. It is and was worth 4 shillings; T.R.E. 5 shillings. This land Edward, a man of the abbot of St. Alban, held and could sell.

\section{In the same Half Hundret}

In SudTone [Sutton] Turbert holds 2 hides of the countess. There is land for 2 ploughs. On the demesne is I plough, and there are 4 bordars with I plough, and meadow (sufficient)

1 i.e. of the Countess.

2 This entry is in the margin by the side of the Sutton entry which precedes it in the text.

${ }^{3}$ i.e. a quarter of a plough-team.

4 This clause is inserted in the margin.

s i.e. half a plough-team. for 2 plough teams. It is and was worth 20 shillings; T.R.E. 25 shillings. This land 2 sokemen held and could sell.

In the same (vill) Goduin holds 3 virgates of the countess. There is land for I plough, but now it is not there. It is worth 3 shillings; (was worth) when received 6 shillings; T.R.E. Io shillings. This land Ulmar a man of Ordui held and could sell.

In the same (vill) Ederic holds half a hide. There is land for a half plough, and it is there with I villein. Meadow is there (sufficient) for a half plough team. It is and was worth 5 shillings; T.R.E. Io shillings. The same man who holds it now held it (T.R.E.). He was a king's man and could sell (his land).

M. In Hatelai [(Cockayne) Hatley] the Countess Judith holds 3 hides and $2 \frac{1}{2}$ virgates as 1 manor. There is land for $6 \frac{1}{2}$ ploughs. In the demesne are I hide and half a virgate, and on it are 2 ploughs. There are 8 villeins with $4 \frac{1}{2}$ ploughs. There are 8 bordars, and meadow (sufficient) for 2 plough teams, and woodland (to feed) 4 swine. It is worth 6 pounds and 5 shillings; (was worth) when received 100 shillings; T.R.E. 6 pounds. This manor Earl Tosti held and it belongs to (jacet in) Potone [Potton], the own (proprio) ${ }^{6}$ manor of the countess, and there a certain sokeman had I virgate. He could assign and sell (his land) and put himself under another lord (ad alterum dominum recedere).

M. Rannulf, Ilger's brother, holds of the countess EURETONE [Everton]. It is assessed at 5 hides. There is land for 5 ploughs. There are 2 ploughs and there could be 3 (more). There are 4 villeins and 5 bordars, and meadow (sufficient) for I plough team. It is worth 3 pounds; (was worth) when received I 00 shillings, and as much T.R.E. This manor Earl Tosti held, and it belonged to (jacuit in) Potone [Potton], the own (proprio) ${ }^{6}$ manor of the countess.

\section{IN THE HundRET OF Wichestanestou [WIXAMTREE]}

In Sudgivele [Southill] Hugh holds of the countess I hide. There is land for 2 ploughs and they are there. There are 3 villeins and 3 bordars and I serf; meadow (sufficient) for 2 plough teams; woodland (to feed) 60 swine. It is worth 30 shillings ; was worth) when received 40 shillings; T.R.E. 60 shillings. This land Tuffa a man of Earl Waltheof (Wallef) held and could sell.

8 i.e. demesne. Compare p. $25^{8}$, note 5. 


\section{A HISTORY OF}

In Hergentone [Harrowden ${ }^{1}$ ] the canons of Bedeforde [Bedford] hold 3 hides of the countess. There is land for 3 ploughs, and they are there, and 6 villeins and 4 bordars, and meadow (sufficient) for 2 plough teams. It is worth 30 shillings; when received (was worth) 20 shillings; T.R.E. 40 shillings. This land Azelin a man of Earl Tosti held. He could not assign or sell without leave of him who held Camestone [Kempston], the countess' (com') manor.

In Chernetone [Cardington] Hugh holds of the countess 3 hides and I virgate and the third part of I virgate. There is land for 4 ploughs, and they are there. There are 12 villeins and 3 bordars and 3 serfs, and meadow (sufficient) for I plough team. It is worth 40 shillings; (was worth) when received 20 shillings; T.R.E. 40 shillings. This land Azelin a man of Earl Tosti held. He could not assign nor sell without leave of him who held Cameston [Kempston].

In Cochepol [Cople] Hugh holds of the countess I virgate of land. This land is and was worth 30 pence T.R.E. and after (semper). This Wlwin a man of King Edward held and could sell to whom he wished.

In Blunham [Blunham] the abbot of St. Edmund holds half a hide of the countess. There is land for I plough, and it is there, and meadow (sufficient) for I plough team. It is worth 20 shillings, (was worth) when received 10 shillings; T.R.E. 20 shillings. This land a man of King Edward held and could sell.

\section{In Clistone ${ }^{2}$ [Chifton] Hundret}

In Chistone [Clifton] Alwin holds of the countess $I$ hide. There is land for a half plough, and it is there, and meadow (sufficient) for a half plough team. It is and was worth 5 shillings; T.R.E. Io shillings. This land Ulvric a man of King Edward held and could sell.

\section{LIIII. THE LAND OF THE WIFE OF HUGH DE GRENTMAISNIL}

\section{IN RADBORGESTOCH [REDBORNESTOKE] HUNDRET}

Adeliz wife of Hugh de Grentemaisnil holds of the king half a hide in Esertone [Shelton ${ }^{3}$ ]. There is land for a half plough, and it is there;

\footnotetext{
1 In Eastcotts. 2 For Cliftone.

In Marston Morteyne.
}

\section{BEDFORDSHIRE}

meadow (sufficient) for a half plough team, and woodland (to feed) 6 swine. There is I bordar. It is and was worth 6 shillings; T.R.E. Io shillings. This land Goduin a man of Earl Guert held and could assign to whom he wished.

In Oustone [Houghton (Conquest)] Ernald holds of Adeliz $4 \frac{1}{2}$ hides as one manor. There is land for 6 ploughs. On the demesne are 2 ploughs, and (there are) II villeins and 7 bordars with $3 \frac{1}{2}$ ploughs, and there could be another half plough. There are 3 serfs ; meadow sufficient for 2 plough teams; woodland (to feed) 225 swine. Of this land'r sokeman holds I hide. It is worth 4 pounds, (was worth) when received 60 shillings; T.R.E. 8 pounds. This manor 3 sokemen held who could assign and sell their land (to whom) they wished. In this same (vill) the aforesaid Adeliz claims half a virgate and 30 acres of woodland and field ( $x \times x$ acras inter silvam et planum) against Hugh de Beauchamp; and the men of the hundred (court) bear testimony that this land T.R.E. belonged to (jacuit cum) the other land which Adeliz holds and he who held this land could assign or sell it to whom he wished. This land Ralf ${ }^{4}$ took possession of unjustly when he was sheriff.

\section{IN Wichestanestou [WIXAMTREe] HUNDRET}

M. Adeliz herself holds Cerlentone [Charlton ${ }^{5}$ ]. It is assessed at 10 hides. There is land for ro ploughs. In the demesne are 5 hides, and on it are 2 ploughs and there could be 3 more. There are 16 villeins and 9 bordars with 5 ploughs. There are 2 serfs, and I mill (worth) 30 shillings; meadow (sufficient) for Io plough teams; woodland (to feed) I6 swine. In all it is worth Io pounds; (was worth) when received 8 pounds; T.R.E. I 2 pounds. This manor King Edward held and it was (before that) (fuit) Earl Tosti's. This land was an outlying part (berewicb) T.R.E. of Potone [Potton], the manor of Countess Judith ${ }^{6}$ and in such wise belonged thereto that no one could alienate it therefrom.

fo. $2 \times 8$

\section{In Stoden [Stodden] Hundret}

M. In Mrldentone [Milton Ernest] Ivo steward (dapifer) ${ }^{7}$ of Hugh de Grent[maisnil]

i.e. Ralf Tallebosc.

5 In Blunham.

'The words 'M[anerium] Juditæ Comit[issa]' are added below the line.

7 This was probably the "Ivo" who held as an undertenant of Hugh in Leicestershire and North- 


\section{THE HOLDERS OF LANDS}

holds 3 hides and 1 virgate as one manor. There is land for 4 ploughs. On the demesne are 2 ploughs, and 8 villeins (are there) with 2 ploughs. There is I serf, and there is I mill (worth) 20 shillings, meadow (sufficient) for 2 plough teams, woodland (to feed) 40 swine. It is (and was) worth 60 shillings; T.R.E. 4 pounds. This manor Goduin a man of Borret held and could sell.

\section{THE LAND OF THE WIFE OF RALF TAILLEB(OSC)}

\section{In Manesheve [Manshead] Hundret}

Azelina wife ${ }^{1}$ of Ralf Tallgebosc holds of the king in BADELESDONE [Battlesden] $\mathrm{I} \frac{1}{2}$ hides. There is land for $I \frac{1}{2}$ ploughs. One is there and there could be a half (plough) (more). There are 2 villeins and I bordar, and meadow (sufficient) for I plough team. It is and was worth 20 shillings; T.R.E. 40 shillings. This land 2 sokemen, Anschil and Alwin, held and could sell to whom they wished.

M. Azelina herself holds Hocheleia [Hockliffe). It is assessed at Io hides. There is land for 8 ploughs. In the demesne are 5 hides and on it are 2 ploughs. There are 13 villeins and ( 11 ?) bordars with 6 ploughs, meadow sufficient for 4 plough teams, woodland to feed Ioo swine. It all it is and was worth 8 pounds; T.R.E. I 2 pounds. This manor Anschil held T.R.E. and could sell.

\section{In Flictham [Flitt] Hundret}

In Cainou [Cainhoe] Turstin holds of Azelina 1 hide. There is land for 2 ploughs. On the demesne is $\mathbf{I}$, and I villein has another. There are 3 bordars, and meadow sufficient for I plough team, and woodland to feed 100 swine. It is worth 20 shillings, (was worth) when received 10 shillings; 'T.R.E. 20 shillings. This land Ulvric, a sokeman of King Edward, held and could assign and sell to whom he wished.

\section{In Bereforde [Barford] Hundret}

In Wiboldestone [Wyboston ${ }^{2}$ ] Judichel

ants. There is no reason to suppose that he was a tenant-in-chief. Moreover this estate was afterwards held of the Earls of Leicester as half a knight's fee. The occurrence, however, of Stodden Hundred after that of Wixamtree is not in accordance with the regular sequence, and might be held to suggest the beginning of a new tenancyin-chief as suggested by Mr. Ragg (J.H.R.)

1 The word is 'femina' instead of the usual ' uxor,' and it is clearly used here to mean 'widow' (J.H.R.)

2 In Eaton Socon. holds $5 \frac{1}{2}$ virgates of Azelina. There is Iand for I plough, and it is there with I villein and 2 bordars; meadow is there (sufficient) for a half plough team. It is worth ro shillings, (was worth) when received 5 shillings; T.R.E. 30 shillings. This land Almar, a man of Ulmar, held and could sell and assign to whom he wished.

\section{In Bicheleswade [Biggleswade] Hundret}

In Aieworde [Eyworth] Brodo holds I hide of Azelina. There is land for I plough, and it is there with I bordar, (and there is) meadow (sufficient) for I plough team. It is and was worth Io shillings T.R.E. and after (semper). 'This land belongs to (Azelina's) marriage portion. This land the same Brodo held and could sell to whom he wished.

\section{In Weneslai Hundret ${ }^{3}$}

M. In Hatel.AI [(Cockayne) Hatley] Azelina holds, (as) of her marriage portion, 5 hides and $\mathrm{I} \frac{1}{2}$ virgates. There is land for 8 ploughs. In the demesne are I hide and I virgate, and on it are 2 ploughs. There are 8 villeins and 4 bordars with 6 ploughs. There are I serf, and I mill (worth) I 8 shillings (xviii solidorum), meadow (sufficient) for 2 plough teams, woodland (to feed) 4 swine and (producing) 3 shillings rent. In all it is worth 6 pounds, when received (was worth) roo shillings; T.R.E. 6 pounds. This manor Ulmar a thegn of King Edward held, and there were 2 sokemen, his men, there. They had $2 \frac{1}{2}$ virgates, and could assign and sell them to whom they wished.

\section{In Wichestanestou [WiXamtree]} HUNDRET

In Stanford [Stanford ${ }^{4}$ ] Roger holds 2 hides of Azelina, and this is (part) of her marriage portion. There is land for 2 ploughs. On the demesne is I plough, and 2 villeins and I bordar (are there) with I plough; meadow is there (sufficient) for 2 plough teams, woodland (to feed) 30 swine, and I mill (worth) I 3 shillings and 4 pence. It is worth 60 shillings, (was worth) when received 20 shillings; T.R.E. 60 shillings. This land 2 sokemen held and could assign to whom they wished.

In WARDONE [Warden] Walter, a monk,

3 Half hundred. Now part of Biggleswade Hundred.

4 In Southill.

5 But possibly 'monachus' was, as in later times, a nickname. Walter also held of her at Tadlow in Cambridgeshire (J.H.R.) 


\section{A HISTORY OF BEDFORDSHIRE}

holds half a hide of Azelina, and this is (part) of her marriage portion. There is land for a half plough, but it is not there. One bordar is there, meadow (sufficient) for a half plough team and woodland (to feed) 40 swine. It is worth Io shillings; when received and T.R.E. (was worth) 20 shillings. This land Goding a man of Edric the bald (calvi) held and could assign to whom he wished.

\section{In Clistone ${ }^{1}$ [Clifton] Hundret}

In HaNESLAwE [Henlow] Widrus holds I hide and 3 virgates of Azelina. There is land for 2 ploughs, and they are there. Two villeins and 2 bordars and 2 serfs are there, and meadow (sufficient) for 2 plough teams. It is worth 30 shillings, (was worth) when received 20 shillings; T.R.E. 30 shillings. This land Anschil held, and it was an outlying part (berewiche) of Stodfald [Stotfold] T.R.E. This land Hugh de Beauchamp (Belcamp) claims against Azelina, saying that she holds it unjustly and that it was never (part of) her dower.

In the same vill Bernard holds I hide of Azelina. There is land for 1 plough, and it is there, and 3 villeins (and) meadow (sufficient) for I plough team. It is and was worth 23 shillings; T.R.E. 28 shillings. This land 2 sokemen held, men of Anschil, and could assign to whom they wished.

In Chichesana [Chicksand] 3 sokemen hold 3 hides of Azelina. (It is part) of her dower. There is land for 2 ploughs; one is there and there could be another, meadow is there (sufficient) for 2 plough teams, woodland (to feed) 20 swine. It is and was worth 20 shillings; T.R.E. 25 shillings. This manor 4 sokemen held and could assign and sell to whom they wished.

In the same vill Walter holds I hide of Azelina, and this is (part) of her marriage portion. There is land for 1 plough, and it is there, meadow (sufficient) for I plough team, woodland (to feed) 50 swine, and I mill worth (de) 10 shillings. It is and was worth 20 shillings; T.R.E. 30 shillings. This land Sueteman a man of Ulmer of Etone [Eaton Socon] held and could assign to whom he wished.

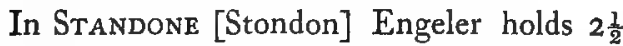
hides of Azelina. There is land for $2 \frac{1}{2}$ ploughs. On the demesne are 2 ploughs, and (there are) 3 bordars with a half plough. There are 2 serfs, and meadow sufficient for $2 \frac{1}{2}$ ploughs. It is worth 60 shillings, (was worth) when received 40 shillings; T.R.E. 4 pounds. This

\section{For Cliftone.}

land Ulmar of Eton [Eaton Socon], a thegn of King Edward, held; and there were there 5 sokemen, men of the same Ulmar, and they could assign and sell (their land) to whom they wished.

\section{THE LAND OF THE BUR- GESSES OF BEDEFORD [BEDFORD]}

IN THE Half Hundret of BochelaI 2

In BIDEHAM [Biddenham] Osgar of Bedeford holds I virgate of land of the king. There is land for 2 oxen $^{3}$ (to plough). It is and was worth 2 shillings T.R.E. and after (semper). He who now holds it held it T.R.E. and could assign to whom he wished.

In the same vill Goduin a burgess holds of the king I hide and the fourth part of I virgate. There is land for I plough, and it is there, and meadow (sufficient) for I plough team. It is and was worth ro shillings T.R.E. and after (semper). A half hide of this land he who now holds held T.R.E. and could assign to whom he wished; half a hide and the fourth part of a virgate he bought after King William came into England; but neither to the king nor to any one else has he done service for it, nor has he had possession given (liberatorem) of it. Against him William Spech claims $I$ virgate and the fourth part of 1 virgate, which had been given into his possession (liberata) and which he afterwards lost. ${ }^{4}$

In the same vill Ordwi a burgess holds of the king I hide and the third part of a half hide. There is land for I plough, and it is there. There are 2 villeins and I bordar, and meadow (sufficient) for I plough team. It is and was worth 10 shillings T.R.E. and after (semper). Half a hide and the fourth part of I virgate of this land was held T.R.E. by him who now holds it, and he could assign (them) to whom he wished. One virgate however he held in mortgage T.R.E., and as yet holds it; so the men of the hundred (court) attest. The same man bought I virgate and the fourth part of I virgate after King William came into England and renders no service for it to the king nor to any one else.

In the same vill Ulmar a burgess holds of the king two-thirds (partes) of I virgate. There is land for $\mathbf{I}$ ox (to plough). It is

2 Now part of Willey Hundred.

a i.e. a quarter of a plough-team. (J.H.R.)

William held 4 hides less $\mathrm{I}$ virgates there

${ }_{5}^{5}$ These fractions amount in all to $1 \frac{1}{8}$ hide; but the man is said to hold $1 \frac{1}{6}$ hide (J.H.R.)

262 


\section{THE HOLDERS OF LANDS}

and was worth 12 pence T.R.E. and after (semper). The same man held it T.R.E., and could assign it to whom he wished.

\section{IN Wilga [Willey] Hundret}

In HENEwICH [Hinwick ${ }^{1}$ ] Edward holds half a hide of the king. There is land for a half plough. There are 2 oxen $^{2}$ and I bordar. It is and was worth 5 shillings, T.R.E. Io shillings. This land this man's father held and could sell T.R.E. This land King William granted to the same man in almoin, as to which he has the king's writ and the witness of the hundred (court).

In SCERnebroc [Sharnbrook] Almar holds half a virgate of the king. There is land for a half plough, but it is not there. It is and was worth 2 shillings; T.R.E. 5 shillings. This land the father of the same man held, and King William gave it back (reddidit) to him by his writ.

\section{IN WichestanEstou [WIXAMTREe] HUNDRET}

In Bistone [Beeston ${ }^{3}$ ] Godmund holds of the king 3 virgates. There is land for 3 oxen (to plough) and they are there and meadow (sufficient) for 3 oxen. It is and was worth 5 shillings; T.R.E. Io shillings. The same man held it T.R.E. and could sell (it) to whom he wished.

\section{In Clistone ${ }^{4}$ [Clifton] Hundret}

In Hanslau [Henlow] Alric holds of the king I virgate. There is land for $2 \operatorname{oxen}^{5}$ (to plough), and they are there and meadow (sufficient) for 2 oxen. It is and was worth 2 shillings T.R.E. and after (semper). The same man held it T.R.E. and could sell it.

In AlRiceser [Arlesey] a certain prebendary of the king, Ulsi, holds of the king two-thirds (partes) of I virgate.

fo. $218 b$

THE LAND OF THE REEVES (PREPOSITORUM) AND ALMSMEN ${ }^{\circ}$ OF THE KING

In Manesheve [Manshead] Hundret

In Euresot [Eversholt] Herbert a king's

1 In Puddington or Podington.

2 i.e. a quarter of a plough-team.

3 In Sandy.

1 For Cliftone.

5 i.e. a quarter of a plough-team.

- The schedule at the beginning of the Survey inserts 'bedelli' between these two classes (J.H.R.) bailiff (prefectus) holds half a hide; in WoBERNE [Woburn] 3 virgates of land; and in Potrsgrave [Potsgrove] I hide. These three lands he holds in the king's service (in ministerio regis). They did not belong to this (jacuerunt ibi) T.R.E., but he states that after Ralf Tallgebosc was sheriff, he had these by grant (concessione) of the king. ${ }^{7}$ There is I villein. In all this is worth 6 shillings; was worth when received 20 shillings; T.R.E. a like sum. This land 5 sokemen of King Edward held and could sell to whom they wished.

In the same Potesgrava [Potsgrove] a certain groom (equarius) of the king holds half a hide. There is land for a half plough and it is there. It is and was worth 5 shillings; T.R.E. Io shillings. This land Oswi, a man of Earl Tosti, held and could assign to whom he wished.

i. ${ }^{8}$ In Prestelai [Priestley ${ }^{\circ}$ ] a king's bailiff holds I hide. There is land for I plough. There are I villein, meadow (sufficient) for I plough team; woodland (to feed) 20 swine. It is worth 5 shillings; (was worth) when received Io shillings; T.R.E. 30 shillings. This land 4 thegns held and could assign and sell to whom they wished.

\section{IN RATBORgESTOC [REDBORNESTOKE] HUNDRET}

ii. In MELDone [Maulden] a certain king's bailiff holds half a hide. There is land for a half plough, and it is there with 2 villeins. Meadow is there (sufficient) for a half plough team. It is and was worth 3 shillings ; T.R.E. Io shillings. This land 2 sokemen of King Edward held and could assign to whom they wished.

\section{In Bicheleswade [Biggleswade] Hundret}

iii. In Tamiseforde [Tempsford] Alwin a bailiff holds $I$ hide and the fourth part of I virgate. There is land for I plough, and it is there with 3 villeins. Meadow is there (sufficient) for a half plough team. It is and was worth 20 shillings ; T.R.E. 27 shillings. This land 6 sokemen held and could sell to whom they wished.

\section{iiii. In Edeworde [Edworth] Alwin, a}

7 The meaning of the text is somewhat obscure, and it is quite possible that this allegation was made by Ralf himself (J.H.R.)

8 The meaning of these numerals is explained lower down in the text.

9 In Flitwick. 


\section{A HISTORY OF BEDFORDSHIRE}

king's bailiff, holds $2 \frac{1}{2}$ hides. There is land for 2 ploughs, and they are there with 2 villeins. It is and was worth 30 shillings T.R.E. and after (semper). This manor Branting, a man of King Edward, held and could sell.

v. In Holme [Holme ${ }^{1}$ ] Alwin, a king's bailiff, holds $I_{2} \frac{1}{2}$ hides. There is land for $I \frac{1}{2}$ ploughs. One plough is there and there could be a half plough (more). There are 2 villeins. It is and was worth 20 shillings T.R.E. and after (semper). This land Alvric and Lemar, bedells, held and could sell.

vi. In Sudtone [Sutton] Alwin holds $I_{\frac{1}{2}}$ virgates. It is and was worth 4 shillings; T.R.E. 5 shillings. This land 2 sokemen held and could assign and sell to whom they wished.

These 6 estates (terras) Ralf Talgebosc assigned to the king's service (apposuit in ministerio regis) when he was sheriff, for they did not belong to (non fuerunt ibi) this (service) T.R.E. They who now hold them hold them by grant of the king as they say.

\section{In Flictham [Flitt] Hundret}

In STRadleI [Streatley] the bailiff (prefectus) of the hundred holds two-thirds (partes) of I virgate for the king's use, which now belong to (jacent in) Lintone ${ }^{2}$ [Luton] the king's manor, but did not belong thereto (non jacuerunt ibi) T.R.E. Bondi the staller assigned (them) to (apposuit in) this manor; Ralf Tallgebosc found them there belonging (ibi appositas). There is land for a half plough. It is and was worth 5 shillings; T.R.E. IO shillings. This land Ulmar a priest held and could assign to whom he wished.

\section{IN WenESLAi ${ }^{3}$ HundRet}

In Sudtone [Sutton] Alwin holds I hide. On the demesne is I plough and there are 3 bordars with I plough; meadow (sufficient) for 2 plough teams and (worth) 12 pence (besides). It is and was worth 20 shillings; T.R.E. ro shillings. Of this land the same man held 3 virgates, and a certain Edward I virgate. They could assign or sell them to whom they wished.

\section{In Wilge [Willey] Hundret}

In Carlentone [Carlton] Chelbert holds $3 \frac{1}{2}$ virgates. There is land for I plough, and

1 In Biggleswade.

2 For 'Luitone.'

3 Half hundred. Now part of Biggleswade Hundred. it is there with 2 villeins and 3 bordars. Meadow is there (sufficient) for I plough team. It is worth 10 shillings, when received (was worth) 2 ' ores,' 4 T.R.E. IO shillings. Of this land the same man held I virgate. He was a man of Queen Edid and could assign to whom he wished. Two virgates and a half however he took possession of for which he has produced (invenit) neither livery (liberatorem) nor a warrantor (advocatum); which land Alli a thegn of King Edward held.

In Wimentone [Wymington] 5 brothers with their mother hold 3 virgates $(d e d \bar{o}){ }^{6}$ There is land for I plough, but it is not there. It is worth 3 shillings, was worth T.R.E. I 5 shillings. This land Lant their father, held and could assign and sell.

\section{IN BEREFORdE [Barford] Hundret}

In Coldentone [Goldington] Alric Wintremelc holds half a hide of the king. There is land for a half plough and it is there, and meadow (sufficient) for 3 oxen. It is and was worth 5 shillings T.R.E. and after (semper). He who now holds it held it T.R.E. He was a man of King Edward, and could assign to whom he wished. He afterwards gave it to the canons of St. Paul, under King William, and in such wise that they should have it after his death absolutely (omnino).

\section{IN Wichestanestou [WIXAMTREe] HUNDRET}

In STANFord [Stanford ${ }^{6}$ ] Alric holds of the king the fourth part of $I$ virgate. 'There is land for a half ox' (dimid' bovi) (to plough) and there is a 'half ox' (semibos) ${ }^{7}$ there. It is and was worth 12 pence. $\mathrm{He}$ who now holds it held it T.R.E., and could assign (it) to whom he wished.

In the same vill Ordui holds [ ] and the fourth part of I virgate. ${ }^{8}$ There is land for 3 oxen (to plough) and they are there, and meadow (sufficient) for 3 oxen. It is and was worth 4 shillings T.R.E. and after (semper). The same man held it T.R.E. He was a man of King Edward, and could sell (it) to whom he wished.

4 'The 'ore' was the ounce of silver, namely sixteen pence. The land therefore had been worth, at that time, two shillings and eightpence (J.H.R.)

5 These words are at the foot of the column, and their meaning is obscure (J.H.R.)

6 In Southill.

7 ? heifer (see Introduction).

8 ' tenet Ordui et quartam partem unius virgæ.' 


\section{THE HOLDERS OF LANDS}

In Bistone [Beeston ${ }^{1}$ ] Alwin holds $\mathrm{I} \frac{1}{2}$ virgates. There is land for a half plough. There are 2 bordars. It is worth 12 pence, when received (was worth) 4 shillings; T.R.E. ro shillings. This land was assigned to the king's service (apposita est in ministerio regis), to which (service) it did not belong T.R.E.; but Dot who held it could assign or sell (it).

\section{IN RADBURNESTOC [REDBORNESTOKE] HUNDRET}

In Wescota [Westcote ? '] Ordui holds I virgate of the king. There is land for a half plough. There are 5 oxen with I bordar and $\mathrm{I}$ serf. It is and was worth 5 shillings; T.R.E. Io shillings. The same man held it then. He was a king's man and could sell it.

\section{In Stoden [Stodden] Hundret}

In Dene [Dean] I I sokemen of King William hold 7 virgates of land and the fourth part of I virgate. There is land for $3 \frac{1}{2}$ ploughs and they are there. It is and was worth 30 shillings T.R.E. and after (semper). This land T.R.E. the same sokemen held who now hold it, and they could assign it to whom they wished. This land Ralf assigned to the king's service, to which (service) it did not belong (apposuit in ministerio regis ubi non fuit) T.R.E.

In the same vill Goduin Dere ${ }^{3}$ of Bedeford [Bedford] holds half a virgate of the king and it is and was worth $\mathrm{I} 2$ pence T.R.E. and after (semper). The same man held it T.R.E. and could do with it what he wished.

In HANEFELD ${ }^{4}$ [ ] Saiet holds I virgate of the king's soke. There is land for a half plough, and it is there. It is and was worth 5 shillings; T.R.E. Io shillings. The same man held it then and could do with it what he wished.

\section{IN THE SAME HUNDRED OF STODEN [STODDEN]}

Turgot and his mother hold of the king half a hide. There is land for I plough, and it is there with 1 villein and 2 bordars. Woodland is there (sufficient) to feed 4 swine.

1 In Sandy. 2 See p. 243, note 7.

3 The Record Commission's edition reads 'Godwidere.'

4 See Introduction.
It is and was worth 10 shillings; T.R.E. 12 shillings. This land the father of this Turgot held. He was a king's thegn and could assign and sell his land.

In Mildentone [Milton (Ernest)] a certain bedell of the king holds half a virgate of the king. There is land for 2 oxen $^{5}$ (to plough). It is and was worth 12 pence. This land was held by the father of him who now holds it and he could assign it to whom he wished.

\section{In the Half Hundred of Buchrlai ${ }^{6}$}

In BRIMEHaM [Bromham] Osiet holds I virgate and two-thirds (partes) of I virgate. There is land for I plough, and it is there, and meadow (sufficient) for a half plough team. It is worth Io shillings, was worth T.R.E. 5 shillings. The same man held it then and could assign it.

\section{IN WIIGE [WILLEY] HUNDRET}

In ToRver [Turvey] Alwin a priest holds of the king the third part of half a hide. There is land for 2 oxen $^{7}$ (to plough), and they are there. It is and was worth 3 shillings. The same man held it T.R.E. and could do with it what he wished. But King William afterwards granted it to him in almoin. On which account he performs every week on the second day (ii feria) a mass for the souls of the king and the queen. ${ }^{8}$

\section{IN THE SAME HUNDRET}

Osiet a king's bailiff holds half a hide of the king. There is land for a half plough and it is there. It is and was worth 3 shillings T.R.E. and after (semper). This land I sokeman held T.R.E. whom King William commended (commendavit), together with this land, to the aforesaid bailiff, to supply food and clothing to him as long as he lived.

In WIM[IN]Trone [Wimmington] Turchil holds of the king I hide. There is land for I plough, and it is there. It is and was worth 5 shillings; T.R.E. ro shillings. The same man held it then, and could sell it to whom he wished.

5 i.e. a quarter of a plough-team.

- Now part of Willey Hundred.

7 i.e. a quarter of a plough-team.

8 This last sentence is added in a note at the foot of the column (J.H.R.) 


\section{A HISTORY OF BEDFORDSHIRE}

\section{[HERTS]}

fo. 133

King William holds WESTONE [Weston(ing)]. It is assessed at 5 hides. There is land for 14 ploughs. In demesne are 2 hides, and 2 ploughs are on it (ibi); and 16 villeins with 3 bordars have 5 ploughs, and 5 more could be (employed). (There are) 4 serfs. (There is) meadow for 7 plough-teams; pasture for the stock of the vill. (There is) woodland for 400 swine and (yielding) 3 shil- lings (besides). Earl Harold held this manor, which did and does belong to (et jacuit et jacet in) $\mathrm{Hiz}$ [Hitchin]. But the assessment (Wara) of this manor belonged to (jacuit in) 'Bedefordscire' T.R.E. (namely) to (in) the Hundret of Maneheve [Manshead]; and the manor is there and always was; and since King Edward's death it has failed to pay the king's geld.

\section{[HUNTS]}

\section{fo. $203 \mathrm{~b}$}

In Partenhale [Pertenhall] Alwin' had I virgate of land (assessed) to the geld. (There is) land for half a plough. This land is situated in 'Bedefordescire,' but renders (its) geld and service in 'Hontedunescyre.' The king's officers claim it for his own use (opus). It is and was in King Edward's time worth 5 shillings. William holds it of Bishop R[emigius] and ploughs (the land) there with his own demesne.

fo. $205 \mathrm{~b}$

S. $^{1}$ In Carssot [Keysoe] Allic (has) 3 virgates of land (assessed) to the geld. There is land for 6 oxen. (It is) soke (of Kimbolton). There (are) I sokeman, and 7 bordars, and 4 acres of meadow, and 5 acres of woodland for feed (pastilis).

fo. 207

M. In Evretune [Everton] Ingewar had 7 hides (assessed) to the geld. (There is) land for 18 ploughs. There are now 2 ploughs on the demesne, and 19 villeins and 2 bordars who have 9 ploughs. There are a priest and a church and I 5 acres of meadow, and 40 acres of underwood (silva min'). In King Edward's time it was worth Io pounds ; now 7 pounds. Rannulf brother of Ilger holds it of the king.

fo. $20 \% \mathrm{~b}$

In CaIssot [Keysoe] Alwine had I virgate of land (assessed) to the geld with sac and soc. There is land for 2 oxen. It lies in ' Bedefordscira,' but pays (dat) geld in 'Hunted[une]scyre.' He himself holds (it) now of the king, and has there I villein with 2 oxen in the plough (in caruca). In King Edward's time it was worth 16 pence; now the same.

fo. 208

Of (the) I virgate of land of Alwin Deule in Partenhale [Pertenhall] King Edward had the soc.

\section{[NORTHANTS]}

[WILLIAM PEVEREL'S LAND] Two sokemen have this (plough) there. fo. 225b

In FARNEDIs [Farndish] (are) 3 virgates of land of soke. (There is) land for I plough.
In Potintone [Podington] (is) half a hide of soke. There are 4 villeins with 1 plough.

1 This stands for Soke. 



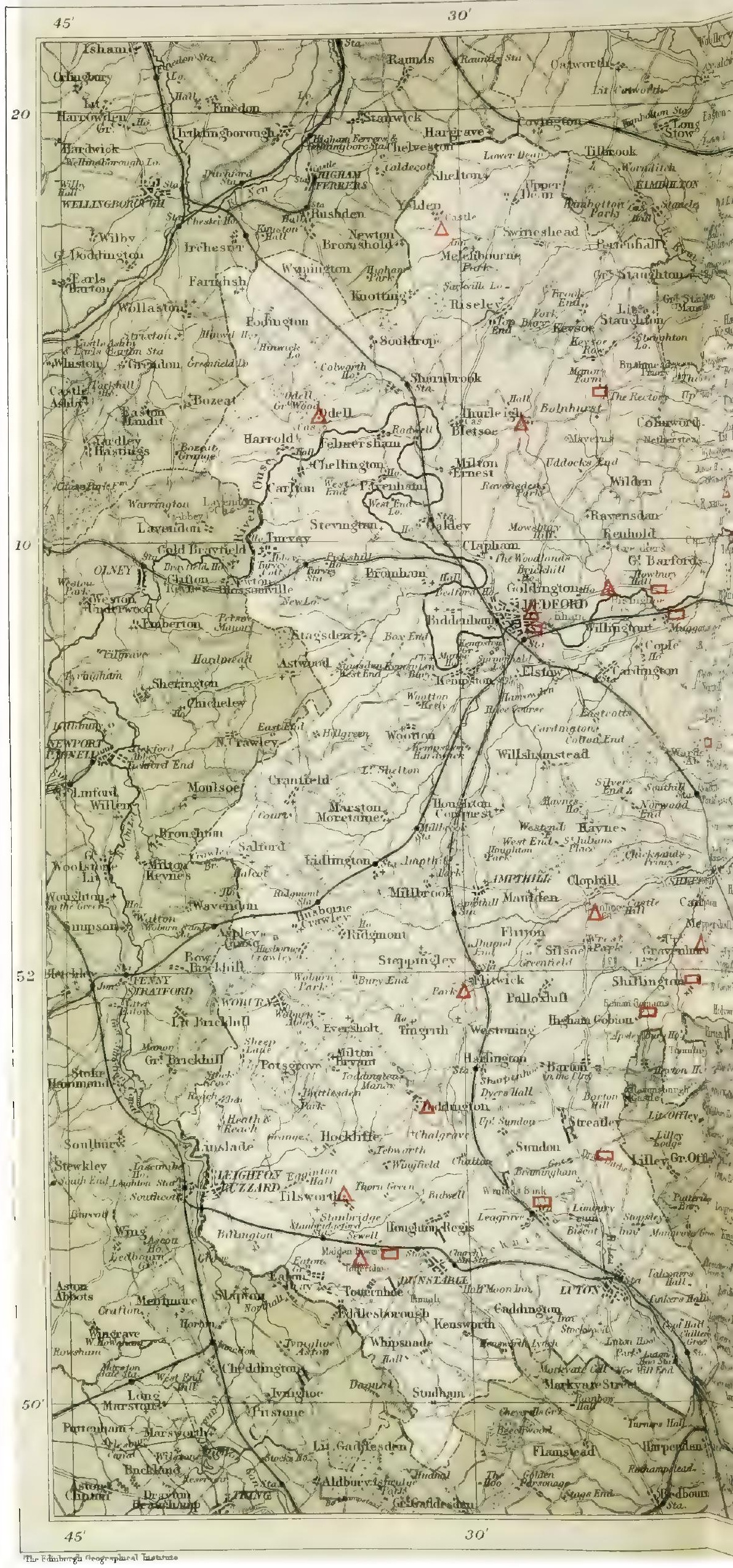


IWORKS

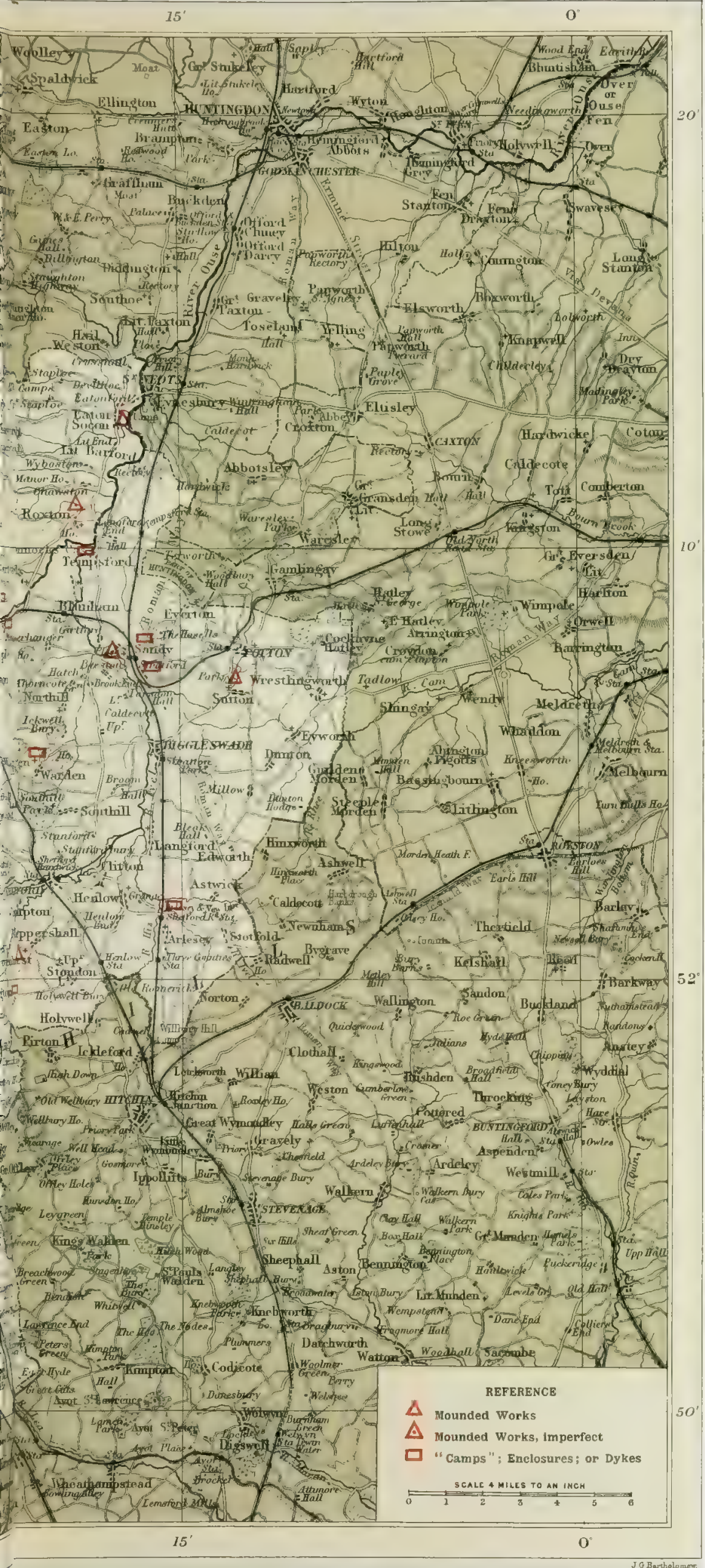





\section{ANCIENT EARTHWORKS}

7 HIS county possesses a very representative series of ancient defensive earthworks, although it has but few examples of the earlier types, and none of these has the large dimensions which distinguish them in other parts of the country.

It is clear to the observer that some works were intended for the occupation of great bodies of men, perhaps a tribe or military force, whilst others were evidently the personal strongholds of chiefs or lords with a more or less numerous following. This distinction presents us with a rough but useful method of classification, whilst it still leaves open questions of actual date or origin.

When we reach the period of the manorial stronghold, or its equivalent, whether of Norman or in some cases perhaps of even earlier foundation, it is interesting to note the gradual change which passes over the style of the work. At first these works, while providing for the residence of the lord, were of a strength and character fitted to withstand military attack, but as times became more settled they weakened into a form intended only for domestic defence or enclosure; the same change, in fact, that has been remarked in our architectural antiquities. Thus we have a natural transition from the mounded and stockaded hold to the meaner defences of the homestead moat. In a county which was poor in building stone, and before the revival of brickmaking, there was nothing left to those who desired even ordinary domestic security but to establish themselves by means of earth and timber.

Of the 'homestead moat' class our examples are very numerous. It is not by any means safe to suppose that they are all of later mediæval times. There are good reasons for believing that not a few of them may have belonged to pre-Conquest inhabitants. This part of our subject, however, calls for fuller investigation.

The very remoteness of many of our outlying villages and hamlets has tended to the better preservation of our earthworks and moats, but it has also increased the difficulty of access and study, so that this attempt to describe these works must be regarded only in the light of a preliminary survey.

Very little has been written about the earthworks of this county, except in the case of a few outstanding examples. This fact has necessitated a personal examination of every instance described, and the omission of some which might have proved well worthy of description. 


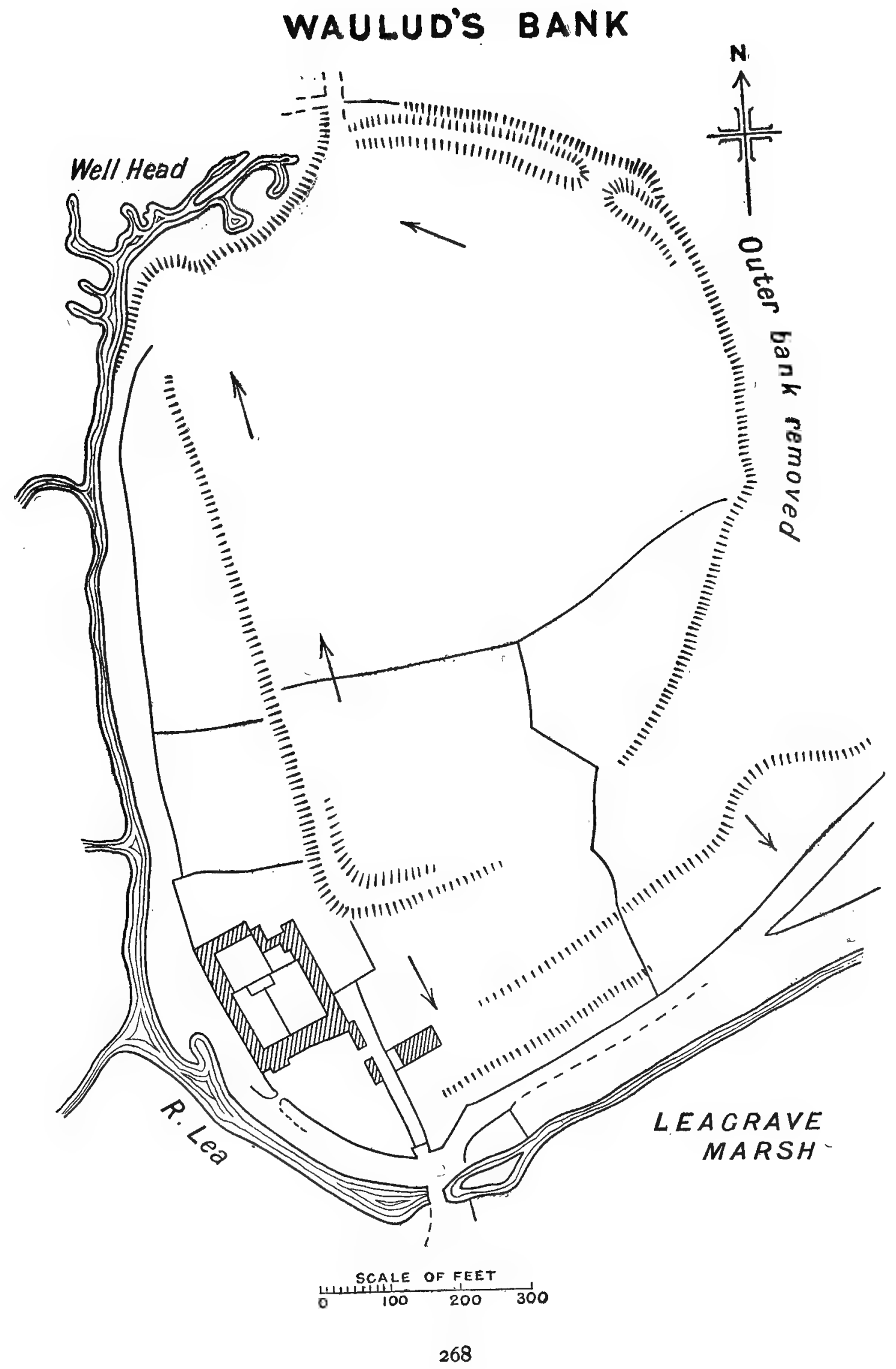




\section{ANCIENT EARTHWORKS}

\section{TRIBAL OR MILITARY WORKS}

(1) Wallud, oR WaUlud's Bank.-In Alfred's pact with Guthrum, 878 , he names the source of the Lea (Ligean) as the point at which the Anglo-Danish boundary was to leave that river and proceed northwards to Bedford. This point is marked by a very early work, which stands a little to the north of the Icknield Way, on a slope rising out of the Leagrave marshes, not far from Limbury. It is an irregular oval in plan, with one straight side, and is said to enclose some ro acres. To the north-west it makes a crescent-shaped bend about the well-head with its seven-branched springs, from which the Lea issues. The straight side next the river consists of a steep scarp 8 or 9 feet high at the south, but lessening in height towards the north. Here are no signs of rampart; probably the river was held to be defence enough. On its curved sides there are still traces of a great rampart and a wide fosse, running round the oval, and of a second rampart and fosse outside this again. Old inhabitants still speak of this outer line and of its destruction, and the ordnance map of 1823 shows the remains as much more perfect than they are at present. A gap in the rampart on the north-east may have been an original entrance. The river also bends round the lines, and on the south in flood times creeps up to them. Over the whole of this area Mr. Worthington G. Smith has found hundreds of neolithic implements. ${ }^{1}$ Sir John Evans also refers to numerous flint implements found on the site. ${ }^{2}$

(2) Maiden Bower, near Dunstable.-This famous work is thus described by Camden : 'At a little distance upon the very descent of Chiltern Hills, there is a round military fortification, such as Strabo has told us the British towns were. It contains 9 acres and is called Madning-bowre and Madin-boure. . . . The swineherds now and then in the neighbouring fields find coins of the emperors, which they call to this day Madning money.' ${ }^{3}$ Stukeley says 'Madan Castle is circular, perhaps oval, the space within is a fine plain; the vallum is small, and the ditch much smaller; so that I am persuaded it was made rather for spectacle than defence.'" But he forgets the gradual reduction of both, which has still further progressed since his day.

An old green road, once an ancient way, parallel, and probably previous to, the Roman Watling Street, passes the field in which Maiden Bower (or Burb) stands, its curving vallum well in view, owing to the level nature of its site. Originally enclosed by a single rampart and fosse, the area within is a little over Io acres. The rampart at its strongest measures 28 feet at the base by $10 \mathrm{ft}$. 6 in. in height, but there remain only slight traces of the outer edge of the fosse, which was once 18 to 20

1 Mr. Worthington G. Smith in Man, the Primeval Savage (p. 342), suggests that the place may have been the Lygeanburh taken by Cuthwulf in his campaign against Bedford (Anglo-Sax. Chron. [Rolls Ser.], i. 33), and that the name survives in Limbury.

${ }_{2}$ Evans' Anct. Stone Implements, pp. 62, 253, 27 1, 369, etc.

3 Camden's Britannia (Gibson's ed. I 695), p. 289.

4 Iter. Boreale, p. 17. 


\section{A HISTORY OF BEDFORDSHIRE}

feet wide. On a portion of the northern circuit the rampart has disappeared. There were five entrances, on the north-west, north, north-east, south-west and south-east, from the last of which two ancient

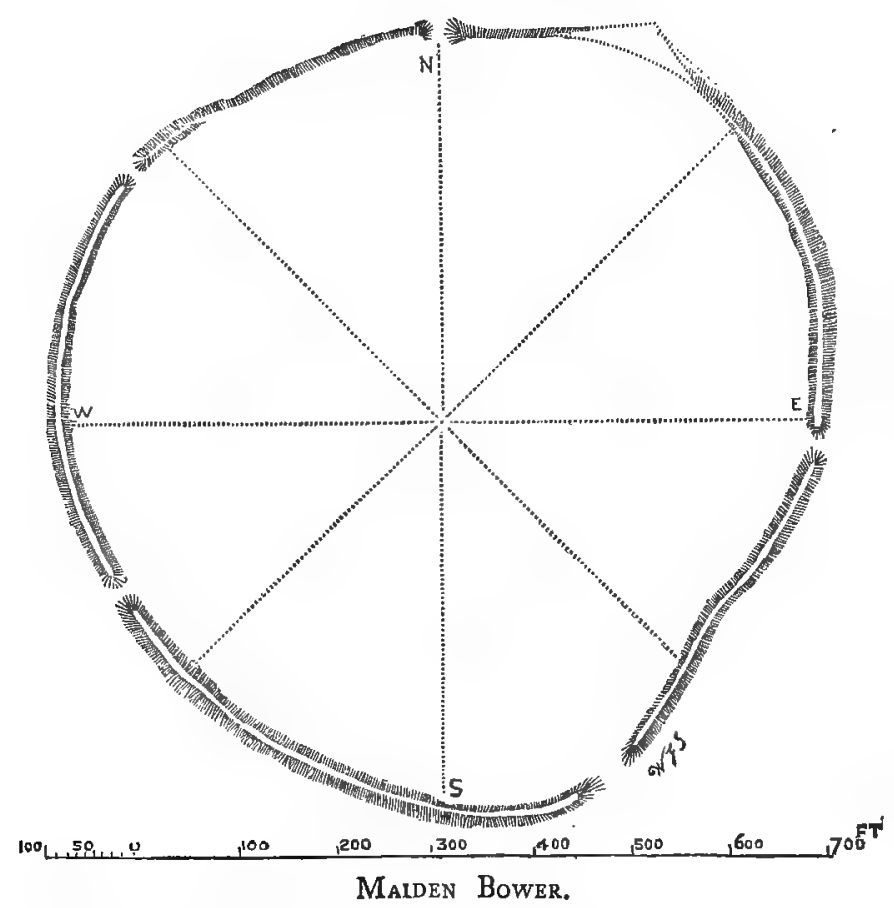
trackways led to a long tumulus on ground where Dunstable now stands, and to the barrows on the downs, known as 'Five Knolls.' The polar diameter is 775 feet across, and the transverse 750. Mr. Worthington G. Smith kindly allows the reproduction of his plan from the book already mentioned, to which I am indebted for the details given above. He states that 'the interior of the camp, and the fields outside, are (or have been) full of neolithic implements, celts, scrapers, arrow-heads,

hammer-stone fabricators and borers. Bronze tools, and a hoard of gold coins have been found, but I have not been able to trace them.' ${ }^{1}$ From the number of hut-circles, tumuli, and pre-historic remains which abound in the immediate neighbourhood, it is evident that these chalk downs must have been the home of man from a very early age.

The prevalence of this name, Maiden Castle, or Maiden Bower or Burh, is a curious fact which should here be noted, as applied to prehistoric, or at any rate very early encampments. It does not follow that the name is pre-Roman, for out of thirty-two examples which have been listed and mapped, ${ }^{2}$ from Aberdeen in the north to Dorchester in the south, it appears only in the country where the Anglo-Saxon speech prevailed, or in the border lands influenced by it. In purely Gadhelic or Cymbric lands where there are many similar strongholds, such as Cornwall, Wales, Ireland or Gaelic Scotland, it does not appear. This is however not the place to enter into the vexed question of its significance.

(3) Quint's Hill, or Quince Hili, Old Warden.-This is a mere fragment of a once redoubtable fortification. It stands on high ground to the north of the church. The site is so thickly covered with wood and undergrowth as to make it difficult even to examine it. There appear to be double ramparts and ditches of large proportions, which curve round towards the park, where the ground rapidly slopes away

1 Man, the Primeval Savage, $318,321$.

a Antiquary, xxxviii. (1902), 256 , and ensuing correspondence. 


\section{ANCIENT EARTHWORKS}

to the east. Faint signs of continuation on the turf of the park seem to suggest that the work may have completed a circuit, either circular

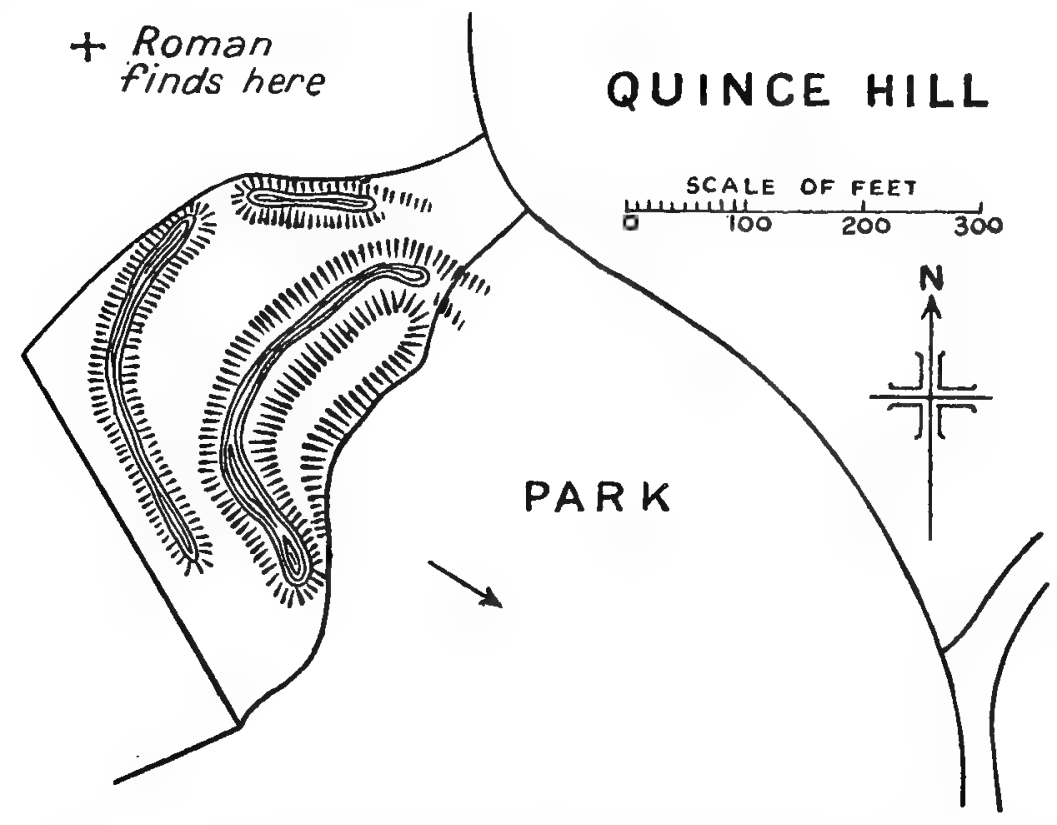

or oval in shape, in that direction. Roman remains have been found in a neighbouring field to the north.

(4) 'Casar's Camp,' Sandy.-At Sandy, which has proved the most fruitful field for the discovery of Roman antiquities in the county, there are two works of great interest, which may usefully be considered together. That it was a site of some importance in Roman days the remains which have been unearthed prove. Two Roman roads pass the spot, and the names Chesterfield and Stratford tell their own story of Roman influence.

' Cæsar's Camp,' so called, appears to be an early fortress or refuge station not unlike Mam Tor, except for the double ramparts. It is placed along the highest ridge of a range of sandy hills, with steep lateral slopes, except at the rear to the north, where the heights broaden out and round themselves into the vales with easier descent. On this side therefore there was the more need of strong defensive lines, but unfortunately this part of the work has been obliterated by the long-standing use of the ground for allotment gardens. The remainder is now occupied by the house and grounds of Guy Pym, Esq., M.P., and to that fact owes its better preservation. His boundary crosses the site from north-east to south-west, and along the whole circuit of the ridge within it the remains may be followed. They are strongest at the southern angle of the hill, which here rises some 80 feet or more above the plain. The enclosing rampart makes a sharp bend at this point, in following the line of the ridge, and ends in a small mound rising 3 or 4 feet above it, and about I I feet above the present level of the interior. The rampart is 8 feet high inside and 20 feet outside, where its steep scarp ends in 


\section{A HISTORY OF BEDFORDSHIRE}

a broad terraced ledge which continues round about two-thirds of the east and west sides, where the descent is at the sharpest. This terrace may be the remains of an external fosse, or it may have been always a road, as it now is, for it slopes away down the hill on the west soon

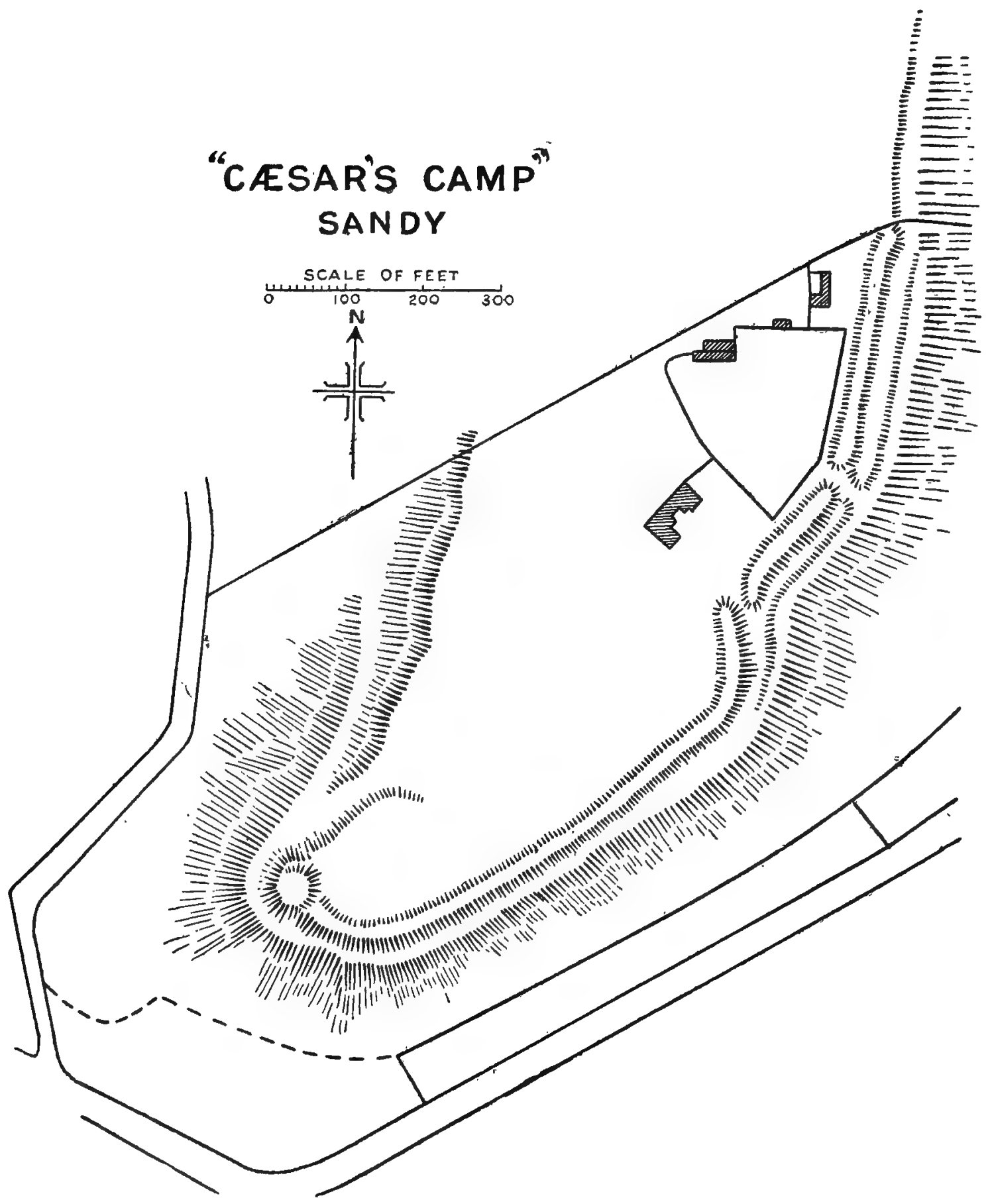

after leaving the mound. On the eastern heights the rampart, if there was one, has disappeared, but on the west it continues along the top of the ridge up to the boundary on the north, and there are clear signs of its course in the fields for some 500 feet beyond, until it dies out at the 


\section{ANCIENT EARTHWORKS}

intersection of the old Cambridge road, which here crosses it at a right angle in the dip below. It is not unlikely that this marks the extent of the encampment at this point, and that the old road turned round its northern end.

About half way along the eastern side, where the slope becomes less steep, the lower terrace referred to becomes a fosse, which follows with the rampart up to the boundary, where it is lost. The commencement of this fosse is close to an original entrance, which is commanded by a bend of the rampart on each side of it. A break of the edge of the heights on the west, near the mound, may also mark an entrance, although the rampart is here missing.

The area of the part which can be defined is about 7 acres, and the interior has been much levelled to form a garden.

In digging, small bronze coins of the minimi type, much defaced, are often found, and fragments of a coarse thick pottery, not made on the wheel. There are no springs in the enclosure; well-water only occurs at a depth of 180 feet; and the present channel of the Ivel below is a quarter of a mile distant. The slopes of the hill are now thickly covered with firs, but Lyson's drawing ${ }^{1}$ shows the whole site bare, a long terraced hill, with rampart well marked, not unlike Old Sarum.

Camden says that the Danes during their Tempsford campaign, ' demolished (as 'tis thought) that British fort, the place whereof is now call'd Chesterfield and Salndy, which often gives fresh proof of it's antiquity by throwing up Roman money. ${ }^{2}$ On what authority is not stated. The position of the work on this commanding height, its irregular following of the line of the ridge, and the style of its defences, seem to mark it as of native construction, before or about the time of the Roman occupation.

(5) The Galley Hill Camp.-On a sister height, covered with wellgrown firs, about three-quarters of a mile south from 'Cæsar's Camp,' stands the second entrenchment, in the grounds of Lord Peel. It is a smaller work, nearly oblong, and shows strong signs of Roman influence, being nearly rectilinear and rectangular, with rounded angles. It is placed on the southwest end of the ridge, which sharply slopes away from the rampart on three sides to the plain 50 or 60 feet below. On the fourth side to the north-west a single vallum and fosse crosses the flat continuous ridge of the hill. Round the rest of the work the rampart is double, except above the eastern scarp, where all traces of it have disappeared. The lower rampart top is 6 feet below that of the upper, and between them the fosse continues round some 20 feet in width. The double work is strongest at the angles, as in the middle of the flanks it has worn away to little more than a lower terrace on the hillside. The interior measurement on the south is 343 feet, and on the east 273 feet; thus its proportions are as $I$ to $I \frac{1}{4}$. There is a gap in the north-west rampart facing the ridge, a little east of the centre, which has the appearance of an

1 Add MS. 9460, f. 25.

2 Camden's Britannia (Gibson's ed. 1695), p. 288. 


\section{A HISTORY OF BEDFORDSHIRE}

original entrance. A footpath also enters the work on this side near the north-west angle, where the rampart is again pierced and the moat partly filled, but this seems to be too near the edge of the scarp to be original. There is a further breach on the north-east, where the angle is entirely removed with all the eastern rampart. This breach shows the section of the vallum, which is here 9 feet above the bottom of the fosse, and about 4 or 5 feet above the interior level. It is composed of the sand and shaly ironstone which is native to the site. The fort could only have been approached on anything like even terms from the level ridge on the north-west. The whole area of the camp was under cultivation up to forty or fifty years ago. Trial trenches dug under Lord Peel's

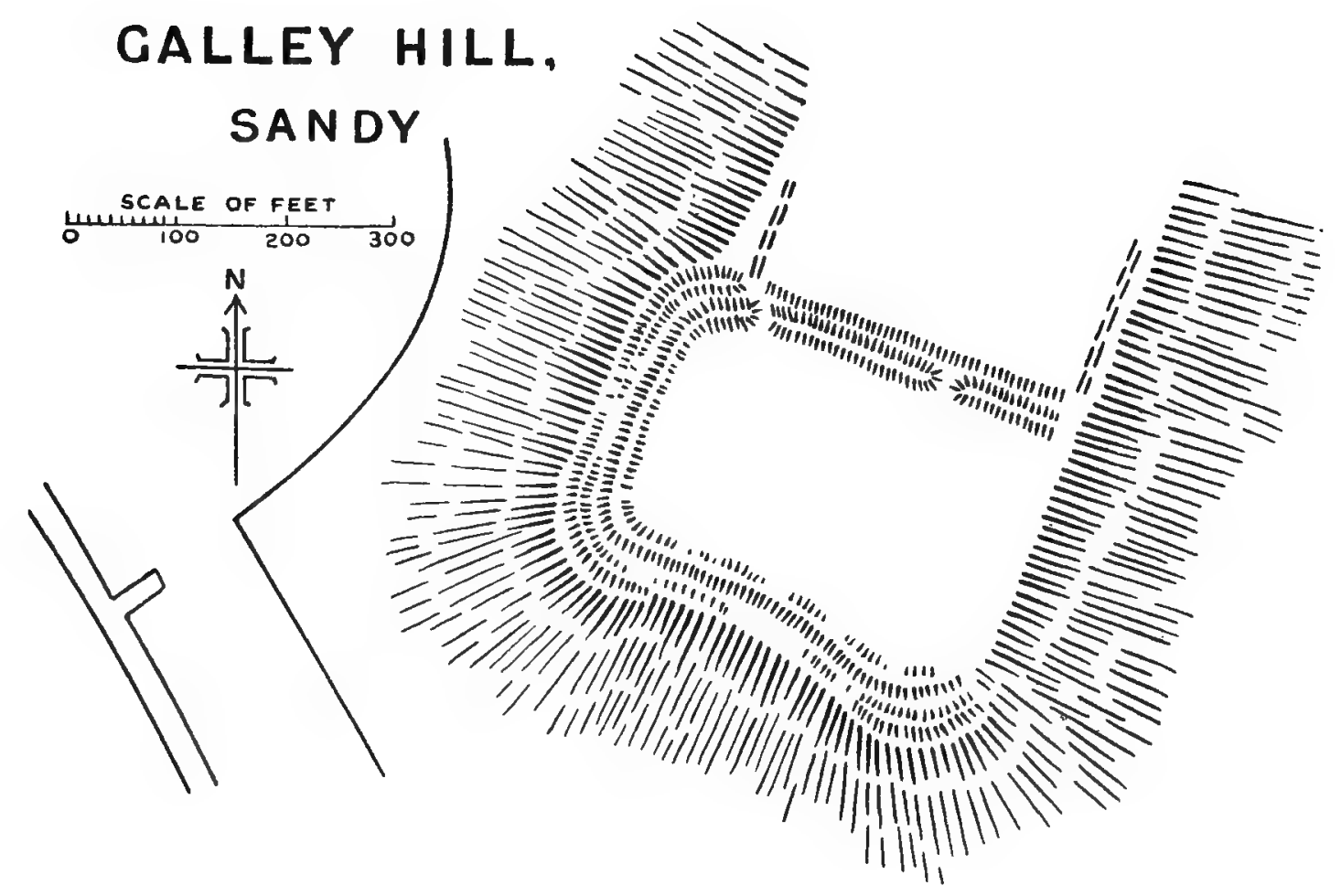

instructions within the entrances in the north-west vallum have revealed nothing of interest.

There is the same want of water as in the case of 'Cæsar's Camp,' and the Ivel is even further off. Chesterfield is the name of the level ground between these two hill stations, now partly occupied by the cemetery. All over this large area, including the part cut off by the Great Northern Railway, Roman remains continue to be found. On the heights round about Lord Peel's residence, Roman coins are dug up, mostly of the middle or later emperors, although there is no record of their having been found within the Galley Hill camp. There are also signs of other earthworks on these heights, which call for further examination. 


\section{ANCIENT EARTHWORKS}

(6) Bolnhurst.-Partly in the ground occupied by the Manor farm, and partly to the south of it, there is a work of large extent, which is here included because of its size and irregular shape. It stands in

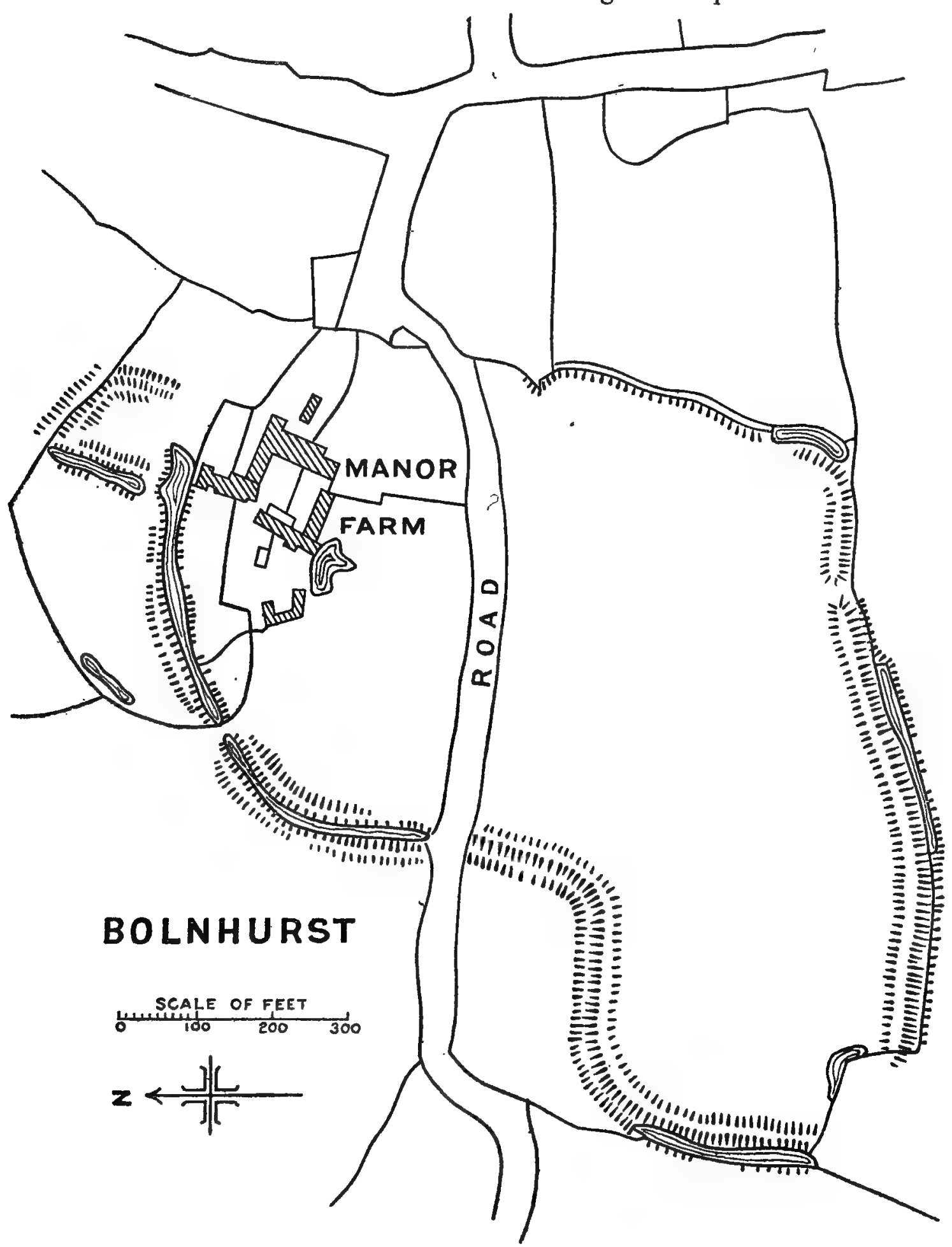

fairly level country, and is cut in two by a road. It was surrounded by a great rampart and ditch, the lines not being straight but curving round the enclosure. It does not often happen that such works 


\section{A HISTORY OF BEDFORDSHIRE}

are divided between different ownerships, which is the case here, the Manor farm holding only about 5 acres of the northern end. It would appear as though the manor had planted its homestead and the moats belonging to it within the area of some earlier work. The interior rampart is only strongly seen on its western side, where there is also a considerable stretch of a second rampart outside the moat, which here has much water in it.

The southern portion of about 10 acres is all pasture; a great close known by the name of 'Obness.' The stretch of rampart to the south of it is very large and fine, with an apparent entrance towards its east end. At the west the corner of the work is gone, but the lines curve round northwards towards the upper portion, with the bank again large and the ditch in parts about 18 feet wide. The ground slopes away gently from the south side of the work. There are no signs of any outer rampart anywhere about this southern portion of the work. The present occupier speaks of finding a number of flints in his moat quite recently, which he describes as curiously shaped and cut. These may have been implements. He intends to try to recover them. Parts of the farm buildings are about two centuries old.

There are three curious works in the low and once marshy lands watered by the Ivel and its branches.

(7) Shildington.-Half a mile to the north-west of the high hill on which the church stands there is an entrenchment, obtusely semioval in plan, known as 'Church Panel.' It encloses a squat knoll, a little less than 3 acres in area, which must once have been an island in the midst of former swamps. The rampart is strong, and continues round the curving sides outside its fosse, which is 30 feet wide. A stream, 8 to 10 feet broad, flows past its straight north-eastern flank, banked up along a great part of its course, both within and without the enclosure. The knoll is highest at its south-east end, and is there scarped down to the ditch to a depth of some ro feet, but falls gradually towards the north-west, where a large interior bank is added round the lower portion of the work. An old watercourse, strongly banked, runs past this end, touching the outer rampart. The neighbouring fields are crossed in various directions by wet ditches and banked-up streams, and 200 yards to the north a larger stream, I 2 to I 5 feet wide, runs past, diked up well above the level of the low-lying lands. In flood times all this low ground is covered and the knoll alone stands out. But for the banks which confine the streams it would lie continually under water. There is a small oblong sinking, near a disused gravel pit on the top of the knoll, which should be examined for foundations. The place has very much the appearance of an old refuge station in the fens, such as Alfred may have made at Athelney. Homestead enclosures were associated with more serviceable land.

(8) Higham Gobion.-Here is a somewhat similar work lying very low in the fields a quarter of a mile to the north of the church. It is called 'The Camp,' and is roughly triangular in shape, fenced in by a 276 

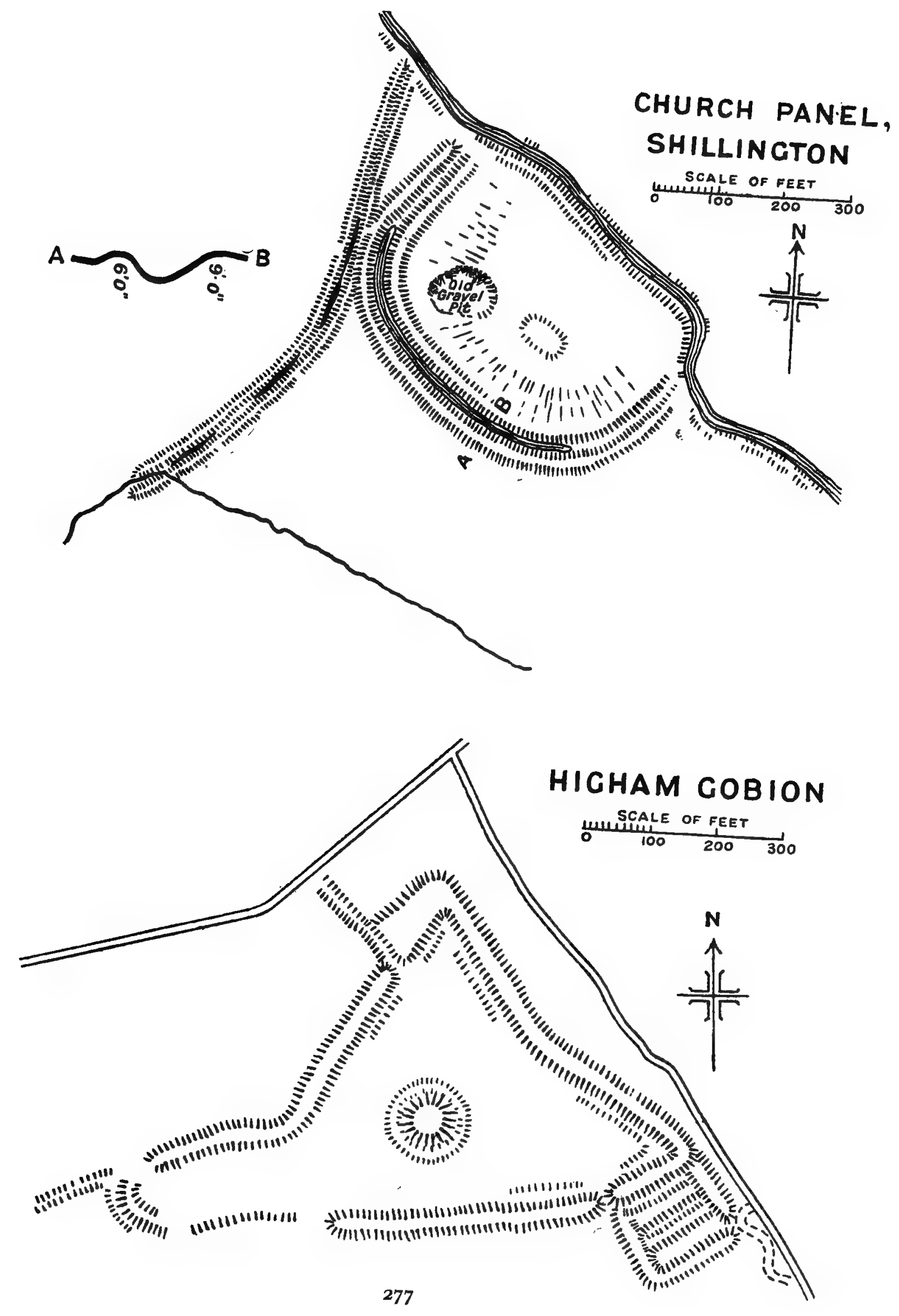


\section{A HISTORY OF BEDFORDSHIRE}

broad low external rampart with faint signs of a shallow interior ditch. The rampart averages 35 feet in breadth by some $4 \frac{I}{2}$ in height, except near its north angle, where it suddenly widens to 5 I feet. At this point a ditch runs through a break between the broad and narrow banks in the direction of the brook. In the centre of the enclosure is a low circular mound, about roo feet across the base, and 45 at the top, with a shal-

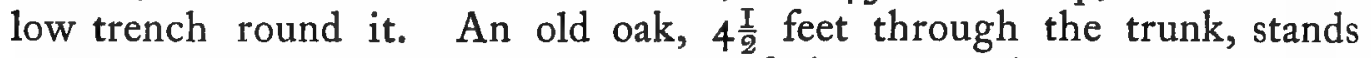
on its north slope. At the east angle of the external rampart are three narrow oblong depressions, with a lower bank enclosing them, which may have been fish stews. The internal area of the triangle is a little over 3 acres, and there seem to have been three entrances-one near the broad rampart on the north, and two near the ends on the south side. It is difficult to tell whether this place was a station secured by surrounding marsh or a piece of artificial water with the mound for an island. In the first case it may be of early origin ; in the latter of much later, and perhaps connected with the former manor-house on the hill.

(9) Etonbury or Stonbury, Ardesey.-These curious remains are within a stone's throw of Arlesey station on the Great Northern Railway, which runs on a great embankment through the western side of the work, thereby making it impossible to decipher its plan.

The position occupies the edge and slope of a great plain. The Ivel flows past it on the west, on the other side of the railway. It consists of two features-a main fort near the river, strongly held to the north by great ramparts and fosses, and with a wide expanse of broad moats on the south where the ground is low, probably fed from the Ivel ; and a very large oblong outer work, which still has the remains of strong entrenchments to the north and east, measuring about 1,200 feet by 600 . The rampart to the north of the oblong is still fine, standing in some places about 8 feet above the bottom of the broad outer ditch. Remains of a second rampart and ditch appear near its eastern end. Much of the larger ditch has been lately filled in, especially where it approaches the main work. There appears to have been an entrance at this point commanded by the towering rampart and mound of the inner defences, of which the outer fosse is almost a ravine, about 50 feet across and 10 feet down to the water level, above which the rampart rises again to a height of $\mathrm{I} 2$ feet, and the mound some 3 feet higher. Each of the ramparts of this inner work ends in a similar mound, and there is another on the east side of the moat, suggesting that there was a bridged main entrance here to all parts of the inner work, strongly commanded by these mounds. On the west, Lyson's drawing ${ }^{1}$ shows the two ramparts as ending suddenly at the top of the slope down to the river and without any return. This part has been broken through by the railway bank. The broad moat on the south is carried round a large flat area raised slightly above the general level. In many places there are the remains of a low rampart on the outer edge of the broad moat, and on the west a small dam stretches across it, leaving

1 Add. MS. 9460 , f. 25. 


\section{ETONBURY}

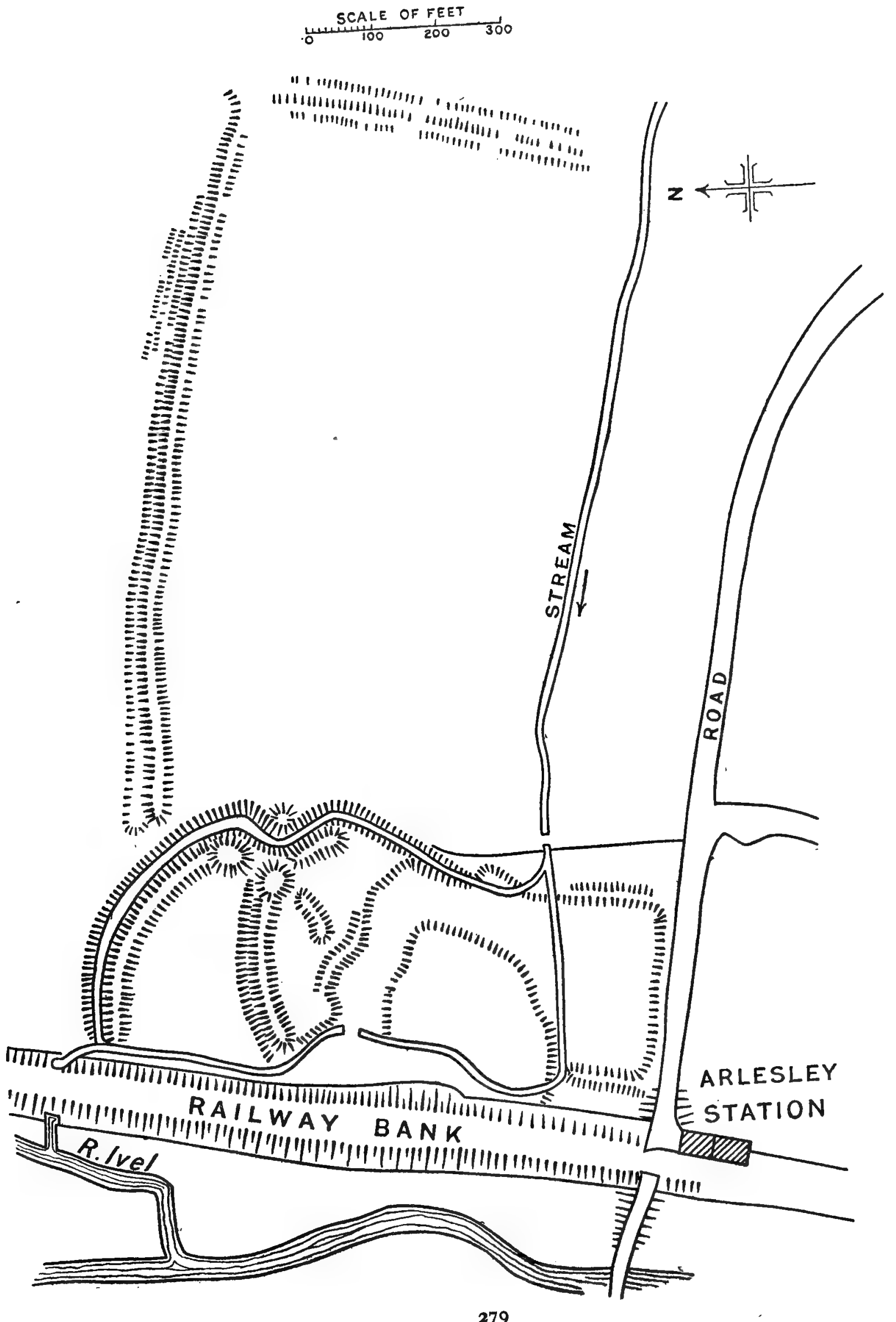




\section{A HISTORY OF BEDFORDSHIRE}

only a narrow mouth for communication with the river. A small stream runs through the lower part of the site, which was a few years ago turned into the outer moat, possibly deepened for the purpose. Formerly it continued into the river, under the railway bank. Whether this stream flows in its original course is uncertain, as it has the appearance of a later straight cutting. There is a short moat-like sinking inside the inner rampart, as though further to divide the ward within. How the work was closed in on the south is not clear. Possibly the road covers the line of the defences.

In the present state of the remains nothing can be suggested as to its origin, except that the small mounds at the ends of the ramparts are found in works reputedly Danish, and the shallows cut near the river, which are unlike defensive moats, may have sheltered their shipping.

(1o) Dray's Ditches near Limbury.-Following along the old Icknield Way from Limbury, in a north-easterly direction, two isolated hills are reached-Warden Hill and Galley Hill. Under the east slope of the latter is a very large irregular enclosure, with slight bank and ditch, evidently not defensive, all round it. The stretch which lines the Icknield Way is more than half a mile in length. The ground within is a dead level and is under cultivation. On the slopes of the hill above, the ordnance map shows four tumuli. To the south, a strong line of entrenchment runs parallel with Dray's Ditch, I,000 feet in length, pierced almost at right angles by the Icknield Way. Much of it has been levelled, but at the western end the rampart rises 9 feet above the bottom of the external fosse to the north, which is here 12 feet across. What was the purpose of this great enclosure it is difficult to conjecture.

EARTHWORKS ALONG THE OUSE FROM BEDFORD TO TEMPSFORD

There is an interesting series of earthworks along the line of the Ouse from Bedford to Tempsford, 8 miles distant, which appears to be

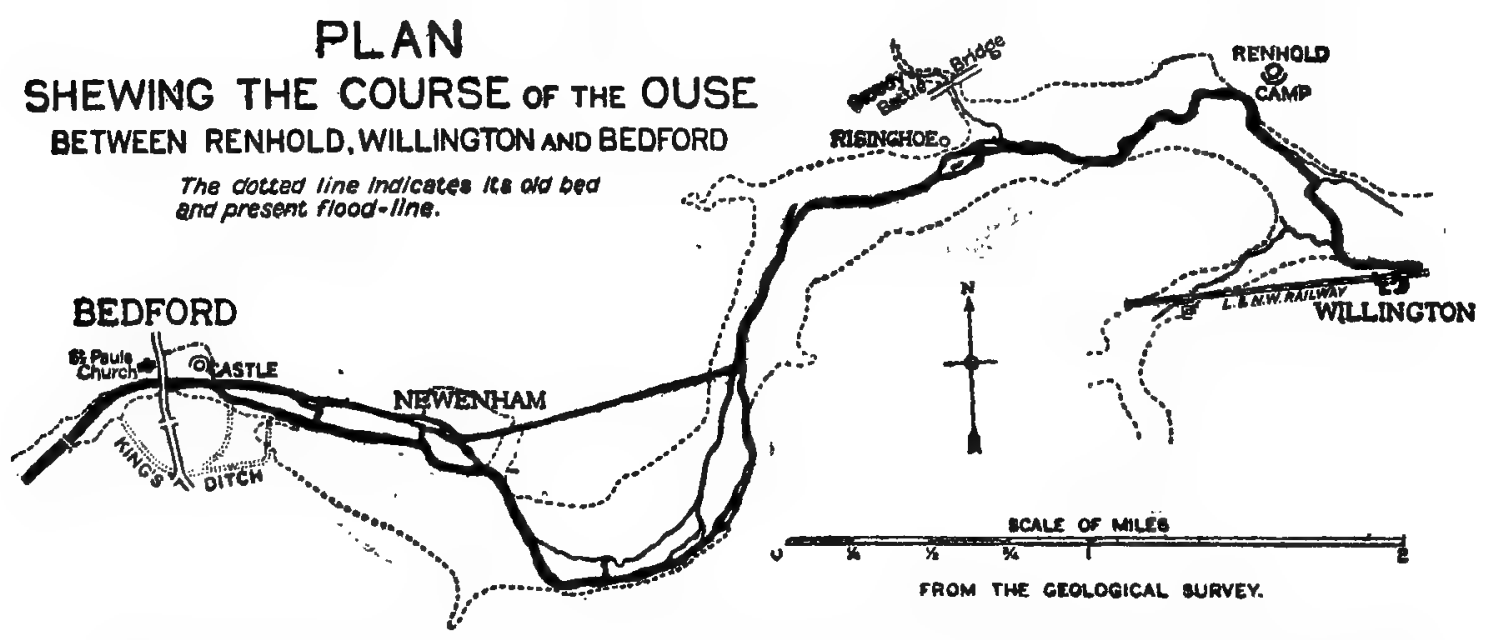

connected with the campaign of 92 I between Edward the Elder and the Danes and Northmen of East Anglia.

1 Anglo-Saxion Chon. (Rolls Ser.), i. 194. 


\section{ANCIENT EARTHWORKS}

(I) The 'King's Ditch,' Bedford.-The Chronicle ${ }^{1}$ tells us that King Edward 'went with the army to Bedanforda, and gained the burgh, .. and he remained there four weeks and commanded the burg on the south side of the river to be built (atimbran) before he went thence.' This was in 9ig. Previously the town, with whatever fort commanded the ford, was on the north side. Mr. G. T. Clark assumes that this entry implied the rearing of a mound, for which there is no evidence, nor even a tradition. There is however a work on the south of the river which may fairly be attributable to this month of labour. It is a very ancient cutting which describes a circuit from a point on the river to the west of the town to a point on the east, about half a mile distant. It is shown in Speed's map of 16 Io. The river still runs through this cutting, and in flood time it is full to the brim, Io or I 2 feet across. In recent times it has been shortened on the east, but the old course is still strongly marked, and flood water takes possession of this too. Some traces of an interior rampart are here still visible. This work goes by the name of the 'King's Ditch,' and when stockaded would form an effective defence for Edward's new garrison. The ditch is carefully maintained and is a notable boundary of property.

It has also been suggested that this cutting may have been a waterway made at the time of Henry the Third's great siege of Bedford Castle in 1224 , but this siege is described with so much minuteness in the old record ${ }^{2}$ that an important detail such as the making of this 'ditch' must have been recorded. Moreover it is evident that the besiegers with their engines were drawn round the castle very closely, and a comparatively remote water-way could have been of little service. It should also be noted that two Norman churches, one very early, stood half-way between river and ditch, on the line of the main road to the bridge.

(2) Tempsford.-Two years later the East Anglian Danes abandoned Huntingdon, their headquarters, and moved up the Ouse to Tempsford, where they 'wrought TEMPSFORD a work' and established themselves. At this place, on the south of the Ivel, near its junction with the Ouse, there remains a strong little fort, which all our earthwork authorities assign to this occupation. Mr. I. C. Gould says: "This example is of great value, as we know the date of its construction.' Mr. J. H. Round describes it as ' an advanced post of the Danes.' It stands about 200 yards

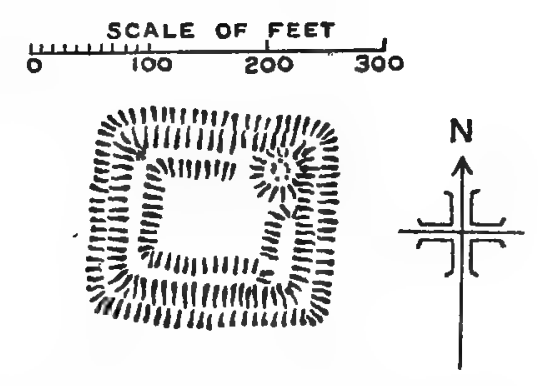
from the former bank of the river, and is oblong in shape, being about I 20 feet by 84 feet within the ramparts, which remain on three sides to a height of I I or I 2 feet above the bottom of the moat. The moat

1 Anglo-Sax. Cbron. (Rolls Ser.), i. I92. $\quad 2$ Ann. Mon. (Rolls Ser.), iii. 86-9.

3 Fourn. Brit. Arch. Assoc. 'Early Defensive Earthworks,' p. $22 . \quad 1$ Quart. Revier, July 1894. I 28 I 


\section{A HISTORY OF BEDFORDSHIRE}

averages 20 feet across, and is strong on all four sides. The eastern rampart has been mostly removed. The entrance appears to have been at the north-east angle close under a small circular mound on the rampart, rising a foot or two above it, and 20 feet across the top, which is edged all round by the root of a small bank which may have been the base of a stockaded tower. The fields to the south and east are scored with traces of other lines, where probably the rest of the station stood, but they are too faint to decipher. The ground slopes from east to west, so that the west end of the little fort rises considerably above the lower levels. It seems to have been a kind of projecting exterior keep. Its local name is 'Gannock's Castle' or 'The

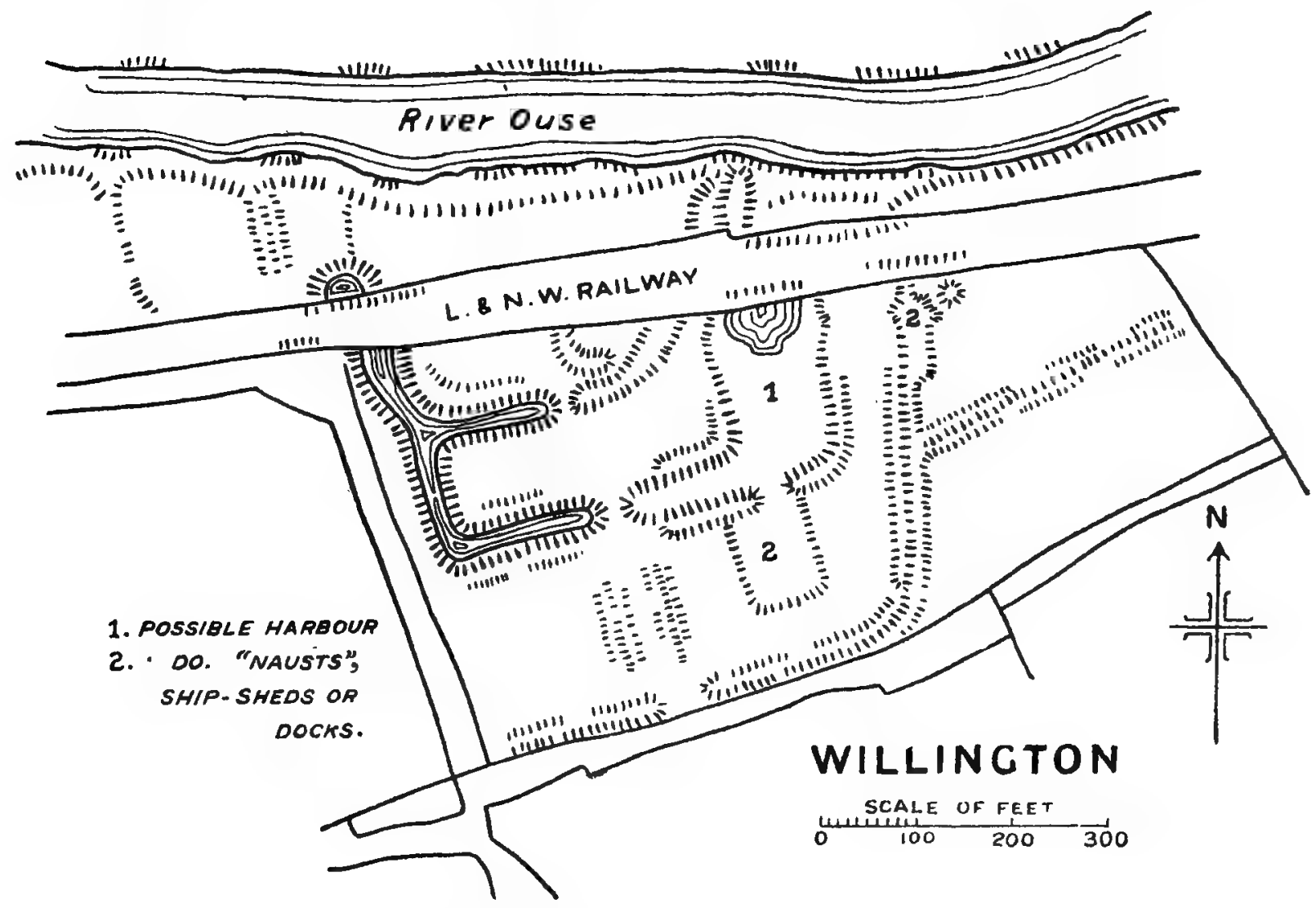

Gannicks.' At the close of the campaign the place was stormed by the English with great slaughter of its defenders. It is very probable that this and other works of the kind became, later on, the site of defended homesteads, as they could easily have been adapted for the purpose.

(3) Willington.-Four miles nearer to Bedford, still on the south of the Ouse, there is another work with certain unusual features, which appear to mark it also as Danish. It stands on the old original bank of the river, which flows immediately beneath it. The former river bed lies between it and the northern original bank, half a mile across, and is wholly covered in times of flood. The site of the camp is a plain, and all the lines of entrenchment are dug out much on one level. There is an inner ward, an outer ward and a wide exterior enclosure. 


\section{ANCIENT EARTHWORKS}

The London and North-Western Railway cut through the work 40 years ago, but the broken lines may be traced on each side of it. A moat, averaging 40 feet in breadth, pierced for the entrance on the south, encloses the inner ward. There are remains of a strong interior rampart, which on the east side leaves the moat and turns back towards the river, starting from a circular mound commanding the entrance. The same moat then continues in a straight line on the west until it bends at a right angle to enclose the outer ward. It also is stopped for the entrance, and then continues, 30 feet wide, until it joins a much broader flatbottomed cutting which comes up from the river at a right angle. This measures 68 feet across the top, and gradually widens to 104 feet at the bottom, shelving down towards the water all the way. It is 170 feet long to the point where the railway embankment interrupts it. On the other side of the line, the old river bank of hard gravel, I 2 feet high, is sliced through to meet it, some 230 feet in width, and the water bays in at this point as into a harbour. The two other moat ends which appear on this side of the line are stopped before they reach the water, with only narrow runnels in communication with it, which may or may not be original. The Rev. A. Orlebar, vicar of the parish, remembers that before the line was made the water invaded the whole extent of this harbour, and in winter it used to be a favourite haunt of skaters. At the harbour head there are ramparts on both sides, some 8 or 9 feet high above its bed ; and also on both sides of the moat which joins it.

Outside all these works, and enclosing them, the outermost entrenchment ran, well preserved on the east side and evident on the south, although a modern road occupies the fosse. The east fosse is 20 feet in width, and the inner rampart 6 feet above the bottom of it. Following down towards the river a curious feature occurs near the railway. The moat suddenly widens into a small oblong 35 feet wide by 72 feet long by 6 feet deep, and then continues down towards the harbour mouth. These dimensions are almost the same as those of the 'nausts,' shipsheds or small docks of the old Vikings in Iceland, such as the Flókanaust on the Vatsnfiord, intended for the single ship of Hrafn Flóki, one of the earliest settlers in the ninth century. His ' naust' was close to his house, and the outer wall of it was an earthen bank, as here. ${ }^{1}$ At the head of the harbour is another oblong sinking, I I 0 feet by 60 feet, and there is a gap in the rampart between it and the harbour of 25 feet to allow of communication. The west side of this enclosure is shelving, but the other two are clearly cut, and its level is slightly above that of the harbour. This may have been another 'naust' or dock.

The distance between the side of the harbour and the small 'naust' is 60 feet. The latter has two shelving entrances at the foot, some 18 feet wide, and there is a similar depression in the side of the harbour. ${ }^{2}$ Close to the eastern entrance to the 'naust' is the root of a circular mound, 25 feet in diameter by 3 feet high. There is a small additional

1 Thorsteinn Erlingsson, Ruins of the Saga Time (Viking Club), p. 87.

2 The Northmen were wont to drag their ships overland on rollers, which they carried with them. 283 


\section{A HISTORY OF BEDFORDSHIRE}

court to the east of the main enclosure, as though for extra defence to 'naust' and harbour. Its bank and ditch are lost in ploughed fields after reaching the hedge, but their return may be traced on the other side of the line.

The Northmen were accustomed to provide some such shelter for their fleets when campaigning, ${ }^{1}$ and this work is described with some detail because of its situation on the line of their advance on Bedford. They may have left their ships under guard here before crossing to the north bank of the Ouse, where the fighting certainly took place. The harbour would have space for between twenty-five to thirty ships of the Gokstad type, which would allow for a force of about 2,500 men. That there is no reference to Willington in the Anglo-Saxon Chronicle may be due to the fact that after their defeat the Danes withdrew on Tempsford, where the next recorded fighting took place. Not having been itself the scene of battle, Willington might easily pass unnamed.

(4) RenHoLd.-On the north bank of the river, opposite to Willington, there is a curious small circular work on a commanding height.

It is surrounded by defences

\section{RENHOLD}

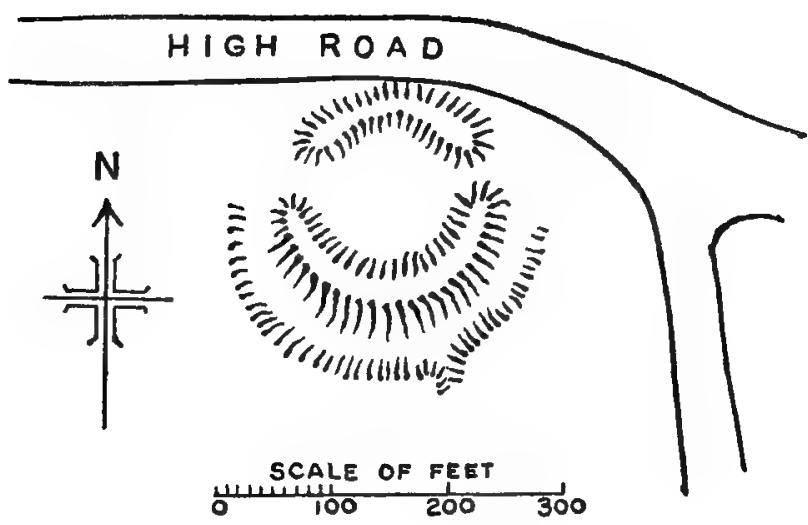

of disproportionate size for the scale of the enclosure, which is only I 20 feet in diameter, whilst the rampart is some 40 feet broad at the base, 8 feet high above the inner level, and I I feet above the fosse outside, which is 50 feet across, and at present of very flat section. This is due to the fact that twenty-five years ago it was drained of its water and then filled up. Formerly the depth must have been in proportion to its breadth. Now it is only 3 feet, and towards the rear the ditch has been almost obliterated. Water still stands in a portion to the south. There are entrances at the east and west, through which an old road once ran, the latter being double the width of the former. As the rampart near it and especially to the north has evidently been tampered with, the gap here may have been widened. The high road between Bedford and St. Neots runs past the north rampart, and the ditch has here disappeared; no doubt the shovel has been at work to level the sides of the road. An old man of eighty remembers the road before it was hedged, when the work lay open and untouched. On the high flat ground between

1 The Jomsviking Saga speaks of a harbour made by Palnatoki the Viking at Jomsborg, perhaps on the Isle of Wollin. "There he had a large and strong sea-burg made. He also had a harbour made within the burg in which 300 long ships could lie at the same time, all being locked in the burg, (The Viking Age, Du Chaillu, ii. 162). 


\section{ANCIENT EARTHWORKS}

it and the steep slopes to the river on the south and west, there are many old lines of trenched work now almost levelled out. As this place is only 3 miles from Bedford, and near the scene of the conflict, ${ }^{1}$ it is possible that it may have been an outpost of the Danes, by means of which, with Willington, they secured the passage of the river. The older ordnance maps call it 'a Roman amphitheatre.'

\section{PERSONAL STRONGHOLDS; THE FORTIFIED SEATS OF MANORIAL LORDS}

The county is rich in various types of earthworks of this class which have certain features common to most of them, such as a strong central position specially fortified for keep or hall; mills, fishponds, and more often than not, the church ; and, outside all, lines of entrenchment enclosing a wide area. In one matter these sites are much alike : they are either deserted and left to the possession of 'conies' and great trees, or they are occupied by small farmhouses, often placed in the central hold. The first is nearly always the case with the moated mound series, which are the least adaptable to later habitation. In these the mounds are generally found in one of two forms, either (a) large, conical and flat-topped, often with a smaller mound superimposed ; or (b) small and semi-globular. (c) A third class consists of works with irregular mounds, or merely moated.

(a) WORKS WITH CONICAL FLAT-TOPPED MOUNDS

(I) Bedford CAstle.-This was the chief and greatest of these. ${ }^{2}$ It is first heard of in Stephen's siege (I I 36 ). The only remains now of its great entrenchments are the lower part of the demolished mound, i 60 feet in diameter by 25 feet in height, with, on the north and east, a fine segment of surrounding ditch, 50 feet wide by 8 or 9 feet in depth ; and parts of mounded work further north again, now covered with buildings. Not many years ago the last of its moats was filled in to make a road down to the river, and traces of others have come to light during excavation for the rebuilding of various business properties in the High Street, which stretched back some distance into the castle area. The mound, with the keep, which stood upon it, and the rest of the castle buildings were ordered to be destroyed after the great siege of 1224 ; since which time it has enjoyed centuries of peaceful life as a famous bowling-green. Leland, Camden, Defoe and Lysons all refer to it in this later capacity. There is no mention of any castle in Domesday.

It is often stated that some earlier stronghold stood on the site to

1 Leland speaks of a number of skeletons having been found 2 miles nearer to Bedford ; and five years ago, whilst the ground was being levelled in making the Russell Park, several more were found, lying east and west, with Saxon swords and spearheads, which are now in the council chamber. Between that point and this Renhold work, also by the river, stands the barrow-like mound of Risinghoe, close to a small bridge, always known as 'Bloody Battle bridge.'

2 Castellum editissimo aggere vallatum (Gesta Stephani [Rolls Ser.], 32). 


\section{A HISTORY OF BEDFORDSHIRE}

dominate the ford, but nothing can be learned about it, and the description of the Norman castle belongs to another section of this work.

(2) Flitwick.-Near the church, on rising ground known as 'Mount Hill,' stands a small ' mound and court' work of the figure-ofeight type. A circular moat averaging $3^{\circ}$ feet in width, and 6 feet

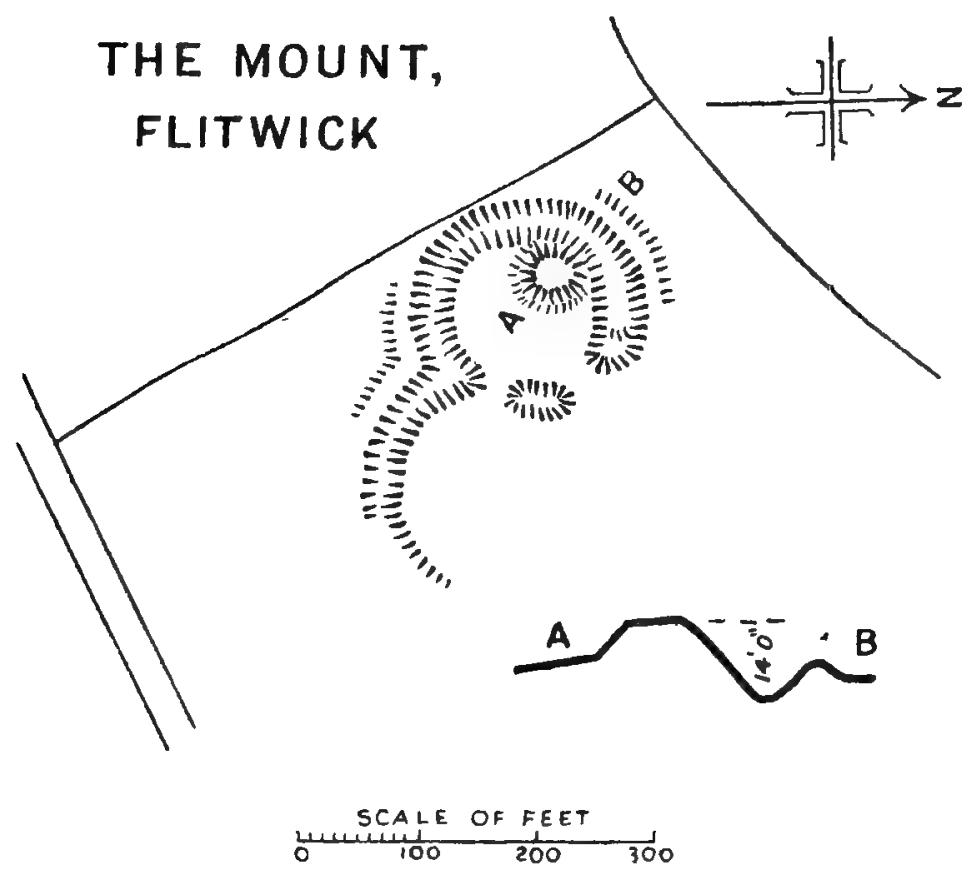

at its deepest, encloses a mound which is 102 feet in diameter across the top, and raised 4 or 5 feet above the general level. Its surface is fairly flat but slopes gradually up towards the west, where it is finished by a small round flat-topped mound, which rises I 4 feet above the bottom of the moat. There are remains of a strong rampart on the outer scarp of the moat, which towards the south commences its sweep to encircle

the base-court, which was considerably larger than the inner enclosure. Towards this court the circular moat is stopped in two places for entrances. There are traces of outer lines in the fields adjoining, but not many years ago these formed part of a large pleasure garden, and the lines have been almost obliterated.

This is true also of the north side of the base-court. The small upper mound was the site of a summer house and may have been modified. The river Flitt, an arm of the Ivel, is near. There is Norman detail in the church."

(3) 'Conger Hill,' Toddington.-This place occupies the highest point of a lofty tableland from which wide views of the country are obtained. A great round moat, 30 to 32 feet wide and 5 to 6 feet deep, entirely encircles the mound, which rises i 8 feet above the present bottom of it, with a flat top of 92 feet diameter. There is no trace of rampart on the summit, but here and there slight sinkings which suggest some sort of small enclosures. There are a few slight entrenched lines to the north-west in the direction of the church, which stands about I 00 yards distant, and a considerable length of moat I 2 feet wide by 2 feet deep runs past quite close to the great moat edge on the east. 


\section{ANCIENT EARTHWORKS}

This outer moat has no rampart, and proceeds almost due north and south, dying out before it shows any sign of turning. From this moat

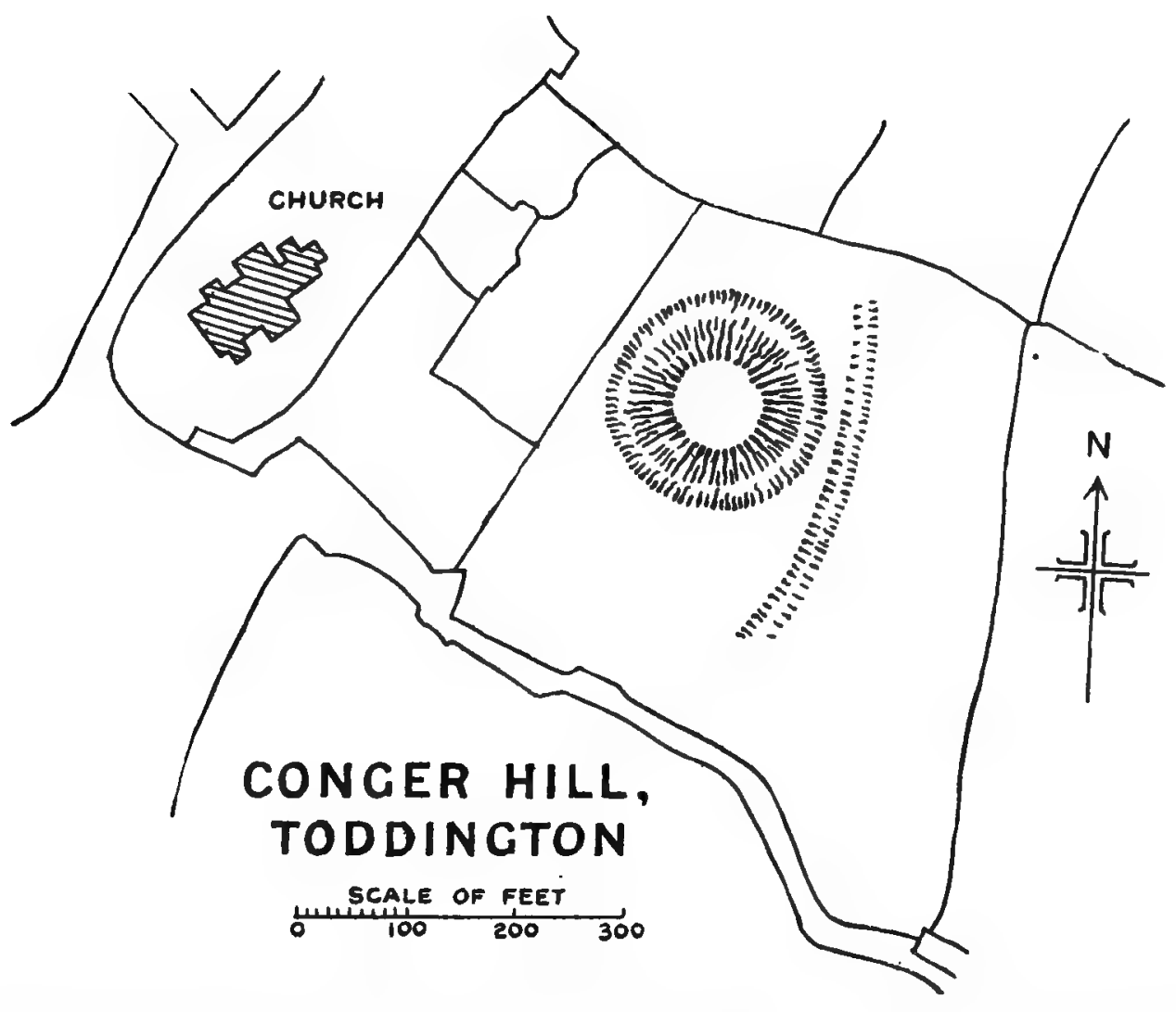

the site slopes gradually away to the south, where there are remains of a large bank near a brook, which was probably a dam. No signs of the outermost enclosing lines are now apparent. Fisher publishes a view of Conger Hill in his Collections (18 12 ). The Lysons ${ }^{1}$ stated that near it were ' considerable earthworks' in their time.'

(4) The 'Bury Hill,' Thurleigh.-Fisher's drawing finely shows the impressive nature of the great moated mound at this place, and its near association with the church, in which is a tower and north door of early Norman date. It also stands on a lofty height, which slopes rapidly down to a low-lying stream on the west and south. The mound was of the conical type with its summit in two levels, the higher of which is crowned by a small circular hold with low ramparted edge. In the centre of this stands a great walnut tree 12 feet in girth. There is no bank anywhere else on the mound, which rises some 23 feet above the bottom of the fosse, on the east, where the work is best preserved. The fosse is about 25 feet across and 8 or 10 feet in depth on the east, north and west. Here there are also fine remains of the great rampart on the outer edge of the scarp. On the south side all these features are almost worked

1 Mag. Brit. i. I43.

2 At the time of Domesday Toddington was a large and very valuable manor held in demesne by Ernulf de Hesdin. 


\section{A HISTORY OF BEDFORDSHIRE}

out, and in recent years the mound itself has here been dug away in order to level the ground. This spoliation has now been stopped. During its progress many skeletons were found in the side of the mound, but no signs of masonry. A farmstead, some two and a half centuries old, occupies

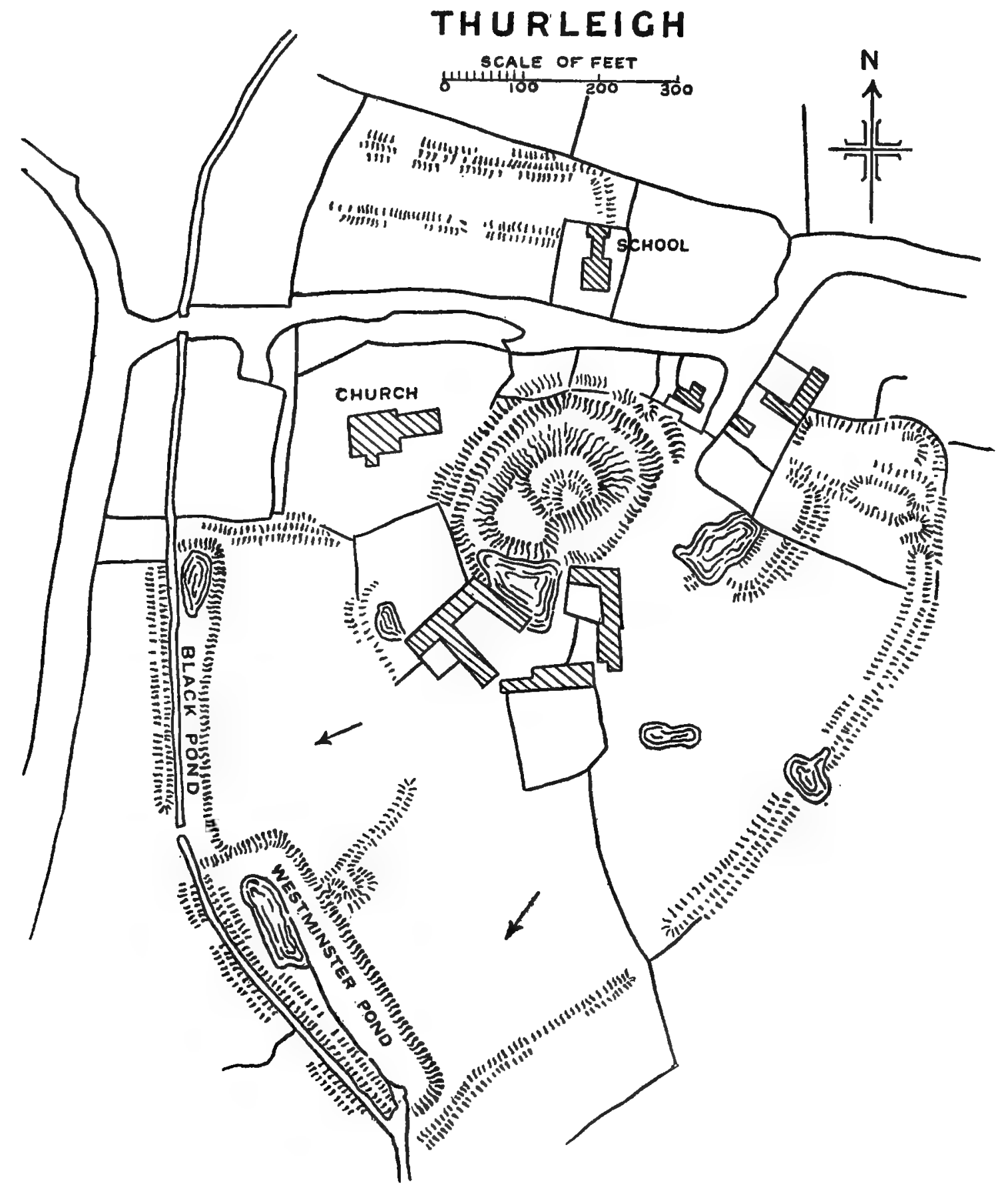

much of the site, with the result that no courts connected with the mound can now be traced. The outer enciente however, well defined by bank and ditch, remains almost entire, and encloses a very large area, within which stands practically the whole of the old village. At the north-east angle there are certain strongly marked projecting lines, which 


\section{ANCIENT EARTHWORKS}

seem to mark a well-guarded entrance. At the bottom of the valley to the south the stream was originally taken through a pond of great length, now known as the 'Black Pond,' and then outside another, the 'Westminster Pond,' very much wider, scooped out of the hillside to a depth of 12 feet on its steeply cut northern edge. The stream was evidently directed into the upper pond by a strong bank, and then flowed past the lower, between two similar dams. Thus the second pond was supplied from the first, which was slightly higher in level. Domesday names no mill, and these arrangements for the storage of water suggest a sluggish flow which was not always equal to the requirements.

(5) Yelden or Yielden Castle.-This is one of the most interesting earthworks of its type in the county, both because of the strength of the remains, and because of the presence of masonry revealed during excavations made about twenty years ago. There is also some degree of certainty as to its date and origin.

It differs from other examples in not standing on high ground but towards the base of a long gradual slope, which continues to rise beyond the site of the castle. From Domesday down to the thirteenth century, it was the stronghold of the Trailly family. Its main defences consist of a great conical keep mound, ending in a rounded oblong at the summit, and of two extensive baileys, inner and outer. Beyond these to the east and south are several large enclosures with strong entrenched lines round them.

The area of the top of the mound at the highest is roughly i 30 feet by 90 feet, and 40 feet above the bottom of its north moat. It is in two levels, and is not surrounded by the moat, its western scarp descending into the inner bailey. Small remains of stone foundations were discovered on the mound in I882. The moat, which is in places $3 \circ, 40,50$, and on the west 100 feet in width, encloses both mound and bailey, and is strongly ramparted entirely round its inner edge. At the north-west angle the base of a stone wall was found during the excavations, and the bases of two small round projecting towers at the south-west angle; also a length of stone foundation lining the south rampart of this wing. The west moat is of great length and of unusual breadth, and is contained along its west edge by a long bank, outside of which a small stream, the Til, runs. In two places this bank is pierced to admit the stream. Opposite the two tower bases referred to, a small mound rises out of this west moat, and the excavations revealed the remains of a round tower in stone, 30 feet in diameter and with 4 feet walls. A chamfered plinth stone which came from it was pronounced to be undoubtedly Norman work. There may have been a drawbridge over to the inner bailey at this point. The north end of this moat is closed by a projection from the outer bailey, where was probably another entrance. Where this projection joins the bailey there is the base of another low mound. Excavation might have shown that there was another stone tower here to cover the entrance, although in I 882 no stone remains were found in this bailey. From this point a strong rampart encloses the west and north sides of the 


\section{A HISTORY OF BEDFORDSHIRE}

bailey, and is returned along the short east end, where it ceases at the mound. Outside this the moat continues, joining those round the mound and the eastern enclosures. On the west side the brook runs through this moat, which appears to have been continued outside the long bank described,

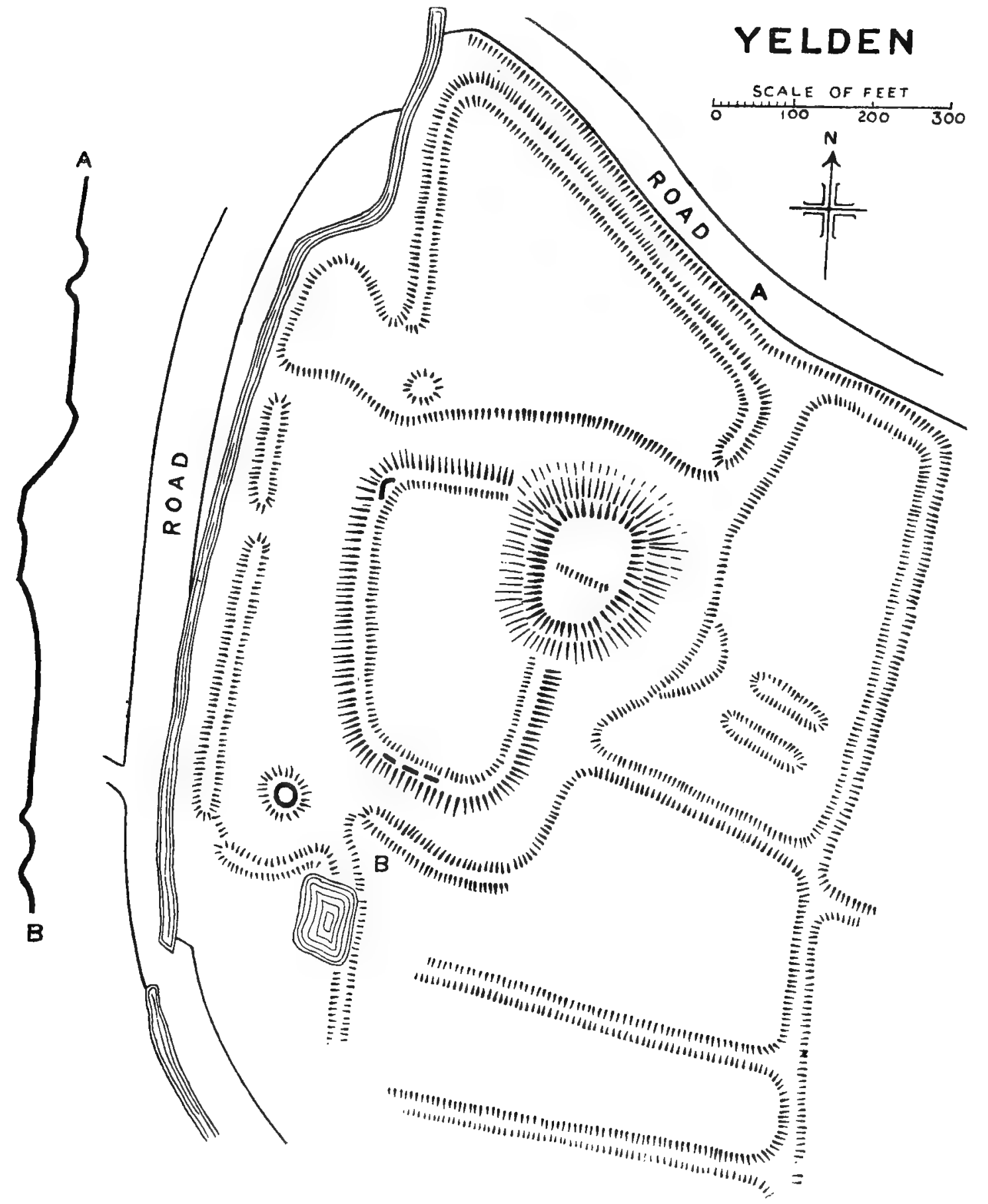

thus making a double moat along this flank. The road has here modified the works to some extent. There appears to have been an eastern approach to the mound and keep between two small moats across the enclosure there. It was quite in keeping with such works that many of the ramparts 


\section{ANCIENT EARTHWORKS}

should be stockaded between stone towers at salient points. The Lysons quote an inquisition of 1360 , which states that the castle had then 'fallen entirely to decay." They also say, "beyond the moat appear traces of walls for a considerable space." ${ }^{\prime 2}$ This may have been on the top of the south rampart already referred to. Nothing of the kind now remains. Much stone burnt red was found in different places, and especially in the round tower in the moat.

In the Bedfordshire Architectural Society's Transactions ${ }^{3}$ there is an interesting account of the castle and the excavations conducted by the writer, Rev. R. S. Baker, with an excellent plan which shows water and mud in all the moats. This is not now the case, but the Til is wont to flood both them and the road every winter. In the old days no doubt the moats were all well filled. By the roadside appear white posts marked in feet, to guide wayfarers as to the depth of water during the frequent floods.

(6) Tilsworth.- In the rectory garden, which is said to have been formed out of the churchyard, there is a mound of considerable size, perhaps some I 5 or 20 feet high, and flat on the top. Its western slope has been cut away in part to make room for a greenhouse, and from this a brick tunnel is formed in the heart of the mound. During the work for this tunnel a sword is said to have been found, which has not at present been traced. Other lines towards a stream on the east can be seen, but much broken and reduced.

\section{(b) WORKS WITH SEMI-GLOBULAR MOUNDS}

(I) Cainhoe Castle near Clophill.-This strong little work stands on a spur of high ground artificially scarped on the north down towards a small stream which partly envelops it, in old days probably making much marsh around it. The site is commanded by a superior height about 80 yards to the eastward. This may point to the construction of the place before the common use of siege engines.

The central mound is small compared with those already described, but its rounded shape rises well above all the rest of the defences, and it is surrounded by a deep fosse some 40 feet wide, except to the north, where it turns out into the steep scarp. This fosse could therefore never have held water. There are two considerable wards to the east and south, facing the superior heights, divided by a fosse which also continues along the greater part of this frontage, which is defended by a strong rampart. The entrance appears to have been on the west side, where the ground slopes up to a re-entering angle, between a small mounded projection on the north and a large rounded platform, about ioo feet across, on the south. There are no signs of ramparts on either, but when stockaded they completely commanded the approach. They are separated from the mound and south ward by the interior moats, and are joined together at the rear by a small platform, slightly lower, which blocked the approach and may have formed the abutment for a flying bridge of

\footnotetext{
1 Mag. Brit. i. 156.

2 Ibid. p. 34 .
}

Vol. xvi. (1882), 251. The plan forms the basis of the one produced. 


\section{A HISTORY OF BEDFORDSHIRE}

timber to the keep-mound, as described in a passage relating to a French example, quoted by Mr. G. T. Clark. ${ }^{1}$ If this entrance were forced, the assailants would find themselves under the necessity of moving round the deep inner ditches to attack the mound and several wards which towered
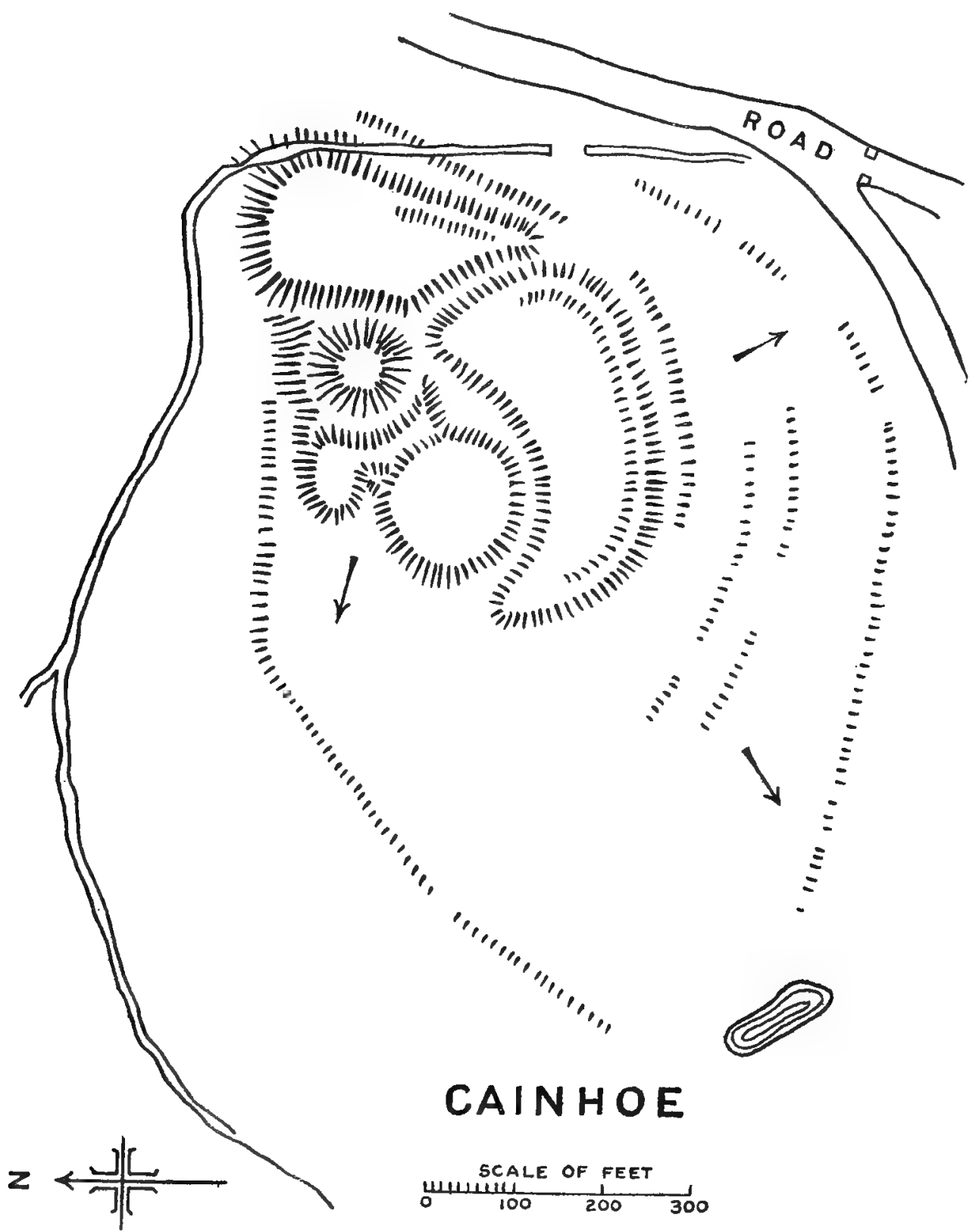

CAINHOE

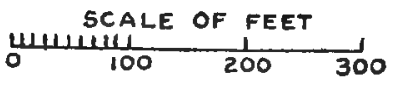

above them, all of them no doubt with stockaded sides. A considerable portion of the lower slopes of the ground is enclosed by the outer enciente, with traces of rampart and ditch. At the western angle is a long piece of standing water towards which the outer lines are tending. There is no church or village here. ${ }^{2}$

1 Mediceval Military Arcbit. (1884), i. 33. The date of the stair and bridge was about the beginning of the twelfth century.

2 'This fortress was evidently the head of the barony of 'Albini of Cainho.' 


\section{ANCIENT EARTHWORKS}

(2) Totternhoe Castle.-This is just such another stronghold, perched on the end of a promontory of the chalk downs two miles to the west of Dunstable, at a point where with very steep sides to the west

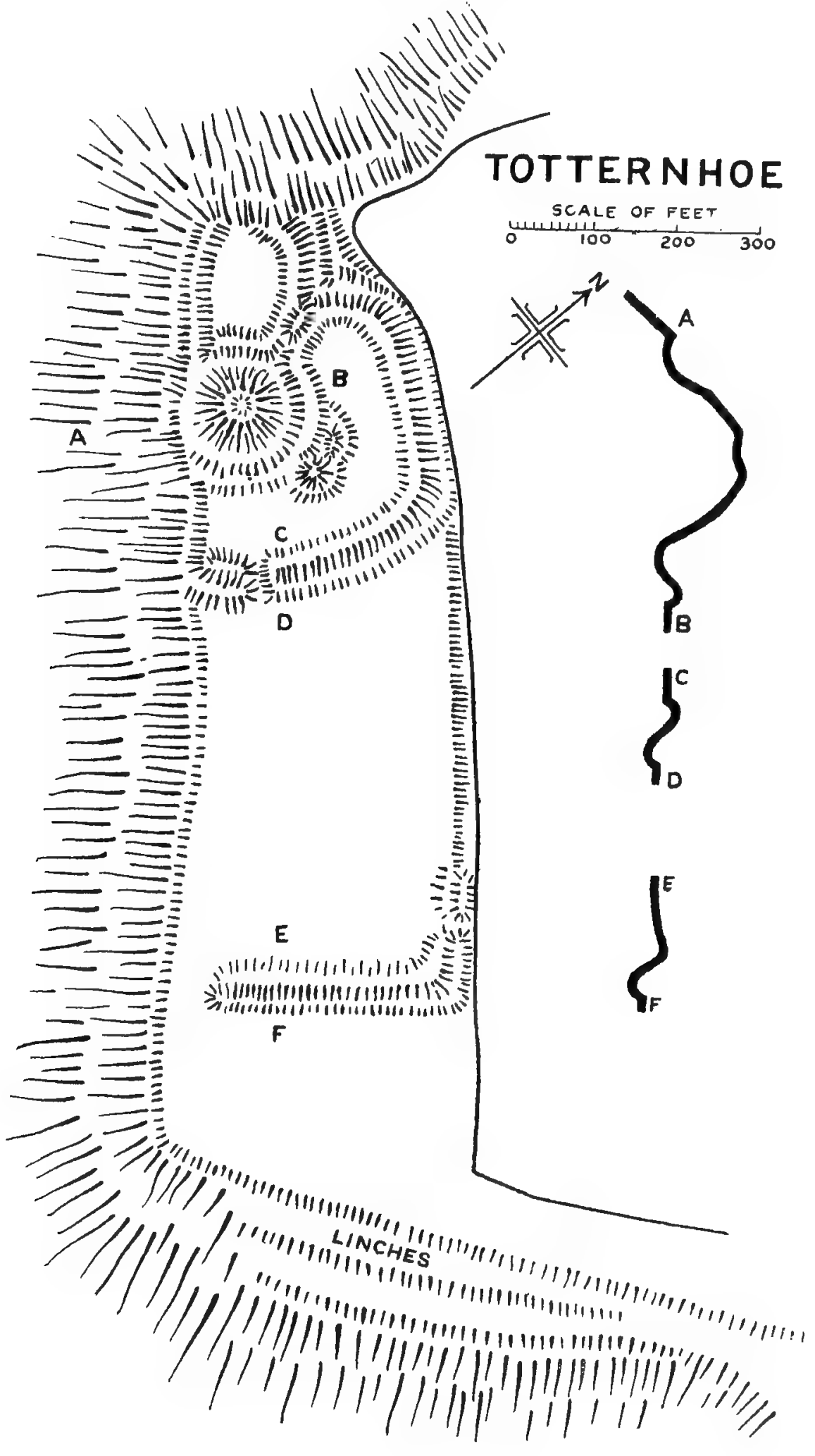




\section{A HISTORY OF BEDFORDSHIRE}

and south the downs rise out of the wide surrounding plain. It is thus only approachable by the old green trackway which leads along the heights from Dunstable past Maiden Bower. The surface of the plateau has been artificially levelled, and fine linches terrace the face of the hill on the east.

From this side an oblong camp-like enclosure is first entered, with straight scarped sides and rectangular. There are no ramparts on the north or south, and the steeps on the latter side are precipitous. The east moat remains in good condition, but there is now no proper rampart, the ground sloping up so as to make a steep scarp to the ditch. It has been maintained that this outer enclosure was originally a Roman camp, but this is not certain since such rectilinear oblongs do occur in connection with manorial strongholds. ${ }^{1}$ On the other hand these mounded works might very well at times be inserted inside earlier stations, as appears to have been the case at Little Wymondley in Herts, where a moated mound and courts are placed within an almost quadrangular enclosure, in which Roman foundations of some length have been uncovered. Only excavation can settle the point.

As to the class of work at the west end of the oblong there can be no question. A great rounded mound with wide enclosing fosse, except where its base touches the scarp of the steep descent, stands in the centre. It rises to a height of some 23 feet above the bottom of the fosse, and is of the same globular form as Cainhoe, except that the top, 40 feet in diameter, is now flattened, and has a slight circular depression at the summit. There are two wards, one small, to the west, the other large and covering the mound both on the north and east, where it ends at the edge of the descent. Both were ramparted, and are separated from each other and the mound by the interior moats. The level of the east ward is some 6 feet above the larger one, and that is about the same above the outer plateau. There is a small stretch of rampart at the north-west angle, outside the exterior moat, and bending inwards, as though to cover an entrance at this point. The inner moat here is twice interrupted to form two banks of communication between the wards. Close to the inner rampart of the large court, near to the mound, is a small circular feature which has given rise to many conjectures. The rampart continues round its edge, producing a central hollow I I feet deep. It is known as the 'Money-pit,' from an old idea that any one jumping into the hollow could hear the rattle of coin below. The place may be the mouth of a shaft, perhaps leading down to the bottom of the heights near the brook. ${ }^{2}$ A smaller excrescence of the same kind adjoins it. The ground outside the work slopes gently away to the north-east.

The position is a majestic one, and to those moving on the lower plains for miles round, the Totternhoe mound seems to keep watch on its height like some great conning-tower.

1 As at Bletsoe, see p. 301 .

2 As at Huntingdon, where the mouth of such a passage was recently discovered leading to another part of the work.

a Compare for a very similar plan the Chateau de Grimbosc.-Du Caumont, Abécédaire d'Archéologie, i. 298. 


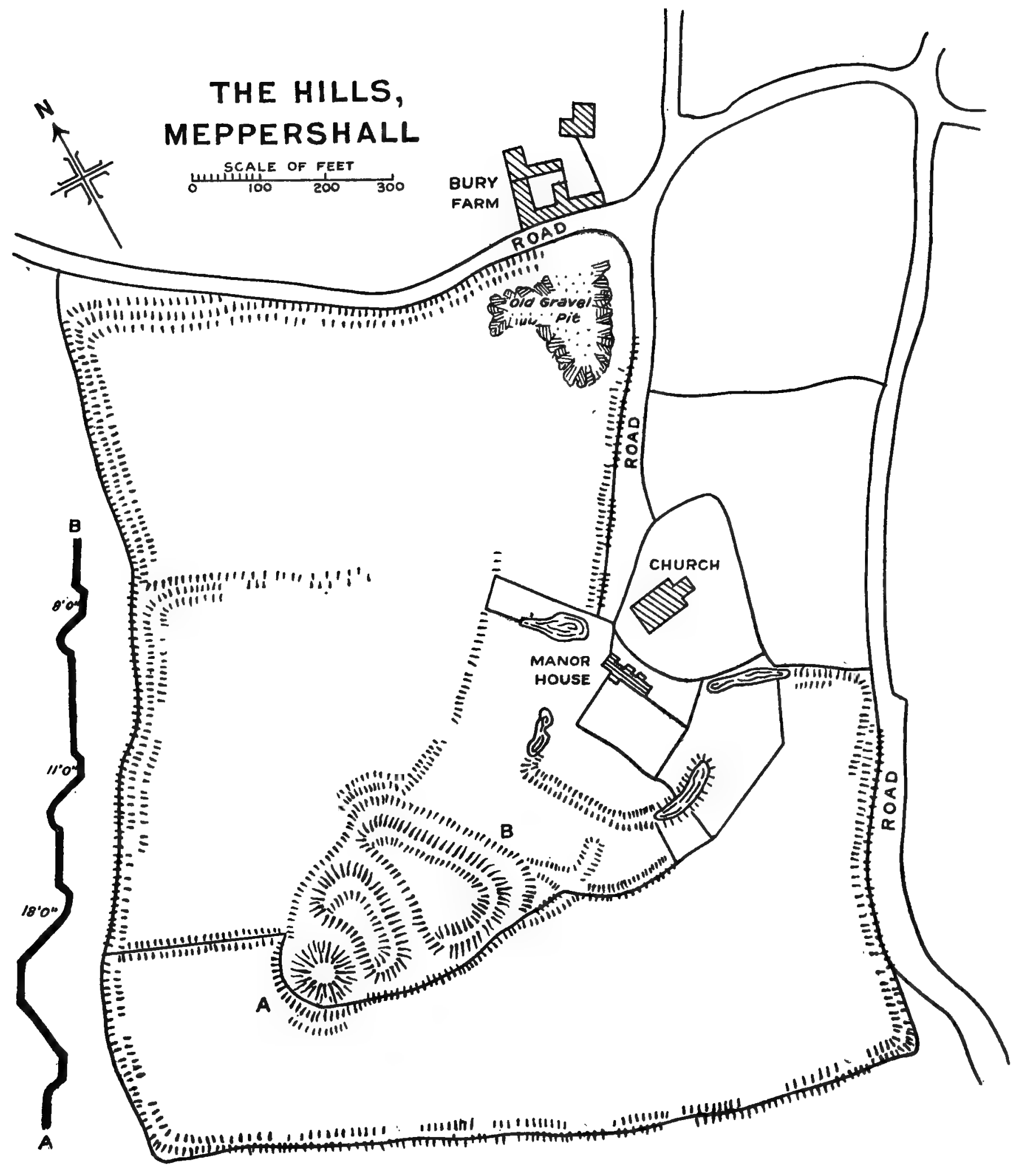




\section{A HISTORY OF BEDFORDSHIRE}

(3) Meppershall.- 'The Hills,' as they are called, form the central hold of a very interesting work of the 'mound and court' type. Its exterior ward is outlined by a great ditch 32 feet wide, with rampart round three sides on the inner scarp, 8 feet high above the ditch bottom. The inner ward, again surrounded by its ditch, is smaller, but several feet above the level of the outer, which is itself 2 or 3 feet above the general field level around it. The rampart of the inner ward is strongest at the ends, where it is I I feet above the ditch bottom. Higher again is the isolated circular mound, I 5 to 16 feet above the floor of the encompassing ditch, which is 35 feet wide towards the ward and about 50 towards the west. Its summit is slightly rounded and measures 26 feet by 30 across its diameters. There is a trace of a rampart on the outermost edge of its circular ditch, and also outside the north-east angle of the outer ward.

There are some moat lines to the east of the hold, but these seem to have been connected with the manor house, as they turn to enclose it.

The bank and sometimes the ditch of the outermost entrenchment lines are strongly marked, and form a rough square about the hold, enclosing, if the road to the west completes the outline, not less than 30 acres. The question again arises as to whether this enciente is contemporary with the main work. There seems little reason to doubt it, as the whole site is bare except for two or three houses at the extreme north-west corner, and most of the village lies away from it. The church, with fine early Norman detail, of the plainest wide-jointed type, stands in close association with the mounded stronghold, and the small intervening manor house of timber and plaster is early Jacobean. There is no mill.

With the exception of Bedford Castle this is the only work of its kind in the county which has any direct connection with history. The editor of the Gesta Stephani ${ }^{1}$ has the following note with reference to it.

'In the original edition of the Monasticon (I655) ${ }^{2}$ there is a charter granted by Stephen 'apud Maperteshalam in obsidione.' The chronicles mention no such event as a siege of Meppershall; but there exists at the present day, close to the church of this small Bedfordshire village, a high mound with a double line of outer ramparts, answering in the clearest way to the type of the hastily-built stockaded 'castles' of this reign. Stephen, it thus appears, had to capture this outpost, perhaps during the siege of Bedford in $1138 .^{\prime 3}$

It does not follow however that the work was of Stephen's time, as the detail in the church attached to it is sixty or seventy years earlier.

(4) Risinghoe Castle.-In Goldington parish, about $2 \frac{1}{2}$ miles east of Bedford, on the north bank of the river, on ground belonging to the 'Castle Mills,' stands the solitary mound of Risinghoe. In its present state it is more like a barrow than anything else, but the traditions and statements that it is the remnant of a former stronghold are too numerous to be passed over without mention. Leland says, "The great

1 Gesta Stephani (Rolls Ser.), p. xxv. ${ }^{2}$ Vol. i. p. 480.

3 In Domesday, Gilbert Fitz Salomon held the manor of Meppershall, and before him Leofwyn Cilt, a thegn of King Edward. 


\section{ANCIENT EARTHWORKS}

round hill where the keep or dungeon stood is clean hole." ${ }^{1}$ The Lysons write, "The keep of the castle is of considerable height, and adjoining it are large earthworks.' ${ }^{2}$ Rev. W. Monkhouse in 1854 wrote to contest the view that there was ever a castle here, ${ }^{3}$ but he had only a stone structure in his view, and he does not appear to have examined the examples we have just described. No traces of earthworks now appear in connection with the mound, but the fields adjoining have been extensively worked out for brick earth. Old inhabitants describe a smaller mound which stood close to the one remaining, which was actually removed for the purpose named. The mound, about 20 feet high, is semi-spherical, though the summit has a small flat space on it made in recent times. There are no signs of a surrounding moat. ${ }^{4}$

It should be noted here that the name Hrisingr is Scandinavian, and that baugr, pronounced boy, is Old Norse and Icelandic for a mound or barrow; in Danish böj. The many instances of this suffix in the place-names of the county on the Danish side of Alfred's boundary is remarkable. Thus Staploe, Duloe or Devilhoe, ${ }^{5}$ Keysoe, Bletsoe, Backnoe, Segenhoe, Sharpenhoe and Silsoe, as well as the mounded sites referred to. Strip Totternhoe and Cainhoe of their outer works, and the result would be similar to the isolated mound of Risinghoe. Excavation only can make known whether these barrow-like mounds may not have been in existence prior to their incorporation with subsequent strongholds. Hows were constructed in Viking times for observation as well as for burial. 'There was usually a how near the houses, from 'which the master could look over his estate.'

At Roxton there is a mound of unusual shape known as ' Round Hill,' which is a prominent object owing to the fence of large closely planted elms which surrounds it. It is 40 feet in diameter by some 4 feet in height, with slight slopes and a flat top, and it stands in the midst of cultivated fields. It has no ditch and its purpose is unknown.

(c) MANORIAL HOLDS WITH MOUNDS OF VARIOUS SHAPES

(I) Eaton Socon. 'The Hillings.'-This formidable work, which has been illustrated and described by Mr. G. T. Clark, stands on the west bank of the Ouse about 4 miles north of Tempsford, and has certain distinctive features of its own.

Its two inner wards are both mounded up some I 5 feet above the outside level, and it is without the isolated moated keep-mound of the examples previously described. 'The work,' to quote Mr. Clark, ' is composed of three parts, an inner, northern and outer ward. The inner and northern wards lie side by side upon the river, separated by a cross

1 Dr. Prior on Eartbworks of Bedfordshire, Beds Arch. Soc. I 886.

2 Mag. Brit. i. 89.

4 Almost all Goldington, in 1086, belonged to Hugh de Beauchamp (who held the mill in demesne), his predecessor, Ralf Talgebosc, having obtained it in exchange for Ware.-J.H.R.

5 Alwin surnamed Deule held Pertenhall according to the Domesday Book (see Introduction to the Domesday Survey, p. 215).

- Vigfussen's Icelandic Dictionary, p. 24 I ; sustained by passages from the Sagas. 


\section{A HISTORY OF BEDFORDSHIRE}

ditch. The two are contained within another ditch, which communicated at each end with the river. Beyond this, covering the southwestern front, is the outer ward, and beyond this again the outer ditch, which commences at the south-east corner of the mill lead, covers the south-western front, and at the north-western angle sweeps round to join
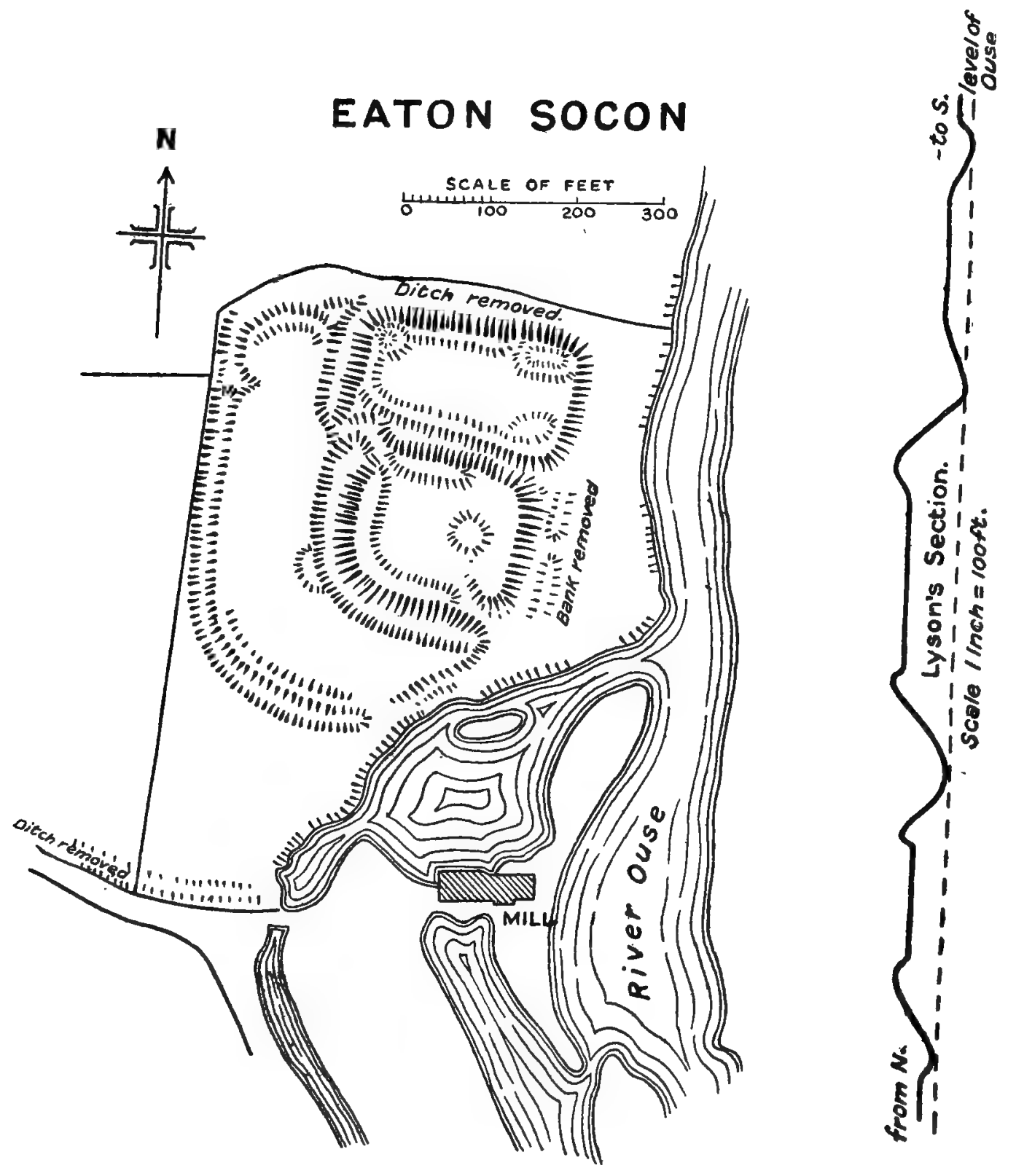

the ditch already mentioned, and thus, through it to communicate with the river at the north-east corner of the work.'

The inner ward is slightly the higher of the two. Around it the fosse is some 40 to 50 feet wide, and still has water in the south return. Round three parts of this ward over the ditch the rampart still remains

1 Mediaval Military Archit. ii. 36. 


\section{ANCIENT EARTHWORKS}

very strong, some 8 to Io feet high. There was none on the river side. A sloping way enters the ward at the south-east, where the rampart ends, and the outer river scarp bends round to cover it. There is a modern path through the north-west angle, which appears to have been a narrow cut through the rampart, later enlarged. Placed centrally, but nearer the river side, is a flat low circular mound, about 40 feet across by 5 high.

The northern ward is also ramparted round three sides, strongly to north and west, and only weakening when it has well covered the junction of the ditches at the south-west angle, and the entrance from the outer ward. At the outer angle to the north of this is the root of a round rampart, about 15 or 20 feet across, mounded up on the very edge of the external scarp. At this point the height and sweep of the work are very impressive. Mr. Clark suggested that there might be the foundations of a stone tower in this mound, but an excavation lately made revealed none. This was the case too on the flat mound in the inner ward. The hole was dug near its edge to the west, but only small bits of broken pottery, a little piece of eighteenth century glass, and a few animal bones, were discovered. No signs of squared stone appeared in either place, and men who have dug about the work in former years report that nothing of the kind was ever found. At the east end of this rampart is a small oblong, slightly banked, apparently like the round referred to, at the other angle the base of a stockaded tower. Again at the south-west angle of this ward there is a low flat platform of irregular shape. There was certainly an entrance where the ditches join, or rather make for each other (for they do not join), with a slight inward and outward bend, at the south-west angle. For between ditch and rampart is a little triangular berm, probably the starting place for the timber passage to the inner ward. Nearly facing this break in the ditches there is also a break in the outer ditch, at a point where its edge turns sharply inwards. Excavation proved that the original bottom was higher here, sloping back on either hand to the ordinary depth of the ditch, and suggesting something of a causeway, which might yet be under water, when emergency required the filling of the moats to a higher level from the river. Even in recent times there was much more water in the moats than at present, and when the stronghold was occupied, the river was much more in evidence. This outer ditch sweeps round all three sides to the river, although, on the north, extensive digging for gravel has obliterated its exterior edge. Lyson's plan shows it entire, and also continuing round on the river front, with a bank pierced about the centre to admit the water. ${ }^{1}$ As the land between this bank and the river was very wet, its level was raised within the last twenty years by cutting down the sides of the mound along this front, thus making the scarp much steeper.

A good many years ago skeletons were found in digging near the entrance in the outer ditch, and also certain long swords, which were reported to have gone to the St. Neots museum. Inquiry there failed to find any trace of them. Human skulls were also found recently in

1 Add. MS. 9460, f. 25. 


\section{A HISTORY OF BEDFORDSHIRE}

digging for ferrets on the north side of the ditch dividing the two chief wards. Large fragments of coarse badly burned pottery came out of the river scarp of the inner ward quite lately.

In the absence of all evidence of any stone buildings, and as there is no mention in the inquisitions of any castle here, in spite of Leland's 'vestigia castelli,' it seems clear that this was a stronghold entirely of earth and timber.' Domesday shows that 'Ulmar of Etone,' or Wolfmar, had his chief seat here before the conquest. Certain unusual features in this earthwork, and the absence of masonry, may suggest a pre-conquest origin.

(2) Odell.-The Lysons write: 'At Odell, a mansion-house has been erected on the site of the castle, the ancient seat of the Barons Wahull, which was a ruin in Leland's time.' The house which has incorporated the earlier remains stands on a high mound, but as this has been much modified in recent times its original form cannot be clearly made out. There is a fine stretch of a great rampart proceeding in a straight line from the north of the mound, within which are the grounds, and outside the high road on the site of the ditch, of which the outer edge can still be traced. To the north, about 80 yards away, stands the church, and round it the roads appear to occupy the lines of entrenchment which connected it with the mound. The site slopes away rapidly to the south, towards the mill on the Ouse. This also appears to have been inside the original enciente. Odell Castle was the head of the important barony of 'Wahull' (Odell).

(3) Sandye Place.- - Here too the house stands on a fine mound, of which it is difficult, owing to changes due to the laying out of the grounds, to ascertain the original shape. On the west boundary of the property there appear to be the remains of former enclosing lines, tending towards remains of fishponds near the Ivel, which has here been widened. The church stands quite close on the north-east, and the mill on the river to the south-west.

(4) 'John of Gaunt's Hill,' Sutton Park.-This deserted mound, on which stand great elms, one of them girthing $14 \frac{\mathrm{I}}{2}$ feet, is of

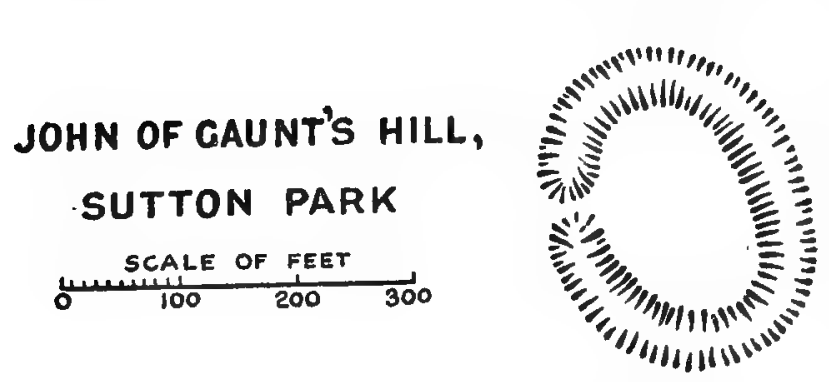
quite different form from any previously described. It is oval in plan, measuring I 80 feet by II 5 feet across its diameters. The ground slopes from east to west towards a small tributary of the Ivel, so that the eastern section of the surrounding ditch is much more marked than the western. At its widest the ditch measures 48 feet across by 10 feet in depth, and the mound rises out of it to a height of 16 feet. The surface of

1 It must have been the head of the barony of Beauchamp ' of Eaton.'-J.H.R. 


\section{ANCIENT EARTHWORKS}

the mound is now level. Red roofing tiles of modern make occur in different points on the south of the oval some few inches below the surface. It is possible that the mound has been occupied for gardening purposes, as the Elizabethan manor house, burnt down eighty years ago, stood near it to the north. The church stands on the south angle of the park, and near the narrow pack-horse bridge of the same date. There are various faint lines of what may possibly be works in the neighbourhood.

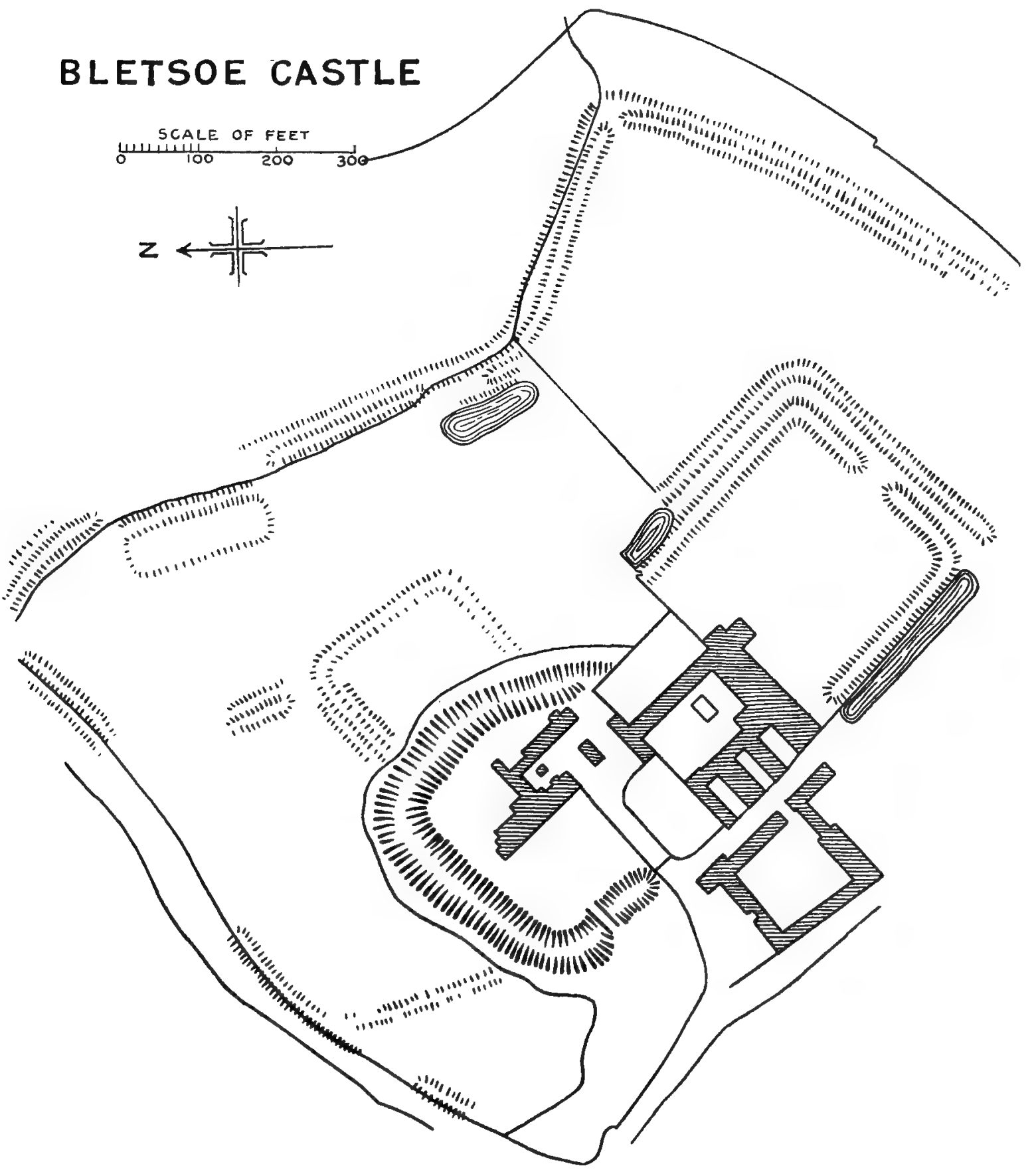

(5) Bletsoe Castle.-The earthworks here are of interest because of the fine fosse, averaging 55 feet in width by about 15 feet in depth, which originally enclosed the central hold. About two-thirds of 


\section{A HISTORY OF BEDFORDSHIRE}

it still exists. The space within is an irregular square with rounded angles, of which the west side measures about $25^{\circ}$ feet. Much of the outer enclosing lines of bank and ditch may be traced in the fields around, and there are two rectangular enclosures jutting out from the main position. One to the north-east is small, outlined by a slight ditch; the other to the south-east encloses a square of an acre and a half within its fine rampart, which in places stands 5 to 6 feet above the interior level. On two sides there is a small berm and then the outer ditch, averaging I 5 feet in width. On the south-west side the ditch has been widened up

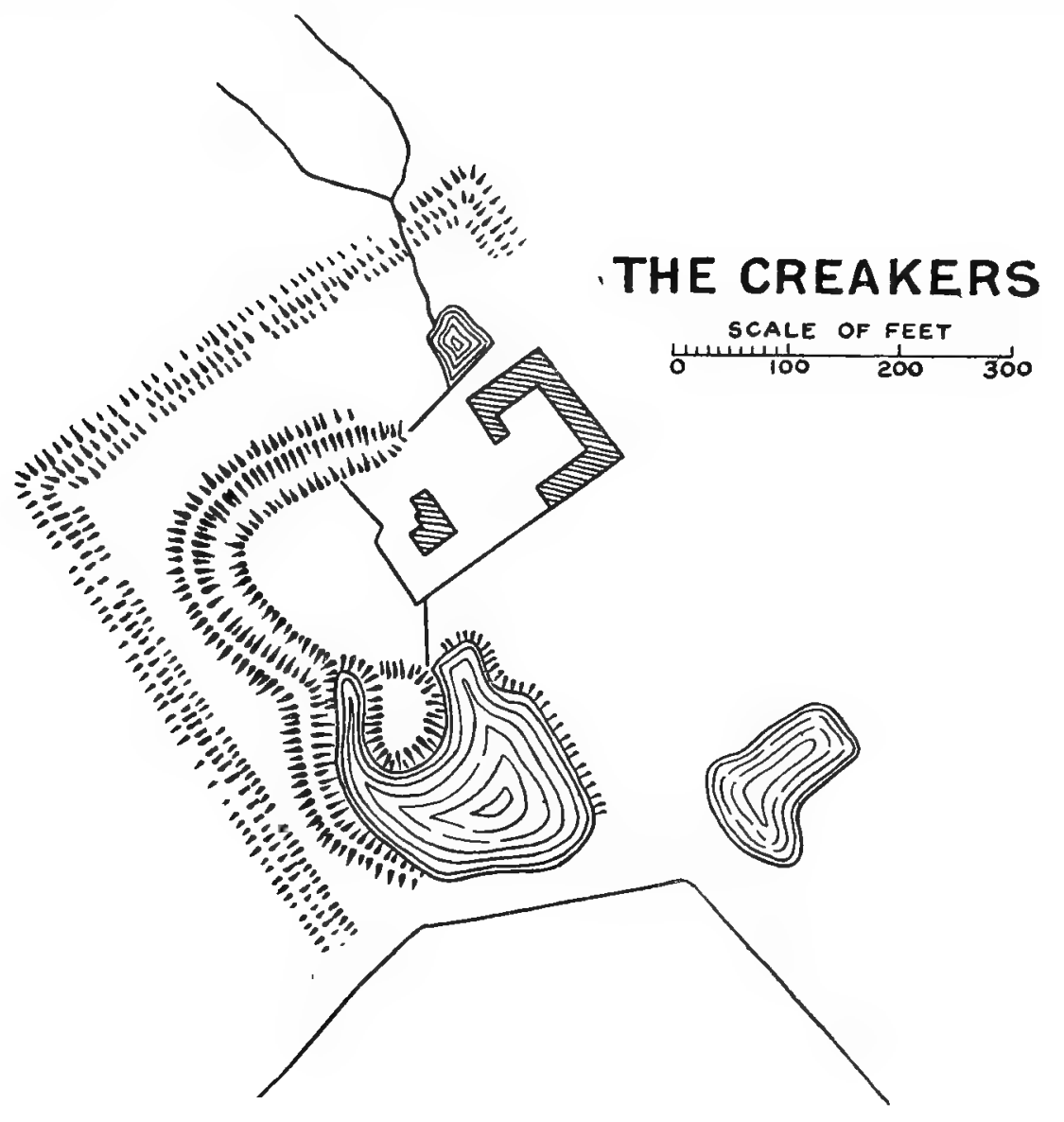

to the rampart and is full of water. There are remains of two fishponds close to the outer lines on the west, past which a small stream still runs. The ground slopes away in all directions from the centre. The great moat is so lined with trees and undergrowth that it is not possible to be sure whether the level of the central space has been artificially raised, but apparently not.

The substitution of a great fosse, about a larger central area, for the moated mound, so as to admit of more space for stone erections, is the most noteworthy feature of this example. At Roxton, in Palace Yard or 'Splashyard ' wood, there is a large circular moat, with a short straight one branching off from it. There are traditions of dressed stone having been found on the site, but at present there is no clue to its origin. A 


\section{ANCIENT EARTHWORKS}

smaller circular moat is also to be found in a wood near the manor house at Westoning.

(6) 'The Creakers' near Great Barford.-The earthwork here stands on almost level ground, which in places collects much water. A considerable moat runs round two sides of an interior central area, after the fashion of Bletsoe. If it ever completed the circuit, the returning sides have been filled in, and a small eighteenth century farmhouse with its garden occupies the position. From this inner area a small mound of irregular shape projects to the south for about 70 feet into what is now a large pond. This mound, at the highest, rises 4 or 5 feet above the level behind it and 9 or Io feet above the water line. It tends to a point at the end of the promontory, and is about 30 feet across at the broadest. On its west side the moat referred to bends round to enclose it and is full of water, being now really a part of the pond. Following this moat along its whole course on both flanks is a large exterior rampart which dies out near the farm to the north and at the edge of the pond on the south. These inner works are covered by strong lines of entrenchment immediately outside them, which now form two sides of a square, the returning angle being still evident on the north-east and a trace of the third side. This square outer work has a large rampart and exterior ditch. Whether the water originally occupied all its present area about the mound is doubtful. There was perhaps a second court below it with surrounding ditch, which may have been converted into a pond for farm purposes. There are other faintly marked lines to the east and south, but nothing very decipherable.

\section{HOMESTEAD MOATS}

There are very many moated sites of this class all over the county, as there are throughout most of eastern and southern England, and but few parishes exist that could not provide us with several examples apiece.

The monastic sites were many of them defended by earthen ramparts and moats, and are of special interest because here we have the help of dates. They are for the most part on low ground near rivers.

Newnham Priory near Bedford should be described because its main enclosing lines are still existing, and because in some places they are being obliterated by having the town rubbish distributed over them. The area enclosed is not less than 35 acres. This priory was founded by Simon de Beauchamp about I 65 . The rampart and moat which outlined the main enclosure may be seen round all its three sides, in parts of it very strong; and to the east they are supplemented by a kind of terraced platform with a smaller moat inside it. The Ouse closed up the fourth side to the south. At the north-east and north-west angles the rampart is strengthened by small mounds; in the latter case some Io feet high and 20 feet across the top, with a circular rim round about it and projecting considerably beyond the line of the ramparts. This type of mound has already been noted in several of the previous descriptions. No doubt both rampart and mounds were stockaded. 


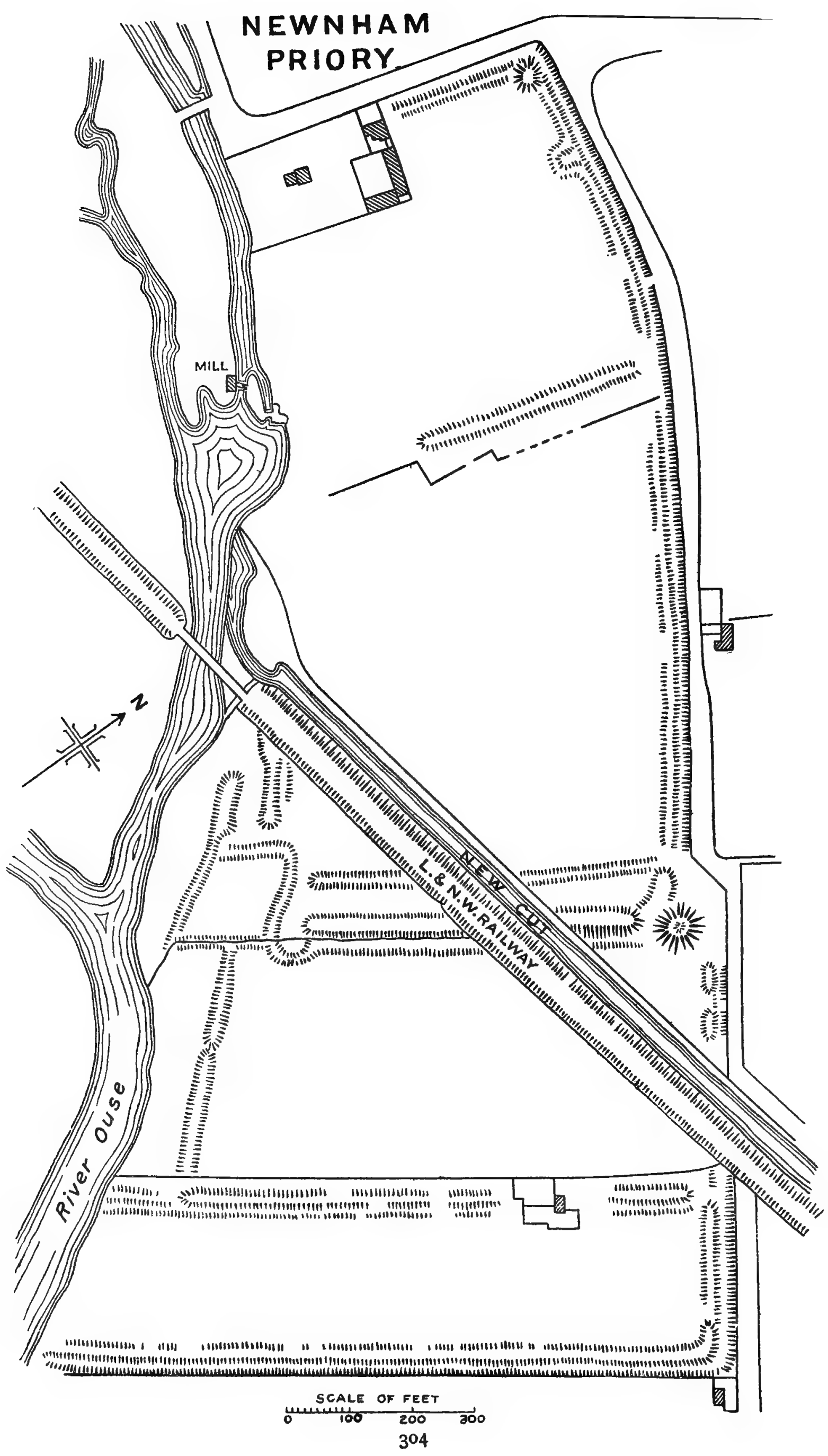




\section{ANCIENT EARTHWORKS}

On the east of this main enclosure are two great closes, each of them also defended by a vigorous bank and moat. On the south near the river are remains of large fishponds. There is no doubt that we have here the original enclosing works of the priory, for at some time in the sixteenth century they seem to have been considered insufficient, and a wall was added outside the exterior moat, built of rubble and clay and coped in red brick. This may have been done when the mansion was erected after the suppression. The cottage belonging to the monastery mill still stands.

At Warden (I I 35), Elstow, Biscot, Harrold and Ruxox there are similar remains of the enclosing ramparts and moats, and no doubt on other monastic sites which have not been examined. In these cases the rampart is always inside the moat.

There are a few instances of moated works on high ground, with the central hold mounded up a few feet to a uniform level, and with a wide deep moat surrounding it. The area thus outlined averages some I 00 to I 50 feet each way. These works have all the extensive outer enceinte of bank and ditch common to both manor and monastery, and often church and fishponds. There are examples at Hockliffe, Colm-

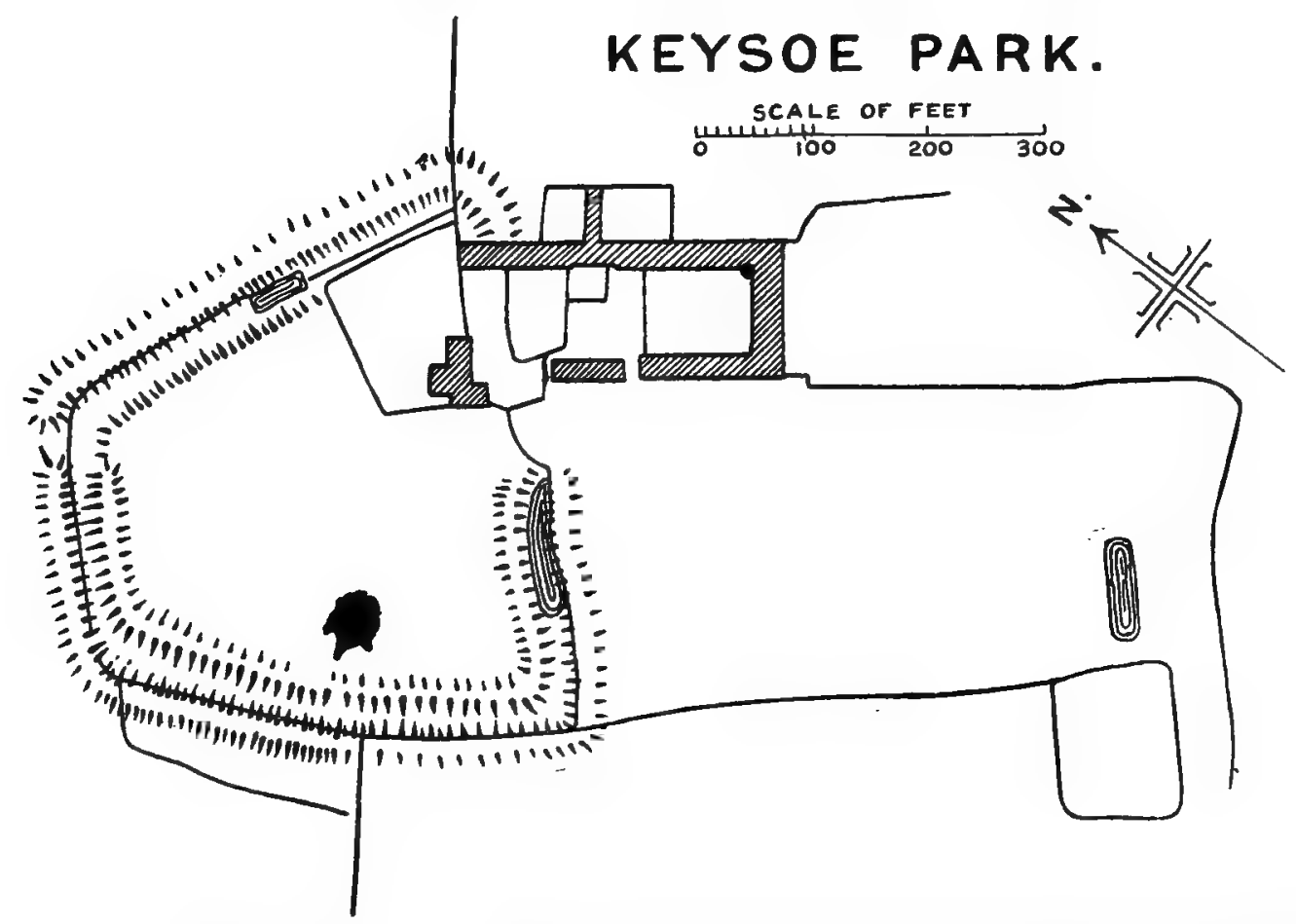

worth and Podington. They are evidently manorial, but being of the weaker transitional type are included in this class.

Amongst later works on lower ground are the castle sites of Someries near Luton, and Eaton Bray, where there were fifteenth-century brick buildings, with considerable remains of quadrangular moats. Later mediæval manor houses also, on low-lying ground, with considerable moats still remaining, stood at Netherstead, Beggary, Chawston, Wybos- 


\section{A HISTORY OF BEDFORDSHIRE}

ton, Cotton End, Bassmead, Cardington and in many other places. Sometimes the moat forms a simple oblong; sometimes another moat divided the space into two. Many of these examples have exterior banks, which from their breadth and flatness apparently formed promenades. Sometimes another ditch is found outside these again, as at Riseley Old Domain and at Mavourn. In the latter the moat has a flat berm under the water line, and then suddenly drops to a depth of 9 feet, an ingenious device for embarrassing intruders. Most of these later works suggest enclosure rather than defence.

A large number of works are found with the -bury in their names, and many of these stand on heights. Brogborough near Lidlington, a small stronghold originally of oval shape, is perched on a little hill-top, and has the remnant of a really mighty rampart turning round its south end, and also remains of a fine fosse. Here too are the remnants of an exterior rampart.

Keysoe Park, or Berrystead, as it used to be called, is another example. This resembles Mr. Gould's 'stirrup-shaped' works ${ }^{1}$ in plan. The ditch was a formidable one, 40 to 50 feet across, with a low rampart inside, of which considerable lengths remain, and a very large one

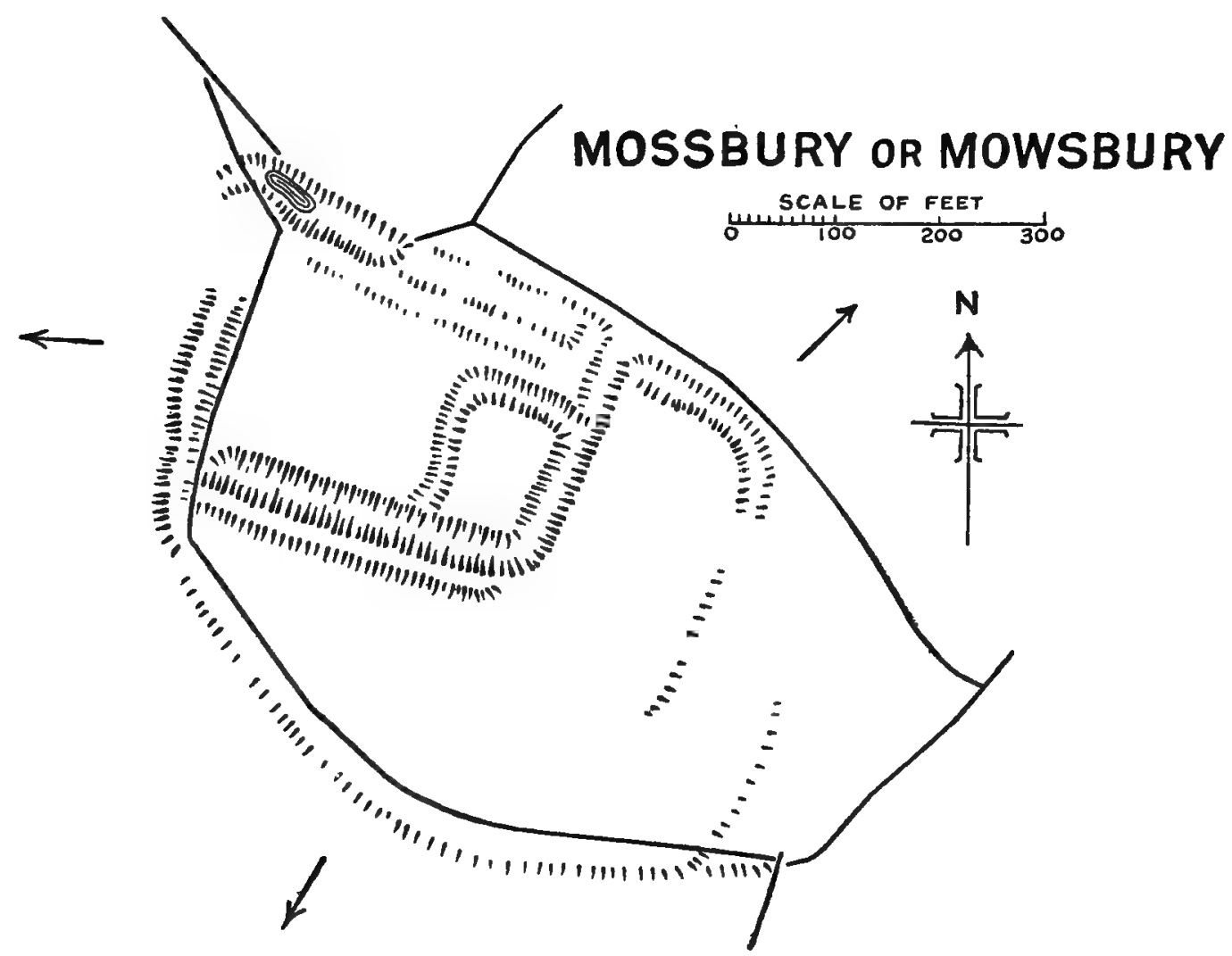

outside, continuing round every side of the enclosure. It is best preserved in a small spinney, where it is some 15 feet in height by 50 broad. There is a narrow berm on both sides of the ditch, and the 


\section{ANCIENT EARTHWORKS}

space intervening between the tops of the two ramparts is at least 100 feet. Yet the inner area is only about 300 feet from the top of the stirrup to the bottom, and somewhat more across it.

Mossbury, near Bedford, also stands very high on the end of a ridge, rising out of once swampy ground to south and east. Old trackways crossed the plain at its foot. There is a long stretch of exterior bank to the south and traces of it on the west. Its interior ditch is 35 feet in width, and the rampart top rises 14 feet above its base. On the northern flank the remains have been much levelled, but here there seems to have been a ditch outside the bank. Within this again at the east end a small enclosure 88 by I 20 feet is cut off from the rest of the interior space by a narrower cross ditch. The hilltop near it, on the south, seems to have been levelled, thus producing a very visible terrace line round the work. Small bits of Romano-British pottery were extracted from a rabbit hole about a foot below the surface. ${ }^{1}$ Water often stands in parts of the moat.

Shillington Bury and Holwellbury are both remains of strongly ramparted and moated sites. They stand on flatter, less elevated ground, as do also Newton Bury and 'Grimesbury,' miscalled Greensbury, both with fine exterior ramparts.

There are many other 'bury' sites in various parts of the county, and the whole group should be carefully examined and compared. The examples described have all the appearance of being very early homesteads, with a fallacious show of strong defence.

Another type of early enclosed homesteads have a square moat inside one corner of a larger square or oblong; as at Moggerhanger, and

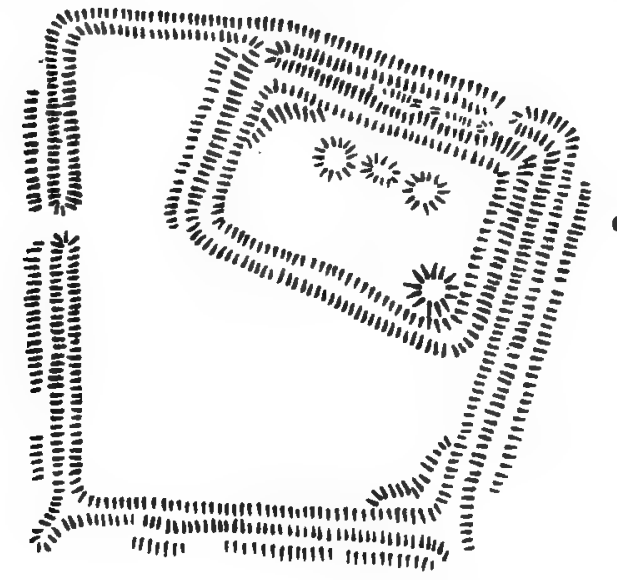

"THE CAMPS" BUSHMEAD

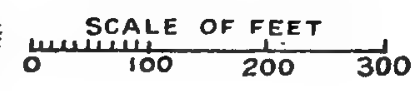

the 'Bigginwood' near Tempsford. Sometimes the two moats are quite distinct, as at 'The Camps' at Bushmead, with only a bank between. This example has also curious rounded banks inside two of its angles, and three or four small mounds. It has an exterior rampart.

1 Over much of the ground rough morsels of coarse burnt brick earth occur. The surface earth below the soil also shows signs of fire. These puzzling appearances may have been due to the burning of the clay of the ramparts dug down for ballast, a practice reported in various parts of the county. 


\section{A HISTORY OF BEDFORDSHIRE}

At Yarlswood near Thurleigh there is a strange little work of the kind, with a fair sized flat mound in one corner, and four other smaller tumps round about it outside. This site has certain strange tales told about it and is avoided by the villagers at night. It is known as the 'Devil's Jumps.'

All the moated places so far mentioned are distinct and isolated, but along the Wyboston road, on both side, for more than a mile, there is a continuous series of lesser moated sites, which must have belonged to much humbler inhabitants. Domesday notes the former presence of twelve sokemen at Wiboldestune. This coincidence led to the special examination of other places where the settlements of sokemen are recorded; as at Keysoe, where there were twelve, and Harrowden (Herghetone), where there were fourteen. In both these places the same series of small, slightly banked and moated enclosures occur, over a distance of about three-quarters of a mile. If these sokemen were of Scandinavian origin, it would be quite in keeping with their custom at home to surround their small 'tunes' or farms with banks of earth. At any rate the coincidence is suggestive, and worthy of further examination.

At Holme there is a small square moat about roo feet each way, with a circular raised platform in the centre some 50 feet across and about 3 feet above the rest of the ground. There are also several detached traces of moat lines in the fields near. At this place Domesday mentions two batches of sokemen, one of three, and the other of two. All these positions have small streams running past them.

Curious works remain behind Limbury Manor farm, consisting of certain moats, which, with their dividing banks, interlace in a maze of squares and triangles, a little after the fashion of what is called the Etruscan, or 'key pattern.' 'These were certain fish-stews which were the subject of a lawsuit in the time of Edward II.

As time goes on it may become possible, by means of further examination and research, to bring our various earthworks more into relation with the periods of human life to which they belong. The spade is, however, the agent most in request to let in fresh light on the subject, and the only one that can really help us to any certain knowledge of those earliest works which are amongst the first achievements of man on the surface of our land. 


\section{ECCLESIASTICAL HISTORY}

7 HE name of Bedfordshire is not connected with any of the more striking memories of early English Church History; nearly all that can be said of its religious institutions before the Conquest is by way of inference and conjecture rather than solid fact. Some of the reasons for this will be found in its political history, and in its position as a border territory up to the tenth century; but perhaps the most important is one which belongs properly to the present subject-it did not produce at that time any great religious houses like those which made the neighbouring counties of Hertford, Huntingdon and Northampton famous at an early date, and consequently had no chronicler specially interested in the details of its local history.

It is not surprising that there should be little or no evidence found of Roman Christianity, which has left so few traces of its presence and influence anywhere. But when we reach what is usually the surer ground of the second conversion in the sixth and seventh centuries, there is still great poverty of information, and an approximate date can only be provisionally fixed. It is possible that the conversion of Bedfordshire had a double origin. If the boundaries of Mercia and Wessex given by Florence of Worcester ${ }^{1}$ are correct, and the county was roughly divided between the two kingdoms by the River Ouse in the early part of the seventh century, it may have been partly evangelised by monks of the Roman school, coming from the West Saxon centre, and partly by the Scotic monks who were working for the conversion of Mercia. In any case its turn would probably come a little late, as it lay on the border of both kingdoms; and its conversion is not likely to have been begun much before the reign of Wulfhere of Mercia (659-75). But as he extended his kingdom far beyond its previous southern limit, and 'utterly destroyed the worship of demons, and made the name of Christ to be preached throughout his dominions," we may safely conclude that the conversion of Bedfordshire was well advanced before 675 , and that it had already some established centres of the usual monastic type for teaching and administration of the sacraments. Where these may have been it is not possible to say with certainty. One might perhaps be connected with the town of Bedford, which was already a place of some importance in the days of Offa $(757-96)$; and it is just within the bounds

$$
1 \text { (Engl. Hist. Soc.) i. } 279 . \quad 2 \text { Ibid. i. } 32 .
$$




\section{A HISTORY OF BEDFORDSHIRE}

of possibility that he bequeathed to a church in Bedford some valuable lands in Kent, which had originally been part of the endowment of the see of Canterbury. 'There may have been another centre in the southern district, where the name of Bissopescote (the modern Biscot) points to an assignment of Church property in the neighbourhood, and is traditionally older than the time of Offa-if indeed it is rightly numbered by the compiler of the St. Alban's Book of Benefactors among the original gifts of the royal founder to that abbey. ${ }^{2}$ It is also stated in one of Offa's charters ${ }^{3}$ that the 'five manses at Lygetun,' which he was presenting to St. Alban's, had belonged to the Church before his time; they had been given to him by Abbot Ahlmund by way of reparation for an attempt to elude the obligations of the Fyrd. Ahlmund's name occurs among signatures to several charters between $79 \mathrm{I}$ and $796,{ }^{4}$ but there is no evidence to show what monastery he ruled; it may quite well have been in some other county, though part of its property was in Bedfordshire. No certain conclusion can be drawn from indications such as these; the utmost that can be said is that the earliest assignments of Church property, the earliest signs of Church life in this county, were probably connected with the town of Bedford and the neighbourhood of Luton.

The tradition that Offa himself was buried at Bedford ${ }^{5}$ is of fairly ancient date; the chapel containing his tomb, which was outside the town on the bank of the river Ouse, is said to have been overthrown by the violence of the stream, after long use, and finally submerged.' Matthew Paris evidently thought that this happened soon after the Conquest; for he blamed not only the earlier abbots for failing to secure to St. Alban's the bones of their royal founder, but also the first Norman abbot, Paul of Caen." By his own time its memory only survived in popular legend. ${ }^{8}$

Such churches or monasteries as there were in Bedfordshire possibly suffered from the plundering raids of the Danes in 870 and $877^{\circ}$, and even after Alfred's second partition treaty the county was still the natural battlefield of Danes and English; not until after 92 I could there have been much opportunity of restoration. It is therefore all the more interesting to find, only fifty years after the last attack, reference made by the English chronicler in $97^{10}$ to an abbot of

1 Kemble identifies the place referred to in a charter of Archbishop Athelheard (Cod. Dipl. mxix. ' ecclesia quæ sita est apud Beodeford ') with Bedanford or Bedford, and is followed by the Rev. H. Cobbe in Luton Cburch; but Mr. W. H. Stevenson is of opinion that the identification is extremely doubtful, and is inclined to locate 'Beodeford' somewhere in Kent. The text from which the charter is printed is a late copy, and it is not at all certain that the name has been correctly transcribed from the original. $\quad{ }^{2}$ Cott. MS. Nero, D vii. f. 4.

3 Kemble, Cod. Dipl. dccclxxxiv. This charter is however of doubtful authenticity.

- Ibid. clv., clvii., clix., clxvi., clxvii. The Rev. H. Cobbe calls him the constant companion of Offa in his later years, and suggests that he may have been abbot of Bedford.

s Matth. Paris, Cbron. Majora (Rolls Series), i. $36_{3}$. ${ }^{6}$ Ibid.

7 Gesta Abbatum Mon. S. Albani (Rolls Series), i. 7, 62.

8 He says that in his own day bathers sometimes saw in the depths of the waters the appearance of a sepulchre ; but no one who deliberately looked for it could ever find it.

Anglo-Saxon Cbron. (Rolls Series), ii. 61, 64. 10 Ibid. 96. 


\section{ECCLESIASTICAL HISTORY}

Bedford, without further comment, as if there had been a monastery there for a long time. It is introduced as the burial-place of Oskytel, Archbishop of York, who was translated from the Mercian see of Dorchester in $956 .^{1}$ His kinsman Thurkytel ${ }^{2}$ was at that time abbot of Bedford; he brought the archbishop's body from Thame, to bury it in the monastery.

Almost immediately after the Conquest we find the county well provided with parish churches. Only four are named in Domesday; but it is well understood that this survey was never intended to supply a complete list of churches; they are only mentioned incidentally in connection with the tenure of land. Complete lists can be made out for the thirteenth century, correcting the returns from the Taxatio of Pope Nicholas by the Episcopal registers at Lincoln and the chartularies of the religious houses; and with the help of these it is possible to work a good way backwards. The total number of parish churches in $129 \mathrm{I}$, not counting the seven ${ }^{3}$ in Bedford town, was I I 5 ; and of these about eighty can be clearly proved to have been in existence in the twelfth century, and a few are mentioned even in documents of the eleventh. Actual proof is impossible without fuller records; but it seems probable that in the century before the Conquest Bedfordshire was as well provided with churches as other counties, ${ }^{4}$ and the archæological evidence will probably tend to the same conclusion.

The four churches of the Domesday Survey-Luton, Houghton (Regis), Leighton, and St. Paul's, Bedford-were probably the best endowed. Luton had belonged in the time of King Edward to Morcar the priest, and now William the Chamberlain held it with five hides of land, a mill and a wood; the whole property being worth 6os. The same man also held Houghton church of the king, with half a hide of land, worth I 2s. a year. Leighton had become a part of the endowment of Lincoln Cathedral, and was held of the king by Remigius the bishop. The foundation charter of the Cathedral granted by the Conqueror ${ }^{5}$ names the four churches of Aylesbury, Buckingham, Leighton and Bedford, as having all belonged to the ancient see of Dorchester; but the church of Bedford here mentioned (St. Mary's) is not named in Domesday, which speaks only of St. Paul's and the secular canons there.

The account of church property in Domesday ${ }^{6}$ is of much interest in relation to later history. Already several important manors and portions of land were claimed by religious houses, as well as by the Bishops of

1 Florence of Worc. (Engl. Hist. Soc.), i. 1 39, 142.

2 The dates make it impossible to identify this Thurkytel with the rebuilder of Croyland Abbey under Edred, as Canon Venables did in the Diocesan History of Lincoln (S.P.C.K.), p. 37.

${ }^{3}$ St. Paul's, St. Mary's, St. Peter Merton and St. Peter Dunstable, St. John's, St. Cuthbert's and All Saints'. They are all found in documents of the twelfth century.

4 The Chronicle of Dunstable records under the year $1220(p .56)$ the dedication of churches at Studham, Chalgrave and Pulloxhill ; obviously after rebuilding, for there had been old churches in all three places, which were given to the monastery in the twelfth century, and they would scarcely have required rebuilding if they had not been Saxon churches. These are small and unimportant places.

5 Confirmed by Henry II. and embodied in the Inspeximus of Henry VI. (Dugdale's Mor. vi. [3] 1250.

See Introduction to Domesday. 


\section{A HISTORY OF BEDFORDSHIRE}

Lincoln. Remigius held in seven different townships altogether $8 \frac{1}{2}$ hides and $2 \frac{3}{4}$ virgates, valued at $\oint_{0}$ I I $s$, , besides the church of Leighton, worth $f_{4}$, and the church of St. Paul's, Bedford, which men said he had wrongfully taken from the canons there. His property has however no special interest, except the church of Leighton, which soon after furnished a prebendal stall to the cathedral; and he did not long hold the church of St. Paul.

The Bishop of Durham's property is small, but has an interest of its own. He held in Millow $4 \frac{1}{2}$ hides, and in Arlesey 8 hides, together worth $£ 7$, which the canons of Holy Cross at Waltham ${ }^{1}$ had held in alms of Edward the Confessor. Both Millow and Arlesey were afterwards recovered by Waltham Abbey. ${ }^{2}$

The abbot of St. Edmund's held land in three places; altogether $7 \frac{1}{2}$ hides and 4 virgates, value $\oint_{0} 76$ s. His property has no further interest in church history.

The abbot of Peterborough had the manor of Stanwick, $2 \frac{1}{2}$ hides, worth 30 s., which still belonged to the abbey in $1346 .^{3} \quad$ This manor is now part of Northamptonshire.

The abbot of Ramsey had very extensive and valuable property ; the five manors of Cranfield, Barton, Pegsdon, Holwell and Shillington, besides land in Wyboston, Barford, Clifton and Standon. It amounted to $50 \frac{\mathrm{I}}{2}$ hides, and was worth $f_{0} 486 s .4 d^{4}{ }^{4}$ Cranfield, Barton and Shillington belonged to the abbey till the dissolution.

The abbot of St. Peter's, Westminster, had only half a hide in Holwell, worth i oos. He still drew a pension of ı os. from Holwell church in $1291 .^{5}$

The abbot of Thorney had 2 hides and I virgate in Bolnhurst, worth 6os. The church remained under the patronage of the abbey till the dissolution.

The abbess of Barking held the manor of Lidlington, $1 \circ$ hides, worth $f_{0} 8$, and continued to do so until the dissolution.

The canons of St. Paul's, London, held Caddington; the Dean and Chapter retain the patronage of the church until this day. The prebends of Caddington, Major and Minor, were endowed from their property in this neighbourhood. The manor was in extent 5 hides and worth 40s.; it had been given to the canons by King William.

Canon Osmund of St. Paul's, Bedford, held 3 virgates of the king in Biddenham, worth Ios. ${ }^{\circ}$ Canon Ansfrid of the same church held another virgate worth $3^{s}$, of the gift of Ralf Taillebois.

Ernuin, a priest, held I carucate in Harrowden.

1 See Domesday Studies, ii. 420-1. It is not clear how these two manors came into the hands of the Conqueror, whether by an exchange or by violence, as they seem to have been part of the original endowment of Waltham Abbey.

2 Feud. Aids, i. 19, 20.

${ }^{3}$ Ibid. i. 8, 25. Series).

4 The history of nearly all these acquisitions may be found in the registers of Ramsey Abbey (Rolls

5 Pope Nich. Tax. (Rec. Com.), 49.

6 One virgate was bequeathed by Leuiet, who held it in alms of King Edward; the other two were the gift of Ralf Taillebois. 


\section{ECCLESIASTICAL HISTORY}

These are all who held land for the church in capite. The property of the Bishops of Bayeux and Coutances was not held for the church, and was moreover very soon forfeited. The manors of Elstow and Wilshampstead with part of Maulden, amounting to II $\frac{I}{2}$ hides $I \frac{I}{2}$ virgates, and worth $£ 205 \mathrm{~s}$. in all, were held by the nuns of Elstow, but under Countess Judith. They need not be further noticed at this point, as their history is bound up with that of Elstow Abbey.

In the case of Arlesey, Cranfield, Barton, Shillington and Lidlington, where the whole manor belonged to a monastery before the Conquest, and afterwards until the dissolution, it seems most probable that the parish churches were built by the religious.

To the period immediately after the Conquest belongs not only the transference of the episcopal seat of the diocese from Dorchester to Lincoln, but its fuller organisation. Hitherto the bishops had needed but one 'eye' ; but now almost every county was provided with its own archdeacon. ${ }^{2}$ The names of the first archdeacons of Bedfordshire are found in Henry of Huntingdon's letter to Walter, ' de contemptu mundi' ${ }^{3}$ Osbert, the first; Ralf, 'miserably slain'; Hugh and Nicholas. The name of Hugh occurs also in the Dunstable chartulary; ${ }^{4}$ but that of Nicholas is very well known. Being archdeacon from I I 45 to I I 8 I, he was in office nearly all through the long interregnum that followed the death of Bishop Robert de Chesney in 1166 , and consequently he was called upon to ratify or witness a great many charters granting land or churches to the religious houses of the county. He witnessed the foundation charter of Chicksand Priory, ${ }^{5}$ and various donations to Beaulieu, ${ }^{6}$ Newnham ${ }^{7}$ and Dunstable. ${ }^{8}$ He had held one of the prebends of St. Paul's, Bedford, ${ }^{9}$ before the founding of Newnham Priory, and is named more than once among the old secular canons. He was succeeded by Laurence, whose name appears under the year II $85 ;{ }^{10}$ and Richard was archdeacon under St. Hugh."

The institution of the rural deans is usually assigned to the same period, ${ }^{13}$ but the time when their territorial limits were fixed is uncertain; a complete list of rural deaneries cannot be made out until the end of the thirteenth century. ${ }^{13}$

A very large majority of the parish churches were in the twelfth century granted to various monasteries of the neighbourhood, either at their foundation or later; the tithes were usually given with the advowson or very soon after. The consideration of these gifts in detail is more appropriate in connection with the ordination of vicarages in the next century. The bestowal of the advowson of a church on a monastery

1 It seems strange that the abbey of St. Alban's should have held nothing in this county, where afterwards it had so much valuable property.

2 Stubbs, Const. Hist. i. 117.

Anglia Sacra, ii. 696.

- Dugdale, Mon. vi. 950.

Harl. MS. 3656, f. 65 .

Ibid. 3656 , f. 47 .

10 Ibid. f. I7b, and ibid. 1885 , f. 24.

12 Stubbs, Const. Hist. i. 233.

I

- Harl. MS. 1885 , f. 20.

- Lansd. MS. 863, f. 83 b.

Ibid. 1885 , ff. 19, 2 Ib, 24 .

11 Ibid. 3656 , f. 60.

13 See p. 344. 


\section{A HISTORY OF BEDFORDSHIRE}

was a real act of generosity on the part of the owner, as he thereby lost what was then and afterwards considered as a natural provision for the cadets of his own family; and it was often resented by his immediate successors. A long series of suits on the subject of advowsons, between monasteries and lay patrons, begins in the twelfth century. The earliest we know of in Bedfordshire was between the abbot of Thorney and William Peverel, concerning the church of Bolnhurst, which lasted from I I I 3 to I I 5 I ; ${ }^{1}$ the priors of Dunstable, ${ }^{2}$ Chicksand $^{3}$ and Newnham ${ }^{4}$ had their rights to certain churches very early called into question. The chartularies of Newnham and Dunstable, both of which houses possessed a great many churches, point very clearly to difficulties of this kind; every grant is fenced about with charters-from the original grantor; from his lord if he had one; from the bishop or archdeacon; and, if possible, from the king and the pope. The bishop's charters were indeed necessary to the validity of the grant since the Council of Westminster in $1 \mathrm{IO} 2,{ }^{5}$ which forbade the religious to possess themselves of parish churches without the consent of the diocesan.

Suits are also recorded, though not in such numbers, between different religious houses; both parties having received some grant of tithes which seemed to justify a claim to the advowson. The abbey of Elstow came in for a large share of these disputes; both the abbot of Newhouse and the prior of Dunstable had to resort to a papal mandate before they could arrive at a peaceful settlement with the ladies, who seem to have been very determined in the effort to secure their rights. ${ }^{B}$

The most interesting of these disputes in the twelfth century was the one which gave Luton church back again to the abbey of St. Alban's. It had been held, jointly with Houghton Regis church, by William the Chamberlain, who, though he may well have been in minor orders, yet held these churches and their lands by knight service, and transmitted them to his heirs under the same tenure. In the reign of Stephen they were no longer however held in capite, but of Robert, Earl of Gloucester ; the desire of this nobleman to put a kinsman of his own into Luton church, and the subsequent complications arising from the Civil War, led at last to the transference of the advowson to St. Alban's abbey. It cost the abbot however i io marks before he finally secured it from

\footnotetext{
1 Dugdale, Mon. ii. 602.

2 Hugh Britton impleaded the prior in 1197 about the advowson of Studham (Feet of F. [Rec. Com.], p. 5).

3 Elias of Astwick brought a suit against the prior and Simon de Beauchamp about the chapel of Astwick, I 198 (ibid. p. 21).

4 The prior recovered Hatley church from Adam de Port, II97 (ibid. p. 8). There was a suit also between the Hospitallers and Stephen of Souldrop about the church of Souldrop, I 197 (ibid. p. 17).

${ }_{5}$ Rev. E. L. Cutts, Parish Priests and their People, p. 98.

- The Bishop of Ely, by mandate of Alexander III., settled the dispute between Dunstable and Elstow concerning the churches of Flitton, Westoning and Pulloxhill (Harl. MS. 1885, f. $23 \mathrm{~b}$ ). The same pope issued a bull forbidding the nuns of Elstow to lay any further claim to a church which belonged to the abbot of Newhouse (Harl. Charters, $43 \mathrm{G}, 23,24$ ). The church of Melchbourne was also claimed both by the prior of St. Neot's and the prior of the Hospitallers (Gorham, History of St. Neot's, II. cxiii.)
} 


\section{ECCLESIASTICAL HISTORY}

the de Clares, to say nothing of the sums that must have been paid for the assent both of Stephen and of Henry II. ${ }^{1}$

The beginning of the next century brought a considerable change to the position of a great many of the parish churches. Since the Conquest nearly four-fifths of the total number had been granted to religious houses. Some of these had been given to monasteries outside the county ; ${ }^{2}$ but a much larger number to the Bedfordshire monasteries. $^{3}$

1 The whole story is set out in full in the Gesta Abbatum (Rolls Series), i. I13-8. Robert, Earl of Gloucester, wishing to put in his kinsman Gilbert de Cimmay, became much shocked at the idea of these churches being held by a layman. The Bishop of Lincoln (Alexander) refused however to dispossess William the Chamberlain without legal forms; but after three days had been appointed for the hearing of the case, and the defendant refused to appear, he was disseised, and Gilbert de Cimmay presented. The disgrace of Robert of Gloucester put the manor of Luton for a time into the hands of Robert de Waudari, a kinsman of the abbot of St. Alban's, who was thus able to mediate between him and Gilbert de Cimmay. A serious illness of the latter, combined with the persuasions of the abbot, moved him to resign the benefice into the hands of the archdeacon, Nicholas of Bedford; it was then conferred on the abbot's nephew. As soon as William de Clare was restored to his father's property, the abbot approached him, and obtained from him first a grant of the church for 80 marks, and a discharge of knight service for another 30 marks (Cott. MS. Otho, D iii. f. I I 5 b). This was confirmed by Stephen (ibid, f. II 6 ), so its date must be between II 5 I and I I 54 ; and afterwards by Henry II.

There is another point of interest in this case, bearing on the tradition of Offa's connection with Luton. At the first trial of the matter, when William the Chamberlain was disseised, the jury declared that 5 hides of land had belonged to the church from the time of its first foundation; but at the beginning of Henry II.'s reign some were found ready to swear that the church was built 'super dominicum regni fiscum,' which was equally true in reference to the eleventh century (see also for all this Cobbe's Luton Church).

2 Bolnhurst to Thorney Abbey; finally in 115 I (Dugdale's Mon. ii. 602).

Dunton to Haliwell Priory, before 1189 (ibid. iv. 393).

Eyworth to St. Helen's, London; before 1225 (Linc. Epis. Reg., 16 Hugh de Wells).

Potton to St. Andrew's, Northampton; about 1094 by Simon de Senliz (Dugdale, Mon. v. 191).

Sharnbrook to St. Mary de Pré, Leicester; before 1162 by W. Tricket (ibid. vi. 468).

Tillsworth to St. Giles in the Wood.

Podington and Thurleigh to Canons Ashby.

Meppershall and Felmersham to Lenton; confirmed 1205 (Cal. of Pap. Letters, i. 18).

Edworth, Knotting, Tempsford and Turvey to St. Neot's (Gorham, History of St. Neot's, II. cxii. cxiii. cxiv. cxv.). (Knotting in I I 76 was a chapel appendant to Melchbourne church; in that year the Bishop of Exeter as arbitrator assigned the church to the Hospitallers and the chapel to St. Neot's. Turvey church is named in the charters of Newnham Priory, but the Lincoln Registers show that the advowson certainly belonged to St. Neot's.)

Eaton Bray, Whipsnade, Upper Stondon, Milton Bryant to Merton (Dugdale, Mon. vi. 247).

Luton, Houghton, Potsgrave to St. Alban's (Potsgrave by W. de Blancfront, Cotton MS. Otho, D iii. f. I 2ob).

Toddington to the abbey of Couture, Le Mans.

Langford and Little Stoughton to the Templars (Cotton MS. Nero, E vi. f. I 37). (Where no reference is given, the evidence of the earliest institutions in the Lincoln Episcopal Registers may be assumed.)

3 To Elstow : Elstow, Wilshampstead, Maulden, Flitton with Silsoe chapel, Kempston and Westoning.

To Dunstable: Dunstable, Chalgrave, Harlington, Studham, Husborne Crawley, Pulloxhill, Segenhoe, Totternhoe, Steppingley with St. Cuthbert, St. Mary and St. Peter Dunstable at Bedford.

To Newnham : St. Paul's and All Saints', Bedford; Ravensden, Renhold, Great Barford, Willington, Cardington, Goldington, Southill, Hatley, Wootton, Stagsden, Aspley, Lower Gravenhurst, Salford, Wrestlingworth and Hulcote.

To Caldwell : Bromham, Roxton and Sandy, Oakley with the chapel of Clapham.

To Chicksand : Chicksand, Haynes, Cople, Keysoe and Stotfold with the chapel of Astwick.

To Beaulieu : Millbrook, Clophill and Ampthill, Campton and Milton Ernest.

To Harrold : Harrold and Stevington.

To Markyate Priory : Sundon, Streatley and Higham Gobion.

To Melchbourne Preceptory : Dean, Eaton Socon, Risley, Eversholt and Melchbourne.

Most of these churches may be found in the foundation charters of the religious houses; the rest may be gathered from the early institutions in the Lincoln Registers. 


\section{A HISTORY OF BEDFORDSHIRE}

The original arrangement in the case of such grants was for the monastery to present a rector in the same way as the lay patrons had done, receiving from him a fixed pension. And the intention of the donor was for the good of the church as well as the monastery; he might well hope that the monks would have higher motives in the selection of rectors, and better opportunities of finding suitable men. But when the tithes were granted as well as the advowson the temptation to look upon their churches as mainly a source of income proved sometimes too much for the religious. Chaplains removable at pleasure might be put into the rectory at a small stipend; monks might be sent merely to perform the necessary duties; and in either case the parish had no one with a continuous interest in its welfare.

Between the worst and the best that might come of such arrangements there were doubtless many grades. But the bishops seem to have been early dissatisfied with the way in which the cure of souls was undertaken in the appropriate churches, and they succeeded in obtaining from the Lateran Council of I 179 the power to provide a remedy. It was to this end that the Council of Westminster in 1200 ordered the establishment of perpetual vicarages.

Certainly among the earliest in England was the vicarage ordained at Pulloxhill in $1204^{1}$ by William, Bishop of Lincoln. And in the Liber Antiquus of Hugh de Wells those at Henlow, Arlesey and Dunton are said to have been ' exdudum ordinatæ,' presumably before his own episcopate began in I209. In Bedfordshire before 1235 there were thirty-six besides the four already mentioned. ${ }^{2}$

The usual amount fixed for the vicar's income was 5 marks; only a few were more or less. This was made up from the small tithes, and the altarage of the church; a competent manse was usually added. The vicars were bound to pay the synodalia, but the religious the archdeacon's fees (except in the case of Luton, where the vicarage was worth $f_{1} 6$ ). There was no attempt to fix any proportion between the value of the whole rectory and the vicar's stipend; the principle being simply to provide the vicar with a proper maintenance, not to give him a fair share in the profits. The benefice might be worth 10 , 12 or 15 marks, but still the vicar's portion was 5 or $5 \frac{\mathrm{I}}{2}$ marks; the monastery took the residue, small or great. The rule was the same for very poor churches. The bishop fixed the stipend of the vicar of Ampthill at 5

1 Ann. Mon. (Rolls Series) iii. 28.

2 Appropriate to Elstow : Flitton, Westoning, Kempston.

To Chicksand : Haynes, Stotfold, Cople, Keysoe.

To Dunstable : Husborne Crawley, Segenhoe, Chalgrave, Totternhoe and Studham. Stagsden.

To Newnham : Salford, Goldington, Cardington, Willington, Barford, Renhold, Ravensden,

To Beaulieu : Ampthill, Clophill, Millbrook and Potsgrave.

To Markyate : Sundon.

To Harrold : Harrold and Stevington.

To Caldwell : Bromham and Roxton,

To St. John's Hospital : St. John's, Bedford.

Besides these, Luton, Houghton, Tillsworth, Eaton Bray, Langford, Podington, were appropriated to monasteries outside the county. 


\section{ECCLESIASTICAL HISTORY}

marks, though the rectory was only worth Ioos.; and he ordered the canons of Newnham to make up the vicarage of Ravensden to 5 marks, even if the tithes greater and less did not amount to so much. Only occasionally, if the rectory was of considerable value, the vicar's portion was made larger; the rectory of Great Barford, worth 22 marks, the vicar received 8 ; the rectory of Luton, worth 100 marks, the vicar had 24.

The arrangement for Harrold is different to the rest and may serve as an example of the treatment of a case where the parish church became conventual. ${ }^{1} \quad$ The vicar was to have his living at the prioress's table, with 2 marks yearly for his clothing, hay for his palfrey, and the oblations at great festivals. His manse might be within the priory enclosure or out of it, according to what was most convenient for his parishioners; and the prioress was to provide him with a deacon and a boy to serve his mass. ${ }^{2}$

Bishop Grossetête continued the work of his predecessor, ordaining however only one vicarage in Bedfordshire-Caddington, ${ }^{3}$ the property of the Dean and Chapter of St. Paul's, London. Bishop Gravesend ordained a vicarage for Wootton in 1272 , Southill ${ }^{4}$ in 1264 , and probably Sharnbrook. He also ordained vicarages for the two prebendal churches of Leighton Buzzard and Biggleswade. ${ }^{\circ}$ Streatley ${ }^{7}$ was ordained before 1289, and Eaton Socon ${ }^{8}$ before I 29I. The last of this century was Oakley, ${ }^{9}$ ordained in 1296.

Mention has been made incidentally already of the parochial chapels, which served for the devotion of villages and hamlets remote from the parish church. They are a special feature of the twelfth century, being built in large numbers all over the country during the reigns of Henry $\mathbf{I}$. and Stephen. They are mostly due to the generosity of lords of manors, who wished to provide not only for themselves and their own households, but also for the villagers amongst whom they dwelt; and the chapels thus built were usually appendant to the parish church. The building of private chapels became common in the thirteenth century, as the bishops' registers show ; but the parochial chapels were nearly all earlier. It is probable that there were several, even in a small county like Bed-

1 No other church of this type in Bedfordshire had a vicarage ordained, except Elstow in 1345 (Linc. Epis. Reg., Inst. Bek. 102); and that was revoked almost at once. The canons of Newnham appointed one of their own brethren as warden of St. Paul's, Bedford (Linc. Epis. Reg., Memo. Grey, 199) and so did the canons of Dunstable (Ann. Mon. [Rolls Series], iii. 220) until 1392 (Linc. Epis. Reg., Memo. Buckingham, 4I I).

All from the Liber Antiquus, Alfred Gibbons, pp. 20-5.

3 A vicar was instituted in 1250 (Excerpta from Linc. Epis. Reg., Harl. MS. 3650). The church had two rectors before.

4 Wootton and Southill are both in Linc. Epis. Reg., Memo. Gravesend; but the pope had ordered the reservation of a vicar's portion for both in 1255 (Cal. of Pap. Letters, i. 314, 316 . Sugmele is evidently a misreading for Sugivele).

5 Vicarage vacant in 1283 (Harl. MS. 3650).

- 1276 and 1277 (ibid.)

7 Ibid.

Vicarage noted in Pope Nich. Tax. (Rec. Com.), p. 35

- Hugh de Wells had compelled the prior and convent of Caldwell to present secular clerks, who were to receive half the tithes (total value, $24 \frac{1}{2}$ marks), but Oliver Sutton preferred to ordain a vicarage in 1296 (Linc. Epis. Reg., Memo. Sutton, 100). 


\section{A HISTORY OF BEDFORDSHIRE}

fordshire, of which no record-not even the name-remains. Some are only mentioned once, and nothing further is known of their history.

Of those which are known to have existed the chief were:-

The chapel of Astwick, ${ }^{1}$ appendant to Studham church.

\begin{tabular}{|c|c|c|c|c|}
\hline & & & & \\
\hline " & $"$ & $\begin{array}{l}\text { Cainhoe } \\
\text { Silsoe }^{3}\end{array}$ & " & lophill \\
\hline$"$ & " & $\begin{array}{l}\text { Silsoe } \\
\end{array}$ & $"$ & Itton \\
\hline ", & $"$ & Radwell & $"$ & Felmersham \\
\hline$"$ & $"$ & Knotting $^{5}$ & $"$ & Melchbourn \\
\hline " & $"$ & Roxhill $^{6}$ & $"$ & Marston \\
\hline$"$ & 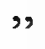 & Clapham & $"$ & Oakley \\
\hline & 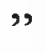 & Barwythe & $"$ & Studham \\
\hline & & Tebworth & " & Cnalgrave \\
\hline
\end{tabular}

Whipsnade 10 and "Woburn are never "described as dependant on any church, and may have been free chapels.

Of these, Knotting, Astwick, ${ }^{11}$ and Whipsnade had become parish churches before the Taxatio of r29I. Pavenham and Silsoe were not independent parishes until the nineteenth century. Woburn and Clapham were still chapels in the reign of Henry VIII. The others have disappeared.

The occasion of a suit in which the abbot of Woburn was involved, with reference to the chapel of Hunderigg in Buckinghamshire, serves to explain very clearly the purpose for which these chapels were intended, and their relation to the parish church; it is interesting also as showing what was then considered a proper provision of services for a small hamlet in the country. The monks undertook to send a clerk three days in the week ${ }^{12}$ - Sunday, Wednesday and Friday, and in Advent and Lent Saturday also; he was to sing mass (probably mattins also) on these days; he was to say the office of 'Tenebra' on the three last days of Holy Week, and at Christmas to sing the midnight mass, and mattins, and the second mass at dawn. ${ }^{13}$ If a feast day were to fall in September, there was not to be an extra mass, but one of the ferial

1 Earliest mention in the foundation charter of Chicksand.

* Only in the foundation charter of Beaulieu ; this priory also served the chapel of St. Machutus in the parish of Haynes (Cott. MS. Nero, D vii. f. 92 ; Claudius, D i. f. I 35b), said to have been given by Robert d'Albini with the cell of Beaulieu.

${ }^{3}$ Earliest mention in the Liber Antiquus; noticed afterwards frequently in the Lincoln Registers.

4 Earliest mention in 1205 (Cal. of Pap. Letters, i. 18); Radwell for the last time in 1363 in the Register of Bp. Gynwell.

${ }_{5}$ Earliest mention in 176 (Gorham, Hist. of St. Neot's, II. cxiii.).

- Earliest mention in 1280 (Linc. Epis. Reg.).

7 Earliest mention in a charter of St. Hugh, quoted in the Linc. Epis. Reg., Memo. Sutton, 100.

8 Harl. MS. I 885 , ff. 51 , 57.

9 Ann. Mon. (Rolls Series), iii. 277 ; already of long standing.

10 Harl. MS. I 885 , f. 52 b. It has a rector, not a chaplain only.

11 Astwick was still a chapel in 1242 (Cur. Reg. R. 125, n. 22). The chapels of Sharpenhoe and Humbershoe (Ann. Mon. [Rolls Series], iii. 14I, 257) were probably also parochial. The chapel of St. Thomas the Martyr near Chicksand Priory belongs to the thirteenth century (Cal. of Pap. Letters, i. 534) and had disappeared before the sixteenth.

12 Three days was the usual allowance at these chapels.

13 In order that the parishioners might fulfil their obligation of hearing three masses on Christmas Day. 


\section{ECCLESIASTICAL HISTORY}

days was to be omitted. On all principal feasts of the year, i.e. Christmas, Candlemas, Good Friday, Easter, Pentecost, and the Dedication of the Church, the parishioners were to attend the solemn high mass at Chesham, to save the rights of the mother church. ${ }^{1}$

As early as 1213 troubles began to arise between the monastic tenants and their lords on the subject of feudal service. There was a suit brought forward in the summer of this year in the Curia Regis ${ }^{2}$ between the prior of Leighton ${ }^{3}$ and his men. Later in the same reign the prior summoned five of his tenants for not rendering the customary services." They in their turn appealed to the judgment of the three towns of Luton, Houghton and Leighton. The result is not recorded, but suits went on between the prior and his tenants up till $1290 . .^{6}$

The difficulty at Leighton seems to have been mainly concerned with feudal services; at Dunstable it was of a different character, and far more serious. In I 2 I $9^{6}$ the prior of Dunstable proved his right to hold a court in the town for all pleas of the Crown. In the following year the archdeacon of Bedford, John Houghton, was called in for the first time to witness a composition between the prior and his burgesses on the subject of fines, tithes of trade, ${ }^{7}$ etc. But it was not till $1228^{8}$ that the townsmen drew up a formal list of grievances. As at Leighton, they said that the prior demanded of them many things contrary to the liberties which they had always enjoyed. The justiciars before whom they laid their grievances sent them on to the King's Court. There they failed to prove their case, in spite of bribes to Hubert de Burgh and others; and the prior had his charters confirmed by Henry III., securing the same rights over the men of Dunstable as the king himself had in his own towns. The ill-feeling of the burgesses. was not likely to be lessened by the prior's demand of roo marks towards the $\oint_{\mathrm{I}} \mathrm{O} 0 \mathrm{he}$ had to pay for this confirmation. Blows and wounds were exchanged by the tenants and the servants of the prior over the collection of the money. Then the burgesses began to withdraw their offerings from the church; excommunication from the prior they wholly disregarded, and paid only a temporary reverence to the threat of excommunication delivered from the pulpit by the bishop himself. For more than two months the solemn high mass in the parish church was discontinued.'

1 Cur. Reg. R. 2 John 24, n. 26.

2 Ibid. 56, n. 17 in dorso.

3 The priory of Leighton, afterwards called La Grave, was a cell of the order of Fontevraud.

4 Cur. Reg. R. John incerti temporis, 35, n. 2.

5 Ibid. n. 5. A jury was impanelled to decide between the prior and William, a certain clerk; who, being required to send his men for given services, pleaded that he and his predecessors had held their land free of the lord king, before the manor was given to the nuns of Fontevraud; and moreover, some of the jury were disqualified, by the fact of being customary tenants of the prior. In I 260 (Cur. Reg. R. 168, n. 2 in dorso) the men of Leighton summoned the prior for distraining them on similar grounds; the prior refused to appear. In 1290 (Coram Reg. R. 18 Edw. I. n. 22) Henry Child impleaded the prior on the same grounds.

B Ann. Mon. (Rolls Series), iii. 54. 7 Ibid. 65. 8 Ibid. 105.

9 It was sung instead in the infirmary of the monastery, to which the townspeople would not have access, from I August to 9 October (Ann. Mon. [Rolls Series], iii. I Io). 


\section{A HISTORY OF BEDFORDSHIRE}

A year later ${ }^{1}$ the king's visit to Dunstable found the town still in revolt. He was entreated by the prior to mediate, and in his presence the burgesses indeed consented to submit; but as soon as his back was turned they resumed hostilities. The case went to Westminster; the amount of fine was limited to $4 d$. as the burgesses had asked, and after a second appeal it was granted that only those who held of the prior in capite should pay the tallage. Peace seemed at last to be secured; but the manner in which the tallage was collected by the burgesses appointed for the purpose provoked a fresh outbreak. Again the people withdrew their offerings, refused to use the prior's mills, and harried his servants in every way they could. Men and women rose in a body against the bailiff who tried to distrain any man's goods; they said they would rather go to hell than pay the tax. They even went so far as to negotiate with William de Cantelow, lord of Eaton Bray, to give them forty acres where they might build another town and leave Dunstable for ever. At this juncture, when justiciars were weary of the matter, and the town was in a state of anarchy, 'the Lord visited the spirit' of John Houghton the archdeacon, and the tempest was turned into a calm. An agreement was made by which the burgesses were to pay $£ 60$ down instead of the tallage, and were no more to be taxed individually. ${ }^{2}$ From this time there seem to have been very few difficulties, and the relations between the prior and the tenants were on the whole quite friendly, until the end of the fourteenth century.

John Houghton, who plays such a prominent part in this dispute, was one of the most notable of the early archdeacons. He held office from 12 I 8 to $123^{*}$ (when he was transferred to Huntingdon), and was employed as a mediator in several matters more important than this. He was sent to Rome in $1228^{\circ}$ with the dean of Lincoln, who had to render an account to the pope for his boldness in summoning to his chapter one of the canons who was a cardinal and an alien. He had been one of those who were sent to negotiate between the king and the followers of Fawkes de Bréauté ${ }^{\circ}$ before the taking of Bedford Castle in 1223 . In $1224^{7}$ he was busy collecting a loan for the king in England, and the next year ${ }^{8}$ in France. He was employed with others by the pope to inquire into the case of the abbot of Tewkesbury, who was suspected of having forged papal letters. ${ }^{\circ} \quad$ All these commissions would call out the same qualities as the troubles at Dunstable; he must have been a man of considerable tact and sympathy, and ready to take some pains to understand both sides of the question at issue.

Another archdeacon of Bedford who did important public work

1 Ann. Mon. (Rolls Series), iii. p. 118.

2 Ibid. p. 122 , where the concordia is printed in full.

3 e.g. in a quarrel between the king's falconers and the prior's men in 1276 . The townspeople were quite ready to take the part of the prior (ibid. pp. 273, 274).

1 Ibid. pp. 53, I 28.

5 Ibid. p. Io9.

Ibid. p. 88

7 Pat. 8 Hen. III. m. 10.

8 Ibid. 9 Hen. III. m. 3 .

- Cal. of Pap. Letters, i. 88, 95. 


\section{ECCLESIASTICAL HISTORY}

besides his ordinary duty was John de Crachely, treasurer to the king; he died in the year 1260, leaving considerable sums of money in charity and also for the endowment of chantries. ${ }^{1}$

Complaints of the usury and fraudulent dealings of the Jews appear early in the thirteenth century. The chronicler of Dunstable records in $122 \mathrm{I}^{2}$ the case of a certain 'Mossy filius Brun' who tried to pass off a forged charter on the prior, claiming the sum of $£_{670}$. He was detected, and his brethren had to pay $\oint_{0} \mathrm{r} 00$ to the king before they could get his death sentence commuted to banishment. Later on, in the reign of Edward I., ${ }^{3}$ certain Jews were hanged and their property confiscated at Bedford. In 1278 Jews were caught clipping the coin "there, as in so many other places. In the same year ${ }^{5}$ commissioners were sent to open the chirographer's chest in the King's Jewry ; to make a scrutiny and take note of all charters and deeds found there. The expulsion of the Jews in 1290 is recorded with approval by the chronicler of Dunstable; but he preserves also an instance of kindness shown to those who were converted. ${ }^{\circ}$

The same chronicler describes at some length the general sentiments of English churchmen as to the papal provisions common at this time; he also records a typical instance (not altogether to the credit of his own house) of the way in which English benefices fared when farmed out by foreign rectors. Peter de Vitella de Ferentino, an Italian, had been presented to the church of Steppingley by the prior of Dunstable in $1247 .^{7}$ In $1250^{\circ}$ he came to Dunstable to arrange his affairs; and finally let the church to the dean, Gilbert of Tingrith, to farm for Ioos. a year, appointing a canon of Dunstable as his proctor. In five years ${ }^{\theta}$ he returned to implead Gilbert, who had only paid his rent twice. He recovered some part of his money, and now let the church to a certain clerk instead of Gilbert, at the same rate as before, departing as soon as this was done for another five years. This case is not however so unsatisfactory as some others, for the church and its ornaments were kept in good repair by the canons, and the expenses charged to the rector; and it may be assumed that if these things were cared for, the services at least were properly performed. But in the long list of complaints drawn up by the king against the Italians, it was alleged that even books and vestments were wanting in some of the churches they held. ${ }^{10}$

In spite, however, of papal provisions, and the exactions from Rome

1 Ann. Mon. (Rolls Series), iii. 216. washed.

2 Ibid. p. 66. The deed was detected by its bad grammar, and also by the fact that it had been

3 Pat. 13 Edw. I. ; Harl. MS. 3656, f. 28.

Ann. Mon. (Rolls Series), iii. 228.

5 Pat. 4 Edw. I. m. 36.

6 The prior of Dunstable was directed in 1275 to provide complete maintenance for a converted Jew and his family; the Bishop of Lincoln ultimately found them a home (Ann. Mon. [Rolls Series], iii. 265).

${ }^{7}$ Ibid. p. 176. 8 Ibid. p. $181 .{ }^{9}$ Ibid. p. 197.

10 Lidlington was farmed by the canons of Dunstable for a foreign rector, who was so little known in England that in $\mathbf{2} 277$ he was thought to be dead. 


\section{A HISTORY OF BEDFORDSHIRE}

under which all the clergy suffered so severely at this time, the spiritual life of the diocese which included Bedfordshire was by no means in a languishing condition. The great bishops of the thirteenth centuryHugh de Wells, Grossetête, Gravesend, Oliver Sutton-were all vigorous and active in their visitations, both of the churches and of the religious houses, correcting abuses, and seeing that vicars were properly provided and paid. Grossetête raised the income of some vicarages which had been ordained by Hugh de Wells; notably in the case of those which belonged to Newnham Priory. ${ }^{3} \quad$ The chronicler of Dunstable explains how careful he was in examining the title deeds of appropriate churches, and how he disapproved of the farming system : 'scarcely,' he says, 'could we obtain from him churches which we had undertaken to farm for three years.' ${ }^{2}$ His visitations were especially severe; he was ready not merely to depose abbots and priors, but to suspend unsatisfactory rectors also. He did not however depose any heads of houses in Bedfordshire; though the prior of Caldwell and the cellarer of Dunstable fled to the Cistercians rather than abide his coming. ${ }^{3} \mathrm{He}$ chose Dunstable as a meeting-place for the bishops who desired to protest against Archbishop Boniface's visitation in $1250,{ }^{4}$ and canons from Dunstable filled up three of the posts left vacant by his depositions; it is probable, therefore, that he found the religious houses of Bedfordshire in a satisfactory condition.

Bishop Gravesend was also watchful against abuses of the farming system. The canons of Dunstable had been farming the church of Lidlington since 1273 , for a foreign rector, Payn by name, at I 8 marks a year. They were careful to pay their rent and to make the necessary repairs. ${ }^{5}$ But in 1276 , as no one claimed any rent, and the rector was thought to be dead, they began to appropriate the whole fruits of the living. They were not suffered to do this with impunity for any length of time. In $1277^{6}$ the bishop came and ejected them altogether from the church, and appointed a clerk as to a vacant living. The visitations of Oliver Sutton were equally energetic, as the same canons had reason to know."

The coming of the friars during this century must also have had its influence upon the spiritual life of the county, especially in the towns. They settled at Bedford and Dunstable; Grey Friars in one, Black Friars in the other. Their mission was to the poor and outcast of the towns; but their example fired with enthusiasm all classes of society. ${ }^{8} \quad$ Even among the monks, who were usually jealous of their in-

1 The canons however appealed to the pope and obtained a confirmation of the original assessment (Gal. of Pap. Letters, i. 31 3).

2 Ann. Mon. (Rolls Series), iii. 147

3 Ibid. 178.

- Ibid. 276. The rectory was appropriate to Barking Abbey; the abbess and convent presented again in 1283 .

7 Ibid. 283 .

8 The second vicar of Luton, Adam of Biscot, resigned his benefice in order to take the Dominican habit; and four other incumbents in Bedfordshire entered religious houses between 1248 and 1251 (Rev. H. Cobbe, Luson Cburch, I 22 [from Linc. Epis. Reg.]) 


\section{ECCLESIASTICAL HISTORY}

fluence, they found some disciples : two young canons of Dunstable fled away by night to join the Friars Minor at Oxford in $1232 .{ }^{1}$ But their great popularity as confessors-partly due indeed to their holiness of life, but partly also to other reasons less exalted-brought them into collision sometimes with the parish clergy. In the memoranda of Bishop Sutton, ${ }^{2}$ side by side with similar admonitions to certain priests of Lincoln, is a mandate to the official of the archdeacon of Bedford to bid the canons of Dunstable (where the conventual church was also a parish church) desist from forbidding and impeding the Friars Preachers from hearing the confessions of the people of that place. Only a few years later, ${ }^{3}$ however, it was the bishop who complained of the number of friars presented to him for licences as confessors; giving as his reason for refusing some of the candidates that those already licensed were surely enough, and that the rectors and curates of his diocese were sufficient for the cure of their subjects.

The dealings of Edward I. with the clergy at the end of the century are matters of general rather than of local history. The names of most of the religious houses of Bedfordshire appear in the lists of those who sought the king's protection in 1295 ; and a few of the clergy also. The 'Placita de Quo Warranto' of I 290 contain also much of local interest. Nearly all the religious superiors, as well as many laymen and one parish priest in Bedfordshire, were required to show by what title they exercised manorial rights, took court fees, and tolls from markets and fairs. The charters brought forward in defence were repeatedly pronounced too vague and undefined; the plea of immemorial custom had to be supported by evidence. Of the religious, only the abbot of St. Alban's and the prioress of Haliwell " seem to have clearly proved their rights in Luton and Dunton; the abbot of Waltham and the vicar of Potton lost theirs ${ }^{5}$; the other cases were many times postponed. It may be added that under the similar inquiry of the fourth year of Edward III. the same parties were again summoned, showing that they had all resumed their rights in the meanwhile; and this time nearly all, including the vicar of Potton, and the parsons of Sandy, Toddington, Eversholt and Old Warden ${ }^{B}$ were reinstated formally on payment of fine.

The Taxatio of Pope Nicholas IV. in I 29 I requires a special notice, as it was the first clear summary of church property in the county since Domesday.

The archdeaconry was divided at this point into six rural deaneries; I I churches were named, 4 in Bedford and 107 in the county besides. The revenue of two prebendaries was drawn from Bedford; one from

1 Ann. Mon. (Rolls Series), iii. 133.

2 Linc. Epis. Reg., Memo. Sutton, 217.

3 Ibid. Memo. Dalderby, 19d. Ten friars from Dunstable were presented at this time amongst others, by the provincial.

Plac. de quo Warr. (Rec. Com.), 2 and 7.

I Ibid. 8 , 9.

Ibid. $62,69,75,78,86$. 


\section{A HISTORY OF BEDFORDSHIRE}

Leighton Buzzard, one from Biggleswade and two from Caddington. ${ }^{1}$ The total value given was: spiritualities, $\oint_{0} \mathrm{r}, 204 \mathrm{r} 4 \mathrm{~s}$.; temporalities, $f_{0} 8$ I I I I s. As the list of churches is not complete, ${ }^{2}$ the valuation cannot be quite accurate. The poorest endowments were those of Ampthill, Chicksand, Goldington and Willington, which were only $\oint_{2}$ I 3 s. $4 d$. each; the richest-those over $\oint_{0} 20$-were Leighton Buzzard, $\oint_{0} 96 \mathrm{I}^{\text {s. }} 4 \mathrm{~d}_{0} ;{ }^{3}$ Luton, $\oint_{0} 66$ I $3^{s}$. 4d.; Biggleswade, $£_{46} \mathrm{I}^{s}$. 4d.; Shillington, $\oint_{40}$; and Felmersham, $f_{2} 6 \mathrm{I}_{3} s .4 d$. The rest of the benefices vary from $£_{4} 4$ to $£_{0} 5$, with a few at $£_{0} \mathrm{I}, £_{0} 12$ or $\oint_{0} 20 . \oint_{0} 4$ to $£_{0} 5$ was evidently considered a sufficient maintenance.

Many of these churches were already held in plurality, though not to the same extent as in the next century. In 1294 the prebendary of Leighton Buzzard had four other churches; in the same year the rector of Shillington had thirteen others. ${ }^{4}$ Master Walter of Wootton, presented to Marston Moretaine in 1282 , received a canonry of Lincoln and two prebends in 1292 ; and in 1295 , when he became archdeacon of Huntingdon, the chronicler of Dunstable, though looking upon him as a real friend to the monastery, notes with a little touch of disapproval that he resigned none of his former benefices. ${ }^{5}$

There is abundant evidence that until the time of the Great Pestilence the generosity and devotion of the English laity to the Church was the same as it had always been. The number of religious houses already built was amply sufficient for the needs of the country ; fresh endowments and direct benefactions were discouraged by the Statute of Mortmain; but there were other ways open. The rebuilding of parochial and conventual churches at the beginning of the fourteenth century, in Bedfordshire and elsewhere, shows how ready men still were to give to objects of this kind. A few chapels were still built for districts not well served; as at Upper Gravenhurst before I $369,{ }^{6}$ and at Stanbridge before $1344 .^{7}$ The bridge chapel at Biddenham was built in $1296,{ }^{8}$ and that of St. Thomas the Martyr at Bedford not long after ; ${ }^{9}$ these were intended for the convenience of travellers, to provide them with an early mass, and sometimes even with a place of refuge from thieves. ${ }^{10}$ But the

1 These two were and still are attached to St. Paul's, London.

2 Eleven are missing : St. John's, St. Cuthbert's and St. Peter's at Bedford, with the parish churches of Tillsworth, Arlesey, Langford, Chellington, Harrold, Stevington, Tingrith, Gravenhurst ; and of nine churches only the pension is mentioned which they paid to some religious house, and not the whole income. A few churches have the value of the vicarage set down as well as the rectory, but by no means all. The total valuation is therefore lower than the real value.

3 As complaints were so often made of the small stipends allowed to the vicars of appropriate churches, it is worth noting that the vicar of Leighton Buzzard only received from the wealthy prebendary $£_{4} 6 \mathrm{~s} .8 \mathrm{~d}$. a year; while the vicar of Luton received $£ \mathrm{I} 6$ from St. Alban's.

Both these are found in the Cal. of Pat. Rolls, 22 Edward I.

5 Ann. Mon. (Rolls Series), iii. 40I.

6 Linc. Epis. Reg., Memo. Gynwell, 84, 87. Licensed for masses to the inhabitants of the vill of Shillington.

7 Ibid. Memo. Bek. 74d. Annexed then to the prebend of Leighton Buzzard.

8 Ibid. Memo. Sutton, ii. I62. Licence to grant lands in mortmain. Pat. 28 Edw. I. m. I 2.

9 Linc. Epis. Reg., Memo. Burghersh, 107 (1323); mentioned as lately built with sumptuous work, and since damaged by the water. In Pat. I 3 Rich. II. pt. 2, m. 2, it is called 'the king's free chapel.'

10 Stated in the licence to the chapel of Biddenham Bridge. 


\section{ECCLESIASTICAL HISTORY}

most popular form of benefaction at that time, and onwards to the Reformation, was the foundation of chantries. There had been a few in the thirteenth century and even earlier; in $1234^{1}$ and $1236^{2}$ the canons of Dunstable had undertaken to provide anniversaries for certain of their benefactors, and other instances might be named; but they did not become common till the beginning of the fourteenth century. They might indeed be only a form of legacy to monasteries, but most often they were attached to the parish churches. Such legacies were not necessarily selfish, as at first sight they may appear to be. Certain lands and tenements, etc., were set apart for the maintenance of a chaplain, to sing mass for the souls of the founder and his relations; but the practical result was the fresh adornment of some altar in the church, and the provision of an assistant to the parish priest.

Besides those founded in parish churches or chapels, ${ }^{3}$ a few were undertaken by the religious in their own churches. The canons of Dunstable conceded a perpetual chantry in 1272 to the archdeacon, John de Crachely ; ${ }^{4}$ another was founded by Thomas Marshall, the prior, about I $379,{ }^{5}$ for his own parents ; a third was granted to Sir Neel Loring in I $3900^{\circ}$

The canons of Caldwell had also three chantries to serve: in their own church one was granted to Adam Flaun, vicar of Newnham, Herts,

1 Ann. Mon. (Rolls Series), iii. I41. 2 Ibid. 144.

3 In the chapel of Barwythe, Studham, for William de Eltesdon, 1236 (Harl. MS. 1 885, f. 5 I ; Ann. Mon. [Rolls Series], iii. I44 ; Linc. Epis. Reg., Rolls of Grossetête $\mathrm{A}^{0} 2$ ).

In the chapel of Silsoe, Flitton, for Thomas de Bray, 1275 (Linc. Epis. Reg., Rolls of Gravesend).

In the church of Elstow, founder unknown, before 1277 (ibid.)

In the chapel of Tebworth, Chalgrave, the parishioners claimed an ancient chantry, I 286 ( $A n n$.

Mon. [Rolls Series], ziii. 329).

In the chapel of Biddenham Bridge, for Matthew of Dunstable, rector of the moiety of Elstow, 1296 (Linc. Epis. Reg., Memo. Sutton, 162 ; ibid. Inst. Dalderby, 267).

In Toddington Church, a chantry of the blessed Virgin, under Bishop Sutton (Linc. Epis. Reg.)

In the church of Dean, by Walter of Ireland, the rector, 130 I (ibid. Inst. Dalderby, 270d, 27I).

In the church of Bletsoe, for the lords of the manor, 1305 (ibid. 305 ).

In the chapel of Silsoe, for Ralph son of Richard, 1327 (ibid. Inst. Burghersh, 314d).

In the church of Westoning, for William Inge, 1328 (ibid. $395 \mathrm{~d}$ ).

In the church of Renhold, for John Picot, 1336 (ibid. Inst. Bek. I 49d, 150 ).

In the church of Sandy, for Roger de Beauchamp, 1337 (ibid. I 53-7).

In the church of Eaton Socon, for Roger de Beauchamp and John Engayne, 1337 (ibid.)

In the church of Elstow for Thos. atte Brugge, rector of Campton, 1349 (Inq. p.m. 2 I Edward

III. No. 72).

In the church of Chalgrave for Sir Neel Loring (Linc. Epis. Reg., Memo. Repingdon, 8I).

In the church of Wootton (founder unknown) before I 260 (Harl. MS. 3656, f. 22).

In the church of St. Cuthbert, Bedford; Chantry Cert. I gives the date I 4 Edw. II.

Chantries were also founded in a few private chapels, e.g. :-

Gravesend).

In the chapel of Sir John de Grey on his manor of Thurleigh, I 320 (Linc. Epis. Reg., Inst. Burghersh, 294).

In the court of William de Cantelow at Eaton Bray (Anct. D. [P.R.O.] A Io6).

In the chapel of St. John Baptist, within the court of Paulin Peyver at Toddington, thirteenth century (Linc. Epis. Reg., Memo. Russell, 47-50).

Ann. Mon. (Rolls Series), iii. 255. This chantry is interesting as being the only one of this period which includes a definite charity; i.e. the maintenance of a blind clerk in the monastery "for the sake of the soul of John Crachely.'

6 Linc. Epis. Reg., Memo. Buckingham, 8zd.

6 Ibid. 367 . 


\section{A HISTORY OF BEDFORDSHIRE}

in $1321 ;^{1}$ another in the same year to Sir John de Grey ${ }^{2}$ and a third, to be kept in the chapel of St. Leonard's Hospital ${ }^{3}$ for Sir John Spark, clerk, of Caldecote, in 1328.

The canons of Newnham granted a chantry in $1303^{4}$ to Roger Brown of Rowell, and another in $1379^{5}$ to Henry of Bedford, in the conventual church.

The list of chantries founded at this period has a special interest in connection with the history of the county families, and with the spiritual life of the county as a whole. It will be noticed that the founders were nearly all descended from the men who built and endowed the religious houses, and many of their names occur again in the lists of benefactors to St. Alban's, Dunstable, Elstow, etc.; so that it would seem that these foundations sprang from the same impulse as that which produced the monasteries-the desire to be remembered in some way that should be for the glory of God and the advancement of the Church.

Very few chapels seem to have been built with the primary intention of perpetuating chantries; there are only three in Bedfordshirethose which once stood in the churchyards of Flitwick, Elstow ${ }^{7}$ and Wilshampstead ${ }^{8}$ - which seem to be clear instances. All the rest, whether they lasted on till the suppression or fell into decay before, were in the first instance parochial or domestic, and the chantries were merely appended to them. ${ }^{\circ}$

The position of the parish churches with relation to the religious houses was little altered during the fourteenth century. Two more were appropriated-Biddenham to the Nuns Minoresses of Waterbeach ${ }^{10}$ (afterwards of Denny), and both moieties of Elstow to the monastery which already held the advowson. ${ }^{11}$ The churches of Felmersham ${ }^{12}$ and Potton ${ }^{13}$ were taken for a time into the hands of the king, but only to be granted away again soon after. ${ }^{14}$ Four more vicarages were ordained - at

1 Linc. Epis. Reg., Inst. Burghersh, 292.

3 Ibid. Inst. Dalderby, 302.4 Ibid. 260. Ordination of a chantry in honour of

7 Ibid. Memo. Burghersh (1334), 273. Indulgence for the chapel of St. Helen in the churchyard of Elstow, and for the soul of . . . Ivota, foundress.

8 Ibid. Memo. Burghersh, ro8d, 1323. "For the fabric of the chapel of St. John Baptist in the churchyard of Wilshampstead.' 'To these should perhaps be added the chapel of Wyboston in Eaton Socon parish (Chant. Cert. Nos. I, 4), but its original purpose is uncertain.

9 The chantries granted to James de Caus ' in his chapel of Sharpenhoe' (1234) (Ann. Mon. [Rolls Series], iii. I 41), and to Bartholomew Young 'in the chapel which he erected at Humbershoe' (1273), which are only once mentioned, are described in similar terms to that of William de Eltesdon at Barwythe, which is distinctly stated to have been a parochial chapel (Harl. MSS. 1885, f. 52b), and also disappears from this time forward.

10 After a long suit with William de Kirkeby (Linc. Epis. Reg., Memo. Sutton, 98, and Inst. of Dalderby, 259) there was an appeal to the pope for appropriation (Cal. of Pap. Letters, ii. 413).

11 Linc. Epis. Reg., Inst. of Bp. Bek, IO2 (1 345 ).

12 Pat. II Edw. I. m. 4.

13 From 1330-I 4I3, when it was granted to the Nuns Minoresses near Aldgate (Linc. Epis. Reg., Inst. Repingdon, 30I).

14 Felmersham to King's Hall, Cambridge ; vicarage ordained at the same time, $13^{6} 5$ (Linc. Epis. Reg., Memo. Gynwell, 48). 


\section{ECCLESIASTICAL HISTORY}

Eyworth, ${ }^{2}$ Felmersham, ${ }^{2}$ Elstow ${ }^{3}$ and Harlington. The Bishops of Lincoln during the fourteenth century were not men of such a high type as their predecessors of the thirteenth, but there is no evidence that they were neglectful of their duty : the religious houses were still visited; no grave scandals among the clergy were allowed to pass unnoticed ; care was taken that the parish churches should be regularly served, even when they were in the hands of absentee or pluralist rectors. Clergy who wished, as many did at this time, to devote themselves for some time to study of canon law were obliged to appoint chaplains to do their parish work, ${ }^{5}$ and it seems probable that the pluralists were obliged to do the same for their additional churches. There is no doubt however that pluralities were at this time very seriously on the increase, and that the results of leaving the cure of souls to chaplains, whose scanty stipends were apt to make them unsettled, and naturally led them to look out for preferment, could not have been satisfactory.

The worst cases of plurality in Bedfordshire, as in the previous century, were connected with the richest benefices-Leighton Buzzard, for instance, and Shillington. It will be enough to mention a few : Simon de Northwood, ${ }^{6}$ chaplain and confessor to Queen Philippa, rector of Colmworth, a moiety of Houghton Conquest and two other benefices, besides a prebend of Hereford, and a canonry and prebend of Shaftesbury ; Gilbert de Roubury, ${ }^{7}$ king's clerk and canon of Auckland, the holder of eight benefices including Shillington, and Matthew de Assheton, ${ }^{8}$ a successor of his somewhat later, who held Shillington in plurality and was clerk of the privy seal. A good instance of how Italians were still provided for in England may be found in the case of John de Podio Barsaco, canon of Lincoln, prebendary of Leighton Buzzard and archdeacon of Stow ; and afterwards, resigning Stow, archdeacon of Alava in the diocese of Calahorra, and also of Winchester at the same time. Earlier popes had condemned the practice, and more than one legate

1 Linc. Epis. Reg., Inst. Burghersh, 3 rod (1334).

2 Ibid. Memo. Gynwell, 48.

3 Ibid. Inst. Bek, IO2 (1 345$)$. This ordination seems to have been revoked at once. In petition to the pope under 1345 the Prince of Wales states that the appropriation was of little avail, on account of the small value, and the reservation of a vicar's portion; wherefore the bishop ordered the cure of souls to be performed by a priest paid by the religious, and the parish church to be transferred to the chapel of St. Helen in the churchyard. The pope was asked to confirm this arrangement ; and as no vicars' names occur in the registers, it seems that the church was served by the chaplains of the monastery and the chantry priests until the dissolution. Harlington was ordained I 3 IO (Linc. Epis. Reg., Inst. of Bp. Dalderby, 266).

4 W. de St. Neot's, vicar of Luton, was deprived and imprisoned, and a substitute appointed in his place, for non-residence and immorality, I $35^{8}$ (Linc. Epis. Reg., Memo. Gynwell, I 2od). In 1315 a coadjutor was appointed to an earlier vicar, who had become infirm. The parishioners of Souldrop complained in $\mathbf{1 3 5 6}$ of their rector, who was evidently quite mad ("he overthrows the barns and buildings of the rectory, and daily sets it on fire !'), and a coadjutor was appointed within a year (Linc. Epis. Reg., Memo. Gynwell, 63d, 87).

5 The rector of Potton (Cal. of Pap. Letters, ii. 3 I 1), absent for five years; the vicar of Bletsoe absented himself twelve years for study (Linc. Epis. Reg., Memo. Dalderby, ccxlv. [1 31 1 3$]$ ).

C Cal. of Pap. Letters, iii. 96, 1344 , and under ii. 276, 292, 521 .

7 Ibid. ii. 3, 25.

8 Ibid. ii. 124, 185, 232, 268 ; Plac. de Quo Warr. (Rec. Com.), 22. His brother, Pontius de Podio Barsaco, had a somewhat similar career. 


\section{A HISTORY OF BEDFORDSHIRE}

had tried to check it; but in the fourteenth century, in spite of the bull Execrabilis and its threats, it was no longer an offence to hold benefices in plurality : the only fault was to do so without dispensation from Rome. At this time, and indeed afterwards, those who held the largest number of benefices were those who had the money or the interest to procure them-the royal clerks and chaplains, and the cathedral clergy.

There is no doubt that the county of Bedford suffered at the time of the Great Pestilence as much as the neighbouring counties. It must have been especially violent in and about the town of Bedford, as the names of the masters of both hospitals, and the priors both of Caldwell and Newnham, are found amongst those who died in I 349 . The prior of Bushmead, the prioress of Markyate, and the rectors of Biddenham, Sutton and Shillington died in the same year. ${ }^{1}$

The period between the Great Pestilence and the Reformation is uneventful in the history of the Church in Bedfordshire. Movements which affected other parts of England were doubtless felt here also, but the records are very scanty. There is a brief account in the Annals of Dunstable $^{2}$ (no longer kept with the same care as in former years) of a rising in the town in the year of the great peasant revolt, similar to those at St. Albans and Bury St. Edmunds, but marked by much less violence. The old ill feeling between the prior and the townsmen was stirred up again-it had probably never quite died out-and the industrial problems raised by war and pestilence had doubtless affected this neighbourhood as much as others. A crowd assembled at the priory gates and demanded a new charter of liberties, 'such as the burgesses had in the days of Henry I.' Knowing what had happened at London and St. Albans, the prior had the tact and prudence to receive them courteously, and to issue the desired charter. It was revoked when the revolt was suppressed; but the prior interceded for his townsmen that they might not suffer the same penalties as the rioters in Hertfordshire and the eastern counties. A few years later an old dispute between the religious and the townsmen, as to their respective rights in the parish church, was brought to a satisfactory conclusion by the efforts of Sir Reynold de Grey and other gentlemen of the neighbourhood. The lower part of the building was set apart for the use of the parishioners, and a new altar erected, where a secular vicar might minister to them on all ordinary occasions; but on the principal feasts of the year they were to hear mass at the altar of St. Peter. ${ }^{3}$

The visitation of the prebendal churches by Bishop Henry Beaufort in $1399^{4}$ brought to light a very unsatisfactory state of discipline, which however cannot cause much surprise when it is remembered how the

1 The chronicler of Dunstable notes under this year, and in connection with the Great Pestilence, that the townsmen made a new bell (probably as a votive offering).

2 Ann. Mon. (Rolls Series), iii. 417.

3 Linc. Epis. Reg., Memo. Buckingham, 41 I. This arrangement was not permanent, no vicarage or vicar being mentioned in the Valor Eccl. 1535 .

4 Ibid. Memo. Beaufort, 67. 


\section{ECCLESIASTICAL HISTORY}

prebends were often bestowed. At Biggleswade the vicar was accused of living in his mother's house the life of a common tradesman, of brewing and selling ale there. This however he denied, and purged himself by oath; but there must have been something unsatisfactory in his service of the cure. Further, the chaplains who belonged to the church did not attend the canonical hours, or, if they came, they only stood in the chancel and took no part in the office. They were ordered by the bishop to remain in choir in future, under penalty of a fine, and to provide themselves with surplices by the coming festival of Easter, unless they wished to be suspended. The high altar of the church had never been consecrated, and the rectory was in ruins owing to the nonresidence of the prebendary.

At Leighton Buzzard also some complaints were made. The proper vestments were not provided, and there was no holy water clerk kept for the parishioners. The stipend of the vicar, always very small, had now become quite insufficient ; it was augmented by Bishop Grey in $1436 .^{\circ}$

Chantries were still founded from time to time, especially in the reigns of Henry VI. and Edward IV.; the civil wars no doubt gave a fresh impulse to this form of devotion. Some well known names still occur among the founders-Sir Neel Loring's chantry at Chalgrave was re-endowed by Robert Braybrook, Bishop of London, at the beginning of the fifteenth century, ${ }^{2}$ and Sir John Trailly and his son made Northill church collegiate, and established a chantry there about the same time $;^{3}$ but the rest of them bear the names of men of the middle class, or else their founders are unknown. ${ }^{4}$

It is expressly stated of the chantry of Biddenham, which belonged to the Grocers' Company, that it involved a distribution of money to the poor; while the priests who served those of Houghton Regis and Tempsford were to keep schools for poor men's children ; ${ }^{8}$ and probably others had like charities attached to them.

The establishment of gilds and fraternities at this period is also connected with the history of the middle class. The object of these was quite as much social as religious; and yet the religious element in them was sufficient to class them, a little later, among foundations whose

1 Linc. Epis. Reg., Memo. Grey, 183d. The last vicarages ordained in Bedfordshire were Lidlington, 1413 (ibid. Inst. Repingdon, 305); Biddenham, 1527 (ibid. Inst. Longland, 248).

Ibid. Memo. Repingdon, 8I (1413).

4 These were :-

A new chantry in the chapel of Biddenham Bridge, 12 Edw. IV.; the chantry in the chapel of Wyboston, Eaton Socon, I6 Edw. IV (both in Chant. Cert. i.)

The chantry of Corpus Christi in St. Paul's, Bedford, 20 Henry VII. (ibid.)

The chantry in the church of Tempsford (ibid. and Hist. MSS. Com. viii. 262).

The chantry in the church of Houghton Regis, 1519; and in the private chapel of Sewell in the same parish (Chant. Cert. i.)

The chantry of St. Anne in Northill church (ibid.)

The chantry of St. William in Biddenham church (ibid.)

5 Chant. Cert. i. The founder of the chantry of Houghton Regis, a citizen and mercer of London, left provision in his will that if the licence for alienation in mortmain could not be obtained, the lands he left were to be sold, and the proceeds used for the ornaments of the church, for the mending of the highways, for the assistance of poor folk, and for poor maidens' marriages.

I 


\section{A HISTORY OF BEDFORDSHIRE}

funds were devoted to superstitious uses. Every gild had its altar where a priest was maintained to sing mass for the good estate of the brethren and sisters while living and for the repose of their souls after death. They were found in Bedfordshire at Blunham, St. Paul's Bedford, Biggleswade, Dunstable, Eaton Socon, Houghton Regis and Luton ; their favourite dedication was to the Holy Trinity. The richest and best known of these was the Gild of the Trinity at Luton ; records of its expenses, etc., are still preserved among the MSS. of the Marquis of Bute. $^{2}$ The object was to maintain a priest and poor brethren. The gilds of Eaton and Dunstable also had funds set apart for distribution to the poor and other charitable purposes.

There are scarcely any records to help us to form an opinion as to how far the teaching of the Lollards was known or welcomed in Bedfordshire. At a time when Bishop Buckingham complained that heresy was rife in Northamptonshire, ${ }^{3}$ when Leicestershire was the centre of Wycliffe's teaching, it is difficult to believe that Bedfordshire remained untouched. There was however only one prosecution in this county recorded by the Lincoln registers : that of John Langeley, vicar of Pulloxhill, in $1417 .^{4}$ His arrest is noted, but nothing further.

There is the same want of detailed information for the first half of the sixteenth century as for the fifteenth; so that it is impossible to gather any clear impression as to the state of popular feeling in Bedfordshire with regard to the many and great changes which were taking place. In a county where so much land and so large a proportion of the churches belonged to religious houses, there must surely have been strong feelings either for or against the dissolution; but very little is recorded. We possess however one vivid picture of the way in which the Act of Supremacy was discussed, not only amongst the religious but amongst some of the clergy and laity in one part of Bedfordshire. The depositions of the abbot of Woburn and others at the surrender of the abbey in $153^{\circ}$ contain references to many well known people. The abbot had evidently discussed the subjects of the supremacy, the royal divorce, the death of More and Fisher, the suppression of the smaller monasteries, quite freely with all his neighbours; with Sir Francis Bryan, though he was in the king's service, and inclined to the new learning; with Lord Grey of Wilton and Lady Grey of Wrest (with whom he never could agree); with Sir Francis Bryan's physician; with the parson of Milton Bryan, some doctors of Cambridge and the warden of Toddington Hospital. All these people had listened to his arguments,

1 All in Chant. Cert. i. The gild of Dunstable also occurs in Inq. a. q. d. 19-23 Henry VI. No. 8r. It maintained (Chant. Cert. 4) a house with three chambers containing beds for poor travellers passing through Dunstable; and four tenements under the same roof for brethren of the gild fallen into poverty, where they might dwell without paying rent. That of Eaton (ibid.) had merely a distribution of money to the poor.

2 Hist. MSS. Com. iii. 207.

3 Linc. Epis. Reg., Memo. Buckingham, 393 (1392).

4 Ibid. Memo. Repingdon, 184 (1417).

5 L. and P. Hen. VIII. xiii. pt. 1, No. 981. The depositions were taken 11 and 12 May I538; the abbey having been surrendered 8 May. 


\section{ECCLESIASTICAL HISTORY}

and agreed or disagreed with a freedom which is rather striking at a time when treason in word only was liable to the same penalties as conspiracy or open rebellion. The physician of Sir Francis Bryan had rebuked the curate of Woburn chapel for loyally railing against the pope and against images; while the same gentleman's servant had fallen out with the schoolmaster of the abbey on the subject of the royal supremacy. In consequence of all these revelations articles were drawn up by the royal visitors against the warden of Toddington, the doctors of Cambridge and the 'doctor of physicke,' and an attempt seems to have been made to implicate Sir Francis Bryan also ; but only the abbot and two of his monks suffered the extreme penalty of the law at this time."

The parish churches ${ }^{2}$ certainly suffered a great loss in the suppression of the chantries and gilds; the reports of those who drew up the certificates show plainly how much the services of these additional chaplains were valued by the parish clergy. ${ }^{3}$ The chantry priests may have been ' meanly learned' (whatever that may actually imply), and ' not able to serve a cure' in most cases; but in nearly every report it is added that there is ' none other priest to help the vicar,' and that many of the parishioners live at considerable distances from the church. In the case of Northill Collegiate Church, it is explained that there are seven hamlets in this parish, "whereof two are three quarters of a mile from the church, and every one as distant from the other' ; and 'it is thought that one priest shall not be able to serve the same." "They were nevertheless suppressed; and though a part of the money thus secured to the Crown may have been put to good uses, the immediate sufferers received no compensation. The chapels of Gravenhurst, Roxhill and Silsoe, originally parochial chapels, fell under the same condemnation because of

1 Stow, Annales, p. 573, Speed, Chronicle, 1026, and Add. MS. 27402, f. 47 (a list of those executed under Henry VIII., once in the possession of Hearne, probably drawn from the chroniclers) state that the parson of Podington, Beds, suffered with the abbot and one monk. The Controlment Roll, Trin. term, 30 Henry VIII., gives the record of the attainder of the abbot and two monks, with no other companion. If a further example had been needed the choice would naturally fall upon Sir John Mylward, the warden of Toddington, who had brought himself well under the treason law by refusing to preach the king's supremacy, and compiling a book from the fathers called De Potestate Petri ; and indeed it seems very unlikely that he should escape at this time. But the record of his attainder is wanting, and the traditional number of victims is complete without him. Moreover the Chantry Cert. of I 546 (No. 4) states that the hospital of Toddington was dissolved 'without the king's warrant, immediately on the death of the last master John Mylward,' which does not suggest an attainder. There is no record either of a parson of Podington, though the Epis. Reg. show a fresh institution in I 539.

Amongst other partisans of the old learning in Bedfordshire we may note Lord Mordaunt, who gave evidence in favour of the unfortunate Friar Forrest in this same year (L. and P. Hen. VIII. xiii. pt. I, 1043); and Sir John Gostwick, a knight of the shire, who had the courage to accuse Cranmer of heresy in open Parliament in 1544 (Canon R. W. Dixon, History of the Church of England, ii. 344-5). Members of the same two families are found amongst the recusants of Elizabeth's reign.

2 Before the end of the reign of Henry VIII. the town of Bedford had lost two very old parish churches. Of the church of All Saints there is no institution recorded after the year 1446 ; but the Valor Eccl. records under the head of Newnham Priory 'Epõ. Lincoln' pro indemnitate ecchie Omn Scõr Bedd. 3s. 4d.' The Church of St. Peter Dunstable is said to have been destroyed about the year 1 545, and its stones used to repair St. Mary's, the bridge and the streets, as well as the other church of St. Peter (Beds Archaol. and Archit. Soc. ix. 260). 'SS. Peter and Mary Dunstable" appear as one rectory in the Valor Eccl. (Rec. Com.)

3 Chant. Cert. Nos. 1, 2, 4 .

- Ibid. I ; No. 4 adds, 'And it were right necessary for an almshouse, if it pleased the King.' 


\section{A HISTORY OF BEDFORDSHIRE}

the chantries attached to them. Endowments for lamps and obits, offered in nearly all the churches by those who could not afford the complete pay of a chaplain, were swept away at the same time.

Some further local details may be gathered from the scanty remains of the inventories taken, at the end of the reign of Edward VI., of the movable goods of the churches. Only fourteen lists relating to Bedfordshire are still preserved. ${ }^{1} \quad$ They serve to show that nearly every church was still in possession of some of the vestments, etc., allowed by the first Prayer Book of the reign. But they are so incomplete that they could not have been still in use ; if they were, the services of the church must have presented a curious appearance. Most churches still retained the two prescribed candlesticks; some had copes, two or three had censers and pyxes for the reservation; one had a holy water stoup of 'lattyn,' more than one a sanctus bell, another a pax, another a processional cross. Stagsden had a nearly complete set of Eucharistic vestments, but no candlesticks; Houghton Regis was the richest in plate, having three chalices, two pyxes and a pair of censers still, although it had been lately robbed-a misfortune not peculiar to this church by any means.

In the Suffragan Bishops Act of $1534^{2}$ the town of Bedford was included amongst the proposed sees for suffragans; and, in accordance with the provisions of the Act, John Hodgkins was consecrated Bishop of Bedford on 19 December $1537^{3}$ As however he was suffragan to the Bishop of London, he had no jurisdiction in this county, and could have no influence on its history." A greater (though melancholy) interest is attached to the plan, formed a little later, of erecting a new bishopric for Bedfordshire and Buckinghamshire ${ }^{5}$ out of a portion of the spoils of the religious houses ; its see was to be at Dunstable, ${ }^{B}$ and its revenues were to be obtained from the property of the dissolved monasteries of Dunstable, Elstow and Newnham. Full details of the proposed cathedral establishment are still preserved ${ }^{7}$; but the plan was never realized. So far as can be discovered, the county of Bedford received no com-

1 Printed in Beds $N$. and $Q$. 277-311. These entries give some examples of the way in which smaller men in those days followed the example of their betters. One good lady had helped herself to a pair of bells which had been left in the churchyard of Sandy at the last inventory-for the payment of her husband's debts. At Meppershall the mutual accusations of present and past churchwardens leave only one thing clear-that some one had been plundering the church. Holcutt was reduced to one broken chalice; Husborne Crawley to one of tin.

2 Documents Illustrative of English Cburch History, pp. 253-6.

3 Rymer, Faedera, vi. (3), 12 ; Beds N. and $Q$. i. 40.

4 The only other suffragan Bishop of Bedford was the Rev. W. Walsham How, consecrated 1879; he was also suffragan to the Bishop of London.

s From the draft in the king's own handwriting, of which a facsimile is printed as frontispiece to Cole's King Henry VIII.'s Scheme of Bishopricks.

B In the first draft (from Cott. MS. Cleop. E iv.) 'Bedfordshire and Buckinghamshire' are bracketed opposite the three monasteries mentioned above ; but in the detailed scheme (printed in the same volume, from a MS. in the Record Office) the name of Dunstable appears.

7 Cole, King Henry VIII.'s Scheme of Bishopricks, pp. 60-6. The scheme for Dunstable is similar to the rest, only it does not begin with ' First a Busshope,' like some of them. It includes a dean, six prebendaries, a reader and four students in divinity, twenty scholars and a schoolmaster, six 'peticanons' to sing in the choir, with six singing men and eight choristers, a gospeller and a ' pisteler,' besides such minor officials as two porters 'to keep the gates and shave the company.' There were also sums of money set apart for distribution to the poor. 


\section{ECCLESIASTICAL HISTORY}

pensation of any kind for the losses suffered under Henry VIII. and Edward VI.

There is no record of any trial for heresy in Bedfordshire under Henry VIII. or Mary ; it is indeed generally agreed that the whole diocese of Lincoln was free from persecution during the latter reign; though the episcopal registers, if they existed, might show some cases of deprivation among the clergy. But the majority both of clergy and laity probably conformed at this time (as it has been shown that they did later) to the established order, whatever it might happen to be. Such a course does not argue a lofty ideal of life and duty; but it was a very natural one for ordinary men, at a time when the learned held such differing views even on fundamental points, and when the next change of government might mean loss of livelihood, even of life itself, for those who were not willing to adopt the prescribed forms of religion. Lofty ideals of life were rare in those unrestful and unhappy years, when change followed change in swift succession, and toleration was neither admired nor desired by the leaders of any party.

There is very little to awaken our admiration in the personal character of such of the clergy as are known to us at this time. A typical instance of the general conformity may be found in John Gwynneth, vicar of Luton from I 537 to I 558. He kept his church through all these changes, but his real opinions found expression at last in 1553 in $A$ declaration of the notable victory given of God to Queen Mary, showed in the Cburch of Luton in the first year of ber reign. His death in I $55^{8}$ saved him from further difficulties; and he was succeeded after a few years by a man of the exactly opposite type, Thomas Rose, ${ }^{2}$ ranked by Foxe among the martyrs. The narrative of Rose's sufferings does not belong to the history of Bedfordshire ; it shows him forth as one of those fiery preachers who were more earnest to bring men to a right belief than to a better life ; and his first arrest under Henry VIII. in 1533 came of the part he took in the destruction of a rood out of Dovercourt church. Coming only four years after Gwynneth, he must have found work to do at Luton after his own heart.

Some of the results of the general confiscation of church property were revealed by the visitation of Cardinal Pole in $1556 .^{3}$ It was then stated that many of the vicarages had been void for years, ${ }^{4}$ because of the smallness of the means of livelihood; and that the chancels of six churches-Harlington, Salford, Potton, Eyworth, Riseley and Woottonwere in ruins. The chancel and rectory of Ampthill were almost down to the ground; the rector explaining that the tithes of the greater part of the parish and its best land had been taken from him by the enclosure

1 Luton Church, by the Rev. H. Cobbe, p. 183. He also wrote : A declaration of the state wherein all bereticks do lead their lives, and $A$ playne demonstration of Fobn Frithes lack of witte and leasning.

2 Foxe's Book of Martyrs, viii. $58 \mathrm{1}-90$.

3 Strype, Eccles. Mem. iii. 482-6. Strype states that nearly all these livings were then in the gift of the cardinal himself; but he can scarcely be blamed for their poverty and neglected condition, which must date further back.

4 The Elizabethan Clergy, Dr. Gee, I 25, 126, 256. 


\section{A HISTORY OF BEDFORDSHIRE}

of King Henry's parks, as they were also from rectors and vicars of neighbouring parishes; and the curates were so impoverished that they could scarce live upon them. It may be noted that the churches mentioned had all belonged (except Ampthill) to various monasteries before the dissolution; and the king or his grantee, while appropriating the rectorial tithes, had evidently forgotten the rector's duty of repairing the chancel. Another sign of the times appeared at Dunstable. The churchwardens complained that their town was populous, but neither rector nor perpetual vicar was found there ; and 'he that was hired could not preach.' The loss of the ideal of the pastor in the ideal of the preacher is always the outcome of an age of controversy, and the balance sometimes takes a long while to readjust.

There were probably very few deprivations in Bedfordshire in the beginning of the reign of Elizabeth. Of the higher clergy two were found ready to subscribe to the new Act of Uniformity-the archdeacon, Richard Barbar, and the prebendary of Biggleswade, Giles Forsterwhile two refused and were deprived-Anthony Draycot, ${ }^{1}$ prebendary of Bedford Major, and George Hunter, prebendary of Leighton Buzzard. No names of the lesser clergy are found on the lists of those deprived before 1562 .

The earliest documentary evidence as to the state of Bedfordshire in ecclesiastical matters during the reign of Elizabeth is the report of the visitations made by the archdeacon in $15780^{2}$ He held his court at Ampthill, Bedford and Woburn; and the presentations do not give a very happy impression of the state of the archdeaconry. In three churches both nave and chancel were out of repair; in eight others only the chancel, by the default of the parson or patron. ${ }^{3}$ Of these some had the windows broken, and others wanted paving. Two or three churchyards were in disorder, with broken hedges. Four of the clergy were called to show by what licence they served; one could show none at all. Three or four did not preach; only one however is presented for not wearing the surplice. A large number of people were presented for not coming to church, or for not making their communions at Easter. Sometimes the parish priest failed to give his people proper opportunities : at Biddenham there had been 'only one communion this year'; but at Clophill there was almost certainly a weekly celebration." Only about thirty parishes are named in this report, and it would be rash to draw conclusions too melancholy from such premises as these; especially as the object of the visitation was to find out what was wrong, and not what was normal. There was probably a great diversity of practice as to the number of services; and the amount of reverence and

1 Draycot was also archdeacon of Huntingdon, and held another prebend and four livings besides.

2 At present in the office of the archdeacon's registrar at Bedford. Some extracts were printed in $B \varepsilon d s N$. and $Q$. iii. 16-1 $8,36-40$.

${ }^{3}$ Wootton had the chancel in decay in 1556 , when it was in the gift of Cardinal Pole; now it is 'by the queen's default.'

* There is mention of a celebration on Palm Sunday; and one who had lapsed promised to prepare himself for next Sunday. 


\section{ECCLESIASTICAL HISTORY}

devotion amongst the people would vary greatly, as it has done ever since, with the character of the parish clergy.

A few years later political causes drew attention to the recusants who still clung to the Roman obedience, and lists were drawn up in some places to show their numbers and status. In I 585 a seminary priest, Thomas Freeman, was arrested and examined by the justices of Bedfordshire and sent up to London with his papers and books. ${ }^{2}$ There is a curious list among the State Papers of female recusants ${ }^{3}$ in Bedfordshire, giving the names of seven wives and three widows of gentlemen of the county, whose incomes varied from $\oint_{2} 200$ to $\oint_{1} 10$ a year. Besides these a few names of servants and poorer people were known to the writer, who was ready when the queen's pleasure was signified ' to take such order with them as I hope shall avoid all inconveniences as hereafter might happen by them or any other.' What these measures were can only be guessed, for they were never taken; but the tone of the letter is very characteristic of the times, and shows clearly the suspicion ${ }^{4}$ with which such recusants were regarded.

Nothing ${ }^{6}$ however seems to have happened to these ladies, and in the lists of $159 \mathrm{I}^{\circ}$ only four names are given of recusants in Bedfordshire. Indeed it seems probable that they never had much influence in the county beyond the little circle of the Mordaunts and their friends at Turvey, where a little later than this, Secretary Coke discovered that William Smith, the titular 'Bishop of Chalcedon,' had a place of residence. When Lord Mordaunt was reconciled to the Anglican Church in $1625,{ }^{8}$ by the influence of his wife and Archbishop Usher, Turvey ceased by degrees to be a gathering place for recusants; and though there were still twenty people presented to the archdeacon for this offence in 1642, none of them was a person of any note. From this time forward the air of Bedfordshire could scarcely be called congenial to popery.

1 At the end of the same book there is an entry under 30 April, of the institution of the rector of Clophill, in the church of Ampthill, ' inter horas 3 a.m. et 4 a.m.' It would be interesting to know if this hour was exceptional or otherwise.

There were a few inscriptions (since destroyed) existing in 1583 , to witness that one pious custom, commonly supposed to have passed away with the Reformation, was still sanctioned by law and by public opinion. Such were : In Dunstable church-Hic jacet Ric'us Denton qui obiit I 8 March 1 564, et Elizabetha uxor eius quor' an' etc. ; and in Sutton, North Chapel-Of your charity pray for the souls of Thomas Burgoyne and Elizabeth his wife ' $w$ 'che Thomas deceased 9 Aug. I 576 on whose sowle and all Xtane sowles Jesu have mercye' (printed in Beds N. and Q. i. 71, 74, from the MS. of Francis Thynne, Lancaster Herald ; Cotton MS. Cleop. C iii.)

2 S. P. Dom. Eliz. clxxviii. No. 26.

3 Ibid. cxcv. No. 116. They are the wives of W. Mordaunt of Oakley, J. Fortescue of Eyworth, J. Charnock of Holcote, Oliver Skroges and Richard Skroges of Renhold, W. Hewet of Millbrook, Robert Willowes of Barford; and widows-the old Lady Catelayne of Dunton, Edith Bredyman of Tingrith and Alice Gostwick of Bedford (the last presented to the archdeacon in 1578 for not coming to church).

- 'The above-named John Charnock . . . is son of Richard Charnock of Holcote . . . a man greatly noted and suspected in religion; and hath as I am credibly informed great and often repair to his house of such as are not to be liked nor trusted in these dangerous times.'

5 There is a letter from the Earl of Kent to the Council in 1588, asking what shall be done with them; no answer is recorded (Cal. of S. P. Dom. Eliz. 22 Jan. I 588 ).

- S. P. Dom. Eliz. ccxxyviii. No. I 26.7 Ibid. Chas. I. xcix. March 1628.

a History of the Willey Hundred, W. M. Harvey, p. I 82 .

- Beds $N$. and $Q$. ii. 16 ; from the parish registers. 


\section{A HISTORY OF BEDFORDSHIRE}

The clergy list of $1605^{1}$ throws light on one point of interest : it seems that the parish priests at the end of the Elizabethan period had at any rate the best education that the times could afford; more than three-quarters of them were University graduates. Their stipends were very small : $f_{0} 7$ was the average, and very few rose above $f_{0} \mathrm{I} 2 ;$ Melchbourne, Bletsoe and Stotfold were less than $£_{0} 6$; while Cranfield with $£_{3} 3$, Luton with $£_{35}$, and Blunham with $\oint_{04} 6$ ss. Iod. were the richest. Pluralities were still common, as indeed they continued to be till very recently ; and with more excuse than in the pre-Reformation period.

The archdeacon's visitations of $16 \mathrm{rO}_{0}-2 \mathrm{O}^{2}$ show a few churches (not the same ones as before) out of repair. Totternhoe in particular is reported ' in great decay and like to fall down,' Ridgmont in I616 had not a 'sufficient Bible.' There are several cases of irreverence, open quarrelling and fighting in church, and presentations for immorality are very numerous. One or two clergy are accused of not being in orders, or not licensed to preach; two for not wearing surplices; two for neglecting their cure ; two for not reading prayers on Wednesdays and Fridays (in one case Saturdays). The presentations which sound strangest to modern ears are those for various forms of Sabbath-breaking, showing the prevalence of Puritan ideas. The open exercise of a trade, or stopping away from Sunday services to join in ' a football play,' we might expect to see condemned, but one man is accused of 'travelling his horses,' another for 'going towards London' upon the Sabbath day ; and we are reminded of archdeacons' visitations of a much earlier date by the presentation of one for fetching a load of wood upon a wagon upon a 'bolliday, about Christmas,' and another for carting on St. Luke's Day, ${ }^{3}$ and several for marrying in Lent. The accusation of 'keeping company with one excommunicate' shows that the ancient discipline of the Church was still occasionally exercised ${ }^{4}$; but the repetition of several of these presentations two or three months running shows that it had become difficult to enforce.

At the Commissaries' Court in 1606 the churchwardens of Podington presented their vicar, Thomas Whytbie, for not catechising and instructing the youth and ignorant persons of the parish according to law, ' being thereunto required by J. Barnes, one of the churchwardens, and made a tushe and skorne thereat.' Whytbie was at the same time presented for not wearing ' a typpet, hoode and square cap at the time of

1 Transcribed by Mr. Alfred Gibbons and printed in Beds $N$. and $Q$. The only notable man among the clergy in Bedfordshire at this time was Thos. Archer, rector of Houghton Conquest, and chaplain to James I. He was a great preacher (ibid. i. 89-98).

${ }_{2}$ The reports are dated in one book, $1610-11$ and 1620 , at Bedford; in 1616-17 at Ampthill, where they seemed to be monthly.

3 At Milton Ernest one Walter Griffin was accused of 'setting his nets and catching larks upon a holiday'! At Elstow a woman was presented for 'churching berself,' and stated that she had given the minister warning over night, but as he did not come she took the Book of Common Prayer and read the Thanksgiving openly herself. She was dismissed with a warning.

4 Another illustration of the survival of ancient discipline is found in a licence dated 22 March 1632 (and renewed 30 March and 7 April) from the parish priest of Clophill, to 'Sir Henry More and his lady Dame Elizabeth,' ' for eating flesh for the space of eight days, upon a Certificate fro' Mir. John More, Dr. of Physicke, $y^{t}$ Abstinence from Flesh would be very pr'iuditious to there health' (Beds $N$. and $Q$. ii. 257); from the parish register at Clophill. 


\section{ECCLESIASTICAL HISTORY}

divine service,' and for not wearing a surplice at the time of common prayer. Oliver, the vicar's son, was also presented for being absent from evening prayer on Sundays and robbing an orchard. The quarrel between the vicar and churchwardens continued for a long time, as similar presentments were made against the former in 1616, which were not proceeded with. At the same time the vicar presented John Barnes, the churchwarden, for refusing to forbid the playing of 'stooleball,' football and swearing on Sunday. ${ }^{1}$

The visitation of Archbishop Laud in I 634 (deputed to Sir Nathaniel Brent) showed Puritan influence to be strong in the county ; but only one deprivation is recorded at this time-that of Peter Bulkley, rector of Odell, ejected for refusing to wear the surplice or to use the sign of the cross in baptism. The visitation was especially directed to the restoration of the chancels ; but very few details are preserved. ${ }^{2}$ Conspicuous among those who sympathized with the reforms of Laud were Hugh Reeve, rector of Ampthill, Dr. Pocklington, rector of Yelden and fellow of Pembroke Hall, and Giles Thorne of St. Mary's, Bedford ; the two latter were deputy commissioners for the archbishop in the ecclesiastical courts of the county. ${ }^{3}$ It was therefore not surprising that when the tables were turned, and the Parliament undertook to reform the Church by measures even more drastic than Laud's, these three men should be reckoned under the head of 'superstitious, innovating and scandalous ministers,' and removed accordingly.

The county of Bedford was one of those which sent in a petition for the abolition of episcopacy on 25 January $1640-r .4$ Several private petitions came in at about the same time. The first was against Dr. Pocklington, whose books, Altare Cbristianum and Sunday no Sabbatb had made him a marked man. The Lords were asked to call him to answer the charge of idolatry and superstition, and for defending in his pamphlets those 'innovations unhappily introduced into the Church.' ${ }^{.8}$ The next was a petition from one parishioner of Ampthill, on behalf of the rest, praying for an inquiry into the popish doctrines and practices of Hugh Reeve, and annexing articles ' whereby it doth plainly appear that he is at heart a popish recusant. ${ }^{6}$ A third came from John Wallinger, churchwarden of St. Paul's, Bedford, complaining of the treatment he had received from Giles Thorne, Dr. Pocklington, and others in the ecclesiastical courts. ${ }^{7}$ Another was sent in by the vicar of Stevington against Dr. Walter Walker, late ecclesiastical commissary for Bedfordshire, because of his exactions, and his enforcing of 'ceremonials of bowings, wearings of surplices, officiating within the communion rails,'

1 Hist. MSS. Com. iii. 275.

2 Cal. of S. P. Dom. Chas. I. 1634 p. 205 ; and History of the Willey Hundred, W. M. Harvey, p. 366 (for the deprivation of Peter Bulkley). The entry in the parish register of Pertenhale under the date 1634 , recording that the church possessed 'a Communion table and rails, a silver chalice and paten, a pewter flagon and a holland surplice,' has evidently some reference to this visitation (Beds N. and $Q$. ii. 319).

S. P. Dom. Chas. I. ccccxcix. No. 89, 1643 (Depositions of John Wallinger).

4 Hist. of the Engl. Church under the Commonwealth, Dr. W. A. Shaw, i. 26.

5 Hist. MSS. Com. iv. 39, I 3 Jan. I640-1.

a Ibid. 6 Jan.

7 Ibid. p. 48,8 Feb.

I 337 


\section{A HISTORY OF BEDFORDSHIRE}

and many other persecutions." Another came from an 'aggrieved parishioner' at Caddington. ${ }^{2}$ A complaint also came from the parishioners of Wootton and Quinton (Northants) against Jeremy Stephens, the prebendary of Biggleswade. ${ }^{3}$ It does not necessarily follow, because these petitions were many and urgent, that they were really the voice of the people; but there can be no doubt, in the light of later events, that there had been discontent in the county, and that the influence of Calvinistic teaching was widespread.

Dr. Pocklington and Hugh Reeve were arrested and deprived of all ecclesiastical preferments early in $\mathrm{I}^{6} \mathrm{II}^{4}$; John Gwyn, the vicar of Cople, ${ }^{5}$ and Giles Thorne of St. Mary's, Bedford, ${ }^{6}$ in I642. Subsequent deprivations were as much political as religious; the charge brought against the deprived was as a rule simply 'malignancy.' The exact number of these is not easy to obtain, as they have to be collected from different sources. But the largest number that can be made out for Bedfordshire, between 1643 and 1648 , reckoning all doubtful cases, is twenty-six, and there were certainly over twenty at the lowest estimate. $^{7} \quad$ If we add to these the names of those deprived before the civil war began, it will be no exaggeration to say that about one-fifth of the clergy of this county were ejected either for Royalist sympathies or for refusal to conform to the modes of Church service and government ordained by Parliament.

It is only fair to say that not all those who were thus deprived were left quite destitute. On petition to the local 'Committee for Plundered Ministers ${ }^{8}{ }^{8}$ it was possible to secure one-fifth of the profits of the sequestered rectory or vicarage for the wives and children of the late incumbent; and this pension was actually secured by Mrs. Thorne, and also by the children of the rector of Tillbrook. ${ }^{\circ}$ An entry of 25 February $1644^{10}$ orders a rector to pay 'what the Parliament ordered" out of the tithes to a curate from whom the living was sequestered. But that many suffered extreme poverty and distress there is little doubt.

One of the hardest cases was that of Hugh Reeve of Ampthill, who

1 Hist. MSS. Com. p. 94, 5 Aug. 1641. ${ }^{2}$ Ibid. p. 53, 23 Feb. $\quad{ }^{3}$ Ibid. iv. 74.

4 Shaw, Hist. of the Engl. Church under the Commonwealth, ii. 296, 297. 5 Ibid. p. 298.

6 Hist. MSS. Com. iv. 45. Christopher Slater, vicar of Leighton Buzzard, would probably have come under the same condemnation if he had not died this year; his parishioners said he was a 'promoter of superstitious innovations,' so that they had to pay a lecturer besides to instruct them in the way of godliness (ibid. v. 4).

7 In Add. MSS. 15669-71, a rough minute book of the 'Committee for Plundered Ministers' names sixteen livings as sequestered; two other incumbents are summoned to appear, but the result is not recorded. Walker in his Sufferings of the Clergy names six other cases. The parish register of Toddington records in 1654 the burial of Thomas Claver, rector, 'but unjustly sequestered.' Other such registers might possibly yield more; none of the other lists pretend to be complete. The archdeacon, John Hacket, and Jeremy Stephens, prebendary of Biggleswade, are not counted above, because they only lost part of their preferment.

8 There had been a local committee for Bedfordshire 'for the discovery of malignant ministers' appointed by the Central Committee for Plundered Ministers in 1643 (Shaw, Hist. of the Engl. Cburch under the Commonwealth, ii. 194).

${ }^{9}$ Add. MS. I 5670, 4 Apr. 1646; although he had 'inveighed with fearefull curses' against the Parliament and said there were none in it but 'rogues and rascalls.' (Add. MS. 15669, 5 July 1645).

10 Ibid. 25 Feb. 1644. 


\section{ECCLESIASTICAL HISTORY}

had been rector there for nearly forty years. ${ }^{1}$ During all this time he had been visited by each successive Bishop of Lincoln, and no fault found with him ${ }^{2}$; the archdeacon's courts had been often held in his church; he had been visited by Laud's commissioner, Sir Nathaniel Brent ${ }^{3}$; and now in his old age he was deprived of his rectory as being ' at heart a popish recusant - the very words of the accusation displaying the ignorance of the accuser. A pension of $f_{\mathrm{r}} \mathrm{O}$ a year was indeed given to him by a noble parishioner; but he ran the risk of losing it by his determined refusal to leave the rectory house, whence he was at last ejected by a fresh order of Parliament."

The case of Giles Thorne of St. Mary's is also noteworthy. He was arrested as he came out of the pulpit by a party of Lord St. John's troops, and carried to the Fleet prison, on the petition of justices of the peace and inhabitants of Bedford. He was accused of being 'turbulent and profane' and causing divisions and factions in the town; but the true cause of enmity against him was probably found in the fact that he had 'prosecuted in the High Commission Court those who desired to abstain from profanation." ${ }^{\circ}$ On the strength of this petition, and the annexed affidavit of one witness that he had in the pulpit used 'blasphemous words' (i.e. had preached in favour of confession), he was imprisoned for more than five years, without any trial, ${ }^{7}$ only being released once for six weeks in 1646 , after repeated petitions, ${ }^{8}$ to go and see his sick wife and to try to make some provision for himself and his family. Returning to prison when he found his friends had become too poor to help him, he sent up yet another petition for release or relief of some kind, and was finally discharged on 23 August $1647 .^{\circ}$ What he did for a living until the Restoration is not known; but his wife had been allowed a pension from his two rectories from November 1646 , limited in October 1647 to one-fifth from St. Mary's only. ${ }^{10}$

The rector of Houghton Conquest, Dr. Edward Marten, was also imprisoned five years; but as he was master of Queen's College, Cambridge, and had two other rectories besides, he does not reckon with the

1 He was parson in 1604 (Parish Register).

2 William Barlow came three times in 1612 ; George Montaigne once. John Williams held his visitation for the whole county there, August 1635 ; all stayed at the rectory house. (From entries at the back of the parish register, kindly noted by the present rector of Ampthill, who says also that Reeve's registers are well kept and in good order.)

3 S. P. Dom. Chas. I. cclxxiv. 12 ; and on parish register.

4 Hist. MSS. Com. v. 19, 30 Apr. 1642.

5 Walker, Sufferings of the Clergy, p. 44.

6 Hist. MSS. Com. iv. 45 .

7 Walker says he was tried and acquitted, and that there was a petition sent in by his parishioners on his behalf; but from his last petition it is clear that he was never tried at all.

8 One in 1642 and two in 1643 , for bail or a speedy trial; one in 1644 , and one in 1646 , to go and see his wife who was sick; two in 1647, for release or relief (Hist.MSS. Com. iv. 53, 87, 155, 179, 193).

9 Ibid. 179, 193.

10 Add. MS. 15670 , f. 230 ; and 15671, f. 104. A certificate was signed by churchwardens of the parish and others in 1642 , declaring that Thorne had 'engrossed the rectory of St. Cuthbert's over the head of the incumbent '; but the proceedings of the committee do not corroborate this. His wife was first granted one-fifth from both benefices, and then given her choice as to which she would retain ; nowhere is it implied that her husband's claim to St. Cuthbert's was not as good as to St. Mary's. 


\section{A HISTORY OF BEDFORDSHIRE}

Bedfordshire clergy as strictly as Hugh Reeve or Giles Thorne. His case is chiefly interesting because the accusation is given in detail; he ' adored the altar, having his eye fixed upon a crucifix in the east window over it'; he insisted on a woman coming up to the altar rails to be churched; and he prayed for the departed. ${ }^{1}$

How the county really fared during the Presbyterian régime it is not easy to say; the witnesses on both sides are so prejudiced that it is hard to arrive at truth between them. Thus, Thomas Holden, who was appointed temporarily to St. Mary's in the place of Giles Thorne, was asked for by the parishioners as a 'godly and painful minister'; while Thorne from his prison petitioned the Parliament to commit his flock to a better man than Holden, who was 'ridiculously ignorant' and incapable of discerning truth from error. ${ }^{2}$ But it is clear that there was a large majority ready to conform to the new order; most of the Puritans among the clergy would naturally welcome it, and others would accept it from the same necessity which always wins a certain measure of conformity. Nominally the whole country became Presbyterian; but so long as the majority of the clergy were men who had been trained in the old ways, it is likely that in many places the order of service, the words of the extempore prayers, had a strong affinity with the ancient liturgy. There is no more striking evidence of the little change of which the less instructed were aware than that which is found in the autobiography of John Bunyan. 'At this time,' he says, 'I was so overrun with the spirit of superstition,' that 'I adored and that with great devotion' all things in the church-'High Place, Priest, clerk, vestment and what else '- 'counting all things holy that were therein contained.' ${ }^{3}$ What other frame of mind could Laud himself have wished? Yet this was in 1649-50, when the 'high place' must have been bare enough; when the only vestment Bunyan could have seen for six or seven years was the Geneva gown. The popular phrase itself-' high place'-is not without interest; it seems out of keeping with days when the altar was nothing but a table which was moved according to the convenience of the minister and congregation.

Two things at any rate may be placed to the credit of the Presbyterians. One was the stand they made against plurality ; even those who

\footnotetext{
1 Walker, Sufferings of the Clergy, p. I 54. In connection with these prosecutions for ritual it should however be noted that they were made by men who objected equally to other points of church custom which no churchmen have ever since attacked. The lists of 'innovations' drawn up by the committee which sat at the Bishop of Lincoln's house in $16_{41}$ is very instructive. There the 'turning of the table altarwise,' compelling the communicants to come up to the rails to receive, standing for the hymns and glorias, reading the litany in the body of the church, are set side by side with the adornment of the altar with crucifix, candlesticks and curtains, bowing to it, turning to the east at the creed, using a credence table, etc., and could only be condemned by those who wished not merely to reform, but to break altogether with the church and all its traditions. The fact that all these things could be called 'innovations' throws light backwards over the previous half-century, and shows how wonderfully successful the Puritans had been in opposing royal and episcopal authority.

" Hist. MSS. Com. iv. 10o. Holden was only a short time at St. Mary's (Add. MS. 15671, f. 104). On 19 July 1647 certain parishioners were again appointed to take the tithes, and pay Mrs. Thorne's fifth, until a fit person was appointed.

3 Grace Abounding to the Chief of Sinners (Clar. Press ed. p. 301).
} 




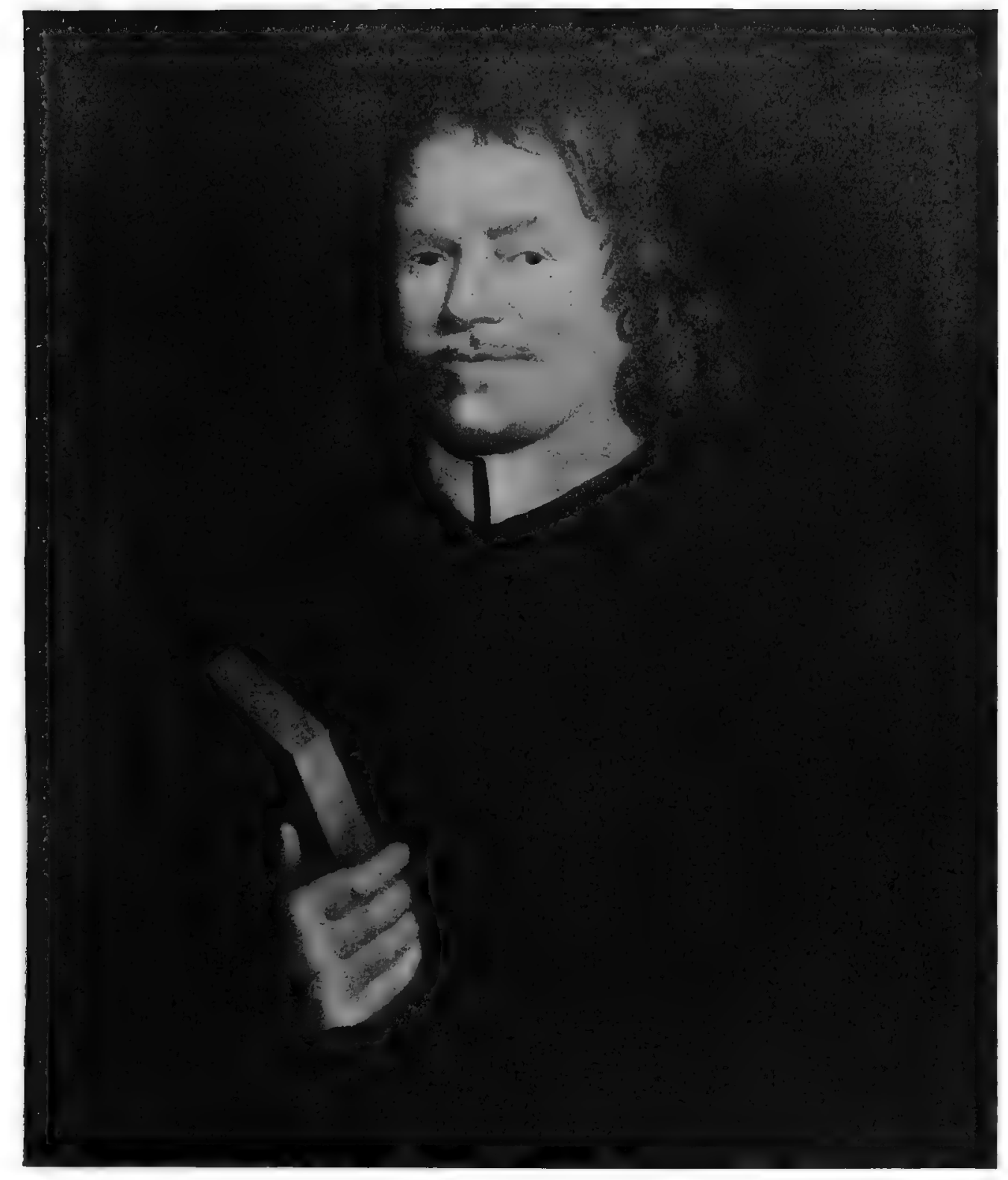

JOHN BUNYAN. 



\section{ECCLESIASTICAL HISTORY}

conformed sufficiently to avoid ejection were only allowed to keep one benefice ; so the archdeacon of Bedford, John Hacket, ${ }^{1}$ remained rector of Cheame in Surrey until the Restoration ; losing St. Andrew's, Holborn, which he had held with his archdeaconry before. The other was the attempt they made to increase the revenues of some of the poorer livings out of others which were better endowed. Thus the vicarage of Leighton Buzzard ${ }^{2}$ was increased by $£, 55$ from the funds of the impropriated rectory, which had belonged to Sir Thomas Leigh, whose estates were now confiscated by Parliament. From the same source the chapelries of Stanbridge, Billington, Eggington, and Heath and Reach ${ }^{3}$ were freshly endowed, as well as the vicarages of Biddenham and Houghton Regis." The stipends of the ministers of Southill, Cople, Goldington, Dunton, Biggleswade, Potton, Sundon and Flitton-cum-Silsoe ${ }^{5}$ were increased at the same time; the last four from the rectorial tithes of Luton. But nowhere are there signs of any fresh energy of devotion, any new outburst of spiritual life within the established church, to justify the great changes that had taken place. The most severe criticism of the Church of the Commonwealth is found indeed in the lives of men like Bunyan and George Fox. Bunyan was never persecuted by the Presbyterians; once indeed he speaks of hearing a sermon in his parish church that helped him; but it remains a fact that at the time when he was first trying to lead a better life and was a regular churchgoer, and again afterwards in his deeper need, when the agony of spiritual conflict for two long years had well-nigh driven him to madness, no hand was ever held out from his own church to help him. He had to turn aside to an obscure sect to find what he wanted-the assurance of pardon, the promise of a new life, and a work to do for God. So also George Fox in his Fournal describes the 'steeple houses' and the 'hireling priests' of $1655^{\circ}$ as a hindrance to the working of the 'free spirit' quite as great as the Church of the Restoration proved to be in later days. It appears to have been under the Commonwealth in I 655 that John Crook of Luton lost his magistracy because of his connection ${ }^{7}$ with the Quakers; while other persecutions of that sect are alleged to have taken place in this county. They nevertheless increased rapidly; Fox speaks of 'many hundreds' of them in his account of his third visit to Bedfordshire in $16550^{\circ}$

There are only a few records of any active discontent in Bedfordshire at the sequestrations and the abolition of the liturgy. Five of

1 Walker's Sufferings of the Clergy, p. 44.

S. P. Dom., Interregnum, F 2, f. 223 , 10 May 1644.

3 Ibid. F I ; Stanbridge in July I 646, Billington in March, Eggington in June, Heath and Reach in August. The existence of the chapel in Stanbridge in the fourteenth century has been already noticed; the other three chapels appear here for the first time.

Ibid. F 2, f. $520 ; F_{1}$, f. 337.

5 Ibid. F 2, f. $655 ; \mathrm{F}$ I, ff. $247,338,142,143,144,147$.

- Fox, fournal (ed. 1694-8), i. 149 .

7 Ibid. 8 Ibid. i. I 70 .

9 The incumbents of Cockayne Hatley, Tempsford, Marston, Potton and St. Cuthbert's, Bedford (Add. MSS. 15670, 15671; from 1645-7; and Hist. MSS. Com. iv. $100 ; 1643$ ). 


\section{A HISTORY OF BEDFORDSHIRE}

the ministers appointed by the Assembly of Divines complained that they could not get in their tithes from the parishioners ; while at Tempsford, Flitton, Marston, Potton, the ejected incumbents refused for a long time to leave their parsonages, and in two cases were clearly supported by parishioners in their refusal. ${ }^{1}$ At Luton the minister who held the living in $165^{8}$ (Thomas Jessopp) complained that for eight years a malicious and prelatical party had withdrawn from his church and worshipped in the prelatical form. ${ }^{2}$ The same thing may very likely have happened elsewhere. But this much is clear: though the numbers of those appointed by Parliament (and therefore probably without episcopal ordination) went on steadily increasing, by sequestration or the death of the old incumbents, during the five and twenty years between the outbreak of Civil War and the Restoration of the Monarchy, there were only eleven ${ }^{3}$ in this county who resigned their livings on St. Bartholomew's Day, I662, rather than submit to the new act of uniformity. The rest conformed and were ordained, if not already in orders. But, as it had been proved before under similar circumstances, such enforced conformity was bound to be very half-hearted in many cases. Calamy tells us of the old vicar of Arlesey, who had kept his living all through the Commonwealth, how he conformed by reading just such parts of the liturgy as he approved of, and leaving out the rest ; ${ }^{4}$ it cannot be doubted that others did the same as they found opportunity.

The only university men among the Nonconformists of this year were William Dell, master of Caius College, Cambridge, and rector of Yelden; Samuel Fairclough, fellow of the same college, and rector of Houghton Conquest ; and John Donne, of King's College, rector of Pertenhall. ${ }^{.}$Dell was a remarkable man in his way, though apparently of shifting views. $\mathrm{He}$ had been chaplain to the Parliamentary army before he came to Yelden. In I 660 his parishioners sent a petition to Parliament accusing him, among other things, of neglecting to administer the sacraments; but the parish registers prove that he certainly had his own children baptized. The rest of his accusations need not be detailed, as they are probably worth about as much as those made at an equally convenient time against Giles Thorne, Hugh Reeve and the ejected of an earlier date. But one of them is of historical interest; he had allowed 'one Bunyan, a tinker,' to preach in his pulpit on Christmas Day. It is probably true that he thought lightly of all outward cere-

1 At Tempsford Mr. Rolt complained that the late incumbent still kept the parsonage house, and 'prohibited' the parishioners from paying tithes, 9 July 1647 ; at Potton the late incumbent had intruded himself with violence into the vicarage house, and also prohibited the payment of tithes, 2 September 1647. At Marston Dr. Cookson, though he left the vicarage, went 'from house to house' and told the people not to pay their tithes, I 7 August 1647. The 'prohibitions' of ejected parsons would not have had much weight with unsympathetic parishioners.

2 Luton Chusch, by the Rev. H. Cobbe, p. 215.

3 Appendix to the Life of Baxter, Calamy, ii. 9I-5. As Dr. Fowler of Northill, though not satisfied at first, afterwards conformed and became Bishop of Gloucester (p. 95), while Shepherd, rector of Tillbrook, conformed at first but afterwards resigned his living (edition of 1727, p. 130), they balance each other, and neither has been counted.

Ibid. 93. $\quad 5$ Ibid. 91, 93, 95.

- Hist. MSS. Corm, vii. roz. 


\section{ECCLESIASTICAL HISTORY}

monies of religion, and was also a republican in politics, so that his resignation in 1662 was quite natural.

A few of the old incumbents, who were still living in exile or retirement, returned, with the king, to enjoy their own again. Giles Thorne came back to St. Mary's, Bedford, which he held with the archdeaconry of Buckingham until his death. ${ }^{1}$ Jeremy Stephens, the learned prebendary of Biggleswade, ${ }^{2}$ had the additional prebend of Ilfracombe bestowed on him in compensation for his losses; the rector of Houghton Conquest, Dr. Edward Marten, became dean of Ely ${ }^{3}$; Francis Walsall, rector of Sandy, received a prebendal stall at Westminster ${ }^{*}$; the archdeacon, John Hacket, became Bishop of Lichfield and Coventry. ${ }^{8}$ The old rector of Tempsford came back to his parish, ${ }^{6}$ as did the rector of St. John's, Bedford," and there may have been others also; but it is probable that most of them had died in the interval.

But besides the Presbyterian and Independent ministers established by the Parliament under the Commonwealth, there were others to be dealt with; others who were already Nonconformist, and even less likely to be reconciled to the church than Baxter and his friends. It was a difficult matter; but in the seventeenth century, and in the reaction of the Restoration period, it was scarcely likely to find any but one solution. It is nevertheless a great loss to the Church that she had nothing to offer men like John Bunyan but silence or a prison. The steady growth of Nonconformity of all types, from this time forward, is due to more causes than one; but the violence of the repressive measures taken at this time has always been reckoned among them. The imprisonment of Bunyan from 1660 to 1672 , though much less rigorous than popular fancy once painted it, made him a martyr in the eyes of many who did not share his opinions, and has left its mark, not merely in Bedfordshire but much further afield, up to the present day.

While Bunyan preached, ${ }^{8}$ by word or suffering, from his prison, George Fox was as energetic as ever on his missionary tours, passing through Bedfordshire eight different times during the reign of Charles II., holding meetings and making disciples everywhere. ${ }^{9}$ Many of the ejected ministers of 1662 had their little secret congregations, meeting where they could. ${ }^{10}$ The parish registers of this period bear marks of the dis-

1 Walker's Sufferings of the Clergy, p. 44. His will, quoted in Beds $N$. and $Q$. ii. 242, shows the conviction which to the last remained uppermost in his mind : 'I, having lived, by the grace of God will die in the true religion established by law, and in the true, ancient, Catholic and Apostolic faith professed in the Church of England: . . . having lived, and by the grace of God will die, as to her external discipline and commands a dutiful son of the Church of England my dear mother.'

${ }^{2}$ Walker's Sufferings of the Clergy, p. 45 ; Hist. MSS. Com. vi. 47. He had helped Sir Henry Spelman in editing the Concilia before the civil war.

3 Walker's Sufferings of the Clergy, p. I 54.

Ibid. p. 390 .

- Appendix to Life of Baxter, Calamy, ii. 94.

5 Ibid. p. 44.

7 From the list of rectors in Cole's MSS. ; Add. MS. 5832 , f. 89 .

a During the first six years of his imprisoninent he was let out constantly to preach, and once even went to London (Grace Abounding, Clar. Press, p. 428).

9 Fournal of Fox, passim (ed. 1694).

10 Appendix to Life of Baxter, Calamy, ii. 92-5. 


\section{A HISTORY OF BEDFORDSHIRE}

cipline vainly exercised to check the spread of Nonconformity. Names are entered of those buried 'without Christian burial' for being 'schismatics, and despisers of church discipline'; Quakers and Anabaptists are ' hurl'd into a grave.' ${ }^{1}$ The Declaration of Indulgence of 1672 only revealed the extent of a mischief which it was too late to help or hinder.

The Baptist congregation of Bedford was one of the first in the kingdom to apply for a licence to hold its meetings ; it was granted on 25 July $1672 .^{2}$ Bunyan had already taken out his preaching licence as a ' congregationall parson, being of that p'swasion' in May, and was using it at Leicester in October of the same year. ${ }^{3}$ The Baptists of Luton claim to have erected a meeting house at the same time. ${ }^{*}$ All kinds of Nonconformity have been well represented in the county ever since.

It is not so easy to get any satisfactory details to show what the churches of this period offered as a counter attraction to the fervid preachings of the new sects. At Toddington there is an interesting record of briefs, copied at the end of one of the parish registers, dating from $\mathrm{I} 66 \mathrm{I}$ to $\mathrm{I} 668$, which not only shows clearly that there was a weekly Eucharist, but also that the parishioners were encouraged to give alms to the necessities of many of the poor and suffering besides those of their own parish. ${ }^{5}$ It is however to be feared that this was an exceptional case ; the visitations of Bishops Gardiner and Wake show very plainly that a quarterly Communion was the common custom of the whole diocese very soon after the Restoration. ${ }^{6} \quad$ The prevailing order at Luton early in the eighteenth century-four Eucharists a year, two services on Sunday, and a catechising in Lent ${ }^{7}$-represents what was then the average conception of a parson's duty towards his parish. At the same time it must not be forgotten that at this time considerable efforts were made in many places to beautify the chancels, and to enrich the churches with handsome plate, as at Ampthill, Harrold ${ }^{8}$ and elsewhere ; and that several charities were endowed, in the form of schools, almshouses, and doles of bread to the poor at the end of the church services. ${ }^{\circ}$ But it cannot be a matter of great surprise that the various sects gained ground steadily.

In 1744 a Moravian congregation was founded at Bedford; and the autocratic behaviour of the 'chief labourer,' and the squabbles that arose on the building of the chapel, were one of the chief causes of John Wesley's final break with that body. He visited them in 1750 , and

1 Registers of Dunton and Toddington quoted in Beds $N$. and $Q$.

2 Ibid. i. 240.

${ }^{3}$ Hist. MSS. Com. viii. $44^{\circ}$.

4 Non-Parochial Registers and Records in custody of the Registrar-General, 1859 ; printed in Beds $N$. and $Q$. ii. 199-201.

5 History of Toddingtom, by the Rev. F. A. Adams. The collections were for churches and parishes all over the kingdom ; several for the sick of the plague in 1665 ; one for the 'captives of Algiers.'

S.P.C.K. Diocesan History of Lincoin, pp. $317-33$.

7 Luton Church, by the Rev. H. Cobbe, p. 230.

8 Beds N. and Q. p. 219 ; Beds Archaol. and Archit. Soc. X. xlviii.

- Cobbe's Luton Church, p. 238. 


\section{ECCLESIASTICAL HISTORY}

wrote very severely of them afterwards. ${ }^{1}$ The next time he came to Bedford it was upon his own mission, in $175^{8}$, when he also preached the sermon for the Bedfordshire assizes, in St. Paul's church. ${ }^{2}$ The Methodists of that time, though not separate from the Church, had a small room for their own services, replaced a few years later by a chapel. ${ }^{3}$ Wesley himself was in Bedfordshire again four times ; but the main work of the Methodists in this county was done by two of his disciples, John Berridge, vicar of Everton, and Hicks of Wrestlingworth ; their ' circuit' embraced the counties of Bedford, Huntingdon, Cambridge, Essex and Hertford. The people of Bedfordshire, as in the previous century, seemed to be specially favourable to missions of this kind. John Crook of Luton had been the first magistrate to join the Quakers; Parker, the mayor of Bedford, was the first of such officials to call himself a Methodist." He mingled preaching with his public duties for forty years, and to such effect that Wesley wrote of him, between $175^{\circ}$ and 1760: 'Mr. Parker hath not borne the sword in vain.' There was no cursing and swearing to be heard in the streets of Bedford, no work done on the Lord's day, no open wickedness of any kind.

There was also in Bedfordshire an unusual display of those extraordinary phenomena which accompanied the preaching of the early Methodists; they attended the ministrations of Berridge and Hicks quite as much as those of Wesley himself. At one of Hicks' preachings at Wrestlingworth fifteen people fell down 'as if dead'; while Berridge preached 'some shrieked, others roared; but the most general sound was a loud breathing like that of people half strangled.' In one case at the church of Everton (where the congregation was always drawn in part from Bedfordshire) as many as two hundred people were crying for mercy at the same time: "the groans, lamentations, prayers and roarings were indescribable,' as also the shouts and songs of those who had found peace. ${ }^{8}$ These things passed away with the novelty of the preaching; in his visit of 1761 Wesley notes that few were affected in this way any more."

It is easy to criticise the methods and the work of the fieldpreachers; but their extraordinary success is a searching criticism on the Church of the eighteenth century, and points to the same conclusion as the lives of Bunyan and of Fox a hundred years before. It is only too plain that religion was not set forth as a vital principle: that the preaching of 'passive obedience' and of loyalty to the Established Church had overshadowed or displaced the preaching of the Church's most distinctive doctrines of regeneration and of grace, with their never-failing

1 He said the elders claimed more authority than the pope himself, and used the lowest means to gain it; and that they thought theirs was the only church on earth (L. Tyerman, Life of Weskey, ii. 159).

Ibid. ii. 300 .

In $1760,1761,1762$.

- Ibid. 274 .

7 We are not told how long these happy results lasted.

8 L. Tyerman, Life of Wesley, ii. 310-3.

3 Ibid. 340.

${ }^{5}$ L. Tyerman, Life of Wesley, 309, 310. 


\section{A HISTORY OF BEDFORDSHIRE}

appeal to the heart and conscience. At the same time it must be borne in mind that these missions were not intended to supplant the services of the Church, or to draw men away from them; they were only meant to re-awaken the careless and ignorant to a sense of the real demands of religion upon daily life. Hicks and Berridge remained churchmen and retained their livings to the end; and though their parish work must have suffered during their travels, yet their lives do not contrast unfavourably with one or two of the contemporary clergy described by Cole the antiquary ${ }^{1}$ - such as Mr. Christopher Hatton of St. John's, Cambridge, rector of Marston Mortaine and of Maulden, who lived entirely at Ampthill 'in a very elegant house' ; or the vicar of St. Paul's (and rector also of Barton), who left his beautiful church to a curate, allowing the chancel to be in a slovenly condition, and entirely unused except at Communions. And the work of Wesley and his followers, in spite of the separation, had a profound effect in rousing the Church to her responsibilities.

The most distinctive mark of renewed vigour in the Church of the nineteenth century - the formation of new parishes, and the building of new churches to meet the needs of an increasing population-is not wanting in Bedfordshire. While the county was still a part of the diocese of Lincoln, the old chapelries of the Leighton district were made into separate parishes; and since it was made an archdeaconry of Ely, a large number of new churches have been built. The town of Bedford, which had only five parishes from the sixteenth century onwards, now embraces eight ${ }^{2}$; while at Luton (as indeed it should be in the chief industrial centre of the county) the old parish church of St. Mary is supplemented by six others-three within the town, and others in the districts of East Hyde, Stopsley and Biscot. The organisation of church work generally during the last thirty or forty years, the increased number of services on Sundays and week days, the frequent administration of the sacraments even in churches where the clergy do not hold advanced views, the reawakened interest in church fabric and church ornaments, all suggest points of contrast with the previous century; but it is too early yet to judge of the results of these things in any particular county or district. That will be better done by a later generation.

\section{APPENDIX I}

\section{ECCLESIASTICAL DIVISIONS OF THE COUNTY}

The churches in Bedfordshire must have been in their earliest days under the jurisdiction of the Bishops of Mercia, until the division of that diocese, planned by Archbishop Theodore in 679 at the Council of Hertford, was complete. They would then fall naturally to the new see

1 Add. MS. 5834, ff. 125, 125. Cole went to hear Berridge preach at Tempsford, on a table under a tree outside the church, and was more impressed by his "wry faces" than his eloquence (Add. MS. 5832, f. 85 ).

2 It is interesting to note that one of these new churches has revived the memory of an old hospital, being dedicated to St. Leonard. 


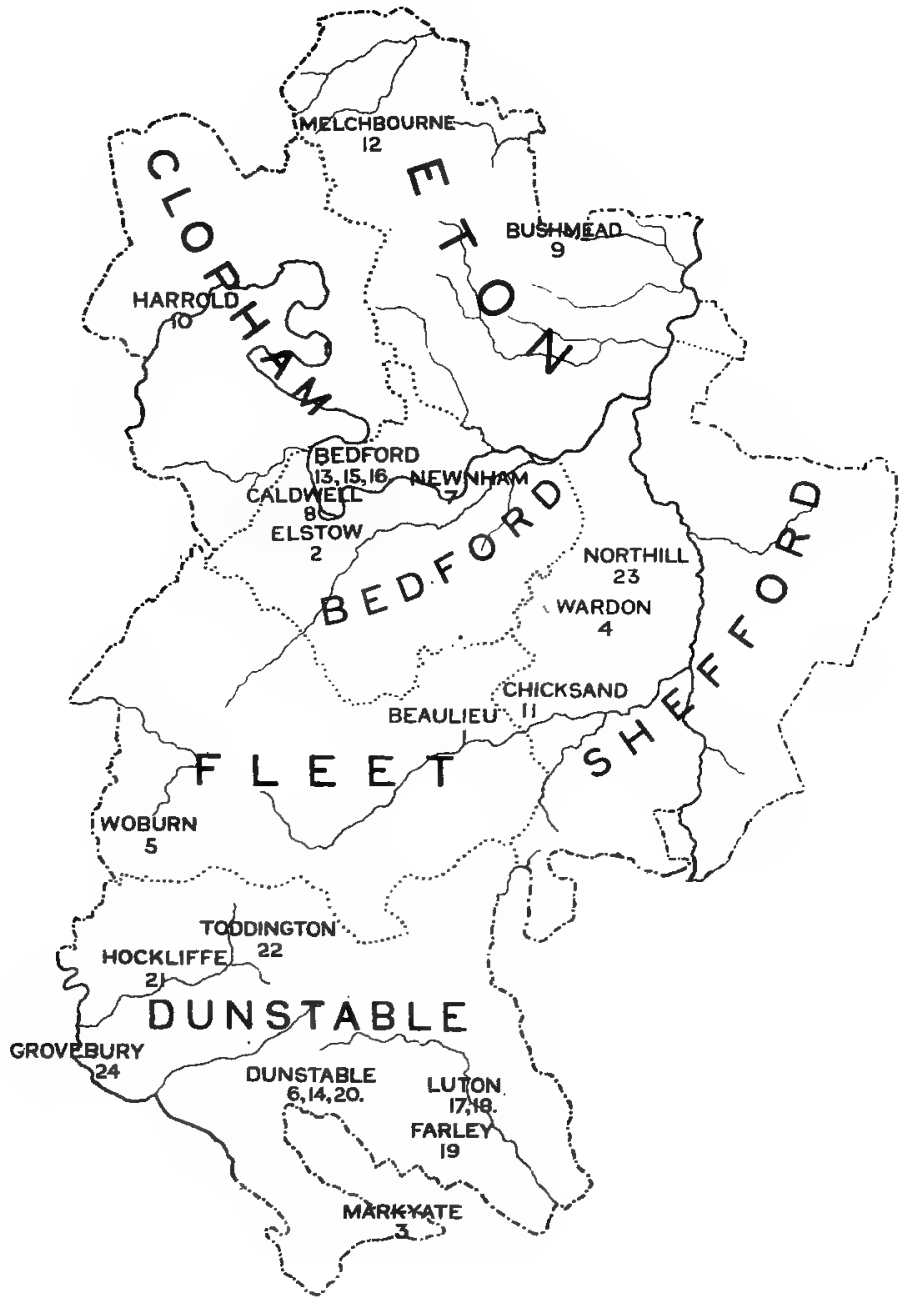

BENEDICTINE MONKS.

I. Beaulieu Priory.

BENEDICTINE NUNS.

2. Elstow Abbey.

3. Markyate Priory.
ECCLESIASTICAL
OF

\section{BEDFORD}

Showing Ancient Rural Deaneries and Relıgious Houses.

Miles ${ }^{2} \mathrm{i}$ i

Darbishire E Stanford Ltd.

\section{CISTERCIAN MONKS.}

4. Wardon Abbey.

5. Woburn Abbey.

AUSTIN CANONS.

6. Dunstable Priory.

7. Newnham Priory.

8 Caldwell Priory.

9. Bushmead Priory. AUSTIN NUNS.

10. Harrold Priory. GILBERTINE HOUSE

I I. Chicksand Priory. KNIGHTS HOSPITALLERS.

12. Melchbourne Preceptory. FRIARS.

13. Bedford, Franciscans.

14. Dunstable, Dominicans. HOSPITALS.

15. Bedford, St. John. I6. " St. Leonard. 17. Luton, St. Mary Magdalene I8. "St. John Baptist. 19. Farley.

20. Dunstable, St. Mary Magdalene.

2 I. Hockliffe, St. 'John Baptist.

22. Toddington, St. John Baptist COLLEGES.

23. Northill.
ALIEN PRIORY.

24. Grovebury. 



\section{ECCLESIASTICAL HISTORY}

of Dorchester, while it was distinct from Leicester and Lindsey. ${ }^{1}$ At the union of these three under Leofwin towards the end of the tenth century, ${ }^{2}$ the county became part of a diocese very much larger, though retaining for some time the same name and centre of government. From $1075^{3}$ until 1837 it formed a single archdeaconry within the diocese of Lincoln, being finally transferred at the latter date to the diocese of Ely. ${ }^{*}$

The names and limits of the rural deaneries were fixed certainly before the Taxation of Pope Nicholas IV. in I291; but how long before it is not easy to say. In I I 99 mention is found of deans of Bedford and Ravensden ${ }^{5}$; of a dean of Luton in $1232,{ }^{\circ}$ a dean of Westoning in $1232,{ }^{7}$ and in 1249 a dean of Pulloxhill $;{ }^{8}$ but it is possible that these places were only the parishes of which the various deans were at the time incumbents, and do not represent the names of their rural deaneries. In 1291 there were six deaneries:-

$\begin{array}{llc}\text { Eaton, containing } & \text { I } 8 & \text { parishes } \\ \text { Clopham ", } & \text { I } 8 & , \\ \text { Bedford ", } & \text { I } 7 & " \\ \text { Dunstable ", } & 20 & " \\ \text { Fleete } & 22 & " \\ \text { Shefford ", } & 27 & \end{array}$

In 1535, the date of the Valor Ecclesiasticus, these divisions remained unaltered; even the total number of parish churches (122) remained as before. ${ }^{9}$ The same names of deaneries are given in the earliest clergy lists till 1880 , with the same schedule of parishes; though from I 870 each deanery has two divisions-Bedford and Dunstable a first and second; Clopham, Fleete and Shefford an eastern and western, and Eaton a northern and southern division. But on 27 February $1880^{10}$ the deaneries were completely reconstituted, with a new schedule of parishes:-

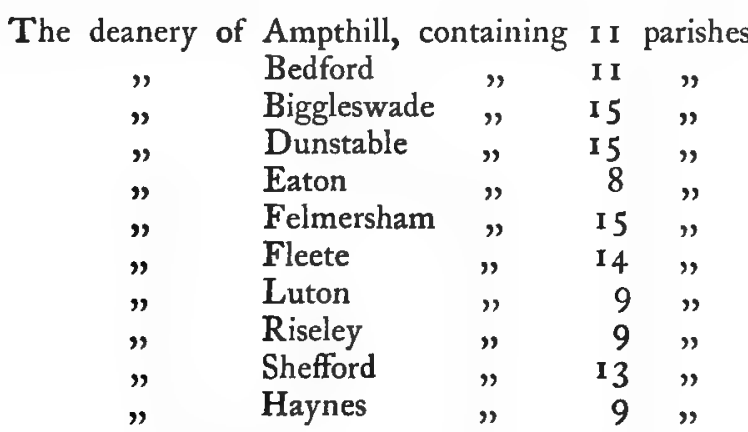

There has been no further change, except by the addition of two parishes to the deanery of Bedford and two to that of Luton.

1 Florence of Worc. (Engl. Hist. Soc.), i. 36, 339.

2 William of Malmesbury, De Gestis Pontif. (Savile ed.) p. 290.

3 The year when Remigius first signed as Bishop of Lincoln (S.P.C.K. Diocesan History, P. 48).

4 London Gazette, 30 May 1837.

5 Harl. MS. 3656, f. 6o ; Add. MS. 24465, f. 29b. ${ }^{\circ}$ Ann. Mon. (Rolls Series), iii. ro8.

7 Harl. MS. 1885 , f. 52 b. $\quad{ }^{8}$ Linc. Epis. Reg., I I Grossetête.

9 The chapel of Clapham is a rectory in the Valor, and the churches of St. Peter and St. Mary Dunstable are reckoned as one ; so that these two items balance each other.

10 London Gawette, 27 Feb. 1880 ; Clergy List, I 881 . 


\section{A HISTORY OF BEDFORDSHIRE}

\section{APPENDIX II}

A seal of John Houghton, archdeacon of Bedford from 1218 to I $23 \mathrm{I}$, is attached to a charter in the British Museum. ${ }^{1}$ It is not of an ecclesiastical type, but the impression of a beautiful antique gem, the figure of a bull at bay. Legend: S(IgIllum) MAGri Johis DE HouTUNE.

1 Add. Ch. 18198 ; a composition between the abbot of Waltham and the archdeacon, concerning rights of visitation, with reference to Arlesey church. 


\section{THE RELIGIOUS HOUSES OF BEDFORDSHIRE}

\section{INTRODUCTION}

The county of Bedford was unusually rich in religious houses in proportion to its size, but none was of very ancient date. The abbey of Elstow was founded before the compiling of Domesday, and followed the Benedictine rule, which was as yet the only one introduced into England; other houses of the same order were the priories of Beaulieu and Markyate, both founded about I I 45. The two Cistercian abbeys of Warden and Woburn were founded respectively in II 35 and I 145. Austin canons had been introduced into this country some twenty-seven years, when Henry I. founded the priory of Dunstable about I I 32 ; the canons of St. Paul's, Bedford, were transferred to Newnham and brought under the same rule about i 166 ; Bushmead Priory was founded a little later. Under the general heading of the Augustinian rule should be reckoned the priory of Caldwell, of the order of the Holy Sepulchre, founded some time during the reign of Stephen or of Henry II. ; and the priory of Harrold, which followed the Arrouasian form of the rule, was founded about II 40 . The Gilbertine priory of Chicksand dates from about II 50 . There was one alien priory, La Grave or Grovebury, at Leighton Buzzard, which was founded under Henry II. ; this, with the Preceptory of Hospitallers at Melchbourne, makes a total of twelve houses in all. The Templars had lands in Sharnbrook ${ }^{1}$ and elsewhere, and the churches of Langford and Little Stoughton ; but they had no Preceptory in this county.

Besides these, there were certainly eight hospitals : four for lepers or the sick at Bedford, Luton (two) and Dunstable; and four for the destitute poor at Bedford, Farley, Hockliffe and Toddington. All of these were probably founded in the twelfth century except Toddington, which belongs to the reign of Henry VI. In the thirteenth century the Friars Minor settled at Bedford, and the Friars Preachers at Dunstable. And in the reign of Henry IV. the church of Northill became collegiate.

It may be noted here that besides these regular and ordinary forms of the religious life, Bedfordshire had also from time to time its hermits and anchorets. The distinction between these two forms ${ }^{2}$ of solitude is

1 Rot. Charta (Rec. Com.), I John, p. 2b; Chart. R. 37 Hen. III. pt. i. m. 3.

2 It has been so often made that there is no need here to repeat it; e.g. Dalgairns' essay on 'The Spiritual Life of Medizval England,' which is the preface to Hilton's Scale of Perfection, ed. Igor. 


\section{A HISTORY OF BEDFORDSHIRE}

of course not primitive, but it was clearly marked in the twelfth and thirteenth centuries. From the time when the religious life in community began first to be well organised, we know by the testimony of Cassian and later of St. Benedict ${ }^{1}$ that men were always discouraged from attempting solitude until they had been first exercised in the ordinary discipline of the conobium; but it was not found possible to enforce this rule in all cases. Roger of Markyate had been a monk of St. Albans ${ }^{3}$ before he was a hermit, and was carried back after his death to the abbey church, where the place of his burial is still marked by an inscription; but of Ralf the hermit, ${ }^{3}$ whose oratory and cell were granted by Robert d'Albini to the priory of Beaulieu ; of Simon the hermit," who bequeathed his little property to Newnham Priory; of the hermit of Bletsoe ${ }^{5}$ and of the hermit who was traditionally the founder of Bushmead, ${ }^{\circ}$ nothing further is known. Amongst solitaries of the other type (more severe in its restraint, but less apart from the common life of men) were 'Simon anachorita,' who came from Lichfield to Dunstable and lived six years beside the priory church, ${ }^{7}$ and doubtless others whose names are not recorded. This form of solitude was as a rule the only one possible for women ; 'Isabella inclusa,' ${ }^{8}$ who died at Bedford near the beginning of the thirteenth century, was probably an anchoress of the ordinary type; but Christine of Markyate, for many years a strict recluse, was not attached to any church. Her career belongs to the history of the house of which she was first prioress.

The Religious Houses of Bedfordshire, if we except Woburn and Dunstable, have few points of contact with general history, and only one produced a chronicle. Little that is definite can be said even of their local influence. The abbey of Elstow had its school, and the Austin canons were patrons of a large number of churches, and must have been well known figures in the county. The canons of Dunstable had many difficulties with their tenants; but these were connected with their feudal lordship of the town rather than with any matter of religion. One point however may be worth noting: in spite of much that has been said of the mutual jealousies of the different orders, in this little county they lived together for the most part ${ }^{\circ}$ on very friendly terms. The Chronicler of Dunstable, who records all the gossip of his neighbourhood, as well as much genuine history, has seldom anything to say of his brethren in other orders but what is sympathetic and kindly. ${ }^{10} \mathrm{He}$

1 Rule, cap. i. Anachoritæ vel Eremitæ, horum qui non conversionis fervore novitio, sed monasterii probatione diuturna didicerunt contra diabolum ... pugnare'.

2 Matth. Paris, Gesta Abbatum (Rolls Series), i. 97-105.

3 Foundation Charter of Beaulieu Priory.

4 Harl. MS. 3656, f. I I.

5 Cat. of Anct. Deeds (P.R.O.), C. 2 I88. His name was Robert Parage : and as he had "brethren" with him in the hermitage, it does not seem likely he had been previously a monk. The same might be inferred of the hermit of Bushmead, if he really existed. Those who began as solitaries were more likely to gather a following than those who had left a monastery to seek solitude.

${ }^{8}$ Leland, Collect. i. 68. ${ }^{7}$ Ann. Mon. (Rolls Series), iii. 77, Iog. ${ }^{8}$ Harl. MS. 3656, f. 22 b.

${ }^{\circ}$ Except Elstow, of which a great many suits with other houses are recorded.

10 Between the four houses of Austin canons there seems to have been much intercourse, and their constant general chapters must have had the effect of promoting corporate feeling amongst them. 


\section{RELIGIOUS HOUSES}

is on the whole least friendly to the Cistercians : he says once that the monks of Warden 'did us much harm,' disputes with Woburn about tolls and tithes, ${ }^{2}$ but he has plenty of sympathy with the misfortunes of both. ${ }^{3}$ Suits there were occasionally amongst them all, and they must have been difficult to avoid, when fields belonging to different houses lay so close together in the same parish, as in many parts of the Bedford, Fleete and Dunstable deaneries; but they are in very small proportion to the suits with seculars. Especially noteworthy is the fact that though the monks of St. Albans had a school in Dunstable, and wide lands at Luton close to those belonging to the canons, not a single suit between the priory and the abbey is on record. The friars indeed, here as elsewhere, were the object of much jealousy to the old religious : and yet their intercourse with Dunstable and Markyate priories was not altogether unfriendly, as will be shown in detail under the history of their houses.

\section{HOUSE OF BENEDICTINE MONKS}

\section{THE PRIORY OF BEAULIEU}

The priory of Beaulieu was founded between 1 I $40^{4}$ and I I 46 upon the site of a hermitage at Moddry in the parish of Clophill, granted to Ralf the hermit by Henry d'Albini, and afterwards by his son Robert d'Albini to the abbey of St. Albans as a cell of that monastery. ${ }^{5}$ A small cell had already been founded at Millbrook under Richard, the fifteenth abbot ${ }^{\circ}$ (1097-III9), and this was merged in the new priory." The house was never an important one, as it was always small and poor. The original endowment only provided for four or five monks, ${ }^{8}$ and it is not likely that their number was increased

1 Ann. Mon. (Rolls Series), iii. I80.

2 Ibid. 74, 93, etc. Mostly about the tithes of Chesham.

3 Ibid. 32, 140, 192.

1 The date falls between the death of Henry d'Albini (who founded Sopwell Nunnery I I 40) and that of Geoffrey, abbot of St. Alban's (I I I9-46).

- Foundation Charter, Arundel MS. 34, f. 32 ; Lansd. MS. 863, f. 83b.

- Granted by Neel de Wast, and confirmed by Henry d'Albini (Foundation Charter, and Matth. Paris, Gesta Abbatum [Rolls Series], i. 67). Henry d'Albini and his brothers had also given to St. Alban's the church of Clophill, and tithes of Cainhoe and Cotes (Cott. MS. Nero, D vii. f. 98 Matth. Paris, Gesta Abbatum [Rolls Series], i. 68). i. $7^{7}$.

Matth. Paris, Gesta Abbatum (Rolls Series),

a The inquisition held in 1433 (J. de Amundesham, Ann. Mon. S. Albani [Rolls Series], ii. Iog) proved that the manor of Beaulieu in the parish of Clophill was granted to sustain for ever four monks to serve the chapel of Cainhoe; and another carucate of land given later was to support one at any time. Early in the thirteenth century the prior was involved in a long suit in the Curia Regis, ${ }^{9}$ concerning the church of Milton Ernest, which the son of the founder wished to recover for himself; but it remained finally with the religious, and was granted to them afresh in proprios usus by Bishop Gravesend in 1275 on account of their poverty. ${ }^{10}$ At some time in the fourteenth century the house was partially destroyed by fire ${ }^{11}$ it suffered probably also from the general depreciation of property after the great pestilence. Finally, near the beginning of the fifteenth century, when Abbot John of Wheathampstead ' went down into the garden of nuts, to see if the vines were flourishing and the pomegranates were bearing fruit ${ }^{12}$ - in other words, made a visitation of the cells-he found Beaulieu in such a poverty-stricken condition ${ }^{13}$ that it

more to serve the chapel of St. Machutus in Haynes.

${ }_{9}$ Cur. Reg. R. I 5 John, 58, No. 4.

10 Linc. Epis. Reg., Rolls of Grossetéte.

11 Cott. MS. Nero, D vii.f. ir I. Margaret, Countess of Norfolk, among other gifts, 'dedit cellæ nostræ de Bello Loco vastate per incendium, $\mathrm{xx}$ marcas.'

12 J. de Amundesham, Ann. Mon.S. Albani (Rolls Series), ii. 105.

13 'Adeo collapsa et facultatibus per sinistros eventus diminuta' (Supplication to the pope, in Arundel MS. 34, f. 33b). The priory had been unable to contribute anything to the abbey between 1396 and 140r, and a wall built round it about this time was erected at the expense of the abbey (Matth. Paris, Gesta Abbatum [Rolls Series], iii. 455,456 ). 


\section{A HISTORY OF BEDFORDSHIRE}

could scarcely support two monks. After reflection he decided to unite the cell with the parent abbey, and apply its revenues to other purposes. There were two things necessary before he could do this. He had to gain the consent of the patron of the house, Lord Grey de Ruthyn; and also to obtain a bull from the pope. Lord Grey signed a full surrender of all his rights in the priory in May, 1434; ${ }^{1}$ and the papal bull which had been asked of Martin V. was granted at last by Eugenius IV. ${ }^{2}$ at about the same time. But it was an expensive matter to claim and use the bull; and while the abbot hesitated, and tried to find out from lawyers whether after all an ordinary prelate could not grant him the necessary licence, the king's escheator stepped in and declared that the house had escheated to the Crown. A jury was summoned to inquire into the abbot's title, which was probably ${ }^{3}$ proved without difficulty; for in a short time he was able to carry out the whole of his original plan. Lord Grey de Ruthyn was granted an anniversary, and a rent of 20s. a year ; ${ }^{4}$ the vicarage of Clophill was re-instituted a rectory, on condition that the rector should say mass three times a week for the soul of the founder, Robert d'Albini ${ }^{5}$; and the income of the priory, amounting to fi 8 a year, was divided amongst the students from the abbey of St. Alban's at Oxford, so that each might receive a pension of $13^{5} .4 d$. annually, ${ }^{8}$ and pray for their benefactor at mass. These arrangements were completed before the death of John of Wheathampstead in 1464 , and the priory disappeared so completely that even its site was for a long time forgotten. ${ }^{7}$

1 I2 May, I3 Henry VI. in Cott. MS. Claudius, D i. f. I 34 b ; Arundel MS. 34, f. 33 has I 2 May 6 Henry VI.

2 A short summary of the whole story is given in Cott. MS. Nero, D vii. f. 33b. The account of John de Amundesham does not explain that the abbot finally released and used the bull, though it names the two popes.

3 The narrative of John de Amundesham ends abruptly without giving the verdict ( $A n n$. Mon. S. Albani [Rolls Series], ii. 105-12).

- Ibid.

- Ibid. and Cott. MS. Nero, D vii. f. 33 b.

- A notice of the payment of this pension to the students and its purposeis found in the Appendix to J. de Amundesham (Ann. Mon. S. Albani [Rolls Series], ii. 292)

7 The reference in the inquisition of $\mathrm{r}_{433}$ to - quoddam manerium vocatum Belewe in parochia de Clophulle in dicta comitate Bedf.' fixes the site.
The original endowment gave to the priory the demesne land in the parish of Clophill afterwards called the manor of Beaulieu (including the hermitage, the church of Moddry and 15 acres for the service of the chapel of Cainhoe three times a week); the churches of Millbrook, Ampthill and Clophill ; the mill of Turnhall, the wood of Hazeldean, with other parcels of land and meadow, and certain rights of pasturage on the founder's demesne. Cecily, mother of the founder, added the church of Milton Ernest ; ${ }^{\circ}$ and Aumary de St. Amand a carucate in Wilshampstead for the service of the chapel of St. Machutus in the parish of Haynes (Hawnes). ${ }^{10}$ The temporalities of the priory in 1291 were valued at $£ 267$ s. 10d.; the spiritualities at $f_{1} 76 \mathrm{~s} .8 d_{0},{ }^{11}$ out of which four vicars' stipends were to be paid. Only two small fractions of a knight's fee in Clophill and Flitton are entered as held by the prior in 1302, and only one in 1346 and I 428.12 At the time of the union of the cell with St. Alban's the abbot stated its whole revenue at $£_{18} 8{ }^{13}$ the jury at the inquisition valued the lands at $f_{12} .^{14}$

No seal of this priory remains, so far as is known.

\section{Priors of Beaulieu}

Walter de Standon, elected $1233^{15}$

Roger, elected $1237^{16}$

Roger de Thebrugg, elected ${ }_{12} 8_{1}{ }^{17}$

John of Stopsley, elected I $285^{18}$

John of Stagsden, transferred $1296^{19}$

William de Parys, elected $1296{ }^{20}$

Peter of Maydenford, elected $1299^{21}$

8 Foundation Charters, Lansd. MS. 863 , f. 83 b. The church of Rinethella here and in Dugdale, Mon. iii. 274 is an evident misreading for Amethella, which is given quite clearly in Arundel MS. 34, f. $32 \mathrm{~b}$, an earlier transcript of the first charter. The Lansd. MS. is a transcript of the seventeenth century.

C Cur. Reg. R., 58, n. 4.

10 Cott. MS. Claudius, D i. f. I34b. The chapel of St. Machutus is said in Cott. MS. Nero, D vii. f. to have been the gift of Rubert d'Albini.

11 Pope Nich. Tax. (Rec. Com.)

12 Feud. Aids (P.R.O.), i. 13, 14, 33, 46.

13 In his supplication to the pope.

14 Cott. MS. Claudius, D i. f. I34b.

15 Linc. Epis. Reg., Rolls of Hugh de Wells.

16 Ibid. Rolls of Grossetête.

17 Ibid. Rolls of Sutton.

18 Ibid.

19 Ibid. Inst. of Sutton

20 Ibid. IO2.

21 Ibid. I04; Cal. of Pap. Letters, i. 601. 


\section{RELIGIOUS HOUSES}

Gregory of St. Alban's, elected $1302^{1}$

Richard of Northampton, elected $1305^{2}$

William of Kirkby, elected $1310,{ }^{3}$ transferred 1312

Richard of Hertford, elected $13^{12} 2^{4}$

Henry of St. Neot's, elected $1316^{5}$
Adam of Newark, elected 1340,occ. 1 $349^{11}$

John of Caldwell, elected $135 \mathbf{I}^{12}$

William of Winslow, elected $1374^{13}$

John Warham, occurs 1396 and $1401^{14}$

Richard Smyth of Missenden, occ. c. $1405^{15}$

\section{HOUSES OF BENEDICTINE NUNS}

\section{THE ABBEY OF ELSTOW}

The Benedictine abbey of Elstow was founded near the end of the eleventh century by Judith, the widow of Earl Waltheof and niece of the Conqueror : ${ }^{8}$ tradition said that it was her act of reparation for the betrayal of her husband to death. ${ }^{7}$ She endowed it with the vills of Elstow and Wilshampstead and a part of Maulden, ${ }^{8}$ the conventual church being identical with the parish church of Elstow; it was dedicated to the honour of St. Mary and St. Helen. ${ }^{\theta}$ From the thirteenth century at any rate the house was reckoned as a royal foundation, and the patronage remained with the Crown until the dissolution. The confirmation charter of Henry I., granted about I I $26,{ }^{10}$ names amongst the benefactors Nicholas and Richard Basset, Nigel de Stafford, and Countess Maud, daughter of Judith and wife of Simon de Senliz. The property of the abbey was considerable, and very widely scattered; the mandates for restitution of the temporalities were addressed to the escheators in twelve counties.

1 Linc. Epis. Reg., Inst. Dalderby, 260d.

2 Ibid. 26Id.

3 Ibid. 265d. Prior of Hertford, I 312-6.

- Ibid. f. 270. Previously prior of Hertford.

6 Ibid. 274d.

- Dugdale, Mon. ii. 4r2, from Leland.

7 Airy, Digest of the Domesday of Beds (Introduction), and S. R. Wigram, Cbronicles of the Abbey of Elstow. From the latter book many of the references to the external history of the abbey have been taken: but it does not give any account of the episcopal visitations, except Longland's.

8 Domesday.

- Leland (quoted by Dugdale) says the Holy Trinity, St. Mary and St. Helen. The name of Elstow is said to be a corruption of Helenstowe, which Leland explains as Helence Statio: but there is no doubt that the usual name of the church was 'the Church of St. Mary Elstow (Elnestowe or Alnestowe),' though ' the Church of St. Helen' is found in Feet of Fines, Bucks, 7 Edw. II. In Domesday, 'the nuns of St. Mary' held 'Elnestou' of Countess Judith.

10 It was witnessed by Thurstan of York IIIg46, Roger of Salisbury I107-42. There was an earlier charter confirmed by the Conqueror, alluded to in Palgrave's Rot. Cur. Reg. i. 39 I.

I
The list of abbesses serves to show that the daughters of baronial families were frequently received at Elstow; the later names are those of the neighbouring gentry. The external history of the house is chiefly gathered from the numerous lawsuits in which it was involved. In the twelfth century there was a long dispute with the monks of Newhouse, concerning the church of Halton-super-Humber ; the terms of the award, and of the papal mandate which afterwards became necessary, suggest that the nuns had been behaving in a somewhat aggressive manner. ${ }^{18} \quad A$ papal mandate was also required to settle a dispute between the nuns of Elstow and the canons of Dunstable $;^{17}$ it is probable that the same abbess, Cecily, was concerned in both these

11 Linc. Epis. Reg., Inst. Burghersh, 32I ; Cal. of Pap. Letters (P.R.O.), iii. 339.

12 Linc. Epis. Reg., Inst. Gynwell, 388d.

13 Ibid. Inst. Buckingham.

14 Matth. Paris, Gesta Abbatum (Rolls Series), iii. 425,480 .

15 Cott. MS. Nero, D vii. f. I $35 \mathrm{~b}$; his father died I405, leaving legacies to St. Alban's.

There was a titular prior of Beaulieu who sent his proctor to Convocation in 1529 ( $L$. and $P$. Hen. VIII. [P.R.O.] iv. 6047). Cole (from MS. notes of Browne Willis) gives the name of ' Thomas Kingsbury, monk of St. Alban's, prior of Beaulieu, and archdeacon of St. Alban's,' under the date I53I. Add. MS. 5827, f. I74b.

${ }_{16}$ The first award (Harl. Ch. 44, i. 3) given by Sylvan, abbot of Rievaulx, and Geoffrey, prior of Bridlington, decided that the church belonged to the monks, and imposed silence on the nuns for ever. The next (Harl. Ch. 43, A 24) was a mandate from Richard, Archbishop of Canterbury, rehearsing a papal bull of Alexander III., in which it is said that the nuns shall not presume to ver the monks further on this matter. It is followed (ibid. $43, G_{23}$ ) by the quitclaim of the nuns. The reasons for placing these charters in this order are given by Wigram, Cbronicles of the Abbey of Elstow, 45-6.

17 Harl. MS. 1885, f. 23b. Cecily, who appears in this charter and in the next reference, was abbess between I I 70 and I I 80 , being contemporary with Alexander III., Thomas, prior of Dunstable, etc., and therefore most probably at the time when the suit with Newhouse was going forward. 


\section{A HISTORY OF BEDFORDSHIRE}

suits, and she had similar dealings with Newnham Priory ${ }^{1}$-all with reference to the advowsons of churches. At another time there were difficulties with St. Alban's Abbey. ${ }^{2}$ Matthew Paris ${ }^{3}$ relates the story of the $a b$ bess of Elstow and the sword: how, at the time of the pulling down of St. Paul's church by Fawkes de Bréauté, she took the sword out of the hand of the image of St. Paul in her own church, and declared that she would not restore it until he avenged himself upon the common enemy. At the beginning of the fourteenth century, in the year 1306, a rather interesting suit was begun between the abbess at that time, Clemence de Balliol, and the brethren of St. Leonard's Hospital." The latter had been erecting new buildings on either side of the pathway which led from Elstow to Bedford, and obtained permission in consequence to close it, and make another which should pass round instead of through the hospital. This the abbess objected to, on the ground that the old way was more direct and convenient for her people. The two paths were carefully measured, and it was decided, against the abbess, that the new way was not appreciably longer than the old. But she was still dissatisfied, and the brethren seem to have been hindered from carrying out their plans for another two years, when they obtained letters patent from the king for the closing of the path.

In I337 Elizabeth Morteyn, who was then abbess, claimed the 'third penny' from the town of Bedford, in virtue of an alleged grant from Malcolm (IV.), King of Scotland; the case was carried before Parliament, and the burgesses were successful in proving that Malcolm never had any lordship in the town. Six years earlier a previous abbess was summoned to show by what title she claimed view of frankpledge and 'judicialia' in Elstow, Wilshampstead, Maulden, and Kempston: she was obliged to confess that her administration had been lax, and could only secure her

1 Harl. MS. 3656, f. 70 .

2 Harl. Ch. 43, A 44 (123I; a bull of Gregory IX.; the dispute was about certain tithes, and the archdeacon of Bucks was ordered to settle it).

3 Matth. Paris, Cbron. Maj. (Rolls Series), iii. 87. The abbess at this time was most probably Mabel. Fawkes de Bréauté held 8 acres of land of the abbess of Elstow (Close, 8 Henry III.)

4 The whole story is set out by Wigram, Cbronicles of the Abbey of Elstow, 93-8, with an account of the measurements, from Chan. Inq. p.m. 34 Edw. I. 226, the final settlement being found in Pat. 2 Edw. II. p. 2, m. I3.

5 Rolls of Parl. ii. 96. rights by the payment of a fine. ${ }^{\circ}$ It was only a short time after this that the parish church of Elstow, as well as the tithes of both rectories, were finally appropriated by the monastery, under the sanction of Bishop Bek ; and 'to avoid the inconvenience caused by the chanting of psalms in the nave of the monastery,' the chapel of St. Helen, which stood in the churchyard, was to serve in future as a parish church. ${ }^{7}$ From this time forward little is known of the external history of the house, except that it was much patronised by seculars, whom the bishops never could succeed in keeping out for any length of time. Not long before the dissolution an attendant of Elizabeth of York, wife of Henry VII., was professed there. ${ }^{8}$

This house was constantly visited by the Bishops of Lincoln; and the records of their injunctions from time to time show us something of its internal history. The first notice of this kind is in a letter, dated 24 June 1270 , from Bishop Gravesend to Walter Giffard, Archbishop of York. ${ }^{9} \quad$ A sister of the latter, Agatha Giffard, was prioress of Elstow at the time, and had been at fault (as had the abbess also) 'through connivance or remissness' in some scandal that had lately occurred. What it was the bishop does not say; only he remarks ' from that house more frequently than from any other false reports of disgraceful acts are brought to us'; and he is evidently putting the case as mildly as he can, so as not to offend the archbishop.

In 1300 the nuns of Elstow, as well as many others, were enjoined to observe the statute De Claustura Monialium of Boniface VIII. ${ }^{10}$ This statute was aimed no doubt at

- Wigram, Chronicles of the Abbey of Elstow, 104 ; from Plac. de $Q$ uo W arr. (Rec. Com.)

7 Cal. of Pap. Letters, iii. I96; and Linc. Epis. Reg., Inst. Bek. 102 (1345). The chapel had been built by a certain Ivota; and a chantry attached in 1334 (Linc. Epis. Reg., Inst. Burghersh, 273).

${ }^{8}$ Beds N. and Q., i. 197, from Nicholas, Privy Purse Expenses of Elizabeth of York, 'delivered to Thabbesse of Elnestowe by thands of John Duffyn for the costes and charges of litle Anne Loveday at the making of her nonne there¿6 r3s. 4d.' (Dated 3 August I 502)

a Wigram, Chronicles of the Abbey of Elstow, 74, where the letter is given at length, from $H_{i s t .}$ Papers and Letters from the Northern Registers (Rolls Series). Whatever the scandal was, it cost the prioress no serious loss of credit, for in I 280-I she was very nearly elected abbess (Wigram, Cbronicles of the Abbey of Elstow, 79, where the letter of Bishop Oliver Sutton reporting on the election is given in full).

${ }_{10}$ Linc. Epis. Reg., Memo. Dalderby, 9, I1. 


\section{RELIGIOUS HOUSES}

a real abuse; but it imposed upon the nuns a degree of enclosure to which they were not bound by the Benedictine rule, and consequently was difficult to enforce. At Elstow it was probably not obeyed at all; for in I 359 Bishop Gynwell ${ }^{1}$ at his visitation reported that there had been 'too much wandering of the nuns out of the monastery.' He had other complaints to make, which show for the first time what was then and afterwards the great snare into which this house fell. The story of Abbess Mabel and the sword of St. Paul shows a right and wholesome interest in the affairs of the church and the world, such as any good religious might take under the common interpretation of the rule of St. Benedict; but as time went on this interest became excessive, and was attended by an inevitable laxity of discipline. From the time of St. Hugh there had been a school in the monastery for children of both sexes ; ${ }^{2}$ most of the nuns were well born and had friends about the Court who sought various pretexts for visiting and lodging in the monastery. Even if the nuns had wished to prevent these visits, it would not always have been easy; the Papal Letters of the fourteenth century show that noble ladies, even queens, often asked licences from the pope to spend a few nights in a nunnery. And the depreciation of the value of property after the great pestilence made the poorer houses sometimes thankful to accept boarders, like many French convents at the present day. But at Elstow it is to be feared that the nuns were really at fault in this matter ; that the spiritual life of the convent was marred by worldliness from first to last.

Bishop Gynwell enjoined that no secular women, except necessary maidservants, should dwell in the convent without special licence ; ${ }^{3}$ all were to depart within fifteen days on pain of excommunication, because 'by the living together of secular women and nuns, the contemplation of religion is withdrawn, and scandal engendered.' Only quite young children were to be allowed to remain ; 4 and there was to be no more laxity or favour shown in the correction of breaches of rule.

1 Linc. Epis. Reg., Memo. Gynwell, I 39 d.

2 Wigram, Chronicles of the Abbey of Elstow, 57, from the Magna Vita S. Hugonis (Rolls Series), 146.

3 In 1350 he had himself granted such a licence to the widow of Sir John Pateshull, to dwell in the monastery with her daughter and maids. One of the brasses still in Elstow church is probably that of a lady who had spent her widowhood as a boarder in the monastery.

- Girls under ten and boys under six.
Bishop Buckingham issued three different sets of injunctions. In $1379^{5}$ he wrote to the Abbess Anstis to order the removal of all secular persons, men and women, from the precincts of the monastery, as 'dangerous to the purity and spiritual devotion of the religious.' In $13^{87}$ he held a regular visitation, and his injunctions, though they do not point to any serious irregularities, are of an interesting character; their aim seems rather to set forth to the nuns their duties in general, and to exhort them to greater fervour, than to correct abuses. There are the usual orders about the singing of the divine office, the administration of the revenues of the convent, the repair of the buildings, the due care of the sick; the nuns are cautioned to avoid scandal by refraining from conversation with all men, both secular and religious, especially the mendicant friars, and their near neighbours, the canons of Caldwell ; not to go out without permission, and to return home before sunset; to be careful that they wear the religious habit of their order and the veil, and not to seek such ornaments as fur, or girdles ornamented with silver; to be humble, obedient, charitable, loving one another in the bond of peace; so that at last 'adorned with the fruit of good works, their lamps burning in their hands, they may be worthy to enter into the marriage chamber of the Heavenly Bridegroom unto whose service they have dedicated themselves." ${ }^{\circ}$ In $13^{88^{7}}$ the bishop only sent a personal admonition to the abbess to be sure and provide a 'fit and secure place' where offenders against the rule might be detained. ${ }^{8}$

Bishop Repingdon visited the monastery at the beginning of the fourteenth century. His injunctions show that no lasting reform had been effected by his predecessors. No secu-

- Linc. Epis. Reg., Memo. Buckingham, Igrd.

- Ibid. 343. In addition to what is given above, the Bishop ordered that the nuns were to speak Frencb among themselves. They were not to talk to the canons of Caldwell ' about the public highways and fields adjoining' under pain of excommunication: which shows that they were in no sense enclosed within the monastery. The last words quoted at the end of the injunctions are a reminder to them of the Office for the Profession of a nun with which they would all be familiar, and would constitute a strong appeal for renewed fervour.

7 Ibid. 348 .

8 The year before he had ordered that the abbess and prioress should use moderation and temperance in making corrections : perhaps this was only too well obeyed. The abbess at each of these three dates was Anstis Dene. 


\section{A HISTORY OF BEDFORDSHIRE}

lars male or female above the age of twelve were to be admitted; the nuns were not to go into Bedford or Elstow; only suitable persons were to be professed. ${ }^{1}$

Bishop Grey ${ }^{2}$ admonished the nuns to increase their numbers, that the divine office might not be neglected; but none was to be admitted unless she could read and sing, and then only with the consent of the 'greater and wiser' part of the convent. No seculars except young children were to be allowed in the monastery; an apostate nun was to be brought back. This was the last visitation before the well known injunctions of Bishop Longland in I $530^{3}$ The tone of these makes it impossible to avoid the conclusion that the house had become thoroughly secularised. The ladies had for the most part given up the most distinctive features of their common life; they had forsaken the use of the refectory, and lived more like pensioners in a boarding-house, having their little private 'households,' where they received and ate with their friends. They were accustomed to wear scarlet stomachers, "voyded shoes" and low-necked dresses like those of secular women, and 'cornered crests' instead of veils. The lady abbess when she walked in procession was followed by a train of servants, and leant upon the arm of one of them. The ' chapelayne,' Dame Katherine Wingate, had been wont to absent herself from matins, and to take her meals in the abbess's buttery with the steward. Nevertheless the bishop evidently thought the case was not past remedy, and it is noteworthy that after all nothing worse than secularity is implied in these injunctions. He reminds them that 'the more secret religious persons be kept from the sight and visage of the world and strangers, the more close and entire their mind and devotion shall be to God'; and so orders a door at least 5 feet high to be erected at the lower end of the choir, so that the nuns might neither see nor be seen by strangers at office time; and the cloister door between the monastery and the church, as well as the

1 Linc. Epis. Reg., Memo. Repingdon, 231. Rules of diet were also given at this visitation. No money was to be exacted from those seeking admission to the community. Two older nuns were to be responsible for all the money of the convent; the collector of rents was to give an account upon oath twice a year. A sacristan and a precentor were to be chosen from the nuns of good reputation: none convicted of immorality was to be admitted to any office. The sick nuns in the infirmary were to be duly visited, and the rest to sleep in the dormitory.

2 Ibid. Memo. Grey, 203d.

3 Arch. xlvii. 5 I-3. outer door towards the court, were to - be kept shut as far as possible. There were to be no more 'households' kept except the abbess's, and a 'misericorde' where four or five of the sisters with 'one sad lady of the elder sort,' nominated by the abbess, might take their meals in turn and meet their friends. The rest were to go to the 'fratry.' 4

How far these injunctions produced any effect it is impossible to say. The house was not mentioned by Layton in the letter ${ }^{5}$ in which he records his visit to Bedfordshire. It did not fall under the Act of 1536, and was not surrendered until 26 August I 539. The deed of surrender is still extant; it contains the ordinary formula, the same as that of Wardon and Chicksand, and has no signatures, but only the seal. The pension lists of $1539-40^{7}$ assign $£ 50$ to the abbess, Elizabeth Boyvill, and smaller sums to twenty-three nuns besides. If there were so many at this time, we may conclude that the house held perhaps twice as many in the thirteenth century, but there is no record of the original number. The usual officials are named from time to time : the prioress, the sacristan, afterwards called the 'chapelayne, the chantress. It appears that in the thirteenth and fourteenth centuries there were a few lay brothers attached to the house, but it is not clear what was their exact status. ${ }^{8}$

The original endowment of the abbey included the vills of Elstow and Wilshampstead with 5 hides and $1 \frac{1}{2}$ virgates in Maulden, and the church of Hitchin in Hertfordshire. ${ }^{8}$ Small portions of land in Buckinghamshire, Leicestershire, Gloucestershire and Northampton-

4 It should be noted that there is no suggestion of actual immorality at this time, or at any other, except in Bishop Repingdon's injunctions (see above). But on the other hand the recurrence of the same corrections makes it clear that the standard of life in the house had never been high since the thirteenth century, and though there were doubtless always some of the 'sadder sort,' as at the end, yet they were in the minority.

5 Wright, Suppression of Monasteries, Letter 42.

6 Deed of Surrender (P.R.O.), No. 88.

7 L. and P.Hen.VIII.(P.R.O.), xv.1032, No. 80.

8 Pat. 6 Edw. I. m. 7 d. Commission of oyer and terminer touching the persons who assaulted Brother Henry of Elstow at Elstow. Cal. of Pap. Letters, iii. 276 (1349), Walter Woodward, lay brother of Elstow, having left his order, desires to be reconciled to it.

๑ Inspeximus, I I Edward II., of the charter of Henry I., which grants the abbess in her lands sac and soc, toll and team, and infangetheof, and all the customs, services and liberties that the free churches of the king's demesne have. (Dugdale, Mon. iii. 413) 


\section{RELIGIOUS HOUSES}

shire were added by other benefactors as portions with the daughters whom they sent to school or into religion. ${ }^{1}$ The churches of Elstow, Wilshampstead, Maulden, Kempston, Flitton, Westoning, with Hitchin (Herts), Inworth (Essex), Clanfield (Oxon), Westbury (Bucks), Harringworth and Wilbarston (Northants) were in the gift of the abbey from the thirteenth century to the Dissolution; while Goddington ${ }^{2}$ (Oxon) and Tingrith (Beds ${ }^{3}$ ) were claimed by it in the thirteenth century, and Halton-super-Humber ${ }^{*}$ (Lincoln) in the twelfth. Portions of tithes from several other churches were paid to the monastery. In 1291 its income was about $\mathrm{fIIO}^{5}$; at the Dissolution it was $£ 284$ I 2s. I I d. clear. ${ }^{\circ}$

In 1316,1346 and $1428^{\circ}$ the abbess of Elstow held the vills of Elstow, Wilshampstead and Maulden in pure alms, and some small fractions of knight's fees in Flitton and Cotes, with a quarter of a fee in Moulsoe, Bucks. ${ }^{7}$ In the ministers' accounts after the Dissolution the property was valued at $E^{2} 348$ s. 7 d. after the subtraction of some parcels of lands annexed to the honour of Ampthill; the site of the monastery and its demesne lands being reckoned as £77 I7s. Iod. ${ }^{8}$

\section{AbBesses of Elstow}

Cecily, ${ }^{9}$ occurs c. I I 80

Mabel, ${ }^{10}$ elected 12 I 3 (?), occurs 12 I 8 and I 222

Wymark, ${ }^{11}$ died 124 I

1 Given in the same charter (see also Dugdale, Mon. v. Igo, for a similar gift from Maud de Amundeville).

2 Feet of F. Oxon, 6 Henry III.

- Cur. Reg. R. 58, I5 John, n. ro dors.

- A pension from this church continued to be paid to the abbess till the dissolution (Harl. Ch. 44, D 35, and Valor Eccl. [Rec. Com.], iv. 188).

- Pope Nich. Tax. (Rec. Com.) The totals from the $\tau_{\text {axatio }}$ here and elsewhere are only approximate; it is not always possible to find out exactly how much a monastery really received from an appropriate church.

- Valor Eccl. (Rec. Com.), iv. I88-9.

7 Feudal Aids (P.R.O.), i. 13, 20, 27, 31, 36, 40, 4I, 46, 104.

8 Dugdale, Mon. iii. 4 I6.

- Harl. MS. 3656, f. 70 ; ibid. 1885, f. 23 b. Contemporary with Geoffrey Ridel, Bishop of Ely, I I73-89, and Pope Alexander III. II 59-8I.

10 An abbess unnamed died 1213 ( $A n n$. Mon. [Rolls Series], iii. 4I. The name Mabel occurs (Cott. MS. Nero, E vi. f. I28), with Almaric de St. Maur, who died I2I9 (Ann. Mon. [Rolls Series], iii. 55 ; and again Feet of F., Beds, 6 Henry III.)

11 Linc. Epis. Reg., Rolls of Grossetête.
Agnes of Westbury, ${ }^{12}$ elected 1241, resigned 1249

Aubrée de Fécamp, ${ }^{13}$ elected 1249

Annora, ${ }^{14}$ died 1281

Beatrice de Scoteny, ${ }^{15}$ elected 1281, died 1294

Clemence de Balliol, ${ }^{18}$ elected 1294, resigned I 3 I 4

Joan de Wauton, ${ }^{17}$ elected I $^{\mathbf{I} 5}$, died 1318

Elizabeth de Beauchamp, ${ }^{18}$ elected 1318 , died I 33 I

Juliane Basset, ${ }^{19}$ elected I 33I, died I 333

Elizabeth Morteyn, ${ }^{20}$ elected 1333, occurs I35 I

Anstis (Anastasia) Dene, ${ }^{21}$ occurs I 370, resigned 1392

Margaret Pygot, ${ }^{22}$ elected 1392, died or resigned I 409

Joan Trailly, ${ }^{23}$ elected I 409, died I 430

Rose Waldgrave, ${ }^{24}$ died 1463

Elizabeth Hasylden, ${ }^{25}$ elected 1463, occ. I 473

12 Ibid.

13 Ibid.

14 Ibid. Memo. Sutton; and Pat. 9 Edw. I. m. 15.

16 Ibid.; a divided election, Agatha Giffard securing some votes (see above, p. 354, note 9).

${ }_{16}$ Linc. Epis. Reg., Inst. Sutton, 98; Pat. $22 \mathrm{Edw}$. I. m. Io.

17 Linc. Epis. Reg., Inst. Dalderby, f. 273d. Another divided election, some choosing Elizabeth de Beauchamp: on 7 Feb. I3I5 (Pat. 8 Edw. II. pt. I, m. 3) the king commissioned the bishop to inquire which election ought to stand. Clemence de Balliol possibly foresaw the dispute, for just before her resignation in November I3I4 she obtained a grant (through Queen Isabel) that the prioress and nuns of her house should have all the issues of the abbey and its temporalities during the next voidance, and be free of the escheator (Pat. 8 Edw. II. pt. I, m. 27). The election of the prioress Joan de Wauton was confirmed I4 May I3I5 by the Archbishop of Canterbury (ibid.)

${ }_{18}$ Linc. Epis. Reg., Inst. Dalderby, 276; ibid. Memo. Dalderby, 379.

19 Ibid. Inst. Burghersh, 304 ; Pat. 5 Edw. III. pt. ii. m. I9 and II.

20 Linc. Epis. Reg., Inst. Burghersh, 306d; Pat. 7 Edw. III. pt. ii. m. 2 I and I9. Occurs Cal. of Pap. Letters, iii. 412 (1351).

${ }^{21}$ Campbell MS. x. 9, dated I370; resigned Linc. Epis. Reg. Inst. Buckingham, 359.

22 Ibid.

23 Linc. Epis. Reg., Inst. Repingdon, 297 ; death recorded (not naming successor) J. de Amundesham, Ann. Mon. S. Albani, i. 47. She was probably the daughter of Sir John Trailly, who founded Northill College (Feud. Aids, i. 40).

24 Pat. 2 Edw. IV. m. 25.

25 Ibid. Occurs again ibid. 13 Edw. IV. pt. i. m. 2 I (July, 1473). 


\section{A HISTORY OF BEDFORDSHIRE}

Margaret Godfrey, ${ }^{1}$ elected 1487 , died or resigned 1501

Elizabeth Hervey, ${ }^{2}$ elected I 501, died I 524

Agnes Gascoigne, ${ }^{3}$ elected 1524 , died 1529

Elizabeth Boyvill, ${ }^{4}$ elected i 529

The seal of the abbey is found attached to the deed of surrender already mentioned. It is dark green, pointed oval, and represents Blessed Mary the Virgin standing with the Holy Child in her arms. St. Helen stands on the right, bearing the cross. An abbess kneels below, with crosier, and a nun on either side.

Another seal (imperfect) bearing only the figure of St. Helen with the cross is attached to Harl. Ch. 44, D 35, and Campbell Charter, x. 9 (B.M.)

\section{THE PRIORY OF MARKYATE}

The priory of Markyate was founded in the year I I 45, in a wood which was then part of the parish of Caddington, and belonged to the Dean and Chapter of St. Paul's, London. ${ }^{5}$ Ralf de Langford, who was dean at the time, granted the site at a rent of $3^{\text {s. }}$ annually; adding to it afterwards another portion at a rent of $6 \mathrm{~s}$. As the house was built under the patronage of Geoffrey, sixteenth abbot of St. Alban's, and endowed by him (though not with the goodwill of his convent) with tithes rrom Cashio and Watford, ${ }^{6}$ it has sometimes been called a cell of that abbey; but this is scarcely a correct description of it, as the patronage remained always with the Dean and Chapter of St. Paul's, ${ }^{7}$ and the nuns were never exempt from episcopal jurisdiction. There can however be no doubt that in its early days the priory was closely connected with St. Alban's, though the history of its origin is somewhat involved in legend. It is said that a monk called Roger ${ }^{8}$ went out from the abbey some time during the reign of Henry I., with the consent of his abbot, to seek a place for a hermit-

1 Lansd. MS. 963, f. 27b (Bishop Kennett's extracts from Rolls de Rest. Temporalium).

a Ibid. f. 55 .

3 L. and P. Hen.VIII. (P.R.O.), iv. 404, 487, from Pat. I6 Hen. VIII. pt. i. and Linc. Epis. Reg., Longland, $24 \mathrm{I}$.

$4 L$. and P. Hen. VIII. (P.R.O.), 62I1, from Pat. 2I Henry VIII., and in Pension List after the surrender.

6 Hist. MSS. Com. ix. 66, and Dugdale, Mon. iii. 368. The grant was confirmed by Alexander Bishop of Lincoln (Cott. Ch. xi. 8).

- Matth. Paris, Gesta Abbatum (Rolls Series), i. 95.

7 Linc. Epis. Reg. (See Institutions of Prioresses).

- Matth. Paris, Gesta Abbatum (Rolls Series), i.

age; and was guided to choose a spot in the woods near Caddington, not far from Watling Street. There he lived for some time in such solitude as he desired, until a damsel from Huntingdon, Christine by name, came and placed herself under his direction, believing that she had a similar vocation. He enclosed her in a shed close by his own hermitage, and fastened the door with planks in such a way that she could not open it herself, nor could she be seen by any passers-by; and in this narrow dwelling she remained for four years, enduring with heroic courage heat and cold alike, and only released from her cramped posture once a day at dusk. At the end of this time her patience was rewarded by heavenly visions, ${ }^{9}$ which convinced Roger that it was indeed her destiny to succeed him in his cell. When he died, and was carried to St. Alban's to be buried ' in a curved place on the south wall near the choir,' it was natural enough that the abbot should take Christine under his special protection and patronage. A woman could scarcely live quite alone in a wood away from either town or church, but it was not difficult in the twelfth century to find a few others who were willing to embrace the stricter forms of the religious life; so Christine was soon surrounded by disciples. The formation of the house into a priory under the Benedictine rule was probably due to the influence of St. Alban's. ${ }^{10}$

97-105. These pages do not form part of the original narrative, but are added by Walsingham or the compiler of the Gesta Abbatum.

a One of these, whether historical or not, is at any rate characteristic of the crusading age to which the real Christine belonged. She thought she saw her Lord standing before her and holding a golden cross; He bade her be of good courage, for they who would go to Jerusalem must needs bear the cross thither.

10 If the dates in the story of Roger and Christine are at all correctly given, it was some time before this was formally done. It is said that Christine acted as an adviser to Abbot Geoffrey in the beginning of the reign of Stephen; while the charter of foundation is dated 1145 . Christine has the distinction of being the only Bedfordshire saint (and after all she was born in Huntingdon!) There is a fifteenth century English life of her by Roscarrok (printed from a MS. in Trinity College, Dublin) appended to John of Tynemouth's Nova Legenda Anglia, ed. C. Horstman. It contains very little of interest, being chiefly an account of her life before she came to Markyate, of which the St. Alban's chronicler apparently knew nothing: and of her contentions with her parents and wouldbe husband, after the manner of St. Frideswide and many other virgin saints. 


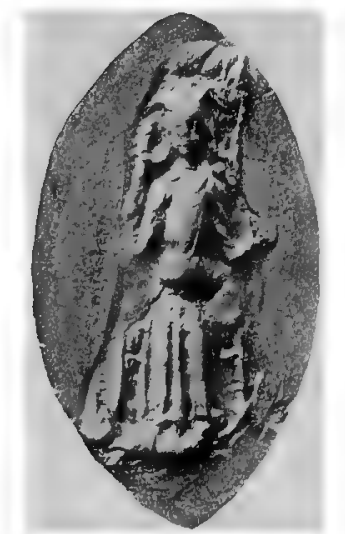

Elstow Abbey.

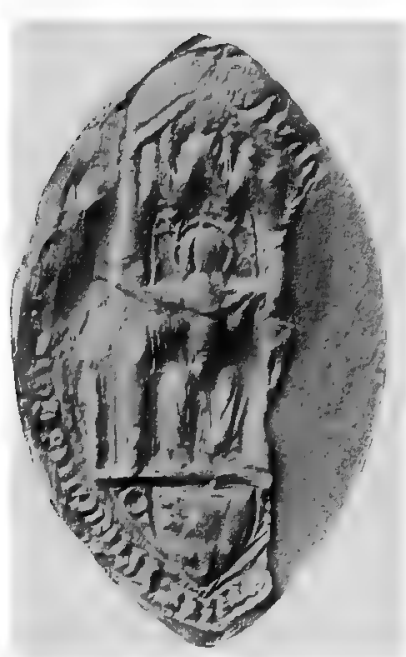

Markyate Prioky.

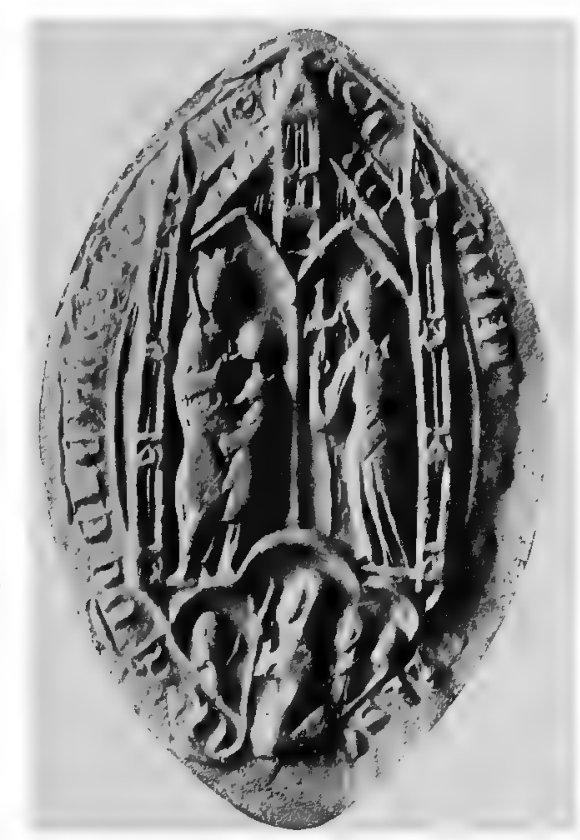

Elstow AbBey.

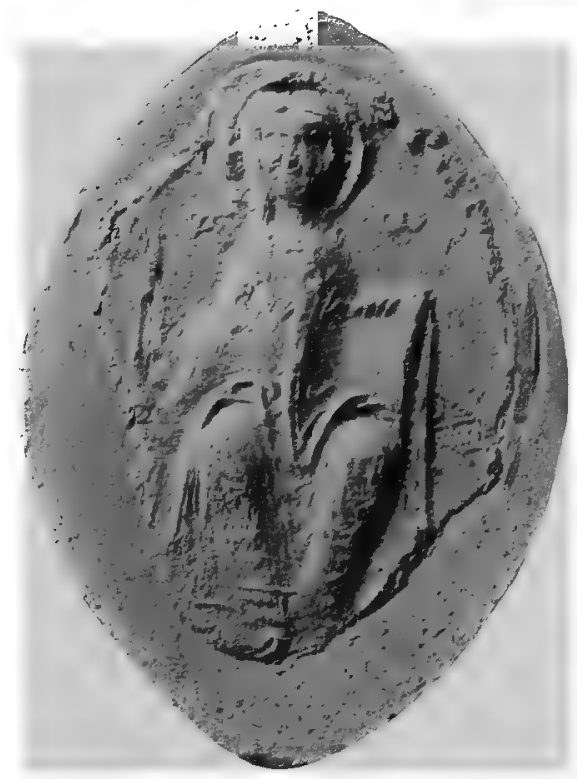

Markyate Priory.

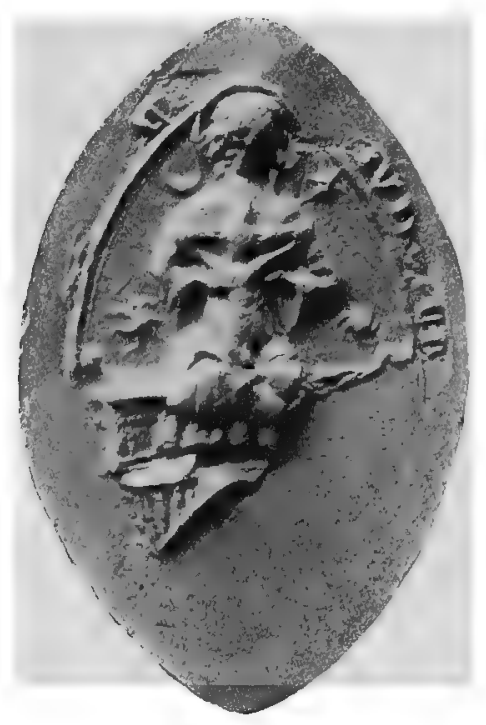

Markyate Priory. 



\section{RELIGIOUS HOUSES}

The priory was dedicated to the Holy Trinity, and the name most commonly given to it was 'Holy Trinity in the Wood.' It seems to have been destroyed by fire almost as soon as built; for Matthew Paris asserts that Abbot Geoffrey built the house twice from the foundation. ${ }^{1}$ The later story says that Christine had great influence with the abbot, and often gave him good advice; which may well have been, without the intervention of any ghosts. ${ }^{2}$ There is happily no doubt of her real existence, as her name appears on the foundation charter and other documents ; ${ }^{3}$ and an entry on the Pipe Roll of $115^{4}$ gives some evidence of the fame to which she attained. During her lifetime the priory acquired some property outside the county $;^{5}$ there were certainly four churches belonging to it in the thirteenth century, and possibly more. But it was never a wealthy house.

In $1259,^{\circ}$ when the Friars Preachers came to Dunstable, the prioress of Markyate, Agnes Gobion, sent them a certain number of loaves every day for their dinner-'out of pure charity,' says the chronicler, because they were then building their church. But her kindness was ill requited, for when the immediate necessity was past, the friars would not allow her to withdraw the dole; they sent to Rome and had it confirmed to them for ever. ${ }^{7}$ This grant would not probably be in itself a heavy burden to the priory; but there is no doubt that the nuns had some difficulty in maintaining themselves during the second half of the thirteenth century. Debts began to press heavily; and in 1290 they sent a petition to Parliament ${ }^{8}$ to say

1 Matth. Paris, Gesta Abbatum (Rolls Series), i. 95. This is not part of the later story.

2 Geoffrey's name appears as a witness on the foundation charter. He had been master of the school at Dunstable before he was abbot (ibid. p. 73), and the neighbourhood of Markyate must have been quite familiar to him before Roger went there.

3 Cott. Ch. xi. 36.

4 'In blado quod rex dedit dominæ Cristinæ de Bosco I sol.' Robert, the eighteenth abbot of St. Alban's, on a visit to Rome, presented to the English pope, Adrian IV., some of the workmanship of Christine-three mitres and a pair of sandals embroidered by her (Matth. Paris, Gesta Abbatum [Rolls Series], i. 127).

- Cott. Ch. xi. 36. Deddington, Oxon.

- Matth. Paris, Gesta Abbatum(Rolls Series), i. 387.

7 'Let this be a warning to others,' adds the chronicler, " to take more care, and to cast forth the serpent from their bosom, before it can do them any further harm.' It seems strange that there is no allusion to this in the Annals of Dunstable.

${ }^{8}$ Dugdale, Mon. iii. 368. that if they were to pay all that they owed (more than two hundred marks) they could not possibly live. The relief they asked was not granted, but perhaps they found some other way out of their troubles, for the priory continued to exist. But its poverty was noticed by the bishop in $1332 .^{\circ}$

The number of nuns in 1406 was twelve, ${ }^{10}$ and in 1433 there were a prioress, subprioress and nine nuns ${ }^{11}$; it is probable that the revenue would never have supported more. The priory had a warden or master in $1323{ }^{12}$ like many other nunneries at that time.

There are records of several visitations of this house in the episcopal registers. In $1297^{13}$ it came under the notice of Bishop Sutton. He had heard that the apparitor of Dunstable had cited 'certain persons of both sexes living in the priory of Markyate' for immorality, whereby these persons had been defamed, and the house had incurred scandal. Evidently the bishop thought the evidence against them insufficient, for he ordered the archdeacon to see that they were not further molested. It seems improbable from the description that the persons alluded to were religious : they were perhaps boarders taken in during the great necessity of the house. At about the same time the prioress and convent were ordered to repair the chancel of one of their appropriate churches. ${ }^{14}$

In 1300 Bishop Dalderby ${ }^{15}$ visited the monastery in person to explain the statute of Boniface VIII., De Claustura Monialium, and found the nuns at first ready to accept it; but when he had concluded his visit, and turned to go, four of them broke away from the rest and followed him to the outer gate, declaring that they would not observe it. Like a wise man, he did not stop then to argue the matter, and went on his way to Dunstable; but the next day he returned to Markyate, inquired the names of the four refractory nuns, and put the whole convent under penance on their account, threatening to excommunicate them if the statute were not observed. But this was not the only house where the bishop had difficulties in enforcing this statute.

In $1323^{18}$ a visitation by the warden and the vicar of Kensworth was ordered by Bishop

${ }^{9}$ Linc-Epis. Reg., Memo. Burghersh, 242d.

10 Ibid. Inst. Repingdon, 288 (1406) : twelve nuns present at an election.

11 Ibid. Memo. Grey, 149

12 Ibid. Memo. Burghersh, i 18.

13 Ibid. Memo. Sutton, I73.

14 Ibid. 125 (1296).

15 Ibid. Memo. Dalderby, Iod.

16 Ibid. Memo. Burghersh, 118. 


\section{A HISTORY OF}

Burghersh, but its results are not recorded; probably there was nothing striking to record, as the house was still in much poverty. In $133^{1}$ an apostate nun was received back again and absolved; three others sought absolution at the same time, for having aided and abetted her in her escape.

A terrible scandal was revealed by the visitation of 1434,2 undertaken by a commission from Bishop Grey. The prioress of the house, Denise Lewelyck, was accused of having broken her vow of chastity, to the very evil example of her sisters. She was called upon to purge herself of the charge, but preferred to confess it, and submit herselr to the ordinance of the bishop; and resigned her office in the presence of the assembled convent and the vicar of Kensworth. It was objected against her at the same time that she had not kept the rule, and that she and others had concealed certain things at the visitation; also that she had allowed one of the sisters to withdraw from the monastery. The house was evidently in a most unsatisfactory condition at the time; and the resignation of Denise was followed by a long interregnum, her successor not being appointed till $1448 .^{3}$ No further visitations are recorded.

The house was surrendered under the Act of 1536,4 as its income was less than $f^{200 a}$ year, and there may not have been by this time as many as twelve nuns. The exact date of the surrender is not known, but it must have been some time before Io February $15379^{\circ}$ when the prioress, Joan Zouche, received for the first time her pension of 20 marks.

The first endowment of the priory consisted of the demesne lands, granted by the Dean and Chapter of St. Paul's, with another portion of land in the neighbourhood, at a total rent of 9 s. annually ; ${ }^{\circ}$ and tithes from Cashio and Watford, Herts, granted by the abbot of St. Alban's." During the lifetime of the first prioress some other small parcels of land in Oxfordshire were acquired; ${ }^{8}$ and during the thirteenth century the tithes of Sundon, Streatley, Higham Gobion and

1 Linc. Epis. Reg., Memo. Burghersh, 353d.

2 Ibid. Memo. Grey, 89, 149.

3 Ibid. Inst. Alnwick, 186d.

4 . and P. Hen.VIII. x. 1238 .

- Ibid. xiii. (I), 1520.

Hist. MSS. Com. ix. 66; Dugdale, Mon. iii. 368.

${ }_{7}$ Matth. Paris, Gesta Abbatum (Rolls Series), i. 95 .

${ }^{8}$ Cott. Ch. xi. 36, xxi. 5: it was land at Deddington, leased by Christine, and alienated by the next prioress Isabel for 30 marks of silver.

\section{BEDFORDSHIRE}

Buckby, Northants. ${ }^{8}$ At the dissolution the Crown bailiff found the house possessed of the manors of Burcester, Oxon; Livesey; and Stokesby, Norfolk; with parcels of lands in Herts, Hunts, Northants, Cambs ; and the tithes of Sundon, Streatley, Watford (Herts), Kingsbury, Coleshill, Bickenhill and three chapels besides in Warwickshire; besides pensions from Higham Gobion, Buckby (Northants), Bushey (Herts), Eversden Parva (Cambs) and Pakinton, amounting altogether to $£_{1} 55$ 5s. $10 \frac{8}{4} d .^{10}$ This is in excess of the amount given in the Valor Ecclesiasticus, which is only f114 I6s. Id.

\section{Prioresses of Markyate}

Christine, ${ }^{11}$ prioress 1145

Isabel ${ }^{12}$

Joan, ${ }^{13}$ occurs $1212,123^{8}$

Agnes Gobion, ${ }^{14}$ occurs 1259, died 1274

Isabel Gobion, ${ }^{15}$ elected 1274, resigned 1280

Alice de Basseville, ${ }^{16}$ elected 1280 , died 1284

Lora de Kantia, ${ }^{17}$ elected I 284 , died 129 I

Maud of Luton, ${ }^{18}$ elected 1291

Bennet or Benedicta of Whitacre, ${ }^{19}$ elected I 332

Joan Power, ${ }^{20}$ died 1349

Alice Spigurnel, elected $1349^{21}$

Isabel of Ashby, ${ }^{22}$ resigned 1350

Joan of Stanbridge, ${ }^{23}$ elected 1350

Sibyl Attelburgh, ${ }^{24}$ died 1406

Elizabeth Benington, ${ }^{25}$ elected 1406

Denise Lewelyck, ${ }^{26}$ occurs 1431, resigned I 434 (1 4 April 1 433)

- The Linc. Epis. Reg. shows these churches in the gift of the priory from the first.

10 Dugdale, Mon. iii. 368.

11 Cott. Ch. xi. 36, etc.

12 Ibid. xxi. 5 (undated).

${ }_{13}$ Joan, 1212 , is in Dugdale, Mon. iii. 368 ; and Joan de Fyret occurs I 238 in Linc. Epis. Reg.

14 Matth. Paris, Gesta Abbatum (Rolls Series), i. 387 ; and Linc. Epis. Reg,, Rolls of Gravesend.

15 Ibid.

16 Ibid. Inst. Sutton.

17 Ibid. (called Loretta in the next institution).

18 Ibid. 96.

19 Ibid. Memo. Burghersh, 242d.

20 Ibid. Inst. Gynwell, 379.

21 Ibid.

22 Ibid. 384.

23 Ibid. These changes in 1349-50 are probably due to the great pestilence.

24 Ibid. Inst. Repingdon, 290.

${ }_{25}$ Ibid. 288. Margaret Fawkeswell was elected on the death of Sibyl Attelburgh, but not instituted (ibid.)

${ }_{26}$ Ibid. Memo. Grey, 89, 149. 


\section{RELIGIOUS HOUSES}

Joan Wyrell, ${ }^{1}$ elected 1448

Agnes Stephens, ${ }^{2}$ elected 1508, died 1508

Joan Zouche, ${ }^{3}$ elected 1508, surrendered 1536

There is a very early seal of the priory attached to a charter of the first prioress, ${ }^{4}$ of a light-brown colour, pointed oval, representing our Lord, with cruciform nimbus, seated on a throne, with rainbow behind it, the right hand raised in benediction, the left resting on a book on the left knee. The inscription is illegible, and very little of it remains.

The ordinary chapter seal ${ }^{8}$ was a representation of the Holy Trinity, pointed oval : a figure seated upon a throne, holding a crucifix ; a crescent on the left and a star on the right. Legend : . . . . MUne c . . . . M ....

There is another ${ }^{9}$ similar to this, only the figure is under a triple canopy with pinnacles, and has a shield of arms below. Legend: SIGILL' . . A ANCTE TRINITATIS DE . ...

\section{HOUSES OF CISTERCIAN MONKS}

\section{THE ABBEY OF WARDEN}

The abbey of Warden or Saint Mary de Sartis (so called from the 'assarts' or forest clearings which formed its first endowment) was the earliest house of the Cistercian order founded in Bedfordshire. Walter Espec, the founder of Rievaulx, one of the most famous houses of the order in England, had lands in Bedfordshire at Old Warden ${ }^{5}$ and it was he who invited the monks to settle there. Warden was not however a cell to Rievaulx: the primitive Cistercian custom was to send out monks with an abbot at their head to form a new and independent house, as St. Bernard did when he left Cîteaux for Clairvaux, and twelve were considered sufficient for this purpose. The foundation charter of Warden was confirmed by Stephen in the first year of his reign, and witnessed by Thurstan of York and Alexander of Lincoln. ${ }^{8}$ There are several interesting names found amongst the benefactors of this abbey: Henry Braybrook (a very well known name in Bedfordshire) and his wife Christine, ${ }^{7}$ the lady of West Warden in Northamptonshire,

1 Linc. Epis. Reg., Inst. Alnwick, 186d. There seems to have been no prioress after the resignation of Denise; Joan Wyrell was elected, it is stated in her institution, 'on the death of Denise.'

2 Ibid. Inst. Smith, 455.

3 Ibid. 455 d.

4 B.M. Cott. Ch. xi. 36.

s See Domesday Translation. "Willelmus Spech' had 9 hides in Warden and $3 \frac{1}{2}$ virgates in Beeston.

- Exch. Trans. of Charters, 13 Edward I. No. 5 The charter is clearly dated Ir35 (Dugdale, Mon. v. 280 [under Rievaulx] has I 136).

7 Add. MS. 24465 (a modern and not very reliable transcript of a chartulary formerly in the possession of B. H. Bright, Esq., of Lincoln's Inn, from which some extracts are given in Dugdale, Mon. vi. 370), f. 27. with their son Wischard Leydet; ${ }^{10}$ Simon, Hugh and William de Beauchamp, ${ }^{11}$ lords of Eaton, and benefactors also of Bushmead, and Sir John Engayne, ${ }^{12}$ to whom their property passed in the fourteenth century; Malcolm IV. of Scotland ${ }^{13}$ and Roger de Quincy, constable of Scotland. ${ }^{\mathbf{1 4}}$ Like the majority of Cistercian houses, Warden depended mainly for its prosperity upon its pasture lands: among the earliest grants are "twenty acres in Warden, with pasturage for two hundred sheep, and for eight days in shearing time, eight hundred.' ${ }^{1 s}$ It had no churches except the parish church of Old Warden, and even to secure that the abbot had to go through one of the usual Curia Regis suits with the grandchildren of Walter Espec. ${ }^{10}$ His claim in 1225 to the

8 B.M. seals, lviii. 38 .

Ibid. lix. 79.

10 Add. MS. f. 27b. Christine Leydet was an heiress and her son took her name. (From notes kindly furnished by Mr. Round.)

11 Ibid. ff. 37-9.

12 Ibid. f. $28 b$.

13 Ibid. $26 \mathrm{~b}$.

14 Ibid. 35 .

15 From Wischard Leydet and his wife Margery (ibid. f. 27, 27b).

16 Palgrave, Rot. Cur. Reg. (I John), i. 199; and Cur. Reg. R., 2 John, 22 . The abbot complained in IIg9 that the advowson of a moiety of the parish church had been wrested from him, though it had been granted by Walter Espec in pure alms: he produced Walter's charter and also the charter of William de Bussey, heir of Walter. The two daughters of William de Bussey, Cecily and Maud, now claimed the advowson, in the person of their respective husbands, on the ground that the last parson, Nicholas de Trailly, granted it to them. The result of the suit is not given, but the church remained finally with the abbot, to whom the foundation charter certainly assigned it: though it seems that the de Busseys had made the last presentation. 


\section{A HISTORY OF BEDFORDSHIRE}

church of Eyworth was unsuccessful. ${ }^{1}$ The temporalities of the abbey in $1291^{2}$ (as well as in the sixteenth century) lay chiefly in the counties of Huntingdon, Hertford, Northampton, Norfolk and Suffolk, and were valued then at about the same amount as those of Woburn; these two, with Elstow, Dunstable and Newnham, were the richest houses in Bedfordshire.

Abbots of Warden were made commissioners by the pope to inquire into some matters of importance-the election of an abbess at Shaftesbury in $1217,,^{3}$ and the case of the abbot of Tewkesbury who was under suspicion of having forged papal letters in 1 224. King John also authorised the abbot of Warden, with the prior of Dunstable and others, to inquire into an election at St. Edmunds in $1215 .^{5}$ A little later, in $1242,{ }^{6}$ Adam, abbot of Warden, was made Bishop of Connor in Ireland; but he returned to his old monastery to die in $1244 .^{\circ}$

None of the religious of Bedfordshire suffered more severely from the outrages and brutal violence of Fawkes de Bréauté than did the monks of Warden. They dared to dispute with him the ownership of a certain grove, and he set upon them with his retainers, killing one and wounding others; and finally dragged about thirty of them 'through the mud' to his castle at Bedford. But even Fawkes de Bréauté was some-

1 The question here was whether the last parson, Nicholas de 'Trailly, had been presented by William de Bussey's son Bartholomew. The jurors found that Walter Espec had given to his nephew, Nicholas de Trailly (father of the said parson) the advowsons of all his churches south of Humber, and that this Nicholas had given Heyworth church to his son Nicholas 'ad se sustendandum ad scolas.' The advowson, they held, had reverted to the heirs of William de Bussey as Walter Espec's heir. See Bracton's Note Bonk, iii. 107. (This note is kindly furnished by $\mathrm{Mr}$. Round.)

2 Pope Nich. Tax. (Rec. Com.)

3 Cal. of Pap. Letters, i. 49, 62.

- Ibid. i. 95. A mandate of Pope Innocent III. in 1205 shows that even in the days when the rule was strictly kept men sometimes assumed the religious habit for their own convenience. A certain $W$. persuaded his wife to retire to a convent, and he himself took the habit at Warden. Soon afterwards he returned to the world; but when she (who had taken no vow) would have come back to him, he refused to have her, and treated her very badly. The pope however insisted on his taking her back (Cal. of Pap. Letters, i. 21).

6 Rot. Litt. Pat., I6 John, m. I3.

- Matth. Paris, Cbron. Maj. (Rolls Series), iv. 227.

7 Ibid. iv. 390 . times aware that he had gone too far; not long afterwards he submitted to penance in the assembled chapter of the monastery, and gave up the disputed grove. ${ }^{8}$ At the siege of the castle the monks of Warden sustained further losses from injuries done to their woods by the royal forces; but these were carefully made up to them by the king. ${ }^{\circ}$ In 1254 the abbot (perhaps Alexander de Reynes, whose name occurs in $1259,{ }^{10}$ or William de Sheldwick, his predecessor) had the courage to attack another enemy of the public peaceWilliam de Beauchamp, son of the founder of Newnham Priory. As many as seventeen writs were issued by the abbot against him before the justices itinerant at Bedford : and when he contemptuously refused to answer any of these, the case was carried before Richard, Earl of Cornwall, then guardian of the kingdom, and William's barony was seized in consequence. ${ }^{11}$

In 1323 the monks began to rebuild their church, as many other religious of the neighbourhood were doing at the same time, but with more zeal than discretion; for before they had completed their buildings they found themselves at the end of their funds, and had to apply to the bishop for a licence to collect alms. ${ }^{12}$ Although such licences were numerous at this time, ${ }^{13}$ they seem to have been successful, for the church was apparently completed in 1366 , when indulgences were granted by Bishop Gynwell to pilgrims who should visit its various chapels and altars. ${ }^{14}$

Of the history of the house during the fifteenth century it is difficult to find any trace. The internal history is even more obscure. As the Cistercians were exempt from ordinary visitations, there is little allusion to them in the episcopal registers, beyond the occasional notice of the benediction of an abbot. There are just a few indications of the state of this house from time to time. Early in the fourteenth century one of the Templars was placed by Bishop Dalderby at

8 Ann. Mon. (Rolls Series), iii. 52.

- Pat. 8 Hen. III. The care with which all the religious who suffered from the violence of Fawkes de Bréau té, or in any way helped forward the siege, were recompensed is worthy of notice (see the histories of Elstow, Caldwell and Newnham).

10 Add. MS. 24465, f. 27,27 b. His sister Sibyl was lady of Langford.

${ }_{11}$ Ann. Mon. (Rolls Series), iii. Ig2.

12 Linc. Epis. Reg., Memo. Burghersh, 108.

13 Bishop Bek had to issue a warning against those who collected alms without episcopal licence (ibid. Memo. Bek, 53); and yet the registers show that many licences were issued.

${ }_{14}$ Ibid. Memo. Gynwell, 31. 


\section{RELIGIOUS HOUSES}

Warden $^{2}$ to do his penance; the choice would scarcely have been made if the house had been in an unsatisfactory state of discipline. Again, towards the end of the same century, when there seems to be no doubt that the abbey of St. Alban's was in excellent order under Thomas Delamere, and the general faithfulness to rule bore indeed its natural and proper fruit in the desire of a few to "live more perfectly,' one of those who left the house with the abbot's permission to follow a more ascetic ideal went 'to the white monks at Warden.' ${ }^{2}$ This is not proof, but it furnishes at any rate a strong probability that the Cistercian rule was really well kept at Warden at this time, and that the restoration of the monastic buildings had been followed, as it should be, by an increase of fervour within the monastery.

Such notices as we possess of the life of the house just before the dissolution are far from happy ones; at the same time they form an interesting illustration of the effect produced by the royal visitors and their injunctions upon a monastery where 'true religion and sound learning' no longer flourished. The royal visitors, Legh and Ap Rice, ${ }^{3}$ delivered the injunctions at $W$ arden, where the abbot, Henry Emery, was well inclined to the new learning, and had only lately been elected by the influence of the Duke of Norfolk. ${ }^{5}$ It was probably not long after the departure of the visitors that he wrote a letter ${ }^{6}$ to Cromwell, complaining bitterly of the conduct of the brethren, and desiring to resign his office. The injunctions ${ }^{7}$

1 Linc. Epis. Reg., Memo. Dalderby, I94 (I3II). 2 Matth. Paris, Gesta Abbatum (Rolls Series), iii. 416 .

3 Named in the abbot's letter.

- At the Convocation of 1529 , the abbot of Warden was Augustine (London). At his resignation he went to live at Woburn, and seems to have had most sympathy with the old learning (Depositions of the Abbot of Woburn, $L$. and $P$. Hen. VIII. [P.R.O.], xiii. pt. i. 98r).

s Norfolk himself says so in a letter to which allusion must be made presently.

- Wright, Suppression of Monasteries, letter xxi. pp. 53-5.

7 The injunctions are fully described in Canon Dixon's History of the English Church, i. 378-81. Some of them only enforced the ordinary rules of community life: but others, like this one of enclosure, and the order that the divine office should be said and not sung, and that in a low voice, could not have been framed except with a view to making the religious life less attractiveespecially when delivered by such men as Legh and Layton. So also with the order that each rule should be tested by Holy Scripture, which looks which seem to have caused most discontent were those which enjoined 'that no monk or brother of this monastery by any means go forth of the precincts of the same'-a restriction which had never been customary amongst English monks; and that which ordered a lesson of Holy Scripture to be read and expounded daily to the assembled convent. His brethren, said the abbot, told him that he was the cause of their being shut up in this way : as for the lecture, he seldom now attempted it, for they would not come and hear it. Dan Thomas London, whom he had appointed to read it, had substituted the book of Ecius Omelies which were 'all carnal and of a brutal understanding, and entreat of many things clean anenst the determination of the Church of England.' The abbot, discovering this, sent Dan Thomas up to London to Dr. Legh, and made his own brother lecturer instead; but then few or none would attend. Thinking this might be ignorance, he bought every one a grammar book, but only two were willing to be instructed. He could not even enforce obedience. One monk who had been sent out on business and had stopped away a whole night (in an alehouse, the abbot said) refused to be corrected on his return, and said the abbot had no authority to rebuke him; further than this, he stirred up all the rest to such violent opposition that the abbot was afraid for his life and had his door guarded by servants for three nights. Besides these offences against order all but four out of the fifteen monks were in 'total ignorance of their rule' and the statutes of their order ; five were 'common drunkards'; one, the sub-prior, was guilty of immorality with the connivance of others. It was a case where an abbot might well be willing to resign : whether his accusations were true or false, he had fairly proved himself incapable of governing the house. But his evidence loses something of its value in the light of subsequent events. The surrender of the house did not immediately

well enough at first sight. Saint Benedict's rule is largely drawn from Holy Scripture and would stand the test well, but the point to consider was the effect among the religious of such criticism. All real reformers of the religious life have found their best success in appealing to the rule itself and the high ideals of holy founders, and contrasting these with the degenerate practice of later days-never in depreciating the rule, or the institution itself. As an attempt to reform the monasteries such injunctions were foredoomed to failure, and their results are excellently shown at Warden. Wolsey's efforts to reform the Augustinians were planned on very different lines. 


\section{A HISTORY OF BEDFORDSHIRE}

follow; if the letter was written some time during the summer of 1536 , there was a year and a half still before it was decided whether Henry Emery, supported by the Duke of Norfolk, or Thomas London, supported by Sir John Gostwick, was to be the last abbot of Warden. Letters from all of these parties are preserved amongst the State Papers, and give some idea of the order of events, though the story is at best a confusing one.

The first letter, ${ }^{1}$ dated 16 July [1537], is from Henry Emery to the Duke of Norfolk's treasurer. He alludes in it to a plan they had devised, whereby a secular steward should manage the pecuniary affairs of the monastery, and the abbot should have a regular allowance for his living, and also an opportunity of dealing with troublesome monks without incurring suspicion. He adds that Sir John Gostwick had been at the monastery, and at first appeared to be his friend; but now he had joined with his enemies and had a commission to sequester the goods of the house.

The next letter, ${ }^{2}$ dated 5 August, from Norfolk to Cromwell, states that the bearer, Henry Emery, has resigned in favour of Dan Thomas London of the same house; but London, in breach of the agreement between them, had 'procured the repair of Dr. Petre for the taking of his resignation.' Cromwell's favour was requested for Emery.

On 23 August Dan 'Thomas London ${ }^{3}$ wrote to Cromwell to ask if it was really by his authority that the "late deposed abbot, Father Emery,' had returned and demanded the keys back again. Norfolk on 3 October ${ }^{4}$ again wrote to Cromwell to thank him for his kindness to his protégé, who was evidently reinstated, and Sir John Gostwick also wrote, ${ }^{5}$ in a letter undated, to thank him for his kindness to "the poor monk of Warden,' who was probably London. The house was finally surrendered ${ }^{6}$ on 4 December by Henry Emery as abbot, and his convent. It is impossible in reading these letters to avoid the conclusion that all these different

1 L. and P. Hen. VIII. (P.R.O.), xii. 264.

2 Ibid. No. $45^{2}$.

I Ibid. 572 .

4 Ibid. 828.

5 Ibid. 576. This letter is placed by Dr. Gairdner just after the letter from London to Cromwell; but it is of course possible that it does not refer to London. But it seems likely that it does, and that the kindness referred to was the promotion of London to some living, as his name does not appear amongst the signatures on the deed of surrender.

- Ibid. I I7I. persons had been working for their own ends, though it is difficult to see exactly what they were. The total impression left to us of the house in its last days is discreditable and unsatisfactory.

The surrender ${ }^{7}$ is in the conventional form, the same as that of Elstow Abbey ; and contains the signatures of Henry Emery and thirteen monks, who probably all received pensions. The abbot in his first letter already quoted speaks of fifteen monks and refers to another who had lately left the monastery. ${ }^{8}$ In the thirteenth century, as has been seen, the numbers were much larger; the thirty monks whom Fawkes de Bréauté dragged to Bedford Castle were not the whole convent; there may have been as many as fifty or sixty altogether. The prior and cellarer are often alluded to in early documents; and the last abbot mentions an official called the ' custos ordinis.'

The original endowment of the abbey comprised all the assarts of Warden and Southill with the wood between those two vills, with permission to cut what wood was wanted for the use of the monastery, and including pannage and herbage, etc., granted by $W$ alter Espec; also the church of Old Warden ; and part of the wood of Middleho which the abbot of Ramsey granted. These grants were confirmed by Stephen, Henry II. and Richard I., and Henry III. added the right to assart or enclose the wood of Middleho, Hunts. ${ }^{\circ}$ Henry Braybrook and his wife granted lands in Westwarden, their son Wischard Leydet and his wife altogether forty-two acres of pasture. ${ }^{10}$ The income of the house in temporalities and spiritualities in 1291 was about $f_{200 .}{ }^{11}$ The manor of Steppingley came into the possession of the abbey some time in the fourteenth century, ${ }^{12}$ and in 1387 the granges of Ravensholt and Burdon (Cambs) were exchanged for the manor of Beeston. ${ }^{13}$

In 1284 the abbey had only one knight's fee, held of the barony of Bedford, and two

7 Deeds of Surrender (P.R.O.), No. 253.

8 A young monk named Hugh, who had probably been sent out under the new regulations as being under twenty-four years of age.

9 All these are found in the Inspeximus of Edward I. (Exch. Trans. of Charters, No. 5).

10 Add. MS. 24465, ff. 27, 27b, 28. A certain Ralph Fleet and his wife gave the monks of Warden land in front of St. Martin le Grand, London, for a hospice, at a rent of 5 s. a year. Date unknown (Dugdale, Mon. v. 373).

11 Pope Nich. T ax (Rec. Com.)

12 Add. MS. 24465, f. 3 ob.

13 Pat. Io Rich. II. m. 24. 


\section{RELIGIOUS HOUSES}

other small fractions. ${ }^{1}$ In $1302^{2}$ the abbot had one fee at Putnoe in Goldington, and one fee at Renhold grange, both of which still were reckoned as the property of Warden in 1346 and $1428 .^{3}$ There were some small fractions besides at Northill, Southill and Stanford, and Swaffham Prior in Cambridgeshire $;^{5}$ in $1428^{6}$ the abbot had three whole fees-Putnoe, Renhold grange and Warden -one half in Beeston, one half in Northill, threequarters in Southill and small portions in Goldington and Stanford.

The clear value of the property of the abbey in 1535 was reckoned at $£ 38916 s .6 \frac{1}{2} d .^{7}$ The report of the Crown bailiff in 1539 showed the abbey to have been in possession of the manors of Putnoe, Ravensden, Rowney, Odsey, Westwarden and Egton (Northants), and Middleho (Hunts), besides other granges, farms, parcels of land and rents in Bedford, Norfolk, Suffolk, Herts, Hunts, Northants and London, amounting altogether to $\AA_{428} 6$ s. I I $\frac{1}{2} d$., after the deduction of two manors conceded to John Gostwick. ${ }^{8}$

\section{ABBots OF WARDEN}

Simon, ${ }^{9}$ first abbot, occurs about i I 50

Payn, ${ }^{10}$ occurs I 186 and I 195

Warin, ${ }^{11}$ occurs 1199

Roger, ${ }^{12}$ occurs I 200-I

Warin, ${ }^{13}$ occurs $1204-5$

Laurence, ${ }^{14}$ occurs I 209-10

Henry, ${ }^{15}$ died 1216

1 Feudal Aids, i. 6.

2 Ibid. 9, I4, 15.

Ibid. 34,45 .

- Ibid. I9, 27, 28.

5 Ibid. 160.

- Ibid. 4I, 43, 45 .

7 Valor Eccl. (Rec. Com.) Amongst the liabilities of the abbey are reckoned: For the support of seven poor people of both sexes in the almonry or infirmary of the abbey, $\{13$ 13s. $4 d$. For the poor on Maundy Thursday, by the gift of the founder, 35s. $4 d$. For seven poor of each sex twice a year, $335.4 d$.

B Dugdale, Mon. v. 375

- Mentioned in the privilege of Innocent II. (1130-43) (Add. MS. 24465, f. 25); and witnessed the Foundation Charter of Chicksand, about II 5 O.

10 Gorham, History of St Neot's, II. lxxiv. (P. abbot of Warden); and Hunter, Feet of $F .8$ Rich. I. (Rec. Com.), 5.

11 Harl. MS. 3656, f. 60 ; and Add. MS. 24465 , f. $26 \mathrm{~b}$ (duplicates of the same charter).

12 Hunter, Feet of $F .2$ John (Rec. Com.), 27. 13 Ibid. 59.

14 Add. MS. 24465, f. 25

15 'Died at Rochford 1216 , and was buried there' 'From a list of abbots of this house, compiled by F. A. Page-Turner, Esq.)
Roger, ${ }^{16}$ occurs 1223

Adam, ${ }^{17}$ occurs 1234 and 1242 , died 1244

William $^{18}$ de Sheldwick, occurs 1254

Alexander ${ }^{18}$ de Reynes, occurs 1259 and I 262

John, ${ }^{20}$ occurs 1290

Ralf of Harrold, ${ }^{21}$ elected 1304 , died I $_{3}{ }^{1} 3$

Geoffrey of Stanford, ${ }^{22}$ elected 1313

Robert of Odell, ${ }^{23}$ occurs 1324

William, ${ }^{24}$ occurs 133 I and 1346

John, ${ }^{25}$ occurs 1428

John Fraunceys, ${ }^{26}$ elected 1447, occurs I 454

Augustine London, ${ }^{27}$ occurs 1509 and I 529

Henry Emery, ${ }^{28}$ surrendered 1537

The common seal of the abbey is attached to the deed of surrender, ${ }^{29}$ and represents

16 Add. MS. 24465, f. 27.

17 Harl. MS. 3656, f. 62 (A. abbot of Warden), and Matth. Paris, Chron. Majora (Rolls Series), iv. $227,390$.

18 Inn. Mon. (Rolls Series), iii. I92 (footnote).

10 Add. MS. 24465 , ff. 35 b, 62 b.

20 Pat. I8 Edw, I. m, 20.

21 Linc. Epis. Reg., Memo. Dalderby, 255.

22 Ibid. 83

23 From the description of the seal once attached to Harl. Ch. 45, A 27, but now lost, it is probable that the abbot alluded to in this charter was Robert of Odell. It is dated 'the seventeenth year of the king'-probably Edward II. 'Dominus Robertus de Wodhulle' is named as the predecessor of the next abbot in Add. MS. 24465, f. 3 ob.

24 Cal. of Pap. Letters, iii. 222 (1346); Add. MS. 24465 , f. 3 ob (William, abbot of 'Helmesle,' abbot of Warden in the 'twentieth year of King Edward "); and William, abbot of Warden, dated ${ }_{4} \mathrm{Edw}$. III. (earlier in the same chartulary). It is most probable that all these are references to the same person.

${ }_{25}$ Pat. 6 Henry VI. pt. I, m. 29.

${ }^{26}$ Linc. Epis. Reg., Memo. Alnwick, 76; and Reg. Bourchier (from Ely Dioc. Remembrancer, No. 219, p. 179).

${ }_{27}$ Add. MS. 5827 , f. 174 b, gives the dates I 488 and 1509 for Augustine London. The second is from the will of John Fisher, a judge, who was to be buried at Warden; but the earlier date, which comes from Browne Willis without reference, seems almost impossible, as Augustine was certainly still alive in 537 (L. and P. Hen. VIII. xiii [1], 981).

${ }_{28}$ Deed of Surrender (P.R.O.), No. 253. Besides the names mentioned above 'Helyas' occurs without any indication of date in Add. MS. 24465, f. 35; 'W. abbot of Warden' in Harl. MS. 3656 , f. 62 , under 1225 ; ' $H$. abbot of Warden' in r 272, in Harl. MS. 3656, f. 64; and Laurence in Add. MS. 24465 , f. $28 \mathrm{~b}$, dated 30 Edw. I.

29 Deed of Surrender (P.R.O.), 253 ; casts of the same B.M. Iviii. 42, and lix. 65. The seal of Robert de (Wodhul)le, once attached to Harl. Ch. 45, A 


\section{A HISTORY OF BEDFORDSHIRE}

our Lady crowned and seated in a canopied niche, with a sceptre in her left hand, and the holy Child standing on her knee. On the left an abbot with crosier, and another figure on the right, under smaller canopies. Legend : s. COM̄UNE ABBATIS ET CŌVẼTUS DE WARDEN.

The counter-seal shows a shield bearing a crosier between three Warden pears. Legend : SPES MEA IN DEO EST.

\section{THE ABBEY OF WOBURN}

The Cistercian abbey of Woburn was founded in the year I I 45, under the patronage of Hugh de Bolebec. It was a colony sent from the abbey of Fountains in Yorkshire, and its first abbot, Alan, was a monk of that house. ${ }^{2}$ To the manor of Woburn other gifts were soon added: Ralf Pirot of Harlington, William of Flitton, Henry and Stephen of Pulloxhill were amongst the earliest benefactors, whose charters were confirmed by Henry II. before $1162 ;{ }^{3}$ and Ralf Pirot (who was a considerable feudal tenant of Robert d'Albini) himself became a monk in the abbey before his death. ${ }^{4}$ On the manor of Medmenham in Bucks, granted by the daughter of Hugh de Bolebec, another abbey was built in the reign of King John. ${ }^{5}$

The early history of the abbey is obscure. A few stray facts relating to the twelfth century and the early part of the thirteenth may be gathered from the annals of Waverley and Dunstable : as, for instance, that a prior of Woburn was made abbot of Combe in I $83^{\circ}$; and that a long suit went on from about the same date until 12.25 , concerning the advowson of the church of Chesham, between the abbots of Woburn and St. Alban's, and the prior of Dunstable. ${ }^{7}$ The final agreement gave the church to Woburn, the other

27, no longer exists. A small seal of the twelfth century in white wax, representing an abbot with staff and book, encircled by the legend SIGILLVM. ABBATIS - DE - SARTIS ' GARDONI, is mentioned by Gorham, History of St. Neot's, II. lxxiv. as existing among the evidences at Montague House, Pyx $\mathrm{xxv}$.

1 Ann. Mon. (Rolls Series), iv. 231.

2 Dugdale, Mon. v. 301.

3 Ibid. p. 478 . One of the witnesses to the charter is Thomas the Chancellor, whose name limits the date to this year.

\& From a note kindly furnished by Mr. Round.

5 Rot. Chart. 2 John, m. 17, gives permission to build; Assize Roll, I3 John, 480, r. 4 in dorso, speaks of the abbey of Medmenham as built, and as the gift of Isabel de Bolebec (Countess of Oxford).

- Ann. Mon. (Rolls Series), iv. 243.

7 Ibid. iii. 74, 93, 96; Cott. MS. Julius, D iii. f. $123 b$. houses receiving pensions. The abbots of this period, like all other heads of large and well known religious houses, took a considerable part in public affairs, and were made arbiters in local disputes as well as matters of wider interest. In 1202 an abbot of Woburn went to Worcester to inquire into the miracles which were alleged to have taken place at the shrine of St. Wulfstan, and in the next year he was made one of the papal commissioners for the process of canonisation. ${ }^{8}$ In I 2 I 5 another abbot is mentioned in one of the Letters Patent of King John, as having been an intercessor with him for Simon de Pateshull. ${ }^{9}$

In 1234 the house was reduced to great poverty ; Abbot Richard, who had evidently been a bad manager, was removed, and Roger, a monk from Fountains, took his place, while nearly all the monks and lay brethren were dispersed amongst other houses until their own abbey should be able to support them again. ${ }^{10}$ The canons of Dunstable did what they could to help their neighbours in distress, and presented them with a mill; they may also have offered a home for the time to some of the monks. But the abbey was not long in recovering its prosperity; for in 1240 a canon of Dunstable fled there, to escape from taking the oath imposed by Bishop Grossetête. ${ }^{11}$ Fifty years later it was one of the wealthiest houses in the county. ${ }^{12}$ There is no indication of the number of monks at this time ; but as Warden Abbey, with very nearly the same income, held probably forty or fifty, we may conclude that Woburn had accommodation for about as many. At the time of the dissolution there were it would seem less than twenty.

Nothing can be gathered from the Lincoln Registers as to the internal history of the abbey during the fourteenth and fifteenth centuries, as it was exempt, like all Cistercian houses, from visitation. One of the unfortunate Templars was placed there in $1311,{ }^{13}$ from which we may perhaps infer that the house was in good order at that time; otherwise its history is almost a blank sheet, except for a few notices of loans to the king, impropriations of churches, etc., such as are common to all religious houses. But the circumstances which led to the suppression of the house furnish us happily with a very full

8 Ann. Mon. (Rolls Series), iv. 391; Cal. of Pap.

Letters, i. I3.

- Litt. Pat. (Rec. Com.), i. 138.

10 Ann. Mon. (Rolls Series), iii. I40.

11 Ibid. I 57.

12 Pope Nich. Tax. (Rec. Com.)

13 Linc. Epis. Reg., Memo. Dalderby, 194. 


\section{RELIGIOUS HOUSES}

and clear account of its last days. From the depositions taken in May $153^{1}$ it may be gathered that there were at least thirteen monks besides the abbot, all of whom were clerks; there were perhaps others also who were not mentioned by name, and most probably, on the analogy of other houses, a few lay brothers. There seems to have been no prior at the time; the most prominent person after the abbot was the sub-prior ; a 'bowser' or bursar had succeeded the old cellarer; among minor officials the sexton and the ' chaunter' or precentor are named, and one monk was secretary to the abbot. Three 'young gentlemen' and their schoolmaster had been recently boarders in the house; and a former abbot of $W$ arden, for reasons unknown, preferred to spend his last days at Woburn. The abbot, Robert Hobbes, ${ }^{2}$ had much friendly intercourse with the gentry of the neighbourhood, and had been the guest of Sir Francis Bryan at Ampthill ; the Bishop of Lincoln was often a near neighbour when he visited his manor at Woburn; so that, in one way and another, the house was well known, and its deficiencies would have been easily observed. But there can be no doubt whatever that it was in excellent order, and the rule well kept. 'Though the abbot's views as to the religious controversies of the time were shared by few of his brethren, they nevertheless yielded him due obedience to the last. The bursar and the secretary might marvel that he kept a dangerous and reactionary book in the abbey ${ }^{3}$; but the one copied it and the other laid it by, according to their obedience. And on the abbot's side there was all the consideration on which the rule of St. Benedict lays such stress ; the penitential exercises from which he hoped so much were dropped as soon as he saw that they were offered by unwilling hearts and lips, and his rebukes were always mild and fatherly. Cross-examined by the king's commissioners, the monks reported the words of their superior, and gave their own opinions; but only two had really laid information against him, and not even these had any per-

1 L. and P. Hen. VIII. xiii. pt. i. 981. The following account of the abbey and of the trial is entirely taken from this source.

2 In I 533, with the abbots of Fountains and Pipewell, he had been appointed to visit the monastery of Vaudey, and had some difference of opinion with Cromwell as to the best means of reforming the house (L. and $P$. Hen. VIII. vi. 778-9).

3 A treatise collated from the fathers, by Sir John Mylward of Toddington, called De Potestate Petri. sonal complaint to make. ${ }^{4}$ During the whole trial, indeed, no word of accusation is raised against the personal character of any of the monks ; and, so far as we can gather, the divine offices were performed with care and reverence to the last.

The house fell for purely political reasons. The full account of its tragic ending is found in the State Papers, and the story has been told more than once. ${ }^{5}$ But there has been a good deal of confusion about the dates of the various stages of proceeding ${ }^{6}$; it seems therefore best to set down the events quite simply in the order in which they occurred, and to let them speak for themselves.

In $1534-5^{7}$ there was a preliminary visitation by Dr. Petre, who administered the oath of supremacy to the whole convent, ordered the delivery of all papal bulls to himself, and the erasure of the pope's name from all service books. These orders were carried out; but the abbot, as he afterwards confessed, had the bulls copied before he delivered them, and also expressed a wish to some of his monks that the pope's name might be struck out with a pen and not erased. $\mathrm{He}$ did not however press the latter point. ${ }^{8}$

During the three years that followed, the new laws and the great events of the time, political and religious, were much discussed in the monastery, and there was a tendency amongst the monks to fall into two parties. It seems however to have been no more than a tendency; there were only two ${ }^{9}$ who were

4 One monk, John Grace, said that he had once petitioned the abbot for better bread for the convent, and that the answer had been, "If they like not this, let them go farther and fare worse. The world is open now, but I trust that it will not long hold thus.' They are the only ungentle words alleged of the abbot; perhaps something in the circumstances may have rendered them quite necessary.

s Froude, Short Studies on Great Subjects (ed. 1878), i. 43I-4I; followed by Canon Dixon, History of the English Church; Dom Gasquet, Henry VIII. and the English Monasteries, ii. I9I202.

B All these assume that the depositions were taken in $\mathbf{1 5 3 6}$, whereas they are dated clearly II and 12 May 30 Henry VIII. The chroniclers Speed and Stow both put the abbot's name in the list of those who were executed after the Pilgrimage of Grace, with which he had no connection whatever. Burnet improves upon this by saying that he joined the rebels and was taken in arms amongst them.

7 Alluded to in the abbot's first deposition.

8 From the deposition of Dan Croxton.

9 Dan Robert Salford and Dan Croxton; the former had sent up a letter to Cromwell by Sir 


\section{A HISTORY OF BEDFORDSHIRE}

decidedly in favour of the new learning, all for the king and the council, and two or three also ${ }^{1}$ (including the sub-prior) who were with the abbot in holding to the old way. The rest had no strong opinions at all, and the discussions in the shaving house and elsewhere, though free, were apparently not violent. At the death of More and Fisher, and again at the dissolution of the smaller monasteries, the abbot imposed certain penitential exercises ${ }^{2}$ upon the whole convent, which were performed, though not with good will; when murmuring arose they ceased.

Meanwhile the abbot was growing more and more troubled as he saw the course events were taking; more and more consciencestricken at his own cowardice in accepting the oath of supremacy, which better and braver men had refused. He did not hide his troubles from his brethren; but they were for the most part irresponsive to his appeals. He confided to the sub-prior that his conscience grudged him daily for taking the oath; he said to more than one of his neighbours and friends that he felt it was their own shameful lives that were bringing so many troubles upon the religious. ${ }^{3}$ In Lent he fell ill of the 'stranguilion,' and in his extreme bodily pain he said that he wished he had died with More and Fisher and the other good men who would not take the oath. And when his mind wandered a little in his illness the words that came to his lips most naturally were quotations from the fathers which seemed to prove the pope's supremacy. Yet, charac-

William Sherborne, and had advised Croxton to report the words of another monk to the visitors.

1 Dan Laurence Blunham, Dan Richard Hopworth.

2 They were bidden to say the Psalm Deus venerunt gentes, with the versicle Exurgat Deus, every Friday after the Litany, prostrate before the altar. Later they were to sing Salvator mundi, salva nos omnes at every mass.

a There is much in the abbot's words and actions at this time that recalls the record of the last days of the London Charterhouse; and yet he could scarcely have heard that story in much detail. It is also significant-though indeed it is only what might have been expected-that the best of the religious at that time, those who were most faithful and devoted to their rule, were also the most ready to confess that it was their 'shameful lives' which brought such trouble on the church.

4. 'Tu quis es ? Primatu Abel, gubernatione Noe, auctoritate Moyses, judicatu Samuel, potestate Petrus, unctione Christus. Aliz ecclesiæ habent supra se pastores, tu pastor pastorum es.' From a letter of St. Bernard to Pope Eugenius III. The sub-prior said the abbot was 'somewhat acrazed' at this time. teristically, at Easter he put the sub-prior on his obedience 'to bid the beads' before the sermon for the king as supreme head of the Church.

The death he desired was indeed nearer than he thought. It was during Lent that one of the assistant priests of Woburn chapel (which served as the parish church) came upon some bulls which had not been delivered up to Dr. Petre, and went straight up to London with them. This man had been engaged by the abbot in the previous summer ${ }^{5}$; he was originally a friar, ${ }^{6}$ who had been dispensed from his obedience by the pope, and was now a violent partisan of the new learning; he had already been rebuked by the abbot for his railing against the pope, and against images. With the bulls he took a letter from Dan Robert Salford, one of the monks who shared his views. On his return he told the abbot what his errand had been, and was dismissed in consequence; but the precaution came too late. Early in May Dr. Legh and John Williams arrived, bringing grave charges against the abbot and convent; on the 8th the house was surrendered. ${ }^{7}$ John Williams, who had taken the deed of surrender up to London, ${ }^{8}$ together with a letter from the abbot (in which he and his brethren protested their innocence and cast themselves on the king's mercy), ${ }^{8}$ returned again at once accompanied by Dr. Petre; and on II and I 2 May depositions were taken, and with articles of accusation appended were submitted to the council. ${ }^{10}$

Four monks were examined besides the abbot and sub-prior; also Sir John Mylward, warden of the hospital at Toddington, and

- From his own deposition. As to the bulls, the abbot said it was merely by an oversight of the bursar that they were not delivered up. This is probably true; as he was willing to confess everything else, there seems no reason why he should deny this.

- From the petition of the sub-prior ( $L$. and $P$. Hen. VIII. x. I 239 [1536]).

7 Ibid. xiii. pt. I, 955 .

8 Ibid.

- This letter is dated 1536 by Wright, Suppression of Monasteries, P. I 45 , but allusion in it to Legh and Williams and the accusations of treason make it clear that its proper place is here, as it is placed in the L. and P. Hen. VIII. xiii. pt. I, No. 956.

10 The articles appended to the depositions by the commissioners included the names of Sir Francis Bryan, his ' doctor of physicke,' Mylward of Toddington, and two doctors (one of Cambridge), besides the abbot, the bursar, and Dan Hopworth. A very different selection was finally made. 


\section{RELIGIOUS HOUSES}

Sir William Sherborne, chaplain of Woburn, to whom allusion has already been made. The substance of the depositions has been already given; they recounted the events of the last few years. The abbot practically confessed all that he was accused of ; he had failed to preach the king's supremacy on divers occasions, and openly expressed his opinions on the subject to a great many people. The sub-prior had also failed to preach the king's supremacy, and had prayed publicly for the pope when he went up to Oxford to take his degree of B.D. The depositions of Dan Robert Salford, who had sent the letter up to Cromwell, and of Sir William Sherborne, who had carried it, implicated others within and outside of the monastery.

Salford testified how the abbot had summoned them all to chapter and exhorted them not to forsake their house or habit, and had advised him personally, in confession, not to complain to the royal visitors against those of his brethren who had railed on the council and spoken against their oath. He gave it as his own opinion that six of these, besides the sub-prior, were papists. But the name which most frequently occurs in all the depositions is that of Dan Laurence Blunham, the sexton, who had evidently made open boast that he had never taken the oath, and never would. It was natural that when the final selection of names was made he should appear beside the abbot and sub-prior as one of the chief offenders. These three were tried at Bedford at the summer sessions, and condemned to suffer the ordinary penalties of treason. ${ }^{1}$ They were probably executed at the end of June $^{2}$; tradition says that an old oak tree outside the abbey gates served them for a gallows. ${ }^{3}$ The whole course of proceeding, from the accusation to the execution, only occupied two or three months, instead of being spread over two or three years, as has been supposed. It was an ordinary case of verbal treason under the law of 1535 , and is

1 Controlment Roll (P.R.O.), 30 Henry VIII. Trinity term, $\mathrm{m}$. 16 dors. contains the record of the attainder of Robert Hobbes, abbot of Woburn; Ralph Barnes alias Woburn, and Laurence Blunham alias Peck, monks of the same house. The margin of the roll had Bedford quite clearly beside this entry, so that the trial could not well have been at Lincoln.

2 An estimate of the goods of the "late attainted" monastery of Woburn was made on 29 June, deducting expenses of maintaining the house till 28 June.

${ }_{3}$ Dom Gasquet, Henry VIII. and the English Monasteries, P. 202.

I parallel to the case of Friar Forrest who was hanged and burned about a month earlier; but it is an even better illustration of the extreme rigour of that law. The Carthusians and Forrest, who finally refused to take the oath, after having it several times tendered to them, might perhaps be looked upon as dangerous men, and enemies to the commonwealth; but there was little enough to fear from the monks of Woburn. The abbot in his final deposition pleaded that he did all he had done 'out of a scrupulous conscience that he then had, considering the long continuance of the Bishop of Rome in that trade being, and the sudden mutation thereof'; he was ready to renounce some of his opinions ${ }^{4}$ at once, and begged the king's mercy, and Cromwell's intercession. ${ }^{5}$ On $27 \mathrm{May}^{6}$ Laurence Blunham sent in a similar plea for mercy, on the ground of his 'foolish scrupulous mind'; he had indeed escaped taking the oath formally, for he did not kiss the book, being passed over in the crowd; but now he was put out of all doubt of the truth 'by the instruction of my Lord Privy Seal.' In June ${ }^{7}$ the sub-prior sent in his petition for mercy, also announcing himself converted, by the reading of the Obedience of a Cbristian Man and the Glass of Truth. But verbal treason, once committed, could not be undone.

It is a pitiful story from any point of view. Robert Hobbes and his monks were no heroes: they were clear enough in their convictions and could admire the steadfastness of More and Fisher; but when it came to the test they found it easier to admire than to imitate. Yet they were good religious; the character of the abbot in particular is a very attractive one, ${ }^{8}$ and if he had fallen upon happier times

4 e.g. the invalidity of holy orders conferred since the breach with Rome.

5 This final deposition of the abbot is not with the others, but in Cott. MS. Cleop. E iv. f. 89 ; but it refers in detail to all the points of accusation contained in the other depositions, and is placed at the end of them in the L. and P. Hen.VIII.

- L. and P. Hen.VIII. xiii. pt. 1, No. 1086.

7 Ibid. $x$. I239. This petition is clearly out of its place in 1536 . It is only dated fune; but it alludes to a conversation with William Sherborne, chaplain of Woburn, who said in May I538 that he only came to assist at the chapel "last midsummer.'

8 We may note his constant exhortations of his brethren to unity and charity, those keynotes of the religious life; his gentleness and reasonableness in dealing with such a man as William Sherborne ('Sir William, I hear that you are a great railer. I pray you teach my cure the Scripture of God, 


\section{A HISTORY OF BEDFORDSHIRE}

it would have secured to him the love of all his brethren and an honourable memory.

The abbey was endowed by the founder with the manor of Woburn, and other parcels of land in the neighbourhood were added by various benefactors before $1162 .^{1}$ The manor of Medmenham (Bucks), for building another abbey, was confirmed to the abbot in $1200-\mathrm{I}^{2}$; and in 1202 Hugh Malet granted the manors of Swanbourne and Mursley (Bucks) in pure and perpetual alms, with the church of Swanbourn, to be held of him and his heirs for ever. $^{3}$ The church of Chesham was in the gift of the abbey in the twelfth century, ${ }^{4}$ and the churches of Birchmore, Whitchurch and Soulbury at a later date. In $129 I^{5}$ the temporalities of Woburn amounted to $f_{12}$ I IOS. $8 \frac{1}{4} d$., and the spiritualities may have added another $£ 50$. A taxation of the property of the abbey taken in $133^{8}$ valued it at $f_{1} 3^{2}$ I 9s. $9 \frac{1}{4} d .^{6}$

The abbots held in $1302^{7}$ one knight's fee in Eversholt, and smaller fractions in Potsgrave, Hare, Holcutt and Harlington; in Buckinghamshire ${ }^{8}$ one fee in Swanbourne and another in Stewkley, and a part of Drayton. In $1316^{9}$ they held half of each of the three vills of Milton Bryan, Eversholt and Birchmore, with Woburn; in 1346 they held half a fee in Woburn, Milton Bryan and Pulloxhill $^{10}$; in 1428 one fee in Eversholt and another in Holcutt, with one half in Milton Bryant, Hare and Pulloxhill ${ }^{11}$; the Buckinghamshire fees remaining much the same, except the one in Stewkley which had passed to the abbess of Fontevraud. The valuation in 1535 of the whole property of the abbey was $\AA_{39}$ I 18 s. 2 d. clear. ${ }^{18}$ The movable goods of the monastery, including plate, money, jewels, church ornaments, household

and that may be to their edification. The Pope is either a good man or an ill; to the Lord he standeth or falleth. The office of a bishop is honourable. What edifying is this to rail ? Let him alone.'); his care to avoid implicating his friend, Sir Francis Bryan; his thought for his own nearest relations when he saw that he was in danger of death.

1 Foundation Charter, Dugdale, Mon. v. 478.

2 Rot. Chart. (Rec. Com.), i. pt. I, 83 ; Rot. de Oblatis et Finibus (Rec. Com.), go. Woburn paid 40 marks, as well as Io marks for two palfreys as the price of this confirmation.

${ }^{3}$ Feet of $F$. (Rec. Com.), I98.

4 Cott. MS. Julius, D iii. f. I23b and elsewhere.

5 Pope Nich. Tax. (Rec. Com.)

- Pat. I I Edw. III. pt. 2, m. 8.

7 Feud. Aids, i. 8.

8 Ibid. 82. 9 Ibid. 2I. 10 Ibid. 25, 33.

11 Ibid. 43, 46, I26, 127, I28, 129.

12 Valor Eccl. (Rec. Com.) stuff, corn, cattle, and debts owing to the house were valued in June $153^{8}$ at $£ 509$ 1 7 s. 4d.; and at the survey of the lands taken at the same time a total of $f 45014 \mathrm{~s} .3 \frac{1}{8} \mathrm{~d}$. in temporalities and $£_{7} 8 \mathrm{I} 4 \mathrm{~s}$. od. in spiritualities was obtained. ${ }^{13}$ The report of the Crown bailiff four years later gave a total of $£ 427$ 8s. $3^{d}$., including the rectories of Birchmore with Woburn chapel, Soulbury, Chesham and Whitchurch in Buckinghamshire, and lands in Beds, Bucks, Oxon, Herts, Northants and London, and the manors of Eversholt, Pulloxhill, Grenfield, Westoning, Potsgrave and Swanbourne. ${ }^{14}$

\section{ABbots of Woburn}

Alan, ${ }^{15}$ first abbot, 1 I 45

William, ${ }^{16}$ occurs circa 1 I 80

Peter $^{17}$ " 1202, died 1204

Nicholas $^{18}$ " 1208

Richard" " 1917 , I 228, deposed 1234

Roger ${ }^{20}$ of Fountains, elected 1234

Adam of Luton, ${ }^{21}$ died 1247

Nicholas, ${ }^{22}$ elected 1247

Roger, ${ }^{23}$ died I 28 I

Hugh of Soulbury, ${ }^{23}$ elected I 28 I

William, ${ }^{24}$ occurs 1286

Robert de Stokes, ${ }^{25}$ elected 1297

Henry, ${ }^{26}$ elected 1312

Thomas de Thornton, ${ }^{27}$ elected I 336

William Manepeny, ${ }^{28}$ ” 1396

William Hawburth, ${ }^{29}$ " 1436

John of Ashby, ${ }^{30} \quad$ " 1458

Robert Charlet, ${ }^{31} \quad$ " 1463

Robert Hall, ${ }^{32}$ " 1483

Thomas Hogeson, ${ }^{33}$ occurs 1499

Robert Hobbes $^{34} \quad$ " 1529

No seal of this abbey remains so far as is known.

${ }^{13} L$. and P. Hen. VIII. xiii. (1), I280. Dated 29 June, 30 Henry VIII.

14 Dugdale, Mon.v. 481; and MS. summary of Ministers' Accounts, P.R.O.

16 Dugdale, Mon. v. 301.

16 Add. MS. 5827, I76b (Cole's transcript of MS. notes of Browne Willis).

17 Feet of F. (Rec. Com.), I98 ; Add. MS. 5827 , $176 \mathrm{~b}$ (ref. to Gale, i. 182).

18 Add. MS. 5827, I76b.

18 Ann.Mon. (Rolls Series), iii. 108.

20 Ibid. 140. 21 Ibid. 174.22 Ibid.

${ }_{23}$ Ibid. p. $287 . \quad 24$ Pat. I4 Edw. I. m. 8.

${ }_{25}$ Linc. Epis. Reg., Memo. Sutton, 182.

26 Ibid. Memo. Dalderby, 241.

27 Ibid. Memo. Burghersh, 344 .

28 Ibid. Memo. Buckingham, 436.

${ }_{29}$ Ibid. Memo. Alnwick, 31 .

${ }_{30}$ Ibid. Inst. Chedworth, 46d.

31 Ibid. 32 Ibid. Inst. Russell.

33 Ibid. Inst. Smith.

${ }^{34}$ L. and P. Hen. VIII. iv. 6047. 


\section{RELIGIOUS HOUSES}

\section{HOUSES OF AUSTIN CANONS}

\section{THE PRIORY OF DUNSTABLE}

The Augustinian priory of Dunstable was founded by King Henry I. about the year I I32, and endowed by him at the same time with the lordship of the manor and town in which it stood. 1 Tradition says that the same king was also founder of the town, and had caused the forest to be cleared away from the point where Watling and Icknield Streets crossed each other, on account of the robbers who infested the highway. ${ }^{2}$ However this may be, he certainly granted to the priory all such liberties and rights in the town of Dunstable as he held in his own demesne lands. His charter was confirmed by Henry II., ${ }^{3}$ who also granted to the prior and convent the lordship of Houghton Regis; and before the reign of Richard I. a great many of the churches of the neighbourhood had been granted to the priory by different benefactors, ${ }^{4}$ as many as thirteen, besides the chapel of

1 Foundation Charter, contained in the Inspeximus of Richard II. (Harl. MS. 1885, f. IO2). The date is fixed between II3I and II 35 by the name of Robert, Bishop of Hereford, among the witnesses: he succeeded 1131 (Flor. of Worc. [Engl. Hist. Soc.], ii. 92).

3 Dugdale, Mon. vi. 238.

3 Harl. MS. I885, f. 102. The churches given below are all contained in this charter : those of SS. Peter, Mary and Cuthbert, Bedford, are there stated to be the gift of Henry I.; St. Cuthbert's in another place (ibid. f. 73b) is stated to be the gift of Abel, son of Roland. The confirmations of nearly all these churches by different twelfthcentury bishops and archdeacons are contained in ff. 20-4 of the same chartulary.

4 The churches of St. Peter (Dunstable), St. Mary and St. Cuthbert in Bedford, in the time of Henry I. ; the church of Cublington, Bucks, of the gift of Hugh, son of Jocelyn; Segenhoe and Totternhoe, with Higham Ferrers and half the church of Pattishall, Northants, by Simon de Wahull and his son Walter ; North Marston, Bucks, of the gift of Thurstan of Hunderigg; Flitwick, Husborne Crawley, and the chapel of Ruxox, of the gift of Philip de Saunvill; Chalgrave, of the gift of Roger Loring, with the consent of Simon de Beauchamp; Aspley Guise (finally assigned to Newnham Priory), of the gift of Roger de Salford; Pulloxhill and Harlington, of the gift of John and William Pirot; Steppingley, of the gift of Richard of Steppingley; Studham, of the gift of Alexander of Studham; and half the church of Chesham, Bucks, of the gift of the abbot of Woburn. Henry II.'s own gift of the lordship of Houghton Regis is alluded to in Rot. Chart. (Rec. Com.), 5 John, m. 24.
Ruxox, in the county of Bedford, with Cublington, North Marston and half Chesham, Bucks, and Higham Ferrers with half Pattishall, Northants. Several of these gifts were disputed before the century was out, ${ }^{5}$ but most of them were retained by the priory throughout its existence.

Bernard, the first prior of the house, was closely associated with the introduction of Austin Canons into England, for he had accompanied his brother Norman (afterwards prior of St. Botolph's, Colchester, and then of Holy Trinity, London) to Chartres and Beauvais, in Anselm's time, to learn the rule of St. Augustine, with a view to introduce it into England. ${ }^{\circ}$

At the beginning of the thirteenth century, in the year 1202, Richard de Morins, a canon of Merton, ${ }^{7}$ became prior of Dunstable, and with his election the priory entered upon the most interesting period of its history. It was probably he who began the annals of the house, and perhaps wrote part of them with his own hand ${ }^{8}$; he was evidently a man of very varied interests, and considerable capacity for affairs. Before he had been prior a year he was dispatched on the king's business to $R_{0} e^{9}$; and it was probably owing to his influence that the lordship of Houghton Regis, with other gifts, were confirmed to the priory in $\mathrm{I} 203 .{ }^{10}$ So far as we know, he only went abroad once again, when he attended the Lateran council of 1215 , and remained afterwards in Paris for a year to study at the University ; ${ }^{11}$ but the annals show that he maintained all through his life a keen interest in the affairs of Europe and the East. In $1206^{12}$ he was made a visitor for all the religious

5 Harl. MS. x885, ff. 20-4. Hunter, Feet of F. 5,47 .

- See 'The Origin of St. Botolph's Priory, Colchester,' by J. H. Round (from whom this reference was obtained), in Essex Arch. Trans. (new ser.), iii. 270.

7 He was not made a priest until the Embertide following his election, and said his first mass on St. Michael's Day (Ann. Mon. [Rolls Series], iii. 28).

- Luard, Introduction to Ann. Mon. (Rolls Series), iii. There are a good many references to events at Merton Priory, e.g. Ann. Mon. iii. 44, I 28 (notices of priors of Merton entering stricter orders), etc.

9 Ibid. 28 .

10 Ibid. ; Rot. Cbart. (Rec. Com.), i. pt. I, Io7.

11 Ann. Mon. (Rolls Series), iii. 46.

12 Ibid. 29. 


\section{A HISTORY OF BEDFORDSHIRE}

houses of the diocese of Lincoln (except those of the exempt orders), by the authority of the papal legate; in 1212 he was appointed by the pope to preach the cross ${ }^{1}$ in Bedfordshire, Hertfordshire and Huntingdonshire, and in the same year was commissioned to make an estimate of the losses suffered by the clergy and the religious in the diocese through the exactions of John. ${ }^{2}$ In $1223^{3}$ and $1228^{4}$ he was made visitor to his own order, first in the province of York, and afterwards in the dioceses of Lincoln and Coventry; and last of all, in $1239,{ }^{5}$ when he must have been quite an old man, he helped to draw up and submit to the pope an account of the difficulties between the Archbishop of Canterbury and his suffragans on the subject of visitation. During his term of office, in the year $1219,{ }^{6}$ he secured the right of holding a court at Dunstable for all pleas of the Crown, and of sitting beside the justices itinerant at their visits to the town : a privilege which brought him into less happy relations with the townsmen, and may have helped to hasten their revolt against his authority in $1228 .^{7} \mathrm{He}$ also successfully established the right of his house to Harlington church in $1223^{8}$ The priory was twice visited by King Henry III. during the time of Richard de Morins: once after the siege of Bedford Castle, ${ }^{\circ}$ and again in the midst of the troubles connected with the burgesses, whom he attempted to pacify, at the prior's earnest request. ${ }^{10}$

1 Ann. Mon. (Rolls Series), iii. 40. They placed collecting boxes in all the churches.

2 Ibid. 38.

3 Ibid. 80; the abbot of Darley being his coadjutor.

1 Ibid. II ; with the prior of Newnham.

5 Ibid. 149.

6 Ibid. 54 .

7 Ibid. 105-22. The details of the quarrel belong to the general ecclesiastical and political histories of the county.

\& Ibid. 80, 85. Richard Pirot, a feudal tenant of the Albinis of Cainhoe, claimed it against him on an assize of darrein presentment. It was common ground to both parties that Richard's grandfather, Ralf Pirot, had given the church to Dunstable Priory temp. Henry II., but Richard claimed that this had been done after Ralf had divested himself of his lands and become a monk at Woburn, which the prior denied (Bracton's Note Book, iii. 454). The prior was successful (ibid. 80). His claim to Aspley Guise is dealt with under Newnham Priory: the details of both suits were kindly supplied by Mr. Round.

\& Henry III. was at Dunstable on 20 August 1224 (Pat. 8 Hen. III. m. 4).

10 Ann. Mon. (Rolls Series), iii. IIg. It is probable that Stephen visited the priory near the end
In spite of the losses under King John and the difficulties with the burgesses, the priory seems to have enjoyed greater prosperity at this time than at any later period of which we have a clear account. In 12 I 3 the conventual church was dedicated by Bishop Hugh de Wells, a great concourse of earls and barons, abbots and priors, assisting at the ceremony. ${ }^{11}$ The lordship of Houghton Regis, though lost for a while in 1212 , was recovered in $1226^{12}$; and the gift of the church of Bradbourne in the Peak, ${ }^{13}$ with its chapels and lands, ${ }^{14}$ provided a maintenance for three canons, ${ }^{15}$ and formed a kind of cell to the priory, besides increasing its income. The death of Richard de Morins in $1242^{18}$ was followed immediately by heavy losses. In 1243 , 800 of the sheep belonging to the priory in the Peak district died, ${ }^{17}$ and a succession of bad seasons led to great scarcity; Henry de Bilenda, the cellarer, upon whom so much depended, was incapable or untrustworthy, and in 1249 fled to the Cistercians at Merivale, rather than render an account of his stewardship. ${ }^{18}$ By 1255 the canons not only had no corn to sell, but not enough for themselves ${ }^{19}$ they had to buy all their food at great expense, for two years after this ; ${ }^{20}$ so that the Friars Preachers, when they arrived in $1259,{ }^{21}$ were even less welcome than they would have been at any ordinary time. When Simon of Eaton became prior in 1262, he found the house 400 marks in debt, and all the wool of the year already sold. ${ }^{22}$

But in spite of the pressure of debt and poverty, which was not diminished during his term of office, the prior was as much interested as his predecessors had been in the course of public events. Like most of the clergy and religious of the period, he was in sympathy with Simon de Montfort, whom he looked upon as the champion of the Church;

of his reign, signing there the confirmation of Iuton church to St. Albans (Cott. MS. Otho, D iii. f. II 8 b).

11 Ann. Mon. (Rolls Series), iii. 42.

12 Ibid. 29, roo.

13 By Geoffrey de Cauceys (ibid. 29).

14 Half the manor of Bradbourne with the chapels of Ballidon and Tissington went with the church (Abbrev. Plac. [Rec. Com.], 255).

15 Ann. Mon. (Roils Series), iii. 149.

16 Ibid. 158.

17 Ibid. 163 .

18 Ibid. 178.

19 Ibid. 199.

20 Ibid. 205-10.

21 Ibid. 213.

22 Ibid. 221. 


\section{RELIGIOUS HOUSES}

and in 1263, when the earl visited Dunstable, the prior went out to meet him, and admitted him to the fraternity of the house. ${ }^{1}$ In 1265 a council was held at Dunstable to consider the possibility of peace with the defeated barons, and the king and queen visited the house in the course of the year ${ }^{2}$; but though Simon de Montfort had been there quite recently, and the sympathy of the prior with his cause could not have been altogether a secret one, no fine was imposed upon the priory on that account.

In 1274 a long and expensive suit was begun between the prior and convent of Dunstable and Eudo la Zouche, ${ }^{3}$ who had become lord of Houghton and Eaton Bray by his marriage with Millicent de Cantelow. Eudo refused to recognise the rights of the prior (established not only by charter, but by long custom) to a gallows and prison in Houghton; he released one of his men from the prison and overthrew the gallows. Under the next prior, William le Breton, the gallows was restored; but Eudo still refused to recognise the prison as the prior's right, and presently erected a gallows of his own. The dispute went on for some years, and, after the death of Eudo, was continued by his wife Millicent until the year 1289 , when it was finally decided in favour of the prior." The poverty and difficulties of the house went on increasing, although great efforts were made, after the deposition of William le Breton and other officers of the monastery in $1279,^{5}$ to curtail expenses and get in ready money for the payment of debts. Corrodies and chantries were granted to several persons, manors and churches were let out to farm, and in the year 1294 the usual allowance for one canon was made to serve for two. ${ }^{6}$

1 Ann. Mon. (Rolls Series), iii. 226. Richard de Morins had been an admirer of the elder Simon de Montfort, whom he calls 'genere nobilis sed fidei fervore nobilior; in armorum exercitio nobilissimus,' and adds that the son was 'debilior patre' (ibid. 52).

2 Ibid. 240.

3 Ibid. 26I-3.

4 Ibid. 343-53. This later dispute turned on the rights of the common of Houghton, and Millicent appealed to Domesday, saying her ancestors held the land of the king by barony. (It is assumed that this Millicent is the same as the wife of Eudo la Zouche.)

5 Ibid. 283.

- Ibid. 387. The amount of white bread used in the honse, and the expenses of the almonry and guesthouse were all lessened at the same time. Shortly before this, in the year I 290, the chronicler records how the body of Queen Eleanor passed
It was just at this time that the king was asking for subsidies for his Welsh war. By an accumulation of misfortune, in the same winter the outer walls of the priory had collapsed in the wet weather, and their hayricks had been destroyed by fire; ${ }^{7}$ and the tithes due to the Hospitallers from North Marston church were in such long arrears that a new arrangement had to be made to pay them off. ${ }^{8}$ In 1295 the house at Bradbourne was so poor that all the wool produced there had to be granted to the support of the three brethren who served the church and chapels. ${ }^{\circ}$ The later pages of the annals are a long story of poverty and struggle to get clear of debt ; and the continuous narrative ends dismally enough with the account of the expenses of the installation of John of Cheddington, which amounted (with the addition of the debts of the previous prior) to $f_{242} 8$ s. $4 d .^{10}$ Of the fourteenth century there are only a few scanty notices, the only events told at any length being those connected with the peasants' revolt in 1381 , when the prior, Thomas Marshall, appears by his courage and moderation to have saved his own house from serious loss, and his burghers from punishment. ${ }^{11}$ In 1349 an attempt was made by Thomas de Beauchamp, Earl of Warwick, and marshal of the kingdom, to prove that the prior held his lands by barony; but the jury which was summoned at that time declared upon oath that the lands had always been held in pure and perpetual alms. ${ }^{12}$ King Henry VI. visited Dunstable in $1459{ }^{13}$ but there is no record of his relations with the priory; its history during the fifteenth century is not recorded in any way. But in the sixteenth century it was again connected with an important historical event, when on 23 May 1533, in the Lady Chapel of the conventual church at Dunstable, Archbishop Cranmer pronounced

through Dunstable on the way to London, and rested a night in the church: at the erection of the memorial cross the prior assisted, asperging with holy water (ibid. 362).

7 Ibid. 388.

8 Ibid. 394. The arrears amounted to 210 marks. By the Concordia made at Westminster 4 marks a year were to be paid in future and all arrears forgiven except 12 marks. The arrangement with the Hospitallers for this church dated from II85 (Harl. I885, f. 24; Nero, E vi. f. 236).

o Ann. Mon. (Rolls Series), 4 or.

10 Ibid. 409.

11 Ibid. 4 I8.

12 Ibid. 412.

13 Ibid. 420. 


\section{A HISTORY OF BEDFORDSHIRE}

the marriage between Henry VIII. and Catherine of Aragon to be null and void. ${ }^{1}$ In 1535 the prior, Gervase Markham, with twelve canons, signed the acknowledgment of the Royal Supremacy, ${ }^{2}$ and on 20 January I 540-1, he surrendered his house to the king and received a pension of $£ 600^{3}$

There were only thirteen at this time besides the prior; eleven canons and two lay brothers; in the early days there were probably more, though never a very large number. Between the years 1223 and 1275 only twenty-five admissions to the novitiate are recorded, and thirteen deaths; but the entries were perhaps not always made with equal care, and the entrance of lay brothers was not noticed at all. ${ }^{5}$ Besides the religious there were a number of other inmates of the priory; a ' new house for the carpenters and wheelwrights within the court' was built in $1250^{\circ}$; there was accommodation also for the chaplains of the monastery, and for boarders who had bought corrodies, as well as pensioners in the almonry. The porter of the great gate was sometimes a secular, ${ }^{7}$ unlike the custom of Benedictine houses. ${ }^{8}$

1 Rymer, Fodera, vi. (2), I8z-3.

2 Ibid. 202.

3 L. and P. Hen.VIII. xv. I032 (333, 350b).

4 In Ann. Mon. (Rolls Series), iii.

- They are mentioned however often in the annals : one was killed in defence of the rights of his brethren by the men of the prior of $\mathrm{La}$ Grave (ibid. 2I3), and one of them, "Brother John the Carpenter,' once invented a new mill, 'novæ structuræ et exterius inauditæ,' which was to be drawn by only one horse; but when they began to use it, four strong horses could scarce move it! (ibid. 402).

- Ibid. 183. Several other handicrafts were practised by the canons and their dependants. In I255 a canon made three windows for Steppingley church (ibid. 197 ), and in $\mathbf{1 2 8 3}$ it is stated 'we made a clock over the pulpit' (ibid. 296).

7 The porter in 1287 must have been a secular, as he was asked by the canons to buy a house and prevent the Dominicans extending their boundaries (ibid. 338), and had an anniversary granted him after his death in I29I (ibid. 37I).

* The account of a disturbance caused by the quartering of some of the king's falconers on the priory in 1276 gives a curious picture of the house in the thirteenth century. The king was staying in the neighbourhood, and his men were quartered partly on the townsmen of Dunstable and partly on the priory. In the evening the party from the priory went out after supper and joined their fellows in the town, and after wandering about in a riotous fashion, they returned to the priory. The monks, who had all retired for the night, were awakened suddenly in the dormitory by a clamour in the court. The falconers had just burst in (probably half intoxicated) after beating
There can be no doubt of the good order of the house during the time of Richard de Morins; he would scarcely have been chosen twice to visit other houses unless he had ruled his own with care and diligence. During his forty years of office canons of Dunstable were at least five times elected priors to other monasteries of the order-at Caldwell, St. Frideswide's, Ashby and Coldnorton. ' Bishop Grossetête visited the house once in 1236 , not so much to inquire into the daily life of the priory as to investigate its title to several appropriate churches; but he exacted an oath on this occasion from all the canons individually, and one of them fled to Woburn rather than submit to it. ${ }^{10}$ The bishop came again in 1248 , while Geoffrey of Barton was prior; when the cellarer, accused by many, fled before his coming to Merivale $^{11}$; but he does not seem to have found fault with the convent in general, and his next visit in 1250 was for purposes of his own. ${ }^{12}$ Archbishop Boniface came in 1253 , but made no complaint. ${ }^{13}$ In 1274 Bishop Gravesend sent a canon of Lincoln to visit Dunstable, who left his corrections in writing ${ }^{14}$; and in Advent of the same year he made a personal visitation. ${ }^{15}$ In November of 1279 Bishop Sutton came and discharged his office 'strictly and without respect of persons.' The sub-prior and certain others were removed from their charge, and forbidden to hold office in future, and certain 'less useful members' of the household expelled; in May of the following year he deposed the prior, William le Breton, from all pastoral care. ${ }^{16}$ It seems most likely that these depositions were on account of mismanagement rather than for any personal failings; the great necessity and heavy debts of the house called for stringent measures, and William le Breton had shown himself (like Abbot Richard of

the porter and knocking down every one who resisted them : they even went so far as to kill one of the chaplains of the monastery, and handled some of the brethren so roughly that the prior had the great bell rung and summoned the townspeople to the rescue. They came very readily, having their own grudge against the falconers, and the prior had at last to defend his enemies against his friends, for fear of incurring the king's displeasure (ibid. 273).

9 See account of Caldwell Priory, and Ann. Mon.

(Rolls Series), iii. I44.

10 Ibid. I52.

11 Ibid. 178.

12 Ibid. I82.

13 Ibid. Igo.

14 Ibid. 264.

15 Ibid. 267

10 Ibid. 283. 


\section{RELIGIOUS HOUSES}

Woburn in a similar case) unable to meet the difficulty. There is no sign of any other grave faults having been committed, nor of anything like luxurious living. ${ }^{1}$ The new prior, according to the bishop's advice, set himself to limit the expenses of the whole house and assigned a fixed income to the kitchen for the future ${ }^{2}$; the deposed prior had a proper maintenance assigned to him at Ruxox. ${ }^{3}$ The canons seem to have borne no illwill to Bishop Sutton for his corrections, and were ready on his next visit to their church (which was made not officially but only in passing) to praise him for his excellent sermon. Other visitations of his are mentioned in $1284,,^{5} 1287,{ }^{\circ} 1288,7$ and $1293^{8}$; the last was only to confer orders. Archbishop Peckham came in 1284 , but found all well ${ }^{8}$ (" as the bishop had been there quite lately,' the chronicler nalvely remarks); and Archbishop Winchelsea in $1293 .{ }^{10}$ The only serious charge that could be laid to the door of the canons all through the thirteenth century was their inability to keep clear of debt; and the record shows that this was often quite as much their misfortune as their fault. There are many incidental remarks of the chroniclers which serve to show that the tone of the house was thoroughly religious, and that the canons were faithful in keeping their rule. ${ }^{11}$ It will suffice to instance, early in the

1 Bread and beer are constantly spoken of as the ordinary fare of the canons and their boarders also; and when the beer failed in 1274 the chronicler notes as an exceptional event the purchase of five casks of wine, adding ' multum profuit nobis,' as if it were a novelty, or perhaps implying that they had been living lately on poorer food than usual, on account of poverty. The chronicle is full of these little life-like touches, which increase both its interest and its trustworthiness.

2 Ann. Mon. (Rolls Series), iii. 287.

3 The prior was allowed fourteen white loaves and fourteen gallons of better beer, with $8 d$. for 'companagium' every week, and an allowance of 20s. a year, with corrodies and pay for a servant and a stable boy. This is a very scanty allowance compared with that granted to a retiring prior in $\mathbf{I} 328$ at Hexham, of the same order (Annals of Hexham [Surtees Society], I. appendix lxxii). The house at Ruxox was used as a residence for priors who had resigned as early as I 202 (Ann. Mon. [Rolls Series], iii. 29).

Ibid. 294.

5 Ibid. 313 .

B Ibid. 340

7 Ibid. 342 .

8 Ibid. 39r.

8 Ibid. 3 I5.

10 Ibid. 39 I.

11 In I 288 a novice was not allowed to make his profession, as being too illiterate, frivolous in be- century, the generous treatment of the two young canons (one only a novice), who escaped by night through a window and went to join the Friars Minor at Oxford. They were indeed solemnly excommunicated and compelled to return; but after they had done their penance in the chapter house and had been absolved, they were allowed a year to consider the matter, and if after that time they preferred the stricter order, they were granted permission to depart; if not, they might remain at Dunstable. ${ }^{18}$ A good deal later than this, in 1283 , the apologetic way in which the chronicler relates how the prior went out to dinner with John Durant ${ }^{13}$ is sufficient to show that the ordinary rules and customs of the order were not commonly broken.

During the fourteenth century there were several visitations. There is no notice of any by Bishop Dalderby; but he commissioned the prior of Dunstable in 1315 to visit the nuns of St. Giles-in-the-Wood in his name. ${ }^{14}$ Bishop Burghersh in 1322 wrote to order the prior and convent to take back a brother who had been on a pilgrimage to the Holy Land, and asserted that he did so with the permission of his superior; and a little later the prior was cited for refusing to obey this injunction. ${ }^{\mathbf{1 5}}$ In $1359^{10}$ Bishop Gynwell, passing by the priory, noticed 'certain insolences and unlawful wanderings' of the canons, and wrote to reinforce the rule that none should go beyond the precincts of the monastery without reasonable cause, nor without the permission of the prior; and ordered further that such permission should not be too frequently given. $\mathrm{He}$ also reminded them of the rule that none should eat or drink outside the monastery, or talk with seculars without permission.

In 1379 Bishop Buckingham confirmed an important ordinance of Thomas Marshall, ${ }^{17}$

haviour, and of a restless disposition (ibid. 342). There are frequent references to the divine office. At the same time the chronicle is full of human nature.

12 Ibid. 133 .

13 Ibid. 302. 'This was quite against the custom observed in our monastery,' says the chronicler, 'but it may be excused, because he owed John so much money, and dared not offend him.'

14 Linc. Epis. Reg., Memo. Dalderby, 317d.

15 Ibid. Memo. Burghersh, 75d, 76d.

18 Ibid. Memo. Gynwell, 340. The prior of Dunstable was elected definitor in this year at the general chapter of the order, as well as in 1340. In I 350 a prior of Dunstable was president, being one of the very few who were able that year to assemble (Cott. MS. Vesp. D i. ff. 47, 50, 54).

17 Linc. Epis. Reg., Memo. Buckingham, f. 8zd. The prior alludes in this ordinance to the "consti- 


\section{A HISTORY OF BEDFORDSHIRE}

setting apart certain funds for the education of one of the canons at Oxford. The prior alludes to the poverty of his house, which was so great that were it not for the help of friends they would not be able to live decently and honestly, and religion would be diminished. Hitherto there had not been enough canons nor enough money to set apart one for special study; but the prior now wished to do so (partly out of the profits of a chantry established by his own family), 'seeing the advantage of learning and the necessity of preaching, the priory being a populous place where a great number of people come together.' All this certainly points to a satisfactory state of the priory under Thomas Marshall, and accords well with what we know of his character from other sources.

Bishop Grey's ${ }^{1}$ injunctions are the only notice that we have of the internal history of the priory during the fifteenth century; they do not indicate any special laxity, and only repeat the usual orders as to silence, singing of the divine office, the unlawfulness of eating and drinking after compline, going to Dunstable or having visitors without permission. And so again at the very end, just before the dissolution, the silence of Bishop Longland, ${ }^{2}$ and the king's choice of the priory for the solemn announcement of his divorce from Catherine of Aragon, constitute an indirect evidence in favour of the house. On the whole the priory of Dunstable shows a very good record in the matter of discipline and order, with only a few lapses.

The original endowment of the priory was, as already stated, the lordship of the

tutions of Saint Benedict and the holy fathers,' ordering one canon to be sent to study. There is nothing of the sort in the rule of St. Benedict; but the reference is interesting, as showing how well aware he was of the similarity of his own rule to that of the Benedictines. The Augustinian was commonly supposed to be a lighter rule; but in all the essential features of the common life it was the same.

1 Linc. Epis. Reg., Memo. Grey, 197d.

2 The bishop's silence in this case is really significant, as he had received information from the ' honest people of Dunstable' about the misdeeds of the Dominican prior of Langley Regis in 1528 , and must surely have heard at the same time of the misdeeds of the canons, if they had been conspicuous. His statement about the house at Langley, that it was ' in utter decay and but little religion kept,' has indeed been thought to refer to Dunstable Priory (S.P.C.K. Diocesan History of Lincoln, 217); but the reference in the original letter is beyond all doubt (L. and P. Hen. VIIII. iv. 43I 5). Henry VIII. visited Dunstable in 1525 (ibid. iv. 2558). manor and town of Dunstable ${ }^{3}$; to which was added under Henry II. the lordship of Houghton Regis, ${ }^{4}$ and under John, the king's house and gardens at Dunstable. ${ }^{5}$ The manors of Stoke and Catesby, and of Ballidon in the Peak, ${ }^{6}$ are mentioned in the annals as the property of the priory during the thirteenth century. In $129 I^{7}$ the tithes of St. Peter and St. Cuthbert, Bedford, Dunstable, Studham, Totternhoe, Chalgrave, Husborne Crawley, Segenhoe, Flitwick, Pulloxhill, Steppingley, Harlington, Higham Ferrers, Newbottle, Cublington, a moiety of Great Brickhill, Pattishall and Bradbourne belonged to Dunstable Priory, ${ }^{8}$ with pensions in other churches. The temporalities at this time were only valued at a little more than $£ 50$; the annals of the house state the total income in 1273 as $£_{107 . .^{9}}$ The knight's fees attributed to Dunstable in $1316^{10}$ were half a fee in Husborne Crawley and Flitwick, and another half in Pulloxhill, with some small fractions besides; they are practically the same in $1346^{11}$ and $1428 .^{12}$

The valuation of the whole property of the priory in $1535^{13}$ amounted to $£ 344$ I 3 s. $4 d$., the first report of the Crown bailiff to $f_{266}$ i 7 s. 63. $d$., including the manors of Studham, Wadlow, Stokehammond, Gledley, Grimscote, Catesby and Shortgrave, and the rectories of Studham, Totternhoe, Pulloxhill,

${ }^{3}$ Harl. MS. I885, f. 102.

4 Rot. Chart. (Rec. Com.), i. Io7.

5 Ann. Mon. (Rolls Series), iii. 28.

- Ibid. 277, 278, 337.

7 Pope Nich. Tax. (Rec. Com.)

s The priory presented clerks to Rushden several times during the thirteenth century, and to North Marston, Bucks, until I45O, when this church was exchanged with Wedonbeck, which had previously belonged to the canons of Windsor (Linc. Epis. Reg., Memo. Rotherham, I-7). St. Mary's, Bedford, had been certainly confirmed to Dunstable by Henry II. ' of the gift of Henry I.,' but it had also at an earlier date been granted by William the Conqueror to Lincoln Cathedral. 'There were several suits between the prior and the dean and chapter on the subject, e.g. Cur. Reg. R. 24, 2 John, n. II in dorso: the presentation being finally yielded to the latter, and the former retaining only a pension of 20s. Even this pension was granted in 1334-5 to the dean and chapter (Inq. ad q. d. 8 Edw. III. n. 9). The church of St. Peter referred to here was the one called St. Peter Dunstable, which was pulled down in the sixteenth century; the priory received a pension from the rector until 1336, when it was granted to the dean and chapter of Lincoln (Pat. 9 Edw. III. pt. i. m. 28).

9 Ann. Mon. (Rolls Series), iii. 259.

${ }_{10}$ Feud. Aids, i. 2 r.

11 Ibid. 24, 33. 12 Ibid. 36, 43, 46.

13 Valor Eccl. (Rec. Com.), 206 et seq. 


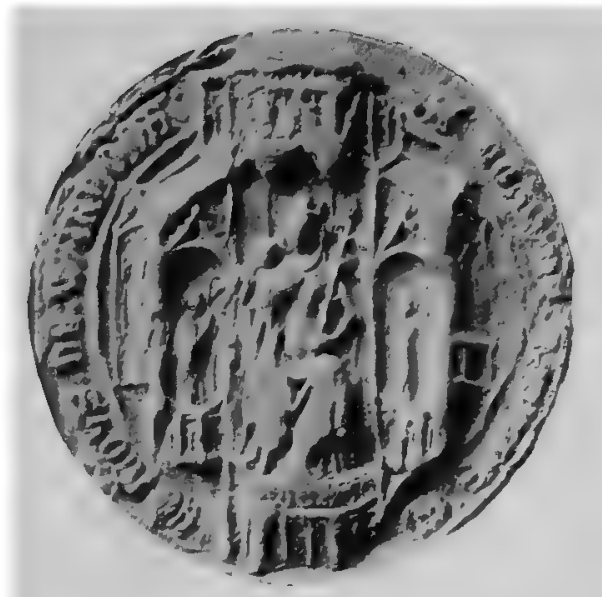

WARDEN ABBEY.

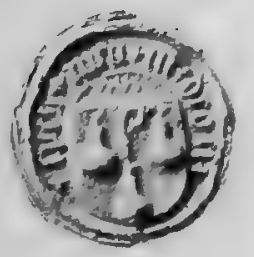

WARDEN ABBEY Counterseal.

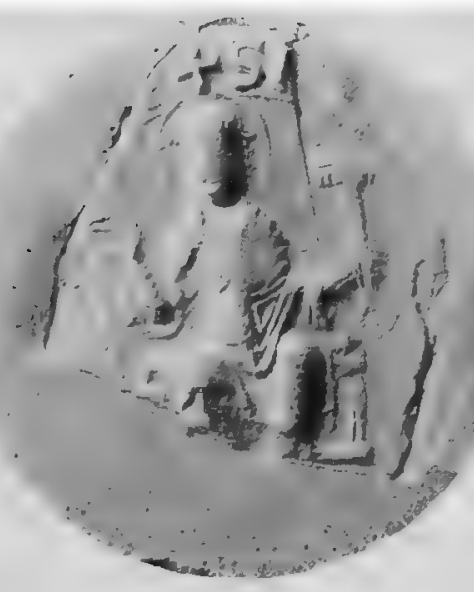

Dunstable Priory.

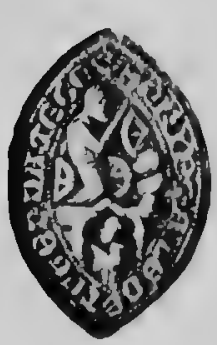

Dunstable

PRIORY. ${ }^{1}$

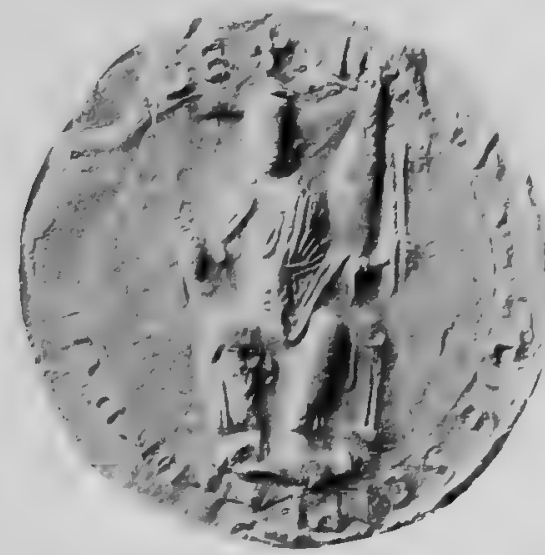

Dunstable Priory.

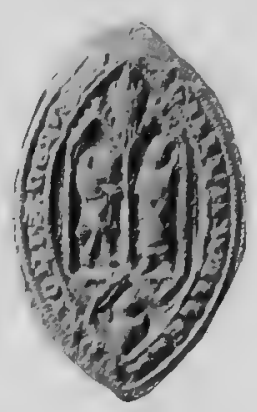

Dunstable Priory Counterseal.

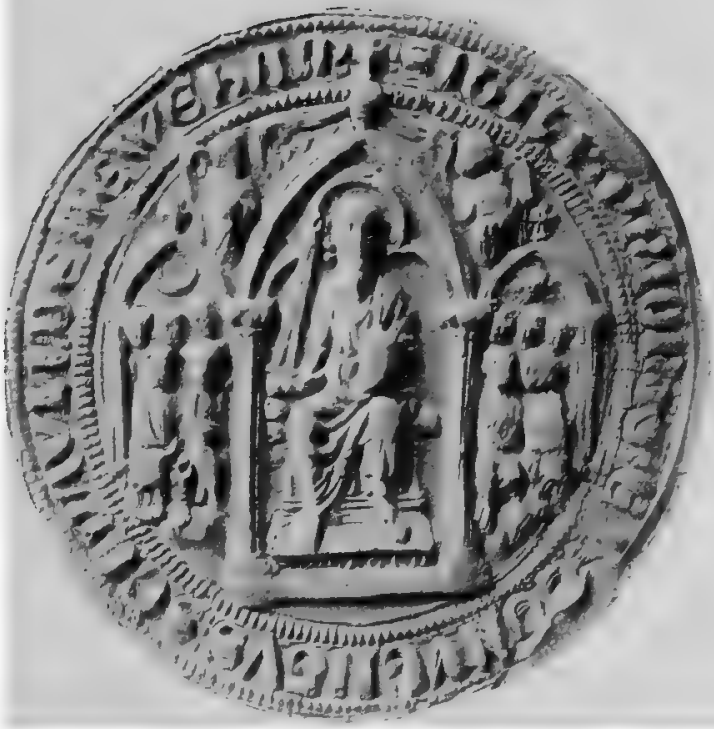

Newnham Priory.

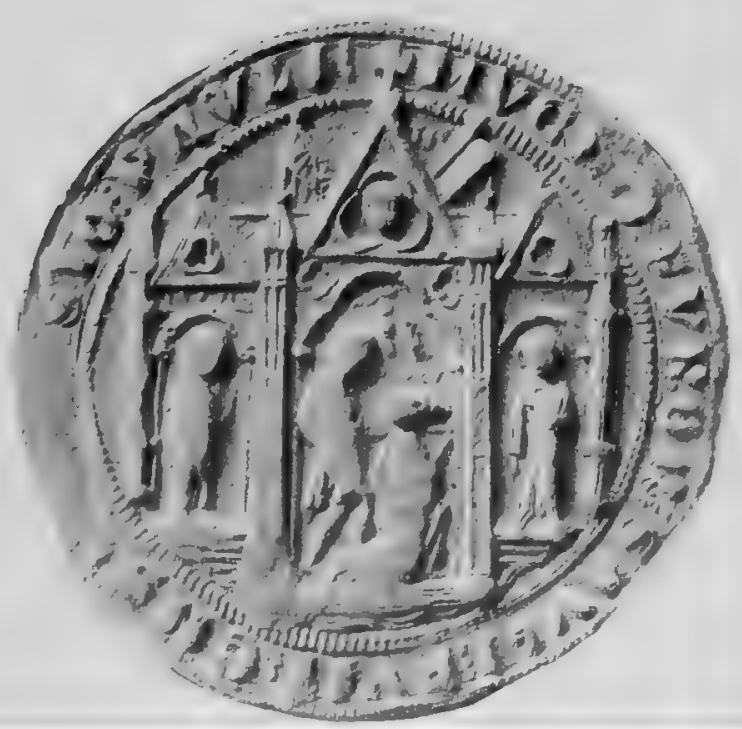

Newnham Priory Counterseal.

1 Mr. Worthington G. Smith kindly called attention to this seal, the matrix of which, now in the possession of Sir John Evans, he found. The subject is supposed to be the martyrdom of St. Katherine. The legend is "sCRIPTA LEGE TEGE PN[EUM]A TEGE." 



\section{RELIGIOUS HOUSES}

Harlington, Husborne Crawley, Flitwick, Segenhoe, Bradbourne, Newbottle, Pattishall and Weedon.'

\section{Priors of Dunstable}

\section{Bernard. ${ }^{2}$}

Cuthbert. ${ }^{3}$

Thomas, ${ }^{4}$ occurs I 185 , resigned 1202

Richard de Morins, ${ }^{6}$ elected 1202, died 1242

Geoffrey of Barton, ${ }^{6}$ elected 1242, resigned 1262

Simon of Eaton, ${ }^{7}$ elected 1 262, died 1274

William le Breton, ${ }^{8}$ elected 1274, deposed 1280

William de Wederhore, ${ }^{9}$ elected 1280 , resigned 1302

John of Cheddington, ${ }^{10}$ elected 1302 , died 134 I

John of London, ${ }^{11}$ elected I 34 I, resigned 1348

Roger of Gravenhurst, ${ }^{12}$ elected 1348, died I35I

Thomas Marshall, ${ }^{13}$ elected $135 \mathrm{I}$, died I 413

John Roxton, ${ }^{14}$ elected 1413, resigned I 473

Thomas Gylys, ${ }^{15}$ elected 1473, resigned 1482

Richard Charnock, ${ }^{18}$ elected ${ }^{4} 42$, resigned 1500

1 Dugdale, Mon. vi. 242.

2 Introd. to Ann. Mon. (Rolls Series), iii. Dr. Luard says that the predecessors of Richard de Morins were Bernard and two persons named Thomas. A charter made in the time of Archbishop Theobald refers to a grant 'tempore B. prioris' (Harl, MS. 1885, f. 25b. See also above, p. 37I).

3 Harl. MS. 1885, ff. 73b, 24, 26b. Mentioned as contemporary with Robert, Bishop of Lincoln (I 148-66), and Cecily, mother of Robert d'Albini, who founded Beaulieu Priory. It is however necessary to add that the reading of the name as 'Cuß.' and 'Cüto' in the two latter references is a little uncertain. On f. $73^{\mathrm{b}}$ it is 'Cutb'tus' beyond doubt.

4 Ibid. f. 24 ; Ann. Mon. (Rolls Series), iii. 29.

- Ann. Mon. (Rolls Series), iii. 28.

a Ibid. 158, 219.

7 Ibid. 220, 263.

s Ibid. 264,284 .

9 Ibid. 284.

10 Ibid. 409, and Linc. Epis. Reg., Inst. Dalderby, 259d.

${ }_{11}$ Linc. Epis. Reg., Inst. Burghersh.

12 Ibid. Inst. Gynwell, 374.

13 Ibid. 389.

14 Ibid. Inst. Repingdon, 305d.

16 Pat. 2 Edw. IV. pt. r, m. 20.

10 Pat. 22 Edw. IV. pt. 2, m. 30 and m. 10.

I
John Wastell, ${ }^{17}$ elected I 500 , died I 525

Gervase Markham, elected 1525, surr. I 540

The seal of the priory ${ }^{18}$ used in the fifteenth century (round and large) represents St. Peter seated, holding the keys in the left hand, and the right raised in benediction. Legend: SIGILLUM ECCLIE SC . PET . L LE.

The seal of Prior William ${ }^{18}$ de Wederhore (affixed to a document dated 1286) is the same as above; the counter-seal has a king and a saint (very indistinct), each standing under a crocketted canopy, the prior kneeling in prayer below. Legend : .... ILLUM WILLELMI PRIORIS DE ...

\section{THE PRIORY OF NEWNHAM}

The Augustinian priory of Newnham was not actually built until some time after the accession of Henry II., but it may fairly claim to be the most ancient religious foundation in Bedfordshire, in so far as it still held the church of St. Paul's and succeeded to the endowments of the secular canons there. It is implied in the Domesday Survey that these latter were in Bedford before the Conquest; and Leland records the tradition that they lived in houses 'round about the Church.' 20 How long they had been there, and whether they were in any way descended from the original monastery of Bedford, named in 971 in the Anglo-Saxon Chronicle, it is difficult now to discover: all we know is that they were living at the Conquest as secular canons, and had property at Biddenham and Bedford. ${ }^{21}$ Their patron at this time must have been Hugh de Beauchamp, who first held the barony of Bedford; a little later Payn de Beauchamp, son of $\mathrm{Hugh},{ }^{22}$ and his sister Ellen are both named as benefactors. ${ }^{23}$ But the foundation of the priory of Newnham was the work of Simon de Beauchamp, son of Payn, about I I66. Tradition ascribes the change to the scandal caused by the affair of

17 Lansd. MS. 963; L. and P. Hen.VIII. iv. 2046. He lived till I56I (Dugdale, Mon. vi. 238), and was buried in the priory church (Beds N. and Q. i. 74).

${ }_{18}$ Harl. Ch. iii. C 27.

19 Wol. Ch. x. 33.

20 Quoted Dugdale, Mon. vi. 373.

21 See ante Domesday Translation.

22 Add. MS. 24465 (Chartul. of Wardon), f.39 says the Hugh of Domesday was father of Payn who succeeded to the barony of Bedford, and also of Simon, who married the heiress of Eaton, and was ancestor of the other line of Beauchamps.

${ }_{23}$ Harl MS. 3656, f. I4b. 


\section{A HISTORY OF BEDFORDSHIRE}

Philip de Broi, ${ }^{1}$ one of the canons, whose name has become famous in connection with the quarrel between Becket and the king. This man was accused of homicide, and cleared himself by oath ; but the evidence was so much against him that Simon Fitz Peter, the king's justiciar, summoned him to a new trial. On receiving the summons, Philip broke out into such angry words and insults against the justiciar that the king considered his own authority slighted in the person of his delegate; and the archbishop, fearing that a very severe punishment would follow, interposed and passed sentence upon the offender in his own court. This sentence-the loss of his prebend, and further some penance for two years only-was considered by the king as a glaring instance of the failure of the ecclesiastical courts in dealing with serious crimes; it contributed something towards the estrangement between him and the archbishop, ${ }^{2}$ and also made it advisable for the canons to change their place of residence.

This story has quite good authority, but it has probably no casual connection with the foundation of Newnham Priory. The change from secular to regular canons was going on in many religious houses at this time; the scandal of Philip de Broi can only at the most have hastened an event already inevitable. All that Simon de Beauchamp says ${ }^{3}$ is that prudent and religious men had often counselled him to turn the gifts and endowments of his ancestors to a use more productive of reverence to God and honour to true religion, and that he was at last convinced of the wisdom of their advice. He names the king, Henry II., Pope Alexander III., Blessed Thomas the Martyr and Bishop Robert of Lincoln as having given their consent. ${ }^{4}$

The transference of all the endowments of the secular canons to William, first prior of Newnham, was solemnly made in the church

1 Mr. Round is of opinion that he was related to Robert de Broy, a feudal tenant of Simon de Beauchamp in II66. He is called 'nobilis genere' by William of Canterbury in Materials for the Life of St. Thomas (Rolls Series), i. I2.

2 The story is told with some variations in Materials for Life of $S t$. $T$ bomas (Rolls Series), i. I2, I3, iii. 45; and Ralph de Diceto, $r$ mag. Hist. (ibid.), i. 213 , under the date 1164 .

${ }^{3}$ Harl. MS. 3656, f. 14b.

- The death of Robert de Chesney in II 66 fixes the decision of Simon to that year at the latest: nor could it have been very much earlier, partly because of the consent of Archbishop Thomas, and partly because of the age of Simon, who could not have been born earlier than 1146. His mother's first husband, Geoffrey de Mandeville, died I 44 . of St. Paul in the presence of many witnesses. ${ }^{5}$ The old canons were six in number : Nicholas archdeacon of Bedford, was one of them. ${ }^{\circ}$ They probably kept some portion of their prebends for the term of their lives ; perhaps being presented to or left in possession of churches in the gift of the house. The priory was specially rich in churches: fourteen are named in the first charter of Simon de Beauchamp, and eleven of these were still the property of the house in 1535. Simon's endowment was a generous one; his mother and other benefactors added to it, ${ }^{7}$ but his own title to the name of founder is unquestionable.

During the first century of their existence the canons of Newnham had a good deal to endure. They had first to suffer from the violence of Fawkes de Bréauté, who with the consent and approval of King John actually pulled down the greater part of the church of St. Paul to strengthen the fortifications of Bedford Castle; he was probably an oppressive neighbour all the time he lived there, until the capture of the castle in 1223 by Henry III. The losses of the canons were partly made good to them by the gift of the church of Tinden, and by a present of stones from the dismantled castle. ${ }^{8}$

It was in the same year (Easter term 1223 ) that the priory was involved in a very interesting suit for the church of Aspley Guise. There were three claimants in the field, namely Fawkes de Bréauté and the priors of Dunstable and of Newnham. The last parson, Nicholas, has been presented by Roger de Salford, who held a knight's fee of Simon de Beauchamp in 1166 . This Roger had then given the advowson to the church of Dunstable, his charter being confirmed by Simon de Beauchamp and by Robert Bishop of Lincoln (1 I 47-66). The prior of Newnham

5 Simon's third charter (Harl. MS. 3656, f. I6). The same parties are named as consenting; and one of the witnesses is 'Count Alberic, my uncle' -Aubrey de Vere, his mother's brother.

a The others were named William, Philip, Gilbert, Richard and Ralf. The foundation charter of Chicksand promises the church of Haynes 'after the death of Philip de Broi '; the churches of Southill, Salford and Aspley certainly belonged to the old canons (Harl. MS. 3656 , ff. $18,49 \mathrm{~b}$; ibid I 885, f. 24).

7 Leland represents Countess Roais as the prime mover, and her son only confirming the act of his mother : but the charters give exactly the opposite impression.

8 Pat. I Henry III. m. I3; Matth. Paris, Cbron. Majora, iii. 87. Close 8 Henry III. makes the stones of the castle a recompense for furnishing mangonels, etc., for the siege. 


\section{RELIGIOUS HOUSES}

pleaded that Guy de St. Walery and Aubreye his wife had given the church to St. Paul's, Bedford, their gift being confirmed by Simon de Beauchamp and Bishop Hugh (1 1861200). It was proved that Roger had only held Aspley as baillee until he was assigned land to the value of $f_{1} 0$ elsewhere (which he afterwards received in Stotfold), and that Guy de St. Walery had recovered Aspley against him by fine. Therefore his gift was invalid, and Newnham was assigned the church under St. Walery's gift. ${ }^{1}$

But new troubles soon arose through the tyrannical behaviour of William de Beauchamp, son of the founder; who, encouraged by his wife Ida, proved himself quite as much an enemy to the religious of the neighbourhood as Fawkes de Bréauté had been. The first difficulty was connected with the church of Wootton, and other property of the priory $;^{2}$ but it was at the election of a prior that William's conduct at last brought him under episcopal censure. The charter of Simon had provided that the convent should have the right of free election, only asking his consent as patron: William wished to do the part of both bishop and patron. There was some unpleasantness over an election in $1247 j^{3}$ but in 1254 William came in person to the priory with his wife, and compelled the new prior, Stephen, to come outside the gate to him to receive the temporalities; then, taking him by the hand, he led him into the church, and installed him in his place in choir. This, however, was too much for the bishop: he at once visited the priory and made William apologise for his invasion of the liberties of the church. ${ }^{5}$ It is possible that the great charter of Newnham, in which William confirmed all the gifts of his father and others, including the licence for

1 Bracton's Note Book, iii. 474-6. There had been several disputes about the church before this. Nicholas the archdeacon (II45-81) confirmed the gift of it by Roger de Salford to Dunstable, and explained that it had once formed a part of his prebend, but now he resigned all his rights in it to the priory (Harl. MS. I885, f. 24); while on the other hand Simon de Beauchamp wrote to the Bishop of Norwich to say that if the prior of Dunstable or any one else should bring forward a charter to prove his right to the church, it would not be with his warrant: and that the charter of Roger de Salford, who, as his tenant, had no power to give the church to any one without his consent, was invalid (Harl. MS. 3656, f. 20).

2 Harl. MS. 3656, ff. I9, 2 I b, 22.

3 Ann. Mon. (Rolls Series), iii. I 72.

- Ibid. IgI.

5 Harl. MS. 3656 , f. 54 . free election, belongs to this time. The next of the Beauchamps, another William, made some reparation for the misdeeds of his father."

When the barony of Bedford passed to the Mowbrays the advowson of the priory went with it. An attempt was made in $1347,^{8}$ at the death of John of Astwick, to prove that it was held of the king in capite; but the jury then called proved conclusively that it was held always of the barony of Bedford, and that Sir John Mowbray was at that time the patron. In 1352 Thomas Mowbray, Earl Marshal, confirmed the charter of William de Beauchamp. ${ }^{9}$ The foundation charter, charter of transference to Newnham and others were confirmed by Henry II., Edward I., Edward II., Edward III. and Richard II. ; the last royal charter was that of Henry IV. dated I 5 February I 408-9. $0^{10}$

Of the internal history of the priory we know very little. It seems to have had a good reputation at all times. Hervey, the prior in 1228 (previously prior of Osney), was commissioned in that year, with Richard de Morins of Dunstable, to visit all the houses of their order throughout the dioceses of Lincoln and Coventry; two priors resigned in consequence. ${ }^{11}$ In Grossetête's unsparing visitations of 1235 and 1249 no charge was laid against this house $;^{12}$ and no other visitation is recorded until that of Bishop Burghersh some time before I 322. The prior at that time, John of Astwick, was very unpopular, and anxious in consequence to resign; but the bishop thought it sufficient to urge the brethren to be more exact in their obedience. ${ }^{13}$ Bishop Buckingham sent an order in 1387 that "peace should be established between the priories of Newnham and Caldwell;' 14

6 Ibid. ff. 8-I2.

7 Harl. MS. 3656, ff. 21b, 22. The elder William died in 1260, the younger in 1262 ( $A n n$. Mon. [Rolls Series], iii. 21 5, 219).

8 The question of the advowson had been before the bishop in I3I4 (Ininc. Epis. Reg., Memo. Dalderby, 280d). The king's escheator, Roger l'Estrange, held it in $127 \mathrm{I}$ and 1272 (ibid. Rolls of Gravesend) in the interval between John de Beauchamp and Sir John Mowbray, and this naturally led to the assumption that it was held of the king.

${ }^{2}$ Harl. MS. 3656 , f. 32.

10 Ibid. ff. 25-36.

11 Ann. Mon. (Rolls Series), iii. II 2.

12 Ibid. 146, I79. It seems, however, that Grossetête purposed a special visitation to Newnham, and was not satisfied with its condition, though the Dunstable chronicler does not allude to this (Introd. to Letters of Grossetête [Rolls Series]).

13 Linc. Epis. Reg., Memo. Burghersh, 38.

14 Ibid. Memo. Buckingham, 342d. 


\section{A HISTORY OF BEDFORDSHIRE}

it would be interesting to know what was the matter in dispute, as there was usually so much goodwill between the various houses of Austin canons in this county. A year later ${ }^{1}$ a brother was received back, who had become an apostate through discontent and was now repentant. At the visitation of Bishop Grey ${ }^{2}$ ( $1431-6)$ the discipline of the house was still good; all that the bishop enjoined was that the sub-prior should do the work of the prior, now grown old and feeble. ${ }^{2}$ Later, when Cardinal Wolsey undertook to reform the whole Augustinian order, it seems that Newnham was still amongst the more satisfactory houses. At the great general chapter summoned at Reading in June 1518 (the first after the lapse of more than a century) the prior of Newnham was chosen as one of the definitors, and made visitor for two counties. $^{3}$

The prior, John Ashwell, with fourteen canons and two lay brothers, signed an acknowledgment of the royal supremacy in I $535^{.4}$ It is probable that these seventeen were but a small proportion of the original number. ${ }^{5}$ Nothing is known of the circumstances of the surrender of the house, except that it was made by a prior who had not been long in office, ${ }^{6}$ and took place on 2 January

1 Iinc. Epis. Reg., Memo. Buckingham, 348.

2 Ibid. Memo. Grey, I99. At this visitation it was enjoined that on every Saturday the warden of the church of St. Paul's, Bedford, should give all the fruits of the church to the bursar of the monastery, to be used for the clothing of the canons and other necessities.

3 Cott. MS. Vesp. D i. ff. 64, 70. General chapters were held at Newnham in 1292 ( $A n n$. Mon. [Rolls Series], iii. 390) and in 1340; priors of Newnham were definitors in 1340 and 1365 (Cott. MS. Vesp. D i. ff. 46b, 56).

4 Rymer, Fadera, vi. (2), 200, and 7th Report of the Deputy Keeper of the Records.

5 There is nothing in the documents relating to the priory to show the number of canons at any time before the end; but the income in the thirteenth century, on the analogy of other houses, would have supported thirty or forty.

6 John Burne signed the surrender. In 1524 the prior of Newnham was ordered to take the fealty of Agnes Gascoigne, the newly-elected abbess of Elstow (L. and P. Hen. VIII. iv. 487). In 1536 the prior of Newnham (unnamed) was accused of having fraudulently denied all knowledge of a box of money deposited with him by the chancellor of Lincoln some time before. A certain priest and servants of the chancellor (who had just died) declared that they consigned the money to the prior, and gave the contents of the box in detail (ibid. zi. 1407). The results of the inquiry are not stated.
I 540-1. 7 A pension of $£ 60$ was granted to the prior, John Burne, and pensions of other sums to fifteen canons besides.

The original endowment of the priory by Simon de Beauchamp comprised the tithes of fourteen churches-St. Paul's Bedford, Renhold, Ravensden, Great Barford, Willington, Cardington, Southill, ${ }^{8}$ Hatley, Wootton, Stagsden, Lower Gravenhurst, Aspley, Salford, Goldington; portions of land in many places which had belonged to the old canons; the tithes of all his markets, assarts and woods; the castle mill and another with some lands and water attached; the free use of all waters belonging to the castle, as far as Fenlake, for fishing, navigation and breeding swans; and the right to pasture a certain number of cattle with his own free of cost. These gifts are rehearsed with much detail and some additions in the Great Charter of William de Beauchamp. At the time of the Taxatio the income of the priory appears as $f_{1} 6_{4}$ I Os. $8 d .{ }^{9}$ of which $£ 92$ 6s. 8d. is made up of spiritualities. The largest items amongst the temporalities are lands, etc., at Goldington, Salpho, Stotfold and Sharnbrook; ${ }^{10}$ and these are found in the Feudal Aids as portions of knights' fees.

In 1302 the prior of Newnham held half a knight's fee in Sharnbrook, several fractions in Goldington, and half a knight's fee in Salpho. 11 In I 316 half a fee in Goldington, a quarter in Salpho, one seventh in Biddenham, one quarter in Southill. ${ }^{12}$ In 1346 half a fee in Cotes and half a fee in Sharnbrook. ${ }^{13}$ In 1428 the same as in 1346 with the addition of half a knight's fee in Salpho, and a quarter in Blunham and Moggerhanger. ${ }^{14}$

A comparison of the $V$ alor and the Taxatio shows however that the property of the priory was almost the same in extent at both dates, varying very little in the course of history. It was all within the county of Bedford. Not one of the churches of the original endow-

\section{Ibid. Xv. II.}

8 Of Southill only two-thirds ; the remaining third was not granted till I 255 (Cal. of $P$ ap. Letters, i. 314 ). Turvey appears in the charters of Simon and William de Beauchamp (Harl. MS. 3656, ff. 8, 14b), but it never could have belonged to Newnham.

9 The church of Gravenhurst is not included, as it does not appear in the Taxatio; possibly other items are missing.

10 These places are all named in the foundation charters, but the largest item there is three hides in Cardington.
11 Feud. Aids, i. I I, I5, 16.
12 Ibid. 17, 18, 19.
13 Ibid. 28, 29.
14 Ibid. 39, 42, 45 . 


\section{RELIGIOUS HOUSES}

ment was quite lost, though three were only paying small pensions in 1535 . Besides divers parcels of land the prior held the manors of Stotfold and Cardington. ${ }^{1}$ The total valuation in 1535 was $6284125.11 \frac{3}{4} d$. ; in 1541 the ministers' accounts give only a total of

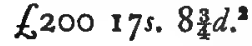

\section{Priors of Newnham}

William, ${ }^{3}$ first prior, appointed 1166

Ralph, ${ }^{4}$ occurs 1198 and 1205

Eustace, ${ }^{5}$ occurs I 214 , died 1225

Harvey, ${ }^{6}$ elected 1225 , died or resigned 1238

Walter, elected I 238 , died 1247

Walter of Chawston, ${ }^{8}$ elected 1247

Stephen, ${ }^{9}$ elected 1254, died 1264

William le Fraunceys, ${ }^{10}$ elected 1264 , died I27I

William le Ros, ${ }^{11}$ elected 1271 , died 1272

Michael of Goldington, ${ }^{12}$ elected 1272 , died 1283

John of Bedford, ${ }^{13}$ elected I 283 , resigned I 300

Adam of Sherborne, ${ }^{14}$ elected 1300, resigned I 300

William of Biddenham, ${ }^{15}$ elected 1300 , died 1307

William of Thorp, ${ }^{16}$ elected 1307 , resigned 1315

John of Astwick, ${ }^{17}$ elected I 315 , resigned I 347

John of Amersham, ${ }^{18}$ elected I 347, resigned 1348

1 There are two royal charters (Harl. MS. 3656 , f. 27) confirming to Newnham the manor of Stanbridge, to be held of Hugh de Beauchamp; this appears in the last valuation as ' Rents in Stanbridge manor- $f 4$.' $^{\prime}$

2 Dugdale, Mon. vi. 377.

a Harl. MS. 3656, ff. 16, 70 .

- Feet of F. (Rec. Com.), 18, 73.

s Ibid. 86. Ann. Mon. (Rolls Series), iii. 93 has 'E. prior of Newnham died; Herveius prior of Oseney elected.'

- Ibid. 93, rgr.

7 Linc. Epis. Reg., Rolls of Grossetête.

${ }^{8}$ Ibid.; Ann. Mon. (Rolls Series), iii. 172.

$\rightarrow$ Ibid. Igr.

10 Linc. Epis. Reg., Rolls of Gravesend. This is the last time that one of the Beauchamps appears as patron.

11 Ibid.

12 Ibid.

13 Ibid. Rolls of Sutton; Ann. Mon. (Rolls Series), iii. 297.

14 Linc. Epis. Reg., Inst. Dalderby, 258.

15 Ibid.

18 Ibid. 263.

17 Ibid. $273 \mathrm{~d}$.

18 Ibid. Inst. Bek, I05; Harl. MS. 3656, f. $28 \mathrm{~b}$
Henry of Woodford, ${ }^{19}$ elected 1348 , died 1349

William of Woodford, ${ }^{20}$ elected 1349

Nicholas Baldock, ${ }^{21}$ elected 1362, died 1369

John of Biddenham, ${ }^{22}$ elected 1369 , died I 395

William of Woughton, ${ }^{23}$ elected 1395

John Bromham, ${ }^{24}$ occurs 1437 and I 44 I

John, ${ }^{25}$ occurs 1477 and I 490

Henry of Newnham, ${ }^{26}$ occurs 1493

John Ashwell, ${ }^{27}$ occurs 1535

John Burne, ${ }^{28}$ occurs I 540

The conventual seal was large and elaborate. It represents St. Paul seated on a throne, under a trefoiled canopy, with sword in his right hand; an angel above on either side, and groups of votaries under arches to the right and left, with the moon above one group and the sun above the other. Legend: SIGILL' PRIORIS ET CONVENTUS SCI PAULI DE NEWEHAM.

Counter-seal : three niches. In the middle St. Paul kneeling with an executioner behind him; above his head Paulv and possibly a hand of blessing. St. Luke and St. Titus on the left and right, with their names above them. Legend : MUCRO - FUROR - SAULI FUIT ${ }^{-}$ENS[IS - PAS]SIO PAULI. ${ }^{29}$

There is a seal of William of Woughton, prior 1395, pointed oval, representing St. Paul seated in a canopied niche, pinnacled and crocketted, holding a sword in the right hand and a book in the left, between two shields, one with a lion and the other a cross paty; and a prior below, half length, with hands folded in prayer. Legend : s. FRATRIS WILLI DE WOKETONE PRIORIS DE NEWE ${ }^{30}{ }^{30}$

The seal of Henry de Newnham (1493) is the same. Legend : s. F'RIS HENRIC' NEWNAM PRIORIS DE NEWEHAM. ${ }^{31}$

19 Linc. Epis. Reg., Inst. Gynwell, 379.

20 Ibid.

21 Ibid.; Harl. 3656, f. 3ob.

22 Linc. Epis. Reg., Inst. Buckingham, 384.

23 Ibid. 366.

${ }_{24}$ Charter in the possession of F. A. Page-Turner, Esq., and Cat. of Anct. Deeds (P.R.O.), A 2315, 287 I.

25 Ibid. A. 552 ; Dugdale, Mon. vi. 373.

20 Dugdale, Mon. vi. 373; Add. MS. 5827,

f. I75b, from Reg. Acad. Cant.

${ }_{27}$ Valor Eccl. (Rec. Com.), iv. 187 ; Rymer,

Feedera, vi. (2), 200.

28 L. and P. Hen. VIII. Xv. II.

29 B. M. seals, lix. 63, 64 .

30 Ibid. Iviii. 40.

31 Ibid. Iviii. 4 I. 


\section{A HISTORY OF BEDFORDSHIRE}

\section{THE PRIORY OF CALDWELL}

The origin of the priory of Caldwell is somewhat obscure. Its earliest charters or endowment are of the reign of Henry II., but undated $;^{1}$ but as a prior of Caldwell witnessed a charter granted by Robert Bruce to Harrold ${ }^{2}$ during the lifetime of Malcolm IV. of Scotland (I I 53-65), we may conclude that this house, like so many others in Bedfordshire, was founded early in the reign of Henry II. or perhaps in that of Stephen. The founder's name is unknown. The Close Roll of I3 Edward III. ${ }^{3}$ speaks only of 'the ancestors of Simon Barescote of Bedford'; Leland, by naming Simon Barescote in one place, and in another assigning the foundation to the Beauchamps or the Beaumonts, shows that there were several contradictory traditions in existence in his time." The priory belonged at first to the order of the Holy Sepulchre, ${ }^{5}$ and was dedicated to St. John Baptist; ${ }^{8}$ but after the thirteenth century it probably ceased to be in any way distinguished from the other Augustinian houses. The canons of the Holy Sepulchre were only separated from other Augustinians by their name, and the scarlet badge on their cloaks ${ }^{7}$; in all probability they kept exactly the same rule, as on two occasions canons of Dunstable were invited to be priors of Caldwell, while it was still called by the name of the Holy Cross.

Four churches in this county-Bromham, Roxton, Sandy and Oakley with the chapel of Clapham-belonged to Caldwell at the beginning of the thirteenth century; Marsworth and Broughton in Buckinghamshire, and Arnesby in Leicestershire before $1291 ;$

1 One is contained in an Inspeximus of Richard II. Pat. 13 Rich. II. pt. I, m. 2I, and witnessed by Hugh de Beauchamp: the other in Pat. 2 Henry VI. pt. 3, m. 23, and witnessed by Richard Bishop of Winchester.

2 Lansd. MS. 59I, f. 4 b.

3 Close, r 3 Edw. III. pt. i. m. 38.

4 Quoted Dugdale, Mon. vi. 391.

5 So called in the charter of 57 Henry III (Dugd. Mon. vi. 393).

${ }_{6}$ The grant under the charter just mentioned is to God, to Blessed Mary and the brothers of the Holy Cross; but this does not necessarily imply that the house was dedicated to St. Mary. The charters of Henry II. are granted to 'his canons regular of St. John Baptist, Bedford,' or ' his poor canons of St. John Baptist': and in the Acknowledgment of the Royal Supremacy they are the canons of St. John Baptist and St. John Evangelist (Rymer, Fodera, vi. [2], I98).

7 Helyot and Bullot, Hist. des Ordres Mon. ii. II6.

8 Pope Nich. Tax. (Rec. Com.), 63.
Tolleshunt Major in Essex at a later date. ${ }^{9}$ Its temporal possessions lay for the most part within the county of Bedford, and were never very extensive; in 1291 they were worth less than $£ 50$.

At the siege of Bedford Castle in 1224 , the canons assisted the king by providing him with materials for mangonels, and received in return a share of the stones from the dismantled walls. ${ }^{10}$ At this time, as well as later, they seem to have been on friendly terms with the canons of Dunstable. It was by the advice of the prior of Dunstable, amongst others, that Prior Eudo of Caldwell resigned and fled to the Cistercians of Merivale, before the visitation of Bishop Grossetête; and the sub-prior of Dunstable took his place. ${ }^{11}$

The reason why he was afraid of the visitation is not stated, only that he was 'accused by many'; he had only been prior five years, and during his term of office had been sent by the pope to settle a dispute as far away as Yorkshire. ${ }^{12}$

In 1287 there seems to have been some uncertainty about the advowson of the priory, and the election of John of Ypres was hurried so as to prevent any claim being made. ${ }^{13}$

In the year 1339, at the death of Prior Roger of Wellington (or Wymington) the king's escheator seized the lands of the priory ; partly on the ground of a rumour that in the time of Henry III. the advowson had been taken into the king's hand, and partly because the prior held two carucates of land and a rent of roos. within Bedford town, and held in fee farm of the king. The canons however appealed to the king himself, who thereupon wrote to the escheator to molest them no further, saying that he had heard from the present prior that Simon de Barescote, whose ancestors founded the priory, gave the advowson to Roger the Marshal, and he to William le Latimer; and that thus it had descended to Robert de Ufford and his wife who then held it. ${ }^{14}$

The churches belonging to the priory

9 Valor Eccl. (Rec. Com.), iv. I89.

iii. 88.

10 Close, 8 Henry III.; Ann. Mon. (Rolls Series), 11 Ibid. 179.

12 Cal. of Pap. Letters, i. 230.

13 Ann. Mon. (Rolls Series), ii. 340.

14 Close, I2 Edw. I. pt. I, m. I8; 13 Edw. III. pt. I, m. 38. This reference to the recent death of Roger of Wellington makes it difficult to account for Robert de Lufwyk, who is said to have resigned at the election of William of Souldrop in 1338 (Linc. Epis. Reg., Inst. Burghersh, 319). 


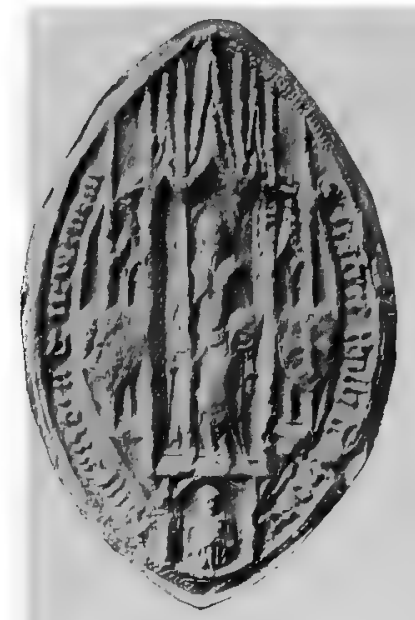

Newnham Priory.

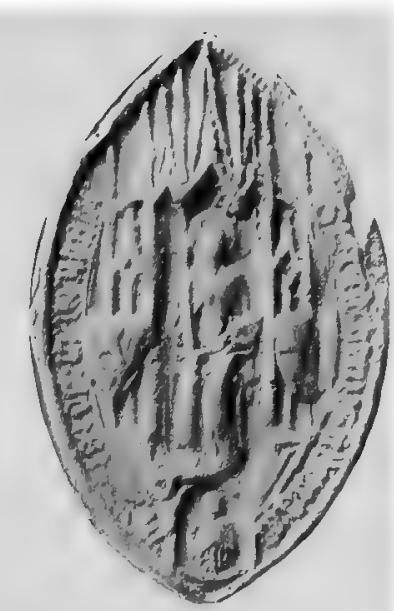

Newnham Priory.

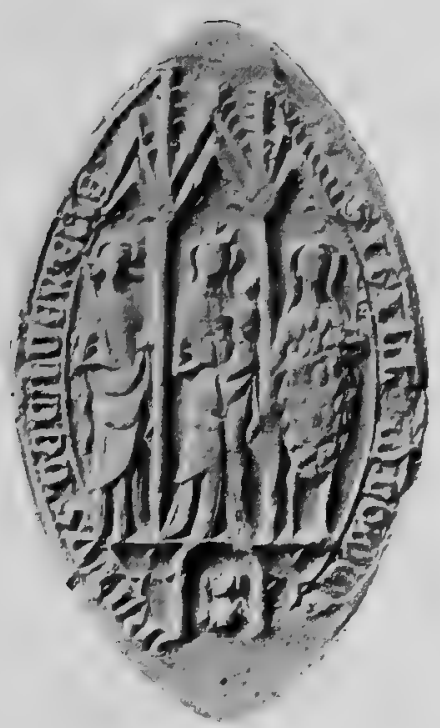

CALDWELL PrIORY.

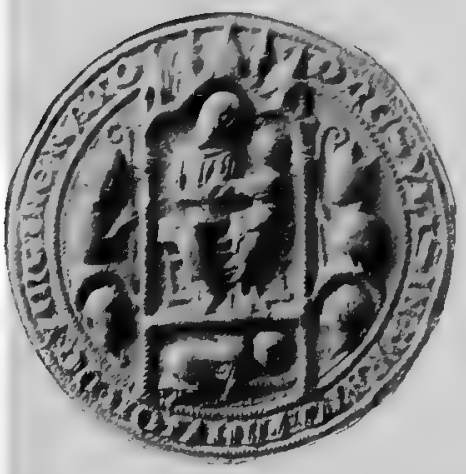

Bushmead Priort.

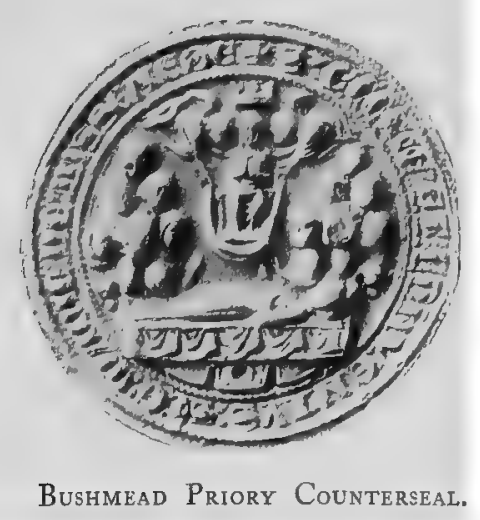

Bushmead Priory Countergeal. 



\section{RELIGIOUS HOUSES}

were not very wealthy, and sometimes they proved a source of expense rather than of revenue. The chapel of Clapham in their own county, and the church of Marsworth in Buckinghamshire must have cost the canons a good deal of money. A part of the tithes from both of these had been granted to Osney Abbey at its foundation, ${ }^{1}$ amounting to a pension of 12 marks; and from the first the canons of Caldwell seem to have made efforts to escape this payment. In $1279^{2}$ they had to be ordered to pay it 'on pain of excommunication'; but in the beginning of the fourteenth century Hugh de Beauchamp, who was prior at the time, began a long series of suits with Osney on the same subject. ${ }^{3}$ $\mathrm{He}$ was seemingly unsuccessful, for this pension was still reckoned among the liabilities of the priory in $1535^{*}$ It was probably the pressure of poverty at this particular time that stirred the prior to make these efforts; he was then rebuilding the conventual church, and only a few years before Bishop Dalderby had granted a licence to the canons to beg alms for this purpose, as they were so poor. ${ }^{5}$ Several chantries were granted at about the same time. ${ }^{6}$

The priory did not grow any richer as time went on. In 1318 the canons parted with the advowson of Broughton church to the dean and chapter of Lincoln $^{7}$; and in 1525 with that of Sandy to Bishop Longland and his brother. ${ }^{8}$ The bishop wrote of it in the

1 Dugdale, Mon. vi. 249.

2 Bodl. Lib. Oxon. Chart. Osney Abbey, No. 22. This charter is described in the calendar as referring to Canwell Priory ; but the name in the charter is 'Caldewelle,' and the mention in it of the tithes of Marsworth and Clopham makes the reference quite clear. It is addressed by the prior and sub-prior of St. Oswald's, Gloucester, to the dean of Bedford. In 1253 the chronicler of Dunstable notices that the canons secured the presentation to Marsworth, but gained nothing from the church (Ann. Mon. [Rolls Series], iii. 189).

3 Ibid. Beds Chart. 2-19; Beds R. i. The latter is dated 1322 ; and the name of Hugh de Beauchamp occurs frequently in the charters. The pension is called the "ancient and accustomed pension,' and valued at 12 marks.

4 Valor Eccl. (Rec. Com.), iv. 190. It was still I 2 marks.

5 Linc. Epis. Reg., Memo. Dalderby, 176d. Licence to prior and convent of Caldwell to beg alms for the repair and rebuilding of their church on account of poverty. Ibid. Memo. Burghersh, f. $39 \mathrm{~d}$. Indulgence for the fabric of the conventual church, I32I.

- Ibid.; Inst. Dalderby, 302; Inst. Burghersh, 292, 294, 294d.

7 Pat. II Edw. II. pt. I, m. 8.

- Harl. Ch. 83, A 29. same year as 'a very poor place,' and said that instead of the $f_{\mathrm{I}} \mathrm{OO}$ which the king had asked for in his letter, he had only instructed the prior to contribute $£ 20$ towards the loan which was being collected from all the religious houses. ${ }^{\theta}$

The prior, Thomas Dey, with six canons and two lay brothers, subscribed to the Royal Supremacy in $1535^{10}$; and as the house had an income of only $f_{1}$ og $8 s .5{ }^{11}{ }^{11}$ clear, it was surrendered under the act of $1536 .^{12}$

The visitation of Bishop Grossetête in I 249, when Prior Eudo fled to the Cistercians, has been already alluded to. Bishop Buckingham visited the house in $13^{8} 7^{13}$ and reminded the canons, according to the custom of a visitation, of the duties of obedience, silence, assistance in choir, and proper administration of the goods of the monastery. He laid special stress on the necessity of instructing the younger canons in song and in grammar, that they might be fit to perform the divine office. They were forbidden under pain of imprisonment and excommunication to enter taverns in Bedford, or to visit the monastery of Elstow.

Bishop Repingdon ${ }^{14}$ repeated these injunctions not to go to Bedford, or to the abbey of Elstow on any pretext whatever; and one of the canons was forbidden to go outside the cloister at all. The canons generally were not to drink anywhere but in the prior's presence, which seems to imply some laxity in this respect.

When Bishop Grey ${ }^{15}$ visited the priory he found John Wymington, the brother whom Bishop Repingdon had ordered to keep within the cloister, holding the office of sub-prior; he had now to be deposed. There is nothing special in the injunctions of this time which

9 L. and P. Hen.VIII. iv. 1330.

10 Rymer, Fadera, vi. (2), 198.

11 Valor Eccl. (Rec. Com.), iv. Igo, I92.

12 L. and P. Hen. VIII. x. 1238. (List of those houses under $£ 200$ revenue.) The actual date of the surrender is not given, nor the pensions.

19 Linc. Epis. Reg., Memo. Buckingham, f. 342. With regard to Elstow, it should be remembered that the two houses were near together; and also that in 1318, when Hugh de Beauchamp became prior of Caldwell, Elizabeth de Beauchamp became abbess of Elstow. If these two were nearly related, it may have led to a certain amount of intercourse between the two houses, which would be natural enough, and yet call for some care and watchfulness on the part of superiors.

11 Ibid. Memo. Repingdon, 232 (undated).

15 Ibid. Memo. Grey, 200d. Just before this the bishop had ordered the prior and convent to receive back an apostate canon who had repented. 


\section{A HISTORY OF BEDFORDSHIRE}

might point to laxity; the bishop only said that the canons were not to go to Bedford, that hunting dogs were not to be kept in the monastery, and that the common seal was to be kept under lock and key. And it seems that Bishop Longland accused the house of no worse fault than poverty.

The original endowment of the priory cannot be exactly stated, as the foundation charter is not in existence. Robert of Houghton granted to the canons the site of the priory in $1272^{x}$; and in 1336 they held lands and tenements in Bedford, Bromham, Milton, Colesden, Roxton, Chalverston, Sandy, Sutton, Potton, Thurleigh, Holwell, Felmersham and Shelton. ${ }^{2}$ The churches held by the priory in $\mathbf{I 2 9 1}^{3}$ were Oakley with Clapham, Roxton, Bromham, Sandy ; with Marsworth and Broughton in Buckinghamshire and Arnesby in Leicestershire. In 1535 they still remained in its gift, except Broughton and Sandy; Tolleshunt Major in Essex being added. ${ }^{4}$ In $1302^{5}$ the prior of Caldwell held half a knight's fee in Chawston and small portions in Milton Ernest and Eaton; in $1346^{\circ}$ the same half-fee; and until 1346 he held also one quarter of a knight's fee in Edlesborough in Buckinghamshire. ${ }^{7}$ The first report of the Crown bailiff gives a total of $f_{0} 134$ I5s. $8 \frac{1}{2} d$, , including the demesne lands of the priory, the manor of Shelton and divers parcels of land in the counties of Bedford, Warwick, Northampton, Leicester, and the rectories of Clapham, Oakley, Roxton-cum-Colesden, Bromham, Marsworth, Arnesby and Tolleshunt Major. ${ }^{8}$

\section{Priors of Caldwell}

Osbert, ${ }^{8}$ occurs I 78 and I I 86

1 Dugdale, Mon. vi. 39I. Dated 7 July, 57 Henry III.

2 Close, I3 Edw. III. pt. I, m. 38.

3 Pope Nicb. Tax. (Rec. Com.), and the Linc. Epis. Reg. Arnesby had been held since the reign of Henry II. Pat. I3 Richard II. pt. I, m. 2 I.

- Valor Eccl. (Rec. Com.), iv. 189.

- Feud. Aids, i. 9 .

a Ibid. i. 34 .

7 Ibid. i. 74.

8 Dugdale, Mon. vi. 39 I.

9 Harl. MS. 3656 , f. 65, and Gorham, History of St. Neot's, II. lxxiv. (O. prior of Caldwell). Probably not the first prior. A charter of Robert Bruce to Harrold (1 $153-65$ ) is witnessed (Lansd. MS. 391, f. 4b) by "Nicholas Archer, prior of Caldwell, Gosbert, dean of Lincoln, etc.'; but the name sounds unlikely at such an early date; and the chartulary in which it occurs is a transcript of the fifteenth century, and contains mistakes in copying. It is suggested that 'Nicholas
Hugh, ${ }^{10}$ occurs 1200-I

Alexander, ${ }^{11}$ elected 1212, died 1229

William, ${ }^{12}$ elected 1229 , died 1244

Eudo, ${ }^{13}$ elected 1244, resigned 1249

Walter of Caddington, ${ }^{14}$ elected 1249, resigned 1272

Matthew of Bedford, ${ }^{15}$ elected 1272, resigned 1287

John of Yprés, ${ }^{18}$ elected 1287, resigned I3 3

John de Lacu, ${ }^{17}$ elected I 303 , died I 318

Hugh de Beauchamp, ${ }^{18}$ elected 1318, resigned $\mathrm{I} 326$

Roger of Wymington, ${ }^{19}$ elected 1326, occurs I 332

Robert of Lufwyk, ${ }^{20}$ resigned 1338

William of Souldrop, ${ }^{21}$ elected $133^{8}$, resigned 1348

Richard of Hardwick, ${ }^{22}$ elected 1348 , died 1349

Ralph of Derby, ${ }^{23}$ elected I 349, died 1375

Thomas of Stratford, ${ }^{24}$ elected 1375 , died 1396

Ralph Portreeve, ${ }^{25}$ elected 1396, resigned 1397

Thomas Pollard, ${ }^{26}$ elected 1397 , died or resigned 1420

Thomas Bole, ${ }^{27}$ elected 1420 , occurs 1425

John Ampthill, ${ }^{28}$ occurs 1437

John Bedford, ${ }^{29}$ resigned 1479

Richard Derby, ${ }^{30}$ elected 1479

Thomas Cople, ${ }^{31}$ elected I 492, resigned 1509

Archer' ought to be 'Nicholas Archid' (the archdeacon of Bedford from I 145-81).

10 Feet of $F$. (Rec. Com.), 27.

11 Ann. Mon. (Rolls Series), iii. 39 (sub-prior of Dunstable).

12 Ibid. I16.

13 Ibid. 166.

14 Ibid. 179.

15 Ibid. 255.

16 Ibid. 340.

17 Linc. Epis. Reg., Inst. Dalderby, $260 d$.

18 Ibid. f. 276.

10 Ibid. Inst. Burghersh, 298d; Close, 6 Edw.

III. m. I8d.

20 Ibid. 319.

21 Ibid.

${ }_{22}$ Ibid. Inst. Gynwell, f. 376.

23 Ibid. 382.

24 Ibid. Inst. Buckingham, 392.

25 Ibid. 369.

28 Ibid.

27 Ibid. Inst. Fleming, 121 ; Pat. 3 Henry VI. pt. I, m. 2 I.

28 In an old charter in the possession of F. A.

Page-Turner, Esq.

${ }_{29}$ Linc. Epis. Reg., Inst. Rotherham, 132.

so Ibid.

${ }^{31}$ Ibid. Inst. Smith, 457 . 


\section{RELIGIOUS HOUSES}

Robert Hanslape, ${ }^{1}$ elected I 509, resigned 1525

John Biggleswade, ${ }^{2}$ elected 1525, died I 531

Thomas Dey, ${ }^{3}$ elected I 531

The common seal of the priory represented our Lady crowned, and standing with the holy Child in her arms; on the right St. John the Baptist, on the left St. John the Evangelist; the prior kneeling below.

Legend : SIGILLUM COMMU ... ORATUS DE CALDEWELle."

\section{THE PRIORY OF BUSHMEAD}

The Augustinian priory of Bushmead ${ }^{\circ}$ was founded some time during the reign of Henry II. by Hugh de Beauchamp, greatgrandson of the Hugh of Domesday." The exact date is difficult to determine, but it must have been before 1187 , as in that year the founder was slain at the Crusades. ${ }^{7}$ Leland $^{8}$ says that the canons of Bushmead venerated a certain hermit as the founder of their house, and perhaps, like Beaulieu, it was built on the site of an old hermitage; but the first prior was a chaplain of Colmworth named William. ${ }^{9}$ The Beau-

1 Linc. Epis. Reg., Inst. Smith; Harl. Ch. 83, A 29 (June, 1525).

2 Linc. Epis. Reg., Inst. Longland; List of priors who attended convocation, $L$. and P. Hen. VIII. iv. 6047.

3 Linc. Epis. Reg., Inst. Longland, 39d; V alor Eccl. (Rec. Com.), iv. 192. Acknowledgment of Supremacy, Rymer, Fadera, vi. (2), 198.

- B. M. seals, lviii. 30. The same seal is attached to Harl. Ch. 83, A 29. A small seal in white wax of the twelfth century, representing a hand embracing a crutch, with the legend sIGILL' PRIORIS DE CALDEWELLE, is mentioned by Gorham, History of St. Neot's, II. Ixxiv.

5 Besides the charters in Dugdale, Mon. vi. 280, there is a chartulary of the priory in the possession of W. Hugh Wade-Gery, Esq., of Bushmead, of which an abstract was printed in Beds $N$. and $Q$. iii. 130-45. All references to the chartulary given below are taken from this account.

- The genealogy followed here is taken from the chartulary of Warden (Add. MS. 24465, ff. $3 \mathrm{Ib}, 39$ ), which states that Hugh of Domesday had two sons: Payn, baron of Bedford, and Simon, whose son Hugh married the heiress of Eaton, and founded the other line of Beauchamps; Hugh's son was Oliver, who had a son Hugh, founder of Bushmead Priory. The Bushmead foundation charters are granted by 'Hugh son of Oliver.' This genealogy is not the same as that in Dugdale's Baronage, 224-5.

7 Ibid. 225, from Roger of Hoveden.

a Leland, Coll.i. 68.

9 Named in the foundation charter (Dugdale, Mon. vi. 280).

I champs of Eaton Socon retained the patronage of the house until the middle of the fourteenth century, when it passed to Sir John Engayne, ${ }^{10}$ and later to the Braybrooks. ${ }^{11}$ Sir Gerard Braybrook, who died in 1427 , and was buried in Colmworth church, left directions in his will for the prior of Bushmead to sing his requiem. ${ }^{12}$ Other benefactors were Simon de Pateshull and several members of the family of Wildeboef of Eaton. ${ }^{13}$ The earliest papal bull securing special privileges to the house was that of Innocent III. in 1198.14 The canons were probably few in number even in the thirteenth century, as their total income in $129 \mathrm{I}^{15}$ was only about $£ 25$; a prior and three canons are mentioned in $1283,{ }^{16}$ and the same number appears in a charter of 1523,17 and in the acknowledgment of the Royal Supremacy a little later. ${ }^{18}$ The house has no history to speak of ; it is only once mentioned in the Annals of Dunstable, under the year $1249,{ }^{19}$ when the prior was present, with the heads of the other Augustinian houses of the county, at the visitation held by Bishop Grossetête at Caldwell, and joined them in counselling Prior Eudo to resign. In $\mathbf{I}_{28} 3$ the prior, Richard Foliott, and three of his canons, with four other persons, were accused by Agnes de Legh

10 Bushmead Chartul., No. 30 (dated 1346). Confirmation of Sir John Engayne (Add. MS. 24465, f. 3 Ib).

11 Henry Braybrook was among the earlier benefactors (Bushmead Chartul., Eaton Charters, Nos. 32, 69 [mentioned with Prior Joseph]).

12 His will (in the Lamb. Lib.) is printed in Beds $N$. and $Q$. ii. 222. It has some interesting directions. On the day after his death was to be said a mass of our Lady and a requiem by note, with two wax tapers each of twelve pounds weight standing the one at his head and the other at his feet all through the service, and twelve poor men clothed in russet frieze, each of them holding a torch throughout the service. Every poor person at the funeral was to have $4 d$., and the prior of Bushmead to do the service and have for his travail $6 s .8 d$., and every canon of his house that was present $3 s .4 d$., and all other priests I $2 d$.

13 Bushmead Chartul, Eaton Charters, Nos. 34, 35, 56-61 ; Foundation Charter, Dugdale, Mon. vi. 280 .

14 Bushmead Chartul. No. I. Other bulls were granted by Honorius III., Gregory VIII. and IX., and Innocent IV.

15 Pope Nich. Tax. (Rec. Com.)

16 Pat. I I Edw. I.m.I3d. An appeal made against Richard Prior, and 'three canons of the house,' which does not necessarily imply that there were no more at that time.

17 Harl. Ch. 83, A 28.

18 Rymer, Fadera, vi. (2), 199.

10 Ann. Mon. (Rolls Series), iii. 178. 


\section{A HISTORY OF BEDFORDSHIRE}

of having been the cause of her son's death ${ }^{\mathbf{1}}$; and in 1342 Prior Robert of Lubenham was involved in a suit with the abbot of St. Alban's about the manor of Caldecote in Herts, which he claimed against a tenant of the abbot's, but finally quitclaimed before the day appointed for the hearing of the case. ${ }^{2}$ The episcopal registers contain very few references to Bushmead, and not a single visitation is recorded. It may be gathered from this source that the conventual church was rebuilt, like so many others, early in the fourteenth century, but the canons were too poor to complete it without a licence to beg ${ }^{a l m s}{ }^{3}$; and that about the same time a canon who had left the monastery 'through levity of mind, and wandered about in secular habit, returned penitent, but found his prior unwilling to receive him back.. ${ }^{4}$ About the same time another of the canons, Richard of Stoughton (who was afterwards prior and probably died of the pestilence), obtained a licence from the bishop to keep a school of sixty boys, and teach them 'the science of grammar' 5 ; but it is not known how long this good work was continued. As the income of the house was less than $£ 100$, it was surrendered under the act of 1536 (probably on 8 February), and the prior received a pension of $f_{8 .}^{\circ}$

The priory was dedicated to St. Mary, and its first endowment by Hugh de Beauchamp and his brother Roger included very little more than the site, with certain rights of way, wood, water and pasture, and the tithes of Eaton Park ; but by 1 236 a number of small rents and parcels of land had been added, not only in the county of Bedford, but also in Huntingdon, Cambridge, Northampton, and

1 Pat. I Edw. I. m. I3d. Nothing further is known of the circumstances, but it may have been a similar affair to that of Christine Mustard, who accused the prior and some canons of Dunstable of causing the death of her husband (Ann. Mon. [Rolls Series], iii. 298, 306). He was really killed at a wrestling match before the hospital of Hockliffe, at which the canons of Dunstable were present.

2 Gesta Abbatum Mon. S. Albani (Rolls Series), ii. 330 .

${ }_{3}$ Linc. Epis. Reg., Memo. Dalderby, I63d (1310); ibid. Memo. Burghersh, 2I, 35d (I32I). (Indulgences for the fabric, and a licence to beg alms.)

- Ibid. Memo. Burghersh, 75d, 77d.

- Ibid. 246d (1332).

- L. and P. Hen.VIII. x. 1238 ; xiii. (1), 1520. The latter, which is a list of pensions paid 28 Henry VIII., has the date $8 \mathrm{Feb}$. after the name of the prior of Bushmead.

7 Dugdale, Mon. vi. 281-2.
Hertford ${ }^{8}$ with the manor of Blisworth, Northants. ${ }^{9}$ The total income of the priory in $129 \mathrm{I}$ was however only $£ 25 \mathrm{I} 3$ s. 7 d. $^{10}{ }^{10}$ a taxation recorded in its chartulary gives a total of $£ 35$ 19s. $4 d^{11}$ The advowson church of Caldecote, Herts, was granted to the prior and convent in $1283,{ }^{12}$ but they do not seem to have retained it long. In 1302 the prior held only one-fortieth of a knight's fee of the barony of Eaton. ${ }^{13}$ The valuation of 1535 amounted to $£ 7$ I I 3 s. 9 d. $;^{14}$ and that which was made immediately after the dissolution to $f_{8} 8$ 19s. $8 \frac{3}{4} d .^{15}$ (all in small sums except the demesne lands, which were worth $f_{20}$ Is. 4d.)

\section{Priors of Bushmead}

William, first prior ${ }^{16}$

Joseph of Copmanford, ${ }^{17}$ occurs 123 I

John de Wildeboef, ${ }^{18}$ elected 1233 , died 125 I

Simon of Colesden, ${ }^{19}$ occurs 1260

Richard Foliott, ${ }^{20}$ occurs 1283 , resigned 1298

Simon of Redburn, ${ }^{21}$ elected I 298, resigned I 321

Robert of Lubenham, ${ }^{22}$ elected 1321, resigned 1348

8 Bull of Gregory IX. dated I236 (Cott. MS. Aug. ii. I I 7).

- Dugdale, Mon. vi. 282, charter of Isabel Pauncefote, and of her daughters, confirming the same. Neither is dated, but the name of Blisworth is on Pope Gregory's bull and in Pope Nich. Tax. (Rec. Com.) among the temporalities of the priory.

10 Pope Nich. Tax. (Rec. Com.)

11 Bushmead Chartul. (undated).

12 Pat. II Edw. I. m. I3. Licence for alienation in mortmain by William de Hurst of the advowson of the church of Caldecote, and a carucate of land.

13 Feud. Aids, i. $15 . \quad 14 \mathrm{Valor}$ Eccl. (Rec. Com.)

15 Dugdale, Mon. vi. 283.

16 Foundation Charter, Dugdale, Mon. vi. 280. The following list of names is taken as it stands from the Bushmead Chartulary, where however no dates are given, only the time that each prior was in office. Fortunately the dates can be supplied for nearly all from other sources.

17 Bushmead Chartul. under Barford Charters, reference to Joseph, I23I.

18 Linc. Epis. Reg., Rolls of Hugh de Wells (on the resignation of Joseph). The Bushmead Chartul. adds : ' qui obiit monachus Wardon, 1251.'

19 Bushmead Chartul. Stilton Charters.

${ }_{20}$ Pat. I I Edw. I. m. I3 d.

21 Linc. Epis. Reg., Inst. Sutton, 104; Jocelyn of Stoughton, the cellarer, was elected, but Simon accepted by the bishop. The chartulary gives him fifty years of office, which the registers do not corroborate.

${ }_{22}$ Ibid. Inst. Burghersh, 29I. This prior has thirty-four years assigned him, which is again in excess of the interval between the institutions. 


\section{RELIGIOUS HOUSES}

Richard of Stoughton, ${ }^{1}$ elected 1348, died 1349

Simon of Grantesden, 2 elected 1349, resigned $135^{\circ}$

Adam of Leverington, elected 1350, resigned 1355

John of Risley, ${ }^{3}$ elected $\times 355$, resigned 1385

William of Lidlington, ${ }^{4}$ elected 1385

William Chanewe, ${ }^{5}$ elected 1444, resigned 1465

William Stoughton, elected 1465, died I 473

Thomas Stoughton, elected 1473, resigned $148 \mathrm{I}$

Robert of Potton, elected I481, resigned 1482

John of Bosworth, elected I 482, died I 493
Gregory Norwich, elected 1493, resigned I 510

Nicholas Smith, elected $1510,{ }^{10}$ resigned I 531

Richard Rogers, ${ }^{11}$ elected 1531, died I 531

Robert Burre, ${ }^{12}$ elected 1531

The seal of the priory, affixed to Harl. Ch. $83, \mathrm{~A} 28$, is in excellent preservation, representing our Lady seated with the holy Child on her knee, a bishop with crosier on either side, and the prior crouching below. Legend: PRESULIS IN PRATO ${ }^{13}$ FaMULOR DE virgine Nato. Reverse: the Assumption, our Lady encircled by angels, a crown suspended above her head. Legend : s. ECCLIE ET CONVENTUS SCE MARIE DE BISSEMEDE.

\section{HOUSE OF AUSTIN NUNS}

\section{THE PRIORY OF HARROLD}

The priory of Harrold was probably founded between 1140 and $1150,{ }^{6}$ on land which was then a part of the honour of Huntingdon, and held by Sampson le Fort ${ }^{7}$ of the Scottish kings. The site of the priory with the churches of St. Peter, Harrold, and Brayfield (Northants) was originally granted to Gervase, abbot of St. Nicholas of Arrouaise, that he might send there some nuns of his $\operatorname{order}^{8}$ : they were at first governed by a prior, with a few canons, ${ }^{9}$ to protect or guide the

1 Linc. Epis. Reg., Inst. Gynwell, 375.

2 Ibid. $362 \mathrm{~d}$. He is said in the chartulary to have resigned after a year and a day, and his successor in 29 Edward III., which corresponds with the next institution.

${ }_{3}^{3}$ Ibid. 393. He is said to have been prior twenty-eight years.

4 Ibid. Inst. Buckingham, 344.

- Ibid. Inst. Alnwick, 184d.

- One confirmation charter of Malcolm IV. (I I53-65) speaks of all the lands which they held in the time of his father and grandfather; and the first charter of Sampson le Fort speaks of the assent and consent of Alexander, Bishop of Lincoln, who died in II 48 (Lansd. MS. 39I, ff. 4, 6).

I'Sampson Fortis' is the name on the charters; but $H$ und. R. (Rec. Com.), ii. 329 speaks of 'Sampson le Fort' as donor of the church of Harewold.

8 The charters of Sampson le Fort and of Simon, Earl of Northampton, were made direct to Gervase, - ad sustentationem sororum suarum sanctimonialium super ecclesiam de Harewolde' (Lansd. MS. $39 \mathrm{I}, \mathrm{ft} .4,5)$.

$\theta$ The prior and canons are mentioned in one charter of Malcolm IV. (Lansd. MS. 391, f. 6); sisters 'according to the institutions of St.

another has 'sororibus et fratribus eas tuentibus secundum institutiones ecclesix Sancti Nicholai de Arrowasia ' (ibid. f. 5), and that of Simon, Earl of Northampton, has 'sororum sanctimonialium et cum eis Deo servientium '; one of Sampson le Fort has only the sisters (ibid. f. 4), and another the 'brothers and sisters' (Dugdale, Mon. vi.). It seems fairly clear that the sisters were the first consideration, and that the brothers were only there for the sake of the sisters (as originally in the Gilbertine rule). It would be easier to speak with confidence if there were any other house of Arrouasian nuns besides this with which to compare it ; but though there were plenty of houses of Arrouasian canons (Nutley, Bourne, St. Peter's Dorchester, etc.), this appears to be the only house of nuns of this order in England.

${ }_{10}$ Linc. Epis. Reg., Inst. Smith, f. 458. Formerly prior of Huntingdon (Dugdale, Mon. vi. 280). L. and P. Hen. VIII. iv. 6047 (Convocation of I529). The five intervening names are given from the chartulary, reckoning the years backwards from Nicholas Smith, in the hope that the later entries are more correct; which at last leaves only twenty years for William Chanewe instead of twenty-five. In the original they stand thus: William Chanewe (or Chanu), twenty-five years; William Stoughton, eight years; Thomas Stoughton, eight years; Robert Potton, one year; John of Bosworth, eleven and a half years; Gregory Norwich, seventeen years.

11 Linc. Epis. Reg., Inst. Longland, 249 (Chartulary: 'quondam prior de Broke et prior istius ecclesie qui obiit post secundam mensam prelationis Suæ $A^{\circ} D$. $153 I^{\prime}$ ').

12 Ibid. $246 \mathrm{~d}$.

18 An allusion to the name Bissemede (Bishop's mead). 


\section{A HISTORY OF BEDFORDSHIRE}

Nicholas of Arrouaise.' $\quad$ The priory has some distinguished names amongst its earlier benefactors. Sampson le Fort's charter was probably confirmed first by David I. of Scotland and his son Henry, Earl of Huntingdon, ${ }^{2}$ and certainly afterwards by Malcolm IV., ${ }^{3}$ William the Lion, ${ }^{4}$ Simon, Earl of Northampton, ${ }^{5}$ and Robert Bruce ${ }^{6}$; while Baldwin des Ardres, Count of Guisnes, granted to the nuns the church of Stevington before $1153{ }^{7}$ and the name of Roger de Quincy, ${ }^{8}$ constable of Scotland, appears later. Before the year I I 8 I however the prior and canons had ceased to exist, and the nuns were making efforts to free themselves from immediate subjection to the abbot of Arrouaise; and after appeals from both parties to Pope Alexander III. the matter was finally referred to the arbitration of St. Hugh of Lincoln. Robert of Bedford, the precentor of the cathedral, was sent to treat with the abbot of Missenden, who was acting as proctor to the abbot of Arrouaise; and the result of his negotiations was that Gervase set the nuns free for ever from subjection to the parent abbey, and yielded to them the two churches of Harrold and Brayfield, with all the other gifts of Sampson le Fort, on condition that they paid half a mark yearly to the abbot of Missenden. ${ }^{9}$ Thenceforward until the dissolution the convent was ruled by a prioress, ${ }^{10}$ having sometimes a warden or master, ${ }^{11}$ like other small houses of nuns, and at one time a few lay brothers. ${ }^{12}$ Of the

1 The charter of Malcolm IV. (Lansd. MS. 39I, f. 6) speaks of lands held in the time of his father and grandfather.

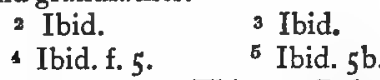

- Ibid. f. 4. This was Robert de Bruce, son of Payn de Bruce, who held lands in Bedfordshire in II3I (Pipe R. [Rec. Com.], I03).

7 Lansd. MS. 39I, f. IIb; it was confirmed by 'Eustace the king's son, which must be before II 53. 8 Ibid. f. I3.

The whole of this transaction is found in Lansd. MS. 39I, ff. I8b, I9; but it is dated quite clearly 1288: which is manifestly impossible. It may perhaps be a mistake for I I88, which would do quite well for St. Hugh and Robert of Bedford. At the same time it seems extraordinary that Gervase, who was made abbot of Arrouaise in 1124 (Helyot and Bullot, Hist.de Ordres Mon. ii. 107), should still be abbot in 1188 . Gervase's name also appears on the foundation charter of Bourne, 1138 .

10. A prioress is first mentioned in connection with Harrold early in the thirteenth century (see list of prioresses).

11 Linc. Epis. Reg., Memo. Sutton, 14.

11 Ibid. Memo. Dalderby, $3 \mathrm{I}$, "To the prioress and convent of Harewold, to receive back a brother who being professed returned to secular life.' number of the nuns there is no indication until the very end, when there were only six at the outside. Nor is it easy to discover whether in giving up their direct connection with the abbey of Arrouaise, they ceased at once to observe the Arrouasian rule and to wear the habit of that order ; or whether, as seems more likely, the change was later. ${ }^{13}$ At the dissolution they were reckoned as ordinary Austin canonesses. ${ }^{14}$ The house has very little history of any kind. The chartulary in the British Museum, ${ }^{15}$ which contains an abstract of the charters in the possession of the priory in the reign of Henry $V$., shows various small grants of lands and tenements in Bedfordshire, and a few suits concerning churches. ${ }^{16}$ The latest item of importance is an account of the impropriation of the church of Shakerstone in $1416 .{ }^{17}$ Early in the thirteenth century the advowson of the priory was probably held by Ralf Morin of Harrold and his son John, ${ }^{18}$ and in 1279 certainly by Sir John de

13 Most of the other Arrouasian houses lost their distinctive features and became Augustinian before the dissolution, except Nutley and St. Peter's, Dorchester. There was probably never much distinction. The order of St. Nicholas of Arrouaise in Artois was founded by Heldemar of Tournay and his hermit companions in 1090 (Helyot and Bullot, Hist. des Ordres Mon. ii. I07), about the same time that the Augustinian order was being reformed or re-organised on the basis of the rule taken from St. Augustine's letter to certain religious women (No. 2I I, ed. Migne), and quite independently; but afterwards it was looked upon as merely a branch of the Augustinian order, so much so that the abbot of St. Peter's, Dorchester, was fined for not appearing at the last great chapter of the order, though he pleaded that his house was Arrouasian, and that he was not therefore bound to come (Cott. MS. Vesp. D i. f. 64). The Arrouasian canons originally wore a white habit and no linen ; they ate no meat, and kept a strict rule of silence (Hist. des Ordres Mon. ii. I07).

14 Leland-quoted Dugdale, Mon. vi. 330.

15 Lansd. MS. 391.

18 Stevington was claimed by the son of Baldwin des Ardres, but finally quitclaimed (ibid. f. I2b), and confirmed by John to the nuns of Harrold (Chart. R. 7 John, m. I). The same church was again claimed in 1405 by Philip de Cornewayle, lord of Stevington, by right of his wife Constance, Countess of Huntingdon; but awarded to the prioress by Bishop Repingdon (Lansd. MS. 39r, $\mathrm{f}$. I3b). The church of Brayfield was also disputed at one time (ibid. f. I 5 b).

17 Ibid. f. 18 (dated $\mathrm{r}_{4} \mathrm{r} 6$ ) and $58 \mathrm{~b}$; also Pat. 7 Henry V. pt. 2, m. 39 ; and Linc. Epis. Reg. Mem. Repingdon, 128d, 129.

18 There are several charters between Ralf and John Morin and the prioress (Lansd. MS. 39r, ff. $7 b, 8)$; and Ralf Morin in 1203 accused the 


\section{RELIGIOUS HOUSES}

Grey. ${ }^{1}$ The name of Sir Gerard Braybrook $^{2}$ occurs frequently in some later charters. The last patron of all was Lord Mordaunt of Turvey, one of whose ancestors had witnessed a foundation charter of the priory. The house was probably never very rich, though no exact statement of its income can be made earlier than the dissolution.

During the time of Bishop Sutton, in 1 298, a nun of Harrold was found guilty of a breach of her vow of chastity $;^{3}$ and in I3 I I Bishop Dalderby issued a commission for the visitation and correction of this house amongst others. ${ }^{4}$ No account of this visitation is preserved, nor are any others recorded; only in $1369^{5}$ Bishop Gynwell appointed Dame Katherine of Tutbury (afterwards prioress) to administer the revenues of the priory during vacancy, and to reform excesses. It may be that during her term of office the house was well governed, and had a better reputation; but this is of course mere conjecture. The name of this prioress and her successor, Emma Drakelowe, are found in many of the charters relating to tenements and leases in the chartulary. Nothing further is known of the state of the priory, internal or external, until it was visited by Dr. Layton in $1535,{ }^{6}$ with other houses in Bedfordshire. If the accusations contained in his letter to Cromwell were true, the priory had certainly ceased to be in any real sense a religious house. He declared that he found there a prioress and four or five nuns, of whom one had 'two fair children' and another 'one child and no more'; and also describes how Lord Mordaunt had induced the prioress and her 'foolish young flock' to break open the coffer containing the charters of the priory,

nuns of trespassing on his lands, assarting his woods, etc., while he was disseised of them for the king's service (Cur. Reg. R. 27, 4 John, n. 2). In 1226 Ralf Morin claimed the church of Eythorne, Kent, against the Archbishop of Canterbury, who vouched to warrant the prioress of Harrold, who claimed that she and her nuns held the church by gift of Ralf's father Ralf. Ralf replied that they were only entitled to a pension of $£_{2}$ a year from the church under a charter of the archbishop (Bracton's Note Book, iii. 543).

1 Hund. R. (Rec. Com.), ii. 329.

2 Lansd. MS. 39I, f. 44.

3 Linc. Epis. Reg., Memo. Sutton, rg2d. The partner of her guilt was condemned to be beaten through the market-place of Harrold; and when he refused to submit, excommunicated.

4 Ibid. Memo. Dalderby, $202 \mathrm{~d}$.

- Ibid. Memo. Gynwell, 83 . xlii.)

c Wright, Suppression of Monasteries, 9r (Letter and to seal a writing in Latin of which they did not understand a word, but were told it was merely the lease of an impropriate benefice. 'All say they durst not say him nay,' he adds; 'and the prioress saith plainly that she would never consent thereto.'

In the case of Chicksand, which is charged with similar misdoings in the same letter, the very form and content of the accusation challenge criticism at once. But if the charges laid against Harrold are denied, it can only be on the simple ground that Layton is a discredited witness. There is no actual evidence for or against his statements. But unhappily there is nothing at all improbable in the story of Lord Mordaunt and the charters. The patron of a house so small and so poor would be in a position to take a very high hand with the little convent, especially as one or two of the nuns would very likely be members of his own family. However this may be, the house was certainly dissolved under the Act of 1536 , and a pension of $£ 7$ assigned to the prioress, Elinor Warren."

The priory was endowed by Sampson le Fort with the churches of St. Peter, Harrold, and Brayfield, Northants, with their appurtenances, and a few acres of land besides. ${ }^{8}$ The church of Stevington ${ }^{2}$ was added soon after, and that of Shakerstone (Leicester) in the fifteenth century. ${ }^{10}$ No statement can be made as to the value of its lands in the thirteenth century, as it is not mentioned at all in the Taxatio of Pope Nicholas, nor in the Feudal Aids. The total income of the priory in 1535 was $£_{4} 40 \mathrm{I} 8 \mathrm{~s} .2 \mathrm{~d} . ;^{11}$ the first valuation after the dissolution, in 1536 , amounted to $£, 57$ Ios., including the four rectories mentioned above, with small parcel of land, rents and tenements in the counties of Bedford, Huntingdon and Buckingham. ${ }^{12}$

\section{Prioresses of Harrold}

Agnes ${ }^{13}$ died 1245

Basile $^{14}$ de la Legh, elected 1245, occurs 1252

7 L. and P. Hen. VIII. xiii. (1), 1520.

B Lansd. MS. 39I, ff. 4-6.

I Ibid. f. 12.

10 Ibid. f. $18 \mathrm{~b}$.

11 alor Eccl. (Rec. Com.), iv. 204.

12 Dugdale, Mon. vi. 331.

13 Occurs Lansd. MS. 391, f. 37 ; and Epis. Linc.

Reg. Rolls of Grossetête (at the election of the next prioress), 1245 .

14 Linc. Epis. Reg., Rolls of Grossetête; her name occurs under the date II November 1245 in Lansd. MS. 391, f. 37 ; and in Willis's Hist. of Bucks, p. 159 (1252). 


\section{A HISTORY OF BEDFORDSHIRE}

Juliane ${ }^{1}$

Amice, ${ }^{2}$ occurs 1264 and 1268

Margery of Hereford, ${ }^{3}$ resigned 1304

Cecily de Cantia, elected 1304

Petronilla of Radwell, ${ }^{5}$ elected I335, resigned 1354

Christine Murdak, ${ }^{6}$ elected 1354, resigned I 357

Maud de Tichemersh, ${ }^{7}$ elected 1357, occurs 1364

Katherine of Tutbury, ${ }^{8}$ elected ${ }^{1369}$, occurs 1384

Emma Drakelowe, ${ }^{9}$ occurs I 405 and I 4 I 3
Elizabeth Chiltern, ${ }^{13}$ resigned 1470

Margaret Pycard, ${ }^{14}$ elected 1470

Helen Crabbe, ${ }^{15}$ died 1501

Eleanor Pygot, ${ }^{16}$ elected I 501, died 1509

Agnes Gascoigne, ${ }^{17}$ elected 1509

Elinor Warren, ${ }^{18}$ surrendered 1536

The seal of the priory represented St. Peter, standing, in mitre and chasuble, two keys in the right hand and a crosier in the left. The legend is very indistinct, only the last two words being legible ... PETRI CATENAS. ${ }^{19}$

\section{HOUSE OF THE GILBERTINE ORDER}

\section{THE PRIORY OF CHICKSAND}

The Gilbertine priory of Chicksand was founded about the year I I 50 by Roais ${ }^{10}$ and her husband Payn de Beauchamp, baron of Bedford. The foundress had been previously the wife of Geoffrey de Mandeville, Earl of Essex, who died in I I 44, and was buried in the abbey of Walden, which he had founded some years before. ${ }^{11}$ After the death of her second husband, the Countess Roais was frequently at Chicksand, and when her eldest son, ${ }^{12}$ Geoffrey de Mandeville, died in

1 Occurs Lansd. MS. 39I, f. 8, in an agreement with Ralf Morin, witnessed by W. de Beauchamp (i.e. before 1260, if this, as seems probable, was the elder William, whose charter to Chicksand Ralf Morin witnessed (Dugdale, Mon. vi. 950).

2 Ibid. ff. 8, 13 .

- Occurs ibid. f. gb with Sir John de Grey; and Linc. Epis. Reg., Inst. Dalderby, 26I.

- Ibid. 26I (John de Grey, patron).

- Ibid. Inst. Burghersh, $320 d$.

- Ibid. Inst. Gynwell.

7 Ibid. 397 ; Lansd. MS. 39I, 44.

8 Linc. Epis. Reg., Inst. Gynwell, 83 ; Lansd. MS. 391,35 , etc.

8 Lansd. MS. 39I, ff. I 3 b, 34b, etc.

10 It seems proper to put Countess Roais first, because the priory was always called her foundation, though it was endowed with lands of the Beauchamps. The witnesses to the foundation charter are Henry Murdak, Archbishop of York 1146-53, and Nicholas, archdeacon II45-8I (Dugdale, Mon. vi. 950). Also in it Payn de Beauchamp and his wife ask the prayers of the nuns for their son Simon; but Geoffrey de Mandeville did not die till 1144 , and therefore Simon could not have been born much before Ir 46 .

11 Dugdale, Mon. iv. 142-3 (Chronicle of Walden Abbey).

12 The chronicler of Walden Abbey says that she
I I66, she endeavoured to secure his burial there; but being defeated in this purpose by the monks of Walden Abbey (who naturally desired that the son of their founder should be buried in their church) she retaliated by carrying off the whole furniture and hangings of his private chapel for the adornment of her own priory. ${ }^{20}$

did her best to draw away the hearts of her sons from their own abbey to the priory of Chicksand, which she was then building (ibid.)

13 Linc. Epis. Reg., Inst. Chedworth, 178.

14 Ibid.

15 Ibid. Inst. Smith, 443d.

16 Ibid.

17 Ibid. 457 d.

18 L. and P. Hen.VIII. xiii. (I), 1520. On the fly-leaf of Lansd. MS. 39I is written : 'Prioresses occurring in this book: Juliana abt. I25I, Agnes I257, Amicia 1260 and I 265, Matildis about I280, Cecilia I3I2, Margeria de Hereford I340, Katherine Tutbury and Emma Drakelowe.' The same list is given in Tanner, Not. Mon. 'from a MS. in the possession of Walter Clavel' (probably the Lansdowne MS.), and in Dugdale, Mon. vi. 330. It has not been followed here, because it is very difficult to make the dates on the fly-leaf correspond with those in the chartulary. The only Agnes who occurs is certainly earlier than Basile; and the latter name, which is quite distinct in the chartulary, with the date 30 Henry III., is not found on the fly-leaf at all; and Margery of Hereford is plainly misdated 1340 .

19 The same seal, much defaced, is attached to Add. Ch. 15726.

${ }^{20}$ Dugdale, Mon. iv. I42-3. The story is rather an amusing one. As soon as Geoffrey died, his followers proceeded at once with his body to Saffron Walden, without sending any message to Countess Roais, whose masterful disposition they evidently knew well : but a certain clerk escaped from their company and carried the message to her at Chick- 


\section{RELIGIOUS HOUSES}

The countess was herself buried at Chicksand; and the wife of Geoffrey Fitz Piers, the heiress of the Mandevilles, was at first laid in the same church, though she was afterwards carried to Shouldham Priory." Simon de Beauchamp and his son William confirmed the gifts of Payn and Roais. ${ }^{2}$ The priory was well endowed, and able at first to support a large number of canons, nuns and lay brothers-perhaps as many as a hundred; but after a succession of bad seasons (which were felt with almost equal severity at Dunstable and other religious houses of the neighbourhood) its resources were so much diminished that in 1257 fifty of the nuns and ten lay brothers had to be dispersed among other houses of the order. ${ }^{3}$ The priory of Chicksand did not recover its prosperity for a very long time. In $1307^{4}$ the nuns received a grant of forty acres of land in the neighbourhood, and the whole manor of Chicksand was confirmed to them ten years later ${ }^{5}$ but they were nevertheless in very heavy debt at the time and continued to be so for a good while after. In $1309^{\circ}$ the prior of Chicksand, William de Hugate, borrowed 100 marks from the prior of Newnham, but this was only a small item. Another prior, John, in $1324^{7}$ acknowledged a debt of 400 marks to a merchant of Florence ; and not long after he owned himself to be under a bond for 3,300 gold florins, for which he was obliged to demise to his creditor for life the manor in Meppershall called 'the chapel of St. Thomas,' with the grange of Haynes, for $£_{200}$ a year; besides selling two

sand. Whereupon she gathered a band of armed retainers in great haste and came up with the train, and ordered it to proceed at once to Chicksand. But early the next morning the servants of the earl turned the bier the other way, and drove it triumphantly to Walden before she could prevent it. As soon as the body was safely laid before the altar in his church, the abbot sent word to Roais, and kindly invited her to the funeral! This is on the authority of the Walden Chronicle, but the dates of the death of the two Geoffreys are taken from Round-Geoffey de Mandeville. The energetic character and strong personality of this lady may account for the tradition which made her foundress also of Newnham Priory, especially as the real founder, her son Simon, was very young at the time when he translated there the canons of St. Paul's.

1 Leland, Itin. i. I I6, and Dugdale, Mon. vi. 975.

2 Dugdale, Mon. vi. 950.

3 Ann. Mon. (Rolls Series), iii. 205.

- Inq. ad q. d. I Edw. II. n. 95.

5 Pat. Io Edw. II. pt. ii. m. 29.

- Harl. 3656, f. 77.

7 Close, 17 Edw. II. m. 22d. woods, and granting the fruits of the church of Haynes for seven years. ${ }^{8}$ Simon his predecessor had demised to the same creditor, a merchant of Genoa, the manor of Wolverton, Bucks. ${ }^{9}$ An agreement was made by which the alienation of the property in Haynes and Meppershall was to be averted by the payment of $£_{1}, 200^{10}$ in instalments; and it seems that this sum was finally paid, ${ }^{11}$ for the grange of Haynes and manor of Meppershall were still a part of the property of the priory at the dissolution. But the whole convent was in sore straits for many years. Four times ${ }^{12}$ between 1340 and 1347 the prior was obliged to sue for a remission of the tenths due to the king ; on the first of these occasions he pleaded that all his lands, manors and churches were in the hands of creditors, and that his brethren and sisters knew not how to live, although many of them had been sent away already to other houses of the order; and the second pardon was granted on the ground that the religious were so poor that they were unable to give alms or carry on any of their ordinary works of charity. In the midst of this distress came the great pestilence; its effects on this particular priory are not known, but it must in one way or other have made matters worse, and it is probable that the number of canons and nuns at Chicksand was never again so large as in the early part of the thirteenth century. During the last hundred years of the priory's existence its material prosperity seems to have been restored in some measure; but the deed of surrender gives the names of only eight canons and eighteen nuns. ${ }^{13}$

Of the internal history of the convent from 1150 to 1535 scarcely a trace remains. In 1324 , the time of their great poverty, the king placed one of his wards under the charge of the nuns of Chicksand ; ${ }^{14}$ from which we may gather that they, like other religious of less strict enclosure, took boarders from time to time for the support of the house. At the

8 Ibid. I8 Edw. II. m. 4 .

- Ibid.

10 Ibid.

11 An instalment of $£ 300$ was paid at the time of the agreement.

12 Close, 4 Edw. III. m. 24 ; ibid. 5 Edw. III. pt. I, m. I; Pat. 9 Edw. III. pt. I, m. I4; Pat. II Edw. III. pt. 3, m. 28.

13 Deed of Surrender (P.R.O.), No. 56.

${ }_{14}$ Close, 17 Edw. II. m. I 5. Three daughters of the Mortimer family were placed in three different Gilbertine monasteries, with an allowance according to their ages. For the youngest, Isabel, the prior of Chicksand was to receive I2d. weekly, and a mark yearly at Michaelmas. 


\section{A HISTORY OF BEDFORDSHIRE}

time of the dissolution it seems that there were only two prioresses ${ }^{1}$ instead of the three prescribed by the rule; but there is no means of finding out whether this was only an accident or whether it was a change of custom. The Gilbertines were exempt from episcopal visitation; and beyond a few grants of indulgences for their chapels and altars, no mention is made of Chicksand in the Lincoln registers. ${ }^{2}$ The argument from silence is not a very valuable one; but in the case of such an order as this, it is certainly the evidence which the nuns themselves would have preferred, if they were faithful to the spirit of their rule. In passing from the rule of St. Benedict to that of Sempringham, we enter a wholly different atmosphere, and have to do with quite another ideal in the religious life. The rule of St. Benedict owes its great and lasting influence mainly to the fact that its author sought to define and organise the normal religious life, to establish a 'school of the service of the Lord' in which large numbers of very varying disposition and attainment might live together in unity. In consequence of this aim his rule is as broad as it is high, and has as much power to tranquillise as to inspire. But the ideal of the Gilbertines was strictly an ascetic one, for the few and not for the many ; and their rule is full of petty regulations and restrictions which would be intolerable to all but those who sought after a 'strange and separate perfection'; who desired not merely to be free from the 'evil that is in the world,' but to shut the world out utterly and for ever. No doubt after a time their asceticism, like that of the Cistercians to whom they were so closely allied, became much modified; but so long as the rule in its main outlines remained the same, nuns of such strict enclosure, separated alike from their brethren in the order and the world outside, bound even to recite their office in so low a tone that it could scarcely be heard beyond the party wall of their choir, ${ }^{3}$ could wish no higher praise than that of being quite unknown. The evil report which Lay-

1 Wright, Suppression of Monasteries, 9I, Letter xlii.

2 Linc. Epis. Reg., Memo. Dalderby, 49d; for the altar of the B.V.M. in the conventual church; ibid. Memo. Burghersh, 28d; the same for the altar of St. Katherine; ibid. Memo. Repingdon, 37, the same for the chapel of the B.V.M. in the priory of Chicksand.

${ }_{3}$ The rule of St. Gilbert is given at length in Dugdale, Mon. vi. x.-rcix.; and summarised in Miss R. Graham's St. Gilbert of Sempringham and bis order; which contains also some of the above references to the Patent and Close Rolls. ton gave them at the last is worth very little consideration. He clearly testified that he found them strictly enclosed; and also that the charges which he laid against two of the nuns on the evidence of 'an old beldame' were absolutely denied by the accused, by their two prioresses, and by all their sisters. If the character of the ladies of the convent (we might add also, the ladies of the Hall) were to stand or fall by the testimony of the village gossips and their own dismissed servants, it would have a poor chance at any period of history.

In spite of Layton's charges, the priory of Chicksand was not surrendered till 22 October I $538,{ }^{5}$ and pensions were then assigned to all the canons and probably all the nuns also; the prioresses received $f_{3} 6$ s. 8d. each."

Payn and Roais de Beauchamp endowed the priory at its foundation with the church of Chicksand and lands attached ; the grange of Haynes with 400 acres, and the church there with its appurtenances; a mill and half a virgate with a house in Willington; 20 acres in Cople and 3 virgates in Campton, besides half the demesne of another benefactress, Adeliza, wife of Walter de Mareis, consisting of wood, plain, meadow and pastures. ${ }^{7}$ To this Simon de Beauchamp added the churches of Cople and Keysoe, Stotfold with the chapel of Astwick, and Linslade, Bucks ; confirming a number of small gifts besides." The income

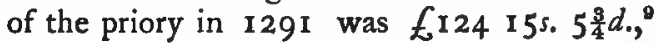
besides the churches in Bedfordshire; but this of course takes no account of its debts. By this time some lands had been acquired in the counties of Northampton, Buckingham, Huntingdon, Norfolk and Suffolk, and portions of tithes in the three London churches of St. Mary's Colechurch, St. Mildred's Wallbrook, and St. Stephen's Jewry ${ }^{10}$; and shortly afterwards the manor of Tadlow, Cambridge-

- Wright, Suppression of Monasteries, Letter xlii. He accused two of the nuns of having broken their vow of chastity; and involves in the same condemnation the sub-prior and a serving man.

- Deed of Surrender (P.R.O.), 56.

- Willis, History of Abbeys, etc. ii. 2, says that in I553 pensions were still paid to seven canons and eight nuns.

7 Dugdale, Mon. vi. 950.

- Ibid. The priory of Chicksand had very few stiits about its churches : only the chapel of Astwick seems to have been disputed in I I98-9 (Feet of F. [Rec. Com.], 21), and in 1242 (Cur. Reg. R. 125, n. 22) Simon de Beauchamp supported the prior's claim on the first occasion, and William de Beauchamp opposed it on the second.

- Pope Nich. Tax. (Rec. Com.)

10 Ibid. 


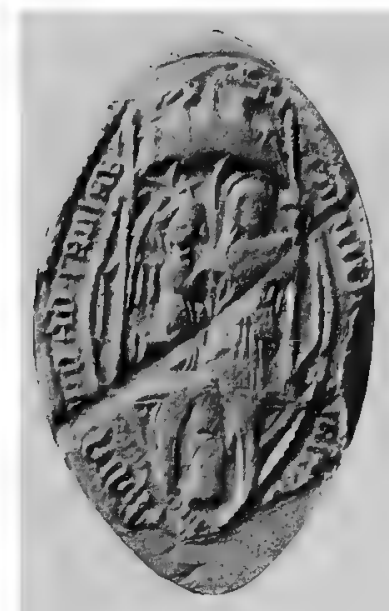

Chicksand Priory.

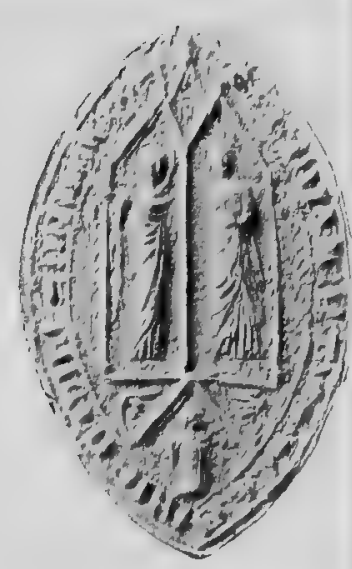

Chicksand Prjory.

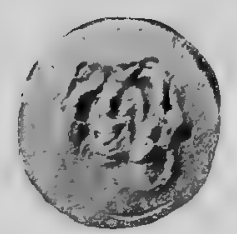

Chicksand Priory.

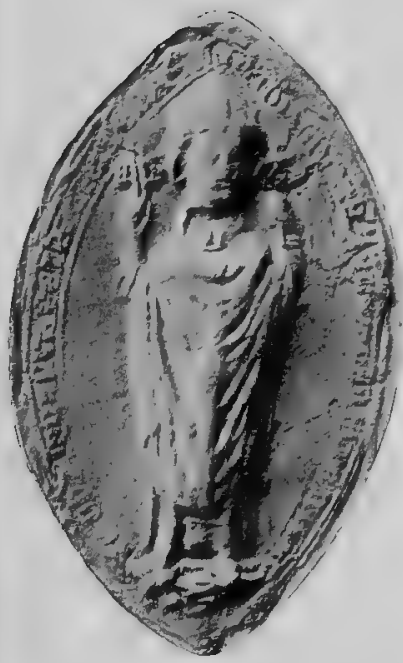

Harrold Priory.

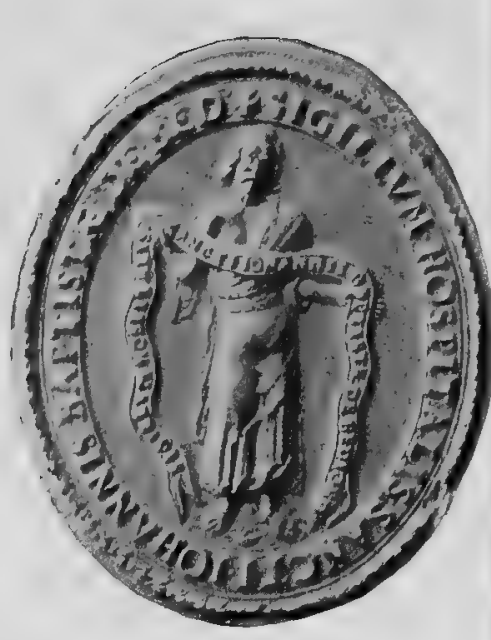

Hospital of $\mathrm{S}$ T. John the BAptist, BEDFord. 



\section{RELIGIOUS HOUSES}

shire, ${ }^{1}$ and the manor of Chicksand. ${ }^{2}$ The priors of Chicksand held in 1284 two knight's fees of the barony of Beauchamp, and a fraction of a fee in Warden ${ }^{3}$; in 1302 a fraction of a fee in Tadlow (which was still held in 1428 and had increased to a quarter of a fee ${ }^{4}$ ); in 1316 half a fee in Campton and a quarter in Southill and in Sandy, with a small fraction in Stanford ${ }^{5}$; in 1346 one fee in Campton and half a fee in Chicksand, with onetenth in Houghton ${ }^{\circ}$; in 1428 half a fee in both Campton and Chicksand, and a fraction in Stanford. ${ }^{7}$ In 1535 the income of the priory was stated at $\mathscr{f}_{2} 123^{s .} 5 d .^{8}$; and just after the dissolution at $£ 2596$ s. $2 d$., including the manors of Meppershall, Stotfold, Chippenham (Suffolk), Wolverton (Bucks) and Hargrave (Northants), and the rectories of Keysoe, Cople, Stotfold, Haynes and Linslade. ${ }^{9}$

\section{Priors of Chicksand}

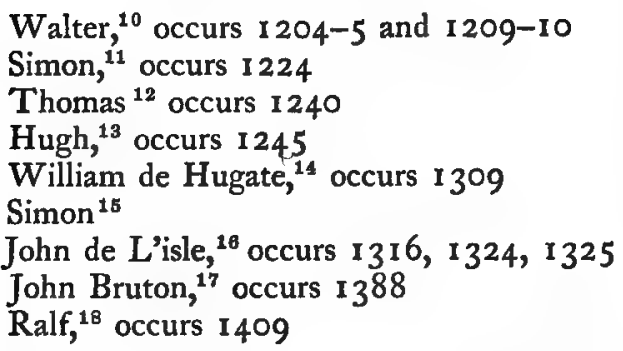

1 Feud. Aids, i. 150, 190, 189 ; L.T.R. Memo. R. I2 Edw. IV.

2 Pat. Io Edw. II. pt. 2, m. 29.

a Feud. Aids, i. 5. 1 Ibid. 150, 170, 189.

I Ibid. 19, $20 .{ }^{6}$ Ibid. 31, $32 . \quad 7$ Ibid. 42.

\& Valor Eccl. (Rec. Com.), iv. 195.

- Dugdale, Mon. vi. 975.

10 Feet of F. (Rec. Com.), 5 John, 55 ; ibid. ro

John, 82. G. prior of Chicksand occurs II86 (Gorham, History of St. Neots, II. lxxiv.).

11 Pat. 8 Henry III. m. 3.

12 Add. MS. 24465, f. 54b.

13 Ibid. 5827, f. I75b (Cole, from MS. notes of Browne Willis).

14 Harl. MS. 3656, f. 77.

15 Alluded to in Close, 17 Edw. II. m. 4, as having recently demised a manor to the same merchant with whom his successor was negotiating.

${ }_{16}$ Feud. Aids, i. 19; Close, 17 Edw. II. and 18

Edw. II. (These latter only mention the name of John, and perhaps do not refer to the same prior.) ${ }_{17}$ Cal. of Pap. Letters, iv. 273 ; made a papal chaplain.

${ }_{18}$ Linc. Epis. Reg. on the institution of a priest to the church of Chicksand.

\section{Stephen, ${ }^{19}$ occurs 1473}

John Atoun, ${ }^{20}$ occurs 148 I and 1493

John Spencer, ${ }^{21}$ occurs 1529 and 1535

John Plomer, ${ }^{22}$ occurs $153^{8}$

\section{Prioresses of Chicksand}

Emma, ${ }^{29}$ occurs $\mathrm{I}_{4} 82$

Margaret Burton and Margaret Graynger ${ }^{24}$ were the two prioresses in $153^{8}$

Four different seals of this priory are extant. The one appended to the deed of surrender is bright red, and represents the Annunciation; the angel kneeling and holding a cross, and our Lady standing, each under a canopy, a figure kneeling below. Legend: s. CONVE .. CHIKESAND AD CAVSAS. ${ }^{25}$

Another seal also represents the Annunciation, and is similar to the above, but both figures are standing. ${ }^{26}$ Legend : $s$ ' conventvs SCE MARIE DE CHIKESAND AD CAVSAS.

A small round seal has our Lady with the holy Child, and another figure on the right. ${ }^{27}$ Legend destroyed all but the letter $\mathbf{E}$.

The fourth has our Lady crowned, holding the Child on her left arm; to the right a monk kneeling, and possibly St. Catherine on the left, holding up her hands in prayer. ${ }^{28}$

19 L.T.R. Memo. R. I2 Edw. IV.

${ }^{20}$ Instituted to Linslade I48I (Lipscombe, Buckinghamshire, iii. 467) and to Woughton in the same county I493 (Add. MS. 5827, f. 175b).

21 Fobn, in the Convocation Lists, $L$. and $P$. Hen. VIII. iv. 6047; and ... Spencer in the Valor Eccl. (Rec. Com.) These may not be the same.

22 Fobn appears in the Deed of Surrender (P.R.O.), 56; but it is said that John Plomer subscribed to the Royal Supremacy (Add. MS. 5827, f. $175 \mathrm{~b}$ ).

${ }_{23}$ Mentioned with John, prior, in Harl. Ch. 44, C 27, dated 7 Nov. 22 Edw. IV.

24 Margaret Burton signed the Deed of Surrender as prioress; and her name is followed by that of Margaret Graynger, who still had a higher pension than the other nuns in 1553 (Willis, History of Abbeys, ii. 2). The lists of priors and prioresses of Chicksand are most unsatisfactory and fragmentary, because no institutions are recorded at Lincoln, nor are to be obtained from any of the ordinary sources.

25 Deed of Surrender (P.R.O.), 56. A cast of the same seal (B.M. lviii. 3 I).

${ }_{26}$ B. M. Seals, lviii. 32.

${ }_{27}$ Harl. Ch. 44, C 26.

28 Ibid. $44, \mathrm{C} 27$. 


\section{A HISTORY OF BEDFORDSHIRE}

\section{HOUSE OF KNIGHTS HOSPITALLERS}

\section{THE PRECEPTORY OF MELCHBOURNE}

The preceptory of Melchbourne was founded in the reign of Henry II. by Alice de Claremont ${ }^{1}$; other benefactors, including Roger de Clare, Earl of Hertford, Hugh de Beauchamp of Eaton, and William, Archbishop of York, added gifts of land and churches. ${ }^{2}$ Richard de Clare, the son of Roger, confirmed the gifts of his father and of Alice de Claremont $;^{3}$ and after the suppression of the Templars some of their property in Bedfordshire was transferred to Melchbourne. ${ }^{4}$ A general chapter was held at this preceptory in 1242, under the presidency of Brother Terricus de Nussa, prior of the hospital in England ${ }^{5}$; but beyond this very little is known of the history of the house. On two occasions the Hospitallers of Bedfordshire came into collision with the canons of Dunstable, on account of one of the customs of their order. They were allowed by a special privilege of the pope to grant Christian burial to all those who had given alms to their fraternity, whatever the manner of their death. $^{6}$ So in $1274,^{7}$ when the canons of Dunstable refused to bury a suicide, the Hospitallers impleaded them, and they had to pay a fine for the sake of peace. Again in $1282,{ }^{8}$ when one of the servants of John Duraunt, a merchant of Dunstable, committed suicide by jumping into a well, and his body in consequence was flung into a ditch

1 Dugdale, Mon. vi. 803,834 .

I Ibid. 834 and Chart. R. I John (Rec. Com.) The church of Melchbourne was also granted by Roger de Clare to the priory of St. Neot's. In I 76 a suit between the Hospitallers and St. Neot's ended in the church being resigned to the former (Gorham, History of St. Neot's, II. criii.) It was finally appropriated in 1378 (Pat. 2 Rich. II. m. 9 and Cott. MS. Nero E. vi. f. 12). The church of Souldrop was also disputed in II98 (Hunter, Feet of F. 9 Rich. I. I7). 3 Ibid. 806.

- e.g. the church of Langford, granted to the Templars by Simon de Wahull and Sibyl his wife in the reign of Stephen, was the property of the Hospital in 1329 (Nero, E vi. f. I37), and their lands in Sharnbrook confirmed to them by John (Chart. R. [Rec. Com.], I6) belonged to Melchbourne at the dissolution. The church of Little Stoughton was in the gift of the Hospitallers in I4I3, and had previously belonged to the Templars (Linc. Epis. Reg.).

- Dugdale, Mon. vi. 803 .

o Pat. 4 Edw. I. m. 32d.

7 Ann. Mon. (Rolls Series), iii. 260.

8 Ibid. 298. outside the town, the Hospitallers found him and buried him in their cemetery.

The Hospitallers, like other religious, received boarders into their houses from time to time. In 1527 a certain William Browne received a grant of board and lodging in the preceptory of Melchbourne, from the prior of the hospital. References to this house are very few and far between : except in a few notices of leases, it is not mentioned in the large chartularies of the order.

The date of the dissolution of the preceptory is not known. ${ }^{8}$ It was refounded for a very short time in 1557 by Queen Mary, and again made a part of the endowment of the order. ${ }^{10}$

The preceptory received at its foundation the manor and church of Melchbourne, and the churches of Dean, Riseley, Souldrop, Eaton Socon, with Hargrave (Northants), and Eakring, Ossington and Winkbourn (Notts), as well as parcels of land and wood in Riseley, Souldrop, Blakesley (Northants), Ossington and Winkbourn (Notts). ${ }^{11}$ The prior of the hospital held in Bedfordshire in $1302{ }^{12}$ one knight's fee and a half in Clifton, and I hide in Pulloxhill; in $13^{1} 6^{13}$ the vill of Melchbourne, half a fee in Podington, one fee in Clifton, and small portions in Souldrop, Sharnbrook and Sandy; in $1346^{14}$ Melchbourne, half a fee in Ickwell, Clifton and Harrold, and one quarter in Souldrop, Steppingley and Sharnbrook, with a smaller portion in Stanford ; in $1428^{15}$ the vill of Melchbourne, half a fee in Sharnbrook, Harrold, Ickwell and Clifton, and a quarter in Souldrop. At the dissolution the property of the preceptory was worth $f_{24}$ I 9 s. $10 \frac{1}{2} d .{ }^{16}$ including the manors of Melchbourne, Ickwell, Eaton, Langford and Blakesley, and rectories of Melchbourne, Eaton, Riseley, Langford, Blakesley, and lands called the Temple in Sharnbrook. ${ }^{17}$

- The first report of the Crown Bailiff is dated 32 Henry VIII., the year of the dissolution of the order generally.

10 Dugdale, Mon. vi. 803.

11 Ibid. 834. This property in Notts seems to have been afterwards transferred to a commandery at Ossington (Cott. MS. Claudius E. vi. f. 24b).

12 Feud. Aids, i. 12, $13 . \quad 13$ Ibid. 17, 18, 20.

14 Ibid. 26, 28, 29, 30, 32 .

${ }_{15}$ Ibid. $38,39,40,42,46$. These knight's fees are only said to be held by the prior of the hospital; and it is possible that they may not all have belonged to the preceptory of Melchbourne.

18 Dugdale, Mon. vi. 803.

17 List of Min. Accts. after the suppression of the monasteries at P.R.O. 


\section{RELIGIOUS HOUSES}

\section{FRIARIES}

\section{THE HOUSE OF FRANCISCAN FRIARS, BEDFORD}

The house of the Grey Friars at Bedford was said by Leland to have been founded by Lady Mabel de Pattishall ${ }^{1}$; the Valor $E_{C-}$ clesiasticus however gives the name of John St. John as the first founder. ${ }^{2}$ It is uncertain at what date the Grey Friars came to Bedford, but their church was completed and dedicated on 3 November $1295,{ }^{3}$ when indulgences were granted by Bishop Sutton to those who should visit it. In I $300^{*}$ some of the friars of Bedford received licences from Bishop Dalderby for hearing confessions. Like their Dominican brethren, they seem to have met with more kindness from the nuns than from the monks of the older orders: for in 1310 the prioress and convent of Harrold ${ }^{5}$ joined with some of the citizens of Bedford in making them a grant of divers small plots of land within the town for the enlargement of their area.

The friars of Bedford ${ }^{6}$ signed the acknowledgment of the royal supremacy on I4 May 1534, John Vyall, S.T.P., ${ }^{7}$ being at that time warden of the house; his name appears again in the Valor Ecclesiasticus of 1 535. The warden of the Friars Observants of Greenwich was sent to this house in 1531 , when the brethren of his own order were dispersed, and was kept there under some kind of restraint. ${ }^{8}$ The deed of surrender, ${ }^{9}$ which is dated 3 October $153^{8}$, gives the names of a warden, vice-warden, and ten other friars ${ }^{10}$; it is in the form which seems

1 Quoted Dugdale, Mon. vi. I509.

- Valor Eccl. (Rec. Com.), iv. Igo.

3 Linc. Epis. Reg., Memo. Sutton, 127.

- Ibid. Memo. Dalderby, i Id.

6 Pat. 4 Edw. II. m. 18.

- L. and P. Hen. VIII. vii. 665.

7 This can scarcely be the same as the warden who signed the deed of surrender; though the Christian name of the latter is John, his surname certainly begins with ' $M$ ' and ends with 'er.'

$\checkmark$ There is a letter printed in Beds $N$. and $Q$. i. I9I from the vicar of the Observants to Sir John Dyve, a knight dwelling in Bedfordshire, asking him to find out how the warden is being treated, whether his friends may resort to him or write. The writer wishes the king knew his virtue and religious conversation and loyalty; and promises to find money, if Sir John will see that he has all he needs.

${ }^{9}$ Deeds of Surrender (P.R.O.), No. 19.

10 The confiscation of the conventual seal was one of the means employed to obtain the surren- to have been offered to the friars only, beginning 'Forasmuch as we the warden and friars of the house of Saint Francis in Bedford ... do profoundly consider that the perfection of Christian living doth not consist in dumb ceremonies, wearing of grey coat, ... ducking and becking and girding ourselves with a girdle full of knots, and other like pharisaical ceremonies'; and has no seal. ${ }^{11}$ The value of the house in 1535 was $\AA_{3}{ }^{1} 3^{\text {s. }} 2$. $^{12}$

\section{4 THE HOUSE OF DOMINICAN FRIARS, DUNSTABLE}

The Black Friars arrived in Dunstable in I $259^{13}$ at the invitation of the king and queen and the magnates of the neighbourhood, and began at once with the help of alms to build their church. They were very unwelcome to the canons of that place, and not without reason; for the novelty of the friars' coming, and of their manner of life, drew many people away from their parish church, and diminished the customary offerings there at a time when they were sorely needed. ${ }^{14}$ But the prioress of Markyate, though her own house was not a wealthy one, was more generous, and helped the friars with a dole of loaves until their church should be finished; a kindness illrepaid, for they insisted on the continuance of the gift after the immediate necessity was passed, and when the nuns were almost as poor as themselves. ${ }^{15}$

The jealousy between the canons and the friars lasted for some time, but there seems never to have been any open quarrel; on the contrary, one of the friars was admitted to

ders of the friars (Canon Dixon, History of the English Church, ii. 38). It would be interesting to know why the friars surrendered in English and the monks in Latin; and also why the special humiliation of signing such a document as this was reserved for friars.

11 The friars, as well as the nuns of Elstow and Chicksand, seem to have been usually known by their family names; the majority of the Cistercians and the Austin canons are called by placenames.

12 Valor Eccl. (Rec. Com.), iv. Igo.

13 Ann. Mon. (Rolls Series), iii. 213; Dugdale, Mon. vi. 1485 .

${ }_{14}$ See Dunstable Priory.

15 See Markyate Priory. Adam of Biscot, the second vicar of Luton, became a Dominican friar (probably in this house) about this time (Rev. H. Cobbe, Luton Cburch; 122). 


\section{A HISTORY OF BEDFORDSHIRE}

the priory in 1265 for nine years, returning to his own house in $1274^{1}$; and in 1278 the prior of Dunstable, William le Breton, visited and ate with the Dominicans. ${ }^{2}$ In $1282,{ }^{3}$ at the funeral of a female parishioner of Dunstable, who had desired to be buried in the church of the friars, the offerings were shared quite amicably by the two churches; but in $1287^{4}$ the porter of Dunstable was made to buy a house near the area of the Friars Preachers, so that they might not be able to enlarge their boundaries without the permission of the canons. Again in $1298^{5}$ the bishop sent a mandate to the official of the archdeacon of Bedford to enjoin the canons of Dunstable to desist from forbidding and impeding the Friars Preachers from hearing the confessions of the people of that place; but in $1311^{6}$ it was the bishop who found that friars who presented themselves to be licensed as confessors were becoming too numerous. Ten were offered to him on this occasion from Dunstable; this number is scarcely likely to include all the friars in the house, as some had probably received licences before.

John Coton, the prior of the Friars Preachers at Dunstable, subscribed the acknowledgment of the royal supremacy on I4 May I $534^{10}$ Nothing is known of the order of the house at this time, but it is somewhat discredited by some scandal that had taken place there in connection with the provincial of the order, who was also prior of (King's) Langley; but Bishop Longland's letter, in which the affair is mentioned, is so allusive and obscure that it is difficult to understand what the scandal was, or whether any others than the provincial were involved in it. ${ }^{11}$

The house was surrendered some time before 8 May 1539, when it was granted to one of the yeomen of the guard ${ }^{12}$; but as the deed of surrender has been lost, the exact date is unknown. The income of the house in 1535 was $£ 418$ s. $8 d^{13}$

\section{HOSPITALS}

\section{THE HOSPITAL OF ST. JOHN, BEDFORD}

The date of the foundation of the hospital of St. John Baptist at Bedford is somewhat uncertain. It is dated 980 in the transcript of the foundation charter which was entered in $\mathbf{1} 399$ in the episcopal registers at Lincoln, ${ }^{7}$ and 1280 in the Chantry Certificates of Henry VIII. and Edward VI. ; ${ }^{8}$ the first date seems too early, and the second is certainly too late. Perhaps the correct date is I I 80 , for the first mention of the hospital is found in $1216,9^{\circ}$

1 Ann. Mon. (Rolls Series), iii. 261.

2 Ibid. 278.

3 Ibid. 289. The body was first carried to Dunstable church, where the canons sang the requiem mass, and had the oblations, including eight candles, four of which they kept and gave the other four to the Dominicans. The chronicler of Dunstable explains here that two candles were given to the brothers, and two to the sisters; this looks as if there were Dominican nuns there at the time, but no other trace of their existence has been found.

4 Ibid. 338.

5 Linc. Epis. Reg., Memo. Sutton, 217d.

- Ibid. Memo. Dalderby, I9d.

7 Ibid. Memo. Beaufort, 22d. The first figure in the date is cancelled and 980 written afterwards (Beds N. and Q. i. 193).

8 Chant. Cert. (Beds), I, 4 .

Pat. I Hen. III. m. 3 d. and not long after this Bishop Hugh de Wells ordained a vicarage for the church of St. John, which belonged then to the brothers of the hospital. ${ }^{14}$

The founder's name was Robert de Parys; other benefactors being John and Henry St. John. ${ }^{15}$ The original endowment was intended to support two or three religious brethren, of whom one should be master; it was to be a house of charity, where all needy persons free born of the town of Bedford (but from no other plàce) who had become poor by misfortune rather than by fault might seek admittance and be maintained; though none should be presented by the mayor and burgesses unless with the consent of the founder and his successors. The brethren were to

10 L. and P. Hen. VIII. vii. 665.

11 Bishop Longland's letter says that he encloses ' the detections of the most honest people of Dunstable' regarding the prior of Langley, who was also provincial of the order. It is therefore natural to conclude that the house of the Friars Preachers at Dunstable had been the scene of some particular scandal during some visit of the provincial, though it was not Dunstable but Langley that was 'in utter decay' (L. and P. Hen.VIII. iv. 4315 [dated I June I 528]).

12 Ibid. xv. I032.

13 Valor Eccl. (Rec. Com.), iv. 210.

14 A. Gibbons, Liber Antiquus, 20-5.

15 Linc. Epis. Reg., Memo. Beaufort, 22d. 


\section{RELIGIOUS HOUSES}

live as religious, having a common refectory and dormitory; they were to have the tonsure of a priest and to wear clothing of any sober colour, covered by a dark mantle. They were to remain in the hospital for life, and, when admitted, to take an oath of obedience to the statutes and to the master ; they were every day to sing the canonical hours and celebrate the divine office for the living and the dead, praying especially for the soul of the founder and other benefactors. The master was to correct the brethren ordinarily, but he might appeal to the bishop in case of necessity. ${ }^{1}$

In I 306 Bishop Dalderby wrote a fuller rule for the brethren, which was practically an adaptation of the rule of St. Augustine to their particular circumstances. ${ }^{2}$ It is clear that though they were so few in number they were expected to live quite as strictly as the religious of large communities.

The church was rebuilt early in the fourteenth century, and the brethren then had a licence to beg alms for this purpose on account of their poverty. ${ }^{3}$ The master of the hospital, Robert Rous, was appointed in 1333 to hear the confessions of all the subjects of the archdeacons of Bedford and Huntingdon. ${ }^{4} \mathrm{He}$ died in $13499^{\circ}$ probably of the pestilence. In $1399^{\circ}$ the hospital was reconstituted on the old foundation by Bishop Beaufort, with the same number of brethren and the same rule as before. When inquiry was being made at the end of the reign of Henry VIII. into the condition of chantries and hospitals, it was said that no poor person was kept there, nor had been for many years. ${ }^{7}$ It appears

1 Linc. Epis. Reg., Memo. Beaufort, 22d.

2 Beds $N$. and $Q$. i. 321 ; transcribed from Camb. Univ. Library MS. Dd x. 28. It is dated 2 Aug. I306. It is an amplification of the shorter rule in the episcopal register, with more than one reference to "the rule of blessed Augustine'; alludes to the three rows of obedience, chastity and poverty, 'but above all things charity'; and prescribes penances for the transgression of the rule. The only regulation that seems a little unusual is the permission to speak briefly in low tones in the refectory; though the usual strict silence is enforced in the church, cloister and dormitory. The colour and shape of their habit was not exactly prescribed; the bishop only orders that they wear a 'uniform and humble habit, marked with a cross."

3 Linc. Epis. Reg, Memo. Burghersh, 38, 106d (1321 and I323).

เ Ibid. 268.

- Ibid. Inst. Gynwell, 378.

- Ibid. Memo. Beaufort, 22d.

7 Cbant. Cert. (Beds), I. also that there were no longer any brethren, but only a master, who was also rector of the church. ${ }^{8}$

The hospital was not taken into the king's hand at that time, but in I59I an attempt was made to prove that it had reverted to the Crown by the death of the master and religious brethren. Oliver St. John and others were commissioned to inquire into the foundation and to find out who were the heirs of Robert de Parys. ${ }^{9}$ It was finally proved that it had been united with the parish church and was the property of the mayor and corporation, who in 1628 petitioned that there should be no further proceedings against them in respect of it, ' except only by course of law.' 10 At the end of the eighteenth century the rector of the church was still called master of the hospital, and ten beadsmen received ninepence weekly from the funds of the old foundation. ${ }^{11}$

Neither the church nor the hospital of St. John is mentioned in the Taxatio of Pope Nicholas, but in 1216 the brothers owned a mill in Bedford. ${ }^{12}$ In 1302 the master held one-twentieth of a knight's fee in Clophill.13 In I 535 the revenue of the hospital, consisting mainly of small rents, amounted to $f_{2} \mathrm{I}$ Os. $8 d . ;^{14}$ at the end of the reign of Henry VIII. to $£^{20.15}$

Masters of ST. John's Hospital, Bedford

Baldwin, ${ }^{\mathbf{1 6}}$ appointed $\mathbf{2} 286$

William of Buckingham, ${ }^{17}$ died 1316

Richard of Buckingham, ${ }^{18}$ appointed 1316

Robert Rous, ${ }^{19}$ appointed I 333 , died I 349

William Rous, ${ }^{20}$ appointed 1349 , died 1374

John Appelond, ${ }^{21}$ appointed 1374

Walter of Swineshead, ${ }^{22}$ occurs 1384 and I 410

8 The $V$ alor Eccl. (Rec. Com.), iv. I9I, gives only the name of a rector, who was also warden.

- S. P. Dom. Eliz. ccxl. 142.

10 Ibid. Chas. I. cxxiv. 84.

11 Add. MS. 5832 (Cole MSS.), f. 86.

12 Pat. I Hen. III. m. 3d. Other small properties are mentioned Pat. $29 \mathrm{Edw}$. I, and Inq. ad q. d. 40 Edw. III. n. 7 .

${ }_{13}$ Feud. Aids, i. I4.

14 Valor Eccl. (Rec. Com.), iv. IgI

15 Chant. Cert. (Beds), I.

18 Linc. Epis. Reg., Memo. Sutton.

17 Ibid. Inst. Dalderby, 274.

18 Ibid.

19 Add. MS. 5832, f. 89. The masters from Richard of Buckingham are nearly all given here by Cole, as he copied them from a parish register of St. John's Church.

${ }_{20}$ Linc. Epis. Reg., Inst. Gynwell, 378.

21 Ibid. Inst. Buckingham, 389.

22 Add. MS. 5832, f. 89. 


\section{A HISTORY OF BEDFORDSHIRE}

Thomas Hore, 1 died 1444

John Thorpe, ${ }^{2}$ appointed 1444

John Brinklo ${ }^{3}$

Richard Hylston, ${ }^{4}$ resigned 1448

William Athall, appointed $1448,{ }^{5}$ resigned 1456

John Goldsmith, ${ }^{6}$ appointed I 456, resigned 1456

Thomas Kynges, ${ }^{7}$ appointed 1456, resigned 1457

John Dovey, ${ }^{8}$ appointed 146I, resigned 1462

Thomas Horne, ${ }^{9}$ appointed 1462

Richard Hyndeman, ${ }^{10}$ appointed I 462, resigned 1470

Henry Rudyng, ${ }^{11}$ appointed 1470, died I 497

William Morgan ${ }_{2}^{12}$ appointed 1497, died 1509

Humphrey Gascoigne, ${ }^{13}$ appointed 1509

William Wroxill, ${ }^{14}$ resigned 1520

William Franklin, ${ }^{15}$ appointed 1520

John Stringer, ${ }^{16}$ appointed $153^{\circ}$

A seal of this hospital represents St. John Baptist standing, holding a long scroll inscribed SIGILLUM HOSPITALIS SANCTI JOHANNIS BAPTISTE DE BEDFORD. The same legend is around the margin of the seal, which is oval and very clear and distinct.

\section{THE HOSPITAL OF ST. LEONARD, BEDFORD}

The date of the foundation of the hospital of St. Leonard is even more uncertain than that of St. John. The first mention of it is found in a charter of King John, dated $1207,{ }^{17}$ in which he granted letters of safe conduct to the brethren and their preachers wherever they might go in England to preach and seek alms on behalf of their sick people. Eight years later another charter announced that the lepers of the hospital of St. Leonard were

1 Linc. Epis. Reg., Inst. Alnwick, 184.

2 Ibid.

add. MS. 5832, 89.

- Linc. Epis. Reg., Inst. Alnwick, 187, 189. The name is given in one place as Hylston and the other as Ilvestone.

5 Ibid.

- Ibid. Inst. Chedworth, 165.

7 Ibid. I65d. 8 Ibid. $168 \mathrm{~d}$.

- Ibid. 172. 10 Ibid. $172 \mathrm{~d}$ 11 Ibid. 178

12 Ibid. Inst. Smith, 438

13 Ibid. 457 d.

14 Ibid. Inst. Longland, 240.

15 Ibid.

${ }_{16}$ Add. MS. 5832, f. 89; and Chant. Cert. (Beds), 4.

17 Pat. 8 John, m. t. taken under the king's protection. ${ }^{18}$ It is probable that one of the Bassets was founder of the house, for in a dispute which was brought before the bishop in 1294 with regard to the patronage it was decided that one Robert Dendon was patron in right of his wife, Agnes Basset, daughter of Simon Basset ; though the burgesses of Bedford also had a share in it. ${ }^{19}$

There were at first six brethren in the house, of whom one was master ; all were at least in minor orders, wore the habit of religion, ${ }^{20}$ and probably kept a rule somewhat similar to that of the brethren of St. John's hospital. In I 294 Bishop Sutton sent an injunction to three of them by name to be obedient to their master until he should visit them. ${ }^{21}$ In 1302 they sent a petition to Parliament for permission to purchase land to the value of $f_{0} 10$, and a rent in Bedford. ${ }^{22}$ This was probably for the enlargement of their area and the re-building of their house, for in 1306 they gave great offence to the abbess of Elstow by closing the pathway which led through their buildings to Bedford, and opening another instead which made a circuit round the hospital. There was a suit in Chancery in consequence, and the final grant for closing the pathway was not issued till $1308 .{ }^{23}$

Bishop Dalderby excommunicated one of the brethren for apostacy in $1306,{ }^{24}$ and visited the house in ${ }^{1} 3^{1} 3$ to inquire into the alleged impotence of the master and to appoint one of the others as coadjutor. ${ }^{25}$ About this time the house was evidently becoming impoverished, for in 1331 an indulgence was granted for the repair of the chapel of the Blessed Mary, ${ }^{26}$ and in 1353 the brethren obtained a licence to beg alms. ${ }^{27}$ From this time for-

18 Ibid. 16 John, m. 4. The first charter has 'Fratres hospitalis infirmorum,' and the second 'leprosos hospitalis Sci. Leonardi.' It was probably for both, like the hospital at Dunstable.

${ }_{10}$ Linc. Epis. Reg., Inst. Sutton, 99. It seems just possible that this Simon Basset may be really Simon Bascot (or Barescote), whose ancestors founded Caldwell Priory, and who was himself an alderman of Bedford.

20 Rolls of Parl. (Rec. Com.), i. I54. The king's grace for a poor house of St. Leonard's, Bedford, where there are 'six brethren, perpetual chaplains, wearing the habit of religion.'

${ }^{21}$ Linc. Epis. Reg., Memo. Sutton, I06d.

22 Rolls of Parl. (Rec. Com.), i. r 54 .

23 Inq. ad q.d. 34 Edw. I. No. 226; Pat. 2

Edw. II. pt. 2, m. 15 (see Elstow Abbey).

${ }^{24}$ Linc. Epis. Reg., Memo. Dalderby, 98.

25 Ibid. 247 d.

26 Ibid. Memo. Burghersh, 24I.

27 Ibid. Memo. Gynwell, 52. 


\section{RELIGIOUS HOUSES}

ward, though there was a regular succession of masters, nothing further is known of the history of the house. ${ }^{1}$ The brethren probably died off gradually and their places were not filled up; and the later masters held the hospital in plurality with other benefices after it had become a sinecure. Its name does not appear in the Chantry Certificates, but at Cardinal Pole's visitation in 1556 it was alleged that it had been 'violated and occupied by laymen a great while in the time of the schism.' 2

In the petition to Parliament of 1302 it was stated that the hospital owned only 67 acres of land and a rent of $26 \mathrm{~s}$, all in lay fees, and held in capite of the king, and no spiritualities. $^{3}$ In 1535 the value in rents, etc., was $£ 16$ 6s. 8d. clear, ${ }^{4}$ and the same amount is mentioned in $1556 .^{\circ}$

Masters of St. Leonard's Hospital, BEDFORD

William, ${ }^{\circ}$ resigned 1288

Walter of Torksey, ${ }^{7}$ appointed 1288, resigned 1294

Robert Cuppe, ${ }^{8}$ appointed 1294 , died 1310

Gerard of Eaton, ${ }^{9}$ appointed 13 10, died I3r 4

John of Woodweston, ${ }^{10}$ appointed 1313

William of Woodweston, ${ }^{11}$ appointed 1349 , resigned 1356

William of Bedford, ${ }^{12}$ appointed 1356

William of Willington, ${ }^{13}$ died 1392

Thomas Fisher, appointed $1392,{ }^{14}$ resigned 1398

Thomas Ulf, ${ }^{15}$ appointed 1398 , resigned 1436

John Leget, ${ }^{18}$ appointed 1436, resigned I 44I

William Barford, ${ }^{17}$ appointed 1441

William Edwards, ${ }^{18}$ resigned 1470

1 See list of masters.

2 Strype, Eccl. Mem. iii. 485 ,

3 Rolls. of Parl. (Rec. Com.), i. 154. To this they were to add land of $\oint_{\text {io }}$ ro value.

4 Valor Eccl. (Rec. Com.), iv. 190.

s Strype, Eccl.Mem. iii. 485 .

- Linc. Epis. Reg., Memo. Sutton. 7 Ibid.

8 Ibid. Inst. Sutton, 99.

- Ibid. Inst. Dalderby, 265.

${ }^{10}$ Ibid. 272d. John de Woodweston's institution is dated before the death of Gerard; he must have been the coadjutor appointed in the impotence of the latter.

11 Ibid. Inst. Gynwell, 382 . 12 Ibid. 396.

13 Ibid. Inst. Buckingham, 358d. 14 Ibid.

15 Ibid. 372 d.

16 Ibid. Inst. Grey, 72.

17 Ibid. Inst. Alnwick, I82.

18 Ibid. Inst. Chedworth, I78.
Richard Hyndeman, ${ }^{19}$ appointed 1470

Edward Exmowe, ${ }^{20}$ died 1480

Thomas Shenkwyn, ${ }^{21}$ appointed 1480, resigned $\mathrm{r}_{493}$

Richard FitzJames, ${ }^{22}$ appointed 1493, resigned 1497

Bernard Andrew, ${ }^{23}$ appointed 1497, resigned I 499

Hugh Oldham, ${ }^{24}$ appointed 1499 , resigned I505

Richard Elwyn, ${ }^{25}$ appointed I 505, resigned I 513

Reginald Bray, ${ }^{26}$ appointed I 5 I3, resigned I 517

John Pitts, ${ }^{27}$ appointed $\times 517$, occurs 1535

\section{THE HOSPITAL OF ST. MARY MAGDALENE, LUTON}

This hospital is said to have been founded by Saint Thomas of Canterbury, on the authority of a charter issued by the brethren and sisters in October $1465 .^{28}$ Another charter dated $1377^{29}$ refers to the same house; there is no other mention of it earlier or later. It was evidently a hospital for the sick, served, like many other such foundations, by brethren and sisters who followed some form of the rule of St. Augustine. The charter of 1465 is a quaint and most pretentious document, ${ }^{30}$ offering indulgences on quite a

19 Ibid. He had just been master of St. John's.

20 Ibid. Inst. Russell, I 5od. 21 Ibid.

22 Ibid. 154d. Bishop of Rochester 1497.

23 Ibid. Inst. Smith, 438.

24 Ibid. 44I. Rector of Shillington and Bishop of Exeter 1505.

25 Ibid. 450. 20 Ibid. 459d.

27 Ibid. Inst. Wolsey and Atwater, 52d, and $V$ alor Eccl. (Rec. Com.), iv. 190.

29 Add. Ch. 28882.

28 Ibid. 28786. These references are given in Rev. H. Cobbe, Luton Church, 74.

so The object of the charter was to appoint a new proctor to collect alms, and to revoke all previous appointments. The indulgence granted by the popes was for eight years and forty days, and covered such offences as forgotten compacts, broken vows (on condition that they were resumed), injuries to father or mother (nfensus patru et matri), forgotten penances, etc.; forty days from the Archbishops of Canterbury, beginning with St. Thomas the founder, with a share in all present and future privileges of the church of Canterbury; and forty or thirty days from all the other bishops. Besides this, benefactors of the hospital were to share in the benefit of as many as 32,000 masses and 47,000 psalters granted by the order of Sempringham; 20,000 masses by the Cistercians and Premonstra- 


\section{A HISTORY OF BEDFORDSHIRE}

magnificent scale to all who should contribute to the support of the hospital; on the authority of five popes, eight Archbishops of Canterbury, and some also of York and many successive Bishops of London, Chester, Chichester, Valence, Hereford, Worcester, Ely, Norwich and Lincoln. It is witnessed by Lord Wenlock, Sir Thomas Hoo and the vicar of Luton. The hospital does not appear in the Valor Ecclesiasticus; it was probably richer in spiritual privileges than in temporal possessions.

\section{THE HOSPITAL OF ST. JOHN BAPTIST, LUTON}

This hospital, which was for the accommodation of lepers, is only known through a single mention of it in the Patent Rolls. In I285 Nicholas le Heyward was put in exigent for burning the house of Richard atte Wynche ; and for binding the lepers of the hospital of St. John Baptist, Luton. ${ }^{1}$

\section{THE HOSPITAL OF FARLEY NEAR LUTON}

The hospital at Farley near Luton was founded early in the reign of Henry II. on lands granted by him in II 56 to the brethren of 'Santingfeld' near Wissant ${ }^{2}$; a master is first mentioned in $1198-9 .{ }^{3}$ The endowment consisted of lands in Ludgershall ${ }^{4}$ near Brill, Bucks, and in Farley near Luton, worth respectively $£ 3$ and $£ 2$ a year. It was a hospital for the poor, and appears to have been dedicated to St. John Baptist like those at Bedford, Hockliffe, Toddington, etc. Its masters are several times mentioned in legal documents, but nothing is known of the history of the house and its inmates generally.

tensians, with other prayers of number unknown, and Paters and Aves also-' no one knows how many but God.' In the list of Bishops of Lincoln Grossetête appears as ' Saint Robert.'

1 Pat. 15 Edw. I. m. 2 d.

2 Dugdale, Mon. vi. 639. Thomas Cancellarius is one of the witnesses to the foundation charter. The Pipe Rolls of II56 and II58 mention 'terris datis fratribus hospitalis de Witsand' in Bedfordshire. The Rev. H. Cobbe, Luton Cburch, 498, suggests that Henry II. had been received at the hospital at Wissant after crossing the Channel in 1156, and gave the lands on that occasion.

${ }^{3}$ Feet of F. (Rec. Com.), io Rich. I. 30.

- The three 'hides' there given by Henry II. are thus entered in the Testa de Neville, p. 245 : - Fratres de Huntingfeud (sic) tenent de feodo de Bruhull' in Lutegareshall 'iij hydas in puram elemosinam.
It is possible that the story of the theft of some relics of St. Luke from the 'hermitage of Farley' in I431, and how the three thieves were pursued by the men of Dunstable as far as Barnet and the relics recovered, may refer to the chapel of the hospital, ${ }^{5}$ though there may have been an actual hermitage in the neighbourhood.

As this hospital was a cell of the hospital at 'Santingfeld,' it was reckoned in the fifteenth century amongst the alien priories, and granted in February 1448 to King's College, Cambridge. $^{6}$

In 1291 the master of Farley had a mill, woods and rents valued at $£ 5$ i 2s. altogether. ${ }^{7}$

A monument in Luton church which was long thought to be that of Lord Wenlock is now proved to be the tomb of William de Wenlock, master of Farley 1377 to $1392 .^{8}$

\section{Masters of FarLeY ${ }^{9}$}

Mauger, ${ }^{10}$ occurs I I 98

William, ${ }^{11}$ " 1239

John de la Rokele, 12 occurs 1296

John of Felmersham, "13 1347

William Lachebury, ${ }^{14}, " 1347$

William of Wenlock, ${ }^{15}$ occurs 1377 , died 1392

\section{THE HOSPITAL OF ST. MARY MAGDALENE, DUNSTABLE}

This hospital was founded, like so many others, near the end of the twelfth century, receiving in 1209 from King John a letter of safe conduct for those who were collecting alms on behalf of the house. ${ }^{16}$ It was probably founded under the patronage of the prior and canons of Dunstable, for the benefit of their town, and was intended for lepers

${ }^{5}$ John of Amundesham, Ann. Mon. S. Albani, i. 59 .

${ }_{6}$ Pat. 26 Hen. VI. pt. I, m. 7.

7 Pope Nich. Tax. (Rec. Com.), 47, 49.

8 Cobbe, Luton Cburch, 283.

a This list is found in Luton Cburch, from which nearly all the references for this hospital have been obtained.

${ }_{10}$ Feet of F. (Rec. Com.), ro Rich. I. 30 ; Cobbe, Luton Cburch, 500.

11 Ibid. 50I.

12 Pat. 22 Edw. I. m. 7.

13 Pat. 2I Edw. III. pt. 3, m. I3. William of Lachebury was restored in this year, having been master before John of Felmersham.

14 Ibid.

${ }_{15}$ Pat. I Rich. II. pt. 5, m. 39. His will was proved in 1391 (Cobbe, Luton Church, 283).

16 Pat. Io John, m. I (28 March I 209). 


\section{RELIGIOUS HOUSES}

as well as other sick people. The masters of the hospital were appointed by the prior, but the name of only one is known early in the thirteenth century ; he was called Roger, and was a chaplain of the priory. ${ }^{1}$ In 1293 the lepers of Dunstable erected a new bell, larger than they had ever had before, and hung it on a crossbar between two poles in front of their house; but the prior seems for some reason to have suspected their motives in doing this, for he sent and had it taken down, restoring it afterwards on the condition that it should never be used for his parishioners nor for calling people together. ${ }^{2}$

The hospital was still in existence in $133^{8}$, for the master and brethren received at that time another letter of protection from the king, and permission to collect alms ; ${ }^{3}$ but it is not heard of at any later date.

\section{THE HOSPITAL OF ST. JOHN BAPTIST, HOCKLIFFE}

The hospital of St. John Baptist at Hockliff is first mentioned in the Lincoln Episcopal Registers in 1248," but it had then evidently been in existence some years. The patron at that time was John Malherbe, ${ }^{6}$ a member of whose family was probably the founder. Its purpose is not stated, nor the number of the brethren mentioned; but it seems most likely that it was a hospital for the destitute poor. ${ }^{8}$ The master and brethren presented rectors to the parish church from 1248 to I $401,{ }^{7}$ if not longer, and their exercise of their patronage brought them once under the displeasure of Bishop Grossetête $;^{8}$ for they presented a young man of their founder's family, who was refused by the bishop for defect of orders and insufficiency of learning. In 1286 the master was deposed by Bishop Sutton, and another substituted ; the cause is not given. ${ }^{10}$ The brethren were allowed in

1 Harl. MS. 1885, f. 36b. Grant by Richard de Morins, prior of Dunstable, 'of the care and custody of our hospital' of St. Mary Magdalene, for lepers and other sick people, to Roger, chaplain (undated).

2 Ann.Mon. (Rolls Series), iii. $38 \mathrm{r}$.

$\therefore$ Pat. I I Edw. III. pt. 2, m. 24.

- Linc. Epis. Reg., Rolls of Grossetête.

5 Ibid.

6 The purpose of the hospitals for the sick and for lepers is usually explicitly stated.

7 Linc. Epis. Reg.

8 Ibid. Rolls of Grossetête, I265.

- William Malherbe.

10 The hospital in this year was 'vacant by the amoval of Alan de Freston, last master.'

I
I30I to collect alms for the rebuilding of their hospital, and an indulgence was granted by the bishop to their benefactors. ${ }^{11}$ In 1310 Bishop Dalderby received a serious complaint from Luke of Nutley, who was then master; he said that during his term of office (only a few months) the brethren had been unwilling to obey him, and were filled with a spirit of rebellion; and that a certain lay brother had laid violent hands upon him and used contumelious words, refusing to recognise his authority. ${ }^{12}$ The difficulty appears to have been settled by the resignation of Luke in favour of a former master, ${ }^{13}$ who was perhaps more acceptable to the brethren.

The hospital was visited by Bishop Bek in $1342,{ }^{14}$ but the results are not recorded. Reference is made to the master and brethren at the institution of John Culryk to the parish church in $1401 ;^{16}$ and masters continued to be appointed till I 422. It was probably soon after this that the hospital was taken over by the prior and canons of Dunstable, perhaps because its income had become insufficient to maintain it any longer as an independent house. Its revenue at the dissolution was only $f_{4}$ I 5s. $4 d$., and it finally ceased to exist at the same time as the priory of Dunstable. ${ }^{16}$

\section{Masters of Hockliffe}

A(dam), ${ }^{17}$ occurs 1248

Walter, ${ }^{18}$ resigned 1264

William de Lethom, ${ }^{19}$ appointed 1264

Thomas ${ }^{20}$ resigned 1286

Alan de Freston, ${ }^{21}$ appointed 1286 , deposed 1288

Thomas of Battlesden, ${ }^{23}$ appointed 1288

Walter de Hoccon, ${ }^{23}$ resigned 1289

Ralph de Eston, ${ }^{24}$ appointed 1289 , resigned I30I

Richard de Newton, ${ }^{25}$ appointed 1301 , resigned I 3 IO

11 Ibid. Memo. Dalderby, 33d, 48.

12 Ibid. 178.

12 See list of masters.

14 Ibid. Memo. Bek, 32d.

15 Ibid. Inst. Beaufort.

16 It appears in the First Report of the Crown Bailiff as part of the property of Dunstable, and its value is given as above (Dugdale, Mon. vi. 242).

It is not in the Chantry Certificates.

17 Linc. Epis. Reg., Rolls of Grossetête.

18 Ibid. 10 Ibid.

20 Ibid. Memo. Sutton.

21 Ibid. He had been a lay brother at Brackley

Hospital, an unusual appointment. ${ }_{22}$ Ibid. ${ }_{23}$ Ibid. 24 Ibid. 25 Ibid. Inst. Dalderby, 259. 


\section{A HISTORY OF BEDFORDSHIRE}

Luke of Nutley, ${ }^{1}$ appointed I 3 10, resigned 1310

Richard de Newton, ${ }^{2}$ appointed 1310

William de Elrichton, ${ }^{3}$ appointed 1321, resigned 1323

Hugh Tracy, ${ }^{4}$ appointed 1323 , resigned I323

William de Edington, ${ }^{5}$ appointed ${ }^{1} 3^{2} 3$, resigned 1323

Robert of Lubenham, ${ }^{6}$ appointed I323, resigned 1338

John Carpenter, ${ }^{7}$ appointed ${ }^{1} 33^{8}$, resigned 1340

Ralph of Esthaddon, ${ }^{8}$ appointed 1340 , resigned 1355

Richard of Dorset, ${ }^{9}$ appointed 1356

Nicholas, ${ }^{10}$ resigned 1400

William atte Mille, ${ }^{11}$ resigned 1405

John King, ${ }^{12}$ appointed 1405, resigned 1405

William Snell, ${ }^{13}$ appointed 1405

William Stortewayle, ${ }^{14}$ resigned I $_{408}$

Richard Ulverton, ${ }^{15}$ appointed 1408, resigned 1410

John Kirkeby, ${ }^{18}$ appointed 14IO, died I 4 II

Thomas Burreth, ${ }^{17}$ appointed I 4 I I, died I 4 I 3

William Colestone, ${ }^{18}$ appointed 1413

Thomas Chase, ${ }^{19}$ resigned 1422

Adam Symond, ${ }^{20}$ appointed 1422

\section{THE HOSPITAL OF ST. JOHN BAPTIST, TODDINGTON}

The hospital of Toddington was founded by Sir John Broughton in $1433,{ }^{21}$ for the support of a chaplain, who was to be warden, and three poor men; they were to pray for King Henry VI., for the founder, and for Thomas Peyvre and his wife Margaret. ${ }^{22}$ It was still in existence in $1538,{ }^{23}$ though its funds were not applied at that time quite in

1 Inst. Dalderby, 265d.

a Ibid. 269.

3 Ibid. Inst. Burghersh, $292 \mathrm{~d}$.

4 Ibid. $293 \mathrm{~d}$.

5 Ibid. 3I4d. Perhaps this is the same as No. 12.

${ }^{6}$ Ibid. 7 Ibid. 3r8d.

8 Ibid. 320 ; ibid. Inst. Gynwell, 392 d.

8 Ibid. 396.

10 Ibid. Inst. Beaufort, 135.

12 Ibid. Inst. Repingdon, 282.

13 Ibid. $284 . \quad 14$ Ibid. 294.

16 Ibid. 298. 17 Ibid. 304.

10 Ibid. Inst. Fleming, 126.

11 Ibid.

21 Pat. 2 I Hen. vi. pt. I, m. Io.

22 Ibid.

${ }^{23} L$. and P. Hen.VIII. xiii. (I), $98 \mathrm{I}$. the way that the founder had intended; the Valor Ecclesiasticus gives the names of a warden or master, and three chaplains instead of poor men. ${ }^{24}$

The name or Thomas Grenefeld, the warden in 1454, is found in a document relating to some property in the neighbourhood. ${ }^{25}$ The last warden, Sir John Mylward, was the compiler of a book called De potestate Petri, a collation from the Fathers of the Church in defence of the papal supremacy; it was several times mentioned at the trial of the monks of Woburn in $153^{8 .^{26}}$ Mylward himself was examined at the same time as the monks, and acknowledged that he had made the book, and also that he had not set forth the royal supremacy in his sermons, but had only read a printed schedule before the bidding prayer. Being further asked what he would do if the law against the pope were yet unmade, and which he would then think better-that the law should be made, or that the pope's power should remain-he very discreetly answered that he doubted what he would then think; he would like in that case to consult with learned men on the subject. ${ }^{27}$ Articles were appended to the depositions taken by the king's commissioners, in which Mylward's name had a prominent place; ${ }^{28}$ but he was probably never brought to trial. ${ }^{29}$ The Chantry Certificate of $1546^{30}$ states that the hospital was 'dissolved already without the king's majesty's license, by the Lord Warden and Sir George Shefford, gentleman'; and that "the said hospital and the use thereof ceased immediately after the death of Sir John Mylward, late parson thereof.' It would therefore appear that Sir John held his benefice until his death, which was soon after that of the abbot of Woburn. The Chantry Certificate goes on to state that no money had been paid to the poor since the dissolution; and that one half of the property of the hospital was held by the lord warden by title of Anne, elder daughter of Sir John Broughton, and a half by Sir George Shefford by title of Katherine, the younger daughter. ${ }^{31}$

The original endowment was only a certain messuage and garden of 2 acres in Toddington; and for divers lands and tenements in Chalgrave, Grove, Broughton and Mentmore (Bucks) the founder assigned a rent of
24 Valor Eccl. (Rec. Com.), iv, 21 r.
26 Beds $N$. and Q. i. 26I.
${ }^{28}$ L. and P. Hen. VIII. xiii. (I), 98I.
${ }_{27}$ Ibid. Deposition of Sir John Mylward.
28 Ibid.
${ }^{20}$ See 'Ecclesiastical History,' 330-I.
so Chant. Cert. (Beds), 4. 


\section{RELIGIOUS HOUSES}

$f 8$ to the prioress of Dartford, with the intention that they should be given to the hospital. ${ }^{1}$ In the Valor Ecclesiasticus the stipend of the warden is valued at $£ 813$ s. 2d., and those of the other priests at $£_{5}$ I $3^{\text {s. }} 4 d$.,$£ 5$, and $f^{8} \mathrm{I}_{2 s .} 4 d$. respectively. ${ }^{8}$ The Chantry Certificate of I 546 gives the clear value of the warden's stipend as $f_{1} 132 s_{0}{ }^{9}$

\section{COLLEGE}

\section{THE COLLEGE OF NORTHILL}

The parish church of Northill was made collegiate by the executors of Sir John Trailly and his son Reynold ${ }^{2}$ in $1405^{3}$; the rectors of the church were from that time forward masters of the college. The endowment was intended to maintain four fellows besides the master, and two choristers ${ }^{4}$; and this increase of the staff of clergy must have been a real benefit to the parish, which consisted of no less than seven hamlets at considerable distances from the parish church and also from one another. ${ }^{5}$

The royal commissioners sent to report on the condition of the chantries, colleges and hospitals in 1546 suggested that the college

\section{ALIEN HOUSE}

\section{THE PRIORY OF LA GRAVE OR GROVEBURY}

The manor of Leighton was granted by Henry II. to the abbess and convent of Fontevraud in $1164^{\circ}$; and it is probable that a house was built there for a cell of the order, not very long after. A prior is first mentioned in $1195-6$, and is then called the prior of Leighton ${ }^{7}$; the name of La Grave or

1 Pat. 2 I Hen. VI. pt. I, m. Io.

2 Chant. Cert. (Beds), I.

3 Tanner, Not. Mon., gives the date 6 Henry IV., and says that Sir Gerard Braybrook was one of the executors. Sir John Trailly died I40I, and his son in 1402. An inscription in memory of the first master, John Warden, and containing these two dates, was in the chancel of Northil church in 1582 (Beds $N$. and $Q . i .67$, from MS. notes of Francis Thynne, Lancaster Herald).

- Chant. Cert. (Beds), I. The master was to have his board, the pay of one servant, and finding for two horses; the fellows their board; the choristers board, lodging and clothing.

5 Ibid.

- Round, Cal. of Doc. France, i. 377; Dugdale, Mon. vi. 1085. The charter was confirmed by John (Chart. R. [Rec. Com.], i. pt. I, 72b, which states that the manor of Leighton was worth (56).

7 Cur. Reg. R. 6 Rich. I. No. 5; Feet of F. (Rec. Com.), 7 Rich. I. p. 3. It would seem that the cell was founded between II89, when the manor of Leighton was apparently held directly might well be turned into an almshouse, if that were the king's pleasure ${ }^{10}$; and in 1548 reported that it was thought one priest alone would not be able to serve the cure. ${ }^{11}$ It does not seem that any notice was taken of either of these suggestions.

In $1428^{12}$ the master of the College held two-thirds of a knight's fee in Tempsford, jointly with Robert Scot, of the barony of Eaton. The Valor Ecclesiasticus assigns to the college an income of $f 6{ }^{1}$ 5s. $^{\text {s clear }}{ }^{13}$; the Chantry Certificate states it at $£ 56$ 3s. 7 d., of which $f 22$ ros. formed the stipend of the master.

The first master was John Warden ${ }^{15}$; the last was Thomas Grene. ${ }^{16}$

Grava does not appear till late in the reign of Henry III. ${ }^{17}$ The dedication of the church is unknown. The prior of Leighton had a good deal of trouble with his tenants on the subject of feudal services during the thirteenth century, which involved him in suits before the Curia Regis from I 2 I 3 to I $290 .{ }^{18}$ William de Lyencourt, who was prior of La Grave during the latter part of the century, was a person of some importance; he was proctor

by Fontevraud, and II95-6, the first date of a prior.

8 Valor Eccl. (Rec. Com.), iv. 2 I I.

9 Chant. Cert. (Beds), 4.

10 Ibid.

11 Ibid. I.

12 Feud. Aids, i. 57.

13 Valor Eccl. (Rec. Com.), iv. I96.

14 Chant. Cert. (Beds), I.

15 Beds $N$. and $Q$.i. 67.

${ }_{18}$ Chant. Cert. (Beds), I.

17 Anct. Deeds (P.R.O.), D. 222. He is called the prior of Leighton as late as 44 Henry III. (Cur. Reg. R. I68, n. 2 in dorso).

${ }_{18}$ These difficulties between him and his men belong to the general ecclesiastical history of the county; they also serve to clear him from blame for the murder of a lay brother of Dunstable, killed by 'the men of the prior of Grava' in I259 in defence of the rights of his church (Ann. Mon. Rolls Series], iii. 213). The property of the two priories lay in the same neighbourhood, and such a quarrel unight easily arise without the knowledge of the head of either house. 


\section{A HISTORY OF BEDFORDSHIRE}

general or the abbess of Fontevraud in England, ${ }^{1}$ and had some journeys to take in this capacity, ${ }^{2}$ for which he had to seek safe conducts from the king.

Both the mother house at Fontevraud ${ }^{3}$ and the priory of Almesbury ${ }^{4}$ in England, where the king's mother and daughter had made their profession, ${ }^{5}$ were in great poverty at this time, but there is no mention made of poverty at La Grave. Its history in the fourteenth century is a little difficult to trace; in 1316 the manor was stated to be the property of the abbess of Fontevraud, but 'now in the hand of the Princess Mary,' ${ }^{\text {" }}$ and in 1349 the pope wrote a letter to King Edward III., asking him to allow the abbess and convent to regain possession of the house of La Grave, of which they had been despoiled." It seems however to have returned to its original position as a cell of Fontevraud, for it was reckoned in the next century among the alien priories, and granted in 1438 to Eton College; and a few years later, in 1481 , its property was

1 Pat. 25 Edw. I. m. I8d.

2 Ibid.; Pat. I5 Edw. I. m. 4 .

3 Pat. 20 Edw. I. m. 28, where it states they had only the blackest of bread to eat on Fridays.

4 Ibid. 21 Edw. I. m. I8.

6 Ann. Mon. (Rolls Series), iii. 326 (in the year 1285).

B The daughter of Edward I. at Almesbury (Feud. Aids, i. 21).

7 Cal. of Pap. Letters, iii. 39-40. transferred to the dean and canons of Windsor.

The original endowment of the house was simply the royal manor of Leighton, with land belonging to Walter Pullan, worth $32 .^{9}$ Some smaller gifts of land in Edlesborough, ${ }^{10}$ and Stewkley ${ }^{11}$ (Bucks) and in Studham ${ }^{12}$ were added later. The value of the manor in Leighton in 1291 was $f_{32}$ $6 s .8 d_{.}$; and other temporalities of the priory in the deanery of Dunstable amounted to $f_{2} 2$ s. $2 d .^{13}$ In $1302^{14}$ the abbess of Fontevraud held one knight's fee in Stewkley; in $1316^{15}$ the manor of Leighton, and half $a$ fee in Studham; in $1346^{16}$ only half a fee in Stewkley.

The names of only two priors remain :-

Nicholas, ${ }^{17}$ occurs 1258 and 1263 ;

William de Lyencourt, ${ }^{18}$ occurs I 283 , I $287, \mathbf{I} 297$

Dugdale, Mon. vi. 1085 and Pat. 20 Edw. IV. 9 Dugdale, Mon. vi. 1085.

${ }_{10}$ Pat. 9 Edw. I. m. 3. Licence for alienation in mortmain of $6 \frac{1}{2}$ acres in Edlesborough.

11 Feud. Aids, i. 82.

12 Ibid. 2 I.

13 Pope Nich. Tax. (Rec. Com.)

14 Feud. Aids, i. 82.

15 Ibid. 21.

${ }^{18}$ Ibid. I28. It was at this time that the abbess said she had been despoiled of the priory.

17 Anct. Deeds (P.R.O.), D. 222, 331.

18 Pat. I Edw. I., 15 Edw. I., 25 Edw. I. 


\section{INDEX TO DOMESDAY OF BEDFORDSHIRE}

[Names sometimes occur more than once on the same page. The index shows only the pages, and not the number of times the name may appear on the page. The personal names are indexed according to the descriptions given in the text, when any is given; but the different descriptions are not necessarily those of different persons, e.g. the same man may be described as 'thegn of King Edward,' ' man of King Edward,' 'man of the Bishop,' etc., in different entries. In only a few cases does the text afford actual proof that the man was the same, and in these instances the descriptions are gathered into one entry in the index.]

\section{PERSONAL NAMES ${ }^{1}$}

Achi. See also Anschil, thegn Almar, thegn of King Edward, Alwin, thegn of King Edward, of King Edward, 238b, $241 a$

Adeliza wife of Hugh de Grentmaisnil, 22I $b, 260 a, 260 b$

Adelold. See Alwold

Adelulf or Adelold, 253a, note $253 a$

Æilmar of Ow, 24I $b$

Ellfleda, $229 b$ $257^{b}$

Almar, man of Earl Tosti, 209, $255^{b}$

Almar, man of Ulmar, 26I $b$

204, 253a
Alwin, man of King Edward,258b

Almsmen of the king, 222 $b, 263 a$

Alric, 235b, $250 b$

Alwin, man of Stori, 254a Alric, burgess of Bedford, 204, $263 a$

Alwin, man of Alestan, 234a

Alwin, man of Borred, 225b, $226 a$

Alwin, man of Earl Harold, $251 b$

Alfric, thegn of King Edward, 208. See also Alvric

Alric, thegn of King Edward,23ra

Alric, king's bailiff, $264 b$

Alfwine, man of the Bishop of

Lincoln, 208

Elveva, Elfgifu, 233 $b$, note $233 b$

Albert of Lorraine, 203, 209, $221 b$, $255^{b}$

Albini of Cainhoe, I99

Albini, Albingi, Nigel de, 198, 199, 200, 2 I I, 221 I $, 228 b, 23 \mathrm{I} b$, note $23 \mathrm{I} b$, note $232 a, 242 b$, $243 b, 244 a, 244 b, 245 a, 245^{b}$

Albini, Robert de, note $244 b$

Alestan, 242a

Alestan of Boscombe, 202, 233b, $234^{a}$

Alric son of Goding, 242 $b, 243 a$

Alric Wintremelc. See Wintremelc

Alsi, brother and man of Alli, $254 b$

Alsi of Bromham man of Queen Eddid [Edith], 223b, 240a

Alvric bedell [of King Edward], $264 a$

Lincoln, 231 $b$

Alwin, man of Bishop Wlwi of Lincoln, 2486

Alwin Sac, man of Bishop of Lincoln, $227 a$

Alwin, man of Eudo Dapifer, $235^{b}$

Alwin the priest, 2656

Alwin, king's bailiff, $263 b, 264 a$, $265 a$

Alvric, man of Alvric the Little, $246 a$

Alvric of Flicteuite [Flitwick], $246 a$

Alvric the Little, $246 a$

Alvric, man of Borred, 226a

Alfred (Alvered, Alvred) of Lin- Alvric, thegn of King Edward, coln, 2II, 222a, 249a, note 249a, 250a

$244 a$

Alvric the priest, $239 b$

Alfric Wintremelc. See Win- Alward Belrap, man of Alric son tremelc and Alric of Goding, 243a

Algar, man of Queen Eddid Alward, man of Alric, 246a [Edith], $255^{b}$

Alli, $254^{b}$

Alward, man of Bishop Wlwi of

Alli, thegn of King Edward, $258 a, 264 b$

Lincoln, $245 a$

Allic, $266 a$

Almær, man of Aschil, 24ra

Alwin, note 246a, 259a, 260a

Alwin, Alwine, 266a, $266 b$

Alwin Deule, thegn and man of

King Edward and man of Bis-

Almar, burgess of Bedford, 204,

206, $263 a$
Almar, man of Alvric of Flitwick, Alwin Horim or Horne, thegn of $246 a$

hop Wlwi, 215, note 215, 226b, 227a, 266

Alwin, sokeman, 26ra

Alwold (Adelold) thegn of King Edward, 201, note 202, note $224 a, 230 b, 23 \mathrm{I} a, 257 a$

Alwold of Steventon (Stiveton), 224a, note $224 a$

Alwold, man of King Edward, 230b, $23 \mathrm{r} a$

Alwold, man of Bishop Wlwi of Lincoln, $25 \mathrm{I} b$

Ambrose, $236 b$

Angers, S. Nicholas of, monks of, I98, $245^{b}$

Anschetil the priest, $241 a$

Anschil, Aschil, Achi of Warres [Ware], 200, note 200, 20I, note 202, 208, note 208, 209, 233a, note $233 a, 233 b, 237 a, 237 b$, $238 a, 239 b, 240 a, 240 b, 24 \mathrm{r} a$, $241 b, 242 a, 262 a$

Anschil a sokeman, 261 $a$

King Edward, 203, 248b ford, 230a

1 Including those of Religious Houses holding lands and the names of Baronies. 


\section{A HISTORY OF BEDFORDSHIRE}

Ansgar. See Asgar

Ansgot of Rochester(Rouecestre), 196, 223b

$\operatorname{Ard}(\mathrm{r}) \mathrm{e}(\mathrm{s})$, Ernulf de, 202, 210, 230b, 23I $a$

Argentan, David de, 221 $b, 256 a$

Asgar the staller, $223 a$

Augi, Avigi, man of Anschil of Ware, 209, 233a, note $233 a$

Auti, housecarl of Earl Algar, $239 a$

Azelin, man of Earl Tosti, 260a

Azelina widow of Ralf Talgebosc, 200, 20I, 2I I, 222b, 26I $a, 26 \mathrm{I} b$, $262 a$

Azor, man of Borred, 223b

Azor. See Henry

Bailiffs, the king's, 222 $b, 263 a$, See Alric, Alwin, Chelbert, Goduin, Herbert, Ordui, Osiet, Saiet, Turchil, Turgot, Wintremelc

Baldric, $247 b$

Barking (Berchinges), abbess of, $221 a, 229 b$

Barking (Berchinges), abbey, 229 $b$

Basset, Richard, 248a

Basset, William, $239 b$

Bayeux, Bishop of, Odo, 195, 196, note 202, $221 a, 223 b, 253 a$

Beauchamp of Bedford, Barony of, 20I, note 20I, note $240 b$

Beauchamp of Bedford, House of, 199, 201, note 201

Beauchamp of Eaton (Socon), Barony of, 20I, note $235 \circ$

Beauchamp, Hugh de (Belcamp), 198, 199, 200, 201, 205, 209, 210, $211,213,217,221 a, 226 b$, 232b, 233a, 235b, 236b, 237a, $237 b, 238 a, 238 b, 239 a, 239 b$, 240a, 240b, 241a, 241 b, 242a, $242 b, 246 b, 260 b, 262 a$

Beauchamp of Worcestershire, house of, 201

Bedells, the king's, $222 b$

Bedford, burgesses of, 204, 206, $222 b, 262 b$. See also Almar, Alric, Edward, Godmund, Godwin, Ordwi, Osgar, Ulmar, Ulsi

Bedford, canons of St. Paul in. See Ansfrid, Osmund

Bedford, church of St. Paul of, I95, 22 I

Belvoir, Lord of [Robert de Todeni], 198

Benedict, St. See Ramsey

Bernard, 24Ib, 245a, 262a. See also Burnard

Blach, man of Avigi, 233a

Blosseville, Gilbert de, $258 a$

Bolbec, Hugh de, 202, 231 a

Bondi the staller, 264a

Borgeret, Borgret, Borred, Bor- ret, Burgret, Burred, Burret, I95, 196, 207, 223b, 224b, 225a, $225 b, 226 a$, note $226 a, 246 b$, 26I $a$

Ulsi son of. See Ulsi

Boulogne, Count of [Eustace], 201, 2 IO, 221 a, note $224 a, 230 b$, 23ra

Branting, 242a, 264a

Breton, Gozelin the, 221 $b, 256 b$

Brictric, Bricxtric, Brihtric, Brixtric, a thegn, 196, 202, 205, $234 a, 249 b$

Brodo, 26I $b$

Broi [or Bray], Robert de, 201

Broilg, Osbern or Osbert de, 20r, $239 b, 240 a$, note $240 a$

Burg. See Peterborough

Bury, St. Edmund of, 198

Butler. See Hugh

Burnard, $233 b$, note $233 b$. See also Bernard

Caron, Robert de, note 235a, note $236 b$

Caron (Carun), William de, 200 $226 b, 227 a, 235 a, 235 b, 236 a$, $245 b$

father of, 210

Chamberlain the See Turstin, Wenesi, William

Chelbert, king's bailiff, $264 a$

Chetel, $244 b$

Chetelbert, 206. See also Chelbert

Cilt. See Lewin

Cioches [Chocques], Gunfrey de, $203,22 \mathrm{I} b, 252 a$

Cioches [Chocques], Sigar de, $203,22 \mathrm{I} b, 225 a, 252 a$

Clare, Gilbert de, 198

Clare, Richard de [or de Tunbridge], I98, note I98, note $252 a$

Cnut [King], note 207

Coutances, Bishop of, Geoffrey, 195, 2 IO, 2 I I , 22 I $a, 224 b, 225 a$, $225 b, 226 a, 249 a$, note $249 a$

Crispin, Miles, 196, 202, 205, $221 a, 234 a, 257^{b}$

Dapifer. See Eudo

David. See Argentan

Derman, 203

Deule. See Alwin

Domnic', 2356

Dot, $265 a$

Durham, Bishop of, 196, $221 a_{4}$ $227 a, 227 b$

Eadwine, father of Leofwine of Caddington, 198

Ederic, $259 b$

Edric the Bald, 262a

Edith [Eddid,Edid], Queen, 223a, $223 b, 240 a, 255 b, 264 b$
Edward, note 212, $264 a$

Edward, burgess of Bedford, 204, 206, $263 a$

Edward, King, Confessor, I98, 203, 210, 222a, 225b, 226a, 226b, 227a, 227b, 230a, 230b, $231 a, 233 b, 234 a, 234 b, 236 b$, $237 a, 238 a, 238 b, 239 a, 240 b$, $241 a, 242 b, 244 a, 244 b, 247 a$, $247 b, 248 a$, note $248 a, 248 b$, $249 b, 250 a, 250 b, 251 a, 252 a$, $253 a, 254 a, 254 b, 256 b, 257 b$, $258 a, 258 b, 259 a, 260 a, 260 b$, $26 \mathrm{I} a, 261 b, 263 b, 264 a, 264 b$, $266 b$

Edwin, man of Asgar the staller, $223 a$

Elstow, abbess of, note 204

Elstow, St. Mary of, nuns of, $257 a$ Elstow nunnery, I98

Ely, abbot of, 2 I5

Ernald, 260 $b$

Erfast, man of Nigel de Albini, $23 \mathrm{I} b, 243 a, 245^{b}$

Ernuin, Ernwi, priest, 206, 221 $a$, $226 b$

Ernulf. See Ard(r)e(s)

Espec, Walter, 203

Espec, Walter, sisters of, 203

Eu. See Ow

Eudo Dapifer [son of Hubert], 197, note 200, 20I, 205, 21 I, $213,221 a, 229 a, 234 b, 235 a$, $235 b, 236 a$, note $236 a, 236 b$, note $236 b, 246 b, 248 a$

Eustace Count of Boulogne. See Boulogne

Eustace sheriff of Huntingdonshire, 214, 215, note 215

Fafiton, Robert, 203, 222a, $248 b$

Fitz Richard, Osbern, 203

Fleming, Hugh the, 203, 221 $b$, $251 b$

Fleming, Walter the, I99, 200, 203, 2 I I, note $21 \mathrm{I}, 22 \mathrm{I} b, 228 b$, 249a, note 249a, 249b, 250a, $250 b, 251 a$

Franpold, Franpalt. See Goduin

Froissart, William, $239 a$

Fuglo [also Suglo] man of Alric son of Goding, 243a

Fulcher of Paris, 232a, 245a, 245b $258 b$

Germund, $232 a$

Ghent (Gand), Gilbert of, 203 , $222 a, 248 a$, note $248 a$

Giffard fief, note $23 \mathrm{I} b$

Giffard (Gifard), Walter, 202, $22 \mathrm{I} a, 23 \mathrm{I} a, 23 \mathrm{I} b$, note 23I $b$, $232 a$

Gilbert, $258 a$

Gilbert de Blosseville, $258 a$

Gilbert son of Salomon, 221 $b$, $248 b, 255 a$ 


\section{INDEX TO DOMESDAY}

Gilbert, Earl, son of. See Richard

Gleu, $249 a$

Gloucester, Earl of, his fief, I97

Gloucester, Robert, first Earl of, 197

Goda, Countess, $236 b$

Godfrey, 226a, $226 b$

Goding. See Alric

Godmar, man of Alestan of Boscombe, $233 b$

Godmund, burgess of Bedford, 204, $263 a$

Godric, thegn of King Edward, $226 b$

Godric, man of Edric the Bald, $262 a$

Godric the sheriff, $239 b$

Godric, man of the sheriff, 233a

Goduin, thegn of King Edward, 2486

Goduin, 259b

Goduin, man of King Edward, $258 b$

Goduin, man of Borret, 261 a

Goduin, man of Earl Harold, $257^{b}$

Goduin, man of Earl Tosti, 254b

Goduin Dere, king's bailiff, $265 a$, note $265 a$

Goduine, man of Earl Guert, $260 b$

Goduin, Franbolt, Franpold, Franpalt, 249a, 250a, 254b

Godwi, $230 b$

Godwin, burgess of Bedford, $262 b$

Godwin, man of Alestan, $233 b$

Godwin son of Lewin, $243 b$

Godwine, 206, 238a

Golderon, man of Levenot, 245a Langetot, Ralf de, 231 $b, 232 a$

Grentmaisnil, Hugh de, 200, $248 b$ Lant, 200, 264b

Grentmaisnil, Hugh de, wife of, $200,221 b, 260 a$

Grentmaisnil, Hugh de, Ivo steward of, $260 b$

Grimbald, 253a

Gudmunt, man of King Edward, $225 b$

Guert [Gyrth], Earl, 204, 208, $257 a, 260 b$

Guines, Counts of, 202

Gunfrey (Gonfridus), 2420

Harold, Earl, 193, note 195, 214, $237 a, 25 \mathrm{I} b, 256 a, 266 b$

Hastings, Henry de, 216

Hastings, Ralf de, note 197

Hastings, Robert de, note 197

Henry son of Azor, 221 $b, 253^{b}$

Henry I., note 194

Henry II., note 204

Henry VI., 198

Henry VIII., I99

Herbert, 224a

Herbert, king's bailiff, 263a

Herbert son of Ivo, I96, 224a

Homdai, man of Earl Harold, $256 a$ $258 b, 259 b, 260 a$

Humphrey, 226a of, note 204 $258 a$

Ilger. See Rannulf

Ingewar, 266a maisnil. See Grentmaisnil

Ivri, Acard de, $238 b$

Judichel, 26ra $260 b$

Kimbolton, Honour of, 2 I 5

Lant, man of Levenot, 250a,

Ledmar, 205, 24I $b$

Leicester, Earls of, note 261 a $264 a$ $247 a$

Leofgifu. See Leveva also Levenot

Leofric, 205

Leofstan, Abbot, 198 Lewin See also Lewin

Lepsi, man of Earl Tosti, $257 a$

Levegar, $259 a$

I.evenot, $245 a$ $249 b, 250 a, 251 a$

Levet, Wlward, $234^{b}$ $257 b$, note $257 b$

Levric, man of Borgred, $246 b$

Levric, man of Brixtric, $234 a$
Levric, man of King Edward, $230 b$

Hubald or Hubold, Hugh 253 ${ }^{\circ}$, Levric, man of Bishop of Lincoln, $253 b$, note $253 b, 243 a$

Hugh, 246a, 247a, 249b, 250a, Levric son of Osmund, thegn

250b, 251 $a, 257 a, 257 b, 258 a$, King Edward, 236b

Lewin, 229a, $250 a$

Hugh the butler (pincerna), 221 $b$, Lewin [Cilt], 230a, note 230a, $244 b, 247 b, 255 a$. See also Leofwine

Hugh. See Fleming; Hubald

Hugh nephew of Herbert, $224 a$

Hugh. See Hubald, or Hubold

Huntingdon, Malcolm IV. Earl

Huntingdon, honour of, 216 , note

Insula, Ralf de, 203, 221 $b, 256 a$

Ivo, steward of Hugh de Grent-

Ivo, Taillebois. See Tallebosc

Judith, Countess [widow of Earl Wal theof], 197, 198, 203, 205, 210 , note $210,214,216,221 b$, note 232a, 234 $b, 256 b, 257 a$, $257 b, 258 a$, note $258 a, 258 b$, $259 a, 259 b, 260 a, 260 b$, note

Lemar, bedell of King Edward,

Lewin, thegn of King Edward, $250 b$

Lewin. See Godwin

Lewine, man of Earl Wallef, 253a

Liboret, $242 a$

Lincoln, Bishop of, 195, 196, 200, 215

Lincoln, Remi [Remigius], Bishop of, 197, 221, $221 a, 226 a, 226 b$, $227 a, 266 a$

Lincoln, Wlwi [Wulfwi], Bishop of, 197, 222a, 245a,248b, 251 $b$. brother of. See Alwin

Lisois [de Moustiers], fee of, $236 a$, note $236 a$

Locels, William de, 201, 239a, $239 b$

London, Bishop of, I97

London, St. Paul of, 198, 229b, note 230

Canons of, 206, note 206, $221 a, 229 b$

Lovet, William, $22 \mathrm{I} b, 253 a$

Malcolm. See Huntingdon

Malet, $236 b$

Matilda, Queen, 222a, 222 $b$

Marwen, 230a

St. Mary. See Barking, Thorney

Moding, man of Queen Edid

[Edith], 240b

Morcar, priest of Luitone[Luton], $222 b, 252 b$

Mordaunts of Turvey, 198, 199

Mortuing, 24I $b$

Moustiers, Lisois de, note $236 a$, note $248 b$

Leofnoth thegn, 200, 203. See Nigel. See Robert

Norman, $242 a$

Norman of Beeston, 205, 236a

Northampton, earldom of, 204

Leofwine Cilt, I98. See also Northumberland, earldom of, 204

Leofwine thegn, 200, 205, 211.

Northumberland, Siward Earl of, 204

Odell [Wahull], barony of, 199, note $250 a$

Odell fee, note 216

Levenot, thegn of King Edward, Olgi, Oilgi, Robert de, 202, 222a

Leveva [Leofgifu], 209, 238b, Ordric, man of Levenot [Leof-

Leviet the priest, 197, 230a, 240b Ordui, king's bailiff, 264b, 265a
$234 a, 248 a$ daughter of, 202 noth], 200, $250 a$

Ordui, Ordwi, burgess of Bedford, $206,211,227 b, 262 b$ 


\section{A HISTORY OF BEDFORDSHIRE}

Osbern the fisher, 2I 3, 22I $b, 254 a$, Robert, 2IO, 24I $b, 242 a, 25 \mathrm{I} b$, $254^{h}$

Osbern [Osbert] son of Richard, $221 b, 253 b, 254 a$

Osbern son of Walter, $22 \mathrm{I} b, 254 a$

Osbern, 229a, $257 b$

Osbert, 249a, 250a

Osgar, burgess of Bedford, $262 b$

Osiet, $242 b$

Osiet, king's bailiff of the Hundred, 209, 265b

Osmund, canon of St. Paul, Bedford, $230 a$

Osulf, thegn of King Edward, $248 a$

Oswi, $236 b$

Oswi, man of Earl Tosti, $263 b$

Oswulf son of Frane, I98, 203, $247 b$

Otto, note 212

Oviet, man of Aschil, 239b, 248a

Oviet, man of King Edward, note $248 a$

Ow [Eu], William de, 221 $a, 233 a$, note $233 b, 234 a$

\section{Paris. See Fulcher}

Peterborough Abbey [St. Peter of Burgh], 214, 228a

Abbot of, 221 a, 228a, note $228 a$

Peverel, Pevrel, William, 196, $221 a$, note $226 a, 236 b$, note $236 b$, $266 a, 266 b$

Pirot, 211 , 236a, 244b, $245 a$

Pirot, John, note $244^{b}$

Pirot, Ralf, note 236a, $244^{b}$

Pungiant, Puniant, Richard, 203 $22 \mathrm{I} b, 252 b$

Rainald. See William

Raineward, $246 b$

Ralf, 236a, 239a, 246a

Ralf Passaqua(m), 246a

Ralf Tallebosc. See Tallebosc

Ramsey, Abbey of St. Benedict of, 196, 197, 199, 212, 228a $228 b, 229 a$

Ramsey, abbot of, 205, 2 I I, $22 \mathrm{I} a$, 228a, 228b, 229a, 234a

Ramsey, monks of, 202

Rannulf brother of Ilger, 2 I I, 2I $222 a, 248 b, 266 b$

Ravan, man of Ulmar of Eaton, $236 a$

Reeves, the king's, $263 a$

Remi, Remigius, Bishop. Lincoln

Richard, 24I $a$

Richard. See Osbern

Richard [de Clare] son of Count Gilbert, 221 $b, 252 a$

Richard's castle, fief of, note $253 b$

Riwalo, Ruallon, Rualon man of Hugh de Beauchamp, 240b, note $240 b, 244 a, 246 b$ $252 b, 259 a$

Robert son of Rozelin, 23I $a$

Robert. See de Olgi, Fafiton

Roches, John de, I99, 2 I I, 228b, $243^{b}$

Roger son of Teodric, 24I $a$

Roger the priest, $242 a$

Roger, 241 $b, 244 a$

Rolland, $236 a$

Ros, house of, 203

Ros, Serlo de, 201, 240a, 246a

Ruallon. See Riwalo

Saiet, king's bailiff, $265 a$

St. Alban's Abbey, 198, note $218,238 a$

St. Alban's Abbot, 259a

St. Edmund's Abbey, 216, 227b $228 a$

St. Edmund's, Baldwin, abbot of $221 a, 227 b, 260 a$

St. Neots Priory, I98, note I98, 216

St. Neots, monks of, $252 a$

St. Paul's, canons of, 212, note $212,264 b$

St. Paul's. See Bedford

St. Peter. See Westminster

Salomon the priest, $248 b$

Samar, man of Lewin, $245^{b}$

Samar the priest, man of Countess Goda, $236 b$

Seier, Seiher, 203, note 2II, $25 \mathrm{I} a$,

Seier, Walter brother of. See Walter

Sigar de Cioches. See Cioches

Spech, Walter, $247 b$

Spech, William, note I96, 203 , $22 \mathrm{r} a, 232 b$, note $240 a, 246 a$, $246 b, 247 a, 247 b, 262 b$

Starcher, thegn of King Edward, $222 a$

Stephen, $243 a$

Stigand, Archbishop, 203, 232a, $252 b, 256 a$

Stori, man of Earl Tosti, 203, $204,253 b, 254 a$, note $254 a$

Sueteman, man of Ulmar of Etone [Eaton Socon], 262a

Sueting, 2590

Suglo, man of Alric son of Goding, 242b. See Fuglo

See Taissel, Wimund de, 20r, note $239 b, 240 b, 241 a$

Talebot, Richard, 23I a, note $23 \mathrm{I}$

Tallebosc, Talliebosc, Taillebosc, Tallgebosc, Taillgebosc, Talgebosc, Iro, 194, 222a, 222 $b, 226 b$, $238 a$

Ralf, 193, 194, note 196, 197, 200, 20I, 205, 207, note 207 , 203, 2IO, 2II, 217, 222a, 408
Robert son of Nigel, $248 b$

St. Paul's. See London 223a, 226b, note $226 b, 230 a$, $232 b, 233 a, 237 b, 238 a$, 241a, 242a, 244a, 254a, $260 b$, note $260 b, 263 b$, note $263 b, 264 a, 265 a$

daughter of, $20 \mathrm{I}$.

Tedbald man of Countess Judith, 234b. See also Tetbald

Tedric, $232 a$

Tedric. See Roger

Tetbald, Tetbaud, 24I $a, 253 a$

Thorney [Tornyg], Abbey of, $229 b$

Thorney, abbot of, 22I $a$

Todeni, Toeni, Robert de [Lord of Belvoir], 203, 222a, $247 b$

Tofig, housecarl of King Edward, 207. See also Tovi

Torchil, 259a. See also Turchil Tosti, Tostig, Earl, 203, 204, 205 , 209, 210, 24I $b, 244 a$, note $253 b$, note $254 a, 254 b, 255 b$, $257 a, 258 b, 259 a, 259 b, 260 a$, $260 b, 263 b$

Tovi, housecarl of King Edward, 254a, 258a. See also Tofig

Tovi the priest, $223^{b}$

Trailly, 203

Trailly, Trailli, barony of, 196, note 2256

Traillgi, Tralgi, Geoffrey de, 196, 2 I0, $224^{b}, 225^{b}$

Tuffa, man of Earl Wallef [Waltheof], $259^{b}$

Turbert, man of King Edward, $225 b, 259 a$

Turchil, king's bailiff, $265 b$

Turchil, thegn of King Edward, $239 a$

Turchil of Warwick, note 207

Turgis, 226a, 242b, 243a, 244b

Turgis, thegn of King Edward, $239 a$

Turgot,almsman of King William, $265 a$

Turstan, $225 b$

Turstin, 26ra

Turstin the chamberlain, 22I $b$, $254^{b}, 255 a$

Ulf, thegn of King Edward, 248a

Ulfech, steersman of King Edward, $258 b$

Ulmar, burgess of Bedford, $262 b$

Ulmar, priest of King Edward, $227 b$, note $227 b, 264 a$

Ulmar of Etone [Eaton Socon] $234 b, 235 a, 235 b, 254 a, 262 a$, $262 b$

Ulmar, thegn of King Edward, $26 \mathrm{I} b$

Ulmar, man of Ordui, $259 b$

Ulnod, man of Ulsi son of Borret, $246 b$

Ulsi son of Borgret [Borred], $246 b$ 


\section{INDEX TO DOMESDAY}

Ulsi, prebendary, burgess of Bedford, $263 a$

Ulvric, $233 b$

Ulvric, man of King Edward, $260 a$

Ulvric, sokeman of King Edward, $26 \mathrm{I} a$

Uvenot, man of Godric the sheriff, $239 b$

Wahull. See Odell

Wallingford, Honour of, note 202

Walrave man of Queen Eddid [Edith], 223a

Walter, 233b, 241 $b, 246 b, 262 a$

Walter the monk, 26r $b$, note $26 \mathrm{I} b$

Walter brother of Seier, 203, 25 I $a$.

Walter. See Osbern and Fleming

Waltham Holy Cross, Abbey, I96, $227 b$, note $227 b$

Waltheof (Wallef), Earl, 198, 204, 209, note $209,228 a$, note 228 a, $238 b, 259 b$

Achelei, Acheleia. See Oakley Aieworde [Aisseworde]. See Eyworth

Ampthill [Ammetelle], I99, note I99, 2436

Arlesey [Alricesei], 227b, 233b, $245^{b}, 263 a$

Aspley Guise [Aspeleia], 209, 218, $238 b$

Astwick [Estwiche], 205, 24I $b$, $250 b$

Aubigny, S. Martin d', I99

Barford [Bereforde], 201

Barford, Great, note 239b, 2406 , 24I $a$

Barford, Little, 229a, $254 a$

Barford, Hundred of, 217,218 , $224 a, 226 b, 228 b$, note $234 b$, note $237 a$, note $237 b, 238 b, 240 b$ $245 a, 246 b, 252 a, 258 a, 261 a$, $264 b$

Barton-in-the-Clay [Bertone], I99, 200, 2I I, 2I 2, 228b

Battlesden [Badelesdone, Badelestone], 197, note 222 $b, 231 a$, $252 b, 261 a$

Beauchamp, Moyaux (Calvados), note 201

Beauchamp, Vouilly (Calvados), note 201

Bec (Normandy), 198

Bedford [Bedeforde], 195, 213, $217,218,221$, note 230a, 265a

Bedford, Church of S. Paul of, 195, 196, 197, 221, 227a, 230a

Beeston [Bistone] in Sandy, 236a, $246 b, 254 b, 263 a, 265 a$
[Judith], wife of, I98, 228a. William the chamberlain, 197 , See also Judith

Wardon Abbey, 203, 208

Ware. See Anschil $22 \mathrm{1} b, 222 b$, note $222 b, 223 a$, $252 b, 253 a$

William Gros, $246 b$

Warenne, William de, 200, 202, 208, 209, note 209, 214, 215, $221 a, 232 b, 233 a$

Warner, $240 a$

Warwick. See Turchil

Wast, Nigel de, 199, 243b, $245 a$

Wenelinc, $241 b$

Wenesi the chamberlain, $222 a$

Westminster, St. Peter of (abbey), 229a, 229b

Westminster, St. Peter of (abbot) 197, $221 a, 229 a$

Widrus, 262a

Wig, thegn of King Edward, $25 \mathrm{I} b, 252 a$

Wigod of Wallingford, 202 daughters of, 202

Wigot, huntsman of King Edward, $256 b$

William, 221 $b, 253 b, 266 a$

\section{PLACE NAMES}

Biddenham [Bideham, Bidenham], 197, 204, 206, 211, note $225 b, 226 b, 227 b, 230 a, 240 a$, note $240 a, 246 a, 262 b$

Biggleswade [Bicheleswade, Bichelesworde, Picheleswade], 203, 208, 212, note 232a, note $233 b$, note $24 \mathrm{I} b$, note $243 b$, note $245 b$, note $250 a$, note $250 b, 256 a$ note $256 a, 256 b$, note $258 b$, note $264 a$

Holme in. See Holme

Stratton in. See Stratton

Hundred of, 216, 217, 227a, $227 b, 229 a, 231 b, 233 b$, $235 a$, note 235a, 24I $b$, $245 a, 247 a, 250 a, 252 b$, $254 a, 256 a, 258 b$, note $258 b, 26 \mathrm{I} b$, note $26 \mathrm{I} b$, $263 b$, note $264 a$

Biscot [Bissopescote] in Houghton Regis, 194, 205, 217, $223 a$ Bleadon [Bledone] (Somerset), I96, $225 a$, note $225 a, 225 b$

Bletsoe [Blacheshou, Blecheshou], $239 b$, note $240 a, 257 b$

Blunham [Blunham, Bluneham], I92, 201, 216, 228a, 235b, 260a, note $260 b$

Charlton in. See Charlton

Bolnhurst [Bulehestre, Bolehestre], 223b $225 a, 229 b, 257^{b}$

Boscombe, (Wilts), 202

Breuil (? Broilg) (Calvados), 201

Bromham [Brimeham, Bruneham], 230b, 240a, 257b, 265b

Broom [Brume] in Southill, $243^{b}$, note $243 b$

409
William, King, note 193 , 197 $203,221 a, 222 a, 222 b, 223 a$, $230 a, 248 b, 249 a, 250 b, 254 a$, $262 b, 263 a, 264 b, 266 a$

William son of Rainald, $246 a$

William son of Raineward, $246 b$ William, steward of Bishop of Coutances, $225 b$

William Spech. See Spech

Wimund, 224a.

Wimund. See de Taissel

Wintremelc, Ælfric [Alric] (king's bailiff), 212, 264b

Wwward Levet. See Levet

Wlwi, Bishop of Lincoln. See Lincoln

Wlwin, man of King Edward, 260 a

Wulfmar of Eaton Socon, 20r, 208. See also Ulmar

Brouay (? Broilg) (Calvados), 201 Buchelai [Bochelai, Bocheleia, Buchelai] (Boclow, Bukelowe), Half Hundred, 217, note 217 , $218,224 a$, note $225 b, 226 b$, $227 b, 230 a, 230 b, 237 a, 239 b$, $248 b, 254 b, 257 b, 262 b, 265 b$

Buckinghamshire, 202, 214, note $225 a$, note $228 a$, note $236 b$, note $248 a$

Caddington [Cadendone], I98, 206, 214, 230a, note $230 a$

Cainhoe [Cainou, Chainehou], I99, 208, 244a, 261 $a$

Caisot [Caissot, Chaisot]. See Keysoe

Cambridge, 195

Cambridgeshire, I94, 217, note $236 a$

Camestone. See Kempston

Campton [Chambeltone], $232 a$, $234 a, 255 a$

Cardington [Chernetone], I93, $204,237 b, 260 a$

Carlton [Carlentone], 206, 224a, $244 b, 245 a, 254 b, 264 a$

Catworth, Little (Hunts), 215

Chalgrave [Celgrave], 203, 234 $b$, $255 b$

Channells End [? Chainhalle], $237 a$

Charlton [Cerlentone] in Blunham, 204, 210, 260b

Chawston [Calnestorne (Caluestorne), Chavelestorne], I93, 20I, 2 I I, note 234b, 235a, 240b, note $240 b, 246 b$, note $246 b$ 


\section{A HISTORY OF BEDFORDSHIRE}

Chellington, note $225 b$

Chenebaltone. See Kimbolton

'Chenemondewiche' (Kimwick, Kym'yke, Kenemu' de Wyk), $216,227 b$

Chenotinga. See Knotting

Chester, r95

Chicksand [Chichesane, and also ? Cudessane], 216, 227a, 232a, $242 b, 262 a$

Clapham [Clopeham], I96, 202, note $202,234 a$

Clifton [Cliftone, also Clistone] 205, 227a, 229a, 236a, 245b, $260 a$

Clifton, Hundred of, 217, 218, $227 a$, note $227 a, 227 b, 229 a$, note $232 a, 233 b, 236 a, 238 a$, $242 b$, note $242 b, 245 b, 25 \mathrm{I} a$, 255 , note $255 a, 260 a$, note $260 a$, $262 a$, note $262 a, 263 a$

Clistone. See Clifton

Clophill [Clopelle], I92, I99, 2 II, $244 a$

Cockayne, Hatley. See Hatley

Colchester, St. John's, note $236 b$

Colchester, St. Peter's, note 197

Coldentone. See Goldington

Colmworth [Colmeborde, Culmeworde], note 200,208 , note 208 , note $237 b, 239 b$, note $239 b$, 241 $a$

Cople [Chochepol, Cochepol], 192, 210, 241 $b, 242 a, 260 a$

Cótentin, The, I99

Cranfield [Cranfelle], 212, 228a

Cravenhest. See Gravenhurst

Crawley (Husborne) [Crawelai], I9I, $242 b, 253 a$

Cudessane. See Chicksand

Cuxwold (Lincolnshire), note $249 a$

Daintone. See Dunton

Dallow, a manor in Luton, 197

Dean [Dena, Dene], 192, 196, 205, $207,214,215,224 b, 226 a, 232 b$, $265 a$

Dodintone. See Toddington

Dunstable, note 194

Dunton [Daintone, Domtone (? Donitone)], 192, 203, 231 $b$, note $231 \mathrm{I}, 252 b$, note $252 b$

Eastcotts, note 230a, note $245 b$, note $260 a$

Eastcotts, Harrowden in, See Harrowden

Easton [Estone] (Hunts), 208, 209, 211, 213, 215, note 215, $225 a, 226 b, 232 b, 233 a, 239 b$, $25 \mathrm{I} b, 252 a, 253 b$

Eaton Bray [Eitone], 223b, note $234 b$, note $253 a$

Eaton Socon[Etone], 192, 198, 201, 208, 2I2, 213, note 223, note $228 b, 234 b$, note $234 b$, note $235 a$, note $240 b$, note $245 a, 252 a$, note note $258 a$, note $26 \mathrm{I} a, 262 a, 262 b$

Wyboston in. See Wyboston Sudbury in. See Sudbury

Echam. See Higham Gobion

Edlesborough [Edingeberge, Edinberge], $248 a$, note $248 a$

Edworth [Edeworde], 233b, 263b

Einulfsbury. See St. Neots

Elstow [Elnestou], 208, $257 a$

'Elvendone,' 254a

Eseltone. See Shelton

Essex, 197, note $236 a$

Estodham. See Studham

Estwiche. See Astwick

Eversholt [Eureshot], 192, 223b, $239 a, 263 a$

Henlow [Haneslawe, Haneslau], 198, 200, 21 2, 245b, 25 I a, 262a

Henwick or Hinwick in Podington [Hanewich, Henewich, Hanewic, Henewic], 206, 225b, note 225b, 246b, 251 b, 252a, $254 b$, note $254 b, 263 a$

Herts, I95, 200, 2I4, 255a

Higham Gobion [Echam], $239 b$ Hitchin (Herts) [Hiz], note 193, I95, note 195,2666

Holcutt [Holecote], 246a

Hocliffe [Hocheleia], 26I a

Holme [Holma] in Biggleswade, 203, note 232a, 233b, $241 b, 245 b, 250 b, 256 a, 258 b$, $264 a$

Everton [Euretone, Evretune], Holwell [Holewelle], 192, 229a, $210,214,259 b, 266 a$

Evesham, Battle of, I99

Eyeworth [Aieworde,Aisseworde], 192, 247a, 26I $b$

Farndish [Farnedis, Fernadis] $214,253 b, 266 a$

Felmersham[Flammeresham], note $245 a$, note $248 b, 255 a, 258 a$, note $258 a$

Radwell in. See Radwell

Flanders, French, 203

Flitt [Flictham], Hundred, I94, $217,218,223 a, 228 b, 229 b$, $233 a, 238 b$, note $239 a, 244 a$, $246 a, 248 b, 251 a, 261 a, 264 a$

Flitton [Flictham], $248 b$

Flitwick [Flictewiche], 213, note $243 a, 246 a$, note $246 a, 253 a$, note $263 b$

Priestley in. See Priestley

Gamlingay (Cambs), 20I

Giveldene. See Yelden

Gladley (farm) [Gledelai] in Kendals in Wrestlingworth, note Heath and Reach, $256 b$

Goldington [Coldentone, Gold- Kent, I96, note $253^{\circ}$ entone], 205, 212, 226b, note $237 a, 237 b$, note $237 b, 24 \mathrm{r} a$, $264 b$

Gravenhurst [Cravenhest], $239 a$

Hanefelde, 214, note 214, 216, $232 b, 265 a$

Hants, note $233 b$, note $254 b$

Harlington [Herlingdone], 212, $243 a$

Harrold [Harewelle], 21 2, $258 a$

Harrowden [Herghetone, Hergentone] in Eastcotts, 197, 204, 206, 230a, 245b, 260a

Hartwell (Bucks), I97

Hatley (Cambs), 20I

Hatley Cockayne [Hatelai], 20r, $210,259 b, 26 \mathrm{I} b$

Haynes or Hawnes [Hagenes], note $200,238 b$

Heath and Reach, note $256 b$ $229 b$

Houghton Conquest [Houstone, Oustone], I92, 238b, 257a, $260 b$

Houghton Regis [Houstone], I94, $222 b, 223 a$, note $223 a$

Church of, 197, 223a

Biscot in. See Biscot

Sewell in. See Sewell

Hunsdon [Hodesdone] (Herts), 201

Huntingdon, 195

Hunts, 203, 214, 215, note 215, note 225 a, note $226 b$, note $227 a$, note $232 b$, note $239 b$, note $25 \mathrm{I} b$, note $252 a$, note $253 b, 266,266 b$

Husborne Crawley. See Crawley.

Irchester (Northants), 196

Ivel river, 2 I 2

Kempston [Camestone], 208, note 208, 257a, 260a $227 b$

Keysoe [Caisot, Caissot, Chaisot] 204, 2I4, 2I5, 237a, 254a, $266 a, 266 b$

Kimbolton[Chenebaltone](Kenebauton), 202, note 202, 2I4, $215,232 b$, note $232 b, 266 a$

Knotting [Chenotinga] 195, $224 b$

Lalega, La Leigh, La Leye, Lega. See Thurleigh note $250 b$

Lavendon (Bucks), note $258 a$

Leagrave, note $223 a$

Lee in Podington (Puddington), 216

Leicestershire, note $260 b$

Leighton Buzzard [Lestone], I93, 194, 205, 21 3, 222a, note 2566 Church of, note 197, 222a, $227 a$ note $194,205,217$, note 217 ,

Langford [Langeford], 21 2, 250b, 


\section{INDEX TO DOMESDAY}

Lidlington [Litincletone], $229 b$

Limbury, note 223a

Lincolnshire, note $249 a$

Lintone. See Luton

Long Stow. See Stow.

Loucelles [Locels] (Calvados), $20 \mathrm{I}$

Luton [Loitone, Luitone, also Lintone], 194, 222a, 223a, note $223 a, 252 b$, note $252 b, 264 a$

Church of, 197, 222b

Manshead [Manesheve, Manehe,ve], Hundred of, note 216 , 217 , note $217,218,223 b$, note $223 b, 231 a, 234 b$, note $236 b$, $238 b, 242 b, 246 a$, note $247 b$, note $248 a$, note $249 a, 252 b$, $253 a, 255 b, 256 b$, note $256 b$, 26ra, 263a, 266b

Marston Morteyne [Merestone, Merstone], 192, 231 $b$, note $231 b, 243 a$, note $243 a$, note $255 b, 260 a$

Shelton in. See Shelton

Maulden [Meldone], I99, note $199,23 \mathbf{r} b, 238 a, 243 b, 256 b$, $263 b$

Melchbourne [Melceburne], I96, $224^{b}$

Meppershall[Malpertesselle], 212, 2I4, note 2I4, 255a

Milbrook, Millbrook [Melebroc], I99, $243 b$

Millow [Melehou], 227a, 232a, $233 b$

Milton Bryant [Mildentone], $223 b, 239 a$

Milton Ernest [Middeltone, Mildentone], 202, 234a, 239b, $244 b$, note $244 b$, note $248 b, 249 b$, $260 b, 265 b$

Newton Bromshold [Newentone], 196, $214,225 b$, note $225^{b}$

Northants, 195, 200, 203, 2I4, 215 , note $225 b$, note $226 a$, note $228 a$, note $236 b$, note $260 b, 266$

Northill [Nortgible, Nortgivele, Nortgive], 192, 236a, 242 $b, 247 b$

Oakley [Achelei], 192, 247b, $257 b$

Odecroft, Hundred of, $217,223 a$

Odeil [Wadelle, Wahull], I92, I99, 210, 212, 23I $a, 249 b$

Otone. See Wootton

Ouse river, note $248 b$

Oustone. See Houghton Conquest

Pavenham [Pabeneham], I92, $211,230 b, 248 b$, note $248 b, 254 b$

Paxton, Little (Hunts), note $252 a$

Pegsdon [Pechesdone] in Shillington, $197,228 b$, note $228 b$

Perry, near Kimbolton (Hunts), note 215
Pertenhall [Partenhale], 215, Shel ton [Eseltone], 225a

266a, $266 b$ Shelton [Eseltone] in Marston

Picheleswade. See Biggleswade Morteyne, 209, 243a, 255b,

Pileworde. See Tilsworth 260a

Podington, Puddington [Podin- Shillington [Sethlindone], 212, tone, Potintone] (Podyngtone), 196,214 , note 216 , note $225 b$, $2496,25 \mathrm{I} b$, note $25 \mathrm{I} b$, note $252 a$, note $253 b$, note $254 b, 266 b$

Potsgrove [Potesgrava, Potesgrave], 192, I97, note $222 b$, $252 b, 256 b, 263 b$

note 228b, $229 a$

Pegsdon in. See Pegsdon

Shrewsbury, I95

Shropshire, note $253^{b}$

Silsoe [Sewilessou, Siwilessou], $244 a, 251 a$

Souldrop, note $225 b$

Potton [Potone], 204, 210, 258b, Southill [Sudgivele], 203, 21 I, $259 b$

Priestley [Prestelai] in Flitwick, $213,243 a, 263 b$

Pulloxhill [Polochessele], $244^{b}$

Putnoe [Puttenehou], 237a, $237^{b}$

Radwell [Radewelle] in Felmersham, 193, 207, 245a, note $254 a, 258 a$

Raunds (Northants), I96

Redbornstoke [Radeburnesoca, Radbernestoche, Radborgestoc, Ratborgestou, Ratbernestoche, Ratborgestoche, Radburnestoc], Hundred of, $217,218,228 a, 229 b, 23 \mathrm{I} b$, $238 a, 243 a$, note $243 b, 246 a$, $25 \mathrm{I} a, 253 a, 255 b, 256 b, 260 a$, $263 b, 265 a$

Richards Castle (Herefordshire), 203

Ridgmont, note $25 \mathrm{I} a$ $2 \mathrm{I} 3,235 b$, note $235 b, 237 b$, note $237 b$, note $24 \mathrm{I} b, 247 a$, note $247 a$, $250 b, 252 b, 259 b$, note 261 $b$, note $264 b$

Broom in. See Broom

Stanford in. See Stanford

Southwark, note $253 a$

Spaldwick (Hunts), 2 I 5

Stagsden [Stachedene], 193, 2I3, $224 a, 230 b, 237 a, 257 b$

Stanburge [Stanbridge], Half Hundred of, 217, note 217 , $223 b, 236 b, 247 b, 248 a, 249 a$, $253 a, 256 b$

Stanford [Stanford] in Southill, $208,235 b, 237 b, 24 \mathbf{I} b, 247 a$, $26 \mathrm{I} b, 264 \mathrm{~b}$

Stanstead Abbots (Herts), 201

Stanwick [Stanewiga, Stanewica] (Northants), 2I4, 228a, note $228 a$

Staughton, Little, 2I 3, 2 I 5

Ridgmont, Segenhoe in. See Stepney, I97 Segenhoe

Riseley [Riselai], I92, ז96, 225a, $226 b, 237 a, 239 b, 253 b, 256 a$

Rothwell (Lincs), note 249a

Rots [Ros] (Calvados), $20 \mathrm{I}$

Roxton [Rochesdon], I92, note $235 a, 240 b$, note $240 b$, note $246 b, 247 a$

Rushden [Risdene, Risedene], 196, $214,226 a$, note 226a, $236 b$, note $249 a$

St. Neot's (Einulfsbury), 198, note I98

Salford [Saleford], $238 b$

Steppingley [Stepigelai], 246a

Stevington [Stivetone, Stiventone], 202, note 202, 224a, note $224 a, 230 b$

Stodden [Stoden, Stodene], Hundred of, $216,217,218,223 b$, $224 b, 226 a, 228 a$, note $229 b$, $232 b, 234 a, 236 b, 239 b$, note $244 b$, note $247 b, 249 b, 25 \mathrm{I} b$, $252 a, 253 b, 256 a, 257 b, 260 b$, note $26 \mathbf{1} a, 265 a$

Stondon [Standone], 229a, 262a

Stotfold [Stotfald, Stotfalt], I98, 200, 201, 238a, 262a

Stow, Long, 2I 5 (Hunts)

Salph End, Salpho [Salchou] in Stratton [Stratone] in BigglesRenhold, $238 b$, note $238 b$

Sandy [Sandeia], 200, 201, 2II, $213,216,235 a$, note $247 b$, note $254 b$, note $265 a$

Beeston in. See Beeston

Segenhoe [Segenehou] in Ridgmont, 203, 212, $251 a$

'Segresdone,' 214, 216, 2516

Sewell [Sewelle] in Houghton Regis, 194, 205, 217, $223 a$

Sharnbrook [Scernebroc, Sernebroc], 202, 206, 207, 213, 225b, 226a, 23I $a, 240 a, 25$ I $b, 254 a$, $255 b, 258 a, 263 a$ wade, 203, 232a, 250a, $256 a$, $258 b$

Streatley [Stradlei, Stradli, Straillei], I92, I98, 200, 21 I, note $228 b, 233 b, 239 a, 244 b, 246 a$, $264 a$

Studham [Estodham], 198

Sudbury [Subberie], in Eaton Socon, note 198, $216,252 a$, note $258 a$

Suffolk, note $231 b$, note $236 a$

Sundon [Sonedone], $233 a$

Sutton [Sudtone, Suttone], 20r, $205,235 b, 259 a, 264 a$ 


\section{A HISTORY OF BEDFORDSHIRE}

Swineshead (Hunts), 2 I4

Tadlow (Cambs), note 26I $b$

Tempsford [Tamiseforde], 192, $201,208,212,227 a, 235 a, 252 b$ $263 b$

Tessel (Calvados), 201

Thurleigh [Lalega], 192, 205, $216,234 a, 240 b$, note $240 b$, $248 a, 250 a$, note $250 a$

Tillbrook [Tilebroc], 200, 208, $214,215,232 b$

Tilly-sur-Seulles (Calvados), 201

Tilsworth [Pileworde], $236 b$

Tingrith [Tingrei], $242 b$

Toddington [Dodintone, Totingedone], note 196, 234b, 246a, note $246 a, 246 b$

Totternhoe [Totenehou], 197, $211,249 a, 253 a$

Trelly near Coutances, 196

Turvey [Torveia, Torveie, Tornai, Tornei, Torneia, Torueia], I98, I99, $210,224 a, 225 b$, note $225 b, 231 a, 240 a, 245 a$, note $245 a, 248 a, 249 b$, note $249 b$, $265 b$

Turweston (Bucks), note $222 a$

Vast, le, near Cherbourg, I99

Wadell [Wabull]. See Odell
Warden [Wardone] 247a, 256a, note $2566,261 b$

Ware [Wares, Warres] (Herts), note 196,200 , note $216,237 b$, $238 b, 24 \mathrm{I} a, 24 \mathrm{I} b, 242 a$

Weneslai, Half Hundred of, 217 , $235 a, 258 b, 26 \mathrm{I} b, 264 a$

Westcote [Wescote], in Willshamstead, $212,243 b$, note $243 b$, $265 a$

Westoning [Westone], note I93, 212, 213, 216, 266a

Wigginton (Herts), 202

Wilden [Wildene], 224a

Willey [Wilga], Ḧundret of, 209, 217 , note $217,224 a$, note $224 a$, $225 b$, note $225 b$, note $226 b$, note $227 b$, note 230a, 23I $a, 234 a$, $236 b$, note $237 a$, note $239 b$, $240 a, 244 b, 246 b, 248 a$, note $248 b, 249 a, 249 b, 251 b, 252 a$, $253 b, 254 a$, note $254 b, 255 a$, $255 b$, note $257 b, 258 a, 262 b$, $263 a, 264 a, 265 b$, note $265 b$

Willington [Welitone, Weltone], $238 a, 242 a$,

Willshamstead [Winessamestede] 208 , note $243 b, 257 a$

Westcote in. See Westcot

Wilts, note $233 b$, note $254^{b}$

Wincot (Gloucestershire), 197

Wixamtree [Wichestanestou,
Wichestavestou], Hundred of, $217,218,228 a, 230 a, 235 b$, $237 b, 24 \mathrm{I} b$, note $243 b, 245 b$, $247 a, 250 b, 252 b, 254 b, 256 a$, note $256 b, 259 b, 260 b$, note $26 \mathrm{I} a$, $26 \mathrm{I} b, 263 a, 264 b$

Woburn [Woburne, Woberne] 202, 23I $a, 263 b$

Wootton [Otone], 209, $255 b$

Wratsworth [Warateworde], in Orwell, 216

Wrestlingworth, 216

Kendals in. See Kendals

Wyboston [Wiboldestone] in Eaton Socon, 193, note 198, 201, 228b, note 228b, note $234 b, 235 a, 240 b, 245 a, 252 a$, 26I $a$

Wymington, Wimmington [Wimentone], I 92, 2 I I , 246b, 249a, $250 a$, note $254 b, 264 b, 265 b$

Yelden [Giveldene], I96, 216, $224 b$

Unnamed in Manshead Hundred, $242 b$

Unnamed in Willey Hundred, $225 b, 265 b$

Unnamed in Biggleswade Hundred, $245 a$ 





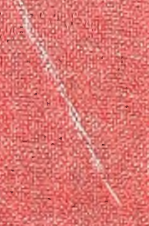

$$
\text { (7) }
$$

7.

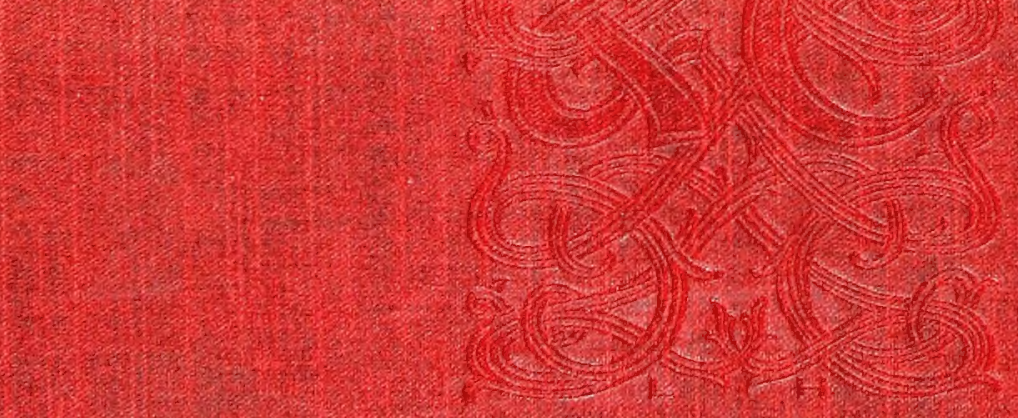

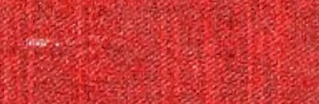

